UNIVERSIDADE DE SÃO PAULO

FACULDADE DE FILOSOFIA, LETRAS E CIÊNCIAS HUMANAS

DEPARTAMENTO DE FILOSOFIA

PROGRAMA DE PÓS-GRADUAÇÃO EM FILOSOFIA

Gustavo Barreto Vilhena de Paiva

\author{
O conhecimento abstrativo \\ em Henrique de Gand (a. 1240-1293)
}

- versão corrigida -

De acordo,

Prof. Dr. José Carlos Estêvão São Paulo, 10 de novembro de 2017 


\section{Gustavo Barreto Vilhena de Paiva}

\section{O conhecimento abstrativo em Henrique de Gand (a. 1240-1293)}

Tese apresentada ao programa de PósGraduação em Filosofia do Departamento de Filosofia da Faculdade de Filosofia, Letras e Ciências Humanas da Universidade de São Paulo, para obtenção do título de Doutor em Filosofia sob a orientação do Prof. Dr. José Carlos Estêvão. 
Autorizo a reprodução e divulgação total ou parcial deste trabalho, por qualquer meio convencional ou eletrônico, para fins de estudo e pesquisa, desde que citada a fonte.

Catalogação na Publicação

Serviço de Biblioteca e Documentação

Faculdade de Filosofia, Letras e Ciências Humanas da Universidade de São Paulo

$\mathrm{P} 142 \mathrm{C}$

Paiva, Gustavo Barreto Vilhena de

O conhecimento abstrativo em Henrique de Gand (a.

1240-1293) / Gustavo Barreto Vilhena de Paiva ;

orientador José Carlos Estêvão. - São Paulo, 2018.

$629 \mathrm{f}$.

Tese (Doutorado)- Faculdade de Filosofia, Letras e Ciências Humanas da Universidade de São Paulo. Departamento de Filosofia. Área de concentração: Filosofia.

1. sentido. 2. intelecção. 3. abstração. 4 . ciência. 5. Henrique de Gand. I. Estêvão, José Carlos, orient. II. Título. 
À memória de meus avós,

Zenóbia Gomes Barreto $(†$ 1998)

José Antunes Barreto $(\dagger$ 1993)

Maria Eugênia Vilhena de Paiva $(†$ 2007)

Anthero Mendes Paiva ( $\uparrow$ 1944)

...não fora

para tão longo amor tão curta a vida

Camões, Soneto XXIX 


\section{AGRADECIMENTOS}

É, sem dúvida, impressionante quando, na paz de havermos terminado um trabalho ou projeto, percebemos quantas pessoas e instituições colaboraram para que ele fosse levado a cabo. Por isso mesmo, é com grande satisfação que estendemos nossos agradecimentos a todos quanto tornaram, pelas mais diversas formas de apoio, o presente trabalho possível.

Em primeiro lugar, dirijo meus sinceros e cordiais agradecimentos ao prof. José Carlos Estêvão, meu orientador no Depto. de Filosofia da USP desde meu primeiro semestre de graduação. Com ele desenvolvi minha Iniciação Científica e, também com ele, tive o enorme prazer de trabalhar durante o Doutorado. É uma verdadeira honra tê-lo como professor desde a primeira disciplina de bacharelado até agora, dez anos depois - e de agora em diante. Cada mínima etapa do presente trabalho foi com ele discutida e ponderada.

Ao mesmo tempo, pude participar em todo esse período das atividades do Centro de Estudos de Filosofia Patrística e Medieval de São Paulo (CEPAME). Lá também tive espaço para discutir muitas das leituras aqui defendidas, ao mesmo tempo em que pude acompanhar as pesquisas dos demais professores e colegas do grupo. Assim, agradeço profundamente ao prof. Carlos Eduardo de Oliveira (USP), à profa. Cristiane Negreiros Abbud Ayoub (UFABC), ao prof. Carlos Arthur Ribeiro do Nascimento (PUC-SP), ao prof. Lorenzo Mammì (USP), ao prof. Moacyr Novaes (USP) e ao prof. Arthur Klik (UFLA). Devo mencionar aqui Júlia Molinari, Júlia Maia, Rodrigo Sote, André Botelho, Rafael Barberino, Fabrício Cristofoletti, Roberto Pignatari, Richard Lazarini, Mizael de Souza e outros tantos colegas a que agradeço muito pelas vezes em que debatemos os mais diversos temas de história da filosofia medieval.

A partir do início da Pós-Graduação, passei a participar das atividades do GT ANPOF História da Filosofia Medieval e a Recepção da Filosofia Antiga, no qual por diversas vezes também tive a oportunidade de discutir a presente pesquisa. Assim, além dos professores e colegas já mencionados, cumpre agradecer também aos membros do GT, especialmente nas pessoas do prof. Rodrigo Guerizoli (UFRJ) e do prof. Alfredo Storck (UFRGS), aos quais sou grato não somente pelas discussões e sugestões, mas também por terem contribuído na obtenção de material bibliográfico para a pesquisa. 
Mencionem-se, igualmente, as importantíssimas sugestões feitas pelos já citados prof. Carlos Arthur e prof. Rodrigo Guerizoli na ocasião de minha Qualificação, pelo que estendo a eles renovado agradecimento. Aproveito ainda para sublinhar as interessantes observações e questões colocadas, no momento da Defesa desta Tese, pela banca composta pelo prof. Marco Aurélio Oliveira da Silva (UFBA) e pelos já referidos prof. Rodrigo Guerizoli, prof. Alfredo Storck e prof. Carlos Eduardo. A eles, mais uma vez, agradeço pela contribuição ao presente trabalho.

Outra pessoa a quem devo dirigir especial agradecimento é a profa. Greti DinkovaBruun (PIMS), a quem tive o prazer de conhecer em um curso de paleografia latina na Durham University no fim de minha graduação, em 2010. Desde então, segui duas séries de seminários sobre paleografia ministradas por ela em São Paulo, contando com sua generosidade e reconhecida habilidade na introdução ao trabalho paleográfico. A ela também agradeço pelo auxílio em obter material bibliográfico.

Como já mencionado acima, desenvolvi tanto minha Iniciação Científica como meu Doutorado na Universidade de São Paulo, instituição que, já há dez anos, vem apoiando minha pesquisa das mais diversas formas. Por isso, estendo um agradecimento especial à USP e, em particular, ao pessoal acadêmico e administrativo da FFLCH e do Depto. de Filosofia, que sempre me auxiliou com presteza quando necessário. Além disso, a presente pesquisa não teria sido possível sem o apoio financeiro da Coordenação de Aperfeiçoamento de Pessoal do Nível Superior (CAPES). Unicamente por tal apoio fui capaz de obter uma enorme parte do material bibliográfico com que pude contar durante a presente pesquisa.

Nesse ponto, devo mencionar a sra. Mariana Queiroz, bibliotecária responsável pelo IFLA na Biblioteca Florestan Fernandes (SIBi/FFLCH/USP). Foi somente pelo esforço dela que pude obter a enorme maioria do material que não estava disponível em bibliotecas brasileiras. Foi uma grande sorte ter podido contar com seu simpático e inestimável auxílio no decorrer desses anos. Na pessoa dela, aproveito também para agradecer a todo o pessoal técnico e administrativo (especialmente, àquele ligado ao COMUT e ao EEB) da Biblioteca Florestan Fernandes. Ademais, devo dirigir especial agradecimento à sra. Maria Aparecida Batista do Nascimento, bibliotecária da Biblioteca dos Redentoristas em São Paulo, com cujo solícito apoio tenho contado desde a Iniciação Científica. Cumpre mencionar também a equipe da Biblioteca Constantino Koser do Instituto Teológico Franciscano em Petrópolis, que gentilmente me auxiliou durante meus dias de pesquisa no instituto. No mais, além dessas três, é preciso mencionar outras tantas bibliotecas que pude consultar pessoalmente, como as 
demais bibliotecas do SIBi-USP, as bibliotecas da PUC-SP, da UNICAMP e, ainda na graduação, a biblioteca da Durham University, bem como, graças ao financiamento da PróReitoria de Pesquisa da USP, as bibliotecas da Universidade do Porto, da Ohio State University e da Rutgers University. Desta última, aliás, tenho a agradável lembrança da sra. Monica Emery, então funcionária da Rutgers University, que me ajudou a obter - na verdade, me presenteou com - a primeira cópia a que tive acesso da edição crítica da Suma, arts. 1-5, de Henrique de Gand, ainda no ano de 2010!

Menciono também o prof. Gordon Wilson (UNC Asheville), que gentilmente me enviou um trabalho seu que não pude obter por outros meios. Pelo acesso a muito do material polonês que cito, agradeço à sra. Anna Starościc (do periódico Roczniki Filozoficzne) e ao prof. Antoni Siemianowski (Uniwersytet im. Adama Mickiewicza w Poznaniu). Devo mencionar também o prof. Jacques Pycke (UCL) e o sr. Pierre Dehove, arquivistas da Catedral de Tournai, não somente pelo acesso ao obituário de Henrique de Gand contido no ms. ACT Reg. 83, mas também pela pequena aula por e-mail sobre obituários medievais de cônegos.

Não seria possível, porém, ter acesso a todo esse material bibliográfico sem um suporte no estudo de línguas estrangeiras. Por isso, é indispensável dirigir aqui profundos agradecimentos à profa. Carmen Fokker, de holandês, à profa. Barbara Rzyski, de polonês, ao prof. Fernando Ferrari, de japonês, e ao prof. Johannes Aleksi Salmi, de finlandês. A eles agradeço não somente pelas aulas, mas também pelo auxílio em problemas específicos de leitura de textos utilizados para a tese. Agradeço aqui também ao prof. Zoljargal Baatarkhuu, com quem tenho estudado a língua mongol. Nesta tese não me utilizo de material em mongol e, justamente por isso, as aulas com o prof. Zoloo, sempre culturais e animadas, têm sido uma oportunidade de fugir um pouco da Idade Média latina, para conhecer uma outra cultura linguística igualmente milenar.

Por fim, agradeço de coração àqueles sem os quais nada do que foi mencionado aqui poderia ter ocorrido, os meus pais Mara Barreto e José Henrique Vilhena. Durante todo esse percurso, eles não somente me apoiaram sempre - e muito! - como filho, mas também intelectualmente, discutindo cada tema, cada ideia, cada hipótese. A eles, honestamente, o maior agradecimento não seria suficiente.

E, falando em família, aproveito para mencionar meu querido tio José Antônio, que desde criança tem me mostrado sempre o que é ser um verdadeiro cultor da língua materna. Cito meus irmãos Anthero, Henrique e Guilherme - com os quais, aliás, me desculpo por 
todas as vezes em que não pude viajar por estar fazendo esta tese... Lembro ainda meus amigos (da escola e de sempre!) Felipe, Samir, Tiago Ferrari, Tiago Fadel - que, na verdade, hoje também já são minha família.

Demais agradecimentos serão mencionados no decorrer do trabalho. 
"Adde quod in unaquaque familia est aliquid insigne, quod non sit ei commune cum ceteris. Atque ut a nostris, ad quos postremo philosophia pervenit, nunc exordiar, est in Joanne Scoto vegetum quiddam atque discussum, in Thoma solidum et aequabile, in Aegidio tersum et exactum, in Francisco acre et acutum, in Alberto priscum, amplum et grande, in Henrico, ut mihi visum est, semper sublime et venerandum".

“Acrescente-se que em cada escola há algo de peculiarmente insigne não comum com as outras, e, para começar com os nossos, aos quais chegou finalmente a investigação filosófica, há em João [Duns] Escoto qualquer coisa de vigoroso e de sutil, em Tomás [de Aquino] de sólido e de equilibrado, em Egídio [Romano] de terso e de exato, em Francisco [de Mayronnes] de penetrante e de agudo, em Alberto [Magno] de antigo, amplo e imponente, em Henrique [de Gand], parece-me, qualquer coisa sempre sublime e veneranda".

Giovanni Pico della Mirandola, Discurso sobre a dignidade do homem. Ed. bilíngue. Trad. e apresentação de Maria de Lourdes Sirgado Ganho, estudo introdutório de Luís Lioa. Lisboa: Edições 70, 2006 pp. 92-3 (adaptado para a ortografia brasileira) [texto latino base para a tradução: ed. Eugenio Garin. Firenze: Vallechi, 1942] 


\section{RESUMO}

PAIVA, G. B. V. de. O conhecimento abstrativo em Henrique de Gand (a. 1240-1293). 2018. 629 f. Tese - Faculdade de Filosofia, Letras e Ciências Humanas. Departamento de Filosofia, Universidade de São Paulo, São Paulo, 2018.

Henrique de Gand pode ser considerado um dos mais importantes mestres em atividade na Universidade de Paris do último quarto do século XIII. Em sua volumosa obra - composta, principalmente, por sua Suma de questões ordinárias e por 15 conjuntos de Questões quodlibetais -, Henrique disserta frequentemente acerca do conhecimento humano. Em particular, ele dedica amplo espaço em seus textos [1] à caracterização do homem como ser capaz de obter conhecimento e [2] à discussão sobre o modo como, uma vez afetado pelos objetos de conhecimento, o homem age (por suas potências cognoscitivas) para produzir tal conhecimento. Esse conhecimento simples, obtido por abstração dos sentidos, será a base para o conhecimento proposicional posterior. Entretanto, é patente uma fundamental dificuldade na filosofia de Henrique: tanto [1] a potência humana para o conhecimento como [2] a atividade humana para tal conhecimento são insuficientes para a produção de um conhecimento estritamente verdadeiro. Sendo assim, a doutrina da intelecção de Henrique, muito embora admita a ocorrência de um conhecimento intelectual por abstração a partir dos sentidos, igualmente aponta para a necessidade de uma ação divina, para além da abstração e da própria alma humana, que permita um conhecimento estritamente verdadeiro. $\mathrm{O}$ presente trabalho se concentra na descrição da noção de conhecimento abstrativo em Henrique de Gand para, ao final, apontar a problemática necessidade, sublinhada por nosso autor, de um ultrapassamento desse conhecimento proveniente dos sentidos.

Palavras-chave: sentido, intelecção, abstração, ciência, Henrique de Gand (a. 1240-1293). 


\begin{abstract}
PAIVA, G. B. V. de. Henry of Ghent (a. 1240-1293) on abstractive knowledge. 2018. 629 f. Thesis - Faculdade de Filosofia, Letras e Ciências Humanas. Departamento de Filosofia, Universidade de São Paulo, São Paulo, 2018.

Henry of Ghent can be considered as one of the most important masters at the University of Paris in the last quarter of the 13th century. In his voluminous work - composed mainly by his Summa of Ordinary Questions and 15 sets of Quodlibetal Questions -, Henry often discusses human knowledge. Specially, he gives ample room in his texts [1] to the characterization of man as a being capable of acquiring knowledge and [2] to the discussion about the way in which man acts (through his cognitive potencies) to produce such knowledge once affected by the objects of knowledge. This simple knowledge, acquired through abstraction from the senses, will be the basis for the posterior propositional knowledge. Nevertheless, a fundamental difficulty is clear in Henry's philosophy: both [1] human potency for knowledge and [2] human activity toward knowledge are insufficient for the production of strictly true knowledge. Thus, although Henry's doctrine of knowledge accepts the occurrence of intellectual knowledge through abstraction from the senses, it also points to the necessity of some divine action - beyond abstraction and the human soul itself - which allows for strictly true knowledge. The present study concentrates on the description of Henry of Ghent's conception of abstractive knowledge pointing at the end to the problematic necessity highlighted by our author of surpassing this knowledge acquired through senses.
\end{abstract}

Key Words: sensation, intellection, abstraction, science, Henry of Ghent (a. 1240-1293). 


\section{SUMÁRIO}

Pág.

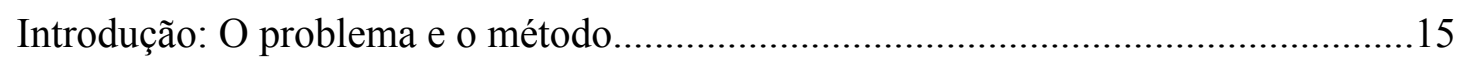

$\S 1$ - A possibilidade do conhecimento humano como problema...........................15

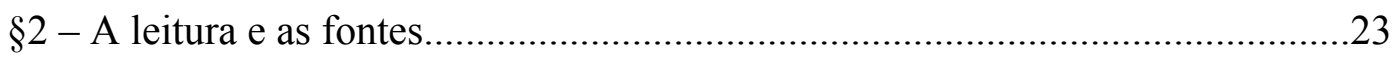

A. Sobre a metodologia de leitura das obras de Henrique de Gand................23

B. Sobre as bibliografias primária e secundária utilizadas..............................26

Parte 1:

O conhecimento como potência e possibilidade

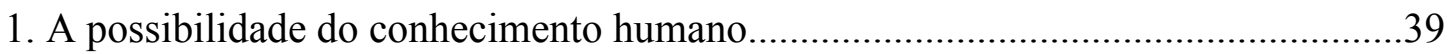

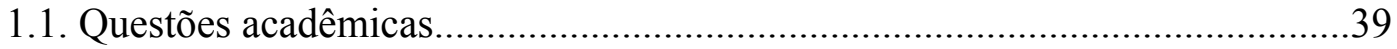

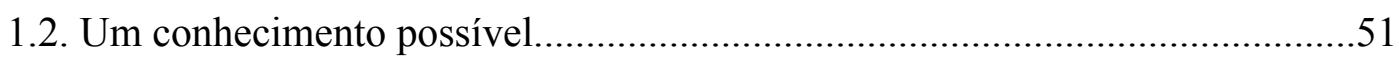

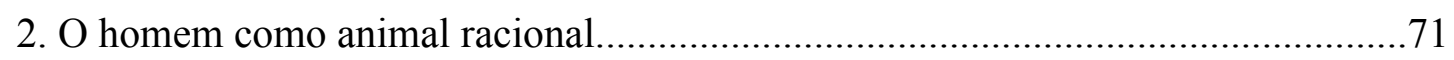

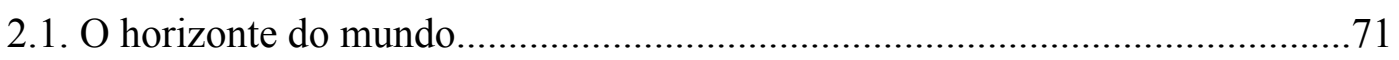

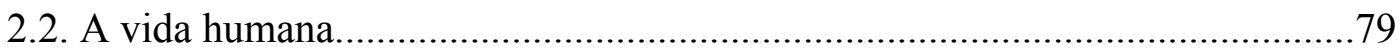

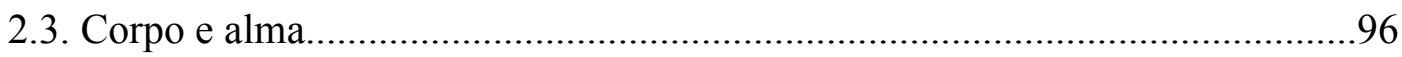

2.3.1. A necessidade da conjunção entre corpo e alma..................................96

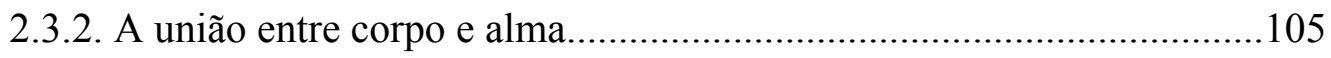

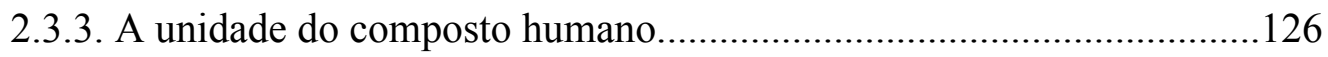

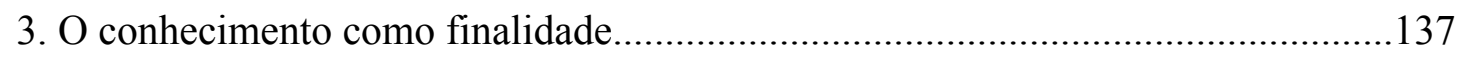

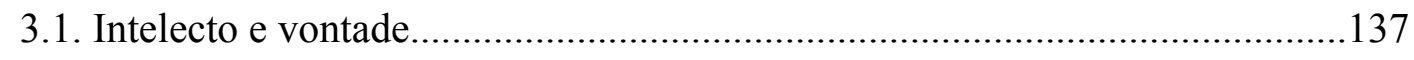

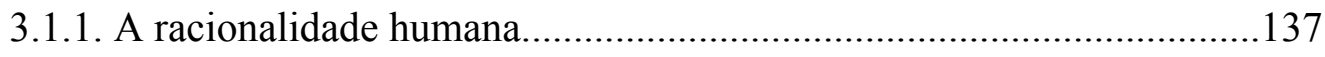

3.1.2. A relação entre intelecto e vontade.....................................................146

3.1.2.1. A distinção entre intelecto e vontade......................................146 
3.1.2.2. A hierarquia entre intelecto e vontade 149

3.1.2.3. A ordem causal entre intelecto e vontade.................................155

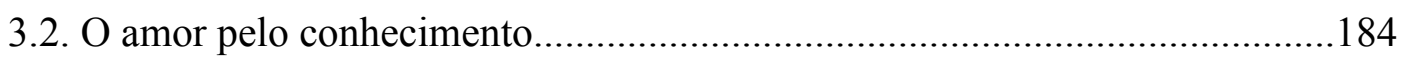

Epílogo da Parte 1: A insuficiência da passividade do intelecto................................206

Parte 2:

A atividade do homem na formação do conhecimento

4. O conhecimento dos sentidos particulares........................................................22

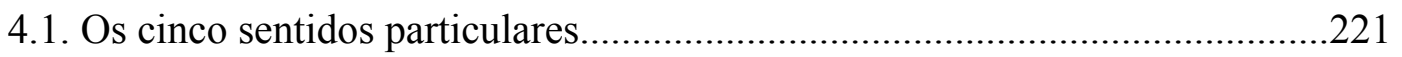

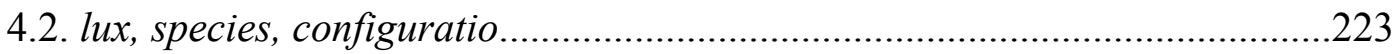

4.3. Passividade, atividade, espécie sensível...................................................235

4.4. O problema da espécie expressa nos sentidos..............................................255

4.5. A descrição do sentido particular em Quodl. 11, q. 5....................................263

4.6. Atividade e passividade nos sentidos particulares.......................................280

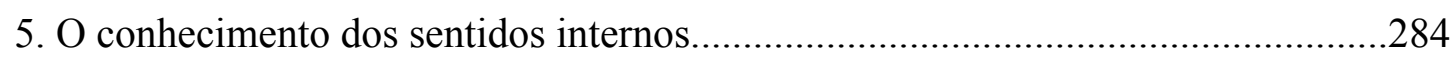

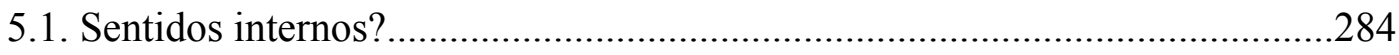

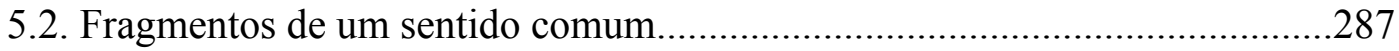

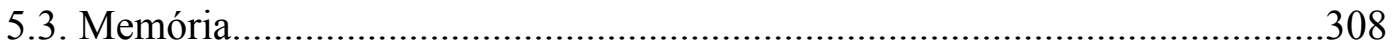

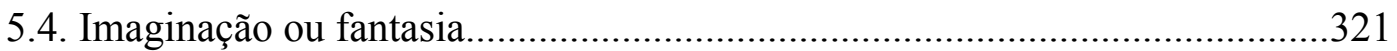

5.4.1. A imaginação face aos demais sentidos..............................................321

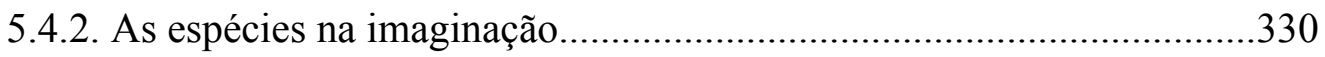

5.4.2.1. A imaginação e as espécies impressas.....................................331

5.4.2.2. A imaginação e as espécies expressas.......................................340

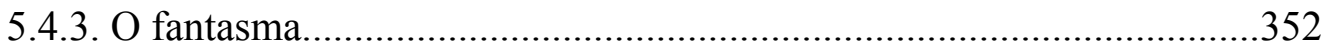

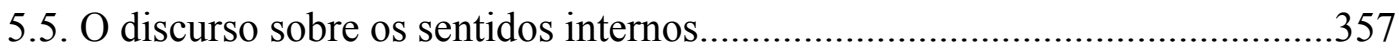

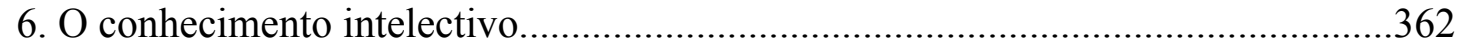

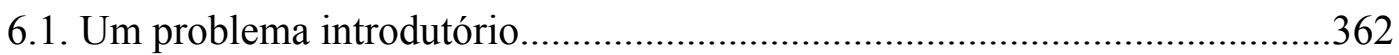

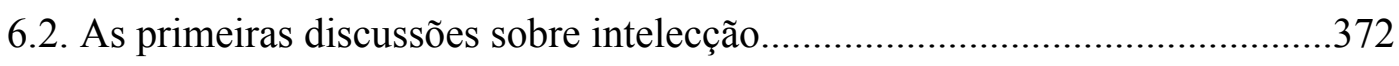

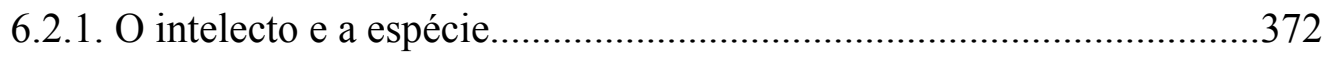

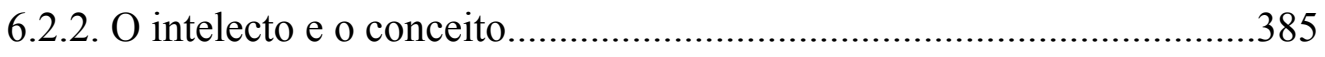

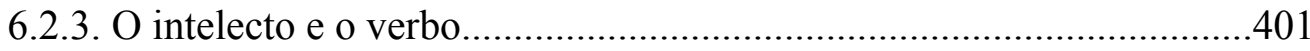

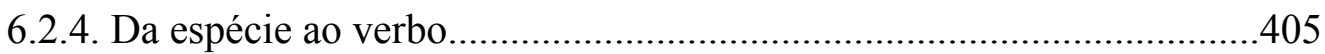




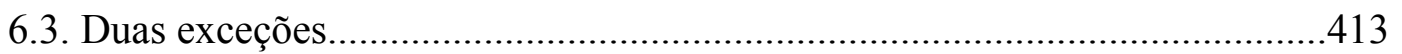

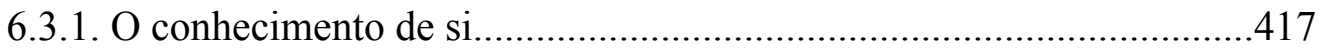

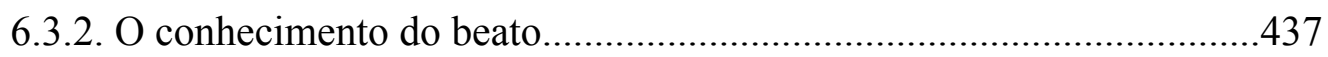

6.4. Os casos de Suma, arts. 33 e 34, e Quodl. 4................................................462

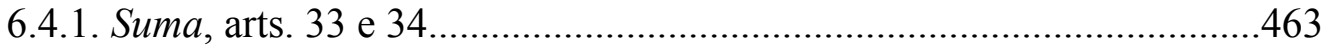

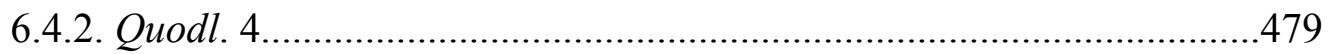

6.5. A espécie expressiva, o fantasma universal e o intelecto imaginário..............506

6.5.1. Das espécies impressas às espécies expressas....................................506

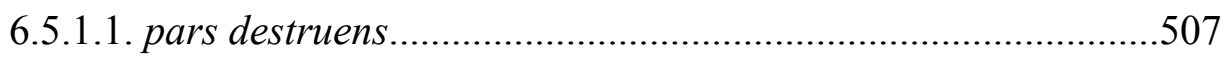

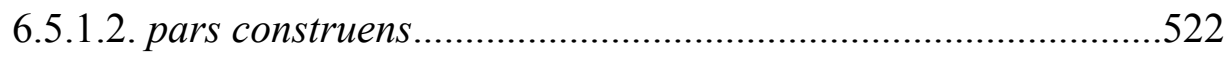

6.5.2. Do fantasma à intelecção - e além..................................................532

Epílogo da Parte 2: A insuficiência da atividade do intelecto.....................................561

Conclusão: Os limites do conhecimento humano.....................................................574

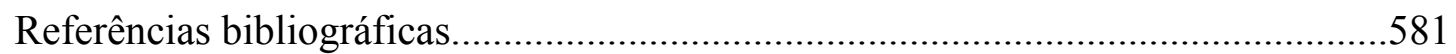

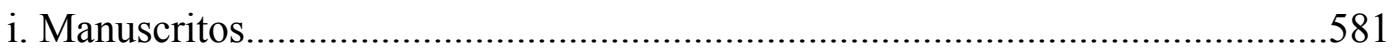

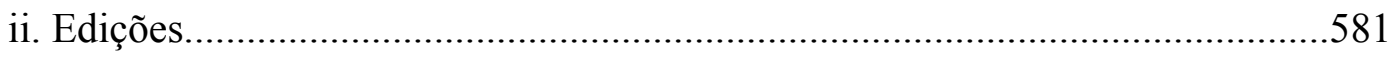

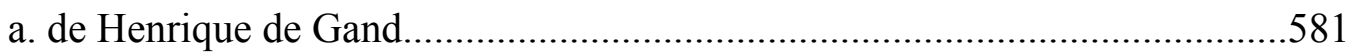

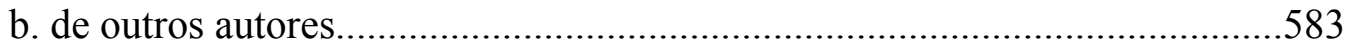

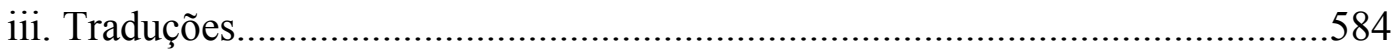

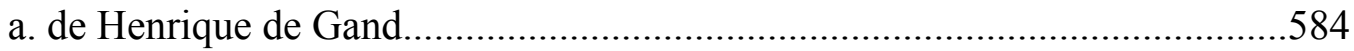

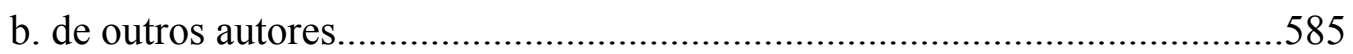

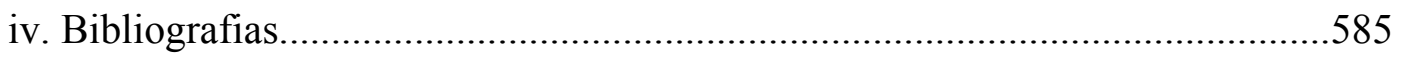

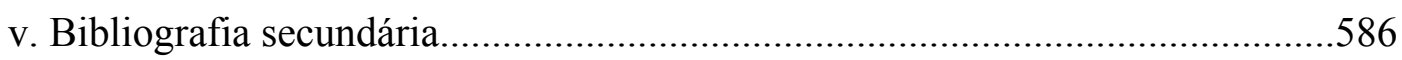




\section{INTRODUÇÃO: \\ O PROBLEMA E O MÉTODO}

\section{$\S 1$ - A POSSIBILIDADE DO CONHECIMENTO HUMANO COMO PROBLEMA}

Talvez o aspecto mais significativo do estudo histórico-filosófico acerca da obra de Henrique de Gand durante o século XX tenha sido o laconismo de Étienne Gilson - vindo dele, um laconismo especialmente eloquente. Não que não possamos encontrar em seus escritos referências ao nosso Doutor Solene. Há, de fato, algumas delas em suas obras de maior fôlego, como La philosophie au moyen âge ${ }^{1}$ ou History of Christian Philosophy ${ }^{2}$. Lemos uma menção a Henrique até mesmo em L'être et l'essence $^{3}$ ou em Being and Some Philosophers ${ }^{4}$. No entanto, Gilson não dedica a nosso autor um livro, como fez com tantos outros - nem mesmo um artigo sequer ${ }^{5}$. Quando teve a chance de se voltar mais atentamente para Henrique, em seu Jean Duns Scot, preferiu preteri-lo em favor de Tomás de Aquino, cuja interlocução com Duns Escoto se mostraria "para nós e em si” mais importante, não obstante Gilson admita que, para Duns Escoto, Henrique seria a referência principal, não Tomás ${ }^{6}$. Ou

\footnotetext{
${ }^{1}$ GILSON, É. La philosophie au moyen âge. 2 vols. Paris: Payot, 1922, vol. 1, pp. 159-60; GILSON, É. La philosophie au moyen âge. Paris: Payot, $2011^{5}\left[1944^{2}\right]$, pp. 439-44.

${ }^{2}$ GILSON, É. History of Christian Philosophy in the Middle Ages. New York: Random House, 1955, pp. 447-54.

${ }^{3}$ GILSON, É. L'être et l'essence. Paris: Vrin, $2008^{3}$ [1948], p. 348 [trad. para o português: GILSON, É. O ser e a essência. Trad. de C. E. de Oliveira, C. N. A. Ayoub, J. M. Madureira, L. M. da Silva Filho, P. C. Ferreira Filho, T. J. R. Leme. São Paulo: Paulus, 2016, p. 418].

${ }^{4}$ GILSON, É. Being and some philosophers. Toronto: Pontifical Institute of Mediaeval Studies, 1949 $\left[1952^{2}\right]$, p. 76.

${ }^{5}$ Há, porém, menções a Henrique de Gand em GILSON, É. "Roger Marston: un cas d'Augustinisme avicennisant". Archives d'histoire doctrinale et littéraire du moyen âge (1933), pp. 37-42 (cf. p. 41, nt. 1); e GILSON, É. "L'infinité divine chez Saint Augustin". Augustinus Magister. Congrès International Augustinien. Paris, 21-24 septembre 1954. Vol. 1. Paris: Études Augustiniennes, 1954, pp. 569-74 (esp. pp. 573-4).

${ }^{6}$ GILSON, É. Jean Duns Scot. Introduction à ses positions fondamentales. Paris: Vrin, 2005² [1952], p. 10: "Duns Scot a dialogué avec plusiers autres théologiens, entre lesquels on peut dire qu'Henri de Gand est son interlocuteur de prédilection. Pour lui, Henri était plus important que Thomas; pour nous, et en soi, le contraire est vrai". Cf. tb. GILSON, History of Christian Philosophy..., 1955, p. 447: "His $<s c$. de Henrique de Gand> influence was considerable, so much so that it is hardly possible to read Duns Scotus without having at hand the writings of Henry of Ghent".
} 
seja, o silêncio sobre Henrique de Gand parece ser uma opção de Gilson. Se houve uma tal opção, porém, não será o caso de discutir suas razões aqui ${ }^{7}$.

Por outro lado, pode ser bem proveitoso notar pequenas mudanças na abordagem que Gilson reserva a nosso autor nos poucos passos em que discute seu pensamento. Na primeira edição de La philosophie au moyen âge, em L'être et l'essence e em Being and Some Philosophers, o fundamental em Henrique de Gand é, para Gilson, sua metafísica, em particular a distinção entre essência e existência. $\mathrm{Na}$ segunda edição de La philosophie au moyen âge, já encontramos a referência bibliográfica à tese de Jean Paulus, Henri de Gand. Essai sur les tendances de sa métaphysique, orientada pelo próprio Gilson e publicada em $1938^{8}$. Ainda assim, parece-me que é somente na History of Christian Philosophy que a influência de Paulus é realmente sentida, pois aí, à especulação mais aprofundada sobre a metafísica de Henrique que já encontramos na segunda edição de La philosophie au moyen âge, soma-se uma consideração introdutória acerca da concepção de conhecimento esposada pelo Doutor Solene ${ }^{9}$.

Com efeito, no livro de Paulus, a exposição sobre a 'noética' de Henrique de Gand precede a longa reflexão acerca de sua metafísica, porque, "embora a compreensão [saisie] do real não tenha de fato sido uma questão para os pensadores antigos, eles a intepretaram de mais de uma maneira e, por exemplo, a opção entre o empirismo e o inatismo não deixa de envolver já, um bom tanto, a sorte futura da metafísica" ${ }^{\prime 10}$. Nesse ponto, não me interessa tanto que esse comentador veja em Henrique um 'inatismo mitigado' (innéisme mitigé), que fundamenta uma metafísica do inteligível (métaphysique de l'intelligible) ${ }^{11}$. Antes, ressalto que, na interpretação

\footnotetext{
${ }^{7}$ Tive a oportunidade de discutir esse tema em PAIVA, G. B. V. de. "Étienne Gilson leitor de Henrique de Gand". Revista SOFiA - Semana de Orientação Filosófica e Acadêmica / UNIFESP 1.1 (2014), pp. $143-51$.

${ }^{8}$ Cf. GILSON, La philosophie au moyen âge, $2011^{5}$, p. 447 . O texto citado é PAULUS, J. Henri de Gand. Essai sur les tendances de sa métaphysique. Préface de Étienne Gilson. Paris: Vrin, 1938.

${ }^{9}$ GILSON, History of Christian Philosophy..., 1955, pp. 447-8.

${ }^{10}$ PAULUS, Henri de Gand. Essai..., 1938, p. 1: “Mais quoique la saisie du réel n'ait point vraiment fait question pour les penseurs anciens, ils l'ont inteprétée de plus d'une manière, et, par exemple, l'option entre l'empirisme et l'innéisme ne laisse pas d'engager déjà, plus qu'à-demi, le sort futur de la métaphysique". A introdução a respeito da 'noética' de Henrique de Gand, na obra de Paulus, compreende Henri de Gand. Essai..., 1938, pp. 1-13.

${ }^{11}$ PAULUS, Henri de Gand. Essai..., 1938, pp. 10-2. A expressão métaphysique de l'intelligence foi tomada por mote na resenha do livro de Paulus produzida por Robert Bourgeois, "Une métaphysique de l'intelligible. La doctrine d'Henri de Gand selon M. J. Paulus". Révue de Philosophie 39 (1939), pp. 143-57.
} 
de Paulus, o estudo da concepção de intelecção esposada pelo Doutor Solene ganha um inesperado papel propedêutico para a compreensão da filosofia metafísica deste último como um todo. A meu ver, é justamente essa a razão que faz o Gilson da History of Christian Philosophy antepor à exposição da metafísica de Henrique uma relevante, conquanto curta, consideração sobre sua doutrina da intelecção.

Essa exposição inicial de Gilson à metafísica de nosso autor é, basicamente, um lembrete de que, para Henrique de Gand, o conhecimento natural deve ser corrigido por uma iluminação divina, assim como a filosofia deve ser corrigida por uma teologia:

\begin{abstract}
“<..> bem no primeiro artigo de sua Suma theologiae, Henrique começa por questionar a validade do conhecimento natural e, como alguns dos seus predecessores agostinianos haviam feito antes dele, ele a nega parcialmente. A razão para essa negação é simples. Henrique afirma que a verdade absolutamente pura não pode ser conhecida pelo homem sem uma iluminação divina; mas ele também pensa que, embora o homem possa receber essa iluminação em sua condição natural presente, Deus a dá quando lhe apetece e a quem lhe apetece. Em suma, ela é um dom gratuito de Deus <...>. Essa desconfiança do conhecimento natural, corrigida pela teologia, condiciona toda a atitude de Henrique de Gand com respeito às doutrinas ensinadas pelos filósofos"12.
\end{abstract}

O fundamental para Étienne Gilson na concepção de conhecimento desenvolvida pelo mestre de Gand é o limite do conhecimento natural humano e, para além desse limite, o fato de que a verdade pura só pode ser conhecida por iluminação divina. A doutrina da intelecção de Henrique é, nessa leitura, fundamentalmente marcada por essa "desconfiança [mistrust]" com respeito ao conhecimento natural. Essa interpretação, no entanto, foi frontalmente combatida posteriormente - em particular, no que tange à intepretação de Suma, art. 1, como uma negação parcial do conhecimento natural.

Meia década após a publicação da History of Christian Philosphy in the Middle Ages de Étienne Gilson, são publicados na Polônia dois trabalhos sobre a concepção de conhecimento de Henrique de Gand sob a autoria de Mieczysław

\footnotetext{
${ }^{12}$ GILSON, History of Christian Philosophy..., 1955, p. 448: “ $<\ldots>$ in the very first article of his Summa theologiae, Henry begins by questioning the validity of natural knowledge, and as some of his Augustinian predecessors had done before him, he partly denies it. The reason for this denial is simple. Henry maintains that absolutely pure truth cannot be known by man without a divine illumination; but he also thinks that, although man can receive this illumination in his present natural condition, God gives it when he pleases and to whom he pleases. In short, it is a free gift of God $<\ldots>$. This mistrust of natural knowledge, corrected by a theology, conditions the whole attitude of Henry of Ghent with respect to the doctrines taught by the philosophers".
} 
Gogacz $^{13}$. Para este último, os primeiros artigos da Suma, muito mais do que uma discussão sobre a validade do conhecimento natural, são um questionamento acerca da autossuficiência do conhecimento humano:

"Nos primeiros cinco artigos de sua Summa quaestionum ordinariarum, Henrique considera o problema do conhecimento humano. Esse problema não seria interessante, não fosse o fato de que Henrique o apresenta pela perspectiva do problema da autossuficiência do conhecimento [samodzielności poznania]"14.

Nessa passagem, há o risco de não atentarmos para o caráter fundamental que a noção de 'autossuficiência' (samodzielność) assume no pensamento de Gogacz ${ }^{15}$. Para ele, a autossuficiência na existência e, mais do que isso, na atividade racional é aquilo que caracteriza o homem como pessoa (osoba):

${ }^{13}$ GOGACZ, M. "Czy według Henryka z Gandawy jest możliwe poznanie czystej prawdy bez pomocy
oświecenia". Roczniki Filozoficzne 8.1 (1960), pp. 161-71; GOGACZ, M. Problem istnienia Boga u
Anzelma z Canterbury i Problem prawdy u Henryka z Gandawy. Lublin: Towarzystwo Naukowe
Katolickiego Uniwersytetu Lubielskiego, 1961. Mencione-se que Gogacz está ciente de sua
contraposição à leitura de Gilson quanto à obra de Henrique de Gand, como fica claro em GOGACZ,
Problem istnienia Boga..., 1961, pp. 98-100. Além disso, é importante notar que Gogacz manteve
contato pessoal com Gilson, como se lê em KLIMSKI, T. "Życie i działalność naukowa Profesora
Mieczysława Gogacza". Studia Philosophiae Christianae 32.2 (1996), pp. 7-10.

${ }^{14}$ GOGACZ, “Czy według Henryka z Gandawy jest możliwe...”, 1960, p. 161: “W pęciu pierwszych artykułach swojej Summae quaestionum ordinariarum Henryk rozważa zagadnienie poznania ludzkiego. Zagadnienie to nie byłoby ciekawe, gdyby nie fakt, że Henryk ujmuje je od strony problemu samodzielności poznania”.

${ }^{15}$ Outro autor a ver uma discussão sobre o caráter 'autossuficiente' (selbständig) do conhecimento humano em Henrique de Gand é Martin Pickavé, em Heinrich von Gent über Metaphysik als erste Wissenschaft. Studien zu einem Metaphysikentwurf aus dem letzten Viertel des 13. Jahrhunderts. Leiden - Boston: Brill, 2007, p. 56: "Durch das Glaubenslicht wiederum stimmen wir den Glaubenssätzen zwar zu und 'glauben' (credere) an ihre Gültigkeit, eine selbständige Einsicht (intelligere) liegt hingegen noch nicht vor". Mais do que isso, Pickavé vê nessa discussão inicial da Suma sobre o conhecimento humano uma reflexão sobre a 'autonomia' do conhecimento humano - op. cit., p. 41-2: "Ist der Mensch fähig, von selbst und aus eigenen Anstregungen, zur Erkenntnis der Prinzipien und Konklusionen zu gelangen? Heinrich von Gent diskutiert diese Frage am Beginn seiner Summa quaestionum ordinariarum als 5. Quästion des ersten Artikel im Zusammenhang mit mehreren anderen Fragen zum menschlichen Erkenntnisvermögen $\langle\ldots$. . Der theologische Kontext lässt bereits vermuten, dass es hierbei auch um die Autonomie des menschlichen Wissens gilt" (além disso, cf. tb. op. cit., p. 79). Outro autor a se utilizar da noção de 'autonomia' para o estudo desse aspecto do pensamento de Henrique de Gand é Dominique Demange (cf. cap. 1, nota 21). Devemos, no entanto, estar atentos para não expandir demasiadamente a expectativa pela defesa de uma 'autonomia' do conhecimento humano em Henrique de Gand. Com efeito, como nos lembra André de Muralt, dificilmente se pode conceber o homem como autônomo em sentido estrito em uma filosofia na qual toda atividade humana exige um pressuposto externo anterior: " $<\ldots>$ la liberté humaine, et plus généralement l'autonomie de l'activité humaine, ne peut être suffisament assurée dans une philosophie qui définit l'acte de l'homme, cognitif ou moral, par une norme à priori et extrinsèque" - MURALT, A. de "Kant, le dernier occamien. Une nouvelle définition de la philosophie moderne". In: MURALT, A. de La métaphysique du phénomène. Les origines médiévales et l'élaboration de la pensée phénoménologique. Paris: Vrin, 1985, pp. $138-59$ (esp. p. 155). No caso de nosso Doutor Solene, esse elemento externo e anterior será Deus, como origem primeira e fim último (ainda que remoto) de toda ação, o que notaremos repetidamente no decorrer deste trabalho. 
"Perguntemos primeiro: quem é o homem do ponto de vista do conhecimento filosófico humano? Depois de uma análise filosófica, respondemos: o homem é uma pessoa. O que é pessoa? Pessoa é um ente, autossuficiente [samodzielnym] na existência, racional. Dito diferentemente: para que algo seja uma pessoa, deve, enquanto ente, existir autossuficientemente [istnieć samodzielnie] e manifestar [ujawniać] uma atividade racional. Assim, as duas condições que fazem com que algo seja uma pessoa são: a autossuficiência da existência [samodzielność istnienia] do dado ser e sua racionalidade" ${ }^{" 16}$.

Destarte, vemos que, para Gogacz, o problema colocado no início da Suma de Henrique de Gand é muito mais do que somente uma discussão acerca da validade do conhecimento natural. Ele é, com efeito, o questionamento sobre aquilo mesmo que nos faz homens ou pessoas, isto é, a autossuficiência para realizar aquela nossa atividade fundamental que é a atividade racional. Curiosamente, ao contrário do que ocorria em Gilson, Gogacz vê em nosso autor um campeão da autossuficiência do conhecimento humano. Para o comentador polonês, Henrique de Gand foi mal interpretado, uma vez que seu objetivo seria justamente separar um terreno do conhecimento natural e outro, esse sim tributário de uma iluminação divina, do conhecimento dos objetos de fé:

\begin{abstract}
"Resulta disso tudo que o homem conhece autossuficientemente [samodzielnie], sem auxílio da iluminação. Essa conviç̧ão é suficientemente justificada em Henrique. O conhecimento sem auxílio da iluminação concerne os objetos que se encontram na mesma ordem na qual se encontra a natureza humana, embora aqui também se encontrem objetos conhecidos pela iluminação, conhecidos tal como os credibilia Há, além disso, os objetos - precisamente, aqueles per se et simpliciter credibilia - que só se pode conhecer por iluminação. Esses objetos estão em uma ordem outra que não a da natureza humana" ${ }^{, 17}$.
\end{abstract}

\footnotetext{
${ }^{16}$ GOGACZ, M. "Chrześcijańska wartość osoby ludzkiej”. Collectanea Theologica 39.2 (1969), pp. 85-90 (esp. p. 86): "Zapytajmy najpierw, kim jest człowiek z punktu widzenia filozoficznej wiedzy ludzkiej? Po analizach filozoficznych odpowiadamy: człowiek jest osobą. Czym jest osoba? Osoba jest samodzielnym w istnieniu bytem rozumnym. Inaczej mówiąc: aby coś było osobą musi jako byt samodzielnie istnieć i ujawniać działanie rozumne. Dwoma więc warunkami sprawiającymi, że coś jest osobą, są: samodzielność istnienia danego bytu i jego rozumność". Aproveito, aqui, para dirigir um agradecimento à profa. Cláudia Maria Rocha de Oliveira (FAJE), com a qual pude discutir certos aspectos do pensamento de Gogacz e, em particular, de sua noção de 'pessoa', tomando por ponto de partida as reflexões sobre tal noção desenvolvidas por Henrique Cláudio de Lima Vaz e cuidadosamente estudadas pela professora em OLIVEIRA, C. M. R. de. Metafisica e ética. A filosofia da pessoa em Lima Vaz como resposta ao niilismo contemporâneo. São Paulo: Loyola, 2013.

${ }^{17}$ GOGACZ, Problem istnienia Boga..., 1961, p. 80: "Wynika z tego wszystkiego, że człowiek poznaje samodzielnie, bez pomocy oświecenia. To przekonanie jest u Henryka udowodnione wystarczająco. Poznanie bez pomocy oświecenia dotyczy przedmiotów, znajdujących się w tym samym porządku, w którym znajduje się natura ludzka, jakkolwiek i tu znajdują się przedmioty, poznawane przy pomocy oświecenia, podobnie poznawane jak credibilia $<\ldots$.. P. Przedmioty te są w innym porządku niż natura ludzka”.
} 
Como se vê, Gogacz busca reduzir o campo da iluminação divina ao âmbito dos credibilia, isto é, da fé: “Credibilia são as coisas que possuem uma tal natureza que, por si mesmas e enquanto tais, são somente objeto da fé (simpliciter credibilia $)^{18}$. Ou seja, temos aqui uma distinção entre [i] o conhecimento autossuficiente daqueles objetos de mesma ordem que a natureza humana e [ii] o conhecimento por iluminação daqueles objetos que são conhecidos por fé (sejam eles unicamente objetos de fé ou não). A essa distinção se sobrepõe uma outra: "Henrique, então, claramente fala sobre uma ordem que pode ser chamada de ordem da fé ou revelação e sobre uma ordem que pode ser chamada de ordem filosófica"19. Destarte, aquilo que diz respeito à filosofia seria, para o Doutor Solene, conhecido naturalmente, enquanto que tudo aquilo que depende da fé e da revelação exigiria uma iluminação divina:

\begin{abstract}
"Os objetos conhecidos por auxílio das forças naturais do homem existem nesta mesma ordem em que existe a natureza humana. Os objetos conhecidos por auxílio da iluminação são per se et simpliciter credibilia, são 'por si mesmos' [same przez się] objetos da fé e não pertencem à ordem da natureza" ${ }^{20}$.
\end{abstract}

Assim, em resposta à tese de Gilson, segundo a qual a verdade pura só poderia ser conhecida por iluminação em Henrique, Gogacz defende a necessidade de distinguir, em nosso autor, duas concepções distintas de 'verdade pura': "no primeiro sentido, a verdade pura é Deus, enquanto causa da imutabilidade da verdade por meio das ideias exemplares; no segundo sentido, é em Deus sua essência tomada em si" ${ }^{21}$. A essa distinção Gogacz adiciona que "o homem conhece pelas forças naturais [siłami naturalnymi], sem auxílio da iluminação, a verdade pura no sentido de Deus,

\footnotetext{
${ }^{18}$ GOGACZ, Problem istnienia Boga..., 1961, p. 79: “Credibilia - to rzeczy, które mają taką naturę, że same przez się i jako takie są tylko przedmiotem wiary (simpliciter credibilia)".

${ }^{19}$ GOGACZ, Problem istnienia Boga .., 1961, p. 79: "Henryk więc wyraźnie mówi o porządku, który można by nazwać porządkiem wiary czy objawienia, i o porządku, który można by nazwać porządkiem filozoficznym".

${ }^{20}$ GOGACZ, Problem istnienia Boga.., 1961, p. 96: "Przedmioty poznawane przy pomocy sił naturalnych człowieka istnieją w tym samym porządku, w którym istnieje natura ludzka. Przedmioty poznawane przy pomocy oświecenia są per se et simpliciter credibilia, są 'same przez się' przedmiotami wiary i nie należą do porządku natury”. Note-se como aqui Gogacz distingue somente dois campos: [i] aquele do conhecimento natural sobre objetos do mesmo nível da natureza humana e [ii] aquele do conhecimento por iluminação dos objetos sobrenaturais de fé. Ou seja, o comentador parece, no fim, reduzir ao campo da fé tout court aquela ordem intermediária, que víamos no trecho citado, acima, na nota 17 , dos objetos que, embora naturais, podem ser conhecidos também pela fé.
}

${ }^{21}$ GOGACZ, Problem istnienia Boga..., 1961, p. 96: “W pierwszym znaczeniu prawda czysta to Bóg, jako przyczyna niezmienności prawdy poprzez idee wzorcze, w drugim znaczeniu prawda czysta to $\mathrm{w}$ Bogu jego istota, wzięta sama w sobie <... ${ }^{\prime}$. 
enquanto ela atua, pelas ideias exemplares, causas da imutabilidade da verdade. $\mathrm{O}$ homem conhece somente por auxílio da iluminação a verdade sincera no sentido da própria essência de Deus em si”,22. Ora, para Gogacz, o conhecimento da essência de Deus em si mesmo diz respeito ao campo do sobrenatural ${ }^{23}$. No fim das contas, portanto, temos em Henrique de Gand uma distinção entre o conhecimento natural e outro sobrenatural e, no que tange ao primeiro - que é, propriamente, o terreno de conhecimento humano -, "o homem, no fim, conhece autossuficientemente [człowiek do końca poznaje samodzielnie]" 24 e, mais, "o homem conhece a verdade pura sem auxílio da iluminação"25. Ou seja, chegamos às antípodas da leitura de Gilson!

Se, para este último, Henrique de Gand surge como um defensor da necessidade de um ultrapassamento do conhecimento natural por uma iluminação divina para que se atinja a verdade, Gogacz vê no Doutor Solene precisamente a defesa de um conhecimento natural da verdade pelo homem. Essa discordância é tanto mais interessante quando notamos que ambos, para suas respectivas interpretações, partem da análise do mesmo texto, a saber, Suma, art. 1. Esse primeiro artigo da Suma de Henrique de Gand é, precisamente, um estudo sobre "a possibilidade de se ter ciência [de possibilitate sciendi]", como veremos adiante. Para comentadores como Gilson e Gogacz esse problema se coloca, precisamente, como a exigência pelo estabelecimento de um limite entre aquilo que pode ser conhecido pelo homem por suas meras potências cognoscitivas e aquilo que o homem só pode conhecer por um

\footnotetext{
${ }^{22}$ GOGACZ, Problem istnienia Boga..., 1961, p. 97: “<..> prawdę czystą w znaczeniu Boga, jako działającej przez idee wzorcze przyczyny niezmienności prawdy, człowiek poznaje siłami naturalnymi bez pomocy oświecenia. Prawdę czystą w znaczeniu samej w sobie istoty Boga człowiek poznaje jedynie przy pomocy oświecenia $<\ldots$..”.

${ }^{23}$ GOGACZ, Problem istnienia Boga..., 1961, p. 93: "Que <o homem> não conheça a essência de Deus não desqualifica sua autossuficiência. O conhecimento da essência de Deus é sempre um dom de ordem sobrenatural [Nie dyskwalifikuje jego samodzielności to, że nie poznaje istoty Boga. Poznanie istoty Boga jest zawsze darem porzadku pozanaturalnego]".

${ }^{24}$ GOGACZ, Problem istnienia Boga..., 1961, p. 93.

${ }^{25}$ GOGACZ, Problem istnienia Boga ..., 1961, p. 97: “ $<\ldots>$ o homem conhece a verdade pura sem auxílio da iluminação. Essa afirmação tem por base, claramente, $<\mathrm{i}>$ a distinção entre dois sentidos da verdade sincera, $<$ ii $>$ a distinção entre a ordem natural dos entes e a ordem sobrenatural, bem como $<$ iii> a distinção do conhecimento próprio ao homem e do conhecimento especial in raptu, que é um dom que depende do conceder-se como cognoscível da essência divina à mente humana $[<\ldots>$ czlowiek poznaje czysta prawde bez pomocy oświecenia. Twierdzenie to oparte jest oczywiście na wyróżnieniu dwu znaczeń prawdy czystej, na wyróżnieniu porzadku naturalnego bytów i porzadku pozanaluralnego oraz na wyróżnieniu poznania właściwego czlowiekowi i poznania specjalnego in raptu, będacego darem, który polega na udzieleniu się poznawczym boskiej istoty umystowi ludzkiemu]".
} 
auxílio divino. Para eles, todo o problema aqui é estabelecer o limite do conhecimento natural humano em Henrique de Gand.

Pois bem, quando comecei a escrever o presente trabalho, meu objetivo era simplesmente - resolver esse problema. Assim, seria preciso primeiramente ver se, para o Doutor Solene, seria realmente possível um conhecimento natural para o homem e, em seguida, estabelecer os limites de tal conhecimento (seja em termos dos objetos abrangidos ou da certeza e verdade propiciada por tal conhecimento). Ao fim, eu pretendia haver estabelecido quais seriam os limites do conhecimento natural para Henrique, marcando, ao fazê-lo, o ponto a partir do qual se mostraria necessária, para ele, uma iluminação divina nesse caminho em direção a conhecimentos mais verdadeiros. Seguindo Gilson e Gogacz, era também meu objetivo tomar como base de minha leitura os primeiros artigos da Suma de Henrique.

Entretanto, à medida que avançava na confecção do trabalho, foi se tornando clara para mim a necessidade de desenvolver muito mais aprofundadamente do que eu previra temáticas anteriores à pergunta que colocava como centro da pesquisa. Em particular, mostrou-se necessário compreender corretamente, ainda partindo de Suma, art. 1, [i] o que seria afirmar a possibilidade de conhecimento para o homem e [ii] em que medida o próprio homem, de fato, age para tal conhecimento. Essas duas temáticas correspondem, respectivamente, às Partes 1 e 2 do presente trabalho. Nelas veremos: [i] que a possibilidade de conhecimento para o homem está atrelada à sua própria caracterização como ente racional e que, no entanto, sendo tal conhecimento somente possibilidade ou potência, o homem deve ser movido por algo externo - isto é, o objeto - para o conhecimento em ato; uma vez movido, [ii] o homem age por suas potências cognoscitivas para obter conhecimentos cada vez mais abstratos, que culminam no conhecimento intelectual abstrativo - este, no entanto, será ainda um conhecimento simples e fundamentalmente ligado à sensibilidade. Somente ao fim do presente trabalho poderemos retornar a essa pergunta inicial sobre os limites do conhecimento humano - não para respondê-la, mas para recolocá-la com bases mais sólidas. Dito isso, o que apresento a seguir é uma tentativa de compreender a concepção de homem, proposta por Henrique de Gand, como ente capaz de conhecer e como ente que, uma vez movido, também age, por suas potências cognoscitivas, em direção a esse conhecimento.

Atualmente, a vasta bibliografia primária e secundária disponível acerca desses temas em Henrique de Gand permite a elaboração de análises textuais 
extremamente finas de determinadas passagens de seus textos, de tal maneira a ressaltar não somente as posições adotadas por nosso autor, mas também os diversos pontos de tensão que derivam da leitura conjunta dos vários excertos dedicados a nosso tema em sua obra. Se, por um lado, essa vasta bibliografia se apresenta como uma inestimável vantagem para o estudioso das obras do Doutor Solene, por outro lado ela o obriga a corretamente expor os critérios com os quais ele a pretende utilizar. Por isso mesmo, antes que passemos à leitura de Henrique de Gand, cumpre dedicar algumas páginas a uma rápida discussão acerca da metologia utilizada no trabalho e à descrição das bibliografias primária e secundária de que nos valemos aqui.

\section{$\S 2-$ A LEITURA E AS FONTES}

A. Sobre a metodologia de leitura das obras de Henrique de Gand:

O elemento principal que se deve destacar quanto à metodologia seguida neste trabalho é o fato de se pretender, aqui, exclusivamente uma leitura interna da obra de Henrique de Gand - ou melhor, dos textos atinentes a uma temática bem delimitada em sua obra. Com efeito, na vasta bibliografia acerca de nosso autor, é possível encontrar obras de diversos matizes teóricos. Em particular, é possível destacar duas vertentes metodológicas distintas: [i] uma série de trabalhos acerca de sua obra busca uma leitura interna de sua filosofia ou teologia, enquanto que [ii] diversos estudos buscam compreender sua obra a partir da comparação aprofundada, cuidadosa e erudita de sua filosofia com aquela de seus contemporâneos. Esses métodos de leitura não são de modo algum excludentes, mas possuem, a meu ver, uma ordem. Destarte, é necessário antes desse estudo comparativo histórico, um estudo interno da obra (ou de aspectos da obra) de cada autor que se almeja inserir em tal narrativa histórica. $\mathrm{O}$ trabalho que apresento a seguir, portanto, se localiza nesse preâmbulo à narrativa histórica propriamente dita.

A necessidade de esclarecer e enfatizar esse ponto ficou clara para mim enquanto elaborava uma resenha sobre um livro de Roland J. Teske ${ }^{26}$. Nesse texto,

\footnotetext{
${ }^{26}$ TESKE, R. J. Essays on the Philosophy of Henry of Ghent. Milwaukee: Marquette University Press, 2012. A resenha a que me refiro é: PAIVA, G. B. V. de. "Resenha de: TESKE, R. J. Essays on the Philosophy of Henry of Ghent. Milwaukee: Marquette University Press, 2012, 275 p. (Marquette
} 
composto pela reunião de todos os seus artigos já publicados e inéditos até 2012 sobre Henrique de Gand, Teske apresenta uma série de estudos técnicos e minuciosos de certos elementos do pensamento do Doutor Solene. A bem dizer, ele pouco se afasta dos excertos por ele analisados, de maneira que o único autor que propriamente surge em seus textos é Henrique e, se outros são abordados, não o são senão enquanto foram fontes para a especulação deste último.

Ora, precisamente essa dedicação a uma análise interna da obra de Henrique patente no livro de Teske foi criticada em uma resenha do mesmo livro produzida por Pasquale Porro ${ }^{27}$. Para este último, "teria sido útil considerar o pensamento de Henrique menos em isolamento, colocá-lo em relação especialmente com mestres contemporâneos (Egídio Romano, Godofredo de Fontaines, Ricardo de Mediavilla) ${ }^{, 28}$. Essa observação, a meu ver, faz lembrar o clássico artigo de Victor Goldschmidt, "Tempo histórico e tempo lógico na interpretação dos sistemas filosóficos" 29 . Mais precisamente, interessa-me aí sua distinção entre uma 'interpretação dogmática' e uma 'interpretação genética' dos sistemas filosóficos.

Deixando de lado a ânsia por uma sistematização da filosofia, podemos derivar desse texto a proposta de dois modos de leitura de um texto filosófico. Primeiramente, podemos lê-lo internamente, isto é, procurar compreender as etapas da argumentação ali exposta e, em um passo anterior, até mesmo que tipo de argumentação é almejada no texto em questão (seja ela de fato produzida ou não). Somente em seguida poderemos buscar escrever uma narrativa histórica na qual

Studies in Philosophy 76)". Translatio. Caderno de Resenhas do GT História da Filosofia Medieval e a Recepção da Filosofia Antiga 6 (2014), pp. 19-30.

${ }^{27}$ PORRO, P. "Review of: TESKE, R. J. Essays on the Philosophy of Henry of Ghent. [...]". Notre Dame Philosophical Reviews. May 19, 2013. Online: http://ndpr.nd.edu/n ews/40083-essays-on-thephilosophy-of-henry-of-ghent/ (consultado em 08/05/2014). A leitura desse texto me foi sugerida pelo prof. Rodrigo Guerizoli (UFRJ).

${ }^{28}$ PORRO, "Review...", 2013, penúltimo parágrafo: "However, it would have been useful to consider Henry's thinking less in isolation, to place him in relation especially to contemporary masters (Giles of Rome, Godfrey of Fontaines, Richard of Mediavilla). Henry never ceased to confront them himself, to differ or to enter into dialogue with them and, as a consequence, sometimes to modify his own position. Adding this dimension would have made it easier for the reader to better understand some of Henry's theoretical choices". Crítica semelhante já era dirigida ao livro de Theophiel Nys (De werking van het menselijk verstand volgens Hendrik van Gent. Leuven: Nauwelaerts, 1949), por Jean Paulus em "À propos de la théorie de la connaissance d'Henri de Gand". Revue philosophique de Louvain 47.16 (1949), pp. 493-6.

${ }^{29}$ GOLDSCHMIDT, V. "Tempo histórico e tempo lógico na interpretação dos sistemas filosóficos". In: GOLDSCHMIDT, V. A religião de Platão. Prefácio introdutório de Oswaldo Porchat Pereira. Tradução de Ieda e Oswaldo Porchat Pereira. São Paulo: Difusão Europeia do Livro, 1970², pp. 139147. A publicação do artigo original, em francês, foi em 1953. 
aquele texto já estudado internamente constitua uma etapa. Assim, a narrativa de uma história da filosofia em fins do século XIII que mostre as relações entre Henrique de Gand, Egídio Romano, Godofredo de Fontaines, Ricardo de Mediavilla, entre tantos outros autores desta época, pressupõe uma leitura interna dos textos de cada um deles. Nessa leitura interna da obra de cada um, os outros, se surgirem, surgirão somente na medida em que forem fontes do autor estudado e tal como foram recebidos por este último, sem qualquer preocupação com a correção desta recepção. Uma discussão acerca da correção da recepção de um autor por seus contemporâneos e destes por aquele só vem ao caso em um segundo momento, isto é, na narrativa histórica.

Assim, está claro que o livro de Teske se propõe como uma leitura interna da obra de Henrique de Gand (ou melhor, como uma séria de leituras internas de excertos dos textos deste último). Desse ponto de vista, a crítica de Porro parece injusta, uma vez que ele critica Teske justamente por estar lançando os fundamentos daquilo que ele próprio, Porro, considera que deva ser feito. Como dissemos, uma série de leituras internas de cada autor em questão é um passo necessariamente anterior à narrativa histórica.

Dito isso, meu objetivo neste trabalho não pode ser senão tentar uma leitura interna dos textos nos quais Henrique de Gand se volta para a doutrina da intelecção, enquanto potência do homem e ato resultante da abstração. De fato, se seguirmos essa concepção de narrativa histórico-filosófica que rapidamente expus aqui, a escrita de uma história da filosofia (mesmo que de um período curto, porém bem documentado como o fim do século XIII) é um trabalho que excede em muito uma tese de doutorado. É quase o trabalho de uma vida... Estando ciente dos limites desta pesquisa, me pareceu que estava igualmente ciente das suas possibilidades. A mais interessante destas últimas era a capacidade de, ao estabelecer um escopo suficientemente preciso, produzir um estudo minucioso sobre um tema que pareceu passível de ser abrangido em uma tese de doutorado. Em poucas palavras, portanto, o que almejo aqui é um estudo interno dos textos em que Henrique de Gand expõe sua concepção de conhecimento humano - em particular, daquele conhecimento abstrativo que o homem pode obter naturalmente como atualização de uma potência natural da alma.

Pois bem, essa opção por um método de leitura interna das obras de um autor torna seus textos o personagem central deste trabalho. Assim, cumpre expor a seguir as fontes primárias que utilizamos para leitura desse corpus textual. De outra parte, 
porém, ter por finalidade uma leitura interna de um texto filosófico, não deve ser uma desculpa para que nos furtemos à utilização de toda sorte de bibliografia secundária disponível. Sem dúvida, a finalidade deste trabalho é a compreensão de certos textos de Henrique de Gand, porém todo outro texto que nos auxiliar nessa compreensão interna será útil no cumprimento desse objetivo. Dessa maneira, podemos dizer que a obra do Doutor Solene constitui, para nós, a bibliografia primária e quaisquer outros autores citados, contemporâneos (como João Duns Escoto) ou posteriores, são considerados aqui como comentadores. Entretanto, há que admitir a necessidade de escolha das fontes bibliográficas (primárias e secundárias), dada a vasta literatura atualmente acessível sobre Henrique de Gand. A seguir, exponho os fundamentos das escolhas aqui realizadas.

B. Sobre as bibliografias primária e secundária utilizadas:

A exposição dessa seleção de nossas fontes em meio à vasta bibliografia primária e secundária a nosso alcance depende de uma pequena (e tentativa) história da recepção de Henrique de Gand a partir do momento em que ele nos lega sua obra. Por motivos práticos, tentarei dividir a recepção doutrinária e editorial de sua obra (pois ambas se entrelaçam) basicamente em cinco períodos, muito embora certamente não se proponha aqui que tais distinções cronológicas sejam exatas ou completas ${ }^{30}$. Eis nossa proposta de divisão cronológica da recepção da obra de Henrique de Gand:

\section{[1 - s. XIIIf-XV]}

Em um primeiro momento, temos a recepção das obras de Henrique de Gand no próprio meio escolástico medieval, basicamente entre fins do século XIII e o século XV. Ainda no período imediatamente após a morte de nosso autor, vemos sua forte influência sobre um pensador como Vital de Furno $^{31}$. A passagem do século XIII para o XIV é

\footnotetext{
${ }^{30}$ Narrativas, decerto, muito mais detalhadas, ainda que com divisões cronológicas distintas, em certos aspectos, daquelas que proponho, podem ser lidas em PORRO, P. "L'immagine storiografica di Enrico di Gand". In: PORRO, P. Enrico di Gand. La via delle proposizioni universali. Bari: Levante, 1990, pp 141-73; PORRO, P. "An Historiographical Image of Henry of Ghent". In: VANHAMEL, W. (ed.). Henry of Ghent. Proceedings..., 1996, pp. 373-403; LAARMANN, M. Deus, primum cognitum. Die Lehre von Gott als dem Ersterkannten des menschelichen Intellekts bei Heinrich von Gent (†1293). Münster: Aschendorf, 1999, pp. 337-457.

${ }^{31}$ Cf. LYNCH, J. E. The Theory of Knowledge of Vital du Four. St. Bonaventure: The Franciscan Institute, 1972; PICKAVÉ, M. Heinrich von Gent über Metaphysik als erste Wissenschaft. Studien zu einem Metaphysikentwurf aus dem letzten Viertel des 13. Jahrhunderts. Leiden-Boston: Brill, 2007, pp. $72-7$.
} 
igualmente o período da querela entre os gandavistae e outros autores, alguns dos quais responsáveis por textos contra Henricum. Além disso, a obra de Henrique de Gand é profundamente estudada nessa época por João Duns Escoto ${ }^{32}$. Ainda no século XIV, ela também é considerada por outros autores, como Guilherme de Ockham ${ }^{33}$. Já no século $\mathrm{XV}$, sua influência ainda é sentida por Dionísio, o Cartuxo ${ }^{34}$. Esse primeiro período de recepção da obra de Henrique é, em linhas gerais, basicamente a sua consideração por autores escolásticos posteriores a ele e que, em determinados temas, optam por manter diálogo com suas obras.

\section{[2-s. XV-XVI]}

Talvez possamos compreender esse segundo período como aquele da recepção humanista das obras de Henrique de Gand. Com efeito, entre os séculos XV e XVI, ele é lido por figuras como Marsilio Ficino, Giovanni Pico della Mirandola, Gianfrancesco Pico, Jacopo Mazzoni, os quais por vezes tomam sua filosofia como expressão de um platonismo ${ }^{35}$. Parece surgir por volta dessa época a identificação de Henrique de Gand

\footnotetext{
${ }^{32}$ Cf., e.g., HÖDL, L. "The Quodlibeta of John of Pouilly ( $\dagger$ ca. 1328) and the Philosophical and Theological Debates at Paris 1307-1312". In: SCHABEL, C. (ed.). Theological Quodlibeta in the Middle Ages. The Fourteenth Century. Leiden - Boston: Brill, 2007, pp. 199-229; HÖDL, L. "Die Opposition des Johannes de Polliaco gegen die Schüle der Gandavistae". Bochumer Philosophisches Jahrbuch für Antike und Mittelalter 9 (2004), pp. 115-77; BROWN, S. F. "Duo Candelabra Parisiensia: Prosper of Reggio in Emilia's Portrait of the Enduring Presence of Henry of Ghent and Godfrey of Fontaines regarding the Nature of Theological Study". In: AERTSEN, J. A., EMERY Jr., K., SPEER, A. (Hrsg.). Nach der Verurteilung von 1277. Philosophie und Theologie an der Unversität von Paris in letzten Viertel des 13. Jahrhunderts. Studien und Texte. Berlin - New York: De Gruyter, 2001, pp. 320-56; HÖDL, L. "Die Unterscheidungslehren des Heinrich von Gent in der Auseinandersetzung des Johannes de Polliaco mit den Gandavistae". In: GULDENTOPS, G., STEEL, C. (eds.). Henry of Ghent and the Transformation..., 2003, pp. 371-86; HÖDL, L. "Zum Streit um die Illuminationslehre des Heinrich von Gent ( $†$ 1293). Text und Diskussion". In: ZUMKELLER, A., KRÜMMEL, A. (Hersg.). Traditio Augustiniana. Studien über Augustinus und seiner Rezeption. Festgabe für Willigis Eckermann OSA zum 60. Geburtstag. Wurzburg: Augustinus-Verlag, 1994, pp. 203-40; STELLA, P. "La prima critica di Herveus Natalis O. P. alla noetica di Enrico di Gand: il 'De intellectu et specie' del cosiddetto 'De quatuor materiis'”. Salesianum 21.1 (1959), pp. 125-70. Quanto à relação entre Henrique de Gand e João Duns Escoto, cf. e.g. BROWN, J. V. "John Duns Scotus on Henry of Ghent's Arguments for Divine Illumination: The Statement of the Case". Vivarium 14.2 (1976), pp. 94-113; e BROWN, J. V. "John Duns Scotus on Henry of Ghent's Theory of Knowledge". The Modern Schoolman 56.1 (1978), pp. 1-29.

${ }^{33}$ Cf., e.g., WOLTER, A. B. "Ockham and the Textbooks: On the Origin of Possibility". Franziskanische Studien 32 (1950), pp. 70-96.

${ }^{34}$ Cf. EMERY Jr., K. "The Image of God Deep in the Mind: The Continuity of Cogntion according to Henry of Ghent". In: AERTSEN, J. A. et al. (Hrsg.). Nach der Verurteilung von 1277. Philosophie und Theologie an der Unversität von Paris in letzten Viertel des 13. Jahrhunderts. Studien und Texte. Berlin - New York: De Gruyter, 2001, pp. 59-124.

${ }^{35}$ Cf. STEEL, C. "Henricus Gandavensis Platonicus". In: GULDENTOPS, G., STEEL, C. (eds.). Henry of Ghent and the Transformation..., 2003, pp. 15-39; EDELHEIT, A. "Henry of Ghent and Giovanni Pico della Mirandola: A Chapter on the Reception and Influence of Scholasticism in the Renaissance". In: WILSON, G. A. (ed.). A Companion to Henry of Ghent. Leiden - Boston: Brill, 2011, pp. 369-97; EDELHEIT, A. "The 'Scholastic' Theology of Giovanni Pico della Mirandola: between Biblical Faith and Academic Skepticism”. Recherches de théologie et philosophie médiévales
} 
como membro da tradicional família flamenga dos Goethals, conhecida em latim como Bonicoli. Além disso, desse período provêm as editiones principes dos Quodlibeta (1518) e da Suma (1520) de Henrique, frutos do trabalho de Jodoco Badio, importante editor humanista em Paris ${ }^{36}$.

\section{[3 - s. XVIf-XVIIIi]}

Esse período é marcado pela elaboração de reedições das obras de Henrique de Gand e comentários sobre elas. Uma primeira reedição dos Quodlibeta com comentários é produzida em Veneza, no ano de 1608 , por Vital Zuccoli, monge camaldulense ${ }^{37}$. No ano seguinte, em 1609, a Ordem dos Servos de Maria passa a tomar Henrique de Gand como doutor da ordem, considerando que nosso autor teria sido, ele próprio, servita. Essa decisão deu vazão à produção de uma reimpressão veneziana da edição de Vital Zuccoli dos Quodlibeta, em 1613 (sob direção de Arcângelo Piccioni), e uma nova edição da Suma, publicada em três volumes entre 1642 e 1646, em Ferrara, por Jerônimo Scarpari, acompanhada de um profundíssimo índice remissivo, no primeiro volume. A adoção de Henrique de Gand como doutor da ordem leva também à fundação, em Roma, do Collegium Gandavense. Tamanha valorização dos trabalhos de Henrique de Gand levou à produção de diversas obras ad mentem Henrici ${ }^{38}$. Pode-se destacar, ainda nesse período, também o uso da obra de Henrique de Gand por um autor que atuou sob forte influência de Descartes, a saber, Robert Desgabets ${ }^{39}$.

74.2 (2007), pp. 523-70 (esp. p. 535, nt. 23); SCHMITT, C. B. "Henry of Ghent, Duns Scotus and Gianfrancesco Pico on Illumination”. Mediaeval Studies 25 (1963), pp. 231-258; PURNELL Jr., F. "Henry of Ghent as Medieval Platonist in the Philosophy of Jacopo Mazzoni". In: WENIN, C. (éd.). L'homme et son univers au moyen âge. Actes du septième congrès international de philosophie médiévale (30 août - 4 septembre 1982). Vol. II. Louvain-la-Neuve: Éditions de l'Institut Supérieur de Philosophie, 1986, pp. 565-72. Em geral, sobre a recepção da obra de Henrique de Gand entre o Renascimento e o século XVII, cf. LAARMANN, Deus, primum cognitum ..., 1999, pp. 383-404.

${ }^{36}$ Cf. RENOUARD, P. Imprimeurs et libraires parisiens du XVI siècle. Tome II: Baaleu-Banville. Paris: Service des Travaux Historiques de la Ville de Paris avec le de la Bibliothèque Nationale, 1969, pp. 6-298.

${ }^{37}$ Cf. MACKEN, R. "Vitale Zuccoli, commentateur des Quodlibets d'Henri de Gand". Bulletin de philosophie médiévale 10 (1976), pp. 84-90.

${ }^{38}$ Sobre esse período, cf. e.g. WULF, M. de. Études sur Henri de Gand. Louvain - Paris: UystpruystDieudonné - Félix Alcan, 1894, pp. 226-8; PIERMEJUS, A. P. M. Memorabilium Sacri Ordinis Servorum B. M. V. Breviarum. Ed. A. M. Vicentini. Vol. 4. Romae: Buona Stampa, 1934, pp. 60-3; BERARDO, S. M. "Enrico di Gand ritorna all'Ordine dei Servi di Maria?". Il commune di Bologna 14.4 (1928), pp. 19-22; CHARBONEAU, D. M. "The Servites of Barcelona”. Studi storici dell'Ordine dei Servi di Maria 30 (1980), pp. 5-87 (esp. pp. 50-4); MONTAGNA, D. M. "I servi ed Enrico di Gand († 1293). Inchiesta sui manoscritti”. Studi storici dell'ordine dei servi di Maria 32 (1982), pp. 197-204; SCHMUTZ, J. "Les paradoxes métaphysiques d'Henri de Gand durant la seconde scolastique". Medioevo 24 (1998), pp. 89-149; LAARMANN, Deus, primum cognitum..., 1999, pp. 392-404, 40510; BARZAZI, A. "I servi di Maria dal cinque al seicento: tra antiche autonomie e centralizzazione romana”. Studi storici dell'Ordine dei Servi di Maria 61-62 (2011-2012), pp. 453-88 (esp. pp. 483-5).

${ }^{39}$ Cf. ADRIAENSSEN, H. T. "The Radical Cartesianism of Robert Desgabets and the Scholastic 


\section{[4 - s. XVIIIf-1884]}

Esse quarto período é marcado pelo início da recepção de Henrique de Gand como parte da narrativa de uma história da filosofia. Podemos assistir tal recepção, por exemplo, nas histórias da filosofia de D. Tiedemann e W. G. Tennemann ${ }^{40}$; na história da lógica de C. Prantl $^{41}$; e na história literária de F. Lajard ${ }^{42}$. Surgem, igualmente, nesse período, as primeiras monografias a respeito da filosofia de Henrique de Gand, como aquelas de F. Huet $^{43}$ ou de K. Werner ${ }^{44}$. Este último, aliás, deixa muito clara a sobrevivência da descrição humanista de Henrique de Gand como autor 'platônico'. Por fim, se a identificação do Doutor Solene como servita já não se mostra mais tão influente nesse período, certamente sua consideração como membro da família Goethals continua a marcar sua recepção, como mostrado por alguns panfletos anônimos do século XIX ${ }^{45}$.

\section{[5 - 1884-presente]}

1884 é marcante para a recepção de Henrique de Gand, pois nesse ano Franz Ehrle publica sua investigação biobibliográfica acerca de nosso autor, argumentando que seu

Heritage". British Journal for the History of Philosophy 23.1 (2015), pp. 46-68. Sobre outro autor do mesmo período que, atuando sob influência de Descartes, teria igualmente sofrido influência direta ou indireta de Henrique de Gand, cf. BÉRUBÉ, C. "Valérien Magni, héritier de Bonaventure, Henri de Gand et Jean Scot Erigène ou précurseur de E. Kant". Cuadernos salmantinos de filosofia 11 (1984), pp. 129-57.

40 TIEDEMANN, D. Geist der speculativen Philosophie. Band 4. Marburg: Akademische Buchhandlung, 1795, pp. 564-81; TENNEMANN, W. G. Geschichte der Philosophie. Band 8.2. Leipzig: Johann Ambrisius Barth, 1811, pp. 678-87.

${ }^{41}$ PRANTL, C. Geschichte der Logik im Abendlande. Dritter Band. Leipzig: Hirzel, 1867, pp. 190-5

${ }^{42}$ LAJARD, F. Histoire littéraire de la France. Ouvrage commencé par des religieux bénédictins de la Congrégation de Saint-Maur et continué par les Membres de l'Institut (Académie royale des Inscriptions et Belles-Lettres). Tome XX: suite du treizième siècle depuis l'année 1286. Paris, 1842 (reprint - Liechtenstein: Kraus, 1971), pp. 144-203.

${ }^{43}$ HUET, F. Recherches historiques et critiques sur la vie, les ouvrages et la doctrine de Henri de Gand. Gand - Paris: De Leroux - Paulin, 1838. A relação entre a obra de Huet e o patriotismo belga da primeira metade do século XIX parece ter sido enfatizada por Silvia Negri no trabalho "Le Docteur Solennel. Heinrich von Gent in der französischen Historiographie des 19. Jahrhunderts", apresentado em congresso recente, como relatado por MANOVA, I. "Congrès terminés - 'Outsiders and Forerunners. Modern Reason and Historiographical Births of Medieval Philosophy'. Freiburg im Breisgau, 28.-30. April 2016". Bulletin de Philosophie Médiévale 58 (2016), pp. $492-504$ (esp. p. 497). Ainda em relação à ligação entre o patriotismo belga e a recepção de Henrique de Gand no século XIX, observe-se o próprio título da segunda obra anônima citada adiante, na nota 45 .

${ }^{44}$ WERNER, K. Heinrich von Gent als Repräsentant des christlichen Platonismus in dreizehnten Jahrhundert. Wien: Carl Gerold's Sohn, 1878.

${ }^{45}$ Notice sur Henri de Gand, fameux dans les annales ecclésiastiques et dans la république des lettres. Gand: Vanryckegem - Hovaere, 1828; Notice sur Henri Goethals, célèbre dans l'histoire de l'église et dans les annales diplomatiques, par un Amateur de l'Histoire de sa Patrie. Gand: Vanderhaegen, 1829; Notice sur quelques membres de l'ancienne famille Des Goethals. Gand: Hebbelynck, 1838. Para mais informações sobre esse quarto período, cf. LAARMANN, Deus, primum cognitum..., 1999, pp. 411-42. 
pertencimento à família Goethals ou à ordem servita devem ser descartados. No mesmo artigo, Ehrle localiza a atividade filosófica de Henrique de Gand no último quarto do século XIII ${ }^{46}$. Todas essas conclusões são aceitas até hoje. A primeira monografia a ser produzida nesse período foi aquela de $M$. de Wulf ${ }^{47}$. A partir de então - e, principalmente, durante os séculos XX e XXI - tem sido produzida a maior parte dos trabalhos histórico-filosóficos sobre Henrique de Gand. Uma amostra desses trabalhos, pode ser encontrada em três importantes coletâneas de artigos sobre Henrique de Gand, publicadas na passagem do século XX para o $\mathrm{XXI}^{48}$. Essa recepção contemporânea encontra seu ápice na publicação da edição crítica dos Opera omnia do Doutor Solene, iniciada em 1979 sob a direção de Raymond Macken e, hoje, continuada sob direção de Gordon A. Wilson ${ }^{49}$.

Decerto, essa narrativa é parcial e as divisões cronológicas necessariamente fluidas. Ademais, estão excluídos, por exemplo, os trabalhos enciclopédicos e

\footnotetext{
${ }^{46}$ EHRLE, F. "Beiträge zu den Biographien berühmter Scholastiker. 1. Heinrich von Gent". Archiv für Litteratur- und Kirchegeschichte des Mittelalters 1 (1885), pp. 365-401 [trad. francesa: Recherches critiques sur la biographie de Henri de Gand, dit le docteur solennel. Trad. par J. Raskop. Tournai: Casterman, 1887].

${ }^{47}$ WULF, M. de. Études sur Henri de Gand. Louvain - Paris: Uystpruyst-Dieudonné - Félix Alcan, 1894 [= Histoire de la philosophie scolastique dans les Pays-Bas et la principauté de Liège jusqu'a la Révolution Française. Louvain - Paris: Uystpruyst-Dieudonné - Félix Alcan, 1895, pp. 46-272].
}

${ }^{48}$ VANHAMEL, W. (ed.) Henry of Ghent. Proceedings of the International Colloquium on the occasion of the 700th anniversary of his death (1293). Leuven: Leuven University Press, 1996; GULDENTOPS, G., STEEL, C. (eds.). Henry of Ghent and the Transformation of Scholastic Thought. Leuven: Leuven University Press, 2003; WILSON, G. A. (ed.). A Companion to Henry of Ghent. Leiden - Boston: Brill, 2011.

${ }^{49}$ Para uma enumeração dos volumes já publicados por parte do projeto dos Opera omnia de Henrique de Gand, cf. a bibliografia do presente estudo. A tradição manuscrita, bem como de comentários medievais e modernos a Henrique de Gand, pode ser consultada na monumental MACKEN, R. Bibliotheca Manuscripta Henrici de Gandavo. 2 vols. Leuven - Leiden: Leuven University Press Brill, 1979 (ed. De Wulf-Mansion Centre, vols. 1-2). Além disso, para a enorme produção desse último período de recepção da obra de Henrique (e, em menor escala, dos períodos anteriores), cf. as bibliografias: PORRO, P. "Bibliografia". In: PORRO, P. Enrico di Gand. La via delle proposizioni universali. Bari: Levante, 1990, pp. 175-98; LAARMANN, M. "Bibliographia auxiliaris de vita, operibus et doctrina Henrici de Gandavo". Franziskanische Studien 73 (1991), pp. 324-366; HACHMANN, B., CARVALHO, M. A. "Henrique de Gand - Bibliografia". Mediaevalia. Textos e estudos 3 (1993), pp. 213-35; PORRO, P. "Bibliography" [até 1994]. In: VANHAMEL, W. (ed.) Henry of Ghent. Proceedings..., 1996, pp. 405-34; PORRO, P. "Bibliography on Henry of Ghent (1994-2002)". In: GULDENTOPS, G., STEEL, C. (eds.). Henry of Ghent and the Transformation..., 2003, pp. 409-26; SCHÖNBERGER, R. et al. (Hrsg.). Repertorium edierter Texte des Mittelalters aus dem Bereich der Philosophie und angrenzender Gebiete. Unter Mitarbeit von A. Schönfeld. Berlin: De Gruyter, 2011², pp. 1823-31; ESTÊVÃO, J. C., PAIVA, G. B. V. de. "Henrique de Gand: Bibliografia Disponível [principalmente em bibliotecas do estado de São Paulo, mas também de outros estados brasileiros]". Projeto Ariadne. São Paulo: CEPAME, última atualização em 04/2015 (endereço online: http://cepame.fflch.usp.br/ bibliografia); "Working Bibliography on Henry of Ghent". Henry of Ghent Series website (consultado online em: https://philosophy.unca.edu/sites/default/files/documents/ HenryBibliographyWeb2015.pdf) [consultada em 19/12/2015]. Além disso, cf. tb., mais uma vez, LAARMANN, Deus, primum cognitum, 1999, pp. 442-57. 
catalográficos modernos e contemporâneos, que são inumeráveis. Dito isso, vejamos a que material bibliográfico se decidiu recorrer neste trabalho para o acesso à bibliografia primária e à bibliográfia secundária, nesta ordem.

No estabelecimento do texto de Henrique de Gand, seguimos o seguinte critério. Para a [i] Suma quaestionum ordinariarum, adotamos as edições críticas da coleção De Wulf-Mansion Centre (1979-) quando disponíveis (Suma, arts. 1-5, 3155); os arts. 21-30 foram lidos com base nas reedições bilíngues de Decorte e Teske ${ }^{50}$, que contêm uma transcrição modernizada e corrigida do texto da edição Badio (1520); para demais passagens, foi utilizada a edição servita de Ferrara (1642-6), corrigida quando necessário pela edição parisiense de Badio (1520). A preferência pela edição seiscentista como texto base se deve ao fato de haver nela a tentativa de destacar citações e referências de Henrique de Gand a outros autores, o que não ocorre na edição de Paris. Para os [ii] Quodlibeta, igualmente adotamos as edições críticas da coleção De Wulf-Mansion Centre (1979-) quando disponíveis (Quodls. 12, 4, 6-7, 9-10, 12-13, 15); nos demais casos, utilizamos o texto da edição servita veneziana (1613) com os importantes comentários de Vital Zuccoli, corrigindo-a se necessário pela edição parisiense de Badio (1518). Sem dúvida, poder-se-ia igualmente ter recorrido sem resultados distintos à edição veneziana de 1608, base da reedição servita de 1613. A única razão da preferência desta àquela foi o fato de havermos obtido uma cópia da edição de 1613 com maior qualidade.

Em alguns trechos do trabalho apresentado a seguir, será relevante uma certa familiaridade com a cronologia estabelecida para a Suma e os Quodlibeta de Henrique de Gand, de maneira que cumpre dedicar algumas palavras a esse tema. As principais pesquisas sobre o assunto foram produzidas por Franz Ehrle, Palémon Glorieux, Jean Paulus, José Gómez Caffarena e Antonio San Cristóbal-Sebastián ${ }^{51}$. De início, fixou-

\footnotetext{
${ }^{50}$ HENRY OF GHENT. "Summa". The Questions on God's existence and essence. Articles 21-24. Latin text, intr., and notes by R. J. Teske. Tr. J. Decorte and R. J. Teske. Louvain: Peeters, 2005; HENRY OF GHENT. "Summa". The Questions on God's unity and simplicity. Articles 25-30. Latin text, intr., tr., and notes by R. J. Teske. Louvain: Peeters, 2006.

${ }^{51}$ EHRLE, "Beiträge zu den Biographien berühmter Scholastiker. 1. Heinrich von Gent", 1885, pp. 399-400; GLORIEUX, P. La littérature quodlibétique de 1260 à 1320. Kain: Revue des sciences philosophiques et théologiques, 1925, pp. 87-95, 177-99; GLORIEUX, P. La littérature quodlibétique II. Paris: Vrin, 1935, pp. 132-3; PAULUS, Henri de Gand. Essai..., 1938, p. xv, nt. 1, xvi, nt. 4; CAFFARENA, J. G. "Cronología de la 'Suma' de Enrique de Gante por relación a sus 'Quodlibetos"”. Gregorianum 38 (1957), pp. 116-133; cf. tb. CAFFARENA, J. G. Ser participado y ser subsistente en la metafísica de Enrique de Gante. Romae: apud Aedes Universitatis Gregorianae, 1958, p. 270; SAN CRISTOBAL-SEBASTIÁN, A. Controversias acerca de la voluntad desde 1270 a 1300 (Estudio histórico-doctrinal). Madrid: Editorial y librería CUL., 1958, pp. 271-5.
} 
se a tese de que os 15 Quodlibeta de Henrique de Gand teriam sido produzidos na ordem em que estão numerados, quase que anualmente, desde o ano letivo de 1276-7 até aquele de 1291-2. Além disso, foi-se paulatinamente firmando a hipótese baseada nas remissões mútuas entre os Quodlibeta e a Suma - de que esta última teria sido, igualmente, produzida, na ordem de numeração de seus artigos, durante esse mesmo período. Assim, antes de 1276 já estariam prontos Suma, arts. 1-20, e, a partir de então, seriam compostos os restantes artigos da Suma até o ano letivo de 1292-3. Matthias Laarmann produziu o melhor resumo das discordâncias pontuais entre Paulus, Caffarena e San Cristóbal-Sebastián no que tange a essa cronologia ${ }^{52}$. Há, porém, um fator complicador nessa proposta, a saber, a hipótese de que Henrique de Gand teria reformulado diversas etapas de sua obra, produzindo, por vezes, várias versões de um mesmo texto. Essa possibilidade já era aventada por Caffarena ${ }^{53}$, porém se tornou aceita recentemente com o advento dos diversos volumes já publicados dos Opera omnia de Henrique de Gand. O problema é que, se há um consenso quanto à possibilidade de reconstrução de diversas camadas textuais para certos excertos da obra de Henrique, não há uma concordância quanto à possibilidade de uma datação precisa de cada camada - é o caso, por exemplo, de Suma, arts. 1-5, Suma, art. 34, e Quodl. $4^{54}$. Essa incerteza quanto à datação de tais modificações arrisca invalidar aquela proposta de uma cronologia linear e paralela da produção dos Quodlibeta e da Suma ${ }^{55}$. Dito isso - e, certamente, não sendo meu objetivo aqui dar conta de tal dificuldade -, contento-me em apontar o problema e frisar que, nas vezes em que me utilizar de referências à cronologia da obra de Henrique de Gand, adotarei metodologicamente a cronologia linear, deixando em suspenso todos os problemas que incidem sobre ela.

Por fim, destaque-se que, na consulta à Suma e aos Quodlibeta, recorremos a manuscritos considerados confiáveis, caso a consulta às edições disponíveis não gerasse resultado satisfatório. Isso foi feito mesmo no caso dos trechos dessas obras

\footnotetext{
${ }^{52}$ LAARMANN, Deus, primum cognitum..., 1999, pp. 49-52.

${ }^{53}$ CAFFARENA, Ser participado y ser subsistente..., 1958, pp. 263-9.

${ }^{54}$ Cf., respectivamente: Henrique de Gand, Suma, arts. 1-5 (ed. De Wulf-Mansion Centre, vol. 21, pp. xxxviii-lvii); Henrique de Gand, Suma, arts. 31-34 (ed. De Wulf-Mansion Centre, vol. 8, pp. xcivcxxi); Henrique de Gand, Quodl. 4 (ed. De Wulf-Mansion Centre, vol. 8, pp. xlvii-lviii).

${ }^{55}$ GOEHRING, B. Henry of Ghent on cognition and mental representation. A dissertation presented to the Faculty of the Graduate School of Cornell University in partial fulfillment of the requirement for the Degree of Doctor of Philosophy. August, 2006, pp. 20-4.
} 
que já contam com edição crítica, respeitando (o tanto quanto possível em nosso estágio de formação) a sugestão de Robert Wielockx: "para se apoiar sobre um texto estabelecido de maneira crítica, o recurso aos manuscritos é indispensável" ${ }^{\prime 56}$. Sendo assim, apresento a seguir a lista de manuscritos utilizados para tanto, a razão de sua seleção, bem como os textos que buscamos, com base neles, corrigir:

\section{- Paris, BNF lat. 14312, s. XIIIf:}

Utilizado na leitura de Suma, art. 1, q. 5. Foi selecionado como uma das lições basilares para o estabelecimento crítico de Suma, arts. 1-5 (ed. De Wulf-Mansion Centre, vol. $21,2005)^{57}$. Acessível em: gallica.bnf.fr.

\section{- Paris, BNF lat. 15355, s. XIIIf-XIVi:}

Utilizado na leitura de Suma, art. 34, q. 5. Foi selecionado como uma das lições basilares para o estabelecimento crítico de Suma, arts. 31-34 (ed. De Wulf-Mansion Centre, vol. 27, 1991 ${ }^{58}$. Esse manuscrito foi legado por Godofredo de Fontaines à Sorbonne e constitui uma das mais importantes lições da Suma de Henrique de Gand, por conter diversos níveis de correções, que possibilitam a distinção de fases na produção de tal texto ${ }^{59}$. Acessível em: gallica.bnf.fr.

\section{- Paris, BNF lat. 15848, s. XIIIf:}

Utilizado na leitura de Quodl. 3, q. 14, e Quodl. 5, qq. 14 e 25. Ambos os Quodlibeta carecem de edição crítica, porém esse é um dos manuscritos utilizados como base da edição crítica do Quodl. 4 (ed. De Wulf-Mansion Centre, vol. 8, 2011) ${ }^{60}$. Esse também foi um manuscrito legado por Godofredo de Fontaines à Sorbonne, contendo

\footnotetext{
${ }^{56}$ WIELOCKX, R. "Henri de Gand et Gilles de Rome à la lumière de la bibliothèque de Godefroid de Fontaines". In: CORDONIER, V., SUAREZ-NANI, T. (éds.). L'aristotélisme exposé, 2014, pp. 181259 (esp. p. 181): "Pour s'appuyer sur un texte établi de façon critique, le recours aux manuscrits est indispensable".

${ }^{57}$ Henrique de Gand, Suma, arts. 1-5 (ed. De Wulf-Mansion Centre, vol. 21, pp. xiii, lxxxii-lxxxv). Cf. tb. MACKEN, Bibliotheca Manuscripta I (ed. De Wulf-Mansion Centre, vol. 1, 1979, pp. 552-6).

${ }^{58}$ Henrique de Gand, Suma, arts. 31-34 (ed. De Wulf-Mansion Centre, vol. 8, pp. xxxix, cxxii-cxxiv).

${ }^{59}$ Cf. MACKEN, Bibliotheca Manuscripta I (ed. De Wulf-Mansion Centre, vol. 1, 1979, pp. 595-8). Sobre os manuscritos legados por Godofredo de Fontaines à Sorbonne e sua importância para o estudo de Henrique de Gand, cf. AIELLO, A., WIELOCKX, R. Goffredo di Fontaines aspirante baccelliere sentenziario. Le autografe "Notule de scientia theologiae" e la cronologia del ms. Paris BnF lat. 16297. Turnhout: Brepols, 2008; AIELLO, A., WIELOCKX, R. "La versione del Quodlibet IV, qq. 78, di Enrico di Gand nel ms. Paris BnF lat. 16297". Documenti e studi sulla tradizione filosofica medievale 19 (2008), pp. 371-499; WIELOCKX, "Henri de Gand et Gilles de Rome à la lumière...", 2014. Para um estudo geral acerca da biblioteca de Godofredo de Fontaines, cf. DUIN, J. J. "La bibliothèque philosophique de Godefroid de Fontaines". Studia Lulliana 3 (1959), pp. 21-36, 137-60.

${ }^{60}$ Henrique de Gand, Quodl. 4 (ed. De Wulf-Mansion Centre, vol. 8, pp. xv-xviii, lxiv).
} 
importantes indícios de revisão de trechos dos Quodlibeta $^{61}$. Acessível em: gallica.bnf.fr.

\section{-Troyes, Médiathèque du Grand Troyes, ms. 493, s. XIV:}

Foi utilizado na leitura de Suma, art. 58, q. 2. Tal texto carece ainda de uma edição crítica, porém esse foi um dos manuscritos utilizados como base para o estabelecimento crítico de Suma, arts. 53-55 (ed. De Wulf-Mansion Centre, vol. 31, 2014) ${ }^{62}$. Acessível em: bibliotheque-virtuelle-clairvaux.com.

Além disso, uma obra de Henrique de Gand utilizada secundariamente no presente estudo, foi o Sermão para a festa de Santa Catarina. Para sua leitura, adotamos a edição de Hocedez, única disponível, que toma por base as duas lições manuscritas disponíveis de tal texto ${ }^{63}$.

Quanto às obras atribuídas ainda tentativamente a Henrique de Gand, pudemos utilizar suas edições recentes, que tomam como base, em cada caso, as únicas lições manuscritas disponíveis. É caso da Lectura ordinaria super Sacram Scripturam ${ }^{64}$ e das Questões sobre a Física ${ }^{65}$. Em um único caso, utilizamos uma obra disponível somente em manuscrito, a saber, as Questões sobre a Metafísica I-VI, também de atribuição incerta a Henrique de Gand ${ }^{66}$. Note-se que a nenhuma dessas três últimas obras foi emprestado caráter central em nossa análise devido à incerteza ainda reinante quanto à sua atribuição. Sendo assim, as utilizamos somente na medida em que pudessem colaborar colateralmente para o esclarecimento de temáticas periféricas

\footnotetext{
${ }^{61}$ Cf. MACKEN, Bibliotheca Manuscripta I (ed. De Wulf-Mansion Centre, vol. 1, 1979, pp. 620-8). Sobre a biblioteca legada por Godofredo de Fontaines à Sorbonne, cf., acima, a nota 59.

${ }^{62}$ Henrique de Gand, Suma, arts. 53-55 (ed. De Wulf-Mansion Centre, vol. 31, pp. xiii, liv-lv). Cf. tb. MACKEN, Bibliotheca Manuscripta II (ed. De Wulf-Mansion Centre, vol. 2, 1979, pp. 720-2).

${ }^{63}$ Henrique de Gand, Sermo in die festi sanctae Catharinae 'Confessio et pulchritudo in conspectu eius'. Ed. E. Hocedez. In: HOCEDEZ, E. Richard de Middleton. Sa vie, ses oeuvres, sa doctrine. Louvain - Paris, Spicilegium Sacrum Lovaniense - Honoré Champion-Édouard Champion, 1925, pp. 484-489, 509-517.

${ }^{64}$ Henrique de Gand, Lectura ordinaria super S. Scripturam (ed. De Wulf-Mansion Centre, vol. 36).

${ }^{65}$ PERRON, R. Les livres trois et quatre des "Quaestiones super VIII libros Physicorum" attribuées à Henri de Gand. Texte inédit et introd. 3 vols. Louvain: Université Catholique de Louvain, Institut Supérieur de Philosophie, 1961; BELLEMARE, L. Les "Quaestiones super VIII libros Physicorum" attribuées à Henri de Gand. Étude sur l'authenticité de l'oeuvre. Étude et texte des Questions sur les livres I et II. 2 vols. Louvain: Université Catholique de Louvain, Institut Supérieur de Philosophie, 1964.

${ }^{66}$ Madri, Bibl. del Escorial, h.II.1, s. XIII-XIV, ff. 1ra-73rb.
} 
ou completares ao presente trabalho ${ }^{67}$.

Dito isso, devemos ainda um esclarecimento final a nosso leitor no que tange à bibliografia secundária aqui utilizada. Pois bem, necessariamente, nossa bibliografia de apoio será formada em sua maior parte por textos da última fase de recepção da obra de Henrique de Gand dentre aquelas descritas acima. Isso, não somente porque esse é um dos períodos de maior produção acerca do pensamento do Doutor Solene, mas principalmente porque essa é a bibliografia em que se discute Henrique de Gand de um ponto de vista histórico-filosófico, aquele que também se adota aqui. Em certos temas, porém, se mostram igualmente valiosas as monografias produzidas no quarto período elencado acima, desde que lidas à luz da bibliografia mais recente. Textos dos demais três períodos de recepção serão utilizados aqui de maneira esparsa, principalmente porque eles não dizem respeito ao estudo histórico-filosófico da obra de Henrique de Gand, mas antes a um uso e adaptação (positivo ou crítico) de sua obra para a solução de problemas filosóficos e teológicos contemporâneos aos próprios comentadores. Em outras palavras, serão privilegiadas aqui aquelas obras que buscam compreender historiograficamente os escritos de Henrique de Gand enquanto produtos do contexto de debate filosófico e teológico de fins do século XIII.

\footnotetext{
${ }^{67}$ Para introduções ao estado atual de pesquisa para o estabelecimento da obra de Henrique de Gand, cf. LAARMANN, Deus, primum cognitum..., 1999, pp. 33-49; e WILSON, G. A. "Henry of Ghent's Written Legacy”. In: WILSON, G. A. (ed.). A Companion to Henry of Ghent, 2011, pp. 3-23.
} 


\section{Parte 1}

\section{O conhecimento como potência}

e possibilidade 



\section{CAP. 1.}

A POSSIBILIDADE DO CONHECIMENTO HUMANO

\subsection{QUESTÕES ACADÊMICAS}

Ainda no início da sua Ordinatio, por volta de 1300, João Duns Escoto se volta para a concepção de conhecimento apresentada por Henrique de Gand no começo de sua Suma das questões ordinárias. Mais precisamente, ele desenvolve uma ferrenha crítica da discussão sobre a possibilidade do conhecimento humano que este último apresenta em Suma, art. 1. Após enumerar os diversos argumentos de Henrique acerca do tema, o arremate de Duns Escoto não poderia ser mais claro e crítico: "esses raciocínios, portanto, parecem concluir toda incerteza e a opinião dos acadêmicos" "1 De fato, para ele a opinião de Henrique é pro opinione academicorum ${ }^{2}$. Mas o que isso quer dizer? E, por que insistir nessa crítica?

Como veremos, o início da Suma de Henrique é precisamente uma tentativa de lidar com a posição dos acadêmicos - isto é, daqueles que hoje denominaríamos 'céticos acadêmicos' - e, em geral, daqueles que, de alguma maneira, negam a possibilidade de 'conhecimento certo' (uma expressão que, apesar da aparente simplicidade, deverá ser retomada e retrabalhada do decorrer do presente estudo). $\mathrm{Ou}$ seja, quando Duns Escoto o acusa de defender os acadêmicos ele está sendo, no mínimo, irônico, pois nesse caso Henrique não só não atinge o objetivo que se impõe, como termina por defender aquilo mesmo que pretende rejeitar.

O curioso é que, ao mesmo tempo em que Duns Escoto não parece captar a complexidade da relação entre o Doutor Solene e 'aqueles que negam o conhecimento', ele de certo modo acerta ao propor que este último não se afasta completamente dos acadêmicos - com efeito, para Henrique, a possibilidade do

\footnotetext{
${ }^{1}$ Duns Escoto, Ord. I, d. 3, p. 1, q. 4, n. 222 (ed. Vaticana, vol. 3, p. 135): "Istae igitur rationes videntur concludere omnem incertitudinem et opinionem academicorum". Tive a oportunidade de estudar com maior detalhe a relação entre Henrique de Gand e Duns Escoto no que diz respeito à noção de conhecimento, em PAIVA, G. B. V. de. "A discussão acerca da possibilidade de conhecimento humano em Henrique de Gand e João Duns Escoto". In: CARVALHO, M., FIGUEIREDO, V. (eds.). ANPOF XV, vol. 1: Filosofia Antiga e Medieval. São Paulo, ANPOF, 2013, pp. 241-258. Nesse artigo, apresento igualmente uma maior bibliografia sobre o tema.

${ }^{2}$ Duns Escoto, Ord. I, d. 3, p. 1, q. 4, n. 218 (ed. Vaticana, vol. 3, p. 132).
} 
conhecimento humano é um problema a ser resolvido. Pois bem, uns duzentos anos depois da Ordinatio, temos a pergunta de Gianfrancesco Pico della Mirandola acerca dessa interpretação do Doutor Solene proposta pelo Sutil: “como pode ser a opinião dos acadêmicos aquela que aceita raios divinamente enviados?"3. De fato, ao mesmo tempo em que Henrique parece flertar com os acadêmicos, ele parece igualmente defender que a verdade pode ser conhecida, ainda que por iluminação divina.

Juntos, Duns Escoto e Gianfrancesco Pico nos mostram muito bem a dificuldade enfrentada por um leitor dos inícios da Suma de Henrique de Gand. O problema é que essas dificuldades se refletem no restante de sua discussão sobre o conhecimento humano. Assim, essa tensão entre a negação de um conhecimento e a afirmação de sua possibilidade (seja ela por meios naturais ou sobrenaturais, como veremos ao fim deste estudo ${ }^{4}$ ), marcante nas primeiras questões da Suma, perpassará toda a noção de conhecimento proposta pelo Doutor Solene. O começo da Suma se mostra, de fato, como uma ótima introdução ao estudo da obra do gandavense - por isso mesmo, começaremos por ele, pelo início.

Já a primeira dissertação a ser escrita sobre Henrique de Gand, ainda no século XIX, apontava com surpresa para o fato de este último parecer se dedicar a uma refutação do ceticismo em Suma, art. 1, q. 1, onde, no contexto do primeiro artigo "sobre a possibilidade de se ter ciência [de possibilitate sciendi]", se pergunta "se ocorre de o homem ter ciência de algo [utrum contingat hominem aliquid scire]"5. Interpela-nos François Huet, em sua dissertação de 1838:

"era necessária uma refutação direta do ceticismo no século de Henrique de Gand? Havia a dúvida estendido sua devastação até esta era de fé? Vemos, pelo menos, que nosso autor se crê obrigado a estabelecer por uma longa discussão a possibilidade da ciência"

\footnotetext{
${ }^{3}$ Giovanni Francesco Pico della Mirandola, Examen vanitatis 5, c. 4 (ed. 1520, f. 142r): "Academicorum autem opinio, quo modo esse potest ea quae radios divinitus missos asciscit?". Sobre a relação entre Henrique de Gand, João Duns Escoto e Gianfrancesco Pico, cf. PORRO, P. "Il Sextus Latinus e l'immagine dello scetticismo antico nel medioevo". Elenchos 15.2 (1994), pp. 229-53 (esp. pp. 251-3); SCHMITT, C. B. "Henry of Ghent, Duns Scotus and Gianfrancesco Pico on Illumination". Mediaeval Studies 25 (1963), pp. 231-258; e SCHMITT, C. B. Gianfrancesco Pico della Mirandola (1469-1533) and his Critique of Aristotle. The Hague: Springer, 1967 (esp. pp. 87 e 114).

${ }^{4}$ Cf., adiante, o Epílogo da parte 2 e a Conclusão.

${ }^{5}$ Henrique de Gand, Suma, art. 1 (ed. De Wulf-Mansion, vol. 21, pp. 4-5).

${ }^{6}$ HUET, F. Recherches historiques et critiques sur la vie, les ouvrages et la doctrine de Henri de Gand. Gand - Paris: De Leroux - Paulin, 1838, p. 117: "Une réfutation directe du scepticisme etait-elle nécessaire dans le siècle de Henri de Gand? Le doute avait-il étendu ses ravages jusque sur cet âge de foi? Nous voyons du moins que notre auteur se croit obligé d'établir par une longue discussion la possibilité de la science".
} 
Tanto mais desenvolvidas quanto sejam atualmente as pesquisas sobre o chamado 'ceticismo' na Idade Média ${ }^{7}$ (especialmente, pela rejeição de uma consideração negativa do ceticismo, clara na passagem citada $^{8}$ ), a interrogação de Huet se mantém ainda hoje e sua opinião final é próxima àquela de leitores

${ }^{7} \mathrm{O}$ termo 'ceticismo', quando utilizado por um historiador da filosofia medieval, é um tanto problemático. Em primeiro lugar, porque essa palavra não deixa de ser um termo genérico que compreende, de uma maneira ou de outra, várias posições surgidas na história que se caracterizaram pela recusa em afirmar o conhecimento (seja uma parte dele ou sua própria possibilidade), sem que essa recusa necessariamente redunde em uma negação. Em fins do século XIII, ao que parece, não havia qualquer escola ou autor que se dissesse 'cético' - de fato, essa palavra, pelo visto, nem mesmo era utilizada (pelo menos, não comumente). Por outro lado, Henrique de Gand parece ter considerado [i] que havia uma posição que se caracterizava como uma negação do conhecimento (ou da possibilidade de conhecimento) e [ii] que essa posição havia sido esposada pelos 'academici', membros da Nova Academia de Platão. Por isso mesmo, ele identificava 'aqueles que negam o conhecimento' com os 'acadêmicos', de maneira que este último seria um termo mais apropriado do que 'céticos' para tratarmos do tema na filosofia de fins do século XIII. No entanto, por muitas vezes, esses 'acadêmicos' surgem associados, nos textos de Henrique, a outros autores que, por qualquer razão, pareçam negar a possibilidade de conhecimento. Assim, por um lado, o termo 'cético' é inapropriado para a caracterização do grupo criticado pelo Doutor Solene, por outro, o termo 'acadêmico' é demasiado restrito. Por isso, o mais preciso seria simplesmente nos utilizarmos de uma locução como 'aqueles que negam a possibilidade do conhecimento' e asseverar que, se nos utilizamos dos termos 'cético' ou 'ceticismo' em nossa discussão, ele é utilizado unicamente por motivos de praticidade, com o uso de uma terminologia sintética e já conhecida pelo leitor, e sempre como a denominação 'daqueles que negam a possibilidade de conhecimento' e de sua posição, respectivamente. Uma obra recente que reúne interessantes artigos sobre a questão do 'ceticismo medieval' é LAGERLUND, H. (ed.). Rethinking the History of Skepticism: The Missing Medieval Background. Leiden: Brill, 2010. Sobre Henrique de Gand, pode-se consultar em especial nesse volume PICKAVÉ, M. "Henry of Ghent and John Duns Scotus on Skepticism and the Possibility of Naturally Acquired Knowledge". In: LAGERLUND, H. (ed.). Rethinking the History of Skepticism, 2010, pp. 61-96. Outro texto interessante a respeito da historicidade de um 'ceticismo' medieval é PERLER, D. Zweifel und Gewissheit. Skeptische Debatten im Mittelalter. Frankfurt am Main: Vittorio Klostermann, 2006, p. 1-31. Ainda acerca da discussão sobre ceticismo entre meados do século XIII e meados do XIV, cf. MICHALSKI, C. Le criticisme et le scepticisme dans la philosophie du XIV siècle. Éxtrait du Bulletin de l'Académie Polonaise des Sciences et des Lettres, Classe d'histoire et de philosophie - année 1925. Cracovie: Imprimerie de l'Université, 1926 (com uma menção a Henrique de Gand na p. 3); CÔTÉ, A. "Siger and the Skeptic". The Review of Metaphysics 60.2 (2006), pp. 30525; GRELLARD, C. “Comment peut-on se fier à l'expérience? Esquisse d'une typologie des réponses médiévales au problème sceptique". Quaestio 4 (2004), pp. 113-35; GRELLARD, C. Croire et savoir. Les principes de la connaissance selon Nicolas d'Autrecourt. Paris: Vrin, 2005; GRELLARD, C. "Scepticism, Demonstration and the Infinite Regress Argument (Nicholas of Autrecourt and John Buridan)". Vivarium 45 (2007), pp. 328-42; BOULNOIS, O. "Ego ou cogito? Doute, tromperie divine et certitude de soi du XIV ${ }^{\mathrm{e}}$ au XVI ${ }^{\mathrm{e}}$ siècles". In: BOULNOIS, O. (éd.). Généalogies du sujet de saint Anselme à Malebranche. Paris: Vrin, 2007, pp. 171-213; SCHMUTZ, J. "L'existence de l'ego comme premier principe métaphysique avant Descartes”. In: BOULNOIS, O. (éd.). Généalogies du sujet de saint Anselme à Malebranche. Paris: Vrin, 2007, pp. 215-68.

${ }^{8}$ Essa concepção pessimista do ceticismo é especialmente visível na influente obra de Étienne Gilson, onde o Renascimento do século XVI, caracterizado pelo ceticismo filosófico, é visto como um período irrelevante para a história da filosofia (cf. The Unity of Philosophival Experience. San Francisco: Ignatius Press, $1999^{2}$ [1937], pp. 93-95). É justamente como um resgate da relevância do estudo do ceticismo de fins da Idade Média e começos da Modernidade que surge o clássico livro de POPKIN, R. The History of Scepticism. From Savonarola to Bayle. Oxford: Oxford University Press, 2003. Aqui, Popkin mostra como, longe de ser filosoficamente estéril, o ceticismo do Renascimento foi justamente um dos elementos que permitiram repensar a herança deixada pelos autores dos séculos XIII e XIV de maneira a que se pudesse produzir a filosofia que tem lugar a partir do século XVII. 
contemporâneos a nós. Como o comentador oitocentista avalia, é difícil compreender a necessidade que Henrique sente de refutar a negação do conhecimento em fins do século XIII, mas é certo que ele o faz no contexto de uma prova da possibilidade do conhecimento para os homens. O problema, então, é: qual seria o papel dessa refutação da negação do conhecimento para a afirmação de sua possibilidade almejada por Henrique?

O primeiro passo para compreendê-lo é notar que aquilo que surge em Suma, art. 1, q. 1, não é precisamente uma refutação de uma posição cética que fosse defendida por um grupo cético ou acadêmico contemporâneo em fins do século XIII. Pelo contrário, a negação da ciência surge, antes, como uma possibilidade lógica que deve ser considerada por quem quer que deseje compreender o que é ter ciência. De certo modo, é como se fosse necessário estabelecer primeiramente o ser da ciência humana (sua possibilidade), para somente em seguida dizer o que seria tal ciência ${ }^{9}$.

\footnotetext{
${ }^{9}$ Sem dúvida, se poderia afirmar que o próprio formato da questão disputada exige que haja a exposição de contraditórios - em especial, da tese contraditória àquela que será defendida ou de extremos contraditórios que, na determinatio, darão lugar a uma via media. Com efeito, só há quaestio disputata se há aquilo que Otto Bird denomina como 'dialectical question': "The first thing about an article <NB: ele se refere à Suma de Tomás de Aquino, onde a unidade do articulus equivale à unidade da quaestio na Suma de Henrique de Gand>, is that it begins with a question, and that question is so framed as to admit of an alternative, either pro or con" ("How to Read an Article of the 'Summa"'. The New Scholasticism 27.2 (1953), pp. 129-59, cit. na p. 133, grifo no orig.). Esse caráter dialético da questão inicial é estendido à disputatio inteira por Bernardo Bazàn: "Elle $<s c$. a disputatio $>$ est une forme régulière d'enseignement, d'apprentissage et de recherche, présidée par le maître, caractérisée par une méthode dialectique qui consiste à apporter et à examiner des arguments de raison et d'autorité qui s'opponsent autour d'un problème théorique ou pratique <...>" (BAZÀN, B. C. et al. Les questions disputées et les questions quodlibétiques dans les facultés de théologie, de droit et de medicine. Turnhout: Brepols, 1985, p. 40) - ainda sobre as questões disputadas, cf. METZ, W. Die Architektonik der Summa Theologiae des Thomas von Aquin. Zur Gesamtsicht des thomasischen Gedankens. Hamburg: Felix Meiner, 1998, pp. 109-17. Ora, sendo precisamente uma quaestio disputata, está claro que, em Suma, art. 1, q. 1, se a questão pergunta 'utrum contigat hominem aliquid scire', é necessário que sejam apresentados e discutidos argumentos pelo sim e pelo não.

No entanto, nosso problema é anterior: por que levantar como quaestio disputata a possibilidade do conhecimento? Por que Henrique sente a necessidade de perguntar 'utrum contigat hominem aliquid scire'? Parece-me que isso ocorre pela necessidade de provar a possiblidade do ser de algo antes de buscar saber o que seria isso precisamente. Em outras palavras, antes de discorrer sobre a scientia (Suma, arts. 2-5) e, em particular, sobre a teologia enquanto scientia (Suma, arts. 6-20), é necessário afirmar que há isso que é a scientia. Tal interpretação vai ao encontro de uma tese defendida por Pasquale Porro, segundo a qual a base para o desenvolvimento de Suma, arts. 21-4 de Henrique seria justamente o par de fundamentais questões científicas 'se é' (an sit) e 'o que é' (quid sit): "È sufficiente prestare attenzione ai titoli $<s c$. dos artigos 21-4 da Suma $>$ per rendersi facilmente conto di come la suddivisione non sia casuale e rimandi alla distinzione degli zetoúmena proposta da Aristotele in apertura del secondo libro degli Analitici Secondi. Le questioni che possiamo sollevare, secondo Aristotele, corrispondono essattamente, nel numero, a ciò che possiamo conoscere di un ente, e cioè: tò hóti, tò dióti, ei ésti, tí estin" (Enrico di Gand. La via delle proposizioni universali. Bari: Levante, 1990, p. 18). Com efeito, se observamos Suma, art. 24, q. 3, co. (ed. Decorte \& Teske, pp. 192-6), lemos Henrique de Gand afirmar que a ordem do conhecimento parte de um preconhecimento (praecognitio) do quid est acerca de algo - nesse ponto, não se conhece mais do que um nome (in ratione nominis). Em seguinda, há a pergunta si est acerca disso - não ainda um si est acerca do 'ser de existência' da coisa, mas acerca de seu 'ser de essência' (sobre essa distinção, cf. cap. 2, nota 95,
} 
Dessa maneira, a negação da ciência ou do conhecimento em geral surge em Henrique antes como uma possibilidade lógica que deve ser afastada em favor de sua contraditória, do que como uma posição defendida por um grupo contemporâneo a ele. Isso, no entanto, não a torna menos perigosa, uma vez que ela é uma possibilidade lógica posta pela própria doutrina da intelecção que Henrique deseja propor. Ou seja, estamos aqui no âmago daquele problema que víamos surgir nas leituras de Duns Escoto e Gianfrancesco Pico: ao mesmo tempo em que o Doutor Solene afirma a possibilidade do conhecimento, a possibilidade lógica de negá-lo atuará como um passo fundamental no estabelecimento de sua doutrina da intelecção. Essa última observação, entretanto, nos leva a aproximar perigosamente Henrique de Gand de um uso metodológico do ceticismo, tese proposta por Dominik Perler.

Em seu livro Zweifel und Gewissheit, este último se vale precisamente do termo 'metodisch' para caracterizar o uso feito do ceticismo nos inícios da Suma. Para Perler, na Idade Media, “as perguntas céticas possuíam primeiramente uma função metódica, não uma < função> dogmática" ${ }^{10}$. Mais adiante em seu texto, Perler afirma

adiante), isto é, buscamos saber se aquilo que conhecíamos unicamente pelo nome é, de fato, algo que possua essência e, portanto, que seja possível (sobre a relação entre essência e possibilidade cf. cap. 6, nota 25). Somente em caso de uma resposta positiva a esta última pergunta, estaremos em posição de perguntar novamente quid est a respeito dessa essência - agora, busca-se um conceito complexo que defina aquilo que pesquisamos. Por fim, é possível perguntar novamente si est, para saber se aquilo que definimos, de fato, existe, ou seja, possui um 'ser de existência'. Dito isso, proponho que estendamos a tese de Porro, de maneira a ver os primeiros artigos da Suma igualmente como tributários da distinção entre as questões 'si est' e 'quid est' tal como o Doutor Solene as compreende. Com efeito, parece-me que esse é precisamente o caminho seguido por Henrique de Gand no início de sua Suma: temos inicialmente o nome scientia (preconhecimento quid est) mas, antes de pesquisarmos quid est scientia buscando sua definição, é necessário fazer a segunda pegunta da série, a saber, si est scientia, algo como perguntar 'se a ciência possui uma essência', que não é senão perguntar 'se a ciência é possível'. Ou seja, que Henrique de Gand inicie sua Suma perguntando de possibilitate sciendi, se deve estritamente à sua concepção de conhecimento científico. Para mais informações acerca da relação entre as questões si est e quid est em Henrique de Gand, cf. o já citado PORRO, Enrico di Gand, 1990. Sobre o mesmo tema, cf. tb. PAULUS, J. "Henri de Gand et l'argument ontologique". Archives d'histoire doctrinale et littéraire du Moyen Âge (1935), pp. 265-323 (esp. pp. 297-311); AERTSEN, J. " "Von Gott kann man nichts erkennen, außer daß er ist' (Staz 215 der Pariser Verurteilung). Die Debatte über die (Un-)möglichkeit einer Gotteserkenntnis quid est". In: AERTSEN, J. A., EMERY Jr., K., SPEER, A. (Hrsg.). Nach der Verurteilung von 1277. Philosophie und Theologie an der Unversität von Paris in letzten Viertel des 13. Jahrhunderts. Studien und Texte. Berlin - New York: De Gruyter, 2001, pp. 22-37 (esp. pp. 31-3); PORRO, P. "Le 'Quaestiones super Metaphysicam' attribuite a Enrico di Gand. Elementi per un sondaggio dottrinale". Documenti e studi sulla tradizione filosofica medievale 13 (2002), pp. 507-602 (esp. pp. 547-52); e PAIVA, G. B. V. de. “'Res a reor reris' e 'res a ratitudine' na metafísica de Henrique de Gand”. In: CARVALHO, M., PICH, R. H., OLIVEIRA DA SILVA, M. A., OLIVEIRA, C. E. (orgs.). Filosofia Medieval. Coleção XVI Encontro ANPOF. São Paulo: ANPOF, 2015, pp. 392-417 (esp. pp. 406-9).

${ }^{10}$ PERLER, Zweifel und Gewissheit, 2006, p. 10: "Skeptische Fragen hatten primär eine methodische Funktion, nicht eine dogmatische" (grifo do original). A mesma posição pode ser lida em PERLER, D. "Skepticism". In: PASNAU, R., DYKE, C. Van. (eds.). The Cambridge History of Medieva Philosophy. Vol. I. Cambridge: Cambridge University Press, 2010, pp. 384-96 (esp. p. 385): “One of 
que esse caráter 'metódico' do ceticismo "se mostra claramente em Henrique de Gand, que parte de um modelo aristotélico, mas depois procura demonstrar que aquele tipo de conhecimento almejado não pode ser esclarecido por esse modelo: o conhecimento certo e estável da estrutura essencial dos objetos"11. A meu ver, Perler acerta ao apontar o papel fundamental desempenhado pelo 'ceticismo' na busca de Henrique de Gand pelo estabelecimento tanto [i] da possibilidade de um conhecimento por vias naturais, como também [ii] dos limites deste último. De fato, ao afirmá-lo, ele se aproxima de Christoph Kann, para o qual, em "Henrique de Gand, a dúvida metódica recebida de Agostinho está a serviço da construção sistemática da ciência" ${ }^{\prime 2}$. Porém, não me parece uma boa saída recorrer ao vocabulário do 'método' para descrever o papel do questionamento cético na Suma, uma vez que o termo 'método' foi extremamente especializado para discussões sobre ceticismo que são mais tardias - a partir do século XVII - e, mais importante, que possuem fontes e contextos distintos daqueles de Henrique ${ }^{13}$.

the first medieval authors in the Latin tradition who made explicit methodological use of skeptical arguments was Henry of Ghent".

${ }^{11}$ PERLER, Zweifel und Gewissheit, 2006, p. 110: "Welche Bedeutung haben dann skeptische Fragestellung in ihren $<s c$. de Henrique de Gand e de Duns Escoto $>$ erkenntinistheoretischer Untersuchungen? Die Bedeutung ist vor allem methodischer Natur $<\ldots>$. Besonder deutlich zeigt sich dies bei Heinrich von Gent, der beim aristotelischen Modell ansetzt, dann aber nachzuweisen versucht dass, mit diesen Modell genau jene Art von Wissen nicht erklärt werden kann, die angestrebt wird: sicheres und stabiles Wissen von der wesentlichen Struktur der Gegenstände".

${ }^{12}$ KANN, C. "Grenzen des Zweifels. Skeptizismuskritik bei Augustinus, Heinrich von Gent und Descartes". Philosophisches Jahrbuch 110.2 (2003), pp. 226-40 (esp. p. 238): "Bei Heinrich von Gent steht der von Augustinus übernommene methodische Zweifel zwar im Dienste des systematischen Wissensaufbaus, hat hier aber wiederum eine weniger weitreichende Funktion als bei Descartes". Cf. tb. KANN, C. "Skepsis, Wahrheit, Illumination. Bermerkungen zur Erkenntnistheorie Heinrichs von Gent". In: AERTSEN, J. A. et al. (Hrsg.). Nach der Verurteilung von 1277. Philosophie und Theologie an der Unversität von Paris in letzten Viertel des 13. Jahrhunderts. Studien und Texte. Berlin - New York: De Gruyter, 2001, pp. 38-58 (esp. p. 45): "Der argumentative Nachweis der Verläßlichkeit von Sinneserkenntnis kann für Heinrich allenfalls erkenntnistheoretisches Etappenziel sein, um dann die Grenzen dieser Sinneserkenntnis bzw. des natürlichen Erkenntnisvermögen aufzeigen zu können - als methodisch-systematische Vorbereitung der Einführung eines anderen, weiterreichenden Erkenntnistyps, worauf noch einzugehen ist".

${ }^{13}$ O termo 'método' é (assim como ocorria com a palavra 'ceticismo' - cf. nota 7) de difícil utilização na historiografia da filosofia medieval. Em primeiro lugar, isso é patente pela centralidade que a noção ganhou na modernidade filosófica, associada à leitura de diversas fontes que não estavam disponíveis para um autor escolástico do século XIII como Henrique de Gand (sobre o surgimento da relevante noção moderna de método, cf. GILBERT, N. W. Renaissance Concepts of Method. New York London: Columbia University Press, $1963^{2}$ [1960]). Decerto, muitos são os casos de utilização do termo 'método' em referência à filosofia medieval - por exemplo, em WULF, M. de. "Méthodes scolastiques d'autrefois et d'aujourd'hui". Revue néo-scolastique 10 (1903), pp. 165-184; mais recentemente, em HOYE, W. J. "Die mittelalterliche Methode der Quaestio". In: HEROLD, N. et al. (Hrsg.). Philosophie: Studium, Text und Argument. Münster - Hamburg - London: LTI, 1997, pp. 155178; ou em estudos sobre o Doutor Solene, como PAULUS, J. "Henri de Gand et l'argument ontologique", 1935, pp. 277; VOOGHT, P. "La méthode théologique d'après Henri de Gand et Gérard 
de Bologne". Recherches de théologie ancienne et médiévale 23 (1956), pp. 61-87, BELLOSO, J. M. R. "Sobre el metòde teològic en Enric de Gand". Revista Catalana de Teologia 8 (1983), pp. 191-202, MACKEN, R. "La personnalité, le caractère et les méthodes de travail d'Henri de Gand. Les épanchements d'Henri dans ses oeuvres scholastiques". Theologische Zeitschrift 45.2-3 (1989), pp. 192-206. Ainda assim, esse uso não é de todo sem problemas, muito pelo contrário. De fato, a utilização do termo 'método' no estudo da filosofia medieval ou escolástica parece estar ligado, principalmente, ao problema da relação entre fé e razão, considerada a partir do ponto de vista do (neo)tomismo de fins do século XIX e começo do XX (é o caso do trabalho de De Wulf, citado há pouco). A expressão mais contundente dessa concepção de 'método escolástico' pode ser encontrada na monumental obra de Martin Grabmann, Die Geschichte der scholastischen Methode. Erster Band. Freiburg im Breisgau, Herdersche Verlagshandlung, 1909, pp. 36-37: "Die scholastische Methode will durch Anwendung der Vernunft, der Philosophie auf die Offenbarungswahrheiten möglichste Einsicht in den Glaubensinhalt gewinnen, um so die übernaturliche Wahrheit dem denkenden Menschengeiste inhaltlich näher zu bringen, eine systematische, organisch zusammenfassende Gesamtdarstellung der Heilswahrheit zu ermöglichen und die gegen den Offenbarungsinhalt vom Vernunftstandpunkte aus erhobenen Einwände lösen zu können. In allmählicher Entwicklung hat die scholastische Methode sich eine bestimmte äußere Technik, eine äußere Form geschaffen, sich gleichsam versinnlicht und verleiblicht”. O estudo de Grabmann é suficiente para mostra que há uma reflexão medieval (e, mais precisamente, escolástica) acerca do próprio pensamento filosófico, de sua cientificidade e da possibilidade de uma ciência da fé (uma teologia). É precisamente essa reflexão, que paulatinamente se desenvolve no decorrer dos séculos da Idade Média, que Grabmann denomina 'método escolástico' uma concepção de método, aliás, que se aproxima daquela de Étienne Gilson (em uma obra como $L e$ réalisme méthodique. Paris: Téqui, $2007^{2}$ [1935]), um autor que igualmente tenta lidar com o problema contemporâneo da relação entre fé e razão de um ponto de vista (neo)tomista. Nesse sentido, a meu ver, cai por terra qualquer possibilidade de rejeitar o uso do termo 'método' em razão da pretensa ausência de uma tal reflexão sobre o próprio pensamento na escolástica - com efeito, é precisamente esse o argumento de Martin Heidegger ao afirmar que não há 'método' na Idade Média, em Die Kategorienund Bedeutungslehre des Duns Scotus. Tübingen: J. C. B. Mohr (Paul Siebeck), 1916, p. 8: "In der Tat, Methode besagt uns nicht so sehr die bestimmt fixierte Form in der Darstellung und Mitteilung der Gedanken als vielmehr den Geist der Forschung und Problemstellung, genauer: Mangel an Methodenbewußtsein soll besagen: es gelingt dem mittelalterlichen Meschen nicht mit einem gewissen geistigen Ruck sich über die eigene Arbeit zu stellen, über die Probleme als Probleme, über die Möglichkeit und Art ihrer Bemächtigung, ihren Zusammenhang mit anderen und ihre Tragweite bewußt zu reflektieren; wenigstens ist das im philosophischen Denken des Mittelalters so". Como se vê, Heidegger recusa a noção de um 'método escolástico' em razão da pretensa ausência de uma reflexão medieval acerca do próprio trabalho filosófico, embora a aceite se tomarmos 'método' como o caminho desde os princípios até as conclusões: "Gewiß kann Methodenbewußtsein verstand werden als Wissen um, eingestellt sein auf Fundamente, die einen gewissen Kreis von Problemen allererst möglich machen; als das Aufweisen vom Bestehen ganz eigenthümlicher Prinzipien, die einen bestimmten Erkenntniszusammenhang fundieren, von denen her ihm erst ein Sinn zukommt <... . Aber der Methodenbegriff dieser Art scheint nun doch auch in der Scholastik eine vertraute Angelengenheit zu sein, wenigstens soweit sie vom echten Geist des Aristoteles erfüllt ist" (Die Kategorien- und Bedeutungslehre des Duns Scotus, 1916, p. 9-10). Portanto, haveria certamente na escolástica um conceito do caminho seguido desde os princípios até as conclusões na resolução dos problemas científicos, porém não haveria uma consciência acerca do próprio trabalho e do pensamento - não haveria reflexão acerca do pensamento, somente um caminho que garantiria a unidade do pensamento filosófico. Ora, justamente uma tal reflexão acerca do pensamento por parte da filosofia escolástica é pressuposta neste meu trabalho, uma vez que tal reflexão consiste no próprio tema deste estudo - de fato, o que pretendemos ao fim de nosso percurso é justamente compreender como Henrique de Gand pensa filosoficamente o conhecimento humano possível por vias estritamente naturais (é fundamental para meu trabalho que o Doutor Solene seja tomado como alguém que pensou e refletiu sobre a própria possibilidade do conhecimento e não como alguém que simplesmente se utilizou de uma caminho silogístico já completamente dado - por exemplo, em Aristóteles). Assim, certamente não rejeito a utilização do termo 'método' no que diz respeito à escolástica tardo-medieval (e, em particular, a Henrique de Gand) por seguir a posição de Heidegger - isso seria negar, de saída, a própria possibilidade do trabalho que aqui busco realizar. Se a rejeito, o faço somente para tampouco me comprometer com o (neo)tomismo contemporâneo de um Wulf, de um Gilson ou de um Grabmann. No mais, acredito que Gilbert está muito correto ao chamar atenção para a noção de 'método' no Renascimento, pois é somente a partir de então que ela começa a assumir o lugar central que será seu 
De fato, aquilo que denominamos 'ceticismo' na obra do Doutor Solene não é senão um termo genérico para os diversos argumentos que ele enumera como formas de negação da possibilidade de se ter ciência para o homem. Pela própria leitura de Suma, art. 1, q. 1, é fácil notar que as fontes de Henrique para esses argumentos são, basicamente, a Metafísica de Aristóteles, os Acadêmicos de Cícero (em especial o Lucullus ou Academica priora) e o Contra academicos de Agostinho ${ }^{14}$. Os dois últimos são fontes antigas do que denominaríamos hoje como 'ceticismo acadêmico', enquanto que Aristóteles surge como uma fonte de argumentações de autores atualmente ditos 'pré-socráticos', as quais de uma maneira ou de outra parecem negar a possibilidade da ciência para Henrique. Ou seja, aquilo que denominamos simplesmente como 'ceticismo' nos textos deste último não condiz precisamente com a distinção atualmente projetada na filosofia antiga e na moderna entre 'céticos pirrônicos' e 'céticos acadêmicos'. A negação da ciência, para o Doutor Solene, é obra daqueles que ele denomina 'acadêmicos' e de alguns autores anteriores a Aristóteles que chamaríamos de 'pré-socráticos'. Como se vê, não há qualquer menção em sua obra ao ceticismo pirrônico, uma vez que ele não se utiliza daqueles textos que pudessem ser fontes sobre este último ${ }^{15}$. Ora, a relação entre ceticismo e

no século XVII.

${ }^{14}$ Não pretendo aqui me aprofundar no estudo das fontes utilizadas por Henrique de Gand para o estabelecimento dos argumentos contrários à possibilidade de conhecimento elencados na questão ainda que esse seja um interessante tema, ele mereceria um estudo à parte. Com efeito, Christophe Grellard considera que o Doutor Solene teria produzido a mais clara síntese da noção de 'cético' partir das fontes disponíveis no século XIII: “Mais c'est indéniablement chez Henri de Gand (ca. 1217-1293) que la redéfinition du sceptique à partir de ces éléments épars et issus de traditions différentes est la plus nette" - GRELLARD, C. "Academicus". In: ATUCHA, I., et al. (éds.). Mots médiévaux offerts à Ruedi Imbach. Porto: FIDEM, 2011, pp. 11-21 (esp. p. 17). Dada a complexidade do tema, não sendo ele nosso foco presentemente, me contento em remeter a dois textos sobre o assunto. Quanto à utilização de Cícero por Henrique de Gand, cf. o já citado PICKAVÉ, M. "Henry of Ghent and John Duns Scotus on Skepticism...”, 2010; no que diz respeito à utilização de Agostinho por Henrique nesse contexto, pode-se consultar TESKE, R. "Augustine's Influence on the Philosophy of Henry of Ghent". In: TESKE, R. Essays on the Philosophy of Henry of Ghent. Milwaukee: Marquette University Press, 2012, pp. 165-189 (em especial, as pp. 166-170). As fontes precisas de Henrique de Gand em cada passagem são fornecidas cuidadosamente na edição crítica do texto produzida por Gordon Wilson. Para uma introdução à discussão sobre as fontes de Henrique de Gand, cf. MACKEN, R. "Les sources d'Henri de Gand". Revue philosophique de Louvain 76 (1978), pp. 5-28; e DECORTE, J. "Aristotelian Sources in Henry of Ghent”. In: VANHAMEL, W. (ed.). Henry of Ghent. Proceedings..., 1996, pp. 107-120. Por fim, cf. tb. a rápida referência à importância dos Contra academicos de Agostinho para a discussão sobre o ceticismo em Henrique de Gand e Duns Escoto em YLINEN, M. Pyrrhonismi renessanssifilosofiassa ja konstruktiivinen skeptisismi 1600-luvulla. Kuusi argumenttia Richard Popkinin tulkintaa vastaan. Tampere: Tampere University Press, 2016, pp. 32-3.

${ }^{15}$ De fato, muito embora tenha havido uma tradução latina das Hipotiposes pirronianas de Sexto Empírico produzida ainda em fins do século XIII (cf. LAGERLUND, H. "A history of Skepticism in the Middle Ages". In: LAGERLUND, H. (ed.). Rethinking the History of Skepticism, 2010, p. 10 e PORRO, "Il Sextus Latinus...", 1994, pp. 229-237), não há registros de que Henrique de Gand tenha se 
método só se torna relevante, como foi dito, a partir do século XVII, justamente no contexto da recepção do ceticismo pirrônico pela leitura de Diógenes Laércio e Sexto Empírico. Em poucas palavras, certamente o que está em jogo em Henrique de Gand não é a relação entre método e ceticismo ${ }^{16}$.

Por isso mesmo, me vejo levado a aceitar as afirmações de Kann e Perler segundo as quais a discussão sobre o questionamento cético é fundamental para a elaboração da doutrina da intelecção de Henrique de Gand, mas tendo a rejeitar a caracterização desse ceticismo como 'metodológico'. Curiosamente, o próprio Kann mostra um caminho alternativo para a compreensão do papel da negação da ciência na Suma, quando ele nos lembra, em um artigo seu anterior, que, além da influência do Agostinho de Contra acadêmicos, é capital para a decisão de Henrique de iniciar sua Suma por uma abordagem do ceticismo o papel que esta abordagem possui como uma fundamentação (Begründung) da sua teologia ${ }^{17}$. Nesse ponto, começamos a nos aproximar mais daquela que parece ser, para mim, a real importância dessa possível negação da ciência evocada em Suma, art. 1.

Esse início da obra do Doutor Solene é mais do que um simples estabelecimento da possibilidade da ciência, uma vez que, para além de uma simples afirmação da ciência, surge aqui um discurso acerca do processo que pode levar o homem a um tal conhecimento científico ${ }^{18}$. Se a afirmação da possibilidade de se ter ciência pela negação de sua contraditória é fundamental - isto é, constitui um

utilizado dela. Pelo contrário, ele em nenhum momento lida com as fontes daquilo que denominaríamos como 'ceticismo pirrônico'. Para uma introdução e discussão crítica a respeito da distinção entre ceticismo acadêmico e ceticismo pirrônico, cf. BOLZANI, R. "Acadêmicos versus Pirrônicos: Ceticismo Antigo e Filosofia Moderna”. Discurso 29 (1998), pp. 57-110; e, mais recentemente, do mesmo autor Acadêmicos versus Pirrônicos. São Paulo: Alameda, 2013.

${ }^{16} \mathrm{O}$ termo 'método' ocorre, até onde pude verificar, somente uma vez em Henrique de Gand e, mesmo assim, no contexto de uma citação dos Tópicos de Aristóteles - Summa, art. 5, q. 5, co. (ed. De WulfMansion Centre, vol. 21, p. 349): "In talibus enim, ut dicitur in principio Topicorum, 'habemus sufficienter methodum <...>”. O termo 'methodus', entretanto, não é desenvolvido em maiores detalhes no comentário do Doutor Solene à passagem. Isso, mais uma vez, nos remete a GILBERT, Renaissance Concepts of Method, $1963^{2}$ [1960], p. 54: "The presence of methodus in Latin versions of Aristotle and other Greek authors did not mean that it was adopted as a technical term by medieval philosophers".

${ }^{17}$ KANN, "Skepsis, Wahrheit. Illumination", 2001, p. 45: "Heinrichs Argumentation gegen den Skeptizismus zielt letztlich darauf, den Wisseschaftsstatus der Theologie rational zu begründen. Diese Begründung selbst erfolgt im Rahmen einer genuin philosophisch-erkenntnistheoretischen Analyse".

${ }^{18}$ É possível, aqui, falar tanto em possibilidade de scientia como em possibilidade de cognitio para o homem, pois como veremos adiante, no item 1.2, há uma acepção ampla do termo scientia que abrange todo o conhecimento possível (sensitivo ou intelectivo). Sobre o termo scientia, cf. BROWN, S. F. "Theology and Philosophy". In: MANTELlO, F. A. C., RIGG, A. G. (eds.). Medieval Latin. An Introduction and Bibliographical Guide. Washington, D.C.: The Catholic University of America Press, 1996, pp. 267-87 (esp. pp. 280-1). 
fundamento - para a discussão que se segue, Henrique não pretende com ela dar as bases de uma filosofia do conhecimento, mas antes de uma teologia ${ }^{19}$. Assim, o Doutor Solene não afirma a possibilidade da ciência sem mais. Pelo contrário, sua defesa da possibilidade de um conhecimento científico não se completa no conhecimento filosófico obtido por abstração, mas redunda necessariamente na afirmação da necessidade de uma iluminação divina que, enquanto certificação do conhecimento filosófico abstraído, é necessária para a teologia e para aquele que a ensina, o teólogo ${ }^{20}$. Ou seja, Henrique de Gand, de fato, flerta com o ceticismo ao afirmar que uma ciência pela qual verdadeiramente se conheçam as coisas no estado presente não é possível naturalmente, mas só por iluminação divina - isto é, não é possível filosoficamente, mas só na teologia. Seguindo precisamente esse caminho interpretativo, Dominique Demange busca contextualizar as primeiras questões da Suma de Henrique relacionando-as às Condenações de 1277, entendidas por ele como uma condenação oficial pelo bispo Estêvão Tempier de qualquer pretensão de autonomia da filosofia com respeito à teologia por parte dos artistae, isto é, dos mestres da Faculdade de Artes da Universidade de Paris. Para Demange, os inícios da Suma podem ser tidos:

\begin{abstract}
"como uma versão teórica e doutrinal que o Doutor Solene pretendia dar da condenação oficial de uma razão filosófica separada da luz teológica. A estratégia que Henrique de Gand adota consiste em mostrar que a autonomia reivindicada pela filosofia é ilusória. Ao pretender fundar uma verdade distinta, autônoma, o filósofo constrói sobre areia, pois a razão natural, se deixada a ela mesma, está irremediavelmente sujeita ao ceticismo"21.
\end{abstract}

\footnotetext{
${ }^{19}$ O próprio prólogo da Suma, tão curto quanto seja, deixa claro que a noção de conhecimento científico, sua possibilidade e descrição, só são aí abordados na medida em que permitem uma melhor apreciação da teologia enquanto ciência - cf. Henrique de Gand, Suma, prol. (ed. De Wulf-Mansion Centre, vol. 21, p. 3): "Quia theologia est scientia in qua est sermo de Deo et de rebus divinis, ut dicit Augustinus VIII ${ }^{\circ}$ De civitate Dei - dicitur enim theologia quasi 'deologia' a 'Theos' Graece, quod est 'Deus' Latine, et 'logos', quod est 'sermo' vel 'ratio', quasi sermo vel ratio de Deo et de rebus divinis —, ideo quaeritur hic primo quomodo theologia de Deo et de rebus divinis sit scientia; secundo quomodo in ea de Deo et de rebus divinis locutio sit habenda; tertio quae et qualia in ea de Deo et de rebus divinis sint cognoscenda. Ut autem iuxta processum Augustini et eius intentionem in libris $D e$ Academicis 'argumenta eorum quae multis ingerunt veri inveniendi desperationem', dicentium scilicet 'omnia esse incerta' et 'nihil posse sciri', 'quantis possumus rationibus amoveantur', paulo altius ordiendo quaerendum est hic primo de scientia et scibili communiter et in generali; secundo de scientia et scibili propriis theologiae in speciali" (grifos no original). Sobre o desenvolvimento da doutrina do conhecimento como base para a caracterização da teologia como ciência em Henrique de Gand, cf. TROTTMANN, C. Théologie et noétique au XIII siècle. À la recherche d'un statut. Paris: Vrin, 1999, pp. 157-92.

${ }^{20}$ Sobre a necessidade de uma iluminação divina para o conhecimento da teologia, cf. a Conclusão.

${ }^{21}$ DEMANGE, D. "Introduction". In: HENRI DE GAND. Sur la possibilité de la connaissance humaine. Textes latin introduits, traduits et annotés par D. Demange. Paris: Vrin, 2013, pp. 7-51 (esp. p. 15): "De toute évidence, les premières questions de la Summa d'Henri de Gand s'inscrivent dans un
} 
Não pretendo agora avaliar a correção da tentativa de Demange de relacionar as condenações parisienses de 1277 e a Suma de Henrique de Gand ${ }^{22}$. Interessa-me, por outro lado, ressaltar esse caráter basilar da discussão sobre o ceticismo para o pensamento de Henrique.

A discussão que surge no começo da Suma sobre a negação da ciência é, portanto, fundamental em três sentidos: [i] para a demonstração da possiblidade de um conhecimento humano obtido por vias naturais, que se confundirá em Henrique com a filosofia; como complemento a essa demonstração, [ii] para a afirmação dos limites de um tal conhecimento humano natural; e, consequentemente, [iii] para a defesa da necessidade de uma teologia que seja superior à filosofia e que surja como única ciência capaz de certificar os conhecimentos obtidos por esta última. O ceticismo não pode ser rechaçado somente pela filosofia - ainda que se estabeleça a possiblidade do conhecimento natural, este permanece incompleto, insuficiente. Assim, essa negação da possibilidade da ciência só deixará de nos assombrar pela demonstração da possibilidade de uma iluminação divina que garanta um conhecimento da verdade. Essa iluminação, no entanto, redunda na confirmação de

tel contexte. Nous n'hésiterons pas à les présenter comme la version théorique et doctrinale que le Docteur Solennel entendait donner de la condamnation officielle d'une raison philosophique coupée de la lumière théologique. La stratégie qu'adopte Henri de Gand consiste à montrer que l'autonomie revendiquée par la philosophie est illusoire. En prétendant fonder une vérité distincte, autonome, le philosophe ne bâtit que sur du sable, car la raison naturelle, si elle est laissée à elle-même, est irrémédiablement sujette au scepticisme".

${ }^{22}$ Note-se que Henrique de Gand é o único membro hoje nominalmente conhecido da comissão reunida pelo bispo Estêvão Tempier para estabelecer a lista de proposições condenadas em março de $1277 \mathrm{em}$ Paris - cf. PORRO, P. "Possibilità ed esse essentia in Enrico di Gand". In: VANHAMEL, W. (ed.). Henry of Ghent. Proceedings ..., 1996, pp. 211-53 (esp. p. 252). Não obstante, a discussão atual acerca da relação entre Henrique de Gand e as condenações de fins do século XIII é extremamente complexa. Para uma introdução ao tema, pode-se consultar: HÖDL, L. "Neue Nachrichten über die Pariser Verurteilungen der thomasischen Formlehre". Scholastik 39 (1964), pp. 178-96; WIELOCKX, R. "Commentaire". In: AEGIDIUS ROMANUS. Apologia. Ed. et commentaire par R. Wielockx. Firenze: Olschki, 1985 (Aegidii Romani Opera omnia III.1), pp. 67-225; WIPPEL, J. F. "Bishop Stephen Tempier and Thomas Aquinas: A Separate Process against Aquinas?". Freiburger Zeitschrift für Philosophie und Theologie 44 (1997), pp. 117-136; PORRO, P. "Metaphysics and Theology in the Last Quarter of the Thirteenth Century: Henry of Ghent Reconsidered”. In: AERTSEN, J. A., SPEER, A. (Hrsg.). Geistesleben im 13. Jahrhundert. Berlin - New York: De Gruyter, 2000, pp. 265-282 (esp. pp. 274-8); WILSON, G. A. "Henry of Ghent and John Peckham's Condemnation of 1286". In: GULDENTOPS, G., STEEL, C. (eds.), Henry of Ghent and the Transformation..., 2003, pp. 261-75; WIELOCKX, R. "Henry of Ghent and the Events of 1277". In: WILSON, G. A. (ed.). A Companion to Henry of Ghent, 2011, pp. 25-61. Sobre as condenações de fins do século XIII em geral, cf. BIANCHI, L. Il vescovo e i filosofi. La condanna parigina del 1277 e l'evoluzione del'aristotelismo scolastico. Bergamo: Pierluigi Lubrina Editore, 1990; PUTALLAZ, F.-X. Insolente liberté. Controverses et condamnations au XIII siècle. Fribourg - Paris: Éditions Universitaires - Éditions du Cerf, 1995; BOUREAU, A. Théologie, science et censure au XIII siècle. Le cas de Jean Peckham. Paris: Les Belles Lettres, 2008² [1999]. 
uma insuficiência do conhecimento filosófico e, portanto, na necessidade de uma teologia. Enfim, iniciar a Suma por uma discussão sobre a negação do conhecimento não se trata de uma decisão metodológica, mas antes de uma necessidade interna à filosofia e à teologia de Henrique de Gand, uma vez que asseverar a possibilidade de se ter ciência passa por rechaçar a negação dessa possibilidade. Recusar o ceticismo é necessariamente o primeiro passo de um longo caminho em direção à demonstração da necessidade de uma teologia como ciência superior à filosofia ${ }^{23}$. Isso, parece-me, é sugerido no próprio prólogo da Suma, quando Henrique propõe o afastamento da

\footnotetext{
${ }^{23}$ Por outro lado, é importante destacar a relevância de uma posição oposta como a de Steven Marrone. Para ele, " $<\mathrm{i}>\mathrm{n}$ other words Henry was willing to accept from the outset the fact that the mind could attain knowledge. He even believed without hesitation that such knowledge was reliable. He was no skeptic, and it was no part of his intention to prove that knowledge was possible for the human mind. Indeed, at this broadest and most fundamental level Henry did not even feel that the value of knowledge had to be more closely scrutinized or explained" (Truth and Scientific Knowledge in the Thought of Henry of Ghent. Cambridge: The Medieval Academy of America Press, 1985, p. 14). Essa posição parece levar Marrone a, em geral, ignorar a primeira questão da Suma e tomar a segunda questão do artigo 1 como ponto de partida para sua leitura, isto é, uma questão na qual a possibilidade de conhecimento certo já está estabelecida. Como veremos no item 1.2., a possibilidade de conhecimento certo para Henrique, embora defensável, não pode ser demonstrada. Isso, porém, não se deve à falta de interesse do autor pela questão ou a uma pretensa sensação de que tal problema não merecesse um maior escrutínio. Pelo contrário, a ausência de uma demonstração silogística da possibilidade de conhecimento certo para o homem se segue precisamente da concepção de 'conhecimento certo' adotada pelo Doutor Solene, como notaremos. Enfim, qualquer posição que desqualifique a relevância daquilo que o próprio Henrique escolheu como primeiro passo de sua maior obra teológica me parece inadequada e pouco fundamentada nos textos de apoio. Vale ressaltar que em uma obra posterior, na qual Marrone retoma o estudo da doutrina da intelecção de Henrique de Gand sob o prisma de sua concepção de iluminação divina, ele mais uma vez ignora a importância da discussão sobre a negação do conhecimento certo como base para o estabelecimento da possibilidade deste último. Isso, aliás, tem como efeito mais uma vez a quase completa ausência de referências a Suma, art. 1, q. 1 - cf. MARRONE, S. P. The Light of Thy Countenance. Science and Knowledge of God in the Thirteenth Century. Vol. 2. Leiden - Boston - Köln: Brill, 2001, pp. 259-298. Por fim, o mesmo esquema interpretativo é retomado em MARRONE, S. P. "Henry of Ghent's Epistemology". In: WILSON, G. (ed.). A companion to Henry of Ghent, 2011, pp. 213-239. O meu objetivo neste primeiro capítulo, por outro lado, será levar ao máximo as reflexões contidas nessa questão inicial da Suma de Henrique, mesmo que para isso tenhamos que recorrer a outras obras e textos seus. Teremos ocasião para estudar melhor as posições de Marrone nos próximos capítulos. Outro autor que parece não atentar para a importância dessa discussão inicial da Suma sobre a negação do conhecimento é Maurice de Wulf, quando afirma em "L'exemplarisme et la théorie de l'illumination spéciale dans la philosophie de Henri de Gand”. Révue néo-scolastique 1.1 (1894), pp. 53-75 (esp. p. 73): "Sans doute, le Docteur Solennel consacre une partie de son premier article à démolir quelques objections parties d'un point de vue sceptique. Mais elles ont une importance minime, et loin de constituer au profit de Henri un mérite d'originalité, elles peuvent être rangées parmi les clauses de style qu'on rencontre dans tous les traités philosophiques de l'époque". Por outro lado, para Robert Pasnau um dos aspectos importantes da obra de Henrique é, justamente, sua cuidadosa discussão acerca do ceticismo: "It is Henry of Ghent who desserves credit as the first scholastic to take seriously both the problem of skepticism and the need to give an analyssis of ordinary empirical knowledge" - "William Heytesbury on Knowledge: Epistemology Without Necessary and Sufficient Conditions". History of Philosophy Quarterly 12.4 (1995), pp. 347-66 (cf. esp. p. 353). De minha parte, afirmo, contra De Wulf, que a relevância de tal discussão não está em uma pretensa originalidade dos argumentos utilizados, mas no uso positivo que ela terá no pensamento de Henrique de Gand, como expusemos neste item.
} 
opinião acadêmica como um passo necessário em direção à determinação do que seria a ciência e, por fim, do que seria a teologia enquanto ciência ${ }^{24}$.

Com essas observações, entretanto, avançamos demais. De fato, este último parágrafo vai muito além do que pretendemos realizar no presente trabalho, que se volta tão somente para a concepção de conhecimento abstrativo desenvolvido por Henrique de Gand. Aliás, ao fim de nosso percurso, veremos que a relação entre teologia, filosofia e iluminação não é tão clara quanto pareceu até aqui. Enfim, tendo avaliado com base em comentadores o papel do questionamento cético acerca da possibilidade de se ter ciência no Doutor Solene, é hora de darmos muitos passos atrás e ver como essa discussão de fato se desenvolve no começo de sua Suma.

\subsection{UM CONHECIMENTO POSSÍVEL}

A primeira questão da Suma - que, como vimos, pergunta "se ocorre de o homem ter ciência de algo" 25 - possui uma longa série de argumentos com diferentes fontes já citadas aqui que são apresentados como diversos meios para se negar a ciência (todos apresentados, de saída, como errores). Não será meu objetivo aqui acompanhar passo a passo essa série ${ }^{26}$. Por outro lado, seria interessante avançarmos por um momento para Suma, art. 2, q. 2, onde todo o tema da negação da ciência é focado nos acadêmicos. De fato, desde o início da Suma, Henrique os têm por alvo privilegiado, provavelmente devido à sua leitura de Agostinho. Com efeito, ainda no já referido prólogo, ele afirma pretender seguir a intenção de Agostinho "nos livros Sobre os acadêmicos, removendo por quantos raciocínios pudermos os argumentos daqueles que geram em muitos um desespero de encontrar a verdade, a saber, dizendo que tudo é incerto e que de nada se pode ter ciência" ${ }^{27}$. Pois bem, é precisamente

\footnotetext{
${ }^{24}$ Henrique de Gand, Suma, prol. (ed. De Wulf-Mansion Centre, vol. 21, pp. 3-4). Cf. notas 19 e 27.

${ }^{25} \mathrm{Cf}$, acima, nota 5 .

${ }^{26}$ Refiro-me à lista de sete erros (cuja consequência é negação do conhecimento) exposta no trecho Henrique de Gand, Suma, art. 1, q. 1, co. (ed. De Wulf-Mansion Centre, vol. 21, pp. 13-8). Sobre essa série de argumentos, cf. PREZIOSO, F. A. La critica di Duns Scoto all'ontologismo di Enrico di Gand. Padova: CEDAM, 1961, p. 73; SORGE, V. Gnoseologia e teologia nel pensiero di Enrico di Gand. Napoli: Loffredo, 1988, pp. 55-6.

${ }^{27}$ Henrique de Gand, Suma, prol. (ed. De Wulf-Mansion Centre, vol. 21, p. 3): "Ut autem iuxta processum Augustini et eius intentionem in libris De Academicis 'argumenta eorum quae multis ingerunt veri inveniendi desperationem', dicentium scilicet 'omnia esse incerta' et 'nihil posse sciri', 'quantis argumentis possumus rationibus amoveantur', paulo altius ordiendo quaerendum est hic primo de scientia et scibili communiter et in generali $<\ldots>$ ". Um excerto maior do prólogo, incluindo o
} 
contra esses acadêmicos, que negam qualquer ciência, que Henrique se volta em um trecho de Suma, art. 2, q. 2:

“ $<\ldots>$ segundo o Filósofo, ter ciência [scire] não é outro que não ter uma notícia certa da verdade. A ciência do que quer que seja, portanto, ou é certa em algum gênero de certeza ou não é ciência. Donde, também os acadêmicos [academici], por crerem que tudo é incerto e envolvido pelas tantas trevas dos erros, tal que de nada pudesse o homem ter notícia certa, negavam de todo a ciência, como foi dito acima $<$ sc. em Suma, art. 1, q. 1>. Donde, como foi ali mesmo alegado contra eles, já que é possível que o homem tenha ciência [scire] e perceba [percipere] a notícia da verdade, cumpre conceder absolutamente que daquilo que o homem tem ciência, ele tem ciência certamente [scit certitudinaliter] $<\ldots>, 28$.

Toda a base desse argumento produzido pelo Doutor Solene é uma identificação entre ter ciência (scire) e ter uma notícia certa da verdade (certam habere veritatis notitiam), do que se segue uma aproximação entre 'ter ciência' e 'certeza' (certitudo). De fato, 'ter ciência' é 'ter ciência certamente' (scire certitudinaliter). Porém, essa identificação é matizada pela referência a "algum gênero de certeza [aliquo genere certitudinis]”. Ora, os acadêmicos negam qualquer certeza e, portanto, qualquer ciência. Henrique, por outro lado, defende que há ciência e, destarte, é possível ter conhecimento certo. A chave para a compreensão da sua doutrina da intelecção como um todo é atentar para quais gêneros de certeza podem ser obtidos naturalmente ou por iluminação divina. Mas, cedo aqui mais uma vez à tentação de avançar além do que devo...

Por ora, notemos somente que a resposta mais cabível aos acadêmicos parece ser afirmar a possibilidade de se ter ciência certa, mas distinguir gêneros da certeza e, assim, também gêneros da ciência. Esse é precisamente o caminho que Henrique de Gand segue nas primeiras questões do artigo 1 da Suma.

presente trecho, é citado acima na nota 19.

${ }^{28}$ Henrique de Gand, Suma, art. 2, q. 2, co. (ed. De Wulf-Mansion Centre, vol. 21, p. 208): “< $<>$ secundum Philosophum scire non est aliud quam certam habere veritatis notitiam. Scientia ergo cuiuscumque sit aut certa est aliquo genere certitudinis aut scientia non est. Unde et Academici, quia omnia credebant esse incerta et tantis errorum tenebris involuta, ut de nullo posset homo certam notitiam habere, scientiam negabant omnino, ut dictum est supra. Unde cum, ut ibidem contra ipsos obtentum est, hominem possibile est scire et percipere notitiam veritatis, absolute concedendum quod homo quaecumque scit certitudinaliter scit $<\ldots$.. ". Embora o verbo pecipere seja utilizado com uma ampla gama de significados por Henrique de Gand - todos próximos do verbo igualmente rico apprehendere -, ele recebe uma significação técnica própria (ainda que rara na obra do Doutor Solene) no contexto da discussão sobre o sentido comum (cf. item 5.2). No que diz respeito à complexa noção de notitia, cf. cap. 6, nota 70. Ainda sobre os gêneros de certeza, cf. FIORENTINO, F. Conoscenza scientifica e teologia fra XIII e XIV secolo. Bari: Edizione di Pagina, 2014, p. 66. 
Seu primeiro passo para responder Suma, art. 1, q. 1, é, dessa maneira, descrever de que modo 'ter ciência' está sendo tomado na discussão: “cumpre dizer que 'ter ciência' tomado amplamente [scire large accepto] < diz respeito $>$ a toda notícia certa pela qual se conhece uma coisa tal como é, sem qualquer falácia ou engano",29. Aqui vemos a primeira formulação na Suma dessa equivalência entre 'ter ciência' e 'ter uma notícia certa', porém são dadas igualmente duas características da descrição da 'notícia certa', as quais serão de grande importância na discussão subsequente. Eles são: [i] por ela "se conhece uma coisa tal como é [cognoscitur res sicut est]" e [ii] isso ocorre "sem qualquer falácia ou engano [absque omni fallacia et deceptione $]^{\prime 30}$. Mas seriam esses dois elementos distintos ou seria o segundo anterior ao primeiro? Isto é, pela notícia certa se conhece uma coisa como é e, além disso, sem qualquer falácia ou engano? Ou pela notícia certa se conhece uma coisa como é, ou seja, sem qualquer falácia ou engano? Seria possível conhecer algo como é e, no entanto, fazê-lo com falácia e engano? Enfim, a locução "absque omni fallacia et deceptione" se refere diretamente à "certa notitia" ou explica a expressão “cognoscitur res sicut est”? Parece-me que aquela locução explica, principalmente, o que seria conhecer uma coisa 'tal como é' (sicut est). Isso ficará claro daqui a pouco, quando virmos como Henrique de Gand se utiliza dessa descrição de scire para apontar a certeza do conhecimento sensitivo e do conhecimento intelectivo. Em ambos os casos, a certeza de que conhecemos uma coisa tal como é será explicada pelo fato de que não há outro conhecimento que contradiga aquele primeiro, de maneira que parece haver uma identificação entre conhecer 'absque omni fallcia et deceptione' e conhecer 'res sicut est', não sendo estes dois passos de um processo.

Antes de seguir adiante, porém, devemos atentar para uma rápida observação do Doutor Solene sobre o ceticismo. Logo após apresentar a formulação do 'scire large accepto' que vimos, ele adiciona que "assim entendida e proposta a questão, é

\footnotetext{
${ }^{29}$ Henrique de Gand, Suma, art. 1, q. 1, co. (ed. De Wulf-Mansion Centre, vol. 21, p. 10): "Dicendum quod scire large accepto ad omnem notitiam certam qua cognoscitur res sicut est absque omni fallacia et deceptione <...>".

${ }^{30}$ Perler caracteriza ambas como "Minimalbedingungen festgehalten, die erfüllt sein müssen, damit überhaupt von Wissen die Rede sein kann" (Zweifel und Gewissheit, 2006, p. 38). Mais uma vez, o que me parece problemático em sua posição é o uso de um vocabulário muito carregado - no caso, Bedingung - para a descrição de dois elementos que, a bem dizer, não são nem mesmo muito bem caracterizados por Henrique nesse texto. Por outro lado, Perler está correto ao destacar, imediatamente acima da passagem destacada, que não há aqui uma definição de scire: "Heinrich spricht nicht von einer Definition von Wissen. Daher darf nicht angennomen werden, dass hier notwendige und hinreichende Bedingungen formuliert werden" (op. cit.).
} 
manifesto e claro, contra os que negam a ciência e toda percepção da verdade, que ocorre de o homem ter ciência de algo - e isso, segundo todo modo de se ter ciência e de conhecer" ${ }^{\prime 31}$. Essa passagem possui diversos elementos interessantes. O primeiro é, sem dúvida, a enganadora simplicidade com que a negação da ciência parece ser rechaçada. Tal impressão, entretanto, é quebrada pelo adendo final: "segundo todo modo de se ter ciência e de conhecer [secundum omnem modum sciendi et cognoscendi]". Ora, o preço de afirmar a ciência é ter que distinguir diversos modos de ciência e conhecimento - o que, como vemos, nos remete àqueles diversos 'gêneros de certeza' que Henrique sugere que haja na passagem de Suma, art. 2, q. 2, que lemos acima. Outro elemento importante nessa curta frase é a referência ao par 'ciência' (scientia) e 'toda percepção da verdade' (omnem veritatis perceptionem). Não temos aqui os elementos para discorrer sobre a 'percepção da verdade', porém o que já fica claro é que, de alguma maneira, assim como há vários modos de se 'ter ciência', de se 'conhecer', de 'ciência' e vários 'gêneros de certeza', talvez a 'percepção da verdade' também possua diversos modos, pois a verdade parece acompanhar a ciência. A isso, porém, só poderemos retornar ao fim de nosso percurso. Por fim, é necessário atentar para outra dupla que surge aqui, a saber, 'manifesto e claro' (manifestum est et clarum). Ambos, unidos ao fato de que (como veremos) não há argumentos demonstrativos possíveis para comprovar a possibilidade de se ter ciência para o homem, parecem apontar para a imediatez da afirmação da possibilidade do conhecimento para o homem. Não cumpre demonstrar que ocorre de o homem ter ciência de algo, pois isso é imediatamente patente. Mais uma vez, o preço de tomar a possibilidade da ciência por manifesta e clara é a necessidade de distinguir várias ciências e vários gêneros de certeza - a necessidade de reconhecer que há distintas ciências para o homem é um Leitmotiv do início da Suma. A simplicidade dessa resposta inicial redunda na enorme complexidade da doutrina da intelecção que a sucede.

Com efeito, logo após essa curta caracterização do 'ter ciência' e essa, aparentemente, sumária recusa do ceticismo, Henrique de Gand já apresenta uma primeira distinção (de muitas) com respeito ao scire: "de fato, alguém pode ter ciência

\footnotetext{
${ }^{31}$ Henrique de Gand, Suma, art. 1, q. 1, co. (ed. De Wulf-Mansion Centre, vol. 21, p. 10): “< $<$..> et sic intellecta et proposita quaestione contra negantes scientiam et omnem veritatis perceptionem, manifestum est et clarum quia contingit hominem scire aliquid, et hoc secundum omnem modum sciendi et cognoscendi".
} 
de alguma coisa duplamente - por testemunho alheio e exterior ou por testemunho próprio e interior" 32 . Que ocorra de se ter ciência "por testemunho alheio e exterior [testimonio alieno et exteriori]" é rapidamente afirmado, por uma autoridade do Sobre a Trindade de Agostinho. É por ela também que esse primeiro caso de ciência é explicado como aquele conhecimento que possuímos a partir do testemunho de outros homens, como aquilo que aprendemos pelas lições de história ou pela fama que algo possui $^{33}$. Apesar da rápida descrição e do pouco cuidado que o Doutor Solene dedica aqui a esse caso de conhecimento, está claro que ele remete ao ensino (doctrina) e ao aprendizado (disciplina), que são longamente tratados em passagens posteriores de Suma, art. $1^{34}$. Aliás, a própria distinção entre 'testemunho exterior' e 'testemunho interior' é reminiscente da importante distinção entre o agente interior e o agente exterior no aprendizado:

\begin{abstract}
“< ..> não pretendemos que o professor $[$ doctor $]$ gere pela sua ciência, como agente natural, a ciência no aluno [discipulus] tal como se objeta, mas que por seu ensino [doctrina] ele propõe signos ordenados. A razão, no aluno, deve formar seus conceitos em semelhança àqueles e, assim, $<$ o aluno deve $>$ adquirir a ciência dirigido pelo professor [directus a doctore] - orientado <por ele>, mas por uma ação própria interior. Pelo que, mais verdadeiramente cumpre que o agente interior seja dito professor [doctor] do que o exterior" ${ }^{\prime 35}$.
\end{abstract}

\footnotetext{
${ }^{32}$ Henrique de Gand, Suma, art. 1, q. 1, co. (ed. De Wulf-Mansion Centre, vol. 21, p. 10): "Scire enim potest aliquis rem aliquam dupliciter: vel testimonio alieno et exteriore vel testimonio proprio et interiori".

${ }^{33}$ Henrique de Gand, Suma, art. 1, q. 1, co. (ed. De Wulf-Mansion Centre, vol. 21, pp. 10-11).

${ }^{34}$ Henrique de Gand, Suma, art. 1, q. 6-10 (ed. De Wulf-Mansion Centre, vol. 21, pp. 133-177). Sobre o ensino em Henrique de Gand, cf. GORIS, W. "De magistro - Thomas Aquinas, Henry of Ghent, and John Duns Scotus on Natural Conceptions". The Review of Metaphysics 66 (2013), pp. 435-468; SPRUYT, J. "Leren ordelijk te denken. Hendrik van Gent (ca. 1217-1293) over de fundamenten van onderwijs". Tijdschrift voor Filosofie 75 (2013), pp. 63-89.

${ }^{35}$ Henrique de Gand, Suma, art. 1, q. 6, ad 7 (ed. De Wulf-Mansion Centre, vol. 21, pp 140-141): "< $<>$ dicendum quod verum est, nec intendimus quod doctor per modum agentis naturalis per suam scientiam generet scientiam in discipulo sicut obiecitur, sed quod ex sua doctrina proponat signa ordinata, ad quae ratio in discipulo consimiles debet formare suos conceptus et per hoc acquirere scientiam directus a doctore, admonitus, sed actione propria interiore; propter quod agens interior verius dicendus est doctor quam exterior”. Em Quodl. 12, q. 2, ad 2 (ed. De Wulf-Mansion Centre, vol. 16, pp. 24-5), Henrique de Gand discute de que maneira se estabelece a persuasão, por parte do aluno, a respeito da autoridade daquele que ensina.

Além disso, sublinhe-se que, como se pode ver pela expressão 'proponat signa ordinata', esse discurso sobre o ensino e o aprendizado pressupõe uma doutrina da fala e da significação, as quais são longa e detalhadamente desenvolvidas por Henrique de Gand em Quodl. 5, q. 15 e Suma, arts. 73-75. Como, no presente trabalho, não poderei dar a devida atenção à associação elaborada por Henrique de Gand entre as noções de signo e de locutio, vale a pena citar os principais trabalhos produzidos acerca do tema: SCHINZER, R. "Gott und die Sprache bei Heinrich von Gent (1293)". Neue Zeitschrift für Systematische Theologie und Religionsphilosophie 15.2 (1973), pp. 148-171; ASHWORTH, E. J. "'Can I speak more clearly than I can understand?'. A problem of religious language in Henry of Ghent, Duns Scotus and Ockham”. Historiographia linguistica 7.1-2 (1980), pp. 29-38; ROSIER, I. "Henri de Gand, le De Dialectica d'Augustin, et l'institution des noms divins". Documenti e studi sulla
} 
Lendo esse trecho, é fácil compreender o porquê de Henrique de Gand não reservar tanta atenção para a ciência 'por testemunho alheio e exterior'. Ora, qualquer conhecimento obtido por meio de um professor exterior - isto é, proveniente de outro homem que o ensine - se resolve em um conhecimento por testemunho interior, de maneira que unicamente este último estará em jogo na discussão sobre a possibilidade de se ter ciência. Com efeito, é a este último que Henrique se dedica com mais afinco.

Pois bem, como vimos há pouco, o gandavense afirmava considerar 'manifesto e claro' que ocorre de o homem ter ciência de algo. Esse caráter manifesto da possibilidade da ciência para o homem é reafirmado quando nos voltamos para a ciência "por testemunho próprio e interior [testimonio proprio et interiori]". De fato, "que ocorre ter-se ciência de algo e perceber-se uma coisa tal como é do segundo modo é manifesto por aquilo que experimentamos em nós e à nossa volta [experimur in nobis et circa nos] - e isso, tanto no conhecimento sensitivo como no intelectivo"36 . O mais importante aqui é notar donde provém esse caráter manifesto da nossa possibilidade de se ter ciência. Ele provém, a saber, do fato de que 'experimentamos em nós e à nossa volta' que ocorre de se ter ciência. E isso é tudo...

Essa experiência da ciência esgota o questionamento sobre sua possibilidade e exclui qualquer necessidade de sua demonstração, como veremos. Nesse trecho, ademais, surge uma distinção fundamental para toda a doutrina da intelecção que estudaremos adiante, nomeadamente, aquela entre o conhecimento sensitivo (cognitio sensitiva) e o conhecimento intelectivo (cognitio intellectiva). Aliás, é notável que aquele 'ter ciência de algo' (aliquid scire) seja igualado a 'perceber uma coisa tal como é' (rem percipere sicuti est) e ambos digam respeito tanto ao conhecimento sensitivo como ao intelectivo. Melhor dizendo, scire e percipere são tomados tão amplamente (lembremos que estamos tratando do scire large accepto do segundo

tradizione filosofica medievale 6 (1995), pp. 145-253 (contém uma edição parcial de Suma, art. 73, nas pp. 192-253); ROSIER-CATACH, I. "Henri de Gand, le 'De Dialectica' d'Augustin, et la sémantique des noms divins". École pratique des hautes études. Section des sciences religieuses. Annuaire. 104 (1995-1996), pp. 409-415; "Henri de Gand, le 'De Dialectica' d'Augustin, et la sémantique des noms divins (2)". École pratique des hautes études. Section des sciences religieuses. Annuaire. 105 (19961997), pp. 381-388; "Le parler des anges et le nôtre". In : CAROTI, S. et al. (eds.). "Ad ingenii acuitionem». Studies in honour of Alfonso Maierù. Louvain-la-Neuve: Fédération Internationale des Instituts d'Études Médiévales, 2006, pp. 377-401 (em especial, a p. 385).

${ }^{36}$ Henrique de Gand, Suma, art. 1, q. 1, co. (ed. De Wulf-Mansion Centre, vol. 21, p. 11): “Quod autem secundo modo contingit aliquid scire et rem percipere sicuti est, manifestum est ex eis quae experimur in nobis et circa nos, et hoc tam in cognitione sensitiva quam intellectiva". 
modo, isto é, por testemunho interno) que podemos dizer que há 'uma percepção ou uma ciência sensitiva' assim como 'uma percepção e uma ciência intelectiva'. Daí fica claro que a scientia a que se faz referência nessa primeira questão da Suma não diz respeito à distinção entre conhecimento simples e conhecimento proposicional de fato, ainda não chegamos a essa distinção ${ }^{37}$. Por ora, estamos em um ponto anterior do caminho, que diz respeito indiferentemente aos conhecimentos simples e complexo, mas distingue já o conhecimento sensitivo e o intelectivo como dois casos daquele scire large accepto por testemunho interior. Por isso mesmo, Henrique se volta agora justamente para a consideração de cada uma dessas duas ciências interiores em particular.

Como já antecipamos acima, ao tratar do conhecimento sensitivo e do conhecimento intelectivo, o Doutor Solene retoma aquela caracterização inicial do scire large accepto como "toda notícia certa pela qual se conhece uma coisa tal como é, sem qualquer falácia ou engano" ${ }^{38}$. Em ambos os casos, esse 'conhecimento da coisa tal como é sem qualquer falácia ou engano' é explicitado como uma ausência de contradição desse conhecimento por outros. Isto é, a chave para o reconhecimento de que a sensação ou a intelecção nos dá a 'conhecer a coisa tal como é sem qualquer engano ou falácia' é a ausência de conhecimentos contraditórios que possam, de alguma maneira, fazer frente ao conhecimento em questão. Seguindo a ordem proposta por Henrique, vejamos o que ele tem a dizer quanto ao conhecimento sensitivo:

"de fato, no conhecimento sensitivo, aquele sentido que não é contradito por
nenhum sentido mais verdadeiro na sua ação própria de sentir o seu objeto
próprio ou por um inteligido tomado a um outro sentido mais verdadeiro (seja
em um mesmo ou em outro) percebe a coisa verdadeiramente tal como é, sem
nenhum engano e falácia. E não se deve ter dúvida de que percebamos tal como
é aquilo que assim percebemos. E não cumpre, quanto a isso, buscar uma outra
causa ulterior da certeza, pois, como diz o Filósofo, 'buscar uma razão daquilo
de que temos um sentido é uma fraqueza do intelecto; de fato, não cumpre buscar
uma razão daquilo de que temos algo mais digno do que a razão'. De fato, a
experiência de dizeres verdadeiros é que convenham com as coisas sentidas
[Experimentum enim sermonum verorum est ut conveniant rebus sensatis]"39.

\footnotetext{
${ }^{37}$ Perler, por outro lado, conclui que tal questão diz respeito estritamente ao conhecimento não proposicional, com base no trecho que lemos acima, na nota 29 (cf. Zweifel und Gewissheit, 2006, p. 38). A meu ver, no entanto, o scire large accepto é anterior à distinção entre conhecimento simples $\mathrm{e}$ conhecimento proposicional, tal como também é anterior à distinção entre conhecimento sensitivo e conhecimento intelectivo.

${ }^{38}$ Cf. nota 29 , acima.

${ }^{39}$ Henrique de Gand, Suma, art. 1, q. 1, co. (ed. De Wulf-Mansion Centre, vol. 21, p. 11): "In
} 
Nesse complexo trecho, entram em jogo várias noções que ainda não haviam sido utilizadas anteriormente na discussão. Em primeiro lugar, é importante notar a situação descrita na passagem: o conhecimento sensitivo considerado é aquele no qual um sentido executa sua ação própria, isto é, sente o seu objeto próprio (in actione propria sentiendi suum proprium obiectum). Assim, o que está sendo discutido aqui é em que medida, quando um sentido percebe o seu sensível próprio (no caso da visão, a cor, da audição, o som etc.), ele verdadeiramente percebe a coisa (vere rem percipit). O que pode querer dizer esse 'verdadeiramente' fica claro pela última frase do trecho que, não obstante pareça um pouco deslocada, nos dá uma boa pista para a leitura do restante da passagem. Ora, Henrique afirma aí que os dizeres de que temos experiência como sendo verdadeiros são aqueles que convêm com as coisas sentidas ("experimentum enim sermonum verorum est ut conveniant rebus sensatis"). Ou seja,

cognitione enim sensitiva sensus ille vere rem percipit, sicuti est sine omni deceptione et fallacia, cui in actione propria sentiendi suum proprium obiectum non contradicit aliquis sensus verior vel intellectus acceptus ab alio sensu veriori, sive in eodem sive in alio. Nec de eo quod sic percipimus dubitandum est quin percipiamus ipsum sicuti est. Nec oportet in hoc aliquam aliam ulteriorem causam certitudinis quaerere, quia, ut dicit Philosophus, 'quaerere rationem cuius habemus sensum, infirmitas intellectus est; cuius enim dignius habemus aliquid quam rationem, non est quaerenda ratio'. Experimentum enim sermonum verorum est ut conveniant rebus sensatis". A nossa tradução de 'experimentum' por 'experiência' é tentativa e a dificuldade de tradução do termo nesse contexto fica clara pela variedade de soluções adotadas pelos tradutores. Robert Pasnau utiliza o inglês 'test' (The Cambridge Translation of Medieval Philosophical Texts. Vol. 3: Mind and Knowledge. Cambridge: Cambridge University Press, 2002, p. 98). Teske prefere 'proof' (HENRY OF GHENT. Summa of Ordinary Questions. Article One: On the Possibility of Human Knowledge. Translated and edited by Roland J. Teske. South Bent: St. Augustine's Press, 2008, p. 8). Kato Masato se utiliza do japonês 証拠 | shōko, que poderíamos traduzir por 'evidência' (GAN NO HENRIKUSU [ガンのヘンリクス]. “Utrum contingat hominem aliquid scire'. Henrici de Gandavo Quaestione ordinariae (Summa), a. 1, q. 1 [人 間は何かを知りうるか (1) - ガンのヘンリクス『定期討論のスンマ』a. 1, q. 1]: a Japanese translation by Kato Masato [加 藤 雅 人]”. 外国語学部紀要 | Foreing Languages Bulletin 7 (2012), pp. 121-47 - cf. p. 137). Finalmente, Dominique Demange, que sigo aqui, prefere simplesmente 'expérience' (HENRI DE GAND. Sur la possibilité de la connaissance humaine. Textes latins introduits, traduits e annotés para D. Demange. Paris: Vrin, 2013, p. 75). As traduções de Teske e Pasnau são interessantes pela escolha heterodoxa (e um tanto anacrônica, a meu ver) de traduzir o latim 'experimentum' por um verbo que indica uma ação da parte do cognoscente, como 'proof' ou 'test'. Kato parece privilegiar a passividade do cognoscente, pois a 'evidência' (証拠 | shōko) pode ser entendida como algo simplesmente apresentado, pelo conhecido, àquele que conhece. Demange, de sua parte, prefere uma tradução neutra, mas que também pode ser lida na direção de um afirmação da passividade do cognoscente. Parece-me que mais do que afirmar a necessidade de uma ação de 'testar' ou 'provar' a verdade dos dizeres, Henrique de Gand está somente afirmando uma passividade da parte do cognoscente, isto é: os dizeres que são experimentados como verdadeiros pelos cognoscentes são aqueles que convêm com as coisas sentidas. Ou seja, ao seguir Demange, afasto-me das traduções de Pasnau e Teske, porque estas leem na passagem a atribuição de uma atividade ao cognoscente, enquanto parece-me haver aí somente a atribuição de passividade a este último. Além disso, já vimos que 'experior' e termos associados (como 'experimentum') apontam, nos trechos de Henrique de Gand que lemos, para uma imediatez do conhecimento. Atribuir uma atividade ao cognoscente (como fazem Pasnau e Teske), pelo contrário, justamente impõe um passo intermediário entre a recepção dos dizeres e seu conhecimento como verdadeiro, o que não me parece ser o caso nesta passagem. 
o advérbio vere inicial e o verus final não estão ainda muito desenvolvidos tecnicamente - eles simplesmente apontam para uma conveniência, por um lado, entre a percepção sensível da coisa e a própria coisa percebida e, por outro, entre os dizeres e as sensações ${ }^{40}$. Como se vê, porém, essa conveniência não é explicada por Henrique aqui. De fato, sua concepção de verdade será longamente desenvolvida em outros trechos da sua obra, mas aqui esse não é o caso.

Pois bem, com o pouco que temos a respeito da verdade nesse trecho, o problema parece ser apontar certos elementos característicos daquela sensação que convém com a coisa sentida, isto é, pela qual se percebe verdadeiramente a coisa. Nesse ponto, a percepção verdadeira (que convém com a coisa percebida) é identificada com o par notitia certa / scire large accepto que vimos mais acima, pois o sentido que "percebe a coisa verdadeiramente" a percebe "tal como é, sem qualquer engano e falácia [sensus ille vere rem percipit, sicuti est sine omni deceptione et fallacia]". Embora aqui a formulação seja um pouco distinta da que vimos acima (agora temos "sicuti est sine omni deceptione et fallacia", enquanto antes líamos "sicut est absque omni fallacia et deceptione" ${ }^{41}$ ), isso não parece afetar o sentido geral da fórmula. Nesse ponto, aliás, podemos responder a uma questão posta há pouco, a saber, qual seria a relação entre as expressões 'sicut est' e 'sine omni deceptione et fallacia'. Ao que parece, a segunda é uma explicitação da primeira, isto é, 'conhecer a coisa tal como é' é conhecê-la 'sem qualquer engano ou falácia'. Isso é claro pelo fato de que o Doutor Solene fornece um único elemento capaz de determinar a ocorrência daquele conhecimento da coisa tal como é, a saber, justamente a ausência de contradição nesse conhecimento. Ora, se a ausência de contradição no conhecimento garante que este último seja da coisa tal como é, isso ocorre justamente porque a ausência de contradição indica uma ausência de engano ou falácia, de maneira que necessariamente deve haver uma identificação entre 'conhecer a coisa tal como é' e 'conhecer a coisa sem engano e falácia', caso contrário, a ausência de contradição não seria suficiente como garantia de uma percepção sensível verdadeira da coisa. Com essa observação, atingimos o núcleo da passagem.

\footnotetext{
${ }^{40}$ Sobre a concepção de fala desenvolvida por Henrique, cf., acima, a nota 35.

${ }^{41}$ Cf. nota 29, acima.
} 
Apontar a ausência de contradição como garantia da percepção sensitiva verdadeira gera o problema de descrever aquela situação que se toma aqui por contraditória - isso redunda no momento mais difícil do excerto. De fato, Henrique busca listar rapidamente os dois casos em que uma tal contradição poderia surgir: [i] um sentido mais verdadeiro (sensus verior) poderia contradizer aquele sentido ou [ii] uma intelecção tomada a um outro sentido mais verdadeiro (intellectus acceptus ab alio sensu veriori) poderia fazê-lo. Essa observação não resolve de maneira alguma nosso problema, antes ela simplesmente o redobra. Ora, se a verdade de um sentido depende de ele não ser contradito por um sentido (ou uma intelecção tomada a um sentido) mais verdadeiro, então teremos que ver se este último sentido também não é contradito e assim ao infinito. A nossa situação só piora pela observação seguinte, pois o Doutor Solene adiciona que esse sentido (ou essa intelecção tomada a um sentido) mais verdadeiro que contradiz um outro sentido, pode ser de um mesmo ou de outro (sive in eodem sive in alio). Mas, 'um mesmo ou outro' o quê? Os tradutores do texto Robert Pasnau, Roland J. Teske, Dominique Demange e Kato Masato são unânimes em interpretar essa alternativa como se referindo a pessoas ou indivíduos $\operatorname{cognoscentes}^{42}$. Se for assim, Henrique está dizendo que uma percepção sensível de um indivíduo pode ser contradita não somente por um sentido (ou uma intelecção tomada a um sentido) mais verdadeiro desse mesmo indivíduo, mas também por aquele sentido (ou aquela intelecção) de um outro indivíduo cognoscente. Essa parece uma boa interpretação do texto, com o porém de que ela parece mesclar a ciência 'por testemunho alheio e exterior' e a 'ciência por testemunho próprio e interior', cuidadosamente distinguidas imediatamente antes da passagem estudada. Como resolver essa série de imbróglios proveniente de uma passagem de somente duas linhas?

Comecemos pelo problema que, me parece, é mais simples. A aparente mescla dos conhecimentos 'por testemunho exterior' e 'por testemunho interior' pode ser

\footnotetext{
42 Pasnau traduz "whether in the same or in another [person]" (The Cambrige Translations of Medieval Philosophical Texts, 2002, p. 97); em Teske lemos "either in the same person or in another" (HENRY OF GHENT, Summa of Ordinary Questions. Article One, 2008, p. 8). No francês de Demange temos: "que ce soit dans le même <individu> ou dans un autre" (HENRI DE GAND, Sur la possibilité..., 2013, p. 97). Por fim, em Kato Masato (GAN NO HENRIKUSU [ガンのヘンリクス]. ““Utrum contingat hominem aliquid scire'...”, 2012, p. 137), lemos a tradução: “同一人物であれ、別の人物であれ। dōitsu jinbutsu deare, betsuno jinbutsu deare [seja uma mesma pessoa, seja outra pessoa]". Como se vê, também na versão japonêsa introduz-se a referência à identidade ou diferença entre 'pessoas' (人物 |jinbutsu).
} 
resolvida se lembrarmos que, segundo o Doutor Solene, todo conhecimento 'por testemunho exterior' se resolve em um conhecimento 'por testemunho interior'. Assim, o simples aprendizado de que outro indivíduo sente uma coisa de maneira contraditória à maneira como eu a sinto me levaria a formar em mim uma sensação 'por testemunho interior' de que 'outro possui uma sensação contraditória à minha'. Se essa saída não parece ter claras bases textuais, ela tem a vantagem de utilizar ferramentas presentes em Suma, art. 1, como vimos acima. Levando adiante essa interpretação tentativa, mesmo quando houvesse contradição entre minha percepção e a percepção de outro indivíduo, o que haveria, de fato, seria a contradição entre a minha percepção da coisa e a percepção que tenho da percepção que outro indivíduo possui da coisa. Dessa maneira, a contradição pode englobar a percepção de diversos indivíduos sem, entretanto, deixar de ser uma ciência 'por testemunho interior' para um único indivíduo que, além de possuir sua própria sensação da coisa, tenha aprendido sobre as sensações contraditórias à sua que outros indivíduos possuem acerca dessa mesma coisa.

Aceitando-se essa interpretação, resta o problema da possibilidade de um recuo ao infinito na busca da verdade das percepções sensíveis. A dificuldade é saber como podemos concluir que um sentido é mais verdadeiro do que outro se, para tanto, temos que justamente compará-los entre si. Essa dificuldade, entretanto, se dilui quando nos lembramos de que o pensamento de Henrique é profundamente pautado por uma concepção hierárquica de mundo (que nos será muito útil, aliás, no próximo capítulo) e que, em um pensamento tão hierarquizante, facilmente deslizamos de 'um sentido mais verdadeiro' para 'um sentido mais digno', de um sensus verior para um sensus dignior. Quando se faz referência a maior ou menor verdade de um sentido (a sua maior ou menor conveniência com a coisa percebida), também está em causa a dignidade dos sentidos, sendo uns mais dignos e verdadeiros do que outros na hierarquia do conhecimento. Veremos isso mais atentamente no próximo capítulo, mas vale a pena citar aqui uma passagem ainda de Suma, art. 1, q. 1:

" $<\ldots>$ sempre cumpre crer no sentido particular não impedido, a não ser que
outro sentido mais digno no mesmo em outro tempo ou em outro no mesmo
tempo $<0>$ contradiga, ou que uma virtude superior perceba o impedimento do
sentido. De fato, os sentidos não são igualmente bem dispostos em todos ou em
diversos tempos e, por isso, não cumpre crer no juízo [iudicio $]^{43}$ deles

\footnotetext{
${ }^{43}$ Notemos aqui o interessante uso do termo 'iudicium' associado não ao intelecto (ou à razão, a que ele propriamente diz respeito, como veremos no cap. 3), mas aos sentidos. Teremos a oportunidade de
} 
igualmente, como é patente no são e no doente. De fato, mais cumpre crer no paladar do são do que do doente, naquele que vê algo de perto do que naquele que vê de longe, naquele que vê algo por um meio uniforme do que naquele que vê por um meio não uniforme - e assim quanto às demais disposições deste tipo" 44 .

Em poucas palavras, cada sentido possui uma verdade / dignidade própria que o torna capaz de contradizer os sentidos inferiores a si e ser tomado ele mesmo por certo. Isso vale tanto em um mesmo indivíduo como em diferentes indivíduos, em um mesmo instante como em diferentes instantes. Melhor dito, a hierarquia dos sentidos perpassa a distinção individual (essa ordenação de verdade / dignidade dos sentidos é, portanto, da espécie) e a distinção no tempo (ao ser própria da espécie, essa ordenação é universal e necessária). Acidentalmente, porém, essa hierarquia pode ser comprometida - como é o caso claro das doenças que afetam os órgãos dos sentidos ou de certas situações externas que comprometam seu correto funcionamento. Nesse caso, muitas vezes se crerá num sentido inferior em detrimento de outro superior. Ainda assim, mesmo nesses casos, a hierarquia é respeitada, uma vez que a decisão sobre o impedimento do sentido superior descartado deve provir de uma virtude superior a todos os sentidos particulares, que julgou aquele sentido superior impedido por qualquer causa que seja - essa virtude superior a todos os sentidos no homem, como veremos, é o intelecto. Portanto, quando Henrique se refere, naquele excerto anterior, à contradição proveniente de um sentido (ou de uma intelecção tomada a um sentido) mais verdadeiro, ele está se referindo a essa hierarquia das potências sensitivas, que é dada na própria natureza humana ${ }^{45}$.

Pois bem, para terminar a leitura do trecho, resta unicamente atentar para a decisão com que Henrique de Gand encerra sua rápida reflexão sobre a percepção abordar essa capacidade judicativa da potência sensitiva nos capítulos 4 e 5 .

${ }^{44}$ Henrique de Gand, Suma, art. 1, q. 1, ad 2 (ed. De Wulf-Mansion Centre, vol. 21, pp. 21-22): “Unde semper oportet credere sensui particulari non impedito, nisi alius sensus dignior in eodem alio tempore vel in alio eodem tempore contradicat vel virtus aliqua superior percipiens sensus impedimentum. Non enim sensus aeque bene dispositi sunt in omnibus vel in eodem diversis temporibus, et ideo non aequaliter iudicio eorum credendum est, ut patet in sano et aegro. Magis enim credendum est gustui sani quam aegri, et ei qui videt aliquid de prope quam qui videt a longe, et ei qui videt aliquid per medium uniforme quam ei qui videt per medium non uniforme, et sic de ceteris huiusmodi dispositionibus".

${ }^{45}$ Perler (Zweifel und Geweissheit, 2006, pp. 41-44) igualmente destaca a importância da reflexão metafísica sobre os sentidos enquanto partes da natureza humana para a compreensão dessa concepção de verior sensus (que ele traduz por "korrekterer Sinn"). Ele o faz ao estudar a passagem que transcrevemos, aqui, na nota 48, adiante. Entretanto, deve ser notado que Perler não faz referência àquela relação que pudemos ver entre verior e dignior, de maneira que ele não parece dar relevo à hierarquização metafísica dos sentidos no contexto dessa discussão. 
sensitiva verdadeira. De fato, nos diz ele, caso não haja nenhum dos casos de contradição enumerados, "não se deve ter dúvida de que percebamos tal como é aquilo que assim percebemos" ${ }^{\sharp 6}$. De fato, ele até mesmo diz, com base em Aristóteles, que o conhecimento sensitivo basta, de maneira que não há necessidade de buscar um raciocínio - isto é, de um discurso intelectual - para conhecer algo que já conhecemos pelos sentidos; buscá-lo, de fato, seria uma fraqueza do intelecto. Tanto é assim, conclui ele naquela última asserção (que inicialmente nos parecia um pouco deslocada), que os sentidos das coisas estão associados à experiência da verdade dos dizeres (sermones) verdadeiros. Sem dúvida, essa parece uma conclusão bem otimista até lembrarmos de que, para o Doutor Solene, o que realmente importa é a teologia. De fato, o sentido não é senão um ponto de partida para conhecimentos muito mais amplos, necessários e importantes que, entretanto, se dão somente ao intelecto. Mais do que fraqueza do intelecto, acredito que buscar demonstrar o que percebemos pelos sentidos seria, para Henrique, perda de tempo, pois os sentidos não são mais do que um ponto de partida: "feita a apreensão pelos sentidos, cumpre desviar dos sentidos, tal que se faça um juízo pela razão" ${ }^{\text {"47 }}$.

Por isso mesmo, o passo seguinte em Suma, art. 1, q. 1, é mostrar que há um scire large accepto não somente nos sentidos (primeiro caso de ciência "por testemunho interior'), mas também no intelecto (segundo caso desta ciência):

\begin{abstract}
"portanto, no conhecimento intelectivo, como já foi dito sobre o conhecimento sensitivo, aquele intelecto que não é contradito na sua ação própria de inteligir por um inteligido mais verdadeiro ou tomado a um sentido mais verdadeiro percebe verdadeiramente a coisa tal como é, sem nenhum engano ou falácia. E não cumpre duvidar mais desse intelecto do que do sentido" ${ }^{48}$.
\end{abstract}

Nesse trecho fica patente a importância da hierarquização das potências cognoscitivas para Henrique de Gand. Se a ausência de contradição ainda é o elemento que garante a caracterização de uma intelecção como scire large accepto /

\footnotetext{
${ }^{46}$ Cf. nota 39 , acima.

${ }^{47}$ Henrique de Gand, Suma, art. 1, q. 1, ad 2 (ed. De Wulf-Mansion Centre, vol. 21, p. 20): "Apprehensione facta per sensus, avertendo a sensibus, ut iudicium fiat a ratione, quod summe monet fieri Augustinus <...”. Entretanto, como veremos na parte 2 deste trabalho, os sentidos são fundamentais para a formação de qualquer conhecimento intelectual.

${ }^{48}$ Henrique de Gand, Suma, art. 1, q. 1, co. (ed. De Wulf-Mansion Centre, vol. 21, p. 12): “Cognitione igitur intellectiva, sicut iam dictum est de cognitione sensitiva, intellectus ille vere rem percipit, sicuti est sine omni deceptione et fallacia, cui in actione propria intelligendi non contradicit intellectus verior vel acceptus a sensu veriori. Nec de tali intellectu plus dubitandum est quam de sensu". Perler estuda cuidadosamente essa passagem em Zweifel und Gewissheit, 2006, pp. 41sg.
} 
certa notitia, essa contradição não pode mais dizer respeito aos sentidos senão quanto à origem do conhecimento. Uma intelecção não poderia ser contradita por um sentido, pois este sempre será menos digno do que ela, como vimos. Por outro lado, uma intelecção pode ser contradita: [i] por um inteligido mais verdadeiro (intellectus verior) ou [ii] por um inteligido tomado a um sentido mais verdadeiro (acceptus a sensu veriori). Se nos permitirmos aqui também igualar verior e dignior (sem o que seríamos levados àquele recuo ao infinito), está claro que uma intelecção só pode ser contradita por outra mais digna ou por outra que possua uma origem sensível mais digna do que a origem sensível daquela primeira que é contradita por esta. Se nenhum desses casos ocorrer, pode-se concluir que o intelecto tem ciência, tem uma notícia certa, pois ele "percebe verdadeiramente a coisa tal como é, sem nenhum engano ou falácia [vere rem percipit, sicuti est sine omni deceptione et fallacia]". Mais uma vez, vemos a ausência de contradição como elemento único e determinante na experiência da verdade do conhecimento - agora, do conhecimento intelectual. É por não ser contradito que ele não é falacioso ou enganador e, portanto, percebe a coisa tal como é. Assim como ocorria com o sentido, não cumpre duvidar (dubitare) dessa intelecção. Lembremo-nos de que estamos, ainda, no campo daquilo que "experimentamos em nós e à nossa volta [experimur in nobis et circa nos]"49. Experimentamos que, quando não há a contradição descrita, temos ciência pelo intelecto e percebemos a coisa tal como é.

Enfim, temos aqui estabelecido - com muitas dificuldades de formulação, é verdade, mas aparentemente com uma confiança tocante - que há ciência tomada amplamente e notícia certa. De fato, ocorre de o homem ter ciência! Mas, e quanto aos que negaram a ciência? E quanto àquela série de argumentos - a bem dizer, de errores - contrários à possibilidade da ciência que Henrique de Gand enumerara ${ }^{50}$ ? A todos eles, o Doutor Solene dedica uma interessante resposta geral:

\footnotetext{
"Mas, contra a posição principal de todos eles, já que quem nega a ciência destrói toda a fé e toda a filosofia, como diz o Filósofo Metafísica IV, é impossível disputar demonstrando que há ciência e que de algo se possa ter ciência [scientiam esse et aliquid posse sciri], pois negam todos os princípios de se ter ciência, mas somente cumpre utilizar, em defesa da ciência contra eles, de dizeres verdadeiros e muito prováveis [sermonibus veris et valde probabilibus], que eles não possam negar. Portanto, a partir de tais dizeres, Túlio, no seu livro
}

\footnotetext{
${ }^{49}$ Cf. nota 36 , acima.

${ }^{50} \mathrm{Cf}$. nota 26 , acima.
} 
Sobre os Acadêmicos, os convence por três patentes [per tria aperta] inconvenientes que se seguem do dito deles. O primeiro daqueles <três> é tomado às ciências artificiais, o segundo aos atos de virtude, o terceiro às obras da convivência humana [ex operibus humanae conversationis]" ${ }^{151}$.

Há dois temas igualmente relevantes postos nessa passagem: primeiro, as consequências da negação da ciência e, em segundo lugar, a caracterização da resposta cabível a essa negação.

As consequências da negação de toda ciência não poderiam ser mais abrangentes e devastadoras: ela destrói toda fé e filosofia (destruit omnem fidem et totam philosophiam). Ora, nesse caso, de fato, a negação da possibilidade do conhecimento elimina não somente a filosofia, mas também a fé. Mas o que isso pode querer dizer? De início, a afirmação deixa claro algo que ainda não havia sido notado, a saber, que aquele scire large accepto / certa notitia, de alguma maneira, inclui filosofia e fé, tal que sua negação seja igualmente a negação destes dois. Vemos, portanto, que não somente a filosofia ou, mesmo, a teologia como ciência estão em jogo aqui, mas também a própria fé religiosa. Essa súbita aproximação (talvez inesperada) entre fé e filosofia é muito compreensível se notamos que em Quodl. 9, q. 13, a fé (fides) é descrita precisamente como um dos modos de conhecimento intelectual $^{52}$. Destarte, do ponto de vista da concepção de conhecimento intelectual esposada por Henrique, negar a possibilidade de conhecimento inclui não somente negar a filosofia, mas igualmente negar a fé.

Se isso torna a discussão um tanto mais urgente, ao mesmo tempo essa abrangência da concepção de scientia que se pretende resguardar leva a um impasse: embora se pretenda defender que há filosofia, teologia e fé religiosa, não é possível

\footnotetext{
${ }^{51}$ Henrique de Gand, Suma, art. 1, q. 1, co. (ed. De Wulf-Mansion Centre, vol. 21, p. 18): "Sed contra positionem omnium principalem, quia negans scientiam destruit omnem fidem et totam philosophiam, ut dicit Philosophus IV ${ }^{\circ}$ Metaphysicae, impossibile est disputare demonstrando scientiam esse et aliquid posse sciri, quia negant omnia sciendi principia, sed tantum utendum est in defensione scientiae contra ipsos sermonibus veris et valde probabilibus quod non possunt negare. Ex talibus igitur sermonibus per tria aperta inconvenientia sequentia ex dicto ipsorum convincit eos Tullius in libro suo De Academicis, quorum primum sumitur ex scientiis artificialibus, secundum ex actibus virtutum, tertium ex operibus humanae conversationis".

${ }^{52}$ Henrique de Gand, Quodl. 9, q. 13, co. (ed. De Wulf-Mansion, vol. 13, pp. 243-4): “ $<\ldots>$ ex parte tamen intellectus invenitur triplex modus cognoscendi, scilicet credendo per fidem, intelligendo per sapientiam, nomine sapientiae comprehendendo omnes habitus cognitivos, et videndo per deitatis claram praesentiam". Sobre esta passagem, cf. EMERY Jr., K. "The Image of God Deep in the Mind: The Continuity of Cogntion according to Henry of Ghent". In: AERTSEN, J. A., EMERY Jr., K., SPEER, A. (Hrsg.). Nach der Verurteilung von 1277. Philosophie und Theologie an der Unversität von Paris in letzten Viertel des 13. Jahrhunderts. Studien und Texte. Berlin - New York: De Gruyter, 2001, pp. 59-124 (esp. pp. 72-4).
} 
demonstrar nenhum dos três. Ou seja, ao negar a filosofia e a fé, aquele que nega a ciência, de fato, não pode ser demonstrativamente respondido, pois não há princípios (evidentes por si ou de fé) que ele vá aceitar como premissas de uma demonstração de que há ciência ${ }^{53}$. Isso nos leva ao segundo tema tratado no trecho, nomeadamente, a determinação do tipo de resposta possível para o cético.

O que resta é defender a ciência contra os que a negam. Isso deve ser feito, nos diz Henrique, pela utilização de 'dizeres verdadeiros e bem prováveis que não possam negar' (utendum est in defensione scientiae contra ipsos sermonibus veris et valde probabilibus quos non possunt negare). Ora, como vimos, "experimentamos em nós e à nossa volta [experimur in nobis et circa nos] "54 que há sensação e intelecção verdadeiras. Porém, não podemos demonstrá-lo aos que as negam - antes temos que utilizar 'dizeres verdadeiros e muito prováveis' que exigem a ciência e, simultaneamente, não possam ser negados por aqueles que negam essa ciência. Certamente, com esses 'dizeres verdadeiros e muito prováveis' não podemos demonstrar que há ciência. Porém, podemos convencer (convincere) aqueles que a negam de que é inconveniente negar a ciência. Assim, em lugar de uma demonstração científica, o que Henrique de Gand oferece como resposta definitiva aos que negam a ciência são argumentos convincentes ${ }^{55}$, isto é, que visam o convencimento de que

\footnotetext{
${ }^{53}$ Em Suma, art. 22, q. 4, co. (ed. Decorte \& Teske, p. 132), o Doutor Solene afirma ser preciso distinguir "sobre o demonstrável, que algo é demonstrável simplesmente pela natureza da coisa e algo é $<$ demonstrável $>$ para nós a partir da disposição de nosso intelecto [Distinguendum tamen est de demonstrabili, quod aliquid est demonstrabile simpliciter ex natura rei, et aliquid nobis ex dispositione nostri intellectus]". Nas linhas seguintes (ed. Decorte \& Teske, pp. 132-4), ele adiciona que o ser de Deus não é demonstrável ex natura rei, porque não há um termo médio entre a essência divina e o ser divino, já que ambos são o mesmo. Por outro lado, o ser de Deus é demonstrável para nós, na medida em que tal demonstração ocorre, em nosso intelecto, como a passagem do conhecimento de algo mais conhecido para algo menos conhecido, sendo este último a enunciação (enunciatio) 'Deus é'. Ao que parece, no caso da possibilidade do scire large accepto ocorreria justamente o oposto: ela é demonstrável ex natura rei (pois em nenhuma criatura ser e essência se identificam, como veremos no cap. 2, nota 95), mas ela não é demonstrável para nós (nobis), uma vez que aquele para o qual não há scire large accepto (que inclui conhecimento sensitivo, intelectual e, como parte deste último, filosofia e fé) não terá nada mais conhecido do qual partir para concluir o menos conhecido, a saber, a possibilidade dessa ciência tomada amplamente, uma vez que ele não aceitará nem mesmo os primeiros princípios da filosofia.

${ }^{54} \mathrm{Cf}$., mais uma vez, a nota 36.

${ }^{55}$ É difícil precisar, neste trecho, o que Henrique de Gand entende que seja convincere. A meu ver, tal verbo parece ser especializado aqui como uma contraposição a demonstrare, pois, justamente por não podermos demonstrar a ciência, nos resta convencer aqueles que a negam de que há um tal conhecimento certo. Mas, como classificar esses 'argumentos convincentes' utilizados por Henrique de Gand?

Uma primeira alternativa seria classificá-los como argumentos retóricos. Essa proposta, no entanto, esbarra na quase ausência de referências à retórica na obra do Doutor Solene. Há uma passagem, em Suma, art. 5, q. 5 (ed. De Wulf-Mansion Centre, vol. 21, p. 348), em que a retórica aparece claramente contraposta à demonstração, porém esse trecho surge como citação de uma autoridade de Aristóteles:
} 
"Primo igitur studendum ad investigandum scientiam circa unamquamque rem secundum naturam subiecti et materiae, secundum quod dicitur in $\mathrm{I}^{\mathrm{o}}$ Ethicorum: 'In unoquoque dicetur sufficienter, si secundum subiectam materiam manifestetur $\langle\ldots\rangle$. Proximum enim et simile inconveniens videtur mathematicum persuadendo scientiam suam investigare et rhetorem demonstrando"'. Nessa autoridade, temos de um lado a demonstração matemática e de outro a persuasão retórica. A mesma referência à persuasio da retórica surge mais adiante na Suma, dessa vez a partir de uma remissão a Agostinho, quando Henrique de Gand se questiona acerca do uso (usus) das outras ciências para a teologia - Suma, art. 7, q. 12, co., n. 7 (ed. 1642-6, p. 153): “Cum enim ad perfectum modum tractandi Sacram Scripturam duo sint necessaria, scilicet modus inveniendi, quae intelligenda sunt, et modus proferendi, quae sunt intellecta, ut dicit August. I. De doctrina Christiana quantum ad modum proferendi duo sunt necessaria, orationis congruentia, et orationis decentia. Quantum ad primum utilis est grammatica $<\ldots>$. Quantum ad secundum utilis est Rhetorica, ut ex ea modos persuasionum Sacra Scriptura accipiat, secundum quod dicit Augustin. 4. De doctrina Christiana: 'cum posita sit in medio facultas eloquii, quae ad persuadenda seu prava, seu recta valet plurimum, cur non bonorum studio comparatur, ut militet veritati, cum mali ad obtinendas pravas, vanasque causas in usus iniquitatis, et erroris usurpent?"'. O interessante nesta última passagem é que a persuasio retórica é justamente associada ao discurso sobre a Sagrada Escritura e, portanto, ao discurso sobre a revelação e os princípios da fé. Ora, o convincere a que Henrique de Gand se referia em Suma, art. 1, q. 1, dizia respeito precisamente aos princípios da filosofia $e$ da fé. Nesse sentido, seria possível aproximar a persuasio que lemos em Suma, arts. 5 e 7 do convincere que lemos em Suma, art. 1, de maneira a afirmar que neste último texto o Doutor Solene responderia aos céticos por um convencimento retórico. Mesmo assim, parece que poucas são as bases textuais para tal interpretação.

Por outro lado, Henrique afirma que esse convencimento não ocorre por demonstração, mas por "dizeres verdadeiros e muito prováveis [sermonibus veris et valde probabilibus]". Pois bem, se frisarmos a referência aos sermones valde probabiles, parece que somos remetidos à noção de disputatio dialectica que lemos no Tractatus VII de Pedro de Espanha: "Dialectica disputatio est que ex probabilibus est collectiva contradictionum. Et huius instrumentum est dialecticus sillogismus. Dialecticus autem sillogismus est qui ex probabilibus est sillogizatus $<\ldots>$. Dialecticus accipit probabile simpliciter. Probabile autem simplicitere est quod videtur omnibus vel pluribus vel sapientibus, et hiis vel pluribus vel omnibus vel maxime notis" (ed. De Rijk, pp. 90-1, nn. 6-8). Como o próprio Pedro de Espanha indica no trecho completo, toda essa descrição da disputa dialética é pautada no princípio dos Tópicos de Aristóteles, onde, nas palavras de Oswaldo Porchat Pereira, "Aristóteles descreve-nos a dialética como uma propedêutica às ciências 'filosóficas' em geral, isto é, às que o são no sentido rigoroso da definição proposta nos Analíticos; como um método que conduz, mediante um raciocínio diaporemático, à apreensão dos princípios científicos. E o filósofo invoca explicitamente a anterioridade absoluta dos princípios $<\ldots>$ para argumentar em favor da necessidade de discorrer sobre eles a partir de éndoxa, isto é, de proposições aceitas pela opinião, que a dialética converte em premissas de seus raciocínios" - grifos do original (Ciência e dialética em Aristóteles. São Paulo: UNESP, 2001, p. 357 - para uma discussão sobre a interpretação avançada por Porchat acerca do papel da dialética no pensamento de Aristóteles, cf. AAVV. Analytica 8.1: "Sobre Ciência e dialética em Aristóteles" (2004), 238p.). Ora, se a dialética for entendida como meio de estabelecer primeiros princípios a partir do probabile, então Henrique de Gand parece estar se referindo a um convencimento por argumentos dialéticos em Suma, art. 1, q. 1. A grande dificuldade com essa interpretação é a aparente ausência de qualquer referência a uma noção de 'dialética' utilizada nesse sentido em Henrique de Gand. Algo próximo a essa noção pode ser encontrado em Suma, art. 22, q. 4, onde se distinguem inteligir demonstrative e analectice (ed. Decorte \& Teske, p. 134). Mais adiante, esta última expressão é retomada na frase "arguitur rationibus analectis et probabilibus", embora Henrique adicione logo em seguida que estas "habent reduci ad rationes superiores $<s c$. já apresentadas no texto da questão $>$ demonstrativas, sicut omne probabile ad necessarium" (ed. Decorte \& Teske, p. 142). Ou seja, aqui, analectice não parece se opor estritamente à demonstrative (como era o caso de convincere em Suma, art. 1), pois os raciocínios analectice podem ser reduzidos a racioncínios demonstrativos. Além disso, não parece que o Doutor Solene necessite de um modo especial (por exemplo, dialético) de obtenção dos princípios a partir de proposições probabiles, uma vez que os primeiros princípios da filosofia são, para ele, evidentes por si - Suma, art. 1, q. 4, co. (ed. De WulfMansion Centre, vol. 21, p. 114): "Sicut enim patent intellectui statim, scilicet sine omni discursu, prima principia ex prima notitia terminorum, ita patere possunt ex proximis principiis proximas conclusiones <... "; e a crença nos princípios da fé (que também terminam por ser aqueles da teologia) provém da graça - Suma, art. 1, q. 7, co. (ed. De Wulf-Mansion Centre, vol. 21, p. 147): "In tertio vero modo docendi $<s c$. sicut lumen aliquod supernaturalis gratiae infusum illuminans ad cognoscendum - 
negar a ciência leva a claros inconvenientes. Estes últimos são coligidos a partir dos diálogos Acadêmicos de Cícero que, segundo Henrique, busca aí justamente convencer os que negam a ciência "por três patentes inconvenientes [inconvenientia] que se seguem do dito deles". Esses três inconvenientes a que ele se refere não são mais do que a afirmação de que, ao negar a ciência, negam-se igualmente as ciências artificiais (scientiae artificiales), as ações virtuosas (actiones virtutum) e, em geral, todas as práticas típicas da convivência humana (opera humanae conversationis) ${ }^{56}$. Negar a ciência impossibilita todos os três. De fato, em poucas palavras, negar a ciência não somente destrói a filosofia e a fé, como impossibilita qualquer moral e política. O problema é que o único argumento contra os que negam a ciência é, justamente, o fato de tal negação levar a essa impossibilidade. Para Henrique, entretanto, isso basta - onde a demonstração não é possível, o convencimento é suficiente ${ }^{57}$.

cf. p. $145>$ docet Deus hominem ea quae sunt supernaturaliter cognoscenda, ut ea quae sunt fidei et revelationis $\langle\ldots$..". Ou seja, em nenhum caso é necessária uma dialética que estabeleça, a partir de opiniões probabiles, os princípios do scire large accepto. Além disso, em nosso trecho de Suma, art. 1, q. 1, Henrique se refere não somente aos sermones valde probabiles, mas também a sermones veri, o que justamente deveria ser excluído do campo de uma disputa dialética, tal como descrita em Pedro de Espanha. Notemos, ademais, que Henrique não parece aceitar que haja um campo de proposições estritamente probabiles, pois ele afirma explicitamente no trecho de Suma, art. 22, q. 4, destacado nesta nota, que todo probabile deve ser reduzido a um necessarium (sobre a relação entre os vocábulos logica e dialectica na filosofia medieval, cf. MICHAUD-QUANTIN, P. "L'emploi des termes logica et dialectica au moyen âge". In: MICHAUD-QUANTIN, P. Études sur le vocabulaire philosophique du moyen âge. Avec la collaboration de M. Lemoine. Roma: Ateneo, 1970, pp. 59-72).

Por fim, outra alternativa seria considerar que Henrique de Gand propõe aqui demonstrações $a$ posteriori (pelos efeitos) da possibilidade da ciência (os efeitos desta seriam indicados por aqueles "tria aperta inconvenientia" a que ele se refere no excerto de Suma, art. 1, q. 1), em oposição a demonstrações a priori (pelas causas). O problema é que, na oposição entre a priori e a posteriori, estamos sempre no campo das demonstrações - de um "demonstrative $<\ldots>$ probare", como diz Henrique em Suma, art. 25, q. 2, co. (ed. Teske, p. 48), cf. tb. Suma, art. 25, q. 3, co. (ed. Teske, p. 80). Ora, em nosso trecho de Suma, art. 1, q. 1, convincere precisamente se opõe a demonstrare.

Enfim, parece-me que a referência a uma utilização de 'sermonibus veris et valde probabilibus' para convincere os que negam a ciência não se reflete em uma concepção de argumentação nãodemonstrativa bem desenvolvida na obra de Henrique de Gand. Por isso mesmo, na compreensão dessa passagem, deve nos bastar a ênfase na distinção e oposição entre demonstrare e convincere. Destarte, no que se segue, utilizo o termo 'convencer' e seus derivados no sentido técnico de 'convencer de maneira não-demonstrativa', embora o próprio verbo convincere permaneça sem uma definição apropriada.

${ }^{56}$ Henrique de Gand, Suma, art. 1, q. 1, co. (ed. De Wulf-Mansion Centre, vol. 21, pp. 18-19).

${ }^{57}$ Para Pasnau, a resposta de Henrique de Gand às objeções céticas é claramente insuficiente. É o que lemos no seguintes trechos de PASNAU, R. Theories of Cognition in the Later Middle Ages. Cambridge: Cambridge University Press, 1997: "In this same question <sc. Suma, art. 1, q. 1>, he defines 'knowing' (scire) in a broad sense as 'every certain apprehension by which a thing is cognized as it is, without any mistake or deception' $<$ cf. nota 29 , acima $>$. And he maintains that apprehensions that meet the above criterion $(7.3)<\mathrm{cf}$. o trecho citado na nota 39 , acima $>$ are certain. Notice that, as he defines knowledge, it may be that we have knowledge even though we can't show that we have it. It is unclear whether Henry has in mind an objective or a subjective sense of certainty - whether the apprehension must actually be certain or merely feel certain. Regardless of this, his criterion for 
Em resumo, ocorre de o homem ter ciência - isso não é demonstrável, mas é convincentemente defensável e, mais importante, nós o experimentamos em nós e à nossa volta. Essa ciência possível para o homem é sensível e intelectual ou, melhor dizendo, ela é sensível na sua origem, mas intelectual no seu ápice de dignidade. Mas o que significa dizer que é possível para o homem ter ciência? E donde provém essa possibilidade? Certamente, que haja ciência não pode ser demonstrado, mas podemos explicar a origem de sua possibilidade. Para tanto, precisamos compreender o que seriam, para o Doutor Solene, o homem e a natureza humana. Com isso, veremos que há possibilidade de ter ciência para o homem porque este último possui, por sua natureza, uma passividade ou potência passiva de ter ciência (scire large accepto) ${ }^{58}$.

knowledge doesn't require that we show our beliefs to be true, justified, or certain. (In this sense, his account of knowledge can be classified as externalist.) But although we may have knowledge, this mere possibility wouldn't satisfy the skeptic, who wants to be shown that we have knowledge" (p. 227 - grifos no original); "What if we're wrong about the world all the time not just occasionally? What if our impressions aren't leading us to any true beliefs about the world? That was the challenge of the general skeptic argument (7.1) <sc. Suma, art. 1, q. 1, arg. 7 (ed. De Wulf-Mansion Centre, vol. 21, p. 8, 11. 50-5)>, a challenge that, as I've argued, Henry fails to meet. Working within the framework of the species theory, he goes some of the way to developing a coherent reply to the skeptic" (p. 229). Minha resposta à posição de Pasnau é que Henrique de Gand justamente não está buscando um critério do conhecimento verdadeiro em Suma, art. 1, q. 1. Com efeito, a descrição de scientia compreendida por Pasnau como critério que responde ao cético é apresentada por Henrique de Gand, antes, como mera descrição de uma noção - scientia - a ser utilizada no decorrer da questão. A resposta à negação do conhecimento se encontra unicamente ao fim do corpo de Suma, art. 1, q. 1, no texto que citamos acima, na nota 51. Destarte, a resposta do Doutor Solene ao cético não é a afirmação de um critério de reconhecimento da scientia verdadeira, mas antes a constatação (meramente convincente) de que a negação do conhecimento leva àqueles três patentes inconvenientes: a negação da arte, da ação virtuosa e das obras da convivência humana. Certamente, é possível discutir se tal resposta seria suficiente, mas, como veremos nas próximas etapas, a força dessa resposta está no fato de que negar a ciência redunda, para Henrique de Gand, na própria negação do homem enquanto animal racional e de toda a ordem do universo. Enfim, se a discussão sobre a suficiência da resposta de Henrique aos que negam o conhecimento é legítima, parece-me que Pasnau a coloca de maneira equivocada ao buscar como base da resposta do gandavense um elemento - o critério de conhecimento - que ali não surge.

${ }^{58}$ De fato, o vocabulário com que Henrique de Gand trabalha aqui é muito cuidadoso, pois ele se utiliza sempre do latim 'possibilitas' e não de 'potestas', uma vez que este é reservado para referências ao caráter ativo de 'potência', enquanto que aquele traz consigo algo de passivo - Suma, art. 35, q. 4, co. (ed. De Wulf-Mansion Centre, vol. 28, p. 34): “<..> potestas enim puram recipit actionem, possibilitas vero aliqualem passionem. Unde hoc nomen 'potentia' primo fuit impositum ad significandum potestatem hominum, secundum quod in hominibus dicebantur potentes, qui potestatem super alios habebant faciendi quod voluerunt; et hinc translatum fuit ad principium activum in rebus naturalibus, et postmodum ad principium passivum". Essa passagem deixa muito claro o caráter ambíguo - ou, mais propriamente, equívoco - da 'potência', o qual será de grande importância para nós mais adiante. Por ora, interessa destacar que a potência que está em jogo na possibilitas sciendi é uma potência passiva (a última, portanto, na ordem de imposição do termo descrita por Henrique). Destarte, na linguagem filosófica do Doutor Solene, é claramente possível concluir da afirmação de uma 'possibilidade de se ter ciência para o homem' a 'potência do homem para ter ciência'. Por outro lado, não é lícito concluir daquela possibilitas uma potestas e, de fato, qualquer atividade ou ação com respeito ao conhecimento. Sendo assim, ainda que mais adiante venhamos a estar em posição de afirmar a necessidade de certas atividades do homem com respeito à geração do conhecimento, neste ponto sabemos somente que ele é uma potência passiva com respeito ao scire large accepto.

Como complemento a essa observação, vale a pena considerar os diversos significados do termo 
Somente após esse discurso sobre o homem, poderemos voltar à Suma, art. 1, q. 1, e finalizar nossa leitura dessa primeira questão da obra.

potentia distinguidos por Henrique de Gand em Suma, art. 28, q. 6, co. (ed. Teske, 2006, pp. 222-4). Aí, a [1] potentia é dividida primeiramente em [1.1] potentia activa e [1.2] potentia passiva. A [1.1] potência ativa se distingue [1.1.1] em um princípio de operação próprio (principium operationis rei in se ipsa), "tal como àquele que tem ciência e o quer é possível considerar, salvo se algo o proibir extrinsecamente [secundum quod sciens et volens possibilis est considerare, nisi aliquid prohibeat extrinsecus]", e [1.1.2] em um princípio de transmutação em outro (principium transmutationis in aliud). Porém, mais importante para nós nesse ponto é a [1.2] potência passiva, que Henrique explica como uma potentia ad possibilitatem recipiendi. Esta também se divide em dois: uma [1.2.1] potência para a corrupção pelo contrário (ad corruptionem a contrario) e [1.2.2] uma potência para a perfeição da coisa (ad rei perfectionem). Esta última é explicada pelo Doutor Solene como uma potência pela qual algo pode se tornar melhor (habet aliquid transmutari in melius). Ela, por sua vez, se distingue ainda em outros dois: [1.2.2.1] uma potência para receber junto a si outro que o aperfeiçoe ( $a d$ recipiendum secum aliud quo perficiatur) e [1.2.2.2] uma potência para se transmutar em seu ser perfeito e completo (ut transmutetur in esse perfectum et completum). Por fim, a primeira destas duas últimas - a saber, a [1.2.2.1] potência para receber em si outro que o aperfeiçoe (mas que não se confunde com a obtenção da perfeição e completude de sua natureza) - se divide em dois últimos: [1.2.2.1.1] uma potência passiva para aqueles que são formas e coisas de natureza (ad ea quae sunt formae et res naturae), tal como a matéria está em potência para a forma, e [1.2.2.1.2] uma "potência passiva possível para a recepção daquilo que é para a salvação segundo hábito e natureza, sem corrupção [alia vero est potentia passiva possibilis ad receptionem eius quod est ad salutem secundum habitum et naturam sine corruptione]". Essa útima divisão é, segundo Henrique, aquela que comporta a potência do sentido e a potência do intelecto (potentia sensus et intellectus). Em Suma, art. 50, q. 1, co. (ed. De Wulf-Mansion Centre, vol. 30, p. 177), o caso [1.2.2.1.2] é dito 'passio' large accepto, enquanto que o caso [1.2.1] é dito 'passio' stricte. Voltando a Suma, art. 28, q. 6, embora o termo possibilis seja utilizado em um caso da potência ativa [1.1.1], a noção de possibilitas é aí explicitamente reservada nesse trecho para a explicação da potentia passiva, no que Suma, art. 28, q. 6, se aproxima bastante do trecho de Suma, art. 35, q. 4, que vimos no início da nota. Além disso, notemos como essa pequena passagem de Suma, art. 28, permite vislumbrar o quão complexa é a concepção do conhecimento como possibilidade ou potência proposta por Henrique de Gand. Em poucas palavras - mesmo porque o próximo capítulo será inteiramente dedicado a esse tema -, a potência para o conhecimento (sensitivo ou intelectivo, isto é, a potência para o scire large accepto) é uma potência passiva que se explica como a possibilidade de receber algo outro que não si próprio, que seja perfectivo do subiectum dessa potência no que diz respeito à sua salus. Elementos dessa descrição ressurgirão constantemente no que vem a seguir (em especial, retomaremos o curioso uso da noção de salus nesse contexto, adiante, no item 4.5). 


\title{
CAP. 2.
}

O HOMEM COMO ANIMAL RACIONAL

\subsection{O HORIZONTE DO MUNDO}

\author{
Como foi dito há pouco, o pensamento de Henrique de Gand é fortemente
} marcado por uma concepção hierárquica de mundo ${ }^{1}$ - isto é, pela tese de que os entes

\footnotetext{
${ }^{1}$ A partir desse ponto, a referência a esse caráter hierárquico fundamental do pensamento de Henrique de Gand será constante em nosso texto. Esse pensamento hierárquico, certamente, não é exclusivo do Doutor Solene. Pelo contrário, pode-se dizer que um dos elementos mais característicos do pensamento medieval e, em particular, da escolástica tardo-medieval, é essa noção de hierarquia e todas as tensões que ela traz consigo - inclusive, a necessidade de, por vezes, afirmar a possibilidade de um ultrapassamento da hierarquia do mundo pelo homem. Quaisquer que sejam as tensões inerentes a esse pensamento hierárquico escolástico que emerge nos trabalhos de Henrique de Gand, a concepção do mundo como um todo hierarquicamente ordenado jamais deixa de ter um papel central em seu pensamento, como veremos no decorrer deste capítulo. Mais importante para nós, a caracterização do homem na obra do Doutor Solene só pode ser compreendida do ponto de vista da localização do homem na ordem do mundo - e arrisco dizer (embora não seja este o local de desenvolver esta afirmação) que Henrique foi um dos autores do século XIII que mais cuidadosamente elaborou uma noção de homem no contexto dessa concepção hierárquica de mundo. $\mathrm{O}$ trabalho clássico sobre a hierarquia e a ordenação do mundo na história da filosofia - centrado, a bem dizer, no chamado 'princípio da plenitude' e suas consequências filosóficas -, ainda é LOVEJOY, A. O. The Great Chain of Being. A Study of the History of an Idea. Cambridge: Harvard University Press, 1936, p. 67: "From Neoplatonism the principle of plenitude, with the group of ideas presupposed by it or derivative from it, passed over into that complex of preconceptions which shaped the theology and the cosmology of medieval Christendom. Two men more than any others determined the formula for this new compound of old ingredients - Augustine and the unknown fifth-century author of that strange collection of misattributed writings or pious forgeries which passed for the work of Dionysius, the Athenian disciple of St. Paul". Mais recentemente, em seu primeiro curso no Collège de France, Alain de Libera chamou a atenção [i] para a forte tensão proporcionada pelas noções de ordenação e hierarquia em fins do século XIII e inícios do XIV e [ii] para a importância desse tema na compreesão da noção escolástica de homem e, mais precisamente, de sujeito (cf. LIBERA, A. de. L'invention du sujet moderne. Cours au Collège de France 2013-2014. Paris: Vrin, 2015; as aulas do curso podem ser acessadas no site: college-de-france.fr): "Quelle figure de la subjectivité a-t-on ici? N'est-ce pas déjà 'la question du sujet' agitée au $\mathrm{XVI}^{\mathrm{e}}$ siècle? Toute question est un essaim de questions. S'agissant du 'sujet', le théologique et le politique sont liés. Ils sont liés dans la question de l'intermédiaire; ils sont dans la question de l'ordre, mais pas n'importe quel ordre: l'ordre hiérarchique et son mode d'organisation" (LIBERA, L'invention du sujet moderne, 2015, p. 24 - grifos no orig.). Ainda sobre a noção de hieraquia na obra de Henrique de Gand (e a dívida deste para com o corpus Dionysiacum), cf. os três artigos de Edward Mahoney: "Metaphysical Foundations of the Hierarchy of Being According to Some Late-Medieval and Renaissance Philosophers". In: MOREWEDGE, P. (ed.). Philosophies of Existence. Ancient and Medieval. New York: Fordham University Press, 1982, pp. 165-257; "Duns Scotus and Medieval Discussions of Metaphysical Hierarchy: the Background of Scotus's 'essential order' in Henry of Ghent, Godfrey of Fontaines and James of Viterbo". In: SILEO, L. (ed.). Via Scoti. Methodologica ad mentem Joannis Duns Scoti. Atti del Congresso Scotistico Internazionale. Roma 911 marzo 1993. Vol. I. Roma: PAA - Antonianum, 1995, pp. 359-74; e "Pseudo-Dionysius's Conception of Metaphysical Hierarchy and its Influence on Medieval Philosophy”. In: BOIADJIEV, T., KAPRIEV, G., SPEER, A. (Hrsg.). Die Dionysius-Rezeption im Mittelalter. Internationales Kolloquium in Sofia vom 8. bis 11. April 1999 unter der Schirmherrschaft der Société Internationale pour l'Étude de la Philosophie Médiévale. Turnhout: Brepols, 2000, pp. 429-475. Sobre a importância
} 
do universo são essencialmente dispostos em uma ordenação que pode ser acompanhada do superior até o inferior ou o contrário. Esse pressuposto emerge por diversas vezes em sua obra, inclusive na caracterização que ele nos fornece daquilo que seria o homem ${ }^{2}\left(h_{o m o}{ }^{3}\right)$. De fato, quando nos voltarmos para Suma, art. 27,

da noção de ordo para a filosofia medieval, cf. MICHAUD-QUANTIN, P "Ordo et ordines". In: MICHAUD-QUANTIN, P. Études sur le vocabulaire philosophique du moyen âge. Avec la collaboration de M. Lemoine. Roma: Ateneo, 1970, pp. 85-101. Por fim, vale notar que a temática da ordenação hierárquica do mundo em Henrique de Gand ainda deveria ser complementada por uma consideração acerca das ideias divinas, que são o fundamento de tal ordem- sobre as ideias, cf. cap. 6, nota 25.

${ }^{2}$ Já tendo uma grande parte desse texto pronta, ao reler esse início do cap. 2, me veio à mente o famoso trecho, ainda no começo de sua Logik, em que Immanuel Kant enumera os principais problemas com que lida a filosofia: "O domínio da filosofia neste sentido cosmopolita deixa-se reduzir às seguintes questões: 1) $O$ que posso saber? 2) $O$ que devo fazer? 3) $O$ que me é lícito esperar? 4) $O$ que é $O$ homem? À primeira questão responde a Metafisica; à segunda, a Moral; à terceira, a Religião; e à quarta, a Antropologia. Mas, ao fundo, poderíamos atribuir todas essas à Antropologia, porque as três primeiras questões remetem à última [Das Feld der Philosophie in dieser weltbürgerlichen Bedeutung lässt sich auf folgenden Fragen bringen: 1) Was kann ich wissen? 2) Was soll ich thun? 3) Was darf ich hoffen? 4) Was ist der Mensch? Die erste Frage beantwortet die Metaphysik, die zweite die Moral, die dritte die Religion und die vierte die Anthropologie. Im Grunde könnte man aber alles dieses zur Anthropologie rechnen, weil sich die drei ersten Fragen auf die letzten beziehen]" (Lógica. Trad. Guido Antônio de Almeida. Rio de Janeiro: Tempo Brasileiro, 1992, p. 42 [Logik. AkademieTextausgabe, Bd. 9. Berlin - Leipzig: De Gruyter, 1923, p. 25]). Tendo essa passagem em vista, não consigo deixar de pensar que esse segundo capítulo de meu texto - de fato, todo presente trabalho, uma vez que aqui nessas primeiras páginas estou dando as bases daquilo que acredito ser a noção de conhecimento de Henrique de Gand - assume um caráter claramente pós-crítico. De fato, após vermos que o Doutor Solene afirma a possibilidade de ciência, meu primeiro passo foi ler nessa sua posição uma afirmação do homem enquanto potência para a ciência - em outras palavras, com certa (quiçá, indevida) facilidade, passei da questão 'was kann ich wissen?' (mais propriamente, 'kann ich wissen?') para a questão 'was ist der Mensch?' em minha leitura de Henrique. Ora, para o Michel Foucault de Les mots et les choses (Paris: Gallimard, 1966, pp. 351-2), o estabelecimento em Kant (por exemplo, na Logik) da posição privilegiada da antropologia com respeito a outros campos de saber filosófico é uma das marcas do pensamento moderno que ainda perduram na atualidade (cf. tb. HABERMAS, J. Der philosophische Diskurs der Moderne. Zwölf Vorlesungen. Frankfurt am Main: Suhrkamp, 1988, p. 285). Ou seja, talvez toda essa leitura que proponho da obra do Doutor Solene seja irremediavelmente contemporânea. Com essa observação, desejo somente chamar a atenção para como a questão da possibilidade de uma história da filosofia (de fato, da própria possibilidade de uma história isenta) emerge inesperadamente em certos pontos de nossa pesquisa. Sobre isso, não consigo dexar de mencionar as linhas conclusivas do magistral estudo sobre Jules Michelet da lavra de Jacques Le Goff: "Comme Flaubert disant: 'Madame Bovary, c'est moi', Michelet aurait pu dire: 'L'Histoire de France, c'est moi'. Dans cette histoire, en définitive, à travers la haine et l'amour, ce qui fut le plus lui-même ce fut le Moyen Age, ce Moyen Age avec lequel toute sa vie il a cohabité, lutté, vécu. Cette autobiographie est devenu notre biographie collective. Ce Moyen Age, c'était lui et c'est nous" ("Les Moyen Age de Michelet". In: LE GOFF, J. Pour un autre Moyen Âge. Paris: Gallimard 1977, p. 45). Se toda história termina sendo uma história do nosso próprio tempo - e, de fato, uma autobiografia -, como estudar filosofia hoje sem se perguntar sobre o homem? Como, depois de Kant, ler os autores medievais sem ler neles algum tipo de antropologia? Como perguntar atualmente para Henrique de Gand 'was kann ich wissen?' sem lhe perguntar 'was ist der Mensch?'? Com isso, parece-me, não fazemos do Doutor Solene aquilo que ele não é, mas buscamos nele aquilo que explica a origem de nosso próprio tempo. Alguém como Alain de Libera diria: fazemos a 'arqueologia' de nosso tempo (cf. Où va la philosophie médiévale? Leçon inaugurale prononcée au Collège de France. Paris: $\mathrm{http} / / /$ books.openedition.org/cdf/3634\#ftn2, 2014). Por outro lado, é legítimo ler um autor medieval a partir de questões do nosso próprio tempo? E, caso não seja, há um alternativa? Lembremos que o próprio Libera pontifica: "Où va la philosophie médiévale ? Elle va là où est la philosophie. Elle est là où va la philosophie" (Où va la philosophie médiévale?, 2014, n. 38 - grifos no orig.). Enfim, e nisso 
me repito, pretendo com essas questões unicamente chamar a atenção para alguns dos problemas teóricos que emergem a cada passo de nossa tentativa de interpretação de um autor escolástico tardomedieval como Henrique de Gand.

${ }^{3}$ Cabe aqui alguma reflexão sobre o próprio vocábulo 'homem', com o qual traduzimos aqui o latim 'homo' utilizado por Henrique. O que primeiro importa notar quanto ao termo latino é que, no seu uso pelo Doutor Solene, ele não é contraposto a 'mulier' ou 'foemina'. Antes, 'homo' é um termo que remete à espécie 'animal racional', na qual há o 'vir / mas' e a 'mulier / foemina'. Isso, porém, parece difícil de se explicar, pois sendo 'homo' uma espécie especialíssima, não deveria se dividir senão em indivíduos, uma vez que 'vir / mas' e 'mulier / foemina' não podem ser espécies sob 'homo'. Como, então, estariam estes dois com respeito àquele? Uma passagem do início da Suma de Henrique talvez nos ajude a compreendê-lo. Nesse ponto, no artigo 11 da Suma, busca-se entender quem pode ensinar a teologia - isto é, quem pode ser um doctor theologiae. Na questão 1 desse artigo, pergunta-se se somente Deus poderia ensinar tal ciência, enquanto que na segunda questão pesquisa-se se a mulher poderia ensinar a teologia. Mas, por que essa ordem de questionamentos? Por que passar do caso de Deus para o caso da mulher? Em poucas palavras, porque a primeira questão coloca o problema da possibilidade absoluta de se ensinar teologia, enquanto que a segunda problematiza a potência de direito. Ou seja, a primeira lida com o problema de saber se o 'homo', enquanto espécie, pode ensinar teologia, ao passo que a segunda trata do direito ('ius') de ensinar teologia possuído por alguns indivíduos (pessoas) da espécie 'homo', de acordo com seus respectivos estados ('status'): "Dicendum ad hoc, quod ista quaestio, et sequentes differunt a praecedenti. Illa enim quaesivit de potentia absoluta facti, cuius est posse docere, an solius Dei, an quodam modo hominis, et angeli. Istae vero quaestiones quaerunt de potentia iuris et auctoritatis, an scilicet status quarundam personarum permittat, quod officium doctoris habeant. Respondens igitur ad istas quaestiones quantum ad potentiam docendi non de facto, sed de iuris permissione. Planum est enim, quod de facto quilibet homo sciens, sive vir, sive mulier, sive senex, sive iuvenis, sive religiosus, sive secularis, sive clericus, sive laicus potest docere quae novit" - Suma, art. 11, q. 2, n. 5 (ed. 1642-6, p. 193a-b). Ora, se a questão "utrum mulier possit esse doctor seu doctrix huius scientiae" se encontra nesse segundo caso, isso significa que Henrique de Gand parece ver a oposição 'mulier / foemina' vs. 'vir / mas' justamente como uma oposição entre dois 'status' da espécie 'homo', oposição esta da qual resultam diferenças 'de iure et auctoritate', mas não 'de facto'. Quanto ao ensino e ao aprendizado de teologia pela mulher (este último tema, tratado em Suma, art. 12, q. 1), cf. BEUMER, J. "Die Stellung Heinrichs von Gent zum theologischen Studium der Frau”. Scholastik 32 (1957), pp. 81-5; MINNIS, A. J. "The Accessus Extended: Henry of Ghent on the Transmission and Reception of Theology". In: JORDAN, M. D., EMERY Jr., K. (ed.). Ad litteram. Authoritative Texts and Their Medieval Readers. Notre Dame - London: University of Notre Dame Press, 1992, pp. 275-326 (esp. pp. 311-6); BLAMIRES, A., MARX, C. W. "Woman Not to Preach: a Disputation in Britisch Library MS Harley 31". The Journal of Medieval Latin 3 (1993), pp. 34-63 (esp. pp. 42sg.); MARTIN, J. H. "The Ordination of Women and the Theologians in the Middle Ages". In: COOKE, B., MACY, G. (eds.). A History of Women and Ordination. Vol. 1: The Ordination of Women in Medieval Context. Lanham - Maryland - London: The Scarecrow Press, 2002, pp. 31-160 (esp. pp. 75-7). Essa idêntica capacidade 'de facto' não deve mascarar, no entanto, a clara inclinação de Henrique de Gand a ver na mulher um 'status' (para manter o vocabulário da Suma) inferior ao varão ('vir', pois guardarei 'homem' para traduzir a espécie 'homo'). Isso fica claro, por exemplo, pelo fato de que a maturação do corpo para recebimento da alma durante a gestação é maior para o macho ('mas') do que para a fêmea ('foemina'), o que trai uma clara consideração da fêmea como a informação, pela alma, de um corpo menos perfeito (menos amadurecido ou maturado) do que aquele do macho - cf. Quodl. 15, q. 13 co. (ed. De Wulf-Mansion Centre, vol. 20, p. 85). Temos aqui, portanto, uma expressão física (em termos de corpo e alma) da oposição metafísica entre a espécie 'homo' e os estados 'vir / mas' e 'mulier / foemina'. De um ponto de vista metafísico, o primeiro (a espécie), sendo embora absoluto, pode se atualizar, segundo Henrique, em um estado mais perfeito ('vir / mas') ou menos perfeito ('mulier / foemina') em diferentes indivíduos (pessoas), uma vez que fisicamente a alma pode informar um corpo mais ou menos maturado durante a gestação. Vemos, portanto, que a ordenação dos estados não diz respeito à espécie (metafísica) ou à alma (física), mas ao indivíduo e seu corpo (para um outro uso da noção de status próxima a essa, cf. cap. 6, notas 122-123). Notemos que essa dupla possibilidade metafísica e física possui claras repercussões morais, uma vez que o 'vir / mas' possui qualidades morais tais que o habilitam ao ensino e aprendizado públicos da teologia, o que não é o caso para a 'mulier / foemina', como fica claro em Suma, art. 11, q. 2, nn. 6-7 (ed. 1642-6, pp. 193b-194a). Por outro lado, é igualmente claro que tal hierarquização dos estados do homem pode ser compensada por uma graça especial divina, que forneça a esta ou aquela mulher em 
particular a possibilidade 'de iure et auctoritate' de ensinar publicamente - cf. Suma, art. 11, q. 2, n. 11 (ed. 1642-6, p. 194b), acerca desse aspecto do tema há poucos trabalhos, como MINNIS, "Accessus Extended...", 1992, pp. 313-4; e uma rápida referência em PILTZ, A. "Birgitta profeten och uppenbarelsens dynamik". In: BESKOW, P., LANDEN, A. (red.). Birgitta av Vadstena. Pilgrim och profet 1303-1373. Stockholm: Natur och Kultur, 2003, pp. 29-44 (cf. esp. 38-41). Sobre um desses casos, pelo menos, Henrique parece haver se debruçado com maior atenção, a saber, aquele de Sta. Catarina de Alexandria, que pode ser tomada precisamente como um exemplo da retidão moral (e, concomitantemente, fisiológica) necessária para o aprendizado, o que se pode ler no "Sermão para a festa de Sta. Catarina" (ed. HOCEDEZ, E. Richard de Middleton. Sa vie, ses oeuvres, sa doctrine. Louvain - Paris: "Spicilegium sacrum lovainiense" bureaux - Champion, 1925, pp. 484-9, 509-17), pregado pelo Doutor Solene em 25 de novembro de 1282 (cf. MACKEN, Bibliotheca manuscripta Henrici de Gandavo II, 1979, p. 1067 e LAARMANN, Deus, primum cognitum..., 1999, pp. 40-1; para um estudo filosófico sobre este sermão associado ao problema do ensino por parte da mulher, cf. PAIVA, G. B. V. de. "Por uma ética do conhecimento: Henrique de Gand e seu Sermão para a festa de Sta. Catarina". Anais do Seminário dos Estudantes de Pós-Graduação em Filosofia da UFSCar 11 (2015), pp. 134-50). Sobre esse sermão, cf. tb. cap. 3, nota 100.

Por fim, cabe sublinhar essa curiosa correlação na obra de Henrique de Gand entre, por um lado, a discussão da distinção entre 'vir / mas' e 'mulier / foemina' e, por outro, um discurso acerca do aspecto moral do conhecimento, do ensino e do aprendizado. Donde proviria uma tal interrelação temática? Por que dedicar espaço à discussão sobre os aspectos morais do ensino (e, em especial, do ensino da teologia) por parte das mulheres? Meu palpite seria que essa preocupação lança luz sobre a reflexão teórica de Henrique de Gand acerca das temáticas com que lidava em suas próprias atividades como arcediago de Tournai (para um resumo do pouco conhecimento que possuímos sobre tais atividades, cf. PYCKE, J. Répertoire biographique des chanoines de Notre-Dame de Tournai, 1080-1300. Louvainla-Neuve - Bruxelles: Collège Erasme - Nauwelaerts, 1988, pp. 48-52, 390-391 e planche 2; cf. tb. PYCKE, J. Le chapitre cathédral Notre-Dame de Tournai de la fin du XI à la fin du XIII siècle. Son organisation, sa vie, ses membres. Louvain-la-Neuve - Bruxelles: Collège Érasme - Nauwelaerts, 1986). Com efeito, a diocese de Tournai - e sua própria cidade sede - foi uma das regiões mais atingidas pelo fenômeno das comunidades de beguinas (cf. LAUWERS, M., SIMONS, W. Béguins et Béguines à Tournai au Bas Moyen Âge. Les communautés béguinales à Tournai du XIII au XV siècle. Tournai - Louvain-la-Neuve: Archives du Chapitre Cathédral - Unversité Catholique de Louvain, 1988; e DELMAIRE, B. "Les béguines dans le Nord de la France au premier siècle de leur histoire (vers 1230 - vers 1350)". In: PARISSE, M. (dir.). Les religieuses en France au XIII siècle. Table ronde organisée par l'Institut d'Études Médiévales de l'Université de Nancy II et le C.E.R.C.O.M., 2526 juin 1983. Nancy: Presses Universitaires de Nancy, 1989, pp. 121-62). Aliás, Henrique parece haver tido que lidar com o tema em sua própria família - pelo menos, é o que se depreende de seu registro obituário contindo no ms. Tournai, ACT Reg. 83, f. 68v, 1. 12, onde surge uma referência à “Ava, sua irmã beguina [ad uitam aue sororis sue beghine]", que deve ter vivido no grande béguinage da paróquia de Sta. Maria Madalena, na cidade de Tournai (cf. PYCKE, Répertoire..., 1988, p. 49 aproveito para agradecer ao prof. Jacques Pycke e ao sr. Pierre Dehove, respectivamente, arquivista e arquivista-adjunto dos Archives et Bibliothèque de la Cathédrale de Tournai, pela disponibilização do refererido manuscrito e por seus comentários a respeito; note-se que esse mesmo documento, porém sem a referência à irmã se Henrique - provavelmente, devido ao fato de tal referência estar riscada no ms. -, se encontra editado em PAUW, N. de. "Dernières découvertes concernant le Docteur solennel Henri de Gand, fils de Jean le Tailleur (Formator ou de Sceppere)". Compte rendu des séances de la Commission royale d'histoire, ou recueil de ses bulletins 16 (1889), pp. 26-138, esp. 121-2). Além disso, Henrique de Gand mantinha, enquanto arcediago, estreitas relações com o béguinage de Sta. Maria Madalena, como mostram [i] o registro de uma doação sua no valor de 70 librae turonenses, no ano de 1289, para a construção de um muro no béguinage (cf. edição do documento a partir de um cartulário em PAUW, N. de. "Dernières découvertes...", 1889, pp. 116-9; e a correção de sua datação em PYCKE, Répertoire..., 1988, p. 52 - neste mesmo documento são citados uma outra irmã de Henrique de Gand, de nome Katherina, e seu pais, não nomeados) e [ii] o fato de ele haver atuado, em 1288, como executor testamentário de Gertrude la Mariscaude, diretora do mesmo béguinage (cf. a edição do documento em PAUW, "Dernière découvertes...", 1889, pp. 113-6; e a correção de sua datação em PYCKE, Répertoire..., 1988, p. 52). Ora, o fenômeno das beguinas coloca, entre outros, precisamente o problema do ensino religioso pela mulher, da tomada da palavra pelas mulieres religiosae da passagem do século XIII para o XIV (cf. VAUCHEZ, A. La spiritualité du Moyen Âge occidental. VIII - XIII $I^{e}$ siècle. Paris: Éditions du Seuil, 1994, pp. 161-8). Viria daí o interesse de Henrique de Gand em discutir e defender o direito e a autoridade da mulher para ensinar quando 
'sobre o viver e a vida de Deus' (de vivere et vita dei) ${ }^{4}$, veremos que o homem aparece como uma simples etapa intermediária na ordenação de todos os entes vivos do universo - das plantas até Deus, passando por animais irracionais, homens e anjos. Sendo essa hierarquização do mundo tão fundamental para a compreensão da concepção de 'homem' exposta pelo Doutor Solene, penso que será interessante buscarmos entender o que seria precisamente essa ordenação dos entes.

Para tanto, podemos avançar mais um pouco e nos voltar para uma passagem de Suma, art. 39, q. 7, onde, no contexto de um estudo sobre a ação de Deus, Henrique expõe os quatro tipos de ordem que, segundo ele, há nas criaturas:

“<..> encontra-se nas criaturas uma quádrupla ordem, a saber: de grau natural [gradus naturalis], de sucessão [successionis], de origem [originis] e de razão [rationis].

A ordem de grau natural é nas partes do universo [partes universi], tal como o mundo - segundo o Filósofo, em Metafísica XII - é um por uma ordem de partes entre si e ao primeiro princípio, tal como o exército é um. De fato, da matéria primeira, que é no mais baixo nas criaturas, até a primeira forma separada, que é Deus, todos os intermediários possuem, segundo graus de natureza, uma ordem além do grau da matéria primeira e aquém do grau da forma primeira.

A ordem de sucessão é tripla, a saber: de sucessão natural [successionis naturalis], de localização [situalis] e de duração [durationis]. Do primeiro modo é a ordem entre o não ser de alguma criatura e o seu ser. Do segundo modo é a ordem daqueles que possuem uma localização em uma grandeza ou em um lugar [in magnitudine aut in loco]. Do terceiro modo é a ordem de uma duração a outra (como da eternidade ao evo e do evo ao tempo) ou daqueles que são no tempo entre si.

A ordem de origem, de fato, é a da luz ao esplendor no fogo.

E a ordem de razão é entre ente, verdadeiro, bom em cada ente"

iluminada pela graça?

${ }^{4}$ Henrique de Gand, Suma, art. 27 (ed. Teske, pp. 136-176).

${ }^{5}$ Henrique de Gand, Suma, art. 39, q. 7, co. (ed. De Wulf-Mansion Centre, vol. 28, p. 242-3): "De primo igitur sciendum, quod in creaturis quadruplex ordo reperitur, scilicet gradus naturalis, successionis, originis et rationis.

Ordo gradus naturalis est in partibus universi, quemadmodum mundus secundum Philosophum, XII ${ }^{\circ}$ Metaphysicae, est unus ordine partium inter se et ad primum principium, sicut exercitus est unus. A prima enim materia quae est in infimo in creaturis, usque ad primam formam separatam, quae Deus est, omnia intermedia secundum gradus naturae ordinem habent supra gradum primae materiae, et citra gradum primae formae.

Ordo successionis triplex est, scilicet successionis naturalis, situalis et durationis. Primo modo est ordo inter non esse cuiuslibet creaturae et eius esse. Secundo modo est ordo illorum quae situm habent in magnitudine aut in loco. Tertio modo est ordo vel unius durationis ad aliam, ut aeternitatis ad aevum, et aevi ad tempus, vel eorum quae sunt in tempore, inter se.

Ordo vero originis est lucis ad splendorem in igne.

Ordo autem rationis est inter ens, verum, bonum, in unoquoque ente". 
Dessas quatro, a que mais me interessa aqui é a primeira, a saber, a 'ordem de grau natural' (ordo gradus naturalis). Com efeito, a ordem de sucessão natural (ordo successionis naturalis) será importante, um pouco adiante, quando falarmos da geração do homem, porém a chave para compreender a localização do homem, enquanto ente, na ordem do universo é a consideração da ordem de grau natural dos entes.

Basicamente, essas ordens estabelecem uma relação de anterioridade e posterioridade entre as criaturas: "de fato, na ordem segundo grau de natureza, sempre é anterior [prius] aquilo que é de grau superior [gradus superioris] e posterior [posterior] aquilo que é de grau inferior [gradus inferioris]"6. Essa observação, no entanto, não nos leva muito adiante, pois para ordenar as criaturas ainda é necessário saber o que seria esse 'grau natural (ou de natureza)' de cada criatura. Uma primeira pista pode ser encontrada em uma passagem anterior da Suma, na qual Henrique de Gand associa à noção de 'grau natural' de cada criatura aquela de 'disposição natural' (dispositio naturalis). De fato, em Suma, art. 33, q. 2, onde se estuda a inteligibilidade de Deus, lemos o seguinte excerto:

\begin{abstract}
“ $<\ldots>$ já que em todo outro que não Ele, $<$ Deus $>$ encontra algum defeito e imperfeição [defectum et imperfectionem], para se inteligir simples e absolutamente, ele é inteligível por si só e para si, mas por nenhum outro senão por algo outro que se requer no inteligente além da sua disposição natural, quanto quer que a criatura seja elevada em grau natural"7.
\end{abstract}

Lida em conjunto com o excerto destacado anteriormente, essa passagem pode nos fornecer muitos elementos para pensar sobre o 'grau natural'. O que está em jogo aqui é o fato de que somente Deus pode inteligir a si mesmo sem qualquer auxílio externo, enquanto que todos os outros - isto é, todas as criaturas - necessitam para tanto de algo outro para além de si mesmos. Isso está ligado, como fica patente na passagem, ao fato de que toda criatura possui 'algum defeito ou imperfeição' que a torna incapaz de compreender Deus. Melhor dito, ao que parece, esse 'defeito ou

\footnotetext{
${ }^{6}$ Henrique de Gand, Suma, art. 39, q. 7, co. (ed. De Wulf-Mansion Centre, vol. 28, p. 243): "Et in quolibet horum modorum ut sunt in creaturis, sine ulla contradictione recipiuntur prius et posterius. In ordine enim secundum gradus naturae semper est prius quod est gradus superioris, et posterius quod est gradus inferioris".

${ }^{7}$ Henrique de Gand, Suma, art. 33, q. 2, co. (ed. De Wulf-Mansion Centre, vol. 27, p. 132): "Unde, quia in omni alio a se invenit aliquem defectum et imperfectionem, ad intelligendum se simpliciter et absolute a solo se ipso est se ipso intelligibilis, et a nullo alio nisi per aliquid aliud, quod requiritur in inteligente super eius dispositionem naturalem, quantumque sit creatura in gradu naturali elevata".
} 
imperfeição' torna a 'disposição natural' dessa criatura para inteligir incapaz de conhecer Deus sem que este último a auxilie. E isso vale para qualquer criatura, não importa o quão elevada (elevata) ela seja em seu grau natural. Ora, o termo 'elevada' só pode se referir àquela ordenação dos entes do universo desde a matéria primeira até a forma primeira que é Deus, que encontramos no excerto anterior. Assim, esta última passagem parece sugerir que a elevação da criatura em grau de natureza está diretamente relacionada a seus 'defeitos e imperfeições' e, também, às suas 'disposições naturais'. Certamente, em nenhum caso ela poderá inteligir Deus sem ser auxiliada por este último, mas esse não é o mais importante para nós. O que devemos notar é que essa passagem nos permite dizer que todas as criaturas estão aquém de Deus em grau de natureza, porque são defeituosas e imperfeitas, embora algumas sejam mais elevadas do que outras. Assim, aquela ordenação de grau natural parece apontar para uma hierarquia de perfeição que é acompanhada pelas disposições naturais de cada criatura. Dessa maneira, quanto mais elevado o grau de natureza de uma criatura, mas próxima ela está de Deus, mais perfeita e menos defeituosa ela é e, assim, mais perfeitas são suas disposições naturais. Por outro lado, quanto menor seu grau de perfeição, mais próxima ela estará da matéria primeira, mais imperfeita e defeituosa ela será e, portanto, menos perfeitas serão suas disposições naturais. Enfim, 'grau de natureza', 'perfeição' e 'disposição natural' parecem estar profundamente ligados na ordem do universo.

Mas, se esse é o caso, qual seria o papel do homem nesse universo ordenado?

Para sabê-lo, podemos nos voltar para um pequeno, porém significativo, trecho de Quodl. 3, q. 16, onde Henrique explica que, na natureza humana:

"a ação da natureza deve ser completada com a ajuda de um agente sobrenatural
[adiutorio agentis supernaturalis], tal que o homem seja o horizonte e os confins
do natural e do sobrenatural [ut sit homo horizon et confinium naturalium et
supernaturalium], um meio [medius] entre eles em natureza, em ser e em modo
de produção, tal como é um meio em sua natural operação intelectiva, como foi
dito".

Quanto à ajuda sobrenatural necessária para a natureza humana, teremos ocasião de mencioná-la mais pausadamente adiante, embora ela não vá ser aqui nosso

\footnotetext{
${ }^{8}$ Henrique de Gand, Quodl. 3, q. 16, co. (ed. 1613, f. 123rb): "Et hoc requirit dignitas humanae naturae, in qua debet compleri actio naturae adiutorio agentis supernaturalis, ut sit homo horizon et confinium naturalium et supernaturalium, medius inter illa in natura et esse et modo productionis, quemadmodum est medius in sua naturali operatione intellectiva ut dictum est".
} 
foco ${ }^{9}$. Assim, voltemos nossa atenção somente para a caracterização do homem como 'o horizonte e os confins' entre o natural e sobrenatural. De fato, tudo no homem aponta para esse seu caráter intermediário na ordem do universo: sua natureza, seu ser e seu modo de produção - até mesmo, sua operação intelectiva, como veremos. Mais do que isso, podemos dizer que o próprio lugar do homem é esse meio entre as primeiras e as segundas criaturas, isto é, entre aquelas criaturas separadas (espirituais) e as aquelas conjugadas (corpóreas). E, nesse ponto, entra em jogo aquilo que melhor caracteriza o homem, a saber, a união de uma alma intelectiva com um corpo capaz de recebê-la. Juntos, ambos - alma e corpo - formam um indivíduo subsistente. Mas, novamente, estamos caminhando rápido demais...

Por ora, vejamos mais detalhadamente o que o Doutor Solene nos diz sobre esse lugar mediano do homem na ordem do universo:

"Agora, o que é forma e ato de outro, propriamente se conjuga àquele de que é forma e ato, não o contrário. Portanto, aquilo que conjuga os anteriores aos posteriores, como a alma intelectiva, segundo Dionísio, deve ser o fim dos primeiros - isto é, a forma última e mais baixa, em si separada e podendo subsistir. E ela deve conjugar este fim - isto é, ela mesma - ao princípio dos segundos, isto é, ao superior e primeiro em dignidade e grau de natureza entre os mais baixos, a saber, os corpóreos aperfeiçoáveis"10.

Pois bem, o homem é a conjunção do que há de mais baixo em grau de natureza entre os espirituais e o que há de mais alto em grau de natureza entre os corpóreos. Sua parte mais alta, a alma intelectiva, pode subsistir separada, como algo puramente espiritual, porém seu corpo é necessariamente atualizado por essa alma, que é sua forma e ato. Sendo a alma principalmente aquilo que age para unir - para elevar - o corpóreo ao espiritual, a própria alma intelectiva é propriamente "o meio e os confins das substâncias espirituais e corporais, ao ser a forma e o ato do corpo"11.

\footnotetext{
${ }^{9} \mathrm{Cf}$. os Epílogos às partes $1 \mathrm{e} 2$.

${ }^{10}$ Henrique de Gand, Quodl. 3, q. 15, co. (ed. 1613, f. 117ra): "Nunc autem quod est forma, et actus alterius, proprie coniungitur ei, cui est forma et actus, non e converso. Quod ergo coniungit priora posterioribus; cuiusmodi est anima intellectiva, secundum Dionysium debet esse finis primorum; hoc est forma ultima, et infima, in se separata potens subsistere; et debet coniungere hunc finem, hoc est, se ipsam principio secundorum, hoc est superiori, et primo in dignitatem, et gradu naturae inter infima, corporalia scilicet perfectibilia $<\ldots>$ ".

${ }^{11}$ Henrique de Gand, Quodl. 7, q. 14, ad 1 (ed. De Wulf-Mansion Centre, vol. 11, p. 106): "Unde anima intellectiva, quia est medium et confinium substantiarum spiritualium et corporalium in essendo formam et actum corporis, aliquas debet habere vires separatas et actiones, in quibus communicat cum spiritualibus omnino separatis, et aliquas coniunctas, in quibus communicat cum pure corporalibus et materialibus". Voltaremos à temática das diversas vires da alma adiante, no item 2.3.
} 
O homem é o meio entre os corpóreos e os espirituais, porque resulta do ato da alma de atualizar o corpo devido. Vemos, portanto, que o papel do homem na ordem o universo é unir o corpóreo ao espiritual ou, como era formulado na passagem anterior, o natural ao sobrenatural.

Com isso, parece-me, fica claro para nós o que é essa hierarquização do mundo que perpassa o pensamento de Henrique de Gand e determina a sua concepção de homem. Assim, estamos finalmente em posição de retornar ao já citado artigo 27 da Suma e ver como o homem é inserido em uma hierarquia dos entes vivos. Em seguida, deveremos nos debruçar sobre o problema da união do corpo e da alma como constituintes do homem nesse lugar intermediário da ordem do mundo e sobre a concepção de potência da alma que resulta dessa noção de homem como composto intermediário entre o natural e o sobrenatural.

\subsection{A VIDA HUMANA}

Embora o estudo da vida em Suma, art. 27, culmine no estabelecimento de uma hierarquia dos entes vivos, esta última é precedida por uma reflexão sobre o próprio significado da 'vida' (vita) e do 'viver' (vivere). O nosso mestre gandavense inicia esse estudo afirmando que "percebemos em algo o ato da vida, que é viver, e julgamos que a vida é nele, porque percebemos nele um movimento - ou seja, uma operação [sive operationem] - por ele mesmo, a partir dele mesmo e nele mesmo"12. Notemos nessa passagem, como 'viver' e 'vida' são relacionados: o primeiro é o ato do segundo, isto é, 'viver' não é senão o próprio 'ato da vida'. Essa relação, entretanto, pode e deve ser desenvolvida de maneira mais precisa pela introdução da noção de 'ser'. Pois bem, nesse caso, como estão um para o outro 'ser', 'vida' e 'viver' no vivente?

Para explicá-lo, Henrique de Gand introduz um dos elementos mais problemáticos de sua metafísica, a saber, a noção de 'distinção intencional' (distinctio intentionalis). Esse elemento central da filosofia do Doutor Solene é descrito por Raymond Macken da seguinte maneira: "Henrique a considerava como um tipo de distinção intermediária entre a distinção real e a distinção de pura razão <..>. A

\footnotetext{
${ }^{12}$ Henrique de Gand, Suma, art. 27, q. 1, co. (ed. Teske, p. 138): "Circa primum istorum sciendum quod in aliquo percipimus actum vitae, qui est vivere, et ei iudicamus vitam inesse, quia percipimus in eo motum sive operationem per seipsum et ex seipso et in seipso".
} 
distinção intencional de Henrique não é uma distinção de razão, pois ela precede, enquanto distinção, a razão humana. Entretanto, ele não admite que se deva situá-la na ordem da existência, mas antes na ordem das essências" ${ }^{" 13}$. Essa descrição em linhas gerais da distinção intencional como intermediária entre a distinção real e a de razão pode ser o bastante para a presente discussão ${ }^{14}$.

\footnotetext{
${ }^{13}$ MACKEN, R. "Les diverses applications de la distinction intentionelle chez Henri de Gand". In: KLUXEN, W. (Hrsg). Sprache und Erkenntnis im Mittelalter. Berlin - New York, 1981, pp. 769-76 (esp. p. 770): "Henri la considérait comme une sorte de distinction intermédière entre la distinction réelle et la distinction de pure raison $<\ldots>$. La distinction intentionelle d'Henri n'est pas une distinction de raison, car elle précède, en tant que distinction, la raison humaine. Cependant il n'admet pas qu'il faille la situer dans l'ordre de l'existence, mais bien dans l'ordre des essences".
}

${ }^{14}$ A temática que envolve a distinctio intentionalis foi, sem dúvida, um dos elementos mais controversos do pensamento de Henrique de Gand já para seus contemporâneos, em especial no contexto da discussão acerca da distinção entre essentia e existentia (cf., adiante, a nota 95) - sobre isso, cf. HOCEDEZ, E. "Gilles de Rome et Henri de Gand sur la distinction réelle (1276-1287)". Gregorianum 8 (1927), pp. 358-84; HOCEDEZ, E. "Deux questions touchant la distinction réelle entre l'essence et l'existence". Gregorianum 10 (1929), pp. 365-86; PAULUS, J. "Les disputes d'Henri de Gand et de Gilles de Rome sur la distinction de l'essence et de l'existence". Archives d'histoire doctrinale et littéraire du moyen âge (1940-2), pp. 323-58; CAFFARENA, J. G. Ser participado y ser subsistente en la metafisica de Enrique de Gante. Romae: apud Aedes Universitatis Gregorianae, 1958, pp. 65-92; WIPPEL, J. F. "Godfrey of Fontaines and Henry of Ghent's Theory of Intentional Distinction between Essence and Existence". In: KÖHLER, T. W. (éd.). Sapientiae procerum amore. Mélange Médiévistes offerts à Dom Jean-Pierre Müller O.S.B. à l'occasion de son $70^{\text {ème }}$ anniversaire (24 février 1974). Roma: Editrice Anselmiana, 1974, pp. 289-321; WIPPEL, J. F. "The Relationship Between Essence and Existence in Late-Thirteenth-Century Thought: Giles of Rome, Henry of Ghent, Godfrey of Fontaines, and James of Viterbo". In: MOREWEDGE, P. (ed.). Philosophies of Existence. Ancient and Medieval. New York: Fordham University Press, 1982, pp. 131-64; CARVALHO, M. A. S. "Sentido e alcance do pensamento de Henrique de Gand. Explicação da nona questão do Quodlibet I: a relação essência / existência". Mediaevalia. Textos e estudos 3 (1993), pp. 161-205; CARVALHO, M. A. S. "Introdução". In: HENRIQUE DE GAND. Sobre a metafisica do ser no tempo: questões quodlibéticas I, 7/8-9 e 10. Tr., intr. e notas de M. S. de Carvalho. Pref. e restabelecimento crítico do texto latino de R. Macken. Lisboa: Edições 70, 1996, pp. 11-94 (esp. pp. 42-62); CARVALHO, M. A. S. A Novidade do Mundo. Henrique de Gand e a Metafisica da Temporalidade no Século XIII. Coimbra: Fundação Calouste Gulbenkian - Fundação para a Ciência e a Tecnologia, 2001, pp. 281386; SURZYN, J. "Stanowisko Henryka z Gandawy w sporze o realną różnicę istoty i istnienia w bytach stworzonych". Folia Philosophica 19 (2001), pp. 107-21; HÖDL, L. "Die Unterscheidungslehren des Heinrich von Gent in der Auseinandersetzung des Johannes de Polliaco mit den Gandavistae". In: GULDENTOPS, G., STEEL, C. (eds.), Henry of Ghent and the Transformation..., 2003, pp. 371-86; TESKE, R. J. "Some aspects of Henry of Ghent's Debt to Avicenna's Metaphysics". In: TESKE, Essays on the Philosophy of Henry of Ghent, 2012, pp. 119-143 (esp. pp. 126-34).

Mas, o que devemos entender por distinção intencional? Como lemos na citação de Macken na nota anterior, ela é uma distinção intermediária entre a distinção real e a distinção de razão. Mas em que sentido é possível que haja algo intermediário entre o real e o racional? Para responder a essas perguntas, vejamos primeiro como Henrique de Gand desenvolve a descrição das três distinções. Uma primeira enumeração das três aparece já em Quodl. 1, q. 9, co. (ed. De Wulf-Mansion Centre, vol. 5, p. 55). Outro texto em que encontramos um interessante estudo da distinção intencional é Quodl. 5, q. 12 (cf. PORRO, "Possibilità ed esse essentia in Enrico di Gand", 1996, pp. 217-20). No entanto, o texto privilegiado para tal estudo parece ser Quodl. 5, q. 6, analisado recentemente em TESKE, R. "Distinctions in the Metaphysics of Henry of Ghent". In: TESKE, Essays on the Philosophy of Henry of Ghent, 2012, pp. 93-115 (esp. pp. 104-11). Lemos aí que, para solucionar a questão, é preciso ver "quae et qualis sit differentia secundum intentionem, et quia hoc dependet a notitia aliorum modorum differentiae, qui quidem sunt secundum rem, et secundum rationem, ideo altius inchoando oportet videre quid hic appelletur res, et quid intentio, ut ex hoc pateat quae sint differentia re, et quae 
intentione, et quae tantum ratione" (ed. 1613, f. 238ra). Comecemos pela ratio, que nesse contexto põe menos problemas.

Ratio aqui nomeia um modo pelo qual uma coisa é nata a ser concebida sem que seja concebida por outro modo sob o qual também é nata a ser concebida - ou seja, dois distintos por razão são dois modos sob os quais uma mesma coisa pode ser concebida, sendo possível concebê-la sob cada um dos modos separadamente. O caso classico desse tipo de distinção é a diferença entre a concepção da definição e a concepção do definido, tal como 'homem' e 'animal racional' são dois modos distintos de conceber uma mesma coisa (o primeiro de modo incomplexo, o segundo de modo complexo), sendo possível conceber 'homem' sem que se conceba 'animal racional' (por exemplo, caso se conheça o conceito incomplexo, mas não sua definição) - Quodl. 5, q. 6, co. (ed. 1613, f. 238va-b): “< ...> ratio hic appellatur generali nomine modus aliquis circa rem, sub quo nata est concipi determinate absque eo, quod concipiatur sub alio, sub quo similiter nata est concipi, et hoc sine omni eius differentia re, vel intentione, ita quod idem re et intentione conceptum diversis modis concipiendi dicitur differre secundum rationem, inquantum concipitur uno illorum modorum, et non alio, sicut patet in conceptione definitionis, et definiti <...>".

O noção de res, por outro lado, põe mais problemas do que a anterior. Para introduzir sua discussão a esse respeito em Quodl. 5, q. 6, Henrique recorre à oposição entre res a reor reris e res a ratitudine, à qual retornaremos adiante (cf. cap. 6, nota 25). Por ora, basta notar que, aqui, a primeira é descrita como a res que significa "figmentum, et ens secundum animam tantum". Pelo contrário, res (sem qualificação) é tomada no sentido daquilo que, em outros escritos - como em Suma, art. 21, q. 4 (ed. Decorte \& Teske, p. 78-80) ou Quodl. 7, q. 1-2 (ed. De Wulf-Mansion Centre, vol. 11, pp. 27-8) -, ele chamará de res a ratitudine. Ou seja, res aqui nomeia aquilo que possui uma essência e, portanto, é naturalmente apto a existir: “< $<$. > quicquid est natura et essentia aliqua absoluta habens rationem exemplarem in Deo, nata existere in existentia operatione divina, sive sit compositum, ut homo, asinus, sive principium compositi, ut materia, forma, sive fuerit universale, sive particulare" (ed. 1613, f. 238ra). Ao que Henrique adiciona que se distinguem realmente aqueles que possuem essências diversas - "re differunt quaecunque diversas naturas, et essentias important secundum rem, sive fuerint simplicia, ut materia, et forma, sive composita, ut homo et asinus" (op. cit.). Ora, nesse caso, a res a que a distinção real se refere não é necessariamente algo existente, mas antes uma essência, de maneira que a distinção real, para Henrique, diz respeito estritamente a essências. Porém, se for assim, não parece que mesmo no campo da distinção real já estamos em uma distinção de razão, uma vez que a essência só é sem existência no conhecimento? Tanto Jean Paulus (Henri de Gand. Essai sur les tendances..., 1938, pp. 208-10) como Roland Teske ("Distinctions in the Metaphysics of Henry of Ghent", 2012, pp. 112-3) colocaram esse problema. A conclusão de ambos parece ser que, de certo modo, a distinção real descrita por Henrique de Gand oscila entre os campos da essência e da existência (nos dizeres de Teske) ou entre os campos da metafísica e da física (nas palavras de Paulus). De fato, lemos em Suma, art. 27, q. 1, ad 5 (ed. Teske, pp. 152-4): "Diversa enim re in diversis aut sunt diversa ut res extra intellectum existentes et in eis quae existunt extra intellectum, aut sunt diversa ut res existens in intellectu primo et deinde in re extra". Sendo assim, poderíamos dizer que a distinção real diz respeito à existência, na medida em que uma essência pode existir no intelecto e/ou existir fora do intelecto? Deixando essa pergunta em aberto (novamente, sobre essência e existência, cf. adiante a nota 95), enfatizemos somente o ponto principal para nosso propósito: a distinção racional diz respeito unicamente a modos de concepção de uma mesma res, enquanto que a distinção real diz respeito à diversidade de essências (e, quiçá, de existências).

Finalmente, estamos em posição de ver o que o Doutor Solene toma por intentio em Quodl. 5, q. 6. Primeiramente, ele afirma que a res, tal como tomada nesse contexto, é o fundamento de intenções e razões diversas - "res autem iam dicto modo intellecta est fundamentum intentionum, et rationum. Super idem enim re fundantur intentiones, et rationes diversae" (ed. 1613, f. 238rb). Em seguida, ele adiciona que o termo intentio não é tomado aqui no sentido da distinção entre 'primeiras intenções' e 'segundas intenções' (op. cit.) - sobre tal distinção, cf. cap. 6, nota 36. Excluído esse sentido, é dito que na distinção intencional toma-se intentio por "algo que pertence realmente [realiter] à simplicidade da essência de algo e é nato a ser concebido precisamente, sem algo outro do qual não difere na coisa absoluta [re absoluta], que similarmente pertence a mesma <essência> [Sed appellatur hic intentio aliquid pertinens realiter ad simplicitatem essentiae alicuius natum praecise concipi absque aliquo alio, a quo non differt re absoluta, quod similiter pertinet ad eandem]" (ed. 1613, f. 238va). Diferentemente da ratio, a intentio não é um modo de conceber, mas é algo que pertence realmente à essência e que se pode conceber sem outra intentio que também pertença realmente à mesma essência. $\mathrm{O}$ termo realiter parece marcar a diferença entre ratio e intentio - a primeira é um produto do intelecto, enquanto que a segunda é algo da essência da res que se dá ao intelecto separadamente (praecise), isto 
é, sem outra intentio, ainda que esta última também venha a ser concebida posteriormente. Henrique busca explicar essa complexa caracterização da intentio por uma etimologia: "diz-se intentio, como que intus tentio, pois a mente tende, por seu conceito, a algo que é em uma coisa determinadamente e não a algo outro, que é algo da mesma coisa [Unde dicitur intentio, quasi intus tentio, eo quod mens conceptu suo in aliquid, quod est in re aliqua determinate tendit, et non in aliquid aliud, quod est aliquid eiusdem rei<...>]" (op. cit.) - sobre essa passagem, cf. SOLÈRE, J.-L. "Tension et intention. Esquisse de l'histoire d'une notion". In: COULOUBARITSIS, L., MAZZÙ, A. (dir.). Questions sur l'intentionnalité. Bruxelles: Ousia, 2008, pp. 59-124 (esp. p. 116). O conceito da intentio é como que a delimitação de algo preciso numa coisa, separando-o de outros que também poderiam ser delimitados na mesma coisa - todos esses, porém, são distintos intencionalmente, mas idênticos na res e são realiter na própria res (não são somente rationes). Na formulação de Martin Pickavé, "Intentiones nehmen eine Zwischenstellung zwischen 'Realem' und nur Verstandesmäßigem ein, weil sie als Wesensmomente keine reinen Produkte des Intellekts sind, aber erst durch die Betrachtung des Intellekts für sich erfasst werden können" (Heinrich von Gent über Metaphysik als erste Wissenschaft. Studien zu einem Metaphysikentwurf aus dem letzten Viertel des 13. Jahrhunderts. Leiden-Boston: Brill, 2007, p. 217; cf. tb. PORRO, "Possibilità ed esse essentia in Enrico di Gand", 1996, p. 217).

A essas observações, Henrique de Gand adiciona, ainda em Quodl. 5, q. 6, co. (ed. 1613, f. 238va), uma série de exemplos de distinções por intenção, os quais dão lugar a uma taxonomia de tal distinção, que redunda em seis modos (que parecem ser, de fato, seis casos) de distinção intencional, nessa ordem: [i] os conceitos das diversas diferenças que ocorrem num mesmo, como no homem o racional, o sensível, o vegetativo (o conceito de uma diferença não inclui a outra); [ii] o conceito do gênero e o da diferença que constituem o conceito de uma espécie simples (o conceito do gênero e aquele da diferença não se incluem mutuamente); [iii] o conceito da espécie com respeito ao do gênero e ao da diferença (o conceito da espécie inclui os dois últimos, mas não o contrário); [iv] o conceito do viver e o do ser nas criaturas (o primeiro conceito inclui o segundo, mas não o contrário); [v] o conceito do suposto (suppositi, sicut hominis) e o da natureza (o conceito do suposto inclui o da natureza, mas não o contrário); e, finalmente, [vi] o conceito do respectus e o conceito da essência (o primeiro inclui o segundo, mas não contrário). Além disso, Henrique separa os dois primeiros modos (nos quais há maxime differentia intentionum) dos quatro restantes, pois nos dois primeiros nenhum conceito inclui nenhum outro, enquanto que nos quatro modos seguinte um dos conceitos inclui o outro sem que o contrário ocorra - sobre essa classificação, cf. tb. PORRO, "Possibilità ed esse essentia in Enrico di Gand”, 1996, p. 218, nt. 20. Em todos esses casos, as diversas intentiones são um mesmo na res, mas podem ser concebidas cada uma por si, sem que se conceba a outra - para outras expressões dessa classificação, cf. Quodl. 5, q. 12, co. (ed. 1613, f. 254ra). Além disso, a distinção intencional também é descrita, em Suma, art. 27 (cf., adiante, nota 48), como uma distinção entre diversos que, em um único não podem ser separados, mas surgem separados em vários - como, por exemplo, o vegetativo e o sensitivo não podem ser separados quando surgem unidos no mesmo animal, mas um pode ocorrer separado do outro, tal como o vegetativo ocorre na planta sem o sensitivo. Como se vê, novamente as diversas potências da alma surgem aqui como um exemplo de distinção intencional em que um contém o outro, sem que o contrário ocorra. Sobre os diversos usos da noção de distinção intencional na obra de Henrique de Gand, cf. o já mencionado MACKEN, "Les diverses applications de la distinction intentionelle...", 1981. Mais adiante, teremos oportunidade de voltar a lidar com alguns desses casos de distinção intencional - no presente capítulo, entretanto, aquele mais importante para nós será a relação entre vida e ser nas criaturas. Restaria diferenciar, ainda, esta noção de intentio daquele implicada da descrição da espécie sensível ou inteligível como intentio (em oposição à res sentida ou conhecida), porém isso será feito mais adiante (cf. item 4.3) Para uma introdução às diversas distinções em Hernique de Gand, cf. DECORTE, J. Een avicenniserend augustinisme: metafysica, wilspsychologie en vrijheidleer bij Hendrik van Gent. Tekstkritische uitgave: Henrici de Gandavo, Quodlibet XIII, qq. 112. 2 delen. Leuven: Katholiek Universiteit Leuven, Hoger Instituut voor Wijsbegeerte, 1983, deel 1, pp. 109-15.

Por fim, note-se que Jules Janssens sugere que a fonte de Henrique na elaboração da noção de 'distinção intencional' pode ter sido Avicena - cf., desse autor, "Some elements of Avicennian Influence on Henry of Ghent's Psychology". In: VANHAMEL, W. (ed.). Henry of Ghent. Proceedings..., 1996, pp. 155-69 (esp. p. 162); "Henry of Ghent and Avicenna". In: WILSON, G. A. (ed.). A Companion to Henry of Ghent, 2011, pp. 63-83 (esp. p. 82). Quanto à sobrevida ou possíveis influências indiretas de tal doutrina em autores posteriores, cf. WOLTER, A. B. The Transcendentals and Their Function in the Metaphysics of Duns Scotus. St. Bonaventure: The Franciscan Institute, 1946, pp. 18-9; e WALLER, J. "Spinoza's Attributes and the 'Intermediate' Distinctions of Henry of Ghent and Duns Scotus”. Florida Philosophical Review 9.1 (2009), pp. 91-105. 
Pois bem, valendo-se dessa complicada 'distinção intencional', o Doutor Solene busca mostrar que 'vida', 'viver', 'ser' e, até mesmo, 'alma' são realmente idênticos no vivente. Eles se distinguem só por intenção e razão:

\begin{abstract}
“< $<$..> 'viver' na coisa vivente não contém nada a mais em seu conceito do que o próprio 'ser', mas precisamente exprime o conceito do 'ser' dela, a saber, como 'em tal grau' [in tali gradu], tal que a determinação de tal grau não se constitui no próprio 'viver' por algo adicionado ao próprio 'ser' naquela coisa $<\ldots>$. Pelo que o conceito 'ser' é incluído no conceito 'viver', mas não o contrário. Pelo que eles diferem intencionalmente.

Porém, digo que diferem em razão somente aqueles que são na mesma coisa e formam um mesmo conceito, mas de modo diverso, como são a definição e o definido $<\ldots>$.

$<\ldots>$ cumpre dizer que viver é pela alma [vivere est ab anima] efetivamente e formalmente de algum modo, como já se dirá. Porém, o viver é pela vida [a vita autem est vivere] tal como por uma disposição formal do próprio ato [tanquam a dispositione formali ipsius actus], do mesmo modo que 'florir' na árvore é pela 'floração'. Donde, difere dizer 'viver pela vida' [vivere vita] e 'viver pela alma' [vivere anima], do mesmo modo que difere dizer 'correr pela corrida' [currere cursu] e 'correr pelos pés' [currere pedibus]. Donde, já que 'por' [a vel $a b]$ denota mais uma circunstância de causa eficiente do que formal, não propriamente se diz que 'viver é pela vida' [vivere est a vita], mas ' $<$ é a $>$ vida' [vita], assim como não propriamente se diz que 'correr é pela corrida' [currere est cursu], mas '<é a $>$ corrida' [cursus]"'
\end{abstract}

Nesse segundo parágrafo desse excerto, é feita uma interessante comparação entre o trio 'viver', 'vida', 'alma' e o trio 'correr', 'corrida', 'pés'. Tal como o pé é aquilo pelo que se corre (no sentido de que é uma causa eficiente do correr), o correr é a própria corrida; só há uma diferença de significação entre eles, pois o 'correr' significa como agir (agere) aquilo que 'corrida' significa como um habitus, isto é, algo possuído pelo corredor. Eles são diferentes somente em razão, pois significam o mesmo de modo diverso. Da mesma maneira, a alma é aquilo que pelo que se vive

\footnotetext{
${ }^{15}$ Henrique de Gand, Suma, art. 27, q. 1, ad 5 et ad 6 (ed. Teske, pp. 154-6): “ $<\ldots$..> vivere in re vivente super conceptum ipsius esse nihil amplius continet in suo concepto, sed praecise exprimit conceptum esse illius, ut, scilicet, in tali gradu, ita quod determinatio talis gradus non constituitur in ipso vivere per aliquid superadditum ipsi esse in illa re $<\ldots>$. Propter quod conceptus esse includitur in conceptu vivere, et non econverso. Propter quod differunt intentione.

Dico autem differre ratione sola quaecumque eadem re sunt et formant eundem conceptum, sed modo diverso, ut sunt definitio et definitum $<\ldots>$.

Ad sextum quod vivere non est nisi a vita, et est ab anima, ergo ipsa est vita, dicendum quod vivere est $\mathrm{ab}$ anima effective et formaliter quodammodo, ut iam dicetur. A vita autem est vivere tanquam a dispositione formali ipsius actus, quemamodum florere in arbore est a floritione. Unde differt dicere, vivere vita et vivere anima, quemadmodum differt dicere currere cursu et currere pedibus. Unde quia $a$ vel $a b$ magis notat circunstantiam causae efficientis quam formalis, non proprie dicitur quod vivere est a vita, sed vita, sicut non proprie dicitur quod currere est a cursu, sed cursus". Note o uso do termo praecise para descrever o modo como o conceito exprime um dos elementos da distinção intencional entre 'viver' e 'ser' na criatura. Como vimos na nota anterior, o mesmo praecise é especializado em Quodl. 5, q. 6, exatamente para essa função.
} 
(diferentemente dos pés na corrida, entretanto, a alma é causa eficiente e formal do viver), enquanto que 'vida' e 'viver' significam o mesmo diferentemente, pois a 'vida' significa como habitus - como algo possuído - aquilo que o 'viver' significa como agir ${ }^{16}$. Assim, ambos - 'viver' e 'vida' - significam o mesmo de modos diferentes, sendo distintos somente em razão. Por isso, faz muito sentido que Henrique de Gand, naquela formulação inicial de que partimos, afirme que o 'viver' é o 'ato da vida'. Isso, porém, não deve ser interpretado como uma afirmação de que a vida seria algo anterior a que o viver se seguiria como seu ato. Antes, ambos são realmente o mesmo - simplesmente, 'viver' é a 'vida' significada e inteligida como 'agir', como um ato. Ora, isso certamente explica a relação entre 'vida' e 'viver' como distintos pela razão, mas não explica o que eles são.

Para compreendê-lo, precisamos ler o primeiro parágrafo deste último excerto destacado, onde Henrique relaciona 'viver' e 'ser'. Segundo ele, 'viver' é precisamente o mesmo que o 'ser' da coisa vivente, porém com a adição da determinação do grau do ser da coisa. Ou seja, 'ser' diz simplesmente que esta coisa é, mas 'viver' diz que esta coisa é 'em um determinado grau de ser'. Dessa maneira, o Doutor Solene pode concluir que, diferentemente de 'viver' e 'vida' (nos quais só há uma diferença de razão na significação), 'ser' e 'viver' são intencionalmente distintos, pois 'viver' determina algo a mais sobre a coisa vivente do que 'ser', embora ambos sejam realmente o mesmo na coisa que vive. Mas, o que seria esse 'grau' determinado no 'ser' pelo 'viver'? Em poucas palavras, “"viver' diz um determinado modo de ser [modum essendi], a saber, sob a razão de uma maior perfeição do que importa a razão de ser simplesmente [ratio essendi simpliciter] - e isso, tanto em Deus como nas criaturas. De fato, 'viver' é um ser nobre [nobile esse] que inclui em si a razão do ser simplesmente <... ${ }^{\prime 17}$. Enfim, 'viver' e 'vida' simplesmente expressam respectivamente, como agir e como habitus - uma nobreza ou perfeição de ser, que não é expressa simplesmente pelo termo 'ser'. Assim, quando atribuímos 'vida' a

\footnotetext{
${ }^{16}$ Henrique de Gand, Suma, art. 27, q. 1, co. (ed. Teske, p. 142): "Absolute ergo dicendum quod vita est in re vivente et quod necesse est ut sit ipsa operatio quae est actus primus, et esse nobile, sicut est et ipsum vivere quemadmodum cursus in currente, non est aliquid re vel intentione aliud quam ipsum currere, et differunt solum secundum rationem, propter diversum modum significandi et intelligendi, unum per modum habitus, alterum vero per modum agere".

${ }^{17}$ Henrique de Gand, Suma, art. 27, q. 1, co. (ed. Teske, pp. 140-142): “<...> vivere dicit quemdam determinatum modum essendi, sub ratione, scilicet, maioris perfectionis quam importet ratio essendi simpliciter, et hoc tam in Deo quam in creaturis. Est enim vivere quoddam esse nobile includens in se rationem esse simpliciter, sicut determinatum confusum".
} 
algo, lhe estamos atribuindo um determinado grau de ser mais perfeito do que o de outros seres. E, se voltarmos à fórmula inicial de Suma, art. 27, vemos que essa maior perfeição está diretamente relacionada ao fato de que percebemos, nesse ser que dizemos possuir vida, um certo movimento ou, melhor, uma certa operação "por ele mesmo, a partir dele mesmo e nele mesmo" ${ }^{\prime 18}$.

Nesse ponto, é muito importante atentar para a correção daquilo que o Doutor Solene propõe: ele não afirma que atribuímos a 'vida' a uma coisa porque percebemos nela o 'ato da vida' que é o 'viver', mas que atribuímos 'vida' e 'viver' a uma coisa, porque percebemos nela uma operação característica. Essa operação não é o próprio 'ato da vida', mas são atos que se seguem ao próprio viver:

"não se julga por esses atos que um tal ente viva senão porque eles pressupõem a vida e o viver, de que eles são signos manifestos para nós. Pois, ainda que tais atos sejam todos atos segundos em qualquer vivente, é necessário que sustentemos que o 'viver' precede, nos viventes, todos os atos segundos"19.

Como se vê, busca-se aqui explicar pela distinção entre atos primeiros e atos segundos tanto a relação entre aquele movimento/operação que percebemos em um ser, como a vida/viver que lhe atribuímos ao percebê-los. Ao 'viver' cabe a caracterização como um ato anterior, enquanto que àquele movimento/operação resta a denominação como ato segundo. O interessante é que somente este último é patente para nós, de maneira que é unicamente por sabermos que tais atos segundos de uma coisa pressupõem um ato primeiro que é 'viver', que concluímos, daqueles atos segundos, que esta coisa vive. Para compreendermos o que são esses atos segundos, será necessário atentar para dois elementos daquela formulação inicial: a descrição deles como 'operações' (operatio) e 'movimentos' (motus).

Se avançarmos para Suma, art. 39, q. 8, leremos que "a operação, propriamente, é um ato perfeito da coisa existente em seu ato perfeito [actus perfectus rei existentis in actu suo perfecto] e é próprio a cada um segundo sua espécie <... $>$. Donde a operação ser a perfeição de algo que existe em ser perfeito, como 'sentir' é a operação do sentido existente segundo o ato do sensitivo e 'inteligir' é a operação do

\footnotetext{
${ }^{18}$ Cf., acima, nota 12.

${ }^{19}$ Henrique de Gand, Suma, art. 27, q. 1, co. (ed. Teske, p. 140): "Non autem per huiusmodi actus tale ens iudicatur vivere nisi quia praesupponunt vitam et vivere, cuius ipsi sunt signa nobis manifesta. Quare cum huiusmodi actus sunt omnes actus secundi in quolibet vivente, necesse est quod vivere ponamus praecedere in vivente omnes actus secundos".
} 


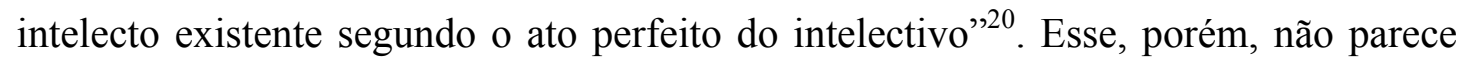
ser o caso daquelas operações que percebemos em algo, pois estas são ditas também motus por Henrique. De fato, se considerarmos que motus pode ser igualado à motio, chegamos a um grave problema, pois “convenientemente tomando 'fazer' [factio], ambos, 'movimento' [motio] e 'mutação' [mutatio], são certos 'fazeres' [factiones quaedam], pelos quais se faz [fit], por um movente ou mutador, em algo outro que não ele, uma disposição que antes não era. De fato, o mesmo enquanto mesmo não transmuta algo em si próprio. E, quando essa disposição é introduzida não toda simultaneamente, mas sucessivamente uma parte após a outra, ela é dita 'movimento' [motio]; quando <ela é introduzida> toda simultaneamente, ela é dita 'mutação' [mutatio]"21. Ora, a operação é algo já perfeito ${ }^{22}$, enquanto que o movimento é de algo que é feito (fit) parte por parte. Está claro, portanto, que a operação exclui o movimento, uma vez que algo perfeito não necessita de qualquer disposição a mais. Porém, Henrique de Gand classifica aqueles atos segundos que percebemos nos viventes justamente como 'motus sive operatio'. Como ele pode fazê-lo?

Isso é possível quando temos em consideração a distinção entre criador e criatura. Em Deus, no qual essência, substância e operação são simplesmente o mesmo, a operação de fato é completamente dissociada de qualquer 'fazer-se' (fieri), uma vez que em algo já perfeito não cabe qualquer movimento ou mutação. Nas criaturas, por outro lado, a operação vem já associada a um fieri, ou seja, aquela

\footnotetext{
${ }^{20}$ Henrique de Gand, Suma, art. 39, q. 8, co. (ed. De Wulf-Mansion Centre, vol. 28, p. 256): “< <..> sed operatio proprie est actus perfectus rei existentis in actu suo perfecto, et est proprius unicuique secundum suam speciem $\langle\ldots>$. Unde operatio est perfectio cuiusque, existens in esse perfecto, ut est sentire operatio sensus existentis secundum actum sensitivi, et intelligere operatio intellectus existentis secundum actum perfectum intellectivi".

${ }^{21}$ Henrique de Gand, Suma, art. 39, q. 8, co. (ed. De Wulf-Mansion Centre, vol. 28, p. 254): "Sed convenienter accepta factione, ambae, scilicet et motio et mutatio, factiones quaedam sunt, quibus fit aliqua dispositio quae prius non erat, a movente et mutante in aliquid aliud ab ipso: idem enim secundum quod idem, non transmutat aliquid in se ipso. Et cum illa dispositio introducitur non tota simul, sed successive pars post partem, dicitur motio; cum vero tota simul, dicitur mutatio".

${ }^{22}$ Nesse sentido, a operatio já é uma completude ou consumação do ente em seu bem, pois algo perfectum é, para Henrique de Gand, justamente aquilo que pode ser tomado como completo ou consumado com respeito a seu bem próprio: "Sic enim perfectum addit super rationem boni simpliciter accepti rationem completionis et consummationis in bonitate, quam bonum absolute dictum non explicat suo nomine, includit tamen ipsum sicut confusum determinatum: ratio enim completionis est ratio bonitatis cuiusdam" - Suma, art. 44, q. 2, ad 2 (ed. De Wulf-Mansion Centre, vol. 29, p. 98). Cf. GILSON, É. "L'infinité divine chez saint Augustin". In: Augustinus magister. Congrès international augustinien. Paris, 21-24 septembre 1954. Vol. 1. Paris: Études Augustiniennes, 1954, pp. 569-74 (esp. pp. 573-4). Essa passagem, além disso, nos mostra que completio e perfectio devem ser compreendidos diferente: completio parece ser a atualização máxima da potência de algo, enquanto perfectio parece ser um termo especializado para a nomeação da atualização máxima da potência de algo com respeito ao bem desse algo, isto é, com respeito a seu fim (sobre a relação entre 'bem' e 'fim', cf. cap. 3, nota 43).
} 
perfeição associada à operação não é dada imediatamente no ser da criatura, mas decorre de um 'fazer-se' na criatura ${ }^{23}$. Exatamente por isso, Henrique tem o cuidado de distinguir dois modos equívocos da operação: "de fato, há uma operação que é o ato perfeito da coisa, pelo que possui ser e é seu fim em ser; e há outra operação, pela qual se adquire para a coisa sua perfeição no ser, tal que possa perfeitamente $<$ chegar> àquela operação primeira, que é sua perfeição no ser" ${ }^{\text {"24 }}$. Assim, vemos que essa operação segunda pode muito bem ser denominada motio ou motus ou, mesmo, actus (no sentido de 'agir'), pois ela é aquela ação pela qual uma coisa adquire aquilo que lhe é necessário para sua perfeição, isto é, para sua operação primeira.

Retornando, portanto, a Suma, art. 27, vemos que o 'viver' é essa operação primeira que, cada vez mais, é aperfeiçoada pelas operações segundas dos viventes. Ou seja, ao adquirir o necessário para seu ser perfeito, eles adquirem o necessário para seu viver perfeito, pois como vimos o viver não é, senão, um modo mais nobre de ser. Com isso, é possível aprofundar também aquela caracterização da 'vida' como habitus, que foi citada de passagem acima.

Se o 'viver' é o ato perfeito da coisa, mas nas criaturas esse ato não está completamente atualizado, devendo ser aperfeiçoado cada vez mais por atos segundos, fica claro que esse agir que é o 'viver' pode ser caracterizado igualmente como uma prontidão e um desembaraço (promptitudo et expeditio) para a produção de um ato - no caso, o ato perfeito de ser do vivente. Ora, essa é precisamente a caracterização do habitus ${ }^{25} \mathrm{e}$, como vimos, no vivente há a vida como habitus. Portanto, são o mesmo no vivente a prontidão e o desembaraço para viver cada vez mais perfeitamente - que não é, senão, a vida - e o próprio viver enquanto operação

\footnotetext{
${ }^{23}$ Henrique de Gand, Suma, art. 39, q. 8, ad 1 (ed. De Wulf-Mansion Centre, vol. 28, p. 258): "Et quod assumitur in argumento de prima operatione, quod 'res fit propter illam, et recipit ab ea complementum suae bonitatis', quod non convenit Deo, dicendum quod huiusmodi operatio aut est ipsa rei substantia et essentia, differens sola ratione ab ipsa, ut contingit in Deo, aut est aliquid praeter eam, ut contingit in creaturis. De prima operatione, scilicet in Deo, non intelligitur illud dictum philosophi quod exprimit per illud quod dicit, 'fit propter operationem', quia in Deo nullum cadit fieri; dicit ergo illud solum de operatione in creaturis". A interpretação que apresento desta passagem é tentativa.

${ }^{24}$ Henrique de Gand, Suma, art. 39, q. 8, ad 1 (ed. De Wulf-Mansion Centre, vol. 28, p. 257): “< ..> est enim quaedam operatio quae est actus perfectus rei, propter quod habet esse, et est finis eius in esse; est et alia operatio, qua acquiritur rei sua perfectio in esse, ut perfecte possit in illam operationem primam, quae est sua perfectio in esse".

${ }^{25}$ Henrique de Gand, Suma, art. 39, q. 8, co. (ed. De Wulf-Mansion Centre, vol. 28, pp. 145-146): "Nunc autem, cum habitus est perfectio potentiae respectu actus egredientis a potentia, et perfectionis simpliciter est in actione, quod egrediatur de potentia per habitum, quia agere ex habitu semper in unoquoque melius est et perfectius quam non agere ex habitu, quia habitus ratione qua habitus est, semper promptitudinem et expeditionem ponit in eliciendo actum $<\ldots$. ".
} 
primeira, uma vez que esta última, ainda que atualizada, é constantemente em potência a ser aperfeiçoada pelos atos segundos do vivente ${ }^{26}$.

Por fim, podemos perguntar: o que caracterizaria esses atos segundos para que, a partir deles, possamos inferir aquela operação primeira que é o viver? A resposta está ainda naquela primeira fórmula que lemos em Suma, art. 27, quando Henrique afirmava que percebemos no vivente um movimento (que, agora, sabemos ser aquelas operações segundas) "por ele mesmo, a partir dele mesmo e nele mesmo [per seipsum et ex seipso et in seipso]"27. O que caracteriza as operações segundas do vivente é que elas são movimentos pelos quais o próprio vivente busca sua própria perfeição. Ou, dito de outra maneira, somente aquilo que vive age para sua própria perfeição.

Pois bem, como não temos acesso diretamente à operação primeira que é o viver, a vida do vivente só nos é conhecida por meio de suas operações segundas. Assim, é importante notar que o grau de perfeição da operação primeira se reflete na perfeição das operações segundas, pois estas últimas se seguem do próprio ser daqueles que a produzem. Por isso, ao ver uma ação tão perfeita como a busca da própria perfeição per seipsum et ex seipso et in seipso, é possível inferir que essa coisa que assim age possui um grau de ser mais perfeito do que outras - a esse grau denominamos 'vida' ou 'viver'. Mas, dentre os viventes, há igualmente uma hierarquia, como foi notado acima. Portanto, quanto mais perfeita for a operação pela qual algo busca sua própria perfeição, mais perfeito será seu grau de ser e, portanto, seu viver:

"De fato, $<$ os entes $>$ diferem essencialmente a partir do grau de natureza e de sua essência, pela qual são aquilo que são de acordo consigo, sem qualquer

\footnotetext{
${ }^{26} \mathrm{Na}$ medida em que 'actus', em certo sentido, pode ser intercambiável com 'operatio', os pares 'operatio prima / operatio secunda' e 'actus primus / actus secundus' são igualmente intercambiáveis - Henrique de Gand Suma 28, q. 6, co. (ed. Teske, 2006, p. 220): "Actus autem a Philosopho distinguitur in secundo De anima, quod alius est sicut scientia, alius vero sicut considerare. Quorum primus est actus ut habitus, secundus vero est actus ut operari ex habitu. Primo nam modo dicitur actus forma et perfectio rei cuiuscumque. Secundo modo dicitur actus operatio ex ipsa egrediens, qui similiter duplex est. Quidam enim dicitur actus primus, quidam vero dicitur actus secundus. Actus primus dicitur ille quem forma et perfectio rei operatur in ipsa re per se, secundum quod lucis dicitur lucere et viventis vivere, et essentiae esse, qui est actus absolutus non determinatus ad aliud. Actus vero secundus dicitur operatio quam operatur forma rei sive res per suam potentiam ad aliud determinata". Ou seja, no caso dos viventes, aquele ato enquanto habitus é a 'vida', da qual se seguem os dois atos ut operari ex habitu. Destes dois últimos, o ato primeiro (operação primeira) é o próprio 'viver', enquanto que o ato segundo (operação segunda) são todos aqueles atos que aperfeiçoam o ato primeiro (operação primeira), isto é, que fazem 'viver melhor' ou 'mais perfeitamente'.

${ }^{27}$ Cf. nota 12 , acima.
} 
consideração do seu ser ou não ser efetivamente [esse vel non esse in effectu]. De fato, eles são natos a [nati sunt] participar de diversos graus de existência de acordo com os graus das essências consideradas segundo si. De fato, não há aí nenhuma diferença. E, de acordo com isso, o ser de alguns é ser simplesmente e não viver, o de alguns é o ser que <é $>$ viver $-\mathrm{e}$ isso de diversos modos, de acordo com os vários graus de vida $<\ldots>$.

Portanto, o vivente e o não vivente se distinguem essencialmente, isto é, por si e pelas próprias essências, enquanto são essências, e isso formalmente pela vida e pela carência dela, tal como por aquilo que se segue a essas essências enquanto $<$ elas> são efeitos do criador, como foi dito" ${ }^{28}$.

A distinção entre essência e existência, bem como a relação entretida por ambas são elementos fundamentais da filosofia de Henrique de Gand, os quais não poderemos desenvolver em seus pormenores aqui ${ }^{29}$. Assim, basta notar que o grau de essência determina o grau de existência, pois Deus cria as coisas de acordo com suas essências e, portanto, de acordo com seu grau de natureza ou seu grau de essência (duas expressões que Henrique, aqui, parece utilizar de maneira intercambiável). Alguns desses entes, com graus de essência e existência superiores, serão tidos por viventes - novamente, dentre estes últimos, haverá igualmente uma hierarquia de perfeição. Como era dito, é justamente porque não podemos perceber diretamente o grau de natureza próprio de cada coisa ${ }^{30}$, que se torna importante a observação final da passagem, a saber, que o vivente e o não vivente se distinguem não somente pelas suas essências, mas também "por aquilo que se segue a essas essências enquanto <elas> são efeitos do criador", isto é, ao serem criadas efetivamente e, assim, existirem. Ora, 'aquilo que se segue à essência' são, precisamente, as operações primeiras e, mais importante para nós, as operações segundas que já vimos acima. É

\footnotetext{
${ }^{28}$ Henrique de Gand, Suma, art. 27, q. 1, ad 7 (ed. Teske, pp. 156-158): “Differunt enim essentialiter ex gradu naturae et essentiae suae qua sunt id quod sunt secundum se absque omni consideratione esse vel non esse in effectu. Secundum gradus enim essentiarum secundum se consideratarum nati sunt participari diversi gradus in esse existentiae, cum fiunt effectus creatoris vel immediate vel mediante opere naturae. In hoc enim nulla est differentia, et secundum hoc quorundam esse est esse simpliciter et non vivere, quorundam est esse quod vivere, et hoc diversimode secundum diversos gradus vitae, ut in sequenti quaestione dicetur.

Quod ergo vivens et non vivens differunt essentialier, hoc est per se et per essentias ipsorum, secundum quod sint essentiae, et hoc formaliter et per vitam et eius carentiam tanquam per illa quae ipsas essentias consequuntur inquantum sunt effectus creatoris, ut dictum est".

${ }^{29}$ Sobre essência e existência, cf. nota 95, adiante.

${ }^{30}$ Mesmo porque só temos acesso diretamente a entes materiais, justamente aqueles em que a forma e a operação essecial primeira são mais ocultas - Quodl. 15, q. 8, ad 1 (ed. De Wulf-Mansion Centre, vol. 20, pp. 46-7): "Semper enim forma substantialis et eius operatio propria essentialis manifestiora sunt in illis quae sunt magis formalia et propinquiora primae formae, et sunt occultiora in illis quae sunt magis materialia et propinquiora primae materiae, quorum formae semper virtute continentur in formis eorum quae sunt magis formalia”.
} 
justamente por isso que estas últimas são signos do grau de natureza da coisa (indicando se ela vive ou não) e, podemos adicionar, no caso dos viventes, são signos do grau de perfeição da própria vida deles ${ }^{31}$. É, portanto, por essas operações segundas - pelas quais os entes atingem sua perfeição - que o Doutor Solene irá estabelecer a hierarquia da vida e dos entes em geral: “já que, segundo o que já foi determinado, diz-se que vivem os viventes por eles serem em um tal ser pelo qual possuem a força de agir algo em si mesmos e a partir de si mesmos [vim agendi aliquid in seipsa et ex seipsis], quanto mais perfeitamente isso convier a algo tanto mais perfeitamente cumprirá dizer que vive e mais perfeitamente a vida será nele”,32.

\begin{abstract}
${ }^{31}$ É, aliás, um princípio geral que as operações segundas de um ente acompanham a perfeição de sua forma em operação primeira - Henrique de Gand, Suma, art. 35, co. (ed. De Wulf-Mansion Centre, vol. 28, pp. 31-2): "Altera vero dicitur potentia activa, cui respondet actus secundus, qui est operatio egrediens a forma, qua res est aliquid existens in actu primo. Unde, quanto aliquid magis perfectum est secundum formam et essentiam in actu primo, tanto magis convenit ei operari et agere in actu secundo et esse principium activum". Assim, quanto mais perfeita a forma (em ato primeiro) de um ente, mais operações (atos segundos) dirão respeito a ele. Precisamente porque as operações segundas se seguem da operação primeira - isto é, do ato da forma ou essência -, embora não se confundam com ela, Henrique de Gand considera que tanto a operação primeira como as operações segundas podem ser ditas 'essenciais' (essentiale) a um ente, desde que tomemos o adjetivo essentiale em dois sentidos distintos. De um primeiro modo, é essentiale aquilo que é da substância da coisa (esse essentiale é expresso por uma proposição per se primo modo, em especial por uma definição ou parte desta) Quodl. 15, q. 9, ad 1 (ed. De Wulf-Mansion Centre, vol. 20, p. 55): “<..> dico quod est essentiale quoddam iuxta primum modum dicendi per se, et aliud iuxta modum secundum. Et essentiale rei primo modo vocatur substantiale eidem, quod non est nisi definitio tota aut pars definitionis rei". Do segundo modo, o essentiale não é substancial, mas acidental, fora da substância e de sua definição, muito embora seja uma operação - um ato segundo - que convém a uma coisa em razão de sua forma substância (isto é, em razão daquilo que lhe é essentiale do primeiro modo) - Quodl. 15, q. 9, ad 1 (ed. De Wulf-Mansion Centre, vol. 20, p. 56): "Essentiale autem rei secundo modo non est ei substantiale, sed accidentale, et bene est extra substantiam rei et extra illud quod est ei essentiale primo modo. Aliter enim non esset accidentale, quale essentiale est propria passio respectu sui proprii subiecti $<\ldots>$. Non enim comprehenditur sub essentia rei quae est ratio indicativa eius quod est de illa, et tale essentiale rei est quaecumque operatio eius quae convenit ei ratione suae formae substantialis, quae est actus eius secundus, maxime circa suum proprium per se et primum essentiale obiectum". A observação final desta passagem deixa claro que é dito essentiale desse segundo modo principalmente aquela operação segunda que convém a uma coisa em razão da sua essência e com respeito a seu objeto próprio. Essa última adição é relevante, porque Henrique distingue [i] atos segundos independentes de algo externo, que nunca podem faltar a uma dada essência (como o luzir do lume) e [ii] atos segundos que dependem de um objeto externo - Quodl. 7, q. 15, co. (ed. De Wulf-Mansion Centre, vol. 11, p. 107): "Est autem actus secundus operatio debita illi formae; quae duplex potest esse: vel independens ab aliquo extra, vel ab illo ut ab obiecto dependens", ao que se adiciona na mesma página que o ato segundo do primeiro modo "non potest abesse formae cui debetur, quemadmodum lucere non potest abesse luci vel lucido, aut calere calori aut calido". É principalmente esse segundo caso de ato segundo (isto é, o ato segundo com respeito a um objeto externo) que é dito essentiale do segundo modo. Em resumo, tão relacionados são operação primeira e operação segunda que ambas - cada uma a seu modo - podem ser ditas algo essentiale àquela coisa de que são operações.
\end{abstract}

${ }^{32}$ Henrique de Gand, Suma, art. 27, q. 2, co. (ed. Teske, p. 168): “< $<>$ Cum secundum iam determinata vivere dicantur viventia ex eo quod sunt in tali esse quod habeant vim agendi aliquid in seipsa et ex seipsis, quanto igitur hoc perfectius alicui convenit, tanto perfectius dicendum est vivere et perfectior vita ei inesse". 
O princípio para o reconhecimento da perfeição de agir 'em si mesmo e a partir de si mesmo' é simples: “tanto mais perfeitamente possui a força de agir e operar [vim agendi et operandi] a partir de si mesmo e em si mesmo [ex seipso et in seipso], quanto menos dependência essa força de agir tiver de outro como de um movente primeiro que move, como de um fim do movimento ou como de um impelente ao movimento [impellens in motum]"33. Portanto, o que se faz aqui é avaliar, primeiro, se um ente se move a si por si e a partir de si mesmo para, caso ele o faça, buscar saber se ele depende de algo outro para tanto e em que medida há uma tal dependência. Eis o resultado dessa pesquisa:

1. No ponto mais baixo da ordenação, temos aqueles entes que são capazes de se mover em direção a um fim, mas o fazem sem qualquer apreensão desse mesmo fim. Eles são impulsionados por algo outro que não eles mesmos e agem, determinados por sua forma e natureza, em direção ao fim, mas não conhecem este último. Há dois gêneros destes entes:

1.1. Um primeiro caso são aqueles que possuem uma força para mover a si mesmos, mas só o fazem por acidente - tal como os pesados, ao serem movidos por outro para cima, tendem naturalmente para baixo. Esse é o caso daqueles que se movem somente se estiverem fora de seu lugar natural e, quando atingem este último, deixam de poder se mover. Estes são aqueles que se movem a partir de si, mas por acidente (ex seipsis, sed per accidens) e são ditos 'inanimados' (inanimata) - portanto, não vivem.

1.2. Por outro lado, temos também aqui aqueles que se movem a partir de si e por si (ex se et per seipsa), sem entretanto apreender o fim desse movimento. Esses entes possuem um princípio pelo qual se movem pela atração do alimento para se nutrir, aumentam e diminuem (a principio intra movent seipsa attractione alimenti, nutritione, augmento, et diminutione). Aqui temos o mais baixo grau de vida (infimus gradus vitae) e esses entes são chamados de 'plantas' (plantae).

\footnotetext{
${ }^{33}$ Henrique de Gand, Suma, art. 27, q. 2, co. (ed. Teske, p. 168): "Tanto autem perfectius habet vim agendi et operandi ex seipso et in seipso, quanto vim agendi habet minus dependentem ab alio tanquam a movente primo qui movet, aut sicut finis motus, aut sicut impellens in motum".
} 
2. Em seguida, há aqueles entes que, ainda que impulsionados por algo outro e determinados por sua natureza, possuem a força de se mover a partir de si e por si (ex se et per se) e, para além disso, possuem uma apreensão do fim e um desejo para perseguir ou um temor para fugir (cum apprehensione finis et appetitu concupiscentiae ad prosequendum, vel timoris ad fugiendum). Nesses entes, o fim só provoca o movimento enquanto é apreendido, sendo essa apreensão sensorial (apprehensio sensus). Esse é o caso daqueles que Henrique denomina como 'animais brutos' (bruta animalia). Possuindo um segundo grau de vida (secundum gradum vitae), há dentre eles diferentes graus de perfeição:

2.1. Alguns deles estão, a bem dizer, no meio do caminho entre aqueles que se movem ex se et per seipsa sem apreensão e aqueles que se movem ex se et per seipsa com apreensão - isto é, entre as plantas e os animais brutos. Aqui, temos seres intermediários que participam da vida de ambos, os quais Henrique denomina 'conchas' (conchylia). Para ele, esses seres têm um mínimo de apreensão (o que os aproxima dos brutos), porém não possuem movimento progressivo (o que os aproxima das plantas). Justamente por não se moverem, eles só possuem sentidos que exigem proximidade, como o tato e o paladar.

2.2. Outros são, de fato, capazes de perseguir seu objeto por desejo (per concupiscentiam) ou de dele fugir por temor (isto é, estes possuem movimento progressivo). Por isso mesmo, eles possuem apreensões sensíveis que lhes permitem conhecer seu objeto à distância, como a visão, a audição e o olfato (além do tato e do paladar, que também as conchas possuíam). Eles possuem um grau de vida ainda superior ao das conchas, porém eles agem por natureza, necessariamente, movidos pelo impulso produzido pela apreensão sensível do objeto.

3. Sendo assim, o caso seguinte é, precisamente, daqueles entes que possuem um princípio pelo qual movem a si e, dessa vez, o fazem sem qualquer impulso por parte de algo outro e sem qualquer determinação de sua forma e natureza. Como vemos, esses entes agem livremente (libere), uma vez que não somente conhecem seu fim pelos sentidos, mas principalmente $o$ apreendem racionalmente. Sendo racionais, eles podem se direcionar ou se afastar de seu fim por livre escolha (per liberam electionem). O problema 
deles é que, justamente, não o podem fazer por um ato de intelecção simples, mas devem discorrer por um raciocínio para se mover. Esses são os homens (homines) e possuem o grau de vida dos racionais, a vita rationalium ${ }^{34}$.

4. Por isso mesmo, são superiores aos homens aqueles entes que, mais do que racionais, são intelectuais (intellectualia). Estes são os anjos (angeli) e possuem um grau de vida maior precisamente porque, sem qualquer necessidade de discurso, escolhem livremente o seu movimento. Nos anjos, a mera apreensão intelectual já traz consigo o movimento do apetite pelo bom (movetur appetitus sub ratione boni). Como se vê, no entanto, o próprio anjo ainda precisa apreender outro que não ele mesmo para se mover.

5. Resta que o grau supremo de vida (debet dici vivere summo gradu) pertença àquele que se move sem apreender nada senão ele próprio e, portanto, sem possuir qualquer fim externo a ele. Este é Deus, para o qual, como já dissemos acima de passagem, viver e ser são o mesmo, já que ele é seu próprio ato perfeito de ser - de fato, a vida é a própria essência de Deus (ipse non est nisi vita quae est sua essentia $)^{35}$.

Essa ordenação dos viventes proposta por Henrique de Gand possui dois elementos de enorme importância para nós. O primeiro deles aqui é o fato de que, embora Deus surja necessariamente como o último elemento na enumeração da ordenação (aliás, justamente porque ele só pode ser conhecido como vivente depois de conhecermos as criaturas como tal $)^{36}$, ele é o próprio lastro de toda ordem dos

\footnotetext{
${ }^{34}$ Notemos que, aqui, não se leva em consideração os diversos status do homem - e isso não somente no que diz respeito à distinção entre vir e foemina (que vimos, acima, na nota 3), mas também no que tange à distinção entre o homem no estado presente ou no estado glorioso (cf. cap. 6, notas 122-123). Com efeito, se o grau do 'viver' se segue ao modo de ser e à essência do vivente, a hierarquia dos viventes não pode dizer respeito aos diversos estados de uma mesma essência, mas somente à própria essência sem consideração a respeito de seus diversos estados possíveis.

${ }^{35}$ Toda essa hierarquia dos viventes pode ser lida em: Henrique de Gand, Suma, art. 27, q. 2, co. (ed. Teske, pp. 170-174). Um resumo de tal hierarquia em poucas linhas pode ser encontrado na passagem citada na nota 55 , adiante.

${ }^{36} \mathrm{Com}$ efeito, todo o conhecimento teológico parte do conhecimento filosófico ou, dito de modo mais geral, todo conhecimento acerca do sobrenatural parte de um conhecimento acerca do natural. Isso é válido mesmo no que diz respeito ao uso de palavras na teologia - Henrique de Gand, Suma, art. 20, q. 1, co. (ed. 1642-3, p. 300, n. 6): "Dicendum igitur absolute, quod ista scientia de Deo, et de rebus divinis uti non debet nisi sermone humano, nec potest, ut videlicet loquatur homini de rebus supernaturalibus, et doceat scientiam supernaturalem per sermonem de rebus naturaliter cognitis, transferendo scilicet nos a naturalibus nobis notis ad supernaturalia naturaliter nobis ignota". O termo transferendo é chave nesta passagem, pois ele também será utilizado para se falar na translatio dos nomes da significação de algo natural para a significação de algo sobrenatural - Suma, art. 20, q. 1, ad
} 
viventes no universo. Por isso, logo após apresentar essa hierarquia, Henrique pode afirmar que "ele $<s c$. Deus> não é senão a vida que é a sua essência e toda outra vida foi participada, por ele, na essência da criatura" ${ }^{\text {37 }}$. Atentemos para o uso do verbo

$1 \&$ 2, nn. 8-9 (ed. 1642-3, p. 301). Ora, é precisamente uma tal translatio que ocorre no caso dos termos vita e vivere nos trechos de Suma, art. 27, que viemos lendo até aqui - primeiro busca-se compreender bem o uso dos termos com respeito a coisas naturais para, em seguida, transferi-lo para o uso com respeito ao sobrenatural. Os diversos modos de realizar tal transferência são estudados em Suma, arts. 73-5 e foram cuidadosamente analisados por Irène Rosier-Catach, nos textos citados acima, no cap. 1, nota 35 (cf. tb. os artigos de Schinzer e Ashworth, citados na mesma nota). Mais precisamente sobre a significação e a imposição de nomes no discurso teológico, cf. SPRUYT, J. "Henry of Ghent on Teaching Theology". Vivarium 49 (2011), pp. 105-83; TESKE, R. J. "Henry of Ghent's Apophatic Theology". In: TESKE, Essays on the Philosophy of Henry of Ghent, 2012, pp. 221-46; SPRUYT, J. "Henry of Ghent and the Power of Inspiration. A Chapter in Neoplatonism". PsyArt 19 (2015), pp. 68-84 (esp. pp. 70-4). Para mais informações sobre a linguagem teológica - e, em especial, sobre a importância de termos sincategoremáticos nesta última - em Henrique de Gand, cf. SPRUYT, J. "Henry of Ghent on the Use of Denials (a Chapter in the History of Negation)". Mediaevalia. Textos e estudos 7-8 (1995), pp. 441-71; SPRUYT, J. "Henricus Gandavensi. Mind Your Language! Henry of Ghent's Overzelous Attention to Linguistic Details". In: ANGOTTI, C., BRÎNZEI, M., TEEUWEN, M. (éds.). Portraits de maîtres offerts à Olga Weijers. Turnhout: Brepols, 2013, pp. 233-40.

${ }^{37}$ Henrique de Gand, Suma, art. 27, q. 2, co. (ed. Teske, p. 174): “< $<>$ ipse non est nisi vita quae est sua essentia et omnis alia vita ab ipso participata est in essentia creaturae, quia ex se non est vita, sed vivens per vitam, ut patet ex praecedenti quaestione". Atentemos para o uso da expressão "vivens per vitam' nesse trecho. Na nota 15, acima, vimos que "non proprie dicitur quod vivere est a vita, sed vita, sicut non proprie dicitur quod currere est a cursu, sed cursus". Ou seja, nesse trecho de Suma, art. 27, q. 1, é dito que 'vivere' e 'vita' (que está no nominativo e não no ablativo, como se vê pelo exemplo do 'cursus') são idênticos: 'viver' não é 'a vita', mas 'viver' é 'vida'. No excerto citado nesta nota, por outro lado, é dito justamente que o vivente é 'vivente é pela vida' (vivens per vitam). Como conciliar as duas afirmações? Acredito que a solução para este problema possa ser encontrada na citação da nota 15 , onde vemos que 'viver' e 'vida', sendo idênticos, significam distintamente a mesma operação primeira do ser, a saber, enquanto ato e enquanto hábito, respectivamente. Como vimos na nota 26 , toda operação (primeira ou segunda) é um 'operari ex habitu', de maneira que o 'viver', sendo idêntico à 'vida', é também 'ex vita'. Talvez, ao afirmar na presente nota que o 'vivens est per vitam', Henrique esteja simplesmente fazendo uma referência a esta necessária relação nutrida entre a operação (no caso, a operação primeira de viver) e o habitus da vida: embora ambos sejam idênticos, um é per alterum ou ex altero - o viver é ex vita ou, o que seria o mesmo nesse caso, per vitam. Se essa interpretação for correta, é interessante notar como as preposições 'a/ab', 'per' e 'elex' se tornam marcadores lógicometafísicos relevantes no discurso do Doutor Solene, pois enquanto a relação de anterioridade do hábito da 'vida' com respeito à operação primeira que é o 'viver' pode ser expressa com as preposições 'elex' e 'per', o uso da preposição 'a/ab' é claramente descartado nesse contexto. Voltando ao trecho da nota 15 , vemos que o uso da preposição ' $a / a b$ ' é recusado neste contexto por ela, segundo Henrique, denotar "mais a circunstância de causa eficiente do que formal [magis notat circunstantiam causae efficientis quam formalis]". O termo circunstantia, aqui, é de grande relevância, pois para o Doutor Solene cada uma dessas preposições que vimos aqui se caracteriza justamente por denotar 'circunstâncias' distintas.

Jerome V. Brown (Divine Illumination and the Theory of Knowledge in the Philosophy of Henry of Ghent. A thesis submitted in conformity with the requirements for the degree of Doctor of Philosophy in the University of Toronto, 1969, pp. 158-9, nt. 7) chama a atenção para a maneira como essa tese é desenvolvida em Suma, art. 54. De fato, lemos em Suma, art. 54, q. 3, ad 5 (ed. De Wulf-Mansion Centre, vol. 31, p. 207): "Et est hic advertendum ad pleniorem intellectum praedictorum quod hae tres praepositiones 'a', 'ab', 'de' et 'ex', si proprie usitentur, diversas circumstantias et habitudines nominant, licet pro invicem saepius assumuntur $<\ldots$.. ’. A isso se segue um pequeno dicionário de preposições. [i] ' $a / a b$ ' denota a circunstância de causa eficiente ou de princípio donde se tem origem e, portanto, também circunstância de efeito e principiado - “"a' praepositio notat circumstantiam et habitudinem causae efficientis sive principii originantis $<\ldots>$. 'Ab' vero notat circumstantiam effectus sive principiati $<\ldots$.. ” (ibid.). [ii] 'ex' e 'de' denotam a circunstância de causa material e eficiente ou 
'participar' que surge como pretérito perfeito passivo (participata est), com o agente da passiva ( $a$ b ipso) sendo Deus. Ou seja, não são as criaturas que participam da vida de Deus, este é que lhes dá a vida ao lhes participar o viver. Enfim, Deus é o último elemento que encontramos em nossa pesquisa, mas é o primeiro na ordem do mundo - algo que também está presente em outras ordenações hierárquicas que encontraremos no presente trabalho.

Para finalizar o estudo dessa hierarquia dos entes vivos, ressalto o segundo elemento importante nela. Este é aquele que deverá prender nossa atenção. Pois bem, se observarmos corretamente, veremos que há, de fato, cinco graus nessa ordenação (desconsiderando as subdivisões do primeiro e do segundo graus). Ora, está claro que o homem está precisamente no meio desse universo - ele é o terceiro degrau na hierarquia de cinco etapas dos graus de perfeição da vida. Isso condiz completamente com aquela concepção de homem como o horizonte e os confins entre os superiores espirituais e os inferiores corpóreos, que lemos no início deste capítulo. De fato, o homem surge aqui como o grau médio de vida: ele apreende intelectualmente e é livre, mas precisa raciocinar para se mover. Ele compartilha os sentidos com os animais, mas compartilha o intelecto com os anjos. Enfim, ele é ser intermediário, pois ele vive com alma e corpo, sendo o superior dentre os corpóreos e o inferior dentre os espirituais.

Tendo visto onde o homem - esse ser como que duplo - se localiza na ordem do mundo, precisamos agora compreender como esse caráter intermediário determina

como que eficiente. No entanto, eles diferem porque, no que diz respeito à causa material, 'de' denota tanto a circunstância da matéria que é distinta realmente da forma (como na preposição 'a faca é de ferro'), como a circunstância da matéria que é idêntica realmente à forma (como na preposição 'a espécie é do gênero'), enquanto que 'ex' denota a matéria somente enquanto distinta realmente da forma ('a faca é ex ferro', mas não é possível a preposição 'a espécie é ex genere'). Além disso, 'ex' e ' $d e$ ' também se distinguem no que tange à circunstância da causa eficiente, pois ' $e x$ ' denota tanto uma origem substancial como uma origem não substancial (pode-se dizer que 'o filho é ex patre' e que 'a casa é ex artifice'), porém 'de' denota somente a origem substancial (pode-se dizer 'o filho é do pai', mas não 'a casa é do artífice' - em português, pelo menos, não no mesmo sentido) - “'De' vero et 'ex' communiter notat circumstantiam causae materialis et efficientis vel quasi $\langle\ldots>$. Sed differunt aliquantulum tam in circumstantia materiali quam in circumstantia causae efficientis vel quasi. In circumstantia enim materiali differunt, quia 'de' indifferenter et aeque proprie notat circumstantiam materiae quae est aliud re a forma eius quod ex ipsa producitur, et illius quae non est aliud re ab illa. Unde dicitur proprie aeque quod cultellus est de ferro et quod species est de genere. 'Ex' vero proprie notat circumstantiam materiae primo modo, non secundo. Unde magis proprie dicitur 'cultellus est ex ferro' quam 'species est ex genere' <... . Differunt etiam in circumstantia causae efficientis sive originantis, quia ex aliquo dicitur sive res sit de illius substantia sive non. Bene enim dicitur, quia filius est ex patre et domus ex artifice. 'De' vero solum dicitur quando alterum de substantia alterius; unde proprie dicitur quod filius est de patre, non autem quod domus est de artifice” (ed. De Wulf-Mansion Centre, vol. 31, pp. 207-8). Esse dicionário de preposições voltará a nos ser importante mais adiante. 
o seu ser, tornando-o justamente essa união de corpo e espírito. Para tanto, deveremos reler a hierarquia da vida à luz daquela que lemos em Suma, art. 39, e que avança desde a matéria primeira no mais baixo das criaturas até a forma primeira que é Deus $^{38}$.

\subsection{CORPO E ALMA}

\subsubsection{A necessidade da conjunção entre corpo e alma}

Se juntarmos as duas hierarquias, vemos que o homem com seu grau de vida exatamente intermediário deve, igualmente, estar em um ponto médio entre a matéria primeira e a forma primeira. Mas que conclusões podemos obter daí? Formulando os dados dessa maneira, não muitas. Agora, se nos voltarmos para Quodl. 3, q. 14, o tema se torna mais instigante.

Nesse texto, vemos Henrique de Gand desenvolver mais uma vez essa sua ordenação do mundo, porém agora ele o faz do ponto de vista da potencialidade. Assim, em um ponto mais baixo da hierarquia temos uma potência puramente passiva e, no outro extremo, uma potência puramente ativa. Vejamos alguns trechos da longa formulação dessa ordem das potências do universo:

“<..> segundo o Filósofo, em Metafísica 5 e 9, o gênero das potências é duplo, a elas toda potência se reduz [omnis potentia habet reduci], a saber, a potência ativa e a passiva. De fato, elas em alguns são puras como em extremos [tanquam in extremis], nos quais elas são encontradas primeiro e por si. Porém, em alguns, misturadas [permixtae], como em meios [tanquam in mediis], nos quais se encontram secundariamente por uma atribuição àqueles primeiros" ${ }^{39}$.

Resumindo em poucas palavras um longo desenvolvimento no qual as teses propostas nesse excerto são expandidas, a primeira potência ativa é o agente primeiro, no qual a essência é a própria atividade - ora, vemos que esse é Deus. No outro extremo, temos a potência passiva pura, que não é senão a matéria primeira,

\footnotetext{
${ }^{38} \mathrm{Cf}$., acima, nota 5 .

${ }^{39}$ Henrique de Gand, Quodl. 3, q. 14, co. (ed. 1613, f. 107vb): “< ..> secundum Philosophum in 5 et 9 Metaphysicae, duplex est genus potentiarum, ad quas omnis potentia habet reduci, potentia scilicet activa, et passiva. Quae quidem in aliquibus sunt purae tanquam in extremis, in quibus inveniuntur primo, et per se. In aliquibus autem permixtae, tanquam in mediis, in quibus inveniuntur secundario per attributionem quandam ad illa prima". Uma tese semelhante se lê em Suma 28, q. 6, co. (ed. Teske, 2006, p. 222): "Potentia vero distinguitur prima divisione in potentiam activam et passivam $<\ldots$..".
} 
puramente receptiva ${ }^{40}$. O que mais nos importa, entretanto, são os entes intermediários entre os dois extremos de passividade e atividade. Nesses meios entre a

${ }^{40}$ Da afirmação de que a matéria primeira é puramente receptiva ou de que ela é a inferior dentre as
criaturas (cf. nota 5) não se deve concluir sua absoluta passividade ou potencialidade - Quodl. 1, q. 10, co. (ed. De Wulf-Mansion Centre, vol. 5, p. 63): "oportet excludere falsam imaginationem quam habent quidam de materia, videlicet quod nihil sit nisi potentia quaedam et ita, quantum est de se, non est, quia quod solum est in potentia, in quantum huiusmodi, non est, ita quod in sui natura tantum appropinquat non enti, quod si careat forma, statim cadat in non ens". A resposta de Henrique de Gand a essa posição que ele recusa é, em resumo, afirmar que a matéria é 'quase nada' (prope nihil), pois ela é "um meio entre o ente em ato perfeito sob a forma e o não ente; ainda assim, ela é algo em sua natureza [Et quamquam materia ita sit prope nihil, quod sit media inter ens actu perfectum sub forma et non ens, ipsa tamen in sua natura aliquid est <..> ]" (p. 64). Ou seja, a resposta de nosso autor é afirmar que há um meio termo entre 'não ser' e 'ser perfeitamente possuindo uma forma', a saber: ser algo em natureza, mas sem forma. Este último é precisamente o caso da matéria primeira. Daí Henrique poder afirmar que a matéria é "certa natureza e substância que é capacitada para as formas [capax formarum] e não possui seu ser, pelo qual é algo capacitado para as formas, a partir de uma forma, mas a partir de Deus, e mais imediatamente do que a própria forma $<\ldots>[<\ldots>$ aliqua natura et substantia quae est capax formarum, differens per essentiam a forma, nec habet esse suum quo est quid capax formarum, a forma sed a Deo, et immediatius quam forma ipsa <..>]" (p. 66). De fato, a criação propriamente é a criação da matéria, enquanto que a produção das formas na matéria durante a criação pode ser mais propriamente descrição simplesmento como formatio - "ipsarum formarum productio quodam modo magis proprie poterit dici formatio quaedam de ipsa materia quam creatio" (p. 66). Como vemos, a matéria primeira possui uma essência própria que a caracteriza precisamente como algo capaz de receber formas. Daí que no composto (cf., adiante, nota 55), ainda que haja uma identidade entre o ser e a unidade do composto, de certa maneira seja possível afirmar que a forma e a matéria mantêm, cada qual, uma sua unidade própria. Ocorre, entretanto, que a unidade e o ser da forma se sobrepõem à matéria no composto, o que resulta no ser uno deste último. Essa sobreposição, entretanto, não anula nenhuma das partes do composto, de maneira que cada uma continue a reter seu ser próprio - Quodl. 10, q. 8, co. (ed. De Wulf-Mansion Centre, vol. 14, pp. 207-8): “Cum ergo in rebus esse et unum eiusdem sunt rationis, sicut nullus potest dicere quod in uno composito ex pluribus non sit alia unitas quam una quae est totius compositi ex pluribus, immo materia et forma et quaecumque sunt in illo sub unitate illius, retinent suas proprias unitates et per unitatem eius quod est formale et principale in illo, causant unitatem totius, sic nullus potest dicere quod in uno composito ex pluribus non sit aliud esse quam unum quod est totius, immo materia et forma et quaecumque sunt in illo, sub esse illius retinent sua propria esse, et per esse principalis et formalis in illo causant esse totius". Sobre este trecho, cf. KÖNIG-PRALONG, C. Avènement de l'aristotélisme en terre chétienne. Paris: Vrin, 2005, p. 155. Como mostrado por Mário Santigo de Carvalho, há também na Lectura ordinaria de Henrique sobre o Gênesis um interessante discurso acerca da matéria primeira e sua relação com a criação (sobre isso, cf. CARVALHO, A Novidade do Mundo, 2001, pp. 354-66). Há uma interessante bibliografia a respeito do tema em Henrique de Gand: WULF, Études sur Henri de Gand, 1894, pp. 45-53; MACKEN, R. "La subsistence de la matière première selon Henri de Gand". In: POMPEI, A. (ed.). San Bonaventura. Maestro di vita franciscana di sapienza cristiana. Vol. 3. Roma: Pontificia Facoltà Teologica 'San Bonaventura', 1976, pp. 107-15; MACKEN, R. "Le statut de la matière première dans la philosophie d'Henri de Gand". Recherches de théologie ancienne et médiévale 46 (1979), pp. 130-82; McALEER, G. J. “Augustinian Interpretations of Averroes with Respect to the Status of Prime Matter". The Modern Schoolman 73.2 (1996), pp. 159-72; CARVALHO, M. A. S. "A essência da matéria prima em Averróis latino (com uma referência a Henrique de Gand)". Revista Portuguesa de Filosofia 52 (1996), pp. 197-221; WILSON, G. A. "Henry of Ghent's Quodlibet I: Initial Departures from Thomas Aquinas". History of Philosophy Quarterly 16.2 (1999), pp. 167-80 (esp. pp. 175-6); CARVALHO, M. A. S. A Novidade do Mundo, 2001, pp. 353-86; PÉREZ-ESTÉVEZ, A. "La materia en Enrique de Gante". Revista Española de Filosofía Medieval 8 (2001), pp. 155-75; PÉREZ-ESTÉVEZ, A. "La materia primera de Enrique de Gante vista por Duns Escoto". Revista Española de Filosofia Medieval 14 (2007), pp. 33-46; KÖNIG-PRALONG, Avènement de l'aristotélisme en terre chétienne, 2005, pp. 151-6. Sobre aspectos religiosos e teológicos da especulação de Henrique de Gand acerca da matéria e dos entes materiais, cf. GENSLER, M. "Fides et ratio. Wiara a rozum w 'kwodlibetach' Henryka z Gandawy". Studia Warmińskie 37 (2000), pp. 141-50. 
potência pura passiva e a potência pura ativa o que há são entes que participam de ambas, sendo passivos e ativos. Como se nota, o Doutor Solene pode, com essas noções, propor uma ordenação de todo o mundo, que o perpassa de um extremo ao outro sob o ponto de vista da potencialidade dos entes que há nele. E essa hierarquia se organiza de uma maneira muito simples: quanto mais ativo um ente, mais próximo ele estará da potência pura ativa e menos potencialidade ele terá; por outro lado, se ele for mais passivo do que ativo, ele estará mais próximo da matéria primeira do que do criador $^{41}$.

Nesse ponto, já está claro para nós o papel intermediário preenchido pelo homem na ordenação do mundo e, como vemos, os entes intermediários são precisamente aqueles que participam tanto da atividade como da passividade. Assim, o lugar do homem no mundo deverá ser descrito e compreendido em termos de suas potencialidades e de suas possíveis atualizações. Uma dessas potencialidades, como vimos no primeiro capítulo, é precisamente a possibilidade de ter ciência, seja pelos sentidos ou pelo intelecto (scire large accepto). Já lemos também em Henrique que o conhecimento sensitivo e o intelectivo são justamente aquilo que determina o grau de ser do homem ou, mais precisamente, o seu grau de vida na hierarquia do universo. Destarte, não será de maneira alguma surpreendente que essa potencialidade do homem igualmente determine o seu caráter duplo, isto é, a uma só vez corpóreo e espiritual. De fato, é precisamente isso que o Doutor Solene parece querer defender:

\begin{abstract}
“< ..> algumas potências da alma são ditas 'não ligadas a órgão' [organo non alligatae], enquanto algumas são ditas 'ligadas' [alligatae]. Isso não ocorre de algum modo da parte da potência, enquanto ela se funda na própria substância, pois toda substância da alma - que, na coisa [re], é todas as potências dela - é ato e perfeição de todo corpo, tal que também seja perfeição substancial para o órgão enquanto é corpo $<\ldots$. .
\end{abstract}

\footnotetext{
Por fim, lembremos que Henrique de Gand rejeita a ocorrência de matéria nas substâncias intelectuais (o que ficará claro durante nossa presente discussão sobre a relação entre a alma e o corpo no composto humano). A composição que há nos entes espirituais é aquela entre algo tal qual matéria (algo de potencial) e algo tal qual forma (algo de atual) - Quodl. 4, q. 16, co. (ed. De Wulf-Mansion Centre, vol. 8, pp. 299-300): "Haec est ergo vera via probandi immaterialitatem naturae intellectualis. Unde etiamsi compositio in ea inveniatur, illa non est ex materia et forma, sed ex aliquo se habente ad modum materiae et aliquo se habente ad modum formae, in quantum omnis creatura deficit a divina simplicitate $<\ldots>$ ". Sobre a discussão acerca da matéria espiritual em Henrique de Gand, cf. SUlliVAN, M. B. The Debate over Spiritual Matter in the Late Thirteenth Century: Gonsalvus Hispanus and the Franciscan Tradition from Bonaventure to Scotus. A dissertation submitted to the Faculty of the School of Philosophy of the Catholic University of America in Partial Fulfillment of the Requirements for the Degree Doctor of Philosophy. Washington D.C., 2010 (cf. pp. 218-39).

${ }^{41}$ Cf. Henrique de Gand, Quodl. 3, q. 14, co. (ed. 1613, f. 107vb-108vb).
} 
A alma não é [adest] somente na massa total do seu corpo [universae moli corporis sui], mas também em cada partícula do corpo [unicuique particulae corporis]; nem, de quanto há em si, algo seu se liga mais a uma partícula do corpo do que a outra. Mas, quando se diz que possui algumas partes ligadas ao corpo e uma parte não ligada, isso ocorre, porque algumas delas - como todas as potências sensitivas - se determinam na própria substância, pela razão e disposição do órgão, para suas operações, embora a potência intelectiva não o faça (mas o faz por algo outro, como ficará patente abaixo). Por isso, diz-se que as potências intelectivas, que são a própria substância da alma, enquanto se determinam de acordo consigo para elicitar operações intelectuais [ad eliciendum operationes intellectuales], são não ligadas a órgão. Porém, diz-se que as potências sensitivas, que similarmente são a própria potência da alma, enquanto se determinam por disposições do órgão para elicitar as operações sensíveis [ad eliciendum operationes sensuales], são ligadas a órgão. E, enquanto são natas a [nata] se diversificarem de diversos modos por diversos órgãos, por isso se distinguem em diversas potências sensitivas, sem qualquer diversidade delas entre si ou para com as potências intelectivas, enquanto possuem o radicarem-se na substância da alma, que de nenhum modo, quanto a si [quantum est ex se], se distingue ou determina para atos de sentir ou de inteligir determinados $<\ldots>$.. 42 .

Podemos notar que há aqui uma clara oposição entre as potências da alma e as operações dessas potências. As potências da alma possuem uma unidade substancial nesta última, uma unidade in re - e isso vale igualmente para a vegetativa, a sensitiva e a intelectiva ${ }^{43}$, ainda que na presente discussão a ênfase recaia sobre as duas últimas. De fato, o próprio termo 'partes' (partes) utilizado por Henrique não deve levar a crer que haja aqui uma distinção real interna à alma. Pelo contrário, a alma é

\footnotetext{
${ }^{42}$ Henrique de Gand, Quodl. 3, q. 14, co. (ed. 1613, ff. 109vb-110ra): “<...> potentiae animae quaedam dicuntur organo non alligatae, quaedam vero dicuntur alligatae, hoc non contingit aliquo modo ex parte potentiae, ut fundatur in ipsa substantia, quia tota substantia animae, quae re est omnes eius potentiae, actus est et perfectio totius corporis, ita etiam quod sit substantialis perfectio organi dans esse substantiale organo inquantum corpus est $<\ldots>$.

Anima non tantummodo universae moli corporis sui, sed etiam unicuique particulae corporis sui tota simul adest, nec quantum in se est, aliquid sui plus alligatur uni particulae corporis, quam alteri. Sed quod dicitur habere partes quasdam alligatas corpori [ms. Paris, BNF 15848, f. 36rb, l. 14 | corporis ed. 1613], et partem aliquam non alligatam, hoc contingit, quia quaedam earum, ut omnes potentiae sensitivae determinantur in substantia ipsa per rationem et dispositionem organi ad operationes suas, potentiae vero intellectivae nequaquam, sed per aliquid aliud secundum seipsas, ut infra patebit. Propter quod potentiae intellectivae, quae sunt substantia ipsa animae, inquantum determinantur secundum se ad eliciendum operationes intellectuales dicuntur esse non alligatae organo, potentiae vero sensitivae, quae similiter sunt ipsa substantia animae, inquantum determinantur per dispositiones organi ad eliciendum operationes sensuales, dicuntur alligatae organo. Et secundum quod per diversa organa nata diversimode determinari, secundum hoc distinguuntur diversae potentiae sensitivae, sine omni diversitate earum inter se, vel ad potentias intellectivas inquantum habent radicari in substantia animae, quae nullo modo quantum est ex se distinguitur, vel determinatur ad actus sentiendi, vel intelligendi determinatos <..>”. Para um estudo sobre essa temática a partir de Quodl. 3, q. 14, cf. SORGE, Gnoseologia e teologia..., 1988, pp. 15-23.

${ }^{43}$ Henrique de Gand, Quodl. 3, q. 14, co. (ed. 1613, f. 110rb): "Et propter hoc totum potentiale praedicatur de qualibet parte. Dicitur enim, quod sensus est ipsa anima. Similiter intellectus, similiter vegetativum, sensitivum et rationale, sive accipiuntur ut in eodem, sive ut in diversis, praedicatione dico substantiali, et essentiali, non accidentali”.
} 
concebida como uma única substância que diz respeito (respicit) a diversos atos. É esse respectum ou, mesmo, essa relação (relatio) que denominamos 'potências' da alma. Com efeito, a potência ainda é menos do que a relação, pois ela é, a saber, a determinação para a relação com o ato. Assim, dado que a alma possui diversas determinações para com diversos atos (isto é, ela é determinada a dizer respeito a diferentes atualizações), cada uma dessas determinações recebe o nome de uma potência distinta ${ }^{44}$. A mesma alma que sente pelo órgão intelige sem este último e a cada uma dessas determinações dá-se o nome de uma diferente potência ${ }^{45}$. Mas, então, qual distinção está em jogo na descrição das potências da alma como realmente idênticas a esta última e entre si?

Em Quodl. 9, q. 8, Henrique de Gand tende a se referir a cada parte da alma como ratio ou intentio ${ }^{46}$. Se o uso desses dois termos afasta a possibilidade de uma distinção real entre as potências da alma, por outro lado, não é suficiente para decidir entre uma distinção intencional ou de razão entre essas potências. No entanto, se voltarmos nossa atenção para Quodl. 5, qq. 6 e 12, veremos que a distinção entre as potências da alma é justamente enumerada como um dos modos de distinção intencional ${ }^{47}$. A meu ver, parece que o Doutor Solene tende a considerar a distinção entre as potências da alma como uma distinção intencional - o intelecto pode distinguir nessa única e mesma coisa que é uma alma humana diversos conceitos de intentiones que são realmente na alma, embora nesta última estejam indistinguidas. Mesmo assim, o interesse principal de nosso autor parece ser não tanto afirmar uma distinção intencional entre as potências da alma, mas antes negar uma distinção real entre elas. $\mathrm{O}$ mais importante na discussão sobre a distinção das potências da alma em Henrique parece ser que tal distinção não é real ${ }^{48}$.

\footnotetext{
${ }^{44}$ Henrique de Gand, Quodl. 3, q. 14, co. (ed. 1613, f. 110ra): "Sic ergo, quod tanta est diversitas ex parte animae, hoc non est propter aliquam diversitatem realem, quam habent ipsae ex parte animae, sed propter diversitatem determinationum substantiae animae solummodo diversos actus respicit, et ex hoc nomina diversarum potentiarum sortitur". E (f. 109vb): “<...> potentia enim non definitur nisi ex relatione ad actum".

${ }^{45}$ Henrique de Gand, Quodl. 3, q. 14, co. (ed. 1613, f. 110ra): “< $<>$ id ipsum quod de ea intelligit sine organo, illud ipsum sentit per organum, et id ipsum quod sentit unum obiectum in uno organo, sentit aliud in alio organo $<\ldots>$.

${ }^{46} \mathrm{Cf}$., adiante, a nota 78 .

${ }^{47}$ Para a passagem de Quodl. 5, q. 6, cf. a nota 14. Cf. tb. Quodl. 5, q. 12, co. (ed. 1613, f. 254ra).

${ }^{48}$ Mesmo assim, a distinção intencional entre as potências da alma foi um tema do pensamento de Henrique de Gand que chamou a atenção dos comentadores - cf. e.g. MACKEN, R. "La volonté, faculté plus élevée que l'intelligence selon Henri de Gand". Recherches de théologie ancienne et médiévale 42 (1975), pp. 25-27; WILSON, G. A. Dymorphism and the Metaphysical Unity of Man in
} 
Quodlibeta magistri Henrici Goethals a Gandavo doctoris solemnis: socii sorbonici: et archidiaconi tornacensis cum duplici. A Dissertation Submitted on the First Day of June, 1975, to the Department of Philosophy of the Graduate School of Tulane University in Partial Fulfillment of Requirements for the Degree of Doctor Philosophy, 1975, pp. 160-1; MACKEN, R. "La liberté humaine dans la philosophie d'Henri de Gand". In: BÉRUBÉ, C. (ed.). Regnum hominis et regnum. Acta Quarti Congressus Scotistici Internationalis, Patavii, 24-29 septembris 1976. Dei. Vol. 2. Romae: Societas Internationalis Scotistica, 1978, pp. 577-584; MACKEN, R. "Lebensziel und Lebensglück in der Philosophie des Heinrich von Gent”. Franziskanische Studien 61 (1979), pp. 107-123 (cf. p. 111); MACKEN, R. "Deseo natural y vocación sobrenatural del hombre en la filosofía de Enrique de Gante". In: $L a$ filosofía del cristiano, hoy. Vetera novis augere et perficere. Primer Congreso Mundial de Filosofía Cristiana, Córdoba, 21-28 octubre 1079. Vol. II. Córdoba: Publicaciónes de la Universidad, 1980, pp. 839-46 (esp. p. 841); MACKEN, R. "Les diverses applications de la distinction intentionnelle...", 1981, p. 770; MACKEN, R. "Selbstverwirklichung in der Anthropologie des Heinrichs von Gent". In: GERWING, M., RUPPERT, G. (Hrsg.). Renovatio et reformatio. Wider das Bild vom 'finsteren' Mittelalter. Festschrift für Ludwig Hödl zum 60. Geburtstag. Münster: Aschendorf, 1985, pp. 131-140 (esp. p. 138); PORRO, "Possibilità ed esse essentia in Enrico di Gand", 1996, p. 218, nt. 20; JANSSENS, "Henry of Ghent and Avicenna", 2011, p. 82.

Tal posição possui claras bases textuais, pois lembremos que (como vimos na nota 14) a distinção entre as potências da alma é consistentemente oferecida por Henrique de Gand como um caso de distinção intencional. Isso ocorre, por exemplo, em Suma, art. 27, q. 1, ad 5 (ed. Teske, p. 148): "Quaedam vero differunt intentione ut diversae differentiae unius speciei, quae in eodem separari non possunt, quia cadunt in idipsum re, ut vegetativum, sensitivum in bruto, sed in diversis possunt separari, secundum quod in plantis est vegetativum sine sensitivo et in brutis sensitivum sine rationali".

Para além disso, vale a pena desenvolver aqui dois elementos adicionais da doutrina da distinção intencional entre as potências da alma em Henrique de Gand.

Primeiramente, um adendo à doutrina. Em Quod. 3, q. 14 (cf. nota 81), Henrique de Gand afirma que as três potências (vegetativa, sensitiva e intelectiva) só se distinguem na alma secundum gradus intentionum - uma expressão semelhante se repete Quodl. 2, q. 3, co. (ed. De Wulf-Mantion Centre, vol. 6, p. 23). Ou seja, mais uma vez encontramos uma hierarquia no homem - agora, das potências da alma entendidas como diferentes graus de intenção. Se extrapolarmos, entretanto, essa distinção de graus de intenção para o âmbito de todo o gênero animal, estamos novamente em presença da hierarquia dos entes vivos - quanto superior for o grau da intenção suprema em sua alma, superior será sua vida e seu grau de ser. Desse ponto de vista, a distinção intencional entre as potências da alma parece nos direcionar para o problema metafísico da possibilidade de intensificação e remissão das formas - sobre isso, cf. SOLÈRE, J.-L. "Plus ou moins: le vocabulaire de la latitude des formes". In: HAMESSE, J., STEEL, C. (éds.). L'élaboration du vocabulaire philosophique au moyen-âge. Actes du Colloque international de Louvain-la-Neuve et Leuven 12-14 septembre 1998, organisé par la SIEPM. Turnhout: Brepols, 2000, pp. 437-88; SOLÈRE, J.-L. "Les degrés de forme selon Henri de Gand (Quodl. IV, q. 15)". In: GULDENTOPS, G., STEEL, C. (eds.), Henry of Ghent and the Transformation..., 2003, pp. 127-55 (esp. pp. 153-4). Sobre a hierarquia de graus de intenções, cf. WILSON, Dymorphism and the Metaphysical Unity of Man..., 1975, pp. 184-94.

Por outro lado, há uma dificuldade na afirmação de uma distinção intencional entre as potências da alma. No mesmo Quodl. 3, q. 14 (cf. nota 81), diz-se que as potências da alma e a própria alma enquanto natureza e essência "non differunt nisi ratione et respectu quodam". A afirmação da distinção por respectus distintos está de acordo com o que vimos aqui, porém a afirmação de uma distinção unicamente por razão parece contradizer a tese da distinção intencional, que lemos em outros textos. Tese semelhante é lida em Quodl. 14, q. 2, co. (ed. 1613, f. 340rb-va): "Respondendo modo eodem dico, quod forma qua voluntas continet virtute omnes volitiones quas potest in se habere est ipsa potentia volitiva ut activa est, quae sola ratione differt a substantia animae cuius est potentia, et est potentia ipsa substantia animae secundum rem, et e converso". Notemos como, agora no que diz respeito à vontade (ao que voltaremos no cap. 3, adiante), Henrique de Gand mais uma vez rechaça uma distinção real entre a alma e sua potência, porém afirma somente uma distinção de razão entre elas (e não uma distinção intencional). Pois bem, o problema aqui não é que a distinção de razão exclua a distinção intencional. Pelo contrário, lemos em Quodl. 5, q. 12, co. (ed. 1613, f. 253vb) que "quaecunque differunt intentione, differunt ratione, non e converso, propter quod frequenter intentio ratio appellatur". O problema é que Henrique sublinha que as potências não diferem da alma senão por razão - Quodl. 3, q. 14 (non differunt nisi ratione) e Quodl. 14, q. 2 (sola ratione differt). Não pretendo apresentar uma solução para esse problema. Noto somente que Raymond Macken, em "La volonté...", 1975, p. 25, apresenta exatamente o trecho problemático da passagem de Quodl. 14, q. 2 que reproduzi 
Ora, sabendo que a alma é aquilo pelo que se vive, podemos ver que essas potências da alma (o termo 'potência', aliás, é a partir de agora sempre usado no sentido de 'potência passiva') são, justamente, aquele ato primeiro que caracteriza o homem. Porém, como em qualquer criatura, essa operação primeira - esse ato perfeito da coisa - está em potência e, no caminho para o aperfeiçoamento, ela deve precisamente ser atualizada pelos atos segundos, que são aquelas operações das potências a que o excerto acima se refere ${ }^{49}$. Ou seja, enquanto mera potência para o conhecimento sensitivo e intelectivo, a alma é simples e una, pois todas as suas potências são idênticas a ela mesma. Por outro lado, essa simplicidade e unidade são perdidas naquele caminho para a atualização de suas potências que passa pelas operações segundas. Isso, antes de tudo, porque, se as potências da alma são realmente o mesmo que ela, a atualização dessas potências - a operação delas - surge na alma como acidentes realmente distintos da substância em que estão (embora essa operação das potências seja sempre imanente à própria alma). Já pela própria atualização de suas potências, portanto, a alma perde sua simplicidade, que deriva para uma multiplicidade, ainda que imanente ${ }^{50}$.

Igualmente significativo é o fato de que nenhuma criatura pode atualizar, por si mesma, suas próprias potências. A alma é idêntica a suas potências, mas não ao ato de suas potências - só Deus, como vimos, é ele próprio ato de sua potência. Por isso mesmo, essas potências da alma (e, ademais, de qualquer criatura) só podem ser

aqui, sem entretanto discurtir tal dificuldade.

${ }^{49}$ De fato, assim como o viver, enquanto ato primeiro, só podia ser conhecido a partir das operações segundas que dele decorriam, também no caso das potência da alma só podemos conhecê-las a partir das operações segundas que delas decorrem enquanto são a própria operação primeira imperfeita Henrique de Gand, Quodl. 1, q. 14, co. (ed. De Wulf-Mansion Centre, vol. 5, p. 84): "Dicendum ad hoc quod potentiae animae cum nobis occultae et ignotae sunt de se sicut et ipsa substantia animae, a posteriori, modo nobis congruo, debemus omnem notitiam circa eas investigare". Nas palavras de Raymond Macken ("La volonté....", 1975, p. 25) ao comentar essa passagem, para Henrique "la doctrine de la substance de l'âme et de ses facultés doit être établie a posteriori, c'est-à-dire en concluant des actions à leur cause" (grifo no orig.).

${ }^{50}$ Henrique de Gand, Quodl. 3, q. 14, co. (ed. 1613, f. 109vb): "Operari autem creaturae omnino accidentale est ei, quia hoc non convenit ei, nisi omnino accidentaliter et est accidens differens re ipsa ab ipsa essentia, et ideo potentia creaturae". A imanência desses atos segundos (operações segundas) da alma fica clara em Suma 28, q. 6, co. (ed. Teske, 2006, p. 222): "Actus vero secundus similiter duplex est, quidam manens in ipso agente, ut sunt intelligere, velle, et omnis actus quo aliquid movetur ex se. Alius vero est transiens in rem extra, qualis est omnis actio qua aliquid movet et transmutat aliud a se, secundum quod amplius declaratum est supra". Como se vê, as operações da alma como sentir, inteligir e querer são agrupadas sob os 'atos segundos imanentes', pois, ainda que as potências da alma dependam de algo externo para sua atualização (como notaremos a seguir), o acidente fruto desta última inere na própria alma que estava em potência para recebê-lo. 
atualizadas por outros que não ela própria, isto é, por outros exteriores a ela ${ }^{51}$. Para ser preciso, cada potência deve ser determinada por algo outro que não ela própria para produzir uma ação determinada acerca de um objeto seu determinado ${ }^{52}$. Dessa maneira, no seu caminho para o aperfeiçoamento a alma não somente perde sua simplicidade, mas também necessariamente estabelece relações com outros entes que não ela própria, a saber, com os objetos determinados de cada uma de suas potências. É justamente por dever estabelecer essas relações que ocorre algo ainda mais significativo na alma, a saber, ela se une a um corpo através do qual possa atualizar algumas de suas potências.

Com efeito, exatamente por ela possuir não somente potências intelectivas, mas também potências sensitivas, ela precisará se ligar a um corpo para poder atualizar estas últimas. Portanto, se enquanto substância potencial a alma não necessita de um corpo, ela certamente deve se ligar a um corpo orgânico para atualizar-se e, ao fazê-lo, aperfeiçoar o seu ser por essas operações segundas. De fato, a apreensão - o scire large accepto, seja ele sensível ou intelectivo - não é senão, como sabemos agora, um ato segundo do homem que o leva a um aperfeiçoamento de seu ato primeiro, o viver pela alma. Os acidentes que advêm à alma pela atualização de suas potências a levam em direção à perfeição. Os acidentes intelectuais, é certo, podem advir à alma subsistente por $\mathrm{si}^{53}$, porém os acidentes sensitivos dependem da determinação da potência sensitiva no corpo e de sua diferenciação pelos órgãos dos sentidos a que a alma se liga como forma substancial. Dito isso, o nosso desafio final para compreender o que é o homem para Henrique de Gand é explicar como é

\footnotetext{
${ }^{51}$ Henrique de Gand, Quodl. 3, q. 14, co. (ed. 1613, f. 109va): “< $<>$ distinguendo de potentia, quod est quaedam potentia, quae ex se sufficienter, et perfecte sine omni exteriori adminiculo procedit in actum suum. Alia vero est potentia, quae non procedit ad actum ex se sine alio adminiculo $<\ldots>$ nulla autem creatura ex sola essentia sua sine exteriori adminiculo sufficit ad operationem sibi debitam eliciendam".

${ }^{52}$ Henrique de Gand, Quodl 3, q. 14, co. (ed. 1613, ff. 108vb-109ra): "Nihil autem in potentia activa est ex nuda essentia sua, quemadmodum est agens primum, immo siquid creatum agit per essentiam suam, ipsum de se solum est in potentia agens, et per aliquam transmutationem accidit ei, quod fiat agens in actu, et hoc aut quia indiget appropinquari materiae in quam aget $\langle\ldots\rangle$. Aut etiam accidit ei, quod fiat agens in actu, quia indiget ut determinetur aliquo, quo fiat in eo potentia ad eliciendum actionem determinatam circa determinatum obiectum; sicut contingit in actionibus animae intellectivis, vel sensitivis, ad quas non habet anima ex nuda essentia sua aliquas potentias determinatas nisi aliquo alio determinetur, quo respiciat determinatum obiectum, et determinatam actionem, ita quod eius substantia quae una est secundum rem, secundum diversa esse et secundum diversas determinationes, sortitur rationes diversarum potentiarum intellectivarum et sensitivarum $<\ldots$. ”. Como tal atualização ocorre será cuidadosamente estudado na parte 2, adiante. Sobre a distinção da alma não somente em potências, mas também em vires, cf. cap. 3, nota 19.

${ }^{53}$ Cf., adiante, item 6.3.2.
} 
possível que uma substância espiritual como a alma - capaz de existir por si mesma se ligue a um corpo de maneira a se aperfeiçoar atualizando suas diversas potencialidades.

Tão independente quanto seja a alma do corpo enquanto ela é substância, a composição entre ambos não deixa de ser fundamental para a compreensão do que é o homem. Isso fica claro, por exemplo, quando se afirma que as potências sensitivas "são, propriamente, potências do composto e não da alma e não são na alma senão como em uma raiz a partir da qual são causadas as disposições do órgão e são determinadas as razões das potências da alma nela própria" ${ }^{54}$. Entretanto, a relevância da composição entre alma e corpo no homem vai muito além de problemas atrelados somente à sensibilidade. Como vimos, ela deriva do próprio caráter intermediário do homem [i] entre o espiritual e o corpóreo, [ii] entre o não-vivente e o vivente em mais alto grau e [iii] entre a matéria primeira (potência puramente passiva) e Deus (potência puramente ativa). Sendo um horizonte entre os extremos em cada um desses pares, o homem participa dos dois aspectos extremos de cada um. Assim, esses três aspectos intermediários que se conjugam no homem explicam a necessidade de uma união entre corpo e alma:

"há uma tripla substância [triplex substantia]: matéria, forma e composto
[materia, forma, et compositum]. A matéria, naquilo que é a partir de si, é em
potência [materia id, quod est ex se, in potentia est]; já a forma, por ser ato, é
causa do ato no composto. Assim, a forma existente efetivamente [existens in
effectu] possui, a partir de si formalmente, ser, pois, como diz <Aristóteles>,
aquilo que é verdadeiramente, é ato e é causa do ser em ato, para o composto e a
matéria. E, tal como um único ser [sicut unum esse] que por si convém à forma,
é no composto e, pela forma, é comunicado à matéria e a todo o composto, uma
vez que possui ser nele, como ato e perfeição de todo composto e da matéria.
Portanto, já que para os viventes viver é ser, assim como convém à forma o ser
por si e, por ela, ao composto e à matéria, similarmente também <esse é o caso>
com o viver nos viventes. De fato, viver nada mais é do que um determinado

\footnotetext{
${ }^{54}$ Henrique de Gand, Quodl. 3, q. 14, co. (ed. 1613, f. 112va): “< $<$..> sunt potentiae compositi, et non animae, nec sunt in anima nisi sicut in radice, ex qua causantur dispositiones organi, et determinantur rationes potentiarum animae in ipsa, secundum quod supra dictum est". Cf. tb. q. 15, co. (ed. 1613, f. 119rb): "Quare cum anima etiam secundum illam opinionem substantialiter sit forma et actus corporis, omnis igitur actio cuius anima in corpore existens est principium et causa per se, debet dici actio compositi per animam, et non ipsius animae, sicut neque esse, quod est in composito, sed solummodo est per se ipsius compositi, ut dictum est". De fato, não somente a potência sensitiva é do composto, como também a operação de tal potência é atribuída, principalmente, ao composto - Quodl. 7, q. 14, ad 1 (ed. De Wulf-Mansion Centre, vol. 11, p. 100): "in actu videndi non videt principaliter virtus visiva, sed totus oculus compositus ex corporali organo et vi visiva, quae est forma et actus eius, quemadmodum anima est forma et actus totius corporis organici $<\ldots>$ " (sobre esta passagem, cf. cap. 4, nota 118). A maneira como ocorre tal atualização da potência sensitiva será vista adiante, nos caps. 4 e 5 .
} 
grau de nobreza no ser que dizem possuírem aqueles que, a partir de sua natureza, possuem o estenderem-se à sua própria operação ou ação - como os vegetativos, ao movimento de crescimento e nutrição, os sensíveis, à apreensão dos sentidos e ao movimento segundo o lugar, os inteligentes, à operação segundo o intelecto e a razão, ${ }^{, 55}$.

Em poucas palavras, o viver está para os viventes corpóreos assim como a forma está para os entes compostos. A forma/alma (pela qual se vive, como vimos acima) possui o ser/viver por si, comunica tal ser/viver à matéria/corpo e, assim, ao composto/vivente. Ou seja, corpo e alma fazem parte da própria constituição física do vivente - em particular, corpo e alma são componentes físicos do homem enquanto vivente racional. Portanto, descrever o homem filosoficamente é descrevê-lo enquanto vivente racional composto de matéria e forma, isto é, de corpo orgânico e alma racional. Isso, no entanto, se mostra mais complicado do que parece de início.

\subsubsection{A união entre corpo e alma}

O problema da união entre corpo e alma é um dos elementos da obra de Henrique de Gand que mais têm recebido atenção por parte de seus leitores atuais ${ }^{56}$.

\footnotetext{
${ }^{55}$ Henrique de Gand, Quodl. 3, q. 8, co. (ed. 1613, f. 93va-b): "Sciendum igitur secundum artem Philosophi in principio secundi de anima, cum triplex sit substantia, materia, forma, et compositum, materia id quod est ex se, in potentia est, forma vero ideo quod est actus, et est causa actus in composito, ita quod forma in effectu existens ex se formaliter habet esse, quia ut dicit, id quod vere est, actus est, et est causa esse in actu, composito et materiae, et sicut unum esse est in composito, quod per se convenit formae, et per formam, communicatur materiae, et toti composito, per hoc quod habet esse in ipso, ut actus et perfectio totius compositi, et materiae. Cum ergo vivere viventibus est esse, sicut convenit formae esse per se, et per illam composito et materiae; similiter et vivere in viventibus. Vivere enim nihil aliud est, quam determinatus gradus nobilitatis in essendo, quem dicunt habere quaecunque in seipsis ex natura sua habent, ut in aliquam sibi propriam operationem, vel actionem sese extendant, ut vegetativa in motum crementi, et nutritionis, sensibilia in apprehensionem sensuum, et motum secundum locum, intelligentia in operationem secundum intellectum, et rationem". Note-se que, se [i] há uma hierarquia da vida e [ii] a vida diz respeito ao grau de ser comunicado pela forma ao composto, parece que deveria haver também uma hierarquia das formas. Ora, é precisamente uma tal hierarquia que vemos surgir em Quodl. 3, q. 5, co. (ed. 1613, f. 87vb): “< $<$. > triplex est forma. Quaedam pure spiritualis, non unibilis materiae, ut essentia Angelorum, si tamen Angeli carent materia, aut aliqua essentia creata. Quaedam vero pure materialis semper materiae unita, ut formae rerum naturales. Quaedam partim spiritualis separabilis a materia, et partim materialis unibilis materiae, sicut sunt animae humanae rationales, ut infra magis patebit". Como vemos, também na hierarquia das formas, o homem encontra-se em um lugar intermendário. Sobre o problema da matéria das substâncias separadas citado de passagem por Henrique neste trecho, cf. nota 40, acima.
}

${ }^{56}$ Cf. HUET, F. Recherches historiques et critiques..., 1838, pp. 154-158; WULF, M. de. Études sur Henri de Gand. Louvain - Paris: Uystpruyst-Dieudonné - Félix Alcan, 1894, pp. 55-73; também, de WULF, M. de. Le traité "De Unitate Formae" de Gilles de Lessines. Texte inédit et Étude. Louvain: Institut Supérieur de Philosophie de 1'Université, 1901; BRAUN, R. Die Erkenntnislehre Heinrichs von Gent. Freiburg: Komminssionsverlag der Universitäts-Buchhandlung, 1916, pp. 9-13; HOCEDEZ, Richard de Middleton..., 1925, pp. 454-479; MAURER, A. "Henry of Ghent and the Unity of Man". Mediaeval Studies 10 (1948), pp. 1-20; ZAVALLONI, R. Richard de Mediavilla et la controverse sur 
Isso se deve, parece-me, a três razões. Em primeiro lugar, porque, por essa discussão, o Doutor Solene se insere - curiosamente, a contragosto ${ }^{57}$ - em uma das mais

la pluralité des formes. Textes inédits et étude critique. Louvain: Éditions de l'Institut Supérieur de Philosophie, 1951, pp. 287-296; WILSON, Dymorphism and the Metaphysical Unity of Man..., 1975; FIORAVANTI, G. "Forma ed esse in Enrico di Gand: preoccupazioni teologiche ed elaborazione filosofica". Annali della scuola normale superiore di Pisa. Classe di Lettere e Filosofia, serie 3, 5.3 (1975), pp. 985-1031; WILSON, G. A. "Henry of Ghent's Quodlibet III: A Response to Giles of Rome's Contra gradus". Proceedings of the Patristic, Medieval and Renaissance Conference 3 (1978), pp. 77-84; MACKEN, R. "Unité et dimorphisme de l'homme selon Henri de Gand”. In: D’AMORE, B., GIORDANO, A. (eds.). Teoria e prassi. Atti del VI Congresso del Centro Internazionale di Studi e Relazioni Culturali e della Fondazione Balmesiana, Genova-Barcelona 8-15 settembre 1976. Vol. 1. Napoli: Edizioni Domenicane Italiane, 1979, pp. 177-182; WILSON, G. A. "Henry of Ghent and René Descartes on the unity of man". Franziskanische Studien 64 (1982), pp. 97-110; WILSON, G. A., "Human Generation according to Henry of Ghent". Proceedings of the Patristic, Medieval and Renaissance Conference 9 (1984), pp. 59-68; SORGE, Gnoseologia e teologia..., 1988, pp. 11-36; WÉBER, E. H. La personne humaine au XIII siècle. Paris: Vrin, 1991 (cf. esp. pp. 113-118, 260-273, 392, 485-509); CROSS, R. The Physics of Duns Scotus. The Scientific Context of a Theological Vision. Oxford: Oxford University Press, 1998, pp. 49-55; WIRTH, J. "Le cadavre et les vers selon Henri de Gand (Quodlibet X, 6)". Micrologus 7 (1999), pp. 283-295; CARVALHO, M. A. S. "O que significa pensar? Henrique de Gand em 1286 e os horizontes da temática monopsiquista: 'contra fundamenta Aristotelis'?". Revista filosófica de Coimbra 19 (2001), pp. 69-92 [cf. tb. a retomada desse tema em CARVALHO, M. S. "Augustinismo e aristotelismo em Henrique de Gand". In: CARVALHO, M. S. de. O problema da habitação. Estudos de (história da) filosofia. Colibri - Faculdade de Letras da Universidade de Coimbra, Coimbra, 2002, pp. 137-192 (esp. pp. 139-75)]; BROWER-TOLAND, S. "Instantaneous Change and the Physics of Sanctification. 'Quasi-Aristotelianism' in Henry of Ghent's Quodlibet XV, q. 13”. Journal of the History of Philosophy 40 (2002), pp. 19-46; KÖNIG-PRALONG, C. "Corps, cadavre, matière. Autour de Gilles de Rome, Henri de Gand et Dietrich de Freiberg". Quaestio 7 (2007), pp. 339-359; KÖNIG-PRALONG, C. "Évaluations des savoirs d'importation dans l'université médiévale : Henri de Gand en position d'expert". Revue européenne des sciences sociales 46 (2008), pp. 11-28; WIELOCKX, R. "Henry of Ghent and the Events of 1277", 2011, pp. 41-50; WILSON, G. A. "Le Contra gradus de Gilles de Rome". In: CORDONIER, V., SUAREZ-NANI, T. (éds.). L'aristotélisme exposé..., 2014, pp. 29-54. Certamente, não teremos ocasião aqui para tratar de todos os muitos detalhes e aspectos levantados por esses textos na doutrina da união entre corpo e alma de Henrique de Gand. O que pretendo a seguir é somente destacar nessa doutrina aqueles seus elementos principais que surgem, de uma maneira ou de outra, na maior parte dos textos elencados nesta nota, a saber: [i] a dualidade da forma do homem e [ii] a consequente dificuldade em justificar a unidade desse mesmo homem enquanto indivíduo existente. Esses serão os aspectos da discussão sobre a união entre alma e corpo, tal como ela surge no Doutor Solene, que mais me interessarão aqui.

${ }^{57}$ A evolução de Henrique de Gand quanto à sua posição acerca da relação entre corpo e alma é extremamente complexa e está, em grande parte, atrelada à controvérsia em torno do tema em fins do século XIII (cf. a próxima nota). O interessante a se notar é que o próprio Doutor Solene considerava a questão extremamente difícil, ela era um labirinto, no qual qualquer movimento poderia trazer consequências indesejadas, uma vez que o problema filosófico da relação entre alma e corpo coloca em jogo diversos outros temas filosóficos, teológicos e religiosos - Quodl. 2, q. 3, co. (ed. De WulfMansion Centre, vol. 6, p. 24): "Sed hoc dixerim ut declarem qualiter in labyrinthum nos ponimus istam materiam nimium perscrutando, quia, unica difficultate decisa, statim pullulant aliae graviores. Propter quod ab initio mihi displicuit eam alio anno inchoare, et quasi intactam reliqui". De fato, quando abordara o tema no ano anterior - em Quodl. 1, q. 4 (ed. De Wulf-Mansion Centre, vol. 5, pp. 13-22) -, o Doutor Solene havia se contentado em dissertar sobre algumas alternativas de resposta (cf. WILSON, "Henry of Ghent's Quodlibet I...", 1999, pp. 172-3). Com efeito, o problema posto era se alguma forma permaneceu no cadáver de Cristo no decorrer do tríduo (cf. nota 60, adiante) e, quanto à questão, Henrique se contentou em mostrar algumas alternativas e seus respectivos problemas. Já a partir de Quodl. 2, é proposta uma alternativa muito própria de Henrique, a saber, a doutrina da dualidade das formas no homem, que estudaremos atentamente a seguir. Por que essa mudança? Decerto, ela diz respeito a elementos internos da filosofia do gandavense - de fato, como veremos, para ele só é possível compreender o homem como ponto médio da hierarquia do mundo, como horizonte entre o espiritual e o corpóreo, se afirmarmos a dualidade da forma no homem. Além disso, no entanto, 
parece haver ocorrido algum tipo de pressão institucional, já nesses primeiros anos de carreira do Doutor Solene como mestre de teologia na Universidade de Paris (ou seja, ainda por volta de 1276), que o levou a adotar sua posição definitiva. Com efeito, ele próprio nos narra o acontecimento em um trecho excluído da redação final de seu Quodl. 10, q. 5 (ed. De Wulf-Mansion Centre, vol. 14, p. 128, apparatus): "Já mesmo há 10 anos, quando foram notados alguns em Paris propondo que no homem não haveria qualquer forma substancial senão a alma racional e eu, ao mesmo tempo, permanecia em dúvida em minha primeira disputa 'de quolibet' (na questão 'se cumpriria pôr no homem várias formas ou somente uma única'), fui chamado pelo senhor Simão (então legado) e, em presença do senhor Estêvão (então bispo de Paris), do senhor Ranoldo (agora bispo de Paris) e do mestre João Aurelianense (então chanceler de Paris e agora irmão da Ordem dos Pregadores), foi perguntado o que eu achava [quid ego sentirem]: se no homem haveria várias formas substanciais ou se somente uma única. E, quando havia respondido achar mais que havia várias, o próprio senhor Simão, após uma pequena consulta com as pessoas supracitadas, trazendo-me à parte, disse a mim: 'queremos e recomendamos a ti [volumus et praecipimus tibi] que determines publicamente em tuas aulas [in scholis tuis] que há no homem várias formas substanciais, não somente a alma racional. Para que, de resto, os estudantes [scholares] não fiquem em dúvida sobre isso'. E uma vez que, ao que me parecia, suspeitava-se que <eu> não executaria eficazmente seu mandado, advertindo [comminando] adicionou: 'sejas solícito em determinar clara e abertamente que há várias formas substanciais no homem, pois na causa da fé <eu> não pouparia a ninguém'. Pelo que, pareceu-me, ele achava que, ao determinar se há várias formas substancias ou somente uma única no homem, se age pela causa da fé. Pareceu-me, também, que dizer que há somente uma única forma no homem era condenado pela deliberação dos ditos homens, embora não publicamente [de consilio dictorum virorum damnaverat, licet non publice]. Porém, tudo o que há de verdade aqui sabem melhor, creio, o senhor bispo de Paris Renaldo e o irmão João Aurelianense, que ainda vivem e poderão fornecer um testemunho fiel sobre o que foi dito [Iam etiam 10 annis, cum quidam notati fuerunt Parisius quasi posuissent quod in homine non esset forma substantialis nisi anima rationalis, et ego eodem tempore in dubio reliquissem in prima disputatione mea de Quolibet quaestione $<m>$ an plures formae ponendae essent in homine vel unica tantum, vocatus a domino Simone, tunc legato, et requisitus in praesentia domini Stephani, tunc episcopi parisiensis, et domini Ranoldi, nunc episcopi parisiensis, et magistri Ioannis Aurelianensis, tunc cancellarii parisiensis et nunc fratris ordinis praedicatorum, quid ego sentirem, an quod in homine essent plures formae substantiales an quod unica tantum, et cum respondissem quod potius sentirem quod plures, ipse dominus Simon post modicam consultationem cum praedictis personis, me tracto in partem, mihi dixit: 'Volumus et praecipimus tibi, quod publice determines in scholis tuis, quod in homine sint formae substantiales plures, non sola anima rationalis, ne scholares de cetero super hoc maneant in dubio'. Et quia, secundum quod mihi visum fuit, suspicabatur ne satis efficaciter mandatum suum in hoc exsequerer, comminando addidit: 'Sis sollicitus ut clare et aperte determines plures formas substantiales esse in homine, quia in causa fidei nemini parcerem'. Ex quo visum est mihi ipsum sensisse quod in determinando an plures formae substantiales vel tantum unica sint in homine, agitur causa fidei. Visum est etiam mihi quod dicere tantum unicam formam esse in homine de consilio dictorum virorum damnaverat, licet non publice. Quid autem in hoc veritatis sit, melius, ut credo, sciunt dominus episcopus parisiensis Renaldus et frater Ioannes Aurelianensis, qui adhuc vivunt et de praedictis fidele testimonium perhibere poterunt]". Essa magnífica narrativa de Henrique de Gand mostra que se, por um lado, sua posição acerca da relação entre corpo e alma provém de uma convicção própria, por outro lado, ela certamente foi influenciada por fatores externos à própria especulação filosófica e científica em geral. Esse vivaz documento acerca da interrelação entre poder institucional e conhecimento científico no século XIII - que, aliás, não deixa de fazer pensar em The Structure of Scientific Revolutions de Thomas Kuhn ou no Against Method de Paul Feyerabend - foi muito bem explorado em HÖDL, "Neue Nachrichten...", 1964; PUTALLAZ, Insolente liberté..., 1995 , pp. 172-5; PORRO, "Metaphysics and Theology in the Last Quarter of the Thirteenth Century...", 2000, pp. 269-270; PORRO, P. "Doing Theology (and Philosophy) in the First Person: Henry of Ghent's Quodlibeta". In: SCHABEL, C. (ed.). Theological Quodlibeta in the Middle Ages: The Thirteenth Century. Leiden - Boston: Brill, 2006, pp. 171-231; e HÖDL, L. "The Theologian Henry of Ghent”. In: WILSON, G. A. (ed.). A Companion to Henry of Ghent, 2011, pp. 103-134. De minha parte, pretendo com essas observações unicamente chamar a atenção para todos os elementos científicos e interesses institucionais que estavam em jogo na posição adotada por Henrique de Gand acerca da relação entre corpo e alma, cujo único aspecto estudado a seguir será sua coerência interna enquanto etapa necessária da especulação científica do Doutor Solene acerca do homem enquanto ser em potência para o conhecimento científico large accepto. 
virulentas e candentes discussões de fins do século XIII, a saber, a chamada 'controvérsia da pluralidade das formas ${ }^{, 58}$. Ora, sendo meu objetivo aqui fazer um estudo interno do pensamento de Henrique, a narrativa da história dessa controvérsia ultrapassaria em muito, não somente o escopo deste trabalho, mas também a capacidade do seu autor.

O segundo ponto de interesse na doutrina da união entre corpo e alma formulada pelo gandavense (e, agora, estamos falando de um elemento interno a seus textos) é o contexto em que ela é formulada. Raramente encontramos em Henrique de Gand uma questão diretamente voltada para esse problema, pois em geral ele é discutido como parte daquilo que ouso chamar (baseado em alguns trabalhos recentes) de uma 'casuística dos extremos da vida' ${ }^{59}$. Com isso, quero dizer que a explicação da

\footnotetext{
${ }^{58}$ Para uma introdução a essa controvérsia, cf. WULF, Le traité "De Unitate Formae" de Gilles de Lessines, 1901; HOCEDEZ, Richard de Middleton, 1925, pp. 454-79; ZAVALLONI, Richard de Mediavilla..., 1951; e WILSON, G. A. "Le Contra gradus de Gilles de Rome", 2014, pp. 29-54. Para uma introdução mais geral acerca de tal controvérsia, cf. os livros citados no cap. 1, nota 22.
}

${ }^{59}$ A utilização do termo 'casuística' pode parecer possuir algo de anacrônico, porém é interessante lembrar que a colocação de um problema a partir de um exemplum ou um casus era um recurso originalmente próprio à especulação jurídica, mas logo adotado pelo corpo da faculdade de teologia como um importante modo de problematização de certos temas - cf. BOUREAU, A. "Droit et théologie au XIII ${ }^{\mathrm{e}}$ siècle”. Annales. Économies, Sociétés, Civilisations. 47.6 (1992), pp. 1113-25. De fato, o 'caso exemplar' (por vezes, um caso limite, um 'cas limite' - MARMURSZTEJN, E. "Du récit exemplaire au casus universitaire: une variation théologique sur le thème de la profanation de l'hosties par les juifs (1290)". Médiévales 41 (2001), pp. 37-64 [cf. esp. p. 43]), se apresenta como uma narrativa que, não obstante particular (ressurreição de Cristo, nascimento de Maria sem pecado etc.) permite uma generalização de maneira à propiciar, a partir de uma formulação particular, uma reflexão universal (e, portanto, científica ao modo escolástico): "Il faut cependant souligner la singularité formelle du casus théologique. Le casus, qui correspondait à une méthode d'enseignement très répandue dans les écoles de droit de la fin du XII ${ }^{\mathrm{e}}$ siècle, consistait dans l'exposé d'un problème lié à une situation particulière, dont la solution devait servir de modèle dans toutes les situations analogues. La forte représentation de questions qui s'apparentent à des casus dans les Quodlibets parisiens de la seconde moitié du XIII ${ }^{\mathrm{e}}$ siècle témoigne de ce que la discussion de cas pratiques n'avait pas été totalement abandonnée aux auteurs de sommes et manuels de confesseurs qui, à la suite du dominicain Raymond de Peñafort, eurent systématiquement recours à la méthode du casus. Depuis le début du $\mathrm{XIII}^{\mathrm{e}}$ siècle, les théologiens avaient en effet intégré à leur enseignement la considération des situations concrètes. Celles-ci entraient cependant dans des cadres d'énonciation spécifiques, propres à assurer à la détermination magistrale un certain degré de généralité et d'abstraction. Dans le casus qui nous occupe, le récit exemplaire de référence est en effet ramené à trois éléments essentiels (la profanation, le miracle eucharistique, la conversion et le baptême du juif) et dépouillé de ses éléments concrets, des indications de noms, de temps ou de lieu qu'il pouvait éventuellement contenir. La narration cédait ainsi la place à la mention sèche de faits logiquement reliés: l'hostie saignait parce qu'elle avait été frappée, le juif se convertissait à la vue du miracle" (MARMURSZTEJN, E. "Du récit exemplaire au casus universitaire", 2001, p. 42 - grifos no orig.). Notemos de passagem o uso nesse trecho do termo 'método' que criticávamos acima, no cap. 1, nota 13; isso porém não é relevante para nós aqui. O que importa é ver como a teologia escolástica do século XIII possuía mecanismos teóricos que lhe permitiam pensar universalmente a partir de narrativas exemplares de casos particulares. Vale notar que a ressurreição de Cristo é tratada justamente como um cas théologique performant em KÖNIGPRALONG, C. "Corps, cadavre, matière", 2007, pp. 349-355 (cf. tb. KÖNIG-PRALONG, C. "Évaluations des savoirs d'importation dans l'université medieval...", 2008, pp. 11-28). No que diz respeito ao caso do Cristo em particular, o próprio Henrique de Gand, parece aceitar que se faça uma distinção, no interior do estudo sobre a natureza humana, entre o estudo especial de algumas pessoas 
união entre corpo e alma não surge, em geral, como uma reflexão acerca daquele homem que poderíamos chamar de 'normal' - isto é, dos indivíduos viventes compostos racionais como ocorrem 'em geral' -, mas de casos extremos que, pela sua própria anormalidade, exigem uma prévia compreensão do normal para serem descritos. Esses casos são, em geral, quatro: o tríduo da morte e ressurreição de Cristo $^{60}$, a geração de Maria e seu pecado ${ }^{61}$, as relíquias de corpos de $\operatorname{santos}^{62}$ e,

humanas privilegiadas ('praerogativas'), como o Cristo, e o estudo dos homens em geral - Quodl. 9, q. 8 (ed. De Wulf-Mansion Centre, vol. 13, p. 152): "Sequuntur quaesita pertinentia ad humanam naturam specialiter. Et quaerebantur ibi quaedam pertinentia ad quasdam personas humanas praerogativas specialiter, et quaedam alia pertinentia ad homines et humanam naturam generaliter". Nesse contexto, de fato, não é raro que o estudo do caso individual de uma 'pessoa privilegiada' pressuponha e, com efeito, seja a ocasião para um estudo do homem em geral. Um autor que tem trabalhado regularmente com a noção de casus para compreender aspectos da teologia e da cultura medievais é o já citado Alain Boureau, em textos como o artigo citado no início desta nota e outros, como "La redécouverte de l'autonomie du corps: l'émergence du somnambule (XII'-XIV s.)". Micrologus 1 (1993), pp. 27-42. Ainda sobre a noção escolástica de casus, cf. MARMURSZTEJN, E. "Loi ancienne, loi nouvelle et normes chrétiennes dans la théologie scolastique du XIII ${ }^{\mathrm{e}}$ siècle". Revue de l'histoire des religions 228.4 (2011), pp. 528-529. Outro autor a se valer da noção de 'cas limite' nesse contexto é Maaike van der Lugt, em Le ver, le démon et la vierge. Les théories médiévales de la génération extraordinaire. Paris: Les Belles Lettres, 2004 (cf. pp. 14sg.). Pode-se, por fim, citar um artigo no qual Boureau discute o uso do casus com respeito à historiografia contemporânea: "Propositions pour une histoire restreinte des mentalités". Annales. Économies, Sociétés, Civilisations. 44.6 (1989), pp. 1491-504 (cf. esp. p. 1496)

${ }^{60}$ A melhor introdução a esse tema em Henrique de Gand é BAYERSCHMIDT, P. Die Seins- und Formmetaphysik des Heinrich von Gent in ihrer Anwendung auf die Christologie. Eine Philosophieund Dogmengeschichte Studie. Münster: Aschendorff, 1941, pp. 187-229 (na p. 187, o autor lista as questões quodlibetais em que nosso autor abordou tal problema). É bom lembrar, aliás, que a determinação da temática da unidade do corpo de Cristo no tríduo está diretamente relacionada à questão da transubstanciação no sacramento católico da Eucaristia, pois a forma corpórea que problematicamente se mantém em ambos os casos - no corpo de Cristo morto e no pão - é a mesma. Assim, Henrique de Gand pode muito bem associar os dois problemas em Quodl. 9, q. 8 (ed. De WulfMansion Centre, vol. 13, p. 153): "utrum scilicet dicendo 'Hoc est corpus meum' tenet ecclesia secundum usum et dicta sanctorum, quod fiat conversio in substantiam animae rationalis secundum quod dat esse corporeum, vel in solam materiam ut habet partes suas extensas sub partibus dimensionum, an in aliquod compositum ex materia et forma alia praeter animam intellectivam". A mesma relação entre a especulação acerca da relação corpo/alma (em particular, mas não somente, em Cristo) e a questão eucarística fica clara em Quodl. 4, q. 13 (ed. De Wulf-Mansion Centre, vol. 8, pp. 108-84). Sobre os dois temas cristológicos, cf. KÖNIG-PRALONG, C. Avènement de l'aristotélisme en terre chétienne, 2005, pp. 207-29. Para uma visão geral sobre esse problemática em Henrique de Gand, cf. HÖDL, L. "The Theologian Henry of Ghent", 2011, pp. 122-125.

${ }^{61}$ Cf. Henrique de Gand, Quodl. 15, q. 13 (ed. De Wulf-Mansion Centre, vol. 20, pp. 76-113). Sobre a mariologia de Henrique de Gand, cf. SCHULTER, A. "Die Bedeutung Heinrichs von Gent für die Entfaltung der Lehre von der Unbefleckte Empfängnis". Theologische Quartalschrift 118 (1937), pp. 312-340, 437-455; GOICOECHEA Y VITERI, J. M. Doctrina mariana de Enrique de Gante [tese de doutorado apresentada ao Pontificio Ateneo Antoniano]. Lima: Scheuch, 1944; LEITE DE FARIA, F. "L'attitude des théologiens au sujet de la doctrine d'Henri de Gand sur la conception de la Sainte Vierge". Études franciscaines 5 (1954), pp. 113-152; e, do mesmo autor, "L'opinion d'Henri de Gand sur la conception de la Sainte Vierge". Marianum 16 (1954), pp. 290-316. É interessante notar como a discussão acerca da presença do pecado original na concepção de Maria leva não somente a uma reflexão sobre a geração humana e a união entre alma e corpo, mas também a uma discussão física acerca da noção de 'tempo' e, em particular, da noção de 'instante temporal'. Acerca disso, cf. DUMONT, S. D. "Time, Contradiction and Freedom of the Will". Documenti e studi sulla filosofia medievale 3.2 (1992), pp. 561-597 (esp. pp. 571-7); BOUREAU, A. "L'immaculée conception de la 
finalmente, o caso do batismo de uma criança nascida com duas cabeças

(provavelmente, um caso similar ao que chamaríamos de gêmeos-siameses), a qual

Henrique denomina - de maneira um tanto censurável nos dias atuais... - de

monstrum $^{63}$. Como se vê, em todas essas discussões, os casos estudados fogem ao

souverainété. Jean Baconthorpe et la théologie politique (1325-1345). (Postille sur Bernard Guenée, Entre l'Eglise et l'Etat, p. 189-201)". In: AUTRAND, F., GAUVARD, C., MOEGLIN, J.-M. (éds.). Saint-Denis et la royauté. Études offertes à Bernard Guenée. Paris: Publications de Sorbonne, Paris, 1999, pp. 733-749 (esp pp. 738-41); LAMY, M. L'immaculée conception: étapes et enjeux d'une controverse au moyen-âge (XII ${ }^{e}-X V^{e}$ siècles). Paris: Institut d'Études Augustiniennes, 2000 (esp. pp. 306-23); BROWER-TOLAND, S. "Instantaneous Change and the Physics of Sanctification", 2002.

${ }^{62}$ Cf. Henrique de Gand, Quodl. 10, q. 6 (ed. De Wulf-Mansion Centre, vol. 14, pp. 132-145). A discussão sobre relíquias de santos importa neste contexto, pois ela justamente põe em jogo a necessidade de explicitar a relação entre alma e corpo, de maneira a justificar o caráter sagrado de um corpo que, embora não mais se encontre informado por aquela alma santa (que recebeu alguma graça divina), ainda possui algo de sagrado justamente por já haver sido informado por uma tal alma. Sobre isso, ver WIRTH, "Le cadavre et les vers selon Henri de Gand”, 1999, pp. 283-295.

${ }^{63} \mathrm{O}$ problema do batismo do monstro de duas cabeças é posto em Quodl. 6, qq. 14-15 (ed. De WulfMansion Centre, vol. 10, pp. 156-169). O interesse no estudo desse caso teológico (cf. KÖNIGPRALONG, “Évaluations des savoirs d'importation dans l'université medieval...”, 2008, pp. 17-21) está no fato de que ele coloca em questão diversos outros temas centrais para a filosofia escolástica: "quaestio ista non quaerit nisi utrum tale monstrum sit una persona ab una anima, cui debetur unum nomen, vel duae, quibus debeantur duo nomina, quia nomina debent esse consona rebus" - Quodl. 6, q. 14, co. (ed. De Wulf-Mansion Centre, vol. 10, p. 156). Como se vê, essa casuística do batismo - ou seja, essa consideração de um caso particular, extremo e (paradoxalmente), por isso mesmo, exemplar de batismo - põe em jogo, em primeiro lugar, a própria concepção de pessoa e sua determinação, pois é preciso saber o que garante a unidade da pessoa. Essa pesquisa redunda em uma caracterização da pessoa em termos fisiológicos e não metafísicos, o que fornece uma visão muito distinta daquela que a reflexão sobre a trindade divina oferece dessa mesma noção de 'pessoa' - sobre o tema da 'pessoa' (e aquele estreitamente associado do 'suppositum') no contexto do estudo da trindade produzido pelo gandavense, cf. SCHINZER, R. "Objektivasion der Existenz. Versuch über die trinitarischen Personen bei Heinrich von Gent". Neue Zeitschrift für Systematische Theologie und Religionsphilosophie 18.2 (1976), pp. 225-245; WILSON, G. A. "Supposite in the Philosophy of Henry of Ghent". In: VANHAMEL, W. (ed.) Henry of Ghent. Proceedings..., 1996, pp. 343-372; FLORES, J. C. Henry of Ghent: Metaphysics and the Trinity. Leuven: Leuven University Press, 2006, pp. 150-161; e WILSON, G. A. "The Human Person in Henry of Ghent's Thought". Medieval Perspectives 17.1 (2002), pp. 15166. Exatamente por isso, Jos Decorte faz referência a essa discussão sobre o monstrum de duas cabeças de Henrique de Gand em sua exposição acerca da noção medieval de alma, pois se perguntar sobre forma substancial e sobre a alma (ou, possivelmente, as almas) de um homem de duas cabeças é, também, se perguntar sobre aquilo mesmo que caracteriza o homem enquanto tal (sua humanidade) e a alma humana enquanto sua forma: "Als de namen moeten overeenkomen met de dingen die ze aanduiden, dan kan men niet één en dezelfde naam gebruiken voor twee verschillende dingen, noch twee verschillende namen voor één identiek ding. Beschouwt men een siamese tweeling dus als één individu (ziel) of als twee individuen (zielen) in één en hetzelfde lichaam? Alles zal hierbij afhangen van de vraag: wat is de ziel? Redeneert men aristotelisch (de ziel is de 'vorm', dat wil zeggen: het constituerende principe van een organisch levend lichaam), dan kan één lichaam slechts één vorm hebben, en moet het benoemd worden naar die 'vorm'. Maar beschouwdt men de ziel als zetel van deken en waarnemen, dan moet men stellen dat een siamese tweeling uit twee individuen bestaat, elk met een apart hoofd, aparte hersenen, aparte centra van denken en waarnemen; vandaar Hendriks vraag naar wat nu precies de individuele eigenheid (de ziel) van een mens constitueert" ("Naar zijn beeld en gelijkenis: de ziel". STOFFERS, M. (red.). De middeleeuwse ideeënwereld, 1000-1300. Heerlen Hilversum: Open universiteit - Verloren, 1994, pp. 201-32 [esp. pp. 205-206]). Da mesma maneira, Alain de Libera vê nessa reflexão sobre os monstros que surge em Henrique de Gand uma etapa interessante no desenvolvimento tardo-medieval da noção de homem (inserida por Libera no contexto do surgimento da noção moderna de sujeito): "Il n'en va pas de même du texte d'Henri de Gand, de proportions plus imposantes, plus philosophique aussi, et dont les objectifs sont multiples. 
'padrão' do homem, porém eles sempre exigem uma explicação da normalidade que sirva de baliza para a especulação sobre o extremo. De fato, aquilo que é tomado por extremo acaba sendo parte da determinação daquilo que é tido por normal ${ }^{64}$. E,

Naturellement, il y a la question théologique, le baptême du 'monstre à deux têtes': mais son traitement est axé sur la nomination, l'acte d'imposition du nom du baptême, et cette question entraîne une méditation explicite des critères de l'identité personelle et de l'individuation d'un humain par rapport à un simple vivant animé. En outre, la discussion théologique est, comme on l'a dit, l'occasion d'engager la polémique sur deux fronts proprement philosophiques, d'une incontestable 'actualité' dans les années 1280, immédiatement consécutives aux condamnations parisiennes et oxoniennes de 1277: le premier relatif à la théorie averroïste latine des deux sujets de la pensée, le second lié à la théorie thomasienne de la forme substantielle unique, seule donatrice d'être au composé humain. La question du baptême fait donc communiquer les deux grands dossiers philosophiques et théologiques (par leur implications ou leur préssupposés) qui dominent la fin du XIII ${ }^{\mathrm{e}}$ siècle: monopsychisme (unité de l'intellect) et unité ou pluralité des formes, tout en confirmant le rôle central de la personne dans le "chiasme de l'agence"' (Archéologie du sujet II. La quête de l'identité. Paris: Vrin, 2008, p. 203 grifos no original). Além disso, está claro pelo texto destacado que essa reflexão sobre a noção de 'pessoa' vem associada ao problema da imposição de nomes que, como vimos na nota 36 , é mais bem desenvolvido em outros trechos da obra do Doutor Solene. Ainda sobre o bastismo do monstrum de duas cabeças, cf. JANSSENS, "Some elements of Avicennian Influence on Henry of Ghent's Psychology", 1996, pp. 157-8; LIBERA, A. de. "Le présent roi du mogol et le baptême des siamois. Sur l'identité personnelle, du Moyen Âge à John Locke". In: BECCARISI, A., IMBACH, R., PORRO, P. (Hrsg.). Per perscrutationem philosophicam. Neue Perspektiven der mittelalterlichen Forschung. Loris Sturlese zum 60. Geburtstag gewidmet. Hamburg: Felix Meiner, 2008, pp. 418-46 (esp. pp. 43941); e JANSSENS, J. "Henry of Ghent and Averroes". In: WILSON, G. A. (ed.). A Companion to Henry of Ghent, 2011, pp. 85-99 (esp. pp. 92-3).

Por fim, surge em Quodl. 6, qq. 14-15, algo muito relevante para a nossa caracterização da noção de 'homem' desenvolvida por Henrique, a saber, uma cuidadosa descrição fisiológica do útero que pode ser associada a uma tipologia de eventos que levem à formação do monstrum a que as questões se referem. Na descrição de Henrique de Gand, o útero humano surge claramente descrito como composto de diversos compartimentos voltados para a recepção da semente ('semen') - isto é, a multiplicidade de compartimentos no útero é visto como o caso normal para este pensador escolástico: "Cum tota materia seminis est una et continua, principium seminale est unum, et cum totum semen cadens recipiatur in una incastratura matricis tamquam in una camera inter duas villulas matricis, - sunt enim in matrice plures incastraturae quasi plures camerae sive monetae secundum numerum fetuum, qui possunt simul formari in femina cuiusque speciei animalis, et singulae incastraturae ab invicem villulis quasi parietibus distinguuntur; quae villulae, quandoque sunt integrae, ut semina recepta in eis nequaquam possunt concurrere, quandoque ex aliqua parte ruptae, ut semina in duabus incastraturis existentia ibi necesse habent concurrere -, cum inquam, ut dictum est, totum semen in una incastratura recipiatur, tunc totum unica vi caloris illius incastraturae confovetur semen, et totum seminale vigens in calore seminis excitatum calore illius partis matricis incipit materiam coagulare ad fetus formationem $<\ldots$. " Quodl. 6, q. 14, co. (ed. De Wulf-Mansion Centre, vol. 10, p. 157). Como se vê, há aqui uma concepção do útero (matrix) como constituído por diversas cavidades (camerae ou incastraturae) separaradas por villulae.

Ainda sobre o monstrum, a questão quodlibetal colocada para Henrique não deixa de lembrar um problema que Michel Foucault abordou no que diz respeito ao século XVII: a grande dificuldade posta pelo monstrum não é o seu caráter arredio à norma da natureza, mas o problema que há em localizá-lo na ordenação jurídica (cf. FOUCAULT, M. Les anormaux. Cours au Collège de France. 1974-1975. Paris: Éditions du Seuil, 1999, pp. 60-1, 320-1). Com efeito, no Quodlibet de Henrique, o próprio fato de existirem homens com duas cabeças não é o mais alarmanente. O que suscita a questão é a dificuldade em inseri-lo no ritual do batismo. Com efeito, as perguntas colocadas são, em Quodl. 6, q. 14 (ed. De Wulf-Mansion Centre, vol. 10, p. 156): "utrum, si duo capita in monstro apparerent, in baptizando debent ei imponi duo nomina, an unum"; e em Quodl. 6, q. 15 (ed. De Wulf-Mansion Centre, vol. 10, p. 168): "utrum, si duo capita in monstro apparerent et si dicat sacerdos 'ego te baptizo', ambo vel alter eorum sit baptizatus".

${ }^{64} \mathrm{O}$ que me parece reclamar um exame mais minucioso aqui é como a oposição entre normal e patológico surge, na obra de Henrique de Gand, expandida para uma oposição entre o normal e o 
portanto, é precisamente por essa 'casuística dos extremos da vida' que Henrique de Gand desenvolve a sua concepção da união entre alma e corpo no homem - sempre como uma reiteração da normalidade em face dos extremos ${ }^{65}$. Embora esse seja um tema interessantíssimo na obra do Doutor Solene, não será este o lugar de tratá-lo, uma vez que ele por si só exigiria um livro à parte.

Sendo assim, me contentarei em abordar o tema pelo terceiro elemento que, a meu ver, atraiu o interesse de leitores atuais, a saber, o fato de que a explicação proposta por Henrique de Gand para a união entre corpo e alma no homem é extremante característica de sua própria obra. Essa tese - descrita como uma 'théorie dualiste' por Roberto Zavalloni ou um 'dimorfismo' por Gordon Wilson e Santiago de Carvalho ${ }^{66}$ - é interessante, antes de tudo, por buscar ressaltar o caráter único do homem na criação ao, precisamente, propor que este último possui necessariamente duas formas inerentes a si, algo que não ocorre a nenhum dos outros compostos. Para piorar, uma dessas duas formas pode subsistir por si, o que parece impedir a sua união a outro como forma substancial. Ou seja, para compreender a união entre corpo e alma é necessário matizar a posição de Henrique de Gand segundo a qual a alma é ato, forma e perfeição substancial do corpo. Ela não deixa de ser tudo isso, mas essa afirmação merece ressalvas.

Os textos em que Henrique de Gand melhor aborda esses temas são Quodl. 3, q. 15, e Quodl. 4, q. 13, os quais acompanharemos aqui - estes são importantes, entre outras razões, justamente porque são duas das poucas passagens em que o Doutor Solene se volta diretamente para o problema aqui posto. Assim, na questão 15 do

\footnotetext{
monstruoso (lembremos, aliás, que, pelo menos no século XVII, o monstruoso inclui, além de homens e outros animais de duas cabeças, todos os eventos inesperados na natureza, dentre os quais os cometas, como ocorre em ALDROVANDUS, U. Monstrorum historia... Bononiae: typis Nicolai Tebaldini, 1642 - seria esse o caso já no século XIII?) e, por fim, para uma oposição entre o normal e o maravilhoso ou o extremo da vida ou, simplesmente, anormal (um homem divino, uma mulher sem pecado, um corpo sagrado, um mostro de duas cabeças). Seria um trabalho interessante ler essas passagens de Henrique de Gand a partir de obras contemporâneas que nos forneçam ferramentas para refletir sobre esse par normal/patológico ou, da maneira expandida como surge no Doutor Solene, normal/anormal - obras como CANGUILHEM, G. La connaissance de la vie. Paris: Vrin, 2009 [1965], pp. 199-236, e Le normal et le pathologique. Paris: PUF, 2013 ${ }^{12}$ [1966] (esp. pp. 109-13) ou o, já citado, FOUCAULT, Les anormaux, 1999.

${ }^{65}$ Quanto a essas observações sobre a noção de corpo e vida em Henrique de Gand, gostaria de agradecer ao prof. André Mota (USP) e às colegas Carolina Kinoshita, Fernanda Izidório e Tamara Prior pelas conversas sobre o tema e, principalmente, pelos esclarecimentos acerca da história das noções de corpo e vida, tanto sob um ponto de vista filosófico como médico e social.

${ }^{66}$ Respectivamente, em ZAVALLONI, Richard de Mediavilla..., 1951, pp. 287-302; WILSON, Dymorphism and the Metaphysical Unity of Man..., 1975; e CARVALHO, "O que significa pensar?", 2001, p. 87.
} 
Quodl. 3, pergunta-se "se o subsistente por si pode se unir a outro como forma [utrum per se subsistens alteri possit uniri ut forma]",67, enquanto que em Quodl. 4, q. 13, a questão é "se na quididade das coisas sensíveis materiais se incluem muitas formas substanciais diferentes na coisa [utrum in quiditate rerum sensibilium materialium cadant plures formae substantiales re differentes]" ${ }^{68}$. Como vemos, esses são precisamente os problemas a que fomos levados pela leitura de Henrique - de fato, são dificuldade que se seguem das próprias teses que ele pretende defender. Sendo assim, sigamos a ordem de sua obra e vejamos como cada uma dessas dificuldades é resolvida.

Podemos começar pelo resumo que Henrique faz de sua resposta à primeira dessas duas questões:

"Portanto, essa alma humana, por não possuir uma parte material de sua essência
[ex eo quod non habet materiam partem suae essentiae], não comunica sua
potência intelectiva a um órgão corpóreo como a um sujeito, nem é totalmente
imersa na matéria, como se proviesse de sua potência. Mas ela é tal como uma
forma mais alta, que excede o poder da matéria [excedens potestatem materiae] e
é produzida na matéria imediatamente pelo primeiro agente [immediate a primo
agente producta in materia]. Daí que ela exceda, quanto a alguma potência sua,
a capacidade da matéria [capacitatem materiae], tal que não lhe comunique essa
força [vim] (embora seja forma e ato dela $<s c$. da matéria $>$ ), a saber, quanto
àquela potência pela qual é o princípio do ato de inteligir. E, ainda assim, é
comprimida pela matéria quanto às outras potências, a saber, sensitivas, que
comunica ao corpo e à matéria, como foi dito"

Como vemos pela passagem, o Doutor Solene parece considerar que o problema da possibilidade de explicar 'como uma forma subsistente por si pode ser forma substancial de outro' pode ser tratado como a tentativa de esclarecer 'como algo pode possuir uma forma substancial que, no entanto, o excede'. Como já estava claro para nós e aqui é reiterado, aquilo em que a alma excede o corpo por ela informado é, precisamente, o intelecto. De fato, a alma é forma do corpo, mas não é

\footnotetext{
${ }^{67}$ Henrique de Gand, Quodl. 3, q. 15 (ed. 1613, f. 115r).

${ }^{68}$ Henrique de Gand, Quodl. 4, q. 13 (ed. 1613, f. 162r).

${ }^{69}$ Henrique de Gand, Quodl. 3, q. 15, co. (ed. 1613, f. 121va-b): "Haec anima ergo humana ex eo, quod non habet materiam partem suae essentiae, neque potentiam suam intellectivam organo corporali velut subiecto communicet, neque est omnino materiae immersa, ut de eius potentia educta, sed est tanquam forma altior excedens potestatem materiae, et immediate a primo agente producta in materia, ex hoc habet, quod ipsa excedit quo ad aliquam potentiam suam capacitatem materiae, ne ei vim illam communicet, licet sit forma, et actus eius scilicet quo ad illam potentiam, qua est principium actus intelligendi, et tamen compressa est a materia quo ad alias potentias sensitivas scilicet, quas communicat corpori, et materiae, ut dictum est".
} 
enquanto potência intelectiva que a alma é comprimida (compressa) ou determinada ${ }^{70}$ pela matéria, mas enquanto potência sensitiva. Ou seja, a alma excede o corpo precisamente porque, ainda enquanto forma do corpo, possui uma potência que não se determina pela matéria, a saber, o intelecto ${ }^{71}$. A matéria, de fato, nem mesmo é capaz de inteligir. Essa é, sem dúvida, uma boa descrição da maneira pela qual o corpo é excedido pela alma, sem que esta deixe de ser sua forma substancial. Um problema mais grave, entretanto, ainda não foi resolvido: se a forma substancial excede a

\footnotetext{
${ }^{70}$ Cf. nota 42, acima.

${ }^{71}$ De fato, não atentar para essa espiritualidade da alma é incorrer em uma excessiva ligação entre
} corpo e alma, que redunda em uma condição patológica do homem, a saber, a melancolia (curiosamente associada por Henrique de Gand à matemática). Sobre isso, cf. Henrique de Gand, Quodl. 2, q. 9 (ed. De Wulf-Masion Centre, vol. 6, pp. 63-64): "Qui ergo non possunt angelum intelligere secundum rationem substantiae suae ut unitatem absque ratione puncti, sunt illi de quibus dicit Commentator super II ${ }^{\mathrm{um}}$ Metaphysicae: 'In quibus virtus imaginativa dominatur super virtutem cogitativam. Et ideo', ut dicit, 'videmus istos non credere demonstrationibus, nisi imaginatio comitetur eas. Non enim possunt credere plenum non esse aut vacuum aut tempus extra mundum. Neque possunt credere hic esse entia non corporea, neque in loco neque in tempore' $<\ldots$. . Unde tales melancholici sunt, et optimi fiunt mathematici, sed pessimi metaphysici, quia non possunt intelligentiam suam extendere ultra situm et magnitudinem, in quibus fundantur mathematicalia, et metaphysicalia per se abstracta sunt secundum rem a situ et magnitudine, quia metaphysica abstractio excedit mathematicam”. De fato, é interessante notar que a melancolia, tomada como essa excessiva ligação entre intelecto e sentidos corpóreos (no caso, o sentido interno da imaginação), possui consequências no campo do conhecimento: o melancólico jamais será um bom metafísico, mas pode ser um ótimo matemático. O melancólico, por estar ligado à imaginação tal que não possa abstrair o lugar e a magnitude, é impedido de praticar a metafísica que exige uma tal abstração. No entanto, ele permanece no campo da matemática, que exige o lugar e a magnitude (e, portanto, os sentidos corpóreos) como seus fundamentos. Sobre o tema, cf. KLIBANSKI, R., PANOFSKY, E., SAXL, F. Saturn and Melancholy. Studies in the History of Natural Philosophy, Religion and Art. Lichtenstein: Kraus, $1979^{2}$ [1964], p. 338: “< ..> Henricus de Gandavo, arguing from purely philosophical premises and conceiving melancholy as a darkening of the intellect, enquires as to the influence of a certain state of the intellectual on emotional life $<\ldots$.. ". Nosso autor "asks why particularly imaginative, and therefore mathematically inclined, men are melancholy $\langle s i c\rangle$; and he finds the answer to this question in the circumstance that a preponderantly imaginative disposition does in fact lead to a marked capacity for mathematics, but at the same time renders the mind incapable of metaphysical speculation”. Destarte, quando é dito ainda no início da Suma que "apprehensione autem facta per sensus, avertendo a sensibus, ut iudicium fiat in ratione, quod summe monet fieri Augustinus in inquisitione veritatis <..." (cf. cap. 1, nota 47), a consequência de ignorar essa advertência de Agostinho é, a um só tempo, científica (a excelência matemática e o desespero da metafísica) e patológica (a melancolia), decorrente de um desequilibrío das potências da alma, a qual, mesmo naquela sua parte puramente espiritual, se torna indevidamente e excessivamente ligada ao corpo. Ainda sobre a melancolia em Henrique de Gand, cf. TELlENBACH, H. Melancholie. Problemgeschichte, Endogenität, Typologie, Pathogene, Klinik. Vierte, erweiterte Auflage mit einem Exkurs in die manisch-melancholische Region. Mit einem Geleitwort von V. E. Von Gebsattel. Berlin-Heidelberg-New York-Tokyo: Springer, 1983, pp. 12-3; MOLLAND, A. G. "Colonizing the world for mathematics: the diversity of medieval strategies". In: GRANT, E., MURDOCH, J. E. Mathematics and its applications to science and natural philosophy in the Middle Ages. Essays in honor Marshall Clagett. Cambridge: Cambridge University Press, 1987, pp. 45-66 (esp. p. 60); FELD, A. N. Melancholy and the Othernesse of God. A Study of the Hermeneutics of Depression. Foreword by M. L. Raposa. Plymouth: Lexignton, 2011, pp. 184-7; FREITAS, E. de., SINCLAIR, N. Mathematics and the Body. Material Entanglements in the Classroom. Cambridge: Cambridge University Press, 2014, pp. 143-5; e SPRUYT, "Henry of Ghent and the Power of Inspiration...”, 2015, pp. 74-8. 
capacidade da matéria que ela informa e, portanto, ela não pode provir desta última, donde provém a alma?

Henrique inicia a resposta a essa pergunta por um esclarecimento que exclui uma das possíveis origens que se lhe poderiam atribuir: ela não provém da potência da matéria (neque est omnino materiae immersa, ut de eius potentia educta). Essa afirmação, por si só, é suficiente para separar os homens de todos os outros casos de viventes (e, em geral, de entes) corpóreos, pois as potências vegetativa e sensitiva podem ser produzidas substancialmente pela natureza a partir da potência da matéria $^{72}$. Ou seja, os outros viventes são naturalmente produzidos a partir da matéria, enquanto que o homem não pode ser produzido assim, pois a sua forma substancial excede a matéria e, portanto, não pode ter esta última como origem. Pois bem, a saída de Henrique de Gand para esse problema é clara: para ele, a alma é produzida na matéria imediatamente por Deus (imediate a primo agente producta in materia). Essa conclusão, no entanto, nos leva a um problema mais complicado ainda, pois agora um ser substancialmente composto como o homem possui uma forma que não é extraída da potência da matéria, vindo a ela de fora. A resposta para essa dificuldade se encontra, me parece, justamente na doutrina da dualidade das formas proposta pelo Doutor Solene. Com ela, estaremos em posição de afirmar que o homem possui sim uma forma introduzida no composto diretamente por Deus e que, entretanto, ele possui igualmente uma forma proveniente da matéria - forma esta que vem a ser completada por aquela dada pelo agente primeiro. Mas, nesse caso, como não dizer que um homem, na verdade, são duas coisas?

\begin{abstract}
"Ainda que as formas se multipliquem, o ser do composto não o faz. E, assim, sempre a forma de uma coisa é uma única [semper unius rei una est forma], pela qual é um ente em ato. Isso, porém, não exclui que na matéria possa a preceder outra forma que, a partir de si, não possui ser senão em potência, enquanto não é nata a [non est nata] ser a disposição da coisa completamente [complete], mas só de maneira inicial [inchoate], como foi dito.

$\mathrm{E}$, por esse modo, não há nenhum inconveniente em que haja muitas formas substanciais para uma única coisa [uni rei $]^{, 73}$.
\end{abstract}

\footnotetext{
${ }^{72}$ Henrique de Gand Quodl. 3, q. 16, co. (ed. 1613, f. 122vb): “Intelligendum tamen quod aliquantulum minus proprie homo dicitur generare hominem, quia intellectum, qui est forma, a qua homo est homo, et habet esse specificum, non extrahit de potentia materiae, sicut bos dicitur generare bovem, et unum agens naturale id cuius formam educit de potentia materiae <... ". A possibilidade de uma geração de potentia materia coloca o problema físico das razões seminais (rationes seminales) - sobre esse tema no Doutor Solene, cf. MAZZARELlA, P. "La critica di Enrico di Gand alla dottrina dell' 'inchoatio formae"”. In: Ethos e cultura. Studi in onore di Ezio Riondato. Padova: Antenore, 1991, pp. 183-193.

${ }^{73}$ Henrique de Gand, Quodl. 3, q. 15, co. (ed. 1613, f. 118va): "Ideo etsi illae formae multiplicarentur, non tamen esse compositi, et sic semper unius rei una est forma, per quam est ens in actu: per quod non
} 
Nesse trecho, a possibilidade de uma multiplicidade de formas é justificada pela distinção de formas entre aquelas que dispõem incialmente (inchoate) o composto e aquelas formas que o dispõem completamente (complete). As primeiras podem ser várias em uma única coisa, porém elas não podem ser capazes de atualizar a coisa por si mesmas. Ou seja, mesmo já informada por essas formas iniciais, a matéria ainda não é em ato aquele composto que possui tais formas. De fato, é somente após a recepção da forma capaz de dispor completamente a coisa que há, de fato, atualmente essa coisa composta. Sendo assim, continua o raciocínio, um mesmo composto com várias formas não será vários seres ou várias coisas, mas um único ser e uma única coisa, pois a forma substancial que determina e completa o seu ser é a forma substancial final. Assim, aquela expressão 'semper unius rei una est forma' claramente é interpretada aqui como remetendo somente à forma substancial que vem completar todas as outras e, assim, dar o ser atual completo à criatura composta.

Com isso, começamos a compreender que a solução de Henrique de Gand caminha no sentido de afirmar a alma como forma do corpo, mas não como única forma desse composto que é o homem. Ainda assim, certamente seria possível e correto dizer que a alma é forma substancial e ato do corpo, pois ela seria aquela forma última que o completa sendo, no entanto, precedida por uma ou várias outras formas anteriores e iniciais do corpo do homem. Que esse parece ser o caso, podemos ver ao nos voltarmos para Quodl. 4, q. 13, onde o Doutor Solene afirma que:

"É preciso, portanto, que no homem duas sejam as formas: uma natural material
extraída [educta] da potência da matéria, que é a forma da mistura [forma mixti]
determinada e apropriada ao homem; e a outra sobrenatural imaterial, isto é, não
proveniente da potência da matéria, que entretanto pode ser forma e ato da
matéria com a supracitada forma material, como foi dito. Donde também, esta
forma imaterial, que é a alma intelectiva, ser intermediária entre as formas
puramente materiais e as puramente imateriais, tal que seja suprema [suprema]
entre as materiais que são ato da matéria e, entre as totalmente imateriais, ínfima
[infima], se portando de modo intermediário [medio modo se habens] para com
ambas e possuindo algo em comum com ambas. De fato, ela possui as forças
supremas [supremas vires] das formas materiais em si (como são o vegetativo e
o sensitivo) e aquela inferior entre as formas imateriais [inferiorem formarum
immaterialium] (como a força intelectiva com ajuda dos sentidos [vim
intellectivam adminiculo sensuum]). E, assim, por meio da alma intelectiva, se
unem os imateriais aos materiais e o homem se faz [fit] por um alma intelectual e

excluditur quin possit alia forma illam praecedere in materia, quae ex se esse non habet nisi in potentia, inquantum non est nata complete, sed tantum inchoate dispositionem esse rei, ut dictum est.

Et per hunc modum nullum est inconveniens, quod unius rei plures sint formae substantiales". 
pela substância corpórea, que nele se juntam como o limite de toda criatura [limes universae creaturae]. Eles, enquanto se unem, possuem também uma conveniência [convenientiam] entre si $<\ldots>$.

Donde, se naturezas tão diversas como a divina e a humana puderam se unir verdadeiramente na unidade de ser e de subsistência pessoal, o que somente pode ser comunicado de uma daquelas naturezas para a outra (como à humana pela divina), o que há para se admirar [quid mirum] se a carne, que é forma natural com a matéria, tenha podido se unir com a alma racional na unidade de ser e da subsistência pessoal? O que é simultaneamente causado pelas duas [simul $a b$ ambabus] (embora por uma imperfeita e inicialmente [imperfecte et inchoative], mas por outra completivamente), também o é simultaneamente por ambas, tal que não poderia ser causado naturalmente por nenhuma das duas (nem no todo nem em parte), antes da outra ou por uma sem a outra, mas somente simultaneamente por ambas e por uma pela outra e com a outra [ab una per alteram et cum altera], tal como de dois que tracionam faz-se uma única e simples tração quanto à força [a duplici trahente secundum virtutem fit unicus et simplex tractus] $]^{174}$.

Em uma primeira leitura, parece haver aqui uma simples oposição entre corpo e alma no homem, porém se prestarmos mais atenção notamos que a posição de Henrique de Gand não é tão simples quanto parece. O que se opõe na etapa inicial do excerto são duas formas do homem, a saber, a 'forma da mistura' (forma mixti) e a 'alma intelectiva' (anima intellectiva). Somente a forma da mistura pode provir da matéria, enquanto que a alma intelectiva provém de Deus mesmo. Agora, apesar de esta última ser denominada por sua potência superior e imaterial, ela possui igualmente as potências sensitiva e vegetativa, pelas quais ela se comprime no corpo, como vimos acima. O intelecto, embora separado, é dependente do corpo por necessitar das potências corpóreas para inteligir - pois, como rapidamente já vimos e

\footnotetext{
${ }^{74}$ Henrique de Gand, Quodl. 4, q. 13, co. (Ed. De Wulf-Mansion Centre, vol. 8, pp. 172-174): "Oportet ergo quod in homine duae sint formae: una naturalis materialis educta de potentia materiae, quae est forma mixti determinata et homini appropriata, et altera supernaturalis immaterialis, hoc est non educta de potentiae materiae, quae tamen possit esse forma et actus materiae cum praedicta forma materiale, ut dictum est. Unde et huiusmodi forma immaterialis, quae est anima intellectiva, media est inter formas pure materiales et pure immateriales, ut suprema sit inter materiales quae sut actus materiae et inter omnino immateriales infima, medio modo se habens ad utrasque et aliquid commune cum utrisque; habet enim supremas vires formarum materialium in se, ut sunt vegetativum et sensitivum, et inferiorem formarum immateralium, ut vim intellectivam adminiculo sensuum, et sic mediante anima intellectiva uniuntur materialibus immaterialia, et fit homo per animam intellectualem et substantiam corporalem quae in se coniunguntur ut limes universae creaturae $<\ldots>$.

Unde si tam diversae naturae, ut divina et humana, uniri potuerunt vere in unitate esse et personalis subsistentiae quod solum ab una illarum naturarum erit aliteri communicatum, ut humanae a divina, quid mirum si caro, quae est forma naturalis cum materia, uniri potuit cum rationali anima in unitate esse et personalis subsistentiae? Quod simul ab ambabus, licet ab una imperfecte et inchoative, ab alia vero completive causatur, et simul ab utraque, ita quod a neutra naturaliter causari posset neque in toto neque in parte priusquam ab altera, neque $a b$ una sine altera, sed tantummodo simul ab utraque et $a b$ una per alteram et cum altera, quemadmodum a duplici trahente secundum virtutem fit unicus et simplex tractus".
} 
leremos mais detalhadamente adiante, o conhecimento intelectual tem origem nos sentidos ${ }^{75}$.

Nesse ponto, é importante destacar que essa dupla forma do homem não é somente resultado do seu lugar intermediário na natureza - isto é, desse seu caráter de limes, que esta passagem volta a enfatizar, mas provém igualmente das ordens de sucessão e de origem implicadas na passagem ao ser de cada homem. Como vimos acima, diversas são as maneiras pelas quais os entes estão ordenados no mundo e, se a ordenação por grau de natureza coloca o homem entre o corpo e o espírito, inculcando-lhe uma duplicidade de formas, também as ordens de sucessão (da passagem do não-ser ao ser) e de origem (da geração) do homem exigem essa dupla forma substancial ${ }^{76}$. Com efeito, sua dupla origem - isto é, humana e divina a uma só vez - só pode ser explicada, segundo Henrique, se afirmarmos que em cada homem se encontram duas formas informando o corpo. De fato, quando o Doutor Solene afirma que a forma da mistura provém da matéria, ele está se referindo claramente ao processo de geração típico das coisas naturais. Essa geração é fruto, a saber, das ações do Sol (que, ademais, age para qualquer geração) e do próprio homem, isto é, dos pais daquele descendente gerado. Assim, está claro que no ato sexual o macho e a fêmea

\footnotetext{
${ }^{75}$ Em Quodl. 7, q. 14, ad 1 (ed. De Wulf-Mansion Centre, vol. 11, pp. 102-4), Henrique de Gand afirma que 'separatum' se diz de muitas maneiras, fornecendo a potência intelectiva como exemplo do segundo desses modos. Assim, do primeiro modo, [i] é dito separatum aquilo que é totalmente para além da matéria e do corpo (omnino praeter materiam et corpus), sem possuir qualquer relação com a matéria (p. 102) - esse é somente Deus, pois mesmo os anjos são motores de corpos (pp. 102-4). De um segundo modo, [ii] algo separatum é aquilo que "não possui matéria ou corpo $<$ como $>$ algo seu, mas é na matéria e no corpo, de nenhum modo porém como ato e perfeição deste [non habet materiam aut corpus aliquid sui, est tamen in materia et corpore, nullo modo tamen ut actus et perfectio eius]" (p. 102) - esse é o caso da potência intelectiva. De fato, ainda que esta última "seja na matéria pela substância, ainda assim ela não é naquela $<s c$. na matéria $>$ imediatamente, tal como a substância, nem pelo mesmo modo que a substância $[<\ldots>>$ licet potentia sit in materia per substantiam, non tamen inest ei immediate sicut substantia, nec per eundem modum quo substantia]" (p. 104). De um terceiro modo, [iii] é separatum aquilo que, "embora não possua matéria ou corpo $<$ como $>$ algo seu, ainda assim seja na matéria enquanto ato e perfeição do corpo e da matéria, enquanto é algo segundo a substância, mas não enquanto é algo orgânico e dimensionado [ $<$... licet non habet materiam aut corpus aliquid sui, est tamen in materia ut actus et perfectio corporis et materiae, in quantum est aliquid secundum substantiam, non autem in quantum est aliquid organicum et dimensionatum]" (p. 102). O exemplo desse terceiro modo de separatum é a substância da alma racional (substantia animae rationalis), pois é unida (coniuncta) ao corpo, mas não possui matéria como sua parte nem é ela própria algo orgânico ou dimensionado (p. 104). Finalmente, do quarto modo [iv], é separatum aquilo que "não possui matéria ou corpo $<$ como $>$ algo seu, mas $<0>$ é como ato e perfeição do corpo e da matéria, enquanto é algo orgânico e dimensionado [<.. > non habet materiam aut corpus aliquid sui, est tamen ut actus et perfectio corporis et materiae, secundum quod est aliquid organicum et dimensionatum]" (p. 102). O exemplo desse último modo é a potência sensitiva (p. 104), uma vez que, sem ela própria possuir matéria, é unida (coniuncta) ao corpo e à matéria enquanto dimensionado e orgânico (dimensivum quid et organicum). Enfim, se a potência intelectiva pode ser dita separada, isso ocorre somente em um sentido bem preciso.

${ }^{76}$ Cf. nota 5, acima.
} 
não fazem mais do que informar uma matéria com a forma da mistura - isto é, da mistura dos quatro elementos. A alma intelectiva, esta, provém de Deus que completa aquela forma inicial da mistura proveniente dos progenitores ${ }^{77}$. O interessante é que, para Henrique, isso não equivale a dizer que os pais geram um corpo que é animado por Deus, pois a própria alma é também forma do corpo - pelo menos, de certa maneira -, como será dito no Quodl. 9, q. 8:

"a alma do homem não é forma e ato do corpo simplesmente enquanto <este> é mistura - ele é tal por outra forma como foi dito, na qual convém com as pedras -, mas é somente forma e ato do corpo orgânico enquanto é orgânico, dando a ele o ser orgânico, incluindo a substância da alma na razão do corpo orgânico [includendo substantiam animae in ratione corporis organici]. Mas <ela o faz $>$ segundo duas intenções, pois segundo a razão ou intenção [secundum rationem sive intentionem] do vegetativo é a perfeição do orgânico nutritivo enquanto é nutritivo (no que o homem convém com as plantas) e segundo a intenção do sensitivo é a perfeição do orgânico sensitivo (e isso não somente segundo a substância da alma, mas segundo potências orgânicas similares nisso às potências orgânicas dos brutos).

Mas ela possui uma intenção ulterior, a saber, a racional ou intelectual [rationalem sive intellectualem], segundo a qual é a perfeição do homem enquanto é homem e do corpo orgânico enquanto é do homem - e isso, segundo a substância, mas não segundo sua potência, pois esta potência é separada, não orgânica, pois possui a operação de inteligir sem que exista como em um órgão $<\ldots>$, 78

Um elemento interessante nesse trecho é o fato de Henrique se referir às partes da alma como ratio sive intentio. Sem precisar se há distinção de razão ou de intenção

\footnotetext{
${ }^{77}$ Henrique de Gand, Quodl. 4, q. 13, co. (Ed. De Wulf-Mansion Centre, vol. 8, pp. 143-144): "Sed homo sive natura in generatione hominis agit ex praesupposita materia, iuxta illud quod dicit Philosophus: 'Homo generat hominem ex materia et sol'. Et Deus agit ad generationem eiusdem non ex praesupposita materia creando animam in corpore disposito, secundum quod dicit Avicenna et fides tenet, et similiter Philosophus dicit De animalibus quod 'intellectus ab extrinseco est'. Sunt ergo diversa agentia et diversis mutationibus, ergo impossibile est terminum actionum eorum esse unum et eundem numero. Cum ergo terminus proprius actionis divinae sit anima rationalis sive intellectualis in homine, oportet quod terminus actionis humanae sit aliqua forma substatialis alia in homine, cum generatio omnis sit mutatio in substantiam et a non-esse in esse substantiale, secundum Philosophum in $\mathrm{V}^{\mathrm{o}}$ Physicorum".

${ }^{78}$ Henrique de Gand, Quodl. 9, q. 8, co. (ed. De Wulf-Mansion Centre, vol. 13, p. 172): "Anima vero hominis non est forma et actus corporis simpliciter secundum quod est mixtum, sed tale est ab alia forma secundum praedicta, in qua convenit cum lapidibus, sed est solum forma et actus corporis organici secundum quod est organicum, dans ei esse organicum, includendo substantiam animae in ratione corporis organici, sed secundum duas intentiones, quia secundum rationem sive intentionem vegetabilis est perfectio organici nutritivi in quantum nutritivum est, in quo convenit homo cum plantis, secundum vero intentionem sensitivi est perfectio organici sensitivi, et hoc non solum secundum substantiam animae, sed secundum potentias organicas consimiles in hoc potentiis organicis brutorum. Sed habet ulteriorem intentionem, scilicet rationabilem sive intellectualem, secundum quam est perfectio hominis in quantum homo est, et corporis organici ut hominis est, et hoc secundum substantiam, sed non secundum eius potentiam, quia potentia ista separata est, non organica, quia habet operationem intelligendi, non ut in organo existens $<\ldots$..
} 
entre as partes da alma, ela deixa claro que não há aqui uma distinção real entre a vegetativa, a sensitiva e a intelectiva ${ }^{79}$. As três são 'razões ou intenções' da alma e atualizam o corpo de diversas maneiras. Com efeito, a vegetativa e a sensitiva o atualizam não somente enquanto são idênticas à substância da alma, mas igualmente enquanto potências orgânicas (isto é, capazes de serem determinadas por certos órgãos ao informá-los) ${ }^{80}$. A intelectiva, por outro lado, é forma do corpo somente enquanto é a própria substância da alma, mas não enquanto potência, uma vez que, não sendo orgânica mas separada, ela não necessita do corpo para operar (excluindo, é claro, o fato de que ela obtém o inteligível a partir da sensação, mas isso é assunto para depois.... ${ }^{81}$. Com essa distinção entre [i] informar enquanto substância e potência

\begin{abstract}
${ }^{79}$ Sobre as distinções, cf. nota 14.
${ }^{80}$ Nos caps. 4 e 5 discorreremos longamente sobre a potência sensitiva. No entanto, não teremos um espaço apropriado para a discussão acerca da potência vegetativa - de fato, nem mesmo Henrique de Gand dedica muita atenção a ela. Na passagem da nota 78, vimos que a potência vegetativa atualiza os órgãos que dizem respeito à nutrição - tal potência é a "perfectio organici nutritivi". Some-se a isso aquilo que vimos na hierarquia da vida exposta no item 2.2., a saber, que as plantas - cuja alma não possui senão a potência vegetativa -, ainda que não possuam qualquer apreensão cognoscitiva, "a principio intra movent seipsa attractione alimenti, nutritione, augmento, et diminutione" - Suma, art. 27, q. 2, co. (ed. Teske, p. 170). Ou seja, diz respeito à potência vegetativa: [i] movimento pela atração do alimento, [ii] nutrição, [iii] aumento e diminuição. A nutrição, em especial, é particularmente bem descrita em Quodl. 2, q. 10. Lemos aí que a nutrição é, basicamente, uma conversão da forma do alimento na natureza corporal daquele que se alimenta - Quodl. 2, q. 10, co. (ed. De Wulf-Mansion Centre, vol. 6, p. 74): “<_.> dicendum est de alito quod in veritatem naturae suae corporalis per nutritionem convertitur substantia alimenti”. No entanto, o resultado da nutrição é estritamente material, uma vez que, pela corrupção da forma do alimento, aquele que se nutre conjuga a si a matéria do alimento e cresce, compensando a carne perdida - Quodl. 2, q. 10, co. (ed. De Wulf-Mansion Centre, vol. 6, p. 74): "nutritio vero sub forma sua eadem numero, corrumpendo formam alimenti, sibi coniungit materiam alimenti, per quod nutritur et augmentatur $\langle\ldots\rangle$, augmentando carnem illam quae deperditur <...>”. Essa 'conversão' do alimento naquele que se alimenta ocorre por meio do calor natural (calor naturalis) deste último. Esse calor, por fim, é (de uma maneira razoavelmente complexa) em parte conservado por meio do próprio alimento - cf. Quodl. 2, q. 10, ad 1 (ed. De Wulf-Mansion Centre, vol. 6, pp. 74-5). Sobre o calor natural, cf. a nota 83, adiante.
\end{abstract}

${ }^{81}$ As três almas - vegetativa, sensitiva e intelectiva - estão contidas na essência humana de maneira eminente, uma vez que o homem é o mais perfeito dos entes animados. Isso ocorre, segundo Henrique, porque, sendo o mais baixo na série das espécies sob o gênero 'animado' (isto é, sendo o último nessa série que parte de 'animado' e desce passando por todas as espécies sob o gênero) o homem é o animal mais atual e, portanto, aquele que contém em si eminentemente todas as diferenças específicas dos outros animais. É interessante notar que, para explicar essa 'eminência' pela qual todas as diferenças específicas se encontram no homem, o Doutor Solene introduz a noção de 'grau de intenção' (cf. nota 48, acima), afirmando que todas as diferenças específicas sob o gênero 'animado' se encontram em grau de intenção no homem. Pois bem, parece ser justamente por conter todas essas diferenças específicas que o homem igualmente contém todas as potências dos outros animais, uma vez que a pluralidade de tais potências no homem parece estar atrelada à pluralidade de diferenças específicas. Sendo assim, podemos ver que o Doutor Solene busca estabelecer a unidade real da essência humana em face da pluralidade das potências desta última ao fazer equivalerem a pluralidade dessas potências e a pluralidade de termos em uma definição. De fato, mesmo que possua diversos termos, a definição nem por isso é a quididade de diversos sujeitos realmente distintos, mas sempre de um único; da mesma maneira, a alma é eminentemente vários, mas que são um único sujeito realmente. Possuindo todas as diferenças específicas sob o gênero 'animal', o homem igualmente se comunica com todos os animados na medida em que possui algo de comum com cada um deles - enquanto possui a vegetativa, 
orgânica e [ii] informar somente enquanto substância, Henrique consegue fornecer uma formulação muito mais precisa da maneira pela qual a alma, ainda sendo forma substancial do corpo material, pode exceder as capacidades deste último. Assim, enquanto substância ela é toda forma do corpo, mas enquanto três intenções ou potências distintas ela só o informa parcialmente, já que uma dessas potências é imaterial. Isso, por si só, já é um resultado interessante. Porém, essa última passagem possui um elemento ainda mais útil para a nossa pesquisa.

Era dito, antes de a citarmos, que, para o gandavense, além da forma da mistura vinda dos progenitores, também a alma dada por Deus informa o corpo. Agora, neste último excerto se torna claro qual é o papel de cada uma das formas na composição do corpo. A forma da mistura diz respeito somente ao caráter misto do corpo - ou seja, ao seu caráter não elementar ${ }^{82}$. Nesse ponto, o corpo humano é

se comunica com as plantas, enquanto possui a sensitiva, se comunica com os brutos, e assim por diante. Sobre isso, cf. Henrique de Gand, Quodl. 3, q. 14 (ed. 1613, f. 109rb): "Nunc autem ita est in linea corporalium, quod quanto plus descendit per differentiarum appositionem, tanto quaeque sunt perfectiora et superiora in gradu essendi quanto sunt inferiora, et quanto posterius stat in eis descensos sub genere, et tanto imperfectiora, et inferiora in gradu essendi, quanto sunt superiora, et quanto prius stat in eis descensos sub genere. Ita quod differentiae specificae omnium superiorum in linea, in quibus primo stat ratio, et divisio generis, inveniuntur secundum gradum intentionis, licet esse eminentioris, in aliquo inferiore; licet non semper in omnibus, sed universaliter inveniuntur omnium animatorum differentiae perfectiores simpliciter in perfectissimo animato quod est homo; et sicut differentiae: ita et potentiae, ut in homine sit assignare omnium animatorum potentiae fundatas super intentiones differentiarum specificarum, quae singulas species habent constituere in diversis animatis, ut quemadmodum videmus distingui vegetabile in plantis et sensibile in brutis, et rationale in hominibus penes specificas differentiae, quae sunt vegetabile, sensibile, rationale, quae sunt nomina differentiarum inquantum sumuntur a substantia animae vegetativae, sensitivae, et intellectivae, et nomina potentiarum inquantum sumuntur a sensu respectu actus sentiendi, et intellectu respectu actus intelligendi, et ab aliquo consimili in nominato in vegetabilibus, quae tria in simplici essentia animae rationalis sunt distincta solum secundum gradus intentionum sub esse simplici et eminentiori, quemadmodum trigonum in tetragono, et tetragonum in pentagono, sicut determinat Philosophus, distincta solum secundum gradus intentionum, inquantum secundum unum eorum communicat cum vegetabili, secundum alium cum sensibili, et distinguitur a vegetabili. Secundum tertium vero perficitur suum esse, et distinguitur ab utroque. Sic intelligimus distingui plurimas in genere sensibilium irrationabilium, quorum omnium perfectiones secundum gradus eminentioris esse inveniuntur in homine, et secundum easdem potentiae distinctae in natura et essentia simplicitatis animae rationalis, quae ab ipsa natura et essentia eius non differunt nisi ratione et respectu quodam, ut dictum est".

\footnotetext{
${ }^{82}$ Embora não tenha podido encontrar muitas referências em Henrique de Gand à relação entre os 'elementos' e a 'mistura' (isto é, a mistura desses elementos na composição de uma coisa corpórea), acredito que algumas passagens esparsas de sua obra são suficientes para termos uma impressão inicial acerca do tema. No contexto do estudo da ordem das pessoas divinas em Deus, o Doutor Solene vê a necessidade de exemplificar uma ordenação a partir das criaturas e, para tanto, ele se volta rapidamente para o caso dos quatro elementos e seus respectivos lugares na ordem que possuem entre si: " $<$... $>$ in creaturis patet in ordine elementorum quod propria ratio ordinis quam habet terra differentem a rationibus ordinis quas habent alia elementa est quod terra dicitur esse infima, et propria ratio ignis est quod dicitur esse supremus; et communis ratio aquae et aeris respectu illorum est quod dicuntur esse media et propriae rationes utriusque quibus differunt ordine inter se est quod aqua dicatur esse sub aere et aer supra aquam" - Suma, art 52, q. 3, co. (ed. De Wulf-Mansion Centre, vol. 30, p. 260). Como vemos, temos entre os elementos a seguinte ordenação, do mais baixo ao mais alto: terra, água, ar e fogo, sendo distribuídas entre eles as qualidades de 'quente' ou 'frio', 'húmido' ou 'seco' - cf. Suma,
} 
art. 5, q. 5, co. (ed. De Wulf-Mansion Centre, vol. 21, pp. 351-352). Se nos voltarmos para o comentário sobre a Física dito de Henrique, um texto de atribuição duvidosa, vemos que a ordenação dos elementos é diretamente relacionada à sua localização no mundo (a terra no centro do universo, e nesta ordem, de baixo para cima, a água, sobre ela o ar e, finalmente, acima de todos, o fogo), de acordo com suas respectivas gravidades ('gravitas') naturais - cf. Questões sobre a Física 4, qq. 17-25 (ed. Pérron, vol. 3, pp. 228-279). Sendo esse texto autêntico ou não, o fato é que para Henrique de Gand os elementos estão entre as criaturas mais imediatamente próximas a Deus na ordem da criação, pois eles são as primeiras formas a informarem a matéria e, se criaturas corpóreas mais complexas (animadas ou inanimadas) podem ser constituídas a partir da ação das esferas celestes, o Doutor Solene é bem cuidadoso em afirmar que os elementos informam a matéria por uma ação imediata de Deus, sem qualquer intermediário: "Ad secundum, quod 'motus caeli generat animata, ergo multo fortius inanimata', dicendum quod verum est, sed materia supposita sub formis elementaribus in quibus quodlibet est in potentia ad quodlibet, et ad illorum eductionem de potentia materiae secundum diversas appropriationes et coniunctiones constellationum et motuum diversitatem multum operantur corpora caelestia. Quod bene dicit Avicenna, sed ut producat essentiam materiae in esse sub formis. Hoc est figmentum, sicut totum illud quod dixit de creatione intelligentiae caeli et animae caeli semper procedere de intelligentia superiori. Hoc enim figmentum est: non enim habet creatura mediandi potentiam in actum creationis, secundum quod alias poterit declarari" - Quodl. 6, q. 33, ad 2 (ed. De Wulf-Mansion Centre, vol. 10, p. 293). Essa imediatez da ação de Deus com respeito aos elementos é muito bem explorada no comentário sobre o Gênesis atribuído a Henrique de Gand, em especial no estudo de dois versículos. Na consideração sobre $G n$ 1,2 ("terra autem erat inanis et vacua et tenebrae super faciem abyssi et spiritus Dei ferebatur super aquas"), claramente é posto o problema de compreender o que seriam 'terra' e 'água' na obra do primeiro dia. Como Henrique defende no Quodl. 6 , os elementos (aqui nomeados somente pelos nomes 'terra' e 'água') são imediatamente criados por Deus, de maneira que, se, no primeiro dia, já há 'céu' e 'terra/água', isso significa que os elementos já foram criados, ainda que de maneira muito imperfeita: "Unde non intelligimus hic materiam informem confusam, quasi habentem aliquam unam formam communem omnibus, quam formam confusionis appellem. Immo intelligo angelos, caelum et terram, et cetera elementa, in suis formis substantialibus fuisse producta, et perfecta in esse primo, sed non in bene esse et in ornatu: immo in angelis ex prima creatione erat informitas spiritualis ante suam conversionem et in caelis erat aliqua materialis informitas et defectus ornatus ut dicetur post, et elementa erant confusione admixta quasi in vaporosa et nebulosa substantia simul suspensa. Et secundum hoc nomine caeli comprehenditur substantia corporum caelestium sine suo ornatu, et spiritualis vita angelica sicut potest esse in se, non conversa ad creatorem: tali enim conversione formatur atque perficitur; si autem non convertatur, informis manet" Lectura super S. Scripturam, cap. 1 (ed. De Wulf-Mansion Centre, vol. 36, pp. 60-61). Essa 'admixtio' ("elementa erant confusione admixta quasi in vaporosa et nebulosa substantia simul suspensa") na qual os elementos se encontravam nesse ponto da criação, não se confunde ainda com 'mixtio' proveniente da 'forma mixtionis'. Pelo contrário, essa 'admixtio' primordial é confusa e ainda está por ser ordenada nos dias seguintes da criação. A ordenação dos elementos ocorre somente no terceiro dia, quando lemos, em $G n$ 1,9, que "dixit vero Deus congregentur aquae quae sub caelo sunt in locum unum et appareat arida factumque est ita" - cf. Lectura super S. Scripturam, cap. 1 (ed. De Wulf-Mansion Centre, vol. 36, pp. 86-87). Nesse terceiro dia, igualmente, Deus distingue os corpos elementares de maneira a permitir a geração natural - de fato, Ele até mesmo germina a terra antes de adornar o céu (o que só ocorrerá no quarto dia), para mostrar como a geração natural não é necessariamente dependente das esferas celestes, podendo ser causada diretamente por Deus: "Sequitur distinctio corporum elementarium ad generationem et propagationem principalium, ad quorum distinctionem naturaliter aliorum duorum, scilicet aeris et ignis, concomitatur distinctio: Dixitque Deus: congregentur aquae"; e " $<\ldots>$ Deus ideo prius produxit videlicet terraenascentia ad ornatum terrae, quam stellas ad ornatum caeli, ne si prius stellas produxisset, putarentur fuisse absolutae causae omnium productorum postmodum in elementis. Ut ergo a posteris occasionem hoc putandi praescinderet, prius terraenascentia quam stellas produxit" - Lectura super S. Scripturam, cap. 1 (ed. De Wulf-Mansion Centre, vol. 36, p. 94, 102-103). Enfim, como vemos, a exegese dos primeiros versículos do Gênesis gera uma interessante ocasião para a discussão daquilo que havia sido afirmado em poucas palavras em Quodl. 6: de fato, os elementos são produzidos na matéria diretamente por Deus e, muito embora as esferas celestes possam contribuir para a geração natural dos corpos, esta geração pode igualmente ser causada diretamente por Deus (vimos, por exemplo, que Ele diretamente introduz uma alma intelectiva no feto durante a geração do homem). Pois bem, com essa impressão inicial acerca dos elementos, cabe retornarmos à questão inicial desta nota e nos perguntarmos sobre a relação entre os 'elementos' e a 'mistura'. Em primeiro lugar, a mistura necessariamente vem do elementar: " $<$.. > non est mixtum, nisi 
semelhante a uma pedra, com a diferença de que a pedra contém uma forma da mistura distinta simplesmente porque é um corpo distinto. Essa forma provém unicamente da matéria, como vimos, e ela não faz mais do que ajuntar os quatro elementos de maneira a produzir um corpo capaz de receber as potências da alma. Em qualquer um dos animais brutos não haveria nada mais a ocorrer, pois neles as potências vegetativa e sensitiva provêm daquela mesma forma da mistura dada pelos progenitores. No caso do homem, porém, há uma alma intelectiva que, ao ser infundida no corpo diretamente por Deus (precisamente, no $35^{\circ}$ dia de gestação no caso da geração de uma mulher e no $42^{\circ}$ dia na geração de um homem ${ }^{83}$ ) dá àquele

ex elementis, neque virtus mixti, nisi ex vi elementari" - Quodl. 4, q. 13 (ed. 1613, f. 171va). Sabemos que a mistura resulta da introdução na matéria de uma forma da mistura. Ao que parece, a introdução desta forma possuirá como resultado a produção de um corpo a partir dos quatro elementos (isto é, a forma de cada elemento é corrompida - uma vez que a introdução de uma forma corrompe qualquer outra que esteja presente, como veremos na nota seguinte - de maneira a que se estabeleça uma forma dos vários elementos em conjunto, ordenados de uma maneira precisamente estabelecida por aquela própria forma). Disso surge um ser metafisicamente superior (em seu grau de natureza) a cada elemento separado: "Et tamen constat quod vivere perfectionem quandam nominat circa esse, ut supra expositum est in quaestionibus de vita $<s c$., em Suma, art. 27, que estudamos extensamente acima $>$, et hoc quemadmodum in corporibus et formis corporalibus generabilium et corruptibilium semper quod prius est simplicitate est minus nobile, ut elementum quam mixtum, et mixtum quam vegetabile, et vegetabile quam sensibile, et sensibile quam rationale, et hoc quia in talibus ultimum vel quasi ultimum semper addit aliquid nobilitatis super praecedens vel quasi praecedens" - Suma, art. 48, q. 2, ad 2 (ed. De Wulf-Mansion Centre, vol. 30, p. 54). Como vemos, o mixtum é mais nobre e complexo do que os elementa, uma vez que precisamente é algo resultante da conjunção dos quatro elementos primordiais. Assim, a forma da mistura no homem deve ser compreendida, antes de tudo, como aquela forma que atualiza uma mistura tal que seja característica do corpo humano. Como se verá nas próximas linhas, esse corpo 'misto' característico do homem é aquele que está em potência para ser organizado (isto é, para adquirir órgãos) pela alma intelectiva (que é, igualmente, a forma vegetativa e sensitiva).

${ }^{83}$ Cf. Henrique de Gand, Quodl. 15, q. 13, co. (ed. De Wulf-Mansion Centre, vol. 20, p. 85): "Ista autem membrorum divisione completa in ultimo instanti illius perficitur totius corporis organizatio et generatur forma corporeitatis humanae atque anima rationalis creando a Deo infunditur ut actus et perfectio illius extrema, a quo in unione cum illo propter morbidam dispositionem fomitis contractam anima rationalis in eodem instanti contrahit maculam peccati originalis et concipitur in peccato homo perfectus in forma humana formatus ex semine, et hoc $35^{\text {a }}$ die a conceptu seminis nudi si sit femina, $42^{\mathrm{a}}$ si sit masculus, et hoc quia fortiori et ampliori digestione maturatur mas quam femina". Sobre a noção de 'geração', é interessante notar que, para Henrique de Gand, se em geral são necessários um macho e uma fêmea para gerar outro homem (lembremos que, no caso do Cristo, isso não ocorreu), ainda assim esses dois indivíduos não geram o outro na medida em que são indivíduos, mas sim enquanto possuem uma natureza, a saber, a natureza humana. Em poucas palavras, a ação de gerar diz respeito à natureza dos indivíduos e não a estes últimos: "unde non dicitur vere quod Sortes generat eo quod est Sortes, id est eo quod est individuum aut individuatum suppositum, quoniam illud, ut dictum est, negatio est, quae nullius est effectiva, sed quod dicitur agere aliquid aut generare, eo quod est formale in ipso, hoc debet intelligi aspiciendo ad formale quod est ratio, qua subsistit in natura speciei, quae est sua humanitas, in qua est considerare duo: scilicet quod est humanitas simpliciter, quia tota natura speciei specialissimae est in quolibet suo individuo, et quod est ista in isto individuata. Quod ergo Sortes humanitate sua aliquid agit aut generat, hoc est ratione qua est humanitas simpliciter et ut existens est in isto <..." - Suma, art. 39, q. 4, ad 5 (ed. De Wulf-Mansion Centre, vol. 28, p. 207); sobre essa concepção negativa de 'indivíduo', cf. a nota 96, adiante. Pois bem, agindo enquanto natureza (e não enquanto indivíduo), o macho (na geração de qualquer animal) fornece uma semente ('semen') que possui em si dois constituintes: a forma característica da espécie do macho e o calor (idêntico na semente de qualquer espécie que seja). Ambos juntos irão agir para a produção de uma 
forma da mistura. Nessa ação conjunta, o calor age e produz o ato, enquanto que a forma da espécie do macho determina a ação do calor para a produção de uma forma atual de mesma espécie: "< $<$.. licet calor sit idem specie in semine asini et semine equi, aliud tamen specie generatur ex semine asini, et aliud ex semine equi, et hoc propter virtutem impressam a forma asini semini suo, aliam speciem ab illa quae impressa est semini equi a forma equi, ita quod calidum ex se, si nulla virtute determinetur, nihil generaret nisi calidum, et non moveret ad determinatam speciem nisi virtute determinante eam ad speciem sibi impressam <... . Ut sic duo concurrunt ad omnem actionem tendentem ad aliquam determinatam formam in mixto, et hoc ex parte eius quod est ratio agendi, scilicet calor ipse qui agit et actum elicit, et virtus ipsam determinans ad actionem determinatam tendentem ad speciem determinatam" - Suma, art. 39, q. 6, co (ed. De Wulf-Mansion Centre, vol. 28, p. 217). O momento da introdução da semente ('semen') no útero ('matrix') da fêmea é crítico, pois caso a semente não se aloque perfeitamente em alguma das diversas concavidades presentes no órgão, é possível que haja problemas de formação do feto (cf., acima, notas 63 e 64). Por outro lado, caso a semente encontre seu local adequado, tem início um processo de coagulação provocado pela adição do calor daquela parte do útero em que a semente se posicionou ao calor que já havia na semente: " $<\ldots$..> cum inquam, ut dictum est, totum semen in una incastratura recipiatur, tunc totum unica vi caloris illius incastraturae confovetur semen, et totum seminale vigens in calore seminis excitatum calore illius partis matricis incipit materiam coagulare ad fetus formationem <..." - Quodl. 6, q. 14, co. (ed. De Wulf-Mansion Centre, vol. 10, p. 157). Da mesma maneira, o nascimento de gêmeos será explicado como um caso no qual a abundância de semente proveniente do macho faz com que ela caia em várias concavidades do útero, sendo colocada uma porção da semente em cada concavidade e sendo gerado um feto plenamente saudável em cada uma: "Cum autem fuerit abundantia seminis, ita quod, cum cadit in matricem, portio una recipiatur in una incastratura sicut in una moneta, et alia recipiatur in alia sicut in alia moneta, et villula matricis integra separaverit perfecte has partes ab invicem in qualibet illarum partium, et inclusum diversis pelliculis, et si plures recipiantur simili modo virtute caloris illius incastraturae, incipit proprium seminarium movere materiam ad productionem proprii fetus, et plura seminaria ad productionem plurium fetuum perfectorum"-Quodl. 6, q. 14, co. (ed. De Wulf-Mansion Centre, vol. 10, p. 158). Durante esse aquecimento ('confovetur') da semente, ocorre um processo descrito como uma 'coagulação' ('coagulare') da matéria e também compreendido como um 'desenvolvimento' ou um 'amadurecimento' ('maturatio', como é dito na primeira passagem citada nesta nota) da matéria, ao fïm do qual há um feto formado. Essa formação do feto implica na corrupção da forma original da semente, uma vez que esta última dá lugar precisamente à forma da mistura que não é, senão, uma disposição para a recepção da alma intelectiva enviada diretamente por Deus: "Non quod aliqua forma mixti manens sit praecedens animam in corpore, sed quod materia existens sub forma corrumpenda disponitur per agens ut fiat necessitas ad formam mixti educendam de potentia materiae, cum qua, cum educitur de potentia materiae per generationem naturalem, simul inducitur anima rationalis per creationem. Illa tamen forma est ut dispositio in materia ad animam, ad illam autem formam mixti generandum agens seminale in materia ordinata ad generationem hominis, antequam incipiat movere materiam" - Quodl. 6, q. 14, co. (ed. De Wulf-Mansion Centre, vol. 10, p. 157). Ou seja, a forma da mistura dispõe aquela matéria amadurecida para a recepção da alma, de maneira que, se a alma é criada no mesmo instante da geração da forma da mistura, esta última é naturalmente (mesmo que não temporalmente) anterior àquela. Como fica claro na primeira passagem citada nesta nota, a geração da forma do misto ou da forma da corporeidade (sobre a problemática identificação entre ambas as formas, cf. a nota seguinte) e a concomitante indução da alma por Deus condizem com a divisão do corpo em membros e com sua 'organizatio', isto é, com sua divisão em órgãos (dada somente pela alma intelectiva). Nessa organização, a primeira parte a se formar é o coração, que será igualmente o primeiro (em natureza, não temporalmente) a ser aperfeiçoado pela alma - cf. Quodl. 6, q. 14, co. (ed. De Wulf-Mansion Centre, vol. 10, pp. 158-9); de fato, "segundo o direito natural, o coração é o mais nobre e principal membro [secundum ius naturale magis nobile et principale membrum est cor]" - Quodl. 9, q. 12, ad 3 (ed. De Wulf-Mansion Centre, vol. 13, p. 236). Como vemos na próxima nota, a 'forma mixti' atualiza a carne, os ossos e tudo aquilo de corpóreo que é necessário para a atualização dos órgãos neste mesmo corpo pela alma intelectiva - ao que parece, é isso que Henrique quer dizer quando afirma que a 'forma mixti' ou a 'forma corporeitatis' dispõe o corpo para a recepção da alma intelectiva - sobre a sucessão das formas na geração humana, cf. WILSON, Dymorphism and the Metaphysical Unity of Man..., 1975, pp. 198-9. Infelizmente, esse mesmo momento da dupla recepção da forma da mistura (ou da corporeidade) e da alma intelectiva, condiz também com a contração da mancha do pecado original. Dessa maneira, ao se tornar homem completo ('perfectus') - com ambas as suas formas -, este último é marcado pelo pecado. No mais, resta agora ao feto crescer e nascer em exatos nove meses (se contarmos os 'menses kalendarii' e não 
corpo, para além do caráter misto que ele já possui, um caráter orgânico. Assim, a forma da mistura o faz corpo, mas a forma intelectiva torna esse corpo orgânico (vegetativo e sensitivo) e, para além de orgânico, intelectivo (se não num órgão, ao menos substancialmente $)^{84}$. Portanto, fica patente o porquê de se poder caracterizar a

os 'menses lunarii', que seriam 8 meses mais 10 dias, tampouco os 'menses usuales', que seriam 10 meses e quatro dias) após a introdução da semente no útero - cf. Henrique de Gand, Quodl. 15, q. 13, co. (ed. De Wulf-Mansion Centre, vol. 20, p. 83). A morte do homem, sendo pensada enquanto privação da vida (isto é, sendo a causa da morte a própria ausência da vida), é simplemente a separação da forma com relação ao sujeito ou à matéria, pois enquanto a matéria (com sua forma mixti) é corruptível, a forma intelectiva é completamente separável e incorruptível. Esse é mais um aspecto no qual o homem se afasta dos demais animados, cuja morte (igualmente concebida como privação da vida, porém sempre tendo em consideração os diferentes graus de vida) é simplemente a corrupção (corruptio) ou o perecimento (interitus) da forma que jaz na matéria. Ou seja, a morte do homem não é per corruptionem, mas antes per separationem e, portanto, não é morte no mesmo sentido que aquela dos outros viventes materiais. Por outro lado, essa 'separação' se deve à corrupção não da própria forma, mas da temperantia que garantia a união da alma com o corpo do homem - cf. Quodl. 3, q. 8, co. (ed. 1613, f. 94ra-96rb). Em Quodl. 2, q. 10, ad 1 (ed. De Wulf-Mansion Centre, vol. 6, pp. 74-5), o Doutor Solene afirma que a morte natural decorre da extinção do calor natural. Novamente, vemos que, também na discussão sobre a morte, o homem é afirmado como limite entre o espiritual e o corpóreo, pois ainda que ele morra como tudo que tem corpo, uma parte sua se mantém perenemente como tudo que é espiritual (cf. WILSON, G. A. "Henry of Ghent's Quodlibet III...", 1978, pp. 77-78). Essa característica 'morte' do homem nos remete, entre outros, aos problemas do tríduo e das relíquias sagradas, que já foram mencionados acima (notas 60 e 62). Para uma tentativa de diferenciação e classificação das mortes natural e violenta, cf. Quodl. 3, q. 8 (ed. 1613, ff. 93v-7r). Por fim, notemos que, assim como na geração era reservada uma primazia ao coração, também na morte é assim, uma vez que segundo o direito natural cumpre considerar que o corpo se encontra sepultado onde jaz o coração e esse é o mesmo local em que ocorrerá a ressurreição do corpo. Com efeito, na ressurreição, ainda que somente o coração se encontre sepultado em um dado local, aí ressurgirá o corpo, sendo seus fragmentos restantes trazidos de onde estiverem - cf. Quodl. 9, q. 12, ad 3 (ed. De Wulf-Mansion Centre, vol. 13, pp. 235-6). Ainda sobre a superioridade do coração com respeito às outras partes do corpo, cf. nota 97.

${ }^{84}$ Henrique de Gand, Quodl. 4, q. 13, co. (ed. 1613, pf. 167va): "Sic ergo patet, quod ante infusionem animae rationalis, est ibi forma aliqua, quam in praedicta positione vocavi formam mixti, quae dat esse carnis, et ossis, et aliarum partium, ex quibus fit corpus organicum". Vemos agora mais claramente qual é a função da forma da mistura antes da infusão da alma intelectiva. Essa 'forma mixti' atualiza todas aquelas partes do corpo a partir das quais a alma intelectiva atualizará os órgãos ('ex quibus fit corpus organicum'). Essa 'forma mixti', no entanto, causou algumas dificuldades para os leitores atuais. Como vimos em uma citação da última nota, Henrique de Gand parece se utilizar de dois termos para nomear essa forma que, no homem, precede a alma: ele a denomina 'forma mixti' e 'forma corporeitatis'. Isso coloca o problema de sabermos se essas duas expressões simplesmente são duas designações distintas para uma mesma forma ou se elas nomeiam, cada qual, uma forma distinta que precede a alma intelectiva no homem. Embora na passagem de Quodl. 9, q. 8 citada acima, na nota 78, o Doutor Solene afirme claramente que a forma pela qual o homem é um corpo $e$ uma mistura é uma mesma forma (na qual ele, aliás, convém com uma pedra) - "Anima vero hominis non est forma et actus corporis simpliciter secundum quod est mixtum, sed tale est ab alia forma secundum praedicta, in qua convenit cum lapidibus" -, Armand Maurer afirma que não se deveria confundir a forma da corporeidade e a forma da mistura, que seriam duas formas completamente distintas na filosofia de Henrique: "The forma mixti and forma corporeitatis seem to have been confused by M. DeWulf $<\ldots>$ and J. Paulus $<\ldots>$. The form of corporeity is simply an intention, and it is commom to every body as such $<\ldots>$. On the other hand, the forma mixti is a real form which in man is appropriate to him, giving him his corporeity and specifically human organic complexity and structure as a disposition for the rational soul" - "Henry of Ghent and the Unity of Man", 1948, p. 14, nt. 30. Temos que concordar com Maurer em criticar o trecho destacado de Wulf, onde este afirma que "Henri de Gand est le seul, à notre connaissance, que restreigne la forma corporeitatis à l'homme" (cf. WULF, M. de Le traité "De Unitate Formae” de Gilles de Lessines, 1901, p. 39, nt. 5). Como vimos, com efeito, o Doutor Solene 
forma da mistura como somente um início do homem - de fato, ela nem mesmo produz um corpo orgânico, embora ela seja responsável por fornecer uma mistura material capaz de receber uma informação orgânica por parte da alma intelectiva. Esta última, por sua vez, leva o composto à perfeição e completude, de maneira que é certamente legítimo, vemos agora, atribuir somente à alma intelectiva (com suas três potências) o ser uno do homem.

\subsubsection{A unidade do composto humano}

Essa observação, entretanto, nos leva a um último problema que deve ser abordado na tentativa de compreender essa noção de homem desenvolvida por Henrique, a saber, justamente a questão da sua unidade enquanto composto com uma dupla forma. Para tratar desse tema, podemos rapidamente voltar a uma parte do penúltimo excerto destacado - aquele de Quodl. 4, q. $13^{85}$-, a qual havíamos metodologicamente deixado de lado. O que me interessa nele é, nesse momento, o

admite que é justamente pela 'forma da corporeidade' que o homem convém, por exemplo, com uma pedra, que é algo completamente corpóreo. Dessa maneira, acredito que esse aspecto da leitura de Wulf é equivocada, mas não pela razão apontada por Maurer. Já no trecho de Paulus citado por Maurer, há uma descrição dos três elementos necessários na formação do homem: "Ce nouvel example de séparation force donc d'admettre en l'homme la conjonction de trois principes: matière, forme de corporéité, âme vitale et rationelle" - Henri de Gand..., 1938, p. 211. A crítica de Maurer é que deveria haver aqui um quarto princípio, a saber, a 'forma mixti', distinta da 'forma corporeitatis'. Com efeito, Maurer afirma até mesmo que há uma base metafísica para tal distinção: a 'forma corporeitatis' seria somente uma intenção (embora ele não explique o que esse termo significa aqui e o trecho a que ele remete de PAULUS, Henri de Gand. Essai..., 1938, p. 16, nt. 2, não faça qualquer menção ao termo 'intenção'), enquanto que a 'forma mixti' seria uma forma real, que organizaria o homem. Pois bem, a última afirmação é claramente problemática, pois vimos que somente a alma intelectiva pode atualizar órgãos no feto, sendo o papel da 'forma mixti', corrompendo a forma seminal, unicamente dispor o corpo para a recepção da alma intelectiva que o organizará. Por outro lado, de fato Maurer parece ter razão quando lemos um dos textos a que ele remete (para justificar a caracterização da 'forma corporeitatis' como 'intencional'), a saber, Quodl. 4, q. 4, co. (ed. De Wulf-Mansion Centre, vol. 8, p. 13): " $<\ldots>$ sic metaphysicus incipit suam considerationem a maxime universali, considerando materiam omnium corporalium, ut unam et simplicem quantum est de se, et ut potentiale quid sub esse formae incompletissimae et communissimae ad omnia corruptibilia, verbi gratia corporeitatis communis ad corpus simpliciter elementare et ad mixtum <...>". Se com 'intencional' Maurer estiver se referindo a algo como 'meramente conceitual', então por esse trecho a 'forma corporeitatis' parece, de fato, ser intencional. Com efeito, nesta passagem Henrique de Gand parece estar se referindo ao fato de que tanto corpos mistos como corpos elementares possuem o 'ser corpo', isto é, estão sob o gênero 'corpóreo', mas não se faz neste caso menção a uma 'forma corporeitatis' no mesmo sentido daquela 'forma corporeitatis' que Henrique de Gand afirma ser introduzida no homem durante a geração (por exemplo, no primeiro excerto citado na nota imediatamente anterior). Assim, acredito que Maurer está correto em chamar a atenção para a complexidade própria ao termo 'forma corporeitatis', porém me parece que sua conclusão é equivocada. Não há no Doutor Solene uma distinção rígida entre 'forma corporeitatis' e 'forma mixti'. O que ocorre é que aquela primeira expressão é equívoca, pois ela ora é usada como sinônimo de 'forma mixti' (típica somente dos corpos mistos), ora como o gênero ‘corpóreo' (comum aos corpos elementares e aos corpos mistos).

${ }^{85}$ Cf. nota 74 , acima. 
fato de que o Doutor Solene recorre aí (como, aliás, dissemos não ser incomum em sua obra) àquela reafirmação da normalidade por recurso a um caso extremo. Em particular, ele reafirma a unidade desse composto de dupla forma que é o homem pelo contraste com algo mais admirável (mirum) que é a unidade do Cristo com sua dupla natureza natural e divina. Não pretendo desenvolver aqui essa comparação, pois isso significaria discorrer longamente sobre a cristologia de Henrique, algo que por si já mereceu uma dissertação ${ }^{86}$. Interessa-me, por outro lado, atentar para a fórmula aí utilizada para caracterizar a unidade própria do homem: a forma natural e a alma racional, nos diz Henrique, se unem na 'unidade de ser e da subsistência pessoal' (uniri <...> in unitate esse et personalis subsistentiae). Minha pergunta é: por que não somente na unidade do ser, mas também nessa 'subsistência pessoal'? Para responder, será interessante separar os dois elementos dessa expressão e compreender o 'pessoal' (personalis) como a indicação de uma 'subsistência' (subsistentia) determinada.

Um problema claro está no fato de que tanto a alma como o homem são caracterizados como 'subsistentes', porém eles certamente não podem ser ditos 'subsistentes' do mesmo modo, pois a alma ainda admite o complemento do corpo, enquanto que o homem possui um ser completo. De fato, se nos voltarmos para Suma, art. 32, q. 5, veremos que ambos - alma e homem - subsistem de diferentes modos.

Há, com efeito, vários modos de 'subsistir', mesmo se de saída excluirmos o “subsistir que é o mesmo que 'sub alio sistere' [praeter subsistere, quod idem est quod sub alio sistere]", isto é, o caso do menos comum que é sob o mais comum ou do sujeito que jaz sob o acidente ou dos acidentes que são em outros acidentes ${ }^{87}$. Os casos de subsistir que nos interessam não são nenhum desses - a bem dizer, ele é quase o contrário disso.

Ignorando, portanto, o 'subsistir' como 'sub alio sistere', há também o caso do 'subsistir' que é 'secundum se sistere' e isso ocorre na criatura de dois modos. De um modo, esse secundum se sistere remete ao fato de que tal subsistente não subsiste 'em outro como sujeito' (in alio ut in subiecto) e, “desse modo, subsistir não é, senão, existir de acordo consigo, donde também se diz 'substância' a partir desse subsistir [hoc modo subsistere non est nisi secundum se existere, unde et dicitur substantia a

\footnotetext{
${ }^{86}$ O principal estudo já produzido sobre a cristologia de Henrique de Gand continua sendo o, já citado, BAYERSCHMIDT, P. Die Seins- und Formmetaphysik, 1941.

${ }^{87}$ Henrique de Gand, Suma, art. 32, q. 5, ad 2 (ed. De Wulf-Mansion Centre, vol. 27, p. 111).
} 
sic subsistendo]" ${ }^{\prime 8}$. Como vimos acima, é justamente nesse sentido que se diz que 'a alma é subsistente', pois ela pode existir por si mesma sem o corpo. Isso, aliás, gerou muitos problemas para nossa leitura de Henrique de Gand, tanto que foi necessário compreender justamente de que maneira algo independente como a alma se ligaria a algo inferior, como o corpo. Vimos que isso ocorre, justamente, porque há certos acidentes (as operações das potências da alma) que só podem ser atualizados pela sua ligação com o corpo, pela qual ela comunica o ser e o viver a este último. Enfim, nesse modo de 'subsistir' é plenamente possível afirmar que a alma 'subsiste', porém este ainda não é o subsistir típico do homem todo, pois o homem não somente pode existir por si, como além disso é completo, não podendo ter nada substancialmente adicionado a si.

Isso nos remete, precisamente, para um último significado de 'subsistir', pelo qual esse termo é explicado como 'nullo modo in alio sistere'. Essa subsistência é introduzida por Henrique de Gand para distinguir o ser que a essência e a matéria possuem em um composto e o ser daquilo mesmo que é composto a partir delas. Decerto, a forma e a matéria possuem, cada qual um ser próprio, porém eles são de maneira completa enquanto composto ${ }^{89}$. Esse ser completo do composto é, precisamente, o subsistir desse terceiro modo - um subsistir tal que não se possa sistere de nenhum modo em nenhum outro. Para nossa sorte, o Doutor Solene utiliza exatamente o homem para exemplificar esse terceiro modo do 'subsistir':

“donde a humanidade não é uma substância subsistente, pois não possui senão ser em outro, que é o composto de alma e corpo. Nem se diz que esse composto subsiste, pois não subsiste senão sob a humanidade. Nem similarmente a alma nem o corpo, pois não possuem ser senão em outro como parte, mas somente por si deve-se dizer que subsiste o homem, que é um composto que participa da humanidade e é informado pela humanidade. Não digo que o homem subsista por si enquanto é composto da natureza a partir da alma e do corpo, sem incluir no seu entendimento [in suo intellectu] o conceito da humanidade participada, mas enquanto é composto a partir daquilo que é da natureza nele e a partir da humanidade participada, incluindo ambos em um só entendimento [in intellectu uno]",90.

\footnotetext{
${ }^{88}$ Henrique de Gand, Suma, art. 32, q. 5, ad 2 (ed. De Wulf-Mansion Centre, vol. 27, p. 111).

${ }^{89}$ Henrique de Gand, Suma, art. 32, q. 5, ad 2 (ed. De Wulf-Mansion Centre, vol. 27, p. 112).

${ }^{90}$ Henrique de Gand, Suma, art. 32, q. 5, ad 2 (ed. De Wulf-Mansion Centre, vol. 27, p. 112): "Unde humanitas non est substantia subsistens, quia non habet esse nisi in alio, cuiusmodi est compositum ex anima et corpore. Neque illud compositum dicitur subsistere, quia non subsistit nisi sub humanitate. Neque similiter anima neque corpus, quia non habent esse nisi in alio ut pars, sed solum per se debet dici subsistere homo, quod est compositum participans humanitatem et informatum humanitate. Non dico quod homo per se subsistat ut est compositum naturae ex anima et corpore, non incluso in suo intellectu conceptu humanitatis participatae, sed ut est compositum ex eo quod est naturae in ipso, et ex
} 
Nem a 'alma' nem o 'corpo' subsistem desse terceiro modo, pois cada um só possui um ser completo quando associado ao outro. O mesmo vale para a 'humanidade', uma vez que ela só é completamente em algo que dela participa. Mais complicado é o caso do 'composto', pois ele só pode ser dito 'subsistir' se ele for entendido (intellectus) como compreendendo a alma e o corpo enquanto partes do composto e, além disso, aquela humanidade de que ele participa - caso contrário, isto é, se esta última relação de participação para com a humanidade não for considerada em seu conceito, não se deve dizer que o homem subsiste. Porém, por que fazer essa distinção? A meu ver, ela é importante por trazer de volta à discussão aquele primeiro modo de subsistir, a saber, como 'sub alio sistere'. De fato, sendo uma criatura, o homem pode não sistere in alio, mas certamente ele deve sistere sub alio, a saber, sob a humanidade de que ele necessariamente participa enquanto homem. Portanto, a noção de subsistência que vimos ser utilizada para caracterizar o homem é extremamente complexa, pois a um só tempo ela o estabelece como composto (de alma e corpo), como completo (não podendo ser in alio) e como participante de algo (a saber, da humanidade).

A isso Henrique de Gand adiciona mais duas precisões. Primeiramente, ele nos diz que aquilo que subsiste desse terceiro modo "possui verdadeiramente a razão de suppositum [hoc quod sic subsistit, vere habet rationem suppositi < ..> ]" ${ }^{\text {,91 }}$. Isso, por si só, não nos diz muito neste contexto ${ }^{92}$... Porém, logo em seguida ele adiciona que "tampouco, além disso, o todo que participa na essência, enquanto inclui em si a razão de coisa participante e da essência participada, verdadeiramente possui daí a razão de suppositum, salvo se for em si um existente separado [existens separatum]". O termo separatum aqui não deve ser tomado como 'separado da matéria ou do corpo', como em outros $\operatorname{casos}^{93}$, mas principalmente como 'separado de quaisquer outros': "não se diga que nada nas criaturas subsiste verdadeiramente, salvo uma

\footnotetext{
humanitate participata, incluso utroque in intellectu uno".

${ }^{91}$ Henrique de Gand, Suma, art. 32, q. 5, ad 2 (ed. De Wulf-Mansion Centre, vol. 27, pp. 112-3).

${ }^{92}$ Sobre a complexa noção de suppositum que encontramos em no Doutor Solene, cf. DECORTE, Een avicenniserend augustinisme..., 1983, deel 1, pp. 123-5; WILSON, "Supposite in the Philosophy of Henry of Ghent", 1996; WILSON, "Henry of Ghent's Quodlibet I...”, 1999, pp. 170-1; e ROIG, V. L. "Cracking intencional en la metafísica de Enrique de Gand". Carthaginensia. Revista de estudios e investigación 33.63 (2017), pp. 1-62.

${ }^{93} \mathrm{Cf}$., acima, nota 75 .
} 
substância individual separada e distinguida de todos os outros"94. No fim, a noção de 'subsistência' dita do homem o expõe como ente composto que, participando de uma essência, existe em ato como indivíduo ${ }^{95}$.

${ }^{94}$ Henrique de Gand, Suma, art. 32, q. 5, ad 2 (ed. De Wulf-Mansion Centre, vol. 27, p. 113): "Nec
etiam adhuc totum participans essentia, ut includit in se rationem rei participantis et essentiae
participatae, vere ex hoc habet rationem suppositi, nisi sit in se separatum existens. Unde compositum
ex corpore et anima rationali participans humanitate assumpta in personalitate Christi, subsistere non
dicitur neque esse suppositum. Ut secundum hoc nihil in creaturis dicatur vere subsistere, nisi
substantia individua ab omnibus aliis separata et distincta".

${ }^{95}$ Com efeito, Gordon Wilson considera que o fundamento da unidade do homem é justamente o seu ser de existência atual - cf. WILSON, Dymorphism and the Metaphysical Unity of Man..., 1975, pp. 288-318. Especialmente, vemos afirmá-lo na p. 318: "Henry accounts for man's unity by means of the esse actualis existentiae which he distinguishes from esse essentiae. This esse actualis existentiae establishes man as a supposit, i.e. a being which is singular by virtue of the fact that it does exist. Being an individual supposit, man lacks any multiplicity of entities within himself".

Embora surjam associadas, as noções de subsistentia e existentia não se confundem, pois esta última possui uma extensão maior. Com efeito, mesmo algo somente inteligido pode existere, embora não se diga dele que 'subsiste', uma vez que não existe distinguido de qualquer outro, mas antes como acidente no intelecto. Como se vê, a caracterização do homem como subsistente é tributária da distinção entre essência e existência, um dos elementos mais complexos da obra de Henrique de Gand. Sem pretender abordar os diversos aspectos dessa complexa distinção, será interessante estabelecermos aqui alguns de seus principais aspectos. Para tanto, contentar-me-ei em tomar por base unicamente Suma, art. 21 e Suma, art. 27.

Lemos em Suma, art. 27, ad 9 (ed. Teske, pp. 158-60), que o [1] ser (esse) se distingue em dois (p. 158). De um lado, temos [1.1] o ser de essência (esse essentiae), que "é uma disposição da coisa em si mesma, pela qual é aquilo que é e nada outro que não ela, se portando com indiferença a qualquer outro que se deva atribuí-la [Esse essentiae proprie loquendo est dispositio rei in seipsa qua est id quod est, et nihil aliud a se, per indifferentiam se habens ad quodcumque aliud sibi attribuendum]" (p. 160). De outro lado, temos [1.2] o ser de existência (esse existentiae), que "é o ser efetivamente acrescido à essência [Esse vero existentiae est esse in effectu acquisitum essentiae $<\ldots>$ ]. Este, por sua vez, se divide em dois. De uma parte, ele é [1.2.1] "dito o ser diminuído da coisa, como é o ser da coisa no conceito da mente ou da alma, sem que o ente seja fora da alma [Unum quod dicitur esse rei diminutum, ut est rei esse in conceptu mentis seu in anima, absque eo quod sit extra animam ens $<\ldots>$ ]" (p. 160 - sobre o 'ser dimuído', cf. cap. 6, nota 171. De outra parte, ele é [1.2.2] "dito o ser verdadeiro da coisa, como é o ser de existência na coisa fora da alma [Alterum vero quod dicitur esse rei verum, ut est esse existentiae in re extra animam] (p. 160). Este último, novamente, se divide em dois. Pois, um [1.2.2.1] é "o ser de existência simplesmente dito que é o ser da coisa fora da alma, mas em outro (como são, no composto, o ser da matéria e o da forma) [Quoddam enim est esse existentiae simpliciter dictum quod est esse rei extra animam, sed in alio, ut sunt esse materiae et formae in composito]" (p. 160). Por fim, temos [1.2.2.2] o ser de existência verdadeiro da coisa, o qual é "o ser de subsistência, que é o ser da coisa suposta subsistente em si [Quoddam vero est esse subsistentiae quod est esse suppositi rei in se subsistentes]" (p. 160). Em resumo, algo pode existir como conceito ou como coisa verdadeira fora da alma, mas esse ser de existência é a adição da efetivação ao ser de essência que a coisa já possuía. Em outras palavras, o ser de existência adiciona uma relação efetivação - ao ser de essência. Ainda sobre esse mesmo tema, cf. tb. Quodl. 10, q. 8, co. (ed. De WulfMansion Centre, vol. 14, p. 202).

Nesse ponto, pareceria que poderíamos distinguir o ser de essência e o ser de existência como o absoluto e o relativo - assim, teríamos uma essência que, ao ser efetivada por algo, vem a existir. Essa é a intepretação defendida por Karl Werner: "Man habe nämlich zu unterscheiden zwischen dem Esse essentiae und dem Esse actualis existentiae; das letztere ist in den Creaturen allerdings ein mitgetheiltes Sein, wie der Begriff des Geschaftenseins involvirt, das Esse essentiae bezeichnet als eigentliches Wesen eines geschaffenen Dinges doch sicher ein selbsteigenes Sein, ein Esse suum desselben, zu welchem das Esse actualis existentiae als Zweites hinzukommt. Wäre das Esse essentiae selber wieder etwas Participatives, so müsste man nach dem denknothwendig vorauszusetzenden theilhabenden Träger desselben fragen, welchem das Esse suum nicht abgesprochen werden könnte, ohne in einen sinnlosen Regressus in infinitum zu verfallen" (Heinrich von Gent als Repräsentant des christlichen 
Platonismus in dreizehnten Jahrhundert. Wien: Carl Gerold's Sohn, 1878, p. 16). Entretanto, já em começos do século XXI, Jos Decorte argumentou que, pelo contrário, tanto o esse essentiae como o esse existentiae são tomados por Henrique de Gand como estabelecidos por relações (respectus). Seguindo a interpretação de Decorte, o retorno ao infinito temido por Werner não tem lugar, pois o absoluto em que tais relações se lastreiam são, em última instância, o próprio Deus. Cf. DECORTE, J. "Heinrich von Gent: Von einer Ontologie der Relation zur Relationsontologie". In: KOBUSCH, T. (Hrsg.). Philosophen des Mittelalters. Eine Einführung. Darmstadt: Primus, 2000, pp. 152-66 [trad. para o português: "Henrique de Gândavo - De uma ontologia da relação a um ontologia relacional". In: KOBUSCH, T. (org.). Filósofos da Idade Média. Uma Introdução. Trad. de Paulo Astor Soethe. São Leopoldo: Editora Unisinos, 2000, pp. 206-24]; cf. tb. PICKAVÉ, M. "Henry of Ghent on Individuation, Essence, and Being”. In: WILSON, G. A. (ed.). A Companion to Henry of Ghent, 2011, pp. 181-209 (esp. pp. 197-8). Esse caráter relacional de ambos - esse essentiae e esse existentiae - é bem formulado em Suma, art. 21, q. 2, co. (ed. Decorte \& Teske, p. 52): “< ..> omnes vero creaturae attribuuntur Deo ut uni fini et uni formae et uni efficienti, ut fini a quo perficiuntur quoad bene esse, ut formae a qua participant quod dicantur habere esse essentiae, ut efficienti, a quo habent quod eis conveniat simpliciter esse actualis existentiae". Como vemos, a mesma criatura possui distintos respectus para com Deus - tais distintos modos de participar em Deus, lhe fornecem diferentes intentiones. Essa última afirmação é confirmada, por exemplo, se nos voltamos para Suma, art. 21, q. 4 (ed. Decorte \& Teske, pp. 74-93), onde Henrique de Gand busca mostrar que não somente o esse essentiae e o esse existentiae são distintos intencionalmente, mas também o esse é distinto intencionalmente da essentia - esta última tese, aliás, ele considera ser especialmente difícil de demonstrar: "Ex quo patet quod licet ut praedictum est, esse existentiae rei non addat aliud re super ipsam essentiam, quod tamen sit omnino alia intentio ipsius essentiae et esse existentiae eius. Et non solum alia est ratio esse existentiae et ipsius essentiae, sed etiam esse essentiae et ipsius essentiae, licet non sit ita clarum" (ibid., p. 78). Por fim, adicione-se que uma das diferenças principais entre o respectus que produz o esse essentiae e o respectus que produz o esse existentiae é o fato de o primeiro ser eterno e o segundo temporal: "Ex hoc enim in ipsa essentia et natura creaturae ut essentia est vel existens, fundatur respectus quidam et relatio ad Deum, ut ad principium efficiens et formam, a quo participat esse non ex aliquo ei superaddito secundum rem, sed ex solo respectum ad ipsum ut ad rationem formalem, vel ad ipsum causans, ut dicatur esse naturae et essentia quaedam in actu existens. Sed primus respectus est ei aeternus <... >. Secundus vero respectus est ei ex tempore" (ibid., p. 84).

Essa fundamental temporalidade da criatura efetuada é mais bem desenvolvida em Quodl. 1, q. 7-8 (ed. De Wulf-Mansion Centre, vol. 5, pp. 27-46). Sobre a temporalidade da criatura em Henrique de Gand, cf. MACKEN, R. Hendrik van Gent's "Quodlibet I". Tekstkritische uitgave. Weerlegging van een mogelijke eeuwigheid der wereld. 2 delen. Proefschrift tot het behalen van de graad van Doctor in de Wijsbegeerte. Leuven: Katholieke Universiteit Leuven, 1968, deel 1, pp. 296-342; MACKEN, [R.] S. "L'argumentation contre une éternité possible du monde chez Henri de Gand". In: De doctrina Ioannis Duns Scoti. Acta Congressus Scotistici Internationalis Oxonii et Edimburgi 11-17 sept. 1966 celebrati. Vol. I: Documenta et studia in Duns Scotum introductoria. Cura Commissionis Scotisticae. Romae, 1968, pp. 307-23; MACKEN, R. "De radicale tijdlijkheid van het schepsel volgens Hendrik van Gent" Tijdschrift voor Filosofie 31.3 (1969), pp. 519-71; MACKEN, R. "La temporalité radicale de l'être selon Henri de Gand”. Recherches de théologie ancienne et médiévale 38 (1971), pp. 211-72; VELDHUIJSEN, P. van. "Hendrik van Gent (vóór 1240-1293) contra Thomas van Aquino (1224/251274). Over de mogelijkheid van een eeuwig geschapen wereld". Stoicheia 2.3 (1987), pp. 3-26; DECORTE, J. "Thomas Aquinas and Henry of Ghent on God's Relation to the World". Mediaevalia. Textos e estudos 3 (1993), pp. 91-107; WILSON, G. A. "Non-Being: Eviternity and Time in the Ontology of Henry of Ghent”. Mediaevalia. Textos e estudos 3 (1993), pp. 77-90; CARVALHO, M. A. S. "The Problem of the Possible Eternity of the World according to Henry of Ghent and his Historians". In: VANHAMEL, W. (ed.). Henry of Ghent. Proceedings..., 1996, pp. 43-70; CARVALHO, M. A. S. "Introdução", 1996, pp. 23-42; CARVALHO, M. A. S. "La pensée d'Henri de Gand avant 1276: les erreurs concernant la création du monde d'après la 'Lectura ordinaria super sacram scripturam"”. Recherches de théologie ancienne et médiévale 63 (1996), pp. 36-67; CARVALHO, M. S. "Sobre o Projecto do Tractactus de productione creaturae de Henrique de Gand". Mediaevalia. Textos e estudos 11-12 (1997), pp. 211-30; WILSON, "Henry of Ghent's Quodlibet I...", 1999, pp. 173-5; PORRO, "Metaphysics and Theology in the Last Quarter of the Thirteenth Century...", 2000, pp. 271-2; CARVALHO, A Novidade do Mundo, 2001, pp. 387-481. Decerto, à discussão sobre a intrínseca temporalidade da criatura está associada a concepção de tempo desenvolvida por Henrique de Gand. Sobre a noção escolástica de tempo e, em especial, a respeito daquela elaborada por Henrique, cf. os seguintes trabalhos de Pasquale Porro: "Enrico di Gand e il 
Ora, com isso, esclarecemos uma parte da descrição da unidade do ser do homem como 'subsistência pessoal' (personalis subsistentia). Resta saber em que medida o 'personalis' modifica o termo 'subsistentia'. Esse passo vai ser um pouco mais fácil para nós: “assim, 'indivíduo’ [individuum] significa algo indeterminado [indeterminatum quid] quanto à natureza racional e à irracional; mas, 'pessoa' [persona] algo determinado e próprio [determinatum et proprium quid] quanto à natureza racional" ${ }^{96}$. Notemos nesta passagem a oposição entre "indeterminado

problema dell'unicità dell'aevum". Medioevo 13 (1987), pp. 123-93; “Tempo e aevum in Enrico di Gand e Giovanni Duns Scoto". In: ALlineY, G., COVA, L. (ed.). Tempus Aevum Aeternitas. La concettualizzazione del tempo nel pensiero tardomedievale. Atti del Colloquio Internazionale. Trieste, 4-6 marzo 1999. Firenze: Olschki, 2000, pp. 89-129; "Il vocabulário filosofico medievale del tempo e della durata”. In: CAPASSO, R., PICCARI, P. (ed.). Il tempo nel medioevo. Rappresentazioni storiche e concezioni filosofiche. Atti del Convegno internazionale di Roma, 26-28 novembre 1998. Roma: Società Italiana di Demodossalogia, 2000, pp. 63-102.

Por fim, note-se que a noção de essentia em Henrique de Gand é pronfundamente associada às noções de res e possibile. Porém, como a referência a res e à noção de 'possibilidade' traz à baila o problema da delimitação do campo do inteligível, retornaremos a isso adiante, em cap. 6, nota 25.

Sobre a distinção entre ser de essência e ser de existência, cf. os trabalhos citados no início da nota 14 e, além disso: WERNER, Heinrich von Gent als Repräsentant..., 1878, pp. 16-7; CHOSSAT, M. "Dieu (sa nature selon les scolastiques)". In: Dictionnaire de Théologie Catholique. Tome 4. Paris: Letouzey e Ané Éditeurs, 1911, cols. 1152-1243 (esp. cols. 1180-1); MANDONNET, P. "Les premières disputes sur la distinction réelle entre l'essence et l'existence, 1276-1287'. Revue Thomiste (1910), pp. 741-65; PAULUS, "Henri de Gand et l'argument ontologique", 1935, pp. 297-311; PAULUS, Henri de Gand..., 1938, pp. 259-326; CAFFARENA, Ser participado y ser subsistente..., 1958; HOERES, W. "Wesen und Dasein bei Heinrich von Gent und Duns Scotus". Franzikanische Studien 47 (1965), pp. 121-86; SIEMIANOWSKI, A. "Teoria istnienia realnego i tzw. sposoby istnienia u Henryka z Gandawy" Roczniki Filozoficzne 13.1 (1965), pp. 33-41; DUDAK, K. "Czy Henryk z Gandawy był esencjalistą?" Roczniki Filozoficzne. 14.1 (1966), pp. 34-41; CUNNINGHAM, F. A. "Some presuppositions in Henry of Ghent". Pensamiento 25 (1969), pp. 103-43; IMBACH, R. "Averroistische Stellungnahmen zur Diskussion über das Verhältnis von esse et essentia. Von Siger von Brabant zu Thaddaeus von Parma". In: MARIERÙ, A., PARAVICINI BAGLIANI, A. (ed.). Studi sul XIV secolo in memoria di Anneliese Maier. Roma: Edizioni di Storia e Letteratura, 1981, pp. 299-339 (esp. pp. 303-9); DECORTE, Een avicenniserend augustinisme..., 1983, deel 1, pp. 115-21; MARRONE, Truth and Scientific Knowledge..., 1985, pp. 105-7; PORRO, Enrico di Gand. La via delle..., 1990, pp. 17-71; PORRO, "Possibilità ed esse essentia in Enrico di Gand", 1996, pp. 211-53; WILSON, "Henry of Ghent's Quodlibet I...", 1999, pp. 168-70; MARRONE, The Light of Thy Countenance..., 2001, vol. 2, pp. 335-58; HOFFMANN, T. Creatura intellecta. Die Ideen und Possibilien bei Duns Scotus mit Ausblick auf Franz von Mayronis, Poncius und Mastrius. Münster: Aschendorff, 2001, pp. 111-22; PORRO, P. 'Universaux et esse essentia: Avicenne, Henri de Gand et le 'troisième Reich'. Cahiers de philosophie de l'université de Caen 38-9 (2002), pp. 9-50; PORRO, P. "Le 'Quaestiones super Metaphysicam'...”, 2002, pp. 507-602 (esp. pp. 547-52); HOFFMANN, T. "Idées divines et essence: Henri de Gand". In: BARDOUT, J.-C., BOULNOIS, O. (éds). Sur la science divine. Paris: PUF, 2002, pp. 226-244 (pp. 233-244: trad. francesa do Quodl. IX, q. 2, de Henrique de Gand); KÖNIGPRALONG, C. "Introduction". In: HENRI DE GAND, GILLES DE ROME, GODEFROID DE FONTAINES. Etre, essence et contingence. Textes de Henri de Gand, Gilles de Rome, Godefroid de Fontaines. Intr., tr. et notes par C. König-Pralong. Paris: Les Belles Lettres, 2006, pp. 7-126; PICKAVÉ, "Henry of Ghent on Individuation, Essence, and Being”, pp. 189-204; PICKAVÉ, Heinrich von Gent über Metaphysik..., 2007, pp. 203-7; BARDOUT, J.-C. Penser l'existence I. L'existence exposée. Époque médiévale. Paris: Vrin, 2013, pp. 255-81; SALAS, V. M. "Henry of Ghent, Duns Scotus, and Edith Stein on Essential Being". In: SALAS, V. M. (ed.). Hircocervi \& Other Metaphysical Wonders. Milwaukee: Marquette University Press, 2013, pp. 285-307; ROIG, "Cracking intencional en la metafísica de Enrique de Gand", 2017.

${ }^{96}$ Henrique de Gand, Suma, art. 53, q. 1, co. (ed. De Wulf-Mansion Centre, vol. 31, p. 13): “< $<$.. sic 
'individuum' significat indeterminatum quid ad naturam rationalem et irrationalem, 'persona' vero determinatum et proprium quid naturae rationali”. O mesmo tema é longamente retomado e discutido em Suma, art. 53, q. 5 (ed. De Wulf-Mansion Centre, vol. 31, pp. 41-68). Vale a pena, neste ponto, dedicarmos algumas linhas aos traços gerais da noção de indivíduo em Henrique de Gand.

No referido Suma, art. 53, q. 5, ao defender sua tese segundo a qual 'pessoa' diz, a respeito de racionais, o mesmo que 'indivíduo' a respeito de irracionais (ou, também, racionais, como vimos na citação inicial desta nota), o Doutor Solene afirma que "cum non sit dubium quin hoc nomen 'individuum' circa substantias irrationales non est nomen rei sed nomen intentionis secundae, quae nihil aliud est quam modus quo intellectus rem concipit respectu superioris et collateralis, ut determinatam et non divisam in aliqua sub se atque divisam ab eo quod est iuxta se, non est dubium quin hoc nomen 'persona' in creaturis rationalibus non sit nomen rei, sed nomen intentionis, dicens praedictum modum individuationis circa illa <... " (ed. De Wulf-Mansion Centre, vol. 31, p. 59). O termo 'indivíduo' nomeia não uma coisa, mas uma intenção segunda - isto é, ele nomeia um conceito acerca de conceitos (sobre a distinção entre intenções primeiras e segundas, cf. cap. 6, nota 36). O conceito nomeado pelo termo 'indivíduo', por sua vez, é um modo de intelecção acerca de uma coisa, a saber, enquanto esta última é tomada como [i] não dividida sob si (o que exclui dessa coisa a universalidade) e [ii] dividida daqueles que são no mesmo nível que ela (o que a distingue de outros sob a mesma espécie especialíssima). Essas duas características da individuação são explicadas por Henrique de Gand como duas negações, que cumprem o papel de princípio de individuação. Uma é a [i] negação ab intra, que nega de uma forma qualquer possibilidade de se multiplicar; outra e a [ii] negação ab extra, que nega dessa mesma forma qualquer possibilidade de identidade com outra. Ora, o indivíduo é precisamente aquele que não pode se multiplicar em vários e não é idêntico a nenhum outro: "Est igitur dicendum, quod in formis creatis specificis, ut specificae sunt, ratio individuationis ipsarum, qua determinantur in suppositis, et quae est ratio constitutiva suppositi, est negatio qua forma ipsa, quae ex se est specifica in esse rationis, ut est terminus factionis, facta est indivisa omnino in supposito, et individualis et singularis privatione omnis divisibilitatis per se et per accidens $<\ldots>$. Quae quidem negatio non est simplex, sed duplex, quia est removens ab intra omnem plurificabilitatem, et diversitatem, et ab extra omnem identitatem $<\ldots>$. Et haec duplex negatio omnino formaliter rationem formae determinat, qua determinatione supra essentiam formae constituitur suppositum absolutum quod vere dicitur hoc aliquid, quasi tantum hoc, et non aliud, nec intra se, nec extra, et sic nullo modo aliud quid"-Quodl. 5, q. 8, co. (ed. 1613, f. 246ra-b).

Por outro lado, ainda que o Doutor Solene enfatize tal concepção negativa de individuação (cf. CARVALHO, "O que significa pensar?”, 2001, pp. 86-8), recentemente Martin Pickavé chamou atenção para o fato de que nosso autor igualmente admite, ao lado desta, uma individuação positiva (cf. PICKAVÉ, "Henry of Ghent on Individuation, Essence, and Being”. 2011, pp. 187-8). Nesse trecho de seu artigo, Pickavé cita um significativo excerto de Quodl. 11, q. 1, co (ed. 1613, f. 181ra-b): "< $<$. non terminatur actus productionis ad essentiam rei simpliciter, ut est essentia sub ratione indeterminati, sed solummodo ut est haec essentia, quia omnis actus et operatio est circa singularia. Formaliter autem habet determinationem in hoc supposito, quia in ipso est secundum hoc esse proprium huic supposito, et sic positiva eius individuatio non fit effective, nisi per producentem, et formaliter non nisi per hoc esse. Qualiter autem habeat fieri individuatio negative alibi sufficienter exposuimus". A individuação negativa a que se faz referência neste trecho é aquela que vimos há pouco nesta nota. Mas qual seria a positiva? Segundo esse trecho de Quodl. 11, q. 1, a individuação positivamente diz respeito [i] efetivamente à ação do produtor do ente individuado e [ii] formalmente ao próprio ser desse ente enquanto indivíduo. Como Pickavé argumenta ("Henry of Ghent on Individuation, Essence, and Being”, 2011, p. 186), essa descrição positiva da individuação já pode ser encontrada em Quodl. 2, q. 8. Aqui, de fato, lemos que "Sic ergo dicendum quod, non repugnante essentia naturae angelicae vel cuiuscumque creaturae essentia, duo individua $\langle\ldots>$ possunt fieri a Deo sub una specie specialissima, in solis sibi substantialibus distincta per diversas subsistentias in effectu" (ed. De Wulf-Mansion Centre, vol. 6, p. 53). Mais uma vez, temos aqui como razões da individuação [i] a efetuação por Deus e [ii] a própria subsistência do indivíduo. Isso, porém, não seria simplesmente dizer que o indivíduo é indivíduo por foi criado como tal e é assim? Não somente, se notarmos - como apontam Jos Decorte (Een avicenniserend augustinisme..., 1983, deel 1, pp. 121-3) e, mais uma vez, Pickavé ("Henry of Ghent on Individuation, Essence, and Being”, 2011, p. 188) - que no mesmo Quodl. 2, q. 8, a consideração de tal ser enquanto subsistente adiciona uma intenção a esse ser. Assim, a distinção entre a essência do indivíduo e esse princípio positivo de sua individuação é uma distinção intencional, uma vez que a efetivação enquanto subsistente deve ser concebida como posterior (logicamente) à própria essência individual, já que a essência, de si mesma, é indiferente à individuação em qualquer suposto e, mais, é indiferente à individuação ou universalização (sobre a indiferença da essência, cf. a nota 
quanto ao racional e irracional' e 'determinado e próprio quanto à natureza racional' tal distinção explica, nessa passagem, aquela entre 'indivíduo' e 'pessoa'. A 'pessoa' é aquilo que, sendo um indivíduo, além disso é um indivíduo com natureza racional.

Ou seja, quando o Doutor Solene caracterizava a unidade do ser do homem como uma

anterior) - Quodl. 2, q. 8, ad 1 (ed. De Wulf-Mansion Centre, vol. 6, p. 54): "Dicendum igitur ad argumentum quod unam et eandem essentiam ex se omnino simplicem, nullo addito, nec re nec intentione, differenti ab ea, distingui et multiplicari per plura individua est omnino inintelligibile et secundum rem impossibile. Sic enim quaecumque essentia in se considerata nullam potest omnino intelligi habere distinctionem, multiplicationem aut diversitatem. Sic enim considerata intelligitur ut neque in unico individuo existens neque ut in pluribus, neque ut universalis neque ut particularis, sed ut cui ambo nata sunt accidere" (sobre a noção de 'universal' em Henrique de Gand, cf. cap. 6, nota 55).

Por fim, é importante enfatizar que essa complexa relação entre essência e indivíduo parece ser igualmente válida para entes espirituais e entes materiais: "Ponendo enim quod non sit materia in incorporalibus et quod tamen omnis essentia creaturae, quatum est de se, indeterminate est et indifferens, ut ei accidat ratio individui et particularis per determinationem in supposito definito in se subsistente, et ratio universalis per determinationem in supposito indefinito per intellectum abstracto a suppositis definitis" - Suma, art. 28, q. 2, ad 2 (ed. Teske, p. 192). Por outro lado, Giorgio Pini argumenta que haveria um desenvolvimento na posição de Henrique de Gand, pois ele primeiro (em Quodl. 2, q. 8) teria defendido a necessidade da matéria para a individuação dos entes materiais (ainda que a individuação prescindisse da matéria nos entes espirituais), tendo depois (em Quodl. 5, q. 8) abandonado tal distinção em favor de um princípio de individuação negativo comum a entes imateriais e materiais (cf. PINI, G. "The Individuation of Angels from Bonaventure to Duns Scotus". In: HOFFMANN, T. (ed.). A Companion to Angels in Medieval Philosophy. Leiden: Brill, 2012 pp. 79115, esp. pp. 99-109). Ainda sobre a matéria como princípio de individuação em Henrique de Gand, cf. PICKAVÉ, M. "Henry of Ghent on Individuation". Proceedings of the Society for Medieval Logic and Metaphysics 5 (2005), pp. 38-49 [edição digital].

Em qualquer caso, note-se que no universo de Henrique de Gand a individuação se estende a todas as criaturas existentes. Esse aspecto de sua doutrina da individuação é bem sublinhado Tiziana SuarezNani: " $<\ldots>$ infolgedessen impliziert seine Theorie, dass Kreatürlichkeit notwendigerweise mit der Existenz als Individuum streng verknüpft ist. Diese Implikation führt zu einer wichtigen Konsequenz: Auf der Ebene des Geschaffenen kann kein Subjekt gedacht werden, das nicht gleichzeitig ein Individuum, analog zum menschlichen Wesen, wäre" - SUAREZ-NANI, T. "Individualität und Subjektivität der Engel im 13. Jahrhundert. Thomas von Aquin, Heinrich von Gent und Petrus Johannis Olivi”. Das Mittelalter 11 (2006), pp. 29-48 (cit. na p. 39). Ainda sobre a estrita relação entre 'existência' e 'individualidade' no pensamento de Henrique, cf. HIPP, S. A. "Existential Relation as Principle of Individuation". The Thomist 72 (2008), pp. 67-106 (esp. pp. 80-1).

Enfim, comportando um aspecto negativo e outro positivo (e, quiçá, um desenvolvimento), a concepção de individuação elaborada pelo Doutor Solene é razoalvemente complexa. Sobre ela, além dos textos já citados na presente nota, cf. PAULUS, Henri de Gand. Essai..., 1938, pp. 353-61; BÉRUBÉ, C. La connaissance de l'individuel au moyen âge. Préface de P. Vignaux. Montréal - Paris: Presses de 1'Université de Montréal - PUF, 1964, pp. 64-8; BROWN, S. F. "Henry of Ghent (b. ca. 1217; d. 1293)". In: GRACIA, J. E. (ed.). Individuation in Scholasticism. The Later Middle Ages and the Counter-Reformation, 1150-1650. Albany: State University of New York Press, 1994, pp. 195-219; BROWN, S. F. "Godfrey of Fontaines and Henry of Ghent: Individuation and the Condamnations of 1277”. In: WŁODEK, S. (éd.). Société et église. Textes et discussions dans les universités d'Europe centrale pendant le moyen âge tardif. Actes du Colloque international de Cracovie 14-16 juin 1993 organisé para la SIEPM. Turnhout: Brepols, 1995, pp. 193-207; AERTSEN, J. "Die Thesen zur Individuation in der Verurteilung von 1277, Heinrich von Gent und Thomas von Aquin". In: AERTSEN, J. A., SPEER, A. (Hrsg.). Individuum und Individualität im Mittelalter. Berlin - New York: De Gruyter, 1996, pp. 249-65; ROIG, "Cracking intencional en la metafísica de Enrique de Gand", 2017, pp. 8-12.

Adiante, trataremos do conhecimento que o homem possui acerca do indivíduo (cf. cap. 6, nota 190). Sobre o conhecimento que Deus possuiria dos indivíduos segundo Henrique de Gand, cf. HOFFMANN, T. "Ideen der Individuen und intentio naturae. Duns Scotus im Dialog mit Thomas von Aquin und Heinrich von Gent". Freiburger Zeitschrift für Philosophie und Theologie 46 (1999), pp. 138-52 (esp. pp. 142-6). 
'subsistência pessoal' ele o estava descrevendo como um ente composto (de alma e corpo), completo (não podendo ser in alio), participante de algo (a saber, da humanidade) e, além disso, intelectual e racional. Pela utilização da expressão 'subsistência pessoal', vemos o ser do homem caracterizado, a um só tempo, pela sua existência como composto intermediário na ordem do mundo e pela potência mais alta de sua alma, a saber, a potência intelectiva ${ }^{97}$.

Enfim, esse longo caminho que percorremos desde a hierarquia dos entes, passando pela vida e chegando à própria composição de alma e corpo do homem como ente intermediário na ordem do mundo, nos levou ao cabo de volta ao problema do conhecimento. Vemos agora que aquela pesquisa inicial da Suma, pela qual se defendia (não demonstrativa, mas convincentemente, como se pode fazer) a possibilidade de se ter ciência para o homem - seja essa ciência sensitiva ou intelectiva (um scire large accepto) - é uma afirmação da própria natureza humana contra os que negam a ciência e, ao fazê-lo, negam a própria humanidade. Com efeito, vemos que negar a possibilidade da ciência para o homem é negar sua potência mais alta e seu caráter de persona. Afirmar uma tal possibilidade, por outro lado, é firmar o homem na ordem do mundo como o intermediário entre os mais baixos e os mais altos, o passivo e o ativo, o corpóreo e o espiritual, o natural e o sobrenatural.

Enquanto criatura na hierarquia do mundo, o homem é fundamentalmente potencial e passivo - o scire lhe é possível, mas não é ainda um ato. Antes de vermos como é possível a atualização desse ato humano que é o conhecimento, precisamos ainda complementar nosso estudo do caráter potencial do homem ao sublinhar que essa potência para o conhecimento vem acompanhada de uma tendência para o conhecimento. Estando em potência para seu próprio aperfeiçoamento, toda criatura também tende à própria perfeição. No caso do homem, isso se reflete em uma

\footnotetext{
${ }^{97}$ Do que se segue, igualmente, uma observação fisiológica. Se o homem se caracteriza como pessoa na medida em que existe como indivíduo corpóreo e racional, então aquela parte de seu corpo mais prontamente associada à alma racional também será o principal signo de sua caracterização como pessoa. Ora, vimos na nota 83 que a primeira parte do corpo, na ordem de natureza, a receber a alma racional é o coração - nesse caso, deveremos admitir que o coração surge como parte fundamental da caracterização corpórea do indivíduo (em nosso caso, o homem). Vemos que esse é o caso quando, ao resolver o já referido problema do batismo do monstro de duas cabeças (cf. notas 63 e 64), Henrique de Gand afirma que a única maneira de saber quantas pessoas há no monstro - uma só ou duas - é saber quantos corações há naquele corpo: "Dico ergo ad quaestionem quod, si possunt percipi duo corda esse in monstro, duae personae sunt re vera, et duo nomina eis imponenda si vero ex aliquo indicio percipi possit quod non sit ibi amplius quam unum cor, tunc procul dubio non est ibi nisi una anima, et non est nisi una persona et non nisi uno nomine nominanda" - Quodl. 6, q. 14, co. (ed. De Wulf-Mansion Centre, vol. 10, p. 167). Se a parte racional da alma é elemento fundante da pessoa humana, o coração é, no corpo humano, o signo fisiológico de sua unidade enquanto composto racional.
} 
tendência para a atividade racional. Porém, a razão humana não é simples. De fato, aquilo que denominamos aqui como 'potência intelectiva' da alma humana comporta duas partes, a saber, o intelecto e a vontade. É a interação entre esses dois que explica a tendência do homem para o conhecimento - seu amor por este último. É justamente pelo estudo do conhecimento como finalidade do homem que encerraremos nossa consideração do homem enquanto ente em potência para ter ciência. 
CAP. 3.

O CONHECIMENTO COMO FINALIDADE

\title{
3.1. INTELECTO E VONTADE
}

\subsubsection{A racionalidade humana}

Se na ordem do mundo o homem é o horizonte entre o material e o espiritual, na ordem dos inteligentes ele aparece como o mais baixo. De fato, já vimos que ele, sendo aquele intelecto mais ligado a corpos (até mesmo necessitando destes últimos para a operação da potência intelectiva), é superado pelos anjos e, no mais alto da hierarquia, por Deus mesmo, enquanto estes últimos são intelectuais e completamente separados do corpo:

\begin{abstract}
"E, desse modo, há um grau e ordem nos inteligentes [intelligentibus] assim como nos outros. Pois o homem é o ínfimo [infimum] dos inteligentes, Deus o supremo [supremum] e o anjo o médio [medium]. O ínfimo do homem, enquanto é inteligente, é a razão [ratio], pela qual ele discorre raciocinando e adquire a notícia [notitiam] para si. Por ela, ele propriamente difere do anjo e é abaixo [infra] deste, pois este não é discursivo ao raciocinar, como foi dito, mas só intelectual, inteligindo sem discurso raciocinativo o que quer que intelija. Nisso, o homem convém com ele, enquanto o supremo nele $<s c$. homem $>$ é a intelectualidade [intellectualitas], pela qual também conhece sem discurso raciocinativo ao inteligir os primeiros princípios. Porém ambos $<s c$. anjos e homens>, inteligem intelectualmente diversos segundo o discurso dito do primeiro modo. Deus, porém, é total e puramente intelectual [pure intellectualis est omnino], inteligindo simultanea e perfeitamente [simul et perfecte], sem qualquer razão de discurso"1.
\end{abstract}

Comecemos a leitura da passagem por essa referência a um 'discurso dito do primeiro modo'. Um pouco antes desse ponto, Henrique havia distinguido dois significados do termo 'discurso', de acordo com os dois inteligíveis que se dão ao

\footnotetext{
${ }^{1}$ Henrique de Gand, Suma, art. 36, q. 7, co. (ed. De Wulf-Mansion Centre, vol. 28, p. 140): "Et per hunc modum gradus est et ordo in intelligentibus sicut in aliis. Nam homo infimum est intelligentium, Deus vero supremum, et angelus medium. Hominis autem infimum, in quantum est intelligens, ratio est, qua ratiocinando discurrit et notitiam sibi acquirit. Qua proprie differt ab angelo, et est infra ipsum, quia ipse ratiocinando discursivus non est, ut dictum est, sed solum intellectualis: sine discursu ratiocinativo intelligendo quaecumque intelligit. In quo convenit cum eo homo, in quantum supremum in eo intellectualitas est, qua etiam hic cognoscit sine discursu ratiocinativo, intelligendo prima principia, sed ambo intelligunt intellectualiter diversa secundum discursum primo modo dictum. Deus autem pure intellectualis est omnino, sine omni ratione discursus simul, et perfecte, intelligendo $<\ldots>$.
} 
conhecimento intelectual, a saber, os inteligíveis incomplexos ou simples (intelligibilia incomplexa $<\ldots>$ simplex intelligentia) e os inteligíveis compostos pela composição e divisão do intelecto (composita, quorum est compositio et divisio intellectus). O discurso com respeito aos inteligíveis simples é apenas o fato de que, uma vez que nenhum intelecto criado pode inteligir vários conceitos simples simultaneamente, é preciso que eles intelijam um após o outro, isto é, discorram pelos vários conceitos simples que possuam no intelecto. Já o discurso quanto aos conceitos compostos diz respeito à passagem de uma proposição (que é um complexo) para outra, isto é, dos princípios às conclusões. Assim, o discurso quanto aos inteligíveis compostos é, precisamente, o discurso silogístico, que o Doutor Solene denomina como ratiocinativus ${ }^{2}$. Com essa distinção pressuposta, estamos agora habilitados a ler o excerto.

Primeiramente, está claro que, enquanto criaturas, os homens e os anjos convêm no discurso quanto aos inteligíveis simples, pois diz-se que "ambos, inteligem intelectualmente diversos segundo o discurso dito do primeiro modo". Isso certamente os separa de Deus que, sendo ato puro, não possui qualquer traço de um discurso intelectual. A distinção, porém, entre anjos e homens está no campo da razão, isto é, dos inteligíveis complexos, pois a necessidade de raciocinar para conhecer aflige unicamente o homem na ordem dos inteligentes. Mais precisamente, Henrique de Gand distingue dois elementos nesse inteligente mais baixo que é o homem - é interessante notar, aliás, que essa divisão pressupõe uma hierarquia interna à própria potência intelectiva humana. Esses dois são, por um lado, a razão e, por outro, a intelectualidade. Nesta última, o homem também convém com anjo, pois ela é a potência pela qual o homem conhece os primeiros princípios que, por

\footnotetext{
${ }^{2}$ Henrique de Gand, Suma, art. 36, q. 7, co. (ed. De Wulf-Mansion Centre, vol. 28, p. 136): "Et hoc per duplicem discursum, secundum quod iuxta duo genera intelligibilium duplex est modus discurrendi a priori in posterius. Sunt enim quaedam intelligibilia incomplexa, quorum est simplex intelligentia, et sunt quaedam composita, quorum est compositio et divisio intellectus", ao que Henrique adiciona sobre a primeira acepção de discurso (op. cit.): "In primis enim fit discursus intelligendo diversa unum post aliud, non omnia simul in uno, quia non nisi de uno simul format conceptum creatus intellectus, nec convertere potest se ad plura ut plura, in quocumque statu fuerit, sive intellectus humanus sive angelicus, sicut in propriis locis declarandum est". Já a segunda acepção de discurso diz respeito somente ao homem, devido a seu caráter racional (op. cit., p. 137): "In illis autem, quorum intelligentia est compositio et divisio, fit discursus intelligendo diversas complexiones unam post aliam, quia non intelligit posterius nisi per medium connectens posterius priori; per quod quidem medium intellectus facit collationem prioris ad posterius, et sic per notitiam prioris acquirit notitiam posterioris: non solum posterius cognoscit post prius. Et iste appellatur discursus ratiocinativus, et est proprius hominibus in vita ista, et non convenit Deo, nec etiam beatis $<\ldots>$ ". Atente-se, aliás, para as últimas palavras desse trecho: tal discurso raciocinativo diz respeito exclusivamente ao homem in hac vita, isto é, no estado da vida presente, limitado por este corpo presente (cf. próxima nota).
} 
definição, são conhecidos sem qualquer discurso silogístico. Já a razão, inferior à intelectualidade, é aquilo que puxa o homem para baixo na escala dos inteligentes, pois ela é justamente a potência que o faz precisar discorrer raciocinativamente (ou seja, silogisticamente) de um inteligível complexo ao outro. Essa necessidade não ocorre ao anjo, que se basta com inteligíveis incomplexos. O homem, pelo contrário, deve discorrer por silogismos para obter conhecimento. Ao que parece, isso é precisamente o característico do homem, pois é o que o torna mais baixo do que o anjo, sendo eles no restante similares.

Essa necessidade de discurso raciocinativo está ligada ao caráter potencial da criatura (lembremos que tanto o anjo como o homem se valem do discurso do primeiro modo) e, especialmente, do homem (que, para além do primeiro modo, também se vale do segundo modo de discurso, que já não diz respeito ao anjo). Nesse ponto, se torna relevante até mesmo a distinção entre o homem no estado presente (in hac vita) e o homem beato (beatus). Este último, ainda que necessite de discurso na medida em que intelige um complexo após o outro, já intelige nos princípios tanto os meios, como as conclusões. O homem in hac vita, por outro lado, ao conhecer os princípios só intelige os meios potencialmente, necessitando de um discurso para conceber os meios a partir dos princípios e as conclusões a partir dos dois anteriores. Isso faz com que somente o homem in hac vita possa ser tomado estritamente como rationalis $^{3}$. Parece-me, portanto, que a diferença fundamental entre o homem in hac vita e o beato é que, muito embora ambos tenham que discorrer de um complexo proposicional a outro (o que os separa igualmente do anjo), somente o homem in hac vita necessita da arte lógica para a formulação do discurso. Donde podemos concluir que, propriamente, é racional o discurso lógico, típico do homem in hac vita (o que mais uma vez expõe o caráter potencial e inferior do homem frente aos demais entes

\footnotetext{
${ }^{3}$ Henrique de Gand, Suma, art. 36, q. 7, co. (ed. De Wulf-Mansion Centre, vol. 28, p. 137): “ $<\ldots>$ beati ex hoc quod intelligunt et considerant principia, etsi non intelligunt simul conclusiones et media, immo post conceptum principiorum necesse habent formare conceptum conclusionum et mediorum iuxta modum iam dicti discursus, quia, si intellectus creatus non potest simul formare diversos conceptus incomplexos, multo minus nec diversos complexos; intelligunt tamen media in principiis suis intellectis, et in utrisque prius intellectis, conclusiones; per quae quidem media conclusiones natae sunt a nobis cognosci per discursum ex principiis. Sed quando illo modo cognoscuntur conclusiones in principiis et in mediis, non oportet, intellectis principiis, aliquo discursu ratiocinativo ad conclusiones procedere". A isso se adiciona (op. cit., p. 138): "Unde tali discursu solum utuntur homines in hac vita, in qua propterea non sunt proprie intelligibiles, sed rationales, in principiis scilicet non concipientes principiata nisi in potentia, ita quod seorsum oportet hominem formare complexiones principiorum mediorum et conclusionum unam post alteram, et per media conclusiones ex principiis intelligere".
} 
intelectuais $)^{4}$. Agora, se nos voltarmos para os trechos expungidos de Suma, art. 34, q. 5, na cópia de Godofredo de Fontaines (ms. BNF, Lat. 15355, f. 159va-b) e registrados por Raymond Macken em sua edição crítica do texto, a necessidade do discurso lógico surge diretamente atrelada à origem sensível do conhecimento intelectual humano. Isso ocorre porque nada se conhece para além dos sentidos senão pela intelecção, isto é, “cavando sob a espécie sensível para compreender algo inteligível que não é captado pelo sentido - isso pertence à quididade do que é compreendido [ad comprehensibilis quidditatem], que não é captada senão pelo intelecto de que é objeto por si. E isso segundo a arte de investigar o que é [artem investigandi quod quid est], transmitida no livro dos Posteriores e no livro das Divisões de Boécio" ". Ainda que esta seja uma passagem expungida da versão final do texto, a utilizamos aqui somente para confirmar a tese já formulada: o discurso lógico é necessário devido ao caráter potencial do homem in hac vita. Este último trecho nos lembra que tal potencialidade está ligada à corporeidade do homem e, principalmente, à origem sensível de seu conhecimento intelectual ${ }^{6}$.

Veremos cuidadosamente a relação entre sensação e intelecção nos próximos capítulos deste trabalho. Por ora, no entanto, pretendo deixar de lado essa relação entre razão e sensibilidade e voltar minha atenção para um outro elemento profundamente relacionado à razão do homem tal como Henrique de Gand a concebe.

Para iniciar nosso estudo desse outro elemento associado à razão humana, podemos atentar novamente, por um instante, para aquela hierarquia dos viventes que

\footnotetext{
${ }^{4}$ Henrique de Gand, Suma, art. 36, q. 7, co. (ed. De Wulf-Mansion Centre, vol. 28, p. 139): "Per hunc enim modum omnis ratiocinativa cognitio, sive sit syllogismo demonstrativo faciente scire per causam, sive syllogismo logico explicante solum quod in medio est implicitum, aliquid habet de potentia et aliquid de actu".

${ }^{5}$ Henrique de Gand, Suma, art. 34, q. 5, co. (ed. De Wulf-Mansion Centre, vol. 27, p. 223, app.): "Et si cognoscit aliquid amplius, hoc est intelligendo, id est intus legendo, et sub specie sensibili fodiendo ad comprehendendum aliquid intelligibile quod non capitur nisi ab intellectu, cuius est per se obiectum, et hoc secundum artem investigandi quod quid est, traditam in libro Posteriorum et in libro Divisionum Boethii”. Voltaremos a esse trecho no item 6.4.1.

${ }^{6}$ Essa relação entre racionalidade e sensibilidade no homem é confirmada por um pequeno trecho de Suma, art. 32, q. 1, co. (ed. De Wulf-Mansion Centre, vol. 27, p. 30), onde lemos que a inferioridade do homem com respeito ao anjo (que sabemos estar ligada ao caráter racional do primeiro) se deve à origem sensível do conhecimento intelectual humano: "Iuxta ea quae videmus in creaturis, conicere debemus ea quae intelligere debemus in Creatore, et hoc maxime in creaturis sensibilibus, ex quibus omnis nostra scientia concipitur ortum habens ex sensu, in quo inferiores sumus angelicis substantiis $<\ldots$. ". Ainda sobre a relação, no intelecto humano, entre racionalidade, potencialidade e inferioridade com respeito às outras inteligências, cf. o trecho de Suma, art. 1, q. 12, citado em cap. 6, nota 50.
} 
estabelecemos acima ${ }^{7}$. Aí justamente se caracteriza o homem como superior aos animais brutos pela potência intelectiva, mas inferior aos anjos pela necessidade do discurso e da dedução pela razão. Agora, compreendemos bem melhor essa caracterização do homem, pois vemos que ela simplesmente descreve duas partes de sua potência intelectiva: a intelecção dos inteligíveis simples e a intelecção dos inteligíveis complexos, sendo esta última possível pela intelectualidade (no caso dos primeiros princípios) e pela razão (no caso das conclusões). Porém, razão e intelecto não são os únicos elementos que surgem para caracterizar os homens nessa hierarquia da vida exposta em Suma, art. 27, pois é dito aí que o homem "possui um princípio de se mover por si mesmo, sem qualquer impulso de um agente e forma natural, mas livremente só pela apreensão da razão e do intelecto determinando o fim, mas por discurso e dedução, não por simples apreensão $<\ldots>$ ".8 . O homem, além de racional, é livre. Entretanto, sua liberdade está profundamente atrelada ao seu modo de conhecimento intelectual, a saber, ao discurso racional. Além disso, nas linhas seguintes de Suma, art. 27, se atribui ao homem um liberum arbitrium ${ }^{9}$... Pergunto: qual seria a relação entre a razão e esse livre arbítrio?

Até aqui a alma foi tratada unicamente como potência. De fato, como qualquer criatura, a alma só pode se atualizar ao estabecer uma relação com algo exterior a ela, que a determine a produzir uma 'ação determinada acerca de um objeto determinado' (ad eliciendum actionem determinatam circa determinatum obiectum), sendo este objeto a própria coisa exterior. Isso vale igualmente para as potências sensitiva e intelectiva da alma - elas são meras potências até serem postas em operação pela relação com algo externo ${ }^{10}$ (donde, como vimos, a alma dever se unir ao corpo para atualizar a sensitiva e, assim, permitir ao intelecto obter conhecimento a partir dos sentidos).

\footnotetext{
${ }^{7}$ Cf. item 2.2.

${ }^{8}$ Henrique de Gand, Suma, art. 27, q. 2, co. (ed. Teske, p. 172): "In homine autem est adhuc superior et perfectior gradus vitae, quia habet principium movendi se a seipso absque omni impulsu agentis et formae naturalis, sed libere ex sola apprehensione rationis et intellectus determinantis finem, sed per discursum et deductionem non per simplicem apprehensionem, quemadmodum determinatur in angelo sive in intelligentia".

${ }^{9}$ Henrique de Gand, Suma, art. 27, q. 2, co. (ed. Teske, p. 172): "Et ideo licet omnia liberum arbitrium habentia gradum vitae habent eminentem super bruta animalia, intellectualia tamen habent gradum vitae eminentem super vitam rationalium $<\ldots$.. ”.

${ }^{10}$ Cf. cap. 2, nota 52.
} 
Ainda assim, vimos também que o homem está a meio caminho entre o puramente ativo e o puramente passivo, de maneira que, se ele como qualquer criatura depende de algo externo para a atualização de suas potências, ele não é simplesmente afetado por esse objeto, mas igualmente pode agir acerca deste último. Isso ocorre, por exemplo, no caso do raciocínio, pelo qual o homem age acerca dos objetos recebidos pelo intelecto de maneira a obter novos conhecimentos por meio de silogismos especulativos. Mais importante, porém, ele pode buscar compreender racionalmente, através de silogismos práticos, aquela ação prática que deve ser adotada em uma determinada circunstância ${ }^{11}$. Aqui, porém, estamos chegando ao limite superior da potência intelectiva humana que constitui, ao mesmo tempo, uma das mais profundas cisões da alma e do homem como um todo, a saber, a distinção entre intelecto e vontade - o primeiro, como princípio passivo e o segundo como princípio ativo da alma ${ }^{12}$. Como veremos, aquela possibilidade de scire large accepto

\footnotetext{
${ }^{11}$ Sobre a distinção entre 'especulativo' e 'prático', cf. a nota 56, adiante.

${ }^{12}$ Nesse ponto, é necessário esclarecer mais cuidadosamente a relação entre estes três termos: intellectus, ratio e voluntas. Depreendemos do que foi dito aqui que a vontade humana se relaciona estreitamente à razão - em particular, no que diz respeito à formação de silogismos práticos. Porém, dependendo de como tomemos a palavra 'ratio', pode-se mesmo dizer que a vontade é rationalis, embora isso não seja o caso estritamente. Assim, em Quodl. 4, q. 22, co. (ed. De Wulf-Mansion Centre, vol. 8, pp. 361-2), Henrique de Gand distingue três maneiras pelas quais se pode tomar o termo 'rationale', a saber: [1] comumente (communiter), [2] amplamente (large) e [3] estritamente (stricte) (p. 361). [1] "É dito racional comumente o que quer que pertença ao homem se movendo por si ao ato da razão. E racional assim é dito, no homem, a alma humana quanto ao intelectivo, ao volitivo e ao apetitivo sensível [Communiter dicitur rationale quidquid ad hominem pertinet per se movens ad actum rationis. Et sic rationale dicitur in homine anima humana quoad intellectivum, volitivum et sensibile appetitivum]" (p. 361). Nesse caso, a parte sensitiva apetitiva é dita racional enquanto é nata a obedecer a razão - "Communiter vero dicitur rationale pars appetitiva, quia nata est rationi oboedire" (p. 362). Ainda assim, o apetite sensitivo é "simplesmente dito irracional, pois não julga racionalmente sobre o conhecido, nem move racionalmente com respeito a ele, mas somente por ímpeto (e mais naturalmente). E só é dito racional, a saber, por participação, pois é nato a obedecer o juízo e o império da razão - a saber, o juízo do intelecto e o império da vontade $[<\ldots>$ dicitur irrationale simpliciter, quia nec de se rationabiliter iudicans de cognito, nec movens rationabiliter ad ipsum, sed impetu tantum et naturaliter magis; et solum dicitur rationale quo, scilicet per participationem, quia natum est oboedire iudicio et imperio rationis, iudicio scilicet intellectus et imperio voluntatis]" (p. 362). [2] "É dito amplamente racional aquilo pelo que o homem se distingue do bruto [Large dicitur rationale id quo homo distinguitur a bruto]" (pp. 361-2) e, nesse caso, "diz-se racional a parte volitiva. E isso porque $<$ ela $>$ é nata a mover racionalmente [Large vero dicitur rationale pars volitiva, et hoc quia nata est rationabiliter movere]" (p. 362). Mais precisamente, a vontade é dita racional desse modo, porque ela move o intelecto para inteligir o bem e, uma vez este inteligido, move a si para querê-lo livremente e impele as potência inferiores ao movimento em direção a ele. Ela é irracional, por outro lado, na medida em que a racionalidade dessas suas ações depende dos juízos racionais do intelecto, ainda que não se possa admitir que o juízo racional do intelecto determine a ação da vontade (essa complexa relação entre intelecto e vontade será o tema principal das próximas páginas) - “< $<>$ dicitur simpliciter per essentiam rationale, quia rationabiliter natum est intellectum ad discernendum movere antequam moveat ad bonum cognitum prosequendum et completa discretione rationabiliter natum est se ipsum ad volendum libere determinare et vires inferiores ad motum impellere. Dicitur autem participans ratione et irrationale quo, scilicet in quantum eius rationalis electio et motus in prosequendo dependet a rationabili iudicio et discretione intellectus; non quod per hoc voluntas ad diiudicatum determinetur
} 
que foi defendida por Henrique de Gand nos inícios da Suma (e explicada, em vários trechos de sua obra, como a potência para inteligir) possui como finalidade, justamente, a apresentação de um objeto para a vontade humana, sendo esta livre para fazer escolhas acerca dos objetos de maneira independente do próprio intelecto.

Antes de nos voltarmos para o tema, entretanto, cabe uma ressalva. Claramente, um estudo da vontade como potência ativa e superior da alma deveria ser o preâmbulo de um estudo da ética de Henrique de Gand. Porém, uma tal pesquisa não teria lugar aqui, já que pretendemos nos ocupar das concepções de ciência e conhecimento defendidas por este último. Cumpre destacar, entretanto, que a ética é um dos temas mais tratados na obra do Doutor Solene e, poderíamos arriscar dizer, foi uma de suas preocupações centrais. Assim, abordar o problema da vontade unicamente do ponto de vista da sua descrição como potência da alma e ápice da natureza humana é, de certa forma, tangenciar aquilo que Henrique talvez considerasse ser o central no seu trabalho (lembremos que uma grande parte de seus

<...>" (p. 362). Por fim, [3] "É dito estritamente racional somente o cognitivo ou intelectivo, tal que estritamente não se diga racional senão a parte intelectiva. E isso porque <ela $>$ é nata a racionalmente discernir [Stricte vero dicitur rationale cognitivum sive intellectivum tantum, ita quod stricte non dicitur rationale nisi pars intellectiva, et hoc quia nata est rationabiliter discernere]" (p. 362). De fato, o intelecto "é dito racional simplesmente, de nenhum modo irracional e, por isso, racional por essência. E isso porque por si próprio julga acerca do conhecido racionalmente e seu juízo não depende de outro de nenhum modo $[<\ldots>$ dicitur rationale simpliciter, et nullo modo irrationale, et ideo rationale per essentiam, et hoc ideo quia se ipso de cognito iudicat rationabiliter et nullo modo dependet ab altero eius iudicium]" (p. 362). Enfim, a racionalidade diz sempre respeito à produção de iudicia, de maneira que algo só é dito racional na medida em que participa de tal produção. Por isso mesmo, somente o intelecto é estritamente racional, uma vez que produz seus próprios juízos. A vontade, em Quodl. 4, q. 22, só é racional na medida em que contribui para ou se aproveita da produção dos juízos pela parte intelectiva.

Por outro lado, se nos voltamos para um curto trecho de Suma, art. 36, q. 5, lemos que: "De intellectu ergo divino, an sit potentia naturalis, an rationalis, si circa idem valet ad oppositos actus intelligendi sed et non intelligendi, debet dici potentia rationalis pure, quemadmodum voluntas in homine dicitur potentia rationalis, quia valet ad opposita. Si autem non valet ad opposita, sed est determinata ad actum, ut ad intelligendum aliquid, ita quod non possit dici quia possit illud non intelligere, tunc debet dici potentia pure naturalis" (ed. De Wulf-Mansion Centre, vol. 28, p. 124). Nesse trecho, ao que parece, a noção de rationalis não está atrelada tanto à produção de juízos, como era o caso em Quodl. 4, q. 22, mas concerne principalmente à indiferença com respeito aos opostos. Tomando 'racional' desse modo, nos diz Henrique, a vontade humana é racional, pois é indiferente a agir ou não agir com respeito a seu objeto, como veremos cuidadosamente no decorrer do presente capítulo (cf., adiante, nota 65). Assim, tal como era o caso em Quodl. 4, q. 22, também em Suma, art. 36, q. 5, a vontade pode ser dita 'racional - no primeiro caso, devido à sua relação com o intelecto na produção de juízos e, no segundo, devido à sua indiferença com respeito aos opostos. Há, porém, uma certa tensão entre as duas compreensões dessa 'racionalidade' da vontade, uma vez que no primeiro caso a vontade é dita 'racional' por poder se determinar livremente levando em consideração o conhecimento intelectual (ainda que possa contrariá-lo), enquanto que no segundo caso ela é dita 'racional' por ser indeterminada quanto aos opostos. Ou seja, parece haver aqui uma tensão entre uma concepção de 'racionalidade' atrelada à determinação para um ato e outra concepção de 'racionalidade' atrelada à indeterminação quanto ao ato. Não me parece que essa dificuldade terminológica seja diretamente abordada por Henrique de Gand. 
Quodlibeta trata de problemas propriamente éticos). Essa centralidade da ética na sua obra é refletida na enorme carga de comentários que esse aspecto de seu pensamento veio recebendo nas últimas décadas - à qual, aliás, não pretendemos fazer justiça aqui ${ }^{13}$.

${ }^{13}$ Cf. HUET, F. Recherches historiques et critiques..., 1838, pp. 162-164 e 177-190; WERNER, Heinrich von Gent als Repräsentant..., 1878, pp. 37-51; WULF, M. de. Études sur Henri de Gand, 1894, pp. 204-219; LICHTERFELD, J. Die Ethik Heinrichs von Gent in ihren Grundzügen. InauguralDissertation zur Erlangung der Doktorwürde der hohen philosophischen Fakultät der FriedrichAlexanders-Universität Erlangen, 1906; VERWEYEN, J. Das Problem der Willensfreiheit in der Scholastik. Auf Grund der Quellen dargestellt und kritisch gewürdigt. Heidelberg: Carl Winter, 1909, pp. 156-164; WITTERBRUCK, W. Die Gewissenstheorie bei Heinrich von Gent und Richard von Mediavilla. Inaugural-Dissertation zur Erlangung der Doktorwürde der Hohen Philosophischen Fakultät der Rheinischen Friedrich-Wilhelms-Universität zu Bonn. Promoviert am 14. November 1928. Elberfeld: Wuppertaler Druckerei, 1929, pp. 4-22; LAGARDE, G. de. "La philosophie sociale d'Henri de Gand et de Godefroid de Fontaines", Archives d'histoire doctrinale et littéraire du Moyen Âge (1943-5), pp. 73-142; SAN CRISTOBAL-SEBASTIÁN, A. Controversias acerca de la voluntad desde 1270 a 1300 (Estudio histórico-doctrinal). Madrid: Editorial y librería CUL., 1958; GELISSEN, M. G. H. Natuur en Genade volgens Hendrik van Gent. 2 delen. Excerpta ex dissertatione ad Lauream in Facultate Theologica Pontificiae Universitatis Gregorianae. Tilburg: Henri Bergmans, 1965, deel 1, pp. 142-167; MACKEN, "La volonté...", 1975; MACKEN, R. "Heinrich von Ghent im Gespräch mit seinen Zeitgenossen über die menschliche Freiheit". Franziskanische Studien 59 (1977), pp. 125-82; MACKEN, "La liberté humaine dans la philosophie d'Henri de Gand", 1978; DECORTE, J. Een avicenniserend augustinisme..., 1983, deel 1, pp. 161-339; DECORTE, J. "Der Einfluß der Willenspsychologie des Walter von Brugge ofm auf die Willenspsychologie und Freiheitslehre des Heinrich von Gent". Franziskanische Studien 65 (1983), pp. 215-40; MACKEN, R. "Selbsverwirklichung in der Anthropologie des Heinrichs von Gent", 1985; MACKEN, R. "L'interpénétration de l'intelligence et de la volonté dans la philosophie d'Henri de Gand". In: WENIN, C. (éd.). L'homme et son univers au moyen âge. Actes du septième congrès international de philosophie médiévale (30 août - 4 septembre 1982). Vol. II. Louvain-la-Neuve: Éditions de 1'Institut Supérieur de Philosophie, 1986, pp. 808-14; SCHÖLLGEN, W. Das Problem der Willensfreiheit bei Heinrich von Gent und Herveus Natalis. Hildsheim: Gerstenberg, 1975; MACKEN, "Selbstverwirklichung in der Anthropologie des Heinrichs von Gent", 1975; MACKEN, R. "Deseo natural y vocación ...", 1980; MACKEN, R. "Will and Intellect in God according to the Philosophy of Henry of Ghent". Franziskanische Studien 71 (1989), pp. 159-67; MACKEN, R. "Der geschaffene Wille als selbstbewegendes geistiges Vermögen in der Philosophie des Heinrich von Gent". MOJSISCH, B., PLUTA, O. (Hrsg.). Historia philosophiae medii aevi. Studien zur Geschichte der Philosophie des Mittelalters. Band II. Amsterdam - Philadelphia: Grüner, 1991, pp. 561-72; TIERNEY, B. "Natural Rights in the Thirteenth Century: A Quaestio of Henry of Ghent". Speculum 67 (1992), pp. 58-68; SORGE, V. Gnoseologia e teologia..., 1988, pp. 24-31; DUMONT, "Time, Contradiction and Freedom of the Will", 1992; KANTOLA, I. Probability and Moral Uncertainty in Late Medieval and Early Modern Times. Helsinki: Luther-Agricola-Society, 1994, pp. 85-94; MACKEN, R. "The Superiority of Active Life to Contemplative Life in Henry of Ghent's Theology". Medioevo 20 (1994), pp. 115-129; MACKEN, R. "The Human Will as Decision-Maker in the Human Person, According to the Philosophy of Henry of Ghent". Mediaevalia. Textos e estudos 7-8 (1995), pp. 427-39; KANTOLA, I. "Henry Ghentiläisen omatuntokäsitys". In: HOLOPAINEN, T. M., HOLOPAINEN, T. J. Sielun liikeitä. Filosofianhistoriallisia kirjoitelmia. Helsinki: Gaudeamus, 1996, pp. 156-166; McEVOY, J. "The Sources and the Significance of Henry of Ghent's Disputed Question, 'Is Friendship a virtue?'. In: VANHAMEL, W. (ed.). Henry of Ghent. Proceedings..., 1996, pp. 121138; PORRO, "Metaphysics and Theology in the Last Quarter of the Thirteenth Century...", 2000, pp. 270-1; OSBORNE Jr., T. M. The Natural Love of God over Self: the Role of Self-Interest in the Thirteenth-Century Ethics. Dissertation submitted as partial fulfillment of the requirements for the degree of Doctor of Philosophy in the Department of Philosophy in the Graduate School of Duke Univesity, 2001, pp. 204-235; CARVALHO, M. A. S. "Para a história da possibilidade e da liberdade. João Duns Escoto, Guilherme de Ockham e Henrique de Gand". CARVALHO, M. A. S. Estudos sobre Álvaro Pais e outros franciscanos (séculos XIII-XIV). Lisboa: Imprensa Nacional - Casa Moeda, 2001, pp. 173-216 [ = Itinerarium 40 (1994), pp. 145-80]; COUNET, J.-M. "Henri de Gand: la prudence dans 
ses rapport aux vertus morales". In: GULDENTOPS, G., STELL, C. (eds.). Henry of Ghent and the Transformation..., 2003, pp. 227-240; FLORES, J. C. "Intellect and Will as Natural Principles". In: GULDENTOPS, G., STEEL, C. (eds.), Henry of Ghent and the Transformation..., 2003, pp. 277-305; EARDLEY, P. S. "The Problem of Moral Weakness, the propositio magistralis, and the Condemnation of 1277". Mediaeval Studies 68 (2006), pp. 161-203; EARDLEY, P. S. "Conceptions of Happiness and Human Destiny in the Late Thirteenth Century". Vivarium 44.2-3 (2006), pp. 276-304; EARDLEY, P. S. "The Foundations of Freedom in Later Medieval Philosophy: Giles of Rome and his Contemporaries". Journal of the History of Philosophy 44.3 (2006), pp. 353-76; KOBUSCH, T. "Willensschwäche und Selbsbestimmung des Willens: Zur Kritik am abendländischen Intellektualismus bei Heinrich von Gent und der franziskanischen Philosophie”. In: HOFFMANN, T. et al. Das Problem der Willensschwäche in der mittelalterlichen Philosophie. Leuven - Paris - Dudley: Peeters, 2006, pp. 249-263; MÜLLER, J. "Willensschwäche im Voluntarismus? Das Beispiel Heinrichs von Gent". Archiv für Geschichte der Philosophie 89 (2007), pp. 1-29; HOFFMANN, T. "Henry of Ghent's Voluntarist Account of Weakness of Will". In: HOFFMANN, T. (ed.) Weakness of will from Plato to the present. Washington D.C.: The Catholic University of America Press, 2008, pp. 115-37; ALLINEY, G. "Introduzione". In: ENRICO DI GAND. Il nodo nel giunco. Le questioni sulla libertà di Enrico di Gand. A cura e con una Introduzione di Guido Alliney. Bari: Edizioni di Pagina, 2009, pp. 7-116; MÜLLER, J. Willensschwäche in Antike und Mittelalter. Eine Problemgeschichte von Sokrates bis Johannes Duns Scotus. Leuven: Leuven University Press, 2009, pp. 569-617; PORRO, P. "La (parziale) rivincita di Marta. Vita ativa e vita contemplativa in Enrico di Gand". In: TROTTMANN, C. (ed.). Vie active et vie contemplative au Moyen Âge et au seuil de la Renaissance. Roma: École Française de Rome, 2009, pp. 155-172; LEONE, M. "Moral Philosophy in Henry of Ghent". In: WILSON, G. (ed.). A companion to Henry of Ghent, 2011, pp. 275-314; MARMURSZTEJN, E. "Loi ancienne, loi nouvelle et normes chrétiennes...", 2011, pp. 509-530; MÜLLER, J. "Einleitung”. In: HEINRICH VON GENT, Quaestionen zur Willens- und Freiheitslehre. Übersetzt von J. Müller. Freiburg: Herder, 2011, pp. 7-65; PORRO, P. "Essere o non essere? Dubbi amletici tra le questioni scolastiche". In: PERFETTI, S. (ed.). Scientia, Fides, Theologia. Studi di filosofia medievale in onore di Gianfranco Fioravanti. Pisa: ETS, 2011, pp. 342-352; NAAB, E. "Si recta ratio, et voluntas recta. Augustinus und die Pariser Verurteilung von 1277'. In: FISCHER, N. (Hrsg.). Die Gnadenlehre als 'salto mortale' der Vernunft? Natur, Freiheit und Gnade in der Spannungsfeld von Augustinus und Kant. Freiburg - München: Karl Alber, 2012, pp. 146-166 (esp. pp. 163-4); PICKAVÉ, M. “Que signifie ‘être libre'? Le cas Henri de Gand”. Médiévales 63 (2012), pp. 91-104; TESKE, R. "Henry of Ghent's Rejection of the Principle: 'Omne Quod Movetur ab Alio Movetur'”. In: TESKE, R. Essays on Henry of Ghent. Milwaukee: Marquette University Press, 2012, pp. 9-40; TESKE, R. "Henry of Ghent on the Freedom of the Will". In: TESKE, R. Essays on Henry of Ghent, 2012, pp. 199-220; PAIVA, G. B. V. de. "Prudência e caridade na ética de Henrique de Gand". Revista do Seminário dos Alunos do PPGLM/UFRJ 4 (2013), pp. 121-138; ALLINEY, G. "La chimera e il girarrosto. Per una storia della libertà". In: TUGNOLI, C. (cur.). Libero arbitrio. Teorie e prassi della libertà. Napoli: Liguori, 2014, pp. 185-231 (esp. pp. 219-29); CORDONIER, V. "Une lecture critique de la théologie d'Aristote: le Quodlibet VI, 10 d'Henri de Gand comme réponse à Gilles de Rome". In: CORDONIER, V., SUAREZ-NANI, T. (éds.). L'aristotélisme exposé, 2014, pp. 83-180; LEONE, M. "Henry of Ghent on Divine Law, Natural Law and Human Law". In: SPEER, A., GULDENTOPS, G. (Hrsg.). Das Gesetzt - the Law - la Loi. Berlin - Boston: De Gruyter, 2014, pp. 383-398; LEONE, M. Filosofia e teologia della vita activa. La sfera dell'agire pratico in Enrico di Gand. Bari: Edizioni di Pagina, 2014; LEONE, M. "Henry of Ghent and the Ethics of Intention". In: d'HOINE, P., Van RIEL, G. Fate, Providence and Moral Responsability in Ancient, Medieval and Early Modern Thought. Studies in Honour of Carlos Steel. Leuven: Leuven University Press, 2014, pp. 571-89; HAMILTON-BLEAKLEY, H. "John of Paris, Henry of Ghent, and the Will as a Rational Appetite". In: JONES, C. (ed.). John of Paris: Beyond Royal and Papal Power. Turnhout: Brepols, 2015, pp. 193-221. Por fim, vale notar que diversos são os estudos sobre Henrique de Gand contidos nos tomos 1, 2, 3.1, 3.2, 4.2 e 6 do monumental LOTTIN, O. Psychologie et morale aux XII et XIII ${ }^{e}$ siècles. 6 tomes. Louvain - Gembloux: Abbaye du Mont César - Duculot, 1942-1960.

Como se pode notar, a bibliografia sobre vontade, liberdade e ética em Henrique de Gand é muito vasta. Dessa maneira, no que se segue não faremos mais do que destacar um elemento central da noção de 'vontade' desenvolvida pelo Doutor Solene - elemento este que encontramos insistentemente repetido em muitos dos trabalhos citados nesta nota -, a saber: a noção de vontade como potência livre, independente do intelecto e superior da alma humana. 
Com essas observações, pretendo somente delimitar o escopo do curto estudo sobre a vontade que realizo aqui: me voltarei unicamente para a relação entre vontade e intelecto, de maneira que a vontade será considerada somente enquanto potência da alma. Dessa discussão, não pretenderei derivar quaisquer consequências éticas (que, de fato, são inumeráveis na obra de Henrique), mas somente desejo arrematar a descrição do homem que iniciei no capítulo anterior. Como veremos, só faz sentido falar em ato da intelecção porque [i] tal ato apresenta à vontade um objeto volível e [ii] a vontade leva o homem a pesquisar (item 3.2). Esses são os dois aspectos da potência volitiva que nos interessarão no restante deste capítulo. Feita essa ressalva, vejamos como se dá, para o gandavense, a relação entre intelecto e vontade enquanto potências da alma humana.

\subsubsection{A relação entre intelecto e vontade}

Dois são os aspectos a serem abrangidos em um estudo da relação entre intelecto e vontade no homem: em primeiro lugar, [i] o problema da distinção entre ambos enquanto potências da alma e, em segundo lugar, [ii] o problema da ordenação causal entre as operações do intelecto e da vontade. Veremos que, no que diz respeito à sua distinção, não vamos muito além da descrição que já havíamos encontrado em trechos anteriores no que dizia respeito às demais potências da alma. Por outro lado, poderemos compreender melhor essa distinção atentando para a superioridade da vontade com respeito ao intelecto, defendida arduamente por Henrique. Quanto ao segundo tema - isto é, a ordenação causal entre as operações dessas potências -, será interessante ver como Henrique de Gand, ao mesmo tempo em que defende a necessidade de uma relação da vontade com respeito ao intelecto, busca manter a liberdade da potência volitiva intacta, principalmente ao caracterizar o intelecto como uma potência fundamentalmente passiva e a vontade, pelo contrário, como totalmente ativa. Dito isto, voltemo-nos para o primeiro desses dois temas.

\subsubsection{A distinção entre intelecto e vontade}

Se bem nos lembramos, o Doutor Solene havia descrito a intelectiva, a sensitiva e a vegetativa como 'intenções ou razões' da alma ${ }^{14} \mathrm{e}$, com isso, nos deixava

\footnotetext{
${ }^{14}$ Cf. cap. 2 , notas 48,81 e 14.
} 
com a certeza de que a distinção entre as partes da alma não é real e, apesar da fluidez de seu vocabulário em certos trechos, parecia defender uma distinção intencional entre elas. Também quanto à distinção entre intelecto e vontade, temos um resultado semelhante. Destarte, assim como a intelectiva, a sensitiva e a vegetativa eram diferentes potências de um mesmo homem (ou seja, possuíam uma unidade substancial), o mesmo ocorre com o intelecto e a vontade enquanto aspectos da potência intelectiva - há uma identidade real entre ambos. O problema, mais uma vez, é saber em que medida ambos são distintos. Se lemos em Quodl. 14, q. 2, que a vontade só se distingue da substância da alma por uma distinção de razão (sola ratione differt $)^{15}$, por outro lado a vontade é apresentada de maneira muito similar às demais potências da alma em Quodl. 3, q. 14: “<...> a vontade é uma potência natural da alma e não é senão a substância da alma, mas a partir de uma determinação natural e de um respeito [respectum] para com o ato de querer o bem enquanto bem - seja simplesmente, seja em aparência [bonum ut bonum, sive simpliciter sive apparens]"16. Portanto, a vontade, tal como qualquer outra potência da alma, não é mais do que a própria substância da alma enquanto diz respeito a outro de determinado modo - no presente caso, enquanto algo outro que é ou aparece como um bem. Ora, essa descrição (principalmente ao destacar o caráter relacional da potência) é bem semelhante à descrição das potências vegetativa, sensitiva e intelectiva que vimos acima, no item 2.3. Sendo assim, parece que, se decidirmos por aceitar a distinção entre estas três potências da alma como uma distinção intencional, então será o caso de estabelecer que, para Henrique, também a distinção entre intelecto e vontade (como partes da potência intelectiva) será intencional. Por outro lado, como dito, em ambos os casos (e, especialmente, no caso da potência volitiva) o vocabulário do Doutor Solene permanece fluído, alternando entre descrever tais potências como rationes ou intentiones.

Isso é igualmente patente em Quodl. 11, q. 6, onde os atos das diversas potências do homem - inclusive, da vontade - são descritas como diversas rationes do homem:

\footnotetext{
${ }^{15}$ Cf. cap. 2, nota 48.

${ }^{16}$ Henrique de Gand, Quodl. 3, q. 14, co. (ed. 1613, f. 112vb): "Similiter in proposito dicendum, quod voluntas est potentia naturalis in anima, et non est nisi substantia animae, sed ex naturali determinatione, et respectu ad actum volendi bonum ut bonum, sive simpliciter, sive apparens $<\ldots$..”. Sobre o termo apparens, cf. cap. 5, nota 107.
} 
"diz-se que o homem todo, que se move pela vontade, que é algo de si [aliquid sui], move por si a si mesmo <...> o homem todo se move segundo o ato de querer pela vontade [secundum actum volendi per voluntatem], segundo o ato de inteligir pelo intelecto [secundum actum intelligendi per intellectum], segundo o ato de sentir pelo sentido [secundum actum sentiendi per sensum] e, igualmente, nos outros movimentos [motibus] seus, os quais ele age por aquilo que é formal nele, enquanto possui as razões [rationes] das diversas potências, às quais não se atribuem os atos como a um agente propriamente falando, mas antes tal como a um meio pelo qual $<_{0}$ homem $>$ age [sicut medio quo agit ${ }^{1,17}$.

Nessa passagem surge algo de novo, a saber, a caracterização das potências da alma como um 'meio pelo qual' (medio quo) se age. Porém, essa fórmula é utilizada unicamente para reiterar um tema que já vimos repetidas vezes, nomeadamente, a unidade do homem. Descrever as potências da alma (aqui, a vontade, o intelecto e o sentido) como meios permite a Henrique de Gand afirmar que aquele que realmente quer, intelige e sente é o homem todo (totus homo) e não alguma de suas potências. Como se vê no texto, essa relação entre o homem e suas potências é expressa pela preposição per, pois ele 'quer pela vontade', 'intelige pelo intelecto' e 'sente pelo sentido'. Nesse ponto, a vontade é simplesmente mais uma potência da alma humana pela qual a alma toda - ou melhor, o homem todo como composto completo - age em suas operações. A vontade é, portanto, um medium para a produção de atos determinados pelo homem. Poderíamos igualmente dizer que a vontade é um instrumentum ${ }^{18}$ que o homem possui para, sem perda de sua unidade substancial, produzir atos determinados - a saber, atos volitivos. Mais uma vez, parece que a distinção a ser feita entre a vontade e as demais potências da alma irá depender de

\footnotetext{
${ }^{17}$ Henrique de Gand, Quodl. 11, q. 6, co. (ed. 1613, f. 200va): "Totus autem homo qui movetur per voluntatem, quae est aliquid sui, dicitur seipsum movere per se. Dicendum, quod re vera quia actus, et operatio omnis ut per se agentis, non sunt nisi suppositi, et hoc sive in creaturis sive in Deo, secundum quod alibi declaravimus, ideo bene verum est, quod totus homo movetur secundum actum volendi per voluntatem, similiter secundum actum intelligendi per intellectum, et secundum actum sentiendi per sensum, et consimiliter in caeteris motibus suis, quos agit per id quod est formale in ipso, inquantum habet rationes diversarum potentiarum quibus non attribuitur actus sicut agenti proprie loquendo, sed potius sicut medio quo agit". Sobre essa passagem, cf. MACKEN, R. "La volonté...”, 1975, p. 27. Vale notar que Macken dá grande destaque, neste seu artigo, também à caracterização, em Quodl. 12, q. 26 das potências da alma e, particularmente, da vontade em termos de 'intrumentos' da alma humana. Com efeito, embora o trecho apresentado por Macken (cf. "La volonté...", 1975, p. 27, nt. 74) seja marcado como uma citação de Anselmo na edição crítica do Quodl. 12 produzida por Jos Decorte, há uma passagem imediatamente anterior na qual o termo 'instrumentum' é utilizado precisamente para caracterizar a voluntas: "Ad actum autem volendi aliquod volibile naturale modo naturali faciliter, adhuc non posset exire voluntas nisi per aliquam dispositionem existentem in ea, cuiusmodi est aliqua aptitudo ad eliciendum actum volendi in instrumento quod est voluntas" (ed. De Wulf-Mansion Centre, vol. 16, p. 145). Enfim, a vontade é um medium, um instrumentum pelo qual (per) o homem, enquanto um todo, executa o ato de querer.

${ }^{18}$ Cf. nota anterior.
} 
uma decisão sobre a distinção entre vegetativa, sensitiva e intelectiva, pois ambos os casos são repetidamente aproximados ${ }^{19}$.

Por esse caminho, entretanto, não vamos muito mais longe do que isso. Há, porém, uma maneira de compreender a distinção entre intelecto e vontade que, sem apelar para a determinação dessa distinção, nos permite, pelo menos, ter uma boa introdução ao problema da relação entre ambos. Essa outra via para a compreensão da distinção consiste em compreender a ordenação das potências intelectiva e volitiva, não ainda de um ponto de vista causal, mas a partir da hierarquia das potências da alma. Com efeito, a ordem de superioridade entre intelecto e vontade foi muito bem estudada pelo Doutor Solene ainda no seu primeiro Quodlibet - mais precisamente, em Quodl. 1, q. 14 -, para o qual nos voltaremos agora ${ }^{20}$.

\subsubsection{A hierarquia entre intelecto e vontade}

Na resposta a essa questão, parte-se de um princípio que já foi alegado acima, a saber, que, sendo as potências da alma ocultas para nós, devemos conhecê-las $a$

\footnotetext{
${ }^{19}$ Note-se, porém, que a mera distinção entre intelecto e vontade como potências da alma não esgota a complexidade da divisão da alma humana vislumbrada por Henrique de Gand, uma vez que, para além das 'potências' (potentiae), seria necessário igualmente atentar para as várias 'forças' (vires) que ocorrem nessas potências. Para distinguir potentia e vis mais precisamente, Henrique de Gand nos diz que as potência da alma distinguem-se de acordo com sues diversos objetos, enquanto que as vires da alma são distinguidas de acordo com os diversos modos pelos quais a alma se porta com respeito a seus diversos objetos. Por isso, é possível que haja mais de uma vis correspondente a uma única potência - a saber, quando a alma pode, com respeito a um mesmo objeto, portar-se de diferentes modos. A distinção entre esses dois termos pode ser lida em Suma, art. 58, q. 2, ad 3 (ed. 1642-6, p. 1006a, n. 37): "Ad cuius intellectum sciendum est, quod alia est distinctio in anima humana per potentias, alia autem per vires. Per potentias enim fit distinctio secundum rationes formales obiectorum diversas, secundum quas solummodo in anima, ut propria est homini, est distinctio penes intellectum, et voluntatem, ut per duas diversas potentias secundum rationes obiectorum, quae sunt verum et bonum. Per vires autem fit distinctio secundum diversos modos se habendi ad obiecta, secundum quod voluntas humana distinguitur per concupiscibile, et irascibile, sicut declaravimus in quadam quaestione de Quodlibet alias, et secundum quod intellectus distinguitur per speculativum, et practicum. Speculativus enim dicitur, ut respicit verum absolute, practicus vero, ut respicit verum, sub ratione boni operabilis, et extensione ad operari illud. Similiter distinctione famosa distinguintur speculativus in agentem, et passibilem". Cf. MARRONE, Truth and Scientific Knowledge..., 1985, p. 71, nt. 98; WILLIAMS, S. M. "Augustine, Thomas Aquinas, Henry of Ghent, and John Duns Scotus: on the Theology of the Father's Intellectual Generation of the Word". Recherches de théologie et philosophie médiévales 77.1 (2010), pp. 35-81 (esp. pp. 49-50, nt. 28). No que se segue, algumas dessas vires serão abordadas, outras não, uma vez que nosso presente estudo acerca do homem e sua alma estabelece as bases para um estudo estritamente voltado para a doutrina da intelecção de Henrique de Gand.

${ }^{20}$ Sobre essa questão, cf. MACKEN, "La volonté...”, 1975, pp. 5-15; MACKEN, "Heinrich von Gent im Gespräch...", 1977, pp. 128-9; KANTOLA, Probability and Moral Uncertainty..., 1994, pp. 85-88; WILSON, "Henry of Ghent's Quodlibet I...", 1999, p. 171.
} 
posteriori, isto é, pelos seus efeitos e objetos ${ }^{21}$. É, portanto, somente dessa maneira a posteriori - que poderemos, também, conhecer a ordenação das potências da alma e, em particular, dessas duas potências que são o intelecto e a vontade. Destarte, Henrique propõe que tentemos responder à pergunta "se a vontade é uma potência superior ao intelecto ou o contrário [utrum voluntas sit potentia superior intellectu vel e converso]" 22 pela comparação dos hábitos (habitus), atos (actus) e objetos (obiectum) de cada uma dessas duas potências. Aquela cujos três forem superiores, será igualmente a potência superior na alma. E a resposta à questão não poderia ser mais direta:

\begin{abstract}
“Agora, porém, assim é: o hábito, o ato e o objeto da vontade superam [praeminent $]$ completamente [omnino] o ato, o hábito e o objeto do intelecto. Por isso, cumpre dizer absolutamente que a vontade supera [praeminet] o intelecto e é uma potência mais alta do que ele"23.
\end{abstract}

O mais importante nessa comparação entre intelecto e vontade não parece serem os respectivos hábitos dessas potências, pois Henrique não faz mais do que nomeá-los - dizendo, a saber, que o hábito da vontade é a caridade (caritas) e o hábito do intelecto é a sabedoria (sapientia) -, para em seguida rapidamente notar que aquele da vontade supera aquele do intelecto. Além disso, todas essas suas afirmações tomam por base unicamente autoridades da Bíblia, sem qualquer referência a uma discussão racional associada a elas ${ }^{24}$. Contrastantemente, as comparações entre os atos e os objetos do intelecto e da vontade são cuidadosamente desenvolvidas.

Começando pelo estudo dos seus atos, diz-se sucintamente que o ato da vontade, que é 'querer' ou 'amar', supera aquele do intelecto, que é 'ter ciência' ou 'conhecer' ('supereminet actus voluntatis qui est velle sive diligere, actui intellectui qui est scire sive cognoscere" ${ }^{, 25}$ ), sendo isso mostrado por uma dupla comparação desses dois atos, nomeadamente: [i] uma comparação de um com outro e [ii] uma

\footnotetext{
${ }^{21}$ Cf. cap. 2, notas 19,30 e 49.

${ }^{22}$ Henrique de Gand, Quodl. 1, q. 14 (ed. De Wulf-Mansion Centre, vol. 5, p. 83). O mesmo tema volta a ser abordado, mais tardiamente e com resultados semelhantes, em Suma, art. 60, q. 4, ad 1-2 (ed. 1642-6, pp. 1099-111).

${ }^{23}$ Henrique de Gand, Quodl. 1, q. 14, co. (ed. De Wulf-Mansion Centre, vol. 5, p. 84): "Nunc autem ita est quod omnino habitus, actus et obiectum voluntatis praeminent actui, habitui et obiecto intellectus. Idcirco absolute dicendum, quod voluntas praeminet intellectu et est altior potentia illo".

${ }^{24}$ Henrique de Gand, Quodl. 1, q. 14, co. (ed. De Wulf-Mansion Centre, vol. 5, pp. 84-5).

${ }^{25}$ Henrique de Gand, Quodl. 1, q. 14, co. (ed. De Wulf-Mansion Centre, vol. 5, p. 85).
} 
comparação de ambos enquanto aperfeiçoam seu sujeito pelo objeto ("ex comparatione utriusque ad suum subiectum perficiendum per obietum"26).

A primeira comparação não vai muito além de afirmar a superioridade do ato da vontade com respeito àquele do intelecto simplesmente pela afirmação de um, por assim dizer, maior âmbito do ato volitivo quando comparado ao intelectivo. De fato, “a vontade é o motor universal e primeiro em todo o reino da alma, movente superior e primeiro de todos os outros para seu fim $<\ldots>$. Donde a vontade imperar à razão que considere, raciocine e delibere [imperat ut consideret, ratiocinetur, et consilietur] quando e sobre o que quer, e igualmente faz com que cesse", enquanto que o intelecto não pode, de maneira alguma, imperar à vontade ou movê-la ${ }^{27}$. Tão lacônica quanto seja essa primeira comparação, há aqui uma importante informação a respeito da concepção de homem defendida por Henrique de Gand, a saber, o homem se move, principalmente, pela vontade. E, o que é igualmente importante, esta observação é válida com respeito às mais diversas ações humanas, sejam elas especulativas (consideret, ratiocinetur) ou éticas (consilietur). Com efeito, em qualquer um desses campos, a ação é imperada pela vontade, de maneira que, se o intelecto raciocina (isto é, produz silogismos) especulativos ou éticos, isso ocorre unicamente porque a vontade impera que ele o faça. Ora, se a vontade impera a ação de uma potência tão alta quanto o intelecto, está claro que ela igualmente impera as ações das potências inferiores a este último, de forma que a potência volitiva surge como 'o primeiro em todo reino da alma'. A base para esse império da vontade é formulada, igualmente, com poucas palavras: ela impera que o intelecto raciocine ou delibere porque ela $\mathrm{o}$ quer (vult); da mesma maneira, se o quiser, ela o fará deixar de raciocinar e deliberar; e, para além disso, o intelecto não somente produzirá ou não essas ações sob o império da vontade, mas ele também o fará acerca daqueles objetos que a vontade

\footnotetext{
${ }^{26}$ Henrique de Gand, Quodl. 1, q. 14, co. (ed. De Wulf-Mansion Centre, vol. 5, p. 85).

${ }^{27}$ Henrique de Gand, Quodl. 1, q. 14, co. (ed. De Wulf-Mansion Centre, vol. 5, pp. 85-6): "Voluntas autem est universalis et primus motor in toto regno animae, et superior, et primus movens omnia alia ad finem suum $<\ldots>$. Unde voluntas rationi imperat ut consideret, ratiocinetur, et consilietur quando vult et de quibus, et similiter facit ut desistat. Non sic ullo modo imperat aut movet intellectus voluntatem <... ”. Cf. tb. p. 89: “Absolute ergo dicendum quod voluntas superior vis est in toto regno animae, et ita in ipso intellectu”. Notemos aqui a utilização do vocabulário típico daquilo que Gilbert Ryle denominou de 'mito parapolítico', isto é, o uso de vocabulário próprio da teoria política para explicitar as relações entre as diversas partes da alma (como no uso da expressão 'in toto regno animae' no trecho citado nesta mesma nota, mas também na apresentação, que veremos mais adiante, da oposição 'intelecto-vontade' como aquela que há entre 'servo-senhor' e o uso do verbo 'imperare' como caracterização da ação da vontade) - cf. RYLE, G. The Concept of Mind. London: Penguin, $2000^{4}$ [1949], pp. 24-25.
} 
quiser. Enfim, pela simples comparação entre os atos da vontade e do intelecto, está claro que a vontade é superior ao intelecto, pois o seu ato determina os atos deste último.

$\mathrm{Na}$ segunda comparação, não são levados em consideração somente os próprios atos dessas potências, mas principalmente a maneira pela qual ambas se aperfeiçoam pelo objeto através de seus respectivos atos:

\begin{abstract}
"<...> pela ação da vontade, a vontade é aperfeiçoada pela própria coisa amada enquanto possui ser em si [ipsa re dilecta ut in se habet esse], pois a vontade se inclina pela sua ação à própria coisa. Pela ação do intelecto, porém, o próprio intelecto é aperfeiçoado pela coisa inteligida enquanto possui ser no intelecto [ipsa re intellecta ut habet esse in intellectu], pois o intelecto traz para si pela sua ação a própria coisa inteligida [intellectus actione sua trahit in se ipsam rem intellectam]. A vontade, porém, se transfere pela sua ação para o próprio querido, devido a si, para dele fruir [voluntas autem actione sua transfert se in ipsum volitum, propter se, ut eo fruatur]. E, por isso, como diz Dionísio no capítulo 4 de Sobre os nomes divinos, o intelecto se assimila pela sua ação à coisa inteligida, enquanto a vontade se transforma no próprio querido [intellectus actione sua assimilat se rei intellectae, voluntas vero transformat se in ipsum volitum $]^{, 28}$.
\end{abstract}

Nessa passagem, Henrique opõe intelecto e vontade por meio de dois pares descritivos de suas respectivas ações: trahit x transfert, assimilat se $\mathrm{x}$ transformat se. Esses dois vêm associados a um duplo ser do objeto, que corresponde ao ser no qual ele pode aperfeiçoar cada uma dessas potências da alma humana: ut habet esse in intellectu x ut in se habet esse. Munido desse vocabulário, é interessante notar como intelecto e vontade se distinguem aqui como potências com maneiras quase que opostas de se aperfeiçoarem por uma atualização pelos seus respectivos objetos. Partindo desses últimos, notamos que aqui os objetos da vontade e do intelecto não são distinguidos por si mesmos, mas de acordo com o ser que eles devem possuir para, de fato, serem objetos de cada uma dessas potências. Assim, a coisa inteligida é objeto do intelecto não em seu próprio ser (isto é, enquanto ela é uma coisa em si mesma), mas de acordo com o ser que ela possui no próprio intelecto que a conhece. Por isso, diz-se que o intelecto 'traz para si' a coisa inteligida - de fato, ela não é

\footnotetext{
${ }^{28}$ Henrique de Gand, Quodl. 1, q. 14, co. (ed. De Wulf-Mansion Centre, vol. 5, p. 86): "Ex secunda comparatione similiter patet intentum, quoniam actione voluntatis perficitur voluntas ipsa re dilecta ut in se habet esse, quia voluntas actione sua inclinatur in ipsam rem, actione autem intellectus perficitur ipse intellectus ipsa re intellecta ut habet esse in intellectu, quia intellectus actione sua trahit in se ipsam rem intellectam, voluntas autem actione sua transfert se in ipsum volitum propter se ut eo fruatur, et per hoc, ut dicit Dionysius $4^{\circ}$ capitulo De divinis nominibus, intellectus actione sua assimilat se rei intellectae, voluntas vero transformat se in ipsum volitum". Cf. tb. Suma, art. 49, q. 6, co. (ed. De Wulf-Mansion Centre, vol. 30, pp. 136-7).
} 
inteligida enquanto é fora da alma, mas unicamente enquanto é no intelecto. Assim, embora o intelecto 'se assimile à coisa inteligida', ele a assimila a si somente enquanto ela já possui um ser no próprio intelecto. Sendo assim, o intelecto não sai de si mesmo ao conhecer, pois seu conhecimento é sempre de algo que é nele próprio. A vontade, por outro lado, quer e ama uma coisa que é em si mesma, fora da própria vontade e fora da alma como um todo. Assim, a vontade não 'traz para si' aquilo que ela ama, mas faz exatamente o oposto, ou seja, se transfere para aquela coisa querida e amada, 'transformando-se' nesta última ${ }^{29}$. Dito isso, o Doutor Solene conclui que o transformar-se em algo amado e querido enquanto é em si mesmo é muito mais perfeito e elevado do que se assimilar a isso enquanto é, não em si, mas no intelecto. Assim, está claro que a vontade é superior ao intelecto também por esse segundo aspecto da comparação entre os seus respectivos atos ${ }^{30}$.

Essa distinção entre os modos de ser dos respectivos objetos da vontade e do intelecto é esclarecida no passo seguinte e último do texto, quando ocorre a comparação, precisamente, entre os objetos das duas potências. Para Henrique, aquele objeto do intelecto, que possui ser no próprio intelecto, é o 'verdadeiro' (verum), enquanto que o objeto da vontade, que possui o ser em si, é o 'bem' (bonum). A distinção entre os dois se torna clara quando adicionamos a essa consideração a noção de 'fim' (finis), pois o 'verdadeiro', sendo somente no próprio intelecto, não é senão o fim unicamente do intelecto, de maneira que necessariamente deve estar ordenado a um outro fim para além dele mesmo. Já o 'bem', sendo em si mesmo, é um fim simplesmente e, melhor dizendo, um fim último, não sendo ordenado a nenhum outro que não ele próprio. Ou seja, o objeto do intelecto é um fim parcial, ordenado ao fim da vontade enquanto este é um fim último propriamente. Assim, não somente com respeito a seus hábitos e atos a vontade é superior ao intelecto, mas também pelos seus objetos, tomados enquanto suas respectivas finalidades, uma vez que o objeto da vontade (bem) se confunde com o fim último do homem, enquanto que o objeto do

\footnotetext{
${ }^{29}$ Começa a ser delineado aqui o elemento fundamental da distinção entre intelecto e vontade: o caráter receptivo daquele (que só pode inteligir por receber em si o objeto) e o caráter ativo desta (que se estende ao objeto). Por outro lado, começa a ficar igualmente claro que esse caráter fundamentalmente receptivo - e, portanto, passivo do intelecto - exige uma certa ação, pela qual esse objeto assimilado seja 'trazido para si'. Por ora, será importante para nós essa distinção basilar entre passividade do intelecto e atividade da vontade. Ao fim desta parte 1, começará a se tornar patente o porquê dessa insuficiência da passividade do intelecto e da consequente exigência de uma atividade intelectual.

${ }^{30}$ Cf. Henrique de Gand, Quodl. 1, q. 14, co. (ed. De Wulf-Mansion Centre, vol. 5, pp. 86-88).
} 
intelecto (verdadeiro) não é senão um seu fim relativo (ad aliud $)^{31}$. Aquilo que o intelecto conhece como algo interno a si, isto é, como verdadeiro, a vontade quer como algo fora da alma, ou seja, como algo bom em si mesmo e, portanto, como um fim em si mesmo, para além do intelecto e da própria vontade ${ }^{32}$. Essa descrição da vontade como tendência ao bem/fim será de grande importância mais adiante para a caracterização do apetite volitivo.

Por ora, temos já estabelecido que a vontade é uma potência superior ao intelecto na alma humana, pois além de seu hábito ser superior àquele deste último, também pelo ato dela o homem se transfere à própria coisa querida e nela se transforma e, o que é mais significativo, por ela o homem se dirige a seu fim último. Entretanto, ainda que por esses argumentos se mostre claramente a superioridade da vontade, eles não deixam de sugerir alguma necessária relação da vontade para com o intelecto. Por exemplo, mesmo que a vontade seja superior por nos transformar no bem que é nosso fim último, não deixa de ser necessário nos assimilarmos antes ao verdadeiro, que é o fim próprio do intelecto, ordenado àquele fim último. Em outras palavras, ainda que o bem querido seja nosso fim último, o verdadeiro inteligido parece ser um passo necessário em direção a ele. Assim, ainda que em uma ordenação hierárquica das potências da alma a vontade surja como anterior e superior ao intelecto, este último parece antecedê-la de alguma maneira, de sorte que antes de nos transferirmos à coisa em si mesma, nos seja necessário assimilarmo-nos a ela enquanto é no intelecto. Destarte, parecem estar em jogo aqui duas ordenações: de um ponto de vista (na hierarquia das potências da alma), a vontade é anterior e superior, enquanto que sob outro ponto de vista o intelecto a antecede:

\begin{abstract}
“ $<\ldots>$ há o dirigente por autoridade, como o senhor $<$ dirige $>$ o servo - aquele é superior, assim a vontade dirige o intelecto; ou à maneira de serviço [ministerialiter], tal como o servo <dirige> o senhor, levando adiante [praeferendo] uma lanterna de noite, tal que o senhor não tropece - este dirigente é inferior e assim o intelecto dirige a vontade. Donde, a vontade, quando quiser, pode fazê-lo deixar de dirigir e inteligir, tal como o senhor ao servo",33.
\end{abstract}

\footnotetext{
${ }^{31}$ Henrique de Gand, Quodl. 1, q. 14, co. (ed. De Wulf-Mansion Centre, vol. 5, pp. 88-89).

${ }^{32}$ Cf. a citação da nota 28 , acima.

${ }^{33}$ Henrique de Gand, Quodl. 1, q. 14, co. (ed. De Wulf-Mansion Centre, vol. 5, p. 90): “< $<>$ dicendum quod est dirigens auctoritate, sicut dominus servum: ille est superior: sic voluntas dirigit intellectum; vel ministerialiter sicut servus dominum, praeferendo lucernam de nocte ne dominus offendat: tale dirigens est inferius et sic intellectus dirigit voluntatem, unde a dirigendo et intelligendo potest ipsum voluntas retrahere quando vult, sicut dominus servum".
} 
De fato, duas ordens surgem aqui: uma de autoridade, outra de serviço. Pela primeira, a vontade antecede o intelecto, enquanto que pela segunda este antecede aquela. Porém, há uma manifesta diferença entre as ordens, pois quando o intelecto dirige a vontade ele não o faz senão porque esta assim o quis. Ou seja, essa segunda ordem na qual o intelecto antecede a vontade só tem lugar, porque a vontade se dispõe a seguir aquilo que o intelecto lhe mostra (tal como o senhor se dispõe a seguir o servo que lhe mostra o caminho) e, mais importante, o intelecto só lhe mostra aquilo que a vontade quis que ele lhe mostrasse (como o senhor pede que o servo ilumine o caminho que ele, senhor, deseja percorrer). Enfim, o intelecto só antecede a vontade quando esta determina que assim aconteça. Por outro lado, independentemente de qualquer volição, a vontade é superior e antecede o intelecto na hierarquia das potências da alma. Portanto, podemos dizer que, pela ordem da natureza humana, a vontade dirige o intelecto, porém faz parte de sua capacidade de imperar as ações das potências inferiores a si que ela dirija o intelecto para mostrar a ela própria um caminho a ser seguido.

Com isso, acredito, fica clara a distinção que há entre intelecto e vontade enquanto potências da alma, pois, se a negação de uma distinção real entre ambos nos deixa ainda sem uma determinação clara acerca do tipo de distinção com que estamos lidando neste caso (se ela seria intencional ou de razão), está determinado que há uma ordenação hierárquica entre eles, segundo a qual a vontade é superior ao intelecto, dirigindo-o. Em contraposição, a própria vontade, querendo-o, pode estabelecer uma ordenação pela qual o intelecto a anteceda. Essa antecedência do intelecto com respeito à vontade certamente não será mais hierárquica, mas meramente causal. Dessa maneira, estamos agora em posição de nos voltarmos para a complexa relação causal que, segundo Henrique de Gand, ocorre entre intelecto e vontade.

\subsubsection{A ordem causal entre intelecto e vontade}

Mais acima, vimos como as operações do intelecto se distinguem em duas, a saber, a inteligência dos conceitos simples e a composição e divisão, que culmina no raciocínio silogístico. Pois bem, assim como há essas duas operações do intelecto, também a vontade poderá se voltar para ele de acordo com essas duas operações. Dito de outra maneira, o intelecto pode propor à vontade unicamente objetos simples ou proposições e, principalmente, conclusões de silogismos. Um bom texto para 
iniciarmos nossa leitura do tema parece ser Suma, art. 45, onde o Doutor Solene se volta para o estudo da vontade divina, novamente estabelecendo uma hierarquia de seres (dessa vez, de entes volitivos) e, sendo assim, necessariamente passando por um discurso sobre a vontade humana.

Quando formulamos aquela hierarquia dos seres viventes, vimos que o elemento a ser observado para determinar se um ser em particular vive ou não é um movimento "por ele mesmo, a partir dele mesmo e nele mesmo" 34 . Quando chegamos no homem, como acabamos de lembrar algumas páginas acima, esse movimento ocorre racional e livremente. Disso se concluiu que o homem possui intelecto e vontade. Porém, essa doutrina da vida e, em particular, dessa vida tal como o homem dela participa (racional e livremente) possui uma dificuldade que não abordamos até agora - de fato, aqui surge uma das dificuldades metafísicas e, principalmente, físicas mais fundamentais na filosofia de Henrique de Gand. Em poucas palavras, este último se vê na necessidade de negar, em sua descrição dessa vida livre do homem, um princípio basilar da ciência escolástica, a saber: 'tudo que se move é movido por outro' ('omne quod movetur ab alio movetur'). O quão significativa é a recusa desse princípio para o Doutor Solene foi notado por Roland Teske, em um artigo onde ele propõe um estudo das principais questões quodlibetais em que se desenvolve essa discussão ${ }^{35}$. Sem pretender aqui seguir esse percurso pelo qual Henrique adentra uma das grandes controvérsias (a um só tempo, metafísica, física e ética) de fins do século XIII, me contento em notar como essa afirmação da possibilidade de um automovimento é fundamental para a caracterização da vontade fornecida por Henrique de Gand em Suma, art. $45^{36}$.

Uma grande parte do caminho seguido nesse trecho da Suma diz respeito ao estabelecimento da já referida hierarquia da vontade. Porém, extrapolando o limite dos entes volitivos, essa hierarquia da vontade (que incluirá homens, anjos e Deus) surge como uma etapa final de uma hierarquia mais ampla de seres que possuem 'apetite' (appetitus). Como vimos enquanto discutíamos a hierarquia da vida, todos os seres que não Deus possuem uma perfeição in fieri, pois ainda não a atingiram e, de fato, jamais a atingirão no mesmo sentido em que Deus a possui - isto é, sendo sua

\footnotetext{
${ }^{34}$ Cf. cap. 2, nota 12 .

${ }^{35} \mathrm{O}$ já citado TESKE, “Henry of Ghent's Rejection of the Principle...”, 2012.

${ }^{36}$ Esse texto é muito detalhadamente estudado em GELISSEN, Natuur en genade..., 1965, deel 1, pp. 142-161; e TESKE, "Henry of Ghent on the Freedom of Human Will”, 2012.
} 
própria perfeição sem qualquer participação. As criaturas, de fato, só são perfeitas por participação e, portanto, estão em uma continua busca por perfeição - tecnicamente, isso era expresso pela distinção entre 'operação primeira' ('ato primeiro') e 'operação segunda' ('ato segundo') das criaturas. Pois bem, nesse ponto em que estamos, Henrique de Gand reintroduz a noção de bem (bonum) precisamente para caracterizar essa perfeição própria de cada criatura - perfeição esta que pode ser entendida também como o fim próprio de cada criatura. Acabamos de ler que a vontade é superior ao intelecto, entre outras coisas, por se inclinar ao bem que é um fim. Podemos generalizar essa afirmação para todos os seres e dizer que o apetite de cada um é essa inclinação para o bem. O que diferencia os seres, mais uma vez, é que cada um tende ao bem de acordo com sua natureza - da mesma maneira, o bem a que todos se inclinam é um só, porém a perfeição de cada um (isto é, a maneira como cada natureza participa desse bem último) é distinta, pois "todos os seres possuem o ter apetite [appetere], mas de diversos modos segundo seu grau de ser e de sua natureza $<\ldots>$ [omnia entia habent appetere, sed diversimode secundum gradum esse et naturae suae $]^{\prime 37}$ - isto é, de acordo com seu lugar na ordem do universo. Daí que se possa fazer uma hierarquia do apetite que, ao fim, conterá uma hierarquia da vontade:

\begin{abstract}
"Mas, aquele ente que possui perfeição simplesmente em sua natureza e o ser tal como o bem de si mesmo, que consiste em sua perfeição, é o bem perfeito, de acordo com o que foi determinado acima. Assim, ele tem apetite [appetit] enquanto aquietado em seu bem - e, desse modo, somente a Deus convém o ter apetite. Porém, o apetite, quando é sem conhecimento, é dito puramente 'natural', como 'a matéria tem apetite pela forma'. E, quando é com conhecimento sensitivo, é chamado 'apetite animal'. E quando é com conhecimento intelectual é dito "vontade",38.
\end{abstract}

\footnotetext{
${ }^{37}$ Henrique de Gand, Suma, art. 45, q. 1, co. (ed. De Wulf-Mansion Centre, vol. 29, p. 102). Essa explicação do termo 'apetite' é obtida a partir de trechos presentes em Suma, art. 45, q. 1, co. (ed. De Wulf-Mansion Centre, vol. 29, p.p 101-103). O vocabulário da 'inclinação', porém, provém de uma passagem de Suma, art. 45, q. 3, co. (ed. De Wulf-Mansion Centre, vol. 29, p. 115), citada abaixo na nota 45 (cf. tb. nota 28 , acima). Se me for permitida uma observação à parte, parece-me curioso que os dois autores que buscaram fazer uma leitura mais atenta de Suma, art. 45 (cf. nota anterior), tomaram o termo 'apetite' como dado, sem enxergarem maior necessidade de defini-lo ou, ao menos, esclarecê-lo.

${ }^{38}$ Henrique de Gand, Suma, art. 45, q. 2, co. (ed. De Wulf-Mansion Centre, vol. 29, p. 103): "Illud vero ens quod habet perfectionem simpliciter in natura sua, et esse sicut bonum ipsius, quod consistit in eius perfectione, est bonum perfectum secundum supra determinata. Sic appetit illud, ut perfecte in suo bono quietatum, et hoc modo soli Deo convenit appetere. Appetitus autem, cum est absque cognitione, tunc dicitur pure naturalis, sicut materia appetit formam. Cum vero est cum cognitiva sensitiva, tunc vocatur appetitus animalis. Quando vero est cum cognitione intellectuali, tunc dicitur voluntas". Essa temática da hierarquia dos volitivos como etapa de uma hierarquia, mais ampla, dos seres que movem a si mesmos (se ipsum movere) é reiterada por Henrique de Gand em Quodl. 9, q. 5, co. (ed. De WulfMansion Centre, vol. 13, pp. 100): "Illa autem sex quae dicto modo se habent per ordinem secundum rationem movendi, sunt ista: primum est voluntas divina in volendo; secundum est voluntas creata in volendo, de qua est quaestio, et propter quam ad maiorem declarationem eius de aliis sermonem
} 
Como se vê, o apetite é a inclinação de cada ente à sua perfeição - à melhor participação possível para ele no bem, isto é, no seu fim último. Atingindo uma tal participação, ele se aquieta. Porém, essa aquietação não é o que nos interessa. Pelo contrário, a ação mais complexa da vontade (aquela que importa para nós) se dá precisamente no espaço desse 'fazer-se' (fieri) da perfeição humana. Estabelecida, portanto, essa noção basilar de 'apetite' como inclinação para a perfeição tomada como participação no bem de cada criatura, vejamos agora como isso se dá precisamente naquelas criaturas racionais e intelectuais, mais elevadas na hierarquia dos seres.

Assim, deixando de lado os inanimados, as plantas e os brutos (que, como sabemos, só se movem ao serem movidos por outros) ${ }^{39}$, concentremo-nos nesses seres racionais e intelectuais, que já reconhecemos serem livres desde nosso estudo da vida (item 2.2., acima). De fato, já encontramos esse vocabulário da 'liberdade' naquela hierarquia dos seres viventes à qual retornamos a todo momento. Nela, vimos que livres são somente os intelectuais e racionais, ordenados, por sua vez, em uma hierarquia própria dos entes intelectuais, que avança desde o homem no nível mais baixo, até Deus, passando pelos anjos ou substâncias separadas. Embora já saibamos que esses seres são livres e, em diferentes graus, determinados por si mesmos, essa relação entre intelectualidade, racionalidade e liberdade se torna mais clara em Suma, art. 45, quando Henrique afirma que:

"Mas, os cognitivos racionais e intelectuais, sendo formas totalmente abstraídas,
pela sua essência, da matéria, recebem formas totalmente abstraídas da matéria e
das condições materiais - e, assim, puramente sob a razão do universal. Pelo
que, nem os cognitivos nem os apetitivos são em si determinados, em sua obra
[in suo opere], à razão de algum particular. Donde, um baú existente na mente
[existens in mente] do artífice é absoluto, universal e abstraído da matéria e de
todas as condições particulares - não estando [non se habens], quanto é da
natureza de sua essência, mais para o ser do que para o não ser, nem para uma
figura triangular ou redonda ou alguma outra. Cabe ao artífice o juízo da razão

inducimus; tertium est intellectus creatus in intelligendo; quartum est grave aut leve in movendo se ipsum, de quo procedit secunda obiectio; quintum est animal in movendo se ipsum motu progressivo; sextum est generans in movendo aliud extra se separatum ad alicuius generationem" - essa ordenação é elaborada por algumas páginas em seguida (ed. De Wulf-Mansion Centre, vol. 13, pp. 100-138), que se constituem como um verdadeiro 'tratado de auto-movimento', como diz Teske ("Henry of Ghent's Rejection of the Principle...”. 2012, pp. 14-19), onde o movimento dos animais é finamente detalhado e classificado no decorrer de diversas páginas.

${ }^{39}$ Henrique de Gand, Suma, art. 45, q. 3, co. (ed. De Wulf-Mansion Centre, vol. 29, pp. 111-114). 
sobre fazer ou não fazer [iudicium rationis de faciendo vel non faciendo], sobre fazer assim ou de outra maneira - e, similarmente, a liberdade do apetite sobre escolher fazer ou não fazer [libertas appetitus de eligendo facere vel non facere], ou fazer assim ou de outro modo. E, quanto a isso, o apetite racional sempre segue a apreensão da razão [appetitus rationalis semper sequitur apprehensionem rationis], a liberdade do apetite depende do modo de conhecimento e o apetite segue o conhecimento. Mas isso é verdadeiro sobre o apetite indeterminado, que é do bem simplesmente [boni simpliciter], e <sobre > o conhecimento indeterminado, que é do bem em universal enquanto é bem [in universale secundum quod bonum]" ${ }^{40}$.

Nessa passagem, a indeterminação do conhecimento intelectual é diretamente relacionada à indeterminação do apetite. Para ser mais preciso, essa indeterminação é aquela do universal com respeito ao particular material - esse universal é igualmente dito 'abstraído da matéria' ou das 'condições materiais'. Como veremos na segunda parte do presente trabalho, essa distinção entre 'abstraído da matéria' e 'abstraído de condições materiais' é necessária para excluir desse discurso sobre a vontade tanto as coisas particulares fora da alma como o conhecimento sensível acerca delas (que, ainda que não conheça essas coisas na própria matéria delas, as conhece sob condições materiais). Ou seja, estamos aqui em um terreno exclusivamente intelectual e, portanto, universal - a indeterminação universal da intelecção possibilita uma indeterminação do apetite com respeito ao inteligido.

Quando avançamos um pouco mais na passagem e nos deparamos com o exemplo do artífice, começamos a penetrar em um terreno propriamente humano. Não que a referência a um 'artífice' seja necessariamente uma referência a um 'homem' (muitas vezes o 'artífice' é uma metáfora para o Deus criador, que possui ideias como arte divina $)^{41}$. O que nos coloca definitivamente aqui em presença de um artífice

\footnotetext{
${ }^{40}$ Henrique de Gand, Suma, art. 45, q. 3, co. (ed. De Wulf-Mansion Centre, vol. 29, p. 114): "Cognitiva vero rationalia et intellectualia, quia sunt formae abstractae omnino per essentiam suam a materia, ideo recipiunt formas omnino abstractas a materia et conditionibus materiae, et sic pure sub ratione universalis. Propter quod nec cognitiva nec appetitiva in ipsis determinatur in suo opere ad rationem alicuius particularis. Unde arca existens in mente artificis est absoluta et universalis, et abstracta a materia et omnibus conditionibus particularibus, non se habens, quantum est ex natura essentiae suae, plus ad esse quam ad non esse, nec ad figuram triangularem vel rotundam vel aliquam aliam. Remanet artifici iudicium rationis de faciendo vel non faciendo, et de sic vel aliter faciendo, et similiter libertas appetitus de eligendo facere vel non facere, vel sic facere vel alio modo. Et quoad hoc appetitus rationalis semper sequitur apprehensionem rationis, et dependet libertas appetitus ex modo cognitionis, et appetitus sequitur omnino cognitionem. Sed hoc verum est de appetitu indeterminato, qui est boni simpliciter, et cognitione indeterminata, quae est boni in universali secundum quod bonum". Sobre a indiferença característica da essência, cf. cap. 2, nota 95.

${ }^{41}$ Vale notar que o termo 'artífice', para Henrique de Gand, tem um significado amplo, pois ele diz respeito àquele que 'dirige' e 'regula' a obra produzida, seja ele o mesmo que faz o trabalho manual seja o trabalho manual feito por outrem. Em outras palavras, o fundamental em um 'artífice' não é que ele próprio trabalhe manualmente, mas sim que ele seja quem dá as 'regras' e quem 'dirige' este
} 
humano é a referência à ratio judicativa que, como vimos há pouco, é característica do intelecto inferior do homem. Esse artífice possui em sua mente o baú absoluto e indeterminado, de maneira que sua razão e seu apetite quanto a esse baú são, igualmente, absolutos e indeterminados. Nesse ponto, Henrique introduz a noção de 'fazer' (facere), fundamental em uma reflexão sobre a alma tomada como vontade, isto é, como princípio de 'obras' (opera). O interessante aqui é atentar para as diferentes relações entre, por um lado, a razão e o apetite e, por outro, o fazer. Retomando o trecho pertinente: "Cabe ao artífice $<\mathrm{i}>$ o juízo da razão sobre fazer ou não fazer, sobre fazer assim ou de outra maneira - e, similarmente, <ii > a liberdade do apetite sobre escolher fazer ou não fazer, ou fazer assim ou de outro modo". A razão fornece um juízo (iudicium) sobre o fazer ou não fazer e sobre o como fazer, enquanto que o apetite livre escolhe (eligendo) fazer ou não fazer e como fazer. Em poucas palavras, a razão julga, o apetite escolhe. Todo o problema está em saber qual é a relação entre 'julgar' e 'escolher'.

A relação entre ambos é formulada claramente ao fim da passagem: o apetite que escolhe segue a razão que julga. Essa afirmação peremptória, entretanto, recebe relevantes nuances na frase seguinte: "Mas isso é verdadeiro sobre o apetite indeterminado, que é do bem simplesmente, e <sobre $>$ o conhecimento indeterminado, que é do bem em universal enquanto é bem". Ou seja, o apetite segue a razão - lembremos, aliás, que ele é denominado na passagem justamente appetitus rationalis $^{42}$-, porém isso só é verdadeiro quanto ao apetite indeterminado, que segue a razão indeterminada. Mas, o que pode querer dizer essa ressalva? Afinal, toda a passagem não lida justamente desde o início com essa indeterminação da razão e do apetite? Por que, então, o caso da razão e do apetite indeterminados surge como um caso em especial? A meu ver, há dois usos de 'determinação' nessa passagem.

Quando, em um primeiro momento, Henrique afirma que "nem os cognitivos nem os apetitivos são em si determinados, em sua obra, à razão de algum particular", ele está se referindo à indeterminação do universal com respeito ao singular. Quando,

trabalho-Suma, art. 9, q. 2, co. (ed. 1642-6, p. 177a, n. 6): "Dicendum ad hoc quod in artificialibus ubi est unus artifex, qui opus dirigit, et regulat, et alius manu operans secundum regulas ab artifice traditas, manu operans non dicitur auctor operis, sed artifex". Arriscando um pouco, talvez possamos dizer que, por isso mesmo, Deus pode ser dito um artífice, uma vez que as ideias que ele possui são regras, artes ou razões (aqui, decerto, não no sentido da faculdade judicativa humana) eternas, que regulam não somente a ação de criação, mas todas as ações das criaturas (mesmo o homem só é livre, uma vez que ele é pensado e criado como livre por Deus). Sobre isso, cf. cap. 6, nota 25.

\footnotetext{
${ }^{42}$ Sobre em que medida o apetite pode ser dito 'racional', cf. a nota 12 , acima.
} 
porém, ele afirma ao fim da passagem que o apetite racional só segue a razão se tomarmos o 'apetite racional' e o 'conhecimento' da razão de maneira 'indeterminada', este último termo faz referência a uma indeterminação oposta aos demais universais e não mais àquela dos próprios universais em oposição ao particulares. Isso se torna evidente quando o Doutor Solene explica o 'apetite indeterminado' como 'o apetite do bem simplesmente' e o 'conhecimento indeterminado' como 'o conhecimento do bem em universal enquanto bem'. Esse 'bem simplesmente, em universal, enquanto bem' é, parece-me, uma formulação sucinta da noção de 'bem' que será desenvolvida por Henrique de Gand em Quodl. 13, q. 9, como aquele 'bem' maximamente universal que, em sua comunidade (mais extensa, aliás, do que aquela dos demais universais), contém em si todos os objetos mais particulares (menos universais e propriamente particulares) que a vontade quer como bens. Assim, em poucas palavras, podemos dizer que o apetite indeterminado é do 'bem simplesmente' (bonum simpliciter), tal como este é conhecido pela razão. Sublinhemos, porém, uma característica fundamental do bem que o faz diferir, por exemplo, do verdadeiro: ele é nas próprias coisas existentes fora da alma, que possuem um ser em si e para as quais a vontade tende; mais importante, esse 'bem simplesmente' se confunde com o fim último, o que será capital para a descrição da vontade dentro em pouco ${ }^{43}$.

\footnotetext{
${ }^{43}$ No que diz respeito à caracterização do 'bonum simpliciter', vale citar uma passagem inicial de Quodl. 13, q. 9, co. (ed. De Wulf-Mansion Centre, vol. 18, pp. 57-58): "Dico secundum Philosophum VII Metaphysicae: 'simpliciter dicitur aliquid' uno modo, 'quod' dicitur 'secundum' communitatem, et sic ens simpliciter est analogum ad decem 'praedicamenta'. Alio modo dicitur simpliciter potissimum contentum sub termino, 'et' sic 'substantia' dicitur 'ens simpliciter'. Secundum hunc modum dico quod bonum simpliciter dupliciter dicitur: vel primo modo, sic bonum simpliciter convertitur cum ente ut dicit secunda ratio, vel secundo modo, et sic bonum simpliciter solummodo est bonum fruibile quod in se habet rationem omnis boni et desiderabilis". Nessa passagem, há uma tentativa de distinção entre um 'bem' transcendente - isto é, que se converte com o ente - e um 'bem' fruível, a partir do qual se atribui o 'bem' a tudo o que é querido como algo bom. Dito de outro modo, esse 'bem fruível' contém em si tudo o que há de bom. Ainda na mesma questão, Henrique determina que o objeto da vontade é esse 'bonum simpliciter' do segundo modo: "Dico igitur quod, sicut respectu visus illud est per se et primum obiectum visus quod per se et primo visibile est, ut lux, quia in huius virtute cetera sunt visibilia, sicut colores, sic respectu voluntatis illud est per se et primum obiectum voluntatis quod per se et primo est volibile, et in cuius virtute vult voluntas quaeque alia sunt ei volibilia. Tale autem est bonum non conveniens ad finem, sed bonum simpliciter, quod est beatificans bonum et habet rationem finis. In illo enim est perfecta ratio commodi et omnis boni alterius, et hoc est bonum commodum in quo est beatitudo, et hoc vel sicut in quodam universali seu generali bono, vel sicut in quodam singulari quod est ipse Deus $<\ldots>$. Et ideo dico quod bonum illud singulare est respectu voluntatis bonum simpliciter secundo modo dictum, et hoc quia sub ratione illius omne aliud bonum appetitur, sive sub ratione commodi, sive sub ratione convenientis appetatur $<\ldots>$. Et contra illud bonum commodum proprie distinguitur bonum conveniens quod est vere conveniens, et ad hunc ut ad finem ordinatur. Et hoc est bonum simpliciter quod per se et primum est obiectum voluntatis, quia hoc est bonum quod non secundum aliud a voluntate iudicatur bonum, sed potius secundum hoc iudicatur bonum quodcumque aliud bonum <...>." - Quodl. 13, q. 9, co. (ed. De Wulf-Mansion Centre,
} 
vol. 18, pp. 61-62). Como vemos, o objeto primeiro da vontade não é o 'bonum simpliciter' enquanto transcendente, mas enquanto aquele 'bem' a partir do qual todos os outros objetos são ditos bons. Este, como vemos, é o bem que se confunde com o 'fim último', em oposição àqueles objetos que só são bons na medida em que se caracterizam como meios que conduzem a este fim. Dessa maneira, vemos que o 'bonum simpliciter' a que Henrique de Gand faz menção em Suma, art. 45, q. 3, é aquele 'bonum simpliciter secundo modo dictum' de Quodl. 13, q. 9 - sendo, como dito na Suma, um 'bem em universal enquanto é bem' (cf. nota 40). Portanto, se, por um lado, esse 'bem em universal' não se confunde nem com os demais universais mais particulares nem com os próprios particulares (ele, de fato, pode ser tomado tanto como algo universal e geral - enquanto é a razão de outros serem ditos bens -, quanto como algo singular, tal qual Deus), por outro lado, ele também não se confunde com o bem 'transcendente' - este último, ao que parece, se converte com o ente precisamente porque tudo que possui ser é um bem, seja enquanto algo que conduz ao fim último seja enquanto o próprio fim último. Sobre esse tema tal como exposto em Quodl. 13, q. 9, cf. MACKEN, R."God as Natural Object of the Human Will, According to the Philosophy of Henry of Ghent”. In: MACKEN, R. Essays on Henry of Ghent II. Leuven: Editions Medieval Philosophers of the Former Low Countries, 1995, pp. 45-53; e OSBORNE Jr., The Natural Love of God over Self, 2001, pp. 206-209. No entanto, vale notar que, se o bem último é o objeto primeiro da vontade, ela não deixa de dizer respeito ao bem transcendente, na medida em que este último é dito analogamente tanto do bem não-participado (objeto último da vontade) como do bem participado (objeto da vontade enquanto é meio para se chegar ao bem último). Torna-se necessário, então, compreender o que significa descrever o 'bem' como um transcendente.

Os transcendentes são, em Henrique de Gand, denominados 'intenções primeiras' (intentiones primae), pois são aquilo que o intelecto primeiro intelige acerca de algo (cf. nota 89, adiante). Há, porém, uma ordem entre elas, o que o Doutor Solene mostra em Suma, art. 1, q. 2, co. (ed. De Wulf-Mansion Centre, vol. 21, pp. 37-9) - nesse texto, busca-se distinguer as diversas maneiras ou 'razões' (rationes) pelas quais um inteligível pode ser inteligido, de acordo com as diversas intenções primeiras pelas quais o intelecto pode concebê-lo.

Pois bem, embora ente (ens) e verdadeiro (verum) sejam conversíveis (como, ademais, já vimos ser o caso de 'ente' e 'bem simplesmente do primeiro modo', no início desta nota), eles são duas intenções distintas na coisa - " $<\ldots>$ alia est intentio rei qua est id quod est et alia qua dicitur vera, licet simul sunt in quacumque re et convertuntur sibi invicem, quia omne ens est verum et e converso" (p. 37). Sendo assim, é possível explicar em que medida uma coisa é inteligida sob a razão de 'ente' ou de 'verdadeiro', 'bem' e assim por diante. Destas intenções primeiras, a que o intelecto primeiro intelige é o 'ente', pois ele não inclui em si nenhuma outra intenção e, de outra parte, toda outra intenção o inclui em si - "Et ideo prima intentio comprehensibilis per intellectum est ratio entis, quam contingit intelligere absque eo quod ulla alia intentio circa ens intelligatur, quia nullam aliarum includit in se et ipsa in omnibus aliis includitur" (p. 37). Sem dúvida, lembra o Doutor Solene, tudo o que é inteligido o é enquanto verdadeiro e, nesse sentido, essa própria intenção primeira de 'ente' é conhecida pelo intelecto como algo verdadeiro. Com efeito, tudo o que é inteligível o é na medida em que é 'verdadeiro' (sobre a noção de inteligível, cf. adiante cap. 6, nota 25), de modo que o 'ente' inteligido é o 'ente verdadeiro' e o 'bem' inteligido é o 'bem verdadeiro'. Nesse caso, porém, Henrique considera que 'verdadeiro' está sendo tomando como uma ratio intelligendi de 'ente', de 'bem' e de qualquer outra intenção, mas não está sendo tomado propriamente como a 'intenção primeira' verum "Quamquam enim intentio entis non intelligitur nisi sub ratione veri, quod est per se obiectum intellectus, non tamen verum in eo quod est ratio intelligendi ens est obiectum intellectus, sicut est ens. Ratio enim veri est ratio intelligibilitatis in quocumque, obiectum tamen est verum ens vel verum bonum, et sic de aliis rerum intentionibus" (pp. 37-8). Ou seja, é preciso distinguir entre o verum enquanto ratio intelligendi (nesse sentido, todo inteligido é verum) e o verum enquanto intenção primeira (nesse sentido, verum se converte com ente). Em poucas palavras, o que primeiro se intelige acerca de uma coisa é 'ente' - essa é a inteção primeira, anterior a todas as outras.

Após a intelecção dessa coisa como 'ente', as intenções mais próximas a essa primeira pelas quais o intelecto pode conceber a mesma coisa são 'uno' (unum), 'verdadeiro' (verum, agora enquanto intenção primeira) e 'bem' (bonum) - a passagem de uma inteção à outra deve, entretanto, ser ordenada, de acordo com os diferentes modos pelos quais toda e qualquer coisa já inteligida como 'ente' pode ser considerada pelo intelecto - "Post intentionem autem entis proximiores sunt in re illae intentiones universales quae sunt unum, verum, bonum, et hoc diversimode et secundum ordinem, quoniam quaelibet res sub intentione entis existens tripliciter potest considerari” (p. 38). Com efeito, para Henrique, o 'ente' é uma 'intentio rei prima et absoluta', enquanto que essas demais intenções que a ele se seguem na ordem do conhecimento são intenções secundárias (p. 39). Assim, enquanto qualquer coisa é concebida como, por sua natureza, separada de outros e indivisível, convém a ela a 
inteção de 'uno' - "Primo in quantum habet esse determinatum in natura sua, quo per formam suam est in se indivisa et a quolibet alio divisa. Sic convenit ei intentio unius: in eo enim quaelibet res est una quo in se est indivisa formaliter et a quolibet alio divisa" (p. 38). Em seguida, enquanto tal coisa é concebida como uma representação de seu exemplar, convém a ela a intenção de 'verdadeiro' "Secundo in quantum in esse suo habet quod de ea exemplar ad quod est repraesentat. Sic convenit intentio veri: in tantum enim vera est quaecumque res, in quantum in se continet quod exemplar eius repraesentat" (p. 38). Além disso, enquanto tal coisa é concebida enquanto diz respeito a seu fim próprio, convém a tal coisa a intenção de 'bem' - "Tertio autem in quantum congruit suo fini ad quem est. Sic convenit ei intentio boni: in tantum enim quaelibet res est bona, in quantum respicit finem, qui bonus est" (p. 38).

Feita essa enumeração, notemos duas característica relevantes dessas primeiras intenções. Em primeiro lugar, como já mencionado, elas se convertem com o 'ente' - por exemplo, 'todo ente é bem', assim como 'todo bem é ente'. Esse tipo de conversão é válido para tudo o que se pode, de alguma maneira, inteligir como 'ente' - nos diferentes graus de perfeição possíveis, de acordo com a natureza de cada coisa. Isso nos leva à segunda característica importante nas primeiras intenções, a saber, elas são predicadas de tudo o que é ente - seja isso substância ou acidente e, no limite, criatura ou criador. Para Henrique de Gand essa comunidade da predicação da intenção de 'ente' se deve ao fato de ela ser um conceito análogo ao criador e à criatura. Em outras palavras, ela é predicada de ambos, mas ordenada e diferentemente: "Et secundum hoc ens per prius dicitur de uno quam de altero, et de uno per alterum, et ita quodam modo analogice" - Suma, art. 21, q. 2, ad op. (ed. Decorte \& Teske, p. 62). Essa analogia da intenção de 'ente' só é possível porque distingue-se entre um ente primeiro (Deus) e os demais entes que se reduzem a ele (pelas relações causais que produzem o 'ser de essência' e o 'ser de existência', como vimos em cap. 2, nota 95). Assim, “ $<\ldots$..> quicquid est in creatura per attributionem quondam reducitur in Deum, ut dictum est, et sic omnis entium multitudo reducitur ad unitatem primi entis, sicut et omnis numerus reducitur ad unitatem primam a qua incipit et quam continet in se" - Suma, art. 21, q. 2, ad op. (ed. Decorte \& Teske, p. 54). Essa distinção entre um 'ente primeiro' e os 'entes' ordenados a ela parece-me estar atrelada à distinção introduzida pelo gandanvense entre duas indeterminações possíveis do conceito de 'ser' (esse): [1] a indeterminação negativa, daquilo que naturalmente não se determina e [2] a indeterminação privativa, daquilo que naturalmente é determinado (embora possa ser concebido como indeterminado, na medida em que é privado de sua determinação natural). O primeiro é o ser de Deus, o segundo é o ser das criaturas: "Intelligendum tamen quod illa indeterminatio alia est respectu esse Dei, et alia respectu esse creaturae, quia duplex est indeterminatio, una negativa, altera vero privative dicta. Est enim negativa indeterminatio quando indeterminatum non est natum determinari, ad modum quo Deus dicitur esse infinitus, quia non est natus finiri. Est autem privativa indeterminatio quando indeterminatum natum est determinari, ad modum quo punctus dicitur infinitus cum non est determinatus lineis quibus natus est determinari. Secundum istam autem duplicem indeterminationem oportet intelligere quod concipiendo esse simpliciter et indeterminate quod est Dei, tunc est indeterminatio negativa, quia esse Dei nullo est natum determinari $<\ldots>$. Concipiendo autem ipsum esse indeterminate indeterminatione privationis illorum quibus natum est determinari, concipitur esse quod creaturae est, quia esse creaturae per proprias naturas quibus invicem differunt, natum est determinari” - Suma, art. 21, q. 2, ad op. (ed. Decorte \& Teske, pp. 56-8). Portanto, o 'ente' é análogo por ser dito primeiramente de Deus (cujo ser é concibido como indeterminado negativamente) e secundariamente, por ordenação a Deus, das criaturas (cujo ser é concebido como indeterminado privativamente). O mesmo vale para as demais intenções primeiras, uma vez que são conversíveis com o 'ente'.

Com isso, parece-me, fica mais clara aquela distinção entre dois modos de 'bem' que vimos Henrique de Gand destacar, ao início desta nota, em Quodl. 13, q. 9. O 'bem', assim como o 'ente', pode tanto ser concebido enquanto intenção primeira (isto é, enquanto transcendente), como enquanto o 'bem' primeiro que é Deus. Ainda que distintos, esses dois sentidos do termo 'bem' são fortemente associados, pois o 'bem' só pode ser dito intenção primeira por analogia, na medida em que há um bem primeiro no qual todos os demais participam para serem bens. Feita essa distinção, parece patente que a vontade tem por objeto primeiro aquele 'bem' último, mas ao mesmo tempo diz respeito ao 'bem' enquanto intenção primeira, na medida em que quer todos os bens - os criados, enquanto meios, e o bem último enquanto fim (o que veremos mais cuidadosamente ainda neste capítulo).

Ainda sobre as intenções primeiras - ou transcendentes - restariam dois problemas a serem vistos. $\mathrm{O}$ primeiro diz respeito ao fato de que, se todo ente o é enquanto se reduz ao ente primeiro, parece que a concepção de qualquer ente enquanto ente deveria pressupor uma intelecção do ente primeiro. Que esse parece ser o caso em Henrique de Gand, mostra-se mais adiante (cf. nota 89). Além disso - e esse é o segundo problema -, perceba-se que, em diversos excertos destacados na presente nota, Henrique de 
Ora, a própria necessidade que sente o Doutor Solene de explicar que o apetite segue a razão enquanto apetite indeterminado traz consigo a conotação de que há outros casos, nos quais o apetite não segue o conhecimento racional. Mas, se for assim, em que sentido é possível dizer que estamos em presença de um apetite racional? Com essa pergunta se inicia um processo de deslizamento conceitual por meio do qual o nosso appetitus rationalis surge, igualmente, como um appetitus liber.

Pois bem, se o appetitus indeterminatus necessariamente segue a razão que conhece o bem, não há uma tal necessidade quando estamos lidando com o particular - e, nesse ponto, particular não parece ser mais do que algo que não aquele 'bem simplesmente', pois falamos aqui de 'razão particular':

“ $<\ldots>$ a liberdade de determinar o apetite para este particular ou para aquele não é de modo algum da parte da razão por possuir um juízo livre [iudicium

Gand se refere a 'coisa' (res) como aquilo que possui as intenções primeiras. Com efeito, notamos aqui que a res não é exatamente enumerada entre as intenções primeiras pelo Doutor Solene, embora surja em seu pensamento associada à delimitação do campo do cognoscível. Voltaremos a esse tema (cf. cap. 6 , nota 25).

Sobre a noção de transcendente em Henrique de Gand, cf. tb. a bibliografia destacada na nota 89 e em cap. 6, nota 25. Atualmente, o principal estudo voltado para os transcendentes (ente, uno, verdadeiro, bom) na obra de Henrique de Gand é PICKAVÉ, Heinrich von Gent über Metaphysik..., 2007, pp. 129181 e 254-306. Cf. tb. AERTSEN, J. "Heinrich von Gent und Thomas von Aquin über die Transzendentalien. Ein Textvergleich". In: GULDENTOPS, G., STEEL, C. (eds.), Henry of Ghent and the Transformation..., 2003, pp. 101-25; e AERTSEN, J. Medieval philosophy as transcendental thought: from Philip the Chancellor (ca. 1225) to Francisco Suárez. Leiden: Brill, 2012, pp. 273-86.

Além disso (e, principalmente, sobre a analogia da noção de 'ente'), cf.: PAULUS, Henri de Gand. Essai..., 1938, pp. 52-60; CAFFARENA, Ser paticipado y ser subsistente..., 1958, pp. 182-93; MONTAGNES, B. La doctrine de l'analogie de l'être d'après saint Thomas d'Aquin. Louvain - Paris: Publications universitaires - Vrin, 1963, pp. 116-9; BROWN, S. F. "Avicenna and the Unity of the Concept of Being: the Interpretations of Henry of Ghent, Duns Scotus, Gerard of Bologna and Perter Aureoli”. Franciscan Studies 25 (1965), pp. 117-50; MARRONE, Truth and Scientific Knowledge..., 1985, pp. 20-1, nts. 20-1; MARRONE, S. P. "Henry of Ghent and Duns Scotus on the Knowledge of Being”. Speculum 63.1 (1988), pp. 22-57 (esp. pp. 28-40); DECORTE, J. "Henry of Ghent on Analogy. Critical Reflections on Jean Paulus' Interpretation”. In: VANHAMEL, W. (ed.). Henry of Ghent. Proceedings..., 1996, pp. 71-105; ZIMMERMANN, A. Ontologie oder Metaphysik? Die Diskussion über den Gegenstand der Metaphysik im 13. und 14. Jahrhundert. Texte und Untersuchungen. Leuven: Peeters, 1998, pp. 243-5; BOULNOIS, O. Être et représentation. Une généalogie de la métaphysique moderne à l'époque de Duns Scot $\left(X I I I^{e}-X I V^{e}\right)$. Paris: PUF, 1999, pp. 271-80; LAARMANN, Deus, primum cognitum, 1999, pp. 104-16; PORRO, "Metaphysics and Theology in the Last Quarter of the Thirteenth Century...", 2000, pp. 278-81; KLIMA, G. "Thomas Sutton and Henry of Ghent on the Analogy of Being". Proceedings of the Society for Medieval Logic and Metaphysics 2 (2002), pp. 3444 [edição eletrônica]; PANNENBERG, W. Analogie und Offenbarung. Eine kritische Untersuchung zur Geschichte des Analogiebegriffs in der Lehre von der Gotteserkenntnis. Göttingen: Vandenhoeck \& Ruprecht, 2007, pp. 132-9; WILKINS, S. Henry of Ghent's Doctrine of Analogy. Its Origins and Interpretations. A thesis presented in partial fulfillment of the requirements for the degree of Licentiate (M.A.) in Philosophy - Hoger Instituut voor Wijsbegeerte, Katholieke Universiteit Leuven, 2007, pp. 44-70; GUERIZOLI, R. "Sobre a refundação tardomedieval da metafísica. Os motivos de Henrique de Gand". Discurso 40 (2010), pp. 207-36; PICKAVÉ, M. "Henry of Ghent on Metaphysics". In: WILSON, G. A. (ed.). A Companion to Henry of Ghent, 2011, pp. 153-79 (esp. pp. 159-71); TESKE, R. "Henry of Ghent and the Analogy of Being". In: TESKE, R. Essays on the Philosophy of Henry of Ghent, 2012, pp. 247-63. 
liberum], de maneira que não ha necessidade de que o apetite siga a razão particular [rationem particularem]. Pelo contrário, o próprio apetite imaterial e abstraído possui, de si mesmo, o determinar-se por sua escolha [sua electione] e isso mais livremente [liberius] do que a razão possui o determinar-se por seu juízo" $"$.

A meu ver, essa 'razão particular' a que se faz menção aqui se opõe ao 'conhecimento indeterminado' do trecho anterior - ou seja, ainda estamos no campo do universal (racional), porém não no âmbito do 'bem simplesmente'. Assim, não estamos mais lidando com o 'bem em universal', mas com o bem de ações particulares. Se no caso daquele 'conhecimento indeterminado' o apetite necessariamente seguia o conhecimento, quando nos voltamos para a 'razão particular' isso não mais ocorre. De fato, no que diz respeito aos particulares (que são aqui, lembremos, simplesmente os universais menos comuns que o 'bonum simpliciter'), o apetite se determina por uma escolha livre, independentemente do juízo da razão acerca do apetecível. Dessa maneira, sempre o apetite tende ao bem indeterminado (aquilo que é conhecido o mais indeterminadamente), porém no que diz respeito a este ou àquele bem particular, o apetite é livre e desimpedido quanto à sua escolha. Com efeito, Henrique de Gand começa a demarcar nessa passagem claramente a distância entre a razão e o apetite com uma oposição entre um 'juízo livre' e o juízo da 'razão particular'. Aquele sempre será mais livre do que este, pois a bem dizer ele é uma escolha livre e não um juízo racional propriamente dito. Ou seja, assim que deixamos o campo de 'bem indeterminado', já está completamente demarcada a distância entre razão e apetite. Essa distância, de fato, só tende a aumentar no decorrer de nossa leitura:

"Nos racionais e nos intelectuais, portanto, o movimento não é determinado por
um princípio motivo apreendido a partir do apetecível e julgado [diiudicato] pela
razão, mas ele possui o movimento [motum] totalmente em seu poder [potestate],
tal que não seja necessário para ele $<$ se $>$ inclinar de acordo com a determinação
do apetecível apreendido enquanto é apreendido. Pelo contrário, se ele $<$ se $>$
move e $<$ se $>$ inclina para o fim segundo ato, não o faz porque algo o impele
violentamente de fora ou naturalmente o incline de dentro ou servilmente o
conduza, mas porque livremente e por escolha (ou como que por escolha) [libere

\footnotetext{
${ }^{44}$ Henrique de Gand, Suma, art. 45, q. 3, co. (ed. De Wulf-Mansion Centre, vol. 29, p. 115): "Sed verius tenendum est, quod tamen non est hic perscrutandum, quod libertas determinandi appetitum ad hoc particulare vel illud nullo modo est ex parte rationis quia habet iudicium liberum, ut necesse non sit appetitum sequi rationem particularem. Immo ipse appetitus immaterialis et abstractus se ipso habet se determinare sua electione, et hoc liberius quam ratio se habeat determinare suo iudicio".
} 
et eligibiliter aut quasi eligibiliter], e como senhor de sua ação [dominus suae actionis], o quer a partir de si mesmo [ex se ipso hoc velit]"

Nesse trecho, não se fala somente da 'potência apetitiva' ou da 'potência volitiva', mas do ser racional ou intelectual como um todo. De fato, um ser com razão não é compelido a nada. Se seu apetite o direciona ao bem indeterminado, suas ações acerca de particulares estão 'totalmente em seu poder', de maneira que nada o inclina a uma ação determinada que não ele próprio. Ora, se voltarmos àquela unidade do homem que estudávamos um pouco acima, fica patente que o mesmo ser racional que conhece, também quer livremente. Curiosamente, entretanto, estamos começando a notar que o querer independe do conhecer ou, mais precisamente, a escolha independe do juízo racional. Mais do que isso, intelecto e apetite começam a se mostrar como potências extremamente distintas, pois, ao mesmo tempo em que o homem, pelo intelecto, é passivo e necessita de algo externo a ele que o afete (nesta vida, só por meio dos sentidos) para que tenha seu conhecimento determinado como conhecimento sobre algo, o homem enquanto ser apetitivo é completamente senhor de si. De fato, retornamos nessa passagem àquela imagem do servo que servilmente carrega a candeia à frente de seu senhor - o apetite aqui é o senhor, o intelecto carrega a candeia. Assim, pela sua potência mais alta o homem é completamente senhor de suas ações particulares. Ora, como sabemos, esse 'apetite racional' é a vontade que encontramos em Quodl. 1. A própria noção de 'vontade', porém surge mais bem formulada na seguinte passagem:

“E tal princípio movente se chama 'vontade' [voluntas]. Ele em si e no seu significado inclui 'apetite' e 'liberdade' [appetitum et libertatem], tal que 'vontade' nada mais é do que 'apetite livre', tal que 'apetite' seria como um gênero e 'liberdade' como uma diferença na significação e na essência da vontade" $"$.

\footnotetext{
${ }^{45}$ Henrique de Gand, Suma, art. 45, q. 3, co. (ed. De Wulf-Mansion Centre, vol. 29, p. 115): "In rationabilibus ergo et intellectualibus non determinatur motus ipsi principio motivo ab appetibili apprehenso et diiudicato per rationem, sed omnino habet in sua potestate motum, ut non sit ipsi necessarium inclinare secundum determinationem appetibilis apprehensi secundum quod apprehensum est, sed quod moveat et secundum actum inclinet in finem, hoc facit, non quia ab extra aliquid ipsum violenter impellat vel ab intra naturaliter inclinet vel serviliter ducat, sed quia libere et eligibiliter aut quasi eligibiliter, et tamquam dominus suae actionis ex se ipso hoc velit".

${ }^{46}$ Henrique de Gand, Suma, art. 45, q. 3, co. (ed. De Wulf-Mansion Centre, vol. 29, p. 115): "Et tale principium movens appellatur voluntas, quod in se et in suo significato includit appetitum et libertatem, ut voluntas nihil aliud sit quam appetitus liber, ut appetitus sit quasi genus, libertas vero quasi differentia in significatione et essentia voluntatis".
} 
A vontade certamente não possui definição, já que ela não é uma essência como vimos acima, não sendo distinta realmente da alma enquanto sujeito ou das outras potências da alma, ela não possui propriamente uma definição em gênero e diferença específica. Entretanto, se a possuísse, nos diz o Doutor Solene, essa definição seria 'apetite livre', pois ainda que haja diversos apetites, a vontade se caracteriza pela liberdade. Assim, saímos de um 'apetite racional' e chegamos a um 'apetite livre', pois partimos de um apetite que segue a razão e chegamos a uma vontade senhora de si. Henrique de Gand não rejeita nenhuma das duas descrições do apetite - ele é racional e livre simultaneamente. Com conciliar ambas as caracterizações?

Para compreendê-lo, precisamos voltar ao texto antecedente ${ }^{47}$, no qual se afirma que o ser racional " $<$ se $>$ move e $<$ se $>$ inclina para o fim $<$.. $>$ livremente e por escolha [libere et eligibiliter]". A pergunta é: qual a diferença entre "se mover e se inclinar livremente' e 'se mover e se inclinar por escolha'? Ao que parece, a liberdade aponta para o fato de que "a vontade $<\ldots>$ se move graças a si mesma, não porque seja impelida por outro, inclinada ou determinada [voluntas libera dicitur, quia sui ipsius gratia movet, non quia ab alio impellatur vel inclinetur vel determinetur]"48. Ora, se 'liberdade' indica o fato de que o movimento da vontade parte dela mesma, resta que a 'escolha' nomeie o próprio movimento de determinação da vontade com respeito a um apetecível. É precisamente nesse ponto que surge a possibilidade de diferenciar a vontade nos diversos seres intelectuais e racionais, pois se movem 'livremente e por escolha' em diversos graus - quanto mais superior a natureza do ser intelectual, mas firme será sua livre escolha ${ }^{49}$. Sabendo que o homem é o mais inferior dentre esses seres, está desde já claro que sua livre escolha será a mais fraca e mutável:

"donde, dado o seu grau de natureza inferior, a liberdade da vontade nos homens
é a mais débil e fraca em todos os intelectuais e, também por isso, a mais
variável, tal que o homem, chegando ao uso do livre-arbítrio [ad usum liberi
arbitrii], pode $<$ se $>$ inclinar por seu primeiro ato para um movimento dirigido ao
fim último [directum in finem ultimum] ou para um movimento que desvie dele,
tal que livremente e por escolha se incline para um ou para outro. Também,
depois que o homem livremente e por escolha tenha $<$ se $>$ inclinado para um

\footnotetext{
${ }^{47}$ Cf. nota 45.

${ }^{48}$ Henrique de Gand, Suma, art. 45, q. 3, co. (ed. De Wulf-Mansion Centre, vol. 29, p. 116).

${ }^{49}$ Cf. Henrique de Gand, Suma, art. 45, q. 3, co. (ed. De Wulf-Mansion Centre, vol. 29, pp. 117-119).
} 
movimento ou para outro, quanto é de sua natureza, pode variar o movimento, até que tenha se firmado [fuerit confirmatus] no bem ou no mal" ${ }^{150}$.

Em poucas palavras, a fraqueza do homem se reflete na mutabilidade de sua escolha livre, de maneira que até se firmar definitivamente no bem ou no mal ele muitas vezes modifica seu movimento - sempre livremente e por sua própria escolha. Essa passagem, entretanto, deixa transparecer algo a mais, a saber, uma distinção que só surgirá definitivamente em um trecho posterior. Isso ocorre quando Henrique de Gand menciona o 'uso do livre-arbítrio', pelo qual o homem pode se inclinar para um movimento que dirija ao fim último ou dele desvie. A expressão 'livre-arbítrio' já apareceu em outros trechos elencados no presente trabalho, porém cabe agora tentarmos compreender mais apropriadamente tal noção.

Primeiramente, a utilização do verbo 'usar' (ad usum) com respeito ao livrearbítrio me parece reminiscente daquela utilização da expressão medio quo agit para caracterizar a ação do homem todo por meio de suas potências, o que vinha associado à caracterização da potência da alma como instrumentum do homem em sua ação ${ }^{51}$. Ou seja, o livre-arbítrio não é um ato, mas uma potência utilizada pelo homem, um instrumento por meio do qual o homem atua. Mais do que isso, se atentarmos bem, veremos que essa potência não diz respeito imediatamente ao fim último, mas antes a um movimento em direção ao fim último (ou que dele se afaste). Isso introduz uma distinção basilar para a ética de Henrique de Gand no seio da própria vontade:

"para que, a saber, a razão da vontade [ratio voluntatis] seja propriamente
distinguida da razão do livre-arbítrio [a ratione liberi arbitrii], cumpre distinguir
a vontade dita simplesmente [voluntatem simpliciter dicta]: naquela que diz
respeito ao ato acerca do fim [respicit actum circa finem], que é dita 'vontade'
absolutamente; e naquela que é acerca daqueles que são para o fim [circa ea
quae sunt ad finem], que é o 'livre-arbítrio' - que o Filósofo chama de 'escolha'
[electionem], quando diz, em Ética 3, que 'a vontade é do fim, mas a escolha
daqueles que são para o fim'. Portanto, a liberdade simplesmente, inteligida no
nome da vontade simplesmente dita, é liberdade simplesmente e absoluta com

\footnotetext{
${ }^{50}$ Henrique de Gand, Suma, art. 45, q. 3, co. (ed. De Wulf-Mansion Centre, vol. 29, p. 116): "Unde propter inferiorem gradum naturae debilior et infirmior est libertas voluntatis in hominibus inter omnia intellectualia, sed et ideo magis variabilis, ut homo statim cum devenerit ad usum liberi arbitrii, suo primo actu potest inclinare in motum directum in finem ultimum vel in motum deviantem ab eo, ut libere et eligibiliter inclinet in unum vel in alterum. Postquam etiam homo libere et eligibiliter inclinaverit in unum motum vel in alterum, quantum est ex natura sua, potest variare motum, quousque fuerit confirmatus in bono vel in malo".

${ }^{51}$ Cf. nota 17 , acima.
} 
respeito a qualquer ato da vontade, mas a liberdade expressa no livre-arbítrio é liberdade com respeito somente ao ato de escolha" ${ }^{52}$.

Ou seja, o fim já está dado! A escolha a que Henrique de Gand faz referência diz respeito somente aos meios que dirigem ao fim, isto é, aqueles que são em vista do fim. De fato, como vimos há pouco, o apetite racional - que, agora, notamos ser essa 'vontade absolutamente' - já se inclina para o fim tal como este é apreendido pelo intelecto, a saber, como aquele verdadeiro amado pela vontade enquanto o bem. Quiçá, podemos até mesmo dizer que essa 'vontade absolutamente' se confunde com aquela inclinação natural de cada coisa para seu fim e que, nos homens, opera por meio do conhecimento intelectual desse fim.

O livre-arbítrio, por outro lado, não diz respeito a esse campo da ação humana - essa inclinação como que natural para o fim último. Esta última será sempre livre para o homem, uma vez que ela parte dele próprio - ou seja, aquele próprio conhecimento do verdadeiro enquanto fim é necessariamente acompanhado de uma espontânea inclinação da vontade para ele como o bem, fim último. É justamente por essa inclinação ocorrer unicamente graças à vontade que esta última é dita livre. Por outro lado, o livre-arbítrio não compartilha dessa necessidade, pois ele diz respeito a algo muito mais particular do que o fim último, a saber, os meios para atingi-lo, os $a d$ finem, aqueles que são em vista do fim último. Este é, portanto, o âmbito da escolha humana: decidir os meios para se chegar ao fim - essa escolha é tanto mais difícil, quanto mais mutáveis somos para estabelecer nosso caminho em direção àquele 'bem em universal'.

Essa dupla relação da vontade com respeito ao intelecto está associada à distinção entre 'sindérese' (synderesis) e 'consciência ' (conscientia), cuja importância para a ética de Henrique de Gand foi destacada há alguns anos por Ilkka Kantola $^{53}$. 'Sindérese' e 'consciência' são os nomes atribuídos, respectivamente, à

\footnotetext{
${ }^{52}$ Henrique de Gand, Suma, art. 45, q. 4, co. (ed. De Wulf-Mansion Centre, vol. 29, p. 125): “< ..> ut scilicet ratio voluntatis distinguatur proprie a ratione liberi arbitrii, distinguendo voluntatem simpliciter dictam in illam, quae respicit actum circa finem quae dicitur voluntas absolute, et in illam quae est circa ea quae sunt ad finem, quae est liberum arbitrium, quod Philosophus appellat electionem, quando dicit, III ${ }^{\circ}$ Ethicorum, quod 'voluntas est finis, electio vero eorum quae sunt ad finem', libertas igitur simpliciter, in nomine voluntatis simpliciter dictae intellecta, est libertas simpliciter et absoluta respectu cuiuscumque actus voluntatis, libertas vero expressa in libero arbitrio est libertas respectu actus eligendi solum".

${ }^{53}$ KANTOLA, I. Probability and Moral Uncertainty..., 1994, pp. 85-94; e KANTOLA, "Henri Ghentiläisen omatuntokäsitys", 1996, pp. 161-165. Ainda sobre a distinção entre synderesis e conscientia, cf. tb. WERNER, Heinrich von Gent als Repräsentant..., 1878, pp. 49-51;
} 
inclinação da vontade com respeito ao fim sumamente universal ('simplesmente bom', como vimos) e à sua inclinação com respeito aos meios mais particulares (os $a d$ finem). Por isso mesmo, essa distinção de atos da vontade é ocasião, igualmente, para a distinção de dois atos distintos do intelecto. Como vimos acima, o intelecto pode ser tanto a inteligência do simples (um incomplexo), como uma proposição da razão (um complexo) - essas são duas operações suas. A vontade pode dizer respeito a ambas. Porém, se nos concentrarmos unicamente nos juízos complexos, é ainda necessário fazer mais uma distinção, pois o intelecto pode conhecer princípios (que são mais universais e cujo conhecimento independe de qualquer outra proposição) ou conclusões (mais particulares, conhecidas a partir daqueles princípios). Essa distinção entre princípios e conclusões põe em causa a noção de 'silogismo' que, como já mencionamos, pode ser distinguida entre o 'silogismo especulativo' e o 'silogismo prático,54. Destes, somente o último nos importará aqui, pois diz respeito a princípios e conclusões éticas. Vemos, portanto, que a distinção entre 'vontade absolutamente' e 'livre-arbítrio' termina atrelada, por meio da distinção entre 'sindérese' e 'consciência', à temática do 'silogismo prático'.

Para o Doutor Solene, os princípios éticos se confundem com 'a lei da natureza' (lex naturae) ${ }^{55}$, enquanto que conclusões éticas são a 'razão reta daquilo particular que cumpre operar' (recta ratio operandorum particularium). Assim, temos

LICHTERFELD, J. Die Ethik Heinrichs von Gent..., 1906, pp. 14-19; WITTERBRUCK, Die Gewissenstheorie bei Heinrich von Gent und Richard von Mediavilla, 1929, pp. 12-6; LOTTIN, O. Psychologie et morale aux XII et ${ }^{e}$ XIII ${ }^{e}$ siècles. Tome II: problèmes de morale. Louvain - Gembloux: Abbaye du Mont César - Duculot, 1948 (cf. pp. 236-71, 338-49, 399, esp. pp. 245-7); DECORTE, Een avicenniserend augustinisme..., 1983, deel 1, pp. 211-8; MACKEN, R. "Synderesis and Conscience in the Philosophy of Henry of Ghent". Franziskanische Studien 70 (1988), pp. 185-95; LEONE, "Henry of Ghent and the Ethics of Intention”, 2014, p. 572.

${ }^{54} \mathrm{Cf}$. item 3.1.1.

${ }^{55}$ Ainda sobre a relação entre 'consciência' e lei natural, Henrique afirma, em Quodl. 2, q. 16, co. (ed. De Wulf-Mansion Centre, vol. 6, p. 102): "Lex divina lex naturae est, quae iubet innocentem non puniri, quae custodienda est a quolibet erga Deum per pacem conscientiae, nihil agendo quod est contra conscientiam, quia secundum Apostolum 'Omne quod non est ex fide (Glossa: contra conscientiam), peccatum est"'. É interessante ver como, nesse trecho, a lei natural é igualada à lei divina e, portanto, a consciência (tal como a 'sindérese', lendo esse texto junto a Quodl. 1, q. 18 - cf., adiante, notas 57-58) se torna atrelada à fé e, por meio dela, a Deus - a paz de consciência é, aqui, ligada fundamentalmente ao respeito à vontade divina que conhecemos pela fé. Deve-se, entretanto, atentar para o fato de que a relação entre lei divina e lei natural é bem fluída nos textos do Doutor Solene, de maneira que essa afirmação da identidade entre ambas que surge em Quodl. 2 não deve ser extrapolada, sem mais, para toda a obra de Henrique. Sobre esse tema, cf. MACKEN, R. "The Sovereign, sometimes forbidden by the divine law to enjoy the money granted to him by the public justice, according to the philosophy of Henry of Ghent". In: MACKEN, R. Essays on Henry of Ghent II. Leuven: Editions Medieval Philosophers of the Former Low Countries, 1995, pp. 7-20; e o já citado LEONE, M. "Henry of Ghent on Divine Law...”, 2014. 
um silogismo prático quando, a partir de um princípio da lei natural (quasi ex propositione maiori), e de alguma outra regra particular derivada daquela mais universal (quasi minori propositione), chegamos a uma conclusão, isto é, a uma razão reta acerca do que cumpre fazer. Notemos que Henrique não está pronto a caracterizar esse caminho exatamente como um silogismo - daí a recorrência do quasi... Em todo caso, há aqui pelo menos um percurso racional que nos permite partir de um princípio universal ético e chegar a um juízo particular acerca da ação. Isso tudo, entretanto, diz respeito unicamente à razão ${ }^{56}$. Decerto, a razão só o faz movida pela vontade para

${ }^{56}$ Henrique de Gand, Quodl. 1, q. 18, co. (ed. De Wulf-Mansion Centre, vol. 5, p. 151): "Ex
universalibus enim regulis operandorum quae sunt de dictamine legis naturae, quasi ex propositione
maiori, et particularibus operandis sumptis sub illis regulis universalibus consilio rationis, quasi ex
minori propositione, formatur ratio recta operandorum particularium. Sed nondum ex hoc habetur
operandi conscientia, quia tunc omnis habens operandorum notitiam haberet de operando conscientiam,
et habens maiorem notitiam haberet strictiorem de operando conscientiam". Sobre a caracterização da ratio recta como 'conclusão', cf. adiante a nota 57.

Note-se que a distinção entre silogismo especulativo e silogismo prático reclama uma distinção anterior entre 'intelecto especulativo' e 'intelecto prático'. Em Quodl. 8, q. 1, Henrique de Gand argumenta que a distinção entre notitia speculativa e notitia practica diz respeito não ao objeto de conhecimento, mas ao fim do conhecimento: " $<\ldots>$ notitia practica proprie dicta et speculativa penes rationes differentes cognitorum non differunt, sed potius secundum rationes differentes finium, ad quos sunt" - Quodl. 8, q. 1, co. (ed. 1613, f. 2ra-b). Os fins possíveis são dois, a saber: [1] o verdadeiro, fim da notícia especulativa, e [2] a obra (opus), fim da notícia prática - " $<\ldots>$ secundum enim Philosophum 2. Metaphys. Finis speculativae est verum. Finis vero practicae opus" (f. 2rb). Essa distinção, porém, independe da determinação do objeto de intelecção como algo operável (operabile) ou não. De fato, mesmo um operabile pode ser objeto de conhecimento especulativo - "Unde quia notitia est de operabilibus, non ex hoc dicitur practica, immo operabilia speculativa notitia considerari possunt, si considerentur ad eundem finem ad quem considerantur pure speculativa in Mathematicis, et in naturalibus $<\ldots$.. " (f. 2rb). Assim, dentre os objetos de intelecção há os 'puramente especulativos', que só podem ser objeto de notícia especulativa com vistas ao conhecimento da verdade, e os operabilia, que podem ser objeto tanto de uma notícia especulativa como de uma notícia prática. Caso consideremos um operabile com a finalidade de conhecer a verdade acerca dele, há um conhecimento especulativo sobre tal operabile - "Unde operabilia duobus modis possunt considerari quemadmodum moralia. Uno modo ut praecise sciatur, quid virtus, et quid vitium, et quomodo virtus consistit in medio, vitium autem divertit a medio, et caetera huiusmodi. Et est omnis talis consideratio speculativa, licet in materia practica, et intellectu speculativo non practico" (f. 2rb). Porém, se estendermos essa consideração especulativa sobre o operabile de tal maneira que ela deixe de ter por fim a verdade e busque o conhecimento com vistas a uma ação voluntária, tal consideração sobre o operabile se torna prática (o que jamais poderia ser feito no caso da especulação acerca de um objeto puramente especulável) - "Sed in tali materia intellectus speculativus extensione quadam secundum Philosophum fit practicus. Dico extensione ad finem alium, quam ad quem erat secundum quod fuit speculativus. Speculans enim operando ad scire verum speculativus est. Extendens autem se ulterius, ut non solum intendat cognitionem veri, sed quaerat scire, ut secundum ea voluntas operetur, statim est practicus $<\ldots>$. Ut sic circa idem sunt speculativus intellectus et practicus, aliter enim speculativus extensione non fieret practicus. Speculativus enim in materia pure speculativa extensione nunquam fit practicus" (f. 2rb). Vemos, então, que o intelecto prático não é senão uma extensão do intelecto especulativo para outra finalidade que não o conhecimento da verdade, a saber, para um conhecimento com vistas à ação prática voluntária. Daí que seja possível falar tanto em silogismo especulativo como em silogismo prático - este último, entretanto, parece ser tomado como um quasi silogismo por Henrique justamente porque ele é um silogismo que perdeu seu fim próprio, a saber, a verdade. Ou seja, ele é um silogismo estendido para outro fim que não sua finalidade original, pois de raciocínio para o conhecimento da verdade ele foi tornado um raciocínio acerca da ação voluntária. Assim, a distinção entre intelecto especulativo e intelecto prático permite melhor compreender aquela entre silogismo especulativo e silogismo prático, permitindo também notar que este último é somente um extensão do primeiro para 
raciocinar acerca desse determinado operandum, como já vimos. Porém que a vontade determine a razão a agir acerca de determinado operandum, não estabelece qual será a ação da vontade com respeito a cada um dos juízos formados pela razão neste raciocío que se seguiu ao império da vontade.

Sabemos que, naquilo que diz respeito ao mais universal - o bem universal -, a vontade segue necessariamente o intelecto, enquanto que no mais particular ela é um livre-arbítrio, que unicamente graças a si mesma se decide por seguir o juízo do intelecto ou não. Sendo assim, no caso desse nosso quasi silogismo, a vontade necessariamente segue os princípios da lei natural - que, nesse raciocínio prático, surgem como proposição maior. Por outro lado, ela não possui uma tal necessidade quanto à ação acerca da ratio recta, mais particular. Utilizando aquele novo vocabulário introduzido há pouco, poderíamos identificar a ação da vontade com respeito aos princípios com a 'sindérese' e sua ação acerca das razões retas como a 'consciência'. Daí, é possível dizer que a sindérese é necessária, enquanto que a consciência depende da escolha:

\begin{abstract}
"De fato, assim como há na cognitiva a lei natural como regra universal dos que cumpre operar [operandorum] e a razão reta como particular, assim da parte da vontade há também um motor universal que estimula para a obra [stimulans ad $o p u s]$ segundo as regras universais da lei da natureza, dito 'sindérese' - ela é, na vontade, uma escolha natural [naturalis electio] que sempre concorda [semper concordans] com o ditame natural da lei da natureza. E, por isso, é dita 'sindérese', isto é, 'com-escolha' (a partir de 'sin', que é 'com', e 'haeresis', 'escolha'). Há também um motor particular que estimula para a obra segundo o ditame da razão reta, dito 'consciência' - ela é, na vontade, uma escolha deliberativa [electio deliberativa] que sempre concorda com a ciência na razão reta. E, por isso, é dita 'consciência', isto é, 'com-ciência', pois é a escolha na vontade deliberativa que concorda com a ciência na razão reta. E a consciência sempre é formada por um consenso e uma escolha da vontade livre de acordo [iuxta] com o juízo e a sentença da razão - assim, se a razão for reta, reta também é a consciência, se a razão for errônea, errônea também é a consciência. $\mathrm{E}$, já que a consciência não se forma senão pela livre-escolha do volente - ainda que de acordo com a notícia da razão -, ocorre que alguns que possuem muita notícia dos que cumpre operar [operandorum], possuem nenhuma ou pouca consciência em si sobre operar segundo a ciência. E isso ou porque não deliberam sobre o operar, agem $<\mathrm{em}>$ tudo precipitadamente ou, se deliberam, livremente escolhem contra a ciência e a recusam completamente ou, ao escolher, a seguem debilmente e agem ao contrário daquilo que souberam [noverunt]. Donde, todos esses agirem contra a ciência, sem nenhum ou pouco
\end{abstract}

outro fim. Para mais informações sobre o tema e o contexto destes excertos do Doutor Solene, cf. WIPPEL, J. F. "Divine knowledge, divine power and human freedom in Thomas Aquinas and Henry of Ghent”. In: RUDAVSKY, T. (ed.). Divine Omnscience and Omnipotence in Medieval Philosophy. Dordrecht: D. Reidel Publishing Company, 1985, pp. 213-41 (esp. p. 239, nt. 71-2). 
remorso de consciência, possuindo somente remorso da sindérese, que não pode ser extinguida" ${ }^{, 57}$.

Nesse trecho, vemos o quão complexo se torna o estudo da ação da vontade com respeito à obra humana. Após a vontade colocar em movimento a razão com respeito a algo volível, tem lugar esse raciocínio prático que estamos discutindo aqui. Este último, parte de uma proposição maior que se confunde com uma lei da natureza e termina em uma reta razão acerca do que cumpre operar (operandorum). À lei da natureza conhecida pela razão, corresponde uma necessária concordância da vontade que se cristaliza nessa 'sindérese'. À reta razão intelectual, pode - mas, somente, pode - corresponder na vontade uma 'consciência'. Isso, porém, só ocorre se a vontade livremente escolher seguir a recta ratio apresentada a ela pelo intelecto. Ou seja, já temos aqui três ações da vontade: [i] aquela pela qual se coloca em movimento o intelecto, [ii] aquela pela qual necessariamente se concorda com a lei da natureza e [iii] aquela, dependente de uma escolha, pela qual se concorda com a razão reta. Há,

\footnotetext{
${ }^{57}$ Henrique de Gand, Quodl. 1, q. 18, co. (ed. De Wulf-Mansion Centre, vol. 5, pp. 152-153): "Sicut enim in cognitiva sunt lex naturalis ut universalis regula operandorum et ratio recta ut particularis, sic ex parte voluntatis est quidam universalis motor stimulans ad opus secundum regulas universales legis naturae, et dicitur 'synderesis', quae est in voluntate quaedam naturalis electio semper concordans cum naturali dictamine legis naturae, et ideo dicitur 'synderesis', hoc est 'cum-electio' a 'syn', quod est 'cum', et 'haeresis', 'electio', et quidam motor particularis stimulans ad opus secundum dictamen rationis rectae, et dicitur 'conscientia', quae est in voluntate quaedam electio deliberativa semper concordans cum dictamine rationis rectae; et ideo dicitur 'conscientia', hoc est 'cum-scientia', quia electio in voluntate deliberativa concordans cum scientia in ratione recta. Et semper formatur conscientia a consensu et electione liberae voluntatis iuxta iudicium et sententiam rationis, ut si sit ratio recta, recta est et conscientia, si sit ratio erronea, erronea est et conscientia. Et quia conscientia non formatur nisi ex volentis libera electione, licet iuxta notitiam rationis, ex hoc contingit quod aliqui multam notitiam operandorum habentes, nullam vel modicam habent in se conscientiam de operando secundum scientiam, et hoc vel quia de operando nihil deliberant sed omnia praecipitanter agunt, vel si deliberant, libere tamen contra scientiam eligunt, et omnino ipsam respuunt, aut debiliter eam in eligendo sequuntur et contraria his quae noverunt, agunt. Unde omnes tales agunt contra scientiam sine omni conscientia remordente aut modica, solum habentes remorsum synderesis, quae omnino exstingui non potest". Parece-me que, ao apontar a 'consciência' como atrelada à 'ciência' da razão, o termo 'scientia' é tomado enquanto 'conclusão de um silogismo', da mesma maneira como ele será utilizado também na descrição dos silogismos especulativos: "Tali autem notitia principiorum supposita ex acquisitione tali, homo via investigationis rationalis rationaliter per potentiam naturalem rationis, ut est ratio, discurrendo acquirit sibi ex notitia illorum principiorum notitiam conclusionum, et per hoc etiam habitum eorum, quo de facili potest se homo, cum vult, convertere super eas intelligendas; qui dicitur scientia. Et dicitur proprie habitus acquisitus, quia per rationis investigationem et industriam advenit" Suma, art. 1, q. 11, co. (ed. De Wulf-Mansion Centre, vol. 21, p. 181). Neste trecho, a ciência é o hábito da conclusão do silogismo especulativo. No caso da consciência, vemos que há uma identificação entre 'recta ratio' e 'scientia', se tomarmos esta última como aquilo que, no silogismo prático, é análogo à conclusão do silogismo especulativo. Mais precisamente, a primeira é a designação da 'scientia' de um 'quasi' silogismo (prático). Cf. tb. a nota precedente. Gostaria aqui de deixar expressos meu débito e gratidão para com a colega María del Mar Castillo (Universidad Nacional de Córdoba, Argentina) pelas discussões sobre o tema e por me ceder alguns de seus textos ainda não finalizados sobre a noção de 'recta ratio' em Henrique de Gand e outros autores do mesmo período.
} 
entretanto, dois problemas: [i] essa ratio pode não ser recta, mas erronea e [ii] é possível agir contra a consciência.

O primeiro problema é facilmente solucionável pela introdução da possibilidade de o intelecto errar ao derivar uma ratio da proposição maior que é a lei da natureza. É curioso, entretanto, o fato de que o Doutor Solene associa esse erro no intelecto a um erro logicamente posterior na vontade, de maneira que, se a vontade escolher seguir uma ratio erronea, ela produz uma conscientia igualmente erronea. Continuar esse percurso, porém, seria o trabalho de um estudo da ética de Henrique, o que não pretendemos aqui. Já o segundo problema é mais importante para nós, pois ele só pode ser resolvido pela introdução de uma última - quarta - ação da vontade com respeito à obra humana.

Ora, se é possível agir contra a sindérese - pois vimos, no último trecho destacado, que há um remorsum synderesis -, isso significa que a ação pela qual a vontade de fato determina o agir do homem é distinta da própria sindérese, sempre necessária; da mesma maneira, se é possível agir contra a consciência, segue-se que a ação pela qual a vontade determina o agir humano é distinta da própria consciência. Ou seja, a vontade é livre para aderir ou não a uma razão particular (reta ou errônea) e, mesmo após aderir a esta última, é livre para determinar o agir de acordo ou não com essa adesão ${ }^{58}$ ! Enfim, todo o movimento da vontade, desde o estopim pelo qual ela põe em ação a razão, até a determinação do agir (passando pela sindérese e, também, pela consciência) possui, pelo menos, esses quatro passos - essas quatro ações da vontade que, ao que parece, Henrique caracteriza durante esse processo como uma 'vontade deliberativa'. Essa 'vontade deliberativa' (voluntas deliberativa)

\footnotetext{
${ }^{58}$ Sobre essa complexa relação de discordância entre 'razão', 'vontade' e 'consciência', cf. Henrique de Gand, Quodl. 1, q. 18, co. (ed. De Wulf-Mansion Centre, vol. 5, p. 153): "Non est igitur idem quantum ad propositam quaestionem, voluntatem discordare a ratione erronea et a conscientia erronea, quamvis omnis discordans a conscientia erronea discordet a ratione erronea, eo quod omnis conscientia sive recta sive erronea formatur iuxta rationem rectam aut erroneam. Potest enim voluntas discordare a ratione erronea, licet non a conscientia erronea, quia forte errans non habet conscientiam formatam iuxta rationem.

Nec tamen restat quoad propositam quaestionem, nisi quod semper magis peccat contra erroneam conscientiam peccans quam solum contra erroneam rationem, eo quod magis contemnit. Agens enim contra conscientiam contemnit iudicium rationis et voluntatis inclinationem simul. Agens autem contra erroneam rationem tantum, non contemnit nisi iudicium rationis tantum, non inclinationem voluntatis, nisi quoad synderesim, ut dictum est". Nesse excerto, pode-se encontrar uma das possíveis formulações do famoso tema da 'akrasia' ou da 'fraqueza da vontade', pelo qual, em poucas palavras, busca-se compreender como um agente conhecedor do bem pode fazer o mal. Sobre esse tema em Henrique de Gand, cf. EARDLEY, "The Problem of Moral Weakness...", 2006; KOBUSCH, "Willensschwäche und Selbsbestimmung...", 2006; MÜLLER, "Willensschwäche im Voluntarismus?", 2007; HOFFMANN, "Henry of Ghent's Voluntarist Account of Weakness of Will", 2008; MÜLLER, Willensschwäche in Antike und Mittelalter, 2009, pp. 569-617.
} 
é a vontade senhora de si, que ordena ao intelecto que a preceda servilmente, mostrando-lhe o caminho com a luz da razão.

Nisso tudo, o mais importante para nós é percebermos o principal com respeito à noção de vontade estabelecida pelo Doutor Solene: ela é fundamentalmente e completamente ativa. Se até há pouco sabíamos que a vontade é superior ao intelecto porque ela, entre outras coisas, pode até mesmo colocá-lo em movimento (o que, como acabamos de ver, ela faz ao deliberar), agora começamos a notar que ela é fundamentalmente ativa e independente do intelecto em sua escolha. Decerto, naquilo que diz respeito à natureza humana, ela segue o intelecto - isto é, assim como o intelecto conhece o verdadeiro que é o fim bom expresso na lei da natureza, a vontade pela sindérese é direcionada a esse 'bonum simpliciter' mais universal. Não obstante, em todo o campo do agir particular - e, portanto, em todo aquele campo do agir ad finem - a vontade é livre, independente do intelecto e completamente ativa. Mais do que isso, mesmo no que diz respeito à sindérese, ela é livre pelo simples fato de querer o bem e amar as leis da natureza por uma ação própria e indeterminadamente ativa - movida unicamente a partir de si mesma. Tomando essa tese pelo seu lado negativo, podemos dizer que a vontade não possui qualquer passividade enquanto parte da alma. Ou seja, se ela é uma potência da alma, ela é uma sua potência completamente ativa. E, dessa maneira, começa a ficar claro que a distinção entre intelecto e vontade como potências da alma estabelece uma profunda cisão no homem, pois temos nele algo passivo como o intelecto e algo ativo como a vontade ${ }^{59}$. Ainda assim, como temos lido, todas as vezes que se faz alguma referência à vontade, o intelecto termina por ser implicado na descrição da ação volitiva.

Isso ocorre porque, mesmo que a vontade não possua qualquer passividade com respeito às demais faculdades da alma, ela necessariamente se utiliza desta últimas (em particular, mas não somente, do intelecto) para agir acerca de algo. De fato, como vimos, a vontade só tem consciência após o intelecto lhe apresentar um juízo, tal como ela só possui sindérese acerca de um princípio formulado pelo intelecto (ainda que o intelecto só tenha formulado tais proposições movido, primeiramente, pela vontade para tanto). Saindo do campo dos juízos racionais e retornando à inteligência dos simples - isto é, dos incomplexos - essa relação entre

\footnotetext{
${ }^{59}$ Essa mesma oposição entre passividade do intelecto e atividade da vontade pode ser lida em Quodl. 6, q. 1, co. (ed. De Wulf-Mansion Centre, vol. 10, pp. 13-8) e Suma, art. 60, q. 4, ad 1-2 (ed. 1642-6, pp. 1099-111).
} 
intelecto e vontade também fica clara, pois esta última necessariamente só possui o apetite para um bem que lhe seja apresentado pelo intelecto. Enfim, seja no campo do incomplexo ou do complexo, a vontade age livremente - isto é, sem depender de qualquer outro e, no que diz respeito aos particulares, por escolha -, porém sua ação é sempre acerca de algo que provém do intelecto. Isso nos traz finalmente àquele tema que é o mais relevante para nossa exposição da noção de vontade, a saber, o problema da curiosa relação causal nutrida entre ela e o intelecto.

Pois bem, nesse ponto, retornamos a uma pergunta que já foi feita acima: como explicar que haja uma anterioridade do intelecto com respeito à vontade, se esta última o antecede? Certamente, a vontade antecede o intelecto ao fazê-lo raciocinar sobre algo determinado. Porém, esse 'algo determinado' tem que ter sido apresentado pelo intelecto à vontade antes mesmo que esta última possa agir com respeito a isso. Ou seja, tanto no campo dos incomplexos como no campo dos complexos, o papel do intelecto é colocar algo em presença da vontade, para que esta última possa se determinar quanto àquilo em cuja presença se encontra:

"É verdadeiro, entretanto, que o intelecto existente em ato precede todo ato da vontade enquanto uma causa sine qua non. $<\ldots>$ o intelecto é uma potência simplesmente passiva, enquanto que a vontade é uma potência simplesmente ativa. Por isso, de fato, o intelecto se faz em ato pelos princípios como por um agente próprio e, depois, a vontade se faz em ato não movida pelos princípios conhecidos de outra maneira que como causa sine qua non, mas a partir de si mesma, em presença deles [a se ipsa ad praesentiam illorum], ela move, por amor dos princípios, o intelecto a investigar a notícia das conclusões. Porém, a vontade feita em ato de querer o fim [in actu volendi finem] a partir de si mesma para a apreensão do fim [a se ipsa ad apprehensionem finis] (não a partir do fim senão tal como a partir de uma causa sine qua non), posteriormente move a si mesma para o ato de querer aqueles que são para o fim [in actum volendi ea quae sunt ad finem]. E isso, movendo antes o intelecto a considerar aqueles que são para o fim [ad considerandum ea quae sunt ad finem], não tal como aqueles a partir dos quais é movida para querê-los [ad volendum] como uma causa propter quam sic, mas somente como uma causa sine qua non" $"$.

\footnotetext{
${ }^{60}$ Henrique de Gand, Quodl. 12, q. 26, co. (ed. De Wulf-Mansion Centre, vol. 16, pp. 156-157): "Verum est tamen quod intellectus existens in actu praecedat omnem actum voluntatis ut causa sine qua non. $\langle\ldots\rangle$ intellectus est potentia simpliciter passiva, voluntas autem est potentia simpliciter activa. Ob hoc enim intellectus primo fit in actu per principia ut per proprium agens, et deinde voluntas fit in actu, non mota a principiis cognitis aliter quam a causa sine qua non, sed a se ipsa ad praesentiam illorum, quae movet ex amore principiorum intellectum ad investigandum notitiam conclusionum. Voluntas autem facta in actu volendi finem a se ipsa ad apprehensionem finis, non a fine nisi sicut a causa sine qua non, ulterius movet se ipsam in actum volendi ea quae sunt ad finem, et hoc movendo intellectum primo ad considerandum ea quae sunt ad finem, non ut a quibus movetur ad volendum ea ut a causa propter quam sic, sed solummodo ut a causa sine qua non".
} 
Esse trecho tem por objetivo principal nos mostrar por que a concordância da vontade com os princípios da razão (isto é, a sindérese) leva essa mesma vontade a colocar o intelecto em ação para gerar as razões retas com respeito ao agir particular ou seja, com respeito às conclusões éticas acerca dos ad finem. Em poucas palavras, ela o faz por amor por esses princípios. Seu amor por eles é tanto, que ela põe o intelecto em ato para investigar os meios de chegar a esse fim. Assim, aquele quasi silogismo acerca do agir que estudamos há pouco, não é senão o fruto do amor da vontade pela lei natural e, em última instância, pelo bem mais universal. Esse amor, como vemos, redunda em um amor pelos meios ad finem e, em geral, pelo conhecimento. Este último, que faz a vontade mover o intelecto em direção ao desconhecido, será muito importante para nós daqui a pouco, no próximo item deste capítulo.

Por enquanto, não obstante esse seja um elemento relevante para o estudo da filosofia (e, em particular, da ética) de Henrique, o que mais me interessa aqui é a caracterização do princípio inteligido e, de fato, do inteligido em geral ou, ainda, do intelecto em ato (intellectus) com respeito a essa autodeterminação da vontade. Em primeiro lugar, a oposição do intelecto e da vontade enquanto potências, respectivamente, passiva e ativa é deixada bem clara nesse trecho. De fato, essa oposição fundamental é mostrada quando Henrique de Gand afirma que, enquanto o intelecto é movido pelos princípios para conhecê-los, a vontade move a si mesma em presença destes últimos enquanto são conhecidos pelo intelecto. Dessa maneira, o papel do intelecto com respeito à vontade é, unicamente, aquele de apresentar o intelegido para que a vontade livremente aja acerca dele: "no ato de querer, sem que algo aja antes na vontade senão metaforicamente, a própria vontade produz de si mesma desde si mesma o ato de querer [se ipsa ex se ipsa elicit actum volendi], pelo qual ela de algum modo age em direção ao querido e se une ao querido [quodam modo facit in volitum et unit se volito]. E, ainda que o ato de querer pressuponha o ato de inteligir, já que a vontade ou, para falar mais propriamente, o volente não se move pela vontade senão para o bem conhecido, mesmo assim o bem conhecido não faz nenhuma impressão ou movimento na vontade, mas a vontade move a si mesma, de si mesma, para o objeto mostrado [in obiectum ostensum se ipsam movet se ipsa] $<\ldots>$.. ${ }^{61}$. É claro que se pode dizer que 'o intelecto (ou o inteligido) move a vontade',

\footnotetext{
${ }^{61}$ Henrique de Gand, Suma, art. 45, q. 2, co. (ed. De Wulf-Mansion Centre, vol. 29, pp. 108-109): "In
} 
porém isso é somente uma metáfora: "estas duas potências, vontade e intelecto, se movem entre $\mathrm{si}<\ldots>$ e, assim, o intelecto move a vontade metaforicamente $<\ldots>$, a vontade, pelo contrário, move o intelecto propriamente" ${ }^{, 62}$. O intelecto nada faz além de mostrar (ostendere) um objeto para a vontade e esta última, em presença (ad praesentiam) deste objeto, livremente (e, no caso de particulares, por escolha) se volta para ele, amando-o. Portanto, o ato do intelecto certamente não é uma causa eficiente do ato volitivo - de fato, isso eliminaria a liberdade da vontade tal como ela vem sendo descrita, isto é, como um 'mover-se a si mesma'. Ainda assim, o intelecto é caracterizado em termos causais com respeito à volição - com efeito, se voltarmos ao último trecho indentado, vemos que ele é uma causa sine qua non (algo como uma 'causa sem a qual não') do ato de querer, em oposição a uma causa propter quam sic (que seria como que uma 'causa pela qual sim'). Mas, o que seria precisamente essa oposição?

Ela é explicada mais atentamente em uma outra passagem, que colocará em jogo de maneira muito interessante três pares, a saber, [i] 'intellectus/voluntas', [ii] 'causa sine qua non/causa propter quam sic' e, finalmente, [iii] 'ostendere/elicere'. A hábil utilização conjunta desses pares torna possível, para Henrique de Gand, apresentar toda a complexa relação entre intelecto e vontade neste curto excerto:

\begin{abstract}
"Digo que algo é requerido para a elicitação de um ato [ad actum aliquem eliciendum] duplamente. De um modo, como causa sine qua non, que totalmente nada age na elicitação [in eliciendo] do ato ou na causação de uma disposição pela qual seja elicitado [eliciatur] o ato ou pela qual seja recebido no passivo, tal como se requer algo que remova o impedimento [removens prohibens] para a descida do grave. E desse modo, como muito frequentemente tratei, necessariamente se requer para elicitar o ato da vontade [ad actum voluntatis eliciendum] o mostrar o objeto [ostensio obiecti] e a forma do intelecto acerca deste. De outro modo, se requer algo para elicitar um ato [ad actum aliquem eliciendum] como causa propter quam sic, que age algo, ou acerca do que recebe $\mathrm{o}$ ato (ou operação) ou acerca daquilo que o elicita [elicitivum eius] <...>.
\end{abstract}

\footnotetext{
actu autem volendi, absque eo quod aliquid agat primo in voluntatem, nisi metaphorice, ipsa voluntas se ipsa ex se ipsa elicit actum volendi, quo se quodam modo facit in volitum et unit se volito. Etenim si actus volendi necessario praesupponit actum intelligendi, quia non movet se voluntas, vel ut magis proprie loquar, volens, per voluntatem nisi in bonum cognitum, bonum tamen cognitum nullam impressionem aut motum facit in voluntatem, sed voluntas in obiectum ostensum se ipsam movet se ipsa $<\ldots>$.

${ }^{62}$ Henrique de Gand, Suma, art. 4, q. 1, co. (ed. De Wulf-Mansion Centre, vol. 21, p. 273): "Et ideo istae duae potentiae, voluntas et intellectus, ad invicem sese movent, immo, ut magis proprie loquar, ipsum volentem et intelligentem, quia intellectus concipiendum finem per modum intentionis sub ratione veri proponit ipsum voluntati, quae ab ipso fine movetur sub ratione boni, et sic intellectus movet voluntatem metaphorice ad modum quo finis movet efficientem. E contra voluntas movet intellectum proprie et per modum agentis et impellentis in opus, ut dictum est".
} 
E digo que, desse modo, não se requer para simplesmente elicitar [ad eliciendum simpliciter] o ato de volição algo outro que não somente o mostrar o objeto [ostensio obiecti], além somente da vontade de livre-arbítrio"63.

Tudo que o intelecto faz é mostrar o objeto à vontade - para ser mais preciso, o objeto enquanto inteligido ("o objeto e a forma do intelecto acerca deste", isto é, a intelecção deste objeto). Porém, esse 'mostrar o objeto' - essa ostensio - não faz mais do que retirar um impedimento para a elicitação (elicere) do ato de vontade. Esse impedimento, ao que parece, é a própria ausência de um volível para o qual a vontade possa se voltar. Assim, a potência volitiva surge como algo completamente em ato que, no entanto, só pode determinar a si mesma com respeito a algo em presença de um objeto que lhe seja mostrado pelo intelecto. A vontade é, portanto, um ato indeterminado, que se volta para o intelecto em busca de um objeto a partir do qual determine a si mesma. Assim, ela própria elicita o seu próprio ato - ela é a própria causa propter quam sic do querer. O intelecto, por outro lado, ao simplesmente apresentar à vontade algo para o qual ela pode se voltar ou não, não a determina em nada, mas, pelo menos, lhe mostra algo sem o qual ela não poderia se determinar por isso mesmo, o intelecto em ato surge como essa causa sine qua non da volição. A relação causal entre intelecto e vontade se resume ao fato de que, tendo sido afetado por um objeto, o intelecto mostra este último para a vontade e ela, por sua vez, elicita livremente - e, no caso de ações particulares, por escolha - em si mesma um ato acerca daquele objeto: "de fato, a vontade, enquanto é apetite simplesmente, não requer nenhuma disposição em si além de si, para receber em si o ato de volição" ${ }^{64}$, de maneira que o objeto é, até mesmo, externo à vontade quando é apresentado a ela. $\mathrm{O}$ intelecto, portanto, é passivamente afetado pelo objeto, enquanto que a vontade

\footnotetext{
${ }^{63}$ Henrique de Gand, Quodl. 13, q. 11, co. (ed. De Wulf-Mansion Centre, vol. 18, p. 88): "Dico quod aliquid ad actum aliquem eliciendum requiritur dupliciter. Uno modo ut causa sine qua non, quae nihil agit omnino in eliciendo actum aut causando dispositionem qua eliciatur actus, aut qua in passivo recipiatur, quemadmodum requiritur removens prohibens ad descensum gravis. Et hoc modo, ut saepius tractavi, ad actum voluntatis eliciendum necessario requiritur obiecti ostensio et forma intellectus circa ipsum. Alio autem modo requiritur aliquid ad actum aliquem eliciendum ut causa propter quam sic, quae agit aliquid vel circa receptivum actus seu operationis, vel circa elicitivum eius. $<\ldots>$. Et dico quod isto modo non requiritur ad eliciendum simpliciter actum volitionis aliud quam solius obiecti ostensio, praeter solam voluntatem liberi arbitrii”. Cf. Quodl. 10, q. 13, ad 1 (ed. De Wulf-Mansion Centre, vol. 14, pp. 289-90), onde a mesma noção de sine qua non é utilizada para a caracterização não somente da relação entre intelecto e vontade, mas também de outras potência da alma (cf. cap. 6, nota 242).

${ }^{64}$ Henrique de Gand, Quodl. 13, q. 11, co. (ed. De Wulf-Mansion Centre, vol. 18, p. 88): "Voluntas enim ut est appetitus simpliciter, nullam dispositionem in se requirit aliam a se ut in se recipiat actum volitionis".
} 
ativamente se volta para este último para determinar aquela sua atividade indeterminada.

Com efeito, a essa determinação da vontade por si mesma a partir do intelecto como causa sine qua non, corresponde uma profunda indeterminação da vontade para ser mais preciso, pode-se dizer que há uma tripla indeterminação na potência volitiva! A primeira indeterminação [i] opõe o 'poder querer' (posse velle) e o 'não poder querer' (non posse velle). Ora, para 'poder querer' algo, como vimos, a vontade deve estar em presença disso, portanto ela 'pode querer' quando em presença do objeto enquanto inteligido e 'não pode querer' quando o objeto não está presente a ela. Porém, já está claro que a vontade move o intelecto, de maneira que, como todas as suas ações, a passagem do 'não poder querer' para o 'poder querer' também está em seu poder, pois ela pode mover o intelecto para pensar algo que, então, estará presente a ela. Além disso, uma vez que 'possa querer', isto é, que esteja em presença de um seu objeto, [ii] a vontade possui uma indeterminação com respeito a 'querer' (velle) esse objeto ou, o contraditório, 'não querer' (non velle) esse objeto ou, o contrário, 'recusar' (nolle). O mais complicado nessa segunda indeterminação é essa distinção entre 'non velle' e 'nolle' enquanto, respectivamente, o contraditório e o contrário de 'velle'. Ao que parece, o 'não querer' é a decisão da vontade de não agir com respeito ao objeto mostrado pelo intelecto. Isto é, embora ela 'possa querer', pois está em presença de um objeto, ela não age com respeito a ele. $\mathrm{O}$ 'recusar', em contraposição, ocorreria quando a vontade decide agir quanto ao objeto mostrado, porém com uma ação negativa - isto é, rechaçando aquele objeto mostrado pelo intelecto (provavelmente, como algo mal, contrário ao bem em universal). Por fim, a vontade é ainda indeterminada [iii] com respeito a, em presença de diversos objetos, 'querer isso ou aquilo' (velle hoc vel illud et quodcumque determinatum volibile) ${ }^{65}$. O

\footnotetext{
${ }^{65}$ Henrique de Gand, Quodl. 13, q. 11, co. (ed. De Wulf-Mansion Centre, vol. 18, pp. 97-8). É interessante notar que, nessa passagem, essas três indeterminações da vontade são apresentadas por Henrique por meio de uma comparação entre a visão e a potência volitiva. Com efeito, é comum em sua obra o parelelo entre os sentidos e o intelecto, porém esse é um dos poucos exemplos de um paralelo entre a vontade e um sentido externo (vejamos bem, não entre o apetite sensitivo e o apetite intelectivo, mas entre a vontade e uma potência cognoscitiva sensitiva).

Essa tripla indeterminação da vontade é retomada, sob o ponto de vista da relação entre potência volitiva e ato de volição, em Quodl 12, q. 36, co. (ed. De Wulf-Mansion Centre, vol. 16, p. 137): "Dico quod voluntas tripliciter comparatur ad actum volendi: uno modo negative, scilicet in eum non volendo, ubi negantur actus et obiectum simul. Sic enim non vult ille qui nec voluntatem ad aliquid agendum habet, nec etiam actum volendi. Alio modo positive, scilicet in omnino volendo aliquid, ubi affirmantur actus et obiectum simul. Sic enim vult ille qui habet voluntatem ad habendum aliquid determinate. Tertio modo privative, scilicet in partim volendo et partim nolendo, ubi affirmatur actus et negatur obiectum. Sic enim vult ille qui habet actum volendi ad non habendum aliquid determinate.
} 
importante é que, em todos esses casos de indeterminação, é a vontade unicamente que se determina, seja movendo o intelecto para lhe mostrar algum objeto, seja para agir ou não com respeito a um objeto já apresentado, seja, enfim, para escolher um objeto dentre vários apresentados. Na raiz dessa indeterminação, está uma atividade basilar da vontade, um agir que nunca cessa e que, se contém alguma imperfeição, esta se deve à sua mutabilidade e à sua necessidade de que algo externo the seja apresentado para que ela possa determinar a si mesma nessa sua ação contínua. Dito isso, resta unicamente buscar conhecer a origem dessa atividade plena - ainda que imperfeita e mutável - da vontade enquanto potência da alma humana.

O mais significativo quanto a esse último problema é o pouco que Henrique de Gand tem a dizer a respeito. Em poucas palavras - mas, ao que parece, não haveriam outras a serem ditas -, a vontade do homem é livre simplesmente porque foi assim que Deus a fez:

\begin{abstract}
“< ..> assim, o apetite humano não-orgânico, se considerado simplesmente, possui do causador [a causante] a forma de livre-arbítrio, pela qual quer segundo $\mathrm{o}$ ato [vult secundum actum] ou livremente por querer, retirado o impedimento que é a ausência do objeto. E, tendo ele sido tornado presente no intelecto pelo conhecimento, então livremente quer, se ele for fim simplesmente, ou pode querer pelo livre arbítrio, se ele for para o fim [ad finem]. E o quanto o homem recebe da forma de liberdade, tanto $<$ ele recebe $>$ de poder para elicitar o ato de volição [de potestate ad eliciendum actum volitionis]. Pelo que, pode-se dizer que os volentes são movidos por Deus em todo ato de querer - diz Anselmo: 'diz-se mais verdadeiramente que faz, aquele que faz por natureza etc.'. Porém, depois que o homem possui, dada a ele por Deus, uma tal forma, ele pode mover de acordo com ela, cessado o impedimento, sem que seja movido por outro. E, assim, é movido primeiramente por si, embora não segundo o todo" ${ }^{\text {"66 }}$.
\end{abstract}

Primo modo non vult aliquid dormiens, secundo modo vult vigilans esse beatus, tertio modo vult non esse miser".

Por fim, reforce-se que a indeterminação da vontade a distingue fundamentalmente do intelecto, uma vez que este último é definitivamente concebido como uma potência determinada: "Dico quod omnis substantia intellectualis potest in contraria: sed sola voluntate, quia ipsa sola libera est, et a nullo determinabilis aut determinata, nisi a summo bono principaliter intellecto, secundum quod hoc de voluntate alias declaravimus sufficienter. Per intellectum autem non potest in contraria, quia ipsa sic determinatur quantum est ex se per verum, vel apparens verum, ut nullo modo possit ab eo dissentire: sed necesse est ei assentire. Similiter per falsum, aut apparens falsum, ut nullo modo possit ei consentire, sed necesse est ab eo ipsum dissentire, et si aliqua quandoque adsit ei facultas assentiendi ei quod sibi apparet falsum, vel e converso dissentiendi ei quod sibi apparet verum, hoc solum potest per dominium et libertatem voluntatis, ita quod libertas voluntatis non dependeat ab intellectu, ut aliqui volunt dicere, sed magis e converso" - Quodl. 11, q. 7, co. (ed. 1613, f. 204ra), sobre o termo apparens, cf. cap. 5, nota 107. Acerca da possível caracterização da vontade como 'racional' devido à sua indeterminação, cf. acima nota 12 .

${ }^{66}$ Henrique de Gand, Quodl. 13, q. 11, ad 3 (ed. De Wulf-Mansion Centre, vol. 18, p. 131): “< <..> sic appetitus humanus non organicus, si simpliciter consideretur, habet a causante formam liberi arbitrii, qua vult secundum actum, aut libere potest velle, amoto impedimento quod est absentia obiecti. Et ipso facto praesente in intellectu per cognitionem, tunc libere vult, si illud sit finis simpliciter, vel potest libero arbitrio velle, si sit ad finem. Et quantum recipit homo de forma libertatis, tantum de potestate ad 
De fato, segundo o todo do universo, o homem é movido por Deus, assim como todo o restante da criação. Porém, diferentemente de todos os corpóreos mesmo aqueles orgânicos brutos -, o homem possui um apetite espiritual, nãoorgânico, que sabemos ser a vontade e que é o princípio de seu movimento. Enfim, o homem move a si mesmo livremente quanto ao fim e, quanto aos ad finem, livremente e por escolha - quanto ao fim, por vontade e, quanto aos ad finem, por livre-arbítrio, respectivamente. E isso ocorre, unicamente, porque Deus assim o fez. Isto é, o fez tal que mova a si mesmo livremente e por livre-arbítrio, deliberando pela razão (o que nem os brutos fazem no que diz respeito à liberdade, nem os anjos no que diz respeito à razão, como vimos). Pelo intelecto, é retirado qualquer impedimento para o agir e, pela vontade, se age - simples assim. E, se perguntarmos: por que o homem é livre? Respondemos: porque Deus assim o fez. Ou, o que é o mesmo: porque o homem é livre $^{67}$.

eliciendum actum volitionis. Propter quod volentes possunt dici moveri a Deo in omni actu volendi, dicente Anselmo: "Ille verius dicitur facere omne quod facit natura" etc. Postquam tamen homo habet a Deo sibi datam huiusmodi formam, potest movere secundum ipsam, cessante impedimento, absque eo quod ab alio moveatur, et sic a se ipso movetur primo, licet non secundum totum".

${ }^{67}$ A caracterização da vontade como uma potência fundamentalmente ativa e livre da alma humana resulta, na filosofia de Henrique de Gand, em um problema igualmente central, a saber, a impossibilidade de uma prova da existência de Deus a partir de uma cadeia causal de movimentos. De fato, em um mundo no qual todo agente intelectual é, em última instância, completamente livre e indeterminado (mesmo Deus determina a ação de anjos e homens somente na medida em que lhes fornece a vontade enquanto uma potência livre para a ação), o estabelecimento de uma cadeia causal de movimento, não obstante possa dar as bases para a afirmação de que todo movimento exige um primeiro motor, ainda assim não é suficiente para afirmar a necessidade e a unidade do primeiro agente. Com efeito, se levarmos a cabo a descrição da vontade que lemos no gandavense, qualquer agente intelectual pode ser tomado como o primeiro motor de uma cadeia de movimentos (sobre essa dificuldade, cf. TESKE, R. "Henry of Ghent's Rejection of the Principle...", 2012, pp. 39-40). Em outras palavras, argumentos que busquem conhecer Deus enquanto causa eficiente das criaturas e, em geral, argumentos que busquem conhecer Deus a partir das criaturas como um retorno do causado à causa são, necessariamente, falhos para o Doutor Solene - cf. Suma, art. 22, qq. 4-5 (ed. Teske \& Decorte, 2005, pp. 130-160); e TESKE, R. "Henry of Ghent's Criticism of the Aristotelian Arguments for God's Existence". In: TESKE, R. Essays on the Philosophy of Henry of Ghent, 2012, pp. 41-64. Por isso mesmo, encontramos no gandavense um segundo tipo de prova da existência da Deus que, ainda sendo dependente do conhecimento que possuímos das criaturas, elabora-se não a partir do conhecimento sensível do ser das criaturas, mas do conhecimento do seu ser essencial (aqui, como se vê, é pressuposta a distinção entre ser de essência e ser de existência, cujos traços gerais apresentamos em cap. 2, nota 95). Isso porque, segundo Henrique de Gand, a partir das criaturas podemos abstrair a noção do ser necessário, que não é senão Deus. Como vemos, não exigindo o discurso por uma cadeia causal de movimentos, essa prova (dita 'metafísica', 'a priori' ou, ainda, 'pela via das proposições universais' por Henrique) escapa à dificuldade imposta pela noção de vontade livre característica da filosofia do Doutor Solene. Com efeito, Teske parece propor que a exigência de uma tal prova por Henrique de Gand estaria relacionada justamente à sua concepção de vontade livre (TESKE, R. "Henry of Ghent's Rejection of the Principle...”, 2012, pp. 39-40). Para uma das descrições de tal prova, cf. o já citado Suma, art. 22, q. 5 (ed. Teske \& Decorte, pp. 148-160). Sobre essa última prova da existência de Deus e a maneira como Henrique a relaciona às provas pelos efeitos, cf.: DANIELS, A. 
Quellenbeiträge und Untersuchungen xur Geschichte der Gottesbeweise im dreizehnten Jahrhundert mit besonderer Berücksichtigung des Arguments im Prologion des hl. Anselm. Münster: Aschendorf, 1909, pp. 79-81, 122; PAULUS, J. "Henri de Gand et l'argument ontologique", 1935, pp. 265-323; CAFFARENA, Ser participado y ser subsistente..., 1958, pp. 215-44; PEGIS, A. "Toward a New Way to God: Henry of Ghent". Mediaeval Studies 30 (1968), pp. 226-247; PEGIS, A. "A New Way to God: Henry of Ghent II". Mediaeval Studies 31 (1969), pp. 93-116; PEGIS, A. "Four Medieval Ways to God". The Monist 54 (1970), pp. 317-58; PEGIS, A. "Henry of Ghent and the New Way to God III". Mediaeval Studies 33 (1971), pp. 158-179; BÉRUBÉ, C. "Henri de Gand et Matthieu d'Aquasparta interprètes de Bonaventure". Naturaleza y Gracia 21, 1-2 (1974), pp. 131-172 (esp. pp. 151-6); DUMONT, S. Henry of Ghent as a Source for John Duns Scotus's Proof for the Existence of God. Centre for Medieval Studies. A thesis submitted in conformity with the requirements for the Degree of Doctor of Philosophy in the University of Toronto, 1982; MACKEN, R. "The Metaphysical Proof for the Existence of God in the Philosophy of Henry of Ghent". Franziskanische Studien 68 (1986), pp. 247-260; ROHLS, J. Theologie und Metaphysik. Der ontologische Gottesbeweis und seine Kritiker. Gütersloh: Gerd Mohn, 1987, pp. 125-8; SORGE, Gnoseologia e teologia..., 1988, pp. 153-79; PORRO, Enrico di Gand, 1990; LATZER, M. "The Proofs of the Existence of God. Henry of Ghent and Duns Scotus as Precursors of Leibniz". The Modern Schoolman 74 (1997), pp. 143-60 (esp. pp. 147-55); BOULNOIS, O. Etre et représentation..., 1999, pp. 356-67; PICKAVÉ, Heinrich von Gent über Metaphysik..., 2007, pp. 315-47; CARVALHO, M. A. S. "O argumento antropológico. Henrique de Gand e Santo Anselmo. In memoriam intentionemque Raymundi Macken (†2008)". Philosophica 34 (2009), pp. 293-308; PICKAVÉ, M. "Henry of Ghent on Metaphysics", 2011, pp. 171-9; TESKE, R. "Henry of Ghent's Metaphysical Argument for the Existence of God". In: TESKE, R. Essays on the Philosophy of Henry of Ghent, 2012, pp. 65-91; TESKE, R. "Some aspects of Henry of Ghent's Debt to Avicenna's Metaphysics" 2012, pp. 119-126; TESKE, "Henry of Ghent on Anselm's Prologion Argument". In: TESKE, R. Essays on the Philosophy of Henry of Ghent, 2012, pp. 145-164; TESKE, R. "Augustine's Influence on the Philosophy of Henry of Ghent". TESKE, R. Essays on the Philosophy of Henry of Ghent, 2012, pp. 178-188; e WIELOCX, R. "Preuves physiques et preuve métaphysique de l'existence de Dieu: Henri de Gand en contexte historique". In: PÉREZ DE LABORDA, M. (ed.). Sapienza e libertà. Studi in onore del Prof. LLuís Clavell. Roma: Edizioni Santa Croce, 2012, pp. $457-$ 526. Sobre a relação entre a prova a priori da existência de Deus e outros temas da filosofia de Henrique de Gand (em particular, as noções de transcendente - isto é, 'intenções primeiras' - e 'ente'), cf. tb. as referências das notas 43 e 89.

No entanto, mesmo essa prova que traz consigo a afirmação da necessidade do ser de Deus não é suficiente para a afirmação da necessária unidade de Deus, que é provada por uma longa reflexão lida em Suma, art. 25 (ed. Teske, 2006, pp. 20-107), que parece (mas isso está longe de ser consenso) conter em si uma reformulação daquela mesma prova metafísica que encontramos em artigos anteriores. Essa retomada da prova 'pela via das proposições universais' - que ressurge em Suma, art. 25 , q. 3, co. (ed. Teske, 2006, pp. 80-100) - coloca o problema de compreender precisamente onde começa e onde termina a prova da existência de Deus em Henrique de Gand. Em outras palavras, é preciso saber se a existência de Deus já está estabelecida desde Suma, art. 22, quando soubemos que o ser de Deus é necessário, ou se essa necessidade só fica, de fato, garantida em Suma, art. 25, onde temos provada a unidade divina. Assim, Anton Pegis afirma que os artigos 22 e 25 funcionam como um todo e que, com efeito, o vigésimo-quinto artigo é aquele que contém os elementos centrais da prova da existência de Deus de Henrique de Gand, sendo os artigos anteriores uma preparação para ele - cf. "Henry of Ghent and the New Way to God III", 1971, pp.158-161. De sua parte, Pasquale Porro afirma que o art. 25 é somente um resultado ulterior da prova metafísica de Henrique, sendo os artigos 23 e 24 (sobre a quididade de Deus) muito mais importantes para a compreesão da prova (que se encontra, unicamente, no art. 22) do que a discussão sobre a unidade divina (cf. Enrico di Gand, 1990, p. 110). Da mesma maneira, Stephen Dumont se utiliza muito mais de Suma, art. 24, em sua descrição da prova metafísica do que do art. 25 (Henry of Ghent as a Source..., 1982, pp. 155-195) - de fato, como nota Teske, este último artigo pouco é mencionado no texto de Dumont (cf. TESKE, R. "Henry of Ghent's Metaphysical Argument...", 2012, pp. 65-67, onde Teske discorre resumidamente sobre as diferentes posições de comentadores acerca da prova metafísica da existência de Deus proposta por Henrique). Ainda com respeito a esse problema da localização da prova a priori da existência de Deus proposta por Henrique de Gand, Martin Pickavé avança a proposta de que não se pode, de fato, encontrá-la na obra do gandavense, porque tal prova jamais haveria sido completamente formulada: "Nach meiner Überzeugung sind sowohl Pegis' Suche in Artikel 25 der Summa als auch die Lokalisierung des Beweises in der Lehre von der quidditativen Gotteserkenntnis erfolglos, weil es in Heinrichs Summa schlichtweg keine Stelle gibt, wo Heinrich dem von Avicenna und ihm 
Assim, atingimos algum tipo de limite em nossa pesquisa, pois chegamos a algo para o qual não há razão senão o próprio fato de que assim é. Esse limite, como se pode notar, é a fundamental e perene ação volitiva do homem, pela qual este último é tomado enquanto ser ativamente direcionado para seu fim - a saber, para o bem último. Chegamos, de certo modo, ao ápice do homem - ao seu elemento mais ativo. E, no entanto, não é aqui que deveremos permanecer. Nem mesmo, como já disse antes, será meu objetivo retirar conclusões éticas dessa atividade fundamental desse homem que vimos ser um ponto mediano do universo. Pelo contrário, tendo atingido o cume da natureza humana, precisamos agora descer novamente a suas potências mais baixas e, em particular, àquela potência passiva que vimos ser, no homem, a base para a sua possibilitas sciendi large accepto, ou seja, as potências cognoscitivas e, em especial, a potência simpliciter passiva do intelecto. Portanto, sabendo que o intelecto enquanto potência fundamentalmente passiva da alma se opõe à vontade enquanto potência fundamentalmente ativa dessa mesma alma, podemos agora buscar compreender como essa atividade da alma faz do intelecto não somente algo passivo com respeito ao conhecimento, mas também algo que tende à operação de conhecer.

\subsection{O AMOR PELO CONHECIMENTO}

Recentemente, Anna Arezzo, Catherine König-Pralong e Juan Carlos Flores, retomando um tema já sublinhado por Christian Trottmann, chamaram atenção para a temática do amor pelo conhecimento na obra de Henrique de Gand e sua importância

\footnotetext{
beschriebenen wahrhaft metaphysischen Beweis zu einer wirklichen Formulierung verhilft. Was wir bei Heinrich finden, ist lediglich eine Verteidigung der Möglichkeit eines solchen Beweises <... >. Der Grund für dieses Fehlen liegt wahrscheinlich in Heinrichs Unvermögen, in Avicennas Werk den von diesem beschriebenen Beweis via propositionum universalium intelligibilium, welcher quasi von 'der Ursache zum Verursachten' fortschreitet, zu finden. Daher sah er sich auch nicht befähigt, eine genauere Beschreibung des Beweises zu geben" (PICKAVÉ, Heinrich von Gent über Metaphysik..., 2007, pp. 345-6 - grifo no original). Enfim, ainda que Henrique de Gand proponha uma prova da existência de Deus que parece contornar o problema posto pela liberdade da vontade para tal temática, não está claro em que parte de sua obra tal prova teria formulada em detalhes, nem mesmo se ela o foi. Para Olivier Boulnois, essa dificuldade na localização da prova anunciada por Henrique de Gand é um sintoma da distância existente entre o projeto de conhecimento de Deus proposto por Henrique e sua realização: "L'écart entre le programme et sa réalisation consiste plutôt en ce que la voie a priori n'établit pas l'existence de Dieu, mais simplement son unicité et son statut de nécessairement être, c'est-à-dire ce qu'établit Avicenne lui-même, tandis que l'existence est établie par l'entrecroisement de diverses voies philosophiques" (Métaphysiques rebelles. Genèse et structures d'une Science au Moyen Age. Paris: PUF, 2013, p. 255). Ainda sobre a relação entre as discussões sobre a existência de Deus e sobre a unidade divina, cf. RUDAVSKY, T. M. "A re-examination of Henry of Ghent's Criticisms in Light of his Predecessors”. The Modern Schoolman 82 (2005), pp. 101-9.
} 
para a compreensão de diferentes elementos do pensamento deste último ${ }^{68}$. Para eles, esse tema abre espaço para diversas considerações acerca da finalidade sobrenatural do homem tal como o gandavense a concebe. Porém, enquanto Arezzo, KönigPralong e Flores enfatizam o fim sobrenatural e divino a que o homem se vê direcionado por tal tendência ao conhecimento, Raymond Macken e Bernd Goehring sublinham que o ato de alcançar tal finalidade sobrenatural é descrito pelo Doutor Solene como a própria felicidade humana ${ }^{69}$. Em outras palavras, ambos deixam entrever que, se a temática da finalidade humana reclama um estudo do conhecimento intelectual, ela exige simultaneamente uma consideração do fim ético do homem e, assim, da vontade enquanto parte da realização dessa finalidade ${ }^{70}$. Pois bem, essa relação entre vontade e intelecto no direcionamento do homem ao conhecimento tomado como finalidade humana será justamente nosso tema no que resta do presente capítulo $^{71}$.

\footnotetext{
${ }^{68}$ Cf. TROTTMANN, Théologie et noétique au XIII siècle..., 1999, pp. 161-2; FLORES, J. C. "The Roots of Love of Wisdom: Henry of Ghent on Platonic and Aristotelian Forms". In: EMERY Jr., K. et al. (eds.). Philosophy and Theology in the Long Middle Ages. A Tribute to Stephen F. Brown. Leiden Boston: Brill, 2011, pp. 623-40; KÖNIG-PRALONG, C. "Le désir naturel de connaître. Autour des Questions métaphysiques attribuées à Gilles de Rome". In: CORDONIER, V., SUAREZ-NANI, T. (éds.). L'aristotelisme exposé, 2014, pp. 1-28; AREZZO, A. Lumen medium. Enrico di Gand e il dibattito sullo statuto scientifico della teologia. Bari: Edizioni di Pagina, 2014, pp. 60-9; e KÖNIGPRALONG, C. "Omnes homines natura scire desiderant. Anthropologie philosophique et distinction sociale". Quaestio 15 (2015), pp. 121-38. Cf. tb. CAFFARENA, J. G. "Metafísica de la inquietud humana en Enrique de Gante". In: L'homme et son destin d'après les penseurs du Moyen Âge. Louvain - Paris: Nauwelaerts - Béatrice-Nauwelaerts, 1960, pp. 629-34.

${ }^{69}$ MACKEN, R. "Deseo natural y vocación sobrenatural...", 1980, pp. 844-6; GOEHRING, B. Henry of Ghent on cognition and mental representation. A dissertation presented to the Faculty of the Graduate School of Cornell University in partial fulfillment of the requirement for the Degree of Doctor of Philosophy. August, 2006, pp. 39-42; e GOEHRING, B. "Henry of Ghent on Human Knowledge and Its Limits". Quaestio 12 (2012), pp. 589-613.

${ }^{70}$ Raymond Macken, com base em Suma, art. 4, q. 3, para o qual nos voltaremos a seguir, destaca justamente a relevância da vontade como fundamento da tendência humana para o conhecimento: "In seiner Summa, art. IV, schon hatte Heinrich, in der 3. Quästion das natürliche Verlangen des Meschen, zu wissen und immer mehr zu wissen, in den Willen verlegt, als die natürliche Folge der Potentialität des Verstandes im Willen" - "Lebensziel und Lebensglück...", 1979, p. 118. Posição semelhante pode ser lida em BÉRUBÉ, C. De l'homme à Dieu selon Duns Scot, Henri de Gand et Olivi. Roma: Edizioni Collegio S. Lorenzo, 1983, pp. 192-3. Cf. tb. TROTTMANN, C. La vision beatifique des disputes scolastiques à sa définition par Benoît XII. Rome: École Française de Rome, 1995, p. 351; TROTTMANN, C. "Henri de Gand, source de la dispute sur la vision réflexive". In: VANHAMEL, W. (ed.). Henry of Ghent. Proceedings..., 1996, pp. 309-42 (esp. pp. 310-2); HÖDL, L. "The Theologian Henry of Ghent", 2011, pp. 115-6.

${ }^{71}$ Tive a oportunidade de tratar alguns aspectos deste tema no já citado PAIVA, "Por uma ética do conhecimento...", 2015. Ainda sobre a finalidade do homem em Henrique de Gand, cf. RENAULT, L. "Félicité humaine et conception de la philosophie chez Henri de Gand, Duns Scot et Guillaume d'Ockham". In: AERTSEN, J. A., SPEER, A. (Hrsg.). Was ist Philosophie im Mittelalter? Akten des X. Internationalen Kongresses für mittelalterlichen Philosophie der SIEPM, 25. bis 30. August 1997 in Erfurt. Berlin - New York: De Gruyter, 1998, pp. 969-76 (esp. pp. 970-1).
} 
Até este ponto, pudemos ver que o homem surge no centro da hierarquia do universo como uma criatura potencial, que necessita de outros que não ele próprio para seu aperfeiçoamento. Em seu âmago, porém, há um princípio ativo que o leva a amar o bem último como fim e, por esse amor, o leva a buscar o conhecimento daquilo que o poderá levar a esse fim último, mais universal. Ora, essa busca é descrita por Henrique de Gand como uma investigação (investigare) acerca dos meios (ad finem) para tal fim - investigação essa que tem lugar na razão e, em geral, no intelecto $^{72}$. Lembremos, além disso, daquilo que Henrique de Gand dizia mais acima sobre o fim do intelecto: o 'verdadeiro' que está no próprio intelecto é um fim relativo, pois ele é somente um passo em direção ao fim da vontade que é aquele 'bem', que está para além dela própria e do próprio homem ${ }^{73}$. Agora está claro para nós que esse caráter intermediário do conhecimento intelectual do verdadeiro se deve a ele ser somente um único passo - necessário, mas não exclusivo - em direção ao ato volitivo que nos dirige ao bem. Em outras palavras, a vontade move o intelecto em direção ao fim deste último (o verdadeiro) para, por meio deste fim intermediário, atingir sua própria finalidade que é o bem. Assim, se há um amor pelo conhecimento isso se deve ao conhecimento ser um meio intelectual para a obtenção de um fim volitivo. Compreender isso deve passar, porém, por um retorno à noção de 'apetite' que, como vimos mais acima, acompanha diversas potências.

Com efeito, no homem, essa potência passiva intelectiva é, sempre, acompanhada por uma inclinação para seu aperfeiçoamento e, assim, para sua atualização própria. É precisamente essa inclinação volitiva para o aperfeiçoamento do intelecto, esse apetite pela atualização da potência intelectiva (ou, o que é o mesmo, daquela possibilidade de se ter ciência), que surge no homem como um amor pelo conhecimento, um apetite por se ter ciência - um appetitus sciendi. Esse 'apetite de se ter ciência' é detalhadamente estudado por Henrique de Gand em Suma, art. 4, e toda sua explicação desse tema pode, me parece, ser reduzida a uma única fórmula que surge ainda no início desse artigo: "o homem, pela vontade, tem apetite por ter ciência, mas segundo o intelecto [homo per voluntatem appetit scire, sed secundum intellectum] "74. Já vimos o quão complexa é essa relação entre intelecto e vontade.

\footnotetext{
${ }^{72}$ Cf. nota 60 , acima.

${ }^{73}$ Cf. acima, nota 28.

${ }^{74}$ Henrique de Gand, Suma, art. 4, q. 1, co. (ed. De Wulf-Mansion Centre, vol. 21, p. 271).
} 
Ela reaparece nesse contexto, principalmente a partir daquela distinção que nos foi apresentada entre a inclinação da vontade para o fim universal e a sua inclinação para os meios particulares ad finem. Agora, entretanto, esta última distinção surge precedida por outra, a saber, a distinção entre um 'apetite natural' (appetitus naturalis) e um 'apetite racional' (appetitus rationalis), pois "a vontade é tanto natureza, como razão [voluntas et est natura et est ratio]" ${ }^{, 75}$.

Essa última afirmação pode parecer desconcertante face a tudo o que lemos até agora e, para ser sincero, não tenho certeza de que a apresentação da potência volitiva que lemos no item anterior e esta última se encaixem completamente. Sendo assim, concentremo-nos primeiro no 'apetite natural', pelo qual a 'vontade é natureza': "algo tem apetite com apetite natural enquanto é natureza e, com tal $<$ apetite>, tem apetite por algo que totalmente não conheceu, pois o apetite natural, enquanto é da natureza da potência volitiva nua, não procede a partir de uma notícia do apetecente $<\ldots{ }^{»} 76$. Esse apetite natural, portanto, é anterior a todo conhecimento de fato, ele é uma inclinação do homem ao bem que, de alguma maneira, antecede qualquer conhecimento deste bem. Esse 'de alguma maneira' de minha frase anterior, aliás, não é gratuito, pois o próprio Henrique de Gand admite que há algo de misterioso nessa inclinação natural, pois tal apetite tem lugar por "algum instinto

\footnotetext{
${ }^{75}$ Henrique de Gand, Suma, art. 4, q. 1, ad 1 (ed. De Wulf-Mansion Centre, vol. 21, p. 271). Esse caráter ambíguo do 'apetite', que possui um aspecto natural e outro livre identificados de certo modo na unidade do homem, mas jamais completamente confundidos, é bem expresso em Quodl. 3, q. 14, co. (ed. 1642-6, f. 112vb): "Similiter in proposito dicendum, quod voluntas est potentia naturalis in anima, et non est nisi substantia animae, sed ex naturali determinatione, et respectu ad actum volendi bonum ut bonum, sive simpliciter sive apparens; quod necesse habet velle naturaliter, cum ei praesentetur in cognitione, licet non de necessitate velit hoc bonum vel illud, et cum bonum ut obiectum ei non praesentetur, velle secundum actum omnino non potest". Este último trecho é estudado em MACKEN, "La volonté...", 1975, pp. 29-30. Como se vê, a vontade naturalmente quer o bem, mas pode livremente escolher entre este bem e aquele bem - em qualquer caso, ela depende de que lhe seja apresentado pelo intelecto o bem acerca do qual ela agirá. Karl Werner relaciona essa vontade natural à lei natural (que vimos acima, na nota 55): "Die Voluntas naturalis steht bei Heinrich in einem wesentlichen Verhältniss zur Lex naturalis als Universalis regula operandorum, deren Kenntniss ein intellectiver Habitus des auf das Gute und auf das Endziel der menschlichen Handlungen gerichteten Denkens ist" (Heinrich von Gent als Repräsentant..., 1978, p. 49). Nesse caso, a vontade natural se confundiria com a sindérese. O problema é que, como veremos, aqui em Suma, art. 4, Henrique de Gand descreve o 'apetite natural' como anterior a todo conhecimento, enquanto que a sindérese, como vimos acima, justamente diz respeito ao bem último apresentado pelo intelecto.

${ }^{76}$ Henrique de Gand, Suma, art. 4, q. 1, ad 1 (ed. De Wulf-Mansion Centre, vol. 21, p. 271): "Unde aliquid appetit appetitu naturali, ut est natura, et tali appetit quod omnino non novit, quia appetitus naturalis ut est a natura potentiae volitivae nudae non procedit ex notitia aliqua in appetente $<\ldots$.." Sobre o 'apetite natural', cf. KÖNIG-PRALONG, "Le désir naturel de connaître...", 2014, pp. 18-23. Nesse artigo, a autora mostra como a formulação de Henrique da noção de 'apetite natural' exige uma doutrina da iluminação e redunda, ao fim, na afirmação da necessidade de uma teologia como complemento ao conhecimento filosófico. Sobre esse tema, cf. o Epílogo da parte 2 e a Conclusão.
} 
oculto da natureza [quodam occulto naturae instinctu]", pelo qual cada ente é direcionado determinadamente para seu fim ${ }^{77}$. Como, no entanto, poderíamos encaixar esse instinto originário no quadro da atividade volitiva que estabelecemos no item anterior?

A meu ver, esse 'apetite natural' é algo próximo daquele 'querer natural' a que Henrique de Gand se refere em Quodl. 3, q. 14. Porém, esse 'querer natural' (velle naturaliter) da vontade, pela qual esta última é direcionada para o bem em universal, depende ainda, se não da determinação do intelecto, pelo menos da apresentação do bem por este último ${ }^{78}$. De fato, toda a doutrina da vontade que estudamos até agora pressupõe o conhecimento (ainda que o mais geral possível) do verdadeiro pelo intelecto e a apresentação deste último como o bem em universal para a vontade. Essa noção de 'apetite natural' como 'instinto' que surge aqui, entretanto, parece ser independente até mesmo dessa ostensio do objeto pelo intelecto. Isto é, ela parece não depender do intelecto nem mesmo metaforicamente ou como causa sine qua non, pois ela é anterior a qualquer notitia. Tal independência radical dessa 'vontade enquanto natureza' com respeito ao intelecto fica clara pelas duas comparações que o Doutor Solene oferece como explicação para esse 'apetite natural': o homem tem o 'apetite natural' [i] assim como a matéria tem apetite pela (ou tende para a) forma ${ }^{79}$ e [ii] assim como a semente do trigo tende a germinar, gerando o trigo (ad pullulandum in triticum $)^{80}$. As duas comparações servem, como vemos, para afirmar que há esse mesmo 'apetite natural' em seres completamente alheios ao intelecto e à racionalidade, seja porque a matéria (mesmo na geração humana) antecede qualquer potência intelectiva, seja porque uma planta, como o trigo, naturalmente não possui potência intelectiva ou cognoscitiva. Enfim, temos aqui um apetite que antecede, enquanto instinto oculto e natural, qualquer ato da vontade que tenhamos visto até agora.

Dito isso, vale perguntar: já haveria um apetite pela ciência nesse apetite natural anterior a qualquer conhecimento? Para Henrique, a resposta é certamente sim, pois o homem, "naquele < apetite $>$ puramente natural, apetece naturalmente ter

\footnotetext{
${ }^{77}$ Henrique de Gand, Suma, art. 4, q. 3, co. (ed. De Wulf-Mansion Centre, vol. 21, p. 281).

${ }^{78} \mathrm{Cf}$. nota 75 , acima.

${ }^{79}$ Henrique de Gand, Suma, art. 4, q. 1, ad 1 (ed. De Wulf-Mansion Centre, vol. 21, p. 272) e q. 3, co. (ed. De Wulf-Mansion Centre, vol. 21, p. 281).

${ }^{80}$ Henrique de Gand, Suma, art. 4, q. 3, co. (ed. De Wulf-Mansion Centre, vol. 21, p. 281).
} 
ciência simplesmente, tal como, depois de recebido [adeptus] algum conhecimento imperfeito, apetece, pelo apetite cognitivo, ter ciência disto ou daquilo, enquanto tem uma notícia imperfeita disso ou daquilo, tal que a ciência imperfeita se aperfeiçoe nele" ${ }^{\nexists 1}$. Esse trecho é importante, em primeiro lugar, por mostrar como, de fato, há um apetite natural pela ciência, isto é, há na natureza do homem, para além da potencialidade, também uma inclinação para a ciência. Além disso, porém, é mostrado aqui que há uma clara passagem do apetite natural pela ciência para um apetite cognitivo (ou racional, para mantermos o vocabulário anterior de Henrique) pela ciência. O 'apetite natural' é aquela inclinação que o homem possui para a ciência antes mesmo de possuir qualquer conhecimento. Uma vez que tenha obtido algum conhecimento, entretanto, ele terá um apetite racional ou cognitivo (isto é, que já possui o intelecto como causa sine qua non, nos termos que estudamos há pouco) para aperfeiçoar esse conhecimento ainda imperfeito que ele possui. Ou seja, o apetite (seja natural ou racional) surge sempre como essa inclinação para a perfeição e para a completude. O apetite racional é a busca pelo aperfeiçoamento de um conhecimento ainda imperfeito e incompleto.

Mas e quanto ao apetite natural? Ele é a inclinação para o aperfeiçoamento do quê? Certamente, ele não será a tendência para o aperfeiçoamento de algum conhecimento, pois ele pressupõe que não há ainda algum conhecimento para ser aperfeiçoado. Com efeito, "não há nenhum conhecimento natural no homem [nulla cognitio naturalis est in homine]" ${ }^{\prime 82}$ ! Sendo assim, o que haveria de natural no intelecto por cujo aperfeiçoamento o homem poderia ter apetite? Em poucas palavras, somente a própria 'potência intelectiva', isto é, o próprio conhecimento ou a própria notícia, mas somente em potência - como é mostrado em Suma, art. 1, q. 11:

\begin{abstract}
"Notícia em potência é a notícia pela qual o homem é inato a ter ciência e conhecer [innatus est scire et nosse]. Ela é no 'judicatório natural' [naturali iudicatorio] existente na alma, que é em potência para se fazer tudo ao conhecer [ut fiat omnia in cognoscendo] <... > Porém, somente essa notícia em potência é inata para nós. Portanto, chamando de 'adquirido' [acquisitum] tudo o que sobrevém àquilo que é inato, toda notícia em hábito ou toda notícia em ato é adquirida" $" 83$
\end{abstract}

\footnotetext{
${ }^{81}$ Henrique de Gand, Suma, art. 4, q. 3, co. (ed. De Wulf-Mansion Centre, vol. 21, p. 281): “< ..> in ipso $<s c$. appetitu $>$ pure naturalis naturaliter appetit scire simpliciter, sicut post adeptam aliqualem cognitionem imperfectam appetitu cognitivo appetit scire hoc vel illud, secundum quod imperfectam habet notitiam huius vel illius, ut scientia imperfecta in ipso perficiatur".

${ }^{82}$ Henrique de Gand, Suma, art. 4, q. 3, co. (ed. De Wulf-Mansion Centre, vol. 21, p. 281).

${ }^{83}$ Henrique de Gand, Suma, art. 1, q. 11, co. (ed. De Wulf-Mansion Centre, vol. 21, pp. 178-179):
} 
Somente a potência para conhecer nos é dada por natureza. Sua atualização, por outro lado, deve ser adquirida - isto é, sobreveniente àquela potência natural primitiva. Essa potência para o conhecimento, como vemos, é descrita por uma expressão bem interessante: ela é um 'judicatório natural'. Ao que parece, Henrique quer, com isso, apontar para o fato de que essa potência inata para o conhecimento não diz respeito somente à capacidade de receber conhecimento de fora através dos sentidos, mas também de produzir juízos acerca dos conceitos adquiridos. De fato, se a potência para julgar nos é inata, os juízos são, eles também, adquiridos. Donde ser importante frisar, como ele faz ao fim do trecho destacado, que essa 'notícia em potência' é anterior não somente ao ato de conhecimento, mas também ao conhecimento em 'hábito' que, como veremos no capítulo 6, é algo que se segue à aquisição inicial do conhecimento intelectivo. Ou seja, essa notícia em potência que nos é inata é uma potência para receber conceitos incomplexos e para formular juízos. Nenhum deles está naturalmente em nosso intelecto, porém estamos naturalmente em potência para adquirir ambos. Retornamos aqui, portanto, àquela caracterização inicial do homem como pura potência passiva para a recepção daquilo, externo a si mesma, que a pode atualizar. Decerto, "aquilo que é somente em potência é simplesmente não ente [illud quod est solum in potentia simpliciter est non ens] ${ }^{84}$, porém, ainda que não seja ato, essa potência será uma tendência para a atualização daquilo que ela pode vir a ser, pois ela "inclina a alma, enquanto potência e uma força natural nela, para que tenda naturalmente a apreender o verdadeiro [inclinat animam tamquam naturalis potentia et vis in ipsa, ut naturaliter tendat ad apprehendendum verum]" ${ }^{\prime 85}$. Embora o intelecto enquanto potência para a intelecção não seja ainda o ato de conhecimento, ele é uma tendência para tal ato. Nesse sentido, ele já é conhecimento em potência e, mesmo que tal potência não seja ainda conhecimento

\footnotetext{
"Notitia in potentia est notitia qua homo innatus est scire et nosse; quae est in naturali iudicatorio existente in anima quae est in potentia ut fiat omnia in cognoscendo $<_{\ldots}$. . . Haec autem notitia in potentia sola nobis innata est. Appellando ergo acquisitum omne superveniens ei quod innatum est, omnis notitia in habitu et omnis notitia in actu acquisita est”. Sobre essa passagem, cf. BETTONI, E. Il processo astrattivo nella concezione di Enrico di Gand. Milano: Vita e Pensiero, 1954, pp. 12-3. Ainda sobre o caráter inato da potência para o conhecimento intelectual, cf. HUET, Recherches historiques et critiques..., 1838, pp. 128-9. Cf. tb., adiante, cap. 6, nota 29, onde Henrique busca defender tal tese com base em uma autoridade neotestamentária.

${ }^{84}$ Henrique de Gand, Suma, art. 1, q. 11, co. (ed. De Wulf-Mansion Centre, vol. 21, p. 179).

${ }^{85}$ Henrique de Gand, Suma, art. 1, q. 11, co. (ed. De Wulf-Mansion Centre, vol. 21, pp. 178-179).
} 
em ato, ela tende a adquirir seu aperfeiçoamento próprio. Sendo assim, aquela vontade natural primordial surge agora como um certo instinto pelo qual o homem (assim como qualquer outro ente) tende para a atualização e o aperfeiçoamento de sua potência (que não é, senão, sua própria atualização e aperfeiçoamento) - no seu caso, para a atualização e aperfeiçoamento de sua potência intelectiva.

Vimos há pouco, entretanto, que, após o recebimento de algum conhecimento mesmo que imperfeito, esse apetite natural dá lugar a um outro apetite que, não sendo mais esse instinto natural para o conhecimento em geral, aparece como um apetite pelo aperfeiçoamento daquele conhecimento ainda imperfeito que, agora, possuímos. Ainda em Suma, art. 1, q. 11, Henrique de Gand já elabora essa mesma tese, não obstante se utilize de um vocabulário ligeiramente distinto. Neste excerto, nosso autor argumenta que, quanto à seguinte afirmação:

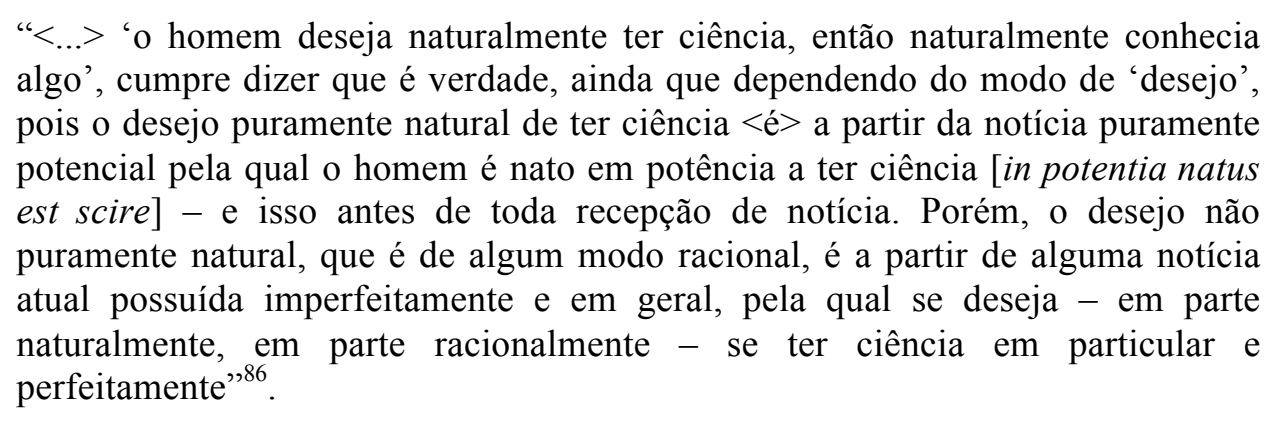

Como vemos, o 'desejo puramente natural de ter ciência' (desiderium sciendi naturale pure) se confunde com o 'apetite natural' que encontramos em Suma, art. 4. Por outro lado, o 'desejo não puramente natural, que é de algum modo racional' é aquele 'apetite racional' que lemos naquele mesmo quarto artigo da Suma. O interessante nessa formulação de Suma, art. 1, q. 11, é justamente chamar a atenção para o fato de que o apetite racional, ainda que seja antecedido e determinado por um conhecimento intelectual imperfeito, é ainda uma tendência natural para a aquisição de conhecimentos cada vez mais perfeitos. Ou seja, esse apetite pelo conhecimento que caracteriza o homem está sempre naturalmente presente nele e, se a razão faz algo quanto a esse desejo pela ciência, é simplesmente determinar, como causa sine qua

\footnotetext{
${ }^{86}$ Henrique de Gand, Suma, art. 1, q. 11, ad 3 (ed. De Wulf-Mansion Centre, vol. 21, pp. 183-184): "Quod arguitur in oppositum, quod homo naturaliter scire desiderat, ergo naturaliter novit aliquid, dicendum quod verum est, secundum modum tamen desiderii, quia desiderium sciendi naturale pure ex notitia potentiali pure qua homo in potentia natus est scire, et hoc ante omnem receptionem notitiae; desiderium autem naturale non pure, quod est quodammodo rationale, est ex aliqua actuali notitia habita imperfecte et in generali, qua desideratur partim naturaliter partim rationaliter sciri in particulari et perfecte, ut patet ex praedeterminatis".
} 
non, aquilo que desejamos (pela vontade) conhecer mais perfeitamente do que já conhecemos.

Essa determinação do apetite pela apresentação de um objeto à vontade pelo intelecto é importante, porque, muito embora o homem deseje por natureza conhecer tudo - e, de fato, esteja igualmente em potência com respeito a todos os cognoscíveis -, ele não pode se voltar em ato para tudo o que se pode conhecer. Assim, se o homem deseja naturalmente conhecer tudo, isso será ou [i] na medida em que é igualmente potencial com respeito a tudo aquilo de que se pode ter ciência (e, assim, possui um apetite natural indistinto e universal com respeito a todos) ou [ii] porque tem um apetite racional (ou seja, aquele desejo em parte natural e em parte racional) indistinto e universal por conhecer algo universal que contém todos sob si. Em ambos os casos, como se vê, o que está em jogo é um conhecimento universal e indistinto seja porque puramente potencial, seja porque sumamente geral. Porém, no que diz respeito a um apetite não universal e indistinto, mas distinto e em particular (distincto et in particulare), não há lugar para um apetite por conhecer tudo, pois sempre o conhecimento - e, portanto, o desejo pelo conhecimento - se voltará para um cognoscível distinto de cada $v e z^{87}$. Com efeito, vimos acima - no estudo da hierarquia dos seres intelectuais -, que o homem, além de discorrer racionalmente pelo conhecimento, só pode se voltar para um cognoscível por vez.

Resumindo, o 'apetite natural' (ou 'desejo puramente natural') é um apetite maximamente indistinto e universal, pois ele é o instinto natural pelo qual tendemos a atualizar nossa potência intelectiva, que naturalmente é pura potência. Já o 'apetite racional' (ou 'desejo em parte natural e em parte racional') é um apetite pelo aperfeiçoamento de um conhecimento que já possuímos imperfeitamente. Se esse conhecimento for universal e indistinto (quiçá, como o conhecimento de um conceito muito geral), ele será um apetite pelo conhecimento mais perfeito de muitos sob uma única notícia; se, por outro lado, esse conhecimento for distinto e em particular, ele será um apetite pelo conhecimento mais perfeito de um único. Em qualquer dos casos, vemos que há um fundamento na natureza para essa tendência ao aperfeiçoamento seja este último a primeira aquisição de conhecimento ou o aperfeiçoamento de um conhecimento já adquirido. Destarte, a tendência para o conhecimento é da natureza humana (é um apetite natural); porém, uma vez que haja algum conhecimento no

\footnotetext{
${ }^{87}$ Henrique de Gand, Suma, art. 4, q. 6, co., ad 1 (ed. De Wulf-Mansion Centre, vol. 21, pp. 298-9).
} 
homem, essa tendência (agora, um apetite racional) acaba por se determinar a partir desse mesmo conhecimento. Como líamos no item anterior, até mesmo no próprio querer conhecer, a vontade, determinada por si mesma e recebendo do intelecto somente a apresentação de um objeto, move a potência intelectiva para o conhecimento. Assim, em todas as etapas do conhecimento intelectivo - desde o mais geral ao mais particular - temos a vontade como potência que impele o intelecto a seu ato de conhecimento.

Mas, ela move o intelecto para o conhecimento do quê? Disso que acabamos de ver: conceitos mais gerais universais e indistintos ou conceitos mais particulares e distintos - isto é, em geral, para algum conhecimento. E, por que ela o faz? Já vimos acima que unicamente pelo conhecimento chegamos aos meios ad finem, que levarão ao fim desejado mais ardentemente pela vontade, isto é, aquele bem em si mesmo, mais universal. Nesse ponto, entretanto, começamos a deixar o campo do 'apetite natural', pois este último não pressupõe qualquer conhecimento, enquanto que aquele apetite pelo qual a vontade quer o bem em universal é antecedido pelo conhecimento do verdadeiro e pela apresentação deste último enquanto bem para a vontade. Ou seja, esse apetite pelo qual a vontade quer o bem final já é um 'apetite racional' - uma expressão que já encontramos, aliás, em Suma, art. $45^{88}$. Assim, o apetite natural nos leva ao conhecimento de algo, porém a partir daqui já estamos em um campo de racionalidade pelo qual tendemos àquele 'verdadeiro'/'bem' último. Como um conhecimento qualquer pode nos levar ao desejo pelo verdadeiro e pelo bem é uma pergunta de enorme importância. Não poderemos aqui abordá-la com a devida atenção, de maneira que me contento em notar que, se tudo o que o intelecto conhece é conhecido por ele como algo verdadeiro e apresentado para a vontade como algo bom, então em qualquer intelecção há um conhecimento do verdadeiro, que é o bem para a vontade. Assim, de alguma maneira, 'neste verdadeiro' e 'naquele verdadeiro' conhecemos 'o verdadeiro' mais universal, tal como 'neste bem' e 'naquele bem' queremos 'o bem' mais universal ${ }^{89}$. Enfim, após termos adquirido algum

\footnotetext{
${ }^{88}$ Cf. nota 40 , acima.

${ }^{89}$ Henrique de Gand, Suma, art. 24, q. 6, co. (ed. Decorte \& Teske, pp. 232-4): “< $<>$ generalissime, et modo summe confuso intelligimus quiditatem Dei in suis attributis, intelligendo id quod est excellentiae et dignitatis in creatura. Et est iste modus cognoscendi divinam essentiam quid sit, ille de quo loquitur Augustinus octavo De trinitate cum dicit: 'Cum audis bonum hoc et bonum illud, quae possunt alias dici etiam non bona, si potueris, sine illis quae participatione bona sunt', percipe 'ipsum bonum cuius participatione bona sunt. Simul enim et ipsum intelligis cum audis hoc aut illud bonum. Si ergo potueris illis detractis per seipsum perspicere bonum, perspexeris Deum'. Vide ergo ex dictis
} 
Augustini, quod contingit bonum intelligere tripliciter: ut iste primus modus tres gradus in se habeat et quolibet illorum intelligere Deum. Uno modo intelligendo hoc bonum et hoc summe indistincte a creatura. Dicendo enim hoc bonum duo dico et quia bonum et quia hoc. Quod dicitur hoc, hoc est creatura; quod dicitur bonum, hoc est commune creatori et creaturae. A quo si substraxeris hoc et illud, est secundus modus intelligendi bonum, scilicet, minus contractum ad creaturam quam prius, et est commune analogum ad Deum et creaturam, et est de primis intentionibus quae per se et primo concipit intellectus de rebus, ut sunt unum et ens". Nesse trecho, Henrique de Gand descreve como ocorre o conhecimento de Deus, no estado presente, 'o mais em geral' (generalissime). De saída, tal conhecimento é descrito como uma intelecção sumamente confusa (modo summe confuso) da quididade de Deus - não precisamente de tal quididade, mas de seus atributos. Esses atributos, nesse contexto, se confudem com aquelas intenções mais gerais que inteligemos em todo objeto e que vimos serem os transcendentes ou intenções primeiras (cf. nota 43, acima). Ou seja, tal conhecimento generalissime de Deus diz respeito não somente às intenções de 'ente' ou 'uno' como destacado na passagem citada aqui, mas também às demais intenções primeiras: “< ..> ens, bonum, unum, verum, pulchrum, et cetera huiusmodi, quae secundum aliquam rationem analogiae sunt communia creatori et creaturae <...>" - Suma, art. 24, q. 6, co. (ed. Decorte \& Teske, p. 228). Entretanto, tal afirmação é complexificada, na passagem inicial desta nota, pela distinção dos três modos pelos quais se conhece Deus generalissime. Além disso, o conhecimento generalissime de Deus é somente um de três possíveis conhecimentos de Deus por seus atributos nesta vida. Vale a pena considerá-los cuidadosamente, pois somente por meio dessa consideração podemos corretamente compreender em que sentido qualquer conhecimento intelectivo contém já em si o conhecimento das intenções primeiras (em particular, de 'bem' e 'verdadeiro', as inteções que mais nos importam neste momento).

Primeiramente, no mesmo Suma, art. 24, q. 6, o Doutor Solene distingue três conhecimentos de Deus possíveis na vida presente: [1] 'em geral' (generaliter), [2] 'mais em geral' (generalius) e [3] 'o mais em geral' (generalissime) - "Et sic in eis quodammodo cognosci potest a nobis quid est Deus per creaturas, et hoc in triplici gradu: primo generaliter, secundo generalius, tertio generalissime" (ed. Decorte \& Teske, p. 232). Em sua exposição, porém, ele segue o caminho inverso, pois parte do mais confuso, que é o conhecimento generalissime, como vimos. Pois bem, se voltarmos à citação inicial da nota, percebemos que, como era dito, esse conhecimento [3] generalissime se distingue em três graus, com base na autoridade de Agostinho. Assim, [3.1] ao se inteligir 'este bem e aquele bem', intelige-se Deus de maneira sumamente indistinta das criaturas, pois nessa expressão 'este' e 'aquele' dizem as criaturas e 'bem' diz algo comum a Deus e às criaturas. Como vemos, já no grau sumamente confuso e indistinto de conhecimento, temos algum conhecimento de Deus em seus atributos. Continuando, [3.2] se retirarmos 'este' e 'aquele', ficamos somente com 'bem', que - sem estar contraído a 'este' e 'aquele' - é um conceito transcendente análogo a Deus e às criaturas (sobre a analogia dos transcendentes, cf. novamente a nota 43). Por fim (e aqui já avançamos além do trecho destacado ao início da nota), [3.3] podemos agora conceber esse 'bem' como subsistente e não participado, mas no qual os outros participam; nesse caso, já inteligimos o 'bem' como um atributo de Deus enquanto distinto da criatura - "Et sic isto modo adhuc intelligit bonitatem Dei quae est eius quiditas modo confuso et indistincto a bono creaturae. Quod si potueris distinguere unum ab altero, intelligendo bonum ut subsistens et non in altero existens, non tamquam bonum participatum, sed tanquam alterum a bonis quae sunt participatione bona, tanquam illud cuius participatione caetera sunt bona, iste est tertius modus intelligendi bonum, scilicet, omnino abstractum a bono creaturae, quod est bonum solius creatoris, quo perspecto magis de propre perspicitur Deus, ut dicit Augustinus" (ed. Decorte \& Teske, p. 234). Um conhecimento menos geral - mesmo que ainda geral - de Deus é o conhecimento [2] generalius. Temos este último quando concebemos aquele 'bem' não somente enquanto subsistente, mas enquanto 'preeminente' - 'Secundo modo, scilicet, generalius, sed non generalissime, cognoscit homo quid sit Deus, intelligendo Deum in suis generalibus attributis, non simpliciter et absolute intellectis, ut in modo praecedenti, sed sub quadam praeeminentia ut, scilicet, est quaedam natura excelentissima <... ” (p. 234). Por fim, pode-se dar ainda mais um passo e possuir um conhecimento generaliter acerca de Deus, concebendo todos esses atributos divinos como uma única essência simples idêntica a seu próprio ser ou existência - "Tertio modo, generali, scilicet, cognoscit homo quid sit Deus, non solum in suis generalibus attributis, reducendo quicquid dignitatis et nobilitatis est in creaturis in Deum simpliciter, ut in primo modo, neque sub quadam excellentia reducendo quicquid dignitatis et nobilitatis est in creaturis in Deum in excellentia, ut in secundo modo, sed cognoscendo quid sit in eius primo atributo simplicissimo, reducendo, scilicet, omnia nobilitatis et dignitatis atributa eius in unum primum simplicissimum, scilicet, per intellectum quia quicquid in ipso est sit eius essentia, et quod eius essentia nihil omnino sit aliud re vel intentione quam eius esse sive existentia" ( $p$. 238). 
conhecimento o mais imperfeito, saímos do campo do apetite natural e chegamos ao

Dito isso, o ponto a ser frisado aqui é não tanto o conhecimento de Deus, mas principalmente o fato de que esse processo é igualmente válido para todas as intenções primeiras (ou transcendentes) enumeradas por Henrique de Gand, de maneira que todo nosso conhecimento - seja ele da criatura mais material ou do conceito mais particular - já contém em si um conhecimento dos conceitos mais gerais (ente, uno, verdadeiro, bem etc.) e, portanto, também do próprio Deus. É justamente esse passo de sua argumentação que leva o gandavense a formular a tese segundo a qual Deus seria o primum cognitum de todo conhecimento humano. E isso não somente no que diz respeito aos conhecimentos mais próprios acerca de Deus a que temos acesso (como o generalius ou o generaliter), mas principalmente no que tange àquele conhecimento generalissime, dito modo summe confuso, mesmo em seus graus mais indistintos: "Absolute ergo dicendum quod in generalissimo modo intelligendi quid est Deus, quoad primum et secundum eius gradum, quid est Deus est primum obiectum quod ab humano intellectu ex creaturis habet intelligi, ut nihil possit cognosci in creaturis et ex creaturis, quia verum, bonum, pulchrum, iustum, ens, unum, aut aliquid huiusmodi determinatum existens per materiam, aut per suppositum, nisi naturaliter prius, licet quandoque simul duratione, cognito eo quod est simpliciter et indeterminatum verum, bonum, pulchrum, ens, unum, et huiusmodi, ut, scilicet, in ipso Deo sit principium et finis nostrae cognitionis: principium quoad eius cognitionem generalissimam, finis quoad eius nudam visionem particularem, ut sic sit principium et finis omnium rerum in esse cognitivo, sicut est principium et finis earum in esse naturae" - Suma, art. 24, q. 7, co. (ed. Decorte \& Teske, p. 248). Enfim, a nossa afirmação que deu a origem a essa nota (a saber, que no conhecimento de um bem ou verdadeiro mais particular já há um conhecimento do bem ou do verdadeiro mais universal) é justificada por Henrique de Gand a partir de sua concepção de Deus como primeiro conhecimento (ainda que de maneira maximamente confusa e indistinta com respeito às criaturas) do intelecto humano.

Sobre o trecho de Suma, art. 24, q. 6, aqui estudado e sobre Deus como primum cognitum em Henrique de Gand, cf. DANIELS, A. Quellenbeiträge und Untersuchungen..., 1909, pp. 148-53; PAULUS, "Henri de Gand et l'argument ontologique", 1935, pp. 281-97; e 321; PAULUS, Henri de Gand..., 1938, pp. 61-66; BARTH, T. "De tribus viis diversis existentiam divinam attingendi. Disquisitio histórico-collativa inter S. Thomam, Henricum Gandavensem, Duns Scotum”. Antonianum 18 (1943), pp. 91-117 (esp. pp. 96-106); CAFFARENA, Ser participado y ser subsistente..., 1958, pp. 203-9; BÉRUBÉ, De l'homme à Dieu..., 1983, pp. 191-4 e 231-4; MARRONE, S. P. "Matthew of Aquasparta, Henry of Ghent, and Augustinian Epistemology after Bonaventure". Franziskanische Studien 65 (1983), pp. 252-90 (esp. pp. 278-85); MACKEN, R. "God as primum cognitum in the Philosophy of Henry of Ghent". Franziskanische Studien 66 (1984), pp. 309-15; LAARMANN, M. "God as primum cognitum. Some Remarks..., 1996, pp. 171-91; GORIS, W. "Die Kritik des Bernhard von Trilia an der Lehre von Gott als Ersterkanntem". Recherches de théologie et philosophie médiévales 65.2 (1998), pp. 248-319 (esp. pp. 258-66); LAARMANN, Deus, primum cognitum, 1999, pp. 235-36; MARRONE, The Light of Thy Countenance..., 2001, vol. 2, pp. 299-334; PICKAVÉ, M. "Heinrich von Gent über das Subjekt der Metaphysik als Ersterkanntes". Documenti e studi sulla tradizione filosofica medievale 12 (2001), pp. 493-522 (esp. pp. 517-21); GORIS, W. "Heinrich von Gent und der mittelalterliche Vorstoß zu einem Ausgand vom Unbedingten”. In: GULDENTOPS, G., STEEL, C. (eds.), Henry of Ghent and the Transformation..., 2003, pp. 61-74; KOBUSCH, T. "Gott und die Transzendentalien: Von der Erkenntnis des Inklusiven, Impliziten, Konfusen und Unbewußten" In: PICKAVÉ, M. (Hrsg.). Die Logik der Transzendentalen. Festschrift für Jan A. Aertsen zum 65. Geburtstag. Berlin - New York: Walter de Gruyter, 2003, pp. 421-32; GORIS, W. Absolute beginners. Der mittelalterliche Beitrag zu einem Ausgang vom Unbedingten. Leinden Boston: Brill, 2007 (passim); PICKAVÉ, Heinrich von Gent über Metaphysik..., 2007, pp. 129-81; GUERIZOLI, "Sobre a refundação tardomedieval da metafísica...", 2010; KOBUSCH, T. "Der neue Weg der Metaphysik: Heinrich von Gent, Meister Eckhart, Duns Scotus”. In: HONNEFELDER, L. et al. Johannes Duns Scotus 1308-2008. Die philosophischen Perspektiven seines Werkes / Investigations into his Philosophy. Proceedings of 'The Quadruple Congress' on John Duns Scotus. Part 3. St. Boanventure - Münster: Franscican Institute Publications - Aschendorff, 2010, pp. 125-38 (Archa Verbi 5) [trad. para o português de R. H. Pich em: Veritas 53.3 (2008), pp. 59-73]; GORIS, W. "TwoStaged Doctrines of God as First Known and the Transformation of the Concept of Reality in Bonaventure and Henry of Ghent". American Catholic Philosophical Quarterly 85.1 (2011), pp. 77-97 (esp. pp. 89-93); PICKAVÉ, "Henry of Ghent on Metaphysics", 2011, pp. 159-66; TESKE, R. "Augustinian Abstraction and Henry of Ghent's Metaphysical Argument". In: SALAS, V. M. (ed.). Hircocervi \& Other Metaphysical Wonders. Milwaukee: Marquette University Press, 2013, pp. 309-28. 
âmbito do apetite racional (em parte natural, é verdade) que nos dirige para o bem último.

Ora, se bem nos lembramos, esse apetite racional será sempre uma busca pelo aperfeiçoamento de um conhecimento já adquirido, mas ainda imperfeito - e esse desejo diz respeito não somente a conceitos mais distintos e particulares, mas também àqueles conceitos mais gerais, universais e indistintos. Dentre estes últimos, é claro, está aquele conceito do 'bem em universal'. Ao que parece, portanto, a vontade move o intelecto a conhecer os meios ad finem - que o intelecto atinge como conhecimentos verdadeiros - para, ao fim, atingir por si própria o bem supremo, conhecido pelo intelecto como aquilo sumamente verdadeiro. Do ponto de vista do indivíduo que conhece e quer, isso parece significar que, pela vontade, ele quer conhecer não com vistas simplesmente a possuir conhecimento, mas a aprender o caminho para o fim último que é o bem e, de fato, terminar por se tornar esse bem mesmo - pois, lembremos, a vontade se lança em direção a seu objeto e se torna ele. Ora, se a vontade só pode chegar ao bem último almejado pelo conhecimento do verdadeiro um conhecimento que é, ele próprio, um meio para o fim que é o bem maximamente amado pela vontade -, resta que a vontade leve o intelecto a conhecer não tudo o que é verdadeiro indistintamente, mas principalmente a suma e perfeita verdade, com respeito à qual todos os outros conhecimentos verdadeiros são somente meios ad finem:

\begin{abstract}
"Pois, já que é impossível que um apetite corra se estendendo ao infinito ou sempre aspirando ao completo sem, porém, nunca se completar, é necessário propor que, em algum momento [aliquando], atinja aquele sumo inteligível, inteligindo $<-0>-$ se proceder na ordem correta e racionalmente [si recto ordine et rationabiliter procedat]. Este, porém, não é senão um, a saber, a primeira e suma verdade, causa de tudo, não causada, que é Deus. 'Somente ele pode tornar repletos nosso desejo no que é bom' <cf. Sl 102,5>; dele diz Agostinho, Sobre a Cidade de Deus 19: 'Dizemos ser o fim do homem. Não que se consume tal que não seja, mas que se aperfeiçoe tal que seja mais plenamente'. Sem ele, porém, não pode fazer-se mais pleno - aquilo que é capacidade do maior não pode se tornar repleto [repleri] pelo menor. Portanto, cumpre dizer absolutamente que há um de que se pode ter ciência [unum est scibile], cuja ciência o homem apetece ter principalmente: ele é a primeira e suma verdade" ${ }^{90}$.
\end{abstract}

\footnotetext{
${ }^{90}$ Henrique de Gand, Suma, art. 4, q. 8, co. (ed. De Wulf-Mansion Centre, vol. 21, p. 308): “Quare cum impossibile est ullum appetitum currere in infinitum extendendo se vel semper anhelando ad completum, et tamen numquam compleatur, necesse est ponere quod illud summum intelligibile intelligendo aliquando attingat, si recto ordine et rationabiliter procedat. Hoc autem non est nisi unum, scilicet prima et summa veritas, causa omnium, non causata, quae Deus est, 'qui solus potest in bonis replere desiderium nostrum' <cf. Sl 102,5>, de quo dicit Augustinus XIX ${ }^{\circ}$ De civitate Dei: 'Finem hominis dicimus, non quod consumatur ut non sit, sed quod perficiatur ut plenius sit'. Sine illo autem plenus fieri non potest; quod enim capax est maioris minori repleri non potest. Absolute igitur est
} 
Porém, sabemos que o próprio conhecimento da verdade - mesmo dessa suma e perfeita verdade - não é mais do que um meio ad finem, isto é, meio para se atingir o sumo bem pela vontade. Agora vemos, portanto, que cabe à vontade colocar em ação o intelecto porque é somente pelo ato deste último que ela pode atingir o seu fim último que é a união com o sumo bem, conhecido pelo intelecto como a suprema verdade.

Dessa maneira, se o caminho do homem em direção a seu fim último culmina na união da vontade com o sumo bem, esse caminho necessariamente passa pelo apetite do conhecimento verdadeiro e, portanto, pelo próprio conhecimento verdadeiro, isto é, pela atualização daquela possibilidade de se ter ciência que vimos ser a própria potência do homem para o conhecimento sensitivo e, principalmente, para o conhecimento intelectual que se obtém a partir do sensitivo. Por outro lado, ainda que a vontade coloque em atividade todo esse percurso desde a pura potência para o conhecimento até o amor pelo sumo bem, pode-se dizer que o conhecimento em ato dessa verdade suprema é um momento-chave da atualização da alma humana e do homem como um todo. De fato, essa contemplação de Deus é a mais alta intelecção a que a alma humana pode chegar e, se a vontade contribui para esse caminho, é por sempre manter intacto aquele desejo, primeiro natural e depois racional, por conhecimentos cada vez mais perfeitos e mais altos (lembremos, aliás, que ela poderia ter se desviado desse caminho a qualquer momento, pois, literalmente, bastava querer fazê-lo). A vontade impõe esse percurso ao intelecto justamente porque ele é capaz de atingir o conhecimento da suma verdade que é fim próprio do intelecto:

\footnotetext{
"Porém, o homem é ordenado para contemplar a Deus [ordinatur ad speculandum Deum], tal como a uma operação melhor e mais perfeita acerca do contemplável melhor e mais perfeito, pois em tal operação consiste a sua beatitude final, segundo o Filósofo, em Ética 10. Pelo que, também, Agostinho determina, em Sobre a Trindade 14, no princípio, que a alma não é dita imagem de Deus ao ser capaz (por inteligência, memória e vontade) de si mesma ou de alguma coisa mutável, mas ao ser capaz do próprio Deus [ex eo quod ipsius Dei capax est]. Porém, essa contemplação não é acerca de Deus, senão enquanto Deus é objeto de conhecimento intelectual. Porém, o objeto do conhecimento intelectual acerca de algo não é, senão, o que é nele [quod quid est in eo]. Portanto, Deus, segundo sua essência e o que é nele, é o objeto de contemplação
}

dicendum quod unum est scibile quod homo principaliter scire appetit, quod est prima et summa veritas". 
e de operação intelectual no homem ao qual <este> é ordenado. Portanto, o homem deve possuir em si um instrumento [organum] pelo qual possa proceder à contemplação da essência e da quididade de Deus pela operação intelectual. De outra maneira [aliter], ele seria em vão [ipse esset frustra]. Porém, aquele instrumento [organum] não é, senão, a potência intelectual nele, pela qual pode conhecer a quididade e a essência de Deus

Portanto, cumpre conceder absolutamente que a quididade e essência de Deus é cognoscível pelo homem, não somente no futuro (do que unicamente parece convencer a declaração acima), mas também no presente" ${ }^{\text {911 }}$.

Entrentanto, essa contemplação da suma verdade apresentada como fim do intelecto não é senão um meio ad finem para o homem todo, pois a operação suprema deste último é aquela pela qual a vontade ama seu objeto supremo, o que não é senão a própria beatitude:

\begin{abstract}
“ $<\ldots>$ a vontade, por seu ato, alcança [adipiscitur] muito mais perfeitamente o fim do que o intelecto. E, ainda que o intelecto de algum modo o alcance, isso não é sob a razão de fim e beatificante - tal como a vontade o alcança -, mas somente sob a razão de forma e como complemento da beatitude que o dispõe devido àquilo que é, tal como a forma da casa, devido à sua habitação",92.
\end{abstract}

Ora, o intelecto é parte necessária da beatitude - ele é disposto ao conhecimento do fim supremo e se realiza por tal ato (como a casa é feita de tal modo a permitir sua habitação). No entanto, a própria beatitude não consiste unicamente no

\footnotetext{
${ }^{91}$ Henrique de Gand, Suma, art. 24, q. 1, co. (ed. Decorte \& Teske, 2005, pp. 180-182): "Homo autem ordinatur ad speculandum Deum, tamquam ad eius operationem optimam et perfectissimam circa optimum et perfectissimum speculabile, quia in tali operatione consistit eius finalis beatitudo, secundum Philosophum in decimo Ethicorum. Propter quod etiam determinat Augustinus decimo quarto De trinitate in principio quod non dicitur anima imago Dei ex eo quod capax est per intelligentiam, memoriam, et voluntatem sui ipsius aut alicuius rei mutabilis, sed ex eo quod ipsius Dei capax est. Speculatio autem talis non est circa Deum nisi in quantum Deus est obiectum intellectualis cognitionis. Obiectum autem intellectualis cognitionis circa quodcumque, non est nisi quod quid est in eo. Ergo, Deus secundum suam essentiam et quod quid est in eo est obiectum speculationis et intellectualis operationis in homine ad quam ordinatur. Debet igitur homo habere in se organum per quod potest in speculationem essentiae et quiditatis Dei per intellectualem operationem procedere. Aliter enim ipse esset frustra. Illud autem organum non est nisi potentia intellectualis in eo per quam quiditatem et essentiam Dei potest cognoscere. Absolute ergo concedendum quod quiditas Dei et essentia ab homine est cognoscibilis, non solum in futuro, quod solum videtur convincere declaratio habita, sed et in praesenti". Esse trecho é estudado em GOEHRING, B. Henry of Ghent on cognition, 2006, pp. 40-42. A esse excerto, Henrique acrescenta: "Monstrat autem possibilitatem cognoscendi ipsum desiderium naturale sciendi verum, quod cessare non potest quousque deveniat in cognitionem perfectam primi veri, ut dictum est supra, cuius cognitionem perfectam nullo modo in praesenti desideraret nisi aliquo modo etiam in praesenti perciperet, ut iam dictum est" - Suma, art. 24, q. 1, co. (ed. Decorte \& Teske, 2005, p. 182). Sobre o conhecimento de Deus no presente, cf. as notas 67 e 89, acima. Ainda sobre o conhecimento do beato, cf. o item 6.3.2.

${ }^{92}$ Henrique de Gand, Suma, art. 49, q. 6, co. (ed. De Wulf-Mansion Centre, vol. 30, p. 141): "Patet igitur ex dictis quod multo perfectius adipiscitur finem voluntas actu suo quam intellectus; et etiam quod licet ipsum intellectus aliquo modo adipiscatur, hoc non est sub ratione finis et beatificantis, sicut ipsum adipiscitur voluntas, sed solum sub ratione formae et ad complementum beatitudinis disponentis propter quam est, quemadmodum forma domus propter eius inhabitationem".
} 
conhecimento do fim, mas antes deve ser uma transformação naquele fim, o que é possível somente pela vontade, por meio da qual aquele que quer algo se transfere àquilo que é querido ${ }^{93}$ :

“ $<\ldots>$ o apetite não cessa sem que a vontade, por seu ato, alcance mais perfeitamente o fim do que fora alcançado pelo intelecto. Donde também o apetite precedente ter sido mais principalmente do fim tal que fosse um objeto em que se transformasse a vontade, do que tal que fosse um objeto pelo qual se informasse o intelecto; igualmente, mais principalmente era do próprio ato da vontade tal que amasse o bem perfeitamente, do que do intelecto tal que perfeitamente conhecesse o verdadeiro. De fato, sempre uma potência mais principalmente apetece o aperfeiçoar a si em seu próprio ato do que a outra no ato seu. Assim, já que é uma mesma a razão do fim, do apetecível e, por consequência, do beatificante enquanto fim, então o beatificante enquanto objeto é, principalmente, o bem sob a razão de bem, tal como o fim sob o fim é o verdadeiro sob a razão de verdadeiro objetivamente. Também, o beatificante e o fim enquanto ato é principalmente o ato da vontade, enquanto o fim sob fim é o ato do intelecto. E, assim, a beatitude é na vontade de maneira mais completamente principal do que no intelecto" $"$.

Portanto, a finalidade do homem consiste, principalmente, em um ato da vontade com respeito a seu objeto último. Tal ato consiste na própria transformação do amante no amado, isto é, do homem enquanto ente volitivo no bem supremo. Porém, ainda que destaque o ato da vontade como aquilo em que consiste principalmente a beatitude, Henrique de Gand não deixa de fornecer ao intelecto seu papel apropriado. Com efeito, a vontade só pode querer o fim último se o intelecto o conhecer e o mostrar para ela. Se o ato da vontade é um fim (finis), o ato do intelecto é um 'fim sob o fim' (finis sub fine), pois ainda que este último não seja o fim propriamente dito, tal fim só pode ser alcançado pela vontade se o intelecto alcançar seu fim próprio anteriormente ${ }^{95}$ : “Aquilo que assim é $<s c$. o fim último $>$ possui a

\footnotetext{
${ }^{93}$ Cf. nota 28 , acima.

${ }^{94}$ Henrique de Gand, Suma, art. 49, q. 6, co. (ed. De Wulf-Mansion Centre, vol. 30, pp. 146-7): "Sed non est ita, quia ut patet ex praedictis, non cessat appetitus, nisi voluntas suo actu perfectius finem adipiscatur quam adeptus sit ipsum intellectus. Unde et appetitus praecedens principalius erat finis ut esset obiectum in quod transformaretur voluntas, quam ut esset obiectum quo informaretur intellectus, et etiam principalius erat ipsius actus voluntatis ut perfecte bonum amaret, quam intellectus ut perfecte verum cognosceret. Semper enim potentia principalius se appetit perfici in suo proprio actu quam aliam in actu suo. Unde cum eadem est ratio finis et appetibilis et per consequens beatificantis, ut finis ergo principaliter beatificans tamquam obiectum, est bonum sub ratione boni; ut finis sub fine est verum sub ratione veri obiective; et principaliter beatificans et finis ut actus est actus voluntatis, et finis sub fine actus intellectus. Et sic omnino principalius est beatitudo in voluntate quam in intellectu".

${ }^{95}$ Mais precisamente, como se vê pelo trecho da nota anterior, a oposição finis x finis sub fine pode dizer respeito tanto ao objeto beatífico como ao ato beatificante. Nesse segundo caso, a distinção entre finis e finis sub fine diz respeito ao modo de união entre o beato e seu objeto beatificante provocado pela operação beatificante. Assim, o finis propriamente dito irá conjugar o beato ao objeto beatificante
} 
razão de primeiro objeto com respeito à vontade e com respeito ao intelecto, pois por certa ordem move primeiro o intelecto para a apreensão de si e, apreendido pelo intelecto enquanto um bem conhecido, move a vontade para desejo e apetite de si $<\ldots>$.. ${ }^{96}$. Em suma, o ato mais superior no homem é uma operação da vontade acerca do bem último. Esta, porém, não pode ocorrer sem que o intelecto antes apresente à vontade tal bem último que, no intelecto, se confunde com a verdade suprema inteligida. Ou seja, o ato do intelecto é, no homem, um meio, um finis sub fine, mas

enquanto algo externo ao beato; o finis sub fine, de sua parte, conjuga o beato ao objeto beatificante, porém não enquanto algo externo ao beato. Uma vez que somente a vontade pode unir o volente ao querido em si (enquanto algo externo ao volente), somente a operação volitiva pode ser tomada como finis nesse sentido. A intelecção, por outro lado, será um finis sub fine, pois conjunga o inteligente ao inteligido enquanto este possui um ser verdadeiro no intelecto. Se, porém, tomarmos o par finis x finis sub fine no que diz respeito ao objeto de cada potência, o objeto beatífico enquanto bem (objeto da vontade) será o finis e o mesmo objeto beatífico enquanto verdadeiro (objeto do intelecto) será um finis sub fine. Isso tudo podemos depreender da passagem citada na nota anterior, como dito. Aliás, a qualificação do objeto do intelecto como finis sub fine em comparação ao objeto da vontade enquanto finis simpliciter é encontrada também em Quodl. 1, q. 14, co. (ed. De Wulf-Mansion Centre, vol. 5, p. 88): “< ..> obiectum voluntatis quod est bonum simpliciter, habet rationem finis simpliciter et ultimi finis, obiectum autem intellectus quod est verum, habet rationem boni alicuius ut intellectus, et ita ut finis sub fine et ordinatum ad aliud ut ad ultimum finem".

No entanto, Henrique adiciona um elemento complicador nesse formulação. Com efeito, se ignorarmos a distinção entre intelecto e vontade e comparamos o objeto beatítifico com a operação da alma em geral, somente o primeiro poderá ser tomado como finis, enquanto a operação da alma como um todo deve ser tida como um finis sub fine. Isso ocorre porque, não importa o quanto uma operação da alma conjugue o beato ao objeto beatífico, sempre tal operação será interna ao beato quando comparada à exterioridade absoluta do objeto beatífico em si: "actus intellectus et voluntatis, quia non possunt esse fines ultimi - nec in hoc aliquis haesitare debet visis determinatis in praecedenti quaestione -, si ergo in ipsis consistat aliqua ratio beatitudinis, oportet quod illa sit tamquam finis sub fine. Actio autem vel operatio non est sicut finis sub fine, nisi quia est sicut finis interior coniungens exterior $<\ldots>$ " - Suma, art. 49, q. 6, co. (ed. De Wulf-Mansion Centre, vol. 30, p. 127). Ver tb. Suma, art. 49, q. 4, ad op. (ed. De Wulf-Mansion Centre, vol. 30, p. 81): "Primo modo beatificans finis est ultimus et tantum unicus, et sic in quantum consistit in tali, consistit in unico. Secundo modo beatificant aliqua quae sunt ut finis sub fine, et sunt duo actus beatificati, scilicet intellectus et voluntatis $<\ldots$.. ". Nesse caso, as operações da alma, sendo internas quando comparadas ao próprio objeto beatífico externo, são tidas como finis sub fine justamente porque conjugam o beato a seu objeto externo: "cum talis finis interior non pertinet ad beatitudinem, nisi quia pertingat exteriorem et ei coniungit intelligentem et volentem, ille igitur actus simpliciter dicetur plus pertinere ad beatitudinem qui magis fini exteriori coniungit, et maxime sub illa ratione qua beatificans est ita etiam quod, si alter eorum tantum coniungat fini illi sub ratione qua beatificans est, licet alius sub alia ratione illi coniungat, ille qui illi coniungit sub ratione qua beatificans est solus dicetur pertinere ad beatitudinem et esse beatitudo quaedam ut finis sub fine, alius vero non" - Suma, art. 49, q. 6, co. (ed. De Wulf-Mansion Centre, vol. 30, pp. 127-8). Ao que parece, portanto, para Henrique de Gand, [1] dentre os atos da parte intelectiva, o ato da vontade é finis e o ato do intelecto é finis sub fine, pois somente o primeiro alcança o objeto como algo externo ao volente; e [2], estritamente falando, o objeto último é o finis e as operações volitiva e intelectiva são finis sub fine. Sobre esse tema, cf. os trabalhos a seguir (que atentam, principalmente, para esse segundo modo da oposição finis x finis sub fine): BELLOSO, J. M. R. La visión de Dios según Enrique de Gante. Barcelona: Seminario Conciliar - Editorial Casulleras, 1960, pp. 123-39; EARDLEY, "Conceptions of Hapiness and Human Destiny...”, 2006, p. 292.

${ }^{96}$ Henrique de Gand, Suma, art. 49, q. 6, co. (ed. De Wulf-Mansion Centre, vol. 30, p. 126): “Quod enim tale est rationem primi obiecti habet et respectu voluntatis et respectu intellectus, quia ordine quodam primo movet intellectum ad sui apprehensionem et ipsum apprehensum per intellectum ut bonum cognitum movet voluntatem ad sui desiderium et appetitum $<\ldots$. ". 
ainda assim algo estritamente necessário para a realização final do homem enquanto ente racional $^{97}$.

Já havíamos visto como todo o homem se explicava como um ponto intermediário na hierarquia do universo. Vemos, agora, como ele também se explica a partir de seu fim último, isto é, daquela mais perfeita operação de que ele é capaz. A vontade coloca livremente o intelecto em movimento, para que este último possa chegar à contemplação da verdade última que é Deus mesmo. De fato, o intelecto só pode ser completamente explicado enquanto potência passiva da alma, pela sua finalidade: como aquilo que permitirá ao homem contemplar essa suma perfeição que é Deus. Essa contemplação (speculatio) de Deus é o último e o mais perfeito passo no longo caminho de aperfeiçoamento do conhecimento humano. De outra parte, porém, ele não é senão um passo intermediário - o último meio - antes que o homem possa atingir seu fim último que é a ação volitiva acerca do bem supremo. Se a vontade é superior ao intelecto tanto por guiá-lo em sua busca pelo aperfeiçoamento como por se unir ao ser em si de seu objeto - em especial, de seu objeto último -, o Doutor Solene afirma também que o fim último da vontade, isto é, aquele bem final que a aperfeiçoa ao mais alto grau enquanto potência da alma, só pode ser mostrado a tal potência volitiva por um conhecimento puramente especulativo e, portanto, intelectual. Ou seja, também no que diz respeito ao fim último - isto é, ao ato final e mais perfeito do homem enquanto ser racional e volitivo -, a vontade, havendo guiado o intelecto até esse bem final, deve igualmente mover o intelecto para este lhe mostre aquilo que ela mais ama.

Com isso se torna claro que a possibilitas sciendi que Henrique de Gand atribui ao homem mais do que uma simples potência para o conhecimento é, também, uma tendência para a ciência. Essa tedência é um apetite que pelo qual a vontade move o intelecto a obter conhecimento, a scire - como era dito acima, "o homem, pela vontade, tem apetite por ter ciência, mas segundo o intelecto" ${ }^{98}$. Como veremos

\footnotetext{
${ }^{97}$ Essa curta apresentação da noção de beatitude desenvolvida por Henrique de Gand somente aponta alguns traços gerais do tema. Para mais informações e análises mais pausadas, cf. a dissertação fundamental BELLOSO, La visión de Dios según Enrique de Gante, 1960. Cf. tb. MACKEN, R. "Lebensziel und Lebensglück...", 1979, pp. 118-21; EARDLEY, "Conceptions of Hapiness and Human Destiny...”, 2006, pp. 290-5; DUBA, W. O. Seeing God: Theology, Beatitude and Cognition in the Thirteenth Century. A thesis submitted in partial fulfillment of the requirements for the Doctor of Philosophy degree in History in the Graduate College of the University of Iowa. May, 2006, pp. 24083.

${ }^{98}$ Cf. nota 74 .
} 
na segunda parte deste trabalho, o intelecto só terá conhecimento se, anteriormente, os sentidos conhecerem algo. Dessa maneira, o apetite da vontade pelo conhecimento move não somente o intelecto, mas também o sentido, cujo ato é um meio para o conhecimento intelectual. Porém, mesmo este último é apenas um meio para o ato da vontade. Destarte, a possibilitas sciendi que o Doutor Solene atribui ao homem é, precisamente, a possibilidade de (ou a potência para) uma atualização de um meio para a que vontade possa se atualizar, sendo este último ato - o da vontade - o superior no homem.

Se já sabemos que o conhecimento intelectual não é, no homem, naturalmente nada mais do que potência, sabemos também que essa potência traz consigo (do modo complexo que vimos neste capítulo) uma tendência para o conhecimento. Essa tendência provém de um ato da vontade - tal tendência é um apetite, um amor pelo conhecimento. Mas seria a vontade a única a agir para o conhecimento intelectual?

Estabelecida a possibilidade do conhecimento para homem, o que é precisamente tal possibilidade e o seu porquê, será preciso ver agora que a potência do intelecto não basta para a realização do ato de conhecimento humano. Sem dúvida, já tivemos no início do capítulo uma pista de que a racionalidade tomada estritamente (isto é, que diz respeito aos juízos especulativos ou práticos) exige ações intelectuais, pois ela se dá por discurso. O problema levantado agora, porém, é anterior - diz respeito ainda ao conhecimento dos conceitos simples incomplexos, que necessariamente antecedem os complexos e as proposições ou silogismos na ordem do conhecimento ${ }^{99}$. Com efeito, mesmo para o conhecimento incomplexo de conceitos simples (que exclusivamente nos ocupará na segunda parte do presente trabalho) é preciso que algo no intelecto aja para o conhecimento. Mas é possível que haja algo ativo nesta potência intelectiva que vimos até agora se caracterizar por sua passividade ${ }^{100}$ ?

\footnotetext{
${ }^{99}$ Henrique de Gand, Suma, art. 1, q. 5, co. (ed. De Wulf-Mansion Centre, vol. 21, p. 126): "Et appellatur eorum intellectus 'indivisibilium intelligentia', qua mens primo naturaliter cognoscit terminos ex quorum collectione ad invicem per intellectum componentem et dividentem consimiliter concipit naturaliter sine omni discursu primas conceptiones intelligibilium complexorum, ut quod 'totum est maius sua parte', 'si ab aequalibus aequalia demas, quae relinquuntur aequalia sunt', 'de quolibet affirmatio vel negatio et non simul de eodem', et cetera huiusmodi, quae sunt prima principia scientiarum complexa naturaliter intellecta, prius tamen intellectis terminis". A partir de tais princípios derivamos o conhecimento das demais conclusões (cf. nota 3, acima).

${ }^{100}$ Antes de finalizar este capítulo é importante frisar uma consequência importante para o pensamento de Henrique de Gand dessa relação aqui descrita entre intelecto e vontade. Sendo posto em movimento, em última instância, por um apetite volitivo, o conhecimento coloca em jogo não somente a reflexão sobre a ciência que estamos desenvolvendo neste trabalho, mas também sobre certos pressupostos
} 
morais do conhecimento humano. De fato, assim como um ato da vontade está atrelado ao ato do intelecto, também uma ética está atrelada à aquisição de conhecimento (isto é, ao aperfeiçoamento e atualização da alma intelectiva e do homem como um todo enquanto ser cognoscente). Isso fica mais claro no já mencionado Sermão para a festa de Santa Catarina, proferido por Henrique de Gand em 25 de novembro de 1282 (cf. cap. 2, nota 3). Nesse sermão, partindo de um tema (uma composição de Ps. 95,6 e 118,7 da Vulgata iuxta LXX: "confessio et pulchritudo in conspectu eius; confitebor tibi in directione cordis") interpretado por ele como a caracterização do pregador e daquele que ouve a pregação, Henrique de Gand busca celebrar sta. Catarina de Alexandria pelas suas virtudes no conhecimento da verdade e em sua pregação. Ora, por dizer respeito precisamente ao conhecimento como virtude, está claro que este sermão traz à baila justamente aquele campo de intersecção da moral e do conhecimento. Mais do que isso, vemos nele o desenvolvimento de algo como uma 'moral fisiológica' do conhecimento, na qual os pressupostos morais e éticos para a obtenção de conhecimento muitas vezes se confundem com uma caracterização fisiológica do homem. Isso fica bem claro no cuidadoso estudo proposto pelo Doutor Solene do termo 'pulchritudo', tal como este último surge no tema. Para ele, essa 'pulchritudo' "pertinet ad partem anime intellectivam, et pertinet specialiter ad scolasticos" (ed. E. Hocedez, 1925, p. 510, 11. 24-25), ou seja, essa 'beleza' de que fala o salmista é, antes de tudo, uma beleza intelectual que diz respeito aos alunos ('ad scolasticos') - é uma beleza pressuposta no aprendizado. Elaborando melhor sua interpretação, Henrique afirma que "sapientia enim non est aliud quam quedam anime pulchritudo" (ed. E. Hocedez, 1925, p. 510, 11. 28-29) e, após notar que sta. Catarina de Alexandria possui muito dessa beleza - sendo, aliás, versada desde cedo em toda ciência secular e filosófica (ed. E. Hocedez, 1925, p. 510, 1. 33-511, 1. 46) -, ele afirma que ela possuía três características que a ajudavam sumamente a aprender: "et notandum est quod ipsa tria habuit multum coadiuvantia ad cito et velociter erudiendum” (ed. E. Hocedez, 1925, p. 510, 11. 46-48). Em primeiro lugar, ela possuía uma limpeza no corpo ('mundiciam in corpore'), a qual ganha contornos a um só tempo morais e fisiológicos: ela era afastada [i] da luxúria e [ii] da gula. Certamente, ambos são vícios de um ponto de vista meramente ético e pecados de um ponto de vista religioso. Porém, para além disso, ambas - luxúria e gula - são, igualmente, entraves corpóreos para a obtenção de conhecimento: "duo multum impediunt scientie acquisitionem; et e contrario munditia vel sobrietas coadiuvat et disponit, ut ait Boetius in libelo de disciplina scolarium. Cuius ratio est etiam naturalis; secundum Philosophum, 'sedando et quiescendo fit anima sapiens' et prudens; motus enim et commotio humorum impedit fantasias, que habetur ex perturbatione appetitus inordinati ad terrena nimis inclinati. Ideo dicit Averroës commentator ibi: quod 'ad acquisitionem sapientie et prudentie confert exercitium virtutum maxime autem castitas" (ed. E. Hocedez, 1925, p. 511, 11. 49-57). Essa citação de Averróis é a deixa para o Doutor Solene incluir mais um elemento em sua descrição moralfisiológica da atividade discente, a saber, a 'virgindade': "hoc <sc. castitas> autem habuit beata Catherina: virgo enim fuit” (ed. E. Hocedez, 1925, p. 511, 11. 57-58). Como vemos, há diversos elementos a um só tempo éticos e fisiológicos (de fato, estamos aqui na presença de uma moral do corpo e da alma) pressupostos no aprendizado, isto é, na obtenção da ciência pelo homem. Se a luxúria e a gula são condenados como fatores impeditivos do aprendizado, isso ocorre não somente por razões religiosas ou éticas, mas também porque eles naturalmente impedem o funcionamento das faculdades corpóreas necessárias para a formação do conhecimento intelectual - em particular, o forte movimento dos humores provocado pelos desejos irrefreados prejudica a formação dos fantasmas na fantasia (faculdade cujo órgão se encontra no cérebro), a partir dos quais, como veremos no próximo capítulo, o intelecto obtém o conhecimento universal. Longe de ser uma caracterização moral-fisiológica restrita a sta. Catarina de Alexandria, essa descrição serve para todo e qualquer estudante: "et similiter nos debemus huius munditiam habere, si velimus fieri sapientes" (ed. E. Hocedez, 1925, p. 511, 11. 58-59) ou seja, sta. Catarina surge como exemplum moral e fisiológico para o scolasticus. Para além dessa munditia, no entanto, a santa alexandrina possuía ainda uma 'simplicidade de mente e intenção': "mentis et intentionis simplicitas, ita quod unum solum intendatur determinate; non modo, hoc; modo, illud. Quia mentis distractio multum impedit studium et acquisitionem Sapientiae" (ed. E. Hocedez, 1925 , p. 511, 11. 60-63). Em particular, não se deve buscar junto ao estudo a honra terrena (terrenum honorem, ed. E. Hocedez, 1925, p. 511, 11. 66-70) Por fim, Catarina possuía ainda "constantia et perseverantia vel diligentia inquisitionis" (ed. E. Hocedez, 1925, p. 512, 11. 72-73), um tema que é mais longamente desenvolvido por Henrique (ed. E. Hocedez, 1925, p. 512, 11. 73-96), mas que não reterá nossa atenção aqui. O que importa notar é que essas duas últimas características de Catarina - a 'simplicidade de mente e intenção' e a 'constância e perseverança ou diligência de pesquisa' - dizem já respeito propriamente ao caminho do estudo (respectivamente, a seu fim e ao caminho da pesquisa para atingi-lo), mas não deixam de pressupor aquela moral fisiológico-psíquica descrita como primeira característica virtuosa de sta. Catarina e como exemplo para todos os estudantes. Enfim, esse sermão, a 
meu ver, mostra que, estabelecida a possibilitas sciendi e havendo o homem sido reconhecido como um ser naturalmente [i] em potência para o conhecimento e [ii] com apetite para conhecer, é preciso igualmente ressaltar o lado moral dessa busca pelo conhecido, uma moral que, ao cabo, deve condicionar o homem como um todo - em sua alma, em sua ação e em seu corpo. Somente seguindo-a, ele poderá se atualizar e aperfeiçoar no mais fundamental elemento de sua natureza: a alma intelectiva e volitiva. Sobre a relação entre moral e conhecimento na legenda de sta. Catarina de Alexandria, cf. BERNAU, A. "A Christian Corpus: Virginity, Violence, and Knwoledge in the Life of St Katherine of Alexandria”. In: JENKINS, J., LEWIS, K. J. Katherine of Alexandria. Texts and Contexts in Western Medieval Europe. Turnhout: Brepols, 2003, pp. 109-30.

Outro campo em que emerge a temática da relação entre ética e conhecimento em Henrique de Gand é a consideração acerca do próprio teólogo enquanto universitário. Não é o caso de buscar em suas obras algo que se assemelhe ao que conhecemos hoje por (auto)biografia. Com efeito, tal reflexão estava praticamente ausente da escrita universitária do século XIII - cf. WEI, I. P. "From Twelth-Century Schools to Thirteenth-Century Universities: The Disappearance of Biographical and Autobiographical Representations of Scholars”. Speculum 86.1 (2011), pp. 42-78. Por outro lado, há nesse período um discurso que permite uma busca por aquilo que Jacques Le Goff chamou de 'consciência de si' da universidade medieval ou que Ian Wei denomina de 'auto-imagem' dos mestres de teologia (cf. LE GOFF, J. “Quelle conscience l'Université médiéval a-t-elle eue d'elle-même?”. In: LE GOFF, J. Pour un autre Moyen Âge. Temps, travail et culture en Occident: 18 essais. Paris: Gallimard, 1977, pp. 18197; e WEI, I. P. "The Self-Image of the Masters of Theology at the University of Paris in the Late Thirteenth and Early Fourteenth Century". The Journal of Ecclesiastical History 46.3 (1995), pp. 398431) é plenamente possível encontrar nos textos do Doutor Solene discussões acerca do teólogo enquanto, nas palavras de Wei, 'tipo social' ('social type', cf. WEI, "From Twelth-Century Schools to Thirteenth-Century Universities”, 2011, pp. 43-9 e 78). Um exemplo desse tipo de discussão é o curtíssimo Quodl. 1, q. 34 (ed. De Wulf-Mansion Centre, vol. 5, pp. 193-5), onde é perguntado "utrum doctor intendens principaliter honorem suum in docendo peccet mortaliter [l. $6 \mid$ moraliter $l$. 3]" (p. 193). A resposta de Henrique não poderia ser mais direta e lacônica: "Etsi enim doctor aliquo modo in docendo quaerere posset honorem suum, ut in ipso Deus amplius honoraretur, et status doctoris in Deo, quod est, quaerere principaliter honorem Dei, quaerere tamen in docendo principaliter honorem suum et sic praeferre honorem suum honori divino, hoc omnino est illicitum et abusus sacrae doctrinae, et ita peccatum mortale" (p. 194). Como se vê, nessa pequena passagem temos uma recusa à busca pela honra própria por parte do doutor que nos remete à temática da incompatibilidade entre estudo e busca por honra que encontramos, também, no Sermão sobre sta. Catarina de Alexandria (ed. E. Hocedez, 1925, p. 511, 11. 66-70). Em Quodl. 1, q. 34, fica claro que à busca pela 'honra própria' (honor suus) se opõe a busca pela 'honra de Deus' (honor Dei), esta sim própria à atividade do doctor. Pois bem, há vários exemplos desse tipo de questão ética acerca da atividade do mestre de teologia na obra de Henrique de Gand - Quodl. 1, q. 35 (ed. De Wulf-Mansion Centre, vol. 5, pp. 195-202): “utrum melius sit stare in studio, spe plus proficiendi, sufficienter instructum quam ire ad procurandum animarum salutem"; Quodl. 14, q. 12 (ed. 1613, f. 356r-v): "utrum Doctores Ecclesiae deberent facere conscientiam de peccato, eo quod non laborant ad conversionem infidelium"; a grande discussão sobre o tema que surge em Suma, arts. 11 e 12 (ed. 1642-6, pp. 190-225), onde Henrique de Gand busca caracterizar, respectivamente, o doctor theologiae e o auditor theologiae. Sobre esses temas em Henrique de Gand, além dos textos já citados na presente nota, cf.: LECLERCQ, J. "L’idéal du théologien au Moyen âge. Textes inédits". Revue des sciences religieuses 21.3-4 (1947), pp. 121-48; BEUMER, "Die Stellung Heinrichs von Gent...", 1957; GABRIEL, A. L. "The Ideal Master of the Mediaeval Philosophy". The Catholic Historical Review 60.1 (1974), pp. 1-40; MINNIS, "The Accessus Extended...", 1992; BLAMIRES \& MARX, "Woman Not to Preach...", 1993; WEI, "The Self-Image of the Masters of Theology...", 1995; KÖHLER, T. W. "Äusserungspflicht und Erörterungverzicht. Ethische Fragen akademischer Lehre und Wissensgewinnung in der Hochscholastik". In: BAZÁN, B. et al. (eds.). Les philosophies Morales et politiques au Moyen Âge: actes du 9e Congrès International de Philosophie Médiévale, Ottawa, 17-22 août 1992. Vol. 3. Ottawa: SIEPM, 1995, pp. 1327-40; AREZZO, A. "La felicità del teologo. Gloria, grazia e scienza in Enrico di Gand”. In: BeTteTINI, M., PAPARELLA, F. D. (ed.). Le felicità nel Medioevo. Atti del Convegno della Società italiana per lo studio del pensiero medievale (S.I.S.P.M.), Milano, 12-13 Settembre 2003. Louvain: FIDEM, 2005, pp. 411-24; MARSCHLER, T. "Zum Selbstvertändnis des theologischen Magisters nach Heinrich von Gent im Ausgang von Quodlibet I, 35". In: OLSZEWSKI, M. (ed.). What is "Theology" in the Middle Ages? Religious Cultures of Europe $\left(11^{\text {th }}-15^{\text {th }}\right.$ Centuries) as reflected in their Self-Understanding. Münster: Aschendorff, 2007, pp. 517-31; KÖNIGPRALONG, C. Le bon usage des savoirs. Scolastique, philosophie et politique culturelle. Paris: Vrin, 
2011, pp. 69-104; KÖNIG-PRALONG, C. "Situations et fonctions sociales du croire dans la scolastique médiévale. Godefroid de Fontaines contre Henri de Gand”. In: GISEL, P., MARGEL, S. (éds.). Le croire au coeur des sociétés et des cultures: différences et déplacements. Turnhout: Brepols, 2011, pp. 81-103; WEI, "From Twelth-Century Schools to Thirteenth-Century Universities...", 2011; WEI, I. P. Intellectual Culture in Medieval Paris. Theologians and the University c. 1100-1330. Cambridge: Cambridge University Press, 2012; AREZZO, Lumen medium. Enrico di Gand e il dibattito..., 2014, pp. 88-96; KÖNIG-PRALONG, "Omnes homines natura scire desiderant...", 2015, p. 130; e NEGRI, S. "Veritatem humiliter investigare. Sul ruolo dell'umiltà in Enrico di Gand". Quaestio 15 (2015), pp. 607-17.

Enfim, com os comentários desta nota pretendo apenas enfatizar que a relação entre vontade e intelecto põe, para além de problemáticas no que diz respeito às doutrinas da alma e da intelecção do Doutor Solene, a exigência de uma abordagem moral do conhecimento humano. Na obra de Henrique, essa moral é expressa em diferentes contextos, porém não será tomada como objeto de estudo no que se segue do presente trabalho. 
EPÍLOGO DA PARTE 1:

A INSUFICIÊNCIA DA PASSIVIDADE DO INTELECTO

Em um primeiro momento, a resposta à pergunta com que encerramos o capítulo 3 deveria certamente ser um peremptório 'não', pois sabemos que o intelecto é, por sua natureza, pura potência passiva e só vem ao ato em presença do inteligível, isto é, quando o objeto, enquanto verdadeiro, vem a ser no intelecto. Mas o que seria essa presença do objeto no intelecto? Basta, o próprio inteligível se apresentar ao intelecto para estar na presença deste último? Se sim, como ocorre de o objeto vir à sua presença? Curiosamente, reafirmar a passividade do intelecto não é, para Henrique de Gand, uma resposta suficiente para nenhuma dessas perguntas - mesmo no que diz respeito ao conhecimento intelectual dos conceitos simples e incomplexos. De alguma maneira, será necessário afirmar que há uma ação própria dessa potência intelectiva que foi, diversas vezes, descrita como fundamentalmente passiva! Para começar a compreender a maneira pela qual o Doutor Solene afirma uma tal atividade na potência passiva que é o intelecto, será interessante retornarmos pelo caminho percorrido até aqui, para chegarmos de volta a Suma, art. 1, q. 1, onde havíamos deixado Henrique com a afirmação - convincente e não demonstrativa, mesmo porque não há outra possível - de que há uma possibilidade de ciência para o homem.

Se no capítulo anterior havíamos atingido o ápice no estudo das potências humanas ao notarmos que, dentre elas, há uma superior - a vontade -, completamente ativa e assim dada ao homem diretamente por Deus, também no estudo da potência intelectiva chegamos ao ápice, pois atingimos aquele seu ato mais perfeito que é a contemplação de Deus, a suma verdade. Ora, se a vontade é ativa por si própria, o intelecto deve ser colocado em movimento a todo o tempo pela vontade - de fato, o intelecto só alcança seu ato mais perfeito, porque a vontade coloca o intelecto em movimento para raciocinar. Assim, na própria constatação da perfeição do ato último do intelecto está clara a sua inferioridade com respeito à vontade, pois ele só atinge sua perfeição movido por esta última (o que, como vimos, exige a explicação de como o ato último da vontade, tal como qualquer ato volitivo, necessita da ação ostensiva do intelecto). Essa inferioridade decorre, em poucas palavras, do caráter fundamentalmente passivo da potência intelectiva humana, que redunda: [i] na 
necessidade que ela possui de passar de um conhecimento intelectual simples a outro, sem poder tê-los todos em ato (o que ela compartilha com os anjos) e, além disso, de passar do conhecido ao desconhecido por raciocínios silogísticos (o que os anjos não precisam fazer); [ii] na necessidade de ser movido pela vontade nesse caminho dedutivo; e [iii] na necessidade de ser atualizado de fora - no estado presente, a partir dos sentidos corpóreos e, mais precisamente, orgânicos.

Ora, tudo isso está estritamente relacionado com o caráter essencialmente potencial do homem enquanto criatura e intermediário enquanto ente, a uma só vez, corpóreo e espiritual, horizonte entre o natural e o sobrenatural na ordem do mundo. Diga-se de passagem, até mesmo a vontade do homem, uma potência totalmente ativa, não é ainda ato puro, pois ela é ativa indeterminadamente para se voltar ou não para um objeto. Este último, no entanto, ainda é necessariamente proveniente de fora da vontade, já que ela deve ter seu objeto mostrado a si pelo intelecto (que, por sua vez, o recebeu dos sentidos, que foram afetados por algo externo ao próprio homem). Mais do que isso, essa potência ativa, ao depender de um intelecto raciocinativo, é extremamente mutável, o que a afasta da vontade mais perfeita - e, portanto, mais fixa - dos anjos. Em poucas palavras, mesmo a vontade humana, puramente ativa, é uma potência in fieri, pois sua atividade é originalmente indeterminada. Ou seja, o homem, mesmo em sua ação, é perpassado pela potencialidade corpórea e espiritual inerente a ele, pela qual ele é sempre dependente, para seu aperfeiçoamento, de agentes externos - igualmente, corpóreos ou espirituais - que o movam em direção ao ato.

Sendo assim, é compreensível que Henrique de Gand inicie o seu estudo do conhecimento humano - e, mais propriamente, do scire large acceptum pelo homem - pela consideração da possibilitas sciendi em Suma, art. 1, q. 1, pois estamos tratando justamente de um ser que se caracteriza como sendo em potência para o conhecimento (sensitivo e intelectivo) e capaz de se voltar volitivamente para tal conhecimento. Destarte, vemos agora que aqueles que negavam a possibilidade de ciência para o homem negavam a própria natureza humana, de maneira que os argumentos meramente convincentes de Henrique de Gand são, no fim, mais fortes do que esperávamos de início. De fato, a negação das obras ligadas à convivência humana e outros semelhantes que certamente exigem aquele scire large accepto $^{1}$ é

\footnotetext{
${ }^{1}$ Cf. cap. 1 , nota 51.
} 
uma negação da própria natureza humana, pois nega-se a própria potência humana de conhecer racionalmente. E, lembremos, o homem não é nada além de uma potência para conhecer racionalmente e, assim, racionalmente querer. Por outro lado, afirmar a possibilitas sciendi é afirmar a própria natureza humana e, ao fazê-lo, reafirmar a ordenação do mundo como um todo, em particular aquele elo mediano que junta o espiritual ao corpóreo, o natural ao sobrenatural.

Temos, portanto, esclarecido que é possível ter ciência e, de fato, faz parte do homem uma tendência para o conhecimento, pela qual ele pode partir da completa potência passiva para a intelecção e chegar ao conhecimento da mais perfeita suma verdade. $\mathrm{O}$ que me interessará a partir de agora é estudar mais precisamente como o homem percorre esse caminho e, especialmente, como o intelecto passa dessa potência inicial para o seu ato primeiro acerca de um objeto que não é senão o ato de conhecimento de um conceito simples.

Pois bem, refeito sumariamente todo trajeto que percorremos até aqui, cabe recolocar a pergunta que fizemos há pouco: para que o intelecto se atualize com a intelecção, bastam [i] a ação de algo externo sobre o intelecto através dos sentidos e [ii] a ação pela qual a vontade põe em movimento o intelecto? Ou seriam necessárias ainda outras ações além dessas? Duas pistas para responder a essas perguntas podem ser encontradas nas resposta às objeções ainda em Suma, art. 1, q. 1, quando Henrique de Gand disserta acerca não mais da mera possibilitas sciendi, mas das atividades implicadas na produção do ato de conhecimento intelectual:

“<..> ainda que o intelecto receba primeiro espécies inteligíveis das coisas
sensíveis e corpóreas [rerum sensibilium et corporearum], enquanto são
sensíveis, as quais intelige primeiramente por aquelas espécies, em segundo
lugar, sob aquelas espécies dos sensíveis, ele concebe, pela investigação da razão
natural [naturalis rationis investigatione] por si mesma, notícias das coisas não
sensíveis, como são as quididades das substâncias e outros desse mesmo modo,
que não possuem próprias espécies no intelecto. E isso é o que Agostinho diz em
Sobre a Trindade 9, cap. 3: 'não podemos discernir pelos olhos a própria força
pela qual discernimos pelos olhos (sejam ela raios ou algo outro), mas a
buscamos pela mente e, se se puder fazê-lo, também pela mente o
compreendemos. Portanto, a própria mente, tal como colige pelos sentidos as
notícias das coisas corpóreas, assim <o faz quanto à notícia > das incorpóreas por
si mesma'. E ele chama 'coisas corpóreas' enquanto são sensíveis e 'coisas
incorpóreas' quaisquer que não sejam sensíveis, como são a matemática e as
quididades das substâncias, a matéria e a forma e outros desse modo. A mente
colige a notícia destes sob as espécies dos sensíveis a partir da ligação natural [ex
naturali colligantia] dos sensíveis aos não-sensíveis, pela indústria da razão
natural [naturalis rationis industria], como que cavando sob a própria espécie
apresentada a ela pela coisa sensível [quasi fodiendo sub ipsa specie a sensibile 
re ei praesentata], do modo pelo qual a ovelha, por um instinto natural, estima por espécies sentidas as não-sentidas, como ao imaginar ou ver pela espécie sensível do lobo, estima que ele é nocivo ou inimigo. E, por isso, diz-se 'inteligir', como a partir de 'interior-ler' [dicitur intelligere quasi ab 'intus legere']"'.

Essa passagem aponta claramente a possibilidade de um discurso acerca da atividade intelectual e, mais precisamente, sobre uma ação do intelecto ou da mente, pela qual ela obtém o conhecimento do não-sensível a partir daquilo que é sensível e corpóreo. Essa naturalis rationis investigatio ou naturalis rationis industria é algum movimento pelo qual o intelecto pode, ainda que sempre recebendo o conhecimento a partir dos sentidos corpóreos, suplantá-los e chegar a conhecer até mesmo aquilo que não pode ser alcançado pelos sentidos. De fato, vimos acima que, pelo intelecto, a alma ultrapassa toda capacidade do corpo, muito embora ela dependa sempre deste último. Agora, longe de aparecer como uma mera passividade, a intelecção surge como uma ação, a saber, um 'cavar' um 'ler o interior' do sensível. Uma busca ativa a partir do sensível, mas, para além dele, pelo não-sensível, pelas essências e quididades, pelas definições. Quanto à introdução do vocabulário das 'espécies' das coisas sensíveis, deixemos seu estudo para o próximo capítulo. Cumpre agora frisar esse caráter ativo da potência intelectiva que vemos surgir nesse trecho.

Aqui, de fato, surgem mescladas referências a duas ações necessárias para que haja conhecimento intelectual, pois, se está claro no excerto o papel da razão em produzir conceitos complexos proposicionais, não é delineada de maneira tão patente a necessidade de uma ação anterior a esta, proveniente também do próprio intelecto. Essa ação, anterior ao discurso raciocinativo, é aquela pela qual o intelecto torna presente a si o que antes estava presente somente para os sentidos. Assim, essa ação

\footnotetext{
${ }^{2}$ Henrique de Gand, Suma, art. 1, q. 1, ad 7 (ed. De Wulf-Mansion Centre, vol. 21, pp. 27-28): “Ad quod dicendum quod, etsi intellectus recipit primo species intelligibiles rerum sensibilium et corporearum, ut sunt sensibiles, quas primo per illas species intelligit, secundario tamen sub illis speciebus sensibilium naturalis rationis investigatione concipit per se ipsam notitias rerum non sensibilium, ut sunt quidditates substantiarum et alia eiusdem modi, quae proprias species non habent in intellectu. Et hoc est quod dicit Augustinus $\mathrm{IX}^{\circ}$ De Trinitate cap. ${ }^{\circ} 3^{\circ}$ : 'Ipsam vim qua per oculos cernimus, sive sint radii, sive aliquid aliud, oculis cernere non valemus, sed mente quaerimus, et si fieri potest, etiam hoc mente comprehendimus. Mens ergo ipsa, sicut corporearum rerum notitias per sensus corporis colligit, sic incorporearum per se ipsam'. Et appellat res corporeas ut sensibiles sunt, res autem incorporeas quaecumque id quod sunt sensibilia non sunt, ut sunt mathematica et quidditates substantiarum, materia et forma et huiusmodi quorum notitiam mens sub speciebus sensibilium ex naturali colligantia sensibilium ad insensibilia naturalis rationis industria colligit quasi fodiendo sub ipsa specie a sensibili re ei praesentata, ad modum quo ovis naturali instinctu per species sensatas aestimat insensatas, ut imaginando vel videndo per speciem lupi sensibilem aestimat ipsum nocivum et inimicum, et ideo dicitur intelligere quasi ab 'intus legere"”.
} 
de 'cavar' o não-sensível que está sob o sensível exige, antes mesmo do uso da razão, uma ação pela qual o intelecto torne presente a si aquele sensível como algo inteligível. Para utilizarmos termos técnicos, antes de o intelecto compor e dividir conceitos complexos, é necessário que ele abstraia o inteligível a partir do sensível de maneira a permitir o ato de inteligência dos conceitos simples ${ }^{3}$.

Mesmo isso, no entanto, não é o suficiente. De fato, ainda que o intelecto aja para a formação de seu conhecimento, essa ação não basta por si só para permitir um conhecimento estritamente verdadeiro - isto é, daquilo que Henrique de Gand denomina como 'verdade sincera da coisa'. Portanto, para além das ações do próprio intelecto humano (a abstração e a formação de juízos), se mostra necessário para o homem algum tipo de acesso ao conhecimento divino, a partir do qual tudo foi feito e única regra capaz de garantir a verdade sincera do conhecimento humano:

"Donde, interpretando Platão de maneira mais sã do que Aristóteles, Agostinho
propõe que os princípios da ciência certa e do conhecimento da verdade
consistem nas regras eternas imutáveis existentes em Deus, por participação nas
quais se conhece o que quer que se conheça da verdade sincera nas criaturas pelo
conhecimento intelectual - assim, tal como pela sua entidade $<$ Ele $>$ é causa do
existir de todos enquanto são, assim também pela sua verdade é causa do
conhecer de todos enquanto são verdadeiros".

Com isso, temos aqui introduzido o tema da iluminação divina, a que já fizemos algumas referências no capítulo 1. Não sendo a atividade do próprio intelecto humano uma garantia suficiente da verdade sincera do conhecimento, a iluminação divina surge como uma ação de Deus que supre essa carência humana, permitindo ao homem atingir a perfeição de seu ser a um só tempo corpóreo e espiritual.

Dito isso, é interessante como ainda na primeira questão da Suma, logo após a determinação da possibilidade de se ter ciência para o homem e, portanto, desse

\footnotetext{
${ }^{3}$ Para o uso do verbo 'abstrair' ainda em Suma, art. 1, q. 1, ad 2 (ed. De Wulf-Mansion Centre, vol. 21, p. 21): "Id tamen quod apprehensum est per sensum non deceptum abstrahendo et iudicium formandum penes intellectum, ubi manet quasi sine transmutatione quod apprehensum est nec verisimilibus speciebus phantasmatum obumbrari potest, certissima veritas a tali sensu capitur, et nobis certissima scientia est illa rerum sensibilium quae ad sensus experientiam potest reduci". Como se vê, nessa passagem, Henrique de Gand distingue claramente 'abstrahere' e 'iudicium formare', as duas ações que, parece-me, estavam incluídas naquele 'cavar' (fodere) a que ele se referia no texto citado na nota anterior.

${ }^{4}$ Henrique de Gand, Suma, art. 1, q. 1, ad 4 (ed. De Wulf-Mansion Centre, vol. 21, p. 25): "Unde Augustinus sanius interpretans dicta Platonis quam Aristoteles, ponet principia certae scientiae et cognitionis veritatis consistere in regulis sive rationibus aeternis incommutabilibus existentibus in Deo, quarum participatione per intellectualem cognitionem cognoscitur quidquid sincerae veritatis in creaturis cognoscitur, ut, sicut sua entitate est causa omnium existendi in quantum sunt, sic et sua veritate est causa omnium cognoscendi in quantum vera sunt".
} 
caráter essencialmente potencial do ser humano enquanto criatura intelectual e racional (além de volitiva), é indicada igualmente a insuficiência dessa potencialidade. Decerto, essa pura potência passiva que é o intelecto é compensada pela atividade da vontade que o coloca em movimento - que o faz tender para o ato de intelecção. Para além disso, no entanto, o próprio intelecto deve agir por si mesmo [i] tanto para colocar-se em presença do objeto de intelecção que, sem a ação abstrativa do intelecto, jamais deixaria de ser unicamente sensível, [ii] como para, em seguida, obter racionalmente outros conhecimentos não-sensíveis a partir desse objeto proveniente dos sentidos. Entretanto, nem mesmo a ação do intelecto humano basta para que o homem possa atingir um conhecimento maximamente verdadeiro, sendo necessária uma ação do próprio Deus para que essa intelecção da verdade seja atualizada em um intelecto humano. Em poucas palavras, a passividade da potência intelectiva do homem é insuficiente para a atualização do conhecimento verdadeiro. Mais do que isso, a potência do homem para o conhecimento não é suficiente por si só para garantir a atualização e o aperfeiçoamento do homem mesmo. Portanto, faz-se mister não somente uma ação do intelecto humano, mas também uma ação divina pela qual o homem seja devidamente aperfeiçoado.

Com essa última afirmação, deixamos já o campo da possibilitas sciendi e adentramos o complexo estudo das ações - internas e externas - necessárias para a atualização do conhecimento intelectual. Como já explicado na Introdução, porém, não é meu objetivo aqui, porém, abarcar toda essa temática. Com efeito, o estudo cuidadoso de cada um dos elementos aqui listados - abstração, formação de juízos e iluminação - exigiria muito mais espaço e tempo do que seria pertinente para a presente pesquisa. Assim, a segunda parte deste trabalho (como, igualmente, já apontei na Introdução), será dedicada exclusivamente ao conhecimento abstrativo, mero primeiro passo no processo de atualização do intelecto que culmina no conhecimento da verdade sincera por raciocínio e iluminação. Daí se nota que, no que se segue, continuaremos no campo do scire large accepto, que, se inclui o conhecimento intelectual, não permite que o intelecto vá muito além daquilo que os sentidos the apresentam. Por outro lado, não há como compreender a formação de juízos e a iluminação sem uma compreensão anterior da abstração na obra de Henrique de Gand. Portanto, sendo o caso de estudar a atividade do intelecto, a compreensão da abstração parece se impor como movimento inicial de tal pesquisa. Após tal estudo - já no Epílogo da Parte 2 -, estaremos em melhor posição para 
compreender, ainda que em linhas gerais, o que seria tal 'verdade sincera' que não se pode atingir unicamente pela abstração e o porquê dessa insuficiência da atividade de abstração para a compreensão da verdade sincera (donde a necessidade de um auxílio divino).

Entretanto, como se pode depreender do que vimos nesses primeiros três capítulos, o estudo do conhecimento abstrativo pressupõe a compreensão do que seria o conhecimento sensitivo para Henrique de Gand, pois o intelecto justamente abstrai seu objeto a partir dos sentidos. Sendo assim, os próximos três capítulos do presente trabalhos serão dedicados ao estudo do sentido externo ou particular (cap. 4), do sentido interno (cap. 5) e, finalmente, da intelecção abstrativa (cap. 6). A união desses capítulos como uma única (segunda) parte deste estudo se justifica pelo fato de que, enquanto a primeira parte - que ora encerramos - se volta para o scire large accepto como potência e possibilidade para homem, essa segunda parte de nosso estudo analisará o scire large accepto como atividade (sensível e intelectiva), buscando compreender em que medida e de que maneira o ato de intelecção simples e incomplexo é formado a partir do ato de sensação.

Se, porém, o homem é fundamentalmente passividade, está claro que nosso estudo sobre a atividade sensitiva e intelectiva humana deverá se desenvolver como a decifração de um complexo jogo entre passividade e atividade das potência cognoscitivas pelo qual o Doutor Solene busca explicitar a passagem da potência ao ato, tanto no sentido, como no intelecto. Com efeito, as diversas potências e atos implicados na formação do conhecimento humano em Henrique de Gand já vêm chamando a atenção de seus comentadores há muito tempo, mesmo porque parece difícil compreender como um intelecto puramente passivo pode agir para $o$ conhecimento.

De fato, já no verão de 1898, Georgius Hagemann ministrou um curso em que criticava a atribuição de um 'sensismo psíquico' (psychischen Sensismus) a Henrique de Gand por Karl Werner ${ }^{5}$. Vale a pena lermos a crítica de Hagemann:

\footnotetext{
${ }^{5}$ Karl Werner enxerga na oposição entre 'sensismo' e 'racionalismo' um dos problemas basilares para a formação da fillosofia italiana do século XIX - cf. WERNER, K. Die italienische Philosophie des neunzehten Jahrhunderts. Zweiter Band: Der Ontologismus als Philosophie des nationalen Gedankens. Wien: Georg Paul Faesy, 1885, p. 43: "Os esforços intelectuais filosóficos de Gioberti partiam da teologia e objetivavam, em última instância, uma filosofia da religião <... . No entanto, como sabemos por uma mensagem de confidência a um amigo citada acima, teve um tempo em que para ele o sentimento religioso e o pensamento filosófico pareciam estar muito afastados, de maneira que ele considerava possível ser cristão no coração e pagão no pensamento. Isso, porém, somente prova que, então, ele ainda não havia avançado até a convicção da incompatibilidade do pensamento e sentimento
} 


\begin{abstract}
"Quando K. Werner descreve a doutrina do conhecimento [Erkenntnislehre] de Henrique como 'sensismo psíquico' - como se para Henrique os conceitos universais [Allgemeinbegriffe] fossem somente imagens sensíveis [Sinnenbilder] universalizadas pelo intellectus agens, as quais a razão [Verstand] (mantendo-se completamente passiva) recebe em si - , há aí uma compreensão fundamentalmente falsa. Decerto, Henrique - ligando-se à expressão de então descreve o intellectus como passivus, mas somente no sentido [in dem Sinne] de que ele, como poder potencial para a auto-atividade [potentielle Kraft zur Selbstthätigkeit], deve ser impulsionado por seu objeto [Objekt] próprio, embora depois imprima por própria ação [selbstthätig] o pensamento espiritual [geistigen Gedanken] em si. De fato, o conhecer [Erkennen] é uma atividade vital do espírito, pelo que este não se pode manter nunca puramente passivo. Ademais, é o mesmo intelecto que não somente apreende as essências das coisas, mas também faz juízos, pensa verdades universais, deriva por raciocínios outras verdades, se alça do sensível ao mundo suprassensível. Isso é tudo menos um manter-se passivo"
\end{abstract}

cristãos com as visões naturalístico-sensistas. Isso não deve impressionar, uma vez que na juventude de Gioberti o empirismo sensista resguardava ainda um amplo terreno na Itália $<\ldots>$ [Gioberti's philosophische Denkbestrebungen nahmen von der Theologie ihren Ausgang und zielten schließlich auf eine Philosophie der Religion ab $<\ldots>$. Gleichwol hatte er, wie wir aus seiner oben angeführten vertraulichen Mittheilung an einem Freund wissen, eine Zeit, in welcher ihm religiöses Empfinden und philosophisches Denken weit auseinander zu liegen schienen, so dass er es für möglich hielt, im Herzen Christ, im Denken ein Heide zu sein. Dieß beweist indeß nur so viel, daß er dazumal noch nicht zu einer philosophischen Überzeugung von der Unvereinbarkeit des christlichen Denkens und Empfindens mit naturalistisch-sensistischen Anschauungen vorgedrungen war. Dieß darf um so weniger Wunder nehmen, als in der Jugendzeit Gioberti's der sensistische Empirismus in Italien noch ein weites Terrain behauptet <...>]"; e p. 45: "O mérito de Rosmini, aos olhos de Gioberti, foi ter sido o primeiro na Itália a lidar com o tratamento metódico de uma Philosophia prima. Ora, por essa empresa, como Gioberti nota em seguida, a filosofia foi primordialmente retirada do terreno do sensismo; a Philosophia prima só pode ser uma pura ciência da razão. Gioberti expressa esse caráter da Philosophia prima com a palavra racionalismo, que para ele significa o oposto de sensismo; daí que ele denomine Gallupi e Rosmini como racionalistas e adicione que, no presente, onde quer que (como na Alemanha) domine um vigoroso movimento da filosofia, o racionalismo será a corrente dominante e o sensismo será visto como algo de espiritualmente superado, como uma filosofia da minoridade [Rosmini's Verdienst in Gioberti's Augen war, der erste in Italien an die methodische Bearbeitung einer Philosophia prima gegangen zu sein. Durch dieses Unternehmen wurde aber, wie Gioberti weiterhin bemerkt, die Philosophie dem Boden des Sensismus principiell entrückt; die Philosophia prima kann nur reine Vernunftwissenschaft sein. Gioberti drückt diesen Charakter der Philosophia prima durch das Wort Rationalismus aus, welches ihm den Gegensatz des Sensismus bedeutet; demzufolge bezeichnet er Gallupi und Rosmini als Rationalisten, und fügt bei, daß gegenwärtig dort, wo, wie in Deutschland, ein schwunghafter Betrieb der Philosophie herrsche, allenthalben der Rationalismus die herrschende Strömmung sei und der Sensismus als etwas geistig Überwundenes, als eine Philosophie der Unmündigen angesehen werde]". Como vemos, a atribuição de um 'sensismo' a Henrique de Gand é uma tentativa, por parte de K. Werner, de compreender a obra do autor escolástico a partir de posições filosóficas presentes a ele próprio no século XIX. Ainda sobre a importância do 'sensismo' no início do século XIX, porém agora na França, cf. GILSON, É. "French and Italian Philosophy”. In: GILSON, É., LANGAN, T., MAURER, A. (eds.). Recent Philosophy. Hegel to the Present. Vol. 1. Eugene: Wipf and Stock, 1966, pp. 169-373 (esp. p. 171): "Philibert Damiron, a good observer writing in 1828 , submitted a satisfactory classification of the main tendencies at work since the beginning of the nineteenth century in French philosophical minds. According to him three doctrines filled up that period. The first is what the French called sensualisme, an ill-chosen word on account of its unfavorable ethical connotations, and which we propose to replace by the ethically neutral designation of 'sensism.' Whatever its name, that school was the direct continuation of the method and philosophy of Condillac. It represented in the first third of the nineteenth century the heritage of the eighteenth".

${ }^{6}$ HAGEMANN, G. De Henrici de Gandavo quem vocant ontologismo. I. Monasterii Guestfalorum: ex 
De fato, a atribuição do 'sensismo psíquico' a Henrique de Gand é a pedra de toque da interpretação de seu pensamento fornecida por Werner em sua monografia sobre o Doutor Solene publicada em $1878^{7}$. Porém, a sua concepção de 'sensismo psíquico’ só fica mais clara no ano seguinte, quando ele afirma ver em Rogério Bacon a mesma posição filosófica: “Temos que descrever Bacon como defensor do sensismo psíquico, porque ele toma toda atividade cognoscitiva [cognoscitiven Thätigkeit] da alma humana como percepções [Apperceptionen] do que é dado [des $<\ldots>$ Gegeben] na realidade sensível ou suprassensível. Pelas atividades cognoscitivas da anima sensitiva nós percebemos as aparições visíveis da realidade sensível; pela atividade cognoscitiva da alma intelectiva, a realidade não-sensível, não-visível, que nos é mostrada na luz da eterna verdade" ${ }^{8}$. Ou seja, lê-se em Bacon um 'sensismo psíquico', porque para ele todo conhecimento é recebido de fora - seja pelos sentidos ou pelo intelecto. Dessa maneira, parece que o termo 'Sensimus' é utilizado por Werner com um significado mais amplo que não o de uma mera sensação corpórea. De fato, ele faz par com 'Apperception', utilizado aqui para a recepção tanto do dado (Gegeben) sensível pelos sentidos como do dado suprassensível pelo intelecto. A meu ver, é por esse caráter geral atribuído ao termo 'Sensismus' que ele vem acompanhado pelo adjetivo 'psychischen', O defensor do 'psychischer Sensismus' vê toda a alma

Typographia Ioannis Bredt, 1898, p. 8: "Wenn K. Werner die Erkenntnislehre Heinrichs als
psychischen Sensismus bezeichnet, als ob nach Heinrich die Allgemeinbegriffe nur durch den
intellectus agens verallgemeinert Sinnenbilder seien, die der sich ganz passiv verhaltende Verstand in
sich aufnehme, so ist das eine grundfalsche Auffassung. Wohl bezeichnet Heinrich, der damaligen
Ausdrucksweise sich anschliessend, den intellectus als einen passivus, aber nur in dem Sinne, dass er
als potentielle Kraft zur Selbstthätigkeit angeregt werden muss durch sein eigenthümliches Objekt,
dann aber selbstthätig den geistigen Gedanken in sich ausdrückt. Das Erkennen ist ja doch eine vitale
Thätigkeit des Geistes, wobei sich dieser niemals rein passiv verhalten kann. Zudem ist es derselbe
Intellekt, der nicht allein die Wesenheiten der Dingen erfasst, sondern auch Urteile fällt, allgemeine
Wahrheiten denkt, durch Schlussfolgerungen andere Wahrheiten ableitet, von der sinnlichen zur
übersinnlichen Welt sich erhebt. Das alles ist nichts weniger als passives Verhalten". Notemos que esse
curso possui ainda uma segunda parte, que se pode ler em: HAGEMANN, G. De Henrici de Gandavo
quem vocant ontologismo. II. Monasterii Guestfalorum: ex Typographia Ioannis Bredt, 1898-1899. ${ }^{7}$ Cf. WERNER, Heinrich von Gent als Repräsentant..., 1878, pp. 4-6, 22-23 e 57.

${ }^{8}$ WERNER, K. Die Psychologie, Erkenntnis- und Wissenschafstlehre des Roger Baco. Wien: Carl Gerold's Sohn, 1879, p. 24 [488]: "Als Vertreter des psychischen Sensismus haben wir Baco zu bezeichnen, weil er alle cognoscitiven Thätigkeiten der menschlichen Seele als Apperceptionen des in der sinnlichen oder übersinnlichen Wirklichkeit Gegeben fasst. Durch die cognoscitiven Thätigkeiten der Anima sensitiva appercipiren wir die sichtbaren Erscheinungen der sinnlichen Wirklichkeit, durch die cognoscitive Thätigkeit der intellectiven Seele die unsinnliche, unsichtbare Wirklichkeit, die uns im Lichte der ewigen Wahrheit gezeigt wird".

${ }^{9} \mathrm{O}$ termo 'sensismo' ganha o mesmo caráter abrangente (isto é, tomando sob si a recepção tanto do conhecimento sensível como daquele suprassensível ou inteligível) em GILSON, É. "French and 
como puramente receptora, sua atividade é somente aquela de recepção, de percepção do que lhe é dado de fora, a partir da realidade (sensível ou suprassensível) externa a ela. Em outras palavras, a característica fundamental desse 'sensismo psíquico' não é afirmar que todo conhecimento vem dos sentidos, mas antes que tanto o conhecimento sensitivo como o intelectual vêm da realidade externa para a alma, que os recebe passivamente.

Ora, essa é precisamente a posição que Werner vê, também, no Doutor Solene, pois "em Henrique as capacidades cognoscitivas [cognoscitiven Vermögen] da alma são tomadas prevalentemente do ponto de vista das potencias receptivas [receptiver Potenzen]; disso se segue que só se pode falar de uma atuação ativa [activen Auswirken] do conhecimento espiritual em um sentido muito relativo e condicionado, a saber, somente com respeito à atividade lógico-formal do pensamento" ${ }^{10}$. Henrique de Gand também é um defensor do 'sensismo psíquico', porque para ele o conhecimento (sensitivo ou intelectivo) é unicamente recepção passiva. Aliás, de modo geral, toda a alma é somente passividade. Se há nela alguma atividade, esta última se limita ao pensamento de caráter lógico que se segue à recepção inicial do conhecimento.

É somente neste último ponto que Hagemann está de acordo com Werner - o raciocínio é uma atividade da alma. Mas, enquanto Werner vê nessa 'atividade lógicoformal do pensamento' um caso relativo e periférico de atividade em um campo onde predomina a passividade, Hagemann enxerga nela justamente a afirmação de uma atividade fundamental para a alma. Com efeito, essa nem mesmo é sua única atividade, como Hagemann deixa claro no trecho de seu curso que destacamos, uma vez que, além de fazer juízos, a alma também "pensa verdades universais, deriva por raciocínios outras verdades". Mais importante para nós, ela "se alça do sensível ao mundo suprassensível" e, impulsionada por seu objeto próprio, imprime "por própria

Italian Philosophy", 1966, p. 172: "The form assumed by sensism in the first third of the nineteenthcentury France bears the name 'ideology'. For those who first used it, the name carried no unfavorable connotations. It is, in fact, a well-chosen appellation. According to Condillac, all objects of human cognition, including sensations themselves, should be called 'ideas.' Moreover, it had become an accepted view, chiefly under the influence of Locke, that just as physics deals with material beings, metaphysics has for its proper object the study of human mind, including the origin of all its 'ideas' and mental powers and faculties".

${ }^{10}$ WERNER, Heinrich von Gent als Repräsentant..., 1878, p. 5: "Nur geht aus der näheren Begründung dieses Gedankens sofort auch hervor, dass die cognoscitiven Vermögen der Seele bei Heinrich vorwiegend unter den Gesichtspunkt receptiver Potenzer fallen, und demzufolge von einem activen Auswirken der geistigen Erkenntniss nur in einem sehr relativen und bedingten Sinne, nämlich nur mit Beziehung auf die logisch-formale Denkthätigkeit die Rede sein könne". 
ação o pensamento espiritual em si" "1 . Aqui onde Werner notava somente a recepção passiva tanto do sensível como do não-sensível pela alma, Hagemann mais uma vez percebe uma atividade: aquela pela qual, impulsionado pelo objeto, o intelecto imprime em si um conhecimento. Enfim, os dois comentadores estão em polos opostos em sua leitura da doutrina da intelecção abstrativa de Henrique de Gand. Enquanto este último defende uma alma fundamentalmente passiva na leitura de Karl Werner, ele surge como teórico da atividade da alma na interpretação de Georgius Hagemann.

No que se segue, esses serão precisamente os extremos em meio aos quais caminharemos. Esses mais de cem anos que nos separam de Werner e Hagemann serviram para mostrar que passividade e atividade se mesclam de maneira bem complexa na descrição do conhecimento sensitivo e do conhecimento intelectivo fornecida por Henrique de Gand. Como Helen Marie Beha, Giuseppina Cannizzo e, na esteira desta última, Juha Teräväinen destacam, a passividade e a atividade (em particular, como lembram Cannizzo e Teräväinen, a 'conversão' ativa) são momentos igualmente basilares do processo de formação do conhecimento para o Doutor Solene $^{12}$. Curiosamente, essa complexa mescla, proposta por Henrique, de atividade e passividade, tanto no sentido como no intelecto, já era notada muito antes, na passagem do século XVIII para o XIX, nas histórias da filosofia de Dietrich Tiedemann e de Wilhelm Gottlieb Tennemann (que segue o anterior de perto), bem como, posteriormente, já no fim dos oitocentos, por De Wulf ${ }^{13}$. É a esse caráter a um

\footnotetext{
${ }^{11}$ Cf., acima, nota 6.

${ }^{12}$ Cf. BEHA, H. M. "Matthew of Aquasparta's Cognition Theory. Part II: Ideogenesis". Franciscan Studies 21.1-2 (1961), pp. 1-79 (esp. pp. 26-7) - Beha se refere aqui ao trecho de De Wulf citado na próxima nota; CANNIZZO, G. "La dottrina del 'verbum mentis' in Enrico di Gand". Rivista di Filosofia Neo-scolastica 54 (1962), pp. 243-66 (esp. pp. 251-255); e TERÄVÄINEN, J. "Henrik Gentiläisen tieto-oppi”. Tampereen Yliopiston Filosofian Laitoksen Julkaisuja / Reports from the Institute of Philosophy, University of Tampere 5 (1975), pp. 12-14. De outra parte, essa mesma confluência de passividade e atividade é vista como um conflito aporético que se instala na doutrina da intelecção de Henrique de Gand e, mais particularmente, em sua tentativa de inserir uma noção de verbum em tal doutrina - sobre isso, cf. ARGOS, B. P. "La actividad cognoscitiva en los escolásticos del primer periodo postomista (1275-1320) - II/III". Pensamiento 4 (1948), pp. 287-309 (esp. pp. 2912).

13 TIEDEMANN, D. Geist der speculativen Philosophie. Band 4. Marburg: Akademische Buchhandlung, 1795, p. 573: "Auch die Seelenlehre bereichert Heinrich mit verschiedenen neuen Bermerkungen. Daß beym Denken und Empfinden nicht bloß Leiden, sondern auch Thätigkeit vorkommt, erblickt er mit vieler Richtigkeit, und in Ansehung des Empfindens mit Neuheit"; TENNEMANN, W. G. Geschichte der Philosophie. Band 8.2. Leipzig: Johann Ambrisius Barth, 1811, p. 684: "In der Psychologie hat Heinrich einige herrschende Vorstellungsarten bereichtiget, und in einigen Punkten einen scharfen Beobachtungsgeist und hellen Verstand geäußert. So bemerkt er, daß beim Empfinden und Denken nicht bloß Leiden, sondern auch eine Thätigkeit vorkomme"; WULF, M.
} 
só tempo - mas, sempre, ordenadamente - passivo e ativo do processo de conhecimento que pretendo dar atenção no que se segue do presente trabalho. Veremos que esse complexa série ordenada de passividade e atividade permeará toda nossa discussão, tanto sobre a sensação como sobre a intelecção abstrativa dos incomplexos.

Tendo visto que em Henrique de Gand, embora fundamentalmente passivas, as potências cognoscitivas humanas possuem alguma atividade própria, estamos em posição de nos voltarmos para o estudo atento do conhecimento humano não mais enquanto estrita passividade, mas também enquanto atividade. Essa exposição inicial dos comentários a respeito do tema, porém, mostra que a atenção ao detalhe será imprescindível para que possamos compreender a minuciosa relação entre atividade e passividade que, para o Doutor Solene, possibilita o ato de conhecimento humano.

de. Études sur Henri de Gand, 1894, pp. 110-111 (onde a posição de Werner acerca da estrita passividade do intelecto é diretamente discutida e rejeitada). 


\section{Parte 2}

\section{A atividade do homem na formação do conhecimento}





\section{CAP. 4. \\ O CONHECIMENTO DOS SENTIDOS PARTICULARES ${ }^{1}$}

\subsection{OS CINCO SENTIDOS PARTICULARES}

Aquilo que Henrique de Gand compreende como o "processo da notícia humana [progressum humanae notitiae]"2 tem início com o conhecimento sensitivo das coisas externas à alma. Com efeito, poderíamos denominar as potências sensitivas que conhecem tais coisas como sentidos externos, uma vez que eles se voltam mais imediatamente (do que outras potências da alma) para aquilo que possui um ser por si

\footnotetext{
${ }^{1}$ A grande dificuldade no estudo do conhecimento sensitivo (externo ou interno) em Henrique de Gand está no fato de que este último não parece ter se debruçado tão longamente sobre o conhecimento sensitivo quanto o fez no tocante a outros temas. De fato, o conhecimento sensitivo é importante para Henrique na medida em que ajuda explicar o conhecimento intelectivo (seja por comparação, seja porque, como já vimos, aquele é a origem deste). Lembremos daquilo que lemos mais acima: "feita a apreensão pelos sentidos, cumpre desviar dos sentidos, tal que se faça um juízo pela razão" (cf. cap. 1, nota 47). O Doutor Solene, de fato, se desvia o quanto antes dos sentidos em seu estudo do conhecimento humano - no entanto, os sentidos ainda são fundamentais para a intelecção e para a compreensão desta última enquanto operação humana. Sendo assim, certamente não deveremos nos abster de estudar a noção de sensação em Henrique, mas devemos ter claros os limites desse estudo, uma vez que a maior parte das observações que faremos são necessariamente reconstruções a partir de textos que, em geral, não estão lidando principalmente com a própria noção de 'conhecimento sensitivo', mas antes como alguma outra (normalmente, a noção de 'intelecção') que seria melhor compreendida por comparação aos (ou pela consideração dos) sentidos.

Some-se a essa dificuldade o pouco material bibliográfico disponível a respeito da sensação em Henrique de Gand: WULF, Études sur Henri de Gand, 1894, pp. 74-82; BRAUN, Die Erkenntnislehre..., 1916, pp. 15-21; BROWN, J. V. "Sensation in Henry of Ghent: A late medieval Aristotelian-Augustinian synthesis". Archiv für Geschichte der Philosophie 53 (1971), pp. 238-266; BROWN, J. V. "Henry of Ghent on Internal Sensation". Journal of the History of Philosophy 10 (1972), pp. 15-28 (ambos adaptados de BROWN, J. V. Divine Illumination and the Theory of Knowledge in the Philosophy of Henry of Ghent. A thesis submitted in conformity with the requirements for the degree of Doctor of Philosophy in the University of Toronto, 1969, pp. 1-46); SORGE, Gnoseologia e teologia..., 1988, pp. 49-75; PIRO, F. "Sensi interni e eziologia degli affeti. A proposito di due quaestiones sul dolore di Enrico di Gand". In: VESCOVINI, G. F. et al. (ed.). Corpo e anima, sensi interni e intelletto dai secoli XIII-XIV ai post-cartesiani e spinozani. Turnhout: Brepols, 2005, pp. 189-210; GOEHRING, Henry of Ghent on cognition..., 2006, passim; ROMBEIRO, M. E. "Intelligible Species in the Mature Thought of Henry of Ghent". Journal of the History of Philosophy 49.2 (2011), pp. 181-220; GOEHRING, B. "Henry of Ghent's Use of Aristotle's De anima in Developing his Theory of Cognition". In: FRIEDMAN, R. L., COUNET, J.-M. (éds.). Medieval Perspectives on Aristotle's De anima. Louvain-la-Neuve - Louvain-Paris-Walpole: Éditions de l'Institut Supérieur de Philosophie - Peeters, 2013, pp. 63-99; PICKAVÉ, M. "Causality and Cognition. An Interpretation of Henry of Ghent's Quodlibet V, q. 14". In: KLIMA, G. (ed.). Intentionality, Cognition, and Metal Representation in Medieval Philosophy. Amazon Kindle Edition. New York: Fordham University Press, 2015, pos. 1109-988. A esses podemos adicionar alguns comentários acerca da noção de abstração em Henrique de Gand que contenham reflexões secundárias sobre a sensação - iremos citá-los na medida em que se mostrarem necessários.

${ }^{2}$ Cf. nota 37 , adiante.
} 
fora da alma - para aquilo que é, por si, externamente à alma. O Doutor Solene, entretanto, prefere a denominação 'sentido particular' (sensus particularis); não porque o próprio sentido seja particular (embora ele o seja, como toda potência de um ser existente particular), mas porque ele é o conhecimento do particular fora da alma. Com efeito, o sentido particular possui "um particular próprio sensível materialmente objetificado fora primeiramente e por si" ${ }^{\prime 3}$. Em outras palavras, o sentido particular é denominado a partir de seu objeto próprio - um particular, material e sensível.

Essa potência do sentido particular distingue-se, de fato, nos conhecidos cinco sentidos: visão, audição, paladar, olfato e tato (muito embora o discurso sobre a visão, tomada como paradigma do conhecimento sensitivo, ofusque qualquer discussão mais apropriada dos outros quatro sentidos). Assim como a denominação dessa potência (que veremos o gandavense chamar de vis ou virtus) advém de seu objeto próprio, também tal divisão em cinco sentidos se deriva dos cinco sensíveis. Mais uma vez, o Doutor Solene se vale da ordenação do mundo para a compreensão do homem e suas capacidades (algo a que ainda assistiremos por diversas vezes):

\begin{abstract}
"Se, portanto, houvesse algo nas criaturas para o qual fosse impossível, na natureza das coisas do universo [in natura rerum universi] atingir seu fim próprio, aquilo sem dúvida seria em vão [frustra] - tal como seria um sexto sentido no animal, já que não há sensíveis, nem pode haver, para além dos cinco. E, assim, seria impossível que aquele sexto sentido se aperfeiçoasse em sua operação de sentir (que é seu próprio fim), pois é impossível que haja um sexto sensível que possa movê-lo. Aquele sentido $<$ seria $>$ totalmente em vão [frustra] no animal, como o Filósofo determina em De anima II" ${ }^{4}$.
\end{abstract}

Vão (frustra), com efeito, é algo "quando não pode de todo atingir aquele fim" próprio naquela ordenação do mundo ${ }^{5}$ que longamente estudamos nos capítulos anteriores na tentativa de localizar o homem no universo. Parece, então, que a finalidade do sentido (enquanto potência da alma humana) é o aperfeiçoamento (isto

\footnotetext{
${ }^{3}$ Henrique de Gand, Quodl. 2, q. 6, co. (ed. De Wulf-Mansion Centre, vol. 6, pp. 31-2): "Unde sensus particularis, quia omnino est materialis, habens particulare proprium sensibile materialiter obiectum extra primo et per se <... ". Voltaremos a essa passagem mais à frente, na nota 29.

${ }^{4}$ Henrique de Gand, Suma, art. 35, q. 6, co. (ed. De Wulf-Mansion Centre, vol. 28, p. 65): "Si igitur in creaturis esset aliquid, quod impossibile esset in natura rerum universi attingere suum finem proprium, illud procul dubio esset frustra, sicut esset sextus sensus in animali, cum non sint sensibilia neque possunt esse, praeter quinque, et ita impossibile esset illum sextum sensum perfici operatione sua sentiendi, quae est suus proprius finis, quia impossibile est esse sextum sensibile quod posset illum movere: ille sensus omnino frustra in animali, ut determinat Philosophus in II $^{\circ}$ De anima".

${ }^{5}$ Henrique de Gand, Suma, art. 35, q. 6, co. (ed. De Wulf-Mansion Centre, vol. 28, p. 64): "Solum ergo in eis quae ordinabilia sunt ad aliquem finem, frustra dicitur esse aliquid, quando non potest omnino finem illum attingere".
} 
é, como também já vimos na parte 1, sua atualização para a sua operação própria que é sentir) ao ser movido pelo seu sensível próprio externo a si - no caso dos sentidos particulares, os sensíveis particulares que possuem um ser próprio externo à alma que está em potência para conhecê-los sensivelmente. Um sexto sentido seria vão, justamente porque não haveria nada que pudesse movê-lo à sua operação própria, de modo que lhe seria impossível atingir seu fim.

Ou seja, a suficiência da divisão do sentido particular em cinco é estabelecida pela própria ordem do mundo: aos cinco sensíveis particulares que ocorrem no universo correspondem os cinco sentidos particulares que por eles podem ser atualizados. Determinada tal suficiência dos cinco sentidos como parte da ordem do universo divisada por Henrique de Gand, toda a dificuldade está em compreender como ocorre tal atualização do sentido particular pelo seu sensível particular próprio. É isso que estudaremos neste capítulo.

\subsection{LUX, SPECIES, CONFIGURATIO}

Ainda no início da sua Suma, Henrique de Gand enumera aqueles que ele considera que sejam os três requisitos para a visão corpórea:

"O primeiro daqueles que se requerem na visão corpórea [in visu corporali] é a
luz que ilumina [lux illuminans] o órgão para aguçar [ad acuendum]. O segundo
é a espécie da cor [species coloris] que a modifica para intuir [ad intuendum]. O
terceiro é a configuração [configuratio] que a determina para discernir [ad
discernendum]"6.

Destaque-se, em primeiro lugar, que esse é precisamente um daqueles momentos a que nos referimos há pouco, nos quais, a saber, o conhecimento sensitivo surge unicamente como termo de comparação para uma melhor compreensão do conhecimento intelectivo. Assim, o objetivo do Doutor Solene nesta passagem, como bem destaca Jerome V. Brown, é mostrar que "luz (lux), espécie (species) e formato (figura) são necessários para sentir e para inteligir"”. Ou seja, desde já se nos coloca o problema a que aludíamos, qual seja, a possibilidade de tomar como expressões de

\footnotetext{
${ }^{6}$ Henrique de Gand, Suma, art. 1, q. 3, co. (ed. De Wulf-Mansion Centre, vol. 21, p. 73): "Primum illorum quae requiruntur in visu corporali est lux illuminans organum ad acuendum. Secundum est species coloris immutans eum ad intuendum. Tertium configuratio determinans eum ad discernendum".

${ }^{7}$ BROWN, J. V. "Sensation in henry of Ghent”, 1971, p. 240: "Light (lux), species (species) and shape (figura) are necessary both for sensing and for understanding".
} 
uma 'doutrina da sensação' consistente textos onde a noção de 'conhecimento sensitivo’ surge unicamente enquanto um elemento dentre outros para clarificação da noção de 'conhecimento intelectivo'. Essa é uma limitação que teremos que levar em consideração na maior parte das fontes textuais desta etapa de nossa trabalho, de maneira que, mais do que ultrapassá-la, meu objetivo aqui será tão só tê-la sempre em mente.

Feita essa retomada dos problemas metodológicos implicados neste momento do trabalho, voltemos ao excerto destacado. O que de início chama a atenção é que não são todos os sentidos a serem abordados na passagem, mas apenas a visão. Como já notado, é muito clara no discurso de Henrique sobre os sentidos externos a preponderância da visão como paradigma do conhecimento sensitivo. Destarte, a maioria dos excertos que estudaremos a seguir versa principalmente sobre a visão ou, pelo menos, se vale da aplicação de ferramentas conceituais utilizadas principalmente no estudo da visão à descrição dos demais sentidos particulares.

Dito isso, os requisitos para a visão são apresentados em tríades que expressam tanto um agente que age para a visão, como a ação que ele produz ao agir e, finalmente, o seu efeito quanto ao ato de visão: [i] 'a luz que ilumina para aguçar' (lux illuminans <...> ad acuendum), [ii] 'a espécie da cor que modifica para intuir' (species coloris immutans <...> ad intuendum) e [iii] 'a configuração que determina para discernir' (configuratio determinans $<\ldots>$ ad discernendum). Temos, assim, três tríades: [i] lux / illuminans / ad acuendum, [ii] species coloris / immutans / ad intuendum e [iii] configuratio / determinans / ad discernendum. Junto a esse paralelismo triádico, entretanto, encontramos importantes dificuldades nas construções das três sentenças.

Se atentarmos bem, veremos que a primeira sentença possui uma possível ambiguidade. Na frase "in visu corporali est lux illuminans organum ad acuendum", parece claro que a lux surge como substantivo caracterizado por "illuminans ... ad acuendum", assim como parece patente que o organum é aquilo que é iluminado, porém não se determina aquilo que é aguçado quando a luz ilumina o órgão. Isto é, poderíamos perguntar: a luz ilumina o órgão ad acuendum o quê? O próprio organum ou o visus corporalis? De certo modo, essa pergunta pressupõe uma ambiguidade da própria noção de 'sentido' em Henrique de Gand, uma vez que ela remete tanto ao órgão como à força sensitiva, ambas as quais têm parte (ainda que diferentemente) na formação do conhecimento sensitivo - como veremos durante o capítulo, o visus 
corporalis diz respeito a um organum e, também, a uma virtus (ou vis) visiva. Embora pareça aqui que o discurso se volta para o próprio ato de visão, veremos, no próximo trecho destacado, que Henrique continua sua exposição pela consideração da relação entre a lux e a virtus visiva, de maneira que não parece haver uma pista totalmente clara para a solução daquela ambiguidade por ora. Deixando ela de lado, basta notarmos que, nessa primeira sentença, o organum surge como aquilo afetado pela ação da luz que, ao afetá-lo, aguça 'algo'.

Se nos voltamos agora para a segunda sentença - "secundum est species coloris immutans eum ad intuendum" -, vemos que não ocorre nenhuma menção ao organum, uma vez que o pronome masculino acusativo eum só pode remeter a visus, substantivo masculino da quarta declinação. Destarte, parece que o visus é 'modificado para intuir' e não o organum. Mas, ad intuendum o quê? Mais uma vez, o verbo final permanece sem objeto...

A terceira sentença - "tertium configuratio determinans eum ad discernendum" - possui estrutura semelhante: o visus (referido novamente pelo pronome eum) reaparece como aquilo que é determinado pela configuratio para discernir. De novo, esse ad discernendum permanece sem objeto.

Enfim, esse pequeno trecho possui uma estrutura muito complexa, uma vez que, através do paralelismo das três sentenças, ele discorre acerca de dois elementos distintos: o organum e o visus corporalis, sendo a exata relação entre esses dois elementos do conhecimento sensitivo ainda pouco compreensível. Para além dessa dificuldade, o que extraímos desse trecho é que a luz é o único dos três destacados lux, species e configuratio - relacionada diretamente ao órgão, sendo os outros dois associados a virtus visiva.

Dito isso, podemos agora atentar para a cuidadosa descrição que Henrique fornece de que cada um desses três requisitos, começando pela luz:

"Primeiro, opera a luz, pois em um órgão tenebroso a virtude visiva [virtus
visiva] jaz como que embotada [obtusa] e, sem que houvesse antes esse ato da
luz no olho, nunca a cor, introduzindo no olho por seu ato a sua espécie, o
modificaria, nem a força visiva [vis visiva] conceberia algo [aliquid conciperet],
mesmo que a espécie da cor se difundisse até o olho sem a luz, tal que de acordo
com isso entendamos o que diz o Filósofo no II De anima: 'a cor é o motivo da
visão [visus] segundo o ato do luzente'.
Mas aqui cumpre entender que a luz pode se difundir no olho a partir de um
corpo luminoso duplamente: de um modo por aspecto direto [aspectu directo]
(assim, ele não só ilumina para que se vejam outros que não ele, mas modifica
também para que se veja e se discirna ele mesmo); de outro modo, pode se 
difundir por aspecto oblíquo [aspectu obliquo] (primeiro, por aspecto direto sobre a cor visível, em segundo lugar, com a cor para a visão). Assim, porém, só ilumina para ver e manifestar outros que não ela. De fato, se houvesse um meio iluminado e não houvesse nenhum obstáculo ao olho por aspecto direto que limitasse [terminaret] a visão e por sua luz ou cor a modificasse (tal como se o meio iluminado fosse infinito), a visão, como que se alçando, se voltaria a seu redor buscando [quaerendo] a seu redor se quiçá ocorreria algo que pudesse intuir" ${ }^{\prime}$.

Notemos, de saída, o jogo de palavras utilizado aqui por Henrique de Gand: a luz age ad acuendum, isto é, para 'aguçar' ou 'afiar', porque, sem que haja luz no órgão, a virtude visiva permanece 'embotada'. Em português diríamos que a luz no órgão está para a virtude visiva tal como a pedra que afia uma faca para que ela não fique cega... Ou seja, nesse ponto aquela pergunta que fizemos há pouco - a saber, a luz ilumina o órgão ad acuendum o quê? O próprio órgão (aqui já descrito como oculus) ou a visão? - ganha uma resposta: aquilo que é aguçado é a virtude visiva e não o próprio órgão que é iluminado. Além disso, agora há uma clara referência a uma virtus visiva ou vis visiva, o que não dá espaço para a ambiguidade gerada pela expressão visus corporalis no trecho anterior.

Pois bem, o primeiro parágrafo desse último trecho se mostra muito rico, pois aponta para a estreita relação entre a espécie e a luz, a virtude visiva e o olho (isto é, o órgão da visão) para o ato de ver. É-nos dito que a luz é em ato no olho (sendo que, através desse ato no órgão, ela aguça a própria virtude visiva) e esse ato é um prérequisito para que uma cor, ao introduzir no olho uma espécie, possa modificá-lo ${ }^{9}$

\footnotetext{
${ }^{8}$ Henrique de Gand, Suma, art. 1, q. 3, co. (ed. De Wulf-Mansion Centre, vol. 21, pp. 73-74): "Primum operatur lux, quia in organo tenebroso virtus visiva iacet quasi obtusa, et nisi iste actus lucis in oculo praecederet, numquam color suo actu speciem suam immitendo oculo ipsum immutaret, nec vis visiva aliquid conciperet, etiamsi sine luce species coloris in organum se diffunderet, ut secundum hoc intelligamus quod dicit Philosophus II $^{\circ}$ De anima: 'Color est motivum visus secundum actum lucidi'.

Sed hic est intelligendum quod lux potest se diffundere in oculo a corpore luminoso dupliciter: uno modo aspectu directo - sic non solum illuminat ad videndum alia a se, sed ad se ipsum videndum et discernendum etiam immutat -; alio modo potest se diffundere aspectu obliquo - primo directo aspectu super visibilem colorem, secundo cum colore ad visum. Sic autem solum ad videndum et manifestandum alia a se illuminat. Si enim esset medium illuminatum et nullum in directo aspectu ad oculum esset obstaculum quod visum terminaret et a sua luce aut colore immutaret, ut si medium illuminatum esset infinitum, visus quasi sese erigindo circumquaque se diverteret, quaerendo circumquaque si forte occurreret aliquid quod intueri posset".

${ }^{9}$ De fato, a cor nem mesmo poderia introduzir no olho uma espécie sem a luz, pois somente em um meio iluminado é possível a difusão de tal espécie (como veremos no decorrer deste capítulo). Portanto, ao admitir uma espécie difundida até o olho e nele introduzida sem o ato da luz, Henrique está propondo um argumento per impossibile, como se parece admitir ao fim do primeiro parágrafo do trecho: "mesmo que a espécie da cor se difundisse até o olho sem a luz". A escolha por tal tipo de argumento parece estar ligada ao interesse de concentrar a discussão no ato da luz no olho e não no meio externo ao órgão - somente um argumento per impossibile permitiria conceber a difusão da espécie de uma cor até o olho na ausência de luz no meio.
} 
(lembremos que, no trecho anterior, o visus como um todo era modificado pela espécie, enquanto agora é precisado que o oculus - isto é, o organum - o é). Igualmente, sem o ato da luz no olho, a força visiva jamais 'conceberia algo' (aliquid conciperet). Ou seja, embora o ato da luz no olho seja fundamental para a visão tanto no que diz respeito ao órgão como no que tange à virtude visiva, cada um desses dois atua diferentemente: o órgão é modificado pela espécie da cor, enquanto a virtude visiva concebe algo. Assim, no caso do órgão, o ato da luz no órgão permite uma atualização passiva (ele é modificado), enquanto que no caso da virtude visiva o ato da luz no órgão permite uma atualização ativa (ela concebe algo). Essa distinção entre a passividade do órgão e a atividade da virtude ou força sensitiva é fundamental para a concepção de conhecimento sensitivo exposta por Henrique de Gand. Vemos aqui introduzido no discurso sobre os sentidos, portanto, aquele necessário equilíbrio entre atividade e passividade que marca a concepção de conhecimento do Doutor Solene ${ }^{10}$.

Após a consideração da necessidade do ato da luz no olho para a visão, há no trecho destacado uma discussão acerca das maneiras pelas quais esse ato da luz no olho pode vir a ocorrer - essa discussão terá por base a distinção entre dois modos de difusão da luz desde um corpo luminoso (corpus luminosum) até o olho: [i] 'por aspecto direto' (aspectu directo) ou [ii] 'por aspecto oblíquo' (aspectu obliquo) ${ }^{11}$. No primeiro caso, o corpo luminoso difunde a luz ao olho tal que ele próprio - corpo lumino - seja visto (algo como se olhássemos para o Sol, de maneira a que não somente nosso olho fosse iluminado, mas igualmente víssemos o próprio Sol). Isto é, a luz está se difundindo diretamente desde o corpo luminoso até o olho. Atente-se para o fato de que o vocabulário utilizado para descrever o conhecimento provocado por essa difusão aspectu directo, a qual permite 'que se veja e se discirna' (se ipsum videndum et discernendum), remete ao tema da configuratio, que vimos acima ser necessária justamente para que a visão seja determinada para discernir (determinans $<\ldots>$ ad discernendum $)^{12}$. Ou seja, agora imputa-se à luz difundida aspectu directo algo que cabia inicialmente somente à configuratio. Isso, parece-me, mostra que a noção de discernere não está aqui bem fixada (mais adiante, com efeito, veremos essa

\footnotetext{
${ }^{10} \mathrm{Cf}$, acima, o Epílogo à parte 1.

${ }^{11}$ Sobre o caráter indireto da ação da luz sobre o olho na visão, cf. BROWN, J. V. "Sensation in Henry of Ghent", 1971, p. 257.

${ }^{12} \mathrm{Cf}$. nota 6 e, mais adiante, a 16.
} 
noção novamente mudar de figura ${ }^{13}$ ). Já no segundo caso de difusão da luz, a luz é difundida pelo corpo luminoso diretamente sobre uma cor, só se difundindo até o olho junto a cor. Sendo assim, parece que a espécie não carrega consigo somente algo da cor daquilo de que provém, mas também traz obliquamente a luz até o olho. Dessa maneira, o próprio corpo luminoso não é visto, mas sim atualiza a visão da cor sob a qual incidiu diretamente. Esta última, por sua vez, deve difundir a luz com sua espécie até o olho diretamente (aspectu directo).

Ora, desses, o segundo caso - aquele que envolve o 'aspecto oblíquo' - parece descrever o funcionamento corrente da visão, de maneira que o gandavense acrescenta uma nota final afirmando a necessidade de obstáculos postos aspectu directo ante os olhos, para que a luz proveniente do corpo luminoso possa nestes incidir aspectu obliquo (isto é, por meio daqueles obstáculos). Aliás, é interessante notar como o caráter simultaneamente ativo e passivo da visão (visus) é destacado ao fim: em presença de um meio iluminado sem nenhum obstáculo direto para a visão que apresente a ela uma cor que a modifique (immutaret), a visão irá buscar (quaerendo) algo que possa intuir. Se antes não sabíamos qual seria o objeto desse verbo intueri no presente contexto, parece agora que a visão intui justamente aquilo que se coloca a ela diretamente como obstáculo colorido - isso ficará mais claro no próximo trecho destacado. Por enquanto, sublinhemos que, nessa sentença final, o visus está incluindo em si a passividade do oculus e a atividade da virtus ou vis visiva. No que se segue, veremos ser cada vez mais reforçado esse paralelismo entre os pares 'atividade x passividade' e 'orgão x vis ou virtus' no discurso sobre os sentidos.

Pois bem, se no último trecho destacado já se fala bastante a respeito da espécie da cor, da modificação que ela produz no olho e da sua estreita relação com o ato da luz no órgão e no meio, agora são dedicadas algumas linhas a ela própria, em continuação da reflexão final acerca da necessidade, para a visão, de obstáculos no meio iluminado:

“Assim, agora, faz-se na visão uma espécie da cor difundida por todo o meio
desde um corpo colorido - desde qualquer ponto do meio - e, no entanto, ela não
modifica para que se a intua a não ser que proceda por aspecto direto desde a
superfície de um corpo colorido no qual a cor possua um ser terminado pelo qual
seja visível por si, mas não em qualquer ponto do meio. Isto, portanto, é o

\footnotetext{
${ }^{13}$ Cf. notas 20 e 91.
} 
segundo que se requer para um ato de ver perfeito: uma espécie difundida segundo aspecto reto desde um visível por si, modificando para intuir" ${ }^{\prime 14}$.

Aquilo que esse trecho introduz de novidade é, principalmente, uma distinção entre a presença de uma espécie de cor no olho e a própria intuição dessa cor. Com efeito, ainda que haja o ato da luz no olho, é possível que uma espécie se difunda até o olho sem que, entretanto, modifique a visão tal que aquele corpo colorido do qual provém a espécie seja intuído. Isso ocorre, porque a mera presença de uma espécie no olho é insuficiente para a intuição daquele corpo de que provém a espécie, sendo necessário além de tal presença a difusão direta dessa espécie, desde o corpo colorido até a visão (que, aqui, parece retomar aquele significado complexo, que congrega a passividade do organum e atividade da vis visiva), pelo meio iluminado. Em outras palavras, uma espécie pode ser feita na visão (facit se in visum) sem que 'modifique para intuir' - isto é, sem que propriamente leve àquilo que agora vemos nomeado como 'ato perfeito de ver' (actum perfectum videndi). Portanto, começa aqui a ficar clara uma maior complexidade do ato de ver do que aquela que havíamos notado: não somente a modificação do olho é insuficiente para a visão, uma vez que se mostra igualmente necessária uma ação de concepção da vis visiva, mas também nem todo fazer-se de uma espécie no olho equipara-se à modificação suficiente para que haja uma intuição do corpo colorido de que provém a espécie. Ou seja, pode haver uma espécie no olho sem a modificação do olho para a intuição; da mesma maneira, tal modificação do olho para a intuição é, em alguma medida, distinta da concepção pela vis visiva.

A precisa maneira como esses elementos se agregam na produção do 'ato perfeito de ver' não está, entretanto, clara ao que me parece - sabemos, unicamente, que tal ato pressupõe que se faça uma espécie no olho diretamente de modo a modificá-lo para intuir e, nesse caso, a vis visiva 'concebe algo'. Não parece uma descrição particularmente completa... Ela, porém, possui duas características claras: [1] a distinção entre [1.1] a mera presença da espécie no olho e [1.2] a presença da espécie suficiente para modificá-lo para intuir; e [2] a distinção entre [2.1] tal

\footnotetext{
${ }^{14}$ Henrique de Gand, Suma, art. 1, q. 3, co. (ed. De Wulf-Mansion Centre, vol. 21, p. 74): "Sicut modo species coloris diffusa per totum medium a corpore colorato a quolibet puncto medii facit se in visum, et tamen non immutat ad intuendum se, nisi ut procedit directo aspectu a superficie corporis colorati in quo color habet esse terminatum quo est per se visibile, non autem in aliquod puncto medii. Hoc ergo est secundum quod requiritur ad perfectum actum videndi species secundum rectum aspectum diffusa a per se visibili, immutans ad intuendum".
} 
modificação passiva e [2.2] a atividade da virtude ou força visiva. A segunda dessas características, como já dito, será de suma relevância para toda a concepção de conhecimento em Henrique de Gand e, em particular, para sua noção de conhecimento sensitivo. Já a primeira, começa a apontar como, ao afirmar a necessidade de espécies na produção do ato de sentir ${ }^{15}$, será necessário melhor problematizar a relação entre a presença da espécie no órgão e a atualização do próprio ato de conhecimento sensitivo. Ambas as questões terão fortes ecos em escritos posteriores de Henrique de Gand.

Com isso, vemos que dois dos requisitos da visão destacados pelo Doutor Solene em Suma, art.1, q. 3 - a saber, lux e species - são aí razoavelmente bem desenvolvidos e terão grande importância em outros textos seus. Por outro lado, o terceiro requisito elencado aqui por ele para a visão - a configuratio - não receberá grande atenção para além do presente texto, onde ela é explicitada da seguinte maneira:

\begin{abstract}
"O visível por si e primeiro - tal como a luz ou a cor, na razão pela qual é luz ou cor - não determina a disposição da coisa vista pela qual ela é distinguida e distintamente se conhece que um colorido é diferente e diverso de outro, mas somente o faz o carácter da figura do corpo colorido, que a cor transporta consigo como similitude e imagem da coisa vista (similitude em razão da cor, imagem em razão do carácter) e <que $>$ caracteriza a visão com perfeita similitude e imagem da coisa vista. Isto, portanto, é o terceiro que se requer para um perfeito ato de ver: a transfiguração [transfiguratio] determinando para discernir" ${ }^{\prime 16}$.
\end{abstract}

Com exceção da afirmação clara da luz ou da cor como os visíveis primeiros e por si (uma tese que já parecia pressuposta nas passagens anteriores, mas não havia sido ainda declarada), esse trecho é profundamente problemático. Comecemos pelas questões de vocabulário. Na passagem inicial desse longo excerto que estamos a ler ${ }^{17}$, dizia-se que o terceiro requisito para a visão é a "configuratio determinans eum $<$ sc.

\footnotetext{
${ }^{15}$ A admissão e exigência de espécies sensíveis por Henrique de Gand é rapidamente discutida em TACHAU, K. H. Vision and Certitude in the Age of Ockham. Optics, Epistemology and the Foundations of Semantics, 1250-1345. Leiden - New York - København - Köln: Brill, 1988, pp. 30-1.

${ }^{16}$ Henrique de Gand, Suma, art. 1, q. 3, co. (ed. De Wulf-Mansion Centre, vol. 21, pp. 74-5): "Quia tamen per se et primo visibile, sicut lux aut color ratione qua lux aut color est, non determinat dispositionem rei visae qua distinguitur et distincte cognoscitur unum coloratum esse differens et diversum ab alio, sed hoc facit solum character figurae corporis colorati quem secum defert color tanquam similitudinem et imaginem rei visae - similitudinem ratione coloris, imaginem ratione characteris - et characterizat visum perfecta similitudine et imagine rei visae. Hoc ergo est tertium quod requiritur ad perfectum actum videndi, transfiguratio determinans ad discernendum".

${ }^{17}$ Cf. nota 6, acima.
} 
visum $>$ ad discernendum"; ora, este último trecho destacado nem mesmo fala em configuratio, mas somente em transfiguratio, não havendo qualquer outra lição discordante no aparato crítico da passagem segundo a edição De Wulf-Mansion Centre. Além disso, busca-se explicar essa configuratio/transfiguratio pela noção mais obscura de character figurae, que seria transmitido junto à cor desde o corpo visível até a própria visão. Aquilo que antes era a espécie da cor - e que já conjugava cor e luz - surge agora sobrecarregado com mais um elemento, pois ela não somente é similitude da coisa no que diz respeito à cor, mas também é imagem da coisa enquanto transporta esse character figurae ${ }^{18}$.

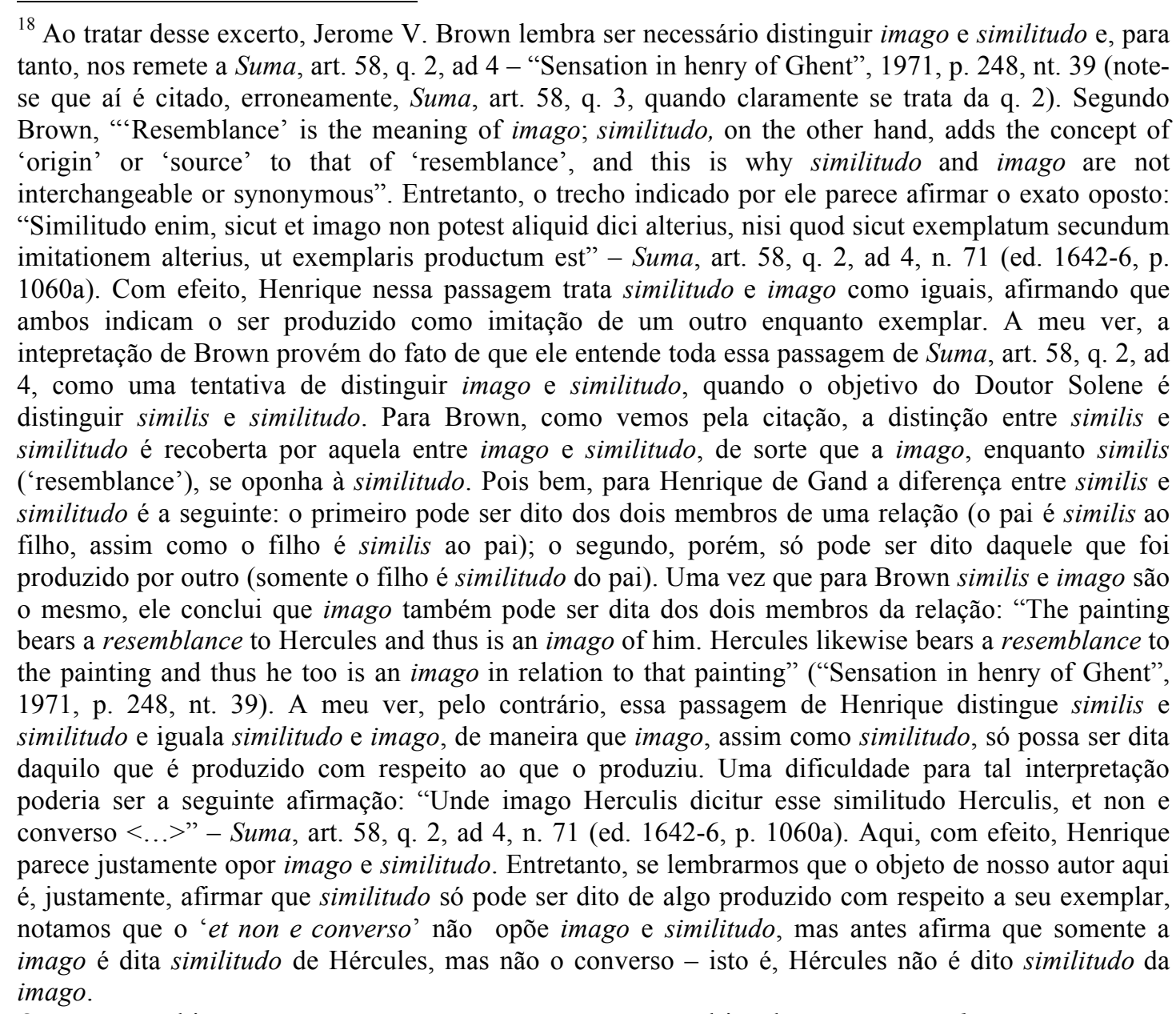
Ora, se essa última passagem mostra que não parece possível igualar imago e similis como opostos à similitudo - pelo contrário, como vimos nesta nota, tanto imago como similitudo só podem ser ditas do produzido com respeito a seu exemplar -, ela parece igualmente indicar que há alguma diferença entre imago e similitudo. Com efeito, se nos voltamos para Suma, art. 59, lemos: " $<\ldots>$ similitudo, quae proprie dicitur secundum tres primas species qualitatis, etiam comprehendit rationem imaginis, quae dicitur proprie secundum quartam speciem qualitatis" - Suma, art. 59, q. 4, co., n. 11 (ed. 1642-6, p. 1049a). Assim, a similitudo é dita a partir de uma qualidade de qualquer tipo (veremos, no próximo item, que a possibilidade da difusão de tal qualidade pelo meio como species se deriva de seu caráter intencional). A imago, de sua parte, é uma similitudo precisa, a saber, aquela que se diz a partir da quarta espécie de qualidade. Esta última, se formos ao Tractatus de Pedro de Espanha, é precisamente a qualidade que diz respeito à figura e à forma (ed. De Rijk, 1972, p. 37). Em resumo, toda similitudo diz respeito a qualidades, mas a similitudo que diz respeito à quarta espécie de qualidade (isto é, a 
De alguma maneira não muito explicada, o Doutor Solene defende que é justamente essa duplicidade da espécie que permite à visão não somente intuir o corpo visível (pela similitude da cor), mas também distingui-lo de outros corpos visíveis (pela imagem do carácter da figura daquela coisa). Se a espécie enquanto similitude modifica o olho (ou o visus) para a intuição do corpo visível, a espécie enquanto imagem transfigura ou configura o visus para discernir este corpo visível daquele parece, destarte, que aquele 'discernir' torna-se sinônimo de 'distinguir' entre um e outro. Porém, o que precisamente seriam essa configuração ou transfiguração, esse discernimento ou distinção permanece obscuro. Da mesma maneira, não é dito o que seria esse character figurae ou como ele transfigura/configura o visus - ao que parece, de algum modo ele seria responsável por emprestar ao visus a figura da coisa vista, embora isso não seja claramente afirmado ou, mesmo, não se explique o que isso quereria dizer.

No mais, como antes dito, esse terceiro requisito do ato de ver parece ser abandonado por Henrique de Gand nos demais trechos de sua obra em que ele discute a sensação. Em especial, esse 'discernir' ou 'distinguir' que surge associado à configuratio / transfiguratio aqui em Suma, art. 3, reaparece em Suma, art. 24, ligado agora à modificação, que vimos ser provocada pela espécie: “< $<>$ o olho do corpo, vendo a cor na luz, primeiro vê a luz e, por ela, julga acerca da cor ${ }^{19}$, embora não discirna quanto à luz tal como quanto à cor [discernat de luce sicut et de colore], devido à sua modificação sutil [propter subtilem eius immutationem]”,20. Mais adiante, no mesmo artigo, Henrique retoma em parte a mesma argumentação: “< ..> se vemos a cor devido à luz, não é preciso, porém, que vejamos mais a luz, pois ela não é vista distinta da cor $<\ldots>$, ${ }^{\text {21 }}$. Decerto, não estamos aqui em uma discussão acerca da

figura ou forma) é dita imago.

Isso nos traz de volta ao trecho de Suma, art. 1, q. 3 que estamos lendo aqui. Quando Henrique de Gand afirma que a espécie é similitudo da coisa quanto à cor (uma qualidade da terceira espécie - cf. Pedro de Espanha, Tractatus (ed. De Rijk, 1972, p. 37)) e imago da mesma coisa quanto à forma, ele está justamente se utilizando dessa distinção técnica que vimos ser desenvolvida em Suma, arts. 58 e 59. Como veremos na continuação, porém, essa distinção no âmago da species entre similitudo e imago, ainda que pareça ter eco em Suma, art. 33, por exemplo (cf. nota 26, adiante), não será particularmente produtiva na obra do Doutor Solene.

${ }^{19}$ Notemos uma retomada da associação entre ‘juízo' e 'sensação' que já havíamos encontrado em cap. 1, nota. 43. Voltaremos a isso adiante, na nota 36.

${ }^{20}$ Henrique de Gand, Suma, art. 24, q. 7, ad 1 (ed. Decorte \& Teske, p. 252): “<..> sicut oculus corporis videns colorem in luce, primo videt lucem, et per illam iudicat de colore, licet non discernat de luce sicut de colore, propter subtilem eius immutationem".

${ }^{21}$ Henrique de Gand, Suma, art. 24, q. 9, ad 1 (ed. Decorte \& Teske, p. 272): “< <.> si videmus colorem 
'distinção' ou do 'discernimento' entre dois corpos visíveis - em lugar disso, o que se retoma é a temática da difusão, no meio iluminado, conjunta da cor e da luz que, junto àquela, se difunde obliquamente até a visão ${ }^{22}$. Porém, os argumento em ambas as passagens traz à baila a noção de 'discernimento' ou 'distinção' entre dois sensíveis, já que pareceria que, ao ser difundida junto à cor, a luz deveria ser vista por si mesma, como algo distinto da cor. Na primeira frase destacada de Suma, art. 24, Henrique afirma justamente que ambas não são distinguidas entre si, porque a modificação (immutationem) da luz é sutil. Decerto, vemos primeiro a luz na medida em que ela é requisito para a visão da cor (aliás, já sabemos que luz e cor são os visíveis primeiros e por $\mathrm{si}^{23}$ ), porém somente a própria cor que vemos na luz propriamente modifica a visão (ou o olho), uma vez que a modificação pela luz, sendo sutil, não nos permite discerni-la da cor ou (como se diz na segunda frase destacada de Suma, art. 24) não nos permite ver a luz como distinta da cor. Assim, parece que, para Henrique de Gand, cor e luz vêm juntas na difusão da espécie pelo meio até a visão, mas somente a cor, de fato, modifica a visão de maneira a podermos ver o corpo colorido, ao passo que a luz a modifica sutilmente, não permitindo uma sua visão. No fim, embora luz e cor modifiquem (cada qual à sua maneira) a visão, o correto é dizer que vemos a cor na luz, ou devido à luz. Ora, nesse argumento o 'discernimento' e a 'distinção' são completamente subsumidos pela discussão acerca da modificação da visão, que sabemos ser fruto da espécie sensível. Assim, aquela tese que diferenciava, em Suma, art. 1, q. 3, similitude e imagem, 'modificação para intuir pela espécie' e 'configuração ou transfiguração para discernir pelo carácter da coisa' parece abandonada em favor de uma espécie sensível que, ao modificar, permite a visão da coisa colorida de que é espécie e o discernimento ou distinção daquilo que é visto.

Da mesma maneira, a 'determinação' que em Suma, art. 1, q. 3, se atribui à configuratio, ressurge em Quodl. 4, q. 7 como ação da espécie: “< ..> o olho do corpo não poderia de todo ver a cor presente na luz sem algo que o determine, como uma espécie pela qual seja informado para ver a cor" ${ }^{24}$. Nessa passagem, não somente a

propter lucem, non opportet tamen quod magis videmus lucem, qui non videtur distincta a colore $<\ldots>$...

${ }^{22}$ Cf. nota 8, acima.

${ }^{23}$ Cf. nota 16 , acima.

${ }^{24}$ Henrique de Gand, Quodl. 4, q. 7, co. (ed. De Wulf-Mansion Centre, vol. 8, p. 30): “<..> oculus corporis colorem praesentem in luce sine aliquo determinante ipsum, ut specie aliqua qua informatur ad colorem videndum, ipsum videre non posset omnino". 
'determinação' do olho é atribuída à espécie sensível (e não a uma configuratio ou transfiguratio ou, mesmo, a um character figurae), mas também aquela 'modificação' do olho pela espécie é explicada como uma informação. Isso já aponta para algo que veremos nos próximos passos, a saber, a paulatina complexificação e melhor descrição da própria noção de espécie sensível. Brevemente, nessas curtas passagens de Suma, art. 24, e Quodl. 4, q. 7, a sensação está centrada na relação entre cor e luz, espécie sensível e modificação (ou informação) da visão por esta última. Esses serão os principais eixos de reflexão acerca da sensação em Henrique de Gand.

Por outro lado, como Jerome V. Brown destaca ${ }^{25}$, em Suma, art. 33, q. 2, ressurge a caracterização da espécie a um só tempo como species e "imagem da coisa vista, que perfeitamente a representa [imago rei visae perfecte ipsam repraesentans]". Agora, em lugar da referência ao vocabulário da configuratio, transfiguratio ou do character que vimos anteriormente, esse aspecto imagético da espécie é explicado como uma imitação da coisa vista. Tal imitação, por sua vez, é concebida como uma simetria entre as partes dessa figura correspondente à simetria das partes da própria coisa. Dessa maneira, a imagem de uma face bela terá a mesma proporção entre as partes, formosura na cor (decori eius in colore) e conveniência (decentia) que a própria face vista ${ }^{26}$. Atentemos para o vocabulário aqui utilizado: a espécie (species) é, também, imagem da coisa (imago rei), que a representa perfeitamente (perfecte ipsam repraesentans) ao imitá-la (imitetur ipsam) na simetria e proporção de suas partes enquanto figura (figura) dessa coisa. Assim, neste trecho, a figura (não mais o character figurae de Suma, art. 1) é explicada em termos uma imitação da proporção da coisa de que ela é figura, sendo tal imitação aparentemente um elemento da espécie. Além disso, não há nesse trecho de Suma, art. 33, referência ao discernere ou à configuratio/transfiguratio como algo para além da species e da lux. Mais uma vez,

\footnotetext{
${ }^{25}$ BROWN, J. V. "Sensation in Henry of Ghent”, 1971, p. 249.

${ }^{26}$ Henrique de Gand, Suma, art. 33, q. 2, ad 3 (ed. De Wulf-Mansion Centre, vol. 27, p. 142): "In prima comparatione, si species sit vera species et imago rei visae perfecte ipsam repraesentans, necesse est quod imitetur ipsam rem visam per ipsam, in hoc quod scilicet repraesentet quidquid visui circa dispositionem rei visae in figura et colore visibile est, et quod in se efigiem omnium talium contineat. Ut si visibile illud sit facies pulchra habens omnium partium suarum in figura 'faciei proportionem in optima commensuratione sibi invicem correspondentium, et similiter decentissimum colorem varie repersum sicut decet diversis partibus, in quibus duobus consistit faciei pulchritudo' secundum Philosophum in $\mathrm{VII}^{\mathrm{o}}$ Physicorum, oportet quod consimiliter species et imago illa corporaliter in oculo habeat in se omnia correspondentia commensurationi partium, similiter decori eius in colore et decentia”. Sobre a noção de imago, cf. a nota 18 , acima.
} 
vemos aquilo que era atribuído à configuratio em Suma, art. 1, ser assumido posteriormente - em Suma, art. 33 - pela própria espécie sensível.

Como era dito, a configuratio não parece ser retomada como elemento do processo de formação do conhecimento sensitivo em outros textos de Henrique que não a própria Suma, art. 1. Por outro lado, aquilo que era associado ali à configuratio acaba por ser explicado por referência à lux e à species, como vimos nesses trechos de Suma, art. 24, Quodl. 4, q. 7, e Suma, art. 33.

De fato, o que sobreviverá da apresentação da visão (e, em geral, da sensação) que lemos em Suma, art. 1, q. 3, serão: [i] a afirmação da necessidade da difusão de espécies sensíveis junto à problematização de sua relação com o próprio ato de sentir e [ii] a distinção entre a necessária correlação e ordenação entre atividade e passividade na sensação. Eventualmente, os dois temas confluem em uma distinção que se mostrará capital, também, na doutrina da intelecção do gandavense, a saber, aquela entre 'espécie impressiva' (species impressiva) e 'espécie expressiva' (species expressiva). De fato, assim como a determinação do sentido pela figura da coisa é subsumida pela modificação provocada pela espécie sensível no sentido, também a discussão acerca da ordenação entre passividade e atividade na atualização da sensação se resolverá em uma elaboração quanto à doutrina das espécies. A seguir, veremos justamente como a relação entre atividade e passividade na sensação se resolve por meio de um estudo da espécie sensível.

\subsection{PASSIVIDADE, ATIVIDADE, ESPÉCIE SENSÍVEL}

A problemática da necessária correlação entre passividade e atividade no conhecimento já é posta muito mais claramente em Quodl. 2, q. 6. Aí a associação entre atividade e passividade é afirmada no que diz respeito a toda ação natural portanto, também no processo de conhecimento e, especialmente, no conhecimento dos sentidos particulares:

\footnotetext{
"Cumpre dizer que em toda ação natural o paciente não somente padece, mas age de algum modo e tanto mais age e menos padece, quanto mais é formal e, pelo contrário, mais padece e menos age, quanto mais é material.

E, por isso, não somente o sentido e o intelecto padecem as paixões do sentido e do intelecto, sendo <elas $>$ naturais a partir do sentido e do inteligível, mas
} 
também, ao padecer a partir do sensível e inteligível, de algum modo contraagem acerca dele - porém, menos os sentidos, quanto mais é material" ${ }^{27}$.

Reencontramos aqui a temática dos graus de ser que já vimos no capítulo 2, pois o que está em jogo é a ordenação de seres mais ou menos pacientes - ou, inversamente, mais ou menos ativos -, de acordo com sua materialidade. Assim, mais uma vez, estamos em presença de uma hierarquia da natureza - nesse caso, restrita às ações naturais produzidas por agentes materiais. Ora, essa é precisamente uma das etapas da hierarquia do mundo em que o homem se enquadra. Mais importante, as diferentes potências do homem podem ser distintamente localizadas em tal ordenação, de maneira que novamente vemos Henrique propor como fundamento para a descrição do homem a hierarquia do mundo.

O que de saída tal ordem nos permite afirmar acerca da potência sensitiva é que, devido à sua grande materialidade (o que, também já foi estudado no capítulo 2), os sentidos mais padecem do que agem. Como vimos no item anterior, tal padecer está em grande parte relacionado à modificação que o sentido sofre pela espécie sensível. No entanto, já notamos que há alguma ação do sentido - esta, porém, até agora não passa de uma 'conceber algo' (em presença da espécie) por parte do sentido (a bem dizer, estamos generalizando o que lemos acerca da visão...). Sendo assim, o princípio geral de que ao padecer do sentido corresponde um contra-agir deste está de acordo com o que viemos lendo até aqui. Em Quodl. 2, q. 6, porém, tais 'padecer' e 'agir' (entendido agora como um 'contra-agir') começam a ganhar uma melhor caracterização:

"Donde, o sentido particular, por ser totalmente material, possuindo um particular próprio sensível materialmente objetificado ${ }^{28}$ fora primeiramente e por

\footnotetext{
${ }^{27}$ Henrique de Gand, Quodl. 2, q. 6, co. (ed. De Wulf-Mansion Centre, vol. 6, p. 31): "Dicendum quod sic est in omni actione naturali quod patiens non solum patitur, sed agit aliquo modo, et tanto magis agit et minus patitur, quanto magis est formale, et e converso magis patitur et minus agit, quanto magis est materiale.

Et ideo passiones sensus et intellectus cum sint naturales a sensibili et intelligibili, non solum sensus et intellectus patiuntur a sensibili, sed etiam in patiendo a sensibili et intelligibili quodammodo contra agunt circa ipsum, minus autem sensus, quanto magis est materialis".

${ }^{28}$ Aqui, 'objetificado' traduz 'obiectum'. Este, porém, poderia ser muito bem simplesmente o substantivo 'objeto' e não um particípio neutro (de obicio) caracterizando 'sensibile', tal como o interpretei (cf. a citação do trecho na próxima nota). Minha interpretação, porém, tem por base o fato de que Henrique de Gand se utiliza desse modo, por vezes, do particípio de obicio - por exemplo, na expressão 'in obiecta substantia', que traduzo por "na substância objetificada" (cf. nota 37, adiante). A meu ver, esse uso de obiectus, a, um permite uma descrição dinâmica do caráter objetual da coisa (ou substância) corpórea: ela não é em si um objeto, mas ao ser posta em relação com uma potência cognoscitiva sensitiva faz-se objeto (objetifica-se). Essa, porém, é uma hipótese tentativa de leitura.
} 
si, maximamente padece a partir do sensível, porém pouco age. E, por isso, dizse que o sentido maximamente se aperfeiçoa ao padecer - age, porém, algo. De fato, quando padece a partir do objeto ao receber, se converte sobre ele ao conhecer e perceber. Isso é patente na visão e audição [in visu et auditu], pois, ainda que o objeto aja se imprimindo por sua espécie no órgão, não é por isso entretanto que o homem vê ou ouve, a não ser que a força visiva ou auditiva [vis visiva vel auditiva] se converta para o objeto para perceber o objeto pelo movimento da espécie, segundo aquilo que diz o Filósofo no livro De sensu et sensato: 'trazido o lume aos olhos, não sentem, se ocorre de eles serem veementemente voltados ou temerosos ou de ouvirem um grande ruído'. Tampouco podes dizer que ele vê ao receber, embora não julgue [iudicat] com a virtude interior, pois ainda que a luz seja presente àquele que dorme com os olhos abertos - ela seria impressa no órgão e, entretanto, ele nada veria, pois a força particular da visão é atada [quia vis particularis visus ligata est]. E, entretanto, padece - signo disso é que, impresso um grande brilho nos olhos, é excitado pela força da paixão e, então, vê pela primeira vez. Isso também é patente nos que dormem, os quais não ouvem os sons pequenos - mesmo que impressos nos ouvidos - e, entretanto, se excitam com um grande ruído"29.

Já consideramos, acima, a descrição do sentido particular proposta ao início desse trecho ${ }^{30}$ - agora, ela nos é útil unicamente para situar a discussão no campo que nos interessa, a saber, precisamente o dos sentidos particulares. Como já dito, o sentido particular é principalmente um padecer, mas nem por isso ele deixa de possuir uma ação própria (um contra-agir próprio). Nesse ponto, surge a primeira descrição mais precisa daquilo que vimos ser a oposição entre a modificação passiva do olho e a concepção ativa da força sensitiva, pois agora esses dois passos surgem apresentados, respectivamente, como um 'receber' (recipiendo) e um 'converter-se' (convertit se). Esses 'receber' e 'converter-se' são, por sua vez, atribuídos ao órgão do sentido e à força sensitiva, respectivamente.

Isso se torna claro pelo exemplo da visão e da audição (aliás, é a primeira menção deste último sentido que vemos nesse contexto), pois ainda que o objeto aja

\footnotetext{
${ }^{29}$ Henrique de Gand, Quodl. 2, q. 6, co. (ed. De Wulf-Mansion Centre, vol. 6, pp. 31-2): "Unde sensus particularis, quia omnino est materialis, habens particulare proprium sensibile materialiter obiectum extra primo et per se, maxime patitur a sensibili, minime autem agit. Et ideo dicitur quod sensus maxime in patiendo perficitur. Aliquid tamen agit. Cum enim ab obiecto patitur in recipiendo, convertit se super ipsum in cognoscendo sive percipiendo. Quod patet in visu et auditu ex hoc quod, quamvis obiectum per speciem suam agit imprimendo se organo, ex hoc tamen non videt vel audit homo, nisi vis visiva vel auditiva ad percipiendum obiectum per motum speciei se convertat ad obiectum, secundum quod dicit Philosophus in libro De sensu et sensato: 'Superlatum ad oculos lumen non sentiunt, si accidit illos esse vehementer intendentes vel timentes vel audientes multum strepitum'. Nec potes dicere quod talis recipiendo videt, licet interiori virtute non hoc iudicat, quoniam etsi dormienti, apertis oculis, lux esset praesens, ipsa organo imprimeretur et tamen nihil videret, quia vis particularis visus ligata est. Et tamen patitur, cuius signum quod, magno splendore oculis impressa, vi passionis excitatur et tunc primo videt. Quod etiam patet in dormientibus, qui non audiunt parvos sonos, etiam auribus impressos, et tamen magno strepitu excitantur". Cf. a nota 99, adiante.

${ }^{30}$ Cf. nota 3, acima.
} 
sobre o órgão do sentido ao nele imprimir sua espécie (notemos como aquele 'receber' por parte do órgão é identificado à 'impressão' da espécie nele por parte do objeto externo), a percepção ou conhecimento do objeto só ocorre quanto, "pelo movimento da espécie [per motum speciei]" a força sensitiva (visiva ou auditiva, no exemplo de Henrique) 'se converte' (convertit se) para o objeto. Destaque-se o cuidado com que o Doutor Solene afirma que a força sensitiva, pelo movimento da espécie, se volta para o objeto de que esta é espécie e não para a própria espécie recebida no órgão. Em outras palavras, o objeto do sentido particular é o próprio particular externo material objetificado - a espécie é somente aquilo por cujo movimento (per motum speciei) no órgão a força sensitiva conhece aquele corpo externo - "o ato de ver começa do visível fora e termina neste",31 ou, nas palavras de Jerome V. Brown, "a coisa extra-mental particular é tanto o terminus a quo da sensação - já que ela produz a espécie sensível -, como o terminus ad quem do mesmo ato - já que ela é conhecida através [through] da espécie sensível”32.

O exemplo seguinte, do dormiens, serve basicamente para defender o mesmo ponto: é possível que se receba espécies no órgão dos sentidos sem que haja, de fato, conhecimento ou percepção, porque durante o sono a força do sentido particular permanece 'atada' (ligata est). Prova de que tais espécies são recebidas é que, conquanto barulhos ou brilhos fracos não sejam suficientes para acordar alguém, um estrondo ou um clarão o são - ou seja, uma recepção suficientemente forte (um movimento forte o suficiente) da espécie do objeto no órgão é capaz de 'desatar' a força sensitiva (ao mesmo tempo, acordando o pobre sonolento...). Essa distinção entre impressões mais fracas ou fortes (parvos sonos x magno strepitu / magno splendore) parecem remeter àquela distinção entre a modificação provocada pela cor no olho, a qual é suficiente para um discernimento da cor, e aquela modificação provocada pela luz que, sendo sutil (subtilis), não é suficiente para que o olho discirna a luz como distinta da $\operatorname{cor}^{33}$.

\footnotetext{
${ }^{31}$ Henrique de Gand, Suma, art. 40, q. 2, co. (ed. De Wulf-Mansion Centre, vol. 28, p. 265): “<_..> quemadmodum actus videndi incipit a visibili extra et terminatur in ipsum $<\ldots$..”.

${ }^{32}$ BROWN, J. V. "Sensation in Henry of Ghent", 1971, p. 247: "The logical conclusion of all this is that the extra-mental particular thing is both the terminus a quo of sensation - since it gives rise to the sensible species - and the terminus ad quem of the same act - since it is what is known through the sensible species".

${ }^{33}$ Cf. notas 20 e 21 , acima.
} 
Outro elemento relevante nessa passagem é a referência ao 'juízo' do sentido que é posto na fala de um possível objetor: "Tampouco podes dizer que ele vê ao receber, embora não julgue [iudicat $]$ com a virtude interior $<\ldots>[$ Nec potes dicere quod talis recipiendo videt, licet interiori virtute non hoc iudicat $<\ldots>$ ]". Decerto, a menção de uma 'virtude interior' (interiori virtute) pode nos fazer pensar nos sentidos interiores e não precisamente nos sentidos particulares, muito embora o que esteja em jogo no argumento seja a oposição entre a passividade do órgão e a atividade da força sensitiva. Além disso, mesmo que essa virtus interior seja a vis ou virtus sensitiva do sentido particular (e não o sentido interior, que estudaremos no próximo capítulo), não se poderia concluir apenas dessa passagem a atribuição de um iudicare à vis visiva ou à vis auditiva, uma vez que ela surge como objeção ao próprio Henrique de Gand. No entanto, se atentarmos para uma passagem de Suma, art. 24, q. 7, que já lemos acima, vemos que: "o olho do corpo, vendo a cor na luz, primeiro vê a luz e, por ela, julga acerca da cor [sicut oculus corporis videns colorem in luce, primo videt lucem, et per illam iudicat de colore]"34. Curiosamente, nesta última passagem, o iudicare não é mais atribuído a uma virtus, mas ao oculus - isto é, ao organum. Se retornamos, agora, a outra passagem de Suma, art. 1, q. 1, lemos o seguinte argumento: "os sentidos não são igualmente bem dispostos em todos ou em diversos tempos e, por isso, não cumpre crer no juízo [iudicio] deles igualmente, como é patente no são e no doente. De fato, mais cumpre crer no paladar [gustui] do são do que do doente, naquele que vê [videt] algo de perto do que naquele que vê de longe $<\ldots>$.. ${ }^{\text {35 }}$. Pela referência ao gustus e ao videre, notamos que estamos em presença de um discurso acerca dos sentidos particulares - assim, o iudicium de que se fala aqui é aquele do 'paladar' ou do 'ver' (e, extrapolando, dos outros três sentidos particulares). Enfim, o que fazemos desse iudicare ou iudicium do sentido? Ora ele é atribuído à virtus sensitiva (Quodl. 2, q. 6), ora ao órgão (Suma, art. 24, q. 7) e, em geral, ao ato de sentir (Suma, art. 1, q. 1) - parece pressuposto que não se trate aqui de um 'juízo proposicional' (isto é, daquele 'juízo’ próprio da razão, que vimos no capítulo 3).

\footnotetext{
${ }^{34}$ Cf. nota 20, acima.

${ }^{35}$ Henrique de Gand, Suma, art. 1, q. 1, ad 2 (ed. De Wulf-Mansion Centre, vol. 21, p. 21): "Non enim sensus aeque bene dispositi sunt in omnibus vel in eodem diversis temporibus, et ideo non aequaliter iudicio eorum credendum est, ut patet in sano et aegro. Magis enim credendum est gustui sani quam aegri, et ei qui videt aliquid de prope quam qui videt a longe $<\ldots>$.. Esse texto já foi estudado aqui em cap. 1 , notas 43 e 44 .
} 
Uma boa saída para tal problema é oferecida por Benoit Garceau, quando ele disserta sobre o que denomina de "technique receptio-judicium": "Receber e julgar designariam, então, as funções respectivas do corpo e da alma no conhecimento das coisas sensíveis: a modificação [immutation] sensorial e o ato de julgar acerca dessa modificação"36. Ambos os termos - receptio e immutatio - já vimos em Henrique de Gand como descrições da presença da espécie sensível no órgão; por outro lado, a ação da força sensitiva já foi explicada como concipere e convertere se. Seria essa última, igualmente, um iudicare ou iudicium? Se admitirmos que sim, será igualmente preciso concordar que o Doutor Solene teria sido pouco preciso ao atribuí-la, em Suma, art. 24, q. 7, ao órgão do sentido (mais precisamente, ao olho) - sendo assim, este último deveria estar sendo tomado enquanto é informado pela vis visiva. Em todo caso, a tese de Garceau parece servir bem para uma leitura de nosso autor, uma vez que o iudicium (seja ele atribuído ao órgão enquanto informado pela força sensitiva ou a esta própria força) é sempre apresentado como um passo seguinte à recepção da espécie. Esse 'julgar' parece identificar-se àquele ato de conversão à que a força sensitiva é levada 'pelo movimento da espécie' (per motum speciei) - voltando, agora, ao último trecho indentado de Quodl. 2, q. 6. Destarte, podemos dizer que primeiro ocorre uma immutatio / receptio da espécie no órgão, pela qual é movida a força sensitiva (nas condições apropriadas - a saber, desde que a espécie incida corretamente sobre o órgão, a força não esteja 'atada' pelo sono etc.) para aliquid concipere / convertere se ad / iudicare de. Estes últimos atos não são acerca da espécie ou da modificação introduzida por esta no órgão, mas são pela espécie direcionadas ao obiectum que é a própria coisa sensível, material e particular fora da alma. Essa immutatio / receptio da espécie é somente aquilo pelo que se percebe pelo

\footnotetext{
${ }^{36}$ GARCEAU, B. Judicium. Vocabulaire, sources, doctrine de saint Thomas d'Aquin. Montréal Paris: Institut d'études médiévales - Vrin, 1968, p. 59: "Si la technique receptio-judicium n'existe pas comme telle chez Augustin, on entrevoit cependant comment certains scolastiques, comme ce sera le cas de Guillaume d'Auvergne, ont pu l'utiliser pour signifier la différence, établie par le Docteur d'Hippone, entre la sensation et le jugement. Recevoir et juger désigneraient alors les fonctions respectives du corps e de l'âme dans la connaissance des choses sensibles: l'immutation sensorielle et l'acte de juger de cette immutation. Mais par contre pour un aristotélicien, qui conçoit l'âme humaine comme forme et perfection d'un corps et ne la pose comme substance spirituelle que parce qu'elle est une forme capable d'exercer par elle-même certaines activités qui lui sont propres, une telle signification de la technique receptio-judicium est irrecevable" (grifo meu). Permito-me aqui citar a descrição dessa 'techinique receptio-judicium', sem entretanto subscrever à tentativa de Garceau de ver na adoção de tal tese uma clara oposição entre 'agostinianos' e 'aristotélicos'. Por outro lado, vale mencionar que Jerome V. Brown lê a concepção de conhecimento sensitivo de Henrique de Gand precisamente como uma tentativa de síntese entre Agostinho e Aristóteles - cf. BROWN, J. V. "Sensation in Henry of Ghent", 1971; e BROWN, J. V. "Henry of Ghent on Internal Sensation", 1972.
} 
sentido particular o seu objeto próprio e por si fora da alma, que não é senão a coisa natural e material objetificada. No entanto, só se chega à coisa por uma ação da virtus sensitiva que, por meio da espécie recebida, age com respeito à coisa fora da alma essa, parece-me, é a ação que Henrique luta para descrever como um 'conceber', um 'converter-se' ou um 'julgar'.

Agora, se partirmos da outra ponta do processo - isto é, da própria coisa que é objeto -, já aprendemos que ela é objeto de conhecimento na medida em que difunde suas espécies sensíveis pelo meio. Estas últimas, em determinadas situações (no caso da visão, ao incidirem sobre o olho aspectu directo), provocam uma modificação suficiente para que, por meio dela, a força sensitiva aja. Se essa modificação já havia sido denominada também como 'recepção', lemos igualmente em Quodl. 2, q. 6, que ela é um 'imprimir-se' (imprimere se) do objeto no órgão pela espécie sensível.

Essa caracterização pelo verbo 'imprimir' da 'recepção' ou 'modificação' provocada pela espécie no olho se torna fundamental para a compreensão da sensação (e do conhecimento, em geral) que encontramos em Henrique de Gand. Isso fica claro no texto a seguir, que retiramos de Quodl. 4, q. 21:

\begin{abstract}
“ $<\ldots>$ cumpre notar, acerca do processo da notícia humana [progressum humanae notitiae], que o sensível - por exemplo, a cor - primeiro possui um ser natural na substância objetificada [substantia obiecta] e é em potência ativa para que gere intencionalmente no meio um similar a si e, desde o meio, ao órgão da visão, porém segundo o ato do lume. Isto é requerido devido a dois: devido ao meio, tal que se faça a matéria que é uma necessidade para a recepção [susceptionis] da intenção (a qual ele não é nato a receber senão mediante a informação do lume) e devido à própria cor, que não age gerando-se no meio senão com a virtude do lume, em presença do qual a cor faz a espécie impressa no meio contíguo a si. Esta é continuamente gerada e difundida diretamente [in directum] por todo o meio até o órgão da visão, no qual a espécie é recebida do ar contíguo a si e, por ela, é formada a visão, isto é, a ação de ver, pela qual $[q u a]$ a virtude visiva percebe o objeto sensível particular presente fora $<\ldots>{ }^{37}$.
\end{abstract}

\footnotetext{
${ }^{37}$ Henrique de Gand, Quodl. 4, q. 21, co. (ed. De Wulf-Mansion Centre, vol. 8, pp. 336-7): “Ad cuius intellectum notandum circa progressum humanae notitiae quod sensibile, puta color, primo esse naturale habet in obiecta substantia et est in potentia activa ut intentionaliter sibi simile generet in medio et a medio in organo visus, secundum tamen actum luminis. Quod requiritur propter duo; et propter medium, ut fiat materia quae est necessitas ad susceptionem intentionis, quam nisi mediante luminis informatione non est natum recipere, et propter ipsum colorem, qui non agit sese generando in medio nisi cum virtute luminis, quo praesente color facit speciem impressam in medio sibi contiguo, quae continue generatur et diffunditur in directum per totum medium usque ad organum visus, in quo species recipitur ab aere sibi contiguo, et formatur per ipsam visio, id est actio videndi, qua percipit virtus visiva sensibile particulare obiectum extra praesens $<\ldots$. ". Sobre esse texto, cf. BROWN, J. V. "Sensation in Henry of Ghent", 1971, pp. 255-6.
} 
Nessa passagem, retoma-se a temática da difusão 'por aspecto direto' (aqui, in directum) das espécies desde a coisa, pelo meio iluminado, até o olho - esse 'ser difundido' (diffunditur) é relacionado a um 'ser gerado' (generatur) da espécie, por parte da cor, no meio sob o ato do lume. Que o ato do lume no meio (ou, mesmo, no órgão) seja pressuposto necessário para a difusão da espécie pelo mesmo meio (ou para sua introdução no órgão) já foi visto desde Suma, art. 1, q. 3 - porém, apenas de certo modo, pois lá se falava em "ato da luz no olho [actus lucis in oculo]"38, enquanto aqui Henrique se refere não a um actus lucis, mas a um actus luminis. Haveria uma diferença? Pela leitura da passagem destacada, parece que não - os termos lumen e lux parecem denominar igualmente aquilo que, difundido desde o corpo luminoso, informa o meio diáfano permitindo a difusão das espécies ${ }^{39}$. Sendo

\footnotetext{
${ }^{38}$ Cf. nota 8 , acima.

${ }^{39}$ Não pude encontrar na obra de Henrique de Gand um local em que se discutam os diversos temas relacionados às noções de lux ou lumen (e aqui refiro-me somente à luz criada, não à incriada que é Deus, por exemplo, em Suma, art. 1). Mesmo em uma questão diretamente voltada para a noção de lux, como Quodl. 3, q. 12 - onde é perguntado "utrum lumen in medio sit res aliqua, an potius intentio quaedam" -, diversos temas são expressamente deixados de lado: "Quomodo autem lux generetur, aut de potentia materiae, aut non, aut continue, aut semel, sed maneat ad praesentiam genereans, de hoc nihil ad praesentem quaestionem" (ed. 1613, f. 105rb). O tema da geração da luz a partir do luzente é tratado em Quodl. 1, qq. 7-8 e 9, porém unicamente na medida em que tal discussão serve como metáfora para a discussão acerca da criação: "Unde, si sol libera voluntate posset radium per se subsistentem producere, radius ille, quantum est de se et natura sua, indifferens esset ad esse et non esse, et quantum esset de se, esset non ens quoddam" (ed. De Wulf-Mansion Centre, vol. 5, pp. 49-50). Que aqui estamos em um campo estritamente hipotético é patente, se não pelos tempos verbais, certamente pela atribuição de uma vontade livre ao Sol... Em suma, esse tipo de raciocínio não nos ajuda muito a compreender a noção de $l u x$.

Por outro lado, se voltarmos a Quodl. 3, q. 12, podemos recolher algumas informações. Ainda que Henrique de Gand não determine aí como se dá a geração da luz - embora ele admita que isso é o fundamental na questão: "dicendum quod difficultas tota huius quaestionis ortum habet ex modo generationis luminis" (ed. 1613, f. 105ra) -, ele pelo menos elenca certas possibilidades de resposta. Assim, ou bem [i] a geração da luz ocorre desde a potência do meio ou bem [ii] tal geração provém exclusivamente do eficiente por difusão ou multiplicação da luz pelo meio a partir do corpo luminoso. Em qualquer dos casos, nos diz Henrique, a luz deve ser tomada como res vera (ed. 1613, f. 105ra). Com efeito, como veremos nas próximas páginas, mesmo seres intencionais (isto é, dependentes continuamente de sua causa eficiente) são, para o gandavense, res verae - esse caráter simultaneamente real e intencional da luz é mencionado em BOURGEOIS, R. "La théorie de la connaissance intellectuelle chez Henri de Gand”. Revue de philosophie 8 (1936), pp. 238-59 (esp. p. 239).

Acrescentemos que, muito embora Henrique não escolha no corpo da questão entre as duas alternativas alencadas a respeito da geração da luz, ainda no Quodl. 3, q. 12, ad 2, lemos uma descrição um pouco mais aprofundada da relação entre a luz, o meio e o agente: "Ad secundum, quod res vera non introducitur subito in materiam, dicendum, quod verum est quando materia non est in summo disposita, sed si sit in summo disposita sine omni contrarietate, et repugnantia ad generandum, quaecunque forma quantuncunque sit res vera subito introducitur. Unde quod generatio formarum substantialium non fit subito sine alteratione praecedente, hoc est propter contrarietatem et in dispositionem subiecti; quae removertur per alterationem. Quare cum in proposito diaphanum nullam habet contrarietatem, vel indispositionem ad suscipiedam lucis impressionem, ad generationem igitur lucis nihil requiritur ex parte subiecti, sed solum ex parte agentis, ut sit in directa oppositione ad medium; ad quam si non fuerit, deducitur per motum localem. Et secundum hoc omnes subitae mutationes de novo factae termini sunt motuum secundum Philosophum 7. Physicorum, vel alterationem ad removendum indispositionem subiecti, vel localium ad praesentandum alteratis" (ed. 1613, f. 105va-b). Em poucas
} 
assim, o ganho que temos nesta passagem está não tanto na referência ao lume, mas na descrição da ação do corpo ou substância que é objeto do sentido como um 'gerar intencionalmente' (intentionaliter <...> generet). Tal corpo gera intencionalmente no meio apropriado (isto é, no caso do corpo visível, no ar sob o ato da luz ou do lume) um 'similar a si' (sibi simile). Reconhecemos nesse 'similar a si' a espécie sensível, porém agora aquela referência a um 'imprimir-se' (imprimere se) do objeto no órgão pela espécie sensível dá lugar a uma classificação mais direta da própria espécie como 'impressa' (species impressa). Assim, agora somos mais precisos: não é qualquer

palavras, o diáfano é o meio em suma disposição para receber a impressão da luz (isto é, sem qualquer forma contrária, que deva ser removida antes da recepção). Assim, uma vez que o corpo luminoso esteja posicionado diretamente (in directa oppositione) com respeito ao meio diáfano, este último recebe a luz (mais precisamente, a recebe como res vera). Caso se aceite essa descrição, somente o agente (corpo luminoso) age para a produção da luz, enquanto que o sujeito (meio diáfano) unicamente padece de sua recepção. Uma vez recebida, "a luz é perfeição acidental do diáfano e uma forma nele inerente $[<\ldots>$ lux est perfectio accidentalis diaphani, et forma ei inhaerens $<\ldots>$ ]" - Quodl. 5, q. 14, co. (ed. 1613, f. 262[258]rb).

Por fim, se formos a Quodl. 11, q. 5, vemos Henrique de Gand distinguir entre duas ações próprias da lux, uma imanente e outra trasitiva. A [i] ação imanente da luz é seu próprio luzir em si mesma - lemos afirmações próximas a essa em Suma, art. 21, q. 4, co. (ed. Decorte \& Teske, p. 86) e Suma, art. 27, q. 1 (ed. Teske, p. 146). Além disso, porém, há uma [ii] ação transitiva da luz que é o movimento de iluminar algo outro - " $<\ldots$.. et habent rationem actionis manentis in agente, quemadmodum operatio lucis est lucere in seipsa, non autem transeuntes in aliud, quemadmodum motus a luce est illuminare aliud a se <...>" (ed. 1613, f. 195rb). Em sua [i] ação imanente, a luz não necessita de nada além de si mesma para luzir; porém, em sua [ii] ação transitiva ela necessita de um objeto que possa ser iluminado, como lemos em Quodl. 7, q. 15, co. (ed. De Wulf-Mansion Centre, vol. 11, p. 108): “<..> lux ex se sola dat actum essendi lucidum et actum ludendi, licet quoad actum illuminandi dependeat ab obiecto illuminabili <...>”.

Com essas observações, acredito, conseguimos obter uma melhor compreensão do que seria a lux para Henrique de Gand, muito embora não se possa considerar esse apanhado um todo satisfatório. Principalmente, ele não nos permite arriscar uma distinção precisa entre lux e lumen - pelo contrário, em Quodl. 3, q. 12, o Doutor Solene parece falar intercabiavelmente de geração do lumen e geração da lux. Por outro lado, a distinção entre lucere e illuminare em Quodl. 11, q. 5, talvez aponte para uma distinção entre lux (<lucere) como ação intrínseca do corpo luminoso ou perfeição no diáfano e lumen (<illuminare) como o efeito dessa perfeição nos corpos coloridos contíguos ao corpo luminoso ou ao diáfano. Essa é precisamente a derivação terminológica que surge na Lectura ordinaria super Sacra Scripturam. Falando da obra do quarto dia, quando são criados os luminaria (Gn 1,14-9), Henrique interpreta a expressão 'ut luceant' $(G n$ 1,15) assim: "Sequitur: ut luceant, ubi tangit duplicem effectum sive actum primus lucis, quorum unum tamen est ab alio: unus manens in se ipso, qui est lucere, transiens in alium, qui est illuminare. Differentia enim est inter lucere et illuminare, quia lux in corpore luminoso splendore suo quem habet, in se lucet, sed illud quod est extra se, lumine quod diffundit, illuminat" (ed. De Wulf-Mansion Centre, vol. 36, p. 124). Dessa passagem poderíamos concluir uma distinção estrita entre lucere / lux e illuminare / lumen, porém o próprio Henrique de Gand admite que, no texto bíblico, tal distinção é, por vezes, ignorada. Isso ocorre, por exemplo, quando se utiliza novamente 'ut lucerent' em Gn 1,17: “ut lucerent: illuminando et lumen effundendo, unde sumitur nunc aliter lucere quam prius, quia ibi sumitur proprie, hic communiter pro illuminare $<\ldots$.. " (ed. De Wulf-Mansion Centre, vol. 36, pp. 126-7).

Enfim, pelo que lemos em Quodl. 11, q. 5, e na Lectura, parece que lux é algo daquilo que age luzindo e lumen é a res difundida no meio pelo corpo luminoso não mais ao luzir, mas ao iluminar. Em todo caso, tal distinção não parece ser fielmente seguida por Henrique de Gand em todos os textos nos quais ele discorre sobre (ou se utiliza das) noções de lux e lumen. Sendo assim, não me parece abusivo, para nossos propósitos, tratar as expressões actus lucis (Suma, art. 1, q. 3) e actus luminis (Quodl. 4, q. 21) como sinônimos. 
espécie aquela que o corpo gera intencionalmente no meio, mas uma 'espécie impressa' - ele imprime no meio, desde si até o órgão, um 'similar a si'. Pois bem, no caso da visão, se a espécie é primeiramente gerada ou impressa no ar contíguo à obiecta substantia e só se imprime no órgão a partir do ar contíguo a este último, isso significa que ela se difunde de um ao outro pelo ar iluminado - como sabemos (e, mais uma vez, se afirma aqui) essa difusão deve ser in directum (caso contrário, ela não será suficiente para provocar a ação da força visiva, como notamos anteriormente). Daí que Henrique se refira aqui a um 'ser continuamente gerado e difundido' (continue generatur et difunditur) da espécie no meio, pois ela deve ser gerada inicialmente no ar contíguo ao corpo objetificado e terminar por ser impressa também no ar contíguo ao olho que verá, sendo introduzida neste último ${ }^{40}$. Essa narrativa da geração do ato de visão - melhor, da modificação do olho pela coisa por intermédio da espécie - decerto parece resolver o problema de explicar a ação à distância da coisa sobre olho, porém ela parece simultaneamente colocar o problema de saber como a espécie sensível impressa pode ser um intermediário entre o sentido e o objeto sem tornar-se, ela própria, o objeto do sentido.

A solução para esse problema está, basicamente, no caráter dependente do ser da espécie com relação à substância que a gera no meio e no órgão - é o que lemos em Quodl. 5, q. 14: “<_..> aquela espécie no olho mais depende, em seu ser, da coisa fora, do que o converso, de maneira que a presença da coisa é a causa pela qual [qua] a espécie possui ser no olho e não o ser no olho da espécie [et non inesse speciei in oculo] é <causa $>$ da presença da coisa fora. Donde, ainda que por um agente sobrenatural aquela espécie fosse impressa [imprimeretur] e conservada no olho, sua

\footnotetext{
${ }^{40}$ Em outras palavras, estamos aqui em presença de uma doutrina da multiplicação das espécies, cujos elementos foram muito bem estudados por autores que se dedicaram à leitura de Rogério Bacon, como David C. Lindbergh, a já citada Katherine Tachau ou Carlos Arthur R. do Nascimento. Cf. e.g.: NASCIMENTO, C. A. R. do. Une théorie des opérations naturelles fondée sur l'optique: le 'De multiplicatione specierum' de Roger Bacon. Thèse presentée à la Faculté des Études Supérieurs en vue de l'obtention du Philosophiae Doctor (Sciences Médiévales). Institut d'Études Médiévales, Faculté des Arts et des Sciences, Université de Montréal. Decembre, 1975; LINDBERG, D. C. Theories of Vision from Al-Kindi to Kepler. Chicago - London: The University of Chicago Press, 1976, pp. 10422; TACHAU, Vision and Certitude..., 1988, pp. 3-26; LINDBERG, D. C. The Beginnings of Western Science. The European Scientific Tradition in Philosophical, Religious, and Institutional Context, Prehistory to A.D. 1450. Chicago - London: The University of Chicago Press, $2007^{2}$ [1992], pp. 31320; LINDBERG, D. C. "Introduction". In: ROGER BACON. Roger Bacon's Philosophy of Nature. A Critical Edition, with English Translation, Introd. and Notes of De multiplicatione specierum and De speculis comburentibus. South Bend: St. Augustine's Press, 1998, pp. xv-lxxxi; NASCIMENTO, C. A. R. do. De Tomás de Aquino a Galileu. Campinas: IFCH/UNICAMP, $1998^{2}$, pp. 89-151. Note-se que o próprio Henrique de Gand se utiliza do vocábulo multiplicatio nesse contexto em Suma, art. 58, q. 2 (cf. cap. 5, nota 90).
} 
presença não faria com que a coisa, assim, fosse presente - tal que pudesse ser vista pelo olho -, mas se requereria que se fizesse presente por outro" ${ }^{\text {41 }}$. Note-se como a dependência do ser da espécie com respeito à coisa resulta em uma necessária anterioridade da coisa quanto à espécie que ela gera. Daí se segue que tal espécie sensível aponta a presença (praesentia) da coisa - essa afirmação, entretanto, deve ser considerada cum grano salis, uma vez que Henrique de Gand admite a possibilidade de uma causa sobrenatural causar a espécie no olho sem a presença da coisa e, nesse caso, a espécie não indicará tal presença. Ou seja, não há (ao menos nesse argumento) a possibilidade de um Deus enganador, uma vez que a espécie só é indicativa da presença da coisa na medida em que o ser dessa espécie depende dessa coisa (e não de alguma outra causa sobrenatural). Para a nossa sorte, interessa-nos aqui (e, ao que parece, também a Henrique de Gand) somente o contexto natural de produção do conhecimento sensível, na qual espécies são necessariamente indicativas da presença da coisa - como lemos em Suma, art. 40: “< ..> o sensível por si não é por si presente ao sentido, mas por [per] sua espécie nele impressa"42. A espécie é, precisamente, aquilo por (per) cuja impressão a coisa sensível, presente por si (per se) apenas externamente, se torna presente ao sentido.

Ressalte-se, porém, que a espécie sensível só pode ser tomada como indicativa de tal presença por depender, em seu ser, daquela coisa sensível de que é espécie. A coisa sensível, de algum modo, está presente no sentido - não por si, mas por algo (a espécie impressa) que dela depende em seu ser. É justamente devido a essa dependência que, naquele trecho destacado de Quodl. 4, q. 21, o Doutor Solene descreve a espécie impressa como 'intenção' (intentio) e o gerar dela no meio pela coisa como 'intencional' (intentionaliter). Como lemos, novamente em Quodl. 5, q. 14, também no próprio sentido tal espécie será tomada como intenção:

“O sentido é em potência para a espécie do sensível, porque, ao receber sua intenção, faz-se não o próprio sensível ou aquele tal segundo a verdade e a perfeição de tal forma (tal qual é no sensível fora), mas faz-se como o sensível

\footnotetext{
${ }^{41}$ Henrique de Gand, Quodl. 5, q. 14, co. (ed. 1613, 259va-260rb): "Sed species illa in oculo in suo esse magis dependet a re extra, quam e converso, ita quod praesentia rei causa est, qua species habet esse in oculo, et non inesse speciei in oculo causa est praesentiae rei extra. Unde, etsi per agens supernaturale species illa imprimeretur, et conservaretur in oculo, praesentia eius non faceret rem sic esse praesentem, ut videri posset ab oculo, sed requiritur quod per aliud fiat praesens".

${ }^{42}$ Henrique de Gand, Suma, art. 40, q. 2, co. (ed. De Wulf-Mansion Centre, vol. 28, p. 265): “< $<>$ quemadmodum actus videndi incipit a visibili extra et terminatur in ipsum, praeter hoc quod per se sensibile non est per se praesens sensui, sed per suam speciem sibi impressa $<\ldots$.." (o início dessa passagem já foi citada acima, na nota 31 ).
} 
[fit ut sensibile] recebendo uma intenção pela qual [qua] de certo modo é aquilo [quodammodo est illud]. Porém, essa forma é algo da coisa [aliquid rei] e faz-se segundo alguma real alteração [fit secundum aliquam realem alterationem], que também se faz no meio que, só não pode se modificar [immutari] para o ato de sentir, porque não é nele a força formal sensitiva [vis formalis sensitiva]"43.

Aqui intensifica-se aquela mesma oposição entre o sensível (essa substância com ser natural fora da alma) e a intenção por ele gerada na alma. O primeiro é caracterizado por uma verdade e perfeição de forma (veritatem et perfectionem talis formae), que não pode ser senão fora da alma, na própria substância objetificada, e jamais nos sentidos; a segunda, recebida no sentido, faz deste último algo 'de certo modo como o sensível' (ut sensibile / quodammodo ... illud). Assim, a mesma forma é na substância sensível e no sentido, mas diferentemente: na substância sensível essa forma sensível (a cor, por exemplo) é em sua verdade e perfeição, enquanto que no sentido ela é 'algo da coisa' (aliquid rei) que provoca uma alteração (alterationem ${ }^{44}$ ) no sentido, tornando este último, de certo modo (quodammodo), como (ut) aquele sensível fora. A bem dizer, completa Henrique, essa mesma alteração é provocada no meio, que só não sente aquela coisa, porque não possui uma 'força formal sensitiva' (vis formalis sensitiva) - diferentemente do sentido, que certamente a possui. Portanto, pode-se dizer que aquela alteração provocada pela coisa sensível no meio contíguo a si (e, continuamente, até o meio contíguo ao órgão, bem como no próprio órgão do sentido) é justamente o tornar (fit) esse meio não idêntico a ela própria, mas, de certo modo (quodammodo), como $(u t)$ ela própria. Isso que torna o meio (e, no limite, o próprio órgão) como (ut) a própria coisa sensível que age é a espécie impressa gerada no meio (ou no órgão) intencionalmente pela mesma coisa sensível. Por ser gerada intencionalmente, essa espécie ganha também o nome de intenção, com o que se parece querer opô-la ao ser em verdade e perfeição que possui, na coisa sensível, aquela mesma forma que é como intenção no meio e no órgão. Brevemente, a intenção é [i] um ser dependente de uma substância e [ii] um ser que, enquanto

\footnotetext{
${ }^{43}$ Henrique de Gand, Quodl. 5, q. 14, co. (ed. 1613, f. 261vb): "Ad speciem sensibilis sensus est in potentia, quia recipiendo eius intentionem fit non ipsum sensibile, vel tale aliquid secundum veritatem et perfectionem talis formae, qualis est in sensibili extra, sed fit ut sensibile recipiendo intentionem, qua quodammodo est illud. Quae tamen formam aliquid rei est, et fit secundum aliquam realem alterationem, quae etiam fit in ipso medio, quod ob hoc solum non potest immutari ad actum sentiendi, quia non est in ipso vis formalis sensitiva".

${ }^{44}$ A noção de alteratio está estreitamente atrelada àquelas de mutatio e immutatio no discurso sobre a sensação de Henrique de Gand - em particular, sobre a immutatio na sensação, cf. SORGE, Gnoseologia e teologia..., 1988, pp. 59-62. Tais noções são mais bem desenvolvidas em Quodl. 11, q. 5 , como veremos no item 4.5 .
} 
depende desta última, torna (fit) aquilo em que ele é impresso algo como (ut) aquela própria forma da substância que o imprimiu.

Interessante é o fato de que, não obstante a intenção impressa no meio (ou no órgão) se oponha à substância na qual aquela forma é verdadeira e perfeitamente, nem por isso Henrique admite que a alteração provocada pela substância no meio (ou no órgão) seja menos real. Pelo contrário, ela é descrita literalmente como 'uma alteração real' (aliquam realem alterationem). De fato, como Martin Pickavé enfatiza, a distinção entre a forma 'segundo a verdade e a perfeição' e a forma como 'intenção' não corresponde a uma oposição entre material e intencional. Pelo contrário, uma intenção pode muito bem provocar uma alteração real, como lemos no excerto assim, no caso de uma coisa (res) material, tal alteração será igualmente material, mesmo se provocada por uma intenção ${ }^{45}$. Sendo assim, começa a ficar claro que a intentio a que o Doutor Solene se refere nesse contexto não se opõe a res, mas nutre com esta última uma relação bastante complexa. É isso, de fato, que constatamos quando nos voltamos para um pequeno trecho de Quodl. 3, q. 12, onde, para descrever a luz ou lume como uma intenção ${ }^{46}$, Henrique afirma ser possível propor uma distinção acerca de 'coisa' (de re):

“<... uma é a coisa que requer somente, para sua permanência [permanentiam],
que seja gerada pelo agente, do mesmo modo como o calor gerado pelo fogo $[a b$
igne] permanece mesmo que o fogo se afaste. Mas, outra é aquela $<$ coisa $>$ que
requer continuamente a presença do engendrante [generantis], tal que, se em um
momento $<$ este $>$ for retirado, instantaneamente evanesça.
E aquelas que são do primeiro gênero, propriamente falando, são coisas
verdadeiras [verae res sunt]. Mas aquelas que são do segundo gênero - e isso
com respeito às coisas que são do primeiro gênero - são intenções [intentiones],
embora em si, como foi dito, sejam certas coisas [aliquae res sint]" ${ }^{47}$.

Uma é aquela coisa (res) que, após gerada, permanece por si mesma - isso merece ser chamado de 'coisa verdadeira'. Por outro lado, aquilo que depende de

\footnotetext{
${ }^{45}$ PICKAVÉ, “Causality and Cognition...”, 2015, pos. 1267-98.

${ }^{46}$ Já comentamos esse texto brevemente acima, na nota 39 , justamente por ocasião da discussão sobre as noções de lumen e lux.

${ }^{47}$ Henrique de Gand, Quodl. 3, q. 12, co. (ed. 1613, vol. 105ra): "Potest tamen distingui de re $<\ldots>$ quod quaedam est res quae ad sui permanentiam solum requirit quod sit generata ab agente, quemadmodum, calor generatus ab igne manet igne recedente.

Quaedam vero est quae requirit continue praesentiam generantis, ut si ad momentum subtrahatur, statim evanescat. Et illa quae sunt de primo genere proprie loquendo res verae sunt. Illa vero quae sunt de secundo genere, et hoc respectu rerum quae sunt de primo genere, sunt intentiones, licet in se, ut dictum est, aliquae res sint".
} 
outro não somente para ser gerado, mas também para permanecer não é uma vera res, mas antes uma 'intenção' (intentio). Sublinhemos, entretanto, a ressalva final de Henrique acerca desta última: "são intenções, embora em si, como foi dito, sejam certas coisas [sunt intentiones, licet in se, ut dictum est, aliquae res sint]" ${ }^{\text {"48 }}$. Daí que se possa dizer que a distinção entre ‘verdadeira coisa' e ‘intenção' seja uma distinção de re - ambas são verae res, mas quando comparadas entre si somente a primeira merece o título de vera res, restando à segunda ser considerada como aliqua res (mas isso, reforcemos, somente com respeito àquela primeira, pois em si mesma a própria aliqua res é uma vera res) ${ }^{49}$. Pois bem, a vera res propriamente dita (do primeiro gênero de res), após gerada, permanece sem o engendrante (generans), enquanto a aliqua res (do segundo gênero) depende de seu engendrante para ser gerada e para permanecer (sem ele, tal coisa evanesce). Ora, é justamente essa concepção da intentio como aliqua res (mesmo que distinta da vera res) que permitia a Henrique afirmar, numa passagem citada anteriormente de Quodl. 5, q. $14^{50}$, que aquela forma da coisa enquanto intenção provoca no meio 'uma alteração real' (aliquam realem alterationem). Com efeito, a intenção no meio é aliqua res - ou 'uma real alteração' no meio -, porém ela não é estritamente uma vera res, quando comparada à forma na própria substância sensível que a gerou ${ }^{51}$.

\footnotetext{
${ }^{48}$ Mas se ambas - vera res e intentio - são res, o que é esta última? Isso será discutido adiante, em cap. 6 , nota 25 .

${ }^{49}$ Com efeito, para Henrique de Gand, só é possível distinguir entre uma vera res e uma aliqua res por comparação entre elas, porque tudo o que é (em qualquer medida) é em si mesmo uma vera res, como ele explica acerca do lumen: "Cum enim non sit medium inter ens et non ens, lumen generatum per talem multiplicationem, aut est non ens, quod est absurdum dicere, et ponere quod aliquo modo sit generatum, quoniam non est generatio nisi terminetur ad aliquod esse, aut necesse est ergo ponere quod sit ens aliquod. Non est autem ens, nisi sit aliqua res vera, substantia scilicet vel accidens" - Quodl. 3, q. 12, co. (ed. 1613, f. 105ra-b). Ainda sobre a relatividade da expressão vera res, cf. a nota 52, adiante.

${ }^{50} \mathrm{Cf}$. nota 43 , acima.

${ }^{51}$ Jerome V. Brown, de sua parte, prefere explicar o uso de intentio no contexto do estudo da sensação por referência ao uso de intentio na caracterização [i] da distinção intencional e [ii] da distinção entre intenções primeiras e segundas (cf. BROWN, J. V. "Sensation in Henry of Ghent", 1971, pp. 254-6). Em poucas palavras, para ele, a intentio é, primeiramente, um modo de intelecção distinto acerca de uma coisa (isto é, de acordo com sua significação no contexto da distinção intencional - sobre isso, cf., acima, cap. 2, nota 14). Ora, como fica claro no discurso acerca das intenções primeiras, os singulares estão justamente listados como primeiras intenções enquanto são conhecidos pelo intelecto (sobre a distinção entre intenções primeiras e segundas, cf., adiante, cap. 6, nota 36). Daí Brown conclui que, ao estabelecerem uma relação com os sentidos, tais singulares também podem ser tomados como intentiones (como ocorre quando estabeleciam relações com o intelecto). Destarte, também são intentiones as espécies sensitivas por meio das quais tal relação é estabelecida. Pois bem, apesar de considerar esta uma interessante tentativa de unificação dos diferentes usos de intentio na filosofia de Henrique de Gand, não me parece que ela possua claras bases textuais. Por essa razão, limito-me aqui a explicar a caracterização da species como intentio simplesmente por recurso à distinção entre res vera e intentio como aliqua res que encontramos em Quodl. 3, q. 12.
} 
No caso da sensação, que estamos estudando, a vera res é precisamente aquela forma na substância sensível (um acidente, como a cor, no caso da visão ${ }^{52}$ ) que imprime no meio uma intenção sua (a espécie sensível). Ambas - forma na substância sensível e intenção da forma no meio - são coisas (res), porém diferentemente. Isso, porque a intenção (a espécie sensível) é aliqua res que depende de outra res - agora, uma vera res - não só para ser gerada, mas também para permanecer. Daí que a espécie seja indício da presença da coisa sensível: caso esta última seja retirada, a sua espécie no meio, por ser apenas uma intenção, evanesce (donde, igualmente, evanescerá a espécie no órgão, que advém daquela no meio). Por outro lado, a permanência da intenção no meio indica a presença da forma de que ela é a espécie sensível. Em outras palavras, o caráter intencional da espécie - isto é, sua dependência intrínseca com respeito a outro para permanecer - a torna capaz de indicar ao sentido a presença deste outro. Assim, na presença da coisa corpórea sensível, algo dessa coisa (aliquid rei) pode ser realmente no meio (não como vera res, que é forma na própria substância, mas como aliqua res, como uma intentio, como uma species) e, assim, essa forma realmente impressa no meio (embora não com a perfeição e verdade que possui na substância corpórea e sensível de que é forma) pode introduzir-se e imprimir-se no olho, dando vazão (se o fizer directo aspectu) à ação de ver (actio videndi).

Essa expressão - actio videndi -, nos traz de volta agora a uma última dificuldade na passagem de Quodl. 4, q. 21, que destacamos mais acima ${ }^{53}$. Logo ao fim dessa passagem, surge um grave problema: toda nossa intepretação parecia caminhar na direção de afirmar que a produção da sensação seria um processo de três passos: [i] recepção passiva da espécie pelo órgão, [ii] conversão, concepção ou julgar ativo per motum speciei da força sensitiva acerca do objeto externo e, finalmente, [iii] o próprio ato de sentir concebido pela ação desta última. Ora, nas últimas linhas do referido trecho de Quodl. 4, q. 21, é dito que 'a ação de ver' (actio videndi) é aquela "pela qual $[q u a]$ a virtude visiva percebe o objeto sensível particular presente fora". Se assim for, parece que a própria visão - tomada como 'ação de ver', que aqui não parece ser outro senão 'o ato da visão' - é anterior à ação da força sensitiva. Para

\footnotetext{
${ }^{52}$ Henrique de Gand admite, precisamente, que acidentes são também 'coisas verdadeiras', em Quodl. 3, q. 12, co. (ed. 1613, vol. 105ra): "Illud enim est vera res quod facit veram transmutationem, non tamen quod sit ita vera quin alia possit ea esse verior. Aliter enim accidens non posset dici esse res vera. Et sic illud quod uno modo est res vera: alio modo bene potest esse intentio".

${ }^{53}$ Cf. nota 37.
} 
piorar nossa situação, a construção utilizada aqui é muito próxima daquela que encontramos em Quodl. 2, q. 6: "a não ser que a força visiva ou auditiva [vis visiva vel auditiva] se converta para o objeto para perceber o objeto pelo movimento da espécie [per motum speciei]" ${ }^{\prime 5}$. Pois bem, se a força sensitiva age para perceber o objeto pelo movimento da espécie e pela ação de ver, pareceria que o movimento da espécie e a ação de ver são o mesmo! Mas, então, de que serve a ação da força sensitiva?

Acredito que essa dificuldade possua uma solução principalmente linguística, se atentarmos para o uso que Henrique faz de certos elementos da língua latina - em particular, no que tange ao uso das preposições e à riqueza semântica do caso ablativo. Com efeito, já notamos no capítulo anterior como o Doutor Solene pode ser sutil (com perdão do trocadilho...) na utilização das preposições latinas ${ }^{55}$. Note-se, agora, que somente a relação entre a força sensitiva e o 'movimento da espécie' (Quodl. 2, q. 6) é marcada por uma preposição - precisamente, pela preposição per ${ }^{56}$.

\footnotetext{
${ }^{54}$ Cf. nota 29 , acima.

${ }^{55}$ Cf. cap. 2, nota 37. Admito, porém, ser difícil unificar os significados atribuídos aqui à preposição per e aqueles que podemos deduzir de seu uso nos trechos discutidos na referida nota do cap. 2. Sobre demais dificuldades da tese apresentada nestes parágrafos, cf., adiante, os comentários no corpo do texto à citação das notas 58 e 89).
}

${ }^{56}$ Para o texto de Quodl. 2, q. 6, cf. nota 29, acima. Jerome V. Brown ("Sensation in Henry of Ghent", 1971, pp. 251-2) chama a atenção para uma passagem de Suma, art. 33, q. 2, co., onde Henrique de Gand mostra, com base em uma citação da Metafísica de Aristóteles, como é possível afirmar que algo é visível per aliud. Aí lemos: "Si vero fuerit visibile aliquid per aliud, uno modo per se et alio modo per accidens, quemadmodum dicimus quod 'superficies est visibilis per se in genere causae materialis et subiecti, et' quod 'est per se colorata', ut dicit Philosophus in $\mathrm{V}^{\mathrm{o}}$ Metaphysicae, 'eo quod ei convenit primo in se sistere et terminare visum et suscipere colorem visibilem; corpus autem non est visibile, neque terminabile in se visus, neque susceptibile coloris, nisi per superficiem; in genere vero causae formalis superficies est visibile per accidens, quia per colorem qui susceptus est in se' <..." (ed. De Wulf-Mansion Centre, vol. 27, pp. 135-6). Sobre essa passagem, nos diz Brown: "As a matter of fact, all that Henry says seems to militate against any interpretation of seeing which would maintain that per se sensation without benefit of a sensible species is a reality. The mistake is to contrast per se with per aliud in the thought of Henry. Per se is not contrasted with per aliud; it is contrasted with per accidens. Thus, we can see 'per aliud per se' and 'per aliud per accidens'. A colored surface is seen per aliud. But, looking at the situation from the viewpoint of surface (since it is the surface which receives the color), we might say that the colored surface is seen per aliud per se; looking at the same situation from the viewpoint of color (since the color is received by the surface), we might say that the colored surface is seen per aliud per accidens" ("Sensation in Henry of Ghent", 1971, p. 251 - grifos no original). Embora tal exposição pareça fiel ao texto de Suma, art. 33, acredito que Brown força tal leitura quando daí conclui que essa descrição do sentido como per aliud é, igualmente, indicativa da necessidade de espécies sensíveis, como ele faz ao início da passagem citada e em sua continuação: "This per aliud character of seeing - perhaps of all sensation - is fundamental to a sound understanding of Henry's teachings on this subject. The sensible object cannot be internally present to the sense; thus the need for a mediating species" (op. cit., p. 252). Como base desta última asserção, cita-se uma passagem de Quodl. 11, q. 5 (à qual voltaremos na nota 89), na qual há o uso da expressão 'per speciem', mas não de 'per aliud'. Enfim, parece-me interessante a proposta de Brown de interpretar a expressão per speciem à luz da distinção entre per aliud, per se e per accidens, porém, não vejo que haja base textual para tanto, uma vez que o texto fundamental para tal interpretação - o 
Como já vimos, a vis visiva ou a vis auditiva se convertem para perceber o objeto externo per motum speciei - quiçá, algo como através (por meio) do movimento da espécie. Já a relação entre a virtus visiva e a ação de ver (actio videndi), que encontramos em Quodl. 4, q. 21, não é marcada pela preposição per e sim pelo caso ablativo no pronome qua, que remete à própria actio videndi. Encontramos uma construção semelhante em Quodl. 4, q. 7: “o ato de ver [actus videndi] pelo qual [quo] o olho percebe a coisa fora vista" ${ }^{\natural 7}$. Aqui, o olho, assim como a virtus visiva em Quodl. 4, q. 21, 'percebe' (percipit) pela (não per, mas o caso ablativo: qua ou quo) ação ou ato de ver (actio ou actus videndi). Parece-me que a preposição per, nesse caso, marca um meio através do qual a vis visiva age para perceber, enquanto que o ato ou ação de ver é aquilo em que se percebe o objeto externo - de certa maneira, essa actio ou actus videndi é a própria percepção e a virtus sensitiva percebe por ela ( qua ou quo, não per) na medida em que, ao possuí-la em ato, possui o conhecimento sensitivo (não no sentido em que aja através dela - este último caso somente tem lugar per motum speciei). Enfim, não sei até que ponto tal distinção é correta ou clara, mas parece-me certo, pelo menos, que cumpre distinguir aqui entre estes dois casos. Se assim fizermos, continuamos com nossos três passos no progressus do conhecimento sensitivo, porém agora com mais sutilezas: [i] recepção passiva da espécie pelo órgão, [ii] conversão, concepção ou julgar ativo per motum speciei da força sensitiva acerca do objeto externo e, finalmente, [iii] o próprio ato ou ação de sentir concebido pela ação daquela força e, pelo qual (actus quo) ou pela qual (actio $q u a)$, esta percebe o objeto. Nesse contexto, a preposição per e o caso ablativo descrevem, respectivamente, a relação [i] entre a força sensitiva e a intenção cuja presença no órgão permite sua ação e [ii] entre a força sensitiva e seu próprio ato. Sob outro ponto de vista, podemos dizer que a potência sensitiva é em potência para dois: [i] para a recepção da espécie sensível no órgão e [ii] para o próprio ato de sentir. Pela (per) primeira impressa no órgão, a força sensitiva se converte para o objeto; pelo (quo) segundo, tal força conhece em ato aquele objeto ${ }^{58}$.

excerto aqui citado de Suma, art. 33 - nem mesmo se refere à espécies sensíveis, tendo por tema central a relação entre 'cor', 'superfície' e 'corpo' na coisa visível na medida em que é dita visível. Com efeito, nesse trecho, o trio per aliud, per se e per accidens nem mesmo caracteriza a visão, mas antes o próprio visível.

${ }^{57}$ Cf. nota 68 , adiante.

${ }^{58}$ Henrique de Gand, Quodl. 5, q. 14, co. (ed. 1613, f. 261vb): "Inchoando igitur ab immutatione virtutis sensitivae et reductione eius de pontentia in actum, sciendum est, quod secundum Philosophum secundo De anima, sensitivi prima immutatio, qua exit in esse de potentia materiae ad actum formae, 
Reunindo todo o resultado da leitura daquele excerto de Quodl. 4, q. 21, podese dizer em poucas palavras que a espécie impressa no órgão dos sentidos, ao indicar (devido a seu caráter intencional) a presença de uma coisa sensível externa objetificada, torna-se aquilo pelo (per) que a força sensitiva se converte para tal coisa. Agora, se essa impressão da espécie - ou melhor, da species impressa - já está razoavelmente esclarecida (principalmente, pela sua caracterização como intentio), resta que compreendamos melhor o ato ou ação de sentir, concebido pela conversão ou juízo da força sensitiva per motum speciei sobre o objeto externo; ação essa pela (qua) qual a força sensitiva atualmente sente a coisa. Se a espécie recebida no órgão era caracterizada como 'espécie impressa', aquela ação ou ato de sentir proveniente do julgar da virtude sensitiva será uma 'espécie expressa':

“<..> o sentido possui, a partir do objeto, uma espécie recebida impressiva, pela
qual é conduzido por transmutação natural do sentido da potência ao ato, não
somente tal que, formado em potência, seja informado em ato pela recepção da
espécie impressiva no sujeito, permanecendo aí [ut ibi sit status], mas tal que
ulteriormente o sentiente em potência faça-se sentiente em ato pela recepção da
espécie expressiva, não como no sujeito, mas no cognoscente" $"$.

est a generante ipsum in forma sensitivi, qualis immutatio non est in aliqua vi intellectiva, quia habet esse a solo creante, quod declarare impertinens est ad propositum.

Cum autem iam generatum est, est in potentia ad duo, et ad speciem sensibilis, et ad sentire secundum actum, et ad utrumque eorum eget aliquo existente in actu, quod educit, et transmittit ipsum de potentia in actum. Et hoc est sensibile extra, sine quo nihil sentit secundum actum, quemadmodum neque combustibile seipso comburitur sine combustivo". Cf. PICKAVÉ, "Causality and Cognition..., 2015, pos. 1324-37.

Note-se como essa passagem aborda a sucessão de potencialidades no homem a partir de uma etapa ainda anterior àquela que estamos aqui discutindo. Com efeito, no segundo parágrafo está a distinção que principalmente nos interessa, a saber, aquela entre a potência para a recepção da espécie e a potência para a recepção do ato de sentir. No primeiro parágrafo, entretando, aborda-se a própria geração da potência sensitiva enquanto potência para aqueles dois - espécie e ato. Assim, na ordem de geração, há uma potência anterior à potência sensitiva que é a potência da matéria para ser atualizada como potência sensitiva pelo engendrante. Assim, há duas etapas na potência para o conhecimento sensitivo: [1] a potência da matéria para a geração nela da potência sensitiva e [2], uma vez gerada esta última, a dupla potência da potência sensitiva para receber [2.1] a espécie e [2.2] o ato, nessa ordem. Sobre isso, cf. BROWN, J. V. "Sensation in Henry of Ghent", 1971, pp. 244-6. Por outro lado, vemos no trecho aqui citado que tal potência na matéria não precede a potência intelectiva, uma vez que esta provém somente de um criador e não também de um engendrante. Mais informações sobre geração e criação das potências da alma humana podem ser encontradas no cap. 2; Henrique também retorna a esse tema no trecho de Quodl. 11, q. 5, citado adiante na nota 107.

${ }^{59}$ Henrique de Gand, Quodl. 4, q. 21, co. (ed. De Wulf-Mansion Centre, vol. 8, p. 337): “< $<$..> sensus ab obiecto habet speciem receptam impressivam, qua deducitur per transmutationem naturalem sensus de potentia in actum, non solum ut in potentia formatum actu informetur receptione speciei impressivae in subiecto, ut ibi sit status, sed ut ulterius potentia sentiens fiat actu sentiens receptione speciei expressivae, non ut in subiecto sed in cognoscente $<\ldots$.. ". Cf. tb. op. cit., p. 338: "<... sensibilia in quantum sunt extra in actu, necesse est ut moveant sensus et ut sensus moveatur ab eis receptione speciei expressae et impressae" (trechos anexos a esse excertos são citados, adiante, em cap. 6, nota 185). O primeiro excerto citado aqui é comentado por Theophiel Nys em De werking van het menselijk verstand volgens Hendrik van Gent. Leuven: Nauwelaerts, 1949, p. 81. Voltaremos a esse importante comentador adiante, no cap. 6. 
Notemos que essa passagem, em seu todo, distingue duas 'recepções' (receptam, receptione). A primeira é aquela que já vimos longamente, a saber, a recepção da espécie impressa (aqui denominada não impressa, mas impressiva), que provém do objeto externo e produz no órgão uma immutatio, uma alteratio ou, com o termo utilizado agora, uma transmutatio. Somente agora esta modificação / alteração / transmutação provocada pela impressão da espécie no órgão é claramente descrita como uma passagem, por parte do sentido, da potência ao ato - essa transmutação é uma atualização do sentido, sendo este último tomado como o 'sujeito' (subiectum) que recebe a espécie do objeto. Ora, sabemos que, no sentido, aquilo que recebe a partir do meio a espécie impressiva é o órgão, de maneira que essa passagem da potência ao ato pela recepção da espécie impressiva é, principalmente, uma atualização do órgão do sentido.

A segunda recepção, ainda que pressuponha a primeira, é completamente distinta, pois ela faz do sentiente em potência um sentiente em ato (potentia sentiens fiat actu sentiens) - em outras palavras, ela não transmuta o órgão da potência ao ato, mas perfaz o próprio ato de sentir. Nesse caso, aquilo que se recebe é recebido pelo sentido não como um acidente num sujeito, mas como 'no cognoscente' (in cognoscente). Destarte, parece que a primeira recepção, ainda que modifique o sentido (em especial, o órgão do sentido) não é suficiente para provocar o conhecimento - isto é, a presença do objeto como em algo que o conheça. Somente a segunda recepção põe no sentido o objeto como em um cognoscente - essa é a recepção da 'espécie expressa' (aqui denominada species expressiva), pela qual se passa da potência de sentir ao ato de sentir. Agora, seriam o mesmo a espécie expressiva e o ato e sentir?

Uma pista aponta para uma resposta afirmativa: assim como o ablativo marcava a relação entre o ato de sentir e a virtude sensitiva em Quodl. 4, q. $21^{60}$, aqui também o mesmo ablativo marca a relação entre a espécie expressiva e o sentido: “ $u t$ ulterius potentia sentiens fiat actu sentiens receptione speciei expressivae". Decerto, a espécie impressiva também é associada nessa passagem ao sentido por um ablativo ("ut in potentia formatum actu informetur receptione speciei impressivae in subiecto"), porém o resultado dessa primeira recepção é - como ocorria no caso da

\footnotetext{
${ }^{60} \mathrm{Cf}$. nota 37 , acima.
} 
relação entre espécie impressa e força sensitiva Quodl. 2, q. $6^{61}$ - igualmente marcado pela preposição per: "deducitur per transmutationem naturalem sensus de potentia in actum". Para ser sincero, tão interessantes quanto pareçam essas já citadas sutilezas na linguagem filosófica de Henrique de Gand, tal argumento não me soa conclusivo, principalmente devido à referida utilização, nesta passagem, do ablativo também para descrever a relação entre 'espécie impressa' e 'sentido'. A bem dizer, o ablativo aqui parece ser utilizado para descrever os dois casos de recepção: aquele da espécie impressiva e aquele da espécie expressiva. Enfim, não parece que aquela distinção entre o uso da preposição per e o uso do ablativo possa nos ajudar aqui o mesmo tanto que o fez em outras passagens. Ademais, não me parece também que haja outro argumento que possamos aduzir a partir deste último trecho destacado de Quodl. 4, q. 21, em favor da identificação entre a espécie expressiva e o ato de sentir.

Por outro lado, tampouco não parece haver um argumento convincente favorável à tese contrária - isto é, à distinção entre espécie expressiva e o ato de sentir. Decerto, um argumento em prol de tal distinção é que Henrique de Gand parece considerar a espécie expressiva, de certo modo, como um meio para o ato de sentir, tal como a espécie impressiva. A diferença entre estas seria simplesmente que, enquanto a espécie impressiva é um meio recebido no sentido como um acidente em um sujeito, a espécie expressiva é um meio recebido no sentido como o objeto no cognoscente. Nesse caso, [i] o primeiro seria um meio entre uma completa potência para o sentir e um ato suficiente para que a força sensitiva se converta para o objeto, enquanto que [ii] o segundo seria o meio entre a conversão da força sensitiva para o objeto e a produção do próprio ato de sentir. Ainda que aceitemos tal explicação, não está nem um pouco claro o porquê da necessidade desse segundo intermediário...

Aparentemente, a referência à expressão de uma espécie reforça a tese de uma atividade do sentido para além da recepção passiva da espécie impressa: o sentido não somente recebe uma espécie impressa que é o meio para que o sentido se converta para o objeto externo, como o sentido também recebe uma espécie expressa por ele próprio em si mesmo, sendo ela o meio para que haja o ato de sentir. Quando o Doutor Solene afirma, nesta última passagem indentada de Quodl. 4, q. 21, que somente pela espécie expressiva o objeto é no sentido como no cognoscente (" $u t$ ulterius potentia sentiens fiat actu sentiens receptione speciei expressivae, non ut in

\footnotetext{
${ }^{61}$ Cf. nota 29, acima.
} 
subiecto sed in cognoscente"), ele parece justamente querer mostrar que somente então o objeto surge como algo cognoscível. Essa afirmação nos lembra que, para Henrique, é plenamente possível uma impressão de espécies no órgão, sem que se siga daí a excitação para que a força sensitiva se volte para a coisa sensível externa ${ }^{62}$. Assim, a afirmação de uma espécie expressiva como intermediário entre a conversão da força sensitiva e o ato de sentir pareceria destacar a distinção entre uma etapa passiva da sensação, que diga respeito ao órgão (o subiectum de um acidente), e outra ativa, que diga respeito à força sensitiva.

Enfim, a espécie expressiva permanece um elemento obscuro em nossa exposição do processo de formação do conhecimento sensitivo - em particular, não se sabe ao certo se ela é ou não o mesmo que o ato de sentir. Ainda que problemática, seria a espécie expressiva, de fato, um elemento necessário para tal distinção?

\subsection{O PROBLEMA DA ESPÉCIE EXPRESSA NOS SENTIDOS}

Parece clara, na última passagem de Quodl. 4, q. 21, que destacamos acima a referência a espécies expressivas nos sentidos. Michael Rombeiro as interpreta como parte necessária do processo de conhecimento sensitivo tal como Henrique de Gand o concebe: "no processo cognitivo, as espécies impressas são próprias do [are particular to] meio [medium] e dos órgãos dos sentidos e são os meios [means] de tornar o objeto presente ao poder cognitivo [cognitive power]. Uma vez presente, o objeto é unido ao poder [power] como uma espécie expressiva e funciona como o princípio formal que elicita e informa o ato de conhecimento <... ${ }^{\text {"63 }}$. Se nos

\footnotetext{
${ }^{62}$ Cf., novamente, a nota 29.

${ }^{63}$ ROMBEIRO, "Intelligible Species in the Mature Thought of Henry of Ghent”, 2011, p. 201: “Thus, in the cognitive process, impressed species are particular to the medium and the sense organs, and are a means of rendering the object present to the cognitive power. Once it is present the object is united to the power as an expressive species and functions as the formal principle that elicits and informs the act of cognition $<\ldots>$ ". Outros autores que igualmente atribuem a Henrique de Gand a afirmação, sem mais, de espécies impressas e espécies expressas no conhecimento sensitivo são Maurice de Wulf e Raphael Braun - WULF, Études sur Henri de Gand, 1894, p. 79: "Nous venons d'étudier la partie affective du phénomène: le sujet sentant subit une influence. Quand l'ébranlement de la substance nerveuse retentit dans la faculté sensitive, celle-ci pose son acte sous l'empire de cette excitation. C'est la seconde face du problème. L'École donnait le nom d'espéce impresse à l'impression organique subit par le sujet sous l'activité des choses extérieures, et appelait espèce expresse la réaction de l'être dans l'acte final de la sensation" (grifos no original); BRAUN, Die Erkenntnislehre..., 1916, p. 18: "Insofern die 'Species sensibilis' von den Außenkörpern auf die Sinne einwirkt, kommt ihr der Name einer 'Species impressa' zu, insofern sie sich auf das sensitive Erkenntnisvermögen bezieht, wird sie 'Species expressa' gennant. - Bei der Sinneserkenntnis haben wir also eine 'Species impressa qua sensus de potentia in actum ut in subjecto' und eine 'Species expressa qua potentia sentiens fiat actu
} 
voltamos, porém, para o já citado artigo de Jerome V. Brown, não encontramos nenhuma referência significativa à espécie expressiva - de fato, nem mesmo ao discutir o lado ativo do processo de formação da sensação (que vimos ser posterior à etapa passiva de tal processo) este último destaca a necessidade de uma espécie expressiva $^{64}$. Donde proviria tamanha discrepância interpretativa?

Acredito podermos encontrar uma resposta em um artigo de Wouter Goris e Martin Pickavé, no qual lemos: “[n]o centro da doutrina da espécie de Henrique está a distinção entre uma species impress(iv)a e uma species express(iv)a, com cuja ajuda ele, principalmente em Quodl. IV, 21, clarifica o modo de funcionamento do conhecimento humano. De acordo com essa distinção, todo processo de conhecimento parte de um objeto que transmita às potências sensitivas [Sinnesvermögen] uma species impressa, isto é, que nelas imprima uma species. A species efetua em uma potência perceptiva [Wahrnehmungsvermögen] uma modificação natural (transmutatio naturalis), pela qual ela é atualizada. Porém, essa impressão possui duas 'consequências', na medida em que uma dupla potencialidade inere na potência sensitiva: enquanto potentia formarum, ela é 'informada' pela recepção de uma species impressa em um sujeito (in subiecto); enquanto potentia sentiens, ela se torna, pela recepção de uma species expressa, atualmente perceptiva [aktuell wahrnehmend]. Esta última recepção, entretanto, não é aquela de uma species como

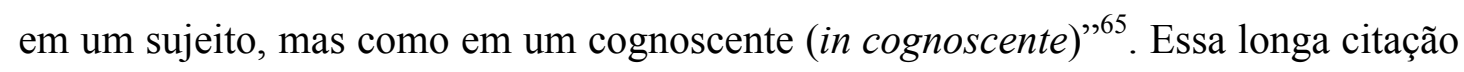
é útil por resumir muito precisamente tudo aquilo que viemos lendo até aqui. $\mathrm{O}$ problema, porém, está justamente duas páginas depois, no mesmo artigo, quando se diz que em "um outro texto (Quodl. V, 14), Henrique busca comprovar sua doutrina

sentiens non ut in subjecto, sed ut in cognoscente"”,

${ }^{64}$ Cf. BROWN, J. V. "Sensation in Henry of Ghent”, 1971, pp. 261-4.

${ }^{65}$ GORIS, W., PICKAVÉ, M. "Von der Erkenntnis der Engel. Der Streit um die species intelligibilis und eine quaestio aus dem anonymen Sentenzenkommentar in ms. Brügge, Stadsbibliotheek 491". In: AERTSEN, J. A. et al. (Hrsg.). Nach der Verurteilung von 1277. Philosophie und Theologie an der Unversität von Paris in letzten Viertel des 13. Jahrhunderts. Studien und Texte. Berlin - New York: De Gruyter, 2001, pp. 125-77 (esp. p. 129): "Im Mittelpunkt der species-Lehre Heinrichs steht die Unterscheidung einer species impress(iv)a von einer species express(iv)a, mit derem Hilfe er vor allem in Quodl. IV, 21 die Funktionsweise der menschlichen Erkenntnis erklärt. Dieser Unterscheidung zufolge geht jeder Erkenntnisvorgang von einem Erkenntnisobjekt aus, welches den Sinnesvermögen eine species impressa mitteilt, d. h. ihnen eine species einprägt. Die species bewirkt in einem Wahrnehmungsvermögen eine natürliche Veränderung (transmutatio naturalis), durch die es aktualisiert wird. Aber diese Einprägung hat zwei 'Konsequenzen', insofern dem Sinnesvermögen eine zweifache Potenzialität innewohnt: Als potentia formarum wird es durch die Aufnahme einer species impressa in einem Subjekt (in subiecto) 'informiert'; als potentia sentiens wird es durch die Aufnahme einer species expressa aktuell wahrnehmend. Die letztgenannte Aufnahme ist jedoch nicht die einer species wie in einem Subjekt, sondern wie in einem Erkennenden (in cognoscente)". 
pela interpretação do famoso dito aristotélico sobre a alma como lugar da species. Ele intensifica sua tese do texto já citado $<s c$. de Quodl. 4, q. 21>, na medida em que ele agora somente aceita species expressae no intelecto $<\ldots>$, ${ }^{\prime 66}$. Ou seja, para Goris e Pickavé, Henrique defende que haja tanto espécie impressa como espécie expressa nos sentidos em Quodl. 4, q. 21, porém rejeita a segunda no que diz respeito ao conhecimento sensitivo em Quodl. 5, q. 14.

De fato, quando estudarmos essa distinção entre espécie impressiva e espécie expressiva em sua aplicação ao conhecimento intelectivo adiante, veremos como a leitura do Quodl. 4 pode ser traiçoeira quanto a esse tema (cf. item 6.4.2). Antes, porém, de nos voltarmos para o trecho de Quodl. 5, q. 14, a que se referem Goris e Pickavé, notemos que no próprio Quodl. 4 (ou seja, onde vimos ser afirmada a necessidade tanto da espécie impressiva, como da espécie expressiva para o conhecimento sensitivo ${ }^{67}$ ), lemos também uma descrição do processo de sensação sem qualquer remissão a espécies expressas - precisamente, no seguinte trecho de Quodl. 4, q. 7:

"Donde, o ato de ver pelo qual o olho percebe a coisa fora vista objetivamente
assimila mais perfeitamente o olho à coisa vista do que $<0$ faz $>$ a espécie da
coisa nele impressa, pois essa espécie não informa nem assimila o olho senão
sob a razão de espelho [sub ratione speculi]. Mas aquele ato informa e assimila o
olho sob a razão do cognoscente e, assim, por aquela espécie, mais
principalmente é informado e assimilado à coisa vista o olho do que a força
visiva, enquanto no ato de ver ocorre o contrário"

Nesse excerto, em lugar de uma [1] distinção entre [1.1] a recepção de uma espécie impressa no órgão como acidente em um sujeito enquanto meio entre a potência do sentido e o converter-se da potência sensitiva e [1.2] a recepção de uma espécie expressa no sentido como no cognoscente como meio entre o juízo da força sensitiva e o ato de sentir, temos [2] uma distinção entre [2.1] a espécie da coisa,

\footnotetext{
${ }^{66}$ GORIS \& PICKAVÉ, "Von der Erkenntnis der Engel”, 2001, p. 131: "In einem anderen Text (Quodl. V, 14) versucht Heinrich seine Lehre durch die Auslegung des berühmten aristotelischen Diktums von der Seele als dem Ort der species zu belegen. Er verschärft seine Position aus dem gerade besprochenen Text, insofern er species expressae nur noch im Intellekt annehmen will <...>".

${ }^{67}$ Cf. nota 59, acima.

${ }^{68}$ Henrique de Gand, Quodl. 4, q. 7, co. (ed. De Wulf-Mansion Centre, vol. 8, p. 35): "Unde actus videndi quo oculus percipit extra rem visam obiective perfectius assimilat oculum rei visae quam species rei impressa ei, quia species ista non informat neque assimilat oculum nisi sub ratione speculi. Actus vero ille informat et assimilat oculum sub ratione cognoscentis et sic specie illa principalius informatur et assimilatur rei visae organum quam vis visiva, in actu autem videndi contingit e converso".
} 
impressa no olho, que assimila o olho ao objeto 'sob a razão de espelho' (sub ratione speculi) e [2.2] o ato de ver que assimila também o olho, porém mais principalmente a força visiva ao objeto 'sob a razão do cognoscente' (sub ratione cognoscentis). Esse ato [2.2], aliás, se constitui como assimilação mais perfeita do olho (e, mais principalmente, da força visiva) ao objeto, do que aquela assimilação [2.1] que ocorre pela espécie impressa.

Resta saber o que se quereria precisamente dizer ao se afirmar que "o ato de ver pelo qual o olho percebe a coisa fora vista objetivamente assimila mais perfeitamente $o$ olho à coisa vista do que $<_{0}$ faz $>$ a espécie da coisa nele impressa [actus videndi quo oculus percipit extra rem visam obiective perfectius assimilat oculum rei visae quam species rei impressa ei]”. Em particular, é mister compreender o que significa esse 'assimilar mais perfeitamente' (perfectius assimilat) do ato de ver com respeito à espécie impressa. A meu ver, a chave para a interpretação desse excerto de Quodl. 4, q. 7 está na oposição entre 'sub ratione speculi' e 'sub ratione cognoscentis'. Ali, a informação ou assimilação do olho ao objeto pela espécie é explicitada como uma informação ou assimilação do olho ao objeto 'sob razão de espelho', enquanto que a informação ou assimilação do olho (mas, principalmente, da força visiva) ao objeto pelo ato de ver é compreendida como uma informação ou assimilação do olho (e, principalmente, da força visiva) ao objeto 'sob a razão do cognoscente'. Ou seja, assim como o ato de ver é recebido pelo olho enquanto este é cognoscente (ou pela força visiva enquanto esta é cognoscente), assim também a espécie impressa é recebida no olho enquanto este é um espelho. Mas, como descrever um espelho? E, mais, como descrever $o$ olho como um espelho?

Comecemos por compreender o que seria um espelho. Em poucas palavras, ele é algo pelo qual se conhece outro. Entretanto, há muitas maneiras de se conhecer um pelo outro - para nossa sorte, Henrique de Gand as enumera em Suma, art. 33, q. 3. Com efeito, embora ele esteja voltado nesse texto para o conhecimento intelectivo de um por meio de outro (e, em particular, pergunta-se aí "se a razão de inteligir Deus seria a razão de inteligir todo outro que não ele" ${ }^{\text {69 }}$ ), ele utiliza justamente o 'espelho' (speculum) como paradigma de um desses modos de conhecimento: "Para a questão, então, cumpre dizer que a razão pela qual [qua] algo é inteligível em si pode ser

\footnotetext{
${ }^{69}$ Henrique de Gand, Suma, art. 33, q. 3 (ed. De Wulf-Mansion Centre, vol. 27, p. 153): "Utrum ratio intelligendi Deum sit ratio intelligendi omnia alia ab eo".
} 
entendida como a razão pela qual [qua] outros são inteligíveis de cinco modos"70. Desses, nos interessarão somente os primeiros dois que, a bem dizer, são apresentados como dois casos de um mesmo modo: "Primeiramente, porque do conhecimento de um depende o conhecimento de outro, tal que não se poderia possuir o conhecimento daquele sem que simultaneamente se possua o conhecimento deste - e isso, duplamente: primeiramente, do modo como um correlativo não pode ser inteligido sem o outro; em segundo lugar, do mesmo modo como, no conhecimento sensitivo da visão corporal, visto o espelho, necessariamente se veem simultaneamente as coisas cujas imagens são contidas no espelho"71. O espelho é algo que pode ser conhecido por si, assim como a imagem no espelho também é algo que se pode conhecer por si mesma (isto é, não enquanto imagem de algo, mas somente enquanto imagem num espelho $^{72}$ ), porém ao olhar o espelho simultaneamente conhecemos aquela coisa cuja imagem o espelho contém. Ou seja, o espelho é algo que contém uma imagem que nos permite conhecer algo outro, a saber, a coisa de que esta é a imagem. Sendo mais preciso, Henrique ainda descreve a maneira pela qual tais imagens estão contidas no espelho, quando diz que Deus “não possui a razão de espelho ao conter as espécies de outros como algo outro que não sua essência, tal como o espelho material contém as coisas ${ }^{73}$. Assim, o espelho contém as coisas nele refletidas ao possuir as espécies das

\footnotetext{
${ }^{70}$ Henrique de Gand, Suma, art. 33, q. 3, co. (ed. De Wulf-Mansion Centre, vol. 27, p. 155): “Ad quaestionem ergo istam dicendum, quod ratio qua aliquid est intelligibile in se, potest intelligi esse ratio qua alia sunt intelligibilia, quinque modis".

${ }^{71}$ Henrique de Gand, Suma, art. 33, q. 3, co. (ed. De Wulf-Mansion Centre, vol. 27, p. 155): "Primo, quia ab unius cognitione dependet cognitio alterius, ita ut cognitio illius haberi non possit, quin simul habeatur cognitio istius, et hoc dupliciter. Primo, ad modum quo unum correlativum sine altero intelligi non potest. Secundo, quemadmodum in cognitione sensitiva visus corporalis, viso speculo, necessario videntur simul res quarum imagines continentur in speculo"

${ }^{72}$ Essa afirmação não está clara no trecho citado, porém podemos extraí-la de uma passagem como Suma, art. 1, q. 1, co., onde se afirma que uma mesma imagem pode ser [i] tomada como objeto em si mesma ou [ii] tomada como ratio cognoscendi de outro objeto, isto é, como um meio para o conhecimento de outro objeto: "Ad septimum, quod 'homo nihil percipit de re cognoscibili nisi idolum solum', dicendum quod percipere idolum rei contingit dupliciter: uno modo tamquam obiectum cognitionis, - hoc modo verum est quod percipiens solum idolum rei non cognoscit rem, sicut videns imaginem Herculis depictam in pariete (ex hoc non videt neque cognoscit [cognosicit ed. De WulfMansion Centre, vol. 21] Herculem) -; alio modo tamquam rationem cognoscendi; sic non est verum. Per solam enim speciem perceptam de re cognoscitur vere res, ut lapis vere videtur per solam speciem suam sensibilem receptam in oculo, et vere intelligitur per solam speciem suam intelligibilem receptam in intellectu" (ed. De Wulf-Mansion Centre, vol. 21, p. 27) - uma distinção semelhante, porém em outro contexto, surge em Suma, art. 1, q. 2, co. (ed. De Wulf-Mansion Centre, vol. 21, p. 50). Ao que me parece, é plenamente possível estender essa distinção do caso da imagem pintada na parede para o caso da imagem refletida no espelho, que principalmente nos interessa aqui. Sobre o trecho citado de Suma, art. 1, q. 1, cf. PASNAU, Theories of cognition in the later Middle Ages, 1997, p. 224.
}

${ }^{73}$ Henrique de Gand, Suma, art. 33, q. 3, co. (ed. De Wulf-Mansion Centre, vol. 27, pp. 155-6): "Secundo autem modo nequequam. Ipse enim non habet rationem speculi in continendo species 
coisas. Esse 'possuir as espécies' não deve ser pensado como algo essencial - isto é, tais espécies não são da essência do espelho, mas são antes acidentes em um sujeito ou substância.

Agora, ao que parece, podemos melhor compreender a afirmação segundo a qual a espécie impressa assimila o olho ao objeto sub ratione speculi: ao receber a espécie impressa, o olho - tal como um espelho - passa a conter essa coisa que difundiu sua espécie pelo meio, ao possuir tal espécie (não essencialmente, mas) como um acidente em um sujeito (lembremos como a recepção da espécie impressa era descrita, em Quodl. 4, q. $21^{74}$, como a recepção de algo ut in subiecto). Ou seja, por essa impressão da espécie, o olho é assimilado ao objeto tal como um espelho é assimilado àquilo que reflete, de maneira que por tal impressão o olho torne-se algo no qual se pode conhecer outra coisa (isto é, uma coisa externa) que não ele próprio.

Resta, porém, uma dúvida: no caso do espelho, é preciso um observador que se volte para o espelho e, ao ver o espelho, veja a outra coisa cuja espécie o espelho possui, mas quem seria este que se volta para o próprio olho para assim conhecer aquela coisa cuja espécie o olho possui? Ora, a essa altura, já sabemos a resposta: aquilo que se converte para a espécie impressa no olho é a própria força visiva. Esta, através dessa reflexão (abusando um pouco da metáfora do espelho...) da coisa no olho, conhece a própria coisa (e não seu reflexo). Nesse instante, o sentido é assimilado à coisa não mais como um espelho que meramente a reflete (ou como um subiectum que recebe um acidente), mas sim como uma força que a conhece em ato ele agora se assimila à coisa sub ratione cognoscentis. Destarte, a espécie impressa no órgão somente torna o objeto presente para o sentido como se o órgão fosse um espelho. Apenas uma vez que a força visiva tenha se convertido para tal espelho (julgando tal reflexo), surge o ato de sensação (não do reflexo, mas da própria coisa refletida).

Assim, quando Henrique afirma que a assimilação do sentido pelo ato de sentir é 'mais perfeita' (perfectius), ele está apenas reiterando o caráter intermediário da espécie - isto é, sua característica intencionalidade, uma vez que, ao depender de uma coisa verdadeira (vera res), a espécie remete a potência sensitiva àquela coisa presente externamente de que ela depende. A assimilação do olho pelo ato de ver é

aliorum tamquam aliquid aliud a sua essentia, sicut continet res speculum materiale".

${ }^{74}$ Cf., acima, nota 59. 
mais perfeita do que sua assimilação pela espécie impressa, porque tem por fim justamente permitir o ultrapassamento da espécie em direção à coisa externa. De fato, como Jerome V. Brown ${ }^{75}$ destaca, aquela passagem de Quodl. 4, q. $7^{76}$, só pode ser entendida justamente pela compreensão da espécie sensível como intentio e, portanto, como algo que, dependendo de outro, remete o sentido a este outro. Assim, ao descrever a assimilação do sentido à coisa vista pelo ato de ver como perfectius, o Doutor Solene está simplesmente dizendo que, no instante em que surge o ato de sentir, a espécie impressa cumpriu seu papel, isto é, serviu de meio para uma conversão da força sensitiva não à espécie da coisa, mas à própria coisa externa.

Voltando, agora, ao nosso problema original, notemos como toda essa narrativa proveniente de Quodl. 4, q. 7, tão complexa quanto seja, não cita em nenhum momento a species expressa ou species expressiva. É como se o caráter intencional da espécie impressa e o converter-se da força sensitiva fossem suficientes, por si sós, para descrever o processo de formação do conhecimento sensitivo. Como vimos, porém, não somente esse é o caso em Quodl. 4, q. 7, como Goris e Pickavé apontavam também Quodl. 5, q. 14 ${ }^{77}$, como um local de clara negação de espécies expressas nos sentidos. De fato, essa ausência de uma espécie expressiva no processo de conhecimento sensitivo parece pressuposta, quando o gandavense, nesta última questão, afirma que o sentido "é em potência para dois: tanto para a espécie sensível, como para o sentir segundo ato [ad sentire secundum actum] e para ambos ele precisa de algo existente em ato que o conduz [educit] e o transmite da potência ao ato" ${ }^{\text {"78. }}$. Não se fala aqui em qualquer recepção de espécie expressiva - ou seja, essa pequena asserção parece se aproximar muito mais do que lemos em Quodl. 4, q. 7 (a oposição entre [i] assimilação pela espécie impressa e [ii] assimilação pelo ato de ver), do que daquilo que vemos em Quodl. 4, q. 21 (a oposição entre [i] a recepção da espécie impressa e [ii] a recepção da espécie expressa). O texto destacado por Goris e Pickavé parece ainda mais assertivo quanto ao problema:

\footnotetext{
${ }^{75}$ BROWN, J. V. "Sensation in Henry of Ghent", 1971, p. 250-2.

${ }^{76}$ Cf. nota 68 , acima.

${ }^{77}$ Cf. nota 66, acima.

${ }^{78}$ Henrique de Gand, Quodl. 5, q. 14, co. (ed. 1613, f. 261vb): “Cum autem iam generatum est, est in potentia ad duo, et ad speciem sensibilis, et ad sentire secundum actum, et ad utrumque eorum eget aliquo existente in actu, quod educit, et transmittit ipsum de potentia in actum". Sobre tal passagem, cf. BROWN, J. V. "Sensation in Henry of Ghent", 1971, p. 244. Ademais, esse trecho já foi estudado acima, na nota 58 .
} 
"Donde, uma vez que esse modo de possuir em si espécies expressas é próprio do intelecto e não do sentido, por isso o Filósofo, em De anima III, aprova os que dizem que a alma é o lugar das espécies - não que toda $<_{0}$ seja $>$, mas a intelectiva.

Ele o diz, para diferenciá<-la $>$ da sensitiva, na qual não há senão espécie impressa, enquanto no intelecto há <espécie> expressa e, por isso, de algum modo tal como em um lugar, mas não tal como em um sujeito [non autem sicut in subiecto]"79.

Não pretendo destrinchar aqui a comparação entre sentido e intelecto, porque já a veremos longamente quando nos voltarmos para o conhecimento intelectivo, no cap. 6. Assim, basta notar que, nesse pequeno trecho, Henrique de Gand restringe as espécies expressas ao intelecto e as espécies impressas ao sentido. Dessa maneira, a impressão de espécies sicut in subiecto torna-se marca exclusiva do conhecimento sensitivo. Por outro lado, há que notar que a recepção de algo 'como em um cognoscente' (ut in cognoscente), caracteristicamente associada à espécie expressa, é excluída dos sentidos. Nem por isso os sentidos deixam de ser cognoscentes - ainda que eles não recebam uma espécie expressa ut in cognoscente, o olho (e, principalmente, a força visiva) é informado e assimilado ao objeto externo sub ratione cognoscentis pelo próprio ato de sentir. Nos sentidos, portanto, restam a recepção da espécie impressa que assimila o olho ao objeto sob a razão de espelho (sub ratione speculi) e o ato de sentir que assimila o olho (e, principalmente, a força visiva) ao objeto sob a razão do cognoscente (sub ratione cognoscentis).

Como viemos lendo, somente nessa segunda etapa há propriamente conhecimento, uma vez que aquele primeiro passo do processo de conhecimento sensitivo - a saber, a recepção da espécie impressa - simplesmente é um movimento da espécie pelo qual (per motum speciei) a força sensitiva se converte para o objeto externo. Mais precisamente, a recepção da espécie sensível no órgão 'excita' a força sensitiva (excitatatur $)^{80}$, tal que esta última se converta / julgue sobre o objeto externo. Não havendo mais uma espécie expressa no sentido, a ação que resta para a força sensitiva (pois, lembremos que apesar de sua enorme materialidade, o sentido

\footnotetext{
${ }^{79}$ Henrique de Gand, Quodl. 5, q. 14, co. (ed. 1613, f. 261va): "Unde quia iste modus habendi in se species expressas proprius est intellectus, et non sensus, ideo Philosophus tertio De anima commendat dicentes animam esse locum specierum, non quod tota, sed intellectiva.

Quod dicit ad differentiam sensitivae, in qua non est nisi species impressa, in intellectu vero est expressa, et propter hoc quodammodo sicut in loco, non autem sicut in subiecto". Cf. GORIS \& PICKAVÉ, "Von der Erkenntnis der Engel”, 2001, pp. 131-2.

${ }^{80}$ Cf. nota 29 , acima.
} 
ainda possui seu quinhão de atividade ${ }^{81}$ ) é esse converter-se ou julgar sobre o objeto por meio da espécie impressa no olho como em um espelho. A espécie expressa, que surgiu rapidamente em Quodl. 4, q. 21, como um recurso para a compreensão do processo de formação do conhecimento sensitivo parece, no fim, ter seu papel preenchido pelo próprio ato de sensação, tal como vimos no item 4.2 a species tomar para si os atributos da configuratio.

Dito isso, nossa última etapa neste estudo sobre o sentido particular será uma leitura de Quodl. 11, q. 5. Nesse ponto, os elementos ativos que restam para a narrativa da formação do conhecimento sensível particular são dois: [i] a alteração do órgão pela espécie que, excitando a força sensitiva, permite a esta última [ii] voltar-se para o objeto. Agora, esses dois são suficientes para a produção da sensação em ato.

\subsection{A DESCRIÇÃO DO SENTIDO PARTICULAR EM QUODL. 11, Q. 5}

A pergunta posta em Quodl. 11, q. 5 é "se aquele que age as operações vitais cognitivas (que são visão, audição e universalmente a sensação [sensatio] da parte do sentido e a inteleção da parte do intelecto) é externamente sentiente e inteligente ou internamente" ${ }^{\prime 22}$. O problema colocado é, assim, a relação entre fatores internos e externos no processo de conhecimento - essa compreensão da questão fica clara já nos argumentos principais, onde primeiro destacam-se o intelecto e o sentido como princípios naturais internos, para em seguida lembrar que, enquanto potências passivas, eles dependem de algo externo que os afete ${ }^{83}$. A saída para a resposta, destarte, será explicar precisamente de que maneira esses princípios internos de agir podem ser afetados por algo externo. Para tanto, retoma-se aqui um tema que já vimos se desenvolver e, agora, leremos mais pausadamente, a saber: a compreensão da recepção por parte do sentido como uma immutatio $^{84}$, transmutatio $^{85}$ ou, mais precisamente agora, como uma alteratio $^{86}$. Aqui, porém, esta última - atrelada à

\footnotetext{
${ }^{81}$ Cf. nota 27, acima.

${ }^{82}$ Henrique de Gand, Quodl. 11, q. 5 (ed. 1613, p. 194v): "Utrum agens operationes vitales cognitivas quae sunt visio, auditio, et universaliter sensatio ex parte sensus, et intellectio ex parte intellectus, sit extra sentientem, et intelligentem, an intra".

${ }^{83}$ Cf. Henrique de Gand, Quodl. 11, q. 5, arg. princ. (ed. 1613, p. 195ra).

${ }^{84}$ Cf. notas 6, 8, 14, 20, 43 e 58.

${ }^{85} \mathrm{Cf}$. notas 52 e 59 .

${ }^{86} \mathrm{Cf}$. nota 43.
} 
noção de 'mutação' (mutatio) -, mais do que unicamente marcar a etapa passiva do processo de formação do conhecimento sensitivo, torna-se noção central para a articulação da sucessão entre passividade e atividade na constituição do ato de sentir.

Com efeito, logo de início, Henrique de Gand se dedica justamente a uma explicação, a partir da noção de alteratio, do que seriam tanto agir (agere) como padecer (pati):

"Cumpre dizer quanto a isso que, segundo o Filósofo em De anima II, agir e
padecer se dizem triplamente, segundos os três modos diversos de alteração:
$<\mathbf{1}>$ De fato, há um modo de alteração que é a mutação [mutatio] segundo
disposições privativas, que é do contrário para o contrário, pela corrupção de um
deles a geração do outro. Assim é aquela pela qual [qua] algo realmente se
muta do quente para o frio ou o contrário. E essa modificação é dita 'retirada do
contrário' [contrarii abiectio].
$<\mathbf{2}>$ Mas, há outro modo de alteração, que é a recepção de uma disposição
conatural, que é a condução [deductio] da potência para o ato, sem qualquer
contrário. E essa modificação é dita 'recepção da salvação' [salutis receptio]. E
ela é dupla. <2.1> Uma pela qual [qua] adquire-se uma disposição na coisa para
sua própria operação. E é aquela pela qual [qua] algo é mutado intencionalmente
pelo sensível ou inteligível. <2.2> Mas, há outra pela qual [qua] elicita-se, desde
a coisa [a re], sua operação própria. E é aquela, pela qual [qua] algo disposto se
induz ao ato, tal que por ela [qua] o não vidente ou não inteligente segundo o
ato, seja feito vidente ou inteligente. E é dita propriamente 'alcançar a salvação'
[adeptio salutis]" ".

O [1] primeiro modo de alteração é a passagem de um contrário a outro, pela corrupção do anterior e geração do posterior. Tal passagem de um contrário a outro é descrita como uma 'mutação segundo disposições privativas' (secundum privativas dispositiones mutatio) - de fato, uma disposição é introduzida pela privação de outra (nomeadamente, de seu contrário). Vimos no item 2.2, que a 'mutação' (mutatio) é um 'fazer' (factio) simultâneo (isto é, não sucessivo, como seria o caso num motus) a partir de um 'mutador' $(a<\ldots>\text { mutante })^{88}$. Nesse caso, parece que aquela alteração de um contrário a outro pressuporá sempre um agente (o mutador) que introduza no

\footnotetext{
${ }^{87}$ Henrique de Gand, Quodl. 11, q. 5, co. (ed. 1613, p. 195ra-b): "Dicendum ad hoc, quod secundum Philosophum in secundo De anima, agere et pati tripliciter dicuntur secundum tres modos alterationis diversos. Est enim unus modus alterationis, quae est secundum privativas dispositiones mutatio, quae est a contrario in contrarium, per unius illorum corruptionem et alterius generationem, ut est illa, qua aliquid realiter mutatur a calido in frigidum, vel e converso et dicitur haec mutatio contrarii abiectio. Alius vero modus est alterationis, quae est a potentia in actum deductio, absque omni contrario, et haec mutatio dicitur salutis receptio, et haec est duplex, una qua acquiritur dispositio in re ad suam propriam operationem, et est illa, qua aliquid intentionaliter mutatur a sensibili, aut intelligibili: altera vero est qua elicitur a re sua propria operatio, et est illa, qua aliquid dispositum seipso inducitur in actum, ut qua non videns, aut non intelligens secundum actum, factus est videns, aut intelligens, et dicitur salutis adeptio proprie".

${ }^{88}$ Cf. cap. 2, nota 21.
} 
paciente a ser mutado uma disposição privativa daquela disposição contrária a esta que ele já possui. Daí que se diga que o primeiro modo de alteração seja uma 'retirada do contrário’ (contrarii abiectio), pois uma alteração numa coisa pressupõe algo outro que retire dessa coisa a disposição contrária àquela que será introduzida por este outro. Enfim, já esse primeiro caso de alteração coloca em jogo um complexo arranjo entre ação e paixão, uma vez que tanto a corrupção de um contrário quanto a geração do outro contrário correspondem a ações e paixões sucessivas do mutado, mas também do mutador.

Quiçá devido a essa complexidade mesma, Henrique afirma que esse primeiro modo de alteração - a mutação de um contrário a outro - corresponde a uma dupla alteração nos sentidos:

\begin{abstract}
"Mas, o primeiro modo, da parte do sentido [ex parte sensus], é duplo:
De fato, há uma alteração do sensitivo principalmente no próprio órgão de sentir, que é pela espécie do sensível recebida nele pelo meio [per medium] desde o sensível fora.

Porém, há outra alteração do sensitivo principalmente na própria força sensitiva [in ipsa vi sensitiva], que nela é uma inclinação para elicitar o ato de sua operação - e <tal inclinação $>$ é pela dita espécie agente em virtude do sensível fora [et est specie dicta agente in virtute sensibilis extra]. E isso da parte dos sentidos $<\ldots>$.

Quanto ao precedente, porém, cumpre entender que no primeiro gênero de alteração, que é a 'retirada do contrário', altera-se o corpo enquanto é um corpo natural simplesmente [alteratur corpus, ut est corpus naturale simpliciter]" ${ }^{\prime 89}$.
\end{abstract}

Não deixa de ser curioso que, no caso da enumeração dos modos de alteração (no penúltimo trecho destacado), apenas o segundo caso seja divido em dois, enquanto que na utilização desses modos ex parte sensus também o primeiro modo se divida em dois.

Pois bem, no primeiro caso desse primeiro modo de alteração nos sentidos, a passagem de um contrário ao outro ocorre na potência sensitiva e, "principalmente, no próprio órgão de sentir [principaliter in ipso organo sentiendi]”. Lembremos que em Quodl. 4, q. $7^{90}$, a assimilação da potência sensitiva ao objeto pela espécie sensível é

\footnotetext{
${ }^{89}$ Henrique de Gand, Quodl. 11, q. 5, co. (ed. 1613, p. 195rb): "Sed primus modus ex parte sensus duplex est. Est enim quaedam alteratio sensitivi principaliter in ipso organo sentiendi, quae est per speciem sensibilis receptam in illo per medium a sensibili extra. Est autem alia alteratio sensitivi principaliter in ipsa vi sensitiva, quae in ipsa est inclinatio quaedam ad actum operationis suae eliciendum, et est specie dicta agente in virtute sensibilis extra $<\ldots>$.

Tamen circa praecedentia intelligendum, quod in primo genere alterationis, quae est contrarii abiectio, alteratur corpus, ut est corpus naturale simpliciter".

${ }^{90} \mathrm{Cf}$. nota 68 , acima.
} 
atribuída 'mais principalmente' (principalius) ao órgão (no caso, o olho), ao passo que a assimilação da potência sensitiva ao objeto pelo ato de sensação é atribuída 'mais principalmente' (principalius) à força visiva (vis visiva). Ou seja, a vis visiva e o órgão surgem, lá e aqui em Quodl. 11, q. 5 (agora mais claramente, parece-me), como dois aspectos da potência sensitiva toda (sensitivus), que é propriamente aquilo que é alterado na sensação. Ora, no primeiro caso do primeiro modo de alteração, o que está em jogo é justamente essa recepção de espécies (difundidas a partir do objeto externo através do meio) pelo órgão - aqui, toda a potência sensitiva é alterada pela espécie, mas essa alteração correspondente à recepção da espécie diz respeito principalmente ao órgão. Porém, dado que esse primeiro modo de alteração é dito 'retirada do contrário', quais contrários estariam em jogo aqui? Em linhas gerais, poderíamos dizer que, nesse caso, os contrários seriam a ausência de ato e o próprio ato: a não-recepção da espécie e a recepção de tal espécie. Essa etapa de não-recepção da espécie, decerto pode ser tomada como uma potência para a recepção da espécie ela não é, porém, uma completa potencialidade.

Se nos voltamos para o Quodl. 5, q. 14, lemos uma curta exposição sobre essa potência da parte sensitiva (em especial, do órgão) para a recepção da espécie: “enquanto é em potência para a recepção da dita espécie, é uma razão média [ratio media] e uma proporção dos sensíveis [proportio sensibilium] - como a pupila não é branca nem preta, nem de cor média, mas de uma qualidade média [qualitatis mediae] igualmente proporcional a todas; do mesmo modo como o temperado [temperatum] é, no tato, o meio excelente [medium ... excellens] entre o quente e o frio. De fato, como diz o Filósofo, o meio é discretivo [discretivum] e faz-se com respeito a ambos aqueles extremos [et fit ad utrumque alterum ultimorum]" 91 . Aqui surge a

\footnotetext{
${ }^{91}$ Henrique de Gand, Quodl. 5, q. 14, co. (ed. 1613, f. 261vb): "Quo enim sentimus est id, in quo est potentia huiusmodi, ut dicit Philosophus. Et est illud, in quo inquantum est in potentia ad receptionem dictae speciei, est media ratio, et proportio sensibilium, ut pupilla, nec alba, nec nigra, nec medii coloris, sed qualitatis mediae aeque proportionalis omnibus, quemadmodum temperatum in tactu est medium inter calidum, et frigidum excellens. Medium enim ut dicit Philosophus discretivum est, et fit ad utrumque alterum ultimorum.

Et propter hoc excellentiae sensibilium intensius imprimentes species suas, quam valet sustinere illud medium, corrumpit illud, sicut Symphonia corrumpitur chordis fortius percussis, quam oportet".

Com efeito, a corrupção permanente dessa qualidade média do órgão (que o torna receptivo e discretivo com respeito a seus sensíveis próprios) é, precisamente, uma 'lesão' (laesio) no órgão. Esta pode ocorrer por duas causas, como lemos em Quodl. 11, q. 8: "Haec autem laesio in organo cuiuscumque sensus etiam dupliciter potest contingere, vel per accidens vel per se. Per accidens, quando organum sentiendi, puta visus inquantum visus est, et media ratio visibilium, laeditur immutatione reali, puta calefactione, et hoc per se inquantum est corpus naturale simpliciter, per accidens inquantum est organum visus, et est simile de organis aliorum sensuum. Omnia enim quoad sua temperamenta habent corrumpi per accidens, qualitatum activarum et passivarum contrarietate,
} 
caracterização do sentido antes da recepção da espécie como um meio (medium) 'discretivo' (discretivum). Ora, a referência ao termo discretivum não deixa de nos remeter a algo que vimos ainda no início deste capítulo, a saber: a caracterização do sentido como capaz de 'discernir' (ad discernendum), seja pela determinação da configuração da coisa sentida (que líamos em Suma, art. 1, q. 3), seja pela difusão da luz aspectu directo (que vimos no mesmo trecho da Suma) ou, ainda, unicamente pela modificação provocada no olho pela própria visão de uma cor sob a luz (o que vimos em Suma, art. 24, q. 7) ${ }^{92}$. Novamente, portanto, o sentido surge como capaz de discernir - como discretivum. Antes se falava do discernir em ato, enquanto agora se explica sua capacidade de discernir por referência a seu caráter de potência média para a recepção de espécies. Assim, aquela não-recepção da espécie é, como se dizia, uma potência para tal recepção, porém ela é uma potência de tipo bem preciso, uma vez que pressupõe um proporção mediana entre os vários sensíveis cognoscíveis por tal sentido. Perceba-se como esse meio entre os sensíveis não pode ser a própria qualidade sensível - o olho não possui uma 'cor mediana', mas uma qualidade que é mediana com respeito às cores; igualmente, o tato não é um pouco frio e um pouco quente, mas é temperado em uma proporção mediana com respeito ao frio e ao quente. O que seriam essas qualidades que são o meio entres as cores ou o meio entre

quae sunt calidum et frigidum, humidum et siccum, quibus etiam corrumpitur totum animal. Per se autem contingit laesio in organo cuiusque sensus, quando laeditur immutatione intentionali per speciem sui proprii sensibilis excessivam, inquantum excellentiae sensibilium corrumpunt per se sensus, secundum Philosophum secundo De anima. Quamvis aliqui dicunt, quod hoc contingit per dictam actionem realem per se. Immo dico, quod species excessiva commensurationem organi ut sensitivum est, corrumpit per se. Sed actio realis, quae per se corrumpit corpus, ut est corpus mixtum, per accidens corrumpit illam commensurationem sicut etiam per accidens corrumpit totum animal <... ” (ed. 1613, f. 206va). Em poucas palavras, [i] ao corromper per se o corpo misto, qualquer ação real pode corromper per accidens a qualidade média do órgão, lesionando-o; por outro lado, [ii] uma espécie excessiva do sensível próprio do órgão corrompe intencionalmente sua qualidade média e, portanto, o lesiona per se (isto é, não enquanto mero corpo misto, mas enquanto órgão sensitivo). Essa lesão no órgão é, além disso, uma das possíveis causas propter quam sic da dor: "Ad quaestionem ergo respondendum, quoad vires sensitivas, quod omnis dolor in animali tanquam ex radice prima, et ex causa propter quam sic, non sequitur ex aliqua apprehensione, sed ex sola organi laesione, vel virtutis offensione, vel operationis defectione tanquam ex inconvenientis coniunctione" (ed. 1613, f. 207rb). Sobre esse tema, cf. PIRO, F. "Sensi interni e eziologia degli affeti...”, 2005, pp. 201-7.

Por fim, voltando ao trecho de Quodl. 5, q. 14, citado ao início da nota, é necessário propor uma precisão. Embora nesse trecho seja dito que a pupila possui a qualidade média que caracteriza o órgão discretivo da visão, em Suma, art. 58, q. 2, ad 3, lemos que a immutatio que de fato permite a ação da vis visiva ocorre não na pupila, mas no ponto em que se encontram os nervos que provêm dos dois olhos: "A quo medio sic informato non vidente sed deferente speciem visibilis, punctus nervui duorum oculorum, et in quo vis visiva est recipiens immutationem secundum actum qui est visio" (ed. 1642-6, p. 1007b, n. 42). Não pude encontrar outros textos que nos permitam decidir entre a pupila e esse ponto de encontro dos nervos óticos como o órgão próprio da visão. Voltaremos, adiante, a esse texto de Suma, art. 58, q. 2 (cf. cap. 5, nota 90).

${ }^{92} \mathrm{Cf}$, respectivamente, notas $6,8,16$ e nota 20 . 
o frio e o quente, mas não são cores, não são frias ou quentes, Henrique de Gand não nos diz precisamente - sabemos unicamente que elas são um meio (isto é, uma qualidade mediana) suscetível de receber tais qualidades extremas com respeito a ele. É justamente por, estando em potência para a recepção da espécie sensível, possuir tal qualidade mediana, que o órgão dos sentidos pode discernir (é discretivum) de cada um dos seus sensíveis próprios - até mesmo de seus extremos: o preto e o branco, no caso da visão, ou o frio e o quente, no caso do tato.

Enfim, retornando a Quodl. 11, q. 5, parece que aqueles contrários em que transita esse primeiro caso do primeiro modo de alteração 'da parte do sentido' (ex parte sensus) são (seguindo Quodl. 5, q. 14): [i] a potência do órgão para receber a espécie (potentia ad receptionem dictae speciei), pelo que se é capaz de discernir (discretivum) seus sensíveis próprios; e [ii] a própria recepção em ato na potência sensitiva (em especial, no órgão) da espécie de um desses sensíveis. A meu ver, eles são concebidos como contrários entre si, porque um exige a corrupção do outro, já que a potência para a recepção é, de fato, o ato de uma qualidade intermediária receptível dos sensíveis. Esta deve ser corrompida ao ser recebida no órgão do sentido aquela qualidade sensível que virá a ser sentida em ato. Assim, o que temos aqui na primeira etapa desse trecho de Quodl. 11, q. 5 (lido à luz da passagem de Quodl. 5, q. 14) é uma discussão mais aprofundada de um tema que já vimos ser recorrente na reflexão sobre o processo de formação do conhecimento sensitivo: a recepção da espécie pela potência sensitiva, mas principalmente pelo órgão do sentido.

Já o segundo caso desse primeiro modo de alteração - de um contrário ao outro ou, melhor, do modo de 'retirada do contrário' (contrarii abiectio) - da parte do sentido (ex parte sensus) elencado em Quodl. 11, q. $5^{93}$, se mostra mais complexo. Com efeito, se a primeira alteração correspondia somente à recepção passiva da espécie pelo órgão (destaquemos, toda ação nesse caso diz respeito somente à espécie), a segunda alteração de um contrário a outro ocorre no sensitivo, mas principalmente 'na própria força sensitiva' (in ipsa vi sensitiva). Essa segunda alteração do sensitivo é o surgimento de uma inclinação (inclinatio quaedam) da força sensitiva para elicitar o ato de sua operação (ad actum operationis suae eliciendum).

Já estudamos a noção de operatio no item 2.2, porém aqui Henrique de Gand volta ao esforço de descrição dessa noção quando afirma que a operação "é o ato ou a

\footnotetext{
${ }^{93}$ Cf. nota 89 , acima.
} 
disposição do perfeito, enquanto é perfeito e não ordenado a outro, mas é o fim e a perfeição última daquilo de que é"94 uma operação. Assim, a 'operação' se distingue do 'movimento' (motus) e da 'mutação' (mutatio), porque o primeiro “é todo ato ou disposição do imperfeito, enquanto é imperfeito, e tende a causar algo outro e a continuar no movido [ad aliquid aliud causandum et reliquendum in moto] <...>, e, assim, toda mutação propriamente dita e, similarmente, o movimento se ordenam a outro como a um fim, não possuem, em si, a razão de fim e não possuem razão senão de uma ação transitiva a outro enquanto é outro" ${ }^{95}$. Ora, como dissemos há pouco, a ‘mutação' é o mesmo que o movimento, porém sendo feita em um único instante ${ }^{96}$. Ou seja, tanto a mutatio como o motus são ad aliud e, mais propriamente, ad finem enquanto este é outro; a operatio, pelo contrário, é o próprio fim ou a própria perfeição última daquilo que opera. Mais importante, a operação é naquilo que opera, pois "as ações vitais, que são a sensação e a intelecção, não são mutações ou movimento, mas são as próprias operações do sentido e do intelecto e possuem razão de uma ação que permanece no agente [manentis in agente] $<\ldots .>{ }^{97}$. Em suma, motus e mutatio são ad aliud como ad finem, enquanto que a operatio é o próprio finis imanente ao agente.

Feitas essas distinções, notemos que Henrique de Gand não afirma que a recepção da espécie pelo órgão provoca a própria operação na força sensitiva. Pelo contrário, ainda estamos no terreno das mutações, pois estão em jogo agentes e pacientes distintos entre si - a espécie age no órgão, que sofre sua ação e a recebe em si. Aquele segundo caso do primeiro modo de alteração é uma inclinação da força

\footnotetext{
${ }^{94}$ Henrique de Gand, Quodl. 11, q. 5, co. (ed. 1613, p. 195rb): “Operatio autem est actus, sive dispositio perfecti, secundum quod est perfectum et non ordinatur ad aliud, sed est finis et perfectio ultima eius, cuius est".

${ }^{95}$ Henrique de Gand, Quodl. 11, q. 5, co. (ed. 1613, p. 195rb): "Motus enim omnis est actus, sive dispositio imperfecti, secundum quod imperfectum est, et tendit ad aliquid aliud causandum et relinquendum in moto $\langle\ldots>$, et sic omnis mutatio proprie dicta, et similiter motus ordinantur ad aliud, ut ad finem, et non habent in se rationem finis, et non habent rationem nisi actionis transeuntis in aliud secundum quod est aliud".

${ }^{96}$ Cf., novamente, cap. 2, nota 21.

${ }^{97}$ Henrique de Gand, Quodl. 11, q. 5, co. (ed. 1613, p. 195rb): “Actiones autem vitales, quae sunt sensatio, et intellectio, non sunt mutationes, aut motus, sed sunt propriae operationes sensus, et intellectus, et habent rationem actionis manentis in agente $<\ldots$.. ". Como veremos adiante (cf. cap. 6, nota 232), o Doutor Solene considera que, ainda que sejam estritamente operações e, portanto, imanentes, os atos de intelecção são operações imanentes pelas quais se percebe outro - isto é, elas são imanentes a um, mas rementem a outro como termo de conhecimento intelectual.
} 
sensitiva, a partir da recepção da espécie pelo órgão, para a operação - não atingimos ainda, no entanto, esta última.

Agora, perceba-se como há aqui uma distinção entre passos sucessivos na descrição processo de formação do ato de sentir proposta pelo Doutor Solene: primeiro, temos uma recepção da espécie sensível pelo órgão; em seguida, temos a inclinação da parte da própria força sensitiva. A bem dizer, há aqui "uma dupla paixão: uma que é principalmente do próprio órgão corpóreo, que é a recepção da dita espécie; outra, que é da própria virtude sensitiva, que é a dita inclinação dela para perceber [ad percipiendum] ${ }^{, 98}$. No entanto, essa segunda paixão já possui algo de ativo, pois "ainda que o órgão, de fato, seja informado pela espécie do sensível, se, entretanto, a força sensitiva estiver impedida (pois atada no sono ou desviada por outra virtute superior muito atenta à sua obra ou por estar atenta a outro), de nenhum modo há sensação, a não ser que seja excitada e como que chamada a uma forte inclinação por uma espécie fortemente impressa no órgão, tal que se converta a perceber [ut convertat se ad percipiendum]" ${ }^{\prime 99}$. Ou seja, vemos que essa segunda paixão - a inclinação - começa a se confundir com aquela ação de conversão que vimos Henrique de Gand atribuir à força sensitiva em Quodl. 2, q. $6^{100}$. Assim, nesse primeiro modo de alteração estamos em face de duas paixões, mas também de uma paixão (a recepção da espécie no órgão) e uma ação (a inclinação ou conversão da força sensitiva) ordenadas. Essa ação, sem dúvida, é a partir da 'espécie agente em virtude do sensível fora' (specie dicta agente in virtute sensibilis extra) ${ }^{101}$; ela não é,

\footnotetext{
${ }^{98}$ Henrique de Gand, Quodl. 11, q. 5, co. (ed. 1613, p. 195vb): "Et est illa passio duplex, una quae principaliter est ipsius organi corporalis, quae est dictae speciei receptio, alia quae est ipsius virtutis sensitivae, quae est dicta inclinatio eius ad percipiendum".

${ }^{99}$ Henrique de Gand, Quodl. 11, q. 5, co. (ed. 1613, p. 195vb-196ra): "Quantuncunque enim organum sit specie sensibilis informatum, si tamen vis sensitiva sit impedita, quia ligata ut in somno, vel detracta per aliam virtutem superiorem operi suo multum intentam, vel quia est circa aliud intenta, nullo modo sit sensatio nisi tantum sit excitata, et quasi vocata forti inclinatione per speciem fortiter organo impressam, ut convertat se ad percipiendum. Unde qui aliquando vocati voce summissa non audiunt, nec percipiunt licet organum auditus informetur specie soni talis non sufficienter excitantis et inclinantis, et quasi ad se vocantis vim auditivam, vocati voce vehementiori statim audiunt, et percipiunt inclinata vi illa sufficienter". Uma situação semelhante é descrita em Quodl. 2, q. 6 (na nota 29, acima), com a diferença de que em lugar de uma fraqueza da voz do falante, lá é colocado em jogo o estado de sono do ouvinte que o impede de ter o ato de sensação apesar de seu ouvido ser afetado pela espécie sensível. Note-se, também, que lá a força sensível é descrita somente como excitata e não como excitata e inclinata, como ocorre aqui.

${ }^{100}$ Cf. nota 29 , acima.

${ }^{101}$ Mais uma vez contrariando nossa leitura do texto da nota 37 , o ablativo surge aqui caracterizando a relação entre a força sensitiva e a espécie sensível. No entanto, no texto que leremos adiante, na nota 105 , tal relação volta a ser expressa pela preposição per. Sobre isso, cf. tb nota 56.
} 
no entanto, propriamente um efeito da espécie. Pelo contrário, ao ocorrer tal recepção da espécie no órgão, a força sensitiva se inclina para operar acerca daquele sensível externo cuja espécie foi recebida. Assim, os contrários entre os quais se transita nesse segundo caso do primeiro modo de alteração dos sentidos parecem ser a potência para tal inclinação e a própria inclinação em ato. Essa inclinação, por si mesma, parece possuir um tanto de paixão e um tanto de ação - sua parte ativa, porém, só será resolvida um pouco adiante, quando nos voltarmos para o primeiro caso do segundo modo de alteração e vermos que, essa alma inclinada, pode ser até mesmo tomada por agente.

Antes de avançar, porém, ainda na última passagem indentada de Quodl. 11, q. 5, Henrique adiciona que, da parte do sentido (ainda que ele próprio se refira a uma recepção por parte do órgão), a alteração desse primeiro modo diz respeito sempre e somente ao corpo natural - a bem dizer, estamos aqui sempre no campo de mutações estritamente corpóreas (e não ainda orgânicas, como será o caso adiante). Aquele corpo que possui uma qualidade média recebe algo (uma espécie ou intenção do sensível) que o determina para uma outra qualidade (no caso do olho, o corpo recebe essa qualidade como se fosse um espelho) e, por tal recepção, a força sensitiva se inclina àquela coisa que difundiu sua espécie. O Doutor Solene parece querer defender que, por ora, não chegamos a nada além de alterações corpóreas (que, como vimos antes, poderiam acontecer igualmente em um espelho) ${ }^{102}$. Isso é mais fácil de admitir no caso da recepção da espécie pelo órgão, do que no caso da sucessiva inclinação da força sensitiva. Ao meu ver, a descrição desse primeiro modo de alteração da parte do sentido diz respeito somente à mutação do corpo e, se a inclinação da força sensitiva é citada, ela só vem ao caso na medida em que se segue àquela mutação do corpo pela recepção da espécie. Poderíamos igualmente acrescentar que esse corpo natural parece ser o corpo concebido, de acordo com o que vimos no item 2.3.2, como informado somente pela forma da mistura e não ainda pela alma, que empresta o caráter orgânico àquele corpo já formado. Como vemos, se é fácil explicar a alteração provocada pela espécie no corpo com essa descrição,

\footnotetext{
${ }^{102}$ Uma clara objeção à minha intepretação é que, em Quodl. 11, q. 8 (cf. nota 91, acima), a qualidade média é apresentada como característica precisamente do corpo enquanto órgão e não do corpo meramente enquanto corpo misto. Nesse caso, fica difícil compreender como, aqui em Quodl. 11, q. 5, uma ação da espécie sobre o corpo poderia ser tomada unicamente como uma ação sobre um corpo tout court e não como uma ação sobre o corpo enquanto órgão. Admito não saber como conciliar essas passagens de Quodl. 11, q. 5, e Quodl. 11, q. 8.
} 
dificilmente se compreende nesse contexto (isto é, considerando o corpo sem referência à força sensitiva da alma) aquela inclinação da força sensitiva.

Por isso mesmo, ao que parece, a caracterização dessa inclinação só é melhor elaborada com referência ao [2] segundo modo de alteração ${ }^{103}$, que vimos ser aquele que é 'a condução da potência para o ato sem qualquer contrário' (a potentia in actum deductio, absque omni contrario). Se o primeiro modo de alteração era de 'retirada do contrário' (contrarii abiectio), esse segundo modo, não dizendo respeito a contrários, é nomeado pelo gandavense como o modo de alteração da 'recepção da salvação' (salutis receptio). Mas, por que esse nome? Em um primeiro momento, o uso do termo salus parece indicar alguma curiosa remissão à doutrina da graça ou algo assim. Entretanto, não me parece que esse seja o propósito da expressão. A meu ver, o fundamental aqui é não a salus, mas a receptio, a 'recepção'. Como vimos no mesmo trecho de Quodl. 11, q. 5, o segundo caso desse segundo modo de alteração será nomeado 'alcançar a salvação' (adeptio salutis) - ou seja, o foco aqui parece ser o jogo de palavras entre 'receber' e 'alcançar': ambas as paixões desse segundo modo de alteração são 'recepções da salvação', pois ambas levam em direção à perfeição da potência alterada. No entanto, enquanto no [2.1] primeiro caso desse segundo modo tal alteração se deve unicamente à recepção de algo que inclina para a salus ou a operação, o [2.2] segundo caso do segundo modo não diz respeito à recepção estritamente, mas à passagem ao ato da potência por si mesma - agora, ela não só recebe a salvação, como a alcança (adeptio salutis). Sendo assim, a salus parece ser aqui uma denominação para essa perfeição própria de cada substância ${ }^{104}$. Que esse 'alcançar a salvação' seja considerado um caso da 'recepção da salvação' não surpreende - simplesmente na adeptio salutis a salus é recebida pela própria ação da potência que a recebe.

Ora, já vimos nos dois primeiros casos do [1] primeiro modo de alteração, como o sentido é movido da potência para receber a espécie ao ato de receber a espécie - ou melhor, da qualidade intermediária excelente para recepção do sensível à

\footnotetext{
${ }^{103}$ Cf. nota 87 , acima.

${ }^{104}$ Vimos em cap. 1, nota 58, que Henrique de Gand, em Suma, art. 28, q. 6, se utiliza precisamente do termo salus para se referir ao ato das potências sensitiva e intelectiva. Além disso, nesse mesmo texto, ele afirma que a recepção que diz respeito à salus das potências sensitiva e intelectiva ocorre, justamente, sem corrupção. Agora, em Quodl. 11, q. 5, vemos que tal recepção pode ocorrer sem corrupção, porque ela pressupõe uma alteração anterior que corrompe a qualidade média contrária à espécie sensível recebida.
} 
qualidade do próprio sensível que será sentida em ato. Como pudemos notar, o trânsito entre essas duas qualidades é tomado como a mutação de um contrário a outro, uma vez que há no órgão a corrupção daquela qualidade intermediária e a atualização da qualidade sensível. Além disso, por tal mutação de um contrário a outro a partir da recepção da espécie sensível no órgão, a força sensitiva se inclina para a elicitação do ato de sentir o objeto sensível externo donde se difundia a espécie. Agora, nesse [2] segundo modo de alteração, não está mais em jogo nenhuma corrupção de um contrário por outro, mas somente uma passagem da potência ao ato pela parte do sentido. Porém, uma melhor caracterização de como ele diz respeito ao sentido depende da distinção dos já citados dois casos do segundo modo de alteração.

Por ora, consideremos o [2.1] primeiro caso dessa segunda alteração, isto é, aquela alteração "pela qual adquire-se uma disposição na coisa para sua própria operação [qua acquiritur dispositio in re ad suam propriam operationem]". Por esse primeiro caso do segundo modo de alteração, diz-se que "algo é mutado intencionalmente pelo sensível ou inteligível [aliquid intentionaliter mutatur a sensibili, aut intelligibili]".

Ora, no caso do sentido, a aquisição dessa 'disposição para sua própria operação' se deve, como vimos no estudo do primeiro modo de alteração, justamente à recepção de uma qualidade sensível no corpo, a saber, da espécie no órgão. Pois bem, se Henrique considerava a recepção da espécie após a qual se dá tal inclinação como algo ainda meramente corpóreo, a disposição no sentido para sua operação já não é igualmente corpórea. Decerto, ela ainda diz respeito ao corpo na medida em que qualquer sentido diz respeito ao corpo, porém percebemos que a mutação que ora ocorre não diz respeito à corrupção de uma qualidade do corpo por outra, mas a uma mutação intencional (intentionaliter mutatur) - isto é, uma passagem simultânea da potência ao ato pela ação de uma intenção. Sendo assim, estamos ainda no campo da recepção da espécie, mas agora na medida em que a partir dessa recepção a força sensitiva, tendo-se inclinado para o sensível, dispõe-se para sua operação própria que é sentir. Essa mutação é intencional porque, como vimos repetidamente acima, é somente por ser uma intenção - isto é, um ser dependente de outro no gerar-se e no permanecer - que a espécie sensível remete o sentido à coisa sensível natural de que ela é espécie (ou intenção). Portanto, recebida a espécie no órgão e inclinada por tal recepção a força sensitiva, esta última dispõe-se para operar com respeito àquilo de que a espécie recebida no órgão é intenção. 
Não se deve, porém, conceber órgão e força sensitiva como coisas completamente díspares - pelo contrário, todo esse processo diz respeito ao sentido como um todo. Simplesmente, em cada etapa, tal sentido pode ser considerado principalmente como órgão ou principalmente como uma força (vis) e virtude (virtus) da alma. Daí que, mais uma vez, o Doutor Solene enfatize que, em alguma medida, também esse segundo modo de alteração diz respeito ao corpo (como ocorria no primeiro modo). Agora, porém, esse corpo não é mais considerado somente enquanto corpo natural (como dissemos, não está mais em jogo aqui a mera corrupção de uma qualidade corpórea por outra), mas enquanto um corpo orgânico - isto é, que serve de instrumento (organum) para a alma:

"Porém, no segundo gênero, que é da parte do sentido pela recepção da espécie, altera-se o corpo natural, não enquanto corpo simplesmente, mas enquanto órgão $<$ sc. instrumento $>$ da alma" ${ }^{, 105}$.

Parece-me que essa tentativa de destacar a organicidade - instrumentalidade do corpo com respeito à alma neste momento se deve à busca por enfatizar certa independência da ação da alma com respeito à recepção da espécie pelo órgão. De fato, na formação da sensação, “o agente principal é a força inclinada da alma, enquanto o agente instrumental é o órgão informado pela espécie" ${ }^{\text {106. }}$.

Desde o começo deste cap. 4, viemos assistindo à construção de uma concepção da sensação como passividade e atividade sucessivas. Agora começamos a notar que a caracterização da sensação como ordenadamente passiva e ativa resulta na afirmação de uma certa independência do agir da força sensitiva com respeito à passividade do corpo. No primeiro modo de alteração, o corpo era mutado pela espécie e, a partir de tal mutação, a força sensitiva se inclinava para o sensível cuja espécie se recebia no órgão. Nesse segundo modo de alteração, explica-se que essa inclinação pela qual a força sensitiva se dispõe a operar acerca daquele sensível externo não é efetuada pela recepção da espécie; antes, a alma é que se utiliza do

\footnotetext{
${ }^{105}$ Henrique de Gand, Quodl. 11, q. 5, co. (ed. 1613, p. 195rb): "In secundo autem genere, quae est ex parte sensus per speciei receptionem, alteratur corpus naturale, non ut corpus simpliciter, sed ut organum animae". Para o uso de 'organum' como 'instrumento' nesse contexto, cf. PICKAVÉ, "Causality and Cognition...", 2015, pos. 1734-38. Cf. tb. cap. 3, nota 17.

${ }^{106}$ Henrique de Gand, Quodl. 11, q. 5, co. (ed. 1613, p. 195vb): "Nota, quod cum dicit <sc. Augustinus $>$, non possumus dicere, quod sensum gignit res, sensum ibi sumit pro visione, sive sensatione, quod pertinet ad quintum praedictorum < remissão a uma citação anterior do De trinitate de Agostinho $>$ in qua agens principale est vis animae inclinata: agens autem instrumentale est organum informatum specie $<\ldots$..."
} 
órgão afetado pela espécie como instrumento (organum) para se dispor com respeito ao objeto externo cuja espécie afetou o órgão. Este, portanto, recebe a espécie enquanto é corpo natural (tal como um espelho o faria); a partir daí (porém, sem qualquer dependência causal) a alma se inclina e se dispõe a sentir o objeto recebido no órgão por meio da espécie. Agora, o órgão deixou de ser mero corpo, para se tornar não causa, mas instrumento da alma que se dispõe a sentir. Aqui não está mais em jogo o corpo natural, mas o corpo natural orgânico. Enfim, aquilo que no [1] primeiro modo de alteração era tomado como inclinação da força sensitiva sucedânea à recepção da espécie no corpo é considerado, no [2] segundo modo de alteração, como um dispor-se dessa força (tomando por instrumento ou órgão o corpo afetado pela espécie) com respeito ao conhecimento daquele objeto cuja espécie foi recebida no corpo.

Dito isso, resta uma dificuldade: se a relação entre a espécie recebida no órgão e a alma que se dispõe para o conhecimento não é de causa e efeito, que tipo de relação seria ela? Instrumental, ao que parece. Mas o que isso quereria dizer precisamente? Melhor, como descrever essa passagem entre a mera recepção passiva da espécie por um corpo natural e o uso ativo desse corpo pela força sensitiva como instrumento quando esta se dispõe para o sentir em ato? Isso é respondido quando Henrique de Gand busca, ainda em Quodl. 11, q. 5, narrar todo o processo de sensação em quatro passos, desde a geração da potência sensitiva no animal até o sentir em ato:

"De fato, a primeira modificação [immutatio], pela qual [qua] o sentido possui
ser em ato, é a partir do engendrante, quanto à força sensitiva e à disposição do
órgão natural - e, assim, ela é a partir de fora.
Porém, a segunda modificação [immutatio] dele é a partir do sensível enquanto
ele insere [immittit] sua espécie no órgão. Existindo ela nele, ainda não existe a
sensação (como a visão ou a audição), pois a virtude sensitiva existente no órgão
não elicita tal operação, senão quando excitada, inclinada e determinada para o
ato [nisi excitata, et inclinata, et determinata ad actum] com respeito a
determinado objeto - isso é o que a espécie existente no órgão age pela virtude
daquele a partir do qual procede até a força sensitiva (signo disso é que, sendo
ela <sc. a força sensitiva $>$ impedida, deve ser excitada por um grande impulso
[magno impulso], tal que elicite seu ato). Ela <sc. a inclinação $>$ é o terceiro, ao
que se segue a visão, como quarto, pois ela é o termo da alteração pela qual
[qua] se inclina a força sensitiva pelo modo já dito.
De fato, completada aquela inclinação, todo composto de órgão, espécie e força
visiva elicita instantaneamente [statim] sua operação, não como um movimento 
sucessivo nem como mutação transitiva para fora, mas como simples ação que permanece dentro [actionem manentem intra $]^{p 107}$.

Em poucas palavras, as quatro modificações necessárias para $\mathrm{o}$ ato de sensação são: [i] a geração da força sensitiva e a geração do órgão correspondente, [ii] a inserção da espécie no órgão, [iii] a excitação, inclinação e determinação da força sensitiva a partir da recepção da espécie no órgão e [iv] o próprio ato de sentir atribuído ao composto de órgão, espécie e força sensitiva. A primeira [i] modificação não nos interessa tanto agora ${ }^{108}$. A segunda [ii], por sua vez, corresponde ao [1] primeiro modo de alteração que estudamos nessa mesma questão - nela o órgão se altera como mero corpo pela recepção da espécie, ao que já se segue a inclinação da força sensitiva com respeito ao objeto. Tal inclinação, enquanto um dispor-se da alma quanto ao objeto (tomando o corpo por instrumento), é a terceira [iii] alteração aqui enumerada e corresponde ao [2.1] primeiro caso do segundo modo de alteração que estudávamos antes dessa última citação. Com efeito, havíamos justamente perguntado: o que caracteriza a passagem entre a mera recepção da espécie e a inclinação e disposição da força sensitiva com respeito ao objeto externo?

A resposta, pela leitura da passagem destacada, é a 'a excitação, inclinação e determinação ao ato' (excitata, et inclinata, et determinata ad actum) da força sensitiva. Sem dúvida, a espécie age para tal excitação da força sensitiva (diz-se, mesmo, que ela procede desde o objeto externo até a força sensitiva) - porém, sua ação parece se limitar à alteração do corpo, pois, dada tal alteração corpórea, cabe à força sensitiva (utilizando-se instrumentalmente de tal corpo) voltar-se para o objeto externo que, por meio de sua espécie, provocou tal alteração corpórea. A recepção da espécie no órgão é instrumental, porque ela somente excita a força sensitiva. Tal excitação, inclinação e determinação da força sensitiva, por seu lado, é fundamental

\footnotetext{
${ }^{107}$ Henrique de Gand, Quodl. 11, q. 5, co. (ed. 1613, p. 195va): "Prima enim immutatio, qua sensus habet esse in actu est a generante, quoad vim sensitivam, et dispositionem organi naturalem, et ita ab extra: secunda autem immutatio eius est a sensibili secundum quod speciem suam immittit in organum, qua existente in ipso non in hoc adhuc existit sensatio, ut visio, vel auditio, quia talem operationem virtus sensitiva in organo existens non elicit, nisi excitata, et inclinata, et determinata ad actum respectu determinati obiecti, quam species existens in organo agit per virtutem eius, a quo processit in vim sensitivam, cuius signum est, quod cum ipsa fuerit impedita magno impulso debet excitari, ut actum suum eliciat, et illa est tertium ad quam sequitur visio ut quartum, quia ipsa est terminus alterationis qua inclinatur vis sensitiva iam dicto modo. Illa enim inclinatione completa, totum compositum ex organo et specie et visiva vi, statim operationem suam elicit, non ut motum aliquem sucessivum, neque mutationem transeuntem extra, sed ut simplicem actionem manentem intra".

${ }^{108}$ Sobre isso, cf. nota 58.
} 
para a produção do ato de sentir, pois somente quando a força sensitiva está excitada, inclinada e determinada para o ato acerca do objeto externo o composto de órgão, espécie e força sensitiva, instantaneamente, sente em ato.

Brevemente, sem dúvida a espécie age no processo de conhecimento sensitivo, porém sua ação é suficiente apenas para excitar a força sensitiva e não para provocar a própria operação de sensação. Nas palavras de Jerome V. Brown, "mesmo depois que a impressão pela espécie sensível teve lugar, pode-se falar do 'sentir' como ainda sendo em 'potência'. A impressão da espécie sensível somente nos 'inclina' para perceber. É por meio da força (vis) sensitiva que nós devemos nos voltar para o objeto de sensação. É esse voltar-se ativo que nos proíbe de identificar a sensação como completamente passiva"109.

Ou seja, resguarda-se, como dizíamos, uma certa independência da ação da força sensitiva perante a recepção passiva da espécie por parte do órgão. A espécie age para excitar a força sensitiva, porém esta última possui uma ação própria em direção à operação do composto de órgão, espécie e força sensitiva. Se há necessariamente passividade no sentido, há um tanto (ainda que pequeno, devido à grande materialidade do sentido) de pura ação na produção da operação de sentir em ato. Enquanto a passividade do sentido se deve ao órgão na medida em que é corpo natural, a ação do sentido se deve à força sensitiva (muito embora se deva também ao corpo, enquanto órgão que instrumentalmente a excitou para a ação). Em presença da passividade e da atividade apropriadas, segue-se instantaneamente (statim) a última alteração nesse percurso, a saber, a própria operação atual de sentir, que corresponde ao segundo caso do segundo modo de alteração [2.2].

Esse último caso de alteração era caracterizado no início de Quodl. 11, q. $5^{110}$, como uma alteração elicitada pela própria coisa a ser alterada: "elicita-se, desde a coisa, sua operação própria [elicitur a re sua propria operatio]". Essa "autoelicitação" é possível unicamente porque a coisa a ser alterada já foi alterada por algo outro (pela alteração do primeiro modo de alteração, no qual o sensível alterou a

\footnotetext{
${ }^{109}$ BROWN, J. V. "Sensation in Henry of Ghent", 1971, p. 262: "The basis for the need of an active element in sensation is, plainly enough, Henry's contention that even after the impression by the sensible species has taken place, 'sensing' can still be spoken of as being only 'in potency'. The impression of the sensible species merely 'inclines' us to perceive. It is by means of the sensitive force (vis) that we must turn ourselves toward the object of sensation. It is this active turning which prevents us from identifying sensation as completely passive".

${ }^{110}$ Cf. nota 87 , acima.
} 
potência sensitiva), havendo se tornado (inclinada a partir da ação de algo externo) disposta para elicitar em si sua própria operação. Assim, esse [2.2] segundo caso do segundo é modo de alteração é uma alteração "pela qual algo disposto se induz ao ato, tal que por ela o não vidente ou não inteligente segundo o ato, seja feito vidente ou inteligente [qua aliquid dispositum seipso inducitur in actum, ut qua non videns, aut non intelligens secundum actum, factus est videns, aut intelligens]"111. Ou seja, já alterada por algo externo, agora a própria potência sensitiva altera a si mesma melhor, excitada pela recepção da espécie no órgão, a potência sensitiva age em si própria, de tal maneira que [i] ela junto ao [ii] sensível presente pela espécie e [iii] o órgão que recebeu tal espécie operem o ato de sentir. Destarte, enquanto [1] os dois casos da primeira alteração diziam respeito somente ao corpo natural e [2.1] o primeiro caso da segunda alteração somente ao corpo natural enquanto órgão da alma, esse [2.2] segundo caso do segundo modo de alteração diz respeito a um todo, a saber, o 'corpo natural orgânico vivo', pois tal alteração atualiza uma das operações vitais, isto é, a sensação em ato:

"Porém, no terceiro gênero $<s c$. o caso [2.2], sem contar a dupla divisão da [1] primeira alteração>, da parte do sentido, altera-se o corpo natural orgânico, não enquanto [inquantum] é um corpo simplesmente nem enquanto [inquantum] é orgânico, mas enquanto [inquantum] é um corpo natural orgânico vivo, que diz algo [quid] composto de um corpo natural orgânico e uma alma, na medida em que [prout] ela é potência e, também, quanto ao [circa] ato, que é a operação seja no sentido, ou no intelecto (que minimamente possui razão de alteração, de mutação ou movimento)" ${ }^{\prime 12}$.

Aqui está em jogo não somente a potencialidade para a recepção ou a inclinação para o ato de sensação, mas a própria operação de sensação que é, como vimos no item 2.2, uma das operações típicas do ente vivo. Como igualmente já lemos no cap. 2 e relemos há pouco ${ }^{113}$, a operação "é um ato ou disposição do perfeito, enquanto é perfeito e não se ordena a outro, mas é o fim e perfeição última daquele de que é <operação>. Ora, as ações vitais, que são a sensação e a intelecção, não são mutações ou movimento, mas são as próprias operações do sentido e do intelecto e

\footnotetext{
${ }^{111}$ Novamente, cf. nota 87 , acima.

${ }^{112}$ Henrique de Gand, Quodl. 11, q. 5, co. (ed. 1613, p. 195rb): "In tertio autem genere ex parte sensus alteratur corpus naturale organicum, non inquantum est corpus simpliciter, neque inquantum est organicum, sed inquantum est corpus naturale organicum vivum, quod dicit quid compositum ex corpore naturali organico, et anima, prout ipsa est potentia, et etiam circa actum, qui est operatio, sive in sensu, sive in intellectu, quod minime habet rationem alterationis, sive mutationis, aut motus".

${ }^{113}$ Cf notas 94 e 95, bem como cap. 2, nota 21.
} 
possuem razão de uma ação que permanece no agente [manentis in agente] <... ${ }^{\prime 114}$. Assim, após a alteração no órgão e a inclinação do sensitivo - isto é, em presença dessas duas alterações - segue-se no composto de corpo e alma que é a potência sensitiva aquela operação própria desta última, operação esta que não é senão aquela operação vital que é o próprio ato imanente de sentir, de conhecer em ato sensivelmente o objeto sensível.

Enfim, parece-me que em Quodl. 11, q. 5, Henrique de Gand apresenta sua mais bem acabada tentativa de conciliar a passividade e a atividade envolvidas na produção do conhecimento sensível particular ou externo. Ele o faz por meio da distinção entre [1] uma alteração pela qual [1.1] a espécie modifica o corpo natural, [1.2] propiciando uma inclinação da força sensitiva; a isso se segue [2.1] uma alteração da força sensitiva, inclinada ou excitada e disposta com respeito ao objeto cuja espécie foi recebida naquele corpo que tal força toma por instrumento (ou órgão); por fim, há [2.2] uma alteração que é a própria operação imanente de sentir em ato aquele objeto no corpo natural orgânico vivo (isto é, sob a operação de viver), a qual é provocada pelo composto todo de espécie, órgão e potência sensitiva. Como vemos, somente no [1] primeiro caso há, de fato, uma ação de algo externo sobre a alma, sendo os outros dois casos [2.1 e 2.2], respectivamente, uma atividade da própria alma excitada pela recepção da espécie no órgão e a operação que instantaneamente (statim) resulta das duas alterações anteriores. Tal distinção entre diversas alterações separa de maneira bem eficaz, a meu ver, as duas etapas - passiva e ativa - de produção da sensação, mostrando sua interdependência e, ao mesmo tempo, sua independência.

Além disso, o crescendo que surge em Quodl. 11, q. 5, desde [1] a alteração do 'corpo natural', passando pela [2.1] alteração do corpo enquanto 'órgão da alma', até [2.2] a alteração do 'corpo natural orgânico vivo', mostra que o corpo está sempre envolvido na produção da sensação. Dessa maneira, nos textos de Quodl. 2, q. $6^{115}$, em que vimos uma oposição entre a passividade do órgão e a atividade de conversão ao objeto da força ou virtude sensitiva, é preciso entender que também no segundo

\footnotetext{
${ }^{114}$ Henrique de Gand, Quodl. 11, q. 5, co. (ed. 1613, p. 195rb): "Operatio autem est actus, sive dispositio perfecti, secundum quod est perfectum et non ordinatur ad aliud, sed est finis et perfectio ultima eius, cuius est. Actiones autem vitales, quae sunt sensatio, et intellectio, non sunt mutationes, aut motus, sed sunt propriae operationes sensus, et intellectus, et habent rationem actionis manentis in agente $<\ldots>$ ".

${ }^{115}$ Cf., acima, nota 29.
} 
caso o corpo está envolvido, porém na medida em que é um corpo orgânico, ou seja, na medida em que é informado pela virtude sensitiva que age para a produção da sensação. Já o órgão tomado como passivo parece estar sendo considerado, antes, como aquilo que Henrique denomina aqui em Quodl. 11, q. 5, como o corpo natural somente, o que parece remeter à distinção entre as duas formas do composto humano que vimos no item 2.3.2 - mais precisamente, esse orgão passivo de Quodl. 2, q. 6, ou esse corpo meramente natural de Quodl. 11, q. 5, seriam o corpo tomado como informado pela forma da mistura e não precisamente pela alma ou, particularmente, pela potência sensitiva (portanto, ainda não como corpo propriamente orgânico).

Em poucas palavras, Henrique de Gand, em Quodl. 11, q. 5, eleva a noção de sentido particular ao máximo de complexidade que o tema adquire em sua obra. Ele o faz ao estabelecer um complexo jogo entre diversos modos de alteração e diversos modos de consideração do corpo. Com isso, parece-me, seu objetivo é esclarecer as diversas atividades e passividades envolvidas no processo de formação da operação do sentido particular, mostrando que o sentido não somente padece, mas também age.

\subsection{ATIVIDADE E PASSIVIDADE NOS SENTIDOS PARTICULARES}

Com efeito, juntas, essas distinções dos diversos modos de consideração das noções de 'alteração' (alteratio) e de 'corpo' (corpus) permitem uma elegante solução para a necessidade de distinguir a passividade e a atividade, bem como a operação destas resultante na produção do conhecimento sensitivo. Sem dúvida, tal solução gera problemas - o mais evidente, aquele que acabamos de ver: uma indecisão a respeito da atribuição da passividade ao órgão (Quodl. 2, q. 6) ou ao corpo natural (Quodl. 11, q. 5) e da atividade ao corpo orgânico (Quodl. 11, q. 5) ou à força sensitiva (Quodl. 2, q. 6 e Quodl. 11, q. 5). Essa indecisão, no entanto, parece parte fundamental da própria concepção de sentido esposada pelo Doutor Solene, pois não obstante haja na sensação um complexo e necessário jogo de passividade e atividade, a sensação sempre diz respeito ao corpo sob a forma da potência sensitiva da alma. Destarte, as distinções entre passividade e atividade, entre corpo e alma, se perpassam, não sendo porém precisamente paralelas ou simétricas.

A centralidade desse jogo de passividade e atividade para a concepção de sensação de Henrique de Gand é bem expressa por Jerome V. Brown, quando ele afirma que "tudo dito por Henrique sobre sensatio em geral e visio em particular - 
tanto em Quodl., XI 5, como em outros lugares - leva à conclusão de que a sensatio está completa somente quando a virtus ou vis sensitiva, finalmente excitada por meio das várias alterationes infligidas pela espécie sensível e pelo que quer que seja que esteja envolvido na produção das dispositiones necessárias, se volta para tais perturbações e as nota. Nem toda 'determinação' do mundo irá produzir sensatio sem que a força sensitiva assim opere" "116. De sua parte, nos diz Valeria Sorge: "permanece fundamental, para Henrique, a consideração segundo a qual a alma não pode se comportar passivamente com relação ao objeto material e que, por tal motivo, o conhecimento se resolve em uma ação que a alma cumpre por si em presença da modificação sofrida pelo órgão corpóreo" ${ }^{" 117}$. Entretanto, não devemos daí concluir que o corpo seja posto completamente à parte da atividade na produção do conhecimento sensitivo. De fato, lemos em Braun: "no conhecimento sensitivo a alma é o mais nobre, o principal, única a que convém a atividade. O corpo serve somente como instrumento [Instrument], meio e estágio intermediário entre o mundo externo e a alma cognoscente $<$... $>$. Os órgãos do sentido são, assim, apenas meio e ferramenta [Werkzeug] ${ }^{, 118}$. Ora, ainda que somente como instrumento, o corpo age utilizado pela

\footnotetext{
${ }^{116}$ BROWN, J. V. "Sensation in Henry of Ghent", 1971, p. 263: "Everything said by Henry about sensatio in general and visio in particular, both in Quod., Xl 5 and elsewhere, leads to the conclusion that sensatio is complete only when the sensitive virtus or vis, finally aroused by means of the various alterationes wrought by the sensible species and by whatever else is involved in producing the necessary dispositiones, turns itself toward these disturbances and takes notice of them. Not all the 'determination' in the world will produce sensatio unless the sensitive force so operates".
}

${ }^{117}$ SORGE, Gnoseologia e teologia..., 1988, p. 58: “<..> fondamentale resta, per Enrico, la considerazione secondo cui l'anima non può comportarsi passivamente in relazione all'oggetto materiale e che, per tale motivo, la conoscenza si risolve in un'azione che l'anima compie da sé in presenza della modificazione subita dall'organo corporeo".

${ }^{118}$ BRAUN, Die Erkenntnislehre..., 1916, p. 16: "Bei der Sinneserkenntnis ist die Seele das Vornehmere, das Prinzipale, ihr allein kommt die Aktivität zu. Der Körper dient nur als Instrument, als Mittelding, als Zwischenstufe zwischen der Außenwelt und der erkennenden Seele. Nicht das Auge sieht beim Sehen, sondern die Seele; nicht das Ohr hört, sondern die Seele, die sich in jedem einzelnen Teile des Körpers befindet. Die Sinnesorgane sind somit nur Mittel und Werkzeug”. Juha Teräväinen reinterpreta essa passagem de Braun como uma oposição entre um aspecto físico e um aspecto psíquico que, juntos, comporiam o todo do ato de sensação, embora a alma conserve sua prerrogativa em tal ato: "O conhecimento sensitivo é sempre necessariamente tanto físico como psíquico. A importância dos sentidos é receptiva, eles recebem e, daí, transmitem o físico ao psíquico. Essa transmissão é o próprio ato de conhecimento sensitivo. R. Braun diz sobre a relação entre os sentidos e a alma em Henrique que o corpo age como instrumento, como meio; ao ver, o olho não vê, mas a alma. As partes mais importantes nesse ato são a assimilação física e psíquica, que são eventos (temporalmente!) sucessivos $<\ldots>$ [Aistitieto on aina välttämättä sekä fyysistä että psyykkistä. Aistien merkitys on reseptiivinen, ne ottavat vastaan ja siten välittävät fyysisen psyykkiselle. Tämä välitys on varsinainen aistitiedon akti. $R$. Braun sanoo aistien ja sielun suhteesta Henrikillä, että ruumis toimii instrumenttina, välikappaleena; ei nähdessä näe silmä vaan sielu. Tärkeimmät osat tässä aktissa ovat fyysinen ja psyykkinen kaltaistaminen, jotka ovat (ajallisesti!) peräkkäiset tapahtumat <...>]" - "Henrik Gentiläisen tietooppi”, 1975, pp. 14-5. 
força sensitiva. Tanto é assim que, como nos é dito em Quodl. 11, q. 5, no último passo para a geração do conhecimento do sentido particular, "todo composto de órgão, espécie e força visiva elicita instantaneamente [statim] sua operação" ${ }^{119}$. Ou seja, o corpo age sim, na medida em que é órgão da alma (enquanto instrumento da força sensitiva), para a operação do sentido particular; caso contrário, o ato de sentir seria apenas espiritual, o que certamente não é o caso. Assim, na simples e direta fórmula de Karl Werner: “o sujeito da apercepção sensível é a alma em composição com o corpo" 120 - corpo e alma, em sua união no composto, sentem. Reitero, as distinções entre passividade e atividade, entre corpo e alma, se perpassam, mas não são simétricas.

De outra parte, não devemos exagerar a ênfase emprestada pelo gandavense à atividade dos sentidos. Com efeito, o problema da oposição entre passividade e agência do sentido não está colocado aqui claramente como o será, de acordo com estudos de Adriaan Pattin, em outros textos na primeira década do século XIV ${ }^{121}$. Por

${ }^{119}$ Cf., acima, nota 107.
${ }^{120}$ WERNER, Heinrich von Gent als Repräsentant..., 1878, p. 20: "Subject der sinnliche Apperception ist die Seele in Verbindung mit dem Leibe $<\ldots$.. $"$

${ }^{121}$ Cf. PATTIN, A. "Les différents traités de Jean de Jandun sur le 'De sensu agente’”. In: WENIN, C. (éd.). L'homme et son univers au moyen âge. Actes du septième congrès international de philosophie médiévale (30 août - 4 septembre 1982). Vol. II. Louvain-la-Neuve: Éditions de l'Institut Supérieur de Philosophie, 1986, pp. 583-90; e PATTIN, A. Pour l'histoire du sens agent. La controverse entre Barthélemy de Bruges et Jean de Jandun, ses antécédents et son évolution. Leuven: Leuven University Press, 1988. Cf. tb. SORGE, V. "Sensi interni e sensi esterni in Taddeo da Parma". In: PACHECO, M. C., MEIRINHOS, J. F. (éds.). Intellect et imagination dans la Philosophie Médiévale / Intellect and Imagination in Medieval Philosophy / Intelecto e imaginação na Filosofia Medieval. Actes du XI Congrès International de Philosophie Médiévale de la SIEPM. Porto, du 26 au 31 août 2002. Vol. 3. Turnhout: Brepols, 2006, pp. 1771-82.

Que, porém, Henrique de Gand se oponha à distinção entre um sensus agens e um sensus patiens, é corroborado em ZUCCOLIUS PATAVINUS, V. "Commentaria”. In: HENRICUS DE GANDAVO. Aurea quodlibeta $<\ldots>$ commentariis $<\ldots>$ Vitalis Zucolii Patavini <..>. 2 vols. Venetiis: apud Iacobum de Franciscis, 1613, coment. a Quodl. 2, q. 6, vol. 1, f. 52v: "Nota igitur, quod tria sunt, quae hic Auctor habere videtur. Primum quod sensus ita sit agens, sicuti patiens, nempe quod patiendo agat pro sensatione. Secundum, quod una et eadem potentia sit, quae agens sit, atque patiens. Tertium, quod non sit duplex sensus, quorum alter sit agens, alter vero patiens. Nota quoque, quod contra primum est D. Thomas. in 2. de anima, tit. 149. contra secundum est Scotus, I. Sentent. distin. 27. quaest. 3. contra tertium est Ioannes Gandan. quaest. 16. super 2. de anima". Um elemento interessante nesse trecho de Vital Zuccoli são os contraditórios por ele apontados para as teses de Henrique de Gand. À primeira tese ('quod sensus ita sit agens sicuti patiens, nempe quod patiendo agat pro sensatione'), opõe-se Tomás de Aquino, em um texto já produzido havia anos quando o Doutor Solene disputou seu Quodl. 2. Já à segunda e à terceira teses elencadas (ambas as quais discutem a possibilidade de se distinguir um sensus agens de um sensus patiens), Zuccoli opõe pensadores cuja produção é posterior a Henrique - respectivamente, Duns Escoto e João de Jandun. A meu ver, isso é um indício de que a discussão sobre a distinção de duas potências, uma ativa e outra passiva, no sentido não surge claramente formulada na obra do gandavense, só podendo ser aí encontrada pela projeção, em sua obra, de discussões cronologicamente posteriores (o que não exclui que se defenda, eventualmente, que o Doutor Solene compõe, junto a outros autores do fim do século XIII, as raízes dessas discussões). Por fim, note-se que o trecho de João de Jandun alegado por Zuccoli (Super II De anima, q. 16) é 
ora, o que encontramos em Henrique de Gand é uma tentativa de integrar à concepção do sentido como um corpo natural informado pela potência sensitiva de uma alma portanto, como um ente fundamentalmente passivo - a exigência de uma atividade, por menor que seja (dada a grande materialidade do sentido), na produção da operação de sentir. Como vimos em Quod. 2, q. 6, quanto menos material a potência, mais ela 'contra-agirá' para a produção de sua operação ${ }^{122}$.

Ora, o sentido particular é a potência cognoscitiva mais material, aquela que menos age. Sendo assim, podemos esperar uma discussão muito mais aprofundada sobre a atividade das potência cognoscitivas quando chegarmos ao estudo do intelecto. Em particular, na discussão sobre o intelecto, reaparecerá a espécie expressa ou expressiva como resultado de tal atividade, o que pareceu ser abandonado no que diz respeito aos sentidos em prol da espécie impressa ou impressiva, que destaca a materialidade da sensação. Antes, entretanto, vistos os sentidos particulares, deveremos agora nos voltar para a concepção de sentido interno elaborada por Henrique de Gand, pois este é justamente o meio entre os sentidos particulares que já consideramos e o intelecto que buscamos compreender.

igualmente estudado no, já citado, PATTIN, A. Pour l'histoire du sens agent, 1988, pp. 111-7.

${ }^{122}$ Cf. nota 29 , acima. 
CAP. 5.

O CONHECIMENTO DOS SENTIDOS INTERNOS

\title{
5.1. SENTIDOS INTERNOS?
}

Se Henrique de Gand agrupa claramente os cinco sentidos que conhecem a coisa em sua presença como 'sentido particular' (sensus particularis), o mesmo não pode ser dito sobre os demais conhecimentos sensitivos que se seguem no "processo da notícia humana [progressum humanae notitiae]"1. Com efeito, até onde pude pesquisar, tais conhecimento que fazem a mediação entre o sentido particular e o intelecto não recebem qualquer nome comum da parte do Doutor Solene. Por isso mesmo, decidimos seguir Jerome V. Brown, denominando tais potências cognoscitivas, em seu conjunto, pela clássica expressão 'sentidos internos' (internal senses) ${ }^{2}$. Mas, o que caracterizaria tais conhecimentos sensitivos, tal que se justifique sua reunião sob o rótulo 'sentido interno'? Acredito que tal pergunta pode ser respondida pela leitura do seguinte trecho de Suma, art. 24, q. 2:

\begin{abstract}
"há um conhecimento sensitivo da coisa a partir de $[e x]$ sua presença nua por [per] sua essência, tal como o olho vê cores na parede. Porém, há um outro conhecimento sensitivo da coisa em sua ausência [in eius absentia] - e este é duplo: um pelo qual [qua] a própria coisa é conhecida por sua própria espécie, tal como um homem nas trevas imagina as cores que vê na luz; outro, pelo qual [qua] a coisa é conhecida por uma espécie alheia, tal como a ovelha vendo o lobo pela espécie de sua cor e figura, $<0>$ estima inimigo e nocivo"”.
\end{abstract}

Nessa passagem, o "conhecimento $<\ldots>$ da coisa a partir de sua presença nua por sua essência" é aquilo que estudamos no capítulo 4: trata-se do conhecimento do

\footnotetext{
${ }^{1}$ Cf. cap. 4 , nota 37.

${ }^{2}$ Cf. BROWN, J. V. "Henry of Ghent on Internal Sensation”, 1972. Para observar a utilização dos pares intra / extra e interius / exterius em uso por Henrique de Gand no contexto da discussão sobre os sentidos, cf., adiante, as notas 45, 46 e 90. Esse uso, no entanto, não parece derivar para um agrupamento comum e frequente de certos sentidos sob o nome de 'sentidos internos'.

${ }^{3}$ Henrique de Gand, Suma, art. 24, q. 2, co. (ed. Decorte \& Teske, p. 186): "Est enim quaedam cognitio sensitiva rei ex eius praesentia nuda per essentiam suam, sicut oculus vidit colores in pariete. Est autem alia cognitio sensitiva rei in eius absentia. Et haec est duplex. Una qua res ipsa cognoscitur per suam propriam speciem, sicut homo imaginatur in tenebris colores quod vidit in lumine. Alia qua res cognoscitur per speciem alienam, sicut ovis videns lupum per speciem coloris eius et figurae aestimat inimicum et nocivum".
} 
sentido particular - em especial, da cor pela visão -, no qual a coisa é conhecida, através de sua intenção ou espécie, em sua presença atual fora da alma. Ao fím do trecho, há novamente uma referência ao conhecimento do sentido particular, porém agora para além da cor, fala-se também em uma espécie da 'figura' (figurae), que nos remete à distinção entre lux, species e configuratio, que lemos em Suma, art. 1, q. 3, no item 4.2. Ambos os casos - isto é, o conhecimento da cor ou da figura -, sendo conhecimentos do sentido particular, dizem respeito ao conhecimento sensitivo de algo "a partir de sua presença nua [ex praesentia sua nuda]". E adiciona-se que essa presença é "por sua essência [per essentiam suam]", pois não está em jogo aqui somente a presença da coisa pela espécie no órgão. Sem dúvida, esta última é parte necessária no processo de formação do conhecimento sensitivo particular, porém, nesse caso, tal presença pela espécie ou intenção serve, precisamente, para remeter intencionalmente à presença da coisa fora da alma, enquanto essência existente em ato.

Pois bem, os dois casos elencados por Henrique para se contrapor ao conhecimento sensitivo em sua presença nua são: [i] o conhecimento sensitivo da coisa na espécie própria dessa coisa, mas sem que esta última seja em sua essência e existência fora da alma; e [ii] o conhecimento sensitivo no qual algo é conhecimento pela espécie de outro (per speciem alienam). O primeiro [i] é descrito pelo verbo 'imaginar' (imaginatur); o [ii] segundo, pelo verbo 'estimar' (aestimat). Ambos se unificam por serem conhecimentos sensitivos de algo 'ausente' (in eius absentia): [i] imaginar algo ausente fora da alma, como a luz nas trevas; ou [ii] estimar algo, pela espécie de sua cor ou figura, como perigoso, não sendo 'o nocivo' uma 'coisa' existente externamente (voltaremos a esse trecho sobre a estimação no item 5.2).

Essa 'ausência' (absentia) afigura-se, a meu ver, como fator unificador desses conhecimentos sensitivos intermediários entre o sentido particular e o intelecto, como já argumentava Maurice de Wulf ${ }^{4}$. Dessa maneira, parece legítimo agrupar tais sentidos intermediários entre o sentido particular e o intelecto sob uma mesma denominação, visto que eles todos dizem respeito ao conhecimento de uma coisa

\footnotetext{
${ }^{4}$ WULF, Études sur Henri de Gand, 1894, pp. 80-1: “Sans sensation, pas d'idée correspondante. Nihil est in intellectu quod prius non fuerit in sensu. Mais les choses auxquelles s'applique la pensée ne sont pas toujours présentes au même instant par les sensations qu'elles peuvent provoquer. Nous avons l'idée de cheval sans voir un cheval réel devant nous; bien plus, nous pouvons penser des être que nos sens n'ont jamais rencontrés. C'est dire qu'entre l'acte intellectuel et la sensation il y a place pour un rouage intermédiaire" (grifo no original).
} 
ausente por uma espécie. Que tal denominação seja 'sentidos internos', justifica-se pelo caráter já estabelecido da expressão.

Feita tal ressalva inicial, põe-se a pergunta: quais são esses sentidos internos? Uma tarefa simples seria ver a que atos de conhecimento sensitivo de algo ausente por sua espécie Henrique de Gand alude para, em seguida, atribuir a cada um uma potência respectiva. Assim, de acordo com o último trecho destacado, teríamos, correspondendo às ações de imaginar e estimar, as potências da imaginação e da estimação. Os problemas, no entanto, já começam aqui, uma vez que o gandavense não se refere a uma 'potência estimativa', muito embora se refira ao ato de estimação (aestimatio) - uma dificuldade que foi muito bem destacada por Francesco Piro ${ }^{5}$. Bem seguras, por outro lado, são as referências do Doutor Solene à memória (memoria) e à imaginação (imaginatio) ou fantasia (phantasia), como potências sensitivas da alma ${ }^{6}$.

Outras dificuldades são acarretadas pelo esparso tratamento dispensado por Henrique ao 'sentido comum' (sensus communis) ou 'sentido universal' (sensus universalis). Em primeiro lugar, o comentador se vê vexado por não poder decidir acerca da caracterização desse sentido como 'interno' ou 'particular' - sem dúvida, o gandavense afirma claramente em Suma, art. 35, q. 6, como vimos ${ }^{7}$, que não há um sexto sentido particular, porém não está claro se o sentido comum diz respeito a coisas presentes ou ausentes. Interessante prova dessa dificuldade é fornecida pela comparação entre o artigo "Henry of Ghent on Internal Sensation" de Jerome V. Brown e a tese deste último donde tal texto se originou. Na tese, a referência ao sensus communis ou sensus universalis surge em uma nota ao cap. 1, o qual tem por título "Sensation in Henry of Ghent" e foi publicado, com uma versão reduzida da dita nota, como um artigo homônimo9. Agora, não obstante o espaço reservado ao sensus communis no segundo capítulo da tese de Brown, intitulado "Sense memory and Imagination in Henry of Ghent", seja bem pouco ${ }^{10}$, o artigo adaptado deste capítulo - dessa vez, não homônimo a este último, mas denominado mais em geral

\footnotetext{
${ }^{5}$ PIRO, “Sensi interni e eziologia degli affetti...", 2005, pp. 201-7.

${ }^{6}$ Cf. itens 5.3 e 5.4 , adiante.

${ }^{7}$ Cf. cap. 4 , nota 14 .

${ }^{8}$ BROWN, J. V. Divine Illumination and the Theory of Knowledge..., 1969, pp. 1-29 e pp. 180-1, nota 88.

${ }^{9}$ BROWN, J. V. "Sensation in Henry of Ghent”, 1971, p. 264, nota 93.

${ }^{10}$ BROWN, J. V. Divine Illumination and the Theory of Knowledge..., 1969, p. 30.
} 
como "Henry of Ghent on Internal Sensation" - dá ao tema um espaço maior, ainda que pequeno ${ }^{11}$. Em poucas palavras, essas mudanças de enfoque parecem sugerir que mesmo Jerome V. Brown (o único autor, até onde pude verificar, a dedicar algum espaço a essa temática em Henrique), permaneceu indeciso quanto à considerar o sensus communis ou universalis como, de alguma maneira, um elemento do sentido particular, ou agrupá-lo junto à memória e à imaginação entre os sentidos internos. Talvez, esse pareça um problema mal-colocado, uma vez que o próprio Henrique não agrupa imaginação e memória (ou, quanto mais, o 'sentido comum') como sentidos internos. Note-se, no entanto, que os dois primeiros são, como veremos, conhecimentos sensitivos de algo ausente (o que estamos denominando de 'sentido interno') e decidir aproximar deles ou não o 'sentido comum' se mostra determinante para compreender o conhecimento típico deste último como o conhecimento sensitivo de uma coisa ausente fora da alma ou presente fora da alma. Esse problema, entretanto, parece-me indecidível no que diz respeito à obra de Henrique de Gand.

Feitas essas ponderações iniciais, proponho que estudemos a seguir, nessa sequência, a memória (item 5.3) e a imaginação ou fantasia (item 5.4.) - essa ordem, como veremos, é aquela na qual tais potências são atualizadas no processo de conhecimento humano. Antes, porém, proponho que atentemos para aquele conhecimento sensitivo que o Doutor Solene aborda de maneira mais fragmentária, a saber: o sentido comum ou universal (item 5.2).

\subsection{FRAGMENTOS DE UM SENTIDO COMUM}

Em suas discussões a respeito do sentido comum, Jerome V. Brown se vale de dois curtos trechos de Quodl. 2, q. 6, e Quodl. 4, q. $21^{12}$. Eu, porém, começarei esse estudo pela citação de um texto que parece lhe ter passado desapercebido, mesmo porque originário de um outro contexto que não propriamente a discussão sobre o conhecimento sensitivo. Essa terceira menção ao sentido comum surge, a saber, em uma curta demonstração do ser de Deus, que Henrique elenca como a segunda prova pela via da causalidade formal em Suma, art. 22, q. $4^{13}$. Leiamo-la:

\footnotetext{
${ }^{11}$ Cf. BROWN, J. V. "Henry of Ghent on Internal Sensation”, 1972, pp. 16-8.

${ }^{12}$ Cf. citações nas notas 17 a 20 .

${ }^{13}$ Sobre as provas da existência de Deus em Henrique de Gand, cf. cap. 3, nota 67.
} 


\begin{abstract}
"Esta é a segunda $<s c$. via de causa formal para provar o ser de Deus $>$ que Agostinho busca no segundo <livro $>$ do De libero arbitrio, também em uma longa disputa. Sendo que é certo e experimentamos em nós que, pelo sentido particular [sensu particulari], julgamos os sensíveis próprios como pela visão as cores, pela audição os sons; não podendo julgar com estes [quibus] o que convém àqueles em comum e em que diferem, julgamos isto com certo sentido comum interior [quodam sensu communi interiori]. Nestes, porém, não podemos discernir entre si tudo aquilo, tanto comum quanto próprio, salvo por alguma virtude superior, que diz-se 'razão' [quadam virtute superiori, quae ratio dicitur]. Uma vez que em todos tais sempre é melhor e mais elevado aquilo que julga sobre outro do que aquilo que é julgado, ou se procederia ao infinito ou se chega em algo elevadíssimo pelo qual todos os outros são julgados e sobre o qual nenhum julga. Isso é, porém, sem dúvida, a sabedoria que existe [existens] sobre as mentes racionais e sobre todos os mutáveis, pois os mutáveis só se podem julgar por algo imutável - chamamos a essa sabedoria imutável 'Deus'. Uma vez que é impossível proceder assim ao infinito, é preciso pôr aquilo a que se chega, que não é senão Deus" ${ }^{\prime 14}$.
\end{abstract}

Como se diz explicitamente, esse trecho se propõe como um resumo - bem lacônico, diga-se de passagem - de elementos do segundo livro do De libero arbitrio de Agostinho. Interessa-nos, entretanto, principalmente a rápida (ainda que fundamental) menção ao sentido comum e interior: "julgamos os sensíveis próprios como pela visão as cores, pela audição os sons; não podendo julgar com estes o que convém àqueles em comum e em que diferem, julgamos isto com certo sentido comum interior. Nestes, porém, não podemos discernir entre si tudo aquilo, tanto comum quanto próprio, salvo por alguma virtude superior, que diz-se 'razão' [sensu particulari iudicamus sensbilia propria, ut visu colores, auditu sonos, quibus non possumus iudicare quae communiter eis conveniunt, et quibus differunt, sed illa iudicamus quodam sensu communi interiori, nec in istis possumus omnia haec tam communia quam propria discernere ab invicem nisi quadam virtute superiori, quae ratio dicitur]". Essas poucas linhas são um rápido apanhado da atenta discussão

\footnotetext{
${ }^{14}$ Henrique de Gand, Suma, art. 22, q. 4, co. (ed. Decorte \& Teske, pp. 138-40): "Secunda est quam venatur Augustinus secundo De libero arbitrio longa disputatione consimiliter talis. Cum certum est et in nobis experimur, quod sensu particulari iudicamus sensbilia propria, ut visu colores, auditu sonos, quibus non possumus iudicare quae communiter eis conveniunt, et quibus differunt, sed illa iudicamus quodam sensu communi interiori, nec in istis possumus omnia haec tam communia quam propria discernere ab invicem nisi quadam virtute superiori, quae ratio dicitur. Quare cum in omnibus talibus semper melius est et praestantius quod de alio iudicat quam id quod iudicatur, aut ergo erit procedere in infinitum, aut stare in aliquo praestantissimo quo omnia alia iudicantur, et de ipso iudicat nullus. Hoc autem proculdubio incommutabilis sapientia est super mentes rationales et super omnia mutabilia existens, quia non nisi in aliquo immutabili mutabilia habent iudicari, quam quidem immutabilem sapientiam Deum appellamus. Quare cum sic procedere in infinitum est impossibile, oportet ponere illud in quo est status, quod non est nisi Deus".
} 
desenvolvida pelo bispo de Hipona em De libero arbitro II, 4,10-5,12 ${ }^{15}$ sobre o sentido que ele denomina preferencialmente como sensus interior - a ênfase na sua caracterização como communis, parece ficar a cargo de Henrique.

Encontramos nesse trecho, portanto, em primeiro lugar, uma oposição entre 'sentido particular' e 'sentido comum interior' - o primeiro são aqueles cinco que já estudamos no capítulo 4. Ora, se a capacidade de julgar é estabelecida, no excerto destacado, como característica do que é superior e o sentido comum interior é, precisamente, aquilo que julga o sentido particular, parece que o sentido comum interior pode ser tomado como superior ao sentido particular - isto é, como capaz de julgá-lo. Mais uma vez, encontramos a referência ao ‘juízo’ dos sentidos que já vimos no item 4.3 - agora, porém, ela é a base para a constituição de uma hierarquia dos sentidos que possibilitará, ao fim, um argumento pelo ser de Deus. Mas, qual seria o objeto de juízo do sentido comum interior?

No sentido particular, vimos que o 'julgar' confundia-se com o converter-se da força sensitiva para objeto fora ao tomar o corpo como instrumento (tendo sido excitada por este último), pondo-se em disposição para elicitar o ato de sentir seu sensível próprio. No sentido comum interior, o juízo diz respeito a algo já sentido nomeadamente, aos sensíveis próprios do sentido particular, não porém enquanto 'sensíveis próprios', mas enquanto convém a eles algo em comum ou enquanto eles diferem entre si. Nas palavras de Henrique, julgamos com o sentido particular "o que convém àqueles $<s c$. os sensíveis próprios $>$ em comum e em que diferem [quae communiter eis conveniunt, et quibus differunt]". Ou seja, o caráter communis desse sentido interior parece dizer respeito ao fato de ele considerar todos os sensíveis próprios que, no sentido particular, são considerados separadamente pelos cinco sentidos. Já a caracterização de tal sentido como interior talvez seja devida a ele não se voltar imediatamente para a coisa externa, mas antes para esta última enquanto conhecida pelo sentido particular - voltaremos a isso com mais atenção adiante.

Entretanto, se o sentido comum interior já nos permite julgar o comum e o diferente nos sensíveis próprios do sentido particular, por ele ainda "não podemos discernir entre si tudo aquilo, tanto comum quanto próprio [nec in istis possumus

\footnotetext{
${ }^{15}$ Agostinho, De libero arbitrio II, 4, 10 (CCSL 29, pp. 243-4): "Manifesta enim sunt: sensu corporis sentiri corporalia; eundem autem sensum hoc eodem sensu non posse sentiri; sensu autem interiore et corporalia per sensum corporis sentiri et ipsum corporis sensum; ratione uero et illa omnia et eandem ipsam notam fieri et scientia contineri. An tibi non uidetur?”.
} 
omnia haec tam communia quam propria discernere ab invicem]" que diz respeito a tais sensíveis próprios do sentido particular - para tanto, necessitaremos da razão. $\mathrm{O}$ que seria, então, esse tanto de comunidade e diferença entre os sensíveis que o sentido comum interior não abarca? Henrique simplesmente não nos diz. Dessa passagem, ainda assim, podemos retirar uma importante informação: tal como o sentido comum interior marca um limite no conhecimento do sentido particular, também a razão marca um limite no conhecimento do sentido comum interior. O juízo da razão sobre o comum e o diferente nos sensíveis é mais completo do que o juízo do sentido comum interior, de maneira que este último está a meio caminho entre o sentido particular e a razão.

Dois elementos, porém, complicam tal interpretação. Em primeiro lugar, não podemos compreender a partir do trecho o que seria esse lugar intermediário ocupado pelo sentido comum interior. Melhor dizendo, se podemos compreender razoavelmente bem aquilo que o demarca como superior ao sentido particular (a saber, sua capacidade de julgar acerca da comunidade e da diferença entre os sensíveis próprios), só nos é dito muito vagamente aquilo que distingue seu juízo do juízo da razão (como vimos, este último é mais abrangente do que aquele). Em segundo lugar, igualmente problemático é o fato de que a descrição da hierarquia das potências cognitivas da alma que lemos no trecho é muito simplificada se comparada a outras passagens de Henrique - em especial, ela deixa de fora a consideração sobre a memória sensitiva e a imaginação ou fantasia, que serão fundamentais para sua compreensão do conhecimento sensitivo.

Por outro lado, começa a ficar claro que o sentido comum interior parece ser dito 'comum' porque, precisamente, já caminha em direção a uma unificação daquilo que é disperso no sentido particular entre os cincos sensíveis próprios. Em outras palavras, já estamos agora a caminho do conhecimento intelectual universal - ainda que estejamos bem longe dele. Talvez, justamente por isso, leiamos em Quodl. 2, q. 6 (no contexto da descrição daquela hierarquia da atividade das faculdades cognoscitivas que vimos $\operatorname{acima}^{16}$ ):

"Depois do sentido particular, o sentido universal age mais. O que é patente, porque não somente é movido para conhecer os objetos de todos os sentidos

\footnotetext{
${ }^{16}$ Cf. cap. 4 , nota 27.
} 
particulares, mas, após o conhecimento, <os $>$ reúne, comparando-os segundo a conveniência e a diferença, como quer o Filósofo"17.

Notemos que, agora, o sentido imediatamente posterior ao sentido particular não se opõe mais a este por ser 'comum' ou 'interior', mas por ser 'universal' (universalis). Que esse sentido 'universal' seja o mesmo que o sentido 'comum' de Suma, art. 22, q. 4, fica claro pela caracterização paralela de ambos: em Suma, art. 22, q. 4, dizia-se que pelo 'sentido comum interior' julgamos "o que convém àqueles $<s c$. aos sensíveis particulares próprios> em comum e em que diferem [iudicare quae communiter eis conveniunt, et quibus differunt]", enquanto em Quodl. 2, q. 6, lemos que o 'sentido universal' "reúne $<s c$. os objetos de todos os sentidos particulares>, comparando-os segundo a conveniência e a diferença [comparando ea secundum convenientiam et differentiam]". Há, no entanto, uma diferença entre as duas formulações: em Suma, art. 22, q. 4, a atividade do 'sentido comum interior' é descrita como um 'julgar' (melhor, é dito que nós julgamos [iudicamus] pelo 'sentido comum interior'), enquanto que em Quodl. 2, q. 6, em lugar de um 'julgar', tal ação é caracterizada como um 'reunir' (conferre) e, mais precisamente, como um 'comparar' (comparando ea). Ou seja, aquela maior proximidade com respeito ao intelecto do 'sentido comum interior' (quando comparado ao sentido particular) que já líamos em Suma, art. 22, no contexto de uma hierarquia do juízo nas potências cognoscitivas da alma é reiterada em Quodl. 2, q. 6, sob três aspectos: [i] a caracterização de tal sentido como 'universal' (termo que, como já vimos no cap. 3 e estudaremos no cap. 6 mais atentamente, é típico do discurso sobre o conhecimento intelectual); tal descrição do sentido como universal é reflexo de [ii] sua descrição como capaz de 'reunir' o que era disperso no sentido particular (o que também é característico do intelecto que, em seu conhecimento universal, reúne em um único os particulares dispersos); por fim, [iii] a afirmação de uma maior atividade do sentido universal quando comparado ao sentido particular aponta para uma maior proximidade do primeiro com relação ao intelecto, uma vez que a potência intelectiva é caracterizada, por Henrique de Gand,

\footnotetext{
${ }^{17}$ Henrique de Gand, Quodl. 2, q. 6, co. (ed. De Wulf-Mansion Centre, vol. 6, p. 32): "Post sensum particularem magis agit sensus universalis. Quod patet quia non solum movetur ad cognoscendum obiecta omnium sensuum particularium, sed post cognitionem confert comparando ea secundum convenientiam et differentiam, ut vult Philosophus". Cf. BROWN, J. V. "Henry of Ghent on Internal Sensation", 1972, p. 17.
} 
como aquela que mais age dentre as potências cognoscitivas ${ }^{18}$ (embora ela seja também fundamentalmente passiva, como vimos nos caps. 2 e 3 ).

No entanto, essa passagem de Quodl. 2, q. 6, não deixa de possuir seus próprios problemas. Assim, ao mesmo tempo em que ela explica aquele juízo pelo sentido comum interior como uma comparação entre os objetos do sentido particular em busca daquilo em que convêm ou em que diferem, não se explica melhor o que seria ou como se produziria tal comparação. Quanto a isso, a referência final da passagem a Aristóteles não contribui muito para a compreensão do trecho ${ }^{19}$. Ela mostra, porém, que Agostinho não é a única fonte antiga de Henrique de Gand para sua noção de 'sentido comum interior' ou de 'sentido universal'.

Para completar esse quadro, o Doutor Solene ainda apresenta tal noção a partir da leitura do Grande comentário ao De anima de Averróis em Quodl. 4, q. 21, em meio a uma discussão sobre a intelecção:

\begin{abstract}
"E, por isso, assim como determina o Filósofo na mesma passagem e $<_{0}>$ expõe o Comentador, tal como 'em todos os sentidos particulares, o movimento chega a um fim que, naqueles movimentos, é como que o ponto que é no meio do círculo, no qual terminam as linhas que partem da circunferência (e naquele ponto é a virtude do sentido comum que julga sobre os sensíveis particulares de todos os sentidos particulares), assim também é quanto ao intelecto material com as intenções inteligidas das imagens' <Averróis, Comment. mag. De anima III, comm. 31 (ed. Crawford, 1953, pp. 470,17-471,21)>, de maneira que o movimento de todos termina no intelecto indivisível, que é uma mediedade que julga sobre todas as intenções imaginárias particulares. De fato, do mesmo modo como aquele que julga o ser diverso no sentido deve ser um, também aquele que julga as imagens das coisas diversas deve ser um <Averróis, Comment. mag. De anima III, comm. 31 (ed. Crawford, 1953, p. 471,34-36)>"20.
\end{abstract}

\footnotetext{
${ }^{18}$ Cf. cap. 6, nota 59.

${ }^{19}$ No aparato crítico ao texto destacado, os editores sugerem a leitura de Aristóteles, De anima III, c. 2 426b13-5 na Translatio vetus de Tiago de Veneza (In: Albertus Magnus, Opera omnia VII.1: De anima, ed. C. Stroick, 1968, p. 161, 1. 80-1). Sobre a versão do De anima de Aristóteles utilizada por Henrique de Gand, cf. DECORTE, “Aristotelian Sources in Henry of Ghent”, 1996.

${ }^{20}$ Henrique de Gand, Quodl. 4, q. 21, co. (ed. De Wulf-Mansion, vol. 8, p. 346): “Ac per hoc secundum quod determinat Philosophus ibidem et exponit Commentator, sicut 'motus pervenit in omnibus sensibus particularibus ad unum finem, qui est in motibus illis quasi punctus qui est in medio circuli, ad quem exeuntes lineae a circumferentia terminantur, et in illo puncto est virtus sensus communis iudicans de sensibilibus particularibus omnium sensuum particularium, ita est de intellectu materiali cum intentionibus imaginum intellectis', quod motus omnium terminatur in indivisibile intellectus, quod est una medietas iudicans de omnibus intentionibus imaginariis particularibus. Quemadmodum enim 'iudicans esse diversum apud sensum debet esse unum, ita iudicans imagines rerum diversarum debet esse unum"”. Cf. BROWN, J. V. "Henry of Ghent on Internal Sensation", 1972, p. 17.
} 
Aqui, segui os editores dos Opera omnia de Henrique, destacando a citação de Averróis com o itálico e deixando sem destaque os trechos do próprio gandavense. Já o caso do trecho sublinhado é mais complexo, mas voltaremos a ele em pouco.

Nesse trecho, a comparação entre sentido comum e intelecto é apresentada da maneira mais elaborada que pudemos encontrar em Henrique. O intelecto é descrito como uma mediedade que, sendo um único, julga acerca das diversas intenções imaginárias particulares. Porém, não somente se diz que o intelecto, enquanto um único, possui a atividade de julgar acerca dessas intenções, mas diz-se que tal intelecto é o fim ou a finalidade dessa intenções. Para explicitá-lo, introduz-se a descrição geométrica de um círculo, no qual diversas linhas partem da circunferência e terminam chegando em um único ponto central do círculo. Nesse caso, as diversas linhas que partem da circunferência são como as diversas intenções imaginárias particulares, ao passo que o ponto central único faz as vezes do intelecto único que julga acerca daquela diversidade que nele termina. Mas, onde entra o sentido comum nisso? Na última passagem, afirmar-se, ainda com base em uma derradeira citação de Averróis, que aquele que julga sobre as várias imagens (isto é, o intelecto) deve ser um único, tal como aquele que julga sobre o diverso no sentido deve ser um único também.

Atentemos, agora, para o trecho sublinhado - a única passagem desse excerto na qual há referência ao sentido comum. Não estando em itálico na edição crítica do Opera omnia de Henrique de Gand, tal trecho deveria ser tomado como uma adição deste último em meio aos diversos excertos do Grande comentário ao De anima de Averróis. Se formos a tal texto do pensador cordubense, porém, veremos que entre aquelas duas citações cujas referências foram apresentadas no trecho de Quodl. 4, q. 21, destacado acima (e que são aquelas referidas pelos seus editores), surge no texto de Averróis a seguinte passagem: “depois ele diz: 'de fato, o último é uno e um meio uno' <Aristóteles, De anima III, c. 7, 431a19>. Isto é, de fato, o último dos movimentos dos sensíveis é uno e aquilo que é deles como que o meio de um círculo é também uno (e isso é o sentido comum) [et hoc est sensus communis]"21. Ou seja, diferentemente do que a edição crítica do Quodl. 4, q. 21, de Henrique nos faz crer, a referência à relação entre o sentido comum e os movimentos dos sensíveis não é

\footnotetext{
${ }^{21}$ Averróis, Comment. mag. De anima III, comm. 31 (ed. Crawford, 1953, p. 471,22-5): "Deinde dixit: Ultimum enim est unum, et medium unum. Idest, ultimum enim motuum sensibilium est unum, et illud quod est ex eis quasi medium de circulo est etiam unum (et hoc est sensus communis)".
} 
estritamente uma adição do Doutor Solene, mas uma paráfrase do próprio texto de Averróis - simplesmente, na versão de Henrique a referência ao sentido comum surge em meio à primeira passagem citada de Averróis e não imediatamente depois dela como ocorre na atual edição crítica do texto produzida por F. S. Crawford. Note-se que isso não significa que tal diferença na ordenação do texto se deva ao próprio Henrique (ela poderia provir, por exemplo, de sua fonte manuscrita para o texto, embora o aparato crítico fornecido por Crawford para a passagem não sustente tal possibilidade). Enfim, o importante é notar que, mais uma vez, a referência ao 'sentido comum' é resultado da paráfrase de um autor (como de Agostinho, no caso de Suma, art. 22, q. 4) ou, pelo menos, da referência a ele (como a Aristóteles, em Quodl. 2, q. 6).

Essa observação em nada retira a legitimidade de um estudo sobre o sentido comum em Henrique de Gand, porém ela aponta ou bem [i] para o fato de que, ao abordar tal tema, ele preferencialmente introduzia autoridades em lugar de se alongar acerca dessa noção ou bem [ii] para o fato de que ele só abordava a noção de sentido comum quando levado a tanto pelas autoridades utilizadas. Em todo caso, o fato de ele não omitir as referências de Agostinho ou Averróis ao sentido comum mostra que ele fez questão de manter um espaço para tal potência da alma em sua hierarquia das forças cognitivas, ainda que, ao cabo, esse sentido comum permaneça um tanto inexplicado em sua reflexão sobre os sentidos internos.

Feitas essas ressalvas, voltemos à aproximação proposta, por meio das citações de Averróis, entre sentido comum e intelecto. A base para tal comparação é a referência à já comentada geometria do círculo. Tal como o intelecto é como aquele ponto único central para o qual convergem as diversas intenções imaginárias como diversas linhas que partem da circunferência ao centro de um círculo, da mesma maneira o sentido comum é como aquele ponto único central para o qual converge o diverso no sentido particular como diversas linhas que partem da circunferência ao centro de um círculo. Em especial, na passagem sublinhada vemos o sentido comum caracterizado, pela primeira vez, como uma 'virtude' (virtus) da alma. Diga-se, uma única virtude da alma que julga acerca do diverso no sentido particular, tal como o intelecto é uma única virtude que julga acerca do diverso nas intenções imaginárias. Ou seja, se em Suma, art. 22, q. 4, o 'sentido comum interior' se caracterizava como 'comum' por julgar acerca de todos os sensíveis próprios do sentido particular e em Quodl. 2, q. 6, o 'sentido universal' surgia como aquele que 'reúne' (confert) o 
disperso no sentido particular, agora o 'sentido comum' aparece como uma única virtude na qual se unifica o que é disperso no sentido particular. Melhor dito, agora vemos que não somente o sentido comum, enquanto uma única virtude, julga o disperso no sentido particular, mas também esse disperso no sentido particular tende à unidade no juízo do sentido comum como a um fim - esses dispersos, terminam (terminantur) na virtude única do sentido comum, tal como diversas linhas que partem de uma circunferência terminam em um mesmo ponto central do círculo.

Tão interessantes quanto sejam tais passagens, elas sem dúvida são insuficientes para que nelas possamos ler algo como uma 'doutrina do sentido comum' - como dito anteriormente, temos aqui no máximo um tratamento fragmentário do tema. E, no entanto, temos um tal tratamento - isto é, embora Henrique não pareça considerar como central o estudo filosófico do sentido comum, ela parece pensar que se faz necessária a afirmação de uma tal virtude na alma. Como diz J. V. Brown, com base no estudo de Quodl. 2, q. 6, e Quodl. 4, q. 21: "uma das principais preocupações de Henrique em sua teoria do conhecimento é preservar a continuidade entre a sensação dos particulares e o conhecimento dos universais. Parece que ele está interessado no sensus communis ou universalis somente na medida em que ele oferece uma fonte para certos juízos elementares e quasesensíveis/quase-universais" ${ }^{22}$. Nessa interpretação, o sentido comum é uma virtude que preenche - ainda que sem maiores explicações - o campo aberto entre [i] o juízo do totalmente sensível e singular do sentido particular e [ii] o juízo totalmente intelectual e universal do intelecto. Resta a pergunta: não bastariam como preenchimento desse campo intermediário a memória e, principalmente, a imaginação ou fantasia, que Henrique aborda de maneira muito mais trabalhada?

Para responder a essa questão, seria necessário encontrar, pelo menos, um exemplo de um conhecimento propiciado tipicamente pela virtude do sentido comum - decerto, ela julga, reúne e compara, mas qual seria o conhecimento resultante dessas atividades? Melhor, dando um passo atrás, qual seria o objeto desse conhecimento? Assim como há cinco sensíveis próprios do sentido particular, haveria sensíveis comuns para o Doutor Solene? Uma pista para resolver esse problema (e, até onde

\footnotetext{
${ }^{22}$ BROWN, J. V. "Henry of Ghent on Internal Sensation", 1972, p. 18: "One of Henry's principal concerns in his theory of knowledge is to preserve the continuity between sensation of particulars and knowledge of universals. It would appear that he is interested in the sensus communis or universalis only to the extent that it provides a source of certain elementary and quasi-sensible/quasi-universal judgments".
} 
pude chegar, a única que o gandavense nos deixou) talvez esteja no seguinte trecho de

Quodl. 11, q. 8:

\begin{abstract}
"Porém, as intenções ditas do conveniente e do desconveniente [convenientis vel disconvenientis] podem ser percebidas duplamente - por exemplo, a intenção do nocivo [intentio nocivi]. De um modo, sob a razão do nocivo iminente e que ameaça um mal futuro [imminentis et comminantis malum futurum]; de outro modo, sob a razão do contemporâneo e do que oferece um mal presente [instantis et inferentis malum praesens].

Do primeiro modo, é uma intenção não-sentida [insensata], pois não é nata a ser percebida pelo sentido particular [a sensu particulari]. Porém, do segundo modo, é uma intenção sentida [sensata] e é percebida pelo sentido particular como sensível comum [percipitur a sensu particulari, ut sensibile commune].

De acordo com isso, portanto, as ditas intenções convenientes e desconvenientes, por vezes, são percebidas não pela mesma [ $a b$ ipsa $]$ virtude apreensiva dos sensíveis ou inteligíveis, mas por outra [ab alia], sensitiva ou intelectiva:

A sensitiva (tal que falemos presentemente sobre a intenção inconveniente a que se segue a dor na força sensitiva) $<$ é $>$ tal como a ovelha que, vendo o lobo, instantaneamente $[$ statim $]<0>$ estima inimigo e, temendo, foge. Ou a intelectiva, $<$ que é> tal como alguém que vê um andarilho à noite suspeita que seja um ladrão e, temendo, esconde seu dinheiro.

Por outras vezes, porém, aquela intenção é percebida pela mesma virtude sensitiva apreensiva e, isso, tanto quanto ao órgão da própria virtude como quanto à própria virtude ou quanto à sua operação",23.
\end{abstract}

Comecemos por destrinchar as várias distinções apresentadas na passagem elas são três distinções que dizem respeito à percepção das intenções convenientes e desconvenientes (voltaremos a tais termos à frente), em especial no que diz respeito à intenção do nocivo. Primeiro [1], distingue-se [1.1] a percepção da intenção do nocivo sob a razão do iminente e futuro; e [1.2] a percepção da intenção do nocivo sob a razão do contemporâneo e presente. Em seguinda [2], distingue-se [2.1] a intenção não-sentida, isto é, que não pode ser sentida pelo sentido particular e [2.2] a intenção sentida, percebida pelo sentido particular como sensível comum. Por fim, parece haver uma distinção que possui somente um dos membros formulado, quando se diz

\footnotetext{
${ }^{23}$ Henrique de Gand, Quodl. 11, q. 8, co. (ed. 1613, f. 206rb-va): "Intentiones autem dictae convenientis vel disconvenientis dupliciter possunt percipi puta intentio nocivi. Uno modo sub ratione nocivi imminentis et comminantis malum futurum. Alio modo sub ratione instantis et inferentis malum praesens. Primo modo est intentio insensata, quia non est nata percipi a sensu particulari. Secundo autem modo est intentio sensata, et percipitur a sensu particulari, ut sensibile commune. Secundum hoc igitur dictae intentiones convenientis et disconvenientis quandoque percipiuntur non ab ipsa eadem virtute apprehensiva sensibilium aut intelligibilium, sed ab alia, et hoc vel sensitiva vel intellectiva. Sensitiva ut ad praesens loquamur de intentione inconveniente, ad quam sequitur dolor in vi sensitiva, quemadmodum ovis videns lupum statim existimat inimicum, et timens fugit. Vel intellectiva, quemadmodum videns errabundum de nocte suspicatur furem, et timens, merces suas abscondit. Quandoque autem illa intentio percipitur ab eadem virtute sensitiva apprehensiva, et hoc vel circa organum ipsius virtutis, vel circa ipsam virtutem, vel circa eius operationem". A essa última frase se segue uma reflexão sobre a lesão no olho, ao que já nos referimos anteriormente em cap. 4, nota 91.
} 
“as ditas intenções convenientes e desconvenientes, por vezes, são percebidas não pela mesma [ab ipsa] virtude apreensiva dos sensíveis ou inteligíveis, mas por outra [ab alia], sensitiva ou intelectiva". Se isso ocorre somente por vezes, parece possível [3] distinguir [3.1] a intenção que é percebida pela mesma virtude que apreendeu o sensível ou o inteligível a que tal intenção diz respeito (quando Henrique se volta para esta possibilidade, no fim do trecho citado, ele considera somente o caso dos sentidos); e [3.2] a intenção que é percebida por uma virtude diferente daquela que apreende o sensível ou inteligível a que tal intenção diz respeito. É para explicar como este caso [3.2] ocorre ora no sentido ora no intelecto, que Henrique introduz, respectivamente, o exemplo [3.2.1] sensível da ovelha e do lobo e o exemplo [3.2.2] inteligível daquele que suspeita do andarilho à noite.

Feitas essas distinções, o desafio está em compreender como elas se encaixam para que possamos ver em que ponto preciso do desenvolvimento da passagem surge aquela referência ao sensível comum. O Doutor Solene afirma um paralelismo entre as duas primeiras distinções ([1 $\mid 2])$ : uma [1.1] percepção da intenção do nocivo sob a razão do iminente e futuro é [2.1] uma intenção não-sentida, uma vez que não pode ser sentida pelo sentido particular; assim como uma [1.2] percepção da intenção do nocivo sob a razão do contemporâneo e presente é uma [2.2] intenção sentida, percebida pelo sentido particular como sensível comum. Ora, já vimos longamente no cap. 4 a profunda relação que há entre sentido particular e presença do objeto, de maneira que não surpreende que aqui, mais uma vez, Henrique afirme que a percepção da intenção de um nocivo ou mal presente diga respeito ao sentido particular. O que impressiona, por outro lado, é a afirmação de que o sentido particular percebe tal intenção 'como sensível comum' ('percipitur a sensu particulari, ut sensibile commune').

A referência ao sentido comum nesse momento não é de maneira alguma gratuita. Notemos que, aqui, pesquisa-se a percepção das 'intenções ditas do conveniente e do desconveniente' ("dictae intentiones convenientis vel disconvenientis"). Ora, esse é precisamente o vocabulário que descrevia o sentido universal em Quodl. 6, q. 2 ("confert comparando ea secundum convenientiam et differentiam") e o sentido comum interior em Suma, art. 22, q. 4 ("iudicare quae communiter eis conveniunt, et quibus differunt") ${ }^{24}$. Adiante, veremos que essa

\footnotetext{
$\overline{{ }^{24} \text { Cf. notas } 17 \text { e } 14 \text {, respectivamente. }}$
} 
proximidade de vocabulário não significa, necessariamente, uma proximidade doutrinal. Por ora, porém, concentremo-nos no seguinte problema: enquanto nesses textos o sentido universal ou o sentido comum interior eram apresentados como algo posterior ao sentido particular, aqui em Quodl. 11, q. 8, 'o sensível comum' (sublinhe-se, não uma faculdade, mas seu objeto ${ }^{25}$ ) é apresentado como percebido pelo próprio sentido particular: trata-se de [2.2] "uma intenção sentida [sensata] e é percebida pelo sentido particular como sensível comum [percipitur a sensu particulari, ut sensibile commune]". Estamos, aqui, portanto, no campo das intenções [1.2] ditas do conveniente e do desconveniente contemporâneo e presente, uma vez que somente estas são sentidas (sensata). Mas, o que significar dizer que o sentido particular sente 'intenções' ou 'sensíveis comuns'? E, além disso, por que descrever esse 'sentir' como um 'perceber' (percipere)?

Já vimos acima, no item 4.3, a importância da noção de intentio para a descrição da espécie sensível: sendo uma intenção de algo (ou seja, disso dependendo causalmente em seu ser), ela aponta a presença disso de que ela é uma intenção mesmo não sendo ela própria realmente esse objeto. Também na descrição do sensível comum como intenção estamos, de certa maneira, em um terreno relacional, pois assim como a espécie sensível ser dita 'intenção' aponta para a relação causal de dependência que ela nutre para com aquilo de que é intenção, também a intenção do conveniente ou do desconveniente aponta para a relação de conveniência ou desconveniência entre [i] aquilo de que esta é a intenção e [ii] aquele ente cujo sentido percebe tal intenção de conveniente ou desconveniente. Nas palavras de Francesco Piro, a "concepção das intentiones do sentido interno que vem a prevalecer progressivamente entre os latinos tendia, de sua parte, a dar à intentio uma função representativa, interpretando-a, isto é, não mais como uma propriedade pertencente a um dado indivíduo que me ocorre de inferir ou supor, mas como um aspecto sob o qual eu tomo, assumo como significativo, me refiro àquele dado indivíduo ou àquela figura. É evidente que Henrique já se move no interior desta segunda acepção <..> ${ }^{\text {26 }}$.

\footnotetext{
${ }^{25}$ A meu ver, não parece possível nesse trecho concluir da menção de um sensível comum que haja a referência a uma faculdade do 'sentido comum'. Assim, quando F. Piro afirma, comentando esse trecho de Quodl. 11, q. 8, que Henrique se refere a um "primo caso di dolore quello dovuto alla perceptio rei praesentis, cioè a un male fisico presente percepito <no original: perceptio $>$ dal senso comune" ("Sensi interni e eziologia degli affeti", 2005, p. 202), ele mascara um dos grandes problemas dessa passagem, qual seja, precisamente a atribuição da percepção de um sensível comum ao sentido particular.

${ }^{26}$ PIRO, "Sensi interni e eziologia degli affeti”, 2005, p. 206: "La concezione delle intentiones del senso interno che venne a prevalere progressivamente tra i Latini tendeva invece a dare all'intentio una
} 
Assim, intentio parece assumir duas conotações na descrição do conhecimento sensitivo: em primeiro lugar, [i] ela caracteriza a espécie sensível que, relacionada causalmente ao objeto presente de que provém, também relaciona o órgão do sentido em que se imprime àquele objeto por uma ação intencional (o que, eventualmente, resultará na apreensão sensitiva daquele objeto); além disso, [ii] a intenção é também aquilo que relaciona o sentiente ao sentido por conveniência ou desconveniência, a partir do momento em que haja a percepção de uma intenção do conveniente ou do desconveniente. O que aproxima ambos os usos de intentio é a relação que ambas as intenções - decerto, diferentemente, em cada caso - estabelecem entre o sensível e o sentiente. O que, então, as diferencia?

Para responder a esse pergunta, é preciso atentar para a distinção que Henrique propõe entre 'apreender' (apprehendere) e 'perceber' (percipere) - aliás, note-se que já na passagem destacada há uma utilização de tal diferenciação quando, na distinção [3], se afirma a possibilidade de que uma potência apreenda algo e outra perceba a intenção acerca disso que foi apreendido. Assim, 'perceber' e 'apreender' são distintos, ainda que nem sempre tal distinção seja respeitada:

"Cumpre, portanto, saber que acerca da apreensão sensitiva há que se considerar
dois: um que é, a saber, o próprio ato de apreensão e outro que é, a saber, a
própria percepção, que é anexa à apreensão <... $>$. E, ainda que, segundo o uso
comum do jargão [secundum usum communem sermonis], constumemos falar
sobre a apreensão enquanto inclui a percepção, <elas, $>$ no entanto, diferem.
Dicernimo-lo a partir da diferença dos objetos, pois o objeto próprio e por si da
apreensão sensitiva é o próprio sensível (como a cor ou a luz da visão, o som da
audição, o tátil do tato e assim por diante). Mas, o objeto próprio da percepção
são as intenções acerca dos sensíveis ou acerca dos inteligíveis - tais intenções
são, por si, a causa das paixões da dor, do deleite e de outros desse modo. De
fato, essas intenções importam a razão do conveniente ou do desconveniente e
possuem em si a força daquelas coisas acerca das quais são para mover as
paixões $<\ldots>$...27.

funzione rappresentativa, interpretandola cioè non più come una proprietà appartenente a un dato individuo che a me capita di inferire o supporre, ma piuttosto come l'aspetto sotto il quale io colgo, ritengo significativo, mi riferisco a quel dato individuo o a quella figura. È evidente che Enrico si muove ormai all'interno di questa seconda accezione, come sembra efetivamente confermato anche dagli usi del termine che ritroviamo nelle discussioni metafisiche".

${ }^{27}$ Henrique de Gand, Quodl. 11, q. 8, co. (ed. 1613, f. 205vb-206ra): "Est igitur sciendum, quod circa apprehensionem sensitivam est considerare duo, unum scilicet ipsum actum apprehensionis, et alterum scilicet ipsam perceptionem, quae annexa est apprehensioni <... . Et quamquam secundum usum communem sermonis de apprehensione loqui solemus ut includit perceptionem: differunt tamen, quod discernimus ex differentia obiectorum, quoniam proprium et per se obiectum apprehensionis sensitivae est ipsum sensibile, ut visionis color vel lux, auditionis sonus: tactus tangibile, et sic de caeteris. Obiectum autem proprium perceptionis sunt intentiones circa sensibilia vel circa intelligibilia, quae quidem intentiones sunt per se causa passionum doloris, delectationis [ed. $1518, f .460 v F \mid$ delectionis, ed. 1613, f. 206ra] et huiusmodi. Illae enim intentiones important rationem convenientis vel 
Sem atentarmos tanto para a complexa noção de 'paixão' que Henrique desenvolve em Quodl. 11, qq. 8-9 ${ }^{28}$, vejamos a maneira pela qual distinguem-se 'apreensão' e 'percepção'.

Em uma acepção comum (usum commune), a 'apreensão' designa não somente o próprio ato de apreensão, mas também a percepção. Isso ocorre, ao que parece, porque essa percepção é anexa à apreensão (annexa est apprehensioni). Isso quereria dizer que a percepção se segue à apreensão? O gandavense não é claro sobre isso, porém essa proposta de que a percepção seria algo anexo à apreensão parece ser suficiente para propor, além disso, que ambas sejam distintas entre si. Nesse ponto, surge um elemento de difícil compreensão. Henrique propõe que elas devem ser distinguidas de acordo com seus objetos próprios - assim, enquanto a apreensão diz respeito ao sensível próprio do sentido que apreende, a percepção diz respeito a uma intenção do conveniente ou do desconveniente acerca daquele sensível. Porém, se lembrarmos que a suficiência dos cinco sentidos particulares era justamente argumentada a partir de seus objetos próprios em Suma, art. 35, q. $6^{29}$, parece que a distinção entre apreensão e percepção pela distinção de seus objetos próprios redundaria na distinção entre duas faculdades distintas - pelo menos, dois sentidos distintos, um apreensivo e outro perceptivo. Nesse ponto, poderíamos comemorar finalmente haver encontrado uma justificativa mais técnica para a distinção entre sentido particular e sentido comum - o primeiro, diria respeito ao sensível e o segundo à intenção acerca do sensível. Tal leitura, porém, cai por terra quando lemos, no penúltimo trecho citado de Quodl. 11, q. 8, que a inteção do conveniente ou desconveniente presente é "percebida pelo sentido particular como sensível comum

disconvenientis et habent in se vim illarum rerum circa quas sunt ad commovendum passiones $<$... $>$ ". Sobre a distinção entre apprehensio e perceptio no contexto de Quodl. 11, q. 8, cf. tb. PERLER, D. "Dolor". In: ATUCHA, I., et al. (éds.). Mots médiévaux offerts à Ruedi Imbach. Porto: FIDEM, 2011, pp. 233-43 (esp. pp. 238-9).

${ }^{28}$ Em Quodl. 11, q. 9 (ed. 1613, ff. 209r-210v), Henrique de Gand basicamente descreve a noção de passio, no animal, enquanto diposição "para causar, continuar ou subtrair uma operação ou movimento [passio animalis dispositio est ad operationem, sive motum, vel causandum, vel continuandum, vel subtrahendum]" (f. 209ra) - isto é, ele basicamente retoma a noção de potentia passiva que vimos no cap. 1, nota 58. Agora, no entanto, ele o faz para mostrar que paixões como a 'dor' (dolor) e o 'deleite' (delectatio) - algo como aquilo que hoje denominaríamos como 'afeto', 'emoção' ou 'sentimento' dizem respeito, no animal, à virtude apetitiva e não à virtude apreensiva. Sobre isso, cf. PIRO, "Sensi interni e eziologia degli affetti”, 2005, pp. 198-201.

${ }^{29}$ Cf cap. 4 , nota 4. 
[percipitur a sensu particulari, ut sensibile commune]" ${ }^{\prime 30}$. Ou seja, parece que a distinção de objetos próprios da apreensão e da percepção é suficiente para distinguir dois atos do sentido particular, mas não duas potências sensitivas. Porém, então, a distinção dos cinco objetos dos cinco sentidos particulares não é suficiente para a distinção de cinco potências sensitivas? Seria o sentido particular um único que produz cinco atos de acordo com os cincos sensíveis? E, para além disso, produziria ele outros atos - agora de percepção, não mais de apreensão - além desses cinco? Essas são perguntas que não me parecem possuir uma resposta precisa em Henrique de Gand - elas, no entanto, não serão capitais para nós.

Assim, basta retermos que, para o Doutor Solene, apreensão e percepção são atos distintos que podem ser produzidos pela mesma potência da alma ou não (lembremos da distinção [3] do penúltimo trecho indentado, à qual retornaremos). Mais do que isso, notemos que, no sentido particular, apreensão e percepção dizem respeito a intenções, uma vez que são atos fundamentalmente relativos: no caso da apreensão, a intencionalidade diz respeito à relação estabelecida entre o objeto externo e o órgão em que a espécie (ou intenção) desse objeto foi impressa; no caso da percepção, ela diz respeito à intenções porque resulta no estabelecimento de relações de conveniência ou desconveniência do cognoscente com respeito àquilo que ele apreendeu.

Nesse contexto, como fica o sentido comum ou universal que vimos em Suma, art. 22, q. 4, Quodl. 2, q. 6, e Quodl. 4, q. 21? Aqui em Quodl. 11, q. 8, parece que ele termina diluído em uma atualização do sentido particular, anexa à apreensão do sensível próprio deste último. Ele diz mais respeito à relação do sentiente para com o sensível do que propriamente a uma relação entre os diversos sensíveis próprios enquanto em Suma, art. 22, q. 4, e Quodl. 2, q. 6, a 'conveniência' e 'diferença' conhecida pelo sentido comum parecia dizer respeito aos sensíveis próprios do sentido particular quando comparados entre si, em Quodl. 11, q. 8, a 'conveniência' e 'desconveniência' remete à uma relação entre o cognoscente e o conhecido, a qual resultará, eventualmente, em uma paixão do cognoscente acerca do conhecido. Daí que não haja em Quodl. 11, q. 8, uma referência a um 'sentido comum', mas somente ao 'sensível comum' enquanto é percebido pelo sentido particular. Em outras palavras, o ato do sentido comum ou universal foi reduzido a um ato de percepção do

\footnotetext{
${ }^{30} \mathrm{Cf}$, acima, nota 23 .
} 
sentido particular com respeito à coisa externa, ato este que surge como anexo ao seu ato de apreensão. Assim, o sentido particular relaciona o sentiente ao sensível de duas maneiras: [i] como o cognoscente ao conhecido e [ii] como convenientes ou desconvenientes, respectivamente, de acordo com [i] a apreensão da intenção tomada como espécie sensível e [ii] a percepção da intenção do conveniente ou desconveniente acerca do apreendido. No primeiro caso, o sentido particular apreende um de seus sensíveis próprios (cor, odor etc.), enquanto que, no segundo caso, ele percebe um sensível comum acerca do sensível próprio apreendido. Daí se deriva a complexa afirmação de que o sentido particular teria dois objetos distintos - um próprio e outro comum -, de acordo com seus diversos atos.

Pois bem, parece-me que a maneira conflitante como as diversas posições expostas por Henrique se comportam entre si - enfim, o imbróglio a que somos levados por sua leitura conjunta - é mais um indício de que ele não possuiu uma concepção acabada de sentido comum (ou, mesmo, de sensível comum). Tal problema se complexifica ainda mais quando nos voltamos para a distinção [3] do penúltimo trecho de Quodl. 11, q. 8, que citamos acima ${ }^{31}$. Como vimos, o paralelismo entre as distinções [1] e [2] resultaram na conclusão de que [1.1 | 2.1] a inteção do conveniente ou desconveniente iminente e futuro é não-sentida pelo sentido particular, enquanto que $[1.2 \mid 2.2]$ a intenção do conveniente e desconveniente contemporâneo e presente é sentida pelo sentido particular como um sensível comum. Como introduzimos nesse esquema a terceira distinção [3]?

Ora, como dito, nessa última distinção, são postos em jogo os casos [3.1] da intenção que é percebida pela mesma virtude que apreendeu o sensível ou o inteligível a que tal intenção diz respeito e [3.2] da intenção que é percebida por uma virtude diferente daquela que apreende o sensível ou inteligível a que tal intenção diz respeito. Os dois exemplos de [3.2] apresentados logo em seguida ([3.2.1] da ovelha e do lobo e [3.2.2] daquele que suspeita do andarilho à noite) são, respectivamente, o caso em que uma virtude sensitiva apreende o sensível e outra virtude sensitiva percebe uma intenção acerca dele e o caso no qual uma virtude sensitiva apreende um sensível e o intelecto percebe uma intenção acerca daquilo que já foi apreendido pelos sentidos. Para nós, sendo nosso tema por ora o sentido comum, o mais interessante é o primeiro exemplo, que lida unicamente com o sensível.

\footnotetext{
${ }^{31} \mathrm{Cf}$, novamente, nota 23.
} 
Se estamos aqui no terreno em que uma virtude sensitiva apreende um sensível e outra virtude sensitiva percebe uma intenção acerca dele, parece que não estamos mais no campo do sensível comum - como vimos, em Quodl. 11, q. 8, o sensível comum é algo percebido pelo próprio sentido particular como anexo à apreensão de seu sensível próprio. Assim, o sensível comum parece surgir apenas naquele caso [3.1] em que uma mesma virtude apreende um sensível e percebe a intenção acerca dele. Aliás, ao final do referido penúltimo trecho destacado, Henrique inicia o estudo da maneira como uma mesma virtude sensitiva pode apreender e perceber uma intenção acerca do apreendido. Para tanto, ele distingue os casos em que ela percebe a intenção [3.1.1] quanto ao órgão da própria virtude, [3.1.2] quanto à própria virtude e [3.1.3] quanto à sua operação. Respectivamente, isso significa que uma mesma virtude sensitiva, ao apreender um sensível, pode perceber intenções [3.1.1] acerca de seu próprio órgão (por exemplo, a inconveniência de uma lesão nele causada durante o processo de apreensão sensível), [3.1.2] acerca de si própria (por exemplo, a inconveniência de uma desarmonia entre o sensitivo e o sensível, tal como um som estridente que provoque incômodo) e [3.1.3] acerca de sua própria operação (por exemplo, a inconveniência de se perceber incapaz de atualizar sua operação) ${ }^{32}$. Ao que parece, em todos esses casos estamos no campo da percepção, pelo próprio sentido particular ao apreender seu sensível, de intenções do conveniente ou desconveniente enquanto sensível comum. Note-se, como já destacado, que o sensível comum sempre se apresenta como uma mesma virtude sensitiva percebendo uma relação que se estabele entre o apreendido e essa mesma virtude que o apreende.

Quando vamos para o terreno em que a apreensão ocorre por uma virtude sensitiva e a percepção por outra virtude sensitiva [3.2], ainda estamos lidando com intenções percebidas e, portanto, com relações de conveniência ou desconveniência estabelecidas entre aquele que apreende e o apreendido, a única diferença sendo que uma virtude apreende o sensível e outra virtude, ao perceber uma intenção, estabelece aquela relação. Para se referir à percepção da intenção neste caso [3.2], porém, não se fala mais em 'sensível comum', mas em 'estimar' - como ocorre no clássico exemplo [3.2.1] da ovelha e do lobo: "tal como a ovelha que, vendo o lobo, instantaneamente $[$ statim $]<0>$ estima inimigo e, temendo, foge [quemadmodum ovis videns lupum

\footnotetext{
${ }^{32}$ Henrique de Gand, Quodl. 11, q. 8, co. (ed. 1613, f. 206va-207rb).
} 
statim existimat inimicum, et timens fugit] ${ }^{\prime 33}$. O curioso é que, mais uma vez, o uso dos termos por Henrique é vexatório para seu leitor: tal como o 'sensível comum' surge aqui em Quodl. 11, q. 8, sem qualquer referência a um 'sentido comum', também a ação de existimare surge sem referência a uma 'virtude estimativa'. Isso levou Francesco Piro a ver no Doutor Solene uma "aestimatio senza aestimativa": Henrique tranforma "a aestimatio de um análogo sensível do juízo ou da inferência discursiva - como o via Avicena -, em um análogo sensível da autoconsciência [autoconsapevolezza] ou do conhecimento reflexivo" ${ }^{\text {34 }}$. Na leitura de Piro, não seria necessária uma 'virtude estimativa', porque a estimação é algo como um reflexo da virtude sensitiva sobre ela mesma.

Essa leitura, no entanto, me parece conflitante justamente com o fato de que o mestre de Gand introduz a referência à estimação, precisamente, como um caso de percepção por uma virtude distinta daquela virtude que apreendeu o que é percebido. Ou seja, mais do que um caso análogo à reflexão ${ }^{35}$ ou ao juízo proposicional

\footnotetext{
${ }^{33} \mathrm{Cf}$. nota 23, acima.

${ }^{34}$ PIRO, "Sensi interni e eziologia degli affeti”, 2005, p. 207: "Il senso del suo contributo sta tutto nella scelta di transformare la aestimatio da analogo sensibile del giudizio o dell'inferenza discorsiva - come lo vedeva Avicenna - in analogo sensibile della autoconsapevolezza o della conoscenza riflessiva". Note-se que M. de Wulf também relaciona a noção de perceptio (em geral, não somente o caso da aestimatio) à 'consciência' - WULF, Études sur Henri de Gand, 1894, p. 80: "Aujourd'hui beaucoup de psychologues diraient qu'il peut y avoir sensation, mais sensation inconsciente. Nous n'avons rencontré aucune distinction de cette nature chez le docteur solennel. Pour lui, le seuil de la sensation brute, inconsciente, est identique au seuil de la perception (sensation consciente)" (grifos no original). Já sobre a ausência de uma vis aestimativa, cf. BROWN, J. V. "Henry of Ghent on Internal Sensation", 1972, pp. 19-20, nt. 22: "Two points are worth noting here. (1) For Avicenna, memory as an internal sense follows, in its function, three other internal senses - the imagination, the vis cogitativa and the vis aestimativa. Imagination retains what has been apprehended by common sense; the vis cogitativa combines and separates images appearing in the imagination; the vis aestimativa, a very original philosophical contribution on the part of Avicenna, enables the one possessing it, basically, to fear the images that should be feared and to be attracted to the images that one should be attracted to. It serves in Avicenna the function that we would today attribute to instinct. $<\ldots>$. (2) Henry thought this division of the internal senses unnecessarily complicated. Memory was portrayed by Avicenna as retaining what was apprehended by the vis aestimativa. In the true spirit of Ockham's razor, Henry will be satisfied with the sensus universalis or communis, memory and imagination - completely surpressing $\langle s i c\rangle$ the vis cogitativa and the vis aestimativa. Imagination is quite successful at performing the tasks assigned to these latter two senses. Memory can easily retain what is apprehended by the sensus communis and the imagination" (grifos no original). Como veremos na sequência, a aestimatio parece pressupor, de fato, uma virtude sensitiva distinta do próprio sentido particular. No entanto, Henrique não parece em nenhum momento se referir a tal outra virtude sensitiva como vis aestimativa. Ou seja, Jerome V. Brown parece correto em afirmar uma virtude própria da estimação para além do sentido particular. Porém, não me parece tão claro que tal ato de estimação se reduza tão facilmente a um ato da imaginação, como quer J. V. Brown. Não que a negação de tal tese esteja clara no Doutor Solene - pelo contrário, parece-me que Henrique simplesmente não resolve o problema de qual seria aquela faculdade que opera a estimação. Como dito, veremos isso mais detalhadamente a seguir.

${ }^{35}$ Sublinhe-se, aliás, que Henrique de Gand exatamente exclui qualquer possibilidade de reflexão nos sentidos devido ao caráter orgânico destes últimos - sobre isso, cf., adiante, a nota 44.
} 
intelectual, a estimação parece ser análoga ao juízo de uma virtude superior acerca de uma virtude inferior que vimos em Suma, art. 22, q. 4. Lá, porém, se nomeava tal virtude superior justamente 'sentido comum', enquanto aqui em Quodl. 11, q. 8, tal virtude surge sem nome, somente com seu ato chamado de 'estimação'. Ou seja, pode ser até que Piro esteja correto ao falar que, em Henrique, o ato de estimação não possui uma virtude estimativa correspondente, mas isso não significa que ele seja uma reflexão de uma mesma virtude sobre si - ele é apresentado claramente como o contrário disso, isto é, como o caso [3.2] em que uma virtude apreende um sensível e outra virtude estima algo (ou seja, percebe uma intenção) acerca daquilo que foi apreendido pela virtude anterior.

Há um outro texto que já encontramos no qual a estimação é descrita em linguagem razoavelmente semelhante e, novamente, com o recurso ao exemplo da ovelha e do lobo - a saber, um pequeno trecho de Suma, art. 24, q. 2, onde se fala dos dois casos de conhecimentos sensitivos de algo em sua ausência ${ }^{36}$. Em um primeiro caso, o da imaginação (ao qual voltaremos no item 5.4), algo é sentido, estando ausente, pela sua espécie própria; há, porém, um segundo caso de 'conhecimento sensitivo da coisa em sua ausência' (cognitio sensitiva rei in eius absentia) no qual uma coisa é sentida por uma espécie alheia "tal como a ovelha vendo o lobo pela espécie de sua cor e figura, $<_{0}>$ estima inimigo e nocivo [sicut ovis videns lupum per speciem coloris eius et figurae aestimat inimicum et nocivum]". Notemos que, nesse segundo caso (diferentemente do que ocorria na imaginação), a coisa sentida está presente ao sentido particular (a ovelha vê o lobo) - portanto, tal coisa sentida está presente em seu ser próprio fora da alma. O que, então, está ausente? Parece-me que, nesse caso, não há propriamente uma coisa (res) externa ausente: o lobo está presente (pois é visto). No entanto, tal conhecimento ocorre por espécies de sua cor e figura não há uma espécie sensível do lobo propriamente, mas antes de suas qualidades. Daí que se diga que esse conhecimento ocorre por espécies alheias: o lobo é conhecido por espécies que, propriamente, são de cores e figuras. Porém, não obstante o lobo só esteja presente por espécies de sua cor e figura, a ovelha produz uma estimação, através desse conhecimento, acerca do próprio lobo, tomando-o como 'inimigo e nocivo'. Assim, mesmo sem ver o lobo propriamente (isto é, unicamente a partir de um conhecimento de sua cor e forma), a ovelha estima o próprio lobo como 'inimigo

\footnotetext{
${ }^{36} \mathrm{Cf}$, acima, nota 3 .
} 
e nocivo'. O 'lobo enquanto inimigo e nocivo' parece ser justamente aquilo que está ausente fora da ovelha, pois seu caráter 'inimigo e nocivo' não é mais do que uma estimação da ovelha e não algo do próprio lobo. Aquela coisa que está ausente fora da alma, nesse caso, é o 'lobo enquanto inimigo e nocivo', já que ele só surge como 'inimigo e nocivo' ao ser, uma vez apreendido pela ovelha, percebido por ela sob a intenção de 'inimigo e nocivo' - isto é, estimado por ela 'inimigo e nocivo'.

Ora, nessa passagem, temos mais uma vez a estimação descrita como um sucedâneo da apreensão pela espécie sensível. Demarca-se nesse trecho de Suma, art. 24, q. 2, igualmente, a distinção entre ambas, uma vez que se distingue [i] a estimação do lobo como nocivo do [ii] conhecimento do lobo pelas espécies de sua cor e figura. Restam, entretanto, diversas questão deixadas sem resposta: como passamos do conhecimento da cor e da figura do lobo para o conhecimento do próprio lobo? Como passamos da apreensão para a estimação? O que na espécie sensível permite a estimação acerca do objeto sensível? Henrique simplesmente não nos diz... O que lemos em Quodl. 11, q. 8, tampouco nos ajuda a responder tais perguntas, pois simplesmente concluímos ali que a virtude apreensiva do sentido particular e a virtude que, percebendo, estima acerca do apreendido são virtudes distintas, porém não é dito qual seria essa segunda virtude ou como, precisamente, ela se relaciona com a primeira. Enfim, se Francesco Piro parecia apressado em compreender a estimação como o análogo de uma reflexão, não atentando para o fato de que estamos falando em virtudes distintas, por outro lado, Henrique não parece oferecer pistas de qual seria essa virtude responsável pela estimação (se é que haveria alguma virtude responsável unicamente por isso).

Dito isso, quais são os resultados da leitura de Quodl. 11, q. 8, para nossa pesquisa sobre o sentido comum? Basicamente, a negação de que haja uma virtude sensitiva que seja, propriamente, um sentido comum. De fato, nesse texto, o sensível comum surge exclusivamente como o objeto próprio da percepção (de intenções do conveniente ou desconveniente) pelo sentido particular acerca do sensível que ele próprio apreende em ato. Mais precisamente, o sensível comum é, no caso [3.1] em que apreensão e percepção de um mesmo sensível ocorrem em uma mesma potência sensível, o contraponto da estimação, que surge [3.2] quando apreensão e percepção sobre o mesmo sensível ocorrem em virtudes sensitivas distintas. Além disso, o sensível comum, em Quodl. 11, q. 8, sempre diz respeito [1.2] à intenção do conveniente e desconveniente contemporâneo e presente, pois unicamente o presente 
pode ser sentido pelo sentido particular (a [3.2.1] estimação, de sua parte, como lemos em Suma, 24, q. 2, já inclui em si algum tanto de ausência com respeito ao sensível ainda que a coisa sentida exista presentemente fora daquele que a sente, a estimação diz respeito à [1.1] intenção de algo iminente e futuro, portanto, [2.1] de algo que não pode ser percebido pelo sentido particular).

Posto claramente, se as leituras apresentadas aqui estiverem corretas, a noção de 'sensível comum' utilizada em Quodl. 11, q. 8, renega a concepção de 'sentido comum interior' de Suma, art. 22, q. 4, de 'sentido universal' que lemos em Quodl. 2, q. 6, e de 'sentido comum' que vimos em Quodl. 4, q. 21. Em primeiro lugar, porque em Quodl. 11, q. 8, não há referências a algo como uma virtude do sentido comum que seja superior e julgue aquilo que provém do sentido particular (se essa posterioridade de um juízo sensitivo sobre o sentido particular surge em Quodl. 11, q. 8 , ela parece recair principalmente sobre a estimação que, esta sim, pressupõe alguma virtude distinta do sentido particular).

Há, porém, uma diferença mais profunda, já mencionada, entre aqueles três textos e Quodl. 11, q. 8: naqueles, o sentido comum julga a conveniência ou diferença entre os diversos sensíveis conhecidos pelo sentido particular (ele, justamente, os reúne por seu juízo); nesta, o sensível comum é o objeto próprio da percepção de uma conveniência ou desconveniência entre o sensível e aquele que sente (uma vez que que apreensão e percepção ocorrem em uma mesma virtude sensitiva). Ou seja, a própria concepção do ato posto em jogo nessa etapa do processo de sensação se modifica completamente da passagem do discurso sobre 'sentido comum' ('sentido comum interior' ou 'sentido universal') que lemos em Suma, art. 22, q. 4, Quodl. 2 , q. 6, e Quodl. 4, q. 21, para o discurso sobre o 'sensível comum' que encontramos em Quodl. 11, q. 8.

Enfim, dadas todas essas dificuldades, não me parece que haja uma concepção acabada de 'sentido comum' ou de 'sensível comum' em Henrique de Gand. Ainda que Jerome V. Brown não tenha levado em consideração, em seu artigo sobre o tema, todos os textos aqui estudados, seu diagnóstico final sobre o sentido comum (ou, podemos adicionar, sobre o sensível comum) parece correto: ele é principalmente um recurso utilizado por Henrique, para preencher um lugar intermediário entre sensação e intelecção ${ }^{37}$. De maneira um pouco mais crítica, poderíamos dizer que o sentido

\footnotetext{
${ }^{37}$ Cf. nota 22 , acima.
} 
comum e/ou o sensível comum são um recurso utilizado pelo Doutor Solene, sem muita precisão, para explicar certas etapas complexas, mas aparentemente consideradas por ele como de somenos importância, no processo de conhecimento humano. Ainda assim, é de suma relevância que, mesmo sem desenvolvê-la mais claramente, Henrique tenha sentido a necessidade de conservar tais noções em certos contextos de seu discurso sobre o conhecimento.

\subsection{MEMÓRIA}

Penetrando o campo da memória, nos vemos agora em terreno mais firme, ao contrário do que ocorria com o sentido comum. Ao fim do estudo deste último, como vimos, não estava claro nem mesmo se ele era uma das virtudes sensitivas posteriores ao sentido particular na ordem de conhecimento ou se o sensível comum seria percebido pelo próprio sentido particular. Já no que diz respeito à memória, começa a valer aquele critério que havíamos estabelecido, com base em Maurice de Wulf ${ }^{38}$, para a reunião dos sentidos internos: lida-se, agora, com o conhecimento daquilo que está ausente em sua existência fora da cognoscente (ainda que vá estar nele presente por uma espécie, como será melhor visto no estudo da imaginação, item 5.4). Que o terreno aqui seja mais firme, no entanto, não significa que teremos uma maior quantidade de fontes para o estudo. Com efeito, Henrique de Gand não dedicou muita tinta à consideração da memória sensitiva (ao contrário do que ocorre, como notaremos, no caso da memória intelectiva); igualmente, seus leitores pouco a estudaram. Os trabalhos que se voltaram para ela, no entanto, deixam entrever que aqui retorna o problema que viemos estudando desde o começo dessa segunda parte, a saber, a tensão entre passividade e atividade no processo de conhecimento. De fato, se a memória tem seu lado de passividade, há nela algo de ativo.

Pois bem, como Jerome V. Brown menciona ${ }^{39}$, o Doutor Solene não é de todo preciso ao apontar o lugar da memória no processo do conhecimento sensitivo. Assim, enquanto em Quodl. 2, q. 6, permite-se uma rápida passagem do sensus

\footnotetext{
${ }^{38}$ Cf. nota 4 , acima.

${ }^{39}$ BROWN, J. V. “Henry of Ghent on Internal Sensation”, 1972, pp. 18-9.
} 
universalis para a imaginativa ${ }^{40}$, se nos voltamos para Quodl. 4, q. 21, vemos um claro espaço reservado para uma 'força memorativa' (vis memorativa):

\begin{abstract}
“<..> a cor faz a espécie impressa no meio contíguo a si. Esta é continuamente gerada e difundida diretamente [in directum] por todo o meio até o órgão da visão, no qual a espécie é recebida do ar contíguo a si e, por ela, é formada a visão, isto é, a ação de ver, pela qual [qua] a virtude visiva percebe o objeto sensível particular presente fora. Daí, é gerada na força memorativa [in vi memorativa], que é retentiva das espécies, e dela na força imaginativa"41.
\end{abstract}

Note-se, de início, como não há aqui qualquer menção de um 'sentido comum' ou 'sentido universal' que tenha parte no processo de conhecimento sensitivo - isso só contribui para o imbróglio com que lidávamos no item anterior. Para nossa sorte, porém, esse não é mais o nosso problema. Sendo assim, o que me interessa destacar nesse trecho é que, agora, no lugar do 'sentido comum', encontramos a 'força memorativa' inserida entre o sentido particular (no caso, a visão) e a força imaginativa.

O que está em jogo nessa passagem é, principalmente, o processo de difusão da espécie, de maneira que enfatiza-se que a espécie 'é gerada' (generatur) na força memorativa e que esta última caracteriza-se por ser 'retentiva das espécies' (specierum retentiva). Uma descrição semelhante surge em Quodl. 5, q. 25: “< ..> a memória intelectual, seja no homem seja no anjo, não é contentiva das espécies impressas, tal como o é a memória sensitiva $<\ldots>$ "42. Esse trecho não somente retoma

\footnotetext{
${ }^{40}$ Henrique de Gand, Quodl. 2, q. 6, co. (ed. De Wulf-Mansion Centre, vol. 6, p. 32): "Post sensum particularem magis agit sensus universalis $\langle\ldots>$.

Deinde amplius agit imaginativa, quae mota format quam plurimas imaginationes quas numquam percepit.

Demum similiter dicendum est de intellectu $<\ldots$..." - cf., acima, nota 17.

${ }^{41}$ Henrique de Gand, Quodl. 4, q. 21, co. (ed. De Wulf-Mansion Centre, vol. 8, p. 337): “<...> color facit speciem impressam in medio sibi contiguo, quae continue generatur et diffunditur in directum per totum medium usque ad organum visus, in quo species recipitur ab aere sibi contiguo, et formatur per ipsam visio, id est actio videndi, qua percipit virtus visiva sensibile particulare obiectum extra praesens, et ab hinc generatur in vi memorativa, quae est specierum retentiva, et ab illa in vi imaginativa $<\ldots>$ ". Já citamos o começo dessa passagem, acerca do sentido particular, em cap. 4, nota 37.

${ }^{42}$ Henrique de Gand, Quodl. 5, q. 25, co. (ed. 1613, f. 305vb): "Ut secundum hoc memoria intellectualis, sive in homine, sive in Angelo, non sit contentiva specierum impressarum, sicut est memoria sensitiva $<\ldots>$ ”. Em pelo menos duas passagens de Henrique, aquilo que fica na memória surge nomeado como phantasia (que será típico para a descrição da virtude imaginativa, como veremos no próximo item), porém ambos os trechos são apresentados claramente como citações de Agostinho Quodl. 3, q. 1, co. (ed. 1613, f. 78rb): "<_..> sicut vult Augustinus nono de Trinitate capitulo undecimo, ubi dicit sic. Quemadmodum cum per sensus corporis discimus corpora, et fit aliqua eorum similitudo in animo nostro, quae phantasia memoriae est <..>"; e Quodl. 4, q. 8, co. (ed. De Wulf-Mansion Centre, vol. 8, pp. 57-8): "bene exponit Augustinus cum dicit VIII ${ }^{\circ}$ De Trinitate cap. ${ }^{\circ} 6^{\circ}$ de verbo in vi
} 
o caráter da memorativa como 'retentiva das espécies' - agora, a bem dizer, a memória sensitiva surge como 'contentiva das espécies' (contentiva specierum) -, mas também enfatiza com precisão aquela espécie que é contida na memória: a espécie impressa. Ora, já vimos ao fim do item 4.4, que a species impressa (ou impressiva) é aquela que, justamente em Quodl. 5, q. 14, Henrique afirma considerar ser a espécie tipicamente envolvida no conhecimento sensitivo. Mais do que isso, aprendemos que essa espécie impressa é relacionada à caracterização do sentido particular como fundamentalmente passivo. Nesse caso, começa a se tornar claro que as descrições da 'força memorativa' ou da 'memória sensitiva' que lemos em Quodl. 4, q. 21, e Quodl. 5, q. 25, respectivamente, a estabelecem principalmente como uma força (vis) passiva da alma. Ela é passiva por receber a geração da espécie impressa a partir do sentido particular; por outro lado, tal recepção mantém um tanto, mesmo que pequeno, de ato, uma vez que a espécie impressa gerada na memória é, daí em diante, retida ou contida nesta última: “de fato, aquela assimilação que se faz pela informação da espécie é ali segundo o ato sem consideração atual, como é patente sobre a assimilação da memória sensitiva pela espécie impressa àquilo de que é <espécie> $<\ldots>$,.43. Ou seja, essa retenção da espécie impressa em si é resultado de uma impressão passiva, mas possui por consequência um certo ato, que não chega a ser a consideração atual do objeto por meio da espécie, mas é suficiente para reter em ato a espécie na alma, assimilando a memória à coisa de esta é a espécie. A memória, ao que parece, é em primeiro lugar essa virtude que retém a espécie impressa sem, ao fazê-lo, considerar em ato aquilo de que tal espécie é intenção.

Se, com tal atuação, a memória sensitiva se distingue de uma potência anterior no processo de conhecimento (o sentido particular, que apreende em ato aquilo de que a espécie impressa em si é intenção), ela também se distingue de uma potência posterior a ela nesse processo (a imaginação, que igualmente apreende o objeto a que

\footnotetext{
sensitiva: 'Carthaginem', inquit, 'cum eloqui volo, apud me ipsum quaero ut eloquar et apud me invenio phantasiam Carthaginis, sed eam per corpus accepi memoriaque retinui, ut apud me invenirem de illa verbum cum eam vellem dicere quod in animo meo cerno". Cf. BROWN, J. V. "Henry of Ghent on Internal Sensation", 1972, p. 18 e, sobre o segundo excerto da presente nota, p. 20, nt. 23 (cit. erroneamente como Quodl. 2, q. 1 - provavelmente, devido ao fato de que a ed. 1518 do texto traz "Quodlibet. Secundum" na margem superior da página oposta ao trecho citado - encontrado, nessa edição, em f. 48vX -, em lugar do correto "Quodlibet. Tertium", que ocorre nos demais fólios retos adjacentes).

${ }^{43}$ Henrique de Gand, Quodl. 4, q. 7, co. (ed. De Wulf-Mansion Centre, vol. 8, p. 43): "Illa enim assimilatio quae fit ex speciei informatione, inest secundum actum absque actuali consideratione, ut patet de assimilatione memoriae sensitivae per speciem impressam ad id cuius est $<\ldots>$.
} 
remete a espécie, tal como veremos no próximo item). Agora, ao que parece, seria plenamente possível reunir como uma mesma potência a memória e a imaginação, uma vez que a primeira simplesmente conserva em si aquilo que será conhecido em ato pela segunda. No intelecto, afinal, a conservação do conhecimento e sua atualização, como notaremos no cap. 6, pertencem a uma mesma potência: a intelectiva. Por que, então, se mostra necessário distinguir nos sentidos uma força memorativa de uma força imaginativa? Em poucas palavras, a necessidade de tal distinção advém do caráter orgânico dos sentidos:

\begin{abstract}
“ $<\ldots>$ no sentido, a uma virtude cabe conservar as espécies sensíveis, tal como a memória sensível, e a outra o mover-se por elas, tal como a imaginativa, pois essas virtudes são orgânicas e, necessariamente, a virtude retém as espécies por uma disposição do órgão e < por outra> é modificada por elas - por isso, uma é a força memorativa e outra a imaginativa. Mas, não são assim a memória e a inteligência, pois tanto a retenção como a modificação se fazem sem órgão e à virtude separada é nato refletir-se sobre seu ato, sobre si e sobre aquilo que é em si - a virtude orgânica não $<$ é $>$ assim" $" 44$.
\end{abstract}

A bem dizer, a necessidade de se distinguir nos sentidos a força memorativa e a força imaginativa não se deve diretamente à organicidade dos sentidos, mas antes a uma consequência de tal caráter orgânico e corpóreo, a saber: a impossibilidade de um "refletir-se sobre seu ato [reflecti super suum actum]". Ou seja, uma potência sensitiva não pode se voltar sobre si mesma - sobre seu próprio ato - e atualizar algo que esteja retido ou conservado em si. Daí que, diferentemente do que ocorre no intelecto (uma virtude sem órgão), nos sentidos haja uma força que unicamente retém em si como ato (mas não como apreensão ou conhecimento em ato) a espécie impressa e outra força que conhece em ato o objeto de que tal espécie é intenção - tais virtudes, como sabemos, são respectivamente a memória sensitiva e a imaginação. Sendo forças orgânicas distintas, cada qual possuirá seu próprio órgão (atentemos, aliás, para a ênfase no caráter orgânico dos sentidos internos que, ausente na discussão sobre o sentido/sensível comum, reaparece aqui como elemento fundamental).

\footnotetext{
${ }^{44}$ Henrique de Gand, Quodl. 8, q. 15, co. (ed. 1613, f. 36ra): “< $<$..> in sensu, alterius virtutis est species sensibiles conservare, ut memoriae sensibilis, et alterius eis moveri, ut imaginativae, quoniam virtutes illae sunt organicae, et necessario alia dispositione organi virtus retinet species, et immutatur ab ipsis. Propter quod alia est vis memorativa, et imaginativa, non sic memoria, et intelligentia, quia et retentio et immutatio fiunt absque organo, et virtus separata nata est reflecti super suum actum, et super se, et super id, quod est in se, non sic virtus organica".
} 
Precisamente, cada força orgânica não pode se refletir sobre si - um corpo não reflete sobre si mesmo. É preciso, porém, que haja alguma interação entre tais forças orgânicas. Ou seja, é preciso que, de alguma maneira, uma virtude orgânica como a memória interaja, por um lado, com a virtude orgânica do sentido particular e, por outro, com a virtude orgânica da imaginação. Se cada virtude não pode refletir sobre si devido a seu caráter orgânico, é preciso que uma aja sobre a outra organicamente de maneira a que seja possível o processo de conhecimento sensitivo. O texto em que melhor se descrevem tais interações surge em Quodl. 5, q. 14. Como perceberemos, entretanto, no momento em que buscamos compreender as relações entretidas pela memória com as demais virtudes sensitivas, começamos a ver que, se a memória sensitiva possui um claro componente de passividade, a ela igualmente é atribuído um caráter ativo próprio. Assim, ultrapassado o mero ato de retenção das espécies que já acentuamos, aponta-se para a capacidade engendrante dessa memória sensitiva:

"E cumpre advertir acerca da transmutação do sentido que, tal como gera-se a
partir sensível fora, pelo meio, a sua espécie no órgão do sentido particular fora e
o modifica para o ato de sentir, também gera-se dentro a partir do sentido
particular fora, por meio dos nervos, a espécie no órgão da memória, na qual é
conservada na ausência do sensível fora. E essa espécie na memória é, com
respeito à virtude imaginativa, como o sensível com respeito ao sentido
particular - tal como, de fato, diz Agostinho no nono do De trinitate, cap. 3 :
‘àquela espécie do corpo que era sentida fora, sucede a memória que retém
aquela espécie, que a alma compôs pelo sentido do corpo' $<$ De trin. XI, c. 3.6
(CCSL 50, p. 340)> - e os corpos ausentes são pensados [cogitantur].
Donde, ela é gerada na imaginativa a partir da memória, tal como no sentido
particular a partir da coisa fora - e a imaginativa é informada pela espécie
[specie]. A espécie existente na memória modifica a imaginativa para o ato de
imaginar, tal como o sensível fora modifica o sentido particular para o ato de
sentir.
$<\ldots .>$
$<\ldots>$ a espécie existente na memória sensitiva age na imaginativa, não somente
imprimindo nela a sua espécie, mas também modificando para o ato de imaginar
$<\ldots>$...

${ }^{45}$ Henrique de Gand, Quodl. 5, q. 14, co. (ed. 1613, f. 262[258]ra-va): "Et est advertendum circa transmutationem sensus, quod sicut a sensibili extra per medium generatur species eius in organo sensus particularis extra, et ipsum immutat ad actum sentiendi, sic a sensu particulari extra species per medium nervorum [ms. Paris, BnF, lat. 15848, f. 138ra, l. $17 \mid$ numerorum ed. 1518, f. 176vM, ed. 1613, f. 262[258]ra - tal correção já havia sido proposta, sem referência manuscrita, em ROMBEIRO, "Intelligible Species in the Mature Thought of Henry of Ghent", 2011, p. 193, nt. 55] intra generatur in organo memoriae, in qua conservatur ad absentiam sensibilis extra. Et est species illa in memoria respectu imaginativae virtutis, sicut sensibile respectu sensus particularis, ut enim dicit Augustinus nono <certius, undecimo $>$ de Trinitate, cap. 3, pro illa specie corporis, quae sentiebatur exterius, succedit memoria retinens illam speciem, quam per corporis sensum condidit [combibit CCSL 50, $p$. 340, l. 10] anima, et absentia corpora cogitantur.

Unde generatur a memoria in imaginativam sicut a re extra in sensum particularem, et imaginativam informatam specie.

Species existens in memoria immutat ad actum imaginandi imaginativam, sicut sensibile extra immutat 
Nessa passagem, pela primeira vez, a memória sensitiva é claramente associada à ausência do sensível fora da alma - se a impressão da espécie no sentido particular dependia da presença do sensível fora, a conservação de tal espécie na memória sensitiva justamente prescinde dessa presença. Melhor dizendo, é justamente devido à manutenção da espécie na memória que os sentidos internos - em especial, a imaginação, como veremos - podem conhecer aquilo que não está presente fora. $\mathrm{O}$ mais importante nessa passagem, entretanto, é a descrição das relações da memória para com as outras potências sensitivas.

Em um momento inicial, há uma referência à relação entre a memória e o sentido particular, descrito aqui como 'externo' (extra). Mais precisamente, diz-se que a espécie que havia sido gerada, através do meio, no órgão do sentido externo é gerada, a partir do sentido externo ou particular, no órgão da memória ${ }^{46}$. A descrição da passagem da espécie desde o sentido particular até a memória é fundamentalmente corpórea: essa espécie é gerada no órgão da memória, a partir do sentido particular, 'por meio dos nervos' (per medium nervorum). Uma vez gerada na memória 'por meio dos nervos', tal espécie é 'conservada na ausência do sensível fora' (conservatur ad absentiam sensibilis extra). Ou seja, temos aqui uma descrição particularmente corpórea - mais precisamente, orgânica - do caráter passivo da memória que viemos encontrando até aqui. Por enquanto, a memória sensitiva é, antes de tudo, receptiva e retentiva - ela conserva aquilo de que padece. Em geral, diga-se, é justamente a essa caracterização passiva da memória sensitiva por Henrique de Gand que os seus comentadores se tem atido. Assim, nos diz De Wulf que "a memorativa de Henrique de Gand apresenta a particularidade de possuir por função única guardar o traço

\footnotetext{
ad actum sentiendi sensum particularem.

$<\ldots>$.

$<\ldots>$ agit in imaginativa species existens in memoria sensitiva, non solum imprimendo ei speciem suam, sed etiam immutando ad actum imaginandi <... $>$. A mesma passagem de Agostinho surge citada também em Quodl. 4, q. 7, co. (ed. De Wulf-Mansion Centre, vol. 8, p. 45).

${ }^{46}$ Sublinhe-se, aliás, ser possível ler tal passagem também como uma caracterização do sentido particular enquanto agente da passiva do verbo generatur na oração: "sic a sensu particulari extra species per medium nervorum intra generatur in organo memoriae". Nesse caso, o sentido particular não seria somente aquilo a partir do qual 'gera-se' a espécie na memória, mas seria o próprio agente de tal geração. Essa interpretação arriscaria atribuir ao sentido particular uma agência com respeito à virtude interna da memória, da qual não poderíamos suspeitar nos textos que lemos anteriormente a respeito desses sentidos externos. De alguma maneira, o sentido particular agiria sobre a memória, gerando nela a espécie que ela retém - sobre como tal ação ocorre, só nos é dito que ela é 'per medium nervorum', sem outras explicações. Reencontraremos outra possível utilização de agentes da passiva dentro em pouco.
} 
deixado para trás por uma sensação evanescida" "47; o mesmo nos é dito por Braun: “a espécie sensível $<\ldots>$ imprime-se na memória sensitiva (in organo memoriae), onde ela permanece conservada" 48 . Observações de teor semelhante podem ser lidas em Jerome V. Brown e Valeria Sorge ${ }^{49}$.

Se todos esses comentadores concordam em atribuir à memória a passividade da recepção da espécie impressa e o ato de retenção de tal espécie, eles igualmente lembram que a memória mantém relações estreitas com a imaginação, pois esta última terá por objeto justamente aquilo que, ausente externamente, é dado a conhecer pela espécie conservada na memória. Já nas dissertações de De Wulf e Braun, vemos referências ao tema da necessidade de uma ação que atualize aquilo que se mantém retido na memória - enquanto o primeiro se refere a tal ação, em geral, como uma 'determinação', sem origem precisa, da imaginação por aquilo que havia na memória, Braun aponta a própria memória sensitiva como possuindo a capacidade (Fähigkeit) de 'apresentar' (vorstellen) um objeto à imaginação ${ }^{50}$. Ora, se seguirmos Braun, a memória começa a adquirir um caráter muito mais ativo do que se esperaria em um primeiro momento. Esta última é justamente a posição defendida por Sorge, que vê na memória descrita pelo Doutor Solene um caráter riproduttivo derivado da leitura de Agostinho $^{51}$ - tal leitura, a meu ver, encontra uma expressão mais clara em Brown,

\footnotetext{
${ }^{47}$ WULF, Études sur Henri de Gand, 1894, p. 81: "La mémorative de Henri de Gand présente cette particularité qu'elle a pour fonction unique de garder la trace laissée derrière elle par une sensation évanouie $<\ldots$.. " (grifo do original).

${ }^{48}$ BRAUN, Die Erkenntnislehre..., 1916, p. 19: "Die Species sensibilis ab extra wird im Abbild (imago) zur Species intra und prägt sich dem sensitiven Gedächtnis ein (in organo memoriae), wo sie aufbewahrt bleibt". Parece-me, porém, equivocada a proposta de que já antes de ser impressa na memória a espécie sensível possa ser tomada como imago - com efeito, veremos que a caracterização da espécie só se modifica no momento em que, a partir da memória, faz-se o ato de imaginação (aí sim teremos uma imago caracterizada de maneira razoavelmente diversa da espécie sensível impressa).
}

${ }^{49}$ Cf. BROWN, J. V. "Henry of Ghent on Internal Sensation", 1972, p. 19: "Since it is a sensible species which is generated in sensation, it is this same sensible species which is generated in the memorative power through the agency of the sense organ. Here, the sensible species is stored - the memory being naturally retentive of species - later to actualize the imaginative power"; e SORGE, Gnoseologia e teologia..., 1988, pp. 70-1: “< ..> essa $<$ sc. la memoria $>$ conserva, di conseguenza, solo le impressioni ricevute dalla percezione sensibile, per cui, quando non è più presente il corpo sentito, nella memoria resta una sua similitudine alla quale se può volgere novamente lo sguardo dello spirito per esprimere un pensiero"

${ }^{50}$ WULF, Études sur Henri de Gand, 1894, p. 81: "Les actes posés par cette faculté <sc. la mémorative $>$ sont inconscients; car, au moment précis où la sensation ressuscitera dans la vie psychique, apparaît une puissance nouvelle, mise en branle par l'action de cette détermination sommeillante: c'est l'immagination reproductrice <...>”; e BRAUN, Die Erkenntnislehre..., 1916, p. 19: "Das sensitive Gedächtnis hat die Fähigkeit, das was ihr als Objekt von der Species sensibilis impressa zukam, der Imagination oder Phantasie vorzustellen”.

${ }^{51}$ Cf. SORGE, Gnoseologia e teologia..., 1988, p. 70. 
quando este lembra, "na linguagem de Agostinho, que a espécie na memória é tal como a 'progenitora' da espécie na imaginação, que é um tipo de 'prole' daquela"52. Em uma nota a essa passagem, somos remetidos a Suma, art. 54, q. 9, texto que leremos a seguir. Antes, porém, interessa-me retornar ao último texto indentado - isto é, o trecho de Quodl. 5, q. 14 - e observar como é feito aí esse trânsito da passividade para a atividade da memória que foi notado pelos comentadores consultados.

A bem dizer, em Quodl. 5, q. $14^{53}$, a relação entre a memória e a imaginação não é descrita extamente em termos de uma ação da memória sobre a imaginação, mas antes como uma ação da espécie na memória sobre a virtude imaginativa. Além disso, essa relação entre a espécie retida na memória e a imaginação é formulada de três maneiras. De início, [i] se afirma que a espécie na memória está para a imaginação tal como a coisa fora está para o sentido particular ("est species illa in memoria respectu imaginativae virtutis, sicut sensibile respectu sensus particularis"). Ou seja, tal como a coisa fora afeta o sentido particular pela difusão de sua espécie no meio, a espécie na memória afeta a imaginação. Ora, essa afecção da imaginação pela espécie na memória não se poderá fazer por outra 'espécie da espécie' e, além disso, não há um meio entre a memória e a imaginação, de maneira que tal comparação demanda certas explicações. Daí que, em seguida, [ii] seja dito que tal comparação diz respeito somente à geração da espécie - isto é, tal como o sensível fora gera sua espécie no órgão do sentido particular, assim também pela memória é gerada uma espécie na imaginativa. Mais precisamente, a própria espécie na memória 'modifica a imaginativa para o ato de imaginar' (species existens in memoria immutat ad actum imaginandi imaginativam). Perceba-se, aliás, como tal ação é relacionada à memória pela preposição $a b$ (o que pode indicar a memória como simplesmente origem da ação ou como agente da passiva de 'generatur' no segundo parágrafo da passagem) e, em seguida, precisada como uma ação da species existens in memoria (retorna-se a esse

\footnotetext{
${ }^{52}$ BROWN, J. V. "Henry of Ghent on Internal Sensation", 1972, p. 21: “< ..> remembering, in the language of Augustine, that the species in the memory is the 'parent' as it were of the species in the imagination, which is a kind of 'offspring' of it". Cf. tb. a nt. 25, na mesma pág. Lemos uma posição semelhante em ROMBEIRO, "Intelligible Species in the Mature Thought of Henry of Ghent", 2011, p. 193: "The impressed species in the memory can then move the imagination to the act of imagining, just as the external sensible object moves the particular senses to the act of sensing". Como confirmação dessa interpretação, Rombeiro remete justamente a trechos do excerto de Quodl. 5, q. 14, que citamos acima, na nota 45.

${ }^{53}$ Cf., novamente, nota 45 .
} 
tema, mais aprofundadamente, em Quodl. 11, q. $8^{54}$ ). A isso, adiciona-se, mais adiante no corpo Quodl. 5, q. 14, uma última observação [iii], segundo a qual a espécie da memória age na imaginativa não somente para imprimir nela uma espécie, mas também para modificar a imaginativa, de maneira a nela gerar o próprio ato de imaginar ("agit in imaginativa species existens in memoria sensitiva, non solum imprimendo ei speciem suam, sed etiam immutando ad actum imaginandi”).

Essa última distinção - entre a impressão da espécie e a atualização do ato de imaginar - é sobremaneira relevante, pois lembremos que no sentido particular a impressão da espécie no órgão e a atualização do ato de apreensão sensível são passos ordenados e completamente distintos do processo de conhecimento. Da mesma maneira, na memória há impressão da espécie sem que haja apreensão sensível em ato. Ou seja, já está bem claro para nós que impressão da espécie e apreensão sensível em ato são momentos distintos da geração do conhecimento. E, no entanto, diz-se aqui que, pela sua ação, a espécie impressa e retida na memória imprime uma espécie na imaginação e, além disso, provoca nesta última o ato de imaginar. Ou seja, parece que, quando nos aproximamos do processo de geração da imaginação, somos postos em face de uma simplificação da descrição da geração do ato de conhecimento, quando comparado ao que lemos acerca do sentido particular, pois agora um mesmo (a memória) parece provocar na imaginação a impressão da espécie e o ato de apreensão. Entretanto, meu objetivo, por ora, não é abordar o ato de imaginação ou sua geração - teremos ocasião de estudá-lo mais atentamente no próximo item. Por ora, pretendo unicamente ver em que medida atribuí-se à memória uma ação nesse processo.

Pois bem, se contarmos unicamente com o texto de Quodl. 5, q. 14, parece que, não obstante sejamos agora apresentados a mais elementos de atividade associados à memória do que em textos anteriores, à memória sensitiva propriamente não se atribui qualquer ação com respeito ao ato de imaginação, sendo toda essa ação reservada para a espécie impressa e retida na memória. Uma tal leitura, porém, complica-se pela consideração da passagem a seguir, de Suma, art. 54, q. 9, mencionada há pouco a partir de um trecho de Jerome V. Brown:

"Porém, na informação da visão corporal no olho, o primeiro princípio é a espécie do corpo visível, da qual, segundo Agostinho De trinitate 11, cap. 2, a

\footnotetext{
${ }^{54} \mathrm{Cf}$., adiante, a nota 58 .
} 
espécie ou forma é impressa no sentido que se chama visão; dessa espécie subtraída ao corpo, permanece a similitude do corpo na memória sensível, à qual se converte internamente [intrinsecus] a agudeza da imaginação [acies imaginationis], tal que dali se forme internamente, assim como do corpo sensível objetificado era formado o sentido externo [sensus extrinsecus]. E, como diz no cap. 7, 'aquela espécie que é na memória dizemos ser como que a progenitora daquilo que se faz na fantasia do pensante $<$ De trin. XI, c. 7.11 (CCSL 50, p. 347,11 . 5-7>'. Mas, ela não é verdadeira progenitora, pois tampouco esta é verdadeira prole' <op. cit., 1. 12>, mas 'com isso se vêem mais exercitada e verdadeiramente o mais interior e mais verdadeiro' [op. cit., p. 348, 11. 23-4] - e isso na própria mente intelectual conhecendo a si mesma" ${ }^{\text {"55. }}$.

Vimos acima que Jerome V. Brown destaca nessa passagem a referência à memória sensitiva como 'progenitora' (parens) e ao ato de imaginação como 'prole' $(\text { proles })^{56}$. Atente-se, porém, para o 'quasi' ('como que') que surge na citação de Agostinho - com efeito, a memória é ‘como que’ progenitora e o ato da imaginação é 'como que' prole. Por que esse 'quasi'? Ao que parece, só é possível dizer que a memória e a imaginação são, respectivamente, progenitora e prole, porque afirmá-lo é o caminho para conhecer aquilo mais interior, que é verdadeiramente progenitor e prole, a saber, a potência intelectiva (o que veremos no cap. 6, adiante). Em outras palavras, a designação da memória e do ato da imaginação como, respectivamente, progenitora e prole, que Henrique toma a Agostinho e Jerome V. Brown enfatiza, deve ser considerada cum grano salis - tal designação é apresentada pelo Doutor Solene como um caminho para o conhecimento interior, não como uma explicação apropriada da própria relação entretida pela memorativa e pela imaginativa.

Isso, porém, não explica o porquê de a memória não poder ser tomada propriamente como 'progenitora' do ato de imaginação, que seria sua 'prole'. A meu ver, a explicação para tal impossibilidade está na explicitação da relação entre essas duas potências que Henrique fornece ao início da passagem. Em Quodl. 5, q. 14,

\footnotetext{
${ }^{55}$ Henrique de Gand, Suma, art. 54, q. 9, co. (ed. De Wulf-Mansion Centre, vol. 31, p. 348): "In formatione autem visionis corporalis in oculo primum principium est species corporalis visibilis a qua, secundum Augustinum, $\mathrm{XI}^{\circ}$ De Trinitate cap. ${ }^{\circ} 2^{\circ}$ : 'species sive forma imprimitur sensui quae visio vocatur, a qua etiam specie corporis subtracta, manet corporis similitudo in memoria sensibili ad quam intrinsecus convertitur acies imaginationis, ut inde formetur intrinsecus, sicut ex corpore sensibili obiecto sensus extrinsecus formabatur'. Et, ut dicit cap. ${ }^{\circ} 7^{\circ}$ : 'Illam speciem quae in memoria est, quasi parentem dicimus eius quae fit in phantasia cogitantis. Sed neque illa vera parens est, quare neque esta vera proles est, sed unde interiora, atque veriora exercitatius veriusque [certiusque CCSL 50, p. 348, l. 24] videantur'. Et hoc in ipsa mente intellectuali in cognoscendo se ipsam $<\ldots>$.. No aparato crítico relativo ao primeiro texto destacado como citação nesta passagem, o editor remete o leitor a Agostinho, De trin. XI, cap. 2.6-3.6 (CCSL 50, pp. 339, 1. 161-340, 1. 165). A meu ver, não há aqui, entretanto, uma citação literal da passagem em questão, mas antes uma paráfrase. Já o segundo trecho destacado é claramento uma citação literal.

${ }^{56}$ Cf. nota 52, acima.
} 
vimos que se atribuía à espécie impressa e retida na memória uma ação não somente de imprimir uma espécie na imaginação, mas também de produzir nesta última o ato de imaginação. Aqui em Suma, art. 54, q. 9, pelo contrário, enfatiza-se uma ação da parte da imaginativa ou, mais precisamente, do acies imaginationis: a agudeza da imaginação se converte internamente (intrinsecus convertitur) para a (ad quam) 'similitude do corpo na memória sensível' (corporis similitudo in memoria sensibili), 'tal que dali se forme internamente' (ut inde formetur intrinsecus). Mais uma vez, aparece aqui a comparação com o sentido particular ou externo: essa formação interna provocada pela imaginação em si quando se converte internamente para a memória ocorre tal "como do corpo sensível objetificado era formado o sentido externo [sicut ex corpore sensibili obiecto sensus extrinsecus formabatur]". Mais uma vez, na comparação entre o interno e o externo, a similitude do corpo na memória está para o corpo sensível objetificado, tal como a imaginação está para o sentido particular. Agora, no entanto, mais do que uma ação da espécie impressa na memória sobre a imaginação, assevera-se uma conversão ${ }^{57}$ por parte da imaginação em direção à similitude na memória. Seria possível conciliar essas duas descrições?

Embora sejam aparentemente conflitantes, Quodl. 5, q. 14, e Suma, art. 54, q. 9 , não são necessariamente contraditórios - eles simplesmente descrevem maneiras diversas pelas quais se entrelaçam a memorativa e a imaginativa na formação do ato de imaginação. Com efeito, que a imaginação se converta para a similitude ou espécie impressa na memória não exclui que tal espécie igualmente aja na imaginação para a produção do ato de imaginação. Se nos lembrarmos que desde o começo desta segunda parte estamos assistindo a um complexo jogo de atividades e passividades na formação do conhecimento sensitivo, não impressiona que reencontremos essas sinuosas relações de atividade e paixão. Assim, talvez a solução de nosso problema seja, mais uma vez, propor uma ordenação das atividades e passividades envolvidas na relação entre memória e imaginação. Ora, no próprio trecho destacado de Suma, art. 54, q. 9, Henrique afirma que a imaginação se converte para a similitude da memória, "tal que dali se forme internamente [ut inde formetur intrinsecus]" - isto é,

\footnotetext{
${ }^{57}$ No texto de Quodl. 8, q. 15, destacado acima (cf. nota 44), Henrique de Gand afirma que uma virtude orgânica não é capaz de refletir sobre seu próprio ato. Note-se, porém, que aqui em Suma, art. 54, q. 9, é dito, precisamente, que a imaginação se converte para a similitude na memória, isto é, para o ato de uma outra virtude orgânica que não ela própria. Essa conversão da imaginação é interna, porque não diz respeito ao corpo externo nem ao sentido particular (afetado diretamente por esse corpo externo), mas antes a uma outra virtude orgânica interna, nomeadamente, a memória.
} 
como entendo, tal que por essa conversão a imaginação venha a ser informada com o ato de imaginação. Nesse caso, vê-se que a conversão da imaginação para a espécie na memória não exclui que, em seguida e devido à tal conversão, a espécie na memória para a qual a imaginação se converteu aja nesta última produzindo não somente a impressão de uma espécie, mas também provocando na imaginação o ato de imaginar, como dito em Quodl. 5, q. 14.

Ainda que essa seja uma possível interpretação, é necessário admitir que o próprio gandavense não formulou claramente tal ordenação nas ações recíprocas da memória e da imaginação. Por outro lado, parece claro que, apesar do que lemos em Suma, art. 54, q. 9, Henrique não abandonou a proposta de uma formulação ativa do papel da memória na formação do ato de imaginação, como se pode ver pelo seguinte trecho de Quodl. 11, q. 8:

"Donde Agostinho, no local citado, sobre os que se desviam dos sentidos e os
que se convertem àquilo que se imagina internamente, diz assim: 'tanta
similitude expressa da espécie se espalha a partir da memória, que nem a própria
razão consegue discernir se vê-se algo fora do corpo ou se isso é pensado dentro,
pois enquanto os homens' < De trin. XI, cap. 4.7 (CCSL 50, p. 341, 1l. 6-9)> etc.,
como <citado $>$ acima. Ora, a forma expressa é formada na imaginativa a partir
da própria forma ou espécie impressa na memória, tal que a partir da memória,
por meio da [per] espécie impressa em si, nada se forme na imaginativa senão a
operação de imaginar, terminada na própria espécie expressa"s8.

Nesse trecho, ressurge a distinção entre espécie impressa e espécie expressa, que já encontramos nos itens 4.3 e 4.4. Vimos aí também o quão complexa é sua utilização no que diz respeito aos sentidos e ao intelecto, de maneira que, por ora, não voltaremos a esse problema. Aqui, basta notar que, no excerto em questão, atribui-se uma espécie impressa à memória sensitiva e uma espécie expressa à imaginativa (isso será mais relevante no próximo item, em que estudaremos em que medida há uma espécie ou fantasma na imaginação).

Feita essa ressalva, notemos que a formação da espécie na imaginativa é descrita agora de duas maneiras distintas. Em um primeiro momento, [i] afirma-se que "a espécie expressa é formada na imaginativa a partir da própria forma ou espécie

\footnotetext{
${ }^{58}$ Henrique de Gand, Quodl. 11, q. 8, co. (ed. 1613, f. 206rb): "Unde Augustinus ubi supra de aversis a sensibus et conversis ad ea, quae intus imaginantur dicit sic. Tanta effunditur [offunditur CCSL 50, $p$. 341 , l. 6] similitudo speciei expressa ex memoria, ut nec ipsa ratio discernere sinatur, utrum foris corpus ipsum videatur, an intus tale aliquid cogitetur: nam interdum homines, etc. ut supra. Formatur autem ipsa forma expressa in imaginativa ab ipsa forma, sive specie impressa in memoria ut a memoria per speciem sibi impressam nihil formetur in imaginativa nisi operatio imaginandi, terminata ad illam speciem expressam".
} 
impressa na memória [formatur autem ipsa forma expressa in imaginativa ab ipsa forma, sive specie impressa in memoria]'. A expressão 'a partir da' verte o latim ' $a b$ ', que rege o ablativo no trecho 'ipsa forma, sive specie impressa in memoria'. Essa observação é importante para nós porque, junto ao passivo 'formatur', que tem por sujeito 'forma expressa in imaginativa', a preposição 'ab' pode demarcar 'a própria forma ou espécie impressa na memória' como agente da passiva na sentença. Ou seja, gramaticalmente, a espécie impressa na memória pode ser caracterizada como o agente da formação da espécie expressa na imaginação. Portanto, tal como era o caso em Quodl. 5, q. 14, aqui também a espécie na memória pode ser considerada como agente na formação da espécie na imaginação ${ }^{59}$ (com a adição de que, agora, tais espécies são diferenciadas como impressa e expressa, respectivamente).

Em um segundo momento, no mesmo excerto de Quodl. 11, q. 8 (e ainda de acordo com essa interpretação), [ii] a construção passiva se repete, porém agora o agente da passiva é outro, complementado por um adjunto adverbial. Diz-se: "tal que a partir da memória, por meio da espécie impressa em si, nada se forme na imaginativa senão a operação de imaginar, terminada na própria espécie expressa [ut a memoria per speciem sibi impressam nihil formetur in imaginativa nisi operatio imaginandi, terminata ad illam speciem expressam]". Nessa oração, seguindo nossa leitura do trecho anterior, o agente da passiva não seria mais 'a espécie impressa na memória', mas a própria 'memoria' - a espécie, por sua vez, é deslocada para um adjunto adverbial introduzido pela preposição per (que traduzi por 'por meio de'). Tão interessante quanto, o sujeito do verbo passivo formetur não é mais a 'espécie expressa', mas a 'operação de imaginar' (operatio imaginandi) - agora, a espécie expressa ressurge como o término dessa 'operação de imaginar'. Ou seja, de acordo com essa leitura, a relação entre memória e imaginação surge, nesse segundo caso, ainda mais complexificada: a memória formaria, por meio da espécie impressa em si, a operação de imaginar e esta última resultaria, ao fim, em uma espécie expressa.

Já em Quodl. 5, q. 14, a ação a que se atribuía a informação da imaginação parecia deslizar entre a espécie impressa na memória e a própria memória. Em Quodl. 11, q. 8, porém, essa descrição surge complexificada: a memória age, por meio da espécie impressa em si, na imaginação gerando, nesta última, a operação de imaginar,

\footnotetext{
${ }^{59}$ Cf. nota 45, acima.
} 
da qual resulta a espécie expressa. Seria necessário adicionar ainda a este quadro a ação da imaginação com respeito à sua operação, descrita em Suma, art. 54, q. 9.

Desse estudo da memória sensitiva, portanto, resta que, sendo principalmente uma potência receptiva e tendo por ato primordial a retenção da espécie impressa que recebe pelos nervos a partir do sentido particular (retenção essa que exclui qualquer apreensão em ato), a memória igualmente possui um caráter ativo no que diz respeito à formação do ato da imaginativa. Quanto a este último, é certo que, em alguma medida, a imaginação depende da espécie sensível existente na memória para se atualizar. Com efeito, a formação do ato da imaginação envolve tanto ações da imaginação quanto da memória (ou da espécie impressa na memória). Disso tudo, parece claro, pelo menos, o seguinte: o Doutor Solene atenta para a memória principalmente enquanto ela permite explicar a passagem entre o sentido particular e a imaginação. De fato, vimos como a discussão sobre a memória já nos aproxima constantemente daquele que será o nosso último passo no estudo sobre os sentidos, a saber, o estudo da imaginação ou fantasia. Mais precisamente, a memória permite explicar como passamos de um conhecimento sensitivo da coisa em sua presença para o conhecimento sensitivo dessa mesma coisa em sua ausência. Sendo o primeiro conhecimento típico do sentido particular, é somente pela retenção da espécie pela memória na ausência da coisa fora que a imaginação pode realizar o segundo tipo de conhecimento sensitivo.

\subsection{IMAGINAÇÃO OU FANTASIA}

\subsubsection{A imaginação face aos demais sentidos}

O discurso sobre a imaginação ${ }^{60}$, novamente, colocará em jogo as diversas relações de passividade e atividade necessárias para a atualização do conhecimento

\footnotetext{
${ }^{60}$ A relação entre imaginatio e phantasia é um dos temas mais intrincados no estudo sobre a filosofia do século XIII. Nas palavras de Jacqueline Hamesse, "En général au XIII siècle les notions se fixent et les auteurs parviennent à des synthèses bien structurées. On l'a vu précédemment dans l'étude de res e de spiritus. Il faut cependant bien reconnaître, au terme de l'enquête qui a été faite, que cette constatation générale ne s'applique pas de la même manière à l'analyse des termes imaginatio et phantasia. Si on rencontre au XIII ${ }^{\mathrm{e}}$ siècle quelques théories bien élaborées concernant ces notions, il existe aussi un certain nombre d'auteurs qui témoignent de l'ambiguïté de ces mots" - HAMESSE, J. "Imaginatio et phantasia chez les auteurs philosophiques du $12^{\mathrm{e}}$ et du $13^{\mathrm{e}}$ siècle". In: FATTORI, M., BIANCHI, M. L. (ed.). Phantasia-Imaginatio. V Colloquio Internazionale. Roma, 9-11 gennaio 1986. Roma: Edizioni dell'Ateneo, 1988, pp. 153-84 (cit. na p. 172). Henrique de Gand parece estar,
} 
sensitivo - nesse caso, o conhecimento imaginativo. A difícil conciliação entre passividade e atividade continua, portanto, a ser o Leitmotiv do discurso acerca do conhecimento dos sentidos. Por isso mesmo, vale a pena começarmos nosso estudo da imaginação pela consideração da relação que ela entretém com as demais potências sensitivas.

Vimos no início do estudo da memória, no último item, que Henrique de Gand não é muito claro quanto ao lugar do sentido comum ou universal e da força memorativa no progressum humanae notitiae que estamos percorrendo - em Quodl. 2, q. 6, havia uma passagem do sentido particular para o sentido universal e, finalmente, para a imaginativa ${ }^{61}$, enquanto que no Quodl. 4, q. 21, vemos um processo que passa pelo sentido particular (em especial, a visão), pela memória e culmina na imaginação ${ }^{62}$. Ou seja, há uma concordância sobre a localização do início do conhecimento sensitivo no sentido particular e sua posterior atualização na imaginação (que será, também, o último estágio do conhecimento sensitivo, uma vez que, como notaremos detalhadamente, o intelecto obtém seu objeto já a partir da imaginação). O que, por outro lado, permanece ambíguo é o momento intermediário entre o conhecimento do sentido particular e o conhecimento da imaginação passaria ele pelo sentido comum (universal) ou pela memória? Essa pergunta se torna

justamente, entre os autores que não estabeleceram uma distinção precisa entre os vocábulos latinos imaginatio e phantasia (e seus derivados). Com efeito, imaginativa e phantastica parecem designar, no contexto de seu estudo do conhecimento sensitivo, uma mesma potência da alma - embora ele não o afirme claramente, não há igualmente uma passagem que o negue, sendo ambos os termos utilizados, ao que parece, intercambiavelmente.

Dito isso, há uma passagem que reclama consideração especial ao buscarmos compreender a relação entre imaginatio e phantasia no Doutor Solene. Esse trecho é Suma, art. 1, q. 8, onde Henrique de Gand estuda a possibilidade de os homens serem ensinados pelos anjos. Dessa questão, interessam-nos duas curtas asserções. A primeira é: "Et est iste modus quod angelus dicatur docere hominem agendo circa imagines in phantasmate receptas a sensu <...” (ed. De Wulf-Mansion Centre, vol. 21, p. 158). A segunda é: "Possunt ergo angeli docere homines per motum spirituum et humorum in hominis phantastico, ordinando imagines existentes in ipso" (ed. De Wulf-Mansion Centre, vol. 21, p. 159). Note-se como, nas duas passagens, Henrique de Gand afirma que as imagines existem ou são recebidas em uma virtude da alma cujo nome se deriva do vocábulo greco-latino phantasia. Este vocábulo, porém, é distinto em cada caso - no primeiro excerto, as imagines são recebidas no phantasma, enquanto que no segundo excerto tais imagines existem no phantasticum. Não há variantes manuscritas relevantes indicadas no aparato crítico a nenhuma das duas passagens; além disso, Henrique de Gand utiliza ambas as expressões na formulação de sua própria posição. Nesse caso, o que fazer? Sem desejar solucionar o problema, noto somente que a expressão "imaginum in phantasmate" surge, também, na descrição de uma posição não aceita por Henrique de Gand na mesma questão (ed. De Wulf-Mansion Centre, vol. 21, p. 158, 1. 8). De toda maneira, como veremos no decorrer deste item, nas demais obras de Henrique de Gand, os termos imaginatio e phantasia, bem como seus derivados, parecem ser usados intercambiavelmente.

${ }^{61}$ Cf., acima, nota 40.

${ }^{62}$ Cf. nota 41 . 
ainda mais complexa quando lemos Henrique de Gand, em meio à discussão sobre a possibilidade do ensinamento de um homem por um anjo, apresentar unicamente o sentido particular como intermediário entre o objeto sensível e a imaginação:

"O segundo modo de propor que os anjos operam acerca de nosso fantástico
[circa nostrum phantasticum] ao ensinar ao homem é que o anjo imprime novas
espécies imagináveis imediatamente na fantasia (as quais é nato ao sentido $<s c$.
particular> imprimir), tal que delas o intelecto abstraia espécies inteligíveis. E,
por esse modo, o anjo ensinaria ao homem, como foi dito antes. Isso é
impossível, pela causa já dita, pois a tais espécies $<s c$. imagináveis $>$ não é nato
serem geradas senão a partir do [ab] objeto sensível e mediante o sentido
particular. Ora, o anjo nada opera de novo acerca das coisas naturais senão
mediante causas naturais, como foi dito"

Em poucas palavras, a geração da espécie imaginável provém de uma ação do objeto sensível (externo) mediante o sentido particular ("non sunt natae generari nisi ab obiecto sensibili mediante sensu particular"). Em uma outra fórmula utilizada por Henrique de Gand algumas linhas acima do trecho destacado, diz-se: "a tal espécie imaginável não é nato ser feita senão a partir do $[a b]$ objeto sensível e no [in] órgão corporal" ${ }^{\prime 64}$. Essa última passagem ajunta à referência à ação do objeto sensível fora e à mediação do sentido particular na geração da espécie imaginável a exigência de que tal espécie imaginável seja feita no órgão corporal (in organo corporali). Ora, se adicionamos a isso o fato de que, justamente, um anjo não pode agir na imaginação prescindindo desses três - uma vez que ele não pode produzir um efeito natural para além das causas naturais deste efeito, como se diz na passagem acima -, torna-se patente que o exigido para que haja espécies imagináveis são que [i] ela seja gerada a partir do $(a b)$ objeto sensível fora, [ii] mediante (mediante) o sentido particular, [iii] no (in) órgão corporal. Mais precisamente, a causa natural da espécie imaginável é o

\footnotetext{
${ }^{63}$ Henrique de Gand, Suma, art. 1, q. 8, co. (ed. De Wulf-Masion Centre, vol. 21, p. 157): "Secundus modus ponendi angelum operari circa nostrum phantasticum in docendo hominem est quod angelus imprimit novas species imaginabiles immediate in phantasia, quales natus est sensus imprimere, ut ab illis intellectus species intelligibiles abstrahat. Et per hunc modum angelus hominem doceat, sicut dictum est prius. Quod est impossibile propter causam iam dictam, quia tales species non sunt natae generari nisi ab obiecto sensibili et mediante sensu particulari. Angelus autem nihil de novo operatur circa res naturales nisi mediantibus causis naturalibus, ut dictum est supra". Cf. BROWN, J. V. "Henry of Ghent on Internal Sensation", 1972, p. 21: "Against those who would contend that it is possible that there is a source of the imaginable species which is other than this extra-mental singular, he steadfastly maintains that a sensible object and only a sensible object can cause this imaginable species in the imagination". Sobre o ensino do homem pelo anjo em Henrique de Gand, cf. BROWN, J. V. "Henry's Theory of Knowledge: Henry of Ghent on Avicenna and Augustine". In: VANHAMEL, W. (ed.). Henry of Ghent. Proceedings..., 1996, pp. 19-42 (esp. pp. 38-9).

${ }^{64}$ Henrique de Gand, Suma, art. 1, q. 8, co. (ed. De Wulf-Masion Centre, vol. 21, p. 157): “< $<>$ talis species imaginabilis non est nata fieri nisi ab obiecto sensibili et in organo corporali”.
} 
objeto sensível fora que, agindo mediante o sentido particular, faz tal espécie imaginável no órgão corporal. Enfim, como dizíamos, Henrique de Gand parece muito confortável em passar direto do conhecimento do sentido particular para o conhecimento da imaginação, sem referências ao sentido comum (universal) ou à memória. Jerome V. Brown diz que "nós podemos mesmo acabar esquecendo esse relato de 'sensação-memória-imaginação' dos fundamentos do conhecimento intelectual à luz do fato de que Henrique prefere mais relacionar a imaginação à sensação <sc. particular> do que à memória" ${ }^{, 65}$. Poderíamos, então, ter ignorado a intermediação do sentido comum (universal) ou da memória na passagem de nossa consideração do sentido particular para este estudo que faremos da imaginação? Teriam os dois últimos itens do presente estudo sido em vão?

Parece que não, quando nos lembramos que a ausência do objeto é elemento fundamental na caracterização do conhecimento próprio da imaginação. Aliás, se o sentido particular e a imaginação são, ambos, conhecimentos sensitivos do objeto sensível externo, eles se diferenciam justamente no que diz respeito a presença ou ausência do objeto sensível:

"Portanto, assim é o processo no ato de visão. Em primeiro lugar, a luz material
irradia sobre a cor particular material existente fora. Em segundo lugar, <a luz>,
abstraindo a espécie da cor sem matéria, age no meio e o informa com aquela
espécie. Em terceiro lugar, o meio, por aquela espécie, elicita o ato de visão e,
igualmente, o ato de fantasiar na fantasia [in phantasia actum phantasiandi], que
- como se num círculo - termina na referida cor. Não obstante, $<$ o ato de visão e
o ato de fantasiar $>$ diferem, pois a visão não terminava nela <sc. cor $>$ senão
enquanto era presente ao sentido, ao passo que a fantasiação [phatasiatio]
termina nela na ausência dela ao sentido. E, em quarto lugar, o lume do intelecto
agente irradia sobre o fantasma particular que existe assim em ato na fantasia"66.

O quarto passo dessa narrativa aponta para o fato, já citado aqui, de que após o conhecimento da fantasia ou imaginação, começamos a adentrar o terreno da

\footnotetext{
${ }^{65}$ BROWN, J. V. "Henry of Ghent on Internal Sensation", 1972, p. 21: "We may well come to forget this 'sensation-memory-imagination' account of the foundations of intellectual knowledge in light of the fact that Henry much prefers to relate imagination to sensation rather than to memory".

${ }^{66}$ Henrique de Gand, Suma, art. 58, q. 2, ad 3 (ed. 1642-6, pp. 1007b-8a, n. 43): "Est igitur processus in actu visionis talis. Primo lux materialis super colorem particularem materialem existentem extra irradiat. Secundo coloris speciem abstrahendo sine materia in medium agit, et ipsum informat illa specie. Tertio medium specie illa actum visionis elicit. Et similiter in phantasia actum phantasiandi, qui terminatur quasi quodam circulo in colorem praedictum, licet differunt, quoniam visio non terminatur ad illum, nisi cum praesens fuerit sensui, phantasiatio vero terminatur ad illum ad absentiam eius a sensu. Quarto vero supra phantasma particulare quo sic phantasia existit in actu, irradiat lumen intellectus agentis".
} 
intelecção - isso, porém, ainda não nos ocupará. Além disso, já estudamos pausadamente acima os dois primeiros passos, aos quais não precisamos voltar. Resta, portanto, que nos concentremos no terceiro, a saber, o momento em que elicita-se, pela espécie, o ato de visão e o ato da fantasia. Notemos como tanto o sentido particular da visão como o sentido interno da imaginação têm seus atos igualmente elicitados pelos mesmos elementos: a luz material, a qualidade sensível (no caso, a cor que inere em uma substância externa) e o meio informado pela espécie sensível dessa qualidade. Ambos, destarte, têm seu ponto de partida no objeto sensível melhor, ambos começam e terminam na qualidade sensível externa! Tanto é assim, que o ato da visão e o ato da fantasia formam algo como um círculo: partem da qualidade sensível e retornam a ela perfazendo um processo de conhecimento. Qual a diferença entre ambas, então?

A diferença está, precisamente, na maneira como cada faculdade retorna ao objeto sensível. Ambas, parece claro, necessitam do objeto sensível presente como ponto de partida (somente uma qualidade sensível presente pode provocar uma espécie no meio iluminado e, em seguida, um ato do sentido particular, o que, como acabamos de ver, são causas naturais do ato da imaginação). Entretanto, a presença dessa qualidade sensível não se mostra igualmente necessária quando consideramos não a origem dos atos dos sentidos, mas o seu termo, isto é, aquilo em que tais atos terminam. Como lemos em Suma, art. 27, q. 1: “O termo, enquanto é termo, importa a razão de algum respeito [cuiusdam respectus] ${ }^{\prime 67}$ - em bom português, poderíamos dizer que 'o termo é aquilo a que algo diz respeito'. Assim, é preciso diferenciar [i] a presença do objeto necessária como origem da ato de sensação e [ii] a presença do objeto necessária como termo do ato de sensação.

Com efeito, é diferente afirmar que o sentido particular tem origem no objeto sensível presente e afirmar que o sentido particular diz respeito a (possui por termo) tal objeto sensível presente, ainda que ambas as asserções sejam verdadeiras. De fato, o sentido particular é causado, em última instância, por algo sensível presente $e$ é o conhecimento sensível em ato acerca disso enquanto presente - isto é, o sentido particular se origina da coisa presente fora da alma e diz respeito a essa coisa também enquanto presente fora da alma. A coisa presente fora da alma é origem e termo do ato do sentido particular.

\footnotetext{
${ }^{67}$ Henrique de Gand, Suma, art. 27, q. 1, ad 5 (ed. Teske, p. 150): “Terminus autem in eo quod terminus, rationem respectus cuiusdam importat".
} 
Isso, porém, não pode ser dito da imaginação, pois ao mesmo tempo em que ela possui por causa natural o objeto sensível presente (isto é, que deve estar presente para afetar o sentido particular, para que só então, mediante este último, seja atualizada a imaginação), ela termina no mesmo objeto sensível enquanto ausente para o sentido. Em outras palavras, o ato da fantasia tem por origem a coisa sensível presente, mas diz respeito à (tem por termo a) qualidade sensível enquanto ausente para o sentido. Embora causada por algo que esteve presente, o ato de fantasia é seu conhecimento enquanto ausente.

Assim, sentido particular e imaginação não se distinguem tanto pela origem (idêntica pela causa natural, diversa pelos estágios intermediários, dado que o próprio sentido particular é meio necessário para a imaginação). Por outro lado, eles certamente diferem por seus respectivos termos: o primeiro possui por termo (e, assim, conhece em ato) o objeto sensível enquanto presente a si, a segunda possui por termo (e, assim, conhece em ato) o objeto sensível enquanto ausente a si. Essa conclusão, porém, só suscita uma outra pergunta. Se o sentido particular e a imaginação se distinguem pela, respectiva, presença e ausência de seu termo, o que ocorre entre essas duas faculdades para permitir, no caso da imaginação, essa ausência do termo que não podia ter lugar no caso do sentido particular?

Em poucas palavras, o que acontece de capital entre o sentido particular e a imaginação é a memória sensitiva! Isso já era afirmado por Raphael Braun: “A memória sensitiva possui a capacidade de apresentar à imaginação ou fantasia aquilo que se lhe advém como objeto da espécie sensível impressa. De agora em diante, a coisa externa realmente existente não é mais de primeira necessidade para o conhecimento. A imaginação possui, em si, a possibilidade de, apoiada na espécie e na memória sensitiva, fazer para si, apesar da ausência da coisa, uma imagem material completa do mundo corpóreo com todas as suas particularidades" ${ }^{\text {,68 }}$. Como prova dessa leitura, Braun cita um trecho da seguinte passagem de Quodl. 4, q. 21:

“<..> a virtude visiva [virtus visiva] percebe o objeto sensível particular presente
fora. Daí, $<$ a espécie $>$ é gerada na força memorativa [in vi memorativa], que é

\footnotetext{
${ }^{68}$ BRAUN, Die Erkenntnislehre..., 1916, p. 19: "Das sensitive Gedächtnis hat die Fähigkeit, das was ihr als Objekt von der Species sensibilis impressa zukam, der Imagination oder Phantasie vorzustellen. Von nun an ist das äußere real-existierende Ding zur Erkenntnis nicht mehr erste Notwendigkeit. Die Imagination hat in sich das Vermögen, trotz der Abwesenheit des Dinges, gestützt auf die Species und das sensitive Gedächtnis, sich ein volkommenes, materielles Bild von der Körperwelt mit allen ihren Einzelheiten zu machen".
} 
retentiva das espécies, e dela na força imaginativa [in vi imaginativa] que, pela informação daquela espécie percebe, pelo ato de imaginar, o mesmo particular segundo a razão de particular ausente" ${ }^{\circ 9}$.

Já vimos - e a isso retornaremos dentro em pouco - o quão complexa pode ser a tentativa de estabelecer a relação entre a memória e a imaginação. No entanto, parece que é justamente essa relação que permite à imaginação, compartilhando a mesma causa natural do sentido particular, possuir um termo diverso daquele deste último, a saber: o mesmo particular conhecido pelo sentido particular, porém enquanto ausente. Se seguirmos a proposta de Braun, é precisamente por obter sua espécie a partir da memória sensitiva que a imaginação pode conhecer o objeto sensível enquanto ausente, dado que a espécie sensível deste último ficara retida na memória após proporcionar o conhecimento de tal objeto sensível enquanto presente no ato do sentido particular. Assim, o elemento intermediário que permite a diferenciação entre os respectivos termos do sentido particular e da imaginação é a memória enquanto força retentiva das espécies sensíveis. Ao retê-las, a memória permite à imaginação conhecer aquilo que é ausente fora, mas cuja espécie ainda se mantém na memória sensitiva.

Porém, que Henrique de Gand se permita, em um texto como Suma, art. 58, q. $2^{70}$, avançar imediatamente desde o ato do sentido particular até o ato da fantasia (algo que, como notamos, impressionava Jerome V. Brown ${ }^{71}$ e nos fazia questionar a necessidade de intermediários entre o sentido particular e a imaginação), se explica pela distinção entre retenção e apreensão da espécie. No item anterior, estabelecemos tal distinção como relevante para a compreensão da memorativa, uma vez que ela, embora possua a espécie em ato, não apreende o objeto de que tal espécie é intenção de fato, o ato da memorativa não é de apreensão, mas antes de retenção da espécie. Ou seja, quando o Doutor Solene descreve o processo de conhecimento sensitivo

\footnotetext{
${ }^{69}$ Henrique de Gand, Quodl. 4, q. 21, co. (ed. De Wulf-Mansion Centre, vol. 8, p. 337): “<...> color facit speciem impressam in medio sibi contiguo, quae continue generatur et diffunditur in directum per totum medium usque ad organum visus, in quo species recipitur ab aere sibi contiguo, et formatur per ipsam visio, id est actio videndi, qua percipit virtus visiva sensibile particulare obiectum extra praesens, et ab hinc generatur in vi memorativa, quae est specierum retentiva, et ab illa in vi imaginativa, quae speciei illius informatione actu imaginandi percipit idem particulare secundum rationem particularis ut absens". Trechos dessa passagem já foram citados, acima, na nota 41 e cap. 4 , nota 37. Note-se como aqui o uso de percipere corresponde àquilo que Henrique de Gand nomeia mais precisamente apprehendere nos trechos de Quodl. 11, q. 8, que lemos no item 5.2.

${ }^{70}$ Cf. nota 66 , acima.

${ }^{71}$ Cf. nota 65, acima.
} 
como uma passagem imediata do sentido particular para a imaginação, ele está simplesmente considerando os atos de apreensão do objeto sensível pela espécie (isto é, o ato do sentido particular e aquele da imaginação) e está desconsiderando o ato de retenção da espécie (o ato da memorativa). Quando, pelo contrário, ele cita a memória como intermediária, ele inclui em sua descrição os respectivos atos de apreensão do sentido particular e da imaginação, enfatizando, ademais, o caráter intermediário (necessário para a imaginação) da retenção da espécie pela memória ${ }^{72}$.

Ainda no que tange à relação entre memória e imaginação, Jerome V. Brown coloca o problema da distinção entre essas faculdades. Uma primeira possibilidade válida, seria distingui-las por seus atos - sabemos que o ato da memória sensitiva é somente a retenção da espécie, enquanto o ato da imaginativa é a apreensão do objeto sensível ausente pela espécie retida na memória. Brown, porém, busca distingui-las a partir da consideração da espécie sensível que diz respeito a cada uma dessas faculdades sensitivas. Com efeito, ele coloca a distinção entre memória e imaginação da seguinte forma: "Que propriedade precisamente é possuída pela espécie imaginável e que serve para distingui-la tanto da espécie sensível como da espécie na memória? A resposta a essa pergunta é da maior importância para uma boa [sound] compreensão não somente da teoria da imaginatio de Henrique, mas para toda sua teoria do conhecimento"73. Como vimos, a resposta para essa pergunta não pode estar na ausência do objeto sensível a que a imaginação vem atrelada, uma vez que já na memória a espécie do objeto é retida mesmo que na ausência deste último - dito de outra maneira, a ausência do objeto sensível tem lugar tanto com respeito à memória como com respeito à imaginação ${ }^{74}$. Sendo assim, Jerome Brown propõe uma reformulação de sua questão anterior: "Nossa pergunta original se resolve, então, nisso: qual é a estrutura entitativa da espécie imaginável ou fantasma, tal que ele

\footnotetext{
${ }^{72}$ Já no que diz respeito à relação entre a imaginação e o sentido comum, quase nada nos é dito. Enfatiza-se unicamente que a imaginação age mais do que o sentido comum, tal como este último é mais ativo do que o sentido particular, em Quodl. 2, q. 6, co. (ed. De Wulf-Mansion Centre, vol. 6, p. 32 ) - cf., acima, nota 40. Ora, se não pudemos estabelecer qual seria precisamente a ação ou o ato do sentido comum, essa comparação ganha bem pouca relevância. De outra parte, retornaremos, ainda no presente item, à afirmação, decorrente do mesmo Quodl. 2, q. 6, de que a imaginação é mais ativa do que o sentido particular.

${ }^{73}$ BROWN, J. V. "Henry of Ghent on Internal Sensation", 1972, p. 22: "What precisely is the property which is possessed by the imaginable species and which serves to distinguish it both from the sensible species and the species in the memory? The answer to this question is of the utmost importance for a sound understanding not only of Henry's theory of imaginatio, but of his whole theory of knowledge".

${ }^{74}$ BROWN, J. V. “Henry of Ghent on Internal Sensation”, 1972, pp. 21-2.
} 
possa ser tão particular quanto a espécie na memória e, ainda assim, não tão particular que não possa ser a fonte do universal?" "75. Nesse caso, aquilo que estritamente caracterizaria a espécie imaginável seria sua aptidão a ser fonte do conhecimento intelectual universal. Destarte, Jerome V. Brown parece crer que a distinção entre memória e imaginação apoia-se sobre o fato de que a espécie na memória diz respeito somente ao particular, enquanto que a espécie na imaginação (o fantasma) pode, igualmente, proporcionar (de uma maneira que veremos adiante) o conhecimento do universal ao intelecto. Brevemente, nessa interpretação, a diferença entre memória e imaginação parece ter origem na distinta 'estrutura entitativa' da espécie imaginável quando comparada à espécie na memória.

A meu ver, o problema apontado por Jerome V. Brown se mostra muito interessante, porém a referência a um possível estudo da 'estrutura entitativa' das espécies na memória e na imaginação se mostra um tanto problemático. Em primeiro lugar, seguramente, porque essa expressão é completamente alheia ao vocabulário de Henrique de Gand ${ }^{76}$. Mas, também, porque o Doutor Solene simplesmente nos diz

\footnotetext{
${ }^{75}$ BROWN, J. V. "Henry of Ghent on Internal Sensation", 1972, pp. 22-3: "Our original question then resolves itself into this: what is the entitative structure of the imaginable species or phantasm, such that it can be as particular as the sensible species in the memory and yet not so particular that it cannot be the source of a universal?".
}

${ }^{76}$ Ainda assim, o uso da noção de 'entitative structure' por Brown nesse ponto não deixa de fomentar algumas reflexões acerca da relação entre o conhecimento humano (nesse caso, imaginativo, mas também como um todo) e a coisa existente externamente. Isso fica ainda mais claro quando nos lembramos de que, anos depois do artigo de Brown, Masato Kato recorrerá a uma expressão japonesa próxima à inglesa, em um de seus estudos sobre Henrique de Gand, para discorrer exatamente acerca das próprias coisas (res - もの|mono) e não precisamente das coisas enquanto conhecidas. Com efeito, Kato se refere exatamente a uma 'estrutura (構造 $\mid k \bar{o} z \bar{o})$ de ser da coisa' (“<もの>の存在構造 [mono no sonzai kōzō]” - cf. KATO M. | 加藤 雅 人. “ガンのヘンリクスにおける<もの>の存在構 造 [A estrutura de ser da “coisa' em Henrique de Gand]”.『中世哲学研究』VERITAS | Veritas: Kyodai Studies in Mediaeval Philosophy 14 (1995), pp. 43-54). Ora, se aceitarmos que tanto o fantasma da coisa como a própria coisa possuem, cada qual, sua estrutura entitativa ou de ser, não deveríamos dar um passo a mais e afirmar que as estruturas entitativas da coisa e do fantasma dessa coisa devem, de alguma maneira, corresponder uma a outra? Além disso, não seria essa própria correspondência a garantia da referência do fantasma à coisa externa ao homem que a imagina? No entanto, como vimos acima (item 4.3), parece-me que tal referência tem por garantia principalmente o caráter intencional das espécies sensíveis em geral (e, em particular, do fantasma) enquanto espécie de uma res vera; tal caráter intencional, por sua vez, funda-se não sobre uma identidade de 'estruturas entitativas', mas antes sobre uma relação de causalidade que torna a espécie (portanto, também o fantasma) sempre, de alguma maneira, dependente da coisa real como de sua causa. Como notaremos adiante (cf. nota 107), dessa dependência entre fantasma e coisa externa resulta uma identidade daquela 'força de modificar' (vim immutandi) as potências cognoscitivas possuída pela coisa externa e pela coisa enquanto imaginada (que é, como veremos, o próprio fantasma). Ou seja, a identidade entre coisa externa e fantasma tem por base não uma identidade entre as pretensas 'estruturas entitativas' respectivas, mas antes uma identidade entre as respectivas forças de modificar as potências cognoscitivas. Em outras palavras, o fantasma modifica a potência imaginativa tal como a coisa real o faria se estivesse presente e o fantasma só pode fazê-lo porque, em última instância, depende desta coisa como de sua causa - é uma intentio dela. 
muito pouco sobre a diferença entre a espécie na memória e a espécie na imaginação. Ele nos diz, por exemplo, em Quodl. 5, q. 14, que a espécie na memória modifica a imaginativa para o ato de imaginar ${ }^{77}$. Ora, nesse caso, a diferença entre os respectivos atos da memória e da imaginação bastam para diferenciá-las: na memória, a espécie está retida e, na imaginação, a mesma espécie surge apreendida - a espécie, em ambos os casos, permanece a mesma. O quadro é diferente quando nos voltamos para o Quodl. 11, q. 8, onde é dito que a espécie impressa na memória forma, na imaginação, o próprio ato de imaginar que termina em uma espécie expressa ${ }^{78}$. Nesse ponto, parece que encontramos uma diversidade não somente nos respectivos atos da memória e da imaginação, mas também nas espécies envolvidas em cada caso - tal diferença, porém, não tem tanto a ver com uma possível 'estrutura entitativa' das espécies, mas antes com aquela sua caracterização como espécie impressa ou espécie expressa, que já encontramos nos itens 4.3 e 4.4 .

Assim, parece que o questionamento levantado por J. V. Brown, embora não seja claro ao reclamar uma compreensão acerca da 'estrutura entitativa' da espécie na imaginação, aponta uma problemática relevante, a saber: a necessidade de buscar compreender o que seria propriamente a espécie que diz respeito ao ato de imaginação. Como Brown bem sugere na segunda formulação de sua questão, a discussão acerca do fantasma ou da espécie própria da imaginação culmina na afirmação de sua capacidade de dar a conhecer o universal - essa afirmação, com efeito, redundará em uma distinção fundamental entre 'fantasma singular' e 'fantasma universal'. Antes, porém, de chegarmos a esse ponto, precisamos compreender se e em que medida é possível utilizar a distinção entre 'espécie impressa' e 'espécie expressa' no que diz respeito à imaginação.

\subsubsection{As espécies na imaginação}

Em um artigo que já citamos acima, Michael Rombeiro propõe que não haveria impressão de espécies na imaginação, sendo esta relacionada por Henrique de Gand somente a espécies expressas: “Assim, a espécie sensível é multiplicada pelo meio interno, mas quando chega ao poder [power] interior da imaginação ela não é

\footnotetext{
${ }^{77}$ Cf., acima, a nota 45 .

${ }^{78} \mathrm{Cf}$. a nota 58 , acima.
} 
impressa nesse poder, pois nesse ponto o objeto já está presente ao poder pela espécie sensível no meio próximo. O poder imaginativo é simplesmente informado por um ato de imaginação. Assim, no processo cognitivo, as espécie impressas são particulares ao meio e aos órgãos dos sentidos e são um meio de tornar o objeto presente ao poder cognitivo. Uma vez que esteja presente, o objeto é unido ao poder como uma [as a] espécie expressiva e funciona como o princípio formal que elicita e informa o ato de conhecimento; assim, não é necessária mais nenhuma espécie intermediária [mediating species]" ${ }^{\prime 79}$. Nesse excerto, Rombeiro parece propor três teses acerca da imaginação: [i] o poder da imaginação não possui espécie impressa em si, pois a espécie no meio interno já basta a ela; [ii] o poder da imaginação recebe o objeto em si como espécie expressiva; e [iii] o objeto, presente por essa espécie expressiva, é o princípio formal que elicita e informa o ato de conhecimento na imaginação. De meu ponto de vista, as três teses possuem grandes dificuldades, muito embora nenhuma delas possa ser de pronto recusada.

\subsubsection{A imaginação e as espécies impressas}

Em primeiro lugar, a negação de uma espécie impressa na imaginação parece, a primeira vista, contradizer o que líamos em Suma, art. 1, q. 8: “< .. > o anjo imprime novas espécies imagináveis imediatamente na fantasia (as quais é nato ao sentido $<s c$. particular> imprimir) [angelus imprimit novas species imaginabiles immediate in phantasia, quales natus est sensus imprimere ${ }^{\prime 80}$. Decerto, o Doutor Solene recusará que o anjo possa imprimir espécie na imaginação, por outro lado ele justamente afirmará que o sentido interno o faz. Ou não seria esse caso? Pois bem, se lemos mais atentamente a passagem, vemos que o verbo imprimere só é utilizado nessa formulação da tese a ser recusada, mas não na solução após tal recusa. Com efeito, nas frases seguintes diz-se somente que "a tais espécies $<s c$. imagináveis $>$ não é nato

\footnotetext{
${ }^{79}$ ROMBEIRO, "Intelligible Species in the Mature Thought of Henry of Ghent”, 2011, p. 201: "So a sensible species is multiplied through the internal medium, but once it reaches the interior power of imagination it is not impressed on that power, because at that point the object is already present to the power through the sensible species in the proximate medium. The imaginative power is simply informed by an act of imagination. Thus, in the cognitive process, impressed species are particular to the medium and the sense organs, and are a means of rendering the object present to the cognitive power. Once it is present, the object is united to the power as an expressive species and functions as the formal principle that elicits and informs the act of cognition; so no further mediating species is necessary".

${ }^{80}$ Cf. nota 63, acima.
} 
serem geradas senão a partir do $[a b]$ objeto sensível e mediante o sentido particular [tales species non sunt natae generari nisi ab obiecto sensibili et mediante sensu particulari]" ${ }^{\prime 81}$. Da mesma maneira, em outra passagem da mesma questão, diz-se que “a tal espécie imaginável não é nato ser feita senão a partir do [ab] objeto sensível e no [in] órgão corporal [talis species imaginabilis non est nata fieri nisi ab obiecto sensibili et in organo corporali] ${ }^{\prime 82}$. Ou seja, nessas passagens de Suma, art. 1, q. 8, Henrique de Gand só utiliza imprimere com respeito à imaginação quando formula a tese adversária, porém ao formular suas próprias posições prefere utilizar 'ser gerada' (generari) ou 'ser feita' (fieri). Nesse caso, caminhamos cada vez mais na direção da interpretação de Rombeiro.

Aliás, se nos voltamos para outras passagens que vimos acima especialmente, aquelas que versam sobre a relação entre memória e imaginação -, sua tese parece ainda mais plausível. Por exemplo, em Quodl. 11, q. 8, líamos: “a forma expressa é formada na imaginativa a partir da própria forma ou espécie impressa na memória, tal que a partir da memória, por meio da [per] espécie impressa em si, nada se forme na imaginativa senão a operação de imaginar, terminada na própria espécie expressa [Formatur autem ipsa forma expressa in imaginativa ab ipsa forma, sive specie impressa in memoria ut a memoria per speciem sibi impressam nihil formetur in imaginativa nisi operatio imaginandi, terminata ad illam speciem expressam]" ${ }^{\prime 3}$. Retornaremos adiante a essa passagem atentando para a espécie expressa (o que se diz aqui sobre ela parece conflitar com outras teses de Rombeiro). Concentremo-nos, por ora, no que se diz sobre a espécie impressa: a 'forma ou espécie impressa na memória' (forma sive species impressa in memoria) forma a 'forma expressa na imaginação' (forma expressa in imaginativa); a memória, 'por meio da espécie impressa em si' (per speciem sibi impressam) forma na imaginativa 'a operação de imaginar' (operatio imaginandi). Nas duas descrições, Henrique se utiliza do verbo 'ser formado' (formari): algo é formado na imaginativa a partir da memória. Porém, toma-se muito cuidado em resguardar a expressão 'espécie impressa' ou 'forma impressa' para a memória, atribuindo-se à imaginação somente uma 'forma expressa', uma 'operação de imaginar' e uma 'espécie expressa'. Caso semelhante encontramos

\footnotetext{
${ }^{81}$ Cf., novamente, nota 63

${ }^{82}$ Cf. nota 64, acima.

${ }^{83}$ Cf. nota 58 , acima.
} 
no seguinte trecho de Quodl. 5, q. 14: "Donde, ela $<$ sc. a espécie> é gerada na imaginativa a partir da memória, tal como no sentido particular a partir da coisa fora e a imaginativa é informada pela espécie [specie]. A espécie existente na memória modifica a imaginativa para o ato de imaginar, tal como o sensível fora modifica o sentido particular para o ato de sentir [Unde generatur a memoria in imaginativam sicut a re extra in sensum particularem, et imaginativam informatam specie. Species existens in memoria immutat ad actum imaginandi imaginativam, sicut sensibile extra immutat ad actum sentiendi sensum particularem]" ${ }^{\prime 84}$. Aqui, a espécie na memória 'modifica' (immutat) a imaginativa para o ato de imaginar; a espécie na imaginativa é 'gerada' (generatur) pela memória; a imaginativa é 'informada' (informatam) pela espécie. Mais uma vez, evita-se atribuir à imaginação uma impressão, embora atribua-se a ela uma espécie e, além disso, uma operação.

Pois bem, nesses trechos lemos que, a partir da memória, algo é gerado (generari), formado (formari), feito (fieri) - a espécie na memória modifica (immutat) a imaginativa. Nada de impressão... Isso muda, entretanto, quando lemos uma outra passagem do mesmo Quodl. 5, q. 14: “<_..> a espécie existente na memória sensitiva age na imaginativa, não somente imprimindo nela a sua espécie, mas também modificando para o ato de imaginar [agit in imaginativa species existens in memoria sensitiva, non solum imprimendo ei speciem suam, sed etiam immutando ad actum imaginandi $]^{\prime 85}$. Note-se que, aqui, a impressão não é excluída da imaginação - diz-se que a memória age (agit) na imaginativa 'imprimindo' (imprimendo) uma espécie e, também (etiam), 'modificando' (immutando) para o ato de imaginar. Mais uma vez, afirma-se que há espécie e ato na imaginativa, sendo ambos provenientes da memória. Agora, no entanto, é dito que tal espécie é, justamente, impressa na imaginativa, o que igualmente se afirma em Quodl. 4, q. $21^{86}$.

Sem dúvida, no corpo de textos de Henrique aqui elecado, a atribuição de uma espécie impressa à imaginação não é unanimidade. Ainda assim, lembremos que ela é condizente com a tese de Wouter Goris e Martin Pickavé que lemos acima (item 4.4), segundo a qual, pelo menos a partir de Quodl. 5, q. 14, o Doutor Solene reservaria a espécie expressa para o intelecto, atribuindo espécies impressas somente ao sentido.

\footnotetext{
${ }^{84}$ Cf. nota 45 , acima.

${ }^{85} \mathrm{Cf}$., novamente, a nota 45 .

${ }^{86} \mathrm{Cf}$., adiante, nota 101 .
} 
Isso é visto, ainda segundo Goris e Pickavé, em Quodl. 5, q. 14: "Ele <sc. Aristóteles $>$ o diz, para diferenciá $<-1 \mathrm{a}>$ da sensitiva, na qual não há senão espécie impressa, enquanto no intelecto há <espécie> expressa e, por isso, de algum modo tal como em um lugar, mas não tal como em um sujeito [Quod dicit ad differentiam sensitivae, in qua non est nisi species impressa, in intellectu vero est expressa, et propter hoc quodammodo sicut in loco, non autem sicut in subiecto]" ${ }^{\prime 87}$. Ou seja, a atribuição de uma espécie impressa à imaginação não parece de maneira alguma um lapso, mas antes uma proposta completamente de acordo com a economia interna de Quodl. 5, q. 14 (haja vista que, como veremos no cap. 6, a espécie impressa é exclusivamente característica da sensitiva por ser esta orgânica, o que ela compartilha com a imaginativa ${ }^{88}$ - em outras palavras, atribuir espécies impressas à sensitiva por sua organicidade, exige que se as atribua, também, à imaginativa). Em face dessa dificuldade, a única pergunta restante é: como interpretar esses textos de Henrique em seu conjunto? Há ou não espécie impressa na imaginativa?

Como último passo na tentativa de compreendê-lo, vejamos agora um texto novo. Mais especificamente, o excerto de Suma, art. 58, q. 2, precisamente no qual Rombeiro baseia sua proposta de que não haveria espécie impressa no poder da imaginação. Note-se que, nesse trecho, não se fala em geral na fantasia, mas precisamente da força da fantasia (vis phantasiativa) - essa modificação será capital para a compreensão do problema $^{89}$ :

\begin{abstract}
"Em segundo lugar, porém, são diferentes $<s c$. a inteleção e a visão>, porque ali $<$ sc. na visão $>$ um é a cor na coisa e outro a espécie da cor e porque a própria espécie da cor é abstraída da cor por como que [per quasi] uma separação real e geração ou [sive] multiplicação dela em todo o meio que é entre a coisa vista e aquilo no olho em que vige a força visiva da alma, informando-o - seja o meio exterior (fora do olho), seja interior (no olho). A partir desse meio, assim informado (que não vê, mas transporta a espécie do visível [non vidente, sed deferente speciem visibilis]), há um ponto interior do nervo em que concorrem os dois nervos dos dois olhos e, nele, a virtude visiva é receptora da modificação segundo o ato, que é a visão - 'de fato, a alma não é no extremo, mas manifestamente no interior', tal como se escreve em De sensu et sensatu. Em verdade, somente naquele interior é a alma segundo a força visiva e, por isso, quando ele padece (tal como pelo que sentimos), daquele meio informado pela
\end{abstract}

\footnotetext{
${ }^{87}$ Cf. cap. 4, nota 79. O texto de GORIS \& PICKAVÉ, “Von der Erkenntnis der Engel”, 2001, p. 131, relevante para nós, pode ser lido em cap. 4, nota 66.

${ }^{88}$ A relação entre 'espécie impressa' e a organicidade dos sentidos é explicada em cap. 6, nota 237. O caráter orgânico da imaginação é enfatizado em Suma, art. 1, q. 8 (cf., acima, nota 64).

${ }^{89}$ Cf., acima, a nota 79 e, em geral: ROMBEIRO, "Intelligible Species in the Mature Thought of Henry of Ghent", 2011, pp. 200-1.
} 
espécie do visível, faz-se o ver, como se diz em De anima II. E, ainda mais no interior, a alma é segundo a força da fantasia [secundum vim phantasiae], tal que o meio - tanto interno, como externo - é informado somente pela espécie visível e não pela visão ou fantasiação, mas aquele interior somente pela fantasiação ou visão e não pela espécie por si (salvo enquanto aquele indivisível, pelo qual se modifica a força visiva ou fantasiativa, é algo daquele divisível, que é informado pela própria espécie). De fato, a espécie, sendo hábito no corpo e, por isso, não movendo senão por contato, não move o que informa, mas o que toca (seja no contíguo ou no contínuo, tomando 'contato' amplamente)" ${ }^{\text {"90 }}$.

O trecho considerado por Rombeiro é somente aquele que sublinhamos acima $^{91}$. Parece-me, porém, que a leitura dessas poucas linhas por ele destacadas reclama sua contextualização no interior dessa passagem maior.

Como vimos no longo excerto de seu artigo destacada acima $^{92}$, o referido comentador interpreta o trecho sublinhado como uma afirmação de que, já havendo a espécie no meio, não é mais necessário que haja uma espécie impressa na força da imaginação. Já vimos que o recurso a outros trechos da obra de Henrique de Gand não nos ajuda muito, dado que eles são também, em seu conjunto, ambíguos quanto à admissão ou recusa de uma espécie impressa na imaginação ou fantasia. Assim, restanos ler o trecho destacado por si mesmo, buscando ver em que medida a interpretação de Rombeiro pode ser admitida ou não.

Que não se afirme neste último trecho a impressão de uma espécie na força da imaginação está, de saída, claro - o verbo imprimere nem mesmo é utilizado na

\footnotetext{
${ }^{90}$ Henrique de Gand, Suma, art. 58, q. 2, ad 3 (ed. 1642-6, p. 1007a-b, n. 42): "Secundo autem in hoc est differentia, quod ibi aliud est re color, et species coloris, et quod ipsa species coloris abstrahitur a colore per quasi quandam separationem realem, et generationem, sive multiplicationem ipsius in totum medium, quod est inter rem visam, et id oculi in quo viget vis animae visiva ipsum informando, sive medium fuerit exterius extra oculum, sive interius in oculo. A quo medio sic informato non vidente sed deferente speciem visibilis, punctus nervui duorum oculorum, et in quo vis visiva est recipiens immutationem secundum actum qui est visio. 'Non enim in ultimo est anima, sed manifestum, quod interius', sicut scribitur in De sensu et sensato. Revera in illo interiori solo est anima secundum vim visivam, et ideo illo patiente, ut quo sentimus, ab ipso medio informato specie visibilis fit videre, ut dicitur in secundo De anima. Et adhuc in amplius interior est anima secundum vim phatasiae, ita quod medium tam intra, quam extra informatur specie visibili tantum, et non visione, aut phantasiatione, illud vero interius phantasiatione, aut visione tantum, et non specie per se, nisi pro quanto illud indivisibile quo immutatur vis visiva, vel phantasiativa, est aliquid illius divisibilis, quod informatur ipsa specie. Species enim cum sit habitus in corpore, et ideo non movens nisi per contactum, non movet quod informat, sed quod tangit, sive in contiguo sive in continuo, large summendo contactum". O comentário de Henrique de Gand sobre o ponto de encontro entre os dois nervos dos olhos já foi discutido acima, em cap. 4 , nota 91.

${ }^{91} \mathrm{Na}$ tradução que Rombeiro oferece do trecho, encontramos: "and still further in the interior is the soul according to the power of imagination, such that the medium inside, as well as outside, is informed by a visible species only, and not by a vision or [act of] imagination; [whereas] indeed that interior [is informed by an act of] imagination or vision only, and not by the species per se" ("Intelligible Species in the Mature Thought of Henry of Ghent", 2011, pp. 200-1).

${ }^{92}$ Cf., acima, a nota 79.
} 
passagem. A pergunta é, então: a posição defendida na passagem redunda necessariamente na recusa de uma espécie impressa no que diz respeito à imaginação? Ou seria ela somente a recusa da espécie impressa quanto à força imaginativa e não quanto ao processo de formação da imaginação como um todo? Em outras palavras, entraria tal passagem em contradição com a afirmação que líamos em Quodl. 5, q. 14, segundo a qual a espécie na memória modifica a imaginação para o ato de imaginar e, além disso, nela imprime uma espécie?

Se levamos em consideração somente o trecho destacado por Rombeiro, o gandavense parece, de fato, estar distinguindo entre um interior, identificado à força da fantasia, e um meio, que seria todo o restante do processo de sensação desde o meio externo, passando pelo meio interno, até a fantasia (lembremos que em Suma, art. 1, q. 8, o sentido particular é tomado como meio entre o objeto sensível e a imaginação ${ }^{93}$ ). Ora, somente o meio é informado pela espécie - além disso, ele é somente informado pela espécie, mas não pelo próprio ato de fantasiar. Dessa maneira, pareceria que a força da fantasia, sendo o interior, justamente se opõe ao meio como aquilo que não recebe espécie, enquanto que o próprio meio receberia uma tal espécie.

O problema com essa interpretação é que, já no excerto destacado por Rombeiro, fantasiação (phatasiatio) e visão (visio) são postos em pé de igualdade: ambos são tomados por interiores que recebem somente o seu ato próprio (respectivamente, os atos de fantasiação e visão), em contraposição ao meio que recebe somente a espécie visível. Porém, vimos longamente nos itens 4.3 e 4.4 que Henrique de Gand admite espécies impressas no sentido particular - portanto, também, na visão. Ou seja, se lermos o trecho sublinhado dessa passagem de Suma, art. 58, q. 2, como uma negação de que haja espécies impressas na fantasia é forçoso que admitamos que tampouco haveria espécies impressas na visão, o que se contraporia a tudo o lemos acima. Daí que seja necessário, para uma leitura mais nuançada, contextualizarmos o trecho apresentado por Rombeiro.

O ponto que o Doutor Solene parece querer defender em todo o excerto é o seguinte: na visão "um é a cor na coisa e outro a espécie da cor [aliud est re color, et species coloris]", pois “a própria espécie da cor é abstraída da cor por como que [per quasi] uma separação real e geração ou [sive] multiplicação dela em todo o meio que

\footnotetext{
${ }^{93}$ Cf. nota 63 , acima.
} 
é entre a coisa vista e aquilo no olho em que vige a força visiva da alma, informandoo [ipsa species coloris abstrahitur a colore per quasi quandam separationem realem, et generationem, sive multiplicationem ipsius in totum medium, quod est inter rem visam, et id oculi in quo viget vis animae visiva ipsum informando]". Ou seja, à distinção entre a cor na coisa e a espécie da cor, segue-se uma referência ao modo de separação entre ambos: a espécie é abstraída ou separada da cor na coisa (tal separação é quasi real, porque, como vimos no item 4.3, ela é propriamente intencional) e multiplicada pelo meio. Daí, se seguirá uma distinção entre o meio e o próprio ato de conhecimento que se segue à multiplicação da espécie por tal meio. Esse meio, de fato, como Henrique adiciona a seguir, pode ser externo ou interno ao órgão de sensação ("sive medium fuerit exterius extra oculum, sive interius in oculo"). Assim, a espécie informa o meio - porém, além disso, ela igualmente informa 'aquilo no olho em que vige a força visiva da alma'. Note-se, porém, que não se afirma que a espécie informa a própria força visiva. Pelo contrário, ela informa todo o meio desde de a coisa sensível, passando pelos olhos, até o ponto em que os dois nervos óticos se encontram, ponto este em que vige a força visiva - porém, força visiva e ponto de encontro dos nervos, não se identificam (o segundo é órgão ou instrumento da primeira, como vimos em 4.5). Ou seja, até esse ponto a concepção de sensação aqui descrita é completamente coerente com aquela que estabelemos no capítulo anterior: a espécie sensível informa o órgão do sentido particular, nele imprimindo-se, mas não a própria força sensitiva; a própria virtude visiva, por outro lado, "é receptora da modificação segundo o ato, que é a visão [vis visiva est recipiens immutationem secundum actum qui est visio]". Com efeito, havíamos também notado que, enquanto a impressão da espécie diz respeito principalmente ao corpo natural, a utilização de tal corpo como órgão e a recepção do ato de sensação diz respeito principalmente à força sensitiva (muito embora todo o processo e ato de sensação sejam da alma e do corpo, uma vez que são do composto como um todo).

O passo seguinte de Henrique nesse trecho de Suma, art. 58, q. 2, é opor ao meio (externo e interno), pelo qual se multiplica a espécie visível, o interior no qual "é a alma segundo a força visiva [in illo interiori solo est anima secundum vim visivam]". Destarte, nesse momento, todos os receptores da espécie visível incluíndo aí o meio externo e o próprio órgão (como, no caso da visão, aquele ponto de encontro dos nervos) - passam a ser tomados como meio (medium) e somente a própria força visiva é interior (interior). Esse interior padece pelo meio informado 
pela espécie sensível e, ao padecer, ele se atualiza - tal interior não é, porém, ele próprio informado pela espécie sensível. Nos termos que líamos em Quodl. 11, q. 5 (cf. item 4.5), poderíamos dizer que o interior é excitado pela impressão da espécie no órgão, sem que ele próprio tenha a espécie impressa em si. Ou seja, voltando ao trecho de Suma, art. 58, q. 2, temos agora: um [1] meio [1.1] externo, outro meio [1.2] interno orgânico (ambos informados pela espécie sensível) e um [2] interior propriamente dito, que é a força do sentido particular (informada somente pelo próprio ato do sentido particular, uma vez que o meio esteja informado pela espécie).

Nesse momento, surge o trecho destacado por Rombeiro. Nele, Henrique apõe mais uma etapa ao processo: "ainda mais no interior, a alma é segundo a força da fantasia [adhuc in amplius interior est anima secundum vim phatasiae]". Assim, um interior é aquele em que a alma é enquanto força visiva; mais no interior, porém, há a alma enquanto força da fantasia. Ora, se mantivermos o paralelismo, essa afirmação significa apenas que a força da fantasia não recebe espécies - no entanto, isso não implica necessariamente uma exclusão da necessidade de espécies impressas no órgão da imaginação. Com efeito, assim como eram necessárias espécies impressas no órgão da visão para que a força visiva fosse informada apenas com o ato de ver, talvez também sejam necessárias espécies impressas no órgão da fantasia para que a força da fantasia seja informada apenas com o ato de fantasiar. Em ambos os casos, o próprio órgão (do sentido particular ou da fantasia) é ainda tomado como meio interno, enquanto que a própria força sensitiva (visiva ou da fantasia) é considerada como interior propriamente dito. Naqueles há apenas recepção de espécies sensíveis, nestas há apenas informação pelo ato de apreensão do objeto sensível cuja espécie informou o meio. É isso que, posto em seu contexto, vemos ser afirmado ao fim da passagem exposta por Rombeiro: "o meio - tanto interno, como externo - é informado somente pela espécie visível e não pela visão ou fantasiação, mas aquele interior somente pela fantasiação ou visão e não pela espécie por si [medium tam intra, quam extra informatur specie visibili tantum, et non visione, aut phantasiatione, illud vero interius phantasiatione, aut visione tantum, et non specie per se]".

A isso, o Doutor Solene adiciona duas explicações omitidas por Rombeiro. Em primeiro lugar, ele volta a destacar a unidade de todo esse processo. Ainda que, propriamente, a espécie sensível informe somente o meio (em particular, os órgãos) e a força sensitiva seja informada somente pelo ato de sentir, de um determinado modo pode-se dizer que mesmo a força sensitiva é informada pela espécie, a saber, enquanto 
a alma (o indivisibile, a que ele se refere) é algo (precisamente, forma) do corpo orgânico (o divisibile). Propriamente, somente o corpo divisível é informado pela espécie, porém, enquanto é forma desse corpo orgânico, pode-se dizer que a força sensitiva também é informada por tal espécie - embora, propriamente, ela não o seja. Isso é explicado pela segunda observação final do Doutor Solene, quando ele diz que a espécie é algo 'tido no corpo' (habitus in corpore) - ela é algo que modifica por contactum. Sendo assim, propriamente a espécie sensível é algo no corpo e só diz respeito à força sensitiva da alma na medida em que esta é forma do corpo orgânico. Por outro lado, propriamente e por si mesma, a força sensitiva da alma diz respeito apenas ao ato de apreensão sensível.

Destarte, quando lido em seu contexto, o trecho apresentado por Rombeiro de maneira alguma exige uma exclusão da referência a espécies impressas no discurso sobre a fantasia. Pelo contrário, Suma, art. 58, q. 2, parece unicamente afirmar a respeito da fantasia aquilo que já lemos no capítulo anterior a respeito do sentido particular: a informação pela espécie sensível convém, propriamente, ao corpo, enquanto a informação pelo ato de apreensão sensível convém propriamente à força sensitiva, embora o ato como um todo tenha unidade no composto. Isso, porém, parece gerar mais problemas para a leitura de Henrique de Gand do que soluções, pois não nos ajuda a esclarecer se haveria ou não espécies impressas na imaginação... Com base no conjunto de textos estudados, o que sabemos é que poucos a afirmam (talvez Suma, art. 1, q. 8, provavelmente Quodl. 5, q. 14, certamente em Quodl. 4, q. 21) $)^{94}$, alguns a omitem (Quodl. 11, q. 8 e Suma, art. 58, q. 2) $)^{95}$, mas nenhum a nega. Ademais, somente em Suma, art. 58, q. 2, há uma referência precisa à força da fantasia em oposição a um órgão da imaginação, o que permite melhor compreender como pode haver uma espécie no órgão sem que haja uma tal espécie impressa na própria força (talvez, por isso mesmo, Henrique possa, por vezes, omitir qualquer referência à espécie impressa, dependendo da ênfase de seu texto recair no órgão da imaginação ou na força imaginativa). Enfim, esse parece ser mais um dos temas que, em seus estudos acerca dos sentidos, Henrique de Gand deixou em aberto.

O que podemos afirmar com mais segurança, parece-me, é que pelo menos alguma alteração orgânica se mostra necessária para que haja um ato da imaginação

\footnotetext{
${ }^{94}$ Cf., respectivamente, notas 63,45 e 101.

${ }^{95}$ Cf., respectivamente, notas 58 e 90.
} 
ou fantasia, ainda que tal alteração não seja necessariamente concebida como uma espécie impressa. Qual seria, nesse caso, a alternativa à concepção dessa alteração orgânica como uma espécie impressa não me parece de todo claro. Rombeiro, de certo modo, está correto ao afirmar, com base em Suma, art. 58, q. 2, que 'o poder do sentido' (sense power) não é afetado por espécies impressas, enquanto o meio e os órgãos o são ${ }^{96}$. Entretanto, ele deixa de lado a ressalva de Henrique sobre a necessidade de afirmar que, enquanto forma do corpo, também a força da fantasia e a força do sentido particular recebem tal espécie. Além disso, ele deixa de notar que diversos são os textos nos quais nem mesmo se fala em espécie impressa no meio no que diz respeito à imaginação - aliás, o próprio trecho citado de Suma, art. 58, q. 2, é um exemplo disso, pois embora haja aí uma oposição entre 'espécie' e 'ato de conhecimento', não há qualquer oposição entre 'espécie impressa' e 'espécie expressa'.

Enfim, esse tema parece complexo demais para admitir uma resposta estritamente assertiva. Parece-me possível afirmar somente que, ainda que a espécie impressa não possa ser admitida como algo que informe a força imaginativa, ela aparece, por vezes, como algo necessário para informar a imaginativa e, quiçá mais propriamente, o órgão da imaginação - se nem todos os textos o afirmam, nenhum parece negá-lo.

\subsubsection{A imaginação e as espécies expressas}

Entretanto, o texto de Rombeiro, além de negar a necessidade de espécies impressas na força da imaginação, ainda propunha duas teses com respeito às espécies expressas que ocorrem na fantasia: [ii] o poder da imaginação recebe o objeto em si como espécie expressiva; e [iii] o objeto, presente por essa espécie expressiva, é o princípio formal que elicita e informa o ato de conhecimento na imaginação ${ }^{97}$. Assim, uma vez modificado o órgão da fantasia (não sabemos bem como, ao que parece...), o objeto de conhecimento se tornaria presente à força fantasiativa por uma espécie expressa que, por sua vez, elicitaria o ato de conhecimento da fantasia.

\footnotetext{
${ }^{96}$ ROMBEIRO, "Intelligible Species in the Mature Thought of Henry of Ghent", 2011, p. 200: "Thus impressed species are particular to the medium and corporeal organs. However, once the object of cognition is present to the sense power, no further species of this kind is needed. The sense power is not informed by another impressed species $<\ldots>$.

${ }^{97}$ Cf., acima, nota 79 .
} 
Para começar, a tese [ii] se contrapõe àquilo que já vimos repetidademente Goris e Pickavé destacarem em Quodl. 5, q. 14: na sensitiva "não há senão espécie impressa, enquanto no intelecto há <espécie> expressa e, por isso, de algum modo tal como em um lugar, mas não tal como em um sujeito [Quod dicit ad differentiam sensitivae, in qua non est nisi species impressa, in intellectu vero est expressa, et propter hoc quodammodo sicut in loco, non autem sicut in subiecto]"98. Como dissemos há pouco, mesmo que consideremos que a sensitiva exclui, nesse caso, a imaginativa, a atribuição de uma espécie impressa à primeira redunda em sua atribuição à segunda, uma vez que a atribuição de espécies impressas está relacionada, entre outras razões, à corporeidade dos sentidos externos e internos. Talvez, no entanto, não se deva concluir dessa passagem de Quodl. 5, q. 14, que as espécies expressas são exclusividade do intelecto - talvez, a sensitiva tenha somente espécies impressas, a intellectiva somente espécies expressas e a imaginativa esteja a um meio caminho, possuindo ambas (embora, como visto, não tenhamos base textual suficiente para afirmar com certeza que espécies impressas estejam envolvidas na imaginação...). De qualquer maneira, deveremos ver se é possível afirmar uma espécie expressa na imaginação e, se sim, de que maneira.

Já a tese [iii] de Rombeiro talvez entre em conflito com o que encontramos em Quodl. 11, q. 8: “a forma expressa é formada na imaginativa a partir da própria forma ou espécie impressa na memória, tal que pela memória, por meio da [per] espécie impressa em si, nada se forme na imaginativa senão a operação de imaginar, terminada na própria espécie expressa [Formatur autem ipsa forma expressa in imaginativa ab ipsa forma, sive specie impressa in memoria ut a memoria per speciem sibi impressam nihil formetur in imaginativa nisi operatio imaginandi, terminata ad illam speciem expressam]" 99 . Com efeito, dependendo do que entendamos por 'terminata' nesta passagem, a espécie expressa pode ser compreendida como algo anterior ou posterior à própria operação de imaginar. Se a operação de imaginar 'termina $n a$ ' (diz respeito à ${ }^{100}$ ) espécie expressa como em um objeto próprio (ou melhor, como naquilo em que o objeto está presente à imaginação), então a espécie expressa é anterior à operação de imaginação. Se, porém, a operação

\footnotetext{
${ }^{98}$ Cf. cap. 4, nota 79.

${ }^{99}$ Cf. nota 58, acima.

${ }^{100}$ Cf., acima, nota 67.
} 
de imaginar termina na (diz respeito à) espécie expressa como um efeito seu, então a espécie expressa é algo posterior à operação de imaginação. No primeiro caso, a tese [iii] de Rombeiro é válida, no segundo caso não. Enfim, fica a pergunta: se houver uma espécie expressa na imaginação (o que ainda precisamos decidir), qual é o papel dela?

Comecemos pela leitura do seguinte texto de Quodl. 4, q. 21, para o qual o próprio Rombeiro chama nossa atenção:

\begin{abstract}
"Para o maior entendimento disso, cumpre advertir que na virtude imaginativa há três, a saber: a espécie impressa pela espécie existente [a specie existente] na memória (sem a qual nada se poderia perceber devido a seu ser orgânico e material), o próprio ato de imaginar e, em terceiro lugar, há o próprio objeto imaginado. Destes, a espécie é na imaginativa como uma forma acidental no sujeito; o ato de imaginar, tal como o movimento no movido; o imaginado, tal como um objeto no cognoscente" ${ }^{\text {101 }}$.
\end{abstract}

Retoma-se aqui a temática da relação entre memória sensitiva e imaginativa e, mais do que isso, traz-se novamente à baila a afirmação de uma espécie impressa na imaginativa, distinta do próprio ato de imaginação (tal como, no mais, a espécie sensível impressa no órgão do sentido particular era distinta do próprio ato do sentido particular). Ademais, a necessidade da espécie impressa é diretamente associada ao caráter orgânico da imaginativa - ainda que a espécie impressa não seja aquilo que causa o ato do sentido interno, sem a sua impressão no órgão não é possível que haja ato de imaginação, sem ela (sine qua) a imaginativa não se atualiza. Ou seja, a espécie impressa surge aqui como um sine qua non do ato de imaginação - e já vimos, no cap. 3, como a noção de causa sine qua non é tecnicamente desenvolvida por Henrique de Gand. Ela não é aquilo 'pelo qual' (propter quam sic) algo se faz, porém isso 'sem ela não' (sine qua non) é feito. Ao que parece, é justamente assim que a espécie impressa é aqui introduzida na imaginativa, devido ao caráter orgânico desta última. Sendo uma forma em um órgão, a espécie impressa 'é na imaginativa' (principalmente, no

\footnotetext{
${ }^{101}$ Henrique de Gand, Quodl. 4, q. 21, co. (ed. De Wulf-Mansion Centre, vol. 8, pp. 339-40): "Ad cuius ulteriorem intellectum est advertendum quod in virtute imaginativa sunt tria, scilicet species impressa a specie existente in memoria, sine qua nihil posset percipere propter esse suum organicum et materiale, et ipse actus imaginandi, et tertium est ipsum obiectum imaginatum. Quorum species est in imaginativa ut forma accidentalis in subiecto, actus imaginandi, sicut motus in moto, imaginatum, sicut obiectum in cognoscente". Cf. a trad. apresentada em ROMBEIRO, "Intelligible Species in the Mature Thought of Henry of Ghent", 2011, p. 207: "[I]n the imaginative power there are three: namely, [1] the impressed species from the species existing in memory, without which nothing could be perceived on account of its organic and material being; [2] the act itself of imagining; and [3] the third is the imagined object itself. Of these, the species is [in] the imaginative [power] as an accidental form in a subject; the act of imagining, as a motion in a moved [thing]; what is imagined, as an object in a knower".
} 
órgão da imaginativa) 'como forma acidental no sujeito' (species est in imaginativa ut forma accidentalis in subiecto). $\mathrm{O}$ ato de imaginar, por outro lado, é na imaginativa "como o movimento no movido [sicut motus in moto]"102 - isto é, ele é a passagem da imaginativa da potência ao ato. Resta "o próprio objeto imaginado [ipsum obiectum imaginatum]", que é na imaginativa "tal como um objeto no cognoscente [sicut obiectum in cognoscente]". Ou seja, em Quodl. 4, q. 21, temos uma espécie impressa na imaginativa como acidente orgânico, o próprio ato da potência imaginativa e o imaginado que é nela como objeto no cognoscente. Concentremo-nos neste último.

Em outro trecho já lido aqui de Quodl. 4, q. 21, no contexto do estudo do sentido particular, Henrique nos diz que a espécie expressiva é recebida "não como no sujeito, mas no cognoscente [non ut in subiecto sed in cognoscente]"103. Ora, essa é precisamente a fórmula utilizada por ele para caracterizar, no excerto acima, o objeto imaginado - este é na imaginativa "tal como $<_{\ldots} .>$ no cognoscente $[$ sicut $<\ldots>$ in cognoscente]". Assim sendo, o Quodl. 4, q. 21, parece nos convidar a identificar, na imaginação, 'objeto imaginado' e 'espécie expressa'. Se esse for o caso, temos uma pista para interpretar a passagem de Quodl. 11, q. 8, que relemos há pouco, segundo a qual "a operação de imaginar" é "terminada na própria espécie expressa [operatio imaginandi, terminata ad illam speciem expressam]" ${ }^{104}$. Se a espécie expressa da imaginação for o próprio objeto imaginado, então a operação de imaginar (ou o ato da imaginativa) termina na espécie expressa na medida em que tal ato é com respeito (respectus) a um objeto próprio. Tal leitura parece confirmar a tese [ii] de Rombeiro, pois dela decorre que haveria uma espécie expressa na imaginativa, nomeadamente, $o$ próprio objeto imaginado. Vimos, porém, que a leitura dessa passagem de Quodl. 11, q. 8, está implicada principalmente na tese [iii] de Rombeiro, segundo a qual o objeto, presente pela espécie expressa seria o princípio formal do ato da imaginativa. Ora, se a espécie expressa for identificada ao objeto imaginado, resta que ela deve ser igualmente anterior ao ato da imaginação, sendo aquilo que determina a imaginação a atualizar-se acerca de um determinado objeto, ou melhor, sendo aquilo expresso pela

\footnotetext{
${ }^{102}$ Como se vê, a caracterização do ato da imaginação como motus parece conflitar com a caracterização do ato do sentido como operatio, que lemos em Quodl. 11, q. 5 (cf. cap. 4, nota 114) associada à oposição entre motus e operatio. Lembremos, porém, que, como vimos no item 2.2, motus e operatio são associados nas criaturas, uma vez que nelas a operatio é sempre in fieri. Nesse sentido, uma operatio em um ente criado pode ser tomado como um motus (ainda que não estritamente).

${ }^{103}$ Cf. cap. 4, nota 59.

${ }^{104}$ Cf. nota 58 , acima.
} 
imaginação por meio do que a própria imaginação se determina a operar acerca de um determinado objeto.

Como, porém, foi estabelecido no item 4.4, Henrique de Gand parece ter restringido ao Quodl. 4 a atribuição de espécies expressas à sensação. Por outro lado, em Quodl. 5, q. 14, Henrique de Gand oporia sentido e intelecto como, respectivamente, o que possui espécies impressas e o que possui espécies expressas. No entanto, como vimos há pouco, não estava claro se a referência à sensitiva, nesse contexto, incluiria a imaginativa ou não. Pois bem, a atribuição de espécies impressas à sensitiva parecia determinar, igualmente, a atribuição de espécies impressas à imaginativa. Mas, seria a exclusão das espécies expressas da sensitiva também uma exclusão de tais espécies no que diz respeito à imaginação? Se não, então a imaginação é fundamentalmente distinta tanto da sensitiva como da intelectiva quanto ao seu processo de atualização, pois enquanto a sensitiva admitiria apenas espécies impressas e a intelectiva somente espécies expressas, a imaginativa se colocaria a meio caminho, exigindo espécies impressas e expressas.

Talvez, nesse ponto, esteja justamente mais claramente destacado o caráter mais ativo com respeito ao sentido particular e menos ativo com respeito ao intelecto que Henrique atribui à imaginação em Quodl. 2, q. $6^{105}$. A imaginação é menos ativa do que o intelecto, porque mais material - segundo alguns textos, necessita de uma espécie impressa (em seu órgão). É, simultaneamente, mais ativa do que a sensação, porque expressa seu objeto, forma seu próprio objeto na espécie expressa - "movida, ela forma muitíssimas imaginações que nunca percebeu [mota format quam plurimas imaginationes quas numquam percepit]" ${ }^{, 106}$. Enquanto compartilha a organicidade com o sentido particular, a imaginação também compartilha um caráter factivo com o intelecto, como lemos no próprio Quodl. 11, q. 8:

"<...> a mesma força de modificar [vim immutandi] que a coisa possui enquanto
é existente fora, possui enquanto é imaginada ou inteligida. E o Filósofo a
chama, enquanto é imaginada ou inteligida, de espécie do factivo [species
factivi], daquilo que possui uma virtude factiva [virtutem factivam]. Assim, não
chama aí de 'espécie factiva' aquilo que é impresso no órgão, mas sim a coisa
imaginariamente ou intelectualmente, enquanto objeto que aparece na ação de
imaginar ou inteligir - isso é a forma (isto é [sive], a espécie) não impressa, mas
expressa" 107 .

${ }^{105}$ Cf., acima, nota 40.
${ }^{106}$ Cf., novamente, a nota 40.
${ }^{107}$ Henrique de Gand, Quodl. 11, q. 8 (ed. 1613, f. 206rb): “ $<\ldots$.. eandem vim immutandi, quam habet 
res ut est existens extra, habet ut est imaginata vel intellecta. Et ipsam ut est imaginata vel intellecta appellat Philosophus speciem factivi, cuius habet factivam virtutem. Non ergo hic appellat id quod organo est impressum speciem factivam, sed potius rem imaginarie vel intellectualiter, ut obiectum apparens in actione imaginandi aut intelligendi, quod est forma sive species non impressa: sed expressa".

Traduzi "obiectum apparens" simplesmente como "objeto que aparece" - o termo apparens aqui não parece criar maiores problemas. Ele parece significar algo como 'surgir' ou 'manifestar-se' (nesse caso, na imaginação ou no intelecto enquanto objeto). Isso, porém, não deve mascarar o fato de que o verbo apparere possui uma complexa utilização e uma grande riqueza semântica em Henrique de Gand.

Comecemos por seus usos mais banais. Pululam nos textos do Doutor Solene expressões como: "Sed quod hoc non potest stare apparet triplici via" - Suma, art. 4, q. 5, co. (ed. De Wulf-Mansion Centre, vol. 21, p. 290); “< ..> secundum quod apparebit infra in quadam quaestione de voluntate Dei" - Suma, 33, q. 2, co. (ed. De Wulf-Mansion Centre, vol. 27, p. 135); “< ..> plura beneficia simul tenere, quanto mihi apparet, non solum illicitum et malum est $<\ldots>$-. Quodl. 2, q. 17, co. (ed. De Wulf-Mansion Centre, vol. 6, p. 125); "Et quantum nobis apparet $<\ldots$..> - Suma, art. 40, q. 7, co. (ed. De WulfMansion Centre, vol. 28, p. 291). Nos dois primeiros casos, apparere parece ter um sentido próximo a 'tornar-se manifesto'; nas duas últimas ocorrências, ele surge em expressões equivalentes ao português 'ao que me (nos) parece'. Até aqui, apparere mantém um sentido positivo, ligado à afirmação ou manifestação de posições verdadeiras - próximo, portanto, ao caso do excerto de Quodl. 11, q. 8, citado ao início da nota, onde o apparens é o objeto próprio de cada potência cognoscitiva na medida em que se manifesta a esta última.

O mesmo verbo apparere pode ser usado no sentido de 'surgir', como quando Henrique de Gand enumera as qq. 14 e 15 de seu Quodl. 6, que versam sobre o monstro de duas cabeças: "Sequuntur quaestiones de homine simpliciter ex parte corporis principaliter. Et erant duae de monstro respectu baptismatis. Quarum prima erat, si duo capita in eo apparerent, utrum in baptizando debent ei imponi duo nomina, an unum" (ed. De Wulf-Mansion Centre, vol. 10, p. 156). Aqui, como se vê, apparere não parece dizer respeito tanto ao conhecimento acerca de algo, mas antes ao surgimento material e real de algo (no caso, de duas cabeças em um monstro) - sobre Quodl. 6, qq. 14-15, cf. cap. 2, notas 63 e 64. Entretanto, o mesmo verbo apparere e o substantivo apparentia, dele derivado, podem receber um significado oposto à noção de 'verdade' ou de algo 'verdadeiro'. Assim, o bem aparente se opõe ao bem verdadeiro, como lemos em Quodl. 1, q. 16, co.: "Et ex tali principio defectivo potest $<s c$. voluntas $>$, malo et bono proposito, praeeligere malum, sub ratione tamen alicuius apparentis boni (quia nihil omnino potest eligere, sive bona sive mala electione, neque omnino velle, nisi sub ratione alicuius boni) <...>" (ed. De Wulf-Mansion Centre, vol. 5, p. 110). Distinções semelhantes entre um bonum e um bonum apparens ocorrem em Suma, art. 46, q. 4, co. (ed. De Wulf-Mansion Centre, vol. 29, p. 153), Quodl. 4, q. 11, co. (ed. De Wulf-Mansion Centre, vol. 8, p. 91), Quodl. 9, q. 5, co. (ed. De WulfMansion Centre, vol. 13, p. 133).

A distinção entre 'verdadeiro' e apparens, porém, não surge somente em contextos éticos. Com efeito, podemos encontrá-la também no estudo dos enganos proporcionados pelo sentido, onde aquilo que 'aparece' aos sentidos se opõe à verdade que pode ser conhecida pelo intelecto. Lemos isso, por exemplo, em Quodl. 10, q. 5, ad 1, onde se afirma que, muito embora o corpo morto e o corpo vivo não sejam o mesmo devido à ausência da alma (com exceção do corpo de Cristo), ele é dito o mesmo secundum quid devido à aparência sensível: "Et non est differentia in hoc apud ponentem in homine cum anima intellectiva unam formam aliam, aut plures quae simul corrumpuntur in separatione animae, sive ante corporis mortui resolutionem sive post dicatur non esse idem cum corpore vivo simpliciter sed secundum quid, nisi quoad sensus apparentiam qui non potest discernere in carne et osse et ceteris partibus consimilibus, quando existunt eadem secundum formam simpliciter et quando non, nisi postquam magna mutatio facta fuerit circa ea per resolutionem in cineres aut in pulveres, aut generationem animalis alterius figurae ex ipsis <..." (ed. De Wulf-Mansion Centre, vol. 14, p. 112). Com efeito, em Suma, art. 1, q. 1, ad 3, o verbo apparere surge relacionado à temática do engano dos sentidos: "Unde et quamvis idem diversimode apparet eidem vel diversis, hoc non est nisi propter deceptionem vel impedimentum alicuius sensus cui non oportet credere in hoc, nec tamen propter hoc dicendum est quod nulli sensui credendum est" (ed. De Wulf-Mansion Centre, vol. 21, p. 23). O mesmo verbo ressurge em Suma, art. 2, q. 1, ad 2, na caracterização do sonho: "Unde et somniantes de speciebus quae eis apparent iudicant quod sunt res ipsae" (ed. De Wulf-Mansion Centre, vol. 21, p. 206). Note-se que a apparentia sensível pode levar o intelecto a asserções falsas, como se vê em Suma, art. 34, q. 6, co. (ed. De Wulf-Mansion Centre, vol. 27, pp. 239-40): “< ..> visus corporis non dicitur esse falsus, remum pro parte submersum in aqua apprehendens curvum, sed dicitur falsa assertio 
Valeria Sorge parece considerar que a caracterização da espécie na imaginação como expressiva ou factiva a afasta fundamentalmente da espécie impressa na memória, pois esta última dependeria da presença do objeto externo e aquela não ${ }^{108}$. Já vimos, porém, que tanto na memória como na imaginação o objeto é dado como ausente. Por outro lado, ambas as virtudes se diferenciam por seus atos, pois a memória conserva a espécie impressa do objeto externo ausente, enquanto que a imaginação conhece em ato tal objeto.

Desse modo, meu palpite seria que a necessidade de uma espécie expressa na imaginação não surge estritamente por referência à ausência do objeto, mas

mentis sequens oculoum apparentiam. Tali enim causa existente non debent oculi aliter nuntiare, et sic iniustum est ab oculis exigere plus quam possunt <... $>$ ". Como vemos, nesses quatro casos o apparere descreve um conhecimento sensível que, de algum modo, não corresponde à verdade, podendo levar o intelecto a conclusões errôneas.

Além disso, raciocínios intelectuais ou suas bases podem ser denominados como apparentia se forem falsos ou conduzirem a conclusões errôneas. Vemos isso, por exemplo, em Quodl. 9, q. 8, co. (ed. De Wulf-Mansion Centre, vol. 13, pp. 154-5): "Sed quia iudicium rectae rationis super hoc ex se non est certum et notum, ideo proposita est quaestio de usu ecclesiae et dictis sanctorum super hoc, ex quibus tamquam ex auctoritatibus illud magis certum nobis esse potest quam argumentis secundum rationem formatis, quae frequenter apparentia sunt, ubi vera esse creduntur, et ideo magis est nobis securum in hoc, et universaliter in eis quae sunt fidei, auctoritati inhaerere quam rationi <..." " Um uso semelhante da noção de apparentia pode ser encontrado em Quodl. 12, q. 31 | Tractatus, p. 2 (ed. De Wulf-Mansion Centre, vol. 17, p. 137): "Unde et talia dubia de fide et moribus et sacramentis terminare pertinet ad cathedram, et si forte contingeret circa tale dubium sedentes in cathedra propter rei profunditatem et obscuritatem aliquando per aliquas apparentias et probabilitates fore deceptos, quemadmodum circa facta aliqua plerumque contingit ecclesiam decipi <... ".

No mais, atentemos para um uso curioso de apparentia em Suma, art. 7, q. 4, co., onde tal palavra é utilizada para designar a ciência naval que, subordinada à astrologia, busca encontrar, pela consideração dos astros, presságios de tempestades ou calmarias. Henrique de Gand atribui a Aristóteles o uso de apparentia nesse sentido, mas tal uso é coerente com outras passagens elencadas nesta nota, na medida em que tal ciência náutica tem por base apenas conhecimento sensitivo e por experiência: " $<\ldots$..> astrologia subalternat sibi navalem scientiam, quam Philosophus in exemplis suis vocat apparentiam. Ambae enim idem considerant, videlicet stellarum coniunctionem in praesagium tempestatis aut tranquillitatis futurae. Quam coniunctionem cognoscit astrologus per rationem ut causam illius, et ita ut propter quid. Nauta vero solum per sensum, et experientiam, ut signum eiusdem, et ita ut quia tantum" (ed. 1642-6, p. 131, n. 7). Aqui, não somente apparentia não designa qualquer conhecimento errôneo, como, pelo contrário, nomeia um conhecimento científico, ainda que fundado unicamente no sentido e na experiência.

Podemos ainda citar o termo relacionado apparitio, que surge na interpretação dada por Henrique de Gand ao termo theophania em Suma, art. 33, q. 2, ad 3 (ed. De Wulf-Mansion Centre, vol. 27, p. 148): "Ad cuius intellectum sciendum, quod theophania idem est quod divina apparitio, alicuius scilicet signi ostensio ad secreta divinorum indicandum et repraesentandum". Tais theophaniae, como o Doutor Solene adiciona logo em seguida (p. 149), podem ser tanto signos sensíveis como signos não-sensíveis. Pois bem, acredito estar clara a complexidade dos significados atribuídos ao verbo apparere (e seus derivados) em Henrique de Gand. No caso que nos interessa de Quodl. 11, q. 8, entretanto, ele não parece pôr tantos problemas. Como dito, ali o obiectum apparens parece ser simplesmente aquilo que se manifesta enquanto objeto à potência cognoscitiva. Por outro lado, é importante destacar que a noção de apparens ganhará cada vez mais importância e complexidade na filosofia escolástica, como se pode notar em TACHAU, Vision and Certitude in the Age of Ockham, 1988, pp. 85-112.

${ }^{108}$ SORGE, Gnoseologia e teologia..., 1988, pp. 72-3. 
particularmente por referência à imaginação como o conhecimento em ato de um objeto ausente (e não meramente como a retenção da espécie impressa de um objeto ausente). Assim, à memória basta uma espécie impressa, porque seu papel é reter a espécie de algo que já esteve presente, a modificou organicamente (por meio do sentido particular) e, agora, se encontra externamente ausente. A imaginação, por outro lado, deve terminar seu ato no próprio objeto conhecido - aquele mesmo objeto que, quando presente externamente, havia sido apreendido pelo sentido particular. Ora, quando tinha seu órgão modificado pela espécie impressa, a força sensitiva particular se voltava não para a espécie impressa, mas para o próprio objeto presente fora da alma. Entretanto, como tal objeto se encontra ausente externamente no caso da imaginação, esta deve - inclinada pela espécie impressa na memória e que é, aparentemente, impressa também no órgão da imaginação - fazer para si aquele mesmo objeto (cuja espécie foi impressa nos órgãos do sentido particular, da memória e da imaginação) enquanto ausente. Donde, a meu ver, ser possível para Henrique afirmar em Suma, art. 54, q. 9, que “dessa espécie subtraída ao corpo, permanece a similitude do corpo na memória sensível, à qual se converte internamente a agudeza da imaginação, tal que dali se forme internamente, assim como do corpo sensível objetificado era formado o sentido externo [a qua etiam specie corporis subtracta, manet corporis similitudo in memoria sensibili ad quam intrinsecus convertitur acies imaginationis, ut inde formetur intrinsecus, sicut ex corpore sensibili obiecto sensus extrinsecus formabatur]" "109. A imaginação, sendo factiva, se converte para a memória sensitiva formando em si (a partir da espécie impressa na memória e, em seguida, impressa no próprio órgão da imaginação) uma espécie do objeto enquanto ausente. Melhor dito, a imaginação forma em si o próprio objeto enquanto ausente (a espécie expressa) que é termo do ato de imaginar - na memória ficara uma marca impressa do objeto e, disso, a imaginação faz para si seu objeto próprio (uma vez que o objeto, em si mesmo, não se encontra mais presente fora da alma). Por isso, a imaginação pode ser caracterizada como factiva juntamente com o intelecto, na última passagem indentada de Quodl. 11, q. 8.

Além disso, nessa mesma passagem, Henrique de Gand afirma uma identidade entre a coisa existente fora (res ut est existens extra) e a coisa imaginada ou inteligida $($ res $<\ldots>$ ut est imaginata vel intellecta), uma vez que a ambas se atribui uma mesma

\footnotetext{
${ }^{109}$ Cf., acima, nota 55 .
} 
'força de modificar' (vim immutandi). Em outras palavras, a coisa enquanto espécie expressa pela imaginação (isto é, enquanto objeto externamente ausente da imaginação) é tão cognoscível quanto (ou seja, possui a mesma capacidade de modificar as virtudes cognoscitivas que) a coisa existente e presente externamente. Enfim, quando a imaginação termina seu ato no (dito de outra maneira, atua com respeito ao) objeto enquanto ausente, ela está conhecendo um objeto idêntico àquele que já foi presente externamente ao sentido particular - presença ou ausência, portanto, em nada modificam o próprio objeto (tal como, aliás, a ação do intelecto também não o modificará, como veremos no cap. 6). Enfim, quando se afirma que, para Henrique de Gand, a imaginação faz seu objeto, isso não significa que ela se desligue do objeto externo que iniciou o processo de conhecimento, pois ela não faz seu objeto tout court, mas faz seu objeto enquanto ausente. Este objeto enquanto ausente feito pela imaginação parece ser a espécie expressa pela imaginação, na qual termina o próprio ato de imaginação.

Seguindo Rombeiro, podemos dar um passo a mais nesse caminho ao notar que, para ele, o trecho destacado há pouco de Quodl. 4, q. $21^{110}$, deve ser lido à luz do seguinte excerto de Quodl. 5, q. $14^{111}$ :

“<..> o objeto universal não existe para nosso intelecto senão no fantasma, que
na força imaginativa não possui ser senão tal como no cognoscente - e isso pela
$[$ per $]$ modificação feita nele $<$ sc. no cognoscente $>$, pela $[a]$ espécie existente na
memória (em lugar do objeto fora $[$ vice obiecti extra $]$ ), para o ato de imaginar,
como dito acima" 112 .

Mais uma vez, retoma-se aqui a relação entre memória e imaginação: há no cognoscente, pela espécie existente na memória, uma modificação para o ato de imaginar (note-se a ausência de referências a espécies impressas...). Porém, nesse excerto, Henrique adiciona que, por essa modificação no cognoscente para o ato de imaginar, vem a ser algo que não é descrito precisamente como 'ato de imaginar'. Com efeito, por tal modificação, vem a ser algo que, na força imaginativa, "não

\footnotetext{
${ }^{110} \mathrm{Cf}$. nota 101 , acima.

${ }^{111}$ Cf. ROMBEIRO, “Intelligible Species in the Mature Thought of Henry of Ghent”, 2011, pp. 207-8.

${ }^{112}$ Henrique de Gand, Quodl. 5, q. 14, co. (ed. 1613, f. 263ra): “<...> universale obiectum intellectui nostro non alibi existit, nisi in phantasmate, quod in vi imaginativa non habet esse, nisi sicut in cognoscente, et hoc per immutationem factam in ipso ad actum imaginandi a specie existente in memoria vice obiecti extra, ut dictum est". Cf. ROMBEIRO, "Intelligible Species in the Mature Thought of Henry of Ghent", 2011, p. 205, nt. 103.
} 
possui ser senão tal como no cognoscente [quod in vi imaginativa non habet esse, nisi sicut in cognoscente]". Ora, já vimos há pouco (com base em Quodl. 4, q. 21), que aquilo que está na imaginativa 'tal como no cognoscente' é o próprio objeto imaginado (apreendido enquanto ausente), também concebido como uma espécie expressa, feita pela imaginação (em oposição à espécie que é impressa a partir da memória no órgão da imaginação). Agora, neste último trecho destacado de Quodl. 5, q. 14, o Doutor Solene se utiliza da mesma fórmula - 'ser tal como no cognoscente' para caracterizar o 'fantasma' (phantasma) na imaginativa. Destarte, parece que há aqui uma identificação possível entre 'objeto imaginado', 'espécie expressa' e 'fantasma' - todos são o mesmo fruto do caráter factivo da imaginação ${ }^{113}$.

Adiante, retornaremos à afirmação que abre esse último trecho destacado, segundo a qual os objetos universais existem no fantasma. Antes, porém, busquemos melhor caracterizar o fantasma enquanto objeto do ato de imaginação. Isso poderá ser feito pela leitura de mais trechos de Quodl. 5, q. 14:

"E são de todo símiles os modos de transmutação $<s c$. do sentido e da imaginação>, com exceção de que, no sentir, o objeto que é sentido é aquilo que imediatamente modifica o sentido com a dupla modificação $<s c$. recepção da espécie impressa e atualização do sentido $>$, já citada, para o ato de sentir. Porém, no ato de imaginar, o objeto que é imaginado não é o modificador próximo [proximum immutans], mas o primeiro, tal que inteiramente o mesmo da substância particular que é objeto do sentido particular em sua presença é objeto da imaginativa em sua ausência, embora não sob a mesma razão de particularidade, como se dirá abaixo ${ }^{114}$.

E nisso termina a obra da virtude imaginativa sob a imaginativa e sua operação, compreendendo todas as virtudes sensitivas cognitivas e suas operações" 115 .

\footnotetext{
${ }^{113}$ Bernd Goehring chega a propor que o fantasma abarcaria 'objeto imaginado', 'espécie expressa' e, também, 'espécie impressa', pois tal fantasma seria, para Henrique, espécie em dois sentidos: como impressão material e como conteúdo intencional expresso (cf. GOEHRING, Henry of Ghent on congition..., 2006, pp. 143 e 153-4). Rombeiro, de sua parte, se opõe a essa interpretação: "Hence it is not the case that the imagined object, which exists in the imagination as an expressive species, is simply the intentional content of the phantasm, whereas the impressed species is the material aspect of the phantasm. The phantasm is itself the imagined object, or expressive species, which is distinguished from the impressed species $\langle\ldots>$. Henry stresses that the imagined object and the impressed species are ontologically distinct" (ROMBEIRO, "Intelligible Species in the Mature Thought of Henry of Ghent”, 2011, p. 205 - na nt. 112 a essa pág., Rombeiro cita o trecho de Goehring a que se remeteu aqui). De fato, afirmar que 'espécie impressa' e 'espécie expressa' se identificam no fantasma parece se contrapor à cuidadosa tentativa de distinguir ambas as espécies que assistimos nos itens 4.3, $4.4 \mathrm{e}$ 6.3. Sem dúvida, ainda que a distinção entre 'espécie impressa' e 'espécie expressa' cause problemas para o leitor da obra de Henrique de Gand, parece claro o interesse deste último em estabelecer tal distinção.

${ }^{114}$ Cf., adiante, a nota 119.

${ }^{115}$ Henrique de Gand, Quodl. 5, q. 14, co. (ed. 1613, f. 262[258]ra): "Et sunt omnino similes modi transmutationum, praeter hoc, quod in sentiendo, obiectum, quod sentitur, est illud, quod immediate immutat sensum duplici immutatione iam dicta ad actum sentiendi. In actum vero imaginandi,
} 
Aqui, parece-me, começa a ficar mais patente a possibilidade de identificação entre objeto imaginado e espécie expressa e, ao mesmo tempo, de distinção entre, por um lado, esses dois e, por outro, o objeto externo. Essa última distinção já era prenunciada pela caracterização da espécie expressa como 'espécie factiva', em Quodl. 11, q. 8 - com efeito, se a espécie expressa é 'feita' pela imaginação, ela não se identifica completamente com o objeto externo, sendo antes algo outro que remete a tal objeto externo. No entanto, essa própria espécie expressa é, também, caracterizada como objeto imaginado, o que parece apontar para uma identidade entre o objeto externo e a espécie expressa (o que, aliás, se concluía no próprio Quodl. 11, q. 8 , onde se dizia que a coisa existente fora e a coisa imaginada possuem a mesma força de modificar a potência cognoscitiva ${ }^{116}$ ).

No último trecho destacado, o gandavense introduz justamente uma distinção que permite lidar com essa complexa relação entre objeto externo e espécie expressa enquanto objeto imaginado, a saber: a distinção, no processo de atualização da imaginativa, entre um 'modificador próximo' (proximum immutans) e um 'primeiro modificador' (immutans <..> primum). Este é o objeto externo que, quando presente, bastara para modificar o sentido particular. Na imaginativa, porém, ele não é suficiente, sendo necessário um movente próximo que, tendo sido provocado por aquele movente primeiro, mova imediatamente a imaginação. A meu ver, essa distinção se sobrepõe àquela entre objeto externo e espécie expressa/objeto imaginado - o objeto externo é o mesmo para o sentido particular e para a imaginação, porém esta última deve fazer para si uma espécie expressa intermediária entre o objeto externo que movera o sentido particular e o próprio movimento da imaginação. Mas, donde proviria tal necessidade?

Como vimos acima e se retoma nesse trecho de Quodl. 5, q. 14, isso se deve à ausência do objeto da imaginação: o objeto externo (a coisa existente) é o imaginado, porém ele o é enquanto ausente, de maneira que algo deve fazer as vezes desse

obiectum, quod imaginatur, non est proximum immutans, sed primum, ita quod idem penitus substantiae particularis, quod est obiectum sensus particularis ad eius praesentiam, est obiectum imaginativae ad eius absentiam, licet non sub eadem ratione particularitatis, ut infra dicetur.

Et in hoc terminatur opus virtutis imaginativae sub imaginativa et eius operatione comprehendendo omnes vires sensitivas cognitivas, et eius operationes".

${ }^{116}$ Cf. nota 107 , acima. 
objeto ${ }^{117}$ para a imaginação - esse algo é, justamente, aquilo que, a partir da espécie impressa na memória (e, quiçá, a partir da espécie impressa no órgão da imaginação), a imaginativa faz para si própria. Daí que a espécie expressa possa ser considerada tanto enquanto é distinta da coisa existente externamente como enquanto é o próprio objeto imaginado. Em outras palavras, retoma-se aqui o caráter intencional da espécie que igualmente víamos no sentido particular. Essa espécie da imaginação, porém, sendo de algo tomado como ausente, deve ser feita não pela coisa (que não está presente), mas pela propria imaginação a partir da espécie meramente retida na memória. Justamente por isso, essa espécie na imaginação (identificada com o próprio objeto imaginado) parece dever ser tomada, precisamente, como feita ou expressa pela imaginação. Tal espécie é uma intenção do objeto ausente expressa e, ainda que feita pela imaginação, continua a ser intenção do objeto, pois a imaginativa a faz a partir daquela espécie que fora impressa nos órgãos dos sentidos pelo próprio objeto externo quando esteve presente e, em seguida, retida na memória na ausência deste objeto.

Por isso, também, pode-se dizer que o ato de imaginação possui dois modificadores (isto é, duas causas de seu movimento). O modificador primeiro ou remoto é o próprio objeto externo quando esteve presente, pois sem a impressão de sua espécie no sentido particular, a imaginação não teria por meio do que se produzir. De outra parte, o modificador próximo ou segundo é a espécie expressa/objeto imaginado (que não é, senão, uma espécie do objeto ausente que a imaginação faz para si, a partir daquela espécie impressa na memória, por meio do sentido interno, quando da presença do objeto).

Assim, a denominação desse 'movente próximo' como 'objeto imaginado' parece enfatizar sua identificação com o objeto externo, ao passo que sua caracterização como 'espécie expressa' o caracteriza como sendo feito pela imaginação a partir da espécie impressa na memória (e no próprio órgão da imaginação). Por sua vez, o termo 'fantasma' destaca tal 'espécie expressa' como sendo aquela típica da imaginação ou fantasia (em oposição àquela que há no intelecto, como veremos) e tal 'objeto' como sendo aquele conhecido enquanto ausente e não enquanto presente, como era o caso no sentido particular.

\footnotetext{
${ }^{117}$ Cf. nota 112 , acima.
} 
Essa interpretação parece, em suas linhas gerais, estar de acordo com as teses [ii] e [iii] de Rombeiro ${ }^{118}$. Segundo a tese [ii], o poder da imaginação recebe o objeto em si como espécie expressiva. Nossa leitura aponta precisamente nessa direção, se considerarmos que a espécie expressa, tal como o próprio objeto da imaginação, é produto do caráter factivo da virtude imaginativa. Já de acordo com a tese [iii], o objeto, presente por essa espécie expressiva, é o princípio formal que elicita e informa $\mathrm{o}$ ato de conhecimento na imaginação. Perguntávamos acima em que sentido se deveria afirmar que o ato da imaginação termina na espécie expressa: caso ele o fizesse enquanto essa espécie lhe fornece um objeto, então a tese de Rombeiro pareceria válida; caso o ato de imaginação terminasse na espécie expressa como em um efeito, a tese de Rombeiro pareceria falsa. Curiosamente, ambas as alternativas parecem verdadeiras para Henrique de Gand: a espécie expressa parece ser fruto da atividade da imaginação (a partir da espécie impressa na memória) e, não obstante, fazer as vezes de objeto da imaginação. Dito de outro modo, o objeto imaginado é termo do caráter factivo da imaginação e, também, termo do conhecimento da potência imaginativa - enquanto tal, ele é, de fato, aquilo que modifica a imaginativa para $\mathrm{o}$ ato de imaginar.

Talvez, precisamente por seu caráter anômalo com respeito à espécie impressa no sentido particular e à espécie expressa do intelecto, essa espécie feita pela imaginação mereça um nome próprio, a saber, phantasma. Como dito, este último é caracterizado como aquele objeto típico da virtude imaginativa, que ela produz para si a partir da espécie impressa deixada para trás na memória por um objeto que esteve outrora presente, fora da alma, ao sentido particular. Precisamente falando, o fantasma é o objeto ausente fora da alma, porém ainda conhecido como particular pela imaginação.

\subsubsection{O fantasma}

Uma cuidadosa caracterização do fantasma enquanto objeto da imaginação nos é oferecida ainda em Quodl. 5, q. 14:

“< ..> os fantasmas adicionam isto aos sensíveis: os sensíveis fora apreendidos são na matéria, materiais e apreendidos pelo sentido enquanto materiais, embora

\footnotetext{
${ }^{118}$ Cf. nota 79 , acima.
} 
receba sem matéria a espécie impressa em si. Os fantasmas apreendidos pela imaginação, porém, enquanto apreendidos por ela, são imateriais - abstraídos da presença da matéria, porém não abstraídos das condições particulares que ocorrem [accidunt] à forma, segundo é individuada na matéria (tal como são figura, onde e outros desse modo). De fato, sob tais condições, esses fantasmas não podem mover o intelecto primeiramente e por si nem ser apreendidos por ele, mas somente segundo são abstraídos - não somente da presença da matéria particular, mas também das ditas condições individuais. Assim, os fantasmas apreendidos na imaginativa não são universais senão em potência e, em potência, moventes do intelecto" ${ }^{\prime 19}$.

Ainda que possua em si espécies impressas sem matéria, o sentido particular apreende os sensíveis externos enquanto materiais (ut materialia). Essa afirmação, porém, não parece clara, pois: o que seria apreender algo enquanto material por uma espécie impressa sem matéria? Essa distinção entre [i] impressão da espécie sem a matéria e [ii] apreensão do sensível enquanto material é explicada quando nos voltamos para o caso da imaginativa, que Henrique almeja contrapor àquele do sentido particular. Na imaginativa, os fantasmas (que são, lembremos, espécie expressa, objeto imaginado e modificador próximo) são apreendidos enquanto imateriais - e, isso, de uma maneira bem precisa, a saber: “abstraídos da presença da matéria, porém não abstraídos das condições particulares que ocorrem à forma, segundo é individuada na matéria [immaterialia abstracta a materiae praesentia, non autem abstracta conditionibus particularibus quae accidunt formae, secundum quod est in materia individuata]". Notemos que o fantasma não é apenas 'abstraído da matéria' - com efeito, a espécie impressa no sentido particular também é abstraída da matéria e, no entanto, dá vazão somente a um conhecimento do sensível enquanto material. A diferença é que, no caso da imaginação, o fantasma é conhecido precisamente enquanto abstraído "da presença da matéria [a materiae praesentia]". Mesmo possuíndo uma espécie impressa em si abstraída da matéria do sensível, o sentido particular depende ainda da presença externa material do sensível e, destarte,

\footnotetext{
${ }^{119}$ Henrique de Gand, Quodl. 5, q. 14, co. (ed. 1613, f. 262[258]rb): “<...> phantasmata addunt hoc super sensibilia, quod sensibilia extra apprehensa a sensu sunt in materia, et materialia, et ut materialia apprehensa a sensu, licet speciem sibi impressam recipiat sine materia. Phantasmata autem apprehensa ab imaginatione, ut apprehensa ab illa, sunt immaterialia abstracta a materiae praesentia, non autem abstracta conditionibus particularibus quae accidunt formae, secundum quod est in materia individuata, sicut sunt figura, ubi, et huiusmodi. Quae quidem phantasmata sub talibus conditionibus intellectum movere non possunt primo et per se, neque ab ipso apprehendi, sed solum secundum quod sunt abstracta: non solum a materiae particularis praesentia, sed etiam a dictis conditionibus individualibus, ita quod phantasmata in imaginativa apprehensa non sunt nisi in potentia universalia, et in potentia moventia intellectum". Cf. BROWN, J. V. "Henry of Ghent on Internal Sensation", 1972, pp. 23 e 27; GOEHRING, "Henry of Ghent's Use of Aristotle's De anima...", 2013, pp. 92-3.
} 
somente pode apreender o sensível enquanto materialmente presente. A imaginação, por outro lado, conhece o objeto imaginado - isto é, aquele mesmo objeto material externo -, porém apreendido como ausente.

Essa abstração “da presença da matéria [a materiae praesentia]”, porém, não é ainda uma abstração "das condições particulares que ocorrem à forma, segundo é individuada na matéria [non autem abstracta conditionibus particularibus quae accidunt formae, secundum quod est in materia individuata]". Ou seja, ainda que o fantasma seja conhecido enquanto abstraído da presença da matéria, ele ainda é apreendido pela imaginação sob as condições (conditiones) de algo individuado na matéria. A listagem dessas condições fornecida por Henrique é aberta: 'figura' (figura), 'onde' (ubi) e 'outros desse modo' (et huiusmodi). A menção da 'figura' é particularmente interessante porque, como vimos no item 4.2 , o ato de distinguir o 'caráter da figura' (character figurae) e, mais propriamente, a figura são associados em Suma, art. 1, q. 3, e art. 33, q. 2, principalmente ao sentido particular - em especial, à visão. Agora, em Quodl. 5, q. 14, a figura surge associada antes à imaginação. Seria o termo figura utilizado com o mesmo significado nos dois casos? Não me parece que os textos forneçam elementos suficientes para uma resposta a essa pergunta. Talvez, se possa dizer somente que, enquanto na visão a figura é apreendida como materialmente presente, na imaginação a mesma figura (assim como o lugar - o $u b i)$ seja apreendida enquanto ausente (isto é, abstraída da presença da matéria). Em todo caso, o importante a destacar é que o objeto é apreendido pela imaginação, muito embora enquanto ausente, ainda sob condições da individuação na matéria. Tais condições, entretanto somente 'ocorrem' (accidunt) à forma na matéria - em outras palavras, elas são acidentais. Destarte, também na imaginação, como no sentido particular, há somente a apreensão de acidentes (mais precisamente, qualidades) sensíveis da coisa externa (agora, ausente). Em outras palavras, ainda que a imaginação conheça o objeto sensível como ausente, ela não conhece mais do que certas qualidade suas sob condições particulares, pois isso é o que lhe fornece o fantasma enquanto objeto da virtude imaginativa. Por isso mesmo, esse fantasma, enquanto espécie expressa/objeto imaginado, pode mover a imaginação, mas não pode mover o intelecto. De fato, ele não é universal, uma vez que é o objeto ausente sob condições de individuação na matéria.

Essa última afirmação, porém, parece contradizer o que lemos acima. Com efeito, era dito há pouco - no mesmo Quodl. 5, q. 14 - que “o objeto universal não 
existe para nosso intelecto senão no fantasma [universale obiectum intellectui nostro non alibi existit, nisi in phantasmate]"120. Como é possível que o fantasma, não podendo mover o intelecto por não ser universal, simultaneamente, tenha em si o objeto universal?

A resposta está em um detalhe do último texto indentado: "os fantasmas apreendidos na imaginativa não são universais senão em potência e, em potência, moventes do intelecto [phantasmata in imaginativa apprehensa non sunt nisi in potentia universalia, et in potentia moventia intellectum]"121. Dessa maneira, assim como a própria virtude imaginativa surge como intermediário entre o sentido particular e o intelecto, o fantasma parece estar a meio caminho entre o objeto do sentido particular, cuja espécie é impressa também na memória (a saber, a coisa existente externamente, materialmente presente), e o objeto do intelecto (aquilo que Henrique, por vezes, chamará de 'coisa universal' ${ }^{122}$ ). Como Jerome V. Brown enfatiza, as próprias condições particulares do fantasma "aliás, contribuem em muito para o caráter peculiar do fantasma. Elas dão a ele um parentesco com a espécie 'progenitora' na memória. Ao mesmo tempo, a ausência do singular extra-mental dá a ele imaterialidade suficiente para que funcione como a base da universalidade

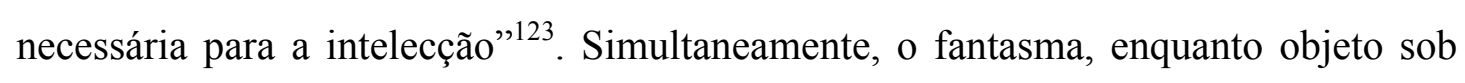
condições de individuação na matéria, é apreendido como singular; porém, enquanto espécie do objeto ausente (abstraído da presença da matéria), pode ser tomado como o universal em potência, isto é, como o objeto ou movente do intelecto em potência.

A passagem da universalidade em potência para a universalidade em ato, no fantasma, ocorre por mais uma abstração. Reiteremos, com efeito, que o fantasma, objeto imaginado, já é o objeto abstraído da presença da matéria; porém, para que tal

\footnotetext{
${ }^{120}$ Cf. nota 112 , acima.

${ }^{121}$ Cf. nota 119 , acima.

${ }^{122}$ Cf. nota 125 , adiante.

${ }^{123}$ BROWN, J. V. 'Henry of Ghent on Internal Sensation”, 1972, p. 23: "Under 'particular conditions,' Henry enumerates 'figure and 'where'.' These 'particular conditions,' moreover, contribute much to the phantasm's peculiar character. They give it a kinship with the 'parent' species in the memory. At the same time, the absence of the extra-mental singular gives it enough immateriality for it to function as the basis of the universality that is needed in intellection". Em nota a esta passagem, Brown remete ao texto aqui citado acima, na nota 119. Ainda sobre o caráter simultaneamente singular e universal (em potência) do fantasma, Brown adiciona op. cit., p. 24: "The phantasm in the imagination may therefore be viewed legitimately in two different ways. Seeing it as the 'offspring' of the 'parent' species in the memory, we may quite properly describe it in terms of particular and material being. Seeing it from the level of the intellect, we may continue to describe it as a hoc, but as a hoc which is quasi-universal; i.e., as a hoc which is a universal-in-potency".
} 
fantasma seja inteligível não somente em potência, mas também em ato, é necessária mais uma abstração, a saber, justamente aquela que não ocorrera ainda na imaginação: a abstração das “condições particulares que ocorrem à forma, segundo é individuada na matéria [conditionibus particularibus quae accidunt formae, secundum quod est in materia individuata]", a que o Doutor Solene se referia há pouco $^{124}$. Essa última abstração é possível somente pela ação do próprio intelecto, como é estabelecido por Henrique de Gand em Suma, art. 58, q. 2:

\begin{abstract}
" $<\ldots>$ o lume do intelecto agente irradia sobre o fantasma particular que existe assim em ato na fantasia. E, do modo predito, $<$ ele $>$ abstrai o fantasma universal do particular e o propõe ao intelecto possível, como objeto próprio modificativo dele, pelo qual é modificado com o ato de intelecção - ou seja [sive], com o ato de inteligir - para o conhecimento não de si $<s c$. do fantasma $>$, mas da coisa universal de que é uma espécie, muito embora não abstraia dela $<s c$. da coisa $>$, mas do fantasma particular abstraído da coisa particular fora na qual o universal existe em potência, tal como a espécie da cor tampouco modifica a visão para o conhecimento de si $<s c$. da espécie>, mas da cor de que é abstraída <tal espécie $>" 125$.
\end{abstract}

Note-se como ao fim dessa passagem todo o processo de conhecimento é descrito como uma série de abstrações. No sentido particular, a espécie impressa é abstraída da coisa, assim como também o fantasma o é (nesse ponto, sabemos que aquela é abstraída da matéria da coisa externa presente e propicia uma apreensão dessa coisa como materialmente presente, enquanto que o fantasma é abstraído da presença da matéria, mas não das condições particulares do indivíduo na matéria). $\mathrm{O}$ objeto do intelecto, por sua vez, é também fruto de abstração, mas dessa vez de uma abstração das próprias condições particulares - esta última abstração propicia, precisamente, o objeto universal.

Enfim, aquele 'processo da notícia humana' (progressum humanae notitiae) de que se falava em Quodl. 4, q. $21^{126}$, surge agora como uma sucessão de abstrações desde o objeto externo presente materialmente até o objeto universal - este último,

\footnotetext{
${ }^{124}$ Cf. nota 119 , acima.

${ }^{125}$ Henrique de Gand, Suma, art. 58, q. 2, ad 3 (ed. 1642-6, pp. 1008a, n. 43): “< ..> supra phantasma particulare quo sic phantasia existit in actu, irradiat lumen intellectus agentis. Et praedicto modo phantasma universale a particulari abstrahit, et intellectui possibili proponit, ut obiectum proprium illius immutativum, per quod actu immutatur intellectione, sive actu inteligendi ad cognitionem non sui, sed rei universalis, cuius est species, licet non ab illa abstrahitur, sed a phantasmate particulari abstracto a re extra particulari, in qua potentia existit universale, sicut neque species coloris immutat visum ad cognitionem sui, sed coloris a quo abstrahitur".

${ }^{126}$ Cf. cap. 4 , nota 37.
} 
aquele objeto propriamente capaz de modificar o intelecto. Se esse processo distingue diversas etapas de abstração, ele garante, ao cabo, a unidade de todo o conhecimento humano - no fim, mesmo o objeto universal é, em última instância (e ainda que com intermediários), abstraído da própria coisa que estivera materialmente presente fora para o sentido particular. A distinção entre essas diversas abstrações permite, em poucas palavras, a manutenção da unidade do processo de conhecimento humano, ainda que este necessariamente seja cindido em diversas etapas (correspondentes a diversos objetos e diversas forças da alma capazes de apreender cada qual seu objeto próprio).

Há, porém, ainda outro elemento peculiar nessa passagem de Suma, art. 58, q. 2. Agora, aquele fantasma que é objeto imaginado/espécie expressa pela imaginação é caracterizado, mais precisamente, como 'fantasma particular' (phantasma particulare), pois ele é oposto ao 'fantasma universal' (phantasma universale). Esse segundo é aquilo que o intelecto agente abstrai do fantasma particular e apresenta ao intelecto possível. Ou seja, o fantasma universal é o próprio fantasma particular abstraído das condições particulares do indivíduo material. Essa abstração, porém, só é possível pela ação do intelecto agente. Essa distinção entre 'fantasma particular' e 'fantasma universal' é fundamental para a compreensão da noção de conhecimento intelectual desenvolvida por Henrique de Gand - Jerome V. Brown, por exemplo, dedica razoável espaço a ela em seu estudo sobre a imaginação no pensamento do Doutor Solene $^{127}$. Eu, por outro lado, reservarei esse tema para a próxima etapa do nosso trabalho, onde iremos lidar com o conhecimento intelectivo.

De fato, pudemos ver como o discurso sobre a imaginação nos leva, paulatinamente, em direção à consideração acerca do intelecto - é nessa direção que seguiremos para concluir nossa pesquisa. Antes, porém, tentemos resumir o que aprendemos nesse esparso discurso de Henrique acerca daquilo que nos permitimos agrupar sob o rótulo de 'sentidos particulares'.

\subsection{O DISCURSO SOBRE OS SENTIDOS INTERNOS}

Parece arriscado nos referirmos ao tratamento dispensado por Henrique de Gand àquilo que denominamos de 'sentidos internos' como 'esparso', dadas as muitas

\footnotetext{
${ }^{127}$ Cf. BROWN, J. V. "Henry of Ghent on Internal Sensation", 1972, pp. 24-7.
} 
páginas pelas quais nos alongamos no estudo do tema. Essas páginas, no entanto, não são reflexo de uma reiterada dedicação do Doutor Solene ao tema. Pelo contrário, elas são justamente o fruto da dificuldade de conciliar entre si as poucas passagens que nos oferecem pistas acerca de sua concepção das operações internas da potência sensitiva.

Em princípio, o problema aqui é o mesmo que encontramos no que dizia respeito ao sentido particular: nosso autor está preocupado com os sentidos, antes de tudo, para estabelecê-los como a origem do conhecimento intelectual, de maneira que não há em sua obra espaço para um discurso estritamente voltado para o conhecimento sensitivo. Entretanto, esse quadro é piorado no estudo dos sentidos internos por Henrique de Gand não haver nem mesmo determinado quais seriam, precisamente, as potências sensitivas de que tratamos nesse campo. Comecemos pelo fato de que, embora sempre descritos como orgânicos, esses sentidos internos não tem seus respectivos órgãos determinados por Henrique (diferentemente do que ocorria no caso do sentido particular). Mais grave, porém, é que há profundas dificuldades próprias ao tratamento de cada um desses sentidos internos. Se parece patente que há uma imaginação ou fantasia como potência da alma necessária para o processo de conhecimento humano, o sentido comum ou universal nem mesmo é coerentemente descrito como virtude da alma (sendo, por vezes, identificado ao sentido particular). Da mesma maneira, a memória se mostra fugidia - ela ora desaparece ora emerge nas diversas narrativas do processo de conhecimento sensitivo oferecidas pelo Doutor Solene.

No caso do sentido comum, a dificuldade em estabelecer seu estatuto no processo de conhecimento parece fundamentalmente conectada à ausência de uma determinação precisa de seu objeto próprio - em outras palavras, não está claro o que seria o 'sensível comum ou universal' para Henrique. Tal sensível comum é, por vezes, apresentado somente como a intenção percebida (não apreendida) pelo próprio sentido particular. Essa solução, porém, termina por dificultar ainda mais a compreensão dessa doutrina, pois traz consigo a exigência de que os sentidos particulares sintam também sensíveis comuns. A isso se soma a difícil compreensão da noção de percepção do sentido particular acerca daquilo que havia apreendido: ela seria como um juízo do sentido ou como uma reflexão do sentido? Ambas as alternativas exigiriam a distinção entre duas virtudes sensitivas, pois forças orgânicas, segundo Henrique, não se convertem sobre seu próprio ato - um sentido só pode ser 
julgado por (ou só pode ser objeto de reflexão de) outra faculdade (ainda que sensitiva) superior. No entanto, Henrique afirma que apreensão do objeto e percepção do sensível comum são justamente produzidas por uma mesma potência cognoscitiva (sendo a estimação aquela que exige a distinção entre duas potências, embora nosso autor não pareça admitir uma potência estimativa). Ou seja, nossa pesquisa acerca da concepção de 'sentido comum ou universal' em Henrique de Gand é, na melhor das hipóteses, aporética. No fim, só sabemos que, se houver um 'sentido comum ou universal' como virtude da alma, ele cumpre seu papel no processo de conhecimento antes da imaginação, pois nos é dito que esta é mais ativa do que ele em Quodl. 2, q. $6^{128}$.

No caso da memória, estamos em terreno mais firme. Ela é consistentemente descrita como uma virtude orgânica da alma que possui por ato a retenção ou conservação da espécie impressa em seu órgão. Além disso, no estudo da memória retornamos à complexa relação entre potência e ato que víamos no estudo do sentido particular: a memória tanto tem a espécie impressa e retida em si como age, por essa espécie, para atualizar a imaginação. Ainda que Henrique admita, com base em Agostinho, não ser essa a melhor descrição da relação entre memória e imaginação, ele procura descrevê-la como a relação entre a progenitora (a memória) e a prole (a imaginação em ato) em Suma, art. 54, q. $9^{129}$. Se, por vezes, a memória é omitida da narrativa do processo de conhecimento sensitivo, talvez isso possa se justificar pelo fato de ela não apreender o objeto de que a espécie impressa nela é intenção, mas antes somente reter tal espécie em si na ausência do objeto externo.

Se o interesse de Henrique nos sentidos se deve, principalmente, a seu foco no estudo da intelecção, não surpreende que, no âmbito do que denominamos aqui 'sentidos internos', sua atenção tenha se voltado principalmente para a imaginação ou fantasia. Aqui, ainda mais do que na memória, a dificuldade é marcadamente a conciliação entre passividade e atividade. Não está claro que o gandavense tenha atingido uma posição final acerca da necessidade ou ausência de espécies impressas (para a além da espécie impressa na memória) no próprio órgão da imaginação nenhum texto as nega claramente, mas também elas não parecem ser veementemente afirmadas ou, ao menos, ganharem um papel preciso no processo de atualização do

\footnotetext{
${ }^{128}$ Cf. nota 40 , acima.

${ }^{129}$ Cf. nota 55, acima.
} 
conhecimento imaginativo. Destarte, fica difícil compreender exatamente como a imaginação padece pela espécie impressa que existe na memória. Por outro lado, a atividade da imaginação é fundamental para a compreensão daquilo que Henrique entende que seja o objeto imaginado, a saber: uma espécie expressa pela imaginação, a partir da espécie impressa na memória (quiçá, também impressa no órgão da imaginação). Tal espécie expressa é a causa próxima do ato de imaginação (uma vez que sua causa remota, o objeto externo material, está ausente fora). Essa espécie expressa, descrita como 'feita' pela imaginação, mantém uma identificação com objeto material externo (de fato, a imaginação propriamente conhece este último pela espécie expressa), porém deste se distingue enquanto intenção que permite o conhecimento deste último enquanto ausente ou, melhor, enquanto 'abstraído da presença da matéria' (ainda que sob as condições particulares de individuação na matéria). Esse objeto feito pela imaginação é, precisamente, o fantasma que, abstraído da presença da matéria, é ainda conhecido enquanto particular - daí que seja, mais precisamente, denominado como 'fantasma particular'. Tal 'fantasma particular' está, com efeito, a um passo de se tornar um objeto universal - ou, rigorosamente, um 'fantasma universal', que será para o intelecto a intenção feita pelo próprio intelecto e que permitirá o conhecimento daquela 'coisa universal' para além do intelecto. Nesse ponto, entretanto, já nos direcionamos para um discurso acerca da potência intelectiva, o que será objeto do próximo capítulo.

Pois bem, se esse rápido resumo de tudo o que vimos neste cap. 5 parece razoavelmente coerente, isso se deve a um certo esforço de leitura conjunta de textos que, embora superficialmente concordes, apresentam profundas discrepâncias após uma leitura mais minuciosa. Se, no que tange a muitos dos problemas abordados nesta etapa, terminamos em uma indecisão, isso se deve principalmente a não havermos buscado disfarçar as diferenças nessas minúcias introduzidas por Henrique, a cada caso, em suas diversas abordagem dos sentidos internos.

Ainda assim, acredito ser possível, restringindo-nos à relação entre sentido particular, memória e imaginação (e, portanto, excluíndo a referência ao sentido comum), obter um quadro geral coerente do processo de conhecimento sensitivo. Ele é, basicamente, uma sucessão de abstrações - desde a abstração da espécie impressa no sentido particular com respeito à matéria própria do sensível até a abstração, pela imaginação, da presença do sensível na matéria (possibilitada pela retenção, já na ausência do sensível, daquela espécie impressa na memória), mas não das condições 
particulares de individuação desse sensível na matéria. A abstração seguinte, destas condições, já será obra do intelecto agente.

Dito isso, obedeçamos, por fim, às instruções do próprio Henrique de Gand em Suma, art. 1, q. 1: "feita a apreensão pelos sentidos, cumpre desviar dos sentidos, tal que se faça um juízo pela razão"130. Com efeito, agora que compreendemos um pouco melhor as operações dos sentidos, voltemo-nos para a operação segunda própria dos animados intelectuais que somos nós mesmos. Agoras estamos em posição de compreender o que seria, para Henrique de Gand, a operação do intelecto humano resultante dessa abstração intelectual a que já nos referimos no estudo da imaginação.

\footnotetext{
${ }^{130}$ Cf. cap. 1, nota 47.
} 


\section{CAP. 6. \\ O CONHECIMENTO INTELECTIVO}

\subsection{UM PROBLEMA INTRODUTÓRIO}

A partir de agora, estamos em um dos terrenos mais polêmicos e estudados do pensamento de Henrique de Gand, a saber, sua doutrina da inteleção abstrativa. Neste campo, duas são as noções que mais alimentaram as discussões dos comentadores: species e verbum. Não obstante pareça algo por demais pontual, a discussão acerca de tais termos é elementos fundamental em uma doutrina da intelecção escolástica como aquela do Doutor Solene, uma vez que nela a species é, em geral, concebida como um ponto de partida da formação da intelecção em ato, enquanto que o verbum surge como, em algum sentido, o resultado de tal intelecção. Ou seja, o estabelecimento preciso do significado dessas duas noções termina por determinar a própria concepção de intelecção, de sua origem e de seu fim. Ora, se os significados de ambos os termos - species e verbum - foram precisamente campos de disputa entre os comentadores do Doutor Solene, começa a ficar claro o porquê da polêmica em torno da noção de intelecção em Henrique de Gand. Se não há entendimento quanto a seus elementos fundamentais, não parece ser possível uma concordância quanto a seu caráter geral. Sendo assim, provavelmente, a melhor maneira de adentrar essa temática é atentarmos para a história dos comentários a respeito.

Voltando a 1795, lemos a seguinte interpretação de Dietrich Tiedemann acerca das espécies inteligíveis no pensamento do Doutor Solene: "[a]s imagens do pensamento [Denkbilder] são unicamente necessárias quando os objetos não estão essencialmente incorporados no intelecto, mas estão ausentes, pelo que a presença interna do objeto inteligível é suficiente para o pensar. Isso quer dizer que há coisas que podem ser pensadas por si mesmas, sem qualquer conceito"1. Notemos que, nessa passagem, Tiedemann afirma que o conhecimento necessita de espécies inteligíveis

\footnotetext{
${ }^{1}$ TIEDEMANN, Geist der spekulativen Philosophie. Vieter Band, 1795, p. 575: "Die Denkbilder sind nur nöthig, wo die Gegenstände dem Verstande nicht wesentlich einverleibt, sondern abwesend sind, mithin ist innere Gegenwart des denkbaren Gegenstandes zum Denken hinreichend; das heißt, es giebt Dinge, die durch sich selbst, ohne alle Begriffe, können gedacht werden".
} 
(em suas palavras, Denkbilder ${ }^{2}$ ) para sua atualização, uma vez que elas suprem a presença do objeto inteligível ausente. Por outro lado, daí ele conclui que há alguns casos em que tais espécies não seriam necessárias - a saber, quando o próprio objeto já estiver suficientemente presente ao intelecto. Brevemente, ressalvadas as exceções, espécies são necessárias para o conhecimento intelectual. Tal posição foi aquela em geral seguida pelos comentadores de grande parte do século XIX. Assim, lemos em Wilhelm Gottlieb Tennemann, um autor claramente dependente de Tiedemann nesse ponto, que Henrique de Gand, em sua Theorie des Verstandes, não foi além "da comparação do pensamento com a sensação, da distinção entre o intelecto passivo e o agente, das imagens pensáveis (species intelligibiles), as quais se imprimem no intelecto e, assim, são concebidas por ele. Entretanto, ele aceitou imagens do pensamento apenas daquelas coisas que são separadas do intelecto e afirmou que haveria também objetos que por si mesmos, sem qualquer conceito, poderiam ser pensados - nomeadamente, aqueles que estão essencialmente incorporados ao próprio intelecto" ${ }^{3}$. Enfim, encontramos posições semelhantes em outros leitores do período e posteriores ${ }^{4}$.

\footnotetext{
${ }^{2}$ Que a noção de Denkbild seja utilizada por Tiedemann como tradução de species intelligibiles parece ser claro pelo seguinte excerto de sua Geist der spekulativen Philosophie. Vieter Band, 1795, p. 574: "Dies bestimmende ist gewissermaßen eine Form des Vertandes, und ein denkbares Bild (species intelligibilis) des Gegenstandes, dem Verstande, wie einem Subjekte, eingedrukt" (note-se que, para Tiedemann, essa era uma opinão padrão que Henrique não somente aceitava, mas à qual ele adicionou apenas incoerências - ibid., p. 575: “<... er mehrt es noch mit neuen Ungereimtheiten"). As mesmas expressões - Denkbild e denkbares Bild - ressurgem, com esse mesmo uso, na passagem de Tennemann destacada na próxima nota.

${ }^{3}$ TENNEMANN, Geschichte der Philosophie. Achter Band, Zweite Hälfte, 1811, p. 685: "Er blieb bei der Vergleichung des Denkens mit dem Empfinden, bei der Unterscheidung des leidenden und thätigen Vertandes, bei den denkbaren Bildern (species intelligibiles), welche sich in dem Verstande abdrucken, und dadurch von ihm begriffen werden, stehen. Indessen nahm er die Denkbilder nur bei denjenigen Dingen an, die von dem Verstande getrennt sind, und behauptete, daß es auch Gegenstände gebe, welche durch sich selbst, ohne alle Begriffe, gedacht werden können, nämlich solche, die dem Verstande selbst wesentlich einverleibt sind".

${ }^{4}$ Cf. GERANDO, J.-M. de Histoire comparée des systèmes de philosophie. Tome IV. Paris: Eymery Rey et Gravier - Aillau, $1825^{2}$ [1822], p. 516: "En souscrivant à l'hypothèse des Péripatéticiens sur le double ordre d'espèces intermédiaires qui se placent entre les objets et l'esprit humain, pour fonder leurs rapports dans la perception sensible et dans la pensée, il <sc. Henrique de Gand>admit cependant certains objets qui s'offrent directement à l'entendement, sans le secours de ces sortes de figures" (grifo no original). Outro autor a destacar o papel das espécies inteligíveis em Henrique de Gand ainda no século XIX é WERNER, Heinrich von Gent als Repräsentant..., 1878, p. 10: "Anders aber verhält es sich bei Heinrich von Gent, welcher die Leiblichkeit als solche der Seele äusserlich gegenüberstehen lässt, und demzufolge die leibliche Sensation nur als Gelegenheitursache des in der Seele selber aus Anlass ihres Contactes mit dem Sinnenobjecte aufleuchtenden Gedankes desselben ansehen kann; und dessungeachtet spricht auch Heinrich von einem Abstrahiren der Species intelligibiles der Dinge aus der sinnlichen Apperception derselben". Mais recentemente, a mesma atribuição de espécies inteligíveis sem mais ao intelecto foi vista em Henrique de Gand por Krescenty Dudak, em "Zarys problematyki poznawczej w Summae quaestionum Henryka z Gandawy”. Roczniki filozoficzne 11.1
} 
Entretanto, a partir de 1838, surge uma leitura mais nuançada nomeadamente, aquela de François Huet. Este distingue duas espécies diferentes que estariam em jogo na discussão escolástica sobre a inteleção: “< ..> Henrique de Gand diz que as espécies inteligíveis são abstraídas e formadas pela inteligência, species sensibiles expressae, enquanto São Tomás as vê simplesmente como impressas na

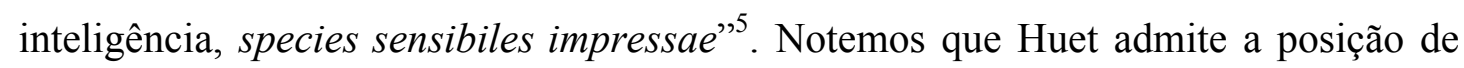
Tiedemann e Tennemann, mas com uma precisão importante: Henrique de Gand aceitaria espécies inteligíveis no processo de intelecção, porém de um tipo bem determinado, a saber, 'espécies expressas' (em oposição às 'espécies impressas') ressurge aqui, portanto, aquela distinção que já vimos acima ao tratarmos dos sentidos particulares, nos itens 4.3 e 4.4. Essa leitura de Huet é acompanhada, já em fins do século XIX, por Georgius Hagemann ${ }^{6}$.

Tal interpretação é desafiada, porém, em 1894, quando da publicação dos Études sur Henri de Gand de Maurice de Wulf. Nessa obra ele desenvolve uma aberta crítica da posição de Huet: “O sr. Huet não é mais feliz ao dizer que em Henrique de Gand 'a espécie inteligível é expressa, formada e abstraída pela inteligência'. Isso tanto se afasta da verdade que Henrique de Gand, como mostraremos, não admite qualquer espécie inteligível no sentido que a tradição científica ligou a esse termo. $<\ldots>$ ele rejeita como supérflua e impossível essa engrenagem intermediária entre o

(1963), pp. 113-35 (esp. p. 125): “Graças à luz o olho enxerga as cores e as formas; graças ao intelecto agente, o intelecto possível entra em contato com a species intelligibilis [Dzięki światlu oko dostrzega kolory i ksztalty; dzięki intelektowi czynnemu intelekt możnościowy wchodzi $w$ kontakt ze species intelligibilis]" (grifo no original).

${ }^{5}$ HUET, Recherches historiques..., 1838, p. 135: “< $<$. > Henri de Gand dit que les espèces intelligibles, sont extraites et formées par l'intelligence, species sensibiles expressae, tandis que S. Thomas les regarde simplement comme imprimées dans l'intelligence, species sensibiles impressae". Huet é seguido de perto por LAJARD, F. "Henri de Gand". In: Histoire littéraire de la France. Tome XX. Paris: Académie royale des Inscriptions et Belles-Lettres, 1842 (Nendeln: Kraus Reprint, 1971), pp. 144-203 (para a citação a seguir, p. 181): "Et tandis que Thomas d'Aquin regarde les espèces sensibles ou intelligibles comme simplement imprimées dans l'intellect, species sensibilies impressae, Henri de Gand declare qu'elles sont, ainsi que les universaux, formées par l'intellect, species sensibilies expressae".

${ }^{6}$ HAGEMANN, De Henrici Gandavensis..., I. 1898, p. 7: "Das Sinnenbild wird von dem thätigen Verstand (intellectus agens) erleuchtet, von den konkreten, individuellen Eigenschaften abgelöset und erregt so als Allgemeinbild den intellectus possibilis, der dadurch veranlasst den geistigen Gedanken des Gegenstandes in sich ausdrückt (species expressa). Diese Erklärung der geistigen Erkenntnis weicht nur in einem einzigen Punkte von jener der damaligen Aristoteliker, insbesondere des $h$. Thomas ab, nämlich darin, dass Heinrich nicht eine species impressa zulassen, also nicht zugeben will, dass in Folge der Erleuchtung des Sinnenbildes durch den intellectus agens ein Gedankenbild (species impressa) im intellectus possibilis entstehe, mittelst dessen der Verstand den Gedanken des Gegenstandes in sich ausprägt”. 
fantasma e o entendimento. Esse é o ponto original de sua doutrina"”. Como se vê, Wulf não somente nega a tese genérica de Tennemann e Tiedemann, segundo a qual Henrique de Gand aceitaria espécies inteligíveis tout court no processo de intelecção, mas recusa particularmente a leitura de Huet, que adiciona a necessidade de distinguir entre 'espécies expressas', que seriam aceitas por Henrique, e 'espécies impressas', por ele recusadas. Em contrapartida, Wulf enfatiza a relação direta estabelecida pelo gandavense entre o intelecto e o fantasma na imaginação - em particular, o 'fantasma universal', que já encontramos acima ${ }^{8}$. Essa foi uma posição aceita por muitos comentadores, sendo possível reencontrá-la até meados do século $\mathrm{XX}^{9}$.

\footnotetext{
${ }^{7}$ WULF, Études sur Henri de Gand, 1894, p. 90: “M. Huet n'est pas plus heureux en disant que chez Henri de Gand 'la species intelligible est expresse, formée et abstraite par l'intelligence'. Cela est si peu vrai que Henri de Gand, comme nous le montreront, n'admet aucune espèce intelligible, dans le sens que la tradition scientifique a attaché à ce terme. Précurseur des Durand, des Occam, mais pour de tout autres motifs, il rejette comme encombrant et impossible, ce rouage intermédiaire entre le phantasma et l'entendement. C'est le point original de sa doctrine sur le mécanisme de la pensée" (grifo no original).
}

${ }^{8}$ Cf. WULF, Études sur Henri de Gand, 1894, p. 94.

${ }^{9}$ BRAUN, Die Erkenntnislehre..., 1916, pp. 29 e 35: "Die Species impressa ist für Heinrich nicht nur überflüssig und unnütz, sondern auch unmöglich $<\ldots>$. Heinrich erklärt somit die Abstraktion mit Ausschluß jeder Species intelligibilis"; UEBERWEG, F. Grundriss der Geschichte der Philosophie. Zweiter Teil. Hrsg. von Matthias Baumgartner. Berlin: Siegfried Mittle und Sohn, $1915^{10}$ [1864], p. 513: "Das Objekt des Intellekts, das Intelligible oder Universale existiert im Phantasma, ja ist nur das phantasma universale und ist dem Intellekt gegenwärtig, weshalb es auch unmittelbar auf den Intellekt wirken kann ohne Zuhilfnahme einer dem Intellekt eingeprägten species $<\ldots$. " - este texto é precedido por uma passagem em que, na prática, se traduz literalmente o texto de Wulf que vimos na nota 7; SASSEN, F. "Een Nederlandsch wijsgeer: Hendrik van Gent". De katholiek 153 (1918), pp. 20-40 (esp. p. 34): "Em contraposição ao conhecimento sensitivo, o intelectivo não ocorre por meio de espécies. Uma vez que as potências de conhecimento sensitivo, o intellectus agens e o intellectus possibilis são, efetivamente, um único e mesmo, a quidditas envolta no fantasma está imediatamente presente para o intellectus possibilis e, assim, não precisa ser transmitida como espécie [In tegenstelling met de zinnelijke voltrekt zich zoo de verstandelijke kennis niet door middel van species. Daar zinnelijk kenvermogen, intellectus agens en intellectus possibilis in werkelijkheid een en dezelfde zijn, is de quidditas, in 't phantasma omhuld, onmiddelijk bij den intellectus possibilis aanwezig en behoeft ze dus niet als species te worden overgebracht]"; BOURGEOIS, "La théorie de la connaissance intellectuelle...", 1936, pp. 245-6: "Il y a là, plutôt qu'une véritable abstraction une simple mise en lumière, une dénudation. L'intellect agent élague, débroussaille, met au net, mais l'intelligible est dans le phantasme en puissance très proche d'actuer l'intellect possible. Il lui suffit d'une toilette pour être présentable et alors, mis en lumière, il provoque sans intermédiaire l'intellection. Nous n'aurons eu besoin d'espèce intelligible ni impresse ni expresse $<\ldots$. . Dans tout cela, il n'y a aucune place pour les espèces intelligibles impresses ou expresses. Henri les repousse absolument". Cf. tb. as rápidas referências ao tema em: KLIMKE, F. Institutiones historiae philosophiae. Volumen primum. Romae - Friburgi Brisg.: Sumptibus Universitatis Gregorianae Herder, 1923, p. 226; HARRIS, C. R. S. Duns Scotus. Vol. 1: The Place of Duns Scotus in Medieval Thought. New York: The Humanities Press, 1959 [1927], p. 241; PAULUS, Henri de Gand, 1938, p. 387; GILSON, É. History of Christian Philosophy in the Middle Ages. New York: Random House, 1955, p. 452; BOULNOIS, Etre et représentation, 1999, pp. 74-6. Um caso mais complexo é o de BEHA, "Matthew of Aquasparta's Cognition Theory. Part II: Ideogenesis", 1961, p. 22: "Sensation is primarily an activity of the sense power to form a species expressa, but the species impressa i.e. the impression made by the object, initiates the whole process $<\ldots>$. It is obvious then that Henry of Ghent requires a species to account for the union of the sense faculty and the object. He just as resolutely denies the need for such an intermediary on the intellectual level. According to Henry, there is no need 
Ora, há algum problema muito grave de interpretação aqui, pois como é possível que comentadores tenham posições frontalmente contrárias em um tema que cumpriria ser patente? A questão, parece, deveria ser direta: Henrique afirma a necessidade de espécies inteligíveis no processo de intelecção ou não? E, no entanto, as respostas são as mais díspares. Com efeito, mesmo Vital Zuccoli, em seu comentário seiscentista aos Quodlibeta do Doutor Solene, se mostra vexado em suas notas ao Quodl. 4, q. 21 (texto a que voltaremos): "ele <sc. Henrique> manifestamente nega, de fato, as espécies impressas, mas cumpre certamente notar que ele nega as espécies impressas que antecedem a intelecção <... > Mas não cremos

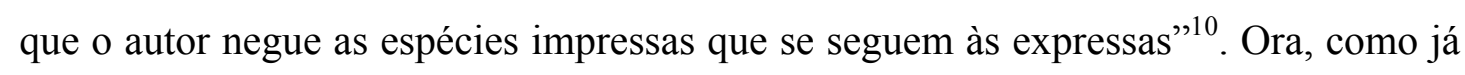
vimos acima no caso da imaginação, se admitirmos ambas as espécies em uma mesma faculdade cognoscitiva, as espécies impressas devem ser necessariamente anteriores às espécies expressas. Destarte, nessa passagem, Zuccoli parece incorrer em uma confusão: como poderia Henrique negar espécies impressas antes das expressas e afirmá-las como posteriores a estas últimas, se por definição as espécies impressas são anteriores às expressas?

Viria a dificuldade de Zuccoli do fato de que ele estaria buscando conciliar textos diferentes do Doutor Solene - alguns dos quais afirmariam espécies

for an intelligible species, since the sense species, transformed by the agent intellect, suffices for cognition. In other words, the intelligible element in the phantasm is directly united to the understanding $\langle\ldots\rangle$. Thus Henry rejects an intelligible species on two grounds: first, it is unnecessary because the intelligible element is already contained in the species expressa, and, secondly, any such similitude in the intellect would be a hindrance rather than a means to cognition since the species is the sign of the individual while the intellect knows only the universal" (grifos no original). Como vemos, a autora atenta para a distinção entre espécie impressa e espécie expressa nos sentidos e exclui a necessidade de espécies inteligíveis justamente por haver uma espécie expressa do intelegível já nos sentidos (aquilo que vimos ser o fantasma universal).

${ }^{10}$ ZUCCOLIUS PATAVINUS, V. "Commentaria", In: HENRICUS A GANDAVO. Quodlibeta. Tomus primus. Venetiis: apud Iacobum de Franciscis, 1613, f. 202r: "Manifeste enim negat species impressas, sed certe notandum, quod negat species impressas antecedentes intellectionem, sicut dantur species sensibiles impressae ante sensationem, quae non dicuntur impressae nisi in sensu tanquam in subiecto, per eas transmutato.

At quod dentur species impressas subsequentes expressas, quae dicuntur impressae, quia sunt in intellectu, non tanquam in subiecto, sed tanquam in cognoscente, non credimus Auctorem negare".

Um autor contemporâneo a se mostrar igualmente vexado com tal situação é Russell Friedman, que chama a atenção para o fato de que Henrique de Gand se utiliza da noção de species com respeito ao intelecto em diversos textos, muito embora recuse tal noção claramente em outras passagem: "One possible explanation for the apparent looseness of Henry's terminology is that he did not in fact reject intelligible species in the way he is most often portrayed to have done.

It should be noted that the modern view that Henry flatly rejected intelligible species has a good medieval pedigree" - FRIEDMAN, R. L. Intellectual Traditions at the Medieval University. The Use of Philosophical Psychology in Trinitarian Theology among the Franciscans and Dominicans, 12501350. 2 vols. Leiden - Boston: Brill, 2013, p. 261, nt. 74. 
inteligíveis, outros dos quais as negariam? Tal possibilidade explicaria igualmente aquela clara discordância que acabamos de ver entre os comentadores. Seria ela, antes de tudo, fruto de diferentes seleções de corpos textuais dentro do conjunto de obras de Henrique de Gand? Se for assim, seria possível elencar aqueles textos em que gandavense afirmaria a necessidade de uma espécie inteligível e aqueles nos quais ele a negaria?

A resposta afirmativa a essas perguntas foi precisamente a solução apontada para esse imbróglio por dois comentadores que escrevem em períodos próximos, mas que parecem desconhecer os trabalhos um do outro. Eles são Theophiel Nys, que publicou em 1949 o seu De werking van het menselijk verstand volgens Hendrik van Gent, e Efrem Bettoni, cujo Il processo astrattivo nella concezione di Enrico di Gand é dado a público em $1954^{11}$.

Ambos defendem a tese de que haveria um desenvolvimento na doutrina da intelecção de Henrique de Gand. Em seus primeiros textos, ele descreveria o processo de intelecção tomando a espécie inteligível como intermediário necessário entre o objeto de conhecimento e o intelecto. Em um segundo momento, ele mudaria de posição e passaria a negar a necessidade de uma espécie inteligível impressa como intermediário no processo de conhecimento intelectual, mantendo, por outro lado, a referência a uma espécies expressa na intelecção. Ou seja, para Nys e Bettoni, haveria grosso modo uma mudança fundamental na doutrina da inteleç̧ão de Henrique de Gand: ele passaria de uma primeira concepção simples de espécie para uma concepção complexa de espécie que permitiria [i] a distinção entre 'espécie impressa' e 'espécie expressa' e [ii] a admissão exclusiva de 'espécies expressas' como parte do

\footnotetext{
${ }^{11}$ NYS, De werking van het menselijk verstand..., 1949 [versão resumida em latim: NYS, T. De psychologia cognitionis humanae secundum Henricum Gandavensem. Excerpta ex dissertatione ad lauream in Facultate Philosophica Pontificiae Universitatis Gregorianae. Romae, 1949]; e BETTONI, Il processo astrattivo..., 1954. Sobre o livro de Nys, cf. a interessantíssima resenha de PAULUS, J. "À propos de la théorie de la connaissance d'Henri de Gand". Revue Philosophique de Louvain 47 (1949), pp. 493-6 (esp., p. 494): “Après 1279, un tournant décisif apparaît dans l'évolution de sa pensée, notament en ce qui concerne l'importante question des species impressae. Il commence par exclure des dites species dans les cas où l'objet connu est intimement présent à la faculté connaissante: connaissance de l'intellect par lui-même et connaissance de Dieu $<\ldots .>$. Dans la suite, l'exclusion des species est étendue à tous les types de connaissance $<\ldots$. ". Sobre estes três textos, cf. BELLAMARE, L. Les "Quaestiones super VIII libros Physicorum" attribuées à Henri de Gand. Vol. 1. Louvain: Université Catholoque de Louvain, Institut Supérieur de Philosophie, 1964, pp. 8-13. Dois autores mais recentes cujas leituras quanto à espécie inteligível em Henrique de Gand se aproximam bastante de Bettoni ou Nys são SORGE, Gnoseologia e teologia..., 1988, pp. 77-108; e PINI, G. "Il dibattito sulle specie intelligibili alla fine del tredicesimo secolo". Medioevo 29 (2004), pp. 267-306 (esp. pp. 27991). Com efeito, ainda que aponte a distinção entre 'impressive' e 'expressive' proposta por Henrique em sua doutrina da intelecção (op. cit., pp. 290-1), Pini considera que a decisão final de nosso autor é a recusa da espécie inteligível.
} 
processo de intelecção, rejeitando qualquer ocorrência de 'espécies impressas' no intelecto.

À consideração dessa mudança doutrinária, Nys adiciona um estudo igualmente fundamental a respeito da modificação da noção de verbum em Henrique. Esta, naquele primeiro momento em que ainda se aceitava a necessidade de uma espécie inteligível, seria identificada ao resultado do ato de intelecção. Num segundo momento, em consonância com a recusa da espécie inteligível, o gandavense deixaria de ver o verbum exclusivamente como resultado do ato de intelecção e passaria a identificá-lo, agora, principalmente com o conhecimento proposicional definitório ${ }^{12}$.

Além disso, ambos os comentadores afirmam igualmente que Henrique de Gand, desde a primeira fase de seu trabalho, já mostraria certa insatisfação com a noção de espécie inteligível ${ }^{13}$ - em particular, Nys destaca como importantes para o desenvolvimento do tema na obra de Henrique aquelas exceções à necessidade de espécies que já eram notadas por Tiedemann e Tennemann ${ }^{14}$ (isto é, a presença do próprio objeto ao intelecto acarretaria a inutilidade de uma espécie intermediária). Por fim, adicione-se que, para Nys e Bettoni, a tardia recusa de espécies impressas no intelecto por parte de Henrique de Gand está profundamente associada à sua doutrina da iluminação divina. De uma maneira ou de outra, ambos os comentadores consideram que, ao recusar espécies impressas no intelecto, o gandavense busca uma melhor expressão para sua concepção de auxílio divino no conhecimento da verdade ${ }^{15}$ (voltaremos à noção de auxílio divino para a intelecção no Epílogo desta segunda parte do trabalho).

\footnotetext{
${ }^{12}$ NYS, De werking van het menselijk verstand..., 1949, pp. 99-115. Além disso, em CANNIZZO, G. "La dottrina del 'verbum mentis' in Enrico di Gand", 1962, pp. 243-266, igualmente se discute um desenvolvimento na noção de verbum de Henrique de Gand. Cf. tb. ARGOS, "La actividad cognoscitiva en los escolásticos... - II/III", 1948, pp. 291-2.

${ }^{13}$ NYS, De werking van het menselijk verstand..., 1949, pp. 61-70; BETTONI, Il processo astrattivo..., 1954, p. 40. O primeiro comentador enfatiza, na passagem referida, que Henrique sempre considerou a ocorrência de diversas exceções quanto à necessidade de espécies inteligíveis intermediárias para o conhecimento; já o segundo destaca que, se - como veremos adiante, no Epílogo da parte 2 - já se admitia desde o início da obra do Doutor Solene que a espécie abstraída dos sentidos deve ser elevada pela iluminação divina para que ocorra o conhecimento intelectual da verdade, então o gandavense sempre admitiu que a espécie inteligível, fundamentalmente, não era mais do que sensível. Qualquer que seja o caminho da argumentação, o que desejo ressaltar aqui é somente que ambos - Nys e Bettoni - parecem considerar que a rejeição da 'espécie inteligível' por Henrique é a culminância de uma desconfiança de longa data com respeito a tal noção.

${ }^{14}$ Cf. notas 1 e 3 , acima.

${ }^{15}$ NYS, De werking van het menselijk verstand..., 1949, pp. 117-35; BETTONI, Il processo astrattivo..., 1954, pp. 21-37.
} 
Enfim, tal proposta de um desenvolvimento na doutrina da intelecção de Henrique de Gand ganhou sua versão mais complexa com a abordagem de Steven Marrone, já no ano de 1985. Este último busca integrar, em uma mesma narrativa, as possíveis mudanças de posição do Doutor Solene quanto às noções [i] de 'verdade', [ii] de species, [iii], de verbum e [iv] de 'iluminação divina' ${ }^{16}$. Pois bem, seria essa proposta de um desenvolvimento da concepção de intelecção na obra de Henrique a última palavra quanto ao tema?

Em certo sentido sim, pois ainda hoje é aceito o fato de que, pelo menos, algum tipo de desenvolvimento pode ser encontrado na doutrina da intelecção de Henrique de Gand. O que essa tese ganhou com o tempo foram nuances. Assim, certos estudos recentes vieram propor - de maneira enriquecedora, a meu ver - que tal discussão não é corretamente colocada em termos de uma radical passagem da aceitação da espécie inteligível para uma negação desta última, sendo antes necessário enfatizar que o Doutor Solene jamais abandona completamente o vocabulário da 'espécie inteligível'. Antes, o que ele faz é buscar modificar ou clarificar a descrição dessa noção, sem a qualquer momento rejeitá-la por completo. Muitos trabalhos atuais propõem que se releia a concepção de intelecção de Henrique de Gand sem uma ênfase tão grande em uma radical mudança de posição, antes entendendo as diversas etapas de sua reflexão sobre a intelecção como sucessivas clarificações de sua posição filosófica quanto ao conhecimento intelectual. Passará por tal releitura uma forte ênfase, por parte dos comentadores, na distinção entre species impressa e species expressa, cuja centralidade já vimos ser destacada por diversas vezes, mas tem sido

\footnotetext{
${ }^{16}$ MARRONE, Truth and Scientific Knowledge..., 1985. Em particular, Marrone concorda com a leitura de Nys, segundo a qual Henrique de Gand teria abandonado completamente a noção de species intelligibilis impressa (cf. op. cit., pp. 101-2), destacando entretanto que permanece ainda uma noção de species expressa na doutrina de Henrique de Gand. Marrone é igualmente devedor de Raymond Macken, que segue uma linha interpretativa próxima daquela de Nys, em MACKEN, R. "Le théorie de l'illumination divine dans la philosophie d'Henri de Gand". Recherches de Théologie ancienne et médiévale 39 (1972), pp. 82-112 (cf. esp., pp. 92-3). Uma versão resumida das mesmas teses presentes em seu livro pode ser lida em MARRONE, "Henry of Ghent's Epistemology", 2011, pp. 213-39. Como já mencionado na Introdução ao presente trabalho, uma das críticas de Paulus (em "À propos de la théorie de la connaissance d'Henri de Gand", 1949, pp. 494-6) a Nys é que este, em De werking van het menselijk verstand..., 1949, deixaria de considerar as razões externas (mas, também, as internas) da pretensa evolução do pensamento de Henrique de Gand acerca da intelecção. Ainda em sua resenha, Paulus destaca possíveis motivos metafísicos para tal evolução. Marrone, de sua parte (e ciente da crítica de Paulus a Nys - cf. Truth and Scientific Knowledge..., 1985, p. 103, nt. 30), dedica boa parte de seu livro (cf. Truth and Scientific Knowledge..., 1985, pp. 103-34) à exposição dos elementos metafísicos que se mostraram fundamentais para o desenvolvimento dos diversos aspectos da noção de intelecção por ele estudados em Henrique de Gand. Outro autor a assumir a tese de uma evolução na doutrina da intelecção de Henrique de Gand é C. Trottmann, em "Henri de Gand, source de la dispute...", 1996, pp. 312-20.
} 
recentemente mais cuidadosamente reconhecida e considerada no que diz respeito à doutrina da intelecção de nosso autor. Talvez possamos dizer que, em lugar de uma 'recusa da espécie inteligível' (como diriam Nys ou Bettoni), haveria em Henrique uma ressignificação da própria expressão "species intelligibilis"17.

Tal proposta, por outro lado, abre espaço para uma descrição que, sem afirmar um desenvolvimento na concepção de espécie inteligível de Henrique, proponha simplesmente uma leitura em conjunto de seus textos, buscando clarificar uns por meio de outros sem qualquer espaço reservado a uma preocupação com sua cronologia - é o que parece fazer, por exemplo, Jerome V. Brown ${ }^{18}$. De fato, se Henrique de Gand em todos os seus textos aceita, em algum sentido, a presença de

${ }^{17}$ Cf. SPRUIT, L. Species intelligibilis. From perception to knowledge. Volume I: Classical Roots and Medieval Discussion. Leiden - New York - Köln: Brill, 1994, pp. 205-12; PASNAU, Theories of cognition..., 1997, pp. 306-10; FIORENTINO, F. "Species nei secoli XIII-XIV”. Mediaevalia. Textos e estudos 26 (2007), pp. 81-135; ROMBEIRO,"Intelligible Species in the Mature Thought of Henry of Ghent", 2011, pp. 181-220; PICKAVÉ, "Causality and Cognition", 2015, pos. 11425-505. Cf. FRIEDMAN, Intellectual Traditions at the Medieval University, 2013, pp. 260-1. Outro autor a enfatizar a importância da distinção entre espécie impressa e espécie expressa na doutrina da intelecção de Henrique de Gand foi Camille Bérubé. Estudando Henrique de Gand em "La connaissance intellectuelle du singulier matériel au XIII ${ }^{\mathrm{e}}$ siècle”. Fransciscan Studies 11.3-4 (1951), pp. 157-201, na p. 176, ele afirma que: “< ..> l'objet de l'intellect, c'est ce même singulier sous la raison de l'universel saisi dans le phantasme sans aucune espèce impresse". Logo em seguida, ele adiciona: "Et ainsi, comme le dit le Philosophe, l'intellect appréhende les espèces intelligibles dans les phantasmes en appréhendant objectivement les phantasmes eux-mêmes. Les espèces universelles intelligibles se comportent à l'égard de l'intellect et des phantasmes comme l'image sensible de la couleur se comportent $<$ sic $>$ à l'égard de l'oeil et de l'objet extérieur $<\ldots>$. Connaître le singulier par l'intelligence et le connaître par l'imagination ne diffère qu'en ceci que l'imagination est mue par une espèce singulière impresse alors que l'intellect est mu par une espèce universelle expresse" (pp. 176-7, grifos no original). É importante notar, entretanto, que das duas passagens citadas do artigo de Bérubé, somente a primeira ainda consta em seu livro La connaissance intellectuelle de l'individuel au Moyen Âge. Montréal - Paris: Presses de l'Université e Montréal - PUF, 1964, p. 67; da segunda, resta somente uma paráfrase sem menção à espécies inteligíveis expressas: "Et ainsi, comme le dit le philosophe, les phantasmes sont à l'intellect, comme les sensibles, aux sens: il ne peut intelliger sans eux" (p. 68).

${ }^{18}$ Com efeito, em seus artigos de 1973-5, Jerome V. Brown se permitia dissertar sobre a noção de abstração em Henrique de Gand sem nem mesmo considerar o problema da presença ou ausência de uma recusa da espécie inteligível, mas simplesmente mostrando a maneira própria como o gandavense se utiliza de tal noção - cf. BROWN, J. V. "Abstraction and the Object of the Human Intellect according to Henry of Ghent”. Vivarium 11.1 (1973), pp. 80-104 (esp., pp. 86-7) e BROWN, J. V. "Intellect and Knowing in Henry of Ghent". Tijdschrift voor Filosofie 37.3-4 (1975), pp. 490-512, 692710. Brown ("Intellect and Knowing...", 1975, pp. 510-1, nt. 69) aponta para COPLESTON, A History of Philosophy II, 1993 [1950], p. 466, como outro texto no qual há a afirmação de uma doutrina das espécies inteligíveis no Doutor Solene. Nessa passagem do artigo de Brown, há igualmente uma referência à posição defendida por Bérube em seu artigo de 1951 (cf. a nota anterior) como uma afirmação de que haveria 'espécies inteligíveis' na filosofia de Henrique. No mais, essa mesma nota de Brown é destacada como "rather enigmatic wordings" por L. Spruit (Species intelligibilis I, 1994, p. 205, nota 140). Por fim, adicione-se que, pouco tempo antes do surgimento daquela tentativa de se reler criticamente a possível atribuição de uma resoluta 'rejeição da species' a Henrique de Gand, detectada a partir de Spruit (cf. a nota anterior), vemos ainda uma caracterização de sua posição final como um repúdio da espécie inteligível (ao modo de Nys ou Bettoni) em TACHAU, Vision and Certitude..., 1988, pp. 28-39. 
espécies no intelecto, não seria certamente um erro falar em qualquer modificação fundamental em sua concepção de intelecção? E, portanto, não seria inoportuno buscar barreiras cronológicas em um pensamento que se mostraria coerente em suas diversas etapas?

Minha resposta a essa pergunta é, mais uma vez, positiva e negativa. Positiva, na medida em que a referência onipresente nos textos de Henrique acerca da inteleção a uma 'espécie inteligível', a um 'verbo', ao 'intelecto agente' e ao 'possível' parecem, de fato, apontar para uma continuidade em sua reflexão sobre $o$ conhecimento e, mais precisamente, para a continuidade de seu arcabouço teórico fundamental de reflexão a respeito do tema. Nesse ponto, não parece haver espaço para a defesa de uma mudança radical promovida pelo Doutor Solene em sua concepção de conhecimento intelectual. Por outro lado - e aqui minha resposta àquelas perguntas é negativa -, a pesquisa recente com vistas à edição crítica da obra de Henrique de Gand tem demonstrado a existência de diversas camadas textuais que apontam para a ocorrência de modificações pontuais em textos acerca da intelecção por parte do mestre de Gand no decorrer de sua carreira. Nesse caso, se não se pode reconhecer claramente uma mudança radical na concepção de conhecimento intelectual esposada por Henrique, uma atenção maior à cronologia de sua obra (e das diversas camadas textuais evidentes em certos trechos de seu trabalho) permite a observação de certas mudanças pontuais, de certas nuances, que enriquecem o estudo da doutrina da intelecção do Doutor Solene. Tal procedimento - já sugerido por Steven Marrone - foi posto em prática muito proveitosamente no recente trabalho de Bernd Goehring ${ }^{19}$. Este foi muito feliz em se utilizar desses resultados recentes do projeto de estabelecimento do texto crítico das obras do gandavense para melhor apontar as diferentes exposições a que são submetidas aí as noções de species e de verbum. No item 6.3.1, adiante, veremos como a discussão sobre a noção de conhecimento intelectual do Doutor Solene pode ser enriquecida pela consideração

\footnotetext{
${ }^{19}$ MARRONE, S. P. "Henry of Ghent in Mid-Career as Interpreter of Aristotle and Thomas Aquinas". In: VANHAMEL, W. (ed.). Henry of Ghent. Proceedings..., 1996, pp. 193-209 (esp. pp. 195-6); e GOEHRING, Henry of Ghent on congition..., 2006. Nesta sua tese, Goehring desenvolve alguns dos elementos de crítica textual relevantes para uma leitura da doutrina da intelecção do Doutor Solene. Ele o faz em meio a uma reflexão sobre o problema do desenvolvimento da noção de verbum no decorrer da carreira de Henrique. Este último tema é retomado, resumidamente, em GOEHRING, B. "Henry of Ghent on the verbum mentis". In: GORDON, A companion to Henry of Ghent, 2011, pp. 241-72. Sobre o mesmo tema, cf. acima a nota 12 .
} 
das camadas textuais que se podem reconstruir para certos trechos de Suma, arts. 33 e 34.

Dito isso, parece-me não haver uma modificação radical da doutrina da intelecção de Henrique de Gand; porém, não há igualmente entre seus diversos textos um tenaz uníssono. Antes, com a devida atenção à cronologia de suas obras e às diversas camadas textuais visíveis na tradição manuscrita de alguns de seus textos, se torna possível acompanhar a paulatina clarificação pela qual passam as noções centrais de sua doutrina da intelecção. Mais precisamente, no que diz respeito à species, veremos que no início de sua Suma e em seus primeiros Quodlibeta, Henrique de Gand não vê a necessidade de distinguir entre espécie impressa e espécie expressa, sendo tal distinção introduzida posteriormente, principalmente a partir dos Quodl. 4 e 5. Da mesma maneira, se em seus trabalhos iniciais a noção de verbum surge simplesmente tomada como o resultado do ato de intelecção, em seus trabalhos posteriores - novamente, principalmente a partir do Quodl. 4 -, começa-se a exigir uma distinção entre um verbo associado ao conhecimento incomplexo e outro associado ao conhecimento complexo. Assim, o Doutor Solene não parece renegar por completo algum elemento de sua doutrina da intelecção; antes, ele parece a cada vez buscar um esclarecimento mais cuidadoso de determinados elementos chave para sua doutrina. Esse é o desenvolvimento doutrinal que buscarei ilustrar neste capítulo.

\subsection{AS PRIMEIRAS DISCUSSÕES SOBRE INTELECÇÃO}

\subsubsection{O intelecto e a espécie}

Uma das primeiras referências que encontramos à abstração ${ }^{20}$ na obra de Henrique de Gand surge ainda em Suma, art. 1, q. 1 (em uma passagem que já vimos

\footnotetext{
${ }^{20}$ Cabe, aqui, alguma explicação acerca da noção de 'abstração' que diz respeito à doutrina da intelecção de Henrique de Gand. Já vimos, no cap. 3, que a caracterização de um conhecimento como 'abstrativo' não é exclusividade do intelecto, pois todo conhecimento - sensitivo, imaginativo e intelectivo - é, cada qual a seu modo, abstrativo. No entanto, há mais usos da palavra de 'abstração' que merecem ser considerados para que melhor delimitemos a noção de 'abstração' que diz respeito ao intelecto. Olivier Boulnois (“Abstractio metaphysica. Le séparable et le séparé, de Porphyre à Henri de Gand”. In: PICKAVÉ, M. (Hrsg.). Die Logik der Transzendentalen. Festschrift für Jan A. Aertsen zum 65. Geburtstag. Berlin - New York: Walter de Gruyter, 2003, pp. 37-59, esp. pp. 55-6) chama a atenção para Suma, art. 48, q. 2, ad 2 (ed. De Wulf-Mansion Centre, vol. 30, pp. 51-2): "< $<>$ sunt diversi modi abstractionis et diversa diversimode sunt abstracta. $<1>$ Est enim quaedam abstractio realis unius ab alio, a quo omnino differt et re et subiecto, qualiter formae separatae, ut intelligentiae, dicuntur esse abstractae, quia non habent materiam partem sui nec cadunt in compositionem alicuius
} 
mais acima), onde se diz que "a mente colige" a notícia das quididades ${ }^{21}$ das substâncias (a matéria, a forma e outros deste tipo) "sob as espécies dos sensíveis a partir da ligação natural [ex naturali colligantia] dos sensíveis aos não-sensíveis, pela indústria da razão natural [naturalis rationis industria], como que cavando sob a própria espécie apresentada a ela pela coisa sensível [quasi fodiendo sub ipsa specie a sensibile re ei praesentata], do modo pelo qual a ovelha, por um instinto natural, estima por espécies sentidas as não-sentidas, como ao imaginar ou ver pela espécie sensível do lobo, estima que ele é nocivo ou inimigo. E, por isso, diz-se 'inteligir', como a partir de 'interior-ler' [dicitur intelligere quasi ab 'intus legere']"22. Vimos, no Epílogo da Parte 1, que esse 'cavar' em busca do não-sensível na espécie sensível diz respeito a uma ação do intelecto anterior ao uso da razão - essa ação é, portanto, anterior ao conhecimento proposicional e é restrita à inteligência dos conceitos simples. Todo nosso esforço neste item será compreender o que seria essa ação do intelecto que Henrique descreve como um 'cavar' nessa passagem.

tertii cum materia. $<2>$ Est autem alia abstractio rationis sive rationalis, et hoc per rationem et intellectum, quae est unius ab alio cum quo est idem, ad minus subiecto. Et est triplex, secundum quod quaedam sunt idem subiecto et differunt re, quaedam vero tantum intentione, quaedam vero ratione. $<2.1>$ Primo modo est abstractio formae materialis vel a materia in qua est. $<2.2>$ Secundo modo est abstractio universalis a particulari. $<2.3>$ Tertio modo est abstractio veri a ratione boni. Primo istorum trium modorum adhuc est duplex abstractio secundum quod forma dupliciter habet esse in materia a qua abstrahitur. <2.1.1> Quaedam enim forma habet esse in materia ut cui dat esse, ut forma substantialis, quae cum materia est idem in subiecto quod cum ipsa constituit, quae abstrahitur ab ipsa per intellectum abstractione metaphysica. $<2.1 .2>$ Alia autem forma habet esse in materia ut a qua recipit esse, ut forma accidentalis quae est idem subiecto cum eo cui accidit, a quo abstrahitur per intellectum abstractione mathematica. Quae duplex est secundum quod sunt genera formarum mathematicarum: $<2.1 .2 .1>$ quaedam quae per se et immediate inhaerent subiecto, ut quantitates continuae, $<2.1 .2 .2>$ quaedam vero quae mediante alia, ut quantitates discretae, sicut numeri mediante continua quae est magnitudo". A abstração que nos interessará aqui é o caso $<2>$ de abstração racional ou intelectual da $<2.1>$ forma e $<2.2>$ do universal; em menor escala, falaremos também da abstração $<2.3>$ que, na palavras de Boulnois, diz respeito ao transcendental (BOULNOIS, "Abstractio metaphysica...", 2003, p. 56). Em particular, no caso $<2.1>$ da abstração da forma, interessará principalmente $<2.1 .1$. $>$ a abstração dita aqui metafísica e não tanto aquela dita $<2.1 .2>$ matemática. Em todo caso, é importante destacar que, em seus discursos sobre a intelecção abstrativa que leremos no decorrer deste capítulo, não há uma separação tão clara entre as abstrações intelectuais aqui distinguidas. Assim, veremos que a abstração intelectual da $<2.1>$ forma já será um $<2.2>$ conhecimento universal e esse mesmo conhecimento universal terá como primeira etapa o conhecimento $<2.3>$ das noções primeiras ou, nas palavras de Boulnois, transcendentais. Cf. tb. a discussão sobre tema em BROWN, J. V. "Abstraction and the Object...", 1973, pp. 84-7.

${ }^{21}$ Sobre a noção de 'quididade', cf. a nota 55, adiante.

${ }^{22}$ Henrique de Gand, Suma, art. 1, q. 1, ad 7 (ed. De Wulf-Mansion Centre, vol. 21, pp. 27-28): “Et appellat $<s c$. Agostinho> res corporeas ut sensibiles sunt, res autem incorporeas quaecumque id quod sunt sensibilia non sunt, ut sunt mathematica et quidditates substantiarum, materia et forma et huiusmodi quorum notitiam mens sub speciebus sensibilium ex naturali colligantia sensibilium ad insensibilia naturalis rationis industria colligit quasi fodiendo sub ipsa specie a sensibili re ei praesentata, ad modum quo ovis naturali instinctu per species sensatas aestimat insensatas, ut imaginando vel videndo per speciem lupi sensibilem aestimat ipsum nocivum et inimicum, et ideo dicitur intelligere quasi ab 'intus legere"”. Cf. Ep. da parte 1, nota 2. 
Para vermos esse tema desenvolvido em maiores detalhes, entretanto, precisamos avançar para Suma, art. 1, q. 5. Nesse texto, diz-se que o intelecto é, "de si, em uma potência essencial receptiva, que não passa ao ato [non exit in actum] por si, mas por aquilo que recebe da espécie dos inteligíveis [de specie intelligibilium]"23. Já vimos mais longamente, nos capítulos 2 e 3, a fundamentação metafísica dessa caracterização do homem e, em particular, de seu intelecto como potências passivas para receber outros. $\mathrm{O}$ que surge de novo nesse excerto é a referência à necessidade de uma 'espécie dos inteligíveis' (species intelligibilium) pela qual o intelecto em potência passe ao ato. No entanto, mais do que resolver uma dificuldade, o recurso à espécie para explicar a passagem da potência ao ato por parte do intelecto simplesmente transfere o problema, pois agora é necessário responder donde proviria essa 'espécie' capaz de passar o intelecto da potência ao ato. Aliás, por que não afirmar que as próprias coisas sensíveis movem também o intelecto? Embora já tenhamos lido algo a respeito ao tratarmos da imaginação, veremos agora como tal problema é desenvolvido na abordagem da intelecção que encontramos ainda em Suma, art. 1, q. 5.

Com efeito, uma primeira resposta para essa pergunta está na linha seguinte àquela que acabamos de citar, quando nos é dito que "também as próprias espécies do intelecto, pelas quais ele deve ser informado, não são inteligíveis em ato nas próprias coisas sensíveis fora do intelecto, mas somente em potência - e, por isso, não podem, de si, fazerem-se em ato tal que movam o intelecto passivo" ${ }^{24}$. Por alguma razão, as próprias coisas não são inteligíveis - mais a frente, compreenderemos melhor o porquê disso. De qualquer maneira, parece que as espécies do intelecto atualizam o intelecto em lugar das coisas sensíveis de que são espécies, uma vez que estas próprias coisas sensíveis não poderiam fazê-lo. Em outras palavras, as species intellectus são substitutos inteligíveis das coisas conhecidas intelectualmente, mas que por si mesmas não são inteligíveis, ou melhor, são inteligíveis somente em potência. Quiçá, poderíamos dizer que a espécie do intelecto é o substituto inteligível em ato

\footnotetext{
${ }^{23}$ Henrique de Gand, Suma, art. 1, q. 5, co. (ed. De Wulf-Mansion Centre, vol. 21, pp. 124-5): "Est ergo $<s c$. intellectus $>$ de se in potentia essentiali receptiva, quae per se non exit in actum, sed per illud quod recipit de specie intelligibilium".

${ }^{24}$ Henrique de Gand, Suma, art. 1, q. 5, co. (ed. De Wulf-Mansion Centre, vol. 21, p. 125): "Ipsae etiam species intellectus quibus informari debet in rebus sensibilibus [BNF, ms. lat. 14312, f. $6 \mathrm{rb}, l l$. 41-2 | quibus in rebus sensibilibus informari debet ed. Wilson, $l .46$ - cf., no aparato crítico a esta passagem, a variante $B$ '] extra intellectum non sunt intelligibiles in actu, sed in potentia solum, et ideo nec de se possunt fieri in actu ut moveant intellectum passivum".
} 
daquilo que é inteligível somente em potência ${ }^{25}$. Outro elemento interessante nesta passagem é a oposição entre 'espécie do intelecto' e 'coisas sensíveis fora do

${ }^{25}$ Mas, o que seria propriamente o 'inteligível'? Determinar o campo do inteligível é, propriamente,
determinar todo o campo daquilo que pode ser abarcado pelo intelecto. Isso deve envolver tanto uma
referência à noção de 'essência', como também uma cuidadosa consideração da noção de 'coisa' (res),
provavelmente um dos termos mais centrais e complexos na obra de Henrique de Gand. Em poucas
palavras, podemos dizer que, para Henrique de Gand, o inteligível é aquilo que possui 'realidade'
(realitas), isto é, aquilo que pode ser dito 'coisa' (res), em algum sentido.
Essa doutrina pode ser lida em Quodl. 7, q. 1-2, ad 2 (ed. De Wulf-Mansion Centre, vol. 11, pp. 26-8). Essa doutrina pode ser lida em Quodl. 7, q. 1-2, ad 2 (ed. De Wulf-Mansion Centre, vol. 11, pp. 26-8).
Aí, Henrique começa por afirmar que haveria algo comuníssimo, que a todos contém por analogia (estamos, portanto, no campo de um nome ou de um conceito, mas não de uma coisa fora da alma). Este communissimum seria 'coisa' (res) ou 'algo' (aliquid) - desses dois termos, o primeiro será preferido. Pois bem, tomando res nesse sentido mais geral só se opõe a ela o 'puro nada' (purum nihil), que é descrito a partir de duas características: esse purum nihil não é nem é nato a ser [i] fora do intelecto ou [ii] em um intelecto como conceito. Assim, o purum nihil [i] não é nem pode ser fora da alma e [ii] não é nem pode ser na própria alma e, mais precisamente, no intelecto. A res, por outro lado, será justamente aqui que, pelo menos, pode - é nata a - ser como conceito no intelecto. Daí que o inteligível (isto é, aquilo que pode ser inteligivel) seja identificado àquilo que pode ser dito res, ou seja, tudo aquilo que possui realitas de alguma maneira: "omnium communissimum, omnia continens in quodam ambitu analogo, est res sive aliquid, sic consideratum ut nihil sit ei oppositum nisi purum nihil, quod nec est nec natum est esse, neque in re extra intellectum, neque etiam in conceptu alicuius intellectus, quia nihil est natum movere intellectum nisi habens rationem alicuius realitatis" (pp. 26-7). Nesse sentido mais comum, res não é um predicamento - com efeito, res não é, propriamente, um universal, porque não é predicado univocamente de muitos, caso contrário seria um gênero que conteria tudo e, em particular, conteria tanto o criador como a criatura. Pelo contrário, res é dito analogamente [i] daquilo que é ou é nato a ser somente em um conceito do intelecto e [ii] daquilo que, além de ser ou ser nato a ser somente em um conceito do intelecto, também é ou é nato a ser na coisa fora do intelecto. Como vemos, o segundo sentido análogo contém o primeiro. Assim, tudo o que [ii] é ou pode ser fora do intelecto, necessariamente [i] é ou pode ser no intelecto; o contrário, porém, não é válido, pois há algo que [i] é ou pode ser no intelecto e, no entanto, [ii] não é nem pode ser fora do intelecto - "Res autem, sive 'aliquid' sic communissime acceptum, non habet rationem praedicamenti, - sic enim esset tantum unum praedicamentum continens Creatorem et creaturam -, sed distinguitur distinctione analogica in id quod est aut natum est esse tantum in conceptu intellectus sive in ipso intellectu, et in id quod cum hoc aut est aut natum est esse in re extra intellectum" (p. 27). Para melhor caracterizar esses dois usos análogos de res, Henrique de Gand se utiliza de duas etimologias do termo: [1] res dita a reor reris e [2] res dita a ratitudine. No primeiro sentido [1] - isto é, no caso da res a reor reris -, é dito res tudo aquilo que é somente enquanto concebido como um todo pelo intelecto, mas não pode ser algo fora do intelecto enquanto esse todo. Exemplos dessas res são 'monte áureo' ou 'hircocervo': embora possa ser inteligido, nenhum dos dois, enquanto totalidade, é ou é nato a ser fora do intelecto. Por outro lado, suas partes - no primeiro caso, 'monte' e 'ouro', no segundo caso, 'bode' e 'cervo' - tanto são inteligidas como são ou são natas a ser fora do intelecto. Como se vê, enquanto os todos 'monte áureo' e 'hircocervo' são ou podem ser somente no intelecto (sendo res apenas a reor reris), suas partes são ou podem ser tanto no intelecto como fora dele (são, portanto, res a ratitudine). Assim, somente tais partes dizem respeito a predicamentos e, destarte, possuem essência - "Res primo modo est 'res' secundum opinionem tantum, et dicitur 'a reor, reris', quod idem est quod 'opinor, opinaris' quae tantum res est secundum opinionem, quoad modum quo ab intellectu concipitur, scilicet in ratione totius, ut est mons aureus, vel hircocervus habens medietatem cervi, medietatem hirci. Est tamen res secundum veritatem quoad partes eius quae sunt mons et aurum et huiusmodi; aliter enim non posset totum esse in intellectu et ens secundum opinionem, nisi partes essent aliquid secundum veritatem, quia ab alio non potest moveri intellectus. Quod sic est ens, secundum totum non est res praedicamenti, sed solum secundum suas partes" (p. 27). No segundo sentido [2] - isto é, no caso da res a ratitudine -, é dito res tudo aquilo que não somente é ou pode ser no intelecto, mas também é ou pode ser fora do intelecto. Nesse caso, a res se distingue analogamente em [2.1] naquilo que é o próprio ser (o criador) e [2.2] naquilo a que convém ou é nato convir o ser (criatura). Nesse sentido [2], há a res que possui essência, mas somente o caso [2.2] diz respeito às res que possuem essência categorial, isto é, sob os predicamentos - "Aliquid autem, sive res nata esse vel quae est aliquid extra intellectum, quae dicitur 'res a ratitudine', adhuc non habet rationem generis aut praedicamenti sicut neque prius, sed dividitur 
divisione analogica in id quod est aliquid quod est ipsum esse, et in id quod est aliquid cui convenit aut natum est convenire esse. Primum est ens increatum. Secundum continet rem omnis creaturae, nec habet rationem generis, quia non potest ei aliquid addi ut differentia, quod sit extra rationem eius quod est aliquid, aut eius quod est esse" (pp. 27-8).

A mesma doutrina é apresentada com certas diferenças em: Suma, art. 21, q. 2, co. (ed. Decorte \& Teske, p. 52), Suma, art. 21, q. 4, co. (ed. Decorte \& Teske, pp. 78-80), Suma, art. 24, q. 3, co. (ed. Decorte \& Teske, pp. 192-200), Suma, art. 34, q. 2, co. (ed. De Wulf-Mansion Centre, vol. 27, p. 174). Uma difereça inicial ocorre na noção de purum nihil, o que não reterá nossa atenção aqui (cf., ao fim desta nota, a citação de Suma, art. 21, q. 4, onde o 'purum nihil em natureza e essência' abarca também a res a reor reris) - sobre o tema, cf. DOYLE, J. P. "Supertranscendental Nothing: a Philosophical Finisterre". Medioevo 24 (1998), pp. 1-30 (esp. pp. 4-6). Mais importante, para nós, é o fato de que a caracterização da relação entre res a reor reris e res a ratitudine na Suma é distinta da (ainda que não contraditória com respeito a) que encontramos em Quodl. 7, q. 1-2. Enquanto que neste último, os dois sentidos análogos de res são simplesmente distinguidos, na Suma enfatiza-se uma continuidade entre os dois na ordem de conhecimento. Assim, uma mesma res pode ser inteligida seja como res a reor reris seja como res a ratitudine, dependendo do modo como ela seja concebida pelo intelecto. Se for concebida como algo meramente inteligível, tal res é tomada somente como res a reor reris, porém ao ser concebida como algo que possui essência e, destarte, existe ou pode existir, essa mesma res é tomada como res a ratitudine. Ou seja, uma coisa tomada inicialmente como res a reor reris (por se desconhecer se possuiria ou não essência), pode vir a ser tomada como res a ratitudine quando se sabe que ela possui essência. Como vemos, nesse ponto a distinção entre os dois sentidos análogos de res é combinada com a distinção entre 'ser de essência' e 'ser de existência' (cf. cap. 2, nota 95): algo concebido como res a reor reris é aquilo que não possui ou não se conhece que possua um ser de essência; já aquilo concebido como res a ratitudine é aquilo que se conhece como possuidor de ser de essência e, portanto, como potencial possuidor de um ser de existência - cf. Henrique de Gand, Suma, art. 24, q. 3, co. (ed. Decorte \& Teske, pp. 192-200). Mas, o que faz com que algo possua essência? Ou, o que é o mesmo, o que faz de algo uma res a ratitudine? Essa pergunta é respondida por Henrique em Suma, art. 34, q. 2, onde se diz que ser uma res a ratitudine é possuir uma razão de 'ente' ou de 'ser quiditativo', que só se possui por relação (respectus) a uma ideia divina ou exemplar divino: “Quod tamen ut amplius eluscescat ex veritate inventa in creaturis, paulo amplius inchoando, sciendum quod ratio rei dictae a reor reris prima est in unoquoque ente creato, et super illam rationem rei prima ratio quae fundatur, est ratio entis sive esse quidditativi, quae convenit ei ex respectu ad formam divini exemplaris, a quo accipitur ratio rei dictae a ratitudine, quae eadem est cum ratione entis quidditativi" (ed. De Wulf-Mansion Centre, vol. 27, p. 174). Ora, como vemos na nota 55, adiante, uma essência tomada segundo seu 'ser quiditativo' é uma essência considerada como anterior à singularidade ou à universalidade, mas como nata a receber ambas. Assim, algo considerado como res a ratitudine é aquilo que se toma como algo que possui essência e, portanto, [i] é inteligido (ser de essência) e, além disso, [ii] é ou pode ser fora do intelecto (ser de existência). Nesse caso, a mera essência - tomada ainda unicamente como inteligida por Deus (como ideia divina) - já pode ser considerada uma res no sentido próprio do termo, o que levou comentadores como Grabmann a verem em Henrique de Gand o defensor de uma 'doutrina das ideias' (Ideenlehre) de caráter platônico - cf. GRABMANN, M. "Des heiligen Augustinus Quaestio de Ideis (De diversis quaestionibus LXXXIII qu. 46) in ihrer inhaltlichen Bedeutung und mittelalterlichen Weiterwirkung”. In: GRABMANN, M. Mittelalterlichen Geistesleben. Abhandlungen zur Geschichte der Scholastik und Mystik. Bd. II. München: Max Hueber, 1936, pp. 25-34 (esp. pp. 32-3) [= Philosophisches Jahrhundert 43 (1930), pp. 297-307] (trad. portuguesa em: GRABMANN, M. "A quaestio de ideis de Santo Agostinho: seu significado e sua repercussão medieval”. Trad. M. Novaes, C. R. Cezar, M. Sattin. Cadernos CEPAME 2.1 (1993), pp. 29-41).

Fica, porém, a pergunta: se tanto a res a reor reris como a res a ratitudine podem ser inteligidas, isso significa que a intelecção diz respeito indiferentemente àquilo que possui essência e àquilo que não a possui? Podemos responder essa dificuldade por um outro trecho de Suma, art. 34, q. 2, onde o Doutor Solene explica que, muito embora a imaginação possa conceber uma res a reor reris (como 'monte áureo' ou 'hircocervo') por si mesma, o intelecto não pode fazê-lo. Pelo contrário, o intelecto só concebe res a reor reris 'sob a razão do ente quiditativo' (sub ratione entis quidditativi), isto é, enquanto esse todo que forma a res a reor reris é composto de partes que, estas sim, são res a ratitudine e, portanto, possuem essência: “ $<\ldots$.. $>$ ratio rei a reor dictae non potest concipi ab intellectu licet possit $\mathrm{ab}$ imaginatione - nisi sub ratione entis quidditativi, et tamen rationem esse nihil potest habere, nisi prius habendo rationem rei dictae a reor, in qua fundatur ratio esse illius" (ed. De WulfMansion Centre, vol. 27, p. 175). Jan Aertsen detacou essa ligação entre res a reor reris e imaginação 
(cf. "Transcendental Thought in Henry of Ghent". In: VANHAMEL, W. (ed.). Henry of Ghent. Proceedings..., 1996, pp. 1-18 - esp. pp. 14-6). Porém, Jos Decorte foi aquele que extraiu a consequência mais interessante dessa dependência do intelecto no ser quiditativo daquilo que ele conhece. Ora, se [i] res é aquilo que possui realitas e, portanto, é nato a mover o intelecto (como vimos em Quodl. 7, q. 1-2) e [ii] somente a res a ratitudine move de fato o intelecto, uma vez que somente ela possui essência e a res a reor reris é um todo sem essência, composto de partes que, possuindo essência, permitem ao intelecto conceber aquele todo, então [iii] parece que o sentido principal ou primeiro de res deve ser res a ratitudine. Assim, seguindo Decorte, res é análogo porque é dito primeiramente das res a ratitudine e, em segundo lugar, devido àquela primeira significação, é dito também das res a reor reris - cf. DECORTE, J. "Henry of Ghent on Analogy. Critical Reflections on Jean Paulus' Interpretation". In: VANHAMEL, W. (ed.). Henry of Ghent. Proceedings..., 1996, pp. 71105 (esp. pp. 92-3). Nesse caso, para responder a pergunta que nos pusemos ao início desta nota, o campo do inteligível é o campo da res a ratitudine, isto é, das coisas que possuem ser de essência (e, pelo menos, potencialmente, ser de existência) por possuírem uma ideia na mente de Deus.

Podemos, neste ponto, dar um passo final. Ora, se o campo do inteligível é o campo das res a ratitudine e estas são as coisas que possuem ser de essência ao possuírem uma ideia ou exemplar na mente de Deus, então o campo do inteligível pode ser tomado igualmente como o campo daquelas coisas que possuem ou são natas a possuir ser de existência. Dito de outra maneira, a intelecção é acerca de essências ou, o que é o mesmo, acerca do potencialmente existente. Como diz Pasquale Porro, "L'essere dell'essenza coincide dunque con la possibilità, con la capacità di ricevere l'esistenza <...” ("Possibilità ed esse essentia...", 1996, p. 226). Assim, o campo do inteligível é, em uma palavra, o campo do possível, pois somente o que é possível possui essência: "Dicitur enim omnis creatura res absolute ex hoc quod de se dicit aliquid de quo saltem natus est formari conceptus aliqualis in anima. Dicitur autem essentia et natura quaedam ex eo quod habet in divino esse rationem exemplaris, secundum quam nata est produci in actuali esse, a quo convenit ei esse essentiae. Unde, ut dictum est supra, quod talem rationem exemplarem in Deo non habet purum nihil est in natura et essentia, nec est res alicuius praedicamenti nec possibile fieri in effectu, quia Deus nihil potest facere in effectu cuius rationem exemplarem in se non habet ut sit in qualibet creatura" - Suma, art. 21, q. 4, co. (ed. Decorte \& Teske, p. 80 - essa passagem é citada por Porro logo após o excerto de seu artigo reproduzido acima). Enfim, o inteligível é toda res, mas é propriamente inteligível aquela res que possui essência (um exemplar na mente de Deus) e é possivelmente uma res existente. Ora, vimos acima (mais uma vez, em cap. 2, nota 95), que só é - isto é, só possui ser - aquilo que possui, pelo menos, essência, pois o primeiro ser de uma coisa advém à sua essência como ser de essência. Nesse caso, tudo o que possui ser - todo ente (ens) - é uma essência e, portanto, uma res a ratitudine. Destarte, a res a ratitudine compreende tudo o que é e, uma vez que estabelecemos que toda res a ratitudine é inteligível, podemos afirmar que o inteligível é tudo aquilo que é - ou o inverso, todo ente é inteligível. No entanto, a res a reor reris contém coisas para além daquilo que possui essência e continua sendo dita inteligível (ainda que somente por meio das res a ratitudine, como vimos). Nesse caso, poder-se-ia dizer que o campo do inteligível (confundindo-se com o campo da res tomada como communissimum) é mais amplo do que o campo daquilo que é? Mas, se tomarmos a res como algo mais amplo do que o ens, primeiro transcendente, que tipo de noção seria essa res? Tão interessantes quanto sejam tais perguntas, elas não tomarão nossa atenção aqui.

A bibliografia com respeito à noção de res em Henrique de Gand é vasta. Além do que já foi citado nesta nota, em cap. 2, nota 95 e cap. 3, notas 43 e 89, cf.: PAULUS, Henri de Gand. Essai..., 1938, pp. 21-8; CAFFARENA, Ser participado y ser subsistente..., 1958, pp. 45-7; COURTINE, J.-F. "Res". In: Historisches Wörterbuch der Philosophie. Bd. 8. Basel: Schwabe \& Co., 1992, cols. 892-901. DOYLE, P. J. "Between Transcendental and Transcendental: the Missing Link?". The Review of Metaphysics 50 (1997), pp. 783-815 (esp. pp. 798-801); HOFFMANN, Creatura intellecta, 2001, pp. 112-6; LAARMANN, Deus, primum cognitum, 1999, pp. 120-8; CARVALHO, A Novidade do Mundo..., 2001, pp. 245-52; AERTSEN, J. “'Res' as Transcendental. Its Introduction and Significance”. In: VESCOVINI, G. F. (éd.). Le problème des transcendentaux du XIV au XVII siècle. Paris: Vrin, 2002, pp. 139-56; LIBERA, A. de. La référence vide. Théories de la proposition. Paris: PUF, 2002, pp. 73-5, 231-9; GUERIZOLI, R. "Au-delà de la scientia transcendens? Le cas Henri de Gand”. In: PICH, R. H. (ed.). New Essays on Metaphysics as Scientia Transcendens. Proceedings of the second International Conference of Medieval Philosophy, held at the Pontifical Catholic University of Rio Grande do Sul (PUCRS), Porto Alegre / Brazil, 15-18 August, 2006. Louvain-la-Neuve: FIDEM, 2007, pp. 69-89; PICKAVÉ, Heinrich von Gent über Metaphysik..., 2007, pp. 183-244; FOLGER-FANFARA, S. Das 'Super'-Transzendentale und die Spaltung der Metaphysik. Der Entwurf des Franziskus von Marchia. Leiden - Boston: Brill, 2008, p. 70; PORRO, P. “Res praedicamenti e ratio praedicamenti. Una nota su 
intelecto' - tal oposição faz parecer que as espécies estão, de alguma maneira, no intelecto.

Justamente para melhor compreendermos tais afirmações, o Doutor Solene adiciona uma explicação mais longa a respeito da intelecção:

Teodorico di Freiberg e Enrico di Gand". BIARD, J., CALMA, D., IMBACH, R. (éd.). Recherches sur Dietrich de Freiberg. Turnhout: Brepols, 2009, pp. 131-43; PORRO, P. "Res a reor reris / res a ratitudine. Autour d'Henri de Gand". In: ATUCHA, I., et al. (éds.). Mots médiévaux offerts à Ruedi Imbach. Porto: FIDEM, 2011, pp. 617-28; AERTSEN, J. A. "Tino-Logia. An Alternative for Ontology?". In: ATUCHA, I., et al. (éds.). Mots médiévaux offerts à Ruedi Imbach. Porto: FIDEM, 2011, pp. 729-37; PAIVA, G. B. V. de. "Sobre as duas utilizações do termo res no Quodlibet 7, q. 1-2, de Henrique de Gand". Revista do Seminário dos Alunos do PPGLM/UFRJ 5 (2014), pp. 62-78; PAIVA, "'Res a reor reris' e 'res a ratitudine'...”, 2015, pp. 392-417. Sobre a história da noção da distinção entre res a reor reris e res a ratitudine, cf. HAMESSE, J. "Res chez les auteurs philosophiques des $12^{\mathrm{e}}$ et $13^{\mathrm{e}}$ siècles". In: FATTORI, M., BIANCHI, M. (ed.). Res. III Colloquio Internazionale. Roma, 7-9 gennaio 1980. Firenze: Olschki, 1982, pp. 91-104; GRONDEUX, A. "Res Meaning a Thing of Thought: The Influence of the Ars donati". Vivarium 45 (2007), pp. 189-202.

Sobre a relação entre essência e possibilidade em Henrique de Gand, além do artigo de Porro já citado nesta nota, cf.: WIPPEL, J. F. "Thomas Aquinas, Henry of Ghent, and Godfrey of Fontaines on the Reality of Nonexisting Possibles". In: WIPPEL, J. F. Metaphysical themes in Thomas Aquinas. The Catholic University of America Press: Washington D.C., 1984, pp. 163-189; STORCK, A. "Eternidade, possibilidade e indiferença: Henrique de Gand leitor de Avicena". Analytica 9.1 (2005), pp. 137-72; CROSS, R. "Henry of Ghent on the Reality of Non-Existing Possibles - Revisited". Archiv für Geschichte der Philosophie 92 (2010), pp. 115-32.

Sobre a noção de ideia divina em Henrique de Gand, cf. HUET, Recherches historiques et critiques..., 1838, pp. 142-51; SCHWAMM, H. Das göttliche Vorherwissen bei Duns Scotus u. Seinen ersten Anhängern. Innsbruck: Felizian Rauch, 1934, pp. 99-107; RÜBMANN, H. Zur Ideenlehre der Hochscholastik unter besonderer Berücksichtigung des Heinrich von Gent, Gottfried von Fontaines und Jakob von Viterbo. Inaugural-Dissertation zur Erlangung der Doktorwürde genehmigt von der philosophischen Fakultät der Rheinischen Friedrich-Wilhelms-Universität zu Bonn. Würzburg: Konrad Triltsch, 1937; WIPPEL, "Divine knowledge, divine power and human...", 1985, pp. 213-41; DE RIJK, L. M. "Un tournant important dans l'usage du mot idea chez Henri de Gand". In: FATTORI, M., BIANCHI, M. L. (ed.). Idea. VI Colloquio Internazionale 'Lessico Intellettuale Europeo'. Roma, 5-7 gennaio 1989. Roma: Ateneo, 1990, pp. 89-98; PORRO, P. "Ponere statum. Idee divine, perfezioni creaturali e ordine del mondo in Enrico di Gand". Mediaevalia 3 (1993), pp. 109-159; HOENEN, M. J. F. M. "Propter dicta Augustini. Die metaphysische Bedeutung der mittelalterlichen Ideenlehre". Recherches de théologie et philosophie médiévales 64 (1997), pp. 245-62 (esp. pp. 256-8); KOBUSCH, T. "Heinrich von Gent und die neuplatonische Ideenlehre". In: BENAKIS, L. G. (éd.). Néoplatonisme et philosophie médiévale. Actes du Colloques international de Corfou 6-8 octobre 1995 organisé para la SIEPM. Turnhout: Brepols, 1997, pp. 197-209; HOFFMANN, "Ideen der Individuen und intentio naturae..., 1999; HOFFMANN, "Idées divines et essence: Henri de Gand", 2002; PLEVANO, R. "Divine Ideas and Infinity". In: GULDENTOPS, G., STEEL, C. (eds.), Henry of Ghent and the Transformation..., 2003, pp. 177-97; STEEL, C. "Henricus Gandavensis Platonicus". In: GULDENTOPS, G., STEEL, C. (eds.), Henry of Ghent and the Transformation..., 2003, pp. 15-39 (esp. pp. 17-24). Para uma introdução à noção de 'ideia' nos séculos XII e XIII, cf. HAMESSE, J. "Idea chez les auteurs philosophiques des $12^{\mathrm{e}}$ et $13^{\mathrm{e}}$ siècles". In: FATTORI, M., BIANCHI, M. L. (ed.). Idea. VI Colloquio Internazionale. Roma, 5-7 gennaio 1989. Roma: Edizioni dell'Ateneo, 1990, pp. 99-135. Para múltiplas abordagens sobre a questão, vejam-se as atas do IV Colóquio de História da Filosofia Medieval (realizado em 2006, no Departamento de Filosofia da USP) publicadas na Revista Discurso: NOVAES, M., STORCK, A. (orgs.). A noção de ideia na Filosofia Medieval. Especificamente, GRELLARD, C. "Do arquétipo à ficção: a ambivalência da ideia em João de Salisbury". Discurso 40 (2010), pp. 45-70; OLIVEIRA, C. E. de. "Ideias: formas, rationes e species. A Quaestio de ideis de Tomás de Aquino". Discurso 40 (2010), pp. 95-122; FERNÁNDEZ, C. J. "Guilherme de Ockham: contra a Ideia como exemplar". Discurso 40 (2010), pp. 183-206. Sobre a origem do tema, cf. o já citado e clássico artigo GRABMANN, "Des heiligen Augustinus Quaestio de Ideis..." 1936 [trad. para o português em Cadernos CEPAME 2.1 (1993)]". 
"É preciso, então, propor alguma virtude existente [existentem] em ato que faça os inteligíveis em potência inteligíveis em ato, tal que possam mover em ato o intelecto passivo. Ora, esta é a força $[v i s]$ que chamamos de 'intelecto agente', que é posta $<$ como $>$ a outra potência da alma $<$ junto $>$ com o possível, tal que o intelecto possível esteja para os inteligíveis tal como o transparente no meio e no órgão para as cores [sicut perspicuum in medio et organo ad colores] e o agente <esteja> para tudo isso tal como a luz - tal que, tal como 'a luz faz as cores serem em ato tal que movam o meio e o olho, assim o intelecto agente faz os inteligíveis serem em ato' tal que movam o intelecto possível e se faça um composto de intelecto em ato, a partir do intelecto e do inteligível, tal como a partir da matéria e da forma" ${ }^{26}$.

Esse trecho é relevante por introduzir o par 'intelecto agente' e 'intelecto possível' como forças (vires), virtudes (virtutes) ou potências da alma ${ }^{27}$. Note-se,

\footnotetext{
${ }^{26}$ Henrique de Gand, Suma, art. 1, q. 5, co. (ed. De Wulf-Mansion Centre, vol. 21, p. 125): "Oportet ergo ponere virtutem aliquam existentem in actu quae intelligibilia in potentia facit intelligibilia in actu, ut possint actu movere intellectum passivum. Haec autem est vis quam appellamus intellectum agentem, qui ponitur altera potentia animae cum possibili, ut possibilis intellectus se habeat ad intelligibilia sicut perspicuum in medio et organo ad colores, et agens ad omnia ista sicut lux, ut sicut 'lux facit colores esse in actu ut moveant medium et oculum, sic intellectus agens facit intelligibilia esse in actu' ut moveant intellectum possibilem et fiat unum intellectus in actu compositum ex intellectu et intelligibili, sicut ex materia et forma". Sobre essa passagem, cf. BETTONI, Il processo astrattivo..., 1954, pp. 11-2. Notemos que, ainda no começo da Suma, Henrique de Gand nos oferece uma exposição, mesmo que rápida, da distinção entre intelecto agente e intelecto possível - isso vai frontalmente de encontro à observação de Valeria Sorge, segundo a qual não haveria referência precisa à distinção entre 'intelecto agente' e 'intelecto possível' nos escritos dos primeiros anos de atividade de Henrique de Gand - cf. SORGE, Gnoseologia e teologia ..., 1988, p. 86: “ $<\ldots>$ in questa prima fase del pensiero del Gandavense restano assulutamente indeterminati nella loro specifica funzione sia l'intelletto agente che l'intelletto possibile; non abbiamo rintracciato infatti alcun testo di Enrico, relativo a questo periodo di formazione della sua gnoseologia, che autorizzi, se letto secondo il significato della sua terminologia ed il contesto complessivo della sua problematica, ad affermare che per il Gandavense l'intelletto agente si presenta nella sua azione universalizzante ed in quel suo carattere di estrazione dell'intelligibile; né, d'altronde, viene mai chiarito il modo in cui l'oggetto conosciuto possa unirsi all'intelletto possibile facendovi sorgere una nuova rappresentazione di sè, cioè la specie" (grifo no original). Como vemos, pelo contrário, são precisamente esses os temas desenvolvidos nos trechos de Suma, art. 1, q. 5, que estamos ora a ler. Se eles virão a ser abordados mais pausadamente em obras posteriores, isso se deve não tanto necessariamente a uma evolução no pensamento de Henrique de Gand, mas ao fato de que, em trechos mais tardios de sua Suma e de seus Quodlibeta, as questões colocadas dirão respeito diretamente a ou exigirão como prossuposto uma descrição mais precisa da produção da intelecção, enquanto que no início da Suma o que temos é, antes, um estudo geral sobre a possibilidade do conhecimento da verdade para o homem, como vimos no cap. 1. Assim, não podemos, de saída, pressupor que qualquer diferença textual aponte para uma evolução no pensamento de nosso autor - menos ainda podemos, como parece fazer Sorge, determinar nossa leitura dos textos do Doutor Solene a partir do pressuposto de que haveria uma evolução em seu pensamento.

${ }^{27}$ A afirmação do intelecto agente como 'força', 'virtude' ou 'potência' da alma está longe de ser uma tese banal. Isso fica imediatamente claro se nos lembrarmos do que o próprio Henrique de Gand afirma, em Quodl. 9, q. 15, co. (ed. De Wulf-Mansion Centre, vol. 13, pp. 264-5): "Ut secundum hoc intellectus agens illustrans mentem ad cognoscendum sinceram veritatem formae materialis in conspiciendo universale in essentia formae secundum se abstractae, licet non secundum se existentis sed in sola mentis notitia, primo increatae, deinde creatae, existentis, dicatur ipse Deus, quemadmodum intellectus agens illustrans mentem ad cognoscendum imaginariam veritatem formae materialis in conspiciendo universale in phantasmate, abstracto a forma particulari existente in materia extra, dicitur aliqua virtus creata, ut potentia animae vel aliquid aliud" (voltaremos a isso no Epílogo desta parte 2, adiante). Ora, se Deus mesmo pode ser tomado como um único intelecto agente para todos os homens,
} 
não é, de fato, banal que se afirme ou defenda também uma noção de 'intelecto agente' como virtude ou força de cada alma, com vemos Henrique fazer tanto em Suma, art. 1, q. 5, como em Quodl. 9, q. 15 (neste último caso, ao lado de Deus como intelecto agente).

Com efeito, a defesa do intelecto agente como virtude ou força da alma humana pode ser encontrada, também, em Quodl. 3, q. 14, ad arg. (ed. 1613, f. 112vb): "Similiter intellectus agens potentia naturalis est in anima, et non est nisi substantia animae, sed ex naturali determinatione, et respectu ad actum abstrahendi species intelligibiles a phantasmate, cum ei proponuntur <...”. Tal tema, no entanto, é mais precisamente abordado em Quodl. 9, q. 14 (ed. De Wulf-Mansion Centre, vol. 13, pp. 246-57), estudada em CARVALHO, “O que significa pensar?", 2001. Nessa questão, propõe-se a pergunta: "se, a partir de fundamentos de Aristóteles, se pode mostrar que o intelecto é em todos um em número e se o contrário pode ser demonstrado [utrum ex fundamentis Aristotelis possit ostendi quod intellectus in omnibus sit unus numero, et an contrario possit demonstrari]" (ed. De Wulf-Mansion Centre, vol. 13, p. 246). Ainda nas primeiras linhas da questão, Henrique sublinha que não se trata aqui de estudar a própria tese segundo a qual há em cada homem um intelecto ou alma racional, mas somente de busca compreender a posição do próprio Aristóteles: "Dico tamen, non dubitando quin singulorum sint intellectus sive animae rationales, sed dubitationem super sententia Aristotelis circa hoc, aliis dicentibus quod sensit unum intellectum esse in omnibus, aliis quod multos, pertractando" (pp. 246-7). Essa tarefa, porém, possui a dificuldade fundamental de que, para Henrique, o próprio Aristóteles nunca teria chegado a uma resposta definitiva acerca desses temas: "Immo, ut arbitror, ipsemet semper super illis in dubio fuit, nec umquam pro supposito quasi principio habuit quod intellectus unus in omnibus fuit, neque quod diversi in diversis, neque quod esset forma et actus substantialis corporis, neque quod non esset, sed inter utrumque horum fluctuans, modo pro una parte, modo pro alia, apparentia protulit, secundum quod quidam expositorum eius, tam graecorum quam arabicorum, exponunt eum in omnibus dictis suis pro una parte, et alii pro alia" (p. 247). No fim - e, aqui, omito a cuidadosa discussão das autoridades de Aristóteles conduzida pelo Doutor Solene -, termina-se por afirmar que certas teses de Aristóteles devem ser rejeitadas para que se possa demonstrar ("pela razão apoiada na fé") que há algo que, não obstante comece a ser no corpo e se multiplique pela multiplicação do corpo, permanece no fim sem o corpo: "Unde nobis, qui fundamenta eius tamquam falsa et erronea negare debemus, ex ratione fulta fide certa debet esse demonstratio tenendi contra fundamenta Aristotelis, quod forma aliqua potest manere in postremo sine corpore, quae tamen non inciperet esse nisi in corpore, et plurificari plurificatione corporis, in numero tamen finito, quia ponimus mundum incepisse et generationem hominum quandoque cessare" (p. 257). Ora, esse algo é a alma racional ou a parte intelectiva da alma humana. Assim, vemos que, para Henrique de Gand, a demonstração da multiplicidade de intelectos de acordo com a multiplicadade de homens é possível, mas desde que sejam rejeitadas certas teses de Aristóteles.

Destarte, não obstante Henrique de Gand admita um uso de 'intelecto agente' para nomear Deus na medida em que age para o conhecimento da verdade pelo homem (Quodl. 9, q. 15), o uso corrente da expressão 'intelecto agente' é, em sua obra, reservado para a designação de uma determinada virtude, força ou potência da alma. No que se segue deste capítulo, 'intelecto agente' será utilizado neste último sentido.

Estabelecido isso, notemos como nos poucos textos destacados aqui de Quodl. 9, q. 14, surgem associadas as teses da unidade do intelecto e da unidade da alma racional (ambas rejeitadas por Henrique de Gand que, muito embora aceite tomar Deus como intelecto agente, não dispensa a necessidade de que haja um intelecto agente em cada alma). A essas duas teses foi atribuída uma grande importância na historiografia da filosofia medieval.

A disputa acerca da chamada 'doutrina da unidade do intelecto' (por vezes, associada à identificação entre Deus e intelecto agente) foi vista como um dos pilares centrais da discussão filosófica da segunda metade do século XIII por Étienne Gilson. Este faz dessa doutrina uma característica principal (junto à exigência de uma iluminação divina para o conhecimento da verdade) do 'agostinismo-avicenizante' posição filosófica que, segundo ele, teria grassado no século XIII, atraíndo a oposição de Tomás de Aquino (cf., de Gilson: "Pourquoi saint Thomas a critiqué saint Augustin". Archives d'histoire doctrinale et littéraire du moyen âge (1926-7), pp. 5-127; "Les sources gréco-arabe de l'augustinisme avicennisant". Archives d'histoire doctrinale et littéraire du moyen âge (1929-30), pp. 5-149; cf. tb. GILSON, É. "Sur quelques difficultés de l'illumination augustinienne". Revue néo-scolastique de philosophie 36 (1934), pp. 321-31). O próprio Gilson, aliás, parece ler Henrique de Gand como partidário desse 'agostinismo-avicenizante' em um texto como "Roger Marston: un cas d'Augustinisme avicennisant", 1933, p. 41, nt. 1, no que é seguido por Paulus, em "Henri de Gand et l'argument ontologique", 1935-6, pp. 272-3 (cf. tb. PAULUS, Henri de Gand. Essai..., 1938, p. 6). Por outro lado, há que mencionar o forte ataque sofrido pela tese de Gilson - segundo a qual a afirmação 
ou repúdio do 'agostinismo-avicenizante' constituiria o embate fundamental da filosofia do século XIII - da parte de Maurice de Wulf ("L'augustinisme 'avicennisant"'. Revue néo-scolastique de philosophie 33 (1931), pp. 11-39). Enfim, se havia uma discussão acerca da unidade do intelecto no século XIII (e Henrique de Gand mostra que havia uma tal discussão), o debate entre Gilson e Wulf não nos permite decidir acerca de sua centralidade para a filosofia de então. Não obstante a crítica de Wulf, porém, os estudos de Gilson são importantes por mostrar que a discussão acerca da unidade do intelecto agente está profundamente associação àquela acerca da necessidade de iluminação divina para o conhecimento da verdade.

Pois bem, o mesmo problema da unidade do intelecto é abordado de um ponto de vista distinto por Alain de Libera, em seu comentário ao De unitate intellectus de Tomás de Aquino ("Introduction", In: THOMAS D'AQUIN. Contre Averroès. Trad. d'Alain de Libera. Paris: Flammarion, 1994, pp. 9-73). Note-se, de passagem, que agora a defesa da unidade do intelecto surge associada principalmente à recepção de Averróis e não àquela de Avicena, como era o caso em Gilson - isso não é, porém, o que mais nos interessa. Antes, devemos atentar para algo que Libera escreve ainda no início da introdução ao volume: "Pour-quoi cette agitation? Thomas lui-même nous répond: une erreur a envahi l'université parisienne - il faut la réfuter. Son auteur? Averroès. Ses partisans? des chrétiens latins qui font profession d'ignorer leur christianisme et de mépriser leur latinité. En un mot: des averroïstes. Quelle erreu? l' 'unité de l'intellect' et l'afirmation, fascinante mais paradoxale, que l' 'homme de pense pas'. D'un mot: le monopsychisme. Deux mots que l'histoire a imposés: Thomas lance la premier; Leibniz forgera l'autre" (pp. 9-10 - grifos no orig.). Concentremo-nos na referência ao 'monopsiquismo'.

Curiosamente, tal noção teve alguma importância no estudo histórico-filosófico da obra de Henrique de Gand. De um lado, temos um artigo de Mário Santiago de Carvalho, no qual o Doutor Solene é visto como contrário ao monopsiquismo por refutar a unidade do intelecto, defendendo que cada homem possui uma própria alma intelectiva (CARVALHO, "O que significa pensar?", 2001). De outro, temos um texto anterior, de Paul Bayerschmidt, no qual Henrique de Gand surge associado ao monopsiquismo por haver discutido o problema da possibilidade de distinção das almas humanas em graus de perfeição (BAYERSCHMIDT, P. "Die Stellungnahme des Heinrich von Gent zur Frage nach der Wesensgleichkeit der Seele Christi mit den übrigen Menschenseelen und der Kampf gegen den averroistischen Monopsychismus". In: AUER, J., VOLK, H. (Hrsg.). Theologie in Geschichte und Gegenwart. Michael Schmaus dargebracht von seinen Freunden und Schülern. München: Karl Zink, 1957, pp. 571-606). Ou seja, lendo esses dois comentadores em conjunto, vemos Henrique de Gand ser associado ao 'monopsiquismo' por discutir [i] a tese da unidade do intelecto e [ii] a tese da distinção das almas em graus de perfeição.

De fato, se retornarmos a Leibniz - que, como Libera (op. cit., p. 10) e Carvalho (op. cit., p. 76) nos lembram, introduziu tal termo -, vemos que a noção de 'monopsiquismo' surge em sua Teodiceia também associada ao problema da unidade do intelecto agente, mas, principalmente, à questão da unidade da alma. Segundo Leibniz, os averroístas afirmavam ser "preciso concluir que as almas, quer dizer, as formas dos corpos orgânicos, devem perecer com esse corpos, ou em todo caso, o intelecto passivo que pertence em particular a cada um. De modo que restará apenas o intelecto ativo, comum a todos os homens, que Aristóteles dizia vir de fora, e que deve operar em todo lugar em que os organismos estão dispostos <...> [il faut conclure que les Ames, c'est à dire les formes des corps organiques, doivent perir avec ces corps, ou du moins l'entendement passif appartenant en prope à chacun. De sorte qu'il ne restera que l'entendement actif, commun à tous les hommes, qu'Aristote disoit venir de dehors, et qui doit travailler partout où les organes y sont disposés <...>]". A essa tese Leibniz acredita estar ligada uma outra afirmação, típica de autores menos ligados a Aristóteles: “ $<$...> outros, menos ligados a Aristóteles, se deparavam com uma alma universal, que era o oceano de todas as almas particulares, e acreditavam ser essa alma universal a única capaz de subsistir, enquanto as almas particulares nasciam e morriam $<\ldots>$. E muitos chegavam a acreditar que Deus é essa alma universal, embora outros tenham acreditado que ela era subordinada e criada $\langle\ldots>$. A alma do mundo de Platão foi tomada nesse sentido por alguns; contudo mais parece que eram os estoicos que iam ao encontro dessa alma comum que absorve todas as outras. Aqueles que são desta opninião poderiam ser chamados de monopsiquistas, pois, segundo eles, só existe verdadeiramente uma alma única que subsiste [<..> d'autres moins attachés à Aristote alloient jusqu'à une ame universelle qui fût l'Ocean de toutes les ames particulieres, et croyoient cette Ame Universelle seule capable de subsister, pendant que les ames particulieres naissent et périssent $<\ldots .$. . Et plusieurs alloient à croire que Dieu est cette Ame universelle, quoyque d'autres ayent cru qu'elle étoit subordonnée et creée <...>. L'ame du monde de Platon a été prise dans ce sens par quelques uns, mais il y a plus d'apparence que les Stoiciens donnoient dans cette ame commune qui absorbe toutes les autres. Ceux qui sont de ce sentiment, pourroient être appellés Monopsychites, puisque selon eux il n'y a veritablement qu'une seule Ame qui 
aliás, que mantém-se uma flutuação entre as expressões 'intelecto possível (possibilis)' e 'intelecto passivo (passivus)' - esta não deixa de revelar uma ambiguidade da própria virtude intelectiva nomeada, uma vez que aquele intelecto que é possivelmente o intelecto em ato se mostra, igualmente, passivo para ser movido por aquilo pelo que passará ao ato (embora, como veremos adiante, não se possa confundir tal passividade com uma pura passividade). Tal 'informação' do intelecto possível é suficiente para que se faça o intelecto em ato. Por outro lado, o 'intelecto agente' é introduzido precisamente como aquela virtude que, de alguma maneira, faz do inteligível em potência um inteligível em ato. Ao passo que aquela virtude anterior

subsiste]" (LEIBNIZ, G. W. Ensaios de teodiceia sobre a bondade de Deus, a liberdade do homem e a origem do mal. Trad., introd. e notas de William de Siqueira Piauí e Juliana Cecci Silva. São Paulo: Estação Liberdade, 2013, pp. 78-80 - grifos meus [LEIBNIZ, G. W. Essais de théodicée sur la bonté de Dieu, la liberté de l'homme et l'origine du mal. In: GERHARDT, C. I. (Hrsg.) Die philosophischen Schriften von Gottfried Wilhelm Leibniz. 6. Bd. Berlin: Weidmannsche Buchhandlung, 1885, pp. 54-5 - grifos no original]). Como vemos, para Leibniz o termo monopsiquismo é mais diretamente associado à afirmação de uma unidade da alma. Por outro lado, tal termo só parece estar associado à tese da unidade do intelecto agente na medida em que esta última tese está, ela própria, ligada à afirmação da unidade da alma.

Visto isso, voltemos aos artigos Carvalho e Bayerschmidt. Em primeiro lugar, este segundo parece forçar os textos de Henrique de Gand ao enxergar, na discussão sobre a possibilidade de distinção das almas em graus de perfeição, um debate sobre o monopsiquismo. Com efeito, como o próprio Bayerschmidt nos mostra em seu referido trabalho, quando o Doutor Solene se volta para o tema, está em pauta não o problema da unidade de uma alma do mundo, mas antes a questão de saber se a alma de Cristo possuiria ou não o mesmo grau de perfeição que as demais almas; o que está em jogo é a ocorrência ou não de uma unidade do grau de perfeição das almas e não a unidade das próprias almas em uma única - cf. Quodl. 3, q. 5 (ed. 1613, ff. 87v-88v). Já Carvalho (como Libera) parece utilizar o termo 'monopsiquismo' com bastante liberdade quando lido à luz de Leibniz, uma vez que este ultimo o introduz principalmente para nomear a doutrina da unidade da alma e não, propriamente, a defesa da unidade do intelecto.

Por outro lado, notemos que os problemas [i] da unidade do intelecto agente e [ii] da unidade da alma que surgem associados nesse trecho da Teodiceia de Leibniz, surgem associados também (por certo, diferentemente) no Quodl. 9, q. 14, de Henrique, que lemos acima, neste nota - com efeito, a associação entre essas duas teses no Doutor Solene é enfatizada, ainda sob a égide do 'monopsiquismo', em SORGE, Gnoseologia e teologia..., 1988, pp. 36-47. Assim, parece-me que Bayerschmidt se equivoca ao identificar o problema dos graus de perfeição da alma ao problema, distinto, da unidade da alma. Com efeito, o próprio Doutor Solene parece distinguir ambas as temáticas, pois mantém a multiplicidade das almas (como vimos aqui) e, no entanto, afirma não ter resposta para o problema da distinção das almas em graus de perfeição, como lembra o mesmo Bayerschmidt ("Die Stellungnahme des Heinrich von Gent..., 1957, pp. 581-4). Assim, lemos: "Quid tamen sentiendum sit iudicio rationis, et intellectus re vera ignoro <..." - Quodl. 3, q. 5, co. (ed. 1613, f. 88vb); o mesmo se repete em Quodl. 4, q. 15, co. (ed. De Wulf-Mansion Centre, vol. 8, p. 275). Com efeito, em Quodl. 9, q. 14, os problemas [i] da unidade do intelecto e [ii] da unidade da alma racional surgem associados, sendo passíveis de uma resposta; porém o problema [iii] da distinção das almas em graus de perfeição não parecer ser associado por Henrique de Gand diretamente àqueles dois.

Enfim, parece-me que a utilização (anacrônica, sem dúvida) da noção de 'monopsiquismo' à obra de Henrique de Gand chama a atenção para a importante associação entre as discussões acerca [i] da unidade do intelecto e [ii] da unidade da alma racional. No entanto, deve-se cuidar que não seja confundido àquele segundo problema a discussão acerca [iii] dos graus de perfeição das almas. Por fim, um último tema importante neste contexto (cuja associação àqueles dois primeiros é sublinhada por Gilson) é o problema [iv] da necessidade da iluminação divina para o conhecimento da verdade. A este último retornaremos brevemente no Epílogo a esta parte 2. 
era passiva, esta última necessariamente age. Ou seja, temos duas potências intelectivas que, cada uma à sua maneira, contribuem na geração da intelecção: [i] o intelecto agente atua para fazer o inteligível em ato; [ii] o intelecto possível está em potência para ser movido pelo inteligível tal que se faça o intelecto em ato.

Como se nota, tal como há na produção da inteleção duas virtudes - intelecto agente e intelecto possível -, há também aí dois atos: o inteligível em ato e o intelecto em ato. Esses dois atos são descritos aqui por meio de comparações: [i] assim como a luz faz as cores em ato no meio transparente, assim também o intelecto agente faz o inteligível em ato (não ainda o intelecto em ato...) no intelecto possível; já [ii] o intelecto em ato é descrito como um composto de intelecto e inteligível, tal como se fosse de matéria e de forma. Esse segundo paralelo não faz mais do que reforçar o vocabulário da 'informação' do intelecto (tomado como fundamentalmente passivo) pela espécie dos inteligíveis, que já vimos em um trecho anterior a este último excerto $^{28}$. Já o primeiro paralelo é mais complexo, uma vez que coloca em jogo três elementos: o intelecto agente (como luz), o inteligível (como cor em ato no meio transparente) e o intelecto possível (como meio transparente). Sendo assim, o intelecto agente tanto age sobre a coisa tornando-a inteligível (assim como a luz age sobre a coisa tornando possível que esta multiplique as espécies de sua cor no meio), como age sobre o intelecto possível tornando-o receptível para o inteligível (tal como a luz torna o meio receptivo para a cor). Assim, o intelecto agente atualiza o inteligível e torna o intelecto possível apto a recebê-lo. Nesse caso, entretanto, essa comparação parece nos dizer que, de alguma maneira, o inteligível em ato já é no intelecto possível, muito embora ainda não haja o intelecto em ato.

Daí, percebemos que parece haver uma lacuna nessa exposição. Diz-se que o intelecto possível está em potência para os inteligíveis - ao ser atualizada, tal potência dá lugar ao intelecto em ato - e, simultaneamente, diz-se que o intelecto agente é uma potência ativa que faz do inteligível em potência um inteligível em ato. Ora, vimos há pouco que o 'inteligível em potência' não são, senão, as coisas sensíveis (res sensibiles) - assim, o intelecto agente surge como aquela potência ativa que torna as coisas sentidas inteligíveis em ato e habilita o intelecto possível a recebê-las. Em poucas palavras, a inteligibilidade em ato é explicada pela ação do intelecto agente sobre as coisas sensíveis, enquanto que o fazer-se do intelecto em ato é explicado

\footnotetext{
${ }^{28}$ Cf. nota 24 , acima.
} 
como o fazer-se, no intelecto possível, de 'um composto de intelecto e inteligível'. A lacuna nessa explicação parece estar na ausência de um passo intermediário que permita a passagem de [i] o inteligível em ato em presença do intelecto possível apto a sua recepção para [ii] o próprio intelecto em ato. Esse espaço será preenchido pela reintrodução da 'recepção' ou 'informação' do intelecto - agora, especialmente do 'intelecto possível' - pela 'espécie dos inteligíveis':

"Ora, o intelecto possível, informado assim pela espécie dos inteligíveis, instantaneamente [statim], na luz do intelecto agente (sem qualquer notícia atual ou habitual, geral ou especial precedente, mas somente em potência - de tal notícia potencial, diz a Glosa sobre aquilo em Aos hebreus I 'já que é o esplendor': 'Deus inseminou os princípios da alma [animae initia], intelecto e sabedoria'), concebe naturalmente as primeiras intenções dos inteligíveis incomplexos, conhecendo primeiro os termos e quididades das coisas" ${ }^{\prime 29}$.

Ora, em uma passagem já citada de Suma, art. 1, q. 5, vimos Henrique afirmar que o intelecto, enquanto potência receptiva, passa ao ato justamente pela recepção das espécies dos inteligíveis ${ }^{30}$. Nesse caso, o "intelecto possível, informado assim pela espécie dos inteligíveis [intellectus autem possibilis sic informatus specie intelligibilium]", a que se refere este último trecho indentado, não é senão o próprio intelecto em ato. Dito de outra maneira, o intelecto em ato é, precisamente, um composto de intelecto e inteligível, ou seja, o intelecto em ato é o intelecto possível informado pela espécie dos inteligíveis. Destarte, quando dizemos que o intelecto agente faz o inteligível em ato, tal 'inteligível em ato' pode ser, agora, identificado à 'espécie dos inteligíveis' - de fato, esta última é precisamente aquela espécie inteligível forjada pelo intelecto agente a partir do fantasma (que vimos ser em ato na imaginação), como lemos em Quodl. 1, q. 12-13 (a que retornaremos adiante): “<..> digo que aquela espécie que propriamente se chama 'espécie' se dá [editur] pelo fantasma e pela luz do intelecto agente em todo o intelecto possível naturalmente, tal como a espécie da cor se dá [editur] naturalmente no órgão pelo ato da luz. E, tal como ela não se dá [editur] no órgão por algum ato de ver, mas é o princípio do

\footnotetext{
${ }^{29}$ Henrique de Gand, Suma, art. 1, q. 5, co. (ed. De Wulf-Mansion Centre, vol. 21, pp. 125-6): "Intellectus autem possibilis sic informatus specie intelligibilium statim in lumine intellectus agentis sine omni notitia actuali vel habituali generali vel speciali praecedente, sed potentiali solum, de qua notitia potentiali dicit Glossa super illud Ad Hebraeos I 'Cum sit splendor': 'Deus inseminavit animae initia intellectus et sapientia', naturaliter concipit primas intentiones intelligibilium incomplexorum primo cognoscendo terminos et quidditates rerum". Note-se como aquele conhecimento potencial inato ao homem que vimos no item 3.2 é, aqui, exposto com base em uma autoridade bíblica.

${ }^{30} \mathrm{Cf}$, acima, nota 23 .
} 
primeiro ato de ver, assim a espécie inteligível dada [edita], como muito já foi dito, não se dá [editur] por algum ato de inteligir, mas é o primeiro princípio do primeiro ato de inteligir" ${ }^{\prime 31}$. Sendo assim, a formação da espécie pelo intelecto agente a partir do fantasma antecede o próprio ato de intelecção. Por outro lado, no momento em que o intelecto forja, a partir do fantasma da imaginação, a espécie enquanto inteligível em ato em presença do intelecto possível habilitado, pelo mesmo intelecto agente, a receber tal inteligível, já se segue a informação do intelecto possível pela espécie dos inteligíveis, pois o intelecto agente coloca um inteligível em ato (a espécie) em presença do seu receptor próprio natural (o intelecto possível sob a luz do intelecto agente). Dessa presença (provocada pelo intelecto agente) de um inteligível em ato a um intelecto passivo para recebê-lo, segue-se o intelecto em ato.

No entanto, um terceiro elemento além da 'espécie dos inteligíveis' e do 'intelecto em ato' parece ser colocado em jogo por Henrique. Com efeito, se voltarmos ao último trecho indentado de Suma, art. 1, q. 5, lemos que, quando o intelecto possível já possui em ato a espécie - ou seja, quando já há o intelecto em ato -, o intelecto possível (ainda na luz do intelecto agente) concebe algo ("intellectus autem possibilis $<\ldots>$ statim in lumine intellectus agentis $<\ldots>$ naturaliter concipit $<\ldots>)^{32}$.

\subsubsection{O intelecto e o conceito}

Para um leitura mais cuidadosa da última passagem indentada, parece-me importante destacar o advérbio statim - por ele, busca-se conectar o fazer-se do intelecto em ato (enquanto informação, sob a luz do intelecto agente, do intelecto possível pela espécie dos inteligíveis) e esse conceber. Quando o intelecto agente faz o inteligível em ato no intelecto possível - isto é, quando ele faz o intelecto em ato -, 'intanteneamente' (statim) há a concepção natural do conhecimento. Essa concepção, frisemos, ocorre ainda 'na luz do intelecto agente' - ou seja, a luz do intelecto agente

\footnotetext{
${ }^{31}$ Henrique de Gand, Quodl. 1, q. 12-13, ad 3 (ed. De Wulf-Mansion Centre, vol. 5, pp. 82-3): "Cum ergo assumitur in argumento quod non potest speciem edere a se nisi suo actu intelligendi, dico quod species illa quae proprie appellatur species, a phantasmate et lumine intellectus agentis editur in toto intellectu possibili naturaliter, sicut naturaliter editur species coloris in organo per actum lucis. Et sicut ipsa non editur in organo per aliquem actum videndi sed est principium primi actus videndi, sic species intelligibilis edita, ut dictum est in pluri, non editur in ipso per aliquem actum intelligendi sed est primum principium primi actus intelligendi”.

${ }^{32}$ Cf. nota 29 , acima.
} 
[i] faz o inteligível em ato a partir da coisa sensível, [ii] torna o intelecto possível apto a recebê-lo (do que resulta o intelecto em ato) e [iii], de alguma maneira, colabora na concepção. Mas, de que maneira? Henrique não é claro a esse respeito, mas talvez se possa dizer que tal concepção também ocorre 'na luz do intelecto agente', porque ela não é, senão, o resultado do intelecto em ato que só se tornou possível, ele próprio, sob a luz do intelecto agente, como vimos. Assim, somente uma vez que se tenha atualizado o intelecto em ato sob a luz do intelecto agente, o intelecto possível está apto a conceber algo. Nesse caso, toda a atualização que ocorre nessa produção da inteleção é, em última instância, possibilitada pelo intelecto agente.

Feita essa rápida (e incerta...) tentativa de interpretar o papel do intelecto agente na concepção, notemos que, segundo Henrique de Gand, uma vez que haja o intelecto em ato, statim o intelecto possível concebe algo. Assim, Henrique parece não querer descrever todo o caminho desde a atualização da espécie dos inteligíveis, passando pelo intelecto em ato até a concepção do conhecimento como um processo antes, esse é um caminho que instantaneamente (statim) ocorre 'na luz do intelecto agente'. Vale lembrar, aliás, que esse mesmo advérbio é utilizado por Henrique, em Suma, art. 1, q. 11, para descrever não a concepção do conhecimento, mas a geração da espécie dos inteligíveis: “o intelecto humano não possui, de si, nenhuma espécie dos inteligíveis inata $\langle\ldots\rangle$, mas, sem que exista impedimento (nem da parte do intelecto nem da imaginação), instantaneamente [statim] é gerada naturalmente pela virtude do intelecto agente, a partir da imaginativa, uma espécie inteligível no intelecto possível <... ${ }^{, 33}$. Não somente a concepção por parte do intelecto possível ocorre statim, mas também a geração da espécie dos inteligíveis no intelecto possível. Entretanto, ainda que se pareça propor todo esse caminho quase que como uma única ação, imediata e instantânea (statim), seu discurso nos sugere a distinção de pelo menos três atos no intelecto: aqueles dois anteriores, a saber, [i] a espécie dos inteligíveis e [ii] o intelecto em ato, ao qual se adiciona [iii] algo concebido, que se

\footnotetext{
${ }^{33}$ Henrique de Gand, Suma, art. 1, q. 11, co. (ed. De Wulf-Mansion Centre, vol. 21, pp. 180-1): “< $<>$ sic intellectus humanus de se nullam habet speciem intelligibilium innatam, sed secundum Philosophum 'solum est omnia intelligibilia in potentia', et 'non est aliquid eorum actu antequam intelligit', et non intelligit nisi specie recepta, quia est 'virtus passiva', sed nullo impedimento existente, neque ex parte intellectus neque ex parte imaginatione, statim naturaliter ab imaginativa virtute intellectus agentis generatur species intelligibilis in intellectu possibili naturaliter, et maxime in prima receptione quam nulla cognitio praecedit. Et tunc facit statim species recepta intellectum intelligere et primos conceptus formare, qui statim naturaliter veritate sua movent potentiam cognoscitivam <...>". ROMBEIRO, "Intelligible Species in the Mature Thought of Henry of Ghent", 2011, p. 199.
} 
segue ao intelecto em ato. Todo esse movimento, porém, deve ser compreendido como algo instantâneo, statim: em presença do inteligível, segue-se instaneamente todo o caminho que leva (passando pela espécie dos inteligíveis e pelo intelecto em ato) à concepção. Essa ênfase na instantaneidade na produção do conhecimento intelectual parece trair alguma ânsia de Henrique por garantir uma unidade dos diversos atos na produção do conhecimento intelectivo - voltaremos a isso dentro em pouco.

Estabelecido, para além [i] da espécie do inteligível em ato e [ii] do próprio intelecto em ato, esse último passo - [iii] a concepção - na geração do conhecimento intelectual, atentemos por enquanto para as palavras finais daquele mesmo último trecho indentado de Suma, art. 1, q. $5^{34}$. No fim daquela passagem, não se faz mais referência a um 'intelecto em ato' como resultado da informação do intelecto pelo inteligível, mas se afirma que aquilo que se segue ao intelecto em ato (este, resultado da informação do intelecto possível pela espécie do inteligível na luz do intelecto agente) é a concepção natural das "primeiras intenções dos incomplexos inteligíveis, conhecendo primeiro os termos e quididades das coisas [naturaliter concipit primas intentiones intelligibilium incomplexorum primo cognoscendo terminos et quidditates rerum]". No trecho que se lê entre parênteses em minha tradução desse excerto de Suma, art. 1, q. 5, é sublinhado que tal concepção intelectual ocorre sem pressupor qualquer conhecimento anterior - ou seja, estamos aqui precisamente no campo da inteligência dos conceitos simples, do conhecimento ainda não racional ou discursivo. Daí que o conhecimento concebido seja dos 'inteligíveis incomplexos' (isto é, dos 'não-complexos'), dos termos (mas, não das proposições) e, mais propriamente, das 'quididades das coisas'. Nesse ponto, completamos um ciclo: partimos das coisas sensíveis (res sensibiles) e, pela luz do intelecto agente, atingimos 'instantaneamente' (statim) as quididades das coisas (quiditates rerum). Mas, Henrique é ainda mais preciso ao afirmar que, nesse primeiro conhecimento das quididades das coisas, o intelecto possível, pela informação da espécie dos inteligíveis e na luz do intelecto agente, naturalmente concebe "as primeiras intenções dos inteligíveis incomplexos [primas intentiones intelligibilium incomplexorum]”. O que fazer dessa expressão?

O problema é que o vocábulo intentio é muito rico no latim escolástico - já vimos no item 4.3, por exemplo, que ele denomina o estatuto de dependência causal

\footnotetext{
${ }^{34}$ Cf. nota 29 , acima.
} 
da espécie sensível com respeito à coisa de que ela é espécie. No que tange à doutrina da intelecção do Doutor Solene, em especial, ele poderia possuir três significados principais: [i] tal como no estudo da sensação a espécie sensível é concebida como intentio da coisa fora, também no estudo da intelecção a espécie inteligível poderia ser tomada como uma intentio inteligível da coisa fora, uma vez que remete a esta última enquanto cognoscível pelo intelecto; [ii] por outro lado, intentio pode designar os conceitos incomplexos mais gerais - e, portanto, primeiros - que concebemos (nesse sentido, ele possui especial ligação com a noção metafísica e lógica de 'transcendente') $)^{35}$; [iii] além disso, primae intentiones pode se opor às intentiones secundae, sendo grosso modo as primeiras conceitos que dizem respeito às coisas fora do intelecto e as segundas conceitos que dizem respeito justamente aos conceitos de 'primeira intenção' (uma distinção que se mostra capital para o estudo da predicação) $)^{36}$.

\footnotetext{
${ }^{35}$ Cf. cap. 3, nota 43 .

${ }^{36} \mathrm{O}$ melhor local para se iniciar um estudo da distinção entre 'intenções primeiras' e 'intenções segundas' em Henrique de Gand parece ser em trecho de Suma, art. 53, q. 5, co. (ed. De Wulf-Mansion Centre, vol. 31, pp. 43-5), cuidadosamente lido em PINI, G. Categories and Logic in Duns Scotus. An Interpretation of Aristotle's Categories in the Late Thirteenth Century. Leiden - Boston - Köln: Brill, 2002, pp. 68-72. Nessa questão da Suma, são estudados os diversos significados que um nomen pode possuir. De início, é dito que os nomes podem significar [1] uma coisa pura (res pura), [2] uma intenção pura (intentio pura) e [3], de maneira intermediária, algo que é parte res e parte intentio " $<\ldots>$ nomina quaedam significant rem puram, quaedam vero significant intentionem puram, quaedam vero significant medio modo se habens, aliquid scilicet quod quodam modo res est et quodam modo intentio" (ed. De Wulf-Mansion Centre, vol. 31, p. 43). Nesse contexto, Henrique de Gand toma 'res pura' como aquilo que não é, de maneira alguma, uma intentio (tomada aqui como, em geral, um produto do intelecto, como veremos em pouco). Assim, res pura é somente aquilo que, de maneira alguma, se deve à ação de um intelecto (provavelmente, de um intelecto criado), como os singulares. Destarte, os nomes [1] que significam 'coisas puras', serão aqueles que significam singulares, como é o caso dos nomes 'Pedro' ou 'Paulo'. Esses nomes são, precisamente, 'nomes de coisas' (nomina rerum) - "Rem puram significant nomina rerum singularium; singularia enim sunt res purae et nullo modo intentiones, quia solummodo habent esse a natura et nullo modo a consideratione rationis, ut sunt iste homo, iste lapis. Unde cum nomina eis fuerint imposita, secundum quod 'Petrus' vel 'Paulus' est nomen istius hominis, illa appellantur simpliciter nomina rerum" (pp. 43-4). Diferente é o caso [2] dos nomes que significam de maneira intermediária algo em parte res e em parte intentio. Esse algo, meio res meio intentio é, segundo Henrique de Gand, o universal. Este é res enquanto representa a natureza nos singulares, mas é intentio enquanto é produzido pela abstração na consideração do intelecto. Assim, os nomes impostos para significar universais são nomes de coisas (enquanto tais universais representam a natureza da coisa), mas são também nomes de intenções (enquanto tais universais são produto do intelecto). Mais precisamente, esses nomes são nomes de 'primeiras intenções', uma expressão que ficará clara a seguir - "Universalia autem rerum singularium et sunt quodam modo res et quodam modo intentiones: res in quantum illam naturam repraesentant quae habet esse in singularibus, intentiones vero in quantum habent rationem abstracti in consideratione intellectus. Propter quod nomina eis imposita sunt quodam modo nomina rerum et quodam modo intentionum sed primarum" ( $p$. 44). Mas, por que 'primeira intenção'? Ora, essa expressão só faz sentido se houver uma 'segunda intenção', como sabemos ser o caso. Com efeito, qualquer universal (enquanto é produto do intelecto) é intenção, porém ele pode ser uma primeira intenção ou uma segunda intenção - "Intentionum enim quaedam sunt primae, quaedam vero secundae, et sic quodlibet universale reale, in quantum habet rationem abstracti, est intentio praedicabilis, quia extra singularia non est nisi in consideratione
} 
intellectus" (p. 44). Pois bem, tudo aquilo que o intelecto produz - seja acerca dos particulares ou acerca do próprios universais - e não representa a natureza de um singular é uma segunda intenção. Por isso, os nomes que significam tais intenções são chamados 'nomes de intenções segundas'. Note-se que, nesse ponto, o conhecimento intelectivo não diz respeito somente à 'coisa pura' fora da alma, mas também ao próprio conhecimento intelectivo. Daí que se diga que tais intenções segundas são, propriamente, intenções puras. Estamos agora, então, no caso [3], daqueles nomes que significam 'intenções puras' e, como dito, são 'nomes de segunda intenção' - 'Cetera vero quae per considerationem intellectus considerantur sive operantur et circa universalia et circa particularia, sive mediate sive immediate, sunt intentiones purae. Propter quod nomina illis imposita vocantur nomina intentionum, sed secundarum, quia post conceptam rationem universalis realiter concipit eas intellectus et circa universalia rerum et circa singularia" (p. 44). Por fim, Henrique distingue dois casos de segundas intenções significadas por nomes. Por um lado, há [i] nomes que significam intenções segundas que são produzidas pelo intelecto acerca de coisas e, por outro, há [ii] nomes que significam intenções segundas produzidas pelo intelecto acerca de nomes - "Sed istae sunt in duplici genere, quia quaedam sunt acceptae ab intellectu ut proprietates circa res principaliter, quaedam vero ut proprietates circa nomina rerum" (p. 44). Os [i] nomes que significam intenções segundas acerca de coisas dizem respeito a intenções produzidas pelo intelecto quando este compara coisas universais entre si (donde provêm as intenções segundas 'universal', 'gênero', 'espécie', 'diferença' etc.) ou quando compara as coisas singulares entre si (donde se derivam as intenções segundas 'indivíduo', 'particular' etc.). Essas são intenções lógicas (logicales) e não são mais do que relações estabelecidas estritamente pela atividade do intelecto entre coisas (universais ou particulares) - "De genere primo sunt intentiones logicales, ut sunt ratio universalis, generis scilicet et speciei et differentiae et huiusmodi circa universalia rerum, individuum et particulare et huiusmodi circa singularia rerum. Ista enim nomina non significant nisi respectus et habitudines inter ipsas res comparatas ad invicem consideratione intellectus" (pp. 44-5). Já os nomes [ii] que significam intenções segundas acerca de nomes são as intenções gramaticais (grammaticales). Eles são ditos nomes de nomes - "De secundo genere sunt intentiones grammaticales, ut sunt ratio nominis et verbi, adiectivi, substantivi et huiusmodi, quae non significant nisi modos nominum, propter quod dicuntur nomina nominum" (p. 45). Ou seja, concentrando-nos precisamente na distinção de intenções, notemos que Henrique de Gand propõe, em Suma, art. 53, q. 5, uma divisão tripartite entre 'coisa pura' (singulares fora da alma), primeiras intenções (conceitos abstraídos pelo intelecto e que representam a natureza de uma 'coisa pura') e intenções segundas (relações entre coisas - universais ou singulares - estritamente estabelecidas pelo intelecto).

Pois bem, ao que me parece, aquilo que fundamentalmente caracteriza a 'intenção segunda' é sua proveniência estritamente intelectual. Com efeito, como estamos estudando no presente trabalho, se o conceito universal (que, agora, vemos ser uma 'intenção primeira') depende de ações do intelecto para ser abstraído, ele igualmente é fruto da ação da coisa - de uma maneira ou de outra, a coisa se dá a conhecer pelos sentidos ou multiplica sua espécie. Já as segundas intenções são produzidas exclusivamente pelo intelecto acerca daquilo que ele conhece: o universal ou, indiretamente, o singular (cf., adiante, a nota 190). Assim, a intenção segunda se caracteriza por ser obra (opus) exclusivamente do intelecto - Quodl. 5, q. 6, co. (ed. 1613, f. 238rb): "Intentio autem hic appelatur, non id quod dicitur intentio secunda, qualia sunt ista, individuum, genus, species, proprium, accidens, definitivo, definitum, et talia, quae dicuntur intentiones non nisi quia opus intellectus sunt”. Além de serem obra do intelecto, tais intenções segundas se caracterizam, também, por não serem mais do que relações (respectus) concebidas pelo intelecto acerca de coisas - Quodl. 7, q. 1-2, co (ed. De Wulf-Mansion Centre, vol. 11, p. 6): “<..> omnes intentiones secundae rationem respectus formaliter important rei illius, circa quam considerantur ad aliam <...”. Ainda no mesmo Quodl. 7, q. 1-2, co., Henrique de Gand adiciona que essas 'segundas intenções' são produtos do intelecto na medida em que são 'concebidas' (concipere) por ele acerca das coisas naturais: "De istis duobus ultimis generibus entium $<s c$. as intenções segundas e as coisas artificiais $>$ dico, quod non habent proprias ideas in Deo, sed solum ideas rerum naturalium circa quas intellectus concipit intentiones secundas, et circa quas ars operatur formas artificiales" (op. cit.). A importância do uso do verbo 'concipere' nesse contexto está no fato de que, como vimos, esse é o mesmo verbo utilizado para descrever a atividade pela qual o intelecto, informado pela espécie, produz o conceito. Ao que parece, com base em Quodl. 7, q. 1-2, podemos dizer que não somente esses conceitos de primeira intenção (isto é, os universais que representam as essências das coisas) são concebidos, mas também as segundas intenções podem ser ditas concebidas pelo intelecto (sendo estas últimas, porém, fruto estritamente do intelecto e não também das coisas fora).

Sobre este tema, cf. KNUDSEN, C. "Intentions and impositions”. In: KRETZMANN, N., KENNY, A., 
O primeiro significado pode ser descartado nesse contexto, pois a concepção a que Henrique se refere ao fim do último trecho indentado de Suma, art. 1, q. 5, já é algo posterior à informação do intelecto possível pela espécie - não é mais esta última que está em jogo no momento da concepção. Sendo assim, podemos dizer que, de certo modo, as 'primeiras intenções' a que o gandavense se refere no trecho parecem lembrar o segundo significado de intentio, uma vez que estamos aqui em uma reflexão acerca daquilo que primeiro é compreendido pelo intelecto. No entanto, parecemos estar no campo do segundo significado de intentio (em especial, da expressão prima intentio), quando se relacionam na passagem as primae intentiones às quiditates rerum - com efeito, as primeiras intenções (em oposição às segundas) são justamente aquelas que dizem respeito a coisas (mais precisamente, a quididades das coisas) e não a outras intenções. A meu ver, Henrique não se utiliza precisamente aqui de nenhum desses dois últimos significados que intentio recebe em sua doutrina da intelecção. Pelo contrário, ele parece conjugar ambos, para denominar como primae intentiones aquilo [i] mais geral, que primeiro se concebe intelectualmente [ii] acerca das coisas fora do intelecto. Dito de outra maneira, essas primae intentiones parecem ser aquilo de mais geral que primeiro se concebe acerca das quididades das coisas, instantaneamente (statim) após a informação do intelecto possível pela espécie dos inteligíveis na luz do intelecto agente.

À pergunta sobre quais seriam essas primeiras intenções, responde-se:

"E, assim, primeiro a inteligência da mente é informada pelos primeiros conceitos das coisas, como pelas mais expressas similitudes da verdade das coisas $[$ ut expressissimis similitudinibus veritatis rerum $]$ inscritas na consideração atual da mente. Tais são as intenções de ente, de um em número [unius numeri], de grandeza e de outros incomplexos que são naturalmente os primeiros inteligidos e incomplexos" ${ }^{37}$.

PINBORG, J. The Cambrige History of Later Medieval Philosophy. Cambridge: Cambridge University Press, 1982, pp. 479-95 (esp. pp. 482-3); KORIDZE, G. Intentionale Grundlegung der philosophischen Logik. Studien zur Intentionalität des Denkens bei Hervaeus Natali im Traktat 'De secundis intentionibus'. Inaugural-Dissertation zur Erlangung des Grades eines Doktors der Philosophie der Fakultät für Philosophie und Geschichte der Eberhard Karls Universität Tübingen. Dezember, 2004, pp. 54-5; PAIVA, "Sobre as duas utilizações do termo res..., 2014, pp. 64-9. Mencione-se, igualmente, TACHAU, Vision and Certitude..., 1988, pp. 33-6, onde se busca integrar a distinção entre 'primeiras e segundas intenções' à doutrina da intelecção de Henrique de Gand sem, entretanto, qualquer discussão mais aprofundada acerca da noção de intentio que surge nesse contexto.

${ }^{37}$ Henrique de Gand, Suma, art. 1, q. 5, co. (ed. De Wulf-Mansion Centre, vol. 21, p. 126): "Et sic primo informatur mentis intelligentia primis rerum conceptibus, ut expressissimis similitudinibus veritatis rerum in actuali consideratione mentis descriptis, ut sunt intentiones entis et unius numeri et magnitudinis et ceterorum incomplexorum quae sunt prima naturaliter intellecta et incomplexa". Acompanhei Teske ao traduzir 'descriptis' por 'inscritas' (no seu inglês, "inscribed" - cf. HENRY OF GHENT, Summa of Ordinary Questions. Article One, 2008, p. 69). 
Notemos, de saída, a flutuação do termo 'informada': até há pouco, dizia-se que o intelecto possível é informando pela espécie dos inteligíveis na luz do intelecto agente $^{38}$; agora, se diz que a 'inteligência da mente' é informada não mais pela espécie, mas pelos 'primeiros conceitos das coisas' ("informatur mentis intelligentia primis rerum conceptibus" $)^{39}$. Ora, a palavra conceptus provém da descrição do resultado subsequente ao intelecto em ato como um concipere do conhecimento. Donde, podemos concluir que, assim como o intelecto possível era informado pela espécie dos inteligíveis quando o intelecto agente fazia esta última e o tornava apto a recebê-la, também a concepção do conhecimento, na luz do intelecto agente, a partir do intelecto em ato, faz com que o intelecto novamente seja informado - agora, por aquilo mesmo que foi concebido, isto é, pelo 'conceito'.

Essa aproximação entre espécies e conceitos fica ainda mais clara quando vemos estes últimos caracterizados como 'similitudes' (similitudinibus). De fato, embora não pareça ser um termo preferencial para Henrique de Gand, 'similitudo' e 'species' encontram-se bastante aproximados em alguns textos que lemos acerca dos sentidos particulares (item 4.2) e internos (item 5.3) ${ }^{40}$. Ou seja, species e conceptus parecem se aproximar na doutrina da intelecção ao serem, ambos, tratados como 'similitudes'.

Porém, não se deve concluir que espécie e conceito sejam o mesmo: a espécie é a coisa inteligível em ato presente ao intelecto, enquanto que o conceito é o próprio conhecimento em ato daquela coisa (ambos sendo separados, na sucessão de atos do intelecto, pelo intelecto em ato). A importância de distingui-los - espécie e conceito na inteleção é que, muito embora o intelecto humano instantaneamente (statim) conceba algo quando em ato (isto é, quando informado pela espécie), ele não concebe instantaneamente (statim) tudo o que se poderia conceber na espécie - pelo contrário, ele concebe statim somente as 'primeiras intenções' da coisa inteligida por meio da espécie. Em outras palavras, deve-se distinguir 'espécie' e 'conceito', porque nem tudo o que se pode conceber pela espécie é instantaneamente (statim) concebido pelo intelecto (outros conceitos para além das 'primeiras intenções' concebidas deverão ser

\footnotetext{
${ }^{38}$ Cf. nota 24 e 26, acima.

${ }^{39}$ Cf. tb. o trecho de Suma, art. 1, q. 11, citado na nota 33, onde igualmente se fala sobre a formação ("formare") dos 'primos conceptus' a partir da recepção da espécie no intelecto.

${ }^{40}$ Cf. cap. 4 , notas 16 e 18 , e cap. 5 , nota 55.
} 
buscados racionalmente, como já mencionamos na parte 1). Por outro lado, é importante aproximar 'espécie' e 'conceito' para destacar que, mesmo no momento em que o intelecto ultrapassa [i] o inteligível em ato, [ii] o intelecto em ato e atinge [iii] o próprio conceito, ainda então permanece no campo das similitudes. Com efeito, das coisas mesmas só há no intelecto similitudes, isto é, espécies e conceitos. Aliás, destes últimos, num primeiro momento, só há no intelecto as 'primeiras intenções' e, mais precisamente, os 'conceitos primeiros' incomplexos acerca dessas coisas.

Pois bem, quando se adiciona, no último trecho indentado ${ }^{41}$, que esses 'primeiros conceitos' são precisamente aquelas "mais expressas similitudes da verdade das coisas [expressissimis similitudinibus veritatis rerum]", acredito que se deva tomar 'mais expressas' como as 'mais anteriores' ou as 'mais primeiramente inteligíveis' - isto é, aquelas que o intelecto primeiramente concebe a respeito de um inteligível ao ser informado por sua espécie. Que tais similitudes primeiras sejam 'da verdade das coisas' (veritatis rerum) deve ser considerado cum grano salis, uma vez que, como veremos adiante (no Epílogo desta parte 2), não se pode facilmente passar deste conhecimento concebido a partir das espécies dos inteligíveis para $o$ conhecimento que é propriamente 'da verdade da coisa' (veritatis rei). Por outro lado, vale ressaltar que, pelo menos neste último trecho indentado, em alguma medida admite-se um conhecimento da 'verdade da coisa' pela ação unicamente do intelecto, ainda que esse conhecimento seja somente daqueles conceitos mais anteriores, mais gerais, que mais expressamente se dão a conhecer após a formação do intelecto em ato. Assim - pelo menos neste excerto, reitero -, parece que a ação do intelecto é suficiente para que atinjamos um conhecimento da verdade da coisa em termos gerais, isto é, somente no que diz respeito àqueles conceitos primeiros que, a partir dela, se pode conhecer mais expressamente.

Agora, a explicação sobre quais seriam esses 'conceitos primeiros das coisas' dá lugar a uma inesperada enumeração daquelas intenções mais expressas "inscritas na consideração atual da mente [in actuali consideratione mentis descriptis]" - ou seja, que são primeiramente atualizadas como conceitos no intelecto, tão logo este esteja em ato informado por uma espécie. Elas são, a saber: 'ente', 'um em número', 'grandeza etc.'! O problema com essa lista é que ela não parece corresponder a

\footnotetext{
${ }^{41}$ Cf. nota 37 , acima.
} 
nenhuma outra enumeração de intenções primeiras ${ }^{42}$. Que o 'ente' surja como uma intenção primeira, não surpreende; o 'um' também não causaria problema, não fosse sua caracterização como unidade numérica; por fim, quanto à 'grandeza', não parece haver muito que possamos dizer, pois Henrique não volta a ela nas cercanias deste excerto. Talvez, o mais útil para nós seja atentar não tanto para a enumeração, mas para a caracterização dessas noções como os 'conceitos primeiros' que, dizendo respeito às quididades das coisas, são ainda assim aqueles conceitos mais anteriormente inscritos no nosso intelecto após a informação pela espécie dos inteligíveis $^{43}$. Esses conceitos nos dão a conhecer o mais geralmente algo sobre a verdade daquela coisa cuja espécie informa o intelecto possível.

\footnotetext{
${ }^{42}$ Cf. cap. 3, nota 43.

${ }^{43}$ Uma possível razão para que Henrique de Gand enumere a magnitudo como um dos primeiros conceitos ou intenções de ente é o fato de tal termo poder ser predicado analogamente de Deus e das criaturas. Como já vimos anteriormente, há certos conceitos primeiros - denominados por um dos usos da expressão "primae intentiones" - que são análogos a Deus e às criaturas, dando a base filosófica para a afirmação de que Deus seria o primum cognitum do intelecto humano (cf. cap. 3, nota 89). Ora, que 'magnitudo' seja predicável analogamente de Deus e das criaturas, lemos em Suma, art. 28, q. 1, ad 3 (ed. Teske, pp. 184-6): "Magnitudo ergo dicitur esse in Deo, non quia sit ibi aliqua moles quantitatis ad quam significandam nomen primo erat impositum creaturis, sed quia in eo est abundantia virtutis, quae in spiritibus respondet magnitudini molis in corporalibus $<\ldots .>$ - esse tema é desenvolvido mais detalhadamente em Suma, art. 54, q. 1 (ed. De Wulf-Mansion Centre, vol. 29, pp. 71-87), onde se estuda a infinitude divina (sobre a noção de infinito e infinitude divina no Doutor Solene, cf. GILSON, É. "L'infinité divine chez saint Augustin", 1954, pp. 573-4; DUBRULE, D. E. Divine Infinity in the Writings of Henry of Ghent. A Thesis Submitted in Conformity with the Requirements for the Degree of Doctor of Philosophy in the University of Toronto, 1968; SIEMIANOWSKI, A. "Pojęcie nieskończoności u Henryka z Gandawy”. Roczniki Filozoficzne 16.1 (1968), pp. 105-111; HÖDL, L. "Die 'doppelte Wahrheit' vom Unendlichen in den Quaestiones ordinariae (Summa) des Heinrich von Gent". Mediaevalia. Textos e estudos 3 (1993), pp. 55-75; HÖDL, L. "Der Begriff der göttlichen Unendlichkeit in der Summa des Heinrich von Gent (†1293)". In: CRAEMER-RUEGENBERG, I., SPEER, A. (Hrsg.). Scientia und ars im Hoch- und Spätmittelalter. Berlin - New York: De Gruyter, 1994, pp. 548-68; DAVENPORT, A. A. Measure of a Different Greatness. The Intensive Infinite, 1250-1650. Leiden - Boston - Köln, 1999, pp. 89-164; CÔTÉ, A. L'infinité divine dans la théologie médiévale (1220-1255). Paris: Vrin, 2002, pp. 207-10; ROIG, "Cracking intencional en la metafísica de Enrique de Gand", 2017, pp. 55-6). Ora, se a magnitudo é predicável analogamente das criaturas e do criador, isso não seria suficiente para que ela seja considerada um dos conceitos ou intenções primeiras, uma vez que estes últimos (como 'ente', 'uno', 'bem', 'verdadeiro') também são analogamente predicáveis de ambos? A resposta a essa pergunta deve ser negativa, pois as intenções primeiras não se caracterizam exclusivamente pela possibilidade de predicação análoga a Deus e às criaturas - pelo contrário, há muitos termos que são predicáveis dessa maneira e, no entanto, não são contados entre as passiones entis. Como diz Pickavé, ao rejeitar a possibilidade de tomarmos pulchrum e iustum como transcendentes em Henrique, "Was das pulchrum und das iustum in die Nähe der primae intentiones stellt, ist nicht, dass sie ebenfalls Ersterkannte sind, sondern dass sie mit diesen Erstbegriffen eine Eigenschaft teilen: Wie die Erkenntnis des Guten und des Wahren das Erfassen des ersten Guten und ersten Wahren implizit voraussetzen, so verweisen auch Bestimmungen wie pulchrum und iustum auf ein primäres pulchrum und ein primäres iustum, d. h. diese Eigenschaften in Gott, ohne die ein Begreifen des anderen nach Heinrich unmöglich ist. Diese Gemeinsamkeit teilen sie mit den transcendentia, weil sie wie diese 'etwas Nobles und Würdiges' bedeuten, was Gott und den Geschöpfen auf analoge Weise gemeinsam ist" (Heinrich von Gent über Metaphysik..., 2007, pp. 302-3 - grifos no orig.). Como vemos, a predicação análoga ao criador e à criatura é uma característica possuída pelas primae intentiones (ens, unum etc.), mas também por outros termos (como iustum,
} 
Atentemos, ademais, para o fato de que tais 'conceitos primeiros' são ainda descritos, ao fim do mesmo trecho, como aqueles "que são naturalmente os primeiros inteligidos e incomplexos [quae sunt prima naturaliter intellecta et incomplexa]"44. Ora, sabemos desde o cap. 3 que não há no intelecto humano conhecimento inato - de fato, lemos em Suma, art. 4, q. 3, que "não há nenhum conhecimento natural no homem [nulla cognitio naturalis est in homine]"45. Mais precisamente, o que há de inato no intelecto humano é somente a potência para inteligir. Sendo assim, o que poderia ser um inteligido ou um incomplexo naturalmente primeiro?

Ao que parece, nesse caso, 'natural' não se identifica a 'inato', mas antes se opõe tanto à 'inato' como à 'racional'. Esse complexo jogo com os termos 'inato', 'natural' e 'racional' pode ser lido no seguinte trecho de Suma, art. 1, q. 11: “< ..> algo que não é inato, mas sobreveniente e adquirido pode ser adquirido duplamente: de um modo, naturalmente [naturaliter], de outro modo racionalmente [rationaliter]. Do primeiro modo, o homem adquire a notícia dos primeiros princípios tanto nos especulativos como nos ativos" ${ }^{\text {46 }}$ - ao que se adiciona algumas linhas em seguida:

pulchrum ou totus - sobre este último, cf. PORRO, P. "La totalité peut-elle être un attribut divin? Les questions De totalitate Dei d'Henri de Gand”. Quaestio 16 (2016), pp. 209-223). Assim, afirmar que magnitudo possui uma tal predição não é suficiente para descrevê-lo como um conceito ou intenção primeira. De fato, lemos em Suma, art. 32, q. 1, co., que pode-se atribuir a Deus algo que se atribui às criaturas como dignidade e nobreza desta última: "Esse igitur ex circumstantia bonorum Deo attribuendum est, non solum esse absolutum. Hoc autem non fit nisi Deo attribuendo aliqua quae sunt dignitatis et nobilitatis absolutae in creaturis" (ed. De Wulf-Mansion Centre, vol. 27, p. 31). Ou seja, há mais conceitos atribuíveis analogamente a Deus do que somente os conceitos primeiros (sobre a origem da linguagem teológica nas criaturas, cf. cap. 2, nota 36). Dito tudo isso, podemos afirmar que a mera possibilidade de ser predicada analogamente de Deus e das criaturas não é suficiente para que a magnitudo possa ser tomada como uma intenção primeira (ao lado de 'ente', 'uno', 'bem' etc.). Mas, então, por que ela é assim tomada em Suma, art. 1, q. 5? Essa pergunta, para mim, permanece sem resposta.

${ }^{44}$ Cf. nota 37 , acima.

${ }^{45}$ Henrique de Gand, Suma, art. 4, q. 3, co. (ed. De Wulf-Mansion Centre, vol. 21, p. 281). Esse trecho já foi citado em cap. 3 , nota 82.

${ }^{46}$ Henrique de Gand, Suma, art. 1, q. 11, co. (ed. De Wulf-Mansion Centre, vol. 21, p. 180): "Sed aliquid quod non est innatum, sed superveniens et acquisitum, dupliciter potest acquiri: uno modo naturaliter, alio modo rationaliter. Primo modo acquirit homo notitiam primorum principiorum tam in speculativis quam in activis". Cf. GELISSEN, Natuur en genade..., 1965, deel 2, p. 9, nt. 64: “Conhecimento 'natural', portanto, não é aqui para Henrique um conhecimento possuído por natureza pelo intelecto, mas a intuição [inzicht] da verdade atingida sem qualquer intermediário. Portanto, o intelecto recebe o conhecimento natural quando ele, uma vez induzido por um objeto conhecido sensivelmente apropriado para tanto, intui sem qualquer raciocínio ou pesquisa a verdade dos primeiros princípios direta e intuitivamente. Portanto, o conhecer naturalmente ('scire naturaliter'), uma vez que está em exata oposição ao conhecer em ato como resultado de uma pesquisa ('scire ex investigatione'), diz respeito não a este último, mas à capacidade [vermogen], a potência [potentie], para conhecer os primeiros princípios antes de tudo, imediatamente e sem interposição de outras verdades $<\ldots>$ ['Natuurlijke' kennis is dus hier voor Hendrik geen van nature door het verstand bezeten kennis, maar het zonder iedere tussenweg bereikte inzicht van de waarheid. Het verstand ontvangt derhalve 
“porém, pressuposta tal notícia dos princípios por tal aquisição <sc. natural $>$, o homem, pela via da investigação racional racionalmente pela potência natural da razão, enquanto é razão, discorrendo adquire para si, a partir da notícia daqueles princípios, a notícia das conclusões $<\ldots{ }^{>}{ }^{47}$. Note-se nestas linhas o duplo uso do termo 'natural': ao mesmo tempo em que a razão é tomada como uma potência natural (no sentido de potência inata para o discurso), a aquisição natural de conhecimento não se confunde com qualquer conhecimento inato (uma vez que nem mesmo há um tal conhecimento inato em ato). Assim, quando se diz que o conhecimento dos princípios é natural, entende-se que tal conhecimento é adquirido naturalmente, sem qualquer discurso racional; de outra parte, as conclusões não são adquiridas naturalmente, mas racionalmente, pois exigem um discurso (que a referência a princípios e conclusões parece caracterizar, precisamente, como 'discurso silogístico').

Ora, se lermos o último trecho indentado de Suma, art. 1, q. $5^{48}$, à luz dessa oposição entre 'conhecimento naturalmente adquirido' e 'conhecimento racionalmente adquirido', fica claro que aquele conhecimento dos conceitos primeiros que ali encontramos é caracterizado como 'naturalmente' inteligido precisamente porque é anterior a qualquer outro conhecimento incomplexo. Esses conceitos primeiros são os conceitos mais expressamente conhecidos a partir da espécie que informa o intelecto possível e não pressupõem qualquer outro conceito anterior, pois eles não pressupõem a passagem de um conceito incomplexo a outro. Sendo assim, podemos dizer que, no conceito resultante do intelecto em ato, o intelecto conhece a quididade da coisa cuja espécie foi por ele recebida - porém, tal conhecimento é, ainda, natural (não discursivo), maximamente primeiro e, ao que parece, demasiado geral.

nauturlijke kennis, als het naar aanleiding van daartoe geëigende, zintuiglijk gekende obiecten de waarheid van de eerste princiepen, direct en intuïtief, zonder enige redenering of onderzoek inziet. En zo heeft derhalve het natuurlijk kennen ('scire naturaliter'), omdat het juist in tegenstelling is met het ten gevolge van een onderzoek actueel kennen ('scire ex investigatione') niet betrekking op dit laatste, maar op het vermogen, de potentie, om vóór al het andere, onmiddellijk en zonder tussenkomst van andere waarheden, de eerste princiepen te kennen <... ]". Por fim, veremos no Epílogo da parte 2 que 'natural' ainda pode se opor a 'por iluminação'.

${ }^{47}$ Henrique de Gand, Suma, art. 1, q. 11, co. (ed. De Wulf-Mansion Centre, vol. 21, p. 181): "Tali autem notitia principiorum supposita ex acquisitione tali, homo via investigationis rationalis rationaliter per potentiam naturalem rationis, ut est ratio, discurrendo acquirit sibi ex notitia illorum principiorum notitiam conclusionum $<\ldots>$ ".

${ }^{48}$ Cf. nota 37 , acima. 
Uma possível objeção a tal leitura seria que, em Suma, art. 1, q. 11, Henrique fala da aquisição natural de conhecimentos proposicionais (primeiros princípios complexos), enquanto que em Suma, art. 1, q. 5, ele se refere a conceitos incomplexos primeiros naturalmente concebidos (intenções primeiras). Se, porém, acrescentarmos a nosso estudo mais uma passagem desta última questão, veremos que o próprio Doutor Solene aproxima a anterioridade dos primeiros conceitos incomplexos à anterioridade dos primeiros princípios. A bem dizer, a anterioridade dos primeiros conceitos incomplexos é, justamente, explicada por um paralelo com os primeiros princípios do conhecimento proposicional e científico:

"E o intelecto deles $<s c$. daqueles que são naturalmente os primeiros inteligidos e incomplexos, citados no último trecho identado> é chamado de 'inteligência dos indivisíveis'. Por ela, a mente naturalmente conhece primeiramente os termos a partir de cuja reunião entre si pelo intelecto que compõe e divide ela similarmente conhece, sem qualquer discurso, as primeiras concepções dos inteligíveis complexos, tais como que 'o todo é maior que sua parte', 'se se retirar um igual de iguais, os que sobram são iguais', 'de qualquer um, afirmação ou negação e não simultaneamente do mesmo' e outros desse modo, que são os primeiros princípios das ciências complexos naturalmente inteligidos - tendo sido, porém, inteligidos primeiramente os termos" $" 49$.

O paralelismo entre as primeiras intenções incomplexas e os primeiros princípios complexos é desenvolvido por Henrique de Gand principalmente em dois aspectos: [i] ambos independem de qualquer conhecimento anterior (na terminologia de Suma, art. 1, q. 11, são adquiridos naturalmente) e [ii] ambos são constituintes de conhecimentos posteriores. Há, entretanto, assimetrias nesses dois aspectos dessa comparação. No que diz respeito ao segundo aspecto, o conhecimento incomplexo só pode ser constituinte de conhecimentos posteriores na medida em que é assumido como elemento de um conhecimento complexo. Além disso, no que diz respeito ao primeiro aspecto da comparação, as primeiras concepções complexas são 'primeiras' com respeito às demais concepções complexas (uma vez que surgem sem qualquer discurso silogístico); entretanto, elas não são primeiras com respeito aos incomplexos,

\footnotetext{
${ }^{49}$ Henrique de Gand, Suma, art. 1, q. 5, co. (ed. De Wulf-Mansion Centre, vol. 21, p. 126): "Et appellatur eorum intellectus 'indivisibilium intelligentia', qua mens primo naturaliter cognoscit terminos ex quorum collectione ad invicem per intellectum componentem et dividentem consimiliter concipit naturaliter sine omni discursu primas conceptiones intelligibilium complexorum, ut quod 'totum est maius sua parte', 'si ab aequalibus aequalia demas, quae relinquuntur aequalia sunt', 'de quolibet affirmatio vel negatio et non simul de eodem', et cetera huiusmodi, quae sunt prima principia scientiarum complexa naturaliter intellecta, prius tamen intellectis terminis".
} 
uma vez que elas dependem da atualidade anterior destes últimos para que sejam concebidas pelo 'intelecto que compõe e divide" ${ }^{50}$.

Esse difícil paralelo foi longamente estudado por Martin Pickavé, que enxerga nessa intersecção entre duas ordenações do conhecimento (aquela do conhecimento incomplexo e aquela do conhecimento complexo) um dos elementos fundamentais para a compreensão da cientificidade da metafísica em Henrique de Gand ${ }^{51}$. Por ora, basta-nos ressaltar como essa comparação restringe todo o discurso que acompanhamos até aqui sobre as relações entre intelecto agente e intelecto possível ao âmbito da primeira operação do intelecto - ou seja, a restringe à inteligência dos indivisíveis. Decerto, conhecimentos menos gerais podem ser derivados daqueles conhecimento gerais incomplexos, no entanto tal derivação ocorrerá sempre pela ${ }^{50}$ A anterioridade dos incomplexos com respeito aos complexos se torna clara quando aqueles
primeiros são descritos como termos (termini) dos complexos - Suma, art. 1, q. 12, co. (ed. De Wulf-
Mansion, vol. 21, pp. 187-8): "Homo autem, cum sit in ultimo ordine intelligentiarum post primum, qui
non habet sibi aliquam notitiam innatam nisi in potentia solum, ut dictum est, primo sibi naturaliter
acquirit notitiam principiorum incomplexorum sub esse incompletissimo et confuso magis, secundum
quod congruit humanae naturae, quia 'innata est nobis via sciendi ex nobis notioribus', quae sunt
confusa magis, procedendo 'in notiora naturae' quae sunt distincta et determinata magis, et hoc per
hunc modum. Homo enim sibi acquirit notitiam primo de terminis et quidditatibus rerum in generali
primo cognoscendo et considerando quid dicitur per nomen. Ex quibus terminis componendo et
dividendo secundo concipit prima principia complexa sub esse confuso, et secundum quod homo magis
est dispositus in lumine naturalis intellectus et ingenii subtilitate, tanto perfectius prima principia, tam
incomplexa quam complexa, ab initio concipit". Sobre o conhecimento inicial per nomen, cf. cap. 1,
nota 9 e, aqui, a nota a seguir.

${ }^{51}$ PICKAVÉ, Heinrich von Gent über Metaphysik.., 2007, pp. 24-41 (esp. p. 30): “Analog zur Ordnung des Beweises, in der sich Sätze auf andere Sätze zurückführen lassen, erfährt die Begriffsordnung eine Hierarchisierung von aufeinander 'rückführbaren' Begriffen. Das erste Prinzip in incomplexis ist ein erster und einfacher Begriff (primus conceptus), auf den alle anderen Begriffe zurückgeführt werden müssen und dem Heinrich Attribute zuspricht, die auch von den obersten Prämissen des Beweises ausgesagt werden, denn er ist der erste (primus) und der bekannteste Begriff (conceptus notissimus)". Sobre a necessária precedência da ordem dos incomplexos com respeito à ordem dos complexos, cf. op. cit., p. 39: "Da der Akt des zusammenfügenden bzw. trennenden Erfassens (intelligentia componens vel dividens) auf das einfache Erkennen folgt und auf ihm aufbaut, geht dem ersten Prinzip in complexis das erste Prinzip in incomplexis voraus". Por fim, note-se que Pickavé toma essa, em suas palavras, 'analogia' entre a ordem dos incomplexos e a ordem dos complexos como "Ecksteine der hochmittelalterlich-lateinischen Erkenntnistheorie" (op. cit., p. 30). Ainda sobre o paralelismo entre a ordem dos conceitos incomplexos e a ordem dos conceitos complexos, cf. Suma, art. 34, q. 3, co. (ed. De Wulf-Mansion Centre, vol. 27, p. 190): “Ad huius ergo quaestionis intellectum sciendum quod, sicut in intellectu complexo oportet fieri reductionem in aliquod primum principium complexum omnino intellectui per se notum - aliter enim procederetur in infinitum -, sic in conceptu intellectus incomplexi de eo quod quid est, quod dicitur per nomen, quod est propria ratio termini, a qua imponitur ad significandum, oportet omnes huiusmodi conceptus reducere ad aliquem conceptum incomplexum primum et notissimum, in quem omnes alii habent reduci, et qui includitur in omnibus aliis. Et est iste 'conceptus entis in quantum ens est', secundum Avicennam in $\mathrm{I}^{\circ}$ Metaphysicae, ut saepius habitum est supra". Ainda sobre a relação entre primeiros princípios do conhecimento incomplexo e aqueles do conhecimento complexo, cf. DWYER, E. Die Wissenschaftslehre Heinrichs von Gent. Inaugural-Dissertation verfasst und der hohen Philosophischen Fakultät der Bayer. Julius-Maximilians-Universität Würzburg zur Erlängung der Doktorwürde. Würzburg: Rita-Verlag und Druckerei, 1933, pp. 45-6; BROWN, J. V. "Intellect and Knowing in Henry of Ghent”, 1975, pp. 700-2; FIORENTINO, Conoscenza scientifica e teologia..., 2014, p. 66. 
passagem de um conhecimento incomplexo a um conhecimento complexo e, destarte, da primeira para a segunda operação do intelecto. Como se vê, em todo esse capítulo, o que nos interessa é principalmente essa inteligência dos incomplexos.

Enfim, temos nesse ponto que a descrição do conhecimento intelectual (em particular, da primeira operação do intelecto) envolve duas potências - o intelecto agente e o possível ou passivo - que, por complexas relações de atividade e passividade, perfazem três atos no intelecto: [i] o intelecto agente faz, das coisas sensíveis inteligíveis em potência, os inteligíveis em ato ao atualizar a espécie dos inteligíveis (nas palavras de Suma, art. 1, q. $1^{52}$, ele 'cava' sob as espécies dos sensíveis em busca das quididades não-sensíveis), ao mesmo tempo em que habilita o intelecto possível a receber tal espécie; [ii] essa atualização da espécie dos inteligíveis no intelecto possível, sob a luz do intelecto agente, compõe o intelecto em ato; e, deste, [iii] concebem-se naturalmente (isto é, sem discurso) conceitos primeiros incomplexos acerca da quididade da coisa conhecida, os quais se tornam inscritos em ato na mente. Todo esse caminho, entretanto, é descrito como algo súbito - tudo isso ocorre não processualmente, mas statim. Feito isso, quando se chega a esses conceitos primeiros da quididade da coisa, temos um conhecimento maximamente geral dessa coisa cuja espécie foi recebida no intelecto: o intelecto a concebe como 'ente', como 'um em número' etc., mas nada muito mas preciso do que isso.

Além disso, destaquemos que toda esse doutrina surge em Suma, art. 1, q. 5, como uma explicação da assimilação entre o inteligido e o intelecto: “de fato, não é preciso que se seja da natureza do fogo para conhecer o fogo, nem da natureza da água para se conhecer a água e assim quanto aos outros, mas é preciso somente que se seja assimilado <ou assemelhado $>$ [assimiletur] a eles $<s c$. ao fogo ou à água $>$, informado pelas espécies delas $<s c$. das naturezas do fogo ou da água ${ }^{\Perp 53}$. Essa

\footnotetext{
${ }^{52}$ Cf., acima, a nota 22.

${ }^{53}$ Henrique de Gand, Suma, art. 1, q. 5, co. (ed. De Wulf-Mansion Centre, vol. 21, p. 124): "Non enim oportet ut sit naturae ignis ad hoc ut cognoscat ignem, nec naturae aquae ad hoc ut cognoscat aquam, et sic de ceteris, sed solum oportet ut assimiletur eis informatus per earum species". Essa noção de 'assimilação' é destacada como basilar para a doutrina da intelecção de Henrique em NYS, De werking van het menselijk verstand..., 1949, p. 52: "Tal como todo ato de conhecimento, o conhecimento intelectivo é consumado em uma assimilação da potência cognoscitiva ao objeto conhecido. Esse princípio era comumente pressuposto pelos peripatéticos medievais. Henrique de Gand também tomou a mesma posição como fundamento em seu esclarecimento de todo conhecimento humano <...>. Encontramos tal posição por todos os trabalhos de Henrique [Zoals elke kendaad wordt ook het verstandelijk kennen voltrokken in een assimilatie van het kenvermogen aan het gekende voorwerp. Dat beginsel werd bij de Middeleeuwse peripatetici algemeen vooropgezet. Ook Hendrik van Gent geeft dezelfde stelling als basis in zijn verklaring van elke menselijke kennis <...>. Wij ontmoeten deze
} 
assimilação, como vemos, não é a própria informação pela espécie, mas se segue dela.

Tal assimilação é aquilo mesmo que é concebido, o próprio conceptus, que o Doutor

Solene irá identificar ao verbum mentis:

“de fato, a espécie universal recebida no possível pelo agente move o possível e informa, tal que especule em ato [ut actu speculetur], tal como uma razão de conceber o verbo da mente no qual se especula a notícia da verdade" ${ }^{94}$.

Vemos, agora, a espécie finalmente descrita como universal, o que ganhará enorme importância adiante ${ }^{55}$, embora não surja ainda em Suma, art. 1, q. 5, como

basis doorheen al de werken van Hendrik]", ao que se segue a citação do trecho de Suma, art. 1, q. 5, que abre esta nota.

${ }^{54}$ Henrique de Gand, Suma, art. 1, q. 5, ad 2 (ed. De Wulf-Mansion Centre, vol. 21, p. 131): "Species enim universalis recepta in possibili per agens movet possibilem et informat, ut actu speculetur, tamquam ratio concipiendi verbum mentis in quo speculatur notitiam veritatis, ut dictum est supra quaestione secunda et tertia". Sobre a noção de notitia, cf. a nota 70, adiante.

${ }^{55}$ Cf. o item 6.5. Embora devamos retornar à noção de 'universal' mais adiante, será interessante propor já aqui uma definição desse termo. Um primeiro texto a que podemos nos voltar para compreender melhor esse tema é Suma, art. 43, q. 2, co. (ed. De Wulf-Mansion Centre, vol. 29, pp. 524). Logo no início desse trecho, Henrique afirma que a 'razão do universal' (ratio universalis) contém dois: [i] a predição de um mesmo acerca de muitos e [ii] a natureza ou essência da coisa predicada (o que não impressiona, uma vez que já enfatizamos, acima, na nota 25 , a profunda identidade que há entre a noção de 'inteligível' e a noção de 'essência'). Assim, ao que parece, todo o problema na compreensão do que seria um 'universal' está em explicar de que maneira uma essência pode ser tomada como um único predicável de muitos - "Est igitur hic sciendum, quod ratio universalis consistit non tam in modo praedicandi idem de pluribus, quam in natura et proprietate rei praedicatae, quae debet esse natura et essentia aliqua. Duo enim includit in se universale: et ipsam rem quae est essentia et natura aliqua, et rationem praedicabilis de pluribus" (p. 52). Pois bem, para expor em que medida uma mesma natureza ou essência pode ou não ser dita 'universal', Henrique de Gand apresentação uma distinção por razão de três considerações possíveis que podem recair sobre uma essência. Uma natureza como 'animal' pode ser considerada [i] segundo seu 'ser quiditativo', [ii] segundo seu 'ser natural' e [iii] segundo seu 'ser de razão' - "Animal igitur secundum rationem triplicis esse consideratur, scilicet esse quidditativi et esse naturalis et esse rationis" (p. 53 - sobre essa passagem, cf. STORCK, "Eternidade, possibilidade e indiferença...", 2005, pp. 153-4). Segundo seu [i] "ser quiditativo', tal natureza é anterior ao [ii] 'ser natural' ou [iii] seu 'ser de razão', tal como o simples é anterior ao composto ("sicut simplex compositum") - "Et secundum primum esse praecedit esse naturale et esse rationis sicut simplex compositum” (p. 53). Já segundo seu [ii] 'ser natural', tal natureza é nos particulares, com acidentes naturais - "Esse vero eius naturale est esse suum in particularibus et cum accidentibus naturalibus” (p. 53). Por fim, segundo seu [iii] 'ser de razão' tal natureza possui ser enquanto abstraída dos particulares pelo intelecto - "Esse vero rationis est esse eius in intellectu, quo abstrahitur a particularibus, in quibus habet esse naturae" (p. 53). Ora, um pouco antes dessa passagem, Henrique já havia introduzido a distinção entre [a] a essência significada por nome absoluto (como 'humanidade' ou 'animalidade') e [b] a essência significada por nome concreto (como 'homem' e 'animal'). Esse segundo caso [b] é, precisamente, decrito como a significação da essência na medida em que 'é de algo' - "Et sicut est de essentia significata nomine absoluto, quod est 'humanitas' vel 'animalitas', similiter est de eo cuius est, ut concreti significati nomine hominis vel animalis” (p. 53). Assim, parece-me que, segundo [i] seu 'ser quiditativo', a essência é significada pelo nome absoluto ('humanidade', 'animalidade' etc.), enquanto que, segundo seu [ii] 'ser natural' e seu [iii] 'ser de razão', a mesma essência sera significada por nomes concretos ('homem', 'animal' etc.) estes últimos, com efeito, significam tanto o particular fora da alma como o universal inteligido ou, melhor, eles significam o particular enquanto inteligido (como vimos na nota 36, acima, estes são nomes de 'primeiras intenções').

Pois bem, o caso que especialmente nos interessa aqui é aquele da essência considerada segundo [iii] 
seu 'ser de razão', isto é, enquanto abstraída dos particulares pelo intelecto e enquanto significada por um nome concreto. É justamente enquanto tal que essa natureza convém a muitos particulares segundo uma mesma definição e, portanto, mantendo sua unidade racional - "Et sic, in quantum sic est forma abstracta a particularibus in intellectu, una et eadem definitione convenit multis particularibus, et per hoc est universalis. Et forma illa sic abstracta est una secundum rationem, existens in multis particularibus multiplicata et de multis, quia per praedicationem eisdem a quibus est abstracta, est applicata" (pp. 53-4). Como vimos acima nesta nota, porém, não é somente a predicabilidade de muitos que determina o universal, sendo também necessário esclarecer que natureza, essência ou forma diz respeito à universalidade. Segundo Henrique de Gand, tal natureza é somente aquela que, por si mesma, não é mais do que uma quididade (isto é, uma natureza que, por si mesma, seja anterior tanto a [ii] ser naturalmente nos particulares ou [iii] ser racionalmente como universal no intelecto). Assim, pode ser universal somente aquela natureza que, de si mesma, seja uma quididade e, portanto, anterior à universalidade ou à singularidade e, por outro lado, nata a receber em si qualquer uma destas duas, ou seja, nata a existir fora da alma como singular ou a existir no intelecto como universal (sobre essas duas 'existências', cf. cap. 2, nota 95) - "His visis patet, quae et qualis natura potest in se recipere rationem universalis, scilicet illa solummodo quae ex se ipsa, in quantum est de ratione quidditatis, est natura et essentia tantum, non concernendo rationem universalis vel particularis, sed nata in se recipere rationem utriusque et singularis et universalis. Singularis per esse determinatum, quod habet in supposito naturali" (p. 54). Tal natureza será universal na medida em que, mantendo sua unidade numérica racional enquanto abstração do intelecto, for igualmente capaz de ser aplicada, pelo intelecto, a vários singulares por predicação. Como se vê, sendo tal unidade do universal apenas racional, ela não implica em qualquer comunidade ou unidade real naqueles particulares de que é predicada. Pelo contrário, só há tal comunidade universal nas coisas enquanto estas são consideradas pelo intelecto "Universalis per hoc quod nata est cadere in consideratione intellectus, ut pluribus in quibus singulariter est multiplicata, nata est per praedicationem applicari, in quibus non est unum numero et re, sed tantum ratione et communitate universalitatis, quae solum est in re ut cadit in consideratione animae" (p. 54).

Essa descrição do universal que vemos em Suma, art. 43, q. 2, é aquela mesma que surge descrita como universal em sentido próprio e estrito em Suma, art. 75, q. 6, co. (ed. 1642-6, p. 1471b, n. 15). Aqui, porém, adiciona-se à consideração do universal não somente o tema da predição do universal aos diversos particulares, mas também o tema da predicação de um universal a diversos outros universais sob ele, tal como um gênero é predicado de várias espécies. A bem dizer, descreve-se aqui o processo pelo qual, a partir de um universal genérico e pela consideração das diferenças contrárias que podem advir a ele, o intelecto desce à consideração dos universais específicos e, destes, à consideração dos indivíduos. Assim, o gênero é um 'todo universal' com respeito às espécies sob ele, tal como a espécie especialíssima é um 'todo universal' com respeito aos indivíduos sob ela: "Loquendo de universali proprie, illo modo est universale, quo secundum rem significatam diversatur in partibus suis subiectis, et sumitur dupliciter, uno modo stricte, alio modo large. Stricte non est nisi forma pluribus communis, non communitate unius rei singularis existentis in illis, et quae est tota in quolibet illorum, sed communitate rei unius secundum rationem tantum abstractae ab illis per intellectum, et in quodlibet illorum consideratione intellectus descendens, ut in subiectivas partes eius per determinationem aliquam, secundum quod genus est totum universale ad species, in quas descendit, determinatum per contrarias differentias, aut per eius significationem, secundum quod species specialissima est totum universal ad individua in quae descendit sua significatione facta per agens, sive etiam per materiam sive absque materia. Et sic totum universale continet plura divisione numerata, sed non nisi unitate" (op. cit.). Ainda sobre a significação do universal tomado estritamente, cf. Suma, art. 75, q. 6, ad 3 (ed. 1642-6, pp. 1476b-7a, n. 35).

Note-se que o próprio nome 'universal' é nome de uma intenção segunda, pois é simplesmente o nome dado à relação de comunidade estabelecida pelo intelecto entre os diversos conceitos que este mesmo formou para si por abstração (cf. nota 36, acima). Com efeito, ao comparar entre si os diversos conceitos que abstrai a partir dos sentidos, o intelecto percebe entre eles algo comum, a saber: [i] são predicáveis de muitos e [ii] são naturezas natas a adquirirem tal predicabilidade.

Por fim, sublinhe-se uma dificuldade com o uso de 'quididade' que vimos acima, nesta nota, em Suma, art. 43, q. 2. Se aí é dito que o 'ser quiditativo' da essência é anterior a seu 'ser racional', enquanto conceito abstraído universal, em outros textos (como Quodl. 2, q. 6 - cf., adiante, nota 59), a 'quididade' aparece justamente como aquilo que é conhecido pelo intelecto acerca da coisa. Essa flutuação de vocabulário, entretanto, parece-me facilmente explicável se considerarmos que a essência da coisa em seu 'ser de razão' - isto é, abstraída e conhecida como universal - não é senão a própria quididade da coisa, na medida em que existe no intelecto como universal. Assim, dizer que a quididade 
algo central. O resultado da informação do intelecto possível por tal espécie universal é a concepção do verbo da mente, que não é senão o conceito. Nele se especula a verdade - de fato, já vimos que mesmo os conceitos primeiros são similitudes da verdade das $\operatorname{coisas}^{56}$. Com esse verbo, portanto, o intelecto atinge uma primeira assimilação com a coisa, ainda que tal conhecimento seja tão anterior ou geral quanto simplesmente o conceito de 'ente'

\subsubsection{O intelecto e o verbo}

Nesse ponto, tendo percorrido todo o caminho que nos leva statim da coisa sensível à concepção do verbo dessa coisa pelo intelecto, podemos deixar de lado Suma, art. 1, q. 5. Agora, cumpre buscar compreender a própria noção de verbum tal como ela é descrita nos primeiros trabalhos de Henrique de Gand. Para isso, retornemos a um velho conhecido nosso, a saber, Quodl. 2, q. 6. Já vimos por diversas vezes que essa questão propõe uma hierarquia das potências cognoscitivas desde as menos ativas até as mais ativas, passando pelo 'sentido particular', o polêmico 'sentido universal' e a 'imaginação'. Agora, chegamos ao ponto central da argumentação dessa questão, pois o gandavense pretende aí justamente afirmar que a potência cognoscitiva mais ativa no homem é, precisamente, o intelecto. Prova disso, é que o intelecto não somente se converte para o objeto que o move (tal como os sentidos fazem), mas ao se converter forma um verbo - e isso é um conhecimento a que os sentidos não têm de maneira alguma acesso. Que Quodl. 2, q. 6, culmine em um discurso sobre o verbo, não surpreende, uma vez que aí se pergunta justamente "se, pelo ato de inteligir, é necessário que se forme um verbo [utrum per actum intelligendi necesse sit formare verbum]",58. O que, por outro lado, chama a atenção é

\footnotetext{
é inteligida é plenamente possível, desde que não se tome 'quididade' aqui em seu sentido mais estrito.

${ }^{56}$ Cf. nota 37 , acima.

${ }^{57}$ Como veremos na nota 211 , adiante, a noção de verbo será cada vez mais associada ao conhecimento complexo manifestativo do objeto. Além disso, a aproximação entre 'verbo' e 'verdade da coisa' é problemática quando lida à luz da doutrina da iluminação de Henrique de Gand (cf. Epílogo da parte 2, nota 23$)$.

${ }^{58}$ Henrique de Gand, Quodl. 2, q. 6 (ed. De Wulf-Mansion Centre, vol. 6, p. 30). Sobre essa questão, cf. ARGOS, "La actividad cognoscitiva en los escolásticos... - II/III", 1948, pp. 291-2; GOEHRING, Henry of Ghent on cognition..., 2006, p. 170-4; e GOEHRING, "Henry of Ghent on the verbum mentis", 2011, pp. 249-52.
} 
o papel absolutamente central que o verbo assume, nesse trecho da obra de Henrique, para a exposição da sua concepção de intelecção:

"Em seguida, similarmente cumpre dizer sobre o intelecto que, por ser uma virtude maximamente imaterial, ao padecer [in patiendo], maximamente age e o mais perfeitamente se converte, pelo conhecimento, sobre seu objeto, não somente percebendo aquilo que é verdadeiro [id quod verum est], pelo que é movido (tal como também $<_{0}>$ apreende o sentido), mas a própria verdade [ipsam veritatem], que é a própria quididade inteligida da coisa. De fato, o objeto próprio do intelecto é aquilo que é [quod quid est]. Este, de fato, enquanto existe [existit] na notícia atual, é como que uma luz concebida no intelecto, na qual <este> vê e discerne mentalmente a coisa - isso é chamado o verbo dele [verbum eius]. Sem isso a ação intelectual de nenhum modo é perfeita [perficitur] - sem isso, não teria mais notícia da verdade da coisa do que o sentido, nem depois da recepção da espécie poderia investigar, reunir e elicitar [investigare et conferre et elicere] a conclusão a partir [ex] dos princípios.

Cumpre dizer, portanto, que em todo ato de inteligir, tão pequeno quanto for [quantumcumque modicus sit], é necessário que se forme um verbo [verbum]. De fato, é da natureza e da perfeição do intelecto que, movido, não se converta sobre o objeto por uma apreensão abstrata, mas é necessário que ele ou nada intelija ou forme em si aquilo que é sobre a coisa [quod quid est de re]" ${ }^{59}$.

Notemos, primeiramente, que a distinção entre a conversão mais imaterial e perfeita do intelecto sobre o seu objeto de conhecimento quando comparada à conversão do sentido tem por base uma distinção anterior, a saber, aquela entre o conhecimento daquilo que é verdadeiro (id quod verum est) e o conhecimento da própria verdade (ipsam veritatem). Voltaremos a essa distinção no Epílogo desta segunda parte, mas já temos nesta passagem, pelo menos, uma pista acerca da diferença entre 'o que é verdadeiro' e a 'verdade': esta “é a própria quididade inteligida da coisa [est ipsa quidditas rei intellecta]". Dessa maneira, se o sentido também pode conhecer 'o que é verdadeiro' na coisa (mesmo porque, como estabelecemos no cap. 1, tanto o sentido como o intelecto nos dão, cada qual a seu

\footnotetext{
${ }^{59}$ Henrique de Gand, Quodl. 2, q. 6 (ed. De Wulf-Mansion Centre, vol. 6, p. 32): "Demum similiter dicendum est de intellectu quod, quia virtus est maxime immaterialis, in patiendo maxime agit et perfectissime per cognitionem convertit se super suum obiectum, non solum percipiendo id quod verum est, a quo movetur (sicut etiam apprehendit et sensus), sed ipsam veritatem, quae est ipsa quidditas rei intellecta. Proprium enim obiectum intellectus est quod quid est. Quod quidem, ut in actuali notitia existit, est quasi quaedam lux in intellectu concepta, in qua rem mentaliter videt et discernit, quod appellatur verbum eius, sine quo actio intellectualis nullo modo perficitur, sine quo non plus haberet notitiam veritatis rei quam sensus, neque post receptionem speciei posset investigare et conferre et elicere conclusionem ex principiis.

Dicendum igitur quod in omni actu intelligendi, quantumcumque modicus sit, necesse est formare verbum. Hoc enim est de natura et perfectione intellectus, quod motus non convertit se super obiectum per abstractam apprehensionem, sed necesse est eum aut nihil intelligere, aut quod quid est de re in se formare". A conversão do intelecto a que se refere aqui é, justamente, aquela destacada por G. Cannizzo ("La dottrina del 'verbum mentis'..., 1962, p. 251-5) e, em sua esteira, J. Teräväinen ("Henri Gentiläisen tieto-oppi”, 1975, pp. 12-4) - cf. Epílogo da part 1, nota 12.
} 
modo, ciência em sentido amplo sobre a coisa), a 'verdade' propriamente só pode ser conhecida pelo intelecto, uma vez que somente este último conhece a quididade da coisa - melhor, este último tem por objeto próprio 'aquilo que é' (quod quid est) da coisa.

Essa quididade, enquanto é conhecida em ato pelo intelecto, é caracterizada por Henrique aqui precisamente como "uma luz concebida no intelecto [lux in intellectu concepta]". Ora, já sabemos que aquilo que é concebido (numa palavra, o conceito) é o fruto da informação do intelecto possível pela espécie dos inteligíveis sob a luz do intelecto agente, de sorte que começa a ficar patente uma identificação entre o conceito (fruto da composição entre intelecto e inteligível, como víamos em Suma, art. 1, q. 5) e a quididade da coisa enquanto conhecida em ato. Já sabíamos, pelo mesmo Suma, art. 1, q. 5, que o conceito é o próprio verbo formado, porém agora esses dois são explicitados como a própria quididade da coisa conhecida em ato. Com efeito, somente a formação desse verbo (formare verbum) traz o ato de inteligir a sua perfeição ou completude (perfectio), pois a intelecção não é somente um padecer (pati), mas também um converter-se (se convertere) sobre seu objeto e uma ação de formar (formare) um verbo - isto é, um conceito em ato identificado à quididade da coisa. De fato, o intelecto não se limita a uma apreensão abstrata - apreensão esta que também os sentidos possuem, pois ainda na imaginação o fantasma é abstraído da matéria (mesmo que não das condições materiais) e mesmo a espécie sensível chega sem matéria ao sentido externo (ainda que provoque uma apreensão material). Já o intelecto, para além dessa apreensão abstrata (após a abstração das condições materiais), forma ainda um conceito, uma quididade, 'aquilo que é sobre a coisa' - em uma palavra, um verbo. Como lemos no ultimo trecho indentado: "é da natureza e da perfeição do intelecto que, movido, não se converta sobre o objeto por uma apreensão abstrata, mas é necessário que ele ou nada intelija ou forme em si aquilo que é sobre a coisa [est de natura et perfectione intellectus, quod motus non convertit se super obiectum per abstractam apprehensionem, sed necesse est eum aut nihil intelligere, aut quod quid est de re in se formare]".

Igualmente importante, neste trecho indentado, é a referência ao verbo como prerrequisito necessário para qualquer ato de inteligir ulterior acerca da coisa conhecida. Com efeito, lemos aí que "em todo ato de inteligir, tão pequeno quanto for, é necessário que se forme um verbo [in omni actu intelligendi, quantumcumque modicus sit, necesse est formare verbum]'. Ora, 'pequeno' (modicus), nesse caso, 
parece remeter ao fato de que mesmo atos incomplexos do intelecto - anteriores, portanto, aos atos complexos - formam verbos. De fato, é justamente por formar o verbo que o intelecto pode, após a recepção da espécie, “investigar, reunir e elicitar a conclusão a partir dos princípios [investigare et conferre et elicere conclusionem ex principiis]". Em sua leitura, Goehring vê nessa passagem precisamente uma afirmação de que "o verbo mental não somente é um importante meio para a compreensão daquilo que um dado objeto é, mas é um prerrequisito para o pensamento proposicional e o raciocínio inferencial" ${ }^{\prime 60}$. Dessa maneira, a segunda operação do intelecto (a saber, aquela de composição e divisão) já pressupõe um verbo. Ao mesmo tempo, porém, elas também formam verbos, uma vez que igualmente são atos de inteligir (nesse caso, complexos). Enfim, todos os atos de inteligir - anteriores e incomplexos ou posteriores e complexos - produzem algo, pois mesmo a mais ínfima e simples intelecção é a produção de um verbo, sem o que tal ato de inteligir não pode atingir sua perfeição e sem o qual não é possível qualquer inteleção mais complexa.

Isso possui duas consequências. Em primeiro lugar, esse trecho de Quodl. 2, q. 6, deixa claro que a ação do intelecto não se restringe à produção de conhecimentos complexos e, em particular, à composição e divisão. Pelo contrário, mesmo o primeiro ato de inteligir acerca de um objeto (statim, após a informação do intelecto possível pela espécie na luz do intelecto agente) produz um verbo que, se confiarmos em Suma, art. 1, q. 5, não será muito mais do que o conhecimento da quididade desse objeto como ente, uno etc. O que se deve destacar é que mesmo esse conhecimento ínfimo (modicus) já é fruto de uma atividade do intelecto pelo qual este forma para si, após a recepção da espécie e como um verbo, o 'aquilo que é' da coisa - novamente, nas palavras de Goehring: “[v]emos que, nessa discussão em Quodlibet II, o verbo mental [mental word] é identificado ao conceito, nomeadamente um conceito que deve asseverar, não importa o quão imperfeitamente, a essência de uma coisa"61 ${ }^{\text {. Em }}$ segundo lugar, é preciso destacar que a distinção subjacente entre 'aquilo que é

\footnotetext{
${ }^{60}$ GOEHRING, Henry of Ghent on cognition..., 2006, p. 174: "The last statement in this passage indicates that even in this early, basic account Henry considers, however implicitly, the mental word not just as an important means for grasping what a given object is, but as a prerequisite for propositional thought and inferential reasoning".

${ }^{61}$ GOEHRING, Henry of Ghent on cognition..., 2006, p. 173: "We find in this discussion in Quodlibet II that the mental word is identified as a concept, namely a concept that is meant to state, however imperfectly, a thing's essence".
} 
verdadeiro' e 'verdade', tal como aqui utilizada (isto é, restringindo a segunda ao intelecto), parece apontar para o fato de que mesmo os conhecimentos anteriores e incomplexos, sendo já resultantes da atividade do intelecto, dizem respeito à verdade da coisa. Destarte, mesmo quando o intelecto só conhece a quididade da coisa como 'ente', ele já possui um conhecimento superior ao dos sentidos e, portanto, já ultrapassou o mero conhecimento 'daquilo que é verdeiro sobre a coisa', atingindo a própria verdade desta última. Como dito, essa passagem entre 'aquilo que é verdadeiro' para a 'própria verdade', descrita aqui de maneira bem singela, deverá ser problematizada ao fim desta parte 2. Mais do que isso, veremos no decorrer deste capítulo que Henrique de Gand se torna cada vez mais pessimista quanto à possibilidade de um ultrapassamento dos sentidos pelo intelecto.

Dito isso, se reunirmos o que lemos em Suma, art. 1, q. 5, e em Quodl. 2, q. 6, temos uma boa primeira impressão acerca do ato de intelecção. Começando por [i] a atualização da espécie universal do inteligível por parte do intelecto agente que, por sua luz, também torna o intelecto possível apto a receber tal inteligível, passamos pela [ii] composição do intelecto em ato pela recepção de tal inteligível no intelecto possível sob a luz do intelecto agente, chegamos à [iii] conversão do intelecto sobre seu objeto a partir da informação do intelecto possível pela espécie e atingimos a [iv] formação do conceito (isto é, do verbo) na luz do intelecto agente, sendo tal formação a culminância de todo esse caminho e sendo o conceito ou verbo formado a própria quididade da coisa vista em ato pelo intelecto. Tão tortuoso quanto pareça, tal caminho é percorrido 'instantaneamente' (statim) e, além disso, não nos leva muito longe: não havendo ainda neste ponto conhecimento complexo, o que temos é antes um conhecimento em geral da quididade enquanto 'ente', 'una' e outras primeiras intenções. Não obstante, tal conhecimento já é da verdade da coisa, pois diz respeito à sua quididade.

\subsubsection{Da espécie ao verbo}

Há ainda mais um aspecto interessante aqui. Neste percurso, partimos de uma espécie dos inteligíveis e chegamos a um verbo - ora, vimos que o verbo é aqui o próprio conceito e, mais acima, já nos era dito que o conceito não é mais do que uma 
similitude da coisa ${ }^{62}$. Nesse caso, partimos de uma similitude (a espécie) e chegamos a outra (o verbo). Sem dúvida, como se dizia antes, aquela é uma similitude por cuja informação se concebe o conhecimento, enquanto que esta última é a própria quididade vista em ato. Essa curiosa aproximação e simultânea contraposição da espécie e do verbo/conceito caracterizados, cada qual à sua maneira, como similitudes é retomada em Quodl. 1, q. 12-13:

"A espécie é a imagem ou ídolo da coisa pela qual a alma é informada, tal que
conceba um verbo determinado sobre a própria coisa e forme $<$ tal verbo $>$ sobre
ela (o que, de nenhum modo, poderia fazer sem ela $<s c$. sem a espécie $>$ ). Porém,
o verbo é a própria notícia da mente que é, na alma [apud animam], a verdade da
quididade da coisa, na qual formalmente intelige aquela coisa que intelige na
espécie tal como formativa, em potência e força, do verbo existente em potência
na alma - ou, o que é mais verdadeiro, tal como por uma disposição que
determina a potência, que é de si indeterminada, a formar um verbo determinado
(assim como o calor natural é determinado pela virtude do agente na semente tal
que aja para gerar uma espécie determinada). Donde, o verbo é como uma forma
na alma, gerada pela potência da alma (assim como o calor natural ativo na
semente, enquanto que a espécie é na alma como a virtude do agente principal no
calor). Donde, embora o verbo seja uma similitude da coisa na alma, é outra e de
outra razão que a espécie (tal como a espécie é uma forma do engendrante e uma
virtude sua na semente, bem como também a forma gerada $<$ o é>, embora de
diferentes maneiras [alterius tamen et alterius rationis])"63.

De fato, verbo e espécie são similitudes - mais do que isso, ambos são, de alguma maneira, a quididade ou a verdade da coisa. No entanto, o são diferentemente. Se considerarmos que a potência intelectiva da alma é indeterminada para todo e qualquer conhecimento intelectual, a espécie dos inteligíveis pode ser tomada como aquilo que determina a potência intelectiva para tal conhecimento intelectual, isto é,

\footnotetext{
${ }^{62} \mathrm{Cf}$., acima, nota 37.

${ }^{63}$ Henrique de Gand, Quodl. 1, q. 12-13, ad 3 (ed. De Wulf-Mansion Centre, vol. 5, p. 82): "Species enim est imago vel idolum rei qua anima informatur, ut determinatum verbum de ipsa re concipiat et formet de illa, quod nullo modo posset facere sine illa. Verbum autem est ipsa notitia mentis quae est veritas quidditatis rei apud animam, in qua formaliter rem intelligit quam per speciem intelligit tamquam potentia et vi formativa verbi in potentia animae existente, immo, quod verius est, tamquam dispositione determinante potentiam ad verbum determinatum formandum, quae de se indeterminata est, sicut calor naturalis virtute agentis in semine determinatur ut agat ad speciem determinatam generandam. Unde est verbum sicut forma quaedam in anima generata potentia animae, sicut naturalis calor activus in semine, species vero in anima sicut virtus agentis principalis in calore. Unde, licet verbum sit quaedam similitudo rei in anima, alia tamen est et alterius rationis quam sit species, sicut est species quaedam forma generantis et virtus eius in semine, et forma generata, alterius tamen et alterius rationis". Note-se, neste trecho, a caracterização da espécie como imago (que se repete no trecho citado adiante, na nota 172) e idolum. Ela nos ajuda a reforçar a compreensão da species como algo que remete à coisa conhecida, como um meio do conhecimento, uma ratio cognoscendi ou uma ratio concipiendi verbum (cf., acima, nota 54). Ainda sobre essa passagem, cf. GOEHRING, "Henry of Ghent on the verbum mentis", 2011, pp. 243-4.
} 
para um conhecimento intelectual precisamente acerca daquele objeto de que tal espécie é intenção ou cuja quididade tal espécie é. Sendo assim, a espécie dos inteligíveis - que, como vimos, é o próprio inteligível universal atualizado pelo intelecto agente - não é senão a própria quididade da coisa tomada não ainda como conhecida em ato, mas como apta a determinar o intelecto (no mais, indeterminado para o conhecimento de qualquer quididade) a conhecê-la (a ela determinadamente, com exclusão de qualquer outra quididade) em ato ${ }^{64}$. Aqui, estamos ainda na ponta inicial da formação da intelecção - estamos ainda na consideração das forças que agem para tal formação.

Sendo assim, no outro extremo do caminho, temos aquilo que é formado pelo intelecto ao ser determinado pela espécie, a saber, o verbo. Este é, tal como a espécie, a própria quididade da coisa - não, porém, como apta a determinar o intelecto e sim como já conhecida em ato. Sendo já o conhecimento intelectual em ato da coisa, o verbo é melhor dito verdade da quididade da coisa na alma (veritas quidditatis rei apud animam) - de fato, como vimos acima, no momento em que o intelecto forma para si a quididade da coisa, ele de alguma maneira (ainda que minimamente), já atingiu a verdade da coisa.

Entretanto, o 'verbo' é igualmente dito “a própria notícia da mente [ipsa notitia mentis]" e a frase que faz os três equivalerem - 'verbo', 'notícia da mente' e 'verdade da quididade da coisa na alma' - não é sem ambiguidades: “o verbo é a própria notícia da mente que é, na alma, a verdade da quididade da coisa, na qual formalmente intelige aquela coisa [Verbum autem est ipsa notitia mentis quae est veritas quidditatis rei apud animam, in qua formaliter rem intelligit]". Notemos que a

\footnotetext{
${ }^{64}$ Vimos em Suma, art. 1, q. 5 (cf., novamente, nota 54), que as espécies são aquilo que move o intelecto para o ato de inteligir. Aqui nesse trecho de Quodl. 1, q. 12-13, Henrique oscila entre uma primeira descrição da espécie como uma vis formativa do verbo (que faz o verbo passar de uma potência da alma a um ato da alma) e uma segunda caracterização, por ele considerada mais verdadeira (quiçá por destacar a atividade e não a passividade do intelecto), da espécie como uma 'disposição que determina' (dispositio determinans) a potência intelectiva para a formação de um verbo determinado. É como se a potência intelectiva, por si mesma, fosse indeterminada para a formação de qualquer verbo e a espécie viesse determiná-la para a formação de um verbo preciso, a saber, aquele da quididade da coisa de que tal espécie é uma imagem ou ídolo. Para melhor explicar essa segunda caracterização, o gandavense introduz uma comparação entre a geração do verbo na alma pela espécie e a geração de um ente específico a partir de uma semente (aliás, atente-se, nessa passagem, para a ambiguidade do termo species com que se joga: na comparação tal termo designa tanto a ratio cognoscendi, que se opõe ao 'verbo', como o ente categorial gerado da semente, que se opõe ao 'gênero'). Assim como o calor é uma potência ativa para a geração de indivíduos de qualquer espécie e é necessário que uma semente determine sua ação para a geração de um indivíduo de uma espécie precisa (uma macieira, por exemplo), também a espécie inteligível determina a potência intelectiva para a formação de um verbo determinado.
} 
expressão "in qua" pode remeter tanto à notitia quanto à veritas. Embora pareça extremamente pontual, é importante salientar esse problema uma vez que Henrique opõe neste trecho dois modos pelos quais a coisa se encontra na alma: [i] na espécie, enquanto "formativa, em potência e força, do verbo existente em potência na alma [tamquam potentia et vi formativa verbi in potentia animae existente]" e [ii] enquanto formalmente (formaliter) inteligida no verbo em ato. Este último modo de ser da coisa no intelecto - isto é, enquanto verbo - é que se explica tanto como 'notícia da mente' quanto como 'verdade da quididade da coisa na alma'. Por essa razão, se faz necessário compreender a qual destas últimas duas o Doutor Solene se refere quando afirma que a alma aí (in qua) intelige a coisa.

De saída, talvez seja possível dizer que o "in qua", de certo modo, se refereria a ambas: 'verdade da quididade na alma' e 'notícia da mente'. Com efeito, na passagem, ambas são identificadas entre si e ao verbo. Por outro lado, lembremos que, se as três expressões são aqui igualadas é porque, muito provavelmente, há alguma importância em distingui-las sob certo aspecto. Portanto, vejamos em que medida 'notícia', 'verdade' e 'verbo' se identificam aqui e em que se distinguem - ao vê-lo, entenderemos como a expressão "in qua" está se referindo justamente à notícia identificada à verdade.

Nesse ponto, torna-se relevante uma observação de Bernd Goehring sobre um problema na leitura de um trecho de Suma, art. 2, q. $6^{65}$. Tanto Tachau como Jerome V. Brown citam tal passagem como: "veritas rei est id quod res scitur et intelligitur, quia ipsa est proprium obiectum intellectus" $" 66$. Embora ambos os comentadores remetam à edição cinquecentesca de Badio Ascencio (f. 27rD), o que lemos nesta última é: “< $<>$ veritas rei est id quo res scitur et intelligitur: quia ipsa est proprium obiectum intellectus <... ” (a mesma lição é seguida na edição crítica contemporânea $)^{67}$. Como vemos, o "id quod" que na leitura de J. Brown e Tachau não encontra um lugar apropriado no texto, faz muito sentido quando lido como "id quo"

\footnotetext{
${ }^{65}$ GOEHRING, Henry of Ghent on cognition..., 2006, p. 166, nt. 8 .

${ }^{66}$ BROWN, J. V. "Abstraction and the Object of the Human Intellect...", 1973, p. 98, nt. 1; e TACHAU, Vision and Certitude..., 1988, p. 35, nt. 24. Ainda como Goehring sublinha, Tachau remete à passagem citada de Jerome Brown, de maneira que talvez ela tenha herdado dele a leitura da passagem.

${ }^{67}$ Henrique de Gand, Suma, art. 2, q. 6, co. (ed. De Wulf-Mansion Centre, vol. 21, p. 235): "Dicendum ad hoc quod veritas rei est id quo res scitur et intelligitur, quia ipsa est proprium obiectum intellectus".
} 
na versão de Badio Ascencio e da edição crítica. A verdade, como traduz Goehring, é “that through which" - 'aquilo pelo que' - o intelecto conhece a coisa ${ }^{68}$.

Há, porém, que se tomar cuidado com a tradução de $i d$ quo por 'pelo que'... Se bem nos lembramos, ao estudarmos o conhecimento sensitivo, encontramos um problema semelhante no item 4.3 e vimos que, por vezes, [i] a preposição per marcava a relação entre a potência cognoscitiva e o meio para o conhecimento e [ii] o ablativo (qua / quo) marcava a relação entre a mesma potência cognoscitiva e o próprio ato de conhecimento. Ora, se voltarmos ao último trecho indentado, de Quodl. 1, q. 12-13, vemos que a relação entre a alma que intelige e a espécie é justamente marcada pela preposição per (“quam per speciem intelligit"), enquanto que neste trecho polêmico de Suma, art. 2, q. 6, a verdade surge precisamente como "id quo" o intelecto intelige - isto é, aqui surge o ablativo como marca da relação entre intelecto e verdade. Porém, a verdade aqui não é descrita como o ato do intelecto, mas como o objeto (obiectum) próprio deste último - isto é, aquele objeto a partir do qual todos os outros são conhecidos ${ }^{69}$. Algo diferente ocorre em Quodl. 1, q. 12-13, pois aí 'verbo', 'verdade da quididade da coisa na alma' e 'notícia da mente' são precisamente já o conhecimento em ato. Ou seja, a 'verdade' está considerada de diferentes maneiras em Suma, art. 2, q. 6 e Quodl. 1, q. 12-13 - lá ela é objeto, aqui ela é ato de conhecimento. Ou seja, assim como a 'coisa' (res) possui uma ambiguidade intrínseca ao ser tanto [i] coisa enquanto existente fora da alma, [ii] coisa enquanto objeto e [iii] coisa enquanto atualmente inteligida, também a verdade pode ser considerada [i] enquanto objeto (que permite o conhecimento de outros na medida em que são verdadeiros) ou [ii] enquanto conhecimento em ato. Simplesmente, em Suma, art. 2, q. 6, a verdade está sendo considerada principalmente como objeto próprio do intelecto, ao passo que no trecho indentado de Quodl. 1, q. 12-13, a mesma verdade é considerada como algo conhecido em ato.

É justamente essa ambiguidade da noção de 'verdade' que permite explicar como, naquela passagem de Quodl. 1, q. 12-13, 'verdade' e 'notícia' podem ser identificadas. Com efeito, Jerome V. Brown possui um interessante artigo acerca dos diversos significados de que se reveste o termo notitia na obra do gandavense ${ }^{70}$. O

\footnotetext{
${ }^{68}$ GOEHRING, Henry of Ghent on cognition..., 2006, p. 166.

${ }^{69}$ Essa tendência do intelecto ao verum como fim e aos demais objetos (na medida em que são verdadeiros) como meios foi estudada acima, no item 3.2.

${ }^{70}$ BROWN, J. V. "The meaning of notitia in Henry of Ghent". In: KLUXEN, W. (Hrsg). Sprache und
} 
comentador aponta aí para o fato de que notitia é utilizado pelo Doutor Solene para nomear, entre outros aspectos do conhecimento, tanto [i] o objeto em ato no intelecto anterior ao ato de intelecção, como também [ii] o próprio ato de conhecimento simples ou incomplexo (pré-científico, como prefere Brown) e, finalmente, também [iii] o ato (ou o hábito) de conhecimento complexo (científico), que não é o foco de nosso estudo. Ou seja, se confiarmos na analise de Brown, notitia parece ser um termo amplo pelo qual Henrique de Gand se refere a atos das potências cognoscitivas e, em especial, a atos do intelecto (tomando ato em sentido amplo - isto é, incluindo ato e hábito, como opostos da potência natural para o conhecimento que é inata ao homem, como vimos no cap. 3) $)^{71}$. Ora, vimos que o verbum em Quodl. 1, q. 12-13, é o fim do processo de conhecimento simples (anterior, portanto, ao conhecimento

Erkenntnis im Mittelalter. Akten des VI. Internationalen Kongresses für mittelalterliche Philosophie der Société Internationale pour l'Étude de la Philosophie Médiévale. 29. August-3. September 1977 in Bonn. Berlin - New York, 1981, pp. 992-8. Nesse artigo, amplamente fundamentado em fontes textuais de Henrique, Brown mostra que a "notitia designates the actualization of a cognitive power, but such an actualization is not possible without a union of that cognitive power and its object. Notitiae must take at least part of their nature from the objects of those acts which they designate. In a very secondary sense, notitia could refer to the object of an operatio rather than to the operatio itself' (p. 993 - grifos no orig.). A isso, adiciona-se: "These acts which are designated as notitiae can be the acts of any cognitive powers, as even animals, while not being rational, can have notitiae. It is evident from the pertinent texts, however, that Henry most often thought of the word as designating the acts of intelectual cognitive powers. In this sense, there are two specifically different kinds of notitia: (1) the pre-scientific notitia; (2) the scientific notitia. On each of these levels, the term notitia can be applied to any one of three different degrees of actuality. Thus, pre-scientific notitia may mean: (a) the perfection of the memorative intellectual power; (b) the perfection of the intelligentia (simplex intelligentia); (c) the very act of intelligentia (simplex intelligentia) itself. On the scientific level, notitia may mean: (a) the intellectual habitus of science; (b) the verbum which is spoken from the habitus; (c) the very act of understanding by which the verbum is conceived from the habitus. Notitia simplex is the name given by Henry to the pre-scientific notitia; the scientific notitia is called the notitia declarativa" (pp. 994-5 - grifos no orig.). Embora, como dito, Brown se utiliza de diversas passagens da obra de Henrique de Gand, os dois trechos destacados têm como fonte (não somente, mas) principalmente Quodl. 4, q. 8, co. (ed. De Wulf-Mansion Centre, vol. 8, pp. 58-64). Especialmente esclarecedora, para nós, se mostra a seguinte passagem de Quodl. 4, q. 8: "Recapitulando igitur dico quod primo modo notitia in intellectu dicitur obiectum universale, ut praesens intellectui et perfectio memoriae, et non est in intellectu nisi de notitia praecedente in imaginativa. Ista autem notitia sicut obiectum movet aciem intelligentiae ad se conversae et elicit ex ea actum intelligendi, qui etiam dicitur notitia alio modo et notitia de notitia. Et terminatur actus iste in obiectum ipsum ut in comprehensum ab intelligentia, et sic illud obiectum dicitur esse notitia in intelligentia et procedens secundum dictum modum a notitia quae praecessit in memoria. Et sunt istae notitiae non scientiales nec possunt dici scientiae, sed cum intellectus illustratur tali modo, incipit negotiari et discurrere et pertractare secundum actum intelligendi ad cognoscendum de unoquoque quid et propter quid" (p. 63). Enfim, a noção de notitia não parece ser, para Henrique de Gand, um conceito estritamente determinado - antes, em algum sentido, ele pode designar diversos elementos envolvidos na formação do ato de intelecção (incomplexo ou complexo), além desse próprio ato. Com efeito, lembremos que, no cap. 1, a notitia certa se mostrava possível tanto para o sentido como para o intelecto. Ainda sobre a noção de notitia em Henrique de Gand, cf. ROMBEIRO, "Intelligible Species in the Mature Thought of Henry of Ghent", 2011, p. 213: "Now, notitia in the intelligence denotes two items: (1) the act itself of understanding, and (2) that by which the act of understanding is informed".

${ }^{71}$ Cf. BROWN, J. V. “The meaning of notitia in Henry of Ghent”, 1981, p. 994. 
complexo), de maneira que a notitia a ele identificada deve ser igualmente reconhecida como o conhecimento simples ou incomplexo em ato.

Destarte, quando lemos, no último trecho indentado, que "o verbo é a própria notícia da mente que é, na alma, a verdade da quididade da coisa, na qual [in qua] formalmente intelige aquela coisa", parece que o "in qua" remete, de fato, tanto à notícia como à verdade - melhor, remete à notícia (neste caso, ao conhecimento incomplexo em ato) na medida em que ele é a própria quididade da coisa (a verdade da coisa, ainda que concebida de maneira maximamente geral - basicamente, como 'ente') em ato no intelecto. Em lugar de um ablativo, temos portanto a preposição in como marca da relação entre a alma e a notícia/verdade/verbo na qual a coisa é inteligida. Sendo assim, podemos dizer resumidamente que verbum, notitia e veritas são o mesmo em Quodl. 1, q. 12-13, enquanto são todos o conceito simples em ato. A importância da distinção dos três, por outro lado, à luz do que estabelecemos até aqui, é que notitia expressa se tratar aqui de um ato no intelecto (embora não determine se tal ato antecede ou se identifica com o próprio conhecimento intelectual em ato); verbum exprime tal ato no intelecto como já gerado pelo próprio intelecto (isto é, como um ato de conhecimento intelectual, um conceito); veritas destaca que tal ato de conhecimento intelectual gerado é, precisamente, a própria quididade da coisa na alma (melhor, é a própria coisa na alma) enquanto inteligível ou inteligida.

Assim, quando Henrique de Gand afirma que a alma conhece a coisa nisso (in qua) que é notitia/veritas/verbum ele está mostrando que o conhecimento em ato se dá naquele ato da quididade da coisa que a própria alma - e, mais particularmente, sua potência intelectiva - gera para si. Daí que o intelecto seja a potência que mais age para o conhecimento, como nos é dito em Quodl. 2, q. $6^{72}$. De fato, o intelecto se converte sobre aquilo que advém dos sentidos e forma seu ato de conhecimento para si, isto é, forma para si o universal conhecido em ato, que não é senão a quididade da coisa (isto é, esta última enquanto abstraída não somente da matéria, mas de todas as condições materiais) enquanto conhecida em ato no intelecto.

Lembremos, entretanto, que tal quididade não possui ser somente enquanto conhecida em ato pelo intelecto, mas também enquanto inteligível (mas não ainda inteligida) em ato. Esses dois seres da coisa são, respectivamente, o verbo e a espécie - aquele já é a quididade conhecida em ato pelo intelecto como conceito simples, esta

\footnotetext{
${ }^{72}$ Cf., acima, nota 59 .
} 
é a quididade abstraída inteligível em ato. Há, necessariamente, uma ordem entre ambos: primeiro, o intelecto faz para si a coisa inteligível em ato (espécie) e, statim em seguida, faz para si a coisa conhecida em ato (o conceito ou verbo). Além disso, há uma sutil diferença entre os dois: o intelecto intelige pela (per) espécie, mas intelige $n a($ in $)$ 'verdade da quididade da coisa na alma' que é o verbo. A espécie é a coisa inteligível enquanto meio para intelecção, o verbo é a própria forma da coisa inteligida na alma - no verbo se intelige formalmente (formaliter) aquilo que se intelige pela espécie, pois esta última é somente o meio para que o intelecto conceba a forma daquela coisa determinada.

Parece-me que essa é uma possível descrição do processo de produção do conhecimento intelectual simples (não-complexo) tal como Henrique de Gand o compreende. No entanto, tomamos por base até aqui somente textos do início de sua carreira. Com efeito, nos vários anos seguintes a esses trabalhos iniciais, diversos pontos de tal doutrina serão revisitados por Henrique de Gand, como veremos adiante. Antes, porém, destaquemos que, ainda nesses primeiros escritos, surgem duas exceções ao processo descrito: [i] o conhecimento de si (item 6.3.1.) e [ii] o conhecimento do beato (item 6.3.2).

Esses dois casos, ainda que não sejam centrais para nós, são importantes para uma correta compreensão da noção de espécie inteligível de que o Doutor Solene se vale nesses primeiros anos. De fato, como vimos, a espécie inteligível é relevante no processo de intelecção por suprir a ausência da coisa existente. Dito de outra maneira: uma vez que a coisa existente fora não pode ser presente enquanto inteligível para o intelecto, o intelecto torna a coisa presente para si enquanto inteligível, isto é, faz em si a quididade inteligível da coisa. Ora, sendo assim, é plenamente possível perguntar se não haveria casos nos quais seja desnecessária uma espécie pelo fato de não se precisar suprir a presença do objeto. Nesses casos, de alguma maneira, a coisa existente já estaria presente enquanto inteligível para o intelecto, de maneira que a produção de uma espécie inteligível por este último seria supérflua. Seriam o conhecimento de si e o conhecimento do beato exceções desse tipo? Em qualquer caso, o estudo dessas duas temáticas nos ajudará a melhor elaborar a noção de espécie inteligível com que Henrique de Gand vem trabalhando até aqui. 


\subsection{DUAS EXCEÇÕES}

Após discutir a doutrina da intelecção desenvolvida por Henrique de Gand em suas primeiras obras, Theophiel Nys se volta para aquilo que ele considera como sendo os sinais de uma evolução no pensamento do Doutor Solene: se em seus textos iniciais este era partidário da necessidade de espécies inteligíveis impressas na atualização da intelecção, já na referida Quodl. 1, q. 12-13, se iniciaria o processo de abandono dessa posição e de adoção da posição oposta, isto é, do repúdio de tais espécies. Nessa questão geminada do Quodl. 1, Henrique investiga a possibilidade de um conhecimento de si para o intelecto humano e, como veremos, ele aí afirma não haver necessidade de espécies para tal conhecimento. Segundo Nys, "temos aqui, portanto, uma primeira exceção à necessidade de uma species intelligibilis impressa: uma exceção que será adotada em sentido geral <...> ${ }^{\text {,73 }}$. O mesmo ocorre, para ele, no caso do conhecimento do beato, estudado no Quodl. 3, q. 1, e em Suma, art. 33, q. 2. $\mathrm{O}$ conhecimento que o beato possui de Deus também consitui uma exceção à exigência de espécies inteligíveis, sendo tal exceção posteriormente generalizada para toda a doutrina da intelecção de Henrique de $\mathrm{Gand}^{74}$. Ou seja, tais estudos do conhecimento de si e do conhecimento do beato seriam ensaios de recusa da espécie inteligível impressa - recusa esta que, em seguida (a partir de Quodl. 4), o Doutor Solene extrapolaria para todos os casos de intelecção.

Notemos, de saída, que há um claro problema na leitura de Nys, a saber, a referência a uma species intelligibilis impressa nos primeiros textos de Henrique de Gand $^{75}$. Pelo que acabamos de ver no item anterior, nosso autor não se vale da noção

\footnotetext{
${ }^{73}$ NYS, De werking van het menselijk verstand..., 1949, p. 63 (grifo no orig.): "Wij hebben hier dus een eerste uitzondering op de noodzakelijkheid der species intelligibilis impressa: een uitzondering, die in bedoelde zin algemeen zal aanvaard worden, omdat bij afwezigheid van het lichaam en de verbeelding geen eigenlijk abstractie meer kan plaats hebben" (cf. a continuação desta passagem adiante, na nota 78). Theophiel Nys vê nessa temática um primeiro caso de exceção à necessidade de espécies inteligíveis impressas e inclui o Quodl. 1, q. 12-13, entre aqueles textos nos quais já haveria uma 'eliminação parcial' ("gedeeltelijke uitschakeling") da noção de 'espécie'. Tal eliminação parcial apontaria já para sua 'eliminação completa' ("volledige uitschakeling") - sobre a 'recusa completa' da espécie, cf. NYS, De werking van het menselijk verstand..., 1949, pp. 70 sg.

${ }^{74}$ Cf. NYS, De werking van het menselijk verstand..., 1949, pp. 61-70. Giorgio Pini acompanha de perto Nys ao ver nos estudos do conhecimento de si e do conhecimento do beato propostos por Henrique de Gand casos iniciais de conhecimentos intelectivos sem espécie inteligível, que tenderão a ser generalizados em seguida - cf. PINI, "Il dibattito sulle specie...", 2004, pp. 285-7. Outro autor a ver o abandono da espécie inteligível como generalização do caso da visão beatífica é BOULNOIS, Etre et représentation, 1999, p. 75.

${ }^{75}$ A bem dizer, Nys admite que a expressão species intelligibilis impressa não surge nas primeiras obras de Henrique de Gand na elaboração de sua própria doutrina, porém o comentador parece
} 
de 'espécie inteligível impressa (ou impressiva)' em suas primeiras exposições de sua doutrina da intelecção - isto é, nos primeiros 5 artigos da Suma e nos Quodl. 1 e 2. A bem dizer, a única utilização de uma expressão próxima a essa que pude encontrar nessas obras iniciais de Henrique foi um argumento principal em Suma, art. 1, q. 9 (“< $<>$ instrumenta intellectus agens, a quibus species imprimit in intellectu possibili $<$..>”), posteriormente repudiado nas respostas às objeções da mesma questão ${ }^{76}$. Ora, nesse caso, a interpretação de Nys já é problemática de início, pois a ausência de uma 'espécie inteligível impressa' nos dois casos em questão (aquele do conhecimento de si e o do beato) não poderia constituir uma exceção à doutrina da intelecção apresentada por Henrique até então, uma vez que tal 'espécie inteligível impressa' nem mesmo fazia parte de tal doutrina.

Sendo assim, parece-me que Efrem Bettoni é mais cuidadoso ao julgar que o Doutor Solene "não é do parecer que também no conhecimento dos seres espirituais como Deus e a nossa alma seja necessária uma 'espécie inteligível'; nesses casos, o determinante cognoscitivo é a própria essência da coisa conhecida",77. Bettoni enfatiza que o interesse da discussão sobre o conhecimento de si ou aquele do beato não está tanto na negação da necessidade de uma espécie inteligível impressa, mas antes na negação em geral de qualquer espécie inteligível para tanto. Nesse ponto, sua interpretação é mais condizente com esse período inicial do pensamento de Henrique, durante o qual este último ainda não se valia da distinção entre 'espécie impressa' e 'espécie expressa' no que diz respeito ao conhecimento intelectivo. Além disso, Bettoni igualmente argumenta que a razão para tal recusa de uma espécie inteligível nesses dois casos seria o fato de que, já estando presentes em essência para o cognoscente, a própria alma e Deus não necessitam de uma espécie inteligível

\footnotetext{
considerar que a species intelligilis a que se faz referência nessas primeiras obras seria um equivalente da species intelligibilis impressa, posteriormente recusada: "Embora a designação completa species intelligibilis impressa não ocorra em nenhum lugar na exposição da própria doutrina - mais tardiamente, ele desaprovará tal expressão -, ainda assim a species é claramente caracterizada, em Henrique de Gand, com sua conhecida função no vir a ser do ato de conhecimento [Alhoewel de volledige benaming species intelligibilis impressa in de uiteenzetting van eigen leer nergens voorkomt - later misprijst hij deze uitdrukking - toch wordt de species bij Hendrik van Gent duidelijk getekend met haar algemeen erkende functie in het tot stand komen van de verstandelijk kendaad]" - NYS, De werking van het menselijk verstand..., 1949, p. 57 (grifos no original).

${ }^{76}$ Henrique de Gand, Suma, art. 1, q. 9, arg. 1 (ed. De Wulf-Mansion Centre, vol. 21, p. 162) e resp. ad arg. 1 (pp. 164-5).

${ }^{77}$ BETTONI, Il processo astrattivo..., 1954, p. 16: "Enrico di Gand, come risulta molto bene dal seguito, non è del parere che anche nella conoscenza degli esseri spirittuali, come Dio e l'anima nostra, sia necessaria una 'species intelligibilis'; in questi casi il determinante conoscitivo è la stessa essenza delle cose conosciute".
} 
intermediária que os apresente ao intelecto que irá conhecê-los. Essa é, também, a leitura de Nys: "retenhamos, antes de tudo, a razão dessa superfluidade da species: a própria alma, o objeto a ser conhecido, é imaterial e intelectivelmente apreensível, intelligibile actu, mas antes de tudo - Henrique de Gand põe enfaze aqui - per suam substantiam (depois dirá ele: per suam essentiam) praesens intelligenti (ou intellectui) e apud intelligentem" ${ }^{, 78}$. Assim, para Nys, a exceção à necessidade de uma espécie inteligível deriva do fato de que, já estando presente em essência ao intelecto cognoscente, torna-se surpérfluo que haja uma espécie como intermediário para o conhecimento.

Pois bem, mas seria essa exceção realmente uma negação da doutrina da intelecção que viemos estudando até aqui, como sugerem Nys e Bettoni? Lembremos que a espécie inteligível era exigida justamente como aquilo pelo que a essência da coisa se torna presente enquanto inteligível no intelecto - isto é, aquilo pelo que a coisa passa a ser presente enquanto quididade no intelecto. Ora, no caso em que essa quididade já possua ser no intelecto, não haveria porque exigir uma espécie inteligível tal como a descrita no item anterior. Ou seja, parece que realmente o conhecimento de si e o conhecimento do beato, ignorando a necessidade de uma espécie inteligível, constituem exceções à doutrina da inteleção que lemos em Suma, arts. 1-5 e nos Quodl. 1 e 2. Porém, longe de serem negações daquela doutrina, poderíamos dizer que esses dois casos são daquelas famosas 'exceções que confirmam a regra': a espécie inteligível é necessária para que a coisa seja presente por essência no intelecto, mas, se tal coisa já estiver assim presente, a espécie não se mostra necessária.

O que Nys e Bettoni deixam de notar, no entanto, é que a posição de Henrique de Gand quanto ao conhecimento de si e ao conhecimento do beato não é expressa de maneira precisamente idêntica nos diversos momentos em que ele se volta para tais temáticas. Em especial, é preciso enfatizar algo que já sublinhamos ao fim do último item, a saber, que toda a doutrina da intelecção desenvolvida por Henrique de Gand nos seus escritos iniciais é, posteriormente, submetida a um escrutínio que, sem negar por completo a doutrina inicial, será uma busca por torná-la mais precisa. Com efeito, o mesmo válido no que diz respeito àquilo que estudaremos neste item. Assim,

\footnotetext{
${ }^{78}$ NYS, De werking van het menselijk verstand..., 1949, p. 63: "Laten wij echter vooral de motivering van deze overbodigheid van de species onthouden: de ziel zelf, het te kennen object, is onstoffelijk en verstandelijk vatbaar, intelligibile actu, maar vooral - Hendrik van Gent legt hierop de nadruk - per suam substantiam (later zegt hij: per suam essentiam) praesens intelligenti (of intellectui) en apud intelligentem" (grifos no original).
} 
veremos aqui que, se Henrique de Gand parece de início recusar qualquer espécie inteligível no caso do conhecimento de si, tal posição é precisada em obras posteriores justamente pela introdução da distinção entre 'espécie impressa' e 'espécie expressa' - isso deixará patente que a espécie inteligível só é negada, no caso do conhecimento de si, em certo sentido. No que tange ao conhecimento do beato, ao que parece, o caso será semelhante.

Como notaremos a partir do item 6.4., a mesma distinção entre 'espécie impressa' e 'espécie expressa' se mostra relevante para toda a doutrina da intelecção de Henrique de Gand em suas obras mais tardias. Em todos os casos, tal distinção redunda na recusa de uma 'espécie inteligível impressa' e na aceitação de uma 'espécie inteligível expressa'. Isso, porém, ao contrário do que pensa Nys, não torna o conhecimento de si e o conhecimento do beato paradigmáticos nos escritos tardios do Doutor Solene - pelo contrário, eles mantém seu estatuto de exceção. De fato, enquanto o conhecimento intelectual em geral remete-se ao fantasma para a formação da espécie inteligível expressa, nos casos do conhecimento de si e do conhecimento do beato, como veremos, há uma espécie inteligível expressa sem que se exija uma remissão a um fantasma na imaginação (justamente, porque aqui os objetos já estão presentes para o intelecto em suas respectivas essências, diferentemente do que ocorre em todos os outros casos).

Em poucas palavras, esses dois casos - o conhecimento de si e o conhecimento do beato - são extremos para a doutrina da intelecção de Henrique de Gand em todas as fases desta última. Justamente por isso, acredito que podemos nesses dois casos observar muito bem o efeito da complexificação da noção de 'espécie inteligível' (que vimos nos primeiros escritos do gandavense) pela introdução da distinção entre 'espécie inteligível impressa' e 'espécie inteligível expressa' (a partir de seu Quodl. 4). Encontraremos esta última distinção rapidamente nas páginas seguintes, para que possamos a ela retornar pausadamente em seguida. Enfim, essas duas exceções apresentadas a seguir aperfeiçoarão nossa compreensão da complexa noção de 'espécie inteligível' esposada por Henrique de Gand em sua doutrina da intelecção. 


\subsubsection{O conhecimento de si}

Muito embora um autor como Maurice de Wulf não considere a noção de conhecimento de si desenvolvida por Henrique de Gand como particularmente digna de atenção ${ }^{79}$, Raphael Braun já apontava a relevância do tema na obra de Henrique, uma vez que para este último o conhecimento de si pode ser tomado como algo anterior ao conhecimento de outro, justamente devido à presença por essência (isto é, sem qualquer fantasma ou espécie intermediária) da alma ao intelecto: “< $<>$ em Henrique, a alma se vê primeiro <...>, ela se conhece diretamente, refletindo-se sobre si mesma, por sua presença próxima, sem species ou conversio ad phantasmata" ${ }^{\sharp 0}$.

\footnotetext{
${ }^{79}$ WULF, Études sur Henri de Gand, 1894, p. 118: "La question de la connaissance de nous-mêmes est capitale en philosophie. Henri la comprend et l'expose dans le même sens que saint Thomas et les autres scolastiques. C'est pourquoi nous n'y insistons pas davantage.

Ce qui doit nous guider dans le choix des problèmes que nous étudions, ce n'est pas leur importance absolue, mais plutôt l'originalité que le docteur solennel a mise à les résoudre". Tal posição parece se refletir no fato de, mais recentemente, François-Xavier Putallaz não dedicar a nosso autor senão apenas algumas palavras no prefácio a seu La connaissance de soi au XIII siècle. De Matthieu d'Aquasparta à Thierry de Freiberg. Paris: Vrin, 1991, pp. 7-8.
}

${ }^{80}$ BRAUN, Die Erkenntnislehre..., 1916, p. 62: "Thomas von Aquin hat für die Seelenerkenntnis gerade den gegensätzlichen Prozeß: bei Heinrich schaut sich die Seele zuerst, bei Thomas zuletzt; bei Heinrich erkennt sie sich direkt auf sich selbst reflektierend durch ihre nächste Gegenwart ohne Species oder Conversio ad Phantasmata, bei Thomas indirekt durch eine Erkenntnisform. <...>. Darum dürfte auch das Urteil von M. de Wulf nicht richtig und mit den Quellentexten nicht in Einklang zu bringen sein $<\ldots>$. Heinrich steht mit seiner Selbsterkenntnislehre gerade Thomas gegenüber und kann somit nicht mit ihm in Einverständnis gebracht werden”. O trecho de De Wulf a que Braun remete é aquele que citamos logo acima, na nota anterior. A mesma imediatez e anterioridade do conhecimento intelectual de si com respeito ao conhecimento intelectual abstraído dos sentidos é enfatizada na obra de Henrique de Gand por Matthias Laarmann, embora eu confesse não compreender precisamente a sua avaliação a respeito de tal doutrina: "For Thomas, self-cognition is founded in a reflexive knowledge of direct external sense-cognition. For Henry it is a pre-reflexive confused determination of the intellect which in principle needs sensually imparted cognition of the external real world only on occasion. The major consequences (Folgenlasten) among others of this theory are an increasing independence of the soul from the body and the de-emphasis of what in modern times is called lifeworld (Lebenswelt)" (LAARMANN, "God as primum cognitum...”, 1996, p. 190). A meu ver, porém, a própria afirmação de Deus como primum cognitum, defendida por Henrique de Gand (cf. cap. 3, nota 89) e estudada por Laarmann (não somente no artigo citado, mas também em LAARMANN, Deus, primum cognitum, 1999), parece refutar a intepretação de tal doutrina do conhecimento de si proposta por este último. Ora, como vimos até aqui, todo conhecimento sensível acarreta, para Henrique de Gand, também um conhecimento inteligível (ainda que apenas maximamente geral, de tal essência enquanto 'ente'). Esse conhecimento, porém, já possui algo de Deus -como vimo em cap. 3, nota 89, em todo conhecimento intelectual já está contido um conhecimento anterior acerca de Deus enquanto ente. Ou seja, se quisermos aplicar à Henrique de Gand alguma noção próxima de Lebenswelt, Deus de alguma maneira fará parte desse mundo. Pois bem, José Gomez Caffarena argumenta, precisamente, que a noção de conhecimento de si desenvolvida pelo Doutor Solene aponta justamente para a dependência de si mesmo com respeito a Deus: "La concepción teocêntrica del universo y del hombre, propia del cristianismo medieval, recibe en las exposiciones de Enrique de Gante una de las estruturaciones más vigorosas. El hombre, aun en su actual estado 'corrupto', está más centrado en Dios que en sí mismo <..>” (CAFFARENA, "Metafísica de la inquietud ...”, 1960, p. 634). Ou seja, longe de nos afastar desse pretenso Lebenswelt que Laarmann busca enxergar na filosofia de Henrique de Gand, a doutrina do conhecimento de si desenvolvida por este último mostra justamente o contrário, 
Mais recentemente, José Gomez Caffarena mostrou como a defesa de uma anterioridade do conhecimento de si em Henrique de Gand deve igualmente, segundo este próprio, ser compatibilizada com a anterioridade do conhecimento que o homem possui de Deus nesta vida ${ }^{81}$. Em outras palavras, Caffarena aponta para o fato de que a doutrina do conhecimento de si proposta pelo Doutor Solene possui complexidades inerentes que, como veremos, levarão à necessidade de precisar diversos pontos de sua formulação. Parece-me que uma dessas precisões necessárias em tal concepção de conhecimento de si dirá respeito, justamente, à noção de espécie inteligível. Nesse caso, como já mencionamos, Henrique de Gand se aproveitará da introdução da distinção entre espécie impressa e espécie expressa em sua doutrina da intelecção como um todo a partir de Quodl. 4 para clarificar, também, sua concepção do conhecimento de si possível para o homem. Daí nosso interesse, aqui, em estudar mais atentamente a noção de conhecimento de si desenvolvida por Henrique.

De início, voltemos a Quodl. 1, q. 12-13, que consideramos rapidamente acima. As perguntas aí colocadas são, respectivamente, "se a alma separada intelige por uma espécie ou por sua essência [utrum anima separata intelligat per speciem vel per suam essentiam]" e "se a alma separada se intelige por uma espécie dada por si [utrum anima separata intelligat se per speciem editam a se]"82. O primeiro problema reterá nossa atenção no próximo item, de maneira que por ora pretendo compreender melhor a maneira como o Doutor Solene elabora sua resposta à segunda questão colocada. Em todo caso, é interessante notar como, na própria organização do Quodl. 1, as duas temáticas já se encontram imbricadas - de fato, ambas se relacionam, parece-me, justamente por colocarem em causa a necessidade de espécies para o conhecimento da alma separada (seja de si mesma, seja de outros).

Ora, para defender que a alma separada pode se inteligir sem espécies (de fato, Henrique afirma que não discutirá aqui o conhecimento de si da alma unida ao

\footnotetext{
a saber, a completa dependência do homem com respeito ao mundo - não, certamente, ao mundo exclusivamente sensível, mais com respeito àquele elemento superior de seu mundo que é Deus. Enfim, seguindo Caffarena, ao afirmar a anterioridade do conhecimento de si com respeito ao conhecimento intelectual do sensível, o gandavense simplesmente enfatiza a dependência de cada um com respeito àquele ente superior e anterior tanto no mundo existente como no mundo conhecido (mesmo no caso do conhecimento intelectual do sensível). De qualquer maneira, talvez a melhor conclusão a derivar disso tudo seja a grande dificuldade de buscar atribuir a um autor escolástico como Henrique de Gand uma noção contemporânea como Lebenswelt.

${ }^{81}$ Cf. CAFFARENA, "Metafísica de la inquietud humana...”, 1960.

${ }^{82}$ Henrique de Gand, Quodl. 1, q. 12-13 (ed. De Wulf-Mansion Centre, vol. 5, p. 77). Sobre essas questões, cf. WILSON, "Henry of Ghent's Quodlibet I...", 1999, p. 175.
} 
corpo $^{83}$ ), será preciso caracterizar em detalhes aqueles casos em que há necessidade de uma espécie. Nesse ponto, entrará em jogo o problema da presença do inteligível ao intelecto, que por sua vez levará à afirmação da necessidade de espécies para que a alma, mesmo separada, intelija outros que não ela (com a exceção da visão de Deus, como notaremos no item seguinte). Com efeito, a relação entre [i] a necessidade de espécies para o conhecimento e [ii] a necessidade da presença da coisa, enquanto cognoscível, à potência cognoscitiva já era sublinhada no estudo dos sentidos e voltou à baila, há pouco, quando nos voltamos para o conhecimento intelectual. Sabemos, assim, que a espécie inteligível apresenta a coisa ao intelecto, mas não é um mero substituto da coisa externa - pelo contrário, ela é a própria coisa externa presente em essência, no intelecto, enquanto um universal (mais precisamente, enquanto uma quididade) e, portanto, enquanto inteligível. Destarte, o estudo de casos em que não há necessidade de tal espécie inteligível é uma importante ocasião para nuançar essa noção de 'presença da coisa ao intelecto enquanto inteligível' que se mostra capital para a doutrina da intelecção de Henrique apresentada até aqui.

Por outro lado, é importante frisar que a afirmação da possibilidade de um conhecimento intelectual sem espécie inteligível (mesmo que somente como exceção à regra) não parece ter sido imediatamente acatada por Henrique de Gand. De fato, uma tal exceção não é reconhecida por Henrique em um texto anterior a 1276, como a seguinte passagem da Suma, art. 3: "nada, portanto, pode ser cognoscível [scibile], senão aquilo a que é nato ser [natum est esse] na alma por sua espécie - tal que, por sua espécie, a alma seja, de algum modo [quodammodo], aquilo" ${ }^{\circledR 4}$. Nessa passagem, todo o campo do cognoscível e daquilo de que se pode ter 'ciência' - e, ao que parece, estamos aqui ainda no terreno do scire large accepto que vimos, no cap. 1, em Suma, art. 1, q. 1 - é identificado ao âmbito daqueles que podem naturalmente 'ser na alma' (esse in anima). Ora, algo não pode 'ser na alma' com o mesmo ser que possui externamente ou, com a inversão que a passagem nos permite, a alma não pode ser a própria coisa conhecida com o ser que esta última contém fora da alma. É necessário, portanto, como se diz algumas linhas acima da passagem citada, que o intelecto e o ciente ('aquele que tem ciência', sciens) 'sejam, de algum modo [quodammodo], a

\footnotetext{
${ }^{83}$ Henrique de Gand, Quodl. 1, q. 12-13 (ed. De Wulf-Mansion Centre, vol. 5, p. 81): "Quomodo autem anima coniuncta intelligit se ipsam, de hoc nihil ad praesens".

${ }^{84}$ Henrique de Gand, Suma, art. 3, q. 1, co. (ed. De Wulf-Mansion Centre, vol. 21, p. 245): "Nihil igitur potest esse scibile, nisi quod per speciem suam natum est esse in anima, ut per speciem anima quodammodo sit ipsum".
} 
forma e a espécie dela $<s c$. da coisa $>$, a saber, informados pela espécie da coisa inteligida e de que se tem ciência [intellectae et scitae] ${ }^{, 85}$. Sendo assim, pode-se dizer que, no conhecimento intelectual (no scire large accepto do intelecto), a coisa é no intelecto pela espécie ou, igualmente, o intelecto é, pela espécie, a coisa conhecida. Isso aponta para uma rígida identidade entre o campo do cognoscível e o campo daquilo que pode ser, por espécie, no intelecto. Em Quodl. 1, q. 12-13, é precisamente essa identidade que se quebra, pois surge um caso no qual há conhecimento intelectual, sem que daí decorra a necessidade de uma espécie do inteligível no intelecto. Em contrapartida, tal exceção, como dito, permite uma melhor compreensão e descrição da situação padrão, isto é, daquele conhecimento intelectual que exige uma tal espécie inteligível.

Pois bem, na passagem de Suma, art. 3, que acabamos de ler, diz-se que o cognoscível não é 'simplesmente' no intelecto - melhor, ele não é no intelecto tal como é fora deste -, mas é no intelecto 'de algum modo' (“quodammodo"), a saber, pela espécie. Essa mesma tese é reafirmada nas questões que ora nos interessam de Quodl. 1:
“Assim, não é verdade que o inteligido deva sempre ser no inteligente, mas é indubitavelmente verdadeiro que deva ser nele de certo modo [aliquo modo], tal que quanto mais verdadeira e atualmente seja nele, tanto mais verdadeira e atualmente intelija a coisa" ${ }^{\prime 6}$.

Nesse trecho, o ser do inteligido no inteligente ganha contornos muito mais precisos do que aqueles que recebera em Suma, art. 3, já que aqui o 'ser no inteligente' é algo mais abrangente do que no texto anterior, que igualava 'ser na alma' e 'ser por uma espécie'. Daí se segue que haveria maneiras mais ou menos atuais e verdadeiras de um inteligido ser em um inteligente, o que redundaria em conhecimentos mais ou menos verdadeiros e atuais do inteligente acerca do inteligido. Há duas razões para tal descolamento entre 'ser no inteligente ou na alma' e 'ser por

\footnotetext{
${ }^{85}$ Henrique de Gand, Suma, art. 3, q. 1, co. (ed. De Wulf-Mansion Centre, vol. 21, p. 245): "Dicendum ad hoc secundum Philosophum in III $^{\circ}$ De anima quod intellectus est 'quodammodo intelligibilia et sciens scibilia', et cum 'non sunt nisi duo modi essendi', ut ibi dicit Commentator, 'necesse est ut intellectus et sciens sint intellectum et scibile extra animam aut forma eius'. Res autem ipsa non possunt esse. Necesse est ergo quod sint quodammodo forma et species eius, specie scilicet rei intellectae et scitae informati. Unde 'lapis non est in anima, sed species lapidis"'.

${ }^{86}$ Henrique de Gand, Quodl. 1, q. 12-13, co. (ed. De Wulf-Mansion Centre, vol. 5, p. 80): "Quod ergo semper intellectum debet esse realiter apud intelligentem, non est verum sed quod debet esse apud ipsum aliquo modo, indubitanter verum est, ita quod quanto verius et actualius est apud ipsum, tanto verius et actualius rem intelligit".
} 
espécie'. Primeiramente, Henrique considera aqui também o caso daqueles inteligidos que são presentes a Deus pela própria substância deste último - ora, eles são no primeiro princípio o mais verdadeira e atualmente possível e, por serem nele substancialmente (decerto, sem qualquer espécie), a inteleção divina acerca deles será sumamente verdadeira e inteligível ${ }^{87}$. Ou seja, o próprio caso do intelecto divino deixa claro que é plenamente possível que um inteligido seja num inteligente sem que nele seja por uma espécie. Em face desse argumento, porém, se poderia dizer que, embora a identificação entre 'ser no inteligente' e 'ser por espécie' não valha certamente em Deus, talvez nem por isso deixe de valer para os homens. Ora, que esse não seja o caso fica claro quando o Doutor Solene apresenta aquilo que vejo como a segunda razão para o descolamento entre esses dois casos de ser (isto é, entre 'ser no inteligente ou na alma' e 'ser por espécie'). Essa segunda razão é a própria temática do conhecimento de si da alma separada:

\begin{abstract}
"Uma vez que a alma separada, quanto é de si, é algo [quid] inteligível em ato, pois é totalmente separada da matéria e é sumamente atual e presente para si mesma, ela intelige a si mesma por si e $<$ intelige $>$ sua essência, entre todas as criaturas, o mais perfeitamente, sem qualquer espécie outra. Isso porque, para que algo seja inteligível em ato, não se requer nada quanto é de si, senão que seja em ato separado da matéria e presente ao inteligente $<\ldots>$.. 88 .
\end{abstract}

Que Henrique exclua do conhecimento que a alma possui de si 'qualquer espécie outra' ("sine omni alia specie"), parece remeter à caracterização da espécie inteligível como a própria essência da coisa enquanto inteligível (enquanto quididade) na alma. Ora, se consideramos a espécie como a essência da coisa presente como inteligível ao intelecto, a própria alma, presente em sua essência como algo inteligível ao intelecto, pode ser caracterizada como uma species que permite o conhecimento dela própria, alma. Entretanto, não é necessária outra (alia) espécie para o conhecimento da alma que não a sua própria essência, isto é, não é necessária uma espécie abstraída pelo intelecto agente a partir dos sentidos. Ou seja, já começamos a notar que a exclusão da espécie inteligível no conhecimento intelectual de si não é

\footnotetext{
${ }^{87}$ Henrique de Gand, Quodl. 1, q. 12-13, co. (ed. De Wulf-Mansion Centre, vol. 5, p. 80): "Et ideo primum verissime et actualissime intelligit omnia ex sua substantia, quia verissime habet in se omnium rationes, per quas res omnes verius habent esse in primo quam in propriis naturis".

${ }^{88}$ Henrique de Gand, Quodl. 1, q. 12-13, co. (ed. De Wulf-Mansion Centre, vol. 5, p. 80): "Quare, cum anima separata quantum est de se, intelligibile quid est actu, quia omnino separata a materia et sibi ipsi summe actualis et praesens est, se ipsam per se et suam essentiam inter omnes creaturas perfectissime et sine omni alia specie intelligit. Hoc ideo, quia ad hoc quod sit aliquid intelligibile in actu, nihil requiritur quantum est de se, nisi quod sit actu separatum a materia et praesens intelligenti $<\ldots$. .
} 
precisamente uma exclusão da espécie inteligível tout court, mas antes exige uma caracterização nuançada da 'espécie'. Nesse caso, Henrique parece admitir um sentido 'próprio' e outro 'impróprio' de 'species' - retomando uma passagem que já lemos acima: “<_..> aquela espécie que propriamente se chama 'espécie’ se dá [editur] pelo fantasma e pela luz do intelecto agente em todo o intelecto possível naturalmente $<\ldots>$ ". 89 . Pois bem, a referência a uma 'qualquer espécie outra' ("omni alia specie") no trecho indentado acima parece estabelecer uma ambiguidade na noção de espécie inteligível. Assim, a espécie propriamente é a essência da coisa tornada presente ao intelecto enquanto inteligível pela abstração, a partir do fantasma, por ação do intelecto agente (esta espécie é excluída do conhecimento intelectual de si). Porém, em sentido menos próprio, também a própria alma, enquanto inteligível e presente a si mesma, conquanto não abstraída, pode ser denominada 'espécie'.

Estabelecido em que sentido a espécie inteligível parece ser excluída do conhecimento de si, vejamos mais cuidadosamente as razões que levam a tal exclusão na passagem indentada acima. Buscando explanar a ausência de necessidade de espécie para o conhecimento de si da alma separada, o Doutor Solene termina por nos fornecer as razões para a necessidade de espécies nos diversos outros casos de conhecimento humano em que elas se mostram necessárias. Ora, a alma separada não precisa ser conhecida por uma espécie, [i] porque é separada da matéria (vimos, no cap. 2, que a matéria diz respeito unicamente ao corpo com a forma da mistura e da corporeidade, mas não à alma por si mesma) e [ii] porque é atualmente presente a si mesma. Essas características são, em seguida, extrapoladas para todos os inteligíveis em ato - o que os caracteriza é o serem [i] 'em ato separados da matéria' e [ii] 'presentes ao inteligente'.

Se lembrarmos do que lemos em Suma, art. 1, q. 5, o intelecto agente justamente era descrito como uma "virtude existente [existentem] em ato" na alma, que faz "os inteligíveis em potência inteligíveis em ato, tal que possam mover em ato o intelecto passivo". Agora vemos que fazer do inteligível em potência um inteligível em ato é retirar a materialidade do inteligível em potência e torná-lo atualmente presente ao intelecto. Daí compreendemos por que aquele discurso dizia respeito principalmente às 'coisas sensíveis' (res sensibiles) - estas perfazem o campo das

\footnotetext{
${ }^{89}$ Cf. nota 31 , acima.
} 
coisas materiais $^{90}$. Começa a ficar claro que tal descrição do intelecto agente, lida à luz de Quodl. 1, q. 12-13, diz respeito unicamente ao caso do conhecimento intelectual que provém do sensível, pois somente este é o caso em que espécies inteligíveis se mostram necessárias para que aquelas quididades que antes surgiam como materiais (e inteligíveis somente em potência), tornem-se imateriais e inteligivelmente presentes em ato no intelecto (aliás, esse mesmo procedimento de conhecimento intelectual a partir dos sentidos - e, em especial, da imaginação - é retomado também aqui em Quodl. 1, q. 12-13 ${ }^{91}$ ). Por fim, para tais coisas sensíveis, ser imaterial e inteligivelmente presente no intelecto é ser no intelecto aliquo modo, isto é, 'por uma espécie'. Igualmente, nos diz o gandavense, serão necessárias espécies para que a alma separada intelija outros que não ela, uma vez que nenhum outro que não ela própria é presente substancialmente a ela ${ }^{92}$ - ou seja, ao que parece, mesmo inteligíveis já por si mesmo imateriais, deverão possuir uma espécie na alma separada que o conhece para suprir não sua imaterialidade (que eles já possuem de si), mas sua ausência na alma. Seria necessário também nesse caso um intelecto agente? Henrique simplesmente não nos diz... O que resta, então, é que 'ser na alma' se identifica a 'ser aliquo modo' ou 'ser por espécie' quando a alma conhece outro que não ela própria (seja este outro um sensível material, caso em que a espécie compensa a materialidade e a ausência da coisa no intelecto, seja ele imaterial, caso em que a espécie compensa somente a ausência do conhecido). No entanto, sublinhe-se: tal identificação não é válida, pelo menos, no caso do conhecimento que a alma possui de si mesma, uma vez que a alma já é, por si, imaterial e presente a si mesma.

Mas, seria o caso, então, de excluir toda espécie do âmbito do conhecimento de si? A resposta a tal questão é tanto mais complexa, quanto mais nuances a noção de 'espécie inteligível' recebe na obra de Henrique de Gand a partir de seu Quodl. 4.

\footnotetext{
${ }^{90}$ Cf. notas 24 e 26 , acima.

${ }^{91}$ Mais uma vez, remeto à nota 31.

${ }^{92}$ Henrique de Gand, Quodl. 1, q. 12-13, ad 2 (ed. De Wulf-Mansion Centre, vol. 5, p. 82): "Quod ergo arguebatur, quod anima separata intelligit alia a se per suam substantiam, quia actu est illa, quia semper inferius est actu in superiori, non e converso, dicendum quod verum est secundum idem genere, non autem secundum idem specie, et ita superius intelligendo seipsum per substantiam suam, intelligit omnia alia in generali, non autem in propria specifica natura vel individuali in qua res vere intelliguntur. Unde qui habet omnes rerum rationes in se, et generales et specificas et individuales, ille solus, ut est Deus, per suam substantiam potest omnia intelligere, et qui sic non habet eas, non potest illas intelligere nisi per suas species, ut dictum est'. Note-se que, nesta passagem, 'species' é utilizado tanto enquanto o universal (isto é, como 'aquilo que está sob o gênero'), como enquanto a forma que é meio para a intelecção (espécie inteligível).
} 
Com efeito, se nos voltamos para Quodl. 4, q. 7, vemos algumas sutis reelaborações na doutrina que lemos em Quodl. 1, q. 12-13. Em Quodl. 4, q. 7, pergunta-se "se o intelecto criado intelige a si mesmo e àqueles que por suas essências são nele sem qualquer espécie da coisa inteligida ou por alguma espécie pela qual ele seja informado [utrum intellectus creatus se ipsum et ea quae per essentiam eorum sunt in ipso intelligat per se absque omni specie rei intellectae vel per aliquam speciem eius qua informatur]"93. Essa questão será abordada no contexto do Quodl. 4 mais adiante. Neste momento, pretendo destacar alguns dos elementos de maior nuance recebidos aqui pela noção de conhecimento de si que já viemos esboçando até agora.

Como vimos há pouco, Henrique de Gand descarta qualquer espécie no conhecimento de si, desde que tomemos espécie em um sentido dito 'próprio', em Quodl. 1, q. 12-13, a saber: “<..> aquela espécie que propriamente se chama 'espécie' se dá [editur] pelo fantasma e pela luz do intelecto agente em todo o intelecto possível naturalmente $<\ldots>$.. ${ }^{94}$. Ou seja, já notávamos aqui que, caso pudéssemos denominar como 'espécie', em geral, qualquer essência presente ao intelecto como inteligível, não haveria qualquer problema em afirmar uma 'espécie' frisemos, nesse sentido 'menos próprio' - anterior ao ato de conhecimento de si. É justamente esse passo que o Doutor Solene torna claro em Quodl. 4, q. 7. Para tanto, ele se vale da vagarosa construção de uma aplicação da distinção entre espécie impressa e espécie expressa (que já vimos o quão complexa e polemicamente é aplicada aos sentidos) à exposição do processo de formação do conhecimento intelectual.

Sem dúvida, em Quodl. 4, q. 7, Henrique parte da afirmação genérica de que não haveria espécies no conhecimento de $\mathrm{si}^{95}$. No entanto, com o desenvolvimento do texto, vemos que tal asserção deve ser lida à luz de uma noção sutil de 'espécie inteligível'. Uma primeira pista para a compreensão dessa caracterização mais nuançada da espécie pode ser lida no seguinte trecho:

"De fato, aquilo que é presente ao intelecto por sua essência [per suam essentiam], similarmente é mais conjugado a ele [magis est coniunctum ei],

\footnotetext{
${ }^{93}$ Henrique de Gand, Quodl. 4, q. 7 (ed. De Wulf-Mansion Centre, vol. 8, p. 28).

${ }^{94}$ Cf. nota 31 , acima.

${ }^{95}$ Henrique de Gand, Quodl. 4, q. 7, co. (ed. De Wulf-Mansion Centre, vol. 8, p. 39): "Et propter eandem causam, ut etiam dictum est, mens se cognoscens sine omni specie media se cognoscet".
} 
como a forma dele nele existente [existens], não como em um sujeito (tal como uma forma inerente impressiva e informando para o ato de ser), mas como um objeto no cognitivo (tal como uma forma exemplar expressiva ou representativa [expressiva sive repraesentativa], presente e movendo para o ato de inteligir) ${ }^{96}$. E isso é essencial para que algo seja, para si, razão de inteligir; é da perfeição, no cognoscente e no conhecido; e é o modo de inteligir pelo qual Deus intelige a si mesmo em si mesmo e, por consequente, em si mesmo, todos os outros que não ele, como se deve determinar em outro lugar. Porém, que nas criaturas se requeira uma espécie outra que não a coisa como razão de inteligir, representativa ou impressiva, isso é de uma imperfeição da parte do inteligente, pois, a saber, a essência dele não é razão exemplar ao conhecer todos os outros que não ele, mas somente $<$ no conhecimento $>$ de si mesmo $<\ldots>$. Similarmente, é de uma imperfeição da parte do inteligido, a saber, pois ele não pode ser por sua essência no intelecto. E, por isso, ambos $<$ inteligente e inteligido $>$, de acordo com isso, quanto é de si, são primeiro em potência com respeito a ambos (aquele para inteligir, este para ser inteligido); em seguida, fazem-se em ato (quando este intelige em ato e aquele quando é inteligido em ato)"97.

O elemento dorsal desta passagem é a comparação entre o intelecto divino e o intelecto criado - em especial, o humano. Deus intelige, em sua própria essência, a si mesmo e a todo outro que não ele próprio (essa afirmação toma por pressuposto a concepção, basilar para a metafísica de Henrique, da essência divina como exemplar para a essência das criaturas ${ }^{98}$ ): "Deus intelige a si mesmo em si mesmo e, por consequente, em si mesmo, todos os outros que não ele [Deus intelligit se ipsum se ipso et per consequens se ipso omnia alia a se]". O intelecto criado, por outro lado,

\footnotetext{
${ }^{96}$ Sobre a distinção entre 'existir fora do intelecto' e 'existir no intelecto', cf. cap. 2, nota 95.

${ }^{97}$ Henrique de Gand, Quodl. 4, q. 7, co. (ed. De Wulf-Mansion Centre, vol. 8, pp. 41-2): "Tale enim quod est praesens per suam essentiam intellectui, similiter magis est coniunctum ei, ut forma eius existens in ipso, non ut in subiecto, tamquam forma inhaerens impressiva et informans ad actum essendi, sed ut obiectum in cognitivo tamquam forma exemplaris expressiva sive repraesentativa, praesens et movens ad actum intelligendi. Et hoc est essentiale ad hoc quod aliquid sit sibi ratio intelligendi, et est perfectionis et in cognoscente et in cognito, et est modus intelligendi quo Deus intelligit se ipsum se ipso et per consequens se ipso omnia alia a se, ut alias habet determinari. Quod autem in creaturis requiritur species alia a re, ut ratio intelligendi sive repraesentativa sive ut impressiva, hoc est imperfectionis ex parte intelligentis, quia scilicet essentia eius non est ratio exemplaris in cognoscendo omnia alia a se, sed sui ipsius solum $<\ldots>$. Similiter est imperfectionis ex parte intellecti, quia scilicet ipsum non potest esse per suam essentiam in intellectu. Et ideo utrumque eorum secundum hoc, quantum est ex se, prius est in potentia respectu utriusque, hoc ut intelligat, illud ut intelligatur; deinde fiunt in actu cum hoc actu intelligit, illud vero cum actu intelligitur".

${ }^{98}$ Sobre a identidade entre as essências das coisas e a essência de Deus, nos diz Henrique que as essências das coisas imitam (imitantur) Deus "non tam in essendo, quam in cognoscendo. In essendo, quia essentia creaturae ex hoc est essentia, quod est ideatum, quodam modo per imitationem divinae essentiae, et illud quod non est tale scilicet quod non habet divinam essentiam, ut ideam sibi respondentem, quam imitatur, ut formam exemplarem, et rationem perfectionalem, purum nihil est, et non intelligibile, nec res alicuius praedicamenti. In cognoscendo autem, quia creaturae non cognoscuntur a Deo, nisi quia cognoscit se imitabilem ab illis, nec potest se intelligere imitabilem ab illis nisi simul cointelligendo illas, non in seipsis, ut obiecta causantia in Deo suam notitiam, sed in sua imitabilitate existente in Deo, ut illa quae sunt creata a notitia, quam Deus habet de ipsis" - Suma, art. 68 , q. 2 , co (ed. 1642-6, p. 1266, nn. 10-11). Sobre as ideias divinas, cf., acima, a nota 25 .
} 
intelige a si mesmo por sua essência; porém, para conhecer outros que não ele próprio, deve se valer de espécies distintas das coisas conhecidas. Notemos, portanto, que aquilo que separa o intelecto divino do intelecto criado não é o conhecimento de si, mas o fato de o intelecto criado não conhecer, a partir de si, os outros - fazê-lo, justamente, é próprio do intelecto divino ${ }^{99}$. Sublinhe-se, porém, a sutileza do texto: no conhecimento de outro, o intelecto criado necessita de uma espécie outra que não a própria coisa conhecida (de fato, é uma imperfeição da coisa conhecida que ela não possa ser, em si mesma, no intelecto que a conhece), porém para conhecer a si mesmo basta a sua própria essência, já presente a si. Ou seja, tal doutrina não exclui que haja espécies no conhecimento de si, mas simplesmente exclui que tal espécie seja outra que não a própria coisa conhecida - no caso, a própria essência do intelecto, que conhece a si mesmo.

\footnotetext{
${ }^{99}$ Embora esse tema não seja desenvolvido em Quodl. 4, q. 7, há um elemento que distingue o conhecimento de si divino e o conhecimento de si do intelecto criado: no conhecimento que Deus possui de si, a operação de intelecção é idêntica à própria essência divina conhecida; nos intelectos criados, pelo contrário, a operação de intelecção de si é realmente distinta da própria essência conhecida. Esse tema é diretamente abordado em Quodl. 15, q. 8, co. (ed. De Wulf-Mansion Centre, vol. 20, p. 46): "Sic ergo dico generaliter et specialiter simul respondendo ad quaestionem propositam quod quaecumque operatio creaturae differt secundum rem ab operante et quod operatio intelligendi angeli aut mentis humanae realiter differt ab intelligente, quia solius Dei est quod in ipso sunt idem substantia et operatio $<\ldots>$. Non tamen solius Dei est quod in ipso non differant secundum rem substantia et virtus sive potentia operandi” (de fato, já vimos no cap. 2, que no caso do homem são realmente idênticas, ainda que formalmente distintas, a alma e suas potências ou virtudes). Essa diferença quanto à operação de intelecção de si, porém, não contradiz o ponto estabelecido em Quodl. 4, q. 7, a saber, a identidade entre a essência do cognoscente e a razão motiva de intelecção dessa essência (isto é, aquela razão que move o intelecto para a operação de conhecer intelectualmente), tanto no conhecimento divino de si como no conhecimento de si pelo intelecto criado. Em outras palavras, o discurso de Quodl. 4, q. 7, é voltado para a razão motiva do conhecimento de si (que no intelecto divino e nos criados é a própria essência cognoscente), enquanto que em Quodl. 15, q. 8, discorre-se acerca da resultado desse movimento, ou seja, da operação de conhecimento intelectual de si (em Deus, idêntica à essência cognoscente e, nos intelectos criados, distinta da essência cognoscente).

Notemos ainda que outro elemento a aproximar, no intelecto criado, o conhecimento intelectual de si e o conhecimento intelectual de outro é que, nos dois casos, o resultado é primeiramente um conhecimento universal. Vimos neste capítulo que, a bem dizer, o primeiro resultado do conhecimento abstrativo não é muito mais do que o conhecimento de algo como 'ente' - isto é, não chegamos a mais do que um conhecimento intelectual maximamente geral nesse primeiro momento da inteleção. Com o conhecimento de si, no diz o Doutor Solene, ocorre o mesmo: primeiramente, o intelecto criado se conhece como universal e somente em seguida (por meio do conhecimento universal) pode chegar a se conhecer como singular - Henrique de Gand, Quodl. 15, q. 9, co. (ed. De Wulf-Mansion Centre, vol. 20, pp. 51-2): "Dico secundum alias a me determinata in quaestionibus de Quolibet quod angelus aut mens non intelligit se, nisi sicut alia a se, primo scilicet intelligendo se sub ratione universalis proximi sui. Universale enim est per se et primum obiectum intellectus creati, sicut singulare est per se et primum obiectum sensus. Igitur si angelus aut mens intelligit se sub ratione singularis, hoc non est primo et immediate et quasi directo aspecto secundum lineam rectam, sed mediante intellectu universalis sui intellecti primo et mediate et quasi aspectu obliquo secundum lineam reflexam, prout determinat Philosophus in $\mathrm{III}^{\circ}$ De anima" (voltaremos a essa questão dentro em pouco). Sobre o conhecimento intelectual do singular, cf. nota 190, adiante.
} 
Porém, então, no que tange ao homem, como pode a alma ser tomada como espécie de si própria? Um primeiro passo para a resposta a esse pergunta já está no início deste último trecho destacado. Cogitam-se aí duas maneiras pelas quais algo poderia ser presente ao intelecto: [i] como forma impressiva, nele existente como em um sujeito, informando-o para um ato de ser determinado ou [ii] como forma expressiva ou representativa, nele existente como um objeto naquele que conhece, movendo-o para um ato de inteligir determinado. Como se vê, o primeiro modo é, por definição, insuficiente para a produção de conhecimento. Dessa maneira, o segundo modo deve vir ao caso nesta discussão sobre o conhecimento de si. Ora, sendo assim, se se deseja defender que não há espécies outras que não a própria essência da alma no conhecimento que o homem possui de si, torna-se necessário mostrar que a alma já está, por si mesma, presente ao intelecto desse segundo modo, isto é, como um objeto no cognoscente e, portanto, como algo capaz de mover para um ato de intelecção acerca de si.

Perceba-se, porém, que a tese de Henrique é geral: é necessário para que algo seja razão de inteligir (ratio intelligendi) que esteja presente no intelecto como um objeto no cognoscente, isto é, como forma expressiva e representativa capaz de mover para um ato de inteligir acerca de si mesmo. Ora, nos intelectos criados, a essência é razão suficiente da intelecção de si mesma, porém não é razão exemplar do conhecimento dos outros. Ou seja, no homem, a alma é forma expressiva de si própria e, portanto, razão de inteligir a si própria - no caso do conhecimento que o homem possui de si, destarte, a coisa conhecida e a forma expressiva que move tal conhecimento se identificam. Já quando o homem conhece outros, há um descolamento entre a coisa conhecida e a forma expressiva que serve como razão de inteligir, isto é, que move o intelecto para o ato de inteligir aquela coisa determinada. Assim, em ambos os casos do conhecimento humano - isto é, na intelecção de si e na intelecção de outros - há a necessidade de uma forma expressiva que mova para o ato. Por outro lado, os dois casos diferem, porque no conhecimento de si a alma já é sua própria forma expressiva, enquanto que no conhecimento dos outros há uma forma expressiva distinta da coisa conhecida, sendo tal forma um intermediário entre o intelecto e a coisa conhecida por meio desta forma.

Porém, há aqui uma clara dificuldade: queríamos provar que há, ainda que diferentemente, espécies no conhecimento humano de si e dos outros, mas mostramos apenas que há formas expressivas implicadas em ambos os casos. Seria possível 
identificar tais formas expressivas às espécies? Que, de fato, seja possível fazê-lo parece se seguir de um trecho posterior da mesma questão, no qual Henrique busca delimitar três sentidos nos quais Agostinho se utiliza do termo species no De trinitate. De uma primeira maneira, [i] species é a própria forma de qualquer coisa: "de um modo, chama-se 'espécie' a forma de qualquer coisa natural que $<$ esta $>$ possua em si mesma. E, de acordo com isso, a forma da essência divina é dita 'espécie' < ..> . Do mesmo modo, chama-se 'espécie' a forma da coisa corpórea fora do intelecto $<\ldots>$. E, ainda segundo esse modo, toda forma de coisa natural pode, em geral [generaliter] ser chamada 'espécie', mas especialmente a forma especialíssima <...>"100. Nesse sentido, a espécie é aquilo que dá o ser determinado da coisa, mas não é aquilo que causa um ato de inteligir determinado, de maneira que essa concepção de species não parece vir ao caso diretamente em nossa presente discussão. Em um segundo sentido, [ii] a species é uma forma impressa caracterizada como uma similitude da coisa natural envolvida no processo de conhecimento, ainda que somente na parte sensitiva: “de um segundo modo, diz-se 'espécie' a similitude da coisa natural que informa impressivamente a parte sensitiva - não digo a intelectiva $<\ldots$.. . De fato, tal espécie não forma nenhuma outra espécie impressiva similar a si na parte intelectiva $<\ldots>$ ".101 . Se lermos este trecho a partir do que estudamos acima acerca do conhecimento sensitivo, parece possível afirmar que esta é a 'espécie impressa ou impressiva' que Henrique de Gand afirmava haver em todo o processo de conhecimento sensitivo, mas ser excluída do conhecimento intelectivo - essa exclusão, aliás, é bem sublinhada nesta passagem. Mais uma vez, portanto, esta não pode ser aquela forma expressiva implicada em toda intelecção. Vejamos, assim, [iii] a terceira concepção de species: “de um terceiro modo, diz-se 'espécie' a coisa conhecida, enquanto é objetivamente existente no cognoscente enquanto é cognoscente, dando forma ao ato de inteligir [ut obiective existens est in cognoscente ut est cognoscens dans formam actui intelligendi], mas não enquanto forma impressa inerindo no inteligente $<\ldots$. . Eis

\footnotetext{
${ }^{100}$ Henrique de Gand, Quodl. 4, q. 7, co. (ed. De Wulf-Mansion Centre, vol. 8, p. 44): "Uno enim modo appellatur 'species' forma cuiusque rei naturalis quam habet in se ipsa et secundum hoc 'species' dicitur forma divinae essentiae $\langle\ldots>$. Eodem modo appellatur 'species' forma rei corporalis extra intellectum $<\ldots>$. Et secundum hunc modum etiam omnis forma rei naturalis 'species' appellari potest generaliter, sed specialiter forma specialissima $<\ldots>$ ".

${ }^{101}$ Henrique de Gand, Quodl. 4, q. 7, co. (ed. De Wulf-Mansion Centre, vol. 8, pp. 44-5): "Secundo modo dicitur 'species' similitudo formae rei naturalis, informans impressive partem sensitivam, non dico intellectivam $<\ldots>$. Huiusmodi enim species ulterius nullam sibi similem speciem impressivam format in parte intellectiva $<\ldots$..
} 
como ele também chama essa espécie de 'notícia' e isso, porque dá forma ao ato de conhecer. E tal notícia possui ser tanto na memória, como na inteligência" ${ }^{\text {102 }}$. Pois bem, nessa caracterização de species, surge a fórmula "objetivamente existente no cognoscente [obiective existens est in cognoscente]", similar à fórmula que encontrávamos no último trecho indentado para caracterizar a forma expressiva que move o intelecto para o ato de conhecimento intelectual. Ou seja, neste terceiro significado de species estamos, precisamente, em presença daquela forma expressiva, que não é senão a própria coisa enquanto presente como objeto no intelecto.

Vemos, portanto, que, no que diz respeito ao conhecimento intelectual humano, tanto no conhecimento dos outros como no conhecimento de si, exige-se a presença ao intelecto da própria coisa enquanto inteligível. Tal presença será sempre por uma forma expressiva da coisa, capaz de mover o intelecto para o ato de inteligir determinadamente tal coisa ${ }^{103}$. A diferença é que, uma vez que a alma já é imaterial e presente ao intelecto por si mesma (como vimos em Quodl. 1, q. 12-13), ela já é sua própria forma ou espécie expressiva ou representativa - isto é, ela já é capaz de mover o intelecto para o conhecimento dela própria e, portanto, de si mesmo. As demais coisas, por outro lado, sendo ou não materiais, não estão imediatamente presentes para o intelecto, de maneira que este deve possuir em si uma forma ou espécie expressiva daquelas coisas - esta forma ou espécie, porém, ainda que seja a própria coisa enquanto objeto no intelecto, é distinta da coisa em seu ser próprio, material ou imaterial, fora do intelecto que a conhece. Enfim, no que diz respeito ao conhecimento de outros, mais uma vez a espécie expressa ganha uma ambiguidade (como já era o caso, também, da espécie impressa no estudo dos sentidos): ela é a coisa enquanto existente objetivamente no intelecto que a conhece, mas não é a coisa no ser próprio desta última enquanto existente por si mesma, fora do intelecto. Nos

\footnotetext{
${ }^{102}$ Henrique de Gand, Quodl. 4, q. 7, co. (ed. De Wulf-Mansion Centre, vol. 8, p. 46): "Tertio modo dicitur 'species' res cognita, ut obiective existens est in cognoscente ut est cognoscens dans formam actui intelligendi, non autem ut forma impressiva inhaerens intelligenti $<\ldots>$. Ecce quomodo istam speciem appellat 'notitiam', et hoc non nisi quia dat formam actui cognoscendi. Et huiusmodi notitia habet esse et in memoria et in intelligentia <... ". Acerca desses três significados de species sublinhados por Henrique de Gand em Agostinho, cf. FIORENTINO, "Species nei secoli XIII-XIV", 2007, p. 83. Sobre as noções de 'memória' e 'inteligência', cf., adiante, a nota 206. Já sobre os diversos usos do termo notitia em Henrique de Gand, cf. acima a nota 70.

${ }^{103}$ Comentando o mesmo Quodl. 4, q. 7, nos diz Jerome V. Brown, em "The knowledge proper to the separated soul: Henry of Ghent and John Duns Scotus”. Franzikanische Studien 66 (1984), pp. 316-34 (esp. pp. 321-2): “< ..> we would simply remark that Henry makes it abundantly clear in the course of his discussion that he is opposed only to the idea of an impressed species being involved in the intellectual life of man pro statu isto. He is not opposed to the efficacy of a species expressiva" (grifo no orig.).
} 
homens, o único caso em que identificam-se existir por si mesmo e existir como objeto no intelecto é o conhecimento que o intelecto possui de si.

Acredito que eu tenha dado um passo longo demais ao passar da identidade entre 'formar expressiva' e o terceiro modo de species para a utilização do termo 'espécie expressiva', visto ser este um termo técnico de primeira importância para o Doutor Solene. Por outro lado, meu 'salto' parece ser avalizado por um trecho que lemos ao fim do mesmo Quodl. 4, q. 7:

“<..> a memória de si é aquela que não possui nenhuma espécie na memória que seja espécie impressiva ou, mesmo, que seja notícia e espécie expressiva diferente de sua essência (tal como ocorre quando intelige aqueles que são ausentes, por essência, a ela) $<\ldots . .>^{104}$.

Esse pequeno trecho mostra o quanto deixamos de lado neste curto estudo de Quodl. 4, q. 7 - em especial, aponta para o papel crucial que a memoria recebe aqui. Com efeito, essa não é a primeira vez que nos deparamos com a memória intelectual (já a tangenciamos no estudo da memória sensitiva, no item 5.3). Não nos estenderemos sobre a memória neste ponto, pois retornaremos a ela adiante neste capítulo. O que importa notar aqui é somente que, estando envolvida, como veremos, em todo conhecimento intelectual, a memória também recebe um papel relevante na explicação do conhecimento de si: temos aqui o famoso tema da 'memória de si' (memoria sui).

Como nos sentidos a memória sensitiva guardava as espécies impressas recebidas de fora, também na memória intelectiva, ainda que diferentemente, haverá os objetos inteligíveis que serão, posteriormente, inteligidos em ato. Assim, Henrique se vê na posição de explicar, mais uma vez a partir do De trinitate de Agostinho (a cuja citação o último trecho indentado se segue), em que medida há espécies na memória no conhecimento intelectual de si. A memória intelectiva de si, com efeito, não possui espécie impressiva (o que era esperado, uma vez que vimos não haver espécies impressivas ou impressas no intelecto), nem possui “espécie expressiva diferente de sua essência (tal como ocorre quando intelige aqueles que são ausentes, por essência, a ela) [species expressiva, differens a sua essentia, sicut contingit cum

\footnotetext{
${ }^{104}$ Henrique de Gand, Quodl. 4, q. 7, co. (ed. De Wulf-Mansion Centre, vol. 8, p. 53): “Aperte etiam insinuat ex hoc quod dicit quod ipsa est memoria sui, quod nullam speciem habet in memoria, quae est species impressiva, sive etiam quae est notitia et species expressiva, differens a sua essentia, sicut contingit cum intelligit ea quae sibi sunt absentia per essentiam, et similiter contingit ex parte intelligentiae, ut patebit in quaestione sequenti”.
} 
intelligit ea quae sibi sunt absentia per essentiam]". Na memória intelectiva em causa no conhecimento de outros, há espécies expressivas diferentes da essência desses outros enquanto existentes fora do intelecto (ainda que elas sejam as essências desses outros enquanto existentes no intelecto). Na memória intelectiva de si, pelo contrário, há uma espécie expressiva completamente idêntica à própria coisa inteligida, que não senão a própria alma (portanto, o próprio intelecto e a própria memória). Sendo o conhecimento de si necessariamente atrelado a essa memoria sui, parece correto dizer que, igualmente, no conhecimento de si há espécie, ainda que tomada precisamente da maneira mostrada aqui, isto é, como uma espécie expressa, idêntica à própria essência do objeto conhecido ${ }^{105}$.

Dito isso, vemos que há uma continuidade das doutrinas do conhecimento de si pelo homem apresentadas em Quodl. 1, q. 12-13, e em Quodl. 4, q. 7. Ambas distinguem o conhecimento de si do conhecimento de outros. Em ambos os casos, tal distinção redunda em uma distinção da espécie inteligível implicada em cada conhecimento. Em Quodl. 1, q. 12-13, diz-se que somente no conhecimento de outros há espécie em sentido próprio (isto é, obtida a partir do fantasma na luz do intelecto agente), mas se deixa em aberto se haveria espécie em algum outro sentido no conhecimento de si. Enquanto isso, em Quodl. 4, q. 7, afirma-se que há espécies expressivas nos dois casos, que se diferenciam pela identidade (no conhecimento de si) ou distinção (no conhecimento de outros) entre a espécie expressiva enquanto coisa existente como objeto no intelecto e a própria coisa em seu ser próprio. Assim, o gandavense não exclui que haja espécies envolvidas no conhecimento de si, porém parece crer na necessidade de dar nuanças à sua concepção de espécie inteligível ao utilizá-la na descrição de tal conhecimento. Portanto, parece-me precipitado aquilo que propõe Nys, a saber, que a doutrina do conhecimento de si tenha começado como exceção e passado à regra ${ }^{106}$. Pelo contrário, ela sempre permanece exceção e, por isso mesmo, exige uma reflexão cada vez mais sutil sobre o papel da espécie

\footnotetext{
${ }^{105}$ Mais do que isso, para Henrique de Gand alguma espécie está implicada em todo conhecimento humano, seja uma espécie da coisa idêntica à própria coisa presente (como no caso do conhecimento de si) seja no conhecimento de algo em si mesmo ausente, presente ao intelecto somente como objeto universal: "Hoc verbum in quantum est actus informatus per obiectum est species de tertio modo speciei, et tale verbum formatur in intellectu de omni eo quod ab ipso percipitur sive per speciem suae praesentiae sive per speciem universalis notitiae" - Quodl. 4, q. 8, co. (ed. De Wulf-Mansion Centre, vol. 8, pp. 67-8). Sobre o terceiro modo de 'species', cf. a nota 102, acima. Ainda sobre o trecho citado na presente nota, cf. a nota 147 , adiante.

${ }^{106}$ Cf., acima, notas 73 e 78 .
} 
inteligível não somente no que diz respeito ao conhecimento de si, mas também no tange ao conhecimento intelectual humano como um todo.

Notemos, portanto, que o caráter excepcional do conhecimento de si provém não da ausência de espécies na produção de tal conhecimento, mas da identificação entre a essência do objeto em seu ser próprio e a essência do objeto enquanto é inteligível na espécie - ambas são a mesma alma. Assim, o que distingue o conhecimento de si do conhecimento de outros é a essencialidade do primeiro quando comparado ao segundo. Tal essencialidade, no entanto, merece explicações, pois há diversos sentidos em que um conhecimento pode ser essencial ao cognoscente. Assim, em Quodl. 15, q. 9, Henrique de Gand aborda a essencialidade do conhecimento humano acerca de si ao compará-la à essencialidade do conhecimento humano acerca de Deus. Sua conclusão, em resumo, é que ambos são essenciais ao homem, mas diferentemente. Será interessante ler essa questão como último passo em nosso estudo da excepcionalidade do conhecimento humano de si.

Como Caffarena nos lembra ${ }^{107}$, esses dois temas - o conhecimento humano de si e o conhecimento humano de Deus - estão profundamente relacionados em Henrique de Gand. Com efeito, este mesmo comentador sublinha tal relação, em seu referido texto, ao comentar uma questão que liga diretamente ambos os temas, a saber, o referido Quodl. 15, q. 9: "se a inteleção pela qual o anjo ou a mente humana intelige a si é mais essencial a si do que aquela pela qual intelige Deus [utrum intellectio, qua Angelus, aut mens humana intelligit se, sit sibi essentialior, quam illa, qua intelligit Deum]" ${ }^{\prime 108}$. Um rápido estudo dessa questão poderá nos mostrar por que, junto ao problema do conhecimento de si, o estudo do conhecimento do beato também constitui uma exceção à descrição geral do conhecimento intelectual fornecida por Henrique de Gand e, ao ser uma tal exceção, abre espaço para elaborações mais precisas acerca do conhecimento intelectual humano.

Em Quodl. 15, q. 9, a bem dizer, o foco não é o conhecimento do beato - pelo contrário, interessa ao Doutor Solene comparar o conhecimento de si possível para o intelecto criado com aquele possível, para este último, acerca de Deus, determinando qual dos dois é mais essencial. Pois bem, se voltamos a Quodl. 4, q. 7, vemos que ali já se dizia algo sobre aquilo que é 'essencial' para o conhecimento intelectual: a

\footnotetext{
${ }^{107}$ Cf. o já citado CAFFARENA, “Metafísica de la inquietud humana en Enrique de Gante”, 1960.

${ }^{108}$ Henrique de Gand, Quodl. 15, q. 9 (ed. De Wulf-Mansion Centre, vol. 20, p. 50). Cf. CAFFARENA, "Metafísica de la inquietud humana en Enrique de Gante”, 1960, p. 629.
} 
presença de algo como objeto do cognoscente é essencial (essentiale) para que haja uma intelecção acerca desse algo ${ }^{109}$. Destarte, se estamos falando, agora em Quodl. 15, q. 9, sobre aquele conhecimento que é 'mais essencial' (essentialior) para o intelecto, provavelmente será relevante compreender qual dos dois objetos implicados na comparação está mais presente para o intelecto e de que maneira.

Há, porém, diversas maneiras possíveis de considerar a essencialidade de um conhecimento com respeito ao intelecto, a saber, de acordo os diversos modos de ser essencialmente 'por si' (per se). Se dizemos que B é essecial a A pelo primeiro modo per se, isso significa que B é da substância de A, de tal maneira que A só possa ser definido com menção a B. Ora, o próprio Doutor Solene afirma que, no que tange aos intelectos criados, tanto no conhecimento de si como no conhecimento de outros, a operação de intelecção é realmente distinta do próprio intelecto que conhece ${ }^{110}$. Ou seja, a operação de intelecção não pode ser dita essencialmente do primeiro modo per se do intelecto cognoscente, pois ela não é parte substancial sua nem cai em sua definição. Esse é um ponto desenvolvido mais amplamente por Vital Zuccoli, em seu comentário ao Quodl. 15, q. 9: “< ..> algo essencial a outro é predicado disso por si. Porém, o que é predicado de outro por si é, de fato, predicado no primeiro modo de se dizer por si ou no segundo modo. E, se no primeiro modo, então é da substância daquilo, tal que não possa ser definida sem ele. Donde, animal ou também racional são essenciais ao próprio homem no primeiro modo, pois não se pode definir o homem sem eles" "111. Note-se, porém, que, embora Vital Zuccoli se refira a dois modos de ser essencialmente per se, Henrique falará de três, deixando de lado o quarto modo.

Ora, se o primeiro modo está de saída excluído e o quarto modo não é tratado, resta que a questão seja respondida de acordo com os terceiro e segundo modos de ser

\footnotetext{
${ }^{109}$ Cf. nota 97, acima.

${ }^{110}$ Cf., acima, a nota 99.

${ }^{111}$ ZUCCOLIUS PATAVINUS, V. "Commentaria", In: HENRICUS A GANDAVO. Quodlibeta. Tomus primus. Venetiis: apud Iacobum de Franciscis, 1613, f. 376r: "In titulo not. diligenter, quod illud est alteri essentiale, quod praedicatur de ipso per se. Quod autem praedicatur de altero per se, profecto praedicatur vel in primo modo dicendi per se, vel in secundo. Et quidem si in primo modo, tunc est de substantia eius, ita quod nequit diffiniri sine ipso. Unde animal, vel etiam rationale sunt essentialia ipsi homini in primo modo, quia nequit homo diffiniri sine ipsis". Cf. tb. a exposição de Henrique sobre o primeiro modo de ser per se nesse Quodl. 15, q. 9, ad 1 (ed. De Wulf-Mansion Centre, vol. 20, pp. 55-6): "Et essentiale rei primo modo vocatur substantiale eidem, quod non est nisi definitio tota aut pars definitionis rei. Et de tali essentiali verum est dictum Philosophi assumptum in argumento de $\mathrm{VII}^{\circ}$ Metaphysicae, ubi ad litteram loquitur de essentiali quod significatur per nomen et definitionem, quae ambo totum quod est intrinsecum et essentiale rei comprehendunt".
} 
essencialmente per se. Esse é, precisamente, o caminho seguido pelo gandavense, que começa pela consideração do terceiro modo pelo qual algo é per se essencial:

"De fato, sempre é mais essencial à qualquer coisa aquela intelecção que é por
sua essência e idêntica ao inteligente, do que qualquer outra que não seja por sua
essência nem idêntica ao inteligente - e isso falando da essencialidade no
terceiro modo daquilo que é por si. No entanto, observando a razão de aquietação
e não aquietação, que pertence ao segundo modo de se dizer por si, pois são
acidente do operante criado, seria mais essencial a intelecção que intelige Deus
$<\ldots$..."112.

Neste pequeno trecho são colocados em causa duas possíveis considerações da ordem de essencialidade do conhecimento de um intelecto criado. Comecemos a leitura por uma clara dificuldade: a referência na passagem a uma identidade entre a intelecção e o inteligente pode soar contraditória com respeito à exclusão do primeiro modo de ser essencial per se, uma vez que tal exclusão ocorria justamente devido à distinção entre a operação de intelecção e o cognoscente. Acredito que a solução para esse problema está no fato de que, no trecho indentado, a identidade essencial entre intelecção e inteligente justamente está pensada não de acordo com o primeiro modo de ser per se, mas de acordo com o terceiro modo de ser per se. Deste último modo, é per se, nas palavras de Dominique Demange, "tudo aquilo que pertence propriamente a um sujeito e que não é atribuível a outro. É nesse sentido que a substância é dita 'por si', no sentido de separada, em oposição ao acidente" ${ }^{113}$. Ou seja, neste terceiro modo, não está em jogo uma identidade entre inteligido e inteligente enquanto distintos, mas a identidade de ambos enquanto um único que não é em outro - ora, nesse caso, só é essencial per se do terceiro modo a própria essência ou substância primeira com respeito a si mesma. Nesse sentido intelecção e inteligente são idênticos por serem um único sujeito, sem que haja qualquer caso de inerência, uma vez que o inteligido é o próprio inteligente.

\footnotetext{
${ }^{112}$ Henrique de Gand, Quodl. 15, q. 9, co. (ed. De Wulf-Mansion Centre, vol. 20, pp. 52-3): "Semper enim est essentialior rei cuique intellectio illa quae est sua essentia et idem cum inteligente quam quaecumque alia quae non est sua essentia nec idem cum inteligente, et hoc loquendo de essentialitate penes tertium modum eius quod est per se, licet aspiciendo ad rationem quietandi et non quietandi quae pertinet ad secundum modum dicendi per se, eo quod sunt accidentia operanti creato, essentialior esset intellectio, qua intelligit Deum, ut procedit secunda obiectio, et bene".

${ }^{113}$ DEMANGE, D. Jean Duns Scot. La théorie du savoir. Paris: Vrin, 2007, p. 86: "Est appelé 'par soi au troisième mode' tout ce qui appartient en propre à un sujet et qui n'est donc pas attribuable à un autre. C'est en ce sens que la substance est dite 'par soi', au sens de séparée, par opposition à l'accident".
} 
Pois bem, nesse terceiro modo de ser essencial per se, nos diz Henrique, o conhecimento de si é, nas criaturas, mais essencial do que o conhecimento de Deus. Com efeito, o primeiro é um conhecimento da essência acerca de si mesma (como vimos em Quodl. 1, q. 12-13, e Quodl. 4, q. 7, a ratio intelligendi do conhecimento de si nas criaturas é sua própria essência), enquanto que o segundo é um conhecimento de um outro - a essência divina -, do qual a essência das criaturas não pode ser exemplar.

Por outro lado, podemos considerar a mesma questão sob o prisma do segundo modo de ser essencial per se. Dele nos diz Vital Zuccoli: "Mas, agora, se tomarmos 'essencial' pelo segundo modo, então $<s c$. aquilo que é dito essencialmente de outro $>$ é uma propriedade da própria coisa <... $>$ "114. Além disso, diferentemente do que ocorre quanto ao terceiro modo de ser per se, o próprio Henrique nos fornece uma curta exposição sobre o segundo modo: "o essencial à coisa do segundo modo não é substancial a ela, mas acidental e, de fato, é fora da substância da coisa e fora daquilo que é essencial a ela do primeiro modo <...> . De fato, ele não está compreendido sob a essência da coisa, que é a razão indicativa daquilo dela que é sobre ela [ratio indicativa quod eius est de illa], e esse essencial é qualquer operação sua que convenha a ela em razão de sua forma substancial, que é seu ato segundo maximamente, acerca de seu objeto próprio por si e primeiro"115. Agora, portanto, não está mais em jogo a unidade essencial do inteligido e do inteligente como uma única substância ou essência (como era o caso no terceiro modo), mas antes a relação da intelecção com o inteligente tomada como a relação de uma operação segunda essencial com respeito à uma operação primeira. Ou seja, o importante agora é a inerência da operação como um acidente em um sujeito, isto é, como a atualização e aperfeiçoamento permitidos pela operação de intelecção no inteligente, que é um sujeito em potência para ela.

\footnotetext{
${ }^{114}$ ZUCCOLIUS PATAVINUS, V. "Commentaria", In: HENRICUS A GANDAVO. Quodlibeta. Tomus primus. Venetiis: apud Iacobum de Franciscis, 1613, f. 376r: "Iam vero si secundo modo accipiatur essentiale, tunc est proprietas ipsius rei in quarto modo".

${ }^{115}$ Henrique de Gand, Quodl. 15, q. 9, ad 1 (ed. De Wulf-Mansion Centre, vol. 20, p. 56): "Essentiale autem rei secundo modo non est ei substantiale, sed accidentale, et bene est extra substantiam rei et extra illud quod est ei essentiale primo modo $<\ldots>$. Non enim conprehenditur sub essentia rei quae est ratio indicativa quod eius est de illa, et tale essentiale rei est quaecumque operatio eius quae convenit ei ratione suae formae substantialis, quae est actus eius secundus, maxime circa suum proprium per se et primum eius obiectum".
} 
Nesse caso, afirma Henrique, a intelecção de Deus é mais essencial nos intelectos criados do que a intelecção de si, pois a intelecção de Deus aquieta o intelecto - isto é, ela esgota sua potência para a atualização, aperfeiçoando ao máximo tal intelecto criado, fornecendo-lhe todo conhecimento a que este intelecto criado está em potência. Justamente por aquietar o intelecto criado, fornecendo-lhe todo o conhecimento necessário para que atue ao máximo, Deus também pode ser dito o primeiro objeto do intelecto criado. Além disso, Henrique também considera que, no fim das contas, a intelecção de Deus é mais essencial do que aquela de si para os intelectos criados, uma vez que, sendo o objeto primeiro do conhecimento, a essência divina é a razão a partir de qual todos os outros são conhecidos ${ }^{116}$. Assim, tão essencial quanto seja o conhecimento de si no terceiro modo per se, o conhecimento de Deus é mais essencial per se do segundo modo, por ser aquela operação que permite todas as outras operações. Nesse sentido, o conhecimento acerca de Deus é mais essencial, até mesmo, do que o conhecimento de si, pois é a operação que possibilita este último.

Enfim, no que diz respeito aos intelectos criados, a consideração da essencialidade da intelecção de Deus enquanto operação segunda que leva ao ato completo seu substrato essencial (segundo modo per se) se sobrepõe à consideração da unidade entre inteligido e inteligente como uma mesma substância primeira ou essência (terceiro modo per se). Sendo assim, em geral, o conhecimento de Deus é tido por mais essencial do que o conhecimento de si. Não obstante, este último constitui sempre uma exceção à doutrina da intelecção de Henrique ao identificar a coisa conhecida e a espécie expressiva da coisa (embora sob outros aspectos se adeque à narrativa padrão de formação do conhecimento intelectual humano). Mais do que isso, vemos agora que o conhecimento humano de si constitui uma exceção

\footnotetext{
${ }^{116}$ Henrique de Gand, Quodl. 15, q. 9, co. (ed. De Wulf-Mansion Centre, vol. 20, p. 53): "Tale autem in cuius effigie et ratione cetera cognoscuntur et amantur est per se primum et essentiale obiectum intellectus et voluntatis; est etiam essentialior et principalior intellectio e volitio qua tale quid intelligit et vult aliquis quam quaecumque alia qua aliud quodcumque intelligit et vult. Idcirco igitur dico quod simpliciter et absolute principalior atque essentialior angelo et menti humanae intellectio et volitio sunt qua Deum intelligit et vult quam qua intelligit et vult se ipsum". Assim é interpretada tal passagem em CAFFARENA, "Metafísica de la inquietud humana...", 1960, p. 630: “<... Dios es el único objeto capaz de saciar y aquietar plenamente el movimiento de la mente. En conjunto, pues, hay que decir sin duda que es más esencial al hombre la intelección con que entiende a Dios que aquella con que se entiende a sí mismo". Sobre Deus como primum cognitum, cf. cap. 3, nota 89.
} 
não somente [i] por nele espécie e coisa serem completamente o mesmo, mas também [ii] por nele cognoscente e o conhecido serem essencialmente idênticos ${ }^{117}$.

Pois bem, vemos agora que o excepcional no conhecimento humano de si não é a ausência de espécies inteligíveis. Pelo contrário, elas continuam presentes nele. Sua excepcionalidade está nessa sua essencialidade no terceiro modo de ser essencial per se - tal essencialidade não tem correspondente no conhecimento humano de outras criaturas (pelos sentidos) nem no conhecimento humano de Deus (embora este, naquele segundo modo de ser per se essencial, seja ainda mais essencial do que o conhecimento de si). Que no conhecimento de si a coisa em seu ser próprio e a coisa em seu ser na espécie sejam o mesmo é mera decorrência da identidade essencial entre conhecido e cognoscente no conhecimento humano de si - nesse conhecimento, a própria alma é o inteligível por ela expresso.

No entanto, o conhecimento acerca de Deus - em especial, o conhecimento que Dele possui o beato - é igualmente excepcional, ainda que por razões diversas. Com efeito, como vimos, este último também é apontado como uma exceção à necessidade de espécies integíveis nas leituras de Henrique de Gand propostas por Theophil Nys e Effrem Bettoni ${ }^{118}$. Sendo assim, é para esse tema que devemos nos voltar agora.

\subsubsection{O conhecimento do beato}

Na leitura de Quodl. 1, q. 12-13, vimos como é complexa a distinção, no que tange ao intelecto humano, não somente entre o conhecimento de si e o conhecimento de outros, mas também entre o conhecimento da alma unida ao corpo e da alma dele separada. Em qualquer dos casos, estando a alma unida ou separada, ela precisará de espécies distintas das coisas inteligidas para inteligir outros que não ela própria ${ }^{119}$, ao passo que, para inteligir a si mesma, ela não necessita propriamente de uma espécie ou, sendo mais preciso, ela não necessita de espécies outras que não a sua própria essência enquanto objeto. Entretanto, não parece claro como a alma separada pode

\footnotetext{
${ }^{117}$ Ainda que a operação de intelecção (isto é, o conhecimento) do cognoscente sobre si não seja idêntica (per se primo modo) ao próprio cognoscente/conhecido, mas seja antes um acidente nele, como vimos acima, na nota 99.

${ }^{118}$ Cf. acima, respectivamente, notas 74 e 77 .

${ }^{119}$ Cf. nota 92 , acima.
} 
necessitar de espécies para inteligir sem, no entanto, poder abstrair tais espécies a partir dos sentidos - a alma separada, lembremos, está justamente separada do corpo e, portanto, dos sentidos! Para compreendê-lo, será necessário distinguir, no beato, o conhecimento sobre outras criaturas e o conhecimento sobre Deus, sendo este último nosso foco.

Dito isso, vale notar que são poucos os trabalhos voltados para a temática do conhecimento da alma separada como um todo em Henrique de Gand - a bem dizer, a respeito do tema, o único título de que tenho notícia é um artigo de Jerome V. Brown, publicado em $1984^{120}$. Aqui, seguiremos de perto esse texto de Brown, começando precisamente por um interessante trecho de Quodl. 4, q. 7, citado neste artigo, no qual Henrique de Gand se esforça por esclarecer os diferentes estados a que a alma intelectiva está sujeita $^{121}$ :

"cumpre dizer que o intelecto humano $<\ldots>$ possui um estado duplo [duplicem
statum]: $<1>$ um separado do corpo, no qual intelige tal como o anjo ou
inteligência (somente por si mesmo aqueles que são nele por suas essências); e
outro $<2>$ conjugado ao corpo, no qual possui ser segundo dois estados, dos
quais um é natural, outro sobrenatural. Segundo o $<2.1>$ estado natural - no
qual não distingo entre $<2.1 .1>$ o estado de natureza instituída por inocência e
$<2.1 .2>$ de natureza destituída pelo pecado, pois não se diferenciam quanto ao
proposto - , segundo o estado, digo, de natureza comumente tomada, não intelige
senão por abstração dos sensíveis e por ajuda [adminiculum] dos sentidos.
Segundo o $<2.2>$ estado sobrenatural, que é o estado de glória, além do dito
modo de inteligir por ajuda dos sentidos, possui dois outros modos de inteligir ao
modo dos anjos: um no Verbo, outro na própria natureza das coisas sem qualquer
ajuda dos sentidos, pois o corpo glorioso não será para a alma, em nenhum ato
de inteligir, um impedimento, mas antes um incentivo [corpus gloriosum in nullo
actu intelligendi erit animae in nocumentum, sed magis in promotionem]"

\footnotetext{
${ }^{120}$ BROWN, J. V. "The knowledge proper to the separated soul”, 1984, pp. 316-34.

${ }^{121}$ BROWN, J. V. "The knowledge proper to the separated soul", 1984, pp. 322-3.

${ }^{122}$ Henrique de Gand, Quodl. 4, q. 7, ad 1 (ed. De Wulf-Mansion Centre, vol. 8, pp. 51-2): “Ad illud quod arguitur quod 'intellectus cognoscit se sicut et alia', dicendum quod intellectus humanus, de quo procedit obiectio, duplicem habet statum: unum separatum a corpore, in quo intelligit sicut angelus seu intelligentia, non nisi per se ipsum illa quae sunt apud ipsum per eorum essentiam; alium vero coniunctum corpori, in quo habet esse secundum duos status, quorum unus est naturalis, alter supernaturalis. Secundum statum naturalem, in quo non distinguo inter statum naturae institutae per innocentiam et naturae destitutae per peccatum, quia ad propositum non differt, secundum inquam statum naturae communiter acceptae non intelligit nisi abstractione a sensibilibus et per sensuum adminiculum. Secundum statum supernaturalem, qui est status gloriae, praeter dictum modum intelligendi adminiculo sensuum, habet duos alios modos intelligendi ad modum angelorum: unum in Verbo, alterum in propria rerum natura absque omni sensuum adminiculo, quia corpus gloriosum in nullo actu intelligendi erit animae in nocumentum, sed magis in promotionem".
} 
Esse trecho é importante, antes de tudo, por apresentar um resumo dos diversos estados em que a alma se encontra ${ }^{123}$ - para nós, ele será relevante para compreendermos o que significa falar em conhecimento do beato. Há uma distinção básica entre dois estados do homem: [1] o separado do corpo e [2] o conjugado ao corpo. Em uma leitura apressada, poderíamos concluir que somente o estado [1] separado é aquele que diz respeito ao beato; no entanto, há que se lembrar que, após o fim dos tempos, esse mesmo beato retomará seu corpo - não mais o corpo atual, mas o corpo glorioso. Essa asserção, aliás, não é exclusivamente religiosa ou teológica, pois (como vimos no cap. 2) a alma só se completa em seu ser enquanto atualiza um corpo, de maneira que só se pode pensar que ela complete sua finalidade também associada a um corpo (nesse caso, glorioso) enquanto forma deste último. Ou seja, o beato pode ser pensado tanto [1] enquanto alma separada do corpo, como [2] enquanto alma conjugada ao corpo glorioso. Por isso mesmo, após afirmar a distinção entre os estados do homem [1] separado e [2] conjugado ao corpo, Henrique de Gand se concentra em distinguir as diversas facetas contidas neste último. Assim, o homem [2] conjugado ao corpo pode surgir em dois estados: [2.1] no estado natural e [2.2] no estado de glória (isto é, na beatitude, já em posse do corpo glorioso). Por fim, há que distinguir no estado [2.1] natural dois outros: [2.1.1] o estado de natureza instituída (isto é, pré-lapsário) e [2.1.2] o estado de natureza destituída ou de pecado (póslapsário) - este dois últimos estados não são atentamente desenvolvidos nesta passagem.

Pois bem, o estado em que nos encontramos é o [2.1.2] estado de natureza destituída - nele, conhecemos intelectualmente por abstração a partir dos sentidos. Ou seja, este é basicamente o estado cujo modo de conhecimento e de ser viemos

\footnotetext{
${ }^{123}$ Atente-se para o fato de que a noção de status que surge aqui é próxima daquela que vimos em cap. 2, nota 3. Ali em Suma, art. 11, o termo status era utilizado para designar diversos modos de ser assumidos por diversas pessoas da espécie humana na vida presente - esses diversos status eram distinguidos em pares, como 'varão / mulher', 'clérigo / laico', 'velho / jovem' etc. Note-se como essa enumeração possui tanto status tidos então como imutáveis ('varão' ou 'mulher') como status mutáveis ('velho' ou 'jovem'). De qualquer modo, o central naquela noção de status era sua não-essencialidade: não importa qual o estado assumido por essas pessoas na vida presente, todos são homo (isto é, indivíduos da espécie humana). A noção de status que encontramos agora em Quodl. 4, q. 7, de sua parte, diz respeito à manutenção da espécie humana sob diferentes modos de relação entre corpo e alma: não importa que a alma esteja ligada ou não ao corpo, ou que o corpo a que ela está ligada seja glorioso ou manchado pelo pecado, a alma permanece sempre da mesma espécie homo. Assim, podemos dizer que tanto em Suma, art. 11, como em Quodl. 4, q. 7, a noção de status busca explicar diferenciações nas diversas atualizações possíveis de indivíduos de uma mesma espécie. Nesse caso, o status se torna também uma possível instância de generalização entre a espécie especialíssima e os indivíduos sob ela, uma vez que diversos indivíduos podem ser agrupados por possuírem status semelhantes, sem que tal status se torne uma espécie, uma vez que ele é estritamente não-essencial.
} 
estudando até aqui. No entanto, Henrique de Gand afirma que todo o [2.1] estado natural (seja de natureza instituída ou decaída) possui em comum esse conhecimento a partir dos sentidos. Em suas palavras, no [2.1] estado natural o homem "não intelige senão por abstração dos sensíveis e por ajuda dos sentidos [non intelligit nisi abstractione a sensibilibus et per sensuum adminiculum]". Nesse caso, como vimos, é sempre necessária, para a intelecção de uma coisa externa à alma, uma espécie inteligível distinta desta coisa, que seja a coisa enquanto inteligivelmente presente no intelecto (sendo a única exceção o caso do conhecimento de si, onde a essência da alma já é a própria espécie expressiva presente a si mesma). Mas, e quanto aos outros estados do homem, isto é, o [1] separado do corpo e o [2.2] unido ao corpo glorioso?

Ora, no [1] estado separado do corpo, por definição, não há como inteligir por abstração a partir dos sentidos, uma vez que a alma só atualiza suas potências sensitivas enquanto é forma em ato de um corpo. Portanto, na ausência de tal corpo, não há espaço para conhecimento sensitivo e, consequentemente, tampouco para o conhecimento por abstração. Destarte, a alma separada "intelige tal como o anjo ou inteligência (somente por si mesmo aqueles que são nele por suas essências) [in quo intelligit sicut angelus seu intelligentia, non nisi per se ipsum illa quae sunt apud ipsum per eorum essentiam]". Assim, não tendo como tornar presentes as coisas para si por espécies através de uma ação de abstração, o intelecto humano separado só pode conhecer aquilo que já lhe é presente por essência. Já no estado [2.2] de união com o corpo glorioso, o intelecto humano poderá conhecer de três modos: [i] por abstração a partir dos sentidos, uma vez que a alma readquiriu seu corpo; [ii] no próprio Verbo que é Deus; e [iii] a partir das próprias naturezas das coisas fora da alma sem auxílio dos sentidos e, portanto, do corpo. Esse último caso é o mais curioso, muito embora não possamos tratá-lo aqui com a devida atenção. Não obstante, ressaltemos que, para justificar a possibilidade de um tal conhecimento, Henrique de Gand distingue o corpo natural e o corpo glorioso do homem no que diz respeito às suas respectivas relações para com a alma. Assim, enquanto o corpo natural é deletério para o conhecimento intelectual, muitas vezes impedindo sua atualização, o corpo glorioso não é "para a alma, em nenhum ato de inteligir, um impedimento, mas antes um incentivo [corpus gloriosum in nullo actu intelligendi erit animae in nocumentum, sed magis in promotionem]".

Dito isso, o que nos interessará neste item será melhor compreender alguns aspectos da atualização do conhecimento humano no [1] estado separado e no [2.2] 
estado de união ao corpo glorioso. Nosso objetivo com isso será delimitar mais cuidadosamente o papel desempenhado pela espécie inteligível no intelecto humano sob o estado [2.1.2] de natureza destituída pelo pecado - isto é, seu estado atual, que viemos estudando até aqui.

Concentrando-nos agora nestes dois estados do homem que neste item nos interessam principalmente, Henrique de Gand parece ser bem claro ao afirmar que a alma, seja separada ou unida ao corpo glorioso, é capaz de conhecer sem remissão a fantasmas na imaginação e, mais importante para nós, sem espécies. É o que lemos ainda em outro trecho de Quodl. 4, q. 7, destacado por Jerome V. Brown:

\begin{abstract}
"Assim, onde ocorre de a coisa ser, por sua essência, no intelecto ou presente a ele, este pode se determinar muito melhor a inteligi-la por sua presença do que por sua espécie informante $<\ldots>$. Assim, tal como agora a espécie da árvore na alma é uma razão e disposição suficiente que determina o intelecto a inteligir a árvore que é fora $<\mathrm{da}$ alma $>$, assim, se ela fosse a verdadeira essência na árvore no intelecto, determinaria por si mesma suficientemente o intelecto a inteligir ela mesma, na medida em que o intelecto fosse disposto para inteligir aquilo que é nele de outra maneira que não por espécies a partir de fantasmas. Nosso intelecto possuirá tal disposição separado ou, na glorificação, também conjugado"124.
\end{abstract}

Aqui o Doutor Solene retoma um motivo que já encontramos por diversas vezes: a espécie inteligível é necessária como substituto da essência da coisa fora da alma. Em outras palavras, a espécie supre a presença inteligível no intelecto de algo que, em sua própria essência, é ausente da potência intelectiva. Por isso mesmo, ao fim da passagem é possível negar que o intelecto separado ou glorioso dependa de espécies. Ora, se ele pode inteligir as coisas por suas essências, por que precisaria de espécies inteligíveis assim descritas?

Há, porém, que ser cauteloso na leitura deste excerto. Note-se que não se exclui aqui as espécies em geral do conhecimento intelectual do intelecto separado e glorioso, mas antes precisamente as "espécies a partir de fantasmas [species a

\footnotetext{
${ }^{124}$ Henrique de Gand, Quodl. 4, q. 7, co. (ed. De Wulf-Mansion Centre, vol. 8, p. 33): "Ubi ergo contingit quod res per suam essentiam est in intellectu aut praesens ei, multo melius potest eum ad se intelligendum determinare per suam praesentiam quam per suam speciem informantem $<\ldots>$. Sicut ergo nunc species balnei in anima est ratio et dispositio sufficienter determinans intellectum ad intelligendum balneum quod est extra, sic si ipsa esset vera essentia balnei apud intellectum, se ipsa determinaret sufficienter intellectum ad intelligendum seipsam, dum tamen esset intellectus dispositus ad intelligendum quae sunt in ipso aliter quam per species a phantasmatibus; qualem dispositionem habebit intellectus noster separatus vel in glorificatione etiam coniunctus. Sed de intellectu secundum hunc statum non est hic quaestio". Cf. BROWN, J. V. "The knowledge proper to the separated soul", 1984, pp. 322-3.
} 
phantasmatibus]". Como vimos no item anterior, excluir espécies abstraídas a partir dos fantasmas não significa excluir as espécies em geral, pois no conhecimento de si a alma é a espécie de si mesma - isto é, sua própria essência é presente enquanto inteligível ao intelecto que é potência desta própria alma. Para expressar essa tese, como também vimos, Henrique de Gand se vale da noção de 'espécie expressa' ou 'expressiva', que não é senão a própria coisa em seu ser inteligível presente ao intelecto. Ora, ainda que tal espécie expressa provenha, em geral (como veremos adiante) de uma abstração a partir dos sentidos, conhecemos um caso no qual isso não ocorre: o conhecimento de si. Assim, do fato de Henrique afirmar um conhecimento sem espécies no intelecto separado ou glorioso, não decorre uma negação das espécies em geral. Com efeito, quando ele afirma que a intelecção só é possível na ausência de espécies se a coisa estiver presente em sua própria essência, ele parece estar se referindo justamente a um caso semelhante ao do conhecimento de si, no qual a espécie expressiva é a própria essência inteligida. Esse aspecto do excerto indentado é bem destacado por Jerome V. Brown: "Certamente, a ideia de que não há presente na alma separada nem uma 'espécie informante' nem uma 'espécie que surja de fantasmas' é uma ideia consistente com a presença de uma 'espécie expressiva' - uma espécie mencionada nessa questão quodlibetal particular, em um lugar não muito

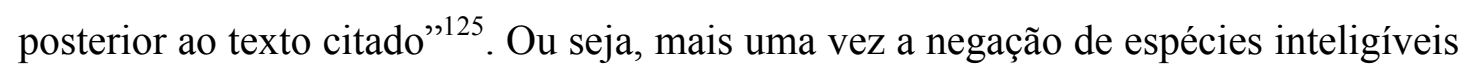
distintas das essências das coisas inteligidas não é prova suficiente de uma negação de toda e qualquer espécies inteligível. No conhecimento de si, havia espaço para uma espécie expressiva idêntica à essência conhecida. Seria esse também o caso do conhecimento do intelecto separado ou glorioso?

Não me parece que haja, na obra de Henrique de Gand, uma resposta direta a essa pergunta - pelo menos, não fui capaz de encontrá-la. Podemos, entretanto, encontrar mais algumas pistas a respeito do tema se avançamos para outro texto igualmente estudado por Jerome V. Brown, a saber, Quodl. 6, q. 8, uma questão na qual Henrique de Gand disserta sobre a recordação que a alma separada possuiria dos

\footnotetext{
${ }^{125}$ BROWN, J. V. "The knowledge proper to the separated soul", 1984, p. 323: "Certainly the idea that there is not present in the separated soul either 'informing species' or 'species arising from phantasms' is an idea consistent with the presence of an 'expressive species' - a species mentioned in this particular quodlibetal question, in a place not long after the quoted text". Essa citação das espécies expressivas a que o comentador se refere ocorre em Quodl. 4, q. 7, co. (ed. De Wulf-Mansion Centre, vol. 8, p. 35).
} 
conhecimento que teve em vida ${ }^{126}$. Com efeito, nessa questão se torna mais claro que a espécie é excluída do conhecimento da alma separada (aqui, não é dispensada atenção ao caso da alma em estado glorioso) estritamente na medida em que se relaciona ao fantasma (o que, como vimos, parece resguardar um espaço para espécies que, não estando atreladas à abstração pelos fantasmas, se identifiquem à essência conhecida, como no caso do conhecimento de si).

Nessa questão, o mestre gandavense afirma "ser preciso propor que algo permanece na alma a partir do ato de inteligir desde os fantasmas, seja isso dito um hábito ou uma espécie [Oportet igitur ponere quod remaneat aliquid in anima ex actu intelligendi a phantasmatibus, sive illud dicatur habitus sive species]" ${ }^{127}$. Para Henrique, todo o problema é saber se, a partir disso que resta na alma depois do ato de inteligir, a alma separada do corpo (e, então, sem recurso ao fantasma de onde abstraíra seu conhecimento) pode produzir em si um ato similar àquele que produzira quando unida ao corpo ${ }^{128}$. Ao desenvolver tal problema, não são oferecidas maiores explicações a respeito das noções de espécie ou hábito enquanto consequências do ato de intelecção na alma ${ }^{129}$ - ambos, parecem ser tomados aqui unicamente como algo

\footnotetext{
${ }^{126}$ Henrique de Gand, Quodl. 6, q. 8, co. (ed. De Wulf-Mansion Centre, vol. 10, p. 77): "Utrum anima separata recordetur eorum quae novit coniuncta". BROWN, J. V. "The knowledge proper to the separated soul", 1984, pp. 323-33.

${ }^{127}$ Henrique de Gand, Quodl. 6, q. 8, co. (ed. De Wulf-Mansion Centre, vol. 10, p. 80). Voltaremos a essa passagem adiante, ao fim do item 6.5.2.

${ }^{128}$ Henrique de Gand, Quodl. 6, q. 8, co. (ed. De Wulf-Mansion Centre, vol. 10, p. 80): "Sed tunc est tota dubitatio, utrum per illud intelligat consimili actu quo prius, ut per actum separatum recordari possit actus coniuncti".

${ }^{129}$ A noção de 'hábito' (habitus) é extremamente complexa na filosofia de Henrique de Gand, uma vez que se reveste de diversos significados tanto na doutrina da intelecção como na ética. Sendo assim, vale a pena buscar uma melhor delimitação dos usos dessa expressão em seu pensamento.

Uma boa definição de habitus da qual podemos partir surge em Quodl. 5, q. 16, co. (ed. 1613, f. 278va): “< $<>$ o hábito, tal como falamos aqui sobre hábito, é uma qualidade gerada no que move a si mesmo por um apetite cognitivo a uma ação, ao ser movido por outro $[<\ldots>$ habitus secundum quod hic de habitu loquimur, est qualitas generata in mouente seipsum per appetitum cognitivum in actionem ex eo, quod est ex alio motum]". Sem dúvida, essa é uma definição complexa; por isso mesmo, Henrique se dedica a explicitá-la por várias linhas. No entanto, já podemos unicamente pela definição precisar algo: o habitus de que falamos aqui é uma espécie da categoria da qualidade. Isso é importante, em primeiro lugar, porque, ao determiná-lo como um acidente, pode-se estabelecer que o hábito é realmente distinto daquilo de que é hábito: "Habitus autem re aliud est ab eo cuius est habitus" - Suma, art. 40, q. 1, ad 1 (ed. De Wulf-Mansion Centre, vol. 28, p. 263). Além disso, é importante que Henrique não somente descreva o habitus como um acidente, mas precise que ele é uma 'qualidade', porque há um outro uso da palavra habitus que designa uma outra categoria que não a qualidade, isto é, aquela categoria que poderíamos traduzir como 'posse' e, em geral (pois ela possui três espécies), diz respeito à relação entre conteúdo e continente - cf. Suma, art. 32, q. 5, co. (ed. De Wulf-Mansion Centre, vol. 27, pp. 104-6).

Ora, a definição de Quodl. 5, q. 16, deixa muito claro que aquele habitus que nos interessa não é a categoria 'posse', mas sim uma espécie da categoria 'qualidade'. Dito isso, vejamos como Henrique explica aquela definição. Para fazê-lo, ele destaca três aspectos dela: [i] 'o que move [movente]', [ii] 'a
} 
si mesmo [seipsum]' e [iii] 'por apetite cognitivo [appetitu cognitivo]'. A importância de destacar [i] o movimento daquilo em que se gera o hábito está no fato de que exige-se atividade daquele em que o hábito é gerado. Assim, algo que somente é movido, mas não move, não gera hábito em se atualizar: "Dico movente, quia ex hoc, quod aliquid movetur solum, et non movet, nunquam in ipso habitus generatur, ut in oculo ad actum videndi" - Quodl. 5, q. 16, co. (ed. 1613, f. 278va). Porém, para que se gere em si um hábito, não basta mover outro, mas é preciso [ii] mover a si mesmo - "Dico movente seipsum, quia ex hoc, quod aliquid non moveat nisi aliud in quod agit, nunquam habitus in ipso movente generatur, ut in igne ex eo, quod calefacti aliud" (op. cit.). Por fim, isso em que se gera o hábito deve mover a si mesmo [iii] por apetite cognitivo sendo movido por outro - "Dico vero movere seipsum appetitu cognitivo ex eo, quod est ex alio motum, quia movens se seipso non moto prius ab alio habitum in se omnino non generat, ut Angelus ex actu suo intelligendi" (f. 278va-b). Em poucas palavras, o hábito é uma qualidade que algo gera em si movido por apetite cognitivo a partir de um movimento proveniente de outro - assim, o hábito é sempre algo gerado e jamais algo natural, pois nesse caso não terá sido gerado por algo que move a si mesmo a partir de um movimento anterior: " $<\ldots$.. habitus non est qualitas nisi eius, quod de se non est naturaliter determinatum ad unum, eo quod habitus generabilis ex actione agentis in agente habet ipsum determinare, ita quod si inesset naturaliter, naturam habitus non haberet, de quo intendimus, qualis est habitus scientialis in Angelis" (f. 278vb). O hábito, portanto, é algo gerado em si mesmo por um agente posto em movimento a partir de outro por apetite cognitivo - isto é, pela potência intelectiva, que possui intelecto e vontade. Essas duas potências podem gerar hábitos em si por suas ações e, em ambos, o hábito será uma qualidade que torna a potência hábil a elicitar ações semelhantes àquelas a partir das quais tais hábitos foram criados - "Est igitur habitus, de quo ad praesens intendimus, qualitas in movente seipsum per appetitum cognitivum motum ab alio, generata in ipso per suam actionem, qua habilis est, ut consimiles actiones eliciat" ( $o p$. cit.).

Ao gerarem hábitos em si, portanto, intelecto e vontade se prontificam a repetirem ações semelhantes àquelas já praticadas. Assim, ao ser movido pela vontade a especular acerca de um objeto específico (como vimos no cap. 3), o intelecto pode gerar em si diversos hábitos especulativos que lhe permitam retomar esse conhecimento posteriormente $-“<\ldots>$ intellectus motus ab aliquo intelligibili appetitu voluntario movetur circa apprehensum ratiocinando, conferendo, dividendo, colligendo, et caeteros actus rationis collativae compositivae, et divisivae exercendo, ex quibus frequentatis generat in se habitum scientialem, per quem prompte, et de facili potest hoc facere. Et secundum hoc secundum diversitatem obiectorum, generat in se diversos habitus speculativos" (op. cit.). Da mesma maneira, a vontade também, ao frequentemente se mover em direção ao bem apreendido, gera em si (e nas potências apetitivas inferiores) o hábito de buscar o bem apreendido - "Similiter voluntas per apprehensionem boni appetitu rationali movetur in ipsum, et ex frequenti motu habitum generat in se, quo expedite, et faciliter potest illud moveri. Et consimilem impressionem facit in vires inferiores appetitivas circa prosecutionem delectabilis, vel tristabilis ex frequenti motu circa obiecta <... " (op. cit.). Ou seja, ao intelecto dizem respeito hábitos científicos acerca de especuláveis, enquanto que à vontade dizem respeito hábitos práticos acerca de operáveis - cf. Suma, art. 59, q. 6, co. (ed. 1642-6, p. 1062a-b, n. 9). Ainda entre esses hábitos especuláveis posteriores à segunda operação do intelecto, podemos enumerar não somente os hábitos científicos, acerca de conclusões de silogismos, mas também os hábitos que dizem respeito aos princípios dos silogismos. Ambos são adquiridos pelo intelecto por suas ações - cf. Suma, art. 1, q. 11, co. (ed. De Wulf-Mansion Centre, vol. 21, p. 181); para outro distinção dos hábitos intelectuais, cf. Suma, art. 37, q. 2, co. (ed. De Wulf-Mansion Centre, vol. 28, pp. 152-3).

Pois bem, está claro que o habitus é algo que uma potência gera em si por sua ação e a torna capaz de repetir uma ação semelhante posteriormente. Porém, nenhum dos exemplos fornecidos até agora disse respeito exatamente ao hábito que nos interessa aqui. Ora, o 'hábito científico' ou 'especulativo' de que se falava em Quodl. 5, q. 16, é intelectual, mas já é proposicional ou, pelo menos, complexo. Já o hábito de que se fala no excerto de Quodl. 6, q. 8, que estamos a ler no corpo do texto, é aquele proveniente ainda do conhecimento incomplexo por meio da espécie inteligível (antes da segunda ou terceira operações do intelecto). Nesse caso, parece que haveria um hábito anterior ao hábito da ciência, hábito anterior este que permanece no intelecto como resto da ação do intelecto agente e do fantasma para o conhecimento do incomplexo. Esse hábito incomplexo, igualmente, parece provir de uma ação do intelecto sobre si mesmo movido por seu objeto (a informação pela espécie inteligível) e permanecer no intelecto, possibilitando a este último atualizar novos atos semelhantes (como a rememoração, no caso de Quodl. 6, q. 8), isto é, acerca do mesmo objeto.

Para encontrarmos referências a esse habitus incomplexo, devemos nos voltar para Quodl. 6, q. 6, co. (ed. De Wulf-Mansion Centre, vol. 10, pp. 67-9), onde lemos que o objeto pode ser presente de duas 
que permanece no intelecto após o ato de intelecção e permite a este último, em

presença do fantasma, retornar a tal ato. Por isso mesmo, como dito, é fortemente

sublinhada aqui a relação entre espécie e fantasma na intelecção humana.

maneiras a uma potência dele receptiva: como disposição passageira ou como qualidade e hábito permanente - "Obiectum autem praesens potest esse dupliciter: uno modo per modum passionis seu dispositionis transeuntis; alio modo per modum passibilis qualitatis et habitus permanentis" (p. 67). Do primeiro modo, o objeto é presente por essência e existência à potência receptiva, tal como o sensível fora com respeito ao sentido particular ou o fantasma com respeito ao intelecto devem ser presentes para que tais potência ajam com respeito a eles - "Primo modo obiectum est praesens potentiae per essentiam et existentiam suam extra ipsam. Et hoc modo est praesens omnibus potentiis materialibus aut a materialibus dependentibus, quemadmodum sensibile extra est praesens sensui particulari et intellectui nostro in phantasmate, ita quod nec sensus noster nec intellectus potest operari sine tali praesentia obiecti sui, et per consequens neque appetitus aut voluntas" (p. 67). Do segundo modo, mais importante para nós nesta nota, o objeto é presente como um hábito ou uma similitude gerada quando o objeto era presente do primeiro modo e conservada na potência a partir de então - "Secundo modo est obiectum praesens potentiae in habitu vel in similitudine conservata in ipsa potentia et adgenerata per actionem obiecti primo modo in ipsa praesentati, quemadmodum similitudines sensibilium sunt in imaginatione, quibus animalia imaginantur obiecta absentia, sub ratione tamen particularis sicut ea sentit sensus" (p. 67). Muito embora o exemplo desse hábito fornecido por Henrique de Gand nesta última passagem diga respeito à imaginação, há hábitos deste tipo também no intelecto e na vontade, os quais dizem respeito a seus respectivos objeto universais: "Habitus vero cognitivi sunt in intellectu et habitus operativi in voluntate, quos necesse est ponere in intellectu et voluntate, et non in aliqua vi sensitiva, quia per se respiciunt intellectus et voluntas suum obiectum sub ratione universalis, omnis autem vis sensitiva sub ratione particularis" (p. 68). Destarte, após a produção do conhecimento pelo intelecto em si mesmo a partir do fantasma, gera-se no mesmo intelecto um hábito que será de um conhecimento incomplexo - diferente, portanto, daquele de que se falava em Quodl. 5, q. 16. Outra diferença está no fato de que, agora em Quodl. 6, q. 6, não há mais referência à necessidade da repetição de um ato para a geração do hábito - após uma única presença em existência (isto é, presença do primeiro modo) do objeto à potência receptiva (no caso do intelecto, pelo fantasma) já é gerado um hábito na potência que agiu acerca de tal objeto.

Mas, em que medida o hábito prontifica o intelecto a repetir sua ação com respeito a algo já conhecido anteriormente? No estado presente, tais hábitos não são suficientes para causar um conhecimento. Eles inclinam para o conhecimento, tornam fácil, deleitável e rápido o conhecimento de determinado objeto, mas somente uma vez que tal objeto esteja presente à potência intelectiva pelo fantasma na imaginação: "Sed huiusmodi habitus non ad idem est in quolibet intellectivo, quoniam in quibusdam est solummodo ad elevandum potentiam et inclinandum eam, ut de facili delectabiliter et expedite inclinetur ad suum obiectum, cum mota fuerit praesentia sui obiecti $<\ldots$. . Primo modo sunt habitus cognitivi in nobis acquisiti admininculo sensuum in parte intellectus nostri conversa ad sensus et phantasmata. Unde, quamquam sunt habitus cognitivi in intellectu, non existente in nobis phantasmate, nihil potest intellectus noster illo habitu cognoscere, neque potest omnino eo uti <...”" (pp. 68-9). No entanto, ainda que necessite da presença do objeto no fantasma, é mais perfeito para o intelecto passar da potência ao ato a partir de um hábito que o incline para tanto. Para Henrique, em geral, é uma perfeição para uma potência passar da potência ao ato a partir de um hábito: " $<\ldots$..> habitus est perfectio potentiae respectu actus egredientis a potentia, et perfectionis simpliciter est in actione, quod egrediatur de potentia per habitum, quia agere ex habitu semper in unoquoque melius est et perfectius quam non agere ex habitu, quia habitus ratione qua habitus est, semper promptitudinem et expeditionem ponit in eliciendo actum $\langle\ldots\rangle$ et hoc in unoquoque agente semper melius est ipsum quam non ipsum <...>" - Suma, art. 37, q. 1, co. (ed. De Wulf-Mansion Centre, vol. 28, pp. 145-6).

Como se vê, portanto, a noção de hábito que nos interessa principalmente no presente trabalho - uma vez que nos voltamos aqui com especial atenção para o conhecimento intelectual incomplexo - é esta última, a saber: uma qualidade gerada no intelecto pelo próprio ato de intelecção que ocorrera em presença do objeto no fantasma. Esse hábito incomplexo, reservado ao intelecto, permitirá a este último, quando novamente em presença daquele fantasma, reatualizar em si mais perfeita e prontamente a intelecção daquele objeto que já fora antes inteligido.

Por fim, note-se que, curiosamente, o adjetivo habitualis é utilizado para nomear a presença do objeto na memória intelectiva como objeto inteligível anterior à qualquer ato de intelecção. Sobre essa derivação de habitus, cf. a nota 203, adiante. 
Destarte, a resposta de Henrique ao problema será afirmar que a alma separada não recorda o que conheceu quando unida ao corpo, justamente porque este conhecimento foi adquirido por meio de fantasmas e a alma separada não pode se valer de tais fantasmas justamente por estar separada. Não importa que reste no intelecto um hábito ou uma espécie a partir do ato de intelecção produzido pela alma quando unida ao corpo, pois tal hábito ou espécie foi produzida pelo todo de corpo e alma, de maneira que somente a alma sozinha não poderá utilizar isso que restou para produzir o ato daquele ser completo que é o composto de alma e corpo:

"Assim, aquilo de que é por si o ato de inteligir, conjugada a alma ao corpo, dele
é também o hábito. Mas, o ato de inteligir, sendo a alma conjugada, é de todo o
homem enquanto inteligente - portanto, também o hábito. Porém, aquilo que é
por si do todo não é da parte senão por acidente, tal como também, pelo
contrário, o que é por si da parte não é do todo senão por acidente. Porém, uma
vez que algo convenha a dois, a um por si, a outro por acidente, é impossível que
aquilo a que isso convém por acidente se utilize $<$ disso $>$ mais perfeitamente do
que aquilo a que isso convém por si. Por isso, uma vez que $<\mathrm{i}>$ o uso do hábito é
mais perfeito ao não somente inclinar por ele para o ato, mas também ao $<$ por
ele $>$ apresentar o objeto pelo qual o ato se aperfeiçoa, do que ao somente inclinar
<por ele $>$ para o ato (tal como o hábito cognitivo do anjo é mais nobre do que o
do homem, como visto acima) e, no entanto, <ii $>$ o homem todo não pode se
utilizar de seu hábito apresentando o objeto a si, mas somente inclinando-se para
o ato acerca do objeto apresentado unicamente no fantasma $<\ldots$,..>, por isso o
homem que possui em si a espécie da coisa ou hábito na alma não inteligirá sem
que apareça o inteligível no fantasma. Portanto, tampouco a alma, a que convém
o hábito por acidente (pois, como à parte) poderia utilizar-se dele apresentando o
objeto, mas somente com o objeto apresentado a si pelo fantasma",

O argumento apresentado neste excerto é um tanto tortuoso, mas pode ser resumido em alguns passos. Primeiramente, Henrique de Gand afirma que algo que convém a um todo por si, só convém à parte por acidente. Ora, o hábito ou espécie da coisa abstraído do fantasma pelo intelecto convém ao homem todo (uma vez que provém tanto do intelecto incorpóreo como do sentido corpóreo). Ora, algo não pode

\footnotetext{
${ }^{130}$ Henrique de Gand, Quodl. 6, q. 8, co. (ed. De Wulf-Mansion Centre, vol. 10, pp. 81-2): "Cuius ergo est per se actus intelligendi, coniuncta anima corpori, eius est et habitus. Sed actus intelligendi, anima coniuncta, est totius hominis ut intelligentis, ergo et habitus. Quod autem est per se totius, non est partis nisi per accidens, sicut et e converso quod est per se partis, non est totius nisi per accidens. Cum autem aliquid convenit duobus, uni per se, alteri per accidens, impossibile est quod perfectius utatur illo id cui convenit per accidens, quam id cui convenit per se. Quare, cum perfectior sit usus habitus non solum per ipsum inclinari ad actum, sed etiam ipsum obiectum praesentare quo perficitur actus, quam ad actum solummodo inclinare, quemadmodum nobilior est habitus angeli cognitivus quam hominis, ut habitum est supra, homo autem totus non potest uti habitu suo, praesentando sibi obiectum sed ipso inclinando solum in actum circa obiectum praesentatum nisi in phantasmate $\langle\ldots\rangle$, sic homo habens in se speciem rei sive habitum in anima non intelliget nisi appareat intelligibile in phantasmate, ergo neque anima cui convenit habitus per accidens quia ut parti multo minus poterit uti eo, praesentando obiectum, sed solummodo obiecto sibi praesentato in phantasmate".
} 
ser utilizado mais perfeitamente por aquilo que o possui por acidente do que por aquilo que o possui por si. No nosso caso, a alma separada não poderá utilizar o hábito ou espécie mais perfeitamente do que a alma conjugada ao corpo. Pois bem, enquanto composto, o homem só se utiliza da espécie ou fantasma para inclinar o intelecto a um determinado objeto, porém, para que haja propriamente um ato de intelecção acerca desse objeto, é preciso que além de tal inclinação haja a apresentação de tal objeto pelo fantasma na imaginação. Ora, se nem o composto todo de corpo e alma pode se utilizar da espécie ou hábito para causar o ato de intelecção (sendo necessário ainda o fantasma), a alma separada (que é somente parte do composto) também não poderá fazê-lo:

"Por isso, uma vez que a <alma $>$ separada não possui fantasmas, ainda que
possua em si um hábito, de nenhum modo pode utilizar-se dele ou elicitar a
partir dele um ato de inteligir similar àquele que elicitara conjugada $<$ ao corpo $>$.
Porém, não ocorre, de outro modo senão deste, de se recordar daquilo que se
soube. Portanto, tal é minha opinião, cumpre dizer que a alma separada não
recorda daquilo que o homem todo conjugado conheceu sem a própria alma tal
como era nele $<$ i.e. no composto $>$ "131.

Temos aqui, portanto, uma descrição do que seria 'recordar' segundo Henrique de Gand: o homem se recorda de algo conhecido quando, inclinado pelo hábito ou espécie que restou em seu intelecto a partir do conhecimento inicial do objeto recordado, tem apresentado a si tal objeto em um fantasma na imaginação e, a partir daí, atualiza seu intelecto acerca de tal objeto. Mais importante para nós é o fato de que a alma separada não pode percorrer todo esse caminho, uma vez que na ausência de fantasmas torna-se incapaz de gerar em si um ato de intelecção sob a inclinação da referida espécie ou hábito. Novamente, é problematizada aqui a possbilidade de um conhecimento por meio de espécies inteligíveis pela alma separada (embora, ao que parece, o problema como descrito aqui não tenha lugar na alma em estado glorioso, uma vez que esta possuirá novamente um corpo). Igualmente, se repete também o fato de que a negação de espécies inteligíveis no conhecimento da alma separada vem atrelada - aqui em Quodl. 6, q. 8, como ocorria em Quodl. 4, q. 7 - à negação de fantasmas na alma separada. Tal associação entre

\footnotetext{
${ }^{131}$ Henrique de Gand, Quodl. 6, q. 8, co. (ed. De Wulf-Mansion Centre, vol. 10, p. 82): “Quare, cum phantasmata non habeat separata, etsi habeat in se habitum, nullo modo potest uti eo aut elicere ex eo actum intelligendi consimilem ei, quem eliciebat coniuncta. Sed aliter, ut dictum est, non contingit recordari eorum quae novit. Igitur, ut opinor, dicendum est quod anima separata non recordatur eorum quae homo totus coniunctus cognovit sine ipsa anima, ut erat in eo".
} 
fantasmas e espécies inteligíveis, entretanto, é suficiente para excluir do conhecimento intelectual da alma separada espécies abstraídas dos fantasmas, mas não quaisquer espécies - por exemplo, não aquelas espécies que se identificam à essência da coisa e dispensam a abstração, como é o caso no conhecimento de si. Com efeito, em seu estudo, Jerome V. Brown conclui que o conhecimento da alma separada, tal como descrito por Henrique de Gand, exclui determinadas espécies inteligíveis, mas não todos os casos de espécie inteligível, pois no caso da alma separada, a "coisa não está presente ao intelecto 'por meio de espécies do fantasma'; ela está presente em sua essência e, nos termos das reflexões tardias de Henrique, isso significa que ela está presente por espécies não conectadas ao fantasma. De fato, como ela poderia estar presente à alma, mesmo em sua essência, sem o benefício de alguma espécie? Estar presente em sua essência diretamente para a alma como objeto conhecido sem qualquer espécie seria ou torná-la inteiramente a alma (nesse caso, o esse essentiae se perderia) ou tornar a alma ela inteiramente (nesse caso, o ser da alma se perderia). A alma separada pode, no entanto < ..>, operar sem fantasma"132.

Como veremos adiante, a espécie expressiva não é tão afastada do fantasma como Jerome V. Brown faz parecer nesse trecho de seu artigo. Pelo contrário, ela é associada por Henrique de Gand também à abstração a partir dos sentidos. Por outro lado, é relevante notar que - mais uma vez, como vimos no estudo do conhecimento de si - é perfeitamente possível para o Doutor Solene pensar em uma espécie expressa não abstraída do fantasma. Esse é o caso daquilo que é por essência presente ao intelecto, como a própria alma humana, espécie de seu próprio conhecimento. Sendo assim, apesar de parecer-me exagerada a distância posta por Brown entre espécie expressiva e fantasma, a posição do comentador me soa acertada: não há nada em Quodl. 4, q. 7, ou Quodl. 6, q. 8, que exclua espécies expressivas do conhecimento da alma separada. O que há aí são negações de que a alma separada conheça por espécies provenientes de fantasmas. É bem verdade, de outra parte, que não encontramos uma afirmação de que haja intelecção por espécies expressas na alma separada ou em

\footnotetext{
${ }^{132}$ BROWN, J. V. "The knowledge proper to the separated soul", 1984, pp. 326-7: "This is what happens in the case of the separated soul $\langle\ldots\rangle$. The thing is not present to the intellect 'through a species from the phantasm'; it is present in its essence and, in terms of Henry's later reflection, this means that is is present through the species not connected with the phantasm. How indeed could it be present to the soul, even in its essence, without the benefit of some species? To be present in its essence directly to the soul as a known object without any species whatsoever would either make it into the soul entirely (in which case the esse essentiae would be lost), or make the soul entirely into it (in which case the being of the soul itself would be lost). The separated soul can however, as we have seen, operate without a phantasm" (grifos no original).
} 
estado glorioso - nada exclui que haja, mas isso não é afirmado. Resta-nos, portanto, continuar o estudo do tema.

Atentemos para a última frase da derradeira citação de Jerome Brown - não obstante a negação, para a alma separada, da recordação por espécies provenientes dos sentidos, não é negado que ela realize sua operação, ainda que sem fantasmas! Com efeito, o próprio Henrique de Gand nos diz que excluir uma recordação propriamente dita da lista de atos possíveis para a alma separada não significa afirmar que ela não possa ter ciência (scire) daquilo que soube quando unida ao corpo: "disso não se segue que não poderá ter ciência daquilo que soube ou operou no corpo, pois nada impede que ela tenha ciência < disso $>$ por outro modo de se ter ciência [secundum alium modum sciendi] < ... . Donde, ainda que a alma tenha sabido algo no corpo, se ela o souber quando separada - e, similarmente, conhecer que ela o soube quando era com o corpo - isso não é 'recordar', mas é 'saber' em algum outro gênero de conhecer aquilo que soube ou agiu antes no corpo"133. Ou seja, excluir que a alma separada possa propriamente recordar o que fez com o corpo não é excluir que ela possa, de alguma maneira (por algum gênero de conhecimento) conhecer o que sabia e fez com seu corpo. Mais do que isso, excluir da alma separada a possibilidade de recordação ou de uso de espécies inteligíveis provenientes de fantasmas não é excluir dela a operação de conhecimento!

Além disso, que a alma separada conheça - isto é, realize sua operação de intelecção (ainda que a seu modo) - é afirmado no mesmo Quodl. 6, q. 8, onde lemos:

\begin{abstract}
"Cumpre propor inteiramente que a alma separada do corpo possui operação intelectual - mesmo daquilo de que nunca soube e de que nada adquiriu no corpo pelo qual pudesse disso possuir notícia. De fato, se a alma não possuísse operação intelectual quando separada do corpo, seria impossível que ela se separasse do corpo: 'de fato, nada é destituído de sua operação própria', segundo Damasceno e o Filósofo; de outra maneira, a <alma $>$ separada é ociosa, devido ao que diz o Filósofo em De anima I: 'Se não há operação própria a ela, é impossível que ela se separe do corpo"”,134.
\end{abstract}

\footnotetext{
${ }^{133}$ Henrique de Gand, Quodl. 6, q. 8, co. (ed. De Wulf-Mansion Centre, vol. 10, pp. 82-3): “Non tamen ex hoc sequitur quod non poterit scire ea quae novit in corpore aut operata est, quia nihil impedit quin secundum alium modum sciendi illa sciat, quemadmodum animae parvulorum separatae scire possunt quod aliquando erant in corpore, quae tamen hoc numquam noverunt cum erant in corpore. Unde, etsi aliqua novit anima in corpore, si noscat illa cum est separata, et similiter cognoscat se illa novisse cum erat cum corpore, hoc non est recordari, sed est nosse alio genere cognoscendi illud quod novit aut egit prius in corpore".

${ }^{134}$ Henrique de Gand, Quodl. 6, q. 8, co. (ed. De Wulf-Mansion Centre, vol. 10, pp. 78-9): "Quod anima separata a corpore intellectualem habet operationem, omnino ponendum, et cum hoc etiam de illis quae numquam novit, et de quibus nihil acquisivit in corpore per quod posset haberi illorum notitia. Nisi enim anima haberet separata a corpore intellectualem operationem, impossibile esset eam
} 
Recorre-se aqui ao princípio de que nada ocorre em vão - se separada do corpo a alma não pudesse realizar sua operação própria, que é a atualização da potência intelectiva, ela não poderia ser em tal estado. Por isso mesmo, o fato de ela poder ser separada já prova que, enquanto separada, ela pode realizar uma operação de intelecção, mesmo que sem recurso a espécies abstraídas de fantasmas, como vimos. Esse argumento, porém, claramente pressupõe que as almas podem ser separadas. Por que se pode pressupor isso?

A afirmação da possibilidade desse estado da alma - isto é, dela ser separadamente - não é artigo de fé ou conclusão teológica, mas antes uma tese filosoficamente defensável pelo que já estudamos aqui. Com efeito, vimos no cap. 2 que a alma possui uma parte separável, a saber, sua parte intelectiva. Além disso, notamos no cap. 3 como o conhecimento do fim último como verdade suprema e o amor pelo fim último como bem supremo são atos necessários para o aperfeiçoamento máximo da alma. Sem dúvida, podemos ter algum conhecimento abstrativo nesta vida acerca desse fim último (e, portanto, podemos amá-lo já nesta vida). Entretanto, tal conhecimento (e, consequentemente, tal amor) é muito mais perfeito na presença intelectual desse fim na própria alma, o que só ocorre quando a alma se separa deste corpo característico desta vida, isto é, deste corpo que impede a completa atualização do intelecto ao ligá-lo estritamente aos sentidos. Em poucas palavras, a existência da alma enquanto separada do corpo é uma etapa passageira (visto que ela deverá receber eventualmente um corpo glorioso), mas necessária de sua atualização completa e, portanto, de seu máximo aperfeiçoamento.

\footnotetext{
separari a corpore: 'nihil enim est destitutum propria operatione', secundum Damascenum et Philosophum aliter enim separata est otiosa, propter quod dicit Philosophus in $\mathrm{I}^{\circ} \mathrm{De}$ anima, 'Si nulla est ei operatio propria, impossibile est eam a corpore separari'”. Ainda no que diz respeito à possibilidade de a alma separada adquirir conhecimentos novos, Henrique de Gand introduz o exemplo da alma separada dos pequenos (parvuli), isto é, daqueles que faleceram antes de poderem, enquanto composto, utilizar o próprio intelecto. Mesmo estes, que jamais inteligiram algo enquanto compostos de corpo e alma, poderão obter conhecimentos enquanto alma separada (e, pressupõe-se, enquanto alma em estado glorioso): "Quod etiam intelligat non intellecta in corpore neque per acquisita in corpore, patet ex animabus parvulorum, quae omnino nihil intellexerunt, nec idcirco aliquid per operationem intellectualem acquisierunt" - Quodl. 6, q. 8, co. (ed. De Wulf-Mansion Centre, vol. 10, p. 79). Sobre as almas dos parvuli (em um trecho que já citamos, acima, na nota anterior), Henrique adiciona que estas, quando separadas, podem até mesmo ter ciência de que foram em um corpo, muito embora não soubessem, quando unidas aos respectivos corpos, que estavam a eles unidas: " $<\ldots>$ animae parvulorum separatae scire possunt quod aliquando erant in corpore, quae tamen hoc numquam noverunt cum erant in corpore" - Quodl. 6, q. 8, co. (ed. De Wulf-Mansion Centre, vol. 10, pp. 82-3).
} 
Mas, se esse é o caso, começa a ficar claro que o conhecimento típico da alma separada é aquele que diz respeito ao fim último - isto é, à essência divina. Com efeito, se Henrique de Gand não se dedica mais aprofundadamente à discussão acerca da necessidade ou não de espécies inteligíveis para o conhecimento da alma separada ou em estado glorioso acerca de outras criaturas ${ }^{135}$, ele certamente se volta com atenção para o problema do conhecimento de Deus pela alma beata. Nessa âmbito, poderemos recolher ainda mais elementos para nossa discussão acerca do papel da espécie inteligível no processo de conhecimento.

Uma questão em que vemos tal tema ser desenvolvido é Quodl. 3, q. 1, também estudada por Jerome V. Brown, onde é perguntado precisamente "se, a saber, na vida beata Deus será visto pelo intelecto criado por alguma espécie média [utrum videlicet ab intellectu creato in vita beata videbitur Deus per aliquam speciem mediam]"136. A resposta a essa questão começa por distinguir dois casos de conhecimento acerca de Deus - por um lado, é plenamente possível conhecer a essência divina a partir de espécies de criaturas (como fazemos nesta vida), porém a

\footnotetext{
${ }^{135}$ Uma questão na qual o conhecimento de intelectos separados também é discutida atentamente é Quodl. 5, q. 26 (ed. 1613, ff. 307r-308v). No entanto, Henrique de Gand aborda aí principalmente o caso do intelecto angélico, sendo, a meu ver, extremamente difícil distinguir que elementos de sua resposta seriam válidos igualmente para intelectos humanos separados. Aliás, o próprio Vital Zuccoli nota, em seu comentário a essa questão, a necessidade de lê-se à luz de Quodl. 5, q. 14 (ao qual voltaremos no item 6.5.1), onde distinguem-se claramente o funcionamento do intelecto angélico e aquele do intelecto humano: "Not. autem, differentiam esse inter Angelicum intellectum, et humanum. Quod ut dictum est in quaestione de speciebus intelligibilibus, paulo superius in hoc Quol. in Angelico intellectu sunt habitus scientiales, per quos sunt omnia illi praesentia in ratione obiecti. Intellectus autem noster est tanquam tabula rasa, in qua nihil depictum est. Et nihil habet in ratione obiecti, nisi quod ministratur mediante ipso phantasmate" - ZUCCOLIUS PATAVINUS, V. "Commentaria", In: HENRICUS A GANDAVO. Quodlibeta. Tomus primus. Venetiis: apud Iacobum de Franciscis, 1613, f. 308v. Como se vê, entretanto, essa observação de Zuccoli diz respeito apenas a uma distinção entre o intelecto angélico e a alma humana unida ao corpo, abstraindo suas espécies dos fantasmas. Ou seja, nem mesmo o comentador seiscentista nos dá uma base sólida para distinguir o caso do intelecto angélico e o caso do intelecto humano separado em Quodl. 5, q. 26. Por essas dificuldades, prefiro não utilizar tal questão como base para este nosso estudo a respeito dos atos de conhecimento da alma humana em estado separado.

${ }^{136}$ Henrique de Gand, Quodl. 3, q. 1 (ed. 1613, f. 77). Cf. BROWN, J. V. "The knowledge proper to the separated soul", 1984, pp. 318-20; EMERY Jr., K. "The Image of God Deep in the Mind: The Continuity of Cogntion according to Henry of Ghent". In: AERTSEN, J. A., EMERY Jr., K., SPEER, A. (Hrsg.). Nach der Verurteilung von 1277. Philosophie und Theologie an der Unversität von Paris in letzten Viertel des 13. Jahrhunderts. Studien und Texte. Berlin - New York: De Gruyter, 2001, pp. 59124 (esp. pp. 78-9). GOEHRING, Henry of Ghent on Cognition ..., 2006, pp. 122-4; FIORENTINO, "Species nei secoli XIII-XIV", 2007, pp. 91-2; e GOEHRING, "Henry of Ghent's Use of Aristotle's De anima...", 2013, pp. 70-3. Sobre demais aspectos da noção de visão beatífica desenvolvida por Henrique de Gand, cf. TROTTMANN, C. La vision beatifique des disputes..., 1995, p. 351; TROTTMANN, "Henri de Gand, source de la dispute...", 1996, pp. 322-8; CROSS, R. "Incarnation, Indwelling, and the Vision of God: Henry of Ghent and Some Franciscans" Franciscan Studies 57 (1999), pp. 79-130; EMERY Jr., "The Image of God Deep in the Mind...", 2001, pp. 76-84. Cf. tb. DONDAINE, H. F. 'L'objet et le 'medium' de la visium béatifique chez les théologiens du XIII siècle”. Recherches de théologie ancienne et médiévale 19 (1952), pp. 60-130.
} 
visão da "divina essência nua como objeto de visão [nuda divina essentia ut obiectum visionis]" é impossível por qualquer espécie, mesmo porque qualquer espécie criada

por Deus em um intelecto já será, por definição, uma criatura:

\begin{abstract}
“<...> é impossível que uma espécie criada represente uma similitude da essência divina, pela qual <esta $>$ imediatamente e segundo a essência possa ser vista enquanto objeto de visão. De fato, é bem verdade que por uma espécie de criatura pode-se [convenit] ver que a essência divina é e que ela é Deus, a saber, sábio, bom e outros desse modo - e isso do modo pelo qual a causa é conhecida pelo efeito como pelo meio silogístico. Também é bem verdade que em uma espécie de criatura a essência divina seja vista como em um objeto e em um espelho, como em certa efígie e similitude sua alheia [peregrina] e não adequada. Porém, que a essência divina nua seja vista como objeto de visão por uma espécie criada por ele <i.e. pelo objeto que é a essência>, quanto quer que $<$ he $>$ seja similar (informando o olho do vidente ao modo pelo qual o artífice vê a arca pela espécie da arca que informa a mente do artífice) isso é totalmente impossível, pois tal espécie, que é a razão de ver outro perfeitamente, deve representar a efígie daquilo por adequação, ao modo pelo qual a espécie de um homem no espelho representa a efígie dele. No entanto, a espécie de qualquer criatura representa mais a efígie de outra criatura (como a espécie do asno a efígie do homem) do que qualquer espécie criada < representa $>$ a efígie de Deus, pois qualquer espécie criada dista infinitamente da efígie da essência divina, uma vez que qualquer espécie criada é de ser finito e determinado, enquanto a efígie da essência divina é de $<$ ser $>$ infinito e indeterminado, pois não é senão $o$ próprio ser. Porém, a espécie de qualquer criatura dista finitamente da efígie de outra criatura. Mas, ocorre que pela espécie de uma criatura não se pode ver a essência de outra criatura (como a essência do homem pela espécie do asno). Portanto, muito menos se pode ver por uma espécie criada a essência nua de Deus"137.
\end{abstract}

\footnotetext{
${ }^{137}$ Henrique de Gand, Quodl. 3, q. 1, co. (ed. 1613, f. 77va-b): “< ..> impossibile est speciem aliquam creatam divinae essentiae similitudinem repraesentare, qua immediate, et secundum essentiam tanquam obiectum visionis videri possit, bene enim verum est quod per speciem creaturae convenit videre divinam essentiam quia sit et quia talis sit Deus, scilicet, sapiens, et bonus, et huiusmodi, et hoc ad modum quo causa cognoscitur per effectum, ut per medium syllogisticum. Bene etiam verum est, quod in specie creaturae, ut in obiecto, et in speculo videatur divina essentia ut in quadam effigie, et similitudine sua peregrina, et non adaequata. Quod tamen videatur nuda divina essentia ut obiectum visionis per speciem aliquam ab ipso creatam quantumcunque ei similem informantem oculum videntis ad modum, quo per speciem arcae informantem mentem artificis artifex videt arcam, hoc omnino est impossile, quoniam species talis, quae est ratio videndi aliud perfecte, debet effigiem eius repraesentare per adaequationem, ad modum quo species hominis in speculo effigiem eius repraesentat. Nunc autem species cuiuslibet creaturae magis repraesentat effigiem alterius creaturae, ut species asini effigiem hominis, quam species quaecunque creata effigiem Dei, eo quo in infinitum distat species quaecunque creata a divinae essentiae effigie, cum quaelibet species creata sit finiti et determinati esse, divinae vero essentiae effigies sit infiniti et indeterminati, quia non est nisi ipsum esse. Cuiuslibet autem creaturae unius species finite distat ab effigie alterius creaturae. Sed ita est, quod per speciem unius creaturae alterius creaturae essentia videri non potest, ut essentia hominis per speciem asini; multo ergo minus per aliqam speciem creatam videri potest nuda essentia Dei”.

Henrique de Gand retoma essa mesma tese no seguinte trecho da Suma (onde ele, também, remete a Quodl. 3, q. 1, que estamos lendo): "Ad tertium, quod 'Deus non est intelligibile nisi specie aliqua sui, qua informat intellectum, et ita non nisi per aliud, et non se ipso'. Quod est multorum et magnorum opinio, cui tamen alii multi et magni contrariantur, qui ponunt quod Deus nulla specie sui informat intellectum, qua intelligatur, quia ad repraesentandum increatam essentiam sicut est, qualiter eum videbunt sancti, nulla sufficit creatura, non solum quia est differens a Deo in natura et essentia, sed quia deficiens a repraesentabilitatis ratione. Ita quod non solum quaelibet creatura convenit plus cum
} 
Há nessa passagem um complexo jogo entre três significados de 'visão' ou 'ver': [i] a visão enquanto ato do sentido externo, [ii] a visão enquanto ato de intelecção e, finalmente, [iii] a visão enquanto ato beatífico. Com efeito, muito do vocabulário e dos argumentos que encontramos aqui são próximos àqueles que vimos quando estudamos os sentidos nos capítulos 4 e 5 do presente trabalho. E, não obstante a loquacidade do excerto destacado, o argumento apresentado aí é razoavelmente simples. Qualquer espécie inteligível será uma criatura - mesmo uma espécie que Deus coloque no intelecto humano para o conhecimento da essência divina será algo criado por Deus. Ora, uma espécie criada dista finitamente de outra espécie criada (por definição, uma vez que toda criatura é finita). Ainda assim, não podemos pela espécie de uma criatura conhecer outra (por exemplo, não podemos pela espécie inteligível de 'homem' conhecer 'cão'). Pois bem, uma vez que a distância entre uma criatura e Deus não é apenas finita, mas é infinita, qualquer espécie inteligível distará infinitamente de Deus, de maneira que nenhuma espécie inteligível será razão suficiente para a visão da própria essência divina nua em sua presença beatificante. Daí que a visão da essência divina não possa ser por espécies inteligíveis.

O interessante desse argumento é que vemos, pela primeira vez, a espécie inteligível distinta do objeto conhecido ser descartada não por superfluidade ou insuficiência, mas por uma incapacidade intrínseca de cumprir seu papel. No caso do conhecimento de si, uma espécie distinta da própria essência era supérflua pelo fato de a essência da alma já estar presente a si mesma enquanto inteligível. No caso da recordação pela alma separada dos seus feitos e conhecimentos quando unida ao corpo, a espécie ou hábito era insuficiente para produzir o conhecimento sem a

qualibet alia creatura in natura et essentia, quam cum Deo, sed etiam in repraesentabilitatis ratione, ut quaecumque creata species plus est repraesentativa cuiuslibet alterius creaturae, et immutativa intellectus ad intelligendum quamcumque creaturam, quam ad intelligendum Deum. Quod, quantum mihi videtur, bene et diffuse exposui in quadam quaestione de Quolibet super hoc mota" - Suma, art. 33, q. 2, ad 3 (ed. De Wulf-Mansion Centre, vol. 27, pp. 141-2). Sobre esse trecho, cf. NYS, De werking van het menselijk verstand..., 1949, p. 67.

Outra razão para a impossibilidade de que haja espécie ou verbo criados no intelecto acerca de Deus é que tais espécies e verbos, dizendo respeito à intelecção, são necessariamente universais, enquanto que a deidade é estritamente singular. Em outras palavras, não se pode conceber (intelectualmente) uma forma inteligível acerca de Deus, pois este é singular e tal forma é necessariamente universal: "Nec potest aliqua talis forma concipi de divina natura. Primo, quia talis forma non est nisi ratio universalis in anima, ut dicit Commentator super III ${ }^{\mathrm{um}}$ De anima, quae habet determinari per particularia; deitas autem rationem universalis habere non potest $<\ldots>$ " - Quodl. 4, q. 8, co. (ed. De Wulf-Mansion Centre, vol. 8, p. 55). 
presença do objeto no fantasma. Agora, no caso da visão beatífica, uma espécie distinta do objeto conhecido se mostra intrinsecamente incapaz de produzir conhecimento devido a seu caráter necessariamente criado - de fato, tudo o que não é Deus é criado por ele. Mas, essa recusa de uma espécie inteligível criada na visão beatífica exclui igualmente uma consideração da essência divina como espécie na medida em que ela se põe como algo presente no intelecto? Lembremos, com efeito, que no caso do conhecimento de si, a própria essência da alma, enquanto inteligivelmente presente a si mesma, era tomada como espécie expressiva. Seria esse o caso também na visão beatífica? Vejamos como o Doutor Solene desenvolve sua questão.

Finda a parte negativa do discurso, faz-se necessário mostrar como, sem uma espécie criada, a essência divina se faz presente ao intelecto beato enquanto objeto de conhecimento. Seu primeiro passo nessa direção é distinguir [i] o caso do conhecimento da essência divina pelo beato e [ii] o caso de todo outro conhecimento acerca de criaturas: "Creio, portanto, ser necessário propor que o intelecto beato não vê a essência divina por uma espécie ou em um verbo dele formado, tal como ocorre [convenit] em toda operação intelectual que se faz por espécies acerca das criaturas <... ${ }^{\text {138 }}$. Tão lacônica quanto seja, essa passagem é fundamental por mostrar que, para Henrique de Gand, aquela incapacidade intrínseca da espécie de cumprir seu papel no conhecimento do beato diz respeito exclusivamente à intelecção que o beato possui de Deus, mas não vale para o conhecimento que o beato possui acerca das criaturas. De fato, toda outra operação intelectual, que é necessariamente acerca de criaturas (uma vez que o único objeto não criado é Deus), se faz por espécies inteligíveis (aliás, como lembrávamos, mesmo nosso conhecimento sobre a essência divina na vida presente é a partir de espécies). Isso parece confirmar nossas suspeitas, no estudo de Quodl. 4, q. 7, e Quodl. 6, q. 8, de que a exclusão de espécies provenientes de fantasmas no conhecimento da alma separada não equivalia à exclusão de espécies em geral (mais precisamente, das espécies expressivas) desse conhecimento. Além disso, a afirmação de que todo conhecimento acerca de criaturas

\footnotetext{
${ }^{138}$ Henrique de Gand, Quodl. 3, q. 1, co. (ed. 1613, f. 78ra): "Credo igitur esse necessarium ponere, quod intellectus beatus divinam videt essentiam, non per speciem, nec in verbo aliquo de ipso informato, sicut convenit in omni operatione intellectuali, quae fit per speciem circa criaturas $<\ldots>$.. Que não haja um 'verbo' na visão beatífica de Deus é reiterado em Quodl. 4, q. 8, co. (ed. De WulfMansion Centre, vol. 8, p. 66): "Cum ergo <... Deus cum videtur visione beata, videtur per praesentiam suae essentiae, in tali visione sive intellectu de ipso nullo modo concipitur verbum quod proprie dicitur 'verbum', scilicet notitia aliqua expressiva eius alia ab ipso $<\ldots>$ ”.
} 
ocorre por espécies (esteja a alma unida ao corpo ou separada) vai ao encontro do que lemos acima, em Quodl. 1, q. 12-13, onde se diz que qualquer um (em particular, a alma separada) que não contenha em si as formas das coisas deve conhecer os outros pelas suas respectivas espécies ${ }^{139}$. Ora, estabelecida a necessidade de espécies no conhecimento acerca de criaturas, o caso da visão beantificante da essência divina é apresentado como o contraposto, isto é, como um caso de conhecimento no qual não há espécies, pelas razões que já estudamos.

Pois bem, para explicar melhor como se torna possível essa visão da essência divina sem espécies, Henrique de Gand propõe uma comparação entre a visão sensitiva do visível mais excelente (a luz solar no próprio Sol) e a visão espiritual (visio spiritualis) do inteligível mais excelente (a essência divina nua). Para tanto, ele parte daqueles que seriam os três requisitos no que diz respeito à visão sensitiva: “<..> para a visão sensitiva acerca do objeto sumamente excelente em visibilidade (como é o esplendor do Sol no círculo <solar $>$ ) são requeridos três, a saber: $<1>$ a sanidade e força [sanitas et fortitudo] da visão; $<2>$ que seja tornado em ato [fiat in $a c t u$ ] pelo próprio visível; e $<3>$ que tenha o visível presente a si" ${ }^{\prime 140}$.

Se comparamos esses três requisitos que encontramos em Quodl. 3, q. 1, àqueles outros três que líamos em Suma, art. 1, q. $3^{141}$, notamos um completo afastamento entre os dois textos. Fundamental para nós é o fato de que, aqui em Quodl. 3, q. 1, não há qualquer menção de uma espécie sensível necessária para a visão. Essa discrepância, provavelmente, está relacionada ao fato de que, neste último texto, não se fala da visão sensitiva em geral, mas da visão sensitiva da própria fonte da luz sensível (luz que, aliás, era um dos requisitos constantes da referida passagem de Suma, art. 1, q. 3). Vimos no cap. 2 o quão complexa pode ser a relação entre species e lux ou lumen, mas agora a referência a uma visão direta da fonte da luz sensível parece permitir uma consideração da visão sensível sem referência imediata à espécie sensível (mesmo porque sem referência imediata à cor vista sob a luz).

Ora, uma vez que Henrique de Gand busca mostrar como ocorre a visão espiritual da essência divina sem espécies inteligíveis, é importante para ele a

\footnotetext{
${ }^{139}$ Cf., acima, nota 92.

${ }^{140}$ Henrique de Gand, Quodl. 3, q. 1, co. (ed. 1613, f. 78ra): "Sciendum igitur, quod sicut ad visionem sensualem circa obiectum summe excellens in visibilitate, cuiusmodi est splendor Solis in rota, tria requiruntur, scilicet visus sanitas et fortitudo, et quod fiat in actu per ipsum visibile, et quod habeat visibile sibi praesens". Esse trecho continua na passagem apresentada a seguir, na nota 142.

${ }^{141}$ Cf. cap. 4 , nota 6.
} 
possibilidade de um discurso acerca da visão sensível que, igualmente, prescinda de espécies. Que se possa falar em visão sensível sem referência imediata a espécies sensíveis somente no caso da relação entre a visão sensível e o esplendor do Sol não é problema, uma vez que também, ao que parece, só se pode falar de conhecimento inteligível sem espécie no caso da visão da essência de Deus. Enfim, com essa comparação entre visão sensível e visão espiritual, Henrique de Gand parece querer mostrar que em casos limites - isto é, no caso do conhecimento de seus sumos cognoscíveis - tanto a visão sensível como a visão espiritual podem ser descritas sem referências a espécies. Por outro lado, a dificuldade dessa afirmação é claramente apontada, a meu ver, pelo fato de o Doutor Solene pouco se dedicar ao lado sensível da comparação, preferindo simplesmente mostrar como aqueles requisitos da visão sensível igualmente podem ser apontados na visão espiritual do sumamente visível: “Assim, nesta visão espiritual acerca do objeto sumamente excelente em visibilidade, como é a essência divina, são requeridos três" ${ }^{142}$.

Como mencionado, o primeiro requisito da visão espiritual do sumo visível (tal como era o caso da visão sensível do sumo visível sensível) é a sanidade e a força da visão:

"O primeiro, que o olho da visão do intelecto criado seja são e forte, é feito [fit]
pelo lume da glória, pelo qual é elevado, disposto e fortificado, tal que se torne
[fiat] idôneo para ver aquele visível, não <como aquilo> pelo que vê, tal qual
meio e espécie de ver [non quo videt tanquam medio et specie videndi]. Pois
bem, a disposição daquele lume não manifesta o objeto, assim como somente a
luz não mostra as cores, mas somente torna apto o sujeito [aptat subiectum]. De
fato, nada $\mathrm{O}<$ sc. Deus $>$ manifesta naturalmente, mas somente ele se manifesta
voluntariamente $<\ldots$-.."

Nesse ponto, não há ainda propriamente um conhecimento beatífico, mas uma preparação necessária para tal conhecimento. Assim, Deus enquanto lume fortifica e sanifica o olho da mente para ver um objeto tão elevado quanto a própria essência divina. Da mesma maneira, é necessária a luz presente no meio e no olho para que,

\footnotetext{
${ }^{142}$ Henrique de Gand, Quodl. 3, q. 1, co. (ed. 1613, f. 78ra): "Sic in ista visione spirituali circa obiectum summe excellens in visibilitate, cuiusmodi est divina essentia, tria requirituntur".

${ }^{143}$ Henrique de Gand, Quodl. 3, q. 1, co. (ed. 1613, f. 78ra): "Primum scilicet oculus visus intellectus creati, quod sit sanus et fortis, quod fit per lumen gloriae, quo elevatur et disponitur, et fortificatur, ut idoneus fiat ad videndum illud visibile, non quo videt tanquam medio et specie videndi. Etenim illius luminis dispositio non manifestat obiectum sicut lux sola non ostendit colores, sed solum aptat subiectum. Nihil enim ipsum manifestat naturaliter, sed solummodo ipse seipsum manifestat voluntarie <...>. Sobre a distinção entre lux e lumen, cf. cap. 4, nota 39.
} 
em seguida, haja a visão da cor (como notamos no cap. 4); além disso, vimos no item 6.2 que, para qualquer intelecção, é necessário que o intelecto agente, pela sua luz, torne o intelecto possível apto para receber a intelecção em ato. Até esse ponto, portanto, o caso da visão beatífica não é muito distinto das outras ocorrências de conhecimento sensitivo e intelectual - em todos esses evento, é necessária uma luz que torne a potência cognitiva apta a receber o conhecimento sobre o objeto. Sendo assim, o que caracteriza a visão beatífica não é a necessidade de uma luz, mas sim o fato de que essa luz é divina ou, melhor, ela é a própria essência divina enquanto lume divino. Sob tal luz, o intelecto humano se torna apto à visão da essência de Deus.

Porém, assim como no caso do conhecimento sensível ou intelectivo acerca de objetos criados, também na visão beatífica a luz não é suficiente para a produção do conhecimento em ato. Sem tal iluminação o conhecimento não ocorre, mas ela não pode produzir o ato de conhecimento propriamente dito. Por isso, é necessário que um objeto aja na potência cognoscitiva (sentido ou intelecto) tornada apta pela luz (sensitiva, intelectual ou divina). No caso do conhecimento acerca de criaturas, o objeto será distinto da fonte da luz (mesmo no caso do conhecimento de si, a essência da alma é intencionalmente distinta do intelecto que a conhece). Porém, no que tange à visão beatífica, objeto e fonte da luz de identificam, pois ambos são a mesma essência divina. Por isso, para a visão beatífica, é necessário não somente que Deus ilumine o intelecto tornando-o apto para tal conhecimento, mas também que se introduza no cognoscente, unindo-se a ele:

"Já o segundo é que se faça em ato [fiat in actu] por tal visível e se faça, de certo
modo, como que um único [fiat quasi unum] a partir do vidente e do visto.
Donde, uma vez que <isso $>$ não se pode fazer por alguma espécie de tal visível
no intelecto, pela qual seja informado, como dito (ao modo pelo qual se faz [fit]
a partir da espécie sensível e do sentido e a partir da espécie inteligível das coisas
coisas e o intelecto), é preciso que isso se faça [fiat] pela essência daquele
visível, tal que se faça [fiat] essencialmente no intelecto tal qual razão de ver,
constituindo, de certo modo, um único [unum], tal que se faça [ut fiat] por aquele
ato o intelecto [intellectus]. Não digo por informação em ser natural (tal como se
faz um único [fit unum] a partir do intelecto e da espécie inteligível nele - de
fato, nenhuma forma natural pode ser a essência divina, como foi declarado em
outro lugar), mas pela presença da própria essência, que é mais íntima ao olho da
mente por aquela presença (unicamente pela qual se verte [illabitur] na mente)
do que poderia ser qualquer espécie informante $<\ldots>$ "...

${ }^{144}$ Henrique de Gand, Quodl. 3, q. 1, co. (ed. 1613, f. 78ra-b): "Secundo vero, quod fiat in actu per tale visibile, et fiat quasi unum ex vidente et viso quodammodo. Unde cum hoc non possit fieri per aliquam speciem talis visibilis apud intellectum, qua informetur, ut dictum est, ad modum, quo fit ex specie sensibilis et sensu, et ex specie intelligibilis aliarum rerum et intellectu, oportet quod hoc fiat per huius visibilis essentiam, ut essentialiter fiat in intellectu, tanquam ratio videndi, et unum quodammodo 
Lembremo-nos que, também no caso do conhecimento intelectual de criaturas, faz-se um único da espécie inteligível e do intelecto possível sob a luz do intelecto agente, sem que haja ainda o conhecimento propriamente dito - isto é, o conceito. Aqui na visão beatífica, o caso parece ser o mesmo: sob a luz da essência divina, esta mesma essência se verte (illabitur) na mente humana, unificando-se a esta última. Essa união é muito mais íntima do que aquela ocasionada por uma espécie inteligível. Com efeito, não há aqui uma espécie da essência divina (pois, como vimos, uma tal espécie é, por definição, impossível), mas a própria essência divina se unifica à mente humana.

Nesse ponto, entretanto, não há ainda propriamente uma visão beatífica, pois, como também era o caso no conhecimento das criaturas, a união entre cognoscente e cognoscível é ainda um último passo antes da atualização do conhecimento propriamente dito. A diferença é que, no caso da visão beatífica, o intelecto humano não age para a geração de um conceito, mas antes o objeto - a essência divina - é que voluntariamente se mostra para o cognoscente beato:

“Já o terceiro que se requer para tal visão intelectual é que tal visível seja presente não somente como razão de ver [ratio videndi], mas como objeto visto e se mostre voluntariamente, como foi dito. De fato, não é por ser presente como razão de ver que ele se mostra como objeto visto - isto, ele é decerto por sua essência, não por algum verbo concebido sobre ele no qual seja visto, como foi dito. Muito embora isso ocorra [conveniat] na visão em que $\mathrm{O}$ inteligimos pelas espécies de criatura ou na espécie da criatura $<\ldots$. ..145.

Nesse momento - ou seja, quando a essência divina [i] ilumina a mente, [ii] se unifica a esta e [iii] a ela se mostra -, temos em ato a visão beatífica. As etapas da produção desse conhecimento não são distintas de outros casos de conhecimento. A grande diferença parece ser que, na visão beatífica, o intelecto humano não age para o

\footnotetext{
constituat cum intellectu, ut fiat illo actu intellectus. Non dico per informationem in esse naturali, sicut unum fit ex intellectu et specie intelligibilis apud ipsum (nullius enim forma naturalis potest esse divina essentia, ut alibi declaratum est), sed per ipsius essentiae praesentiam, quae intimior est oculo mentis per praesentiam illam, qua solus menti illabitur, quam possit esse aliqua species informans $<\ldots>$ ”. Cf. GOEHRING, "Henry of Ghent's Use of Aristotle's De anima ...", 2013, p. 71.

${ }^{145}$ Henrique de Gand, Quodl. 3, q. 1, co. (ed. 1613, f. 78rb): "Tertium vero, quod requiritur ad huiusmodi visionem intellectualem est, quod huiusmodi visibile sit praesens, non solum ut ratio videndi, sed ut obiectum visum, et se voluntarie ostendat, ut dictum est. Non enim ex hoc, quod est praesens, sicut ratio videndi, ostendit se, sicut obiectum visum, quod revera est per suam essentiam, non per aliquod verbum conceptum de ipso, in quo videatur, ut dictum est. Licet hoc conveniat in visione, qua intelligimus ipsum per species creaturae vel in specie creaturae $<\ldots>$.
} 
conhecimento. Pelo contrário, toda ação - [i] iluminação, [ii] unificação do cognoscente e cognoscível e [iii] produção do conhecimento em ato - se deve à própria essência divina e não poderia ser de outro modo, uma vez que uma potência finita como o intelecto humano não poderia agir com respeito à potência infinita que é a essência nua de Deus.

Dito isso, o importante para nosso estudo é constatar que esse conhecimento que o beato possui de Deus parece ser, de fato, uma exceção à necessidade de espécies inteligíveis para o conhecimento. No caso do conhecimento de si, não havia uma espécie distinta do objeto conhecido, mas Henrique de Gand admitia que a própria essência - enquanto razão do conhecimento de si mesma - era uma espécie expressiva que possibilitava ao intelecto o conhecimento dela própria. Isto é, o conhecimento de si admitia uma espécie idêntica ao objeto conhecido, que era o cognoscente enquanto objeto de si mesmo.

Já no caso da visão beatífica, toda espécie parece ser recusada. De fato, o Quodl. 3, q. 1, ao mesmo tempo em que parece afirmar a necessidade de espécies inteligíveis para qualquer conhecimento acerca de criaturas (em qualquer estado que esteja o homem), também parece excluir peremptoriamente a possibilidade de que haja espécie inteligível na visão beatífica. Essa é, com efeito, a intepretação defendida por Jerome V. Brown: "No que diz respeito ao modo natural de conhecer próprio à alma separada, a implicação do Quodlibet III, questão 1, pareceria ser que, onde há uma essência presente diretamente ao intelecto separado, nenhuma espécie é necessária. Mas, isso ocorre somente no caso em que a alma separada conhece Deus. Henrique não afirma isso especificamente aqui, mas a implicação a que apontamos é que para o conhecimento de todo o resto, a alma separada tem a necessidade de uma espécie inteligível"146. Mas, se for assim, por que a essência da alma, enquanto presente ao intelecto, pode ser tomada como espécie no caso do conhecimento de si e a essência divina, também enquanto presente ao intelecto, não pode ser tomada como espécie no caso da visão beatífica?

O problema em fornecer uma resposta a essa questão é que, pelo menos em

\footnotetext{
${ }^{146}$ BROWN, J. V. "The knowledge proper to the separated soul", 1984, p. 320: "As regards the natural mode of knowing proper to the separated soul, the implication of Quodlibet III, question 1 would seem to be that where an essence is present directly to the separated intellect, no species is needed. But this happens only in the instance of the separated soul's knowing God. Henry does not specifically state it here, but the implication we are pointing to is that for knowledge of all else, the separated soul would have need of an intelligible species" (grifos no original).
} 
uma passagem de sua obra, Henrique de Gand parece aceitar que haja uma espécie no conhecimento que o beato possui de Deus. Isso ocorre, a saber, na seguinte passagem do Quodl. 4, q. 8:

"Este verbo, enquanto é um ato informado pelo objeto, é uma espécie do terceiro
modo de espécie e tal verbo é formado no intelecto sobre tudo aquilo que por ele
é percebido, seja por uma espécie de sua presença seja pela espécie da notícia
universal. Assim, dizemos que tal verbo é formado sobre Deus na visão beata
pela espécie de sua essência e a partir dela [per speciem suae essentiae et ab
ipsa]. E dizemos que esse verbo é a espécie pela qual Deus é formalmente visto e
pela qual o intelecto criado, vendo Deus, é informado e a ele sumamente
assimilado $<\ldots>$ "..147.

Esse trecho não necessariamente contradiz tudo o que lemos até aqui acerca da visão beatífica, mas certamente problematiza bastante nossa leitura dos textos anteriores. Em particular, ele mostra que, como ocorria no caso do conhecimento de si, também no conhecimento do beato acerca de Deus é aceitável que se fale em espécie inteligível ou verbo, desde que em um sentido muito preciso, isto é, como idênticos à própria essência daquilo que é conhecido em ato. Lidos à luz desta última passagem, os textos que consideramos anteriormente parecem ser antes a recusa por uma espécie inteligível distinta de Deus na beatitude, mas não a exclusão de qualquer espécie. Em particular, eles não implicavam a exclusão de uma espécie tomada como a própria essência de Deus presente ao cognoscente enquanto cognoscível. Neste último sentido - e, ao que parece, somente neste - pode-se falar em espécie na beatitude.

Novamente, para tanto, faz-se necessária a referência a uma espécie inteligível "do terceiro modo [de tertio modo]", isto é, que não se confunde com a espécie impressiva que inere no sujeito como um acidente. Sendo assim, ao que parece, só se pode falar em espécie no conhecimento beatífico (como também era o caso no conhecimento de si), se tomarmos species como a espécie expressiva - isto é, como o ser que a coisa possui enquanto cognoscível no cognoscente ${ }^{148}$. Algumas coisas

\footnotetext{
${ }^{147}$ Henrique de Gand, Quodl. 4, q. 8, co. (ed. De Wulf-Mansion Centre, vol. 8, pp. 67-8): “Hoc verbum in quantum est actus informatus per obiectum est species de tertio modo speciei, et tale verbum formatur in intellectu de omni eo quod ab ipso percipitur sive per speciem suae praesentiae sive per speciem universalis notitiae. Tale ergo verbum dicimus formari de Deo in visione beata per speciem suae essentiae et ab ipsa, et hoc verbum dicimus esse speciem qua Deus formaliter videtur et qua intellectus creatus Deum videns informatur et ei summe assimilatur $<\ldots$.. $>$ ". Parte deste trecho é citada acima, na nota 105 .

${ }^{148}$ Cf., acima, nota 102. Um comentador que claramente destaca a identidade estabelecida por Henrique de Gand entre Deus, 'espécie expressiva' e 'verbo' em sua concepção de visão beatífica é
} 
possuem esse ser por si mesmas (como a alma com respeito a si ou a deidade com respeito ao beato), enquanto outras (todas as demais criaturas que não uma alma com respeito a si mesma) devem ser inteligíveis no cognoscente de algum outro modo, isto é, por uma espécie distinta de seu ser de existência, expressa pelo intelecto agente por sua ação de abstração a partir dos sentidos. Da mesma maneira ocorre com o verbo, pois, como notávamos ao início do item 6.2.4, espécie inteligível e verbo se identificam no serem similitudes da coisa conhecida. Sendo assim, pelo que lemos no último trecho indentado, também nos casos em que a espécie for a própria coisa presente em sua essência, o verbo será essa mesma presença essencial. Parece, portanto, que na visão beatífica, como no conhecimento de si, pode-se falar em espécie inteligível, desde que esta seja tomada como a própria essência do objeto conhecido presente em si mesma ao intelecto.

Enfim - e para concluir esta etapa de nosso trabalho -, Nys e Bettoni acertam ao chamar a atenção para a discussão sobre o conhecimento de si e o conhecimento do beato como exceções à doutrina da intelecção de Henrique de Gand ${ }^{149}$. No entanto, não me parece que tais exceções tenham eventualmente se tornado regras na doutrina da intelecção do Doutor Solene. Pelo contrário, sempre o conhecimento de si e a visão beatífica permanecem anômalos por não partirem dos sentidos e, no caso da visão beatífica, por tal intelecção ser produzida unicamente pela ação do objeto. Por outro lado, o estudo desses dois casos limítrofes de conhecimento apontam a direção para a qual caminhou a doutrina da intelecção de Henrique de Gand: como veremos no que se segue, é patente em sua discussão sobre o conhecimento humano uma tentativa de clarificação da noção de espécie inteligível. Tal tentativa parece estar associada a uma busca por clarificar o modo como o objeto cognoscível é no cognoscente, isto é, clarificar qual seria o ser do objeto no cognoscente. Ao mesmo tempo em que vimos o Doutor Solene afirmar que a coisa dever ser de algum modo no intelecto e, portanto, por espécie, ele também começa a estabelecer (nas discussões sobre o conhecimento de si e o conhecimento do beato) que tal ser do objeto pela espécie não se confunde

\footnotetext{
William J. Hoye: "Heinrich von Gent (†1293) stellt sich die für Thomas noch undenkbare Frage, 'utrum beatus videns seu intelligens deum nude per essentiam suam formet in se verbum de deo'. Heinrich antwortet, daß Gott selber das verbum (species expressiva) werde" ("Gotteserkenntnis per essentiam im 13. Jahrhundert”. In: ZIMMERMANN, A., VUILLEMIN-DIEM, G. (Hrsg.). Die Auseinandersetzungen an der pariser Universität im XIII. Jahrhundert. Berlin - New York: De Gruyter, 1976, pp. 269-84, esp. p. 284).

${ }^{149}$ Cf., acima, notas 73,74 e 77.
} 
com o ser de um acidente em um sujeito, mas antes deve ser caracterizado como o ser do conhecido no cognoscente. Para expressar tal distinção, vimos ser introduzida uma diferenciação entre 'espécie impressiva' e 'espécie expressiva', sendo esta última resguardada para o caso da intelecção (seja da própria alma, seja das demais criaturas, seja, quiçá, de Deus mesmo da beatitude).

Essa espécie expressiva é apresentada, justamente, como o ser que o objeto possui no intelecto, qualquer que seja ele - a própria essência da coisa (no conhecimento de si ou no conhecimento beatífico) ou a coisa somente de certo modo (como no conhecimento de todas as demais criaturas). Nos itens seguintes, veremos mais pausadamente como é desenvolvida por Henrique essa concepção mais precisa de espécie inteligível e quais são seus efeitos em sua doutrina da intelecção no que diz respeito ao homem no estado presente.

\subsection{OS CASOS DE SUMA, ARTS. 33 E 34, E QUODL. 4}

Para continuarmos tomando por referência os dois comentadores que viemos lendo criticamente no último item, voltemos a Bettoni e Nys. Este último aponta o Quodl. 4 como representativo de um momento de virada na doutrina da intelecção de Henrique de Gand. Neste Quodlibet, se tornaria explícita a recusa da espécie inteligível impressa que, antes, era aceita (ainda que com ressalvas) por nosso autor $^{150}$. Já Bettoni sublinha que o Quodl. 4 é, antes, um esclarecimento do que se lia anteriormente em Henrique de Gand, uma vez que nele finalmente se exclui a espécie impressa do processo de intelecção ${ }^{151}$. De fato, vimos que a história não parece tão linear quanto propõe Nys, pois o Doutor Solene não se volta - mesmo nos casos do

\footnotetext{
${ }^{150}$ NYS, De werking van het menselijk verstand..., 1949, pp. 70-88; p. 137: “A partir do quarto Quodlibet, em 1279, notamos uma impressionante mudança de curso da teoria da abstração de Henrique de Gand, originalmente aristotélica com tons averroistas. Gradualmente, ele descarta a species intelligibilis impressa e faz o intellectus possibilis entrar em ação pela presença, na alma cognoscente, do objeto inteligivelmente cognoscível - seja em presença própria, seja em uma imagem universalizada da fantasia [Van af het vierde Quodlibet, in 1279, noteren wij een opvallende koersvarandering in de oorspronkelijk-aristotelische averroïstisch-getinte abstractietheorie van Hendrik van Gent. Trapsgewijze schakelt hij de species intelligibilis impressa uit en laat de intellectus possibilis in werking treden door de aanwezigheid in de kennende ziel van het verstandelijk kenbaar object, ofwel in eigen wezenheid, ofwel in een geüniversaliseerd phantasiebeeld]" - grifos no original.

${ }^{151}$ BETTONI, Il processo astrattivo..., 1954, p. 41: "La questione 21 del quarto Quodlibet ci dà già la misura de quanto le sue idee si siano oramai schiarite: vi si sostiene infatti che se la 'species impressa' è necessaria per spiegare la conoscenza sensibile, non ha più alcuna ragione di essere nella spiegazione di quella intellettiva". Outro autor a enxergar no Quodl. 4 o momento de abandono da espécie inteligível é Giogio Pini em "Il dibattito sulle specie...”, 2004, p. 287.
} 
conhecimento de Deus ou do conhecimento de si - contra a noção de espécie em geral, mas somente contra uma certa compreensão de espécie inteligível como impressa, o que, de resto, o próprio Nys aceita. Nesse caso, longe de rejeitar o que dissera sobre a espécie em suas primeiras obras (onde não havia uma tal distinção plenamente estabelecida), Henrique de Gand parece paulatinamente nuançar sua concepção de espécie inteligível e, ao fazê-lo, sua concepção de intelecção.

Se a Nys e Bettoni parecem apressados em ver no Quodl. 4, o sinal de uma completa e fundamental modificação na doutrina da intelecção de Henrique de Gand, eles, por outro lado, acertam em apontar esse Quodl. 4 como aquele em que primeiro surge uma caracterização mais aprofundada acerca da espécie inteligível compreendida como expressiva ou expressa e não como impressiva (muito embora tal caracterização só vá ser melhor delimitada no Quodl. 5). Por isso, acredito ser importante nos voltarmos para a maneira como o mestre gandavense disserta acerca do conhecimento intelectual nesse quarto Quodlibet. Como porém, além disso, Nys mostra que já há referências à noção espécie impressiva em Suma, art. $33^{152}$, torna-se relevante associar Quodl. 4 a Suma, art. 33, uma vez que ambos parecem ter sido produzidos em datas próximas, isto é, no ano letivo 1279-1280. A essa equação deve ser acrescentado, como veremos, Suma, art. 34, proveniente do mesmo período ${ }^{153}$.

\subsubsection{Suma, arts. 33 e 34}

No que diz respeito a Suma, art. 33, interessam-nos principalmente dois pequenos trechos da resposta à terceira objeção da questão dois, onde é perguntado "se Deus, por si mesmo, é inteligível [Utrum Deus se ipso est intelligibilis]"154. Como se vê, essa questão traz consigo o problema mais geral de saber o que seria precisamente ser inteligível por si ou por meio de outro. Essa consequência da questão fica bem clara no terceiro argumento quod non, onde lemos: "o que não é inteligível senão por outro que não si mesmo não é inteligível por si mesmo. Deus é assim, pois não é inteligido, mesmo pelos beatos, senão por alguma espécie sua, pela

\footnotetext{
${ }^{152}$ Cf. NYS, De werking van het menselijk verstand..., 1949, pp. 67-70.

${ }^{153}$ Sobre a cronologia da obra de Henrique de Gand, cf. Introdução, § $2 \mathrm{~B}$.

${ }^{154}$ Henrique de Gand, Suma, art. 33, q. 2 (ed. De Wulf-Mansion Centre, vol. 27, p. 128). Sobre a noção de conhecimento descrita nessa questão, cf. GOEHRING, B. "Henry of Ghent's Use of Aristotle's De anima...", 2013, pp. 73-6.
} 
qual o intelecto dos beatos seja informado tal que seja conduzido da potência ao ato, pois a própria divina essência não é forma inerente de nada"155. Como se vê, essa objeção coloca diversos problemas com que viemos lidando até aqui não somente no caso preciso do conhecimento acerca de Deus, mas na doutrina da intelecção como um todo. Com efeito, o problema de determinar o modo de presença do objeto no cognoscente não diz respeito apenas à visão beatífica, mas é basilar para toda discussão acerca do processo de intelecção. Assim, não impressiona que, em sua resposta a esse terceiro argumento quod non, Henrique discorra abrangentemente sobre diversos aspectos da intelecção humana e, uma vez que já vimos como nosso autor explica o conhecimento beatífico (dele excluíndo espécies feitas pelo próprio intelecto ou que neste iniram como acidentes, mas não a espécie expressa que é o próprio Deus presente no intelecto como inteligível), podemos nos dedicar aqui exclusivamente àqueles dois trechos já referidos dessa resposta.

Em um primeiro excerto importante para nós, Henrique de Gand retoma um tema de que já tratamos acima, a saber, o fato de que tanto a espécie como o verbo podem ser descritos como 'similitudes' da coisa conhecida, não obstante sejam atos distintos no processo de intelecção - a primeira, anterior à intelecção em ato e o segundo, posterior (cf. o item 6.2.4). O que principalmente chama a atenção, porém, é que, agora, surge uma referência à species impressiva nessa comparação entre species e verbum:

"Donde, uma vez que a criatura é conhecida por sua espécie no intelecto e que,
pelo ato de inteligir, se forma sobre a mesma o verbo da sua notícia no intelecto,
o intelecto é similar à coisa por aquela espécie e por aquele verbo. E a similitude
da coisa no intelecto é mais verdadeira do que a espécie impressiva abstraída
pelos sentidos [quam ipsa species impressiva a sensibus abstracta]. E mais
verdadeiramente o intelecto se assimila à coisa pelo verbo da notícia que é nele
sobre ela do que por alguma espécie que é nele"156.

\footnotetext{
${ }^{155}$ Henrique de Gand, Suma, art. 33, q. 2, quod non 3 (ed. De Wulf-Mansion Centre, vol. 27, p. 129): "Tertio sic. Quod non est intelligibile nisi alio a se, non est intelligibile se ipso. Deus est huiusmodi, quia non intelligitur, etiam a beatis, nisi per aliquam speciem sui, qua intellectus beatorum informatur ut educatur de potentia ad actum, quia ipsa divina essentia nullius est forma inhearens".

${ }^{156}$ Henrique de Gand, Suma, art. 33, q. 2, ad 3 (ed. De Wulf-Mansion Centre, vol. 27, p. 146): "Unde, cum creatura cognoscitur per suam speciem in intellectu, et per actum intelligendi formatur de eadem verbum notitiae eius in intellectu, similis est intellectus rei per illam speciem et per illud verbum, et est similitudo rei in intellectu verior quam ipsa species impressiva a sensibus abstracta, et verius intellectus assimilatur rei per verbum notitiae quod de ea est in eo, quam per aliquam suam speciem quae est in eo". Cf. NYS, De werking van het menselijk verstand..., 1949, pp. 68-9.
} 
Em face desse excerto, Nys considera que Henrique de Gand não havia ainda abandonado a afirmação de espécies impressas no intelecto ${ }^{157}$ (muito embora elas venham a desaparecer poucas páginas adiante, na mesma questão, como o próprio Nys admite ${ }^{158}$ ). Mas seria esse o caso? Melhor, seria essa a única leitura possível de tal passagem?

Na primeira sentença da passagem indentada, há somente uma comparação entre 'espécie no intelecto' (speciem in intellectu) e 'verbo da notícia no intelecto' (verbum notitiae eius in intellectu) - não há, nesse início, qualquer referência a uma caracterização dessa 'espécie no intelecto' como impressa ou impressiva. Pois bem, na última sentença da passagem, é dito que o intelecto se assimila à coisa conhecida mais pelo 'verbo da notícia que é nele sobre ela' (verbum notitiae quod de ea est in $e o$ ) do que pela 'espécie da coisa que é nele' (suam speciem quae est in eo). Mais uma vez, não há aqui qualquer menção a tal espécie no intelecto como impressa ou impressiva. Nesse caso, por que surge na segunda sentença justamente uma referência a uma "espécie impressiva abstraída pelos sentidos [ipsa species impressiva a sensibus abstracta]"?

A resposta a essa pergunta depende de uma consideração acerca da preposição $a / a b$ que é utilizada para relacionar a espécie aos sentidos: tal espécie impressiva é abstraída a sensibus. Em um primeiro momento - e essa parece ser a leitura de Nys -, isso parece querer dizer que 'o intelecto abstrai tal espécie impressa a partir dos $(a / a b)$ sentidos'. Se, porém, atentarmos à sentença completa, vemos que tal interpretação não se sustenta, pois essa segunda frase compara dois elementos: [i] 'a similitude da coisa no intelecto' (similitudo rei in intellectu) e [ii] “ipsa species impressiva a sensibus abstracta". Ora, uma vez que a primeira frase estabelece que tanto a "espécie no intelecto' como o 'verbo no intelecto' são similitudes da coisa no intelecto (pois, por ambos - espécie e verbo - o intelecto é similar à coisa), a 'similitude da coisa no intelecto' (similitudo rei in intellectu) a que Henrique se refere nessa segunda frase

\footnotetext{
${ }^{157}$ Ao apresentar o trecho destacado na nota anterior, Nys afirma: "Quando nosso intelecto conhece essas coisas, tal conhecimento ocorre com ajuda de uma species impressa a sensibus abstracta, mas a assimilação completa da potência cognoscitiva a seu objeto tem lugar somente no verbum. Assim, Henrique de Gand não havia ainda neste instante abandonado sua posição sobre a necessidade de uma species impressa [Wanner ons vertand deze dingen kent, gebeurt dit kennen met behulp van de species impressa a sensibus abstracta, maar de volledige assimilatie van het denkvermogen aan zijn object heeft slechts plaats in het verbum. Hendrik van Gent heeft dus zijn stelling over de noodzakelijkheid van de species impressa op dit ogenblik nog niet prijsgegeven]" (De werking ven het menselijk verstand..., 1949, p. 68 - grifos no original).

${ }^{158} \mathrm{Cf}$., adiante, a nota 160.
} 
deve envolver tanto a espécie como o verbo. Nesse caso, não faz sentido que o segundo elemento dessa comparação seja, novamente, espécie no intelecto, pois estaríamos comparando [i'] 'espécie no intelecto e verbo no intelecto' com [ii'] a 'espécie no intelecto', para concluir que os primeiros são mais verdadeiro do que o segundo, o que é contraditório. Por isso mesmo, parece-me que a preposição $a / a b$ não está marcando, nessa sentença, a origem de uma espécie impressa no intelecto, mas antes marca o agente da passiva. Assim, o que há aqui é uma comparação entre [i”] 'a similitude da coisa no intelecto' (incluíndo espécie e verbo) e [ii”] 'espécie impressiva abstraída pelos/por obra dos $(a / a b)$ sentidos'. O resultado dessa comparação é a afirmação de que a similitude da coisa no intelecto é mais verdadeira do que a similitude da coisa nos sentidos. Que esta última seja tomada como uma espécie abstraída por obra dos sentidos não impressiona, uma vez que já vimos no item 5.4.3 que os conhecimentos sensitivos e imaginativos já são formas de abstração, embora não tão completas quanto a abstração pelo intelecto agente ${ }^{159}$.

Assim, esse curto excerto possui três passos: [1] primeiro, se estabelece que pela 'espécie' e pelo 'verbo' o intelecto é similar à coisa conhecida; [2] em seguida, diz-se que essa similitude da coisa no intelecto é mais verdadeira do que aquela espécie impressa que há nos sentidos; [3] por fim, afirma-se que, dentre as duas similitudes no intelecto, o verbo assimila o intelecto mais perfeitamente à coisa do que a espécie. Como se vê, não há qualquer atribuição de espécie impressa ao intelecto - pelo contrário, o Doutor Solene toma cuidado em resguardar tal espécie impressa para os sentidos, referindo-se à espécie inteligível unicamente como 'espécie no intelecto' (speciem in intellectu).

Assim, parece-me que Nys foi apressado em ver no último trecho indentado uma atribuição de espécies impressas ao intelecto. Uma confirmação de minha leitura é o fato de que, como já mencionado, o próprio comentador admite que, em passagens posteriores do mesmo Suma, art. 33, q. 2, ad 3, a referência a espécies impressas no intelecto é abandonada. Para Nys, essa diferença teria origem no fato de que Henrique começaria suas resposta ainda sob influência da objeção (razão pela qual admite espécies impressas no intelecto), para em seguida dar, de fato, sua própria opinião (na qual exclui tais espécies) ${ }^{160}$. Como vimos, porém, não há uma tal mudança no texto -

\footnotetext{
${ }^{159}$ Cf. cap. 5, nota 119.

${ }^{160}$ NYS, De werking van het menselijk verstand..., 1949, pp. 68-9: "Mas, quando Henrique de Gand busca responder ao próprio argumento e considera a necessidade da species em geral - e não tal como
} 
tanto no trecho já citado de Suma, art. 33, q. 2, ad 3, como no outro trecho destacado por Nys, que veremos a seguir, as espécies impressas são excluídas do conhecimento intelectual. Nesse excerto que leremos a seguir, porém, não somente são excluídas do intelecto as espécie inteligíveis, como nos é fornecida uma pista sobre qual seria a espécie que Henrique de Gand considera típica do intelecto:

“<..> o inteligente em potência não é conduzido efetivamente ao ato por alguma
forma impressa em si, mas somente pelo próprio inteligível objetivamente
presente ao intelecto tal como o cognoscível ao cognoscente - em si mesmo por
essência ou naquilo que é sobre ele [in eo quod quid est de ipso]. Tal que, se a
própria coisa inteligível se apresenta a si mesma no inteligente, então o
inteligente intelige por ela formalmente (não por ela em sua espécie) e ela é
inteligida por ela"161.

Esse trecho não somente exclui do conhecimento intelectivo a forma impressa, como mostra o porquê de tal exclusão, a saber: o conhecimento intelectual só passa da potência ao ato movido pelo próprio objeto presente ao intelecto como o cognoscível no cognoscente. Nys vê nesse trecho a descrição de uma condição: caso o objeto esteja presente como o cognoscível no cognoscente, então não é necessária a espécie impressa no intelecto ${ }^{162}$. A meu ver, no entanto, o que há aqui é a explicação do porquê da ausência de espécies impressas no intelecto: uma vez que o inteligível é objetivamente presente ao intelecto como o cognoscível no cognoscente, não são necessárias espécies impressas no intelecto. Nessa passagem, com efeito, Henrique de Gand está precisamente opondo o intelecto, enquanto não necessita de impressão, ao sentido, enquanto potência que necessita da impressão de seu objeto para passar da

o texto da objeção, que a limitava somente ao caso da visão de Deus -, sua resposta é bem ampla e ele já admite, em princípio, que todo conhecimento intelectivo pode ocorrer sem species, se o objeto estiver, de um ou outro modo, objective praesens no intelecto cognoscente [Maar wanneer Hendrik van Gent op de redenering zelf tracht te antwoorden en de noodzakelijkheid van de species in 't algemeen onderzoekt, en niet zoals de tekst van de opwerping ze beperkte tot het geval der Godsschouwing, is zijn antwoord te ruim en geeft hij in princiep reeds toe, dat alle verstandelijke kennis kan geschieden zonder species, indien het object maar op een of andere manier objective praesens is bij het kennend verstand]" - grifos no original.

${ }^{161}$ Henrique de Gand, Suma, art. 33, q. 2, ad 3 (ed. De Wulf-Mansion Centre, vol. 27, pp. 151-2): " $<\ldots>$ potentia intelligens non educitur effective in actum per aliquam formam sibi impressam, sed solummodo ab ipso intelligibili obiective, praesenti intellectui sicut cognoscibile cognoscenti, vel in se ipso per essentiam, vel in eo quod quid est de ipso. Ita quod, si ipsa res intelligibilis se ipsam praesentat in intelligentem, tunc ipsa non specie eius formaliter ea intelligit intelligens, et ipsa se ipsa intelligitur". Cf., novamente, NYS, De werking van het menselijk..., 1949, p. 68-9, onde são citadas também passagens adjacentes a este trecho.

${ }^{162} \mathrm{Cf}$., acima, a nota 160 . 
potência ao ato ${ }^{163}$. Por isso, parece-me que o foco da passagem é não tanto mostrar condições determinadas sob as quais o intelecto não necessita de espécies impressas, mas antes salientar que é típico do intelecto (em oposição aos sentidos) não necessitar de espécies impressas, já que possui em si seu objeto como o cognoscível no cognoscente. Mais do que a descrição de um caso condicionado, tal passagem é uma descrição geral do conhecimento intelectual ${ }^{164}$.

Ora, a fórmula 'como o cognoscível ao cognoscente' (sicut cognoscibile cognoscenti) é reminiscente das fórmulas que já vimos ser utilizadas, em Quodl. 4, q. 7, para caracterizar o terceiro modo de espécie, que é in cognoscente (em oposição a qualquer forma impressa inerente) ${ }^{165}$ e, em Quodl. 4, q. 21, para caracterizar a espécie expressa no sentido, pela qual o objeto é presente " $u t<\ldots>$ in cognoscente" ${ }^{\text {"166 }}$. Ou seja, o último trecho destacado de Suma, art. 33, q. 2, ad 3, não somente exclui espécies impressas do intelecto, mas (lido à luz de Quodl. 4) parece apontar para a ocorrência exclusiva de espécies expressas no processo de intelecção. Essa é a leitura defendida por Jerome V. Brown e que me parece mais apropriada ${ }^{167}$.

Por essa última observação, vemos o quão próxima é a relação entre Suma, art. 33, e Quodl. 4 - isso justificaria que passássemos imediatamente do primeiro para o segundo texto. No entanto, antes de nos voltarmos para Quodl. 4, será interessante atentarmos para alguns trechos de Suma, art. 34, onde é notável o esforço que Henrique de Gand leva a cabo em sua obra para melhor delimitar os atores envolvidos na produção do conhecimento intelectual.

O tema principal de Suma, art. 34, é "a verdade de Deus [De veritate Dei]", o que torna tal artigo particularmente relevante para os estudos sobre a noção de verdade em Henrique de Gand produzidos por Steven P. Marrone, Jos Decorte ou

\footnotetext{
${ }^{163}$ Henrique de Gand, Suma, art. 33, q. 2, ad 3 (ed. De Wulf-Mansion Centre, vol. 27, pp. 151): “< $<>$ potentia sentiens educitur in actum per formam sensibilis, alterando sensitivum ut formam sibi similem ipsi imprimat $<\ldots$.. ”. Nesse trecho, tal caracterização do sentido é apresentada como tendo por base o De anima II de Aristóteles.

${ }^{164}$ Essa parece ser, também, a leitura de Bernd Goehring, quando ele, ao considerar tal passagem, conclui que, para Henrique de Gand, "at the level of intellect cognitive actualization is to be understood in terms of content, rather than in terms of physiological processes. Here the intentional features of representations, rather then the intrinsic features of representations will be important" ("Henry of Ghent's Use of Aristotle's De anima...", 2013, p. 76).

${ }^{165}$ Cf., acima, nota 102.

${ }^{166}$ Cf. cap. 4, nota 59.

${ }^{167}$ BROWN, J. V. “Intellect and Knowing in Henry of Ghent”, 1975, p. 509.
} 
Theo Kobusch ${ }^{168}$. No entanto, não será nosso interesse aqui abordar com maior profundidade o tema central desse artigo, aí verbosamente desenvolvido. Antes, pretendo atentar para alguns trechos de Suma, art. 34, que deixam entrever modificações da lavra do próprio Henrique de Gand, cujos rastros podem ser seguidos por meio da lição desse artigo da Suma contida no ms. BNF lat. 15355, legado por Godofredo de Fontaines à Sorbonne. Como veremos a seguir, as correções marginais registradas por diversas mãos nesse manuscrito apontam para diversas camadas textuais em alguns trechos de Suma, art. 34. A importância da diferenciação dessas camadas para a compreensão da doutrina da intelecção do Doutor Solene já foi bem apontada por Steven Marrone e Bernd Goehring ${ }^{169}$. Aqui, tal diferenciação nos interessa principalmente na medida em que mostra o quanto Henrique de Gand se dedicou à expressão de certos aspectos de sua doutrina da intelecção.

Um primeiro exemplo de correção relevante para nosso estudo é o trecho apresentado a seguir. Na coluna à esquerda, vemos a tradução daquilo que constitui o corpo do texto do ms. BNF lat. 15355 e surge no aparato crítico da ed. de Raymond Macken; na coluna à direita, apresento a tradução do texto após as correções marginais, que também é aquele que surge na corpo da ed. de Raymond Macken. Em ambas as colunas, os trechos sublinhados são aqueles afetados pelas mudanças. Em nota, apresento uma tentativa de reconstituição do texto manuscrito anterior às correções e, entre colchetes, apresento estas últimas. Vejamos:

\section{antes da corr.}

Ao terceiro, que 'a verdade que diz respeito ao intelecto é a entidade diminuída da coisa, que não convém a Deus', cumpre dizer que a verdade que é a entidade diminuída da coisa é aquela que possui ser no intelecto sobre a coisa por outro que não a própria coisa inteligida, abstraído dela, como a pedra pelo verbo formado a partir da pedra no intelecto

\section{após a corr.}

Ao terceiro, que 'a verdade que diz respeito ao intelecto é a entidade diminuída da coisa, que não convém a Deus', cumpre dizer que a verdade que é a entidade diminuída da coisa é aquela que possui ser no intelecto sobre a coisa por outro que não a própria coisa inteligida, abstraído dela, como a pedra pelo verbo formado a partir da pedra no intelecto

\footnotetext{
${ }^{168}$ Cf. MARRONE, Truth and Scientific Knowledge..., 1985, pp. 41-69; DECORTE, J. "Henri de Gand et la définition classique de vérité”. Recherches de théologie et philosophie médiévales 68.1 (2001), pp. 34-74; MARRONE, The Light of Thy Countenance, vol. 2, 2001, pp. 362-6; KOBUSCH, T. "Adaequatio rei et intellectus. Die Erläuterung der Korrespondenztheorie der Wahrheit in der Zeit nach Thomas von Aquin”. In: ENDERS, M., SZAIF, J. (Hrsg.). Die Geschichte des philosophischen Begriffs der Wahrheit. Berlin - New York: De Gruyter, 2006, pp. 149-66 (esp. pp. 152-6). Ainda sobre Suma, art. 34, cf. tb. MARRONE, "Henry of Ghent in Mid-Career...", 1996, pp. 193-209.

${ }^{169}$ Cf. MARRONE, "Henry of Ghent in Mid-Career...", 1996, p. 195; GOEHRING, Henry of Ghent on Cognition..., 2006, pp. 225-35. Cf. tb. AIELLO \& WIELOCKX, "La versione del Quodlibet IV, qq. 7-8...”, 2008, pp. 497-9.
} 
criado, que é de algum modo a pedra - e não verdadeiramente a pedra, mas diminuidamente. $E$ tal verdade é somente no intelecto criado sobre a coisa que <ele $>$ concebe por uma espécie outra que não a coisa. Porém, não no intelecto não-criado, que apreende a essência dela por si mesma e, por isso, a entidade é tão perfeita enquanto é captada pelo intelecto divino, quanto é em si. criado, que é de algum modo a pedra - e não verdadeiramente a pedra, mas diminuidamente. $\mathrm{E}$ tal verdade é somente no intelecto criado sobre a coisa pelo verbo que é outro que não a própria coisa que <ele> concebe. Porém, não no intelecto não-criado, que apreende a essência dela por si mesma e, por isso, a entidade é tão perfeita enquanto é captada pelo intelecto divino, quanto é em $\mathrm{si}^{170}$.

\section{O foco desse pequeno trecho é a diferenciação entre [i] a verdade do ser que a} coisa possui fora da alma e [ii] a verdade do ser que ela possui enquanto conhecida no intelecto. Henrique de Gand busca diferenciá-las ao estabelecer entre elas uma relação: a verdade da coisa no intelecto é a verdade diminuída dessa coisa, isto é, diminuída com respeito àquela verdade que tal coisa possui fora da alma ${ }^{171}$. A bem

${ }^{170}$ Henrique de Gand, Suma, art. 34, q. 3, ad 3 (ed. De Wulf-Mansion Centre, vol. 27, p. 194, 11. 33-41)
$-\mathrm{A}=\mathrm{BNF}$ lat. 15355 , f. 155va-b: "Ad tertium, quod 'veritas quae respicit intellectum, est diminuta rei
entitas, quae non convenit Deo', dicendum quod veritas quae est diminuta rei entitas, est illa quae habet
esse in intellectu de re per aliud ab ipsa re intellecta, abstractum ab ipsa, ut lapis per verbum formatum
in intellectu creato a lapide, quod est quodam modo lapis et non vere lapis, sed diminute. Et est talis
veritas solummodo in intellectu creato de re quam [quam A, sed om. in corpore et app. Macken, sed. cf.
ed. Macken, . cvi, ubi notat istum quam cum sequente corr. expungendum fuisse] per speciem aliam a
[speciem... exp. A, et corr. supra lineam in verbum quod est aliud ab ipsa] re quam [quam add. supra
lineam A] concipit. Non autem in intellectu increato, qui suam essentiam per se ipsam apprehendit, et
ideo tam perfecta entitas est ut capitur a divino intellectu, quam in se est". ${ }^{171}$ Henrique de Gand, Suma, art. 34, q. 5, co. (ed. De Wulf-Mansion Centre, vol. 27, pp. 205-6): "Rationem autem veritatis in intelligibili habet intelligentia dupliciter, secundum quod in intelligentia comparata ad intelligibile duo considerantur, scilicet intelligendi ratio et intelligendi actio consistens circa intelligibile ut est intelligenti praesens. Ratio intelligendi in intelligentia est esse formale quo intelligibile facit intelligentiam talem in actu, quale ipsum est, cum de se, in quantum intelligentia est, non est nisi in potentia tale. Quae in Deo sola ratione differunt. In creatura autem intelligibilia differunt aliquando re. Res enim existens extra animam notitia sua existente in intelligentia informat intelligentiam, et facit eam quodam modo esse talem qualis ipsa est. Secundum hunc enim modum 'anima per intellectum quodam modo est omnia intelligibilia, sicut secundum sensum omnia sensibilia', ut determinat Philosophus III $^{\circ}$ De anima. Similitudo autem illa in intelligentia re differt ab eo quod est extra, quia est accidens in intelligentia creata. Unde, sicut inter se sunt res diversae, sic habent diversas veritates, et illa veritas rei in anima diminuta est respectu veritatis quae est in re extra, quemadmodum et ipsa est res diminuta respectu illius quae est extra, et est veritas signi respectu veritatis rei". Essa passagem é relevante por duas razões.

[i] Em primeiro lugar, por explicar claramente que a denominação 'diminuta' dada à coisa (e à sua verdade) na alma remete a uma comparação entre o ser da coisa na alma e o ser da coisa fora da alma. Nesse sentido, a noção de 'verdade diminuída da coisa' possibilita a manutenção da identidade entre a coisa fora e a coisa na alma, compensando tal identidade pela distinção do ser (próprio, fora da alma, e diminuído, na alma) que a coisa possui em cada caso. Com tal distinção no ser é possível, igualmente, estabelecer uma distinção real entre a coisa fora e a sua similitude - um acidente na alma (que, considerando a espécie inteligível como expressiva, não pode ser a própria espécie, mas deve ser a operação de intelecção ou algo a ela associado, como o verbo). A distinção entre a coisa fora e a coisa em seu ser diminuído, por sua vez, é recoberta pela distinção entre a 'verdade da coisa' (veritas rei) e a 'verdade do signo' (veritas signi). A primeira é a verdade que a coisa possui em seu ser próprio fora da alma, enquanto que a segunda é a verdade da coisa em seu ser diminuído, na alma: "Sicut enim veritas signi tunc est, quando signum facit hoc quod facere debet, sive quod natura sua requirit ut faciat, videlicet quod faciat omne id quod pertinet ad suam significationem scilicet ut indicet ipsum 
significatum secundum quod est in re extra, sic veritas rei oportet quod sit, quando res id existit quod natura sua requirit ut sit, videlicet quod in se contineat omne id quod ad naturam suam pertinet, et quidditatem" - Suma, art. 34, q. 1, co. (ed. De Wulf-Mansion Centre, vol. 27, pp. 164-5). Como se vê, portanto, tal distinção entre veritas signi e veritas rei pressupõe uma definição precisa da própria noção de veritas: " $<\ldots>$ haec est perfecta ratio veritatis, quod ipsa habeat hoc quod natura sua requirit ut habeat, continendo scilicet in se quidquid ad essentiae suae perfectionem pertinet" - Suma, art. 34, q. 1, co. (ed. De Wulf-Mansion Centre, vol. 27, pp. 165-6). Sobre a distinção entre veritas rei e veritas signi, sua fundamentação e fontes em Henrique, cf. MARRONE, Truth and Scientific Knwoledge..., 1985, pp. 44-50; DECORTE, "Henri de Gand et la définition classique de vérité", 2001, pp. 41sg; GOEHRING, B. "Truth as Rightness in Anselm of Canterbury and Henry of Ghent". In: GASPER, G. E. M., LOGAN, I. (eds.). Saint Anselm of Canterbury and his Legacy. Toronto: Pontifical Institute of Mediaeval Studies, 2012, pp. 174-202 (em particular, ele estuda o trecho aqui citado na p. 191).

[ii] Além disso, ainda na passagem citada no início desta nota, é possível observar a ênfase emprestada por Henrique à distinção entre a 'ação de inteligir' (actio intelligendi) e a 'razão de inteligir' (ratio intelligendi). A 'ratio intelligendi' é a forma - o ser formal - pelo qual a coisa fora informa o intelecto, tornando este último semelhente à própria coisa fora. Nesse trecho, entretanto, o Doutor Solene deixa claro que tal informação ocorre somente no momento em que a coisa existe na mente em sua notícia (notitia sua existente in intelligentia informat intelligentiam) - ou seja, esse 'ser formal' não pode ser a espécie que antecede a notícia, mas parece ser o verbo que é coetâneo à notícia acerca da coisa. Portanto, vemos que a ratio intelligendi é a coisa enquanto conhecida na alma - ou ser formal, no intelecto, da coisa fora - e, assim, é o ser diminuído (ou verdade diminuída) da coisa. Destarte, neste trecho, verbum, ratio intelligendi e veritas rei diminuta parecem todos confluir. Isso faz com que essa passagem esteja plenamente de acordo com a correção imposta por Henrique ao texto de Suma, art. 3, q. 3, citado na nota anterior.

Além disso, é preciso destacar que a identificação entre 'espécie inteligível' e 'ser diminuído da coisa' que surge na primeira versão do excerto de Suma, art. 3, q. 3 (cf. nota precedente) pareceria problemática com respeito a demais textos do Doutor Solene sobre o tema. Isso porque a espécie inteligível, de uma maneira ou de outra, é tida como algo anterior ao ato de intelecção, sendo aquilo mesmo que o possibilita. Assim, a espécie inteligível é também principalmente associada à inteligência simples ou dos incomplexos, uma vez que ela fornece o primeiro conhecimento acerca de algo. Ora, se dissermos que a espécie já é o ser diminuído da coisa, será necessário admitir que o próprio conhecimento incomplexo (e, mesmo, aquilo que porventura seja tomado como sua causa) já são a verdade diminuída da coisa. O problema com tal afirmação é que esse não parece ser o caso para Henrique de Gand em alguns textos seus. Com efeito, a noção de ser diminuído ou verdade diminuída é utilizada por ele, por vezes, para caracterizar estritamente o conhecimento complexo acerca da coisa. É o que ocorre, por exemplo, em Suma, art. 24, q. 3, co. (ed. Decorte \& Teske, p. 200), onde se afirma que o conhecimento "sobre o complexo é da verdade da composição, que é a entidade diminuída da coisa na alma $[<\ldots>$ de complexo, est de veritate compositionis, quae est diminuta rei entitas apud animam]". De outra parte, porém, a noção de entitas diminuta surge, por vezes, como caracterização do ser da coisa na alma em geral (isto é, não somente do seu ser enquanto conhecida por um conceito complexo). É o que vemos, por exemplo, em Suma, art. 21, q. 3, co. (ed. Decorte \& Teske, p. 64): "Est enim ens per se duplex, et illud quod significat essentiam rei, et illud quod significat veritatem rei. Et dicit hic veritas, non quae idem est quod rei per se entitas in natura et essentia eius qua habet esse in se, sed diminuta rei entitas qua habet esse apud animam apprehedentem eam, ut dicitur sexto Metaphysicae"; Suma, art. 27, q. 1, ad 9 (ed. Teske, p. 160): "Esse vero existentiae est esse in effectu acquisitum essentiae, et hoc est duplex secundum Philosophum in sexto, Metaphysicae. Unum quod dicitur esse rei diminutum, ut est rei esse in conceptu mentis seu in anima, absque eo quod sit extra animam ens, ut dicit ibi Commentator" (sobre este trecho, cf. cap. 2, nota 95); e Quodl. 10, q. 8, co. (ed. De Wulf-Mansion Centre, vol. 14, p. 202): "Sed esse essentiae, in quantum per essentiam entia sunt apud intellectum, est esse diminutum, esse vero existentiae verum et perfectum non habet nisi extra intellectum in rerum natura" (sobre esta passagem, cf. MARRONE, The Light of Thy Countenance, vol. 2, 2001, pp. 351-2). Pois bem, Henrique de Gand parece oscilar entre dois usos da noção de 'ser diminuído', 'entidade diminuída' ou 'verdade diminuída': nestes últimos trechos, uma mais abrangente (segundo a qual tudo o que é no intelecto é diminuído) e, naquele trecho anterior, outra mais restrita (pela qual é diminuído somente o conhecimento complexo). No primeiro caso, tanto a espécie inteligível, como o verbo (seja no conhecimento incomplexo ou complexo) podem ser ditos o 'ser diminuído' da coisa, enquanto que no segundo caso somente o verbo complexo poderia ser dito, propriamente, o ser ou a verdade diminuída da coisa. Cf. os rápidos comentários sobre o tema em MARRONE, Truth and Scientific Knowledge..., 1985, p. 42; PORRO, "Possibilità ed esse essentia in 
Enrico di Gand", 1996, p. 239; e a referência de Janssens a este último em "Henry of Ghent and Avicenna", 2011, p. 72.

Por fim, destaque-se que nas Questões sobre a Metafísica do ms. Escorial, h.II.1, ff. 1ra-73rb, de atribuição duvidosa a Henrique de Gand, a noção de 'entitas diminuta' surge, principalmente, tomada naquele sentido mais abrangente. Assim, lemos em Qq. sobre a Metafísica II, q. 1 [34], co. (ms. Escorial, h.II.1, f. 6bv, 11. 12-4): "dicendum quod ueritas duobus modis dicitur: uno modo dicitur ueritas rei entitas et tunc nominat ens ut sui est declaratiuum apud animam, et hec ueritas idem est cum re; alio modo dicitur ueritas rei diminute entitas". Da mesma maneira, lemos em Qq. sobre a Metafisica VI, q. 24 [325], co. et ad 1 (ms. Escorial, h.II.1, f. 72va, 11. 24-30): “< $<>$ dicendum quod uerum est in diminuto genere entis non respectu ad ipsam animam, sed uerum prout est in anima dicitur esse diminutum ueri existentis in rebus. Unde ueritas in suo esse completo est in rebus, sed in suo esse diminuto est in anima $<\ldots>$. Ad primum argumentum dicendum est quod uerum est in genere entis simpliciter non diminuto prout informat ipsam animam, sed est diminutum in ratione ueri prout est in anima respectu ueri existentis in rebus". Como se vê, nessas passagens, a noção de 'ser diminuído' abrange tudo aquilo que se opõe ao ser da coisa existente realmente (in re) e fora da alma - nesse caso, tanto o conhecimento incomplexo como aquele complexo poderiam ser ditos 'diminuídos'. Que esse seja o caso é explicado em Qq. sobre a Metafísica VI, q. 23 [324], co. (ms. Escorial, h.II.1, f. 72rb, 11. 14-25): "Similiter uerum dicitur dupliciter. Uno modo secundum quod dicit ueram rei entitatem; alio modo secundum quod dicit rei diminute entitatem. Primo modo ueritas idem est quod quiditas et essentia ipsius $\langle\ldots>$. Secundo modo dicitur dupliciter. Uno modo dicitur similitudo uel intentio rei extra que derelinquitur in anima. Alio modo nominat habitum cognitionis derelicto in anima per tales species apprehensas. Unde notandum quod duplex est operatio anime: una est apprehendere, alia est componere uel diuidere. A prima operatione causatur uerum incomplexum, quia anima apprehendit speciem simplicem ipsius rei et quiditatem et essentiam ipsius. Et talis ueritas est incomplexa quia fit per intentiones simplices. A secunda operatione anime, que est componere uel diuidere, causatur ueritas complexa <... >. Ou seja, para o autor dessas Qq. sobre a Metafísica do ms. Escorial, h.II.1, tanto o incomplexo como o complexo podem ser caracterizados como diminuídos com respeito ao ser da coisa fora da alma. Dessa maneira, como era dito, sua noção de 'ser diminuído' se aproxima daquele uso mais amplo que Henrique de Gand fazia dessa expressão (e seus demais equivalentes).

Sobre a noção de verdade nas Qq. sobre a Metafísica do ms. Escorial, h.II.1, cf: GRABMANN, M. Mittelalterliche lateinische Aristotelesübersetzungen und Aristoteleskommentare in Handschriften spanischer Bibliotheken. München: Verlag der Bayerischen Akademie der Wissenschaften, 1928, pp. 73-4, 83-8; PORRO, 'Le 'Quaestiones super Metaphysicam' attribuite a Enrico di Gand..., 2002, pp. 516-26. Ainda sobre essas Qq. sobre Metafisica, cf. ZIMMERMANN, Ontologie oder Metaphysik?, 1998, pp. 235-40; PICKAVÉ, Heinrich von Gent über Metaphysik..., 2007, pp. 369-74.

Para uma introdução geral à noção de ens diminutum, cf. o clássico MAURER, A. "Ens Diminutum: a Note on its Origin and Meaning". Mediaeval Studies 12 (1950), pp. 216-22. Note-se, porém, que, ao se referir a Henrique de Gand (op. cit., p. 220), Armand Maurer avança a tese de que, para nosso autor, as ideias divinas possuiriam um 'ser diminuido': "In order to extend the notion of diminished being to the divine ideas, all that was necessary was to conceive them as produced by the divine mind analogous to the way in which we give being to things within our mind. It appears that Henry of Ghent was the first to take this step. For him, the divine ideas are really distinct from the divine essence. God gives them their intelligible being as our intellect gives being to its ideas. And as the latter are diminished being with respect to existing things, so the divine ideas are diminished with respect to God Himself'. A passagem apontada por Maurer para justificar sua posição é um longo trecho de Quodl. 9, q. 2, co. (ed. De Wulf-Mansion Centre, vol. 13, pp. 30-1): "Et est talis haec Dei cognitio in cognoscendo se secundum rationem formae exemplaris, a quo secundum rationem causae formalis habent esse aliquid per essentiam ipsa exemplata in esse suo cognito. Et hoc quemadmodum intellectus noster entia facta ab ipso constituit in esse cognito. Quae sicut sunt diminuta entia respectu aliorum existentium, quorum intellectus noster non est causa, neque quod habent esse simpliciter, quia quod sic habent esse, non habent nisi a Deo, neque quod habent esse cognitum, quia quod sunt in esse cognito intellectus nostri, huius ipsa potius sunt causa quam ipse intellectus noster, quia non sunt in cognitione intellectus nostri ut obiecta cognita et operata ab intellectu, sed ut obiecta agentia intellectum et facientia ut intellectus noster sit intellectus secundum actum, per quod se ipsa faciunt esse in esse cognito intellectus, quod non facerent nisi ex se secundum actum essent entia vera, respectu quorum intellectus quodam modo est ens in potentia, - sic enim ista eadem entia respectu entis quod Deus est, sunt diminuta entia, non tamen sic diminuta sicut sunt entia operata ab intellectu nostro, quia illa nullo modo nata sunt habere aliquod esse verum extra intellectum praeter esse cognitum quod habent in intellectu. Ista autem non sunt sic diminuta respectu entis quod Deus est, et existentia in esse cognito, quin in illo esse sint aliquid 
dizer, a verdade da coisa no intelecto é a entidade diminuída (diminuta rei entitas) que ela aí possui, sendo tal entidade caracterizada como 'diminuída' por ser a presença da coisa por meio de outro - no intelecto, a coisa não é em si mesma como fora, mas possui ser por outro, abstraído dela (abstractum ab ipsa), mas que não é ela própria (habet esse in intellectu de re per aliud ab ipsa re). O Doutor Solene termina a passagem atentando para o fato de que, no conhecimento divino, não ocorre uma tal 'entidade diminuída da coisa', porque a própria coisa é em si no intelecto, enquanto que no intelecto criado ela é por outro. Ora, que o intelecto criado necessite de um meio para o conhecimento não é novidade para nós; nossa maior dificuldade tem sido, antes, a caracterização desse meio.

Pois bem, também nesse excerto destacado, a caracterização desse meio melhor, desse outro pelo qual a coisa possui ser no intelecto - é aquilo que leva Henrique de Gand a modificar seu próprio texto. Na primeira versão, surgiam dois 'outros' pelos quais a coisa possuía ser no intelecto: [i] ao início, o "verbo formado a partir da pedra no intelecto criado, que é de algum modo a pedra [verbum formatum in intellectu creato a lapide, quod est quodam modo lapis et non vere lapis, sed diminute]"; [ii] em seguida, "uma espécie outra que não a coisa [speciem aliam a re]". Ou seja, são relacionados como meios para o ser da coisa no intelecto tanto a espécie como o verbo, isto é, aquelas duas similitudes intelectuais da coisa que já viemos estudando até aqui. No entanto, após a correção introduzida no texto, qualquer referência à espécie desaparece e resta unicamente o verbo como o 'outro' pelo qual a coisa adquire ser no intelecto. A passagem que antes introduzia a espécie inteligível no argumento torna-se, após a correção marginal, uma reafirmação da distinção entre a coisa e seu verbo no intelecto ${ }^{172}$.

Essa expunção da referência a species no intelecto em Suma, art. 34, q. 3, ad 3, poderia passar desapercebida não fosse o fato de que um movimento extremamente semelhante volta a ocorrer em Suma, art. 34, q. 4. Aqui, mais uma vez em uma passagem voltada para a comparação entre a simplicidade do ato divino de intelecção

ad se per essentiam, quod natum est, Deo efficiente, etiam existere extra divinum intellectum praeter esse cognitum, in esse existentiae quod est esse verum et perfectum”.

${ }^{172}$ Note-se, porém, que lemos em uma passagem sem qualquer correção de Suma, art. 34, q. 2, co. (ed. De Wulf-Mansion Centre, vol. 27, p. 172): "Sed in creaturis est diminutum esse quando non habent esse in intelligente nisi per suam speciem, quae non est veritas, sed imago rei". Como se vê, essa passagem concorda com a primeira versão do trecho de Suma, art. 34, q. 3, ad 3, citada na nota 170, onde a espécie inteligível é descrita como aquilo outro pelo qual a coisa possui verdade diminuída no intelecto. 
e a complexidade da intelecção humana, é possível notar outra tentativa eliminação de referências a espécies inteligíveis. Esse caso, porém, é mais complexo, pois comporta três camadas textuais. Na coluna à esquerda, lemos a tradução da primeira versão, que constitui o corpo do texto no ms. BNF lat. 15355; na coluna do meio, vemos o resultado de correções marginais iniciais no manuscrito; na coluna da direita, notamos que uma última leva de correções retira do texto final todo o trecho que nos interessa. Essa versão final é aquela que surge como corpo do texto na edição de Raymond Macken. Note-se, além disso, que a maior parte das correções marginais presentes nesse excerto do ms. BNF lat. 15355 é notada por Macken no aparato de sua edição e as poucas que escaparam ao editor foram, porém, registradas por Aiello e Wielockx. Sendo assim, com base no trabalho destes últimos, na edição de Macken e na consulta ao manuscrito em questão, apresento em nota uma tentativa de reconstrução do trecho anterior às correções e registro entre colchetes tais correções posteriores. Novamente, os trechos mais relevantes para nosso estudo surgem sublinhados nas traduções a seguir:

\section{$1^{a}$ versão ( $1^{a}$ camada)}

Ora, em Deus a forma inteligida é, na coisa, a mesma que o inteligente, diferindo somente pela razão, embora, em nós, estes quatro sejam diferentes na coisa [re, corr. de de, A]: $<\mathrm{i}>\quad \mathrm{o}$ intelecto, $<\mathrm{ii}>$ a coisa fora inteligida, <iii $>$ sua espécie no intelecto pela qual a

\section{corr. inicial ( $2^{a}$ camada)}

Ora, em Deus a forma inteligida é, na coisa, a mesma que o inteligente, diferindo somente pela razão, embora, em nós, estes quatro sejam diferentes na coisa [re, corr. de de, A]: $<\mathrm{i}>\mathrm{o}$ intelecto, $<\mathrm{ii}>$ a coisa fora inteligida, $<$ iiii $>$ o ato de inteligir e $<$ iv $>$ o verbo na

\section{última corr. $\left(3^{a}\right.$ camada $)$}

Ora, em Deus a forma inteligida é, na coisa, a mesma que o inteligente, diferindo somente pela razão ${ }^{173}$.

\footnotetext{
${ }^{173}$ Henrique de Gand, Suma, art. 34, q. 4, co. (ed. De Wulf-Mansion Centre, vol. 27, p. 197, 11. 69-70) - A = BNF lat. 15355, f. 156rb - AIELLO \& WIELOCKX, "La versione del Quodlibet IV, qq. 7-8...", 2008, p. 498: "In Deo autem est forma intellecta [intellecta supra lineam A] re eadem cum inteligente, differens sola ratione. Ut, cum in [in om. Macken] nobis ista quattuor sint re [corr. supra lineam a de A] differentia [differentia, om. Macken]: intellectus, res extra intellecta, species eius in intellectu, qua ipsam intelligit [species...intelligit per va-cat suppr. A], actus intelligendi de quidditate et essentia rei, quae est verbum mentis memoriae [ed. Aiello \& Wielockx $\mid$ mentis in esse ed. Macken], ut est apud animam [de quidditate...apud animam per va-cat suppr. et corr. in marg. per signum interpositum post intelligendi in et verbum mentis quo rem intelligit $A$-postrema corr. non notatur a $R$. Macken in editione sua, sed notatur a Aiello \& Wielockx], quod secundum philosophum est 'diminuta rei entitas' quam vocat 'ens quod est verum', ista, inquam, quattuor in cognitione Dei, qua intelligit se ipsum Deus, differunt ratione sola, quia id ipsum est intelligens [ed. Macken | intellectus ed. Aiello \& Wielockx], intellectum, actus, ratio intelligendi et notitia de intellecto quae respondet verbo nostro $<\ldots>$ [ut, cum... per va-cat suppr. A]". Acrescente-se que Aiello e Wielockx (no local indicado ao começo da nota) propõem, ainda, a distinção dos diversos copistas responsáveis por cada nível de correção. Em sua edição, estes autores apresentam como corpo do texto aquilo que, aqui, denomino como $2^{\mathrm{a}}$ camada textual.
} 
intelige, $<$ iv $>\quad o$ ato de inteligir sobre a quididade e a essência da coisa, a qual é o verbo da memória da mente enquanto é na alma, o qual é, segundo o Filósofo, a 'entidade diminuída da coisa', que ele chama de 'ente que é verdadeiro'. Estes quatro, digo, diferem somente pela razão no conhecimento de Deus, pelo qual Deus intelige a si mesmo, pois são o mesmo $<\mathrm{a}>\mathrm{o}$ inteligente, $<\mathrm{b}>\mathrm{o}$ intelecto, $<\mathrm{c}>$ o ato, $<\mathrm{d}>$ a razão de inteligir e $<\mathrm{e}>\mathrm{a}$ notícia sobre o inteligido, que corresponde ao nosso verbo $<\ldots>$. mente pelo qual intelige a coisa,

o qual é,

segundo o Filósofo, a 'entidade diminuída da coisa', que ele chama de 'ente que é verdadeiro'. Estes quatro, digo, diferem somente pela razão no conhecimento de Deus, pelo qual Deus intelige a si mesmo, pois são o mesmo $<\mathrm{a}>\mathrm{o}$ inteligente, $<\mathrm{b}>\mathrm{o}$ intelecto, $<\mathrm{c}>$ o ato, $<\mathrm{d}>\mathrm{a}$ razão de inteligir e $<\mathrm{e}>\mathrm{a}$ notícia sobre o inteligido, que corresponde ao nosso verbo $<\ldots>$.

Nas três versões, vemos a referência inicial à identidade real, no intelecto divino, de todos os elementos necessários para o conhecimento intelectual de Deus. No entanto, somente na primeira e na segunda versões é contraposto, ao caso de Deus, o caso do intelecto humano, no qual esses mesmos elementos necessários para a atualização do conhecimento intelectual diferem 'na coisa' (in re). Estabelecida tal contraposição, Henrique se volta para a enumeração desses elementos que, no caso da intelecção humana, são distintos realmente. Nas duas versões, há quatro elementos enumerados, sendo os dois primeiros [i] o intelecto e [ii] a coisa fora inteligida, havendo no quarto elemento uma referência ao verbum, “o qual é, segundo o Filósofo, a 'entidade diminuída da coisa', que ele chama de 'ente que é verdadeiro' [quod secundum philosophum est 'diminuta rei entitas' quam vocat 'ens quod est verum ']". Por fim, mais uma vez nas duas primeiras versões, reitera-se que, em Deus, todos estes são um mesmo realmente, diferindo somente em razão. Como se vê, portanto, o que muda da versão inicial para a segunda camada textual são os dois últimos itens enumerados dentre aqueles quatro necessários para o ato de intelecção humana.

Na primeira versão, os quatro itens são: " $<\mathrm{i}>$ o intelecto, $<\mathrm{ii}>$ a coisa fora inteligida, $<$ iii $>$ sua espécie no intelecto pela qual a intelige, $<\mathrm{iv}>\mathrm{o}$ ato de inteligir sobre a quididade e a essência da coisa". Como dito, a necessidade de que haja [i] um intelecto cognoscente e [ii] a coisa fora a ser inteligida é ponto pacífico nas duas versões. Por outro lado, todo o problema reside na enumeração dos dois itens 
seguintes, que caracterizam o ser que a coisa possui no intelecto enquanto cognoscível ou conhecida. Nessa primeira camada, Henrique de Gand introduz dois elementos internos ao intelecto: [iii] a espécie inteligível e [iv] o ato de inteligir. Essa enumeração está plenamente de acordo com o que vimos no decorrer desta capítulo: à presença da coisa como cognoscível ao intelecto pela espécie inteligível se segue essa coisa como atualmente conhecida no ato de inteligir. De fato, Henrique de Gand sublinha que o ato de inteligir é "sobre a quididade e a essência da coisa [de quidditate et essentia rei]", não sendo tal quididade ou essência senão a própria coisa naquele ser que ela possui na alma, isto é, naquele ser que ela possui como 'verbo' ("verbum mentis memoriae, ut est apud animam"). Perceba-se, porém, que o verbum não surge como um dos quatro requisitos necessários da intelecção, embora tampouco se identifique completamente a nenhum dos outros quatro. Talvez possamos dizer que o verbo é, aqui, o ser que a coisa possui na alma enquanto inteligida em ato e não somente enquanto inteligível na espécie inteligível. Mesmo assim, o 'verbo' parece não encontrar um lugar apropriado nessa primeira versão da enumeração.

Já na segunda enumeração o caso é o oposto, pois agora o verbo adquire um local apropriado e desaparece a referência à espécie inteligível. Os quatro elementos são, agora: " $<\mathrm{i}>\mathrm{o}$ intelecto, $<\mathrm{ii}>$ a coisa fora inteligida, $<\mathrm{iii}>\mathrm{o}$ ato de inteligir $\mathrm{e}<\mathrm{iv}>$ o verbo na mente pelo qual intelige a coisa”. Agora, o 'verbo na mente' não é mais apresentado como parte do ato de inteligir, mas surge como um elemento posterior a esse ato e, mais precisamente, como aquilo 'pelo que' o intelecto intelige a coisa (“quo rem intelligit"). Mais uma vez, o verbum é a própria coisa em seu ser diminuído, mas agora a ênfase recai sobre o ser que a coisa possui enquanto já inteligida, uma vez o ser somente inteligível da coisa (que, antes, era destacado pela remissão à espécie inteligível) não é nem mesmo mencionado.

Como vemos, as alterações realizadas tanto em Suma, art. 34, q. 4, como em Suma, art. 34, q. 3, ad 3, possuem em comum o fato de enfatizarem o papel do verbum no processo de intelecção e, ao fazê-lo, excluir as referências originais à species. Note-se que, em ambos os casos, o verbum já era citado na versão original ao lado da species, porém as supressões das menções à species e as alterações contíguas fizeram com que a ênfase nos dois casos recaísse sobre o verbum como o ser (diminuído) que a coisa inteligida possui no intelecto. Mas, por que razão Henrique suprimiria as referência à espécie inteligível nesses textos e não em obras contemporâneas, como os trechos de Quodl. 4, que leremos adiante? 
Meu palpite seria que a supressão das menções à species nesses trechos de Suma, art. 34, está conectada à tentativa, que assistimos nos trabalhos de Henrique de Gand nesse período, de repensar o papel da espécie inteligível na intelecção. Em particular, talvez essa supressão seja fruto de uma incerteza sobre como caracterizar a relação entre intelecto e sentido por meio da espécie inteligível (agora, ao que parece pela leitura de Suma, art. 33, q. 2, já tomada como expressa, em oposição àquela impressa). O que seria esse 'ser inteligível' que a coisa possui na espécie inteligível? Seria isso algo no sentido ou no intelecto? E em que medida o intelecto, que abstrai a partir dos sentidos, poderia obter algo inteligível, isto é, que não possuía ser dessa forma nos sentidos? Que essa fosse uma dificuldade enfrentada por Henrique de Gand no período em que fez tais correções fica claro no trecho que apresentamos a seguir. Esse trecho surge no corpo do texto no ms. BNF lat. 15355 e no aparato crítico da edição de Raymond Macken, tendo sido, após correções, retirado da redação final de Suma, art. 34, q. 5:

\begin{abstract}
"De fato, uma vez que $<$ o intelecto $>$ nada recebe da coisa fora senão a espécie sensível na cor e similares, nos outros sensíveis próprios e comuns - primeiro no sensitivo particular, em segundo lugar na fantasia, em terceiro lugar no intelecto -, por ela, não conhece senão o sensível, seja sob a razão do universal ou sob a razão do particular.

E, se conhece algo para além disso, é inteligindo - isto é, 'lendo o interior' [intus legendo] - e cavando sob a espécie sensível para compreender algo inteligível que não é captado pelo sentido, o que diz respeito à quididade compreensível, que não é captada senão pelo intelecto, de que é objeto por si, e isso segundo a arte de investigar o que é [quod quid est], transmitida no livro dos Posteriores e no livro das Divisões de Boécio. Essa arte, de fato, é demasiado universal e não mostra o que é [quod quid est], mas somente ensina a buscar [venari] as partes, mas não mostra a verdade delas $<\ldots>$, ${ }^{174}$.
\end{abstract}

Nesse trecho, notamos que Henrique de Gand vê o conhecimento intelectual como estritamente limitado pelos sentidos. Nada que se conhece intelectualmente vai

\footnotetext{
${ }^{174}$ Henrique de Gand, Suma, art. 34, q. 5, co. (ed. De Wulf-Mansion Centre, vol. 27, p. 223, app.) - A = BNF lat. 15355, f. 159va, 11. 37-50: "Cum enim de re extra nihil recipit nisi speciem sensibilem in colore et similia, et aliis sensibilibus propriis et communibus, primo in sensitivo particulari, secundo in phantasia, tertio in intellectu, per ipsam non cognoscit nisi sensibile, vel sub ratione universalis, vel sub ratione particularis.

Et si cognoscit aliquid amplius, hoc est intelligendo, id est intus legendo, et sub specie sensibili fodiendo ad comprehendendum aliquid intelligibile quod non capitur a sensu, quod pertinet ad comprehensibilem [correxi, sed comprehensibilis legitur in A, Macken] quiditatem, quae non capitur nisi ab intellectu, cuius est per se obiectum, et hoc secundum artem investigandi quod quid est, traditam in libro Posteriorum et in libro Divisionum Boethii. Quae quidem ars multum universalis est, nec ostendit quod quid est, sed tantum docet venari partes, sed non ostendit earum veritatem $<\ldots$... [esse trecho é parte de um excerto maior excluído por va-cat em $A$ ]. Cf. GOEHRING, Henry of Ghent on Cognition..., 2006, pp. 227-35.
} 
além do conhecimento sensível e, se podemos compreender algo de não sensível pelo intelecto, tal conhecimento, ainda que complexo, será sempre demasiado geral. Ou seja, voltamos a uma temática que já encontramos no começo deste capítulo, a saber, a caracterização do conhecimento intelectual como maximamente geral - a diferença é que, aqui, tal caracterização parece também atingir o conhecimento complexo e não somente o incomplexo. Com efeito, se em Suma, art. 1, q. $5^{175}$, o conhecimento incomplexo era descrito como maximamente geral (ele era o conhecimento de conceitos primeiros como 'ente', 'um' etc.), agora em Suma, art. 34, q. 5, o conhecimento incomplexo nem mesmo escapa aos sentidos e o conhecimento complexo, que os ultrapassa, assume o posto daquele conhecimento intelectual que, embora escape aos sentidos, permance demasiado geral.

Sem dúvida, devemos manter em mente que o trecho destacado de Suma, art. 34, q. 5, foi excluído da versão final dessa questão pelo Doutor Solene. Por outro lado, a temática da estreita relação entre a intelecção incomplexa - isto é, dos conceitos simples - e o conhecimento sensitivo surge em trechos não expungidos por Henrique, como é o caso de Suma, art. 24, q. 8, onde se afirma que dois são requeridos para a perfeição do conhecimento intelectivo: “o primeiro destes é o verbo do intelecto pelo qual é informado ao conceber o que é sobre a coisa [quod quid est de re], enquanto o segundo é o juízo sobre tal conceito, sem o qual o intelecto não é puro, mas permanece sempre fantástico. E o primeiro é o intelecto dos simples [intellectus simplicium] <... ${ }^{176}$. Como se vê, aqui o conceito simples é tão fortemente limitado ao conhecimento sensível - e, particularmente, imaginativo - que tal intelecção pode ser, mesmo, descrita como um 'intelecto fantástico' (intellectus $<\ldots>$ phantasticus). Por outro lado, nesse trecho de Suma, art. 24, q. 8, o juízo intelectivo surge descrito como um conhecimento capaz de ultrapassar o conhecimento sensível. Isso não é de todo incompatível com o que líamos no trecho expungido de Suma, art. 34, q. 5, onde se adicionava, porém, que, não obstante o juízo do intelecto ultrapasse o conhecimento sensível, este mesmo juízo permanece em um

\footnotetext{
${ }^{175}$ Cf., acima, nota 37.

${ }^{176}$ Henrique de Gand, Suma, art. 24, q. 8, co. (ed. Decorte \& Teske, p. 256): "Et in hoc perficitur cognitio intellectiva, ad quam duo requiruntur. Quorum primum est verbum intellectus quo informatur concipiendo quod quid est de re. Secundum vero est iudicium de tali conceptu sine quo intellectus purus non est, sed semper phantasticus manet. Et est primus intellectus simplicium <...". Cf. MARRONE, "Henry of Ghent's Epistemology", 2011, p. 218. Voltaremos a esse trecho adiante, no Epílogo da parte 2, nota 3.
} 
âmbito demasiado geral, não fornecendo um conhecimento apropriado acerca da coisa inteligida por meio dos sentidos.

Enfim, parece-me que a leitura dos artigos 33 e 34 da Suma de Henrique de Gand (diferenciando, neste último, as diversas camadas textuais) nos mostra como parecia problemática, a seus olhos, a relação entre intelecto e sentido. Mais do que isso, ela mostra como a articulação dessas duas similitudes da coisa no intelecto - isto é, a espécie e o verbo - surgiam como atores centrais na tentativa de desvendar aquela relação. Nesse contexto, introduz-se a distinção entre 'espécie impressiva' e 'espécie expressiva' na tentativa de melhor delimitar o ser que o objeto possui no intelecto em contraposição ao ser que ele possui no sentido (embora, como visto na capítulo 5, a caracterização do estatuto da espécie na imaginação permaneça polêmica). Um primeiro texto em que o Doutor Solene aborda tal problemática sob esse prima é o seu quarto Quodlibet, para o qual nos voltamos agora.

\subsubsection{Quodl. 4}

Já tivemos a aportunidade de ler alguns excertos de Quodl. 4, q. 7, em nosso estudo sobre o conhecimento de si e sobre o conhecimento do beato (item 6.3). Notamos que nesse texto Henrique de Gand desenvolve uma clara problematização da noção de 'espécie inteligível', estabelecendo certas bases para sua distinção entre 'espécie impressiva' e 'espécie expressiva'. Isso, porém, não é tudo. Se, nos casos do conhecimento de si e do conhecimento beatífico, o uso da noção de espécie (ainda que expressiva), se mostra dificultado por diversos fatores (em particular, pela identificação completa entre o objeto de conhecimento e a coisa conhecida), já há em Quodl. 4, q. 7, algumas pistas do papel central que a espécie expressiva ganhará na doutrina da intelecção de Henrique como um todo:

“ $<\ldots>$ o inteligido é conjugado ao inteligente mais verdadeiramente pela
presença da essência do que por alguma espécie sua. $\mathrm{E}<$ isso $>$ é a sua forma não
inerente como em um sujeito para elicitar uma ação em outro ou acerca de outro,
mas é a forma objetivada àquele $<s c$. ao intelecto $>$ como ao cognoscente, de
maneira a mover o intelecto para percebê-la. E, por esse modo, deles faz-se um
único, como do inteligente e do inteligido, isto é, como do movente e do movido,
porém não como da forma e do sujeito. E, uma vez que o ato de inteligir
elicitado no inteligente por tal união é informado segundo uma espécie e forma
não impressiva, mas expressiva de tal objeto e o próprio ato informa o intelecto 
tal como operação intrínseca inerente a ele, também por isso o próprio inteligido se assimila ao inteligente" ${ }^{177}$.

À primeira vista, essa passagem nos põe em face de uma situação claramente condicionada: se o objeto estiver presente ao intelecto por sua essência, então não há necessidade de espécies para que haja a união entre inteligido e inteligente. Essa tese, porém, se complexifica no passo seguinte do argumento, onde Henrique de Gand afirma que, nesse caso de conhecimento, não há espécies se a tomamos como uma forma inerente a um sujeito. Entretanto, é plenamente admissível que consideremos a própria essência como uma forma dada como objeto ao intelecto como a um cognoscente - nesse sentido, essa própria forma é uma espécie expressiva do objeto cognoscível. Interpretado dessa maneira, o caso de intelecção descrito pelo Doutor Solene começa a abandonar seu caráter de exceção para tomar contornos de uma doutrina da inteleção mais generalizada. Começamos a ver que, para Henrique, a presença do objeto no intelecto se dá, em geral, não por um acidente que inere em um sujeito, mas pela essência dada como objeto inteligível ao intelecto como ao cognoscente - ou, o que é o mesmo, não por espécie impressiva, mas por espécie expressiva. No que se segue deste item, veremos que muitos elementos de Quodl. 4 apontam para uma tal concepção de conhecimento intelectivo sem, no entanto, formulá-la explicitamente. Por isso mesmo, tal texto tem sido recentemente de interesse para os estudiosos da doutrina da intelecção do Doutor Solene, ainda que seja, em geral, lido à luz de outras obras suas ${ }^{178}$.

\footnotetext{
${ }^{177}$ Henrique de Gand, Quodl. 4, q. 7, co. (ed. De Wulf-Mansion Centre, vol. 8, pp. 34-5): “<..> intellectum coniunctum est intelligenti verius per essentiae praesentiam quam per aliquam eius speciem, et est forma illius non inhaerens ut subiecto ad aliquam actionem eliciendum in aliud vel circa aliud, sed est forma ipsi obiecta ut cognoscenti ad intellectum movendum ad se percipiendum. Et per hunc modum unum ex eis fit, ut ex intelligente et intellecto, id est ut ex movente et moto, non autem ut ex forma et subiecto. Et quia actus intelligendi elicitus in intelligente ex tali unione informatur secundum speciem et formam non impressivam, sed expressivam talis obiecti, et ipse actus informat intellectum tamquam operatio intrinseca ei inhaerens, ac per hoc ipsum intellectum assimilat sibi intelligentem".

${ }^{178}$ Cf. NYS, De werking van het menselijk verstand..., 1949, pp. 70-88; BETTONI, Il processo astrattivo..., 1954, pp. 39-63 (passim); BROWN, J. V. "Abstraction and the Object the Human Intellect...", 1973, pp. 85-90; BROWN, J. V. "Intellect and knowing in Henry of Ghent", 1975 (passim); TERÄVÄINEN, Henrik Gentiläinen tieto-oppi, 1975, pp. 14-7, 24, 30, 34; MARRONE, Truth and Scientific Knowledge..., 1985, pp. 70-92; SORGE, Gnoseologia e teologia..., 1988, pp. 77108 (passim); TACHAU, Vision and Certitude..., 1988, pp. 28-39 (passim); SPRUIT, Species intelligibilis I, 1994, pp. 205-12 (passim); PASNAU, Theories of Cognition..., 1997, pp. 306-10 (passim); BOULNOIS, Être et représentation, 1999, p. 74; GORIS \& PICKAVÉ, "Von der Erkenntnis der Engel", 2001, pp. 128-32; MARRONE, The Light of Thy Countenance..., 2001, vol. 2, pp. 366-88 (passim); PINI, "Il dibattito sulle specie intelligibili...", 2004, pp. 287-8; FIORENTINO, "Species nei secoli XIII-XIV”, 2007, pp. 92-6; MARRONE, "Henry of Ghent’s Epistemology”, 2011, pp. 233-6;
} 
Dito isso, no Quodl. 4 de Henrique de Gand, para além da q. 7, duas são as questões mais relevantes para nós, a saber, as qq. 8 e 21. Destas, a primeira pergunta "se o beato, que vê ou intelige Deus nuamente por sua essência, forma em si um verbo sobre Deus [utrum beatus videns seu intelligens Deum nude per essentiam suam formet in se verbum de Deo]"179. Uma vez que já vimos a resposta de nosso autor a essa pergunta ${ }^{180}$, nos interessarão aqui principalmente certos elementos coadjuvantes da solução dessa questão, nomeadamente, suas referências à espécie e ao verbo envolvidos na intelecção humana tomada de modo geral (isto é, não na consideração do caso sui generis do conhecimento que o beato possui sobre Deus). Como veremos adiante, a referida q. 21 do Quodl. 4 é importante por precisar a noção de 'espécie inteligível' utilizada na q. 8, onde o central é o verbum.

Pois bem, já no início da determinação de Quodl. 4, q. 8, Henrique de Gand introduz a distinção entre 'espécie (ou forma) impressiva' e 'espécie (ou forma) expressiva':

\begin{abstract}
"Cumpre dizer quanto a isso que aquele que vê ou intelige a divina essência nua por um intelecto glorioso intelige aquilo que é Deus - isto é, o que é dele [quod quid est eius] -, que é o seu ser totalmente simples e puro, ao qual nada outro pode ser similar, seja como espécie ou forma impressiva e razão de conhecer (como é patente na questão precedente), seja similarmente como forma expressiva pela qual objetivamente se conheça (tal como a forma de homem, enquanto quididade e essência, é objeto do intelecto enquanto conhecido nele e enquanto razão de conhecer tudo o que ocorre a nós - a saber, se é homem ou não -, como foi dito segundo Agostinho, na questão precedente). E tal forma possui ser no intelecto enquanto conhecido no cognoscente, não enquanto em um sujeito <... . E, assim, esta forma e aquela, de que há menção na questão, se portam de modo quase que contrário com respeito ao intelecto. Aquela, de fato, possui ser no cognoscente não enquanto conhecido, mas enquanto acidente no sujeito, esta forma possui ser no cognoscente enquanto conhecido e possui nele o seu ser diminuído. Porém, na coisa fora, possui ser perfeito, embora seja a mesma razão formal dela, enquanto é no intelecto e na coisa fora" ${ }^{181}$.
\end{abstract}

ROMBEIRO, "Intelligible Species in the Mature Thought of Henry of Ghent", 2011 (passim); COLLI, A. "Ab utroque notitia paritur. Il De trinitate e il processo asttrativo aristotelico tra XIII e XIV secolo". Medioevo 37 (2012), pp. 231-59 (esp. pp. 249-54); GOEHRING, "Henry of Ghent's Use of Aristotle's De anima...", 2013, pp. 76-96; PICKAVÉ, "Causality and Cognition...”, 2015 (passim). Cf. tb., adiante, as notas 192-196.

${ }^{179}$ Henrique de Gand, Quodl. 4, q. 8 (ed. De Wulf-Mansion Centre, vol. 8, p. 53).

${ }^{180}$ Cf., acima, notas 147.

${ }^{181}$ Henrique de Gand, Quodl. 4, q. 8, co. (ed. De Wulf-Mansion Centre, vol. 8, p. 55): "Dicendum ad haec quod videns sive intelligens intellectu glorioso nudam divinam essentiam intelligit id quod est Deus, sive quod quid est eius, quod est omnino simplex et purum esse eius, cui non potest aliquid aliud esse simile, aut tamquam species sive forma impressiva et ratio cognoscendi, ut patet ex quaestione praecedenti, neque similiter sicut forma expressiva qua obiective cognoscatur, quemadmodum forma hominis, ut quidditas et essentia, obiectum est intellectus ut cognitum in ipso, et ut ratio cognoscendi omne quod nobis occurrit, an scilicet sit homo vel non, ut dictum est secundum Augustinum in 
Pois bem, como dito, não nos importa tanto neste momento a negação de que haja espécies no conhecimento beatífico, mas antes a distinção entre espécie impressiva e espécie expressiva avançada neste trecho. Note-se, primeiramente, que a descrição de cada uma é bem semelhante àquelas que vimos no cap. 4. Assim, a espécie impressiva "possui ser no cognoscente $<\ldots>$ enquanto acidente no sujeito [habet esse in cognoscente <... ut accidens in subiecto]", enquanto que a espécie expressiva "possui ser no intelecto enquanto conhecido no cognoscente [habet esse in intellectu ut cognitum in cognoscente]”. Além disso, adiciona-se aqui que a espécie expressiva possui, no intelecto, um 'ser diminuído' (esse suum diminutum) com respeito ao ser perfeito (esse perfectum) que a coisa conhecida possui fora do intelecto. Além disso, sublinhe-se que, se o Doutor Solene se utiliza do termo 'species' nesse trecho, ele prefere a palavra 'forma' - destarte, temos uma distinção entre forma impressiva e forma expressiva. Se, em um primeiro momento, não fica claro o porquê dessa preferência, as frases finais do excerto mostram sua utilidade: a forma expressiva possui um 'ser diminuído' no intelecto, porque ela mesma - ou seja, essa própria forma - possui ser perfeito na coisa fora do intelecto. Portanto, a palavra forma, mais do que a palavra species, estabelece a identidade formal entre coisa fora, espécie impressiva e espécie expressiva, distinguindo-as somente por seu modo de ser (respectivamente, perfeito, como acidente no sujeito e como o conhecido no cognoscente com um ser diminuído).

Dito isso, há um patente problema no trecho em questão, pois ele parece sugerir que haveria tanto espécies impressivas como espécies expressivas no intelecto, quando lemos que "esta forma e aquela $<\ldots>$ se portam de modo quase que contrário com respeito ao intelecto [forma ista et illa, de qua mentio est in quaestione, modo contrario quasi se habent ad intellectum]". Nessa caso, tal excerto de Quodl. 4, q. 8, seria frontalmente oposto ao que líamos em Quodl. 5, q. 14, onde as espécies impressas pareciam ser reservadas para os sentidos ${ }^{182}$. Para esclarecer essa dificuldade, será útil avançarmos para a leitura de Quodl. 4, q. 21, onde se pergunta

quaestione praecedenti. Et huiusmodi forma habet esse in intellectu ut cognitum in cognoscente, non ut in subiecto $\langle\ldots\rangle$. Et sic forma ista et illa, de qua mentio est in quaestione, modo contrario quasi se habent ad intellectum. Illa enim habet esse in cognoscente non ut cognitum, sed ut accidens in subiecto, et haec forma in cognoscente habet esse ut cognitum et habet in eo esse suum diminutum. In re autem extra habet esse perfectum, licet sit eadem ratio formalis eius, ut in intellectu est et in re extra".

${ }^{182}$ Cf. cap. 4, nota 79 . 
"se o intelecto conjugado pode inteligir algo [utrum intellectus coniunctus possit aliquid intelligere]"183. Como vemos, essa questão, diferentemente de Quodl. 4, q. 8, aborda precisamente o problema do conhecimento intelectual da alma unida ao corpo.

No início de sua determinação, após notar que o intelecto humano unido ao corpo pode sim inteligir ${ }^{184}$, Henrique se volta para a explicação do modo pelo qual se gera tal conhecimento, onde é pressuposto que o intelecto possível, assim como o sentido, está em potência para o cognoscível. Isso não é nada novo para nós. Por outro lado, interessa-nos sobremaneira a distinção introduzida a seguir, pois o Doutor Solene adiciona que, embora ambos - intelecto e sentido - sejam potenciais, eles não o são igualmente. Assim, tanto o sentido está em potência para o sensível, como o intelecto está em potência para o inteligível, mas cada um está em potência a seu modo próprio para receber a forma de seu cognoscível próprio. A partir dessa distinção do modo de potencialidade de cada uma das potência cognoscitivas, introduz-se aqui a distinção entre ‘espécie impressiva' e 'espécie expressiva’:

"Para entendê-lo, é preciso saber que, segundo o Filósofo em De anima 3 e o
Comentador, o nosso intelecto possível é 'do gênero das virtudes passivas' de
algum modo, a saber, pois recebe a forma que apreende e é em potência para ela,
mas não é transmutável por ela, pois não é material tal como é o sentido, tal que
o intelecto não é em potência o inteligível tal como o sentido o sensível. Já que, a
saber, o sentido possui, a partir do objeto, uma espécie recebida impressiva, pela
qual é conduzido por transmutação natural do sentido da potência ao ato, não
somente tal que, formado em potência, seja informado em ato pela recepção da
espécie impressiva no sujeito, permanecendo aí [ut ibi sit status], mas tal que
ulteriormente o sentiente em potência faça-se sentiente em ato pela recepção da
espécie expressiva, não como no sujeito, mas no cognoscente. Porém, o intelecto
material não recebe nenhuma espécie impressiva a partir do objeto, mas somente
expressiva, pela qual de inteligente em potência se torna inteligente em ato. De
fato, é preciso que, segundo alguma similitude, tal como o sentido está para os
sensíveis, assim também o intelecto esteja para os inteligíveis. De fato, uma vez
que uma coisa não se move senão enquanto é em ato e é movida enquanto é em
potência, é necessário que, enquanto as formas são em ato fora da alma, movam
a alma racional enquanto <esta> as apreende, embora nada imprimam nela, tal
como é necessário que os sensíveis, enquanto são fora em ato, movam o sentido
e tal que o sentido seja movido a partir deles pela recepção da espécie expressa e
impressa"

${ }^{183}$ Henrique de Gand, Quodl. 4, q. 21 (ed. De Wulf-Mansion Centre, vol. 8, p. 335).

${ }^{184}$ Henrique de Gand, Quodl. 4, q. 21, co. (ed. De Wulf-Mansion Centre, vol. 8, p. 336): "Dicendum ad hoc quod intellectus nobis coniunctus potest ex natura sua intelligere et universalia rerum sensibilium, ut obiecta abstracta ab imaginativa existente in actu virtute intellectus agentis proponentis ea, sicut in cognoscente in intellectu possibili, et similiter particularia, ut sunt existentia in imaginativa secundum actum per universalia abstracta, ut per rationes intelligendi”. Sobre o conhecimento intelectual do singular, cf. a nota 190 , adiante.

${ }^{185}$ Henrique de Gand, Quodl. 4, q. 21, co. (ed. De Wulf-Mansion Centre, vol. 8, pp. 337-8): “Ad cuius intellectum oportet scire quod secundum Philosophum in III $^{\circ}$ De anima et Commentatorem intellectus 
Já vimos longamente no cap. 4 o quanto deve ser problematizado, no contexto da obra de Henrique de Gand, a atribuição de espécies impressivas $e$ expressivas aos sentidos nesse trecho de Quodl. 4, q. 21. Assim, interessa-nos aqui, antes, a atribuição exclusiva de espécies expressivas ao intelecto, com a exclusão de qualquer 'espécie impressiva intelectual'. Concentremo-nos, portanto, em compreender o porquê da necessidade de tais espécies expressivas no intelecto de acordo com esse último trecho.

Primeiramente, como já mencionado antes da citação, é fundamental aqui o limite da aproximação entre sentido e intelecto: ambos são potências para o recebimento de formas, porém elas são potências diferentemente. O problema está, precisamente, em saber qual seria a diferença relevante neste caso. Mas, antes, pergunto: o que significa, nesse contexto, dizer que ambos são potências? Henrique parece nos dizer quando afirma: "é preciso que, segundo alguma similitude, tal como o sentido está para os sensíveis, assim também o intelecto esteja para os inteligíveis [Oportet enim quod secundum aliquam similitudinem sicut sensus se habet ad sensibilia, sic et intellectus se habeat ad intelligibilia]". Assim, sentido e intelecto são potências na medida em que estão para seus objetos segundo uma similitude. Essa similitude é resultado, como também nos explica o trecho, de um movimento da alma provocado por uma forma fora dessa mesma alma. Portanto, ao que parece, dizer que sentido e intelecto são potência significa, aqui, afirmar que ambos se relacionam com seus objetos por meio de similitudes neles produzidas e recebidas a partir de uma forma externa à alma.

noster possibilis est 'de genere virtutum passivarum' quoquo modo, scilicet quia recipit formam quam apprehendit et est in potentia ad eam, sed non transmutabilis ab ea, quia non est materialis sicut est sensus, ut per hoc non sic est intellectus in potentia intelligibile, sicut est sensus sensibile, in eo videlicet quod sensus ab obiecto habet speciem receptam impressivam, qua deducitur per transmutationem naturalem sensus de potentia in actum, non solum ut in potentia formatum actu informetur receptione speciei impressivae in subiecto, ut ibi sit status, sed ut ulterius potentia sentiens fiat actu sentiens receptione speciei expressivae, non ut in subiecto sed in cognoscente, intellectus vero materialis ab obiecto nullam recipit speciem impressivam, sed solum expressivam, qua de potentia intelligente fit actu intelligens. Oportet enim quod secundum aliquam similitudinem sicut sensus se habet ad sensibilia, sic et intellectus se habeat ad intelligibilia. Cum enim res non movet nisi secundum quod est in actu, et movetur secundum quod est in potentia, necesse est in quantum formae sunt in actu extra animam, quod moveant animam rationalem secundum quod apprehendit eas, licet nihil imprimant in eam, quemadmodum sensibilia in quantum sunt extra in actu, necesse est ut moveant sensus et ut sensus moveatur ab eis receptione speciei expressae et impressae". O trecho dessa passagem relativo aos sentidos já foi citado, acima, em cap. 4, nota 59. Cf. NYS, De werking van het menselijk verstand..., 1949, p. 81; BROWN, J. V. "Intellect and Knowing...”, 1975, p. 509. 
A diferença dessas duas potências está no modo como cada uma recebe tal similitude ou, dito de outra forma, no modo como a forma externa produz tal similitude em cada potência. Nos sentidos, a forma externa imprime uma espécie, porém ela não o faz no intelecto - "é necessário que, enquanto as formas são em ato fora da alma, movam a alma racional enquanto <esta $>$ as apreende, embora nada imprimam nela [necesse est in quantum formae sunt in actu extra animam, quod moveant animam rationalem secundum quod apprehendit eas, licet nihil imprimant in eam]". Não obstante, o surgimento da espécie expressa no intelecto ainda é caracterizado como a recepção de uma similitude - por outro lado, é claramente excluído que tal recepção possa ser dita uma 'impressão' ou caracterizada como a recepção de um acidente em um sujeito. Em poucas palavras, a distinção entre 'espécie impressiva' e 'espécie expressiva' surge, neste trecho, no contexto de uma distinção mais ampla entre sentido e intelecto como duas potências receptoras da ação de algo externo, mas diferentemente receptoras.

Ora, isso não nos diz muito acerca da exclusão de qualquer espécie impressa da atividade intelectual. Decerto, sabemos que ela não corresponde ao modo típico de recepção do objeto pelo intelecto, mas não sabemos ainda o porquê disso. Com efeito, argumentos precisos para a possibilidade exclusiva da recepção de espécies expressivas pelo intelecto só serão encontrados no Quodl. 5, de maneira que buscá-los aqui em Quodl. 4, q. 21, será vão. De outra parte, essa última questão oferece ainda diversas informações que nos ajudam a compreender o papel da espécie expressa para a atualização do conhecimento intelectual, de modo que vale a pena avançarmos em sua leitura.

Pois bem, se retornamos ao último trecho indentado, vemos que tanto o sentido como o intelecto são potências porque precisam ser movidos por algo para passarem ao ato. Ambos são movidos por algo externo, porém cada qual à sua maneira - isto é, como se dizia, cada qual recebe seu objeto a seu modo próprio. Há porém, como já vimos repetidamente, uma ordem nessa recepção, pois primeiro a forma externa se imprime nos sentidos e, somente em seguida, ela age (por meio dos sentidos) no intelecto. Como, entretanto, a forma nada pode imprimir no intelecto (uma vez que este possui somente espécies expressivas), é preciso que o intelecto se atualize a partir do conhecimento sensível - nas palavras de Henrique, ele deve inteligir com a ajuda dos sentidos: 


\begin{abstract}
"E, por isso, é preciso [oportet] que a alma racional, por não possuir nada das coisas impresso pelos sentidos, intelija ainda assim com a ajuda dos sentidos ela precisa [indiget] considerar as intenções que são na virtude imaginativa, tal como os sentidos [precisam] inspecionar os sensíveis fora. Mas, antes que as intelija em ato, é preciso [oportet] que a mente primeiro as retire das condições particulares e, assim, as faça inteligidas em ato depois de serem inteligidas em potência" ${ }^{\prime 86}$.
\end{abstract}

Note-se como, apesar da caracterização fundamentalmente passiva do intelecto em Quodl. 4, q. 21, a alma racional surge associada a atividades, nesse trecho, quando comparada aos sentidos: os sentidos não imprimem algo na alma racional, mas esta última 'considera' (considerare) as intenções na virtude imaginativa (tal como, aliás, os sentidos também se volta para o externo, pois há uma atividade dos sentidos, como também vimos no cap. 4). Da mesma maneira, antes mesmo de poder considerar o objeto na virtude imaginativa, a alma racional deve agir 'retirando' (auferat) dele as condições particulares. Ou seja, muito embora a caracterização geral do intelecto seja aquela de uma potência passiva por ser fundamentalmente receptivo, ele nada recebe diretamente da coisa fora ou dos sentidos, mas antes deve preparar seu próprio objeto. Assim, antes mesmo de agir para a produção da intelecção em ato, o intelecto deve agir para produzir seu objeto a partir daquele que havia no fantasma:

De acordo com isso, concorre necessariamente para o intelecto atual uma dupla ação. $<\mathrm{i}>$ Uma, que é a primeira, do intelecto acerca do objeto que, de si, não é senão inteligível em potência, tal que pela abstração torne-se inteligível em ato. $<$ ii $>$ Outra, que é a segunda, do objeto abstraído acerca do intelecto, para elicitar [ad eliciendo], a partir dele, o ato de inteligir que, novamente, termina no mesmo objeto, pelo qual informa o ato de inteligir. De acordo com isso, a mente racional, enquanto os inteligidos a movem, é uma força passiva, enquanto são movidos por ela, é uma força ativa. Tal que, por isso, seja necessário propor nela duas virtudes - a saber, uma de ação e uma virtude de paixão, das quais uma é dita 'intelecto agente' e outra é dita 'intelecto possível'. E o intelecto agente é o que abstrai o inteligível em ato do inteligível em potência, pondo-o como objeto inteligível no intelecto possível como inteligente, extraindo-o da potência de inteligir ao ato e fazendo um inteligente em ato de um inteligente em potência. E, para tanto, primeiro desnuda as formas das matérias e, depois, as torna, já tornadas universais, inteligidas em ato depois de serem inteligidas em potência" $" 187$.

\footnotetext{
${ }^{186}$ Henrique de Gand, Quodl. 4, q. 21, co. (ed. De Wulf-Mansion Centre, vol. 8, p. 338): "Et ideo anima rationalis, quia nihil sibi habet de rebus per sensus impressum, oportet tamen adminiculo sensuum intelligere, indiget considerare intentiones quae sunt in virtute imaginativa, sicut sensus inspicere sensibilia extra. Sed antequam illas actu intelligat, oportet quod mens primo auferat eas a condicionibus particularibus et sic faciat eas intellectas in actu postquam erant in potentia intellectae $<\ldots>$.

${ }^{187}$ Henrique de Gand, Quodl. 4, q. 21, co. (ed. De Wulf-Mansion Centre, vol. 8, pp. 338-9): “< ..> ut
} 
A bem dizer, reencontramos aqui aquela distinção similiar àquela líamos em Suma, art. 1 (no item 6.2) entre [i] uma ação de abstração pela qual o inteligível em potência é tornado inteligível em ato e [ii] uma ação pela qual o inteligido em potência é tornado inteligido em ato, pelo que há a intelecção em ato. Destas, a primeira é descrita como uma ação do intelecto acerca do objeto, enquanto que a segunda é, pelo contrário, uma ação do objeto acerca do intelecto. Como se vê, porém, o objeto que age acerca do intelecto já é aquele objeto produzido pelo próprio intelecto a partir das intenções que considerava na imaginação. Ou seja, não há algo externo (fora da alma ou nos sentidos) que se imprima no intelecto; antes, o próprio intelecto faz o inteligível em ato e este, por sua vez, atualiza o intelecto acerca de si, isto é, produz a sua intelecção em ato. Mais uma vez, para distinguir os aspectos passivo e ativo da 'mente racional' (mens rationalis) necessários para que haja essa sucessão de ações e paixões, Henrique introduz a distinção entre as duas forças (vires) da mente racional: o intelecto agente e o intelecto possível.

Nesse ponto, porém, há um certo afastamento com respeito à caracterização da segunda ação do intelecto como proveniente exclusivamente do objeto. De fato, se no início do excerto era dito que a produção da intelecção em ato era uma ação "do objeto abstraído acerca do intelecto [obiecti abstracti circa intellectum]", após a introdução da noção de 'intelecto agente' afirma-se que este último age para os dois atos do intelecto: ele [i] abstrai a forma da matéria (e, mais precisamente, das condições materiais), tornando-a inteligível e, portanto, universal, bem como [ii] a torna inteligida em ato. Assim, não obstante a cuidadosa distinção das duas ações, dos dois atos e das duas forças no intelecto, esse trecho não parece permitir uma decisão acerca do agente que move o intelecto para seu segundo ato, isto é, para o ato de intelecção. Como veremos mais a frente, a solução de Henrique de Gand será afirmar

secundum hoc ad actualem intellectum duplex actio necessario concurrit: una, quae est prima, intellectus circa obiectum quod de se non est nisi in potentia intelligibile, ut per abstractionem fiat actu intelligibile; alia, quae est secunda, obiecti abstracti circa intellectum ad eliciendum ex ipso actum intelligendi, qui iterato terminatur in idem obiectum, per quod informat intelligendi actum, ut secundum hoc mens rationalis, in quantum intellecta movent eam, est vis passiva, secundum quod moventur ab ea, est vis activa, ut ideo necesse sit ponere in ea duas virtutes, scilicet actionis et virtutem passionis, quarum una dicitur intellectus agens, alia vero dicitur intellectus possibilis. Et est intellectus agens abstrahens de potentia intelligibili actu intelligibile, ponens illud ut obiectum intelligibile in intellectu possibili ut intelligente, extrahendo ipsum de potentia intelligendi in actum, et faciens de potentia intelligente actu intelligentem. Et per hoc primo denudat formas a materiis, et deinde eas iam factas universales facit intellectas in actu postquam erant intellectae in potentia". 
que o objeto co-age junto ao próprio intelecto na geração da intelecção em ato ${ }^{188}$. Essa resposta, entretanto, não está clara aqui em Quodl. 4, q. 21, onde permanece uma tensão entre a caracterização da intelecção em ato como fruto da ação do objeto ou como fruto da ação do intelecto agente.

Essa tensão, de sua parte, é somente um elemento de um problema maior, a saber, a caracterização do intelecto como ativo, apesar de sua descrição como potência fundamentalmente passiva. De fato, muito embora a passividade do intelecto esteja na base de toda elaboração de Quodl. 4, q. 21, acerca do conhecimento intelectual humano, o Doutor Solene termina por atribuir a cada passo de sua exposição mais ações à potência intelectiva. Ao fim, como vemos, ela é responsável tanto por abstrair seu objeto como por torná-lo inteligido em ato. Esse papel preponderante emprestado ao intelecto agente, em detrimento de qualquer afecção produzida no intelecto pela coisa fora da alma ou pelo sentido, termina por reclamar uma explicação sobre a necessidade de tal ação, a qual não deixa de pôr em risco a relação entre o conhecimento intelectual e a coisa conhecida, uma vez que se introduz uma ação do intelecto entre a coisa e o conhecimento em ato desta última.

Por isso mesmo, me parece, Henrique de Gand introduz em Quodl. 4, q. 21, uma pequena passagem na qual não somente sublinha a identidade entre a coisa fora e a coisa conhecida, mas também busca explicar (ainda que sem o detalhamento que veremos em Quodl. 5, q. 14) a necessidade de se afirmar a abstração sem espécie impressiva pelo intelecto agente:

\begin{abstract}
"O objeto da visão particular, da imaginação e do intelecto é, profundamente, o mesmo em número. Exceto que é objeto da visão enquanto é singular presente na coisa fora; objeto da imaginação enquanto singular ausente e enquanto existente somente na alma tal como no cognoscente; mas, é objeto do intelecto o mesmo sob a razão do universal, aquilo que $<0$ intelecto $>$ observa no fantasma sem qualquer espécie impressiva. De fato, se houvesse uma tal <espécie impressiva>, ela seria uma razão de conceber o objeto sob a razão do particular, tal como também ela própria é em si particular e outra em número que não a espécie impressa no intelecto de outrem, pela qual compreenderia o objeto sob a razão de outro particular. E o intelecto seria, no inteligir, este determinado por aquela espécie impressa, o que é contra a determinação do Filósofo" ${ }^{189}$.
\end{abstract}

\footnotetext{
${ }^{188}$ Cf., adiante, nota 259.

${ }^{189}$ Henrique de Gand, Quodl. 4, q. 21, co. (ed. De Wulf-Mansion Centre, vol. 8, p. 340): "Penitus enim id ipsum numero obiectum est visus particularis et imaginationis et intellectus, praeter hoc quod obiectum est visus, ut est singulare praesens in re extra, obiectum imaginationis, ut est singulare absens et ut existens in anima tantum, sicut in cognoscente, obiectum vero intellectus est idem sub ratione universalis, quod conspicit in phantasmate absque omni specie impressiva. Si qua enim esset, illa esset ratio concipiendi obiectum sub ratione particularis, sicut et ipsa in se particularis est, et alia in
} 
Como dito, vemos aqui claramente formulado o caráter ambíguo do objeto de conhecimento, que deve ser caracterizado simultaneamente como idêntico à coisa fora e dela distinto em alguma medida. Nesse trecho, Henrique busca conciliar essas duas exigências ao manter a identidade do objeto nas diversas potências em que é conhecido, distinguindo somente o modo como cada potência o conhece. Assim, o sentido particular o conhece "enquanto é singular presente na coisa fora [ut est singulare praesens in re extra]"; a imaginação o conhece "enquanto singular ausente e enquanto existente somente na alma tal como no cognoscente [ut est singulare absens et ut existens in anima tantum, sicut in cognoscente]" (o que, como vemos, aponta para a afirmação de uma espécie expressiva na imaginação, como notávamos no item 5.4.2.2); e o intelecto, por sua vez, conhece esse mesmo objeto "sob a razão do universal [sub ratione universalis]". Esse paralelo entre essas três potências cognoscentes quanto [i] à identidade de seu objeto e [ii] a distinção dos respectivos modos de conhecimento de tal objeto não é nova para nós - simplesmente, aqui, ela é apresentada muito claramente. O que é, de sua parte, uma novidade é que justamente esse paralelo serve, neste excerto, para introduzir a necessária ausência de espécies impressivas no conhecimento intelectual.

Com efeito, para o Doutor Solene, o próprio fato de o conhecimento intelectual ser estritamente do universal ${ }^{190}$ exclui terminantemente que haja espécies

numero a specie impressa in intellectu alterius, qua ille comprehenderet obiectum sub ratione alterius particularis, et esset intellectus in intelligendo hoc determinatum per illam speciem impressam, quod est contra determinationem Philosophi”. Cf. BROWN, J. V. "Intellect and Knowing...”, 1975, p. 511; ROMBEIRO, "Intelligible Species in the Mature Thought of Henry of Ghent", 2011, p. 208. Ainda sobre o caráter necessariamente universal do objeto inteligível, cf. a nota 137, acima.

${ }^{190}$ Um elemento da doutrina da intelecção de Henrique de Gand que estamos deixando de lado neste trabalho, embora mereça menção, é a temática do conhecimento intelectual do singular. Não há muitos comentários contemporâneos acerca desse tema no Doutor Solene, mas os poucos que pude encontrar são unânimes em destacar o caráter indireto ou reflexivo que o conhecimento do singular adquire em sua doutrina da intelecção - cf. PAULUS, Henri de Gand. Essai..., 1938, pp. 367-70; BÉRUBÉ, "La connaissance intellectuelle du singulier...", 1951, pp. 175-8; BÉRUBÉ, La connaissance de l'individuel..., 1964, pp. 64-8; LYNCH, J. E. The Theory of Knowledge of Vital du Four. St. Bonaventure: The Franciscan Institute, 1972, pp. 48-9 [= "The Knowledge of the Singular According to Vital du Four”. Franciscan Studies 29 (1969), pp. 271-301 (esp. pp. 290-1)]. Este é, com efeito, o fundamental na posição de Henrique de Gand acerca do conhecimento do singular possível para o homem no estado presente: só se pode conhecer intelectualmente o singular por meio do universal, uma vez que, propriamente, a coisa singular fora da alma é conhecida como universal pelo intelecto.

Para diferenciar [i] a intelecção do universal e [ii] a intelecção do singular por meio do universal, o Doutor Solene introduz a distinção entre [i] o conhecimento direto ou por linha reta e [ii] o conhecimento indireto ou por linha reflexa. Encontramos tal distinção, por exemplo, em Quodl. 2, q. 8, ad 1 (ed. De Wulf-Mansion Centre, vol. 6, p. 54): “<..> individuum singulare uno modo est intelligibile a nobis, alio autem modo non est. Intelligitur enim a nobis ut linea reflexa, non autem ut 
linea recta, secundum quod determinat Philosophus in III $^{\circ}$ De anima, ut statim declarabitur". De fato, ainda na mesma questão, Henrique retoma tal distinção: “< ..> intellectus noster tendere potest super essentiam ad ipsam apprehendendam aspectu recto vel reflexo. Primo modo intellectus noster non intelligit essentiam rei specificae nisi ut essentia est et universalis, vel indifferens ad universale et particulare, et ut in ipsa omnia individua, quotquot sub ipsa sunt, unum sunt, et sic ut est omnino abstracta, non ut aliquibus accidentibus est determinata" (p. 56). Como se vê, esse conhecimento por linha reta é precisamente aquele que viemos estudando no corpo de nossa trabalho, a saber, o conhecimento do universal por abstração (o qual pode, além disso, ser concebido intelectualmente também somente como essência, isto é, como anterior à determinação para o universal ou o singular e em potência para ambas - cf. nota 55 e cap. 2, nota 95). No entanto, como dito, é possível que o intelecto conheça o singular, embora ele só possa fazê-lo por linha reflexa: "Intellectu autem reflexo contingit intelligere essentiae individuationem et diversificationem a nobis secundum dictum modum $<\ldots>$. Sed quia intellectus plurimum ista non discernit, ideo redit ad accidentia posteriora et secundum illorum diversitatem distinguit individua sub eadem specie; et hoc vel singula accidentia posteriora $<\ldots>$; vel per plurium illorum coniunctionem in unum $<\ldots$.. $"-($ p. 57). Ou seja, a intelecção reflexa dos singulares materiais é um conhecimento a partir de acidentes. O conhecimento intelectual do singular a que temos acesso nesta vida é estritamente por acidentes - uma vez que não podemos, de fato, conhecer a singularidade própria a algo (cf. cap. 2, nota 96), resta-nos ajuntar diversos acidentes a uma essência (esta sim, conhecida pelo intelecto em sua indiferença) na esperança de conseguir expressar elementos caracterísiticos de um determinado indivíduo sob tal essência. Destarte, nosso conhecimento intelectual sobre os singulares não permite mais do que descrições vagas com base em acidentes: " $<$...> nos singularia signata a nobis cognita sub ratione signati alteri loquendo exprimere non possumus nisi verbis indicantibus singularia vaga cum qualibuscunque proprietatibus designantibus, et determinantibus exprimantur <..." - Quodl. 5, q. 15, co. (ed. 1613, f. 270va-b). Enfim, o conhecimento intelectual que possuímos acerca do singular é, propriamente, a associação de um apanhado de acidentes a um universal ou a uma essência concebida como anterior à singularidade, não dizendo respeito à própria individualidade essencial daquele indivíduo. Mas, por que dizer que tal conhecimento é indireto ou reflexo? Por que falar em 'reflexão aos acidentes'?

Fala-se aqui em 'reflexão' porque o intelecto só pode associar tais acidentes a uma essência de maneira a conhecer um indivíduo determinado ao voltar-se para o fantasma na imaginação: “<... nisi ex reflectione non cognoscit singularia, ut in phantasmata <...” - Quodl. 5, q. 26, co. (ed. 1613, f. 307ra). Para compreendermos mais precisamente como se dá tal reflexão ao fantasma, podemos atentar para alguns trechos de Quodl. 4, q. 21, co. (ed. De Wulf-Mansion Centre, vol. 8, pp. 343-6). Nessa questão, Henrique de Gand afirma ser necessário defender a possibilidade do conhecimento intelectual do singular pelos homens para que seja possível, por meio de tal conhecimento, também o amor voluntário com respeito a singulares: "intellectus coniunctus intelligit universale. Quomodo autem intelligat singulare, de hoc est alia difficultas, et tanta quod aliqui omnino negabant intellectum humanum posse intelligere singularia. Quod non est ponendum, quia si intellectus rationalis singularia non cognosceret, nec voluntas rationalis ad singularia amorem habere posset, neque naturalem neque deliberativum neque gratuitum, quia secundum Augustinum incognita diligere non possumus, quod falsum est. Vanum enim esset praeceptum de dilectione proximi, qui non nisi singularis est" (p. 343). Em seguida, Henrique de Gand reintroduz a distinção que vimos entre [i] linha direta e [ii] linha reflexa, mas agora pelo oposição entre [i] um conhecimento direto do universal e [ii] um conhecimento indireto do singular: "Directe ergo et per se intellectus noster non cognoscit nisi universale abstractum a singulari; indirecte autem et quasi quadam reflexione convertendo se ad phantasmata, in quibus sunt formae sub ratione singularis <...” (p. 344). Como vemos, explica-se também aqui a reflexão envolvida no conhecimento do singular como uma reflexão ao fantasma, adicionando-se que tal reflexão é necessária porque somente no fantasma há, sob a razão do singular, aquela mesma forma que o intelecto conhece enquanto universal (ou indiferente ao universal e ao singular) - GOEHRING, "Henry of Ghent's Use of Aristotle's De anima...", 2013, pp. 93-4. Mas, como se daria tal reflexão do intelecto ao fantasma? Para explicá-lo, Henrique propõe uma comparação com a geometria, explicando que a reflexão envolvida aqui é como a reflexão de uma linha que vai, primeiro, diretamente de um ponto a outro e, por uma curvatura, retorna ao mesmo ponto de que partira - "Et debemus conicere modum ex hoc quod dicit Philosophus quod dispositio qua intellectus noster intelligit singularia est sicut linea spiralis sive reflexa, attendendo videlicet quod linea reflexa in sphaeram primo intelligitur procedere directe a puncto in punctum, et deinde incurvatione punctum extremum puncto initiali coniungere, ut cedant in unum punctum secundum rem, differentem solum secundum rationem" (pp. 344-5). Ao que parece, portanto, a reflexão de que se fala na intelecção do singular diz respeito a um movimento de retorno à origem do conhecimento intelectual do universal, isto é, a intelecção vai [i] por linha reta do singular 
impressivas na produção de tal conhecimento. Assim, o objeto de conhecimento intelectual é precisamente aquilo que, sob a razão do universal, o intelecto "observa no fantasma sem qualquer espécie impressiva [conspicit in phantasmate absque omni specie impressiva]". Mas, por que a descrição do conhecimento intelectual como universal excluiria as espécies impressivas deste conhecimento? Em poucas palavras, porque, para Henrique, as espécies impressivas são fundamentalmente singulares. Uma espécie impressiva no intelecto "seria uma razão de conceber o objeto sob a razão do particular [esset ratio concipiendi obiectum sub ratione particularis]", uma vez que ela própria é necessariamente particular (sicut et ipsa in se particularis est) e é uma espécie impressiva distinta em número no intelecto de cada indivíduo humano (alia in numero a specie impressa in intellectu alterius). Ora, esse caráter necessariamente particular da espécie impressiva muito provavelmente está conectado à sua caracterização (que já vimos ser corrente) como acidente de um sujeito -

no fantasma para o universal abstraído e retorna [ii] por linha reflexa do universal abstraído ao singular no fantasma, de onde partira - "Cum igitur intelligere universale sit sicut secundum dispositionem lineae rectae abstrahendo a particulari phantasmate formam universalem, obiciendo eam intellectui possibili, ut actu eam intelligat per hoc quod universale movet ipsum sicut color visum, vel ad modum quo litterae se scriberent in tabula obiectae illi $\langle\ldots\rangle$. Intelligere ergo singulare, cum est per lineam reflexam, oportet quod fiat retorquendo et reflectendo universale conceptum ab intellectu ad suum singulare phantasma, reducendo ambo in id ipsum secundum rem, ut sit universale in singulari" (p. 345); o mesmo é retomado mais laconicamente algumas linhas depois: “< ..> species universalis primo quasi secundum lineam rectam est abstracta a phantasmate et obiecta intellectui et deinde est ratio in intellectu ad intelligendum ipsa phantasmata quasi linea reflexa in id a quo incepit” (p. 346). Ao retornar, por linha reflexa, do universal abstraído para o singular no fantasma, o intelecto não abandona o universal - não há como fazê-lo, pois só possuímos conhecimento intelectual do universal -, mas reúne ambos (universal abstraído e singular no fantasma) em um único. Assim, passa a haver um universal no singular, expressão que parece designar aquilo que víamos ser, em Quodl. 2, q. 8, ou Quodl. 5, q. 15, o universal conjugado aos diversos acidentes que o determinavam vagamente para uma singularidade.

Dito isso - e para concluir sua exposição sobre o tema -, Henrique faz questão de destacar que ambos os conhecimentos (por linha reta e por linha reflexa) são conhecimentos intelectuais a partir dos sentidos: " $<\ldots>$ uno modo intellectus intelligit per sensum, universale scilicet abstrahendo ab ipso sicut ab obiecto $\langle\ldots>$. Alio vero modo intellectus intelligit per sensum universale abstractum a particulari in id ipsum reducendo" (p. 345). Assim, também em seu discurso acerca do conhecimento do sigular, o Doutor Solene destaca a profunda ligação entre os sentidos e o intelecto humano no estado presente. Nem a abstração do universal nem a intelecção reflexa do singular escapa ao conhecimento sensitivo.

Por fim, note-se como a discussão acerca do conhecimento intelectual que possuímos sobre o singular possui um certo afastamento com respeito à discussão acerca da própria noção de individualidade (cf. novamente, cap. 2, nota 96). Nosso conhecimento sobre o indivíduo é, sempre, o conhecimento de um universal vagamente conhecido como indivíduo por associação com acidentes característicos, mas jamais atinge a própria individualidade da coisa que se busca conhecer. Essa distinção entre o conhecimento do indivíduo possível para o homem e a própria individualidade da coisa é bem destacada por Paulus: “ $<\ldots>$ il est trop clair que de tels signes caractéristique des individus, s'ils permettent de les discerner entre eux, ne mettent point pour autant en mesure d'appréhender ce qui constitue leur individualité même" (Henri de Gand. Essai..., 1938, p. 369); e por Bérubé: “<...> si les individus sont constitués par la réalité de leur subsistence, ce n'est pas ainsi que nous les connaissons" (La connaissance de l'individuel..., 1964, p. 66). Por fim, ainda sobre o conhecimento intelectual do singular, cf. Henrique de Gand, Quodl. 8, q. 13 (ed. 1613, f. 33r). 
lembremos do que se diz, por exemplo, em Quodl. 4, q. 8: a forma impressa é como um acidente em um sujeito ${ }^{191}$ !

Sendo assim, nesse ponto, começamos finalmente a compreender melhor o que Henrique de Gand espera obter [i] ao distinguir espécies impressas ou impressivas e espécies expressas ou expressivas e [ii] ao manter o intelecto como território exclusivo dessas segundas. A saber, seu objetivo é resguardar o intelecto como campo do universal. Uma vez que as espécies impressivas são acidentes singulares provocados num sujeito, elas não podem ser coerentemente tomadas como o fundamento imediato de um conhecimento universal. Assim, torna-se necessário negar a ocorrência de acidentes singulares no intelecto como causas do conhecimento intelectual e, ao mesmo tempo, manter a ocorrência, no intelecto, da essência a ser conhecida intelectualmente. Daí que esta venha a ser considerada como espécie expressiva - não como um acidente em um sujeito, mas como um objeto sob a razão do universal feito pelo intelecto em si mesmo, a partir daquilo que era impresso sob a razão do particular no sentido. Que se modifique essa 'razão sob a qual o objeto é conhecido', porém, não significa que seja quebrada a identidade do objeto em todo esse processo de conhecimento. Simplesmente, o mesmo objeto é conhecido sob diferentes razões a cada passo.

Dito isso, o Quodl. 4, q. 21, não nos permite avançar muito mais no que diz respeito à necessária ausência de espécies impressivas no intelecto - para uma discussão mais aprofundada, teremos que esperar o Quodl. 5, para o qual nos voltaremos no próximo item ${ }^{192}$. Antes, no entanto, será interessante voltarmos ao Quodl. 4, q. 8. De fato, sabemos que há um momento posterior à atualização do conhecimento intelectual pela espécie, a saber, a produção do verbo. Este último, tal como a espécie, também ganha contornos mais precisos em Quodl. 4.

Um aspecto fundamental na caracterização do verbum em Quodl. 4, q. 8, é o aprimoramento na descrição de sua produção, principalmente pelo recurso a uma noção que já abordamos de passagem acima - especialmente, nos itens 5.3 e 6.3.1 -, a saber, a 'memória intelectiva'. Com efeito, como sublinha Bernd Goehring em seu

\footnotetext{
${ }^{191}$ Cf. nota 181 , acima.

${ }^{192}$ Um autor a apontar os argumentos de Quodl. 5, q. 14, acerca da espécie inteligível como um desenvolvimento de Quodl. 4, q. 21, é Prospero Stella em "La prima critica di Herveus Natalis O.P. alla noetica di Enrico di Gand: il 'De intellectu et specie' del cosidetto 'De quattuor materiis"'. Salesianum 21.1 (1959), pp. 125-70 (esp. p. 127). Porém, como veremos no próximo item, há importantes diferenças entre as argumentações apresentadas em cada caso.
} 
estudo de Quodl. 4, q. 8, a relação entre memória e verbo se torna um aspecto importante para a caracterização da intelecção em Henrique de Gand ${ }^{193}$. Além disso, nosso autor deixa clara também, nesse ponto, uma distinção mais precisa entre [i] o verbo que diz respeito ao conhecimento incomplexo e [ii] o verbo que diz respeito ao conhecimento complexo e, propriamente, à ciência. Com efeito, muito embora Goehring veja, dessa fase em diante do pensamento de Henrique de Gand, uma concepção de verbum como exclusivamente complexo ${ }^{194}$, parece-me antes que o Doutor Solene mantém os dois usos referidos. Essa ênfase na distinção entre dois significados do termo verbum - um incomplexo, outro complexo -, já era notada por Nys ${ }^{195}$, sendo retomanda por Steven Marrone e Michael Rombeiro ${ }^{196}$. Assim, há um

${ }^{193}$ GOEHRING, Henry of Ghent on Cognition..., 2006, pp. 182-7. Cf. tb. GOEHRING, "Henry of Ghent on the verbum mentis", 2011, p. 255.

${ }^{194}$ GOEHRING, Henry of Ghent on Cognition..., 2006, p. 177: "In his mature, developed conception of the mental word Henry maintains the basic components of his initial account, most notably the insight that in human cognition and concept-acquisition there is first a receptive and then a productive stage. Yet Henry expands his conception, by re-interpreting Augustine's views on the mental word, in order to explicate the productive stage of forming a mental word. No longer is any kind of concept identified with the mental word. Rather, the mental word is now clearly characterized as a definitional concept or account that is expressive and explanatory of thing's essential struture - a concept marks the result of a discursive inquiry into a thing's essence". Cf. tb. GOEHRING, "Henry of Ghent on the verbum mentis", 2011, p. 255.

${ }^{195}$ NYS, De werking van het menselijk verstand..., 1949, pp. 105-6: "O conceito, a notitia simplex et confusa, daí formada no intelecto era, antes de 1279 , simplesmente nomeada verbum <...>. Depois de 1279, esse primeiro produto da atividade intelectual não é mais o verbum propriamente; isso pode, no máximo, ser chamado de verbum com um significado menos estrito, mas, nesse caso, preferencialmente, como verbum obiecti e não verbum intellectus [Het concept, de notitia simplex et confusa, hierbij in het verstand gevormd, werd vóór 1279 eenvoudig verbum genoemd <...>. Na 1279 is dit eerste product van de vertandelijke werking niet langer meer het eigenlijke verbum; het kan ten hoogste verbum genoemd worden in minder strenge betekenis, maar dan liever verbum objecti en niet verbum intellectus]" (grifos no original). Acrescente-se que Giuseppina Cannizzo ("La dottrina del 'verbum mentis' in Enrico di Gand”, 1962, p. 265) também considera que não há uma quebra absoluta entre o período anterior e posterior ao Quodl. 4, no que diz respeito à noção de verbum.

${ }^{196}$ Propriamente, Marrone afirma ler, após as primeiras obras de Henrique de Gand (e, portanto, já a partir de Quodl. 4), a distinção entre duas acepções ou dois níveis (level) de verbum - um inferior (lower) e outro superior (higher): "The word was, he added, the word of the quiddity (verbum de eo quod quid est), and thus it differed from the word the intellect had formed on the lower, more primitive level of knowledge, before it had come to see distinctly the essential characteristics of the object it was coming to know. Henry also called this word declarative knowledge (notitia declarativa). It was the finished product of the simple intellection, ready to be uttered and expressed in the logical terms suitable for scientific discourse <...>. Most important, of course, was the fact that this word, because it was the word of the quiddity and equivalent to the definition of the object, stood on a higher and more significant plane than the word of simple intelligence" - Truth and Scientific Knowledge..., 1985, pp. 86-7. Em qualquer caso - isto é, seja no nível superior ou inferior - o ato do intelecto é, segundo Marrone, mais bem caracterizado como verbum: "It was this formal content that provided the metaphysical kernel of knowing, in relation to which such potencies and acts as habitual knowledge and the act of understanding could be situated, and Henry called it not only actual knowledge but also the word (verbum) most properly understood" - op. cit., p. 72. Por fim, adicione-se que, para Marrone, essa identificação geral entre verbum e ato de intelecção (ao que parece, nesse sentido geral, que inclui os níveis inferior e superior de atividade do intelecto) ocorre ainda no próprio texto de Quodl. 4, q. 8 
verbo resultante do conhecimento dos conceitos simples e outro verbo resultante do conhecimento dos conceitos complexos ${ }^{197}$. Destes, nos interessará aqui principalmente o primeiro, que, a meu ver, é cuidadosamente descrito pelo mestre gandavense em Quodl. 4, q. 8.

Como dito, um elemento especialmente desenvolvido nesse texto por Henrique de Gand é a temática da produção do verbo. Para tanto, ele se esforça por distinguir cuidadosamente o ato de intelecção (que já sabemos ser proveniente da ação conjuta da espécie e do intelecto agente) e o verbo que dele resulta:

“Eis, pela expressa sentença de Agostinho, que ele denomina 'verbo' a notícia formada na inteligência sobre a coisa cuja notícia possuímos na memória. Nessa notícia da inteligência, há que considerar dois, a saber: o próprio ato de saber, inteligir ou pensar e aquilo pelo que é informado. O primeiro destes, como já disse Agostinho, não possui razão de verbo senão em potência. Que tenha a razão de verbo não é senão em razão daquilo pelo que é informado, não tal como por uma forma no cognoscente, mas tal como por um objeto conhecido"198.

Este excerto possui uma estrutura muito interessante. Ele começa por apontar [i] uma identificação entre 'notícia da inteligência' (notitia intelligentiae) e o verbum e [ii] a notícia na memória como elemento antecedente a tal verbum. Em outras palavras, há notitia na memória e na inteligência, porém somente a notícia nesta última pode ser denominada 'verbo'. Isso, porém, não é tudo, pois, estritamente falando, a notitia intelligentiae não é inteiramente 'verbo', mas pode ser distinguida em dois: [i] "o próprio ato de saber, inteligir ou pensar [ipsum noscendi sive intelligendi sive cogitandi actum]", que "não possui a razão de verbo senão em potência [ex se non habet rationem verbi nisi in potentia]" e [ii] "aquilo pelo que" esse ato "é informado [id quo informatur]", sendo tal informação produzida por algo "não tal como por uma forma no cognoscente, mas tal como por um objeto conhecido [non sicut forma in cognoscente, sed sicut obiecto cognito]". Em meio a tais

(cf. op. cit., p. 72, nt. 102). Cf. tb. ROMBEIRO, "Intelligible Species in the Mature Thought...", 2011, p. 215: "Now, Henry goes on to state that 'verbum' properly speaking does not apply to simple notitia. But loosely speaking he does call the simple notitia in intelligence a verbum insofar as it proceeds like an offspring from the notitia in memory and is a "notitia from a notitia."'.

${ }^{197}$ Cf., adiante, a nota 221.

${ }^{198}$ Henrique de Gand, Quodl. 4, q. 8, co. (ed. De Wulf-Mansion Centre, vol. 8, p. 57): "Ecce expressa sententia Augustini quid appellet 'verbum', quoniam formatam notitiam in intelligentia de re cuius notitiam habemus in memoria. In qua notitia intelligentiae est duo considerare, scilicet ipsum noscendi sive intelligendi sive cogitandi actum, et id quo informatur. Quorum primum, ut iam dixit Augustinus, ex se non habet rationem verbi nisi in potentia. Quod ergo habet rationem verbi, hoc non est nisi ratione eius quo informatur, non sicut forma in cognoscente, sed sicut obiecto cognito". 
distinções, Henrique nos diz que é somente por receber tal informação que o ato de intelecção pode ser dito verbum ${ }^{199}$. Ou seja, o determinante no verbo não é tanto que ele seja uma ato de intelecção tout court, mas antes que ele seja um ato de intelecção informado por algo enquanto objeto conhecido (e não enquanto forma em um sujeito). Assim, o verbo surge agora adequado à distinção entre espécie impressiva e espécie expressiva: ora, se o verbo provém de algo que é no intelecto como objeto e não como forma num sujeito, então está claro que o verbo não pode provir de uma espécie impressiva! Daí que o ato de inteligir não seja verbo senão em potência: o intelecto é ato de inteligir somente em potência e, portanto, é verbo somente em potência, pois para que haja um tal verbo é necessário que o intelecto seja informado por um objeto ou notícia que já era na memória.

Nesse ponto, torna-se premente refazer todo o percurso de produção do conhecimento intelectual, que não víamos ser descrito por inteiro desde os primeiros artigos da Suma. Mais uma vez, aqui em Quodl. 4, q. 8, o Doutor Solene toma como ponto de partida a completa potencialidade do intelecto antes da recepção de seu objeto: "o nosso intelecto de si é nu como uma tabuinha aplainada e é tal como a matéria, carecendo de toda informação de notícia ou ciência (tanto segundo o ato como segundo o hábito), antes que seja movido pelo objeto que é o universal e o que é sobre a coisa [quod quid est de re] compreendida sob a razão do singular na imaginativa existente em ato"200. Há aqui, porém, diversos elementos que não se mostravam centrais na descrição da intelecção nos artigos iniciais da Suma. Em particular, como veremos no trecho a seguir, agora a distinção binária entre 'intelecto agente' e 'intelecto possível' como forças do intelecto deve dividir espaço com a tríade 'memória', 'inteligência' e 'vontade'. Ambas as distinções, em um complexo jogo de correspondência não completamente elucidado nessa etapa da obra de Henrique de Gand $^{201}$, são conjuntamente utilizadas na tentativa esclarecer a produção

\footnotetext{
${ }^{199}$ A mesma tese é repetida por Henrique de Gand alguns passos adiante, na mesma questão: "De essentia ergo verbi creati non est actus intelligendi nisi in quantum ipso informatur" - Quodl. 4, q. 8, co. (ed. De Wulf-Mansion Centre, vol. 8, p. 67).

${ }^{200}$ Henrique de Gand, Quodl. 4, q. 8, co. (ed. De Wulf-Mansion Centre, vol. 8, p. 58): "Sed quia in hoc verbo et in scientia seu notitia de qua nascitur, magna adhuc latet quaestio, ut ipsam determinemus, sciendum quod intellectus noster de se nudus est sicut tabula complanata et est sicut materia carens omni informatione notitiae sive scientiae et secundum actum et secundum habitum, antequam moveatur ab obiecto quod est universale et quod quid est de re comprehensa sub ratione singularis ab imaginativa existente in actu $<\ldots>$ ".

${ }^{201}$ Cf., adiante, a nota 206.
} 
do conhecimento humano descrito como verbum. Por fim, a descrição que leremos a seguir é centrada não na noção de species (como ocorria no início da Suma), mas naquela de 'verbo'.

Notemos como, no trecho apresentado a seguir, Henrique de Gand sutilmente parte de um discurso que toma por base a noção de intelecto (distinguido em intelecto agente e possível) e passa a um discurso acerca da mente (dividida nas três potências, memória, inteligência e vontade):

“<...> o ato de inteligir segundo o intelecto possível é precedido pela ação do intelecto agente que desnuda o objeto imaginado no fantasma das condições particulares e, ao fazê-lo, o propõe ao intelecto possível, tal que seja presente a ele, o mova em ato por sua presença e elicite, a partir dele, o ato de inteligir que termina nele próprio tal como no objeto pelo qual é informado; da percepção deste sob a razão de verdadeiro, concebe-se seu amor na vontade sob a razão de bem. E, assim, o próprio objeto aperfeiçoa a mente segundo suas três potências. De fato, enquanto possui o ser presente ao intelecto possível enquanto inteligente em potência, aperfeiçoa a memorativa intelectual; já enquanto o modifica elicitando o ato de inteligir terminando nele próprio $<s c$. no objeto $>$ enquanto é presente na memória, é a perfeição da inteligência; já enquanto move a vontade, sob a razão de bem, para o ato de amor (melhor ainda, a vontade se move a ele pelo ato de amor) é a perfeição do volente que conjuga a inteligência, pelo ato de inteligir, à própria memória, tal que não desvie a agudeza $<$ da mente $>$ da visão daquilo que observa presente na memória"202.

O começo da passagem não possui grande novidade para nós - afirma-se que, antes que haja a atualização do intelecto possível pelo ato de inteligir, é necessária uma ação do intelecto agente que, ao retirar as condições particulares do objeto, torne este último presente ao intelecto enquanto objeto inteligível (isto é, como sabemos, enquanto objeto sob a razão do universal). Como também já vimos (dessa vez, no cap. 3), uma vez que tal objeto seja conhecido enquanto verdadeiro pelo intelecto, ele é apresentado à vontade sob a razão de bem e, caso ela resolva-se por amá-lo (lembremos de sua fundamental atividade e livre-arbítrio), ele será também objeto de

\footnotetext{
${ }^{202}$ Henrique de Gand, Quodl. 4, q. 8, co. (ed. De Wulf-Mansion Centre, vol. 8, pp. 58-9): “< $<$..> actum intelligendi secundum intellectum possibilem praecedit actio intellectus agentis denudantis obiectum imaginatum in phantasmate a condicionibus particularibus, et per hoc proponentis illud intellectui possibili ut sit praesens ei et per suam praesentiam actu moveat ipsum et eliciat ex ipso actum intelligendi terminatum ad ipsum sicut ad obiectum a quo informatur, ex cuius perceptione sub ratione veri concipitur amor eius in voluntate sub ratione boni. Et per hoc obiectum id ipsum perficit mentem secundum tres potentias suas. In quantum enim habet esse praesens intellectui possibili, ut intelligenti in potentia, perficit memorativam intellectualem; in quantum vero immutat ipsum eliciendo actum intelligendi terminatum ad id ipsum, ut est praesens in memoria, est perfectio intelligentiae; in quantum vero sub ratione boni movet ad actum amoris voluntatem, immo potius voluntas per actum amoris movetur in ipsum, est perfectio volentis coniungentis intelligentiam per actum intelligendi ipsi memoriae, ne scilicet avertat aciem ab aspectu eius quod conspicit praesens in memoria". Cf. BROWN, J. V. "Intellect and Knowing in Henry of Ghent", 1975, pp. 707-8.
} 
seu amor. Isso tudo já sabemos - a novidade está naquilo que Henrique de Gand conclui dessa narrativa: "o próprio objeto aperfeiçoa a mente segundo suas três potências [obiectum id ipsum perficit mentem secundum tres potentias suas]", isto é, a memória, a inteligência e a vontade. Vemos agora, portanto, que, tal como um mesmo objeto - ora sob a razão do particular, ora sob a razão do universal - aperfeiçoava a potencia sensitiva e a intelectiva, também esse mesmo objeto - ora sob a razão do verdadeiro, ora sob a razão de bem - aperfeiçoa toda a potência intelectiva: intelecto e vontade ou, o que é o mesmo, a mente. Mas, como fazer equivaler um discurso acerca do intelecto agente e possível a um discurso acerca da memória e inteligência? $\mathrm{O}$ Doutor Solene busca fazê-lo a partir dos diversos atos do objeto no processo de atualização do intelecto.

Assim, enquanto o objeto é ainda somente inteligível (e não inteligido), há o aperfeiçoamento da memória intelectiva - este é o ato do objeto que antecede a formação do conhecimento atual e, portanto, é o ato do objeto enquanto o intelecto intelige ainda em potência: “enquanto possui o ser presente ao intelecto possível enquanto inteligente em potência, aperfeiçoa a memorativa intelectual [In quantum enim habet esse praesens intellectui possibili, ut intelligenti in potentia, perficit memorativam intellectualem]". Nesse ponto, o objeto universal está presente ao intelecto possível, mas ainda não é inteligido por ele em ato - nas palavras de nosso autor, o objeto é ainda um hábito na memória (ou uma notícia habitual), anterior ao ato propriamente dito: "aquele objeto universal, enquanto presente à memória e perfeição dela segundo um modo de 'ciência' ou 'notícia', diz-se ser a notícia habitual existente na memória",203.

Em seguida, ao produzir o ato de intelecção - isto é, ao atualizar o intelecto possível - o objeto inteligido em ato é a perfeição da inteligência: “já enquanto o

\footnotetext{
${ }^{203}$ Henrique de Gand, Quodl. 4, q. 8, co. (ed. De Wulf-Mansion Centre, vol. 8, p. 59): "Illud autem obiectum universale, ut est praesens memoriae et perfectio eius secundum unum modum scientiae sive notitiae, dicitur esse notitia habitualis existens in memoria". Na nota 129, acima, vimos que o termo habitus é, geralmente, reservado para nomear uma qualidade produzida por um agente em si mesmo a partir da realização (repetida ou não) de uma ação movido por outro, de tal maneira que esse mesmo agente possa reproduzir esta ação mais facilmente em seguida. Parece ser claro que o termo notitia habitualis não possui esse sentido no excerto aqui citado, uma vez que a notitia habitualis existente na memória é, nesse caso, anterior a qualquer ato de intelecção - com efeito, ela é o próprio princípio de tal ato. Ao que me parece, o uso do adjetivo habitualis aqui está ligado, precisamente, ao fato de tal notícia não ser ainda o ato de intelecção, mas ser aquilo que propicia ou acarreta tal ato. Nesse sentido - isto é, enquanto é um objeto produzido por um agente (o intelecto) para si de maneira a provocar um ato outro (a intelecção) em si mesmo -, a objeto na memória pode ser compreensivelmente tomado como uma notícia habitual (por comparação ao habitus em sentido próprio).
} 
modifica elicitando o ato de inteligir terminando nele próprio <sc. no objeto $>$ enquanto é presente na memória, é a perfeição da inteligência [in quantum vero immutat ipsum eliciendo actum intelligendi terminatum ad id ipsum, ut est praesens in memoria, est perfectio intelligentiae]". Note-se, porém, como essa atualização do intelecto possível é descrita como um círculo: o objeto presente na memória intelectiva elicita o ato de intelecção, porém este último possui por termo o próprio objeto inicial enquanto este possui ser na memória. Assim, a intelecção em ato parte da memória e a ela retorna, pois o objeto que é notícia da memória é o mesmo objeto que é notícia da inteligência, de tal modo que o objeto inteligido não é senão a mesma notícia que era na memória, mas agora em ato na inteligêcia. Assim, o objeto de intelecção é uma notitia de notitia. Nas palavras de Henrique, o objeto universal "enquanto move em ato a inteligência e o ato de inteligir nele termina, segundo outro modo de notícia, diz-se ser a notícia atual na inteligência; e, uma vez que se faz na inteligência porque anteriormente por natureza, ainda que não por tempo, possui ser, como dito, presente na memória, donde move a inteligência, por isso Agostinho diz que é notícia da notícia [notitia de notitia] e é o mesmo na coisa [id ipsum re] enquanto é na memória, parturiente com respeito a si, <e $>$ enquanto é na inteligência, como prole e verbo" ${ }^{204}$. Como vemos, há uma identidade do objeto, que é o mesmo tanto enquanto perfeição (ou notícia) da memória, como enquanto perfeição (ou notícia) da inteligência. A bem dizer, esta última é um ato com respeito àquela. Além disso, se lermos essa passagem à luz de Quodl. 4, q. 7, vemos que a notitia na memória e na inteligência a que Henrique de Gand se refere aqui se identifica àquela espécie que (diferentemente da forma impressiva) é no intelecto como o conhecido no cognoscente. Ou seja, essa notícia é a própria espécie expressiva ${ }^{205}$ - respectivamente, enquanto ato da memória (e objeto inteligível) e enquanto ato de intelecção (e objeto inteligido). Porém, na mesma passagem de Quodl. 4, q. 7, ainda nos é dito que essa species só é dita notitia enquanto dá forma ao ato de conhecimento. Se for assim, o

\footnotetext{
${ }^{204}$ Henrique de Gand, Quodl. 4, q. 8, co. (ed. De Wulf-Mansion Centre, vol. 8, p. 59): "Et id ipsum $<s c$. o objeto universal>, in quantum actu movet intelligentiam et ad ipsum actus intelligendi terminatur, secundum alium modum notitiae dicitur esse notitia actualis in intelligentia. Et quia fit in intelligentia per hoc quod prius natura, etsi non tempore, habet esse, ut dictum est, praesens in memoria, unde movet intelligentiam, ideo dicit Augustinus quod est notitia de notitia et est id ipsum re ut est in memoria, parens respectu sui ipsius, ut est in intelligentia, velut proles et verbum". Cf. ROMBEIRO, "Intelligible Species in the Mature Thought...". 2011, p. 215.

${ }^{205} \mathrm{Cf}$. nota 102 , acima. Sobre a relação entre verbum, notitia e species expressa, cf. ROMBEIRO, "Intelligible Species in the Mature Thought...", 2011, pp. 212-6. Cf. tb. COLLI, "Ab utroque notitia paritur...", 2012, p. 253.
} 
mais correto seria dizer que a espécie expressiva não é precisamente a perfeição da memória ou da inteligência, mas antes o objeto que as leva à perfeição. Nesse caso, como vemos, o significado do termo 'espécie expressiva' termina por abarcar (no campo do conhecimento simples ou incomplexo) o próprio verbo, que vimos ser o objeto enquanto atualmente move a intelecção em ato. Nisso, porém, estamos nos afastando um tanto da letra do excerto de Quodl. 4, q. 8, que estamos a acompanhar.

Assim, voltando ao último trecho indentado, após a atualização do intelecto sob a razão de verdade, a vontade se volta para o mesmo objeto, tomando-o sob a razão de bem. Curiosamente, porém, ao amá-lo, não somente a vontade pressupõe que o objeto na memória seja em ato na inteligência, mas também estreita o laço entre essas duas potências da mente, pois amando-o a vontade deseja conhecê-lo mais e, para tanto, ela fixa o olhar da inteligência sobre o objeto que é na memória: "enquanto $<$ o objeto $>$ move a vontade, sob a razão de bem, para o ato de amor (melhor ainda, a vontade se move a ele pelo ato de amor) é a perfeição do volente que conjuga a inteligência, pelo ato de inteligir, à própria memória, tal que não desvie a agudeza $<$ da mente $>$ da visão daquilo que observa presente na memória [in quantum vero sub ratione boni movet ad actum amoris voluntatem, immo potius voluntas per actum amoris movetur in ipsum, est perfectio volentis coniungentis intelligentiam per actum intelligendi ipsi memoriae, ne scilicet avertat aciem ab aspectu eius quod conspicit praesens in memoria]". Como vimos no cap. 3, a vontade direciona o intelecto para o conhecimento verdadeiro. Agora, porém, percebemos que ela não somente direciona o intelecto, como também reforça sua unidade - é pelo amor ao conhecimento que a inteligência se mantém voltada para o objeto inteligível que atualiza a memória, de maneira que este último mantenha tal inteligência igualmente atualizada ${ }^{206}$.

\footnotetext{
${ }^{206}$ Nesse ponto, vale perguntar: qual o interesse de Henrique de Gand em associar [i] o discurso sobre o intelecto (com sua dúplice divisão em intelecto agente e intelecto possível) e [ii] o discurso sobre a mente (com sua tríplice divisão em memória, inteligência e vontade)? Em especial, por que isso surge no contexto do estudo da noção de 'verbo'? A meu ver, isso fica mais claro ao em uma passagem já próxima ao fim de Quodl. 4, q. 8, co. (ed. De Wulf-Mansion Centre, vol. 8, p. 67): “<..> verbum in creaturis debet esse proportionale Verbo increato quod concipitur de mente paterna intellectuali operatione $<\ldots>$ ". O verbo na criatura é associado diretamente ao verbo no criador - isto é, ao resultado da ação paterna de conhecer, que gera o Filho -, de maneira que o discurso filosófico acerca do conhecimento humano está diretamente atrelado ao discurso teológico acerca da trindade. Daí que seja de interesse, para Henrique, resolver o binômio intelecto agente / intelecto possível no trinômio memória / intelecto / vontade: a caracterização trinitária da mente humana é elemento fundamental de sua concepção filosófico-teológica de homem. Com efeito, deve-se atentar para o fato de que a aproximação entre a trindade na mente humana e a trindade em Deus não é apenas um jogo de palavras (muito embora, boa parte do discurso teológico tenha por base uma 'transferência' de significado de certos termos, como lembrado em cap. 2, nota 36). Como diz Olivier Boulnois, "A la fin du XIII ${ }^{\mathrm{e}}$ siècle et au $\mathrm{XIV}^{\mathrm{e}}$ siècle, on peut élaborer en théologie trinitaire des points de noétique valant aussi pour
} 
l'homme. Toute analyse est réversible: ce qui est pertinent pour Dieu doit aussi l'être pour l'homme $<\ldots>$. Quand Henri de Gand use de la psychologie pour décrire la vie divine, il faut sous-entendre aussi le contraire: la structure de la pensée humaine devra s'articuler en vue d'une constitution trinitaire" (Être et représentation, 1999, p. 111); cf. tb. BOURGEOIS, "La théorie de la connaissance intellectuelle...", 1936, pp. 252-3; FRIEDMANN, R. L. "Divergent Traditions in Later-Medieval Trinitarian Theology: Relations, Emanations, and the Use of Philosophical Psychology, 1250-1325". Studia Theologica 53 (1999), pp. 13-25 (esp. p. 20); FRIEDMAN, Intellectual Traditions at the Medieval University..., 2013, pp. 223-80. A base para a possibilidade de tal aproximação entre a mente humana e a trindade é, em uma palavra, a concepção da mente humana como 'imagem' (imago) de Deus. O problema é que, em fins do século XIII (com efeito, já antes), defender a doutrina da imagem na mente humana exigia uma complexa aproximação entre a doutrina da intelecção lida no De anima de Aristóteles e a doutrina da mente lida no De trinitate de Agostinho - sobre isso, cf. COLLI, " $A b$ utroque notitia paritur...", 2012; e, no mesmo volume da Medioevo, PAIVA, G. B. V. de. "One Single Yet Manifold Soul. Agustine's De trinitate and Aristotle's De anima in John Duns Scotus's Doctrine of Intellection". Medioevo 37 (2012), pp. 261-89. Nesse contexto, torna-se patente a importância associada à noção de verbo, que é concebido não somente como o fím da intelecção humana, mas também como o fim da intelecção divina (em especial, da atividade paterna). Isso é igualmente válido em Henrique de Gand, onde a discussão sobre o verbum é um importante ponto de contato entre o discurso sobre o homem e o discurso sobre Deus - cf. FRIEDMAN, R. L. "Relations, Emanations, and Henry of Ghent's use of the 'verbum mentis' in Trinitarian Theology". Documenti e study sulla tradition filosofica medievale 7 (1996), pp. 131-82; PINI, G. "Henry of Ghent's Doctrine of verbum in its Theological Context". In: GULDENTOPS, G., STEEL, C. (eds.), Henry of Ghent and the Transformation..., 2003, pp. 307-26; FLORES, Henry of Ghent: Metaphysics and the Trinity, 2006, pp. 65-76; WILLIAMS, “Augustine, Thomas Aquinas, Henry of Ghent, and John Duns Scotus...”, 2010, pp. 47-65.

Como vimos, entretanto, a aproximação entre a noção tríplice de mente e a noção dúplice de intelecto exige não somente uma clarificação da noção de verbo, mas antes de tudo coloca em jogo a possibilidade de fazer corresponderem os dois pares 'intelecto agente / intelecto possível' e 'memória / inteligência' (uma vez que a vontade é concebida como posterior, na ordem de atualização, a todos esses). Essa tarefa é enfrentada mais frontalmente por Henrique de Gand em Quodl. 13, q. 8, onde se pergunta precisamente "se o intelecto agente diz respeito à imagem no homem [utrum intellectus agens pertineat ad imaginem in homine]" (ed. De Wulf-Mansion Centre, vol. 18, p. 49) - cf. EMERY Jr., "The Image of God Deep in the Mind...", 2001, pp. 108-10. Um princípio fundamental da resposta a esse problema é a afirmação de que "segundo a determinação de Agostinho, a imagem não consiste propriamente nas potências da alma com a substância dela, senão enquanto pode produzir, pelos seus atos, a partir da primeira delas $<s c$. das potência $>$ como de um progenitor a segunda como uma prole, como da memória a inteligência (tal como notícia de notícia) e, a partir de ambas, uma terceira, como das duas o amor, a saber, a partir da memória e da inteligência, a vontade $<\ldots>[<\ldots>$ secundum determinationem Augustini imago non consistit proprie in potentiis animae cum ipsa substantia eius, nisi ut per actus suos a prima illarum ut a parente habet produci secunda sicut proles, ut a memoria intelligentia, sicut notitia de notitia, et ab ambabus tertia ut a duplici notitia amor, videlicet a memoria et intelligentia voluntas <..> ]" (ed. De Wulf-Mansion Centre, vol. 18, p. 53). Ora, nesse caso, a presença ou ausência de uma determinada potência na imagem deve ser estabelecida a partir dos atos produzidos por tal potência. Por isso mesmo, Henrique de Gand se volta cuidadosamente para a descrição dos atos do intelecto agente nessa questão. De tal estudo, conclui-se que o intelecto agente possui quantro ações, duas acerca do fantasma e duas acerca do intelecto possível - "Et in summa facit duo circa phantasmata, et duo circa possibilem intellectum" (op. cit., p. 51). Quanto [1] ao fantasma, o intelecto agente [1.1] faz o fantasma ser inteligível e [1.2] dá a ele a força de mover o intelecto possível - "Circa phantasmata enim quasi resplendendo super illa et illuminando ea, non egrediendo a possibili sed convertendo se ad illa, quia in eadem substantia animae sunt phantasia, in qua sunt phantasmata, et intellectus agens. Primo facit illa esse actu intelligibilia, secundo dat eis vim movendi secundum actum intellectum possibilem, in quantum scilicet sunt quasi imbuta et commixta lumini agentis" (op. cit., p. 51). Já quanto [2] ao intelecto possível, o intelecto agente [2.1] o torna indeterminadamente receptivo para a intelecção e [2.2], determinado o intelecto agente pelo inteligível, o torna intelecção em ato - "Circa possibilem autem non quasi resplendendo et illuminando eum, sed quasi lucendo in eo. Primo, ut est lux indeterminata, disponit ipsum ut sit receptivum actus qui est intellectio, sine qua media non reciperet illum, sicut nec visus actum visionis, nisi in eo luceret media lux connaturalis. Secundo autem, ut est lux determinata ab intelligibili, disponit ipsum ut sit actus actionis quae est intellectio, sine qua determinante vim elicitivam, ipse intellectus possibilis illam non 
eliceret, sicut vis visiva in oculo non eliceret actum visionis, nisi esset disposita luce determinata a colore" (op. cit., pp. 51-2). É com base nesse jogo de passividade e atividade entre fantasma, intelecto agente e intelecto possível que Henrique de Gand buscará estabelecer uma correspondência entre, por um lado, a mente dividida em memória e inteligência e, por outro, o intelecto dividido em intelecto agente e intelecto possível.

Pois bem, se como fora estabelecido com base em Agostinho, a imagem consiste na memória que gera a inteligência e pela vontade gerada por ambas em conjunto, então parece que o intelecto agente, não diz respeito à imagem ao realizar as ações [1.1] e [1.2] acerca do fantasma, pois tais ações não estão ainda gerando nenhum conhecimento. Com efeito, [1.1] tornar o fantasma inteligível e [1.2] torná-lo capaz de mover o intelecto possível são uma preparação para que, em seguida, seja produzido o ato de intelecção (isto é, a pefeição da inteligência), mas não são ainda a própria produção desse ato. Ou seja, enquanto age sobre o fantasma, o intelecto agente não é parte nem da memória (pois não age ainda para a produção do conhecimento em ato), nem é parte da inteligência (pois não é o conhecimento em ato) "<...> agens intellectus, ut convertitur ad phantasmata secundum dictas operationes duas circa illa, quia non includitur in memoria ut de ipsa et de notitia quae est in ea, procedit notitia intelligentiae, neque similiter includitur in ipsa intelligentia, neque etiam in ambabus ut ab ipsis procedit voluntas, nequaquam pertinet ad imaginem, nisi ut praeparativum et activum circa intelligibilia quae sunt in potentia universalia, ut fiant actu universalia, et actu possint movere intellectum possibilem ut informetur notitia simplici rerum sensibilium a quibus erant phantasmata in vi imaginativa, et sic ut fiat memoria actualis intelligentiae" (op. cit., pp. 53-4). Por outro lado, é preciso admitir que, enquanto prepara o terreno para que haja um ato da memória no intelecto - isto é, enquanto produz o objeto inteligível que é a notícia na memória - o intelecto agente já é parte da memória, pois é parte de sua formação - "Quia tamen agens intellectus ut conversus est ad phantasmata dicto modo, praeparativus est et activus ad informationem memoriae, ut fecundetur notitia simplici et possit esse parens, ideo quoad hoc dici debet pertinere ad memoriam ut ad parentem, et non ad intelligentiam" (op. cit., p. 54). Disso já podemos depreender que faz parte da memória o objeto ainda inteligível, isto é, a notícia na memória, anterior à notícia na inteligência, e que participará da produção desta última - "Omnis enim notitia simpliciter primo generata in intellectu adscribitur memoriae <...> (op. cit., p. 54).

Porém, Henrique considera que o intelecto agente diz respeito à imagem em sentido verdadeiro (voltaremos a isso a seguir, ainda nesta nota) enquanto age com respeito ao intelecto possível (ações [2.1] e [2.2]), já havendo produzido o objeto inteligível - "Si igitur intellectus agens pertineat ad veram rationem imaginis, hoc non potest esse, nisi ut consideratur in ordine ad intellectum possibilem secundum alias duas operationes suas praedictas. Et dico quod ita est" (op. cit., p. 55). Dessa maneira, parece que o intelecto agente termina por dizer respeito tanto à memória, como à inteligência, uma vez que age sobre o fantasma [1.1/1.2] para produzir a memória e [2.1 / 2.2], já na presença da memória, age sobre o intelecto possível para a produção da própria inteligência - "Et secundum hoc dico quod intellectus agens secundum dictas duas operationes communiter pertinet et ad memoriam, et ad intelligentiam, sicut ad intellectum possibilem, ut qui est eadem potentia simpliciter in re et in substantia animae, a quo solummodo distinguitur ut vis alia <..>” (op. cit., p. 55). A remissão final desse último trecho à unidade da alma nos lembra que, não obstante as possíveis distinções entre suas vires - tríplice, no caso da mente, e dúplice, no caso do intelecto -, a alma enquanto substância mantém sempre sua unidade, como vimos no cap. 2.

Por fỉm, é necessária uma última precisão. Ainda que, nos trechos aqui elencados de Quodl. 13, q. 8, Henrique de Gand faça referência à ação do intelecto agente sobre o fantasma, ele mesmo considera que a imagem, propriamente dita ou verdadeidamente considerada, só tem lugar quando as ações do intelecto - e, principalmente, o próprio ato de intelecção - dizem respeito a Deus como objeto nãocriado. Daí compreendemos que o intelecto agente só possa verdadeiramente pertencer à imagem (como dito em uma das passagem aqui citadas) no que diz respeito às suas ações acerca do intelecto possível. Somente estas últimas, com efeito, têm lugar no conhecimento do objeto incriado, pois neste conhecimento jamais haverá fantasmas - "Sed quia secundum determinationem Augustini imago non est proprie in potentiis animae, nisi ut suis actibus convertuntur per cognitionem et amorem ad aeternum et increatum (eo enim anima imago Dei est, quo capax Dei est vel capax esse potest - ad quod nullo modo potest se convertere intellectus agens per illas duas operationes suas quas habet circa phantasmata, quia aeternum non habet phantasma), nullo igitur modo intellectus agens, ut consideratur in ordine ad phantasmata, secundum operationes eius circa illa pertinet ad veram rationem imaginis, sicut nec memoria et intelligentia ut convertuntur ad cognoscendum temporalia et inferiora, et universaliter quaecumque creata per notitiam quae proprie dicitur scientia, sed tantummodo ut convertuntur ad cognoscendum aeternum et aeternas regulas per notitiam quae proprie dicitur sapientia" (op. cit., pp. 54-5). Sendo assim, ainda que se possa falar em memória e inteligência no 
Mas, e quanto ao verbo que esperávamos encontrar ao fim desse caminho?

Lembremos que, algumas passagens atrás ${ }^{207}$, Henrique de Gand dizia que o ato de intelecção só pode ser dito 'verbo' na medida em que for tomado como informado pelo objeto. Agora, ele retorna a esse mesmo tema. Estabelecido que tanto o objeto na memória como o objeto na inteligência são notícias em ato, nos diz ele, também o próprio ato de intelecção (isto é, o intelecto possível atualizado por seu objeto) pode ser dito 'notícia'. Pois bem, à notícia nesse sentido (isto é, enquanto ato de intelecção), pode ser identificado o 'verbo'. Mas, novamente, isso só é possível na medida em que o ato de intelecção é informado pelo objeto que é, esse sim, propriamente verbum: “do terceiro modo diz-se 'notícia' o próprio ato de inteligir que, também, por vezes, é dito 'verbo' por Agostinho - mas isso somente enquanto é

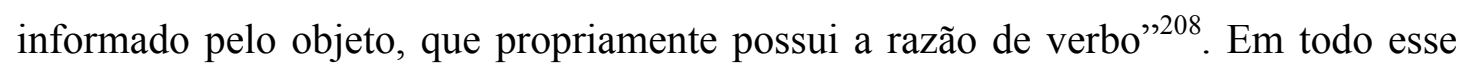
percurso de Quodl. 4, q. 8, portanto, o verbo é caracterizado, em sentido amplo, como $\mathrm{o}$ ato de intelecção. Porém, em seu sentido mais estrito, o termo 'verbum' é resguardado para significar o objeto enquanto informa em ato a intelecção atual - em outras palavras, o verbum não é o objeto inteligível na memória, mas é o mesmo objeto inteligido em ato.

Temos, portanto, mais uma precisão com respeito ao que líamos ao início do presente capítulo, nas primeiras obras de Henrique de Gand. Lá o verbo, muito embora já fosse apresentado como resultado da intelecção e similitude da coisa fora, não era estritamente caracterizado como o próprio objeto enquanto inteligido em ato, como ocorre em Quodl. 4, q. 8. Agora vemos que esse sucedâneo da intelecção em ato dito 'verbo' não é senão o próprio objeto enquanto informa a intelecção, isto é, enquanto é inteligido - em outras palavras, o resultado da intelecção em ato é que esse objeto se torne um objeto inteligido em ato. E isso é válido, mesmo, para o

conhecimento acerca de criaturas (mesmo aquelas temporais) e, nesse sentido, se possa também falar de maneira bem restrita em imagem, a imagem em sentido estrito e verdadeiro - "ad veram rationem imaginis" (op. cit., p. 55) só ocorre no conhecimento intelectual que o homem possui de Deus enquanto objeto não-criado.

Como vemos, portanto, a referência ao verbo em Quodl. 4, q. 8, é somente um elemento mais aparente na obra de Henrique de Gand da complexíssima aproximação entre Deus e homem acarretada pela noção teológico-filosófica de imago. Não sendo nosso objetivo, porém, aprofundarmo-nos nesse tema, remeto o leitor, para maiores informações, à bibliografia já citada na presente nota.

${ }^{207}$ Cf., acima, nota 198.

${ }^{208}$ Henrique de Gand, Quodl. 4, q. 8, co. (ed. De Wulf-Mansion Centre, vol. 8, p. 59): “Tertio autem modo dicitur 'notitia' ipse actus intelligendi qui etiam quandoque ab Augustino dicitur 'verbum', sed hoc non nisi in quantum informatur obiecto quod proprie habet rationem verbi $<\ldots$." 
conhecimento incomplexo: "informados a memória e a inteligência, desse modo, pela notícia e pelo ato de inteligir, não há ainda propriamente ciência nem em hábito na memória nem em ato na inteligência, pois aquela notícia é somente a compreensão dos simples" ${ }^{209}$. Ou seja, embora estejamos ainda no campo do conhecimento simples ou incomplexo, já há um verbo dele resultante - já há um objeto inteligido em ato. Tal verbo não é científico nem complexo, mas já é um objeto conhecido em ato, cujo conhecimento pode servir de base para a intelecção de conceitos complexos.

Dito isso, é hora de avançarmos para além de Suma, arts. 33-34 e Quodl. 4. Vimos que nessas obras Henrique de Gand retoma muito do que havíamos visto em obras suas anteriores, relendo sua própria doutrina da intelecção e, em particular, buscando melhor determinar certos termos chave nela utilizados. Com efeito, isso parece ocorrer tanto com respeito à species como com respeito ao verbum. A primeira começa a ser fortemente problematizada já em Suma, art. 33, onde vemos elementos que apontam na direção da distinção entre 'espécie impressiva' e 'espécie expressiva'. A problematização da noção de species fica clara, igualmente, em Suma, art. 34, quando vemos, pela tentativa de reconstrução de diversas camadas textuais de certos trechos desse artigo, a indecisão de Henrique de Gand quanto a citar ou não a species em determinados contextos de sua doutrina da intelecção. Por fim, em Quodl. 4, notamos a aplicação da distinção entre 'espécie impressiva' e 'espécie expressiva' à doutrina da intelecção, com uma tendência à aceitação de espécies expressivas no ato de conhecimento intelectual e uma concomitante exclusão de qualquer espécie impressiva do ato de intelecção. A razão de tal exclusão (a universalidade do conhecimento intelectual) é oferecida em Quodl. 4, q. 21, ainda de forma rudimentar, porém o fato de tal exclusão está estabelecido. Ao fim, não está claro ainda qual seria

\footnotetext{
${ }^{209}$ Henrique de Gand, Quodl. 4, q. 8, co. (ed. De Wulf-Mansion Centre, vol. 8, p. 59): "Hoc igitur modo informatis per notitiam et actum intelligendi memoria et intelligentia, nondum habetur proprie scientia, neque in habitu in memoria neque in actu in intelligentia, quia notitia illa solummodo simplicium est comprehensio $<\ldots$.. ".

Um pouco adiante, o Doutor Solene mostra que, tal como ao conhecimento dos conceitos simples corresponde um verbo, também ao conhecimento dos conceitos complexos corresponderá outro verbo - um verbum scientiale: "Immo sicut in concipiendo verbum praedictum simplicis intelligentiae intellectus agens ponit ut praesens memoriae obiectum universale incomplexum, ex quo sicut ex notitia memoriae procedit duplex notitia intelligentiae, scilicet ipse actus intelligendi et ipsum obiectum perceptum, sic in concipiendo istud verbum scientiale intellectus componentis ipse intellectus sui investigatione habet ut praesens in memoria illam notitiam ut obiectum universale complexum, ex quo sicut ex notitia memoriae procedit duplex notitia scientialis in intelligentia, scilicet ipse actus intelligendi complexus et ipsum obiectum ut verbum conceptum, quod adhuc praecedit omnem habitum scientiae, sed est primum principium adgenerandi secundum dictum modum habituum scientiae <..." - Quodl. 4, q. 8, co. (ed. De Wulf-Mansion Centre, vol. 8, p. 64). Sobre a distinção entre verbo incomplexo e verbo complexo, cf. a nota 211 , adiante.
} 
o resultado exato da descrição do objeto inteligível como 'espécie' ou 'forma expressiva'. Por outro lado, é notável que Henrique consiga estabelecer, em Quodl. 4, q. 8, toda uma narrativa da formação do conhecimento intelectual sem menção literal à espécie. Com efeito, a narrativa da produção do conhecimento pela combinação das noções de 'intelecto' (com sua dúplice divisão) e de 'mente' (com sua tríplice divisão) que lemos em Quodl. 4, q. 8, apresenta apenas uma menção vaga à noção de espécie expressiva (que, se lida à luz de Quodl. 4, q. 7, tende a estranhamente abarcar o próprio verbo), mas caracteriza muito bem o verbum como o objeto inteligido em ato, fruto da própria ação deste mesmo objeto, enquanto objeto meramente inteligível na memória, sobre o intelecto possível. Ainda que haja um verbum complexo, vemos que Henrique de Gand se utiliza claramente da noção de verbum para caracterizar o objeto incomplexo enquanto é inteligido em ato.

Como dito acima, o verbo complexo não nos interessará aqui, visto ser nosso trabalho voltado para o conhecimento incomplexo ${ }^{210}$. Além disso, parece-me que a noção de verbo incomplexo proposta por Henrique de Gand em Quodl. 4, q. 8, não sofre grandes modificações posteriores, sendo o verbum incomplexo em outras obras igualmente descrito como o objeto inteligido em ato ${ }^{211}$. Assim, parece-me que o fim

${ }^{210}$ Para um estudo aprofundado do verbum que diz respeito ao conhecimento complexo, cf. GOEHRING, Henry of Ghent on Cognition..., 2006, pp. 176-205; e GOEHRING, "Henry of Ghent on the verbum mentis", 2011, pp. 255-69. Cf. tb. os textos sobre a noção de verbum citados acima, na nota 206.

${ }^{211}$ Embora Henrique de Gand admita o uso do termo verbum para denominar os resultados tanto do conhecimento incomplexo como do conhecimento complexo, ele parece estabelecer uma clara hierarquia nesses usos diversos de tal termo, como apontado por Theophiel Nys e, principalmente, por Steven Marrone (cf. notas 195 e 196, acima). Destarte, podemos dizer que o verbum propriamente dito seria o conhecimento perfeito e complexo, sendo a denominação do conhecimento incomplexo como verbum também possível, porém imprópria.

Com efeito, o Doutor Solene chega mesmo a dizer que "multum deficiunt a ratione verbi, qui dicunt quod prima notitia simplex concepta in intellectu de re intellecta verbum est. Ista enim notitia non est discursu et cogitatione intellectus formata de alia. Et est ista notitia quaedam simplex rei manifestatio. Verbum autem est quiddam declarativum et manifestativum eius tamquam praebens in se ampliorem rei manifestationem. Et est in prima notitia operatio intellectualis incompleta, et in verbo completa" Quodl. 6, q. 1, co. (ed. De Wulf-Mansion Centre, vol. 10, p. 16). Com efeito, em Quodl. 6, q. 1, o verbo é aquele conhecimento final e mais verdadeiro, no qual o intelecto se aquieta: "Intellectus enim in intelligente numquam secundum actum intelligendi perficitur donec ex actu intellectus procedat aliquid quod sit et dicatur verbum. $\langle\ldots>$ in verbo quiescit intellectus in vero et non perficitur in actione intellectuali donec ipsum attingat <... " (ed. De Wulf-Mansion Centre, vol. 10, p. 13). Da mesma maneira, em Suma, art. 40, q. 7, co., Henrique de Gand introduz seis condições requeridas para que algo possa ser dito verbum: "Est igitur sciendum quod ad rationem et naturam verbi mentalis perfecti, tam in creatura quam in Creatore, sex conditiones requiruntur, quibus coniunctis et ordinatis, potest verbum describi hoc modo. Verbum est $<$ i $>$ terminus $<$ ii $>$ actionis intellectualis, $<$ iii $>$ emanans $<$ iv $>$ ab intelligente secundum actum, $<\mathrm{v}>$ manens in ipso intelligente, $<$ vi $>$ alterius declarativum" - (ed. De Wulf-Mansion Centre, vol. 28, p. 285). A última condição, em especial, é introduzida por Henrique para excluir qualquer outro conceito posterior ao primeiro conceito simples, mas que ainda não chegue a ser uma declaração completa da coisa - "Ultimo autem dicitur 'declarativum alterius', ad 
differentiam cuiuscumque concepti post primum intellectum simplici intelligentia, qui non est declarativus illius <...” (ed. De Wulf-Mansion Centre, vol. 28, pp. 285-6). Sobre essa última condição, Goehring no diz: “< ..> a complete mental word fully clarifies something else, unlike, says Henry, any kind of confused concept that is gained after the intellect's first, simple understanding" (Henry of Ghent on Cognition..., 2006, p. 202). Em poucas palavras, tanto o trecho de Quodl. 6, q. 1, como aquele de Suma, art. 40, q. 7, parecem excluir o uso de verbum para nomear o conceito simples oriundo da intelecção do simples.

Por outro lado, em um texto como Quodl. 5, q. 25, é possível ver o Doutor Solene nomear todos os conhecimentos - desde o mais simples ao mais completo - como verbum: "Ex quo patet, quod respectu tali verbi intellectus noster, sive se habeat ex parte memoriae, sive ex parte intelligentiae omnino passivus est. Et inquantum intellectus habet rationem memoriae continentis obiectum, et verbum illud sic movens intelligentiam, ut ipsa post completam formationem huius verbi incipiat quasi fodere acumine naturali, et discutere in unoquoque quid sit, et cui, et propter quid insit, componendo, et dividendo, et ratiocinando, et per hoc format se verbum incomplexum de eo, quod quid est secundum se, vel complexum, applicando quod quid est ei, cuius est, vel quod inest ei, cui inest <...>" (ed. 1613, f. 305vb). Neste excerto, 'verbo' nomeia [i] o objeto movendo em ato a inteligência (sentido que se aproxima àquele que vimos em $Q u o d l .4$, q. 8), [ii] um conhecimento incomplexo oriundo da operação de composição e divisão (provavelmente, algo como o conceito 'substância' ou 'animal') e, finalmente, [iii] um conceito complexo oriundo dessa mesma operação. Ou seja, aqui todo resultado - inicial, intermediário ou final - de um ato de intelecção pode ser tomado como verbum.

Agora, voltando ao já citado Suma, art. 40, q. 7, há mais um fator complicador na noção de verbum complexo descrita por Henrique de Gand. A bem dizer, esse verbo não é exatamente fruto imediato do ato de intelecção (como seria o verbo incomplexo), mas se deriva do ato de dizer (actus dicendi): “'Quod quid est' ergo de unaquaque re simplici, intellecta intelligentia simplici, verbum est, existens in intellectu non per actum intelligendi qui formatur per obiectum cognitum, sed per actum dicendi, vel cum discursu, vel absque discursu" - Suma, art. 40, q. 7, co. (ed. De Wulf-Mansion Centre, vol. 28, p. 287 - sobre esse dicere anterior ao verbo, cf. ARGOS, "La actividad cognoscitiva en los escolásticos... - II/III", 1948, p. 297). Nesse trecho um tanto lacônico, o Doutor Solene chama a atenção para o fato de que o verbo da inteligência simples já será o dizer a quididade da coisa (isto é, seu quod quid est). Destarte, o verbo não é tomado aqui como um conceito incomplexo derivado do ato de intelecção simples, mas como um conceito complexo que diz a quididade do que fora antes inteligido como conceito simples. Que Henrique de Gand afirme nessa passagem a possibilidade desse ato de dizer com ou sem dicurso se deve ao contexto da passagem: nela fala-se do verbo tanto no anjo, que conhece sem discurso racional, como no homem, que necessita de tal discurso (cf. cap. 3). Sendo assim, não há uma tal opção para o intelecto humano - se tomarmos o verbum dessa maneira, ele sempre dependerá de um discurso racional. Mas, o que seria esse ato de dizer discursivo de que se deriva tal verbo no homem? Parece-me que a resposta mais clara para essa questão pode ser encontrada em Suma, art. 58, q. 2 texto ao qual voltaremos adiante, no item 6.5.2 -, onde lemos que "intellectus, ut habet rationem intellectus simpliciter conversi super se ipsum post discursum praedictum agente in ipsum huiusmodi memoria, informatur notitia declarativa determinata, et terminata ad definitivam rationem sive quod quid est eius quod confuse cognitum est in memoria, et tenet rationem prolis, et intelligentiae $<\ldots>$. Et per hunc modum gignitur [ed. 1520, f. 131rK | gignitor ed. 1642-6, p. 1009a] notitia de notitia, declarativa de simplici $<\ldots>$. Ex parte vero prolis, et verbi se tenet intellectus idem, ut est informatus notitia illa declarativa, et ipsum obiectum cognitum in sua definitiva ratione" (ed. 1642-6, p. 1009a, n. 46). Mais uma vez encontramos a fórmula notitia de notitia, porém agora ela serve a outro propósito: ela caracteriza a relação entre a notícia declarativa da definição da coisa conhecida e a notícia simples, anterior, da qual aquela primeira nasce. $\mathrm{O}$ ato de dizer, ao que parece, é esse ato que resulta da conversão ativa do intelecto sobre o próprio conceito simples que ele concebera - disso resulta o verbo complexo, que diz a quidadidade da coisa. Sobre essa reflexão ou conversão anterior ao verbo, cf. GOEHRING, Henry of Ghent on Cognition..., 2006, pp. 203-5 e GOEHRING, "Henry of Ghent on the verbum mentis", 2011, pp. 269-72 - nesses textos, essa doutrina é apresentada com base em Suma, art. 54, q. 9, e Suma, art. 58, q. 1. Cf. tb. FRIEDMAN, R. L. In principio erat verbum: the Incorporation of Philosophical Psychology into Trinitarian Theology, 1250-1325. 2 vols. A thesis submitted in partial fulfillment of the requirements for the Doctor of Philosophy degree in History in the Graduate College of The University of Iowa. May 1997, pp. 143-7; PANACCIO, C. Le discours intérieur de Platon à Guillaume d'Ockham. Paris: Éditions du Seuil, 1999, pp. 186-7, 200-1; PINI, "Henry of Ghent's Doctrine of verbum", 2003, pp. 324-5; FRIEDMAN, Intellectual Traditions at the Medieval University..., 2013, pp. 267-8. É interessante notar, também, que o caráter final do verbum é bem enfatizado em BRAUN, Die Erkenntnislehre..., 1916, pp. 38-9. 
ou termo do ato de intelecção está razoavelmente esclarecido nesse ponto: ele é o verbum incomplexo, que não é senão o próprio objeto em ato na memória, tomado agora como inteligido em ato e, portanto, como possível base para outros conhecimentos (agora complexos) acerca dele mesmo. De outra parte, porém, pareceme igualmente que, se o fim do ato de conhecimento incomplexo está bem esclarecido, não está nada claro o princípio deste ato - isto é, não está nada claro como a espécie (agora, tomada precisamente como 'expressiva') elicita o ato de intelecção.

Sendo assim, é a este último problema que pretendo dedicar esta última etapa do capítulo 6. Nela, veremos mais claramente - com base em Quodl. 5, q. 14 - o que leva Henrique de Gand a rejeitar espécies impressivas no intelecto. Em seguida, notaremos que a afirmação de espécies expressivas como princípios da intelecção está associada a uma profunda e problemática aproximação, por parte de Henrique de Gand, entre conhecimento intelectivo e conhecimento sensitivo, algo que já víamos ser anunciado por passagens retiradas pelo Doutor Solene da redação final de Suma, art. $34^{212}$. Essa aproximação ficará especialmente clara em Suma, art. 58 e Quodl. 9, q. 15 , como veremos mais à frente.

\subsection{A ESPÉCIE EXPRESSIVA, O FANTASMA UNIVERSAL E O INTELECTO IMAGINÁRIO}

\subsubsection{Das espécies impressas às espécies expressas}

Como já antecipado, o Quodl. 5, q. 14, é um texto extremamente relevante para a doutrina da intelecção de Henrique de Gand por nele encontrarmos, pela primeira vez, uma exposição organizada das razões pelas quais não se pode admitir

Dito isso e, como já mencionado diversas vezes, não sendo meu objetivo aqui o estudo aprofundado do conhecimento complexo em Henrique de Gand, contento-me em apontar essas dificuldades referentes à noção de verbum em sua obra. Uma bibliografia maior a respeito do tema já foi citada acima, nas notas 206 e 210. Por fim, com essa rápida referência a alguns dos textos centrais para a doutrina do verbo de Henrique de Gand, parece claro que ele tende a tomar o conhecimento complexo e declarativo como aquele mais apropriadamente dito verbo. De outra parte, ele mantem em diversos textos um uso mais abrangente do termo verbum, de maneira a que também se possa defender denominação do conceito simples - ou do objeto em ato da intelecção simples - como verbum, ainda que em sentido menos próprio. Sendo assim, contento-me em abandonar essa discussão nesse ponto, considerando que, em um sentido menos estrito, também o conceito simples foi (pelo menos, em algumas obras) tomado como verbum por Henrique de Gand.

${ }^{212}$ Cf., acima, nota 174 . 
espécies impressas ou impressivas na narrativa da formação do conhecimento intelectual humano. Ademais, para além dessa pars destruens, encontramos nesse texto ainda uma pars construens - nela, o Doutor Solene mostra como é possível explicar a formação da intelecção unicamente por recurso àquilo que ele denomina como 'espécies expressas' ou 'expressivas'. E, no entanto, o recurso a essa questão não é sem seus problemas.

O principal deles é o fato de que, como muito bem destacado por diversos comentadores, Quodl. 5, q. 14, lida principalmente com o conhecimento angélico ${ }^{213}$. Por isso mesmo, parece difícil estabelecer até que ponto os argumentos aqui apresentados seriam igualmente válidos para o intelecto humano, um problema já levantado por Martin Pickavé ${ }^{214}$. Para tentarmos compreender os limites da aplicação das conclusões acerca desse texto ao intelecto humano, será interessante atentarmos bastante para a estrutura da questão na medida em que a lermos. Como veremos, se na colocação do problema e em sua resposta inicial Henrique parece ter em mente exclusivamente o conhecimento angélico, em certos trechos é possível ver a generalização de suas conclusões de maneira a incluir em sua análise, igualmente, reflexões acerca do conhecimento humano.

\subsubsection{1. pars destruens}

A pergunta feita em Quodl. 5, q. 14, é precisamente "se o intelecto do anjo intelige outras coisas que não ele por sua essência, por similitudes das coisas ou pela presença da quididade delas [utrum intellectus angeli intelligat res alias a se per suam essentiam, an per rerum similitudines, an per praesentiam quiditatum earum] ${ }^{, 215}$. De fato, o problema posto é explicitamente angelológico, de maneira que sua determinação final não será nosso principal interesse aqui. Por outro lado, interessanos assaz o caminho seguido rumo a tal determinação, uma vez que em diversos pontos desse percurso Henrique de Gand se volta para um discurso acerca do

\footnotetext{
${ }^{213}$ SORGE, Gnoseologia e teologia, 1988, p. 91; BROWN, J. V. "Henry's Theory of Knwoledge...", 1996, pp. 33-5; GORIS \& PICKAVÉ, "Von der Erkenntnis der Engel", 2001, p. 132; GOEHRING, "Henry of Ghent's Use of Aristotle's De anima...", 2013, pp. 81-3; PICKAVÉ, "Causality and Cognition...", 2015, pos. 1145.

${ }^{214}$ PICKAVÉ, “Causality and Cognition...”, 2015, pos. 1517. Cf., adiante, a nota 217.

${ }^{215}$ Henrique de Gand, Quodl. 5, q. 14 (ed. 1613, f. 259va).
} 
intelecção humana. Todo o problema, portanto, está em delimitar que elementos desse percurso dizem, de fato, respeito ao intelecto do homem.

$\mathrm{Na}$ formulação inicial de sua resposta, nosso mestre de Gand deixa claro que pretende negar a ocorrência de espécies inteligíveis no conhecimento intelectual. Entretanto, é necessário ter cautela na leitura da passagem, pois não há aqui uma negação da espécie inteligível simpliciter, mas sim uma recusa da espécie inteligível impressa. O que, mais adiante, abrirá espaço para a introdução da noção de espécie inteligível expressa. Em todo caso, vejamos como o Doutor Solene introduz sua solução para o problema:

"Na dissolução dessa questão, não há outra dificuldade além daquela que foi tocada pelo argumento, a saber, pela ação do que [quo scilicet agente] o intelecto de inteligente em potência se faz inteligente em ato. E para fugir dessa dificuldade (não pela notícia de alguma causalidade que a espécie ou similitude da coisa impressa no intelecto opere no intelecto para o ato de inteligir) foi introduzida a opinião sobre essas espécies inteligíveis impressas. Donde, cumpre mostrar que tais espécies, se propostas, não operam para elicitar o ato de inteligir, tal que não se deva propô-las devido a ele; pelo contrário, mesmo que elas sejam propostas, é preciso propor outro motivo para elicitar o ato de inteligir, que mesmo sem elas (tal como com elas) seria nato a elicitá-lo. Investigado isso, será patente que é completamente vão e inútil [frustra, et otiosum] propô-las $<\ldots>$. Isso porque não se deve propor algo vão no fundamento da natureza e da criatura; portanto, de nenhum modo se deve propor que haja na virtude intelectiva tais espécies" ${ }^{216}$.

Como se vê, o primeiro passo aqui é delimitar com precisão o problema abordado: para Henrique, saber se há ou não espécies no intelecto depende de um problema anterior, a saber, a determinação do motor do ato de intelecção, isto é, daquilo por cuja ação o intelecto passa de inteligente em potência para inteligente em ato (quo scilicet agente intellectus de potentia intelligente fiat actu intelligens). $\mathrm{Na}$ sua visão, a noção de espécie impressa só faz sentido se servir para explicar a

\footnotetext{
${ }^{216}$ Henrique de Gand, Quodl. 5, q. 14, co. (ed. 1613, f. 259va): "In dissolutione huius quaestionis non est difficultas alia, quam illa, quae tacta est in argumento, quo scilicet agente intellectus de potentia intelligente fiat actu intelligens. Et propter fugam huius difficultatis, non propter notitiam alicuius causalitatis, quam species sive similitudo rei intellectui impressa operaret in intellectu ad actum intelligendi, introducta est opinio de ipsis speciebus intelligibilibus impressis. Unde ostendendum est quod huismodi species, si ponantur, non operantur ad eliciendum actum intelligendi, ut propter ipsum non oporteat eas ponere, immo etiam ipsis positis oportet ponere aliud motivum ad eliciendum actum intelligendi, quod etiam sine ipsis aequaliter natum est ipsum elicere, et cum ipsis. Quo investigato patebit, quod omnino frustra, et otiosum sit ponere illas, et esse similiter si sunt. Quare cum non sit ponere aliquid esse frustra in fundamento naturae, et creaturae; nullo igitur modo ponendum est in virtute intellectiva esse aliquas huiusmodi species". Cf. TACHAU, Vision and Certitude..., 1988, p. 32; GORIS \& PICKAVÉ, "Von der Erkentnnis der Engel...", 2001, p. 133; PICKAVÉ, "Causality and Cognition...", 2015, pos. 1155-71.
} 
passagem do intelecto da potência ao ato de intelecção - é precisamente com esse fim que a noção de espécie impressa teria sido introduzida. Destarte vemos que, de saída, Henrique de Gand problematiza a própria noção de espécie inteligível impressa - não há nada que prove sua necessidade, sendo ela proposta somente como solução de um problema complexo da doutrina da intelecção ("propter fugam huius difficultatis, non propter notitiam alicuius causalitatis <...> introducta est opinio de ipsis speciebus intelligibilibus impressis"). Sendo assim, se se puder provar que a espécie impressa não resolve tal problema - isto é, se for estabelecido que a espécie impressa não é algo capaz de mover o intelecto para o ato de inteligir, pode-se descartá-la, uma vez que ela terá se tornado em elemento vão, inútil ou supérfluo na doutrina da intelecção. Essa será, portanto, a estratégia de Henrique, a saber, demonstrar a superfluidade da espécie impressa para a narrativa da formação da intelecção em ato ${ }^{217}$. Em seguida,

\footnotetext{
${ }^{217}$ Note-se que, para Martin Pickavé, não é possível extrair tal recusa geral da espécie impressa a partir dos argumentos apresentados por Henrique de Gand em Quodl. 5, q. 14. Em particular, o comentador afirma ser difícil compreender a seguinte passagem da questão: "Ad propositum igitur descendendo dicimus, quod sola vis sensitiva species habet impressas a sensibus, et nulla vis intellectiva habet species impressas intelligibilium, ut supra ostentum est" (ed. 1613, f. 262[258]vb). Sobre essa passagem, nos diz Pickavé: "But where exactly has Henry shown that there are no intelligible species inhering in the intellect? Strictly speaking, Henry provides nowhere in Quodlibet V, q. 14, an argument that directly establishes that can be no such species. The most he does is to argue that such species are useless for an account of intellectual cognition. But because nature does nothing in vain, it would be wrong to posit the existence of such needless entities. This is Henry's overall strategy. And as should be clear from the overview given earlier, there are altogether eight arguments Henry advances against the need for species in the angelic intellect. Are all of these arguments also establishing that there is no need for species in any kind of intellect?" - PICKAVÉ, "Causality and Cognition...", 2015, pos. 1511-7 (grifos no original). Mais adiante, após estudar cuidadosamente os argumentos a que se refere, Pickavé conclui que somente dois argumento (aqueles apresentados aqui, adiante, nas notas 223 e 232) de fato podem ser base para uma generalização da recusa de espécies impressas, embora ele não pareça considerar tal generalização como um resultado patente da discussão em Quodl. 5, q. 14: "Fiding Henry's arguments against impressed intelligible species in Quodlibet 5, q. 14 turned out to be much more complicated than expected. As we were able to see, only two arguments are developed enough to explain the general rejection of such species $<\ldots>$. This result is in sharp contrast to the general antispecies arguments medieval authors ascribe to Henry of Ghent" - PICKAVÉ, "Causality and Cognition...", 2015, pos. 1630. (cf. tb. pos. 1184). A meu ver, porém, a argumentação de Henrique de Gand é mais eficiente do que Pickavé faz parecer. Com efeito, Henrique de Gand - como o comentador bem nos mostra - se contenta em provar a superfluidade da espécie inteligível impressa. Daí, diz Pickavé, não se pode concluir que não haja, em geral, espécies impressas. Esse passo do comentador seria válido não fosse pela noção de espécie impressa que o Doutor Solene pretende atacar. Com efeito, se retornarmos à passagem citada na nota anterior, veremos que, para Henrique de Gand, a espécie impressa não é um dado positivo da doutrina da intelecção - isto é, sua necessidade não é comprovada dedutivamente. Pelo contrário, ela é apenas uma hipótese introduzida como solução de um problema, nomeadamente, a passagem do intelecto da potência ao ato de intelecção. Assim, a demonstração da superfluidade da espécie impressa na solução deste problema pode sim ser tomada como uma recusa, em geral, da espécie impressa, uma vez que, nesse caso, estaria derrubado aquele que é, para Henrique de Gand, o único pilar de sustentação da afirmação da necessidade de espécies impressas no conhecimento intelectual. Esse é, parece-me, o caminho seguido pelo Doutor Solene em sua argumentação. De outro lado, não acredito ser possível ler Quodl. 5, q. 14, uma negação completa da doutrina da espécie inteligível, como se propõe em PINI, "Il dibattito sulle specie...", 2004, pp. 288-91.
} 
veremos como se propõe a formulação de tal narrativa sem recurso à espécie impressa.

Pois bem, nosso autor vê a afirmação da espécie impressa como um problema que se divide em dois âmbitos: [1] por um lado, ela poderia ser necessária da parte da potência intelectiva para sua atualização; de outro, [2] sua necessidade poderia provir do inteligível, que talvez não possa atualizar o intelecto sem uma espécie. Em ambos os casos, será o objetivo de Henrique de Gand mostrar que, seja pela parte do intelectivo seja pela parte do inteligível, não há nenhum argumento que mostre a necessidade de espécies impressas para o conhecimento. No mais, note-se como no trecho a seguir, em que se apresenta a divisão desses âmbitos de argumentação, fica muito claro o contexto angelológico da questão, ao contrário do que ocorria no último trecho indentado, onde ela era formulada em termos mais gerais:

"Que o intelecto separado a partir de si, sem qualquer informação de uma espécie, seja capaz do ato de inteligir [possit in actum intelligendi], argumenta-se assim. Se para, o ato de inteligir, precisar de uma espécie pela qual seja informado, $<$ isso é $>$ ou $<1>$ devido à razão do intelectivo nele, tal que sem ela $o$ intelectivo, que consiste na essência do anjo, de nenhum modo seja suficiente para que intelija em ato (tal como a forma substancial do fogo tampouco <é suficiente $>$ para que o fogo aqueça sem que seja informado pela forma do calor); ou $<2>$ é requerida devido à razão do inteligível, pois é preciso que, no ato, sejam um único o inteligente e o inteligido, e o inteligido não é nele nem verte-se $<$ nele> por sua essência" ${ }^{218}$.

Atentemos para as razões que, em cada âmbito de discussão, tornariam necessária a espécie impressa. Da parte do intelectivo [1], poderia ocorrer de somente a potência intelectiva, sem algo que a informe de determinado modo (subentende-se, nela imprimindo-se), seja insuficiente para a atualização do conhecimento ao ato em si. Já da parte do inteligível [2], poderia ocorrer de o próprio objeto não poder, por si só, unir-se ao inteligente, de maneira a necessitar de um meio pelo qual isso se pudesse fazer. Ora, sabendo-se que Henrique de Gand justamente se oporá a essas hipóteses, vê-se que ele deve mostrar, da parte do intelecto [1], que a potência intelectiva é suficiente para a atualização do ato em si sem que nela seja impresso

\footnotetext{
${ }^{218}$ Henrique de Gand, Quodl. 5, q. 14, co. (ed. 1613, f. 259va): "Quod intellectus separatus ex se absque omni informatione speciei possit in actum intelligendi, arguitur sic. Si ad actum intelligendi indigeat specie, qua informetur, aut ergo propter rationem intellectivi in ipso, ut sine ipsa intellectivum, quod consistit in essentia Angeli, nullo modo ex se sufficit, ut actu intelligat, sicut neque forma substantialis ignis, ut ignis caleficiat, nisi informetur forma caloris. Aut requiritur propter rationem intelligibilis, quia oportet quodammodo esse unum in actu intelligens, et intellectum, et intelligibile non inest ei, neque illabitur per suam essentiam".
} 
algo e, da parte do inteligível [2], que o objeto pode se unir ao intelecto por si mesmo, sem necessitar de um meio impresso no intelecto. Como se esperaria de um autor escolástico, para cada um desses casos, Henrique de Gand introduzirá diversos argumentos. A seguir, discutiremos os mais relevantes para o estudo do intelecto humano $^{219}$.

Os três argumentos apresentados [1] da parte do intelectivo são sucintos e podem ser lidos na passagem a seguir. Como se notará, os dois últimos já foram cuidadosamente estudados por nós neste capítulo:

"Não do primeiro modo, pois $<1.1>$ há uma única razão comum para que algo seja intelectivo e inteligível, a saber, que seja uma forma separada da matéria. Assim, quando separado da matéria é, a partir de si, inteligível segundo o ato sem qualquer outro informante que seja nele uma razão pela qual é inteligido em ato. Assim, similarmente, o separado da matéria, quando é de si, é intelectivo segundo o ato, sem qualquer outro informante que seja nele uma razão pela qual intelige em ato.

$<1.2>$ Além disso, nesse caso $<s c$. se a espécie impressa fosse necessária para a intelecção devido à razão do intelectivo>, nenhum intelectivo sem exceção poderia inteligir sem que fosse informado por uma espécie (tal como o fogo, não informado pelo calor, tampouco poderia aquecer). O consequente é falso, pois, como mostramos alhures, ele $<s c$. o intelectivo $>$ vê intelectualmente e intelige Deus sem qualquer informação de qualquer espécie.

$<1.3>$ Além disso, ele intelige a si mesmo sem a informação de qualquer espécie que possua de si.

Assim, da parte do intelectivo, enquanto intelectivo, não se requer nele espécie" ${ }^{, 220}$.

Como se dizia, os dois últimos argumentos são bem conhecidos para nós. Se a espécie impressa fosse necessária da parte da potência intelectiva, o conhecimento intelectual de qualquer objeto exigiria espécies impressas, inclusive [1.2] o conhecimento beatífico e [1.3] o conhecimento de si. Esse, porém, não é o caso, como

\footnotetext{
${ }^{219}$ Sobre a divisão dos argumentos de Quodl. 5, q. 14, cf. PINI, "Il dibattito sulle specie...", 2004, p. 289; FIORENTINO, "Species nei secoli XIII-XIV", 2007, pp. 93-6; e PICKAVÉ, "Causality and Cognition...", 2015, pos. 1164-85. A divisão que apresento aqui possui traços das três, sem porém se identificar estritamente a elas.

${ }^{220}$ Henrique de Gand, Quodl. 5, q. 14, co. (ed. 1613, f. 259va-b): "Non primo modo, quoniam eius, quod aliquid sit intellectivum, et intelligibile, una ratio communis est, scilicet, quod sit forma separata a materia. Cum ergo separatum a materia, quantum est ex se, intelligibile est secundum actum absque omni alio informante, quod sit ratio in eo, qua actu intelligatur: separatum ergo a materia consimiliter, quantum est ex se, est intellectivum secundum actum absque omni alio informante, quod sit ratio in eo, qua actu intelligat.

Praeterea tunc nullum intellectivum omnino intelligere posset, nisi specie illius informatus, sicut nec ignis non informatus calore calefacere posset, consequens falsum est, quia, ut alias ostendimus, Deum intellectualiter videt, et intelligit absque omni informatione alicuius speciei. Praeterea, seipsum intelligit absque omnis speciei informatione, quam de se habeat. Ex parte ergo intellectivi, inquantum intellectivum non requiritur species in ipso".
} 
já vimos pausadamente no item 6.3 - tanto a intelecção beatífica como o conhecimento de si ocorrem sem espécie impressa (ainda que, como estabelecemos, deixem espaço para uma espécie expressa ou expressiva). Assim, só esses dois argumentos já são suficientes para demonstrar que o intelectivo não exige espécies impressas - com efeito, se um único conhecimento intelectual prescinde de espécies, então a potência intelectiva, pelo menos, pode inteligir sem espécies, uma vez que ela é a mesma potência em todos os casos.

Mais interessante neste ponto, porém, é o primeiro argumento elencado, onde se põe em discussão as próprias noções de 'intelectivo' (intellectivus) e de 'inteligível' (intelligibilis). Segundo Henrique, o caráter intelectual de ambos - da potência intelectiva e do objeto inteligível - advém de uma única razão, a saber, que sejam uma "forma separada da matéria [forma separata a materia]". Ou seja, a própria separação da matéria torna o objeto algo inteligível e o intelecto algo intelectivo. Portanto, não há qualquer necessidade da ocorrência de espécies impressas para que algo seja tomado como 'intelectivo' ou 'inteligível'; o que há é a exigência da ausência de matéria para que algo seja inteligível em ato ou intelectivo em ato. A meu ver, ao contrário do que Pickavé parece supor ${ }^{221}$, esse argumento de modo algum se limita ao intelecto angélico ou exclui o intelecto humano por sua referência à imaterialidade do intelecto ou do inteligível. De fato, lembremos que, como estabelecido no cap. 2, a parte intelectiva, mesmo no homem, é imaterial. E, se se pode dizer que o intelecto está na matéria, isso é válido somente na medida em que o intelecto é realmente idêntico à substância da alma. Tomado, porém, como uma potência ou força intencionalmente distinta das outras potências da alma, o intelecto humano é algo separado da matéria, mesmo quando a alma está unida ao corpo no homem. Por isso mesmo, já vimos a abstração ser descrita por Henrique como uma retirada as condições materiais do objeto. Enfim, parece-me que o argumento [1.1] é válido igualmente para o intelecto humano e o intelecto angélico - melhor, ele é um argumento geral acerca da intelectividade.

\footnotetext{
${ }^{221}$ PICKAVÉ, “Causality and Cognition...", 2015, pos. 1519: “The first three arguments against species (A 1-3) are, as we saw above, all formulated ex parte intellectivi. Their aim is to establish that at least ex parte intellectivi species are not required for intellective acts to occur. The first one says that for an intellective power to be actually understanding it is enough to be separated from matter, and the angelic intellect is obviously separated from matter < grifo meu >. Arguments two and three point out that there are certain kinds of intellectual activities, such as the beatific vision or self-knowledge, which do not required species. Therefore species are never required ex parte intellectivi".
} 
Com isso, estabelece-se que, da parte do intelectivo (para ser preciso, no argumento [1.1], já se aborda inicialmente também o inteligível), não há qualquer necessidade de referência a espécies impressas para a explicação do conhecimento intelectual. Desse modo, podemos passar aos argumentos que dizem respeito propriamente [2] à parte do inteligível. Esses argumentos também são, basicamente, três. No entanto, eles possuem uma formulação mais longa, que exigirá um tratamento mais pausado para cada um. Mais adiante, veremos que o argumente [2.3] só deverá ser abordado parcialmente.

Por outro lado, é possível dizer que todos possuem um teor comum, que fica claro na apresentação inicial que recebem: "Tampouco, similarmente, da parte do inteligível, tal que por ela $<s c$. pela espécie impressa $>$ ele seja presente ao inteligente e constitua, de certo modo, um único com ele, pois não se requer a presença do inteligível no inteligente para o ato de inteligir senão enquanto objeto inteligido em ato por sua presença $<\ldots>$,222 . Pretende-se aqui mostrar que o inteligível pode ser presente ao intelecto de maneira suficiente para o ato de intelecção sem que haja espécies impressas na potência intelectiva. Melhor dito, algo pode ser presente ao intelecto enquanto objeto inteligível sem que haja espécies impressas. Ora, uma vez que a mera presença de algo ao intelecto como objeto inteligível é suficiente para que ocorra a intelecção, então a necessidade de espécies impressas está excluída se se puder provar que tal presença de algo ao intelecto enquanto objeto inteligível pode ocorrer sem espécies impressas.

Pois bem, destes argumentos [2] da parte do inteligível, o primeiro tem por base uma reflexão acerca do caráter universal do objeto de intelecção:

$<2.1>$ Mas, o inteligível não possui ser por uma espécie sua no intelecto, como objeto conhecido, pois não é objeto senão sob a razão do universal e a espécie impressa não pode ser representativa de algo senão sob a razão do singular, pois se a espécie de algo for impressa em algo por outro que não aquele de que é, é preciso - se ela for uma verdadeira espécie representativa daquilo - que seja impressa por isso segundo o mesmo modo pelo qual seria nata a ser impressa imediatamente pela própria coisa. Porém, nenhuma espécie é nata a ser impressa no intelecto por um universal, enquanto é universal em si, mas somente enquanto assinalado em um suposto. E nada é nato a agir uma impressão de sua espécie em outro senão enquanto possui ser por existência na natureza das coisas. Porém, assim não pode imprimir senão uma espécie do particular sob a razão pela qual é

\footnotetext{
${ }^{222}$ Henrique de Gand, Quodl. 5, q. 14, co. (ed. 1613, f. 259vb): "Quod similiter neque ex parte intelligibilis, ut per ipsam praesens sit intelligenti, et quodammodo unum cum ipso constituat, quoniam praesentia intelligibilis non requiritur in intelligente ad actum intelligendi, nisi tanquam obiecti actu intellecti ex sua praesentia $<\ldots$..”.
} 
particular, a qual nunca é representativa do universal sob a razão pela qual é universal. Assim, etc., ${ }^{223}$.

Esse argumento [2.1] é semelhante àquele que já encontramos em Quodl. 4, q. $21^{224}$, segundo o qual haveria uma fundamental oposição entre o caráter necessariamente universal do objeto de intelecção e o caráter necessariamente singular do objeto apresentado por qualquer espécie impressa. Para que o presente argumento seja válido, portanto, é necessário mostrar que a espécie impressa necessariamente dá a conhecer ou representa somente o singular, ou melhor, algo sob a razão do singular ("species impressa non potest esse repraesentativa alicuius, nisi sub ratione singularis"). Perceba-se, destarte, que há aqui em Quodl. 5, q. 14, uma sutil, porém importante mudança com respeito à formulação lida em Quodl. 4, q. 21. Neste último, dizia-se que uma espécie impressiva no intelecto [i] "seria uma razão de conceber o objeto sob a razão do particular [esset ratio concipiendi obiectum sub ratione particularis]", assim como [ii] a mesma espécie impressiva "é em si particular [sicut et ipsa in se particularis est]"225. Ou seja, em Quodl. 4, q. 21, Henrique de Gand atrela dois elementos distintos, nomeadamente: [ii] o caráter singular da espécie impressiva e [i] a razão do particular sob a qual tal espécie apresentaria o objeto ao intelecto.

Aqui em Quodl. 5, q. $14^{226}$, o fato de a espécie impressa representar o objeto sob a razão do singular não é atrelado ao ser singular da própria espécie, mas antes ao ser singular de sua causa. De fato, ao ser intenção, a espécie impressiva remete àquilo que a causa (e de que, portanto, ela depende como efeito). Ora, algo só é causa de um

\footnotetext{
${ }^{223}$ Henrique de Gand, Quodl. 5, q. 14, co. (ed. 1613, f. 259vb): "Sed intelligibile per speciem suam non habet esse apud intellectum, ut obiectum cognitum, quia non est obiectum nisi sub ratione universalis, et species impressa non potest esse repraesentativa alicuius, nisi sub ratione singularis, quoniam si species alicuius alicui imprimatur ab alio, quam ab eo cuius est, si sit vera species eius repraesentativa, oportet, quod secundum eundem modum imprimatur ab illo, sicut ab ipsa re immediate nata esset imprimi. Sed nulla species nata est imprimi in intellectu ab universali, secundum quod est universale in se, sed solum secundum quod habet esse signatum in supposito particular, quia secundum se non habet existere in rerum natura, sed solum, ut signatum in supposito, et nihil natum est agere impressionem suae speciei in alio, nisi secundum quod habet esse per existentiam in rerum natura. Sic autem non potest imprimere, nisi speciem particularis sub ratione, qua particulare est, quam nunquam est repraesentativa universalis sub ratione, qua $[e d .1518, f .174 v Y \mid$ quae ed. 1613] universale est, ergo etc.". Cf. BRAUN, Die Erkenntnislehre..., 1916, pp. 29-30; GORIS \& PICKAVÉ, "Von der Erkentnnis der Engel...", 2001, pp. 133-4; ROMBEIRO, "Intelligible Species in the Mature Thought of Henry of Ghent”, 2011, p. 209; PICKAVÉ, “Causality and Cognition...", 2015, pos. 1536-80.

${ }^{224}$ Cf., acima, a nota 189.

${ }^{225}$ Cf., novamente, a nota 189.

${ }^{226}$ Cf., acima, nota 223.
} 
efeito em outro (nesse caso, de uma impressão) enquanto é algo existente na natureza das coisas (per existentiam in rerum natura) e, assim, enquanto é algo singular. Sendo assim, a espécie impressiva só pode ser causada por algo singular e, uma vez que devido a seu ser intencional ou representativo, ela remete fielmente à sua causa, ela dará necessariamente a conhecer algo singular ou, melhor, sob a razão do singular. Como se vê, Henrique de Gand desatrela, em Quodl. 5, q. 14, [i] a singularidade da representação e [ii $\left.{ }^{\mathrm{i}}\right]$ a singularidade do ser da espécie impressiva, atrelando a primeira $\left[\mathrm{iii}^{\mathrm{ii}}\right]$ à singularidade da causa da espécie impressiva (o que se coaduna muito bem à noção intencional de espécie que encontramos no cap. 4$)^{227}$.

Pois bem, conclui o Doutor Solene, uma espécie impressa só pode ser causada por algo singular e, por isso mesmo, só pode ser representiva de algo sob a razão do singular. Assim, essa mesma espécie impressa jamais poderá mover o intelecto para o conhecimento intelectivo, que é do universal, pois ela jamais poderá representar algo para o intelecto sob a razão do universal. Nas palavras de Pickavé, "para poder representar à mente objetos universais, uma espécie inteligível teria que ser impressa por algo universal qua universal, o que é impossível, pois universais enquanto tal não

\footnotetext{
${ }^{227}$ A esse argumento, Pickavé propõe a seguinte objeção: "But why, so might a species proponent object, can the particular imprint on the sand not represent all possible feet capable of producing such an imprint? And what about a particular triagle drawn on the blackboard? Can it not represent a multitude of particular triagles?" - "Causality and Cognition...", 2015, pos. 1568. O comentador considera que Henrique de Gand não responde a tais objeções, mas que uma possível resposta ad mentem Henrici para o problema seria afirmar que o intelecto pode, por sua atividade, considerar tanto a pegada como o triângulo desenhado universais - "if the intellect is actively thinking, it can consider particulars as universal representations" - "Causality and Cognition...", 2015, pos. 1576. Parece-me, porém, que nenhuma das duas perguntas feitas por Pickavé vale, de fato, como objeção a Henrique e, por outro lado, ambas são claramente respondidas por ele. Quanto à pegada, é patente a posição em Quodl. 5, q. 14, segundo a qual um efeito (como uma espécie impressiva) representa singularmente aquilo que a causou - ou seja, a pegada remeteria singularmente àquilo que a deixou. Da mesma maneira, o triâgulo desenhado não é, senão, o próprio desenho deste triângulo singular. Que ambos - a pegada e o triângulo - possam suscitar um conhecimento universal não se deve a nada mais do que o próprio fato de que o conhecimento intelectual, muito embora parta do conhecimento sensível, é sempre universal. Destarte, não há propriamente um conhecimento intelectual desta pegada ou deste triângulo desenhado - isso só se pode conhecer pelos sentidos. Assim, a partir desta pegada ou deste triângulo desenhado o intelecto só pode conhecer propriamente a 'pegada' e o 'triângulo' universais (associados, de modo universal, a outros entes, como suas causas, efeitos etc.).

Note-se, também, que Giorgio Pini não atenta para a relação estabelecida por Henrique em Quodl. 5, q. 14 , entre [i] a singularidade da representação e [iii $\left.{ }^{\mathrm{ii}}\right]$ à singularidade da causa da espécie impressiva. Pelo contrário, ele lê essa passagem como uma afirmação da [i] singularidade da representação devido a [iii ${ }^{i}$ a singularidade do ser da espécie impressiva - isto é, ele lê aqui algo semelhante ao que víamos em Quodl. 4, q. 21: "Il secondo argomento contro le specie intelligibili ricorda che, per gli stessi sostenitori delle specie, esse sono accidenti realmente inerenti nell'intelletto, e dunque, poiché tutto ciò che existe realmente è un individuo, le specie sono entità individuali. Ma se le specie sono entità individuali, esse non possono essere rappresentazioni di un oggetto universale" - PINI, "Il dibattito sulle specie...", 2004, p. 289. Como vimos, porém, esse não é o caminho seguido pelo Doutor Solene no trecho em questão.
} 
existem e o que não existe não possui eficácia causal"228. Por tanto, [2] da parte do inteligível e, em especial, [2.1] de sua universalidade, mostra-se que a espécie impressa não pode ter um papel na formação do conhecimento intelectual.

Isso abre espaço para o segundo argumento da parte do inteligível. Esse argumento [2.2] tem por foco não a universalidade do objeto, mas a sua presença ao intelecto:

\begin{abstract}
"Além disso, tal como está a espécie visível no olho para o visível particular fora sob a razão do particular, assim também a espécie impressa no intelecto está para o inteligível sob a razão pela qual é universal. Mas, aquela espécie no olho depende mais, em seu ser, da coisa fora do que o contrário, tal que a presença da coisa é a causa pela qual a espécie possui ser no olho e não o ser da espécie no olho é causa da presença da coisa fora. Donde, ainda que aquela espécie fosse impressa por uma agente sobrenatural e conservada no olho, sua presença não faria a coisa ser assim presente, tal que pudesse ser vista pelo olho, mas seria requerido que fosse tornada presente por outro. Assim, similarmente também a espécie impressa no intelecto por outro que não pela própria coisa universal e nele conservada não pode causar a presença da coisa, tal que seja conhecida pelo intelecto sob a razão de objeto; pelo contrário, resta ainda que seja representada por outro, tal que seja reduzido da potência ao ato de inteligir por aquele representante ou pelo próprio objeto apresentado. Pelo que, uma vez que não é senão devido a tal representação que se propõe uma espécie impressa no intelecto, é vão [vanum] nele propô-la",229.
\end{abstract}

Aqui, mais uma vez, torna-se relevante a estreita relação causal que há entre espécie e coisa conhecida na doutrina do conhecimento de Henrique de Gand. Em

\footnotetext{
${ }^{228}$ PICKAVÉ, "Causality and Cognition...", 2015, pos. 1548: "But in order to be able to represent universal objects to the mind an intelligible species would have to be impressed by something universal qua universal, which is impossible. For universals as such do not exist and what does not exist does no have causal efficacy".

${ }^{229}$ Henrique de Gand, Quodl. 5, q. 14, co. (ed. 1613, f. 259vb-260ra): "Praeterea sicut se habet species visibilis in oculo ad visibile particulare extra sub ratione particularis, sic species impressa in intellectu se habet ad intelligibile universale sub ratione, qua universale. Sed species illa in oculo in suo esse magis dependet a re extra, quam e converso, ita quod praesentia rei causa est, qua species habet esse in oculo et non inesse speciei in oculo causa est praesentiae rei extra. Unde, etsi per agens supernaturale species illa imprimeretur, et conservaretur in oculo, praesentia eius non faceret rem sic esse praesentem, ut videri posset ab oculo, sed requiritur quod per aliud fiat praesens. Ergo et similiter species impressa in intellectu ab alio, quam ab ipsa re universali, et conservata in ipso non potest causare praesentiam rei, ut cognoscatur ab intellectu sub ratione obiecti, immo restat adhuc, ut per aliud repraesentetur, ita quod per illud repraesentans, aut per ipsum obiectum praesentatum reducatur de potentia ad actum intelligendi. Quare, cum non nisi propter huiusmodi repraesentationem ponitur species impressa in intellectu, vanum est ergo eam ponere in ipso". Cf. BRAUN, Die Erkenntnislehre..., 1916, pp. 29-30; GORIS \& PICKAVÉ, "Von der Erkentnnis der Engel...", 2001, p. 134; PICKAVÉ, "Causality and Cognition...", 2015, pos. 1568-94. Nesse trecho de seu artigo, o comentador, mais uma vez, considera que esse argumento não poderia dizer respeito ao intelecto humano, pois pressuporia hipoteticamente um intelecto dotado de espécies de todos os inteligíveis possíveis: "Obviously this argument does not apply to the human intellect, for human beings are not commonly held to be endowed with impressed species of all possible objects" - (op. cit., pos. 1591). Parece-me, porém, que tal hipótese só se torna relevante no argumento seguinte [2.3], como mostrarei no corpo do texto no momento oportuno.
} 
especial, é bem enfatizada a relação de dependência que a espécie possui com relação à coisa e não o oposto. Precisamente, ele nos diz que de a espécie depender mais da coisa fora do que o oposto decorre que a presença da coisa seja a causa da presença da espécie e não o oposto (praesentia rei causa est, qua species habet esse). Em outras palavras, não é porque há uma espécie presente no olho que há uma coisa vista fora, mas antes o contrário: por haver uma coisa presente fora, torna-se presente no olho uma espécie. De fato, se uma espécie fosse causada no olho por um agente sobrenatural sem que houvesse uma coisa fora, nem por isso se poderia dizer que há essa coisa presente fora do olho. Com esse exemplo extremo, ao que parece, o mestre gandavense parece pretender mostrar como a relação de causalidade entre uma coisa e sua espécie é uma via de mão única: jamais a presença da espécie (ainda que ela fossa sobrenaturalmente causada sem a presença da coisa) é causa da presença da coisa. Só o contrário é válido: a presença da coisa fora ao órgão (como sabemos, sob as condições necessárias de iluminação no meio, saúde do órgão etc.) é causa da espécie nele impressa.

Estabelecida essa relação entre coisa e espécie com base no conhecimento sensível, Henrique (em um movimento que já vimos em diversas ocasiões) aplica o resultado obtido ao conhecimento intelectual. Ora, o objeto do intelecto não é, como já determinado, o singular fora, mas o universal. Assim, se uma espécie fosse impressa no intelecto pela coisa (ou por qualquer outro) ela não seria causa suficiente da presença do objeto universal, pois esse próprio objeto ainda não esteve presente em nenhum momento do processo de conhecimento. Assim, ainda que uma espécie fosse impressa no intelecto e, portanto, estivesse nele presente, ela não poderia garantir a presença do objeto universal - que o Doutor Solene, nesse caso, denomina como 'coisa universal' (res universalis) -, pois esse objeto é que deveria estar presente antes para que, somente em seguida e devido à sua presença, também sua espécie se tornasse presente.

Porém, como vimos no início de nossa leitura de Quodl. 5, q. 14, a mera presença do objeto universal ao intelecto já é suficiente para o ato de intelecção. Assim, uma vez que a espécie impressa não somente não pode tornar presente um objeto universal (como dizia o argumento [2.1]), mas não pode em geral tornar um objeto presente ao intelecto ou a qualquer potência cognoscitiva (como estabelecido no argumento [2.2]), vê-se mais uma vez que a espécie impressa é supérflua. 
Em seguida, como antecipado, Henrique de Gand introduz um último argumento [2.3]. Esse é um argumento muito mais longo do que os demais, sendo desdobrado em diversas etapas. Sua maior parte diz respeito exclusivamente ao conhecimento angélico, uma vez que o próprio argumento tem por base diversos complexos problemas derivados da hipótese de uma infinitude de espécies impressas no intelecto angélico por Deus ${ }^{230}$. Não será meu objetivo aqui desenvolver pausadamente esse longo argumento - a bem dizer, nem mesmo estou certo sobre sua correta interpretação. No entanto, é interessante notar que há uma passagem em meio a esse complexo argumento acerca do intelecto angélico no qual Henrique de Gand parece propor uma nova afirmação geral acerca do conhecimento intelectual - isto é, válida para anjos e homens. Em seu estudo de Quodl. 5, q. 14, Martin Pickavé apresenta a passagem a seguir como um argumento autônomo ${ }^{231}$ - de minha parte, parece que Henrique de Gand está antes introduzindo um elemento (agora generalizante) ao mesmo argumento [2.3] sobre as espécies impressas por Deus no intelecto:

\begin{abstract}
"Igualmente, se seguiria que o intelecto ao inteligir não seria paciente senão por acidente, a saber, enquanto recebe a espécie por impressão a partir de Deus, recebendo-a tal como o sujeito <recebe $>$ seu acidente. E, isso, enquanto é algo no gênero de ente, não enquanto é algo no gênero dos inteligíveis. E, assim, tal paixão não seria a partir do inteligível enquanto é um inteligível nato a mover o intelecto sendo do gênero dos inteligíveis; e, assim, o intelecto, sendo do gênero dos inteligíveis, seria, com respeito ao ato de inteligir, como que ativo, e de nenhum modo passivo. E o inteligir não seria um certo padecer [pati quoddam] nem o movimento da alma para a coisa seria de todo um ato intelectual, pois tal ato é de todo absoluto, não terminando em algo, mas permanecendo [stans] no agente (tal como o luzir não possui o terminar em algo) e, assim, a coisa inteligida não seria percebida pelo ato de inteligir",232.
\end{abstract}

\footnotetext{
${ }^{230}$ Cf. Henrique de Gand, Quodl. 5, q. 14, co. (ed. 1613, f. 260ra-261rb). GORIS \& PICKAVÉ, "Von der Erkentnnis der Engel...", 2001, pp. 134-8 e, especialmente, o resumo do argumento em p. 134: "Der Kern des sehr umfangreichen dritten Arguments besteht in der Feststellung, dass den Engeln, wenn sie eingeprägter species bedürften, eine unendlichen Anzahl von species eingeprägt sein müßte, weil sie doch - zumindest der Möglichkeit nach - eine unendliche Zahl von Dingen erkennen können. Dass diese species dann im Intellekt alle zugleich in Akt sind - ist doch die species auch principium actionis -, macht diese Annahme in Heinrichs Augen unhaltbar" (grifo no original). Cf. tb. PICKAVÉ, “Causality and Cognition...", 2015, pos. 1776-85.

${ }^{231}$ Cf. PICKAVÉ, “Causality and Cognition...”, 2015, pos. 1176-85, 1594-629.

${ }^{232}$ Henrique de Gand, Quodl. 5, q. 14, co. (ed. 1613, f. 259vb-260ra): "Item sequeretur, quod intellectus in intelligendo non esset patiens, nisi per accidens, inquantum scilicet recipit speciem per impressionem a Deo quam recipit sicut subiectum suum accidens. Et hoc inquantum est aliquid in genere entis, non inquantum est aliquid de genere intelligibilium. Et sic talis passio non sit ab intelligibili, inquantum est intelligibile natum movere intellectum, ut est de genere intellectivorum, et sic intellectus ut est de genere intellectivorum respectu actus intelligendi se haberet, ut activus, et nullo modo passivus, et non esset intelligere pati quoddam, nec intellectualis actus esset motus ab anima ad rem omnino, quia talis actus est omnino absolutus, non terminatus ad aliud, sed stans in agente, sicut
} 
O fundamental nesse argumento é a reintrodução da distinção entre [i] o ser que a espécie impressa possui no intelecto como um acidente no sujeito e [ii] o ser que o inteligível e o intelecto possuem enquanto intelectuais, a saber, aquilo que Henrique de Gand denomina aqui como 'ser do gênero dos inteligíveis' (est de genere intellectivorum). Contrapondo-se ao 'ser num sujeito como espécie', esse 'ser do gênero dos inteligíveis' - pelo menos na medida em que o objeto inteligível diz respeito a tal ser -, lembra as referência que vimos em Suma, art. 34, e Quodl. 4, ao ser da espécie expressa como 'conhecido no cognoscente' ou ao ser da verdade como 'entidade diminuída da coisa' ${ }^{\text {233 }}$. Agora, porém, não somente o inteligível possui esse ser diferenciado, mas também o próprio intelecto que o conhece.

Pois bem, como Pickavé argumenta, o presente raciocínio parece admitir hipoteticamente tanto que espécies possam ser impressas no intelecto como que elas possam apresentar o objeto universal a este último ${ }^{234}$ - mesmo assim, nos diz Henrique, a espécie não poderia nos dar a conhecer o objeto de intelecção. Isso porque uma espécie impressa - por exemplo, por Deus - no intelecto seria neste um acidente e, portanto, seria nele impressa enquanto ele diz respeito a um gênero de ente e não ao gênero dos inteligíveis. Em outras palavras, mesmo que uma espécie fosse impressa no intelecto, ela não o afetaria de um modo que diga respeito à intelecção ou ao objeto inteligido, pois acidente e objeto inteligível são de ordens diferentes do ser. Nesse caso, o ato de intelecção não seria fruto da passividade do intelecto, pois este já estaria em ato, por um acidente, com respeito a seu objeto.

Além disso, já possuindo tal objeto em si como acidente, o ato de intelecção seria completamente imanente ao intelecto, não sendo um movimento do intelecto para algo outro que não ele mesmo. Sem dúvida, como estabelecemos ainda no cap. 4

lucere non habet ad aliquid terminari, et sic actu intelligendi res intellecta non perciperetur". Cf. PICKAVÉ, “Causality and Cognition...", 2015, pos. 1594-629. Nesse trecho, o comentador igualmente destaca esse argumento como válido para intelectos angélicos e humanos, principalmente devido à referencia à passividade do intelecto, comum a ambos: "It is easy to see that the key idea with which the argument operates is not restricted to the angelic intellect. Human understanding is fundamentally passive because our cognition is essentialy receptive (although there might also be some spontaneity involved)" (op. cit., pos. 1623).

${ }^{233} \mathrm{Cf}$, respectivamente, notas 181 e 170 , acima.

${ }^{234}$ PICKAVÉ, “Causality and Cognition...", 2015, pos. 1595: “The most important argument against impressed intelligible species is the one Henry mentions last (A 8). Its aim is to establish that even if species existed impressed on the intellect and even if they were able to represent universals, they could play no role in actualizing the intellect and would therefore be useless in explaining the occurence of a simple act of the intellect". 
com base em Quodl. 11, q. $5^{235}$, as operações cognoscitivas, enquanto operações, são imanentes. Porém, vemos agora em Quodl. 5, q. 14, que elas não são de todo imanentes, pois devem possuir um termo outro - diferentemente da luz que luze ainda que não ilumine nada outro, o intelecto deve inteligir percebendo, ao fazê-lo, algo outro que não ele próprio ou um acidente seu. Sendo assim, chegamos a um ápice da argumentação de Henrique de Gand, pois agora entendemos que a presença da espécie impressa não somente é supérflua para explicar o conhecimento intelectual, como, além disso, caso houvesse uma tal espécie impressa no intelecto, ela seria um empecilho para a intelecção. Sendo um acidente em um sujeito, uma espécie impressa faria com que o intelecto não pudesse atingir seu objeto como algo outro e, assim, não pudesse inteligi-lo como algo universal que seja 'no gênero dos inteligíveis'. Nas palavras de Pickavé, esse argumento mostra que a própria presença de uma espécie impressa excluiria a intencionalidade do conhecimento ${ }^{236}$.

Esses, parece-me, são os elementos fundamentais da recusa da espécie impressa no intelecto apresentada em Quodl. 5, q. 14. Se o tema principal da questão é o conhecimento angélico, acredito que os argumentos destacados são suficientemente gerais de maneira a dizerem respeito não somente aos anjos, mas também à intelecção humana. No fim, a superfluidade da espécie impressa fica pantente: [1] da parte do intelectivo, [1.1] por não ser necessária para a própria caracterização do 'intelectivo' (tal como do 'inteligível'); [1.2-3] porque há conhecimentos (como a visão beatífica e o conhecimento de si) que claramente não exigem uma tal espécie; e, [2] da parte do inteligível, [2.1] porque por uma espécie impressa por algo singular não se poderia conhecer o universal; [2.2] porque uma espécie impressa não poderia tornar um objeto presente ao intelecto; e, enfim, segundo o excerto lido do argumento [2.3], porque a espécie impressa, sendo um acidente e não um ser inteligível, colocaria o intelecto em ato, impedindo-o tanto de receber um objeto inteligível como de, por sua operação intelectual, tomá-lo como termo do conhecimento ${ }^{237}$. Disso tudo, conclui-se que a exclusão da espécie impressa

\footnotetext{
${ }^{235}$ Cf. cap. 4, nota 97. Sobre o luzir como ação imanente, cf. cap. 4, nota 39.

${ }^{236}$ PICKAVÉ, “Causality and Cognition...", 2015, pos. 1620: "Under these circumstances intellectual understanding is hardly intentional, but resembles a purely diffusive and indeterminate activity like the shining of a light source".

${ }^{237}$ Ainda sobre as razões de Henrique de Gand para a rejeição da espécie inteligível impressa, cf. BROWN, J. V. “Intellect and Knowing...”, 1975, pp. 509-12, 692-3; e SPRUIT, Species intelligibilis I, 1994 , p. 208. Note-se, porém, que o primeiro toma base de seu estudo, principalmente, o Quodl. 4, q. 21, enquanto que o segundo comentador lê Quodl. 4 e Quodl. 5, q. 14, paralelamente.
} 
Sublinhe-se também que, além dos argumentos apresentados contra a necessidade de espécies impressas aqui em Quodl. 5, q. 14, há pelo menos mais um argumento que surge da correlação entre dois elementos da filosofia de Henrique de Gand, a saber, [i] a organicidade dos sentidos e [ii] a consubstancialidade das potências da alma. Com efeito, esses dois temas aparecem claramente relacionados no argumento contra as espécies impressas que lemos em Quodl. 13, q. 11, ad 1 (ed. De Wulf-Mansion Centre, vol. 18, p. 96): “< ..> dico quod, etsi cum illis duobus ad actum intellectionis requiritur aliquid aliud, secundum quod iam declarabitur, non tamen illud est species impressa intellectui, quasi consimilis ei quae imprimitur organo visus et necessaria est ad actum videndi. Secundum enim quod alias declaravi, in vi sensitiva apprehensiva requiritur species obiecti, quia ipsum obiectum non potest esse simul cum vi sensitiva existente in organo, et proximum agens debet esse simul cum patiente; et ideo requiritur species sua in organo, qua simul est cum vi sensitiva, quae habet in se vim obiecti ad movendum vim sensitivam in organo existentem. In vi autem apprehensiva intellectiva nulla species requiritur de obiecto, quia ipsum existens in phantasmate factum universale virtute agentis praesens est et simul cum intellectu, quia vis phantastica, in qua sunt phantasmata, et vis intellectiva sunt in eadem substantia animae indivisibili. Propter quod obiectum universale immediate potest agere in intellectum absque specie aliqua intellectui impressa, quantum de actione eius requiritur ad eliciendum actum intelligendi <...>”. Cf. BRAUN, Die Erkenntnislehre..., 1916, p. 28. A mesma referência à consubtancialidade dos intelectos agente e possível, bem como da fantasia ressurge em Quodl. 8, q. 12, co. (ed. 1613, f. 32rb). Voltaremos a tal consubstancialidade adiante (cf. nota 245).

Pois bem, o argumento apresentado tem por base a organicidade (e, portanto, corporeidade) dos sentidos, em oposição à não-organicidade do intelecto. O princípio fundamental aqui é que "o agente próximo deve ser simultaneamente com o paciente [proximum agens debet esse simul cum patiente]". Ora, o próprio objeto sensível - material e corpóreo - não pode ser simultaneamente com a força sensitiva, pois esta é num órgão igualmente material e corpóreo, pois (presumo), para tanto, objeto e órgão (ambos corpóreos) deveriam ocupar o mesmo espaço, o que é impossível. Sendo assim, é necessário que tal objeto esteja presente no órgão por uma espécie sensível, isto é, algo já abstraído da matéria (ainda que não das condições materiais e da presença da coisa particular existente fora). $\mathrm{O}$ intelecto, de sua parte, não põe tal exigência, uma vez que, não sendo ele próprio material ou corpóreo, ele é indivisivelmente (isto é, sem divisão por partes do corpo) consubstancial à imaginação ou vis phantastica. Por isso, o intelecto pode ser imediatamente presente ao fantasma na imaginação, o qual ele torna universal de maneira a conhecer seu objeto próprio universal. Essa relação entre a presença do objeto da imaginação ao intelecto e a consubstancialidade das potências da alma é destacada também em Quodl. 5, q. 25, co. (ed. 1613, f. 305va-b): “<..> intellectus noster ex se nudus est, sicut tabula complanata, qui nihil novit, aut intelligit ab initio, nisi opere intellectus agentis, qui irradiando $[\mathrm{ms}$. BNF lat. 15848, f. 161vb, l. 50 | irradicando ed. 1518, f. 204rI, ed. 1603, f. 305va] super phantasmata spiritualiter, sicut lux materialis super colores, dat eis rationem universalis, et movent intellectum possibilem simplici intelligentia, in qua intellectus noster pure passivus est, et universale activum. Per hoc enim quod in eadem substantia animae sunt phantasticum, et intellectivum idem, quod ut singulare est obiectum imaginativae, et tanquam cognitum in ea, idem ut universale est obiectum intelligentiae, et simpliciter ut cognitum in ea, et ut praesens est simpliciter est in ipso quodam modo, ut in memoria intellectuali: ut autem immutat ipsum ad actum intelligendi, est in ipso ut in intelligentia actualiter cognoscente, cuius notitia terminatur ad obiectum" (grifo meu). Voltando ao argumento de Quodl. 13, q. 11, a organicidade que exige uma mediação - ou seja, que exige espécies - nos sentidos, está ausente do intelecto, sendo este último imediatamente presente a seu objeto (ou à imaginação, em que encontra seu objeto) por ser potência imaterial. Note-se, portanto, que este argumento não é precisamente semelhante àqueles que lemos em Quodl. 5, q. 14 - nestes últimos, pretende-se mostrar que a espécie impressa não é necessária para explicar o movimento do intelecto, enquanto que no argumento aqui lido de Quodl. 13, q. 11, pretende-se mostrar que aquele argumento que determina a necessidade de espécies nos sentidos não é válido para o intelecto.

Por fim, note-se que tal argumento contra a necessidade de espécies no intelecto a partir da organicidade do sentido é retomando em Quodl. 11, q. 5, co. (ed. 1613, f. 196ra): "Ex parte autem intellectus sunt duo correspondentia duobus praedictis in sensu, quae ad vitalem operationem requiruntur. Prima enim immutatio, qua intellectus habet esse in actu est a causante ipsum, et hoc quo ad nudam vim intellectivam. Secunda autem eius immutatio est ab intelligibili sibi praesente, et hoc non mediante aliqua specie ab illo impressa intellectui, sed ab ipso intelligibili immediate. In quo differt secunda immutatio, quae fit in intellectu, ab illa quae fit in sensu, cuius ratio est, quia sensibile, eo quod non potest per suam substantiam esse in organo, et praesens vi sensitivae ad ipsam movendam, oportet, quod sit ei praesens per suam speciem $<\ldots>$. Intelligibile autem quia bene potest esse praesens intellectui humano, et Angelico <...>". Cf. WULF, Études sur Henri de Gand, 1894, p. 92; BRAUN, 
parece abrir espaço, na doutrina da intelecção de Henrique de Gand, para uma presença ao intelecto do próprio objeto enquanto inteligível. Sendo assim, torna-se necessário agora ver como ocorreria a atualização do conhecimento sem recurso a essa espécie impressa que, por todas aquelas razões, se mostrou supérflua. Para nossa sorte, ainda no mesmo Quodl. 5, q. 14, nosso autor oferece uma narrativa da formação do conhecimento intelectual tal como ele a compreende.

\subsubsection{2. pars construens}

Já vimos mais acima - precisamente, no item 4.4 - que a estratégia de Henrique de Gand para explicar o conhecimento intelectual em Quodl. 5, q. 14, passa por afirmar espécie expressas na intelecção, em contraponto à negação das espécies impressas no intelecto. Isso fica bem claro, por exemplo, na seguinte passagem:

"Donde, uma vez que esse modo de possuir em si espécies expressas é próprio do intelecto e não do sentido, por isso o Filósofo, em De anima III, aprova os que dizem que a alma é o lugar das espécies - não que toda $<_{0}$ seja $>$, mas a intelectiva.

Ele o diz, para diferenciá<-la $>$ da sensitiva, na qual não há senão espécie impressa, enquanto no intelecto há <espécie> expressa e, por isso, de algum modo tal como em um lugar, mas não tal como em um sujeito [non autem sicut in subiecto]"238.

É interessante notar como, nessa passagem, Henrique de Gand se vale da referência ampla ao intelecto como 'lugar das espécies' (esse locum specierum) que ele lê em Aristóteles, para contrapor a ocorrência de espécies nesse locus que é o intelecto à ocorrência de espécies impressas no subiectum que é o sentido. Para Henrique de Gand, como já notamos repetidamente, o subiectum recebe acidentes. Mas, e quanto a esse locus que é o intelecto? O que ele receberia? Ao que parece,

Die Erkenntnislehre..., 1916, p. 29; GOEHRING, "Henry of Ghent's Use of Aristotle's De anima...", 2013, pp. 91-2. Lemos o Quodl. 11, q. 5, mais pausadamente acima, no item 4.5, em nosso estudo sobre os sentidos. Para um estudo mais aprofundado dessa mesma questão (e, em particular, do argumento aqui apresentado) sob o ponto de vista da doutrina da intelecção, cf. GOEHRING, Henry of Ghent on Cogntion..., 2006, pp. 149-52.

${ }^{238}$ Henrique de Gand, Quodl. 5, q. 14, co. (ed. 1613, f. 261va): "Unde quia iste modus habendi in se species expressas proprius est intellectus, et non sensus, ideo Philosophus tertio De anima commendat dicentes animam esse locum specierum, non quod tota, sed intellectiva.

Quod dicit ad differentiam sensitivae, in qua non est nisi species impressa, in intellectu vero est expressa, et propter hoc quodammodo sicut in loco, non autem sicut in subiecto". GORIS \& PICKAVÉ, "Von der Erkenntnis der Engel”, 2001, pp. 131-2. Já vimos esse texto no cap. 4, nota 79. Cf. tb. FIORENTINO, "Species nei secoli XIII-XIV”, 2007, pp. 120-1. 
espécies expressas que, de algum modo, se confudem com o próprio objeto presente ao intelecto como algo inteligível. Mas, o que essa identificação entre objeto inteligível e espécie expressa quereria dizer precisamente? E quais são seus resultados para a doutrina da intelecção de Henrique de Gand? Isso é o que pretendemos responder nessa última etapa de nossa leitura de Quodl. 5, q. 14, bem como no próximo item deste capítulo.

Pois bem, como apontado por Pickavé, a narrativa da formação do conhecimento intelectual se inicia aqui - aliás, como seria esperado pelo que já vimos - pela referência à ação do intelecto agente sobre aquilo que fora conhecido pelos sentidos: "Depois disso, segue-se a operação do intelecto agente em nós acerca do fantasma, isto é, não acerca das espécies impressas na memorativa ou na imaginativa, mas acerca do objeto particular imaginado dentro, que antes era sentido $<\ldots$.. ${ }^{\text {,239 }}$. Note-se a precisão de Henrique de Gand: a operação do intelecto agente não é acerca da espécie impressa nos sentidos, mas diz respeito ao fantasma e, mais precisamente, ao "objeto particular imaginado dentro [obiectum particulare imaginatum intra]". Essa afirmação remete a dois elementos relevantes para a sua doutrina da intelecção.

Em primeiro lugar, a afirmação de que o intelecto agente age com respeito ao fantasma $e$ com respeito ao objeto particular imaginado, mas não com respeito à espécie impressa aponta para uma identifição entre fantasma e objeto particular imaginado, contrapondo ambos à espécie impressa. Com efeito, já vimos no cap. 5 o quão problemática pode ser a caracterização do fantasma na doutrina do conhecimento elaborada pelo Doutor Solene. Aqui, porém, ele parece estar claramente oposto ao acidente impresso pela coisa fora no sentido, sendo, portanto, o próprio objeto conhecido em ato pela fantasia ou imaginação. Disso resulta um primeiro dado relevante acerca da ação do intelecto agente: ela não diz respeito ao acidente orgânico (a espécie impressa) deixado no sentido pela coisa fora, mas antes diz respeito ao próprio objeto enquanto conhecido em ato pela fantasia. Ou seja, não somente o intelecto não recebe qualquer espécie impressa, como o intelecto agente não age sobre espécies impressas. Pelo contrário, sua ação diz respeito unicamente ao objeto que a fantasia conhece em ato por ocasião da impressão da espécie em seu

\footnotetext{
${ }^{239}$ Henrique de Gand, Quodl. 5, q. 14, co. (ed. 1613, f. 262[258]ra): "Post hoc sequitur operatio intellectus agentis in nobis circa phantasmata, hoc est non circa species impressas in memorativa vel imaginativa, sed circa obiectum particulare imaginatum intra, quod prius sentiebatur <... ". Cf. PICKAVÉ, "Causality and Cognition...", 2015, pos. 1424-35.
} 
órgão (lembremos que, para Henrique, o ato de sensação provém principalmente da ação da potência sensitiva sobre aquilo que fora recebido no corpo enquanto órgão dessa potência, como mostrado no cap. 4).

Um segundo aspecto relevante da passagem citada é a referência ao caráter interno (intra) do objeto imaginado sobre o qual age o intelecto agente. Essa oposição entre o objeto externo dos sentidos e o objeto interno do intelecto será melhor desenvolvida em Suma, art. 58, q. $2^{240}$. Já podemos adiantar, porém, que a caracterização como 'interno' daquele objeto para o qual se volta o intelecto aponta, novamente, para o fato de que o intelecto não age sobre um acidente ou uma substância, mas sim sobre algo que é fruto do ato de imaginação - ou melhor, sobre o objeto em ato da imaginação que é o fantasma.

Enfim, sabemos já a que diz respeito a ação do intelecto agente. O problema, então, passa a ser explicar mais detalhadamente como se dá tal ação e qual seria o seu produto $^{241}$. É para isso que o mestre gandavense se volta em trechos seguintes de Quodl. 5, q. 14:

“ $<\ldots>$ os fantasmas apreendidos na imaginativa não são universais senão em
potência e, em potência, moventes do intelecto. Por isso, uma vez que nosso
intelecto possível não possui os inteligidos senão a partir dos fantasmas, ele
necessita de uma virtude que, abstraindo os fantasmas, universais e inteligidos
em potência, das condições materiais, os faça ser universais em ato e inteligidos
em ato. Ela é chamada de intelecto agente, o qual é como uma força ativa no
intelecto possível para abstrair os fantasmas daquelas ditas condições.
Feito isso, há o universal em ato, movendo objetivamente e modificando o
intelecto possível para a apreensão simples da essência e quididade da coisa" "242.

${ }^{240} \mathrm{Cf}$., adiante, nota 271.

${ }^{241}$ PICKAVÉ, “Causality and Cognition...”, 2015, pos. 1438-43: "Moreover, from the imaterial nature of the intellect it follows that the object of the intellect can only be something universal, and not some singular thing. This leads to the central problem medieval accounts of intellectual cognition have to deal with: How can there be a connection between the senses and the intellect if the senses, as is obvious, are involved with matter and singularity? No doubt we have intellectual understanding of sensible object. So in principle there has to be a transfer from the sensory to the intellectual level. The question is simply how this transfer exactly works".

${ }^{242}$ Henrique de Gand, Quodl. 5, q. 14, co. (ed. 1613, f. 262 [258]rb): “< ..> phantasmata in imaginativa apprehensa non sunt nisi in potentia universalia, et in potentia moventia intellectum. Propter quod, cum intellectus noster possibilis non habet intellecta nisi a phantasmatibus, eget virtute, quae phantasmata potentia universalia, et intellecta abstrahendo ea a dictis conditionibus materialibus faciat ea esse actu universalia, et actu intellecta, quae appellatur intellectus agens, qui est sicut vis quaedam activa in intellectu possibili ad abstrahenda phantasmata a dictis conditionibus.

Quo facto est actu univerale, et movens obiective, et immutans intellectum possibilem ad simplicem apprehensionem essentiae, et quiditatis rei". Cf. FIORENTINO, "Species nei secoli XIII-XIV", 2007, pp. 120-1. O início dessa passagem de Henrique, junto a um trecho que o precede, já era citado no cap. 5 , nota 119 .

Nesse ponto, cabe perguntar: por que o intelecto agente age em presença do fantasma na imaginação? Com efeito, vimos no cap. 4 como Henrique de Gand é cuidadoso ao apontar a recepção orgânica da 
espécie sensível impressa somente como uma primeira etapa da formação do conhecimento sensitivo, após a qual a própria alma se volta para tal impressão e forma uma sensação em ato. No entanto, nosso autor não parece ter o mesmo cuidado de detalhar o modo pelo qual a presença do fantasma na imaginação faz com que o intelecto aja acerca de tal fantasma. Na interpretação de Jean Paulus, devese entender que o fantasma é somente uma ocasião para que o intelecto constitua seu objeto próprio: "La quiddité n'est point, aux yeux de notre docteur, lue à même le phantasme, sous forme d'espèce intelligible, mais constituée par l'intellect à l'occasion du phantasme et de l'espèce" - PAULUS, Henri de Gand. Essai..., 1938, p. 8 (grifo no original). O problema é que, para este comentador, essa relação de ocasião entre fantasma e intelecto está atrelada àquilo que Paulus vê como um innéisme mitigé (op. cit., p. 10), isto é, a suposta posição de Henrique de Gand segundo a qual a noção primeira de 'ente' seria formada naturalmente pelo próprio intelecto para si mesmo, sem que ela seja produto da experiência (op. cit., p. 9): "le savoir humain se constitue, sans doute, à l'occasion de la sensation, et il ne pourrait point, sans dommage, se passer de son 'choc'; l'ensemble des notions qui composent ce savoir procèdent cependant d'un petit nombre de notions premières, qui sont comme l'apport promordial de l'esprit et ne doivent rien au sensible" (op. cit., p. 10). Ou seja, para Paulus, a sensibilidade é somente ocasião do conhecimento intelectual, no que ele segue Werner, para o qual a sensação seria apenas "Gelegenheitursache” em Henrique de Gand (cf. a citação de Werner acima, na nota 4). Porém, para Paulus esse caráter ocasional dos sentidos está ligado ao fato de que, haveria certos conhecimentos intelectuais primordiais que não se deveriam à sensação - sobre essa posição de Paulus, cf. tb. BEHA, "Matthew of Aquasparta's Cognition Theory. Part II: Ideogenesis”, 1961, pp. 20, 77-8; BROWN, J. V. Divine Illumination and the Theory of Knowledge..., 1969, p. 158, nt. 5. Disso se seguiria, continua Paulus, que haveria na filosofia do Doutor Solene, espaço para uma noção primeira que seja "l'indice le plus général qui affecte, en commun, nos représentations, la forme transcendentale, au sens kantien, de tout produit de l'intellect" (PAULUS, Henri de Gand. Essai..., 1938, p. 22), que ele identifica à noção de res (op. cit., p. 22). Enfim, caso aceitemos a interpretação de Paulus, a sensação é somente ocasião do conhecimento intelectual, porque o fundamento primeiro deste último é a priori (op. cit., pp. 65-6) ou inato - cf. BROWN, J. V. Divine Illumination and the Theory of Knowledge..., 1969, p. 158, nt. 5. Pois bem, essa visão de um caráter apriorístico na noção de res delineada por Henrique de Gand foi críticada em AERTSEN, "Transcendental Thought in Henry of Ghent", 1996, pp. 1-2, 16-7 (sobre as leituras de Paulus e Aertsen, cf. PAIVA, “'Res a reor reris' e 'res a ratitudine'...”, 2015). Além disso, a própria afirmação de que haveria algum tipo de inatismo em Henrique de Gand é rejeitada em MARRONE, The Light of Thy Countenance..., vol. 2, 2001, p. 303, nt. 17 (onde também se remete a outros autores envolvidos na questão). Mais importante para nós, porém, é notar como tal tese vai de encontro àquilo que lemos em Suma, art. 1 (acima, no item 6.2) sobre o surgimento dos primeiros conceitos incomplexos. Ali, tais conceitos são explicados justamente como fruto da ação do intelecto acerca do sensível. Ou seja, não parece possível defender, como Paulus, que o Doutor Solene afirme uma independência do intelecto com respeito aos sentidos a tal ponto que as noções mais gerais não possam ser consideradas como abstraídas dos sentidos, mas somente como produzidas pelo intelecto para si sem recurso aos sentidos. Pelo contrário, tais noções são o conhecimento maximamente geral que o intelecto adquire ao se voltar para o fantasma modificado pela luz do intelecto agente, isto é, tornado inteligível em ato e, portanto, universal.

Porém, ao rejeitar a posição de Paulus, simplesmente retornamos ao problema inicial desta nota. Com efeito, Paulus dizia que o intelecto produz, por uma ação própria, um conhecimento para si por ocasião da presença do fantasma. Nós recusamos tal interpretação e afirmamos que o intelecto age sim com respeito ao fantasma para a produção do conhecimento intelectual. Ou seja, voltamos ao primeiro problema que era justamente saber por que, em presença do fantasma, o intelecto age.

Pois bem, Jerome Brown (Divine Illumination and the Theory of Knowledge..., 1969, p. 157, nt. 5) indica um texto que pode contribuir para nossa pesquisa sobre o tema, a saber, Quodl. 10, q. 13, ad 1 (ed. De Wulf-Mansion Centre, vol. 14, p. 290): “< ..> sensus in nobis naturaliter prior est intellectu, non tamen actio sentiendi est causa actus intelligendi nisi sine qua non <..>. In homine autem non necessario ad intellectum sequitur voluntas, neque intellectus ad positionem sensus". Valeria Sorge interpreta essa passagem como a remissão a um caráter (mais uma vez) ocasional do sensível com respeito ao intelecto, quando ela nos diz que na doutrina da intelecção de Henrique "l'atto intellettivo scaturisce direttamente dall'anima: all'oggetto si può attribuire, al massimo, il ruolo di ocasione, di causa sine qua non, di causa terminativa, quindi, dell'intelligere" - Gnoseologia e teologia..., 1988, p. 86 (grifo no original). A meu ver, porém, não podemos confundir a noção técnica de causa sine qua non aqui utilizada com a noção de 'ocasião' utilizada por Paulus em seu comentário. Como vimos no item 3.1.2.3, Henrique se utiliza na noção de causa sine qua non, principalmente, para caracterizar a relação entre intelecto e vontade (tema este que também é o contexto do trecho de Quodl. 10, q. 13, que 
Frisemos, em primeiro lugar, a caracterização do intelecto agente como uma "força ativa no intelecto possível [vis quaedam activa in intellectu possibili]". Se, à primeira vista, afirmar que há algo ativo no intelecto possível parece contraditório, tal posição se justifica por seu contexto no pensamento de Henrique de Gand. Lembremos, como vimos nos caps. 2 e 3, que o intelecto humano é, primordialmente, concebido como uma potência passiva, assim como o próprio homem (muito embora este possua, no cume de sua alma, uma vontade completamente ativa). Além disso, as potências, virtudes ou forças da alma não são senão a própria alma na medida em que possui diversos respectus ou relações para com objetos externos que a afetam (o que notamos no cap. 2). Nesse sentido, é plenamente possível conceber o intelecto como, principalmente, um intelecto possível que, no entanto, traz consigo um tanto de atividade, a saber, na medida em que, para receber seu objeto deve, primeiramente, abstraí-lo da singularidade. Daí parece claro que, muito embora Henrique de Gand

destacamos aqui). Em Quodl. 13, q. 11, ele nos diz que algo é requerido "como causa sine qua non, que totalmente nada age na elicitação do ato ou na causação de uma disposição pela qual seja elicitado o ato ou pela qual seja recebido no passivo, tal como se requer algo que remova o impedimento para a descida do grave. E desse modo, como muito frequentemente tratei, necessariamente se requer para elicitar o ato da vontade o mostrar o objeto e a forma do intelecto acerca deste [ut causa sine qua non, quae nihil agit omnino in eliciendo actum aut causando dispositionem qua eliciatur actus, aut qua in passivo recipiatur, quemadmodum requiritur removens prohibens ad descensum gravis. Et hoc modo, ut saepius tractavi, ad actum voluntatis eliciendum necessario requiritur obiecti ostensio et forma intellectus circa ipsum]" (cf. cap. 3, nota 63). A vontade é completamente indeterminada com respeito a qualquer volível, de maneira que a apresentação de um objeto inteligido se mostra necessária para que ela determine seu ato com respeito a um volível determinado - a indeterminação é um impedimento para o ato volitivo, sendo tal impedimento retirado pela apresentação de um objeto, pelo qual a vontade possa determinar a si mesma. Mas, como isso se aplica ao intelecto?

A bem dizer, Henrique de Gand não parece entrar em detalhes quanto à resposta desse problema. Mas podemos arriscar uma proposta. Como veremos adiante, ao estudarmos o texto da nota 264, o intelecto agente é, no intelecto possível, um hábito universal que, para causar no próprio intelecto um conhecimento em ato, deve ser determinado em ação pela presença de um objeto universal. Sem dúvida, se há aqui um objeto universal determinando o intelecto agente, estamos já em uma etapa posterior à abstração - nesse etapa, com efeito, objeto e intelecto agem em conjuto para a produção da intelecção em ato (cf., adiante, a nota 259). Pois bem, pode ser que Henrique de Gand esteja se referindo a algo semelhante quando afirma que, na abstração, o sensível é causa sine qua non com respeito ao intelecto. Talvez possamos dizer que o intelecto agente, sendo capaz de abstrair universais a partir de quaisquer sensíveis ou fantasmas, deva ter sua ação determinada para a abstração de um universal determinado pela presença, em um fantasma, de um sensível determinado. Isso, porém, não termina aproximar demasiadamente o modo de ação do intelecto ao modo de ação da vontade? E, nesse caso, o intelecto não pareceria ser tão ativo quanto a vontade, tese precisamente oposta àquela que vimos Henrique defender no cap. 3? Para mim, todas essas dificuldades apontam para o fato de que, se o Doutor Solene desenvolveu diversos detalhes de sua concepção de abstração, ainda assim não parece haver nele uma reflexão mais pausada sobre o por que da abstração, isto é, sobre a razão pela qual, em presença do sensível, o intelecto agente abstrai um universal. No fim das contas, talvez a resposta para isso seja, simplesmente, que abstrair o universal em presença do fantasma é a natureza do intelecto (e, em especial, do intelecto agente), tal como a própria vontade foi criada de maneira a ser ativa (cf. cap. 3 , nota 66). 
aceite a ocorrência de um intelecto agente - e, mesmo, a exija como parte de sua doutrina da intelecção -, tal agência em nenhum momento se sobrepõe à fundamental passividade do intelecto, concebido sempre primordialmente como uma potência receptiva $^{243}$.

Dito isso, o intelecto agente - essa "força ativa no intelecto possível" - tem sua ação descrita aqui sucintamente. Ele abstrai ("ad abstrahenda") os fantasmas das condições materiais e "abstraindo os fantasmas, universais e inteligidos em potência, das condições materiais", os faz "ser universais em ato e inteligidos em ato [abstrahendo ea a dictis conditionibus materialibus faciat ea esse actu universalia, et actu intellecta]". Mais uma vez, encontramos aqui a temática da abstração das condições materiais do fantasma pelo intelecto agente. Para nós, porém, o mais importante está no resultado dessa ação ou, melhor, na maneira como ele é aqui descrito. Com efeito, para Henrique, o resultado da ação do intelecto agente sobre o fantasma não é algo outro, mas o próprio fantasma enquanto universal e inteligido em ato. No entanto, essa descrição está eliminando um passo do processo, pois entre [i] o fantasma inteligível em ato e [iii] o fantasma inteligido em ato, deve haver [ii] um fantasma inteligivel em ato, isto é, um fantasma habilitado, pelo intelecto agente, a mover o intelecto possível. Se esse for o caso, vemos que, para Henrique de Gand, não há estritamente algo que seja trazido do fantasma ao intelecto pelo intelecto agente - antes, o que ocorre, é que o próprio fantasma é inteligível em potência, posteriormente inteligível em ato e, finalmente, inteligido em ato ${ }^{244}$.

Que esse seja o caso, vemos na passagem a seguir. Embora longa, ela merece ser citada inteiramente:

"E o respeito [respectus] dele - a saber, do intelecto agente $-<1>$ para com o intelecto possível é tal como o respeito da luz para com o diáfano e $<2>$ para com os fantasmas é tal como o respeito do diáfano para com as cores. Com

\footnotetext{
${ }^{243}$ Por outro lado, Martin Pickavé sublinha que a atribuição de uma atividade ao intelecto seria importante, igualmente, para a afirmação do conhecimento como sendo, propriamente, intelectual "Causality and Cognition...", 2015, pos. 1682-88: "Notice that this model allows us to understand why for Henry the human intellect is both passive and 'actively proceeding' toward the act of understanding. The intellect is passive insofar as it has to be triggered by its object and because in the process of becoming similar to the intelligible object it is 'receptive' of the form of that object by becoming in a certain sense like it. Yet, the intellect must also be active. For thought and understanding are attributed to the intellect and not to the intelligible object. But they could hardly be attributed to the cognitive power if it would not play the role of an agent". Com efeito, lembremos que os próprios sentidos são concebidos como parcialmente ativos por Henrique de Gand, não sendo a alma afetada diretamente por corpos.

${ }^{244}$ Cf. PICKAVÉ, “Causality and Cognition...”, 2015, pos. 1670-83.
} 
exceção $<i>$ de que a luz é uma perfeição acidental do diáfano e uma forma inerente, enquanto que o agente não é uma perfeição do intelecto possível nem nele inere, mas $<$ é $>$ somente uma força e potência ativa consubstancial a ele, tal como ambos - a saber, intelecto agente e possível - são consubstanciais à alma intelectiva. E com exceção <ii > de que o diáfano, pela ação da luz que faz a cor, quanto é de si movente somente em potência $<_{0}$ diáfano $>$, ser movente do diáfano em ato recebe a espécie dela $<s c$. da cor $>$ impressa em si. Porém, o intelecto possível não recebe nenhuma espécie impressa pelo fantasma, mas $<$ recebe algo $>$ pela ação do agente que faz os fantasmas, quanto é de si moventes somente em potência o intelecto, serem moventes em ato e nele existentes somente enquanto cognoscente. E isso sob a razão do universal, que é o mesmo na coisa [idem re est], enquanto é no cognoscente - a saber, na imaginativa sob a razão do particular e no intelecto sob a razão do universal -, tal que nele especulam o intelecto e a imaginativa, não sendo ele presente ao intelecto senão porque é presente à imaginativa. $\mathrm{E}$ isso pela ação que a espécie existente na memória sensitiva age na imaginativa, não somente imprimindo nela a sua espécie, mas também modificando para o ato de imaginar, tal que o nosso intelecto nada intelija senão conjugado com uma imaginação disso. De fato, para que ele especule os fantasmas sob a razão de universal, é necessário que a imaginativa simultaneamente especule o mesmo sob a razão do particular,"245.

${ }^{245}$ Henrique de Gand, Quodl. 5, q. 14, co. (ed. 1613, f. 262[258]rb-va): "Et est respectus eius scilicet intellectus agentis ad intellectum possibilem, sicut est respectus lucis ad diaphanum, et ad phantasmata, sicut est respectus diaphani ad colores, praeter hoc quod lux est perfectio accidentalis diaphani, et forma inhaerens, agens autem non est perfectio intellectus possibilis, neque ei inhaeret, sed solum vis et potentia activa consubstantialis ei sicut uterque, scilicet intellectus agens, et possibilis, est consubstantialis animae intellectivae, et praeter hoc quod diaphanum actione lucis facientis colorem, quantum est de se solum in potentia moventem esse in actu moventem diaphanum recipit speciem eius sibi impressam. Intellectus autem possibilis speciem impressam nullam recipit a phantasmate, sed actione agentis facientis phantasmata, quantum est de se solum in potentia moventia intellectum esse actu moventia [ed. 1580, f. 176vO | esse actu moventia intellectum esse actu moventia ed. 1613], et existentia in eo, ut in cognoscente solum, et hoc sub ratione universalis, quod idem re est, ut est in cognoscente, scilicet imaginativa sub ratione particularis, et in intellectu sub ratione universalis, ita quod in ipsum speculantur intellectus, et imaginativa, nec est praesens intellectui, nisi quia praesens est imaginativae. Et hoc per actionem, quam agit in imaginativa species existens in memoria sensitiva, non solum imprimendo ei speciem suam, sed etiam immutando ad actum imaginandi, ita quod intellectus noster nihil intelligit, nisi coniunctum cum sua imaginatione, ut enim ipse speculetur phantasmata sub ratione universalis, necesse est imaginativa idem simul speculari sub ratione particularis" (um trecho dessa passagem já foi citado em cap. 5, nota 45). Cf. ROMBEIRO, "Intelligible Species in the Mature Thought of Henry of Ghent”, 2011, p. 205. Note-se como, aqui, o 'fantasma' é associado a um speculari por parte da imaginativa e do intelecto. Seria possível relacionar esse atrelamento do verbo speculari ao fantasma, que encontramos nessa passagem, àquela caracterização da espécie sensível como speculum, que lemos acima (cf. cap. 4, notas 68 e 71)? Isto é, haveria um jogo de palavras entre speculari e speculum que aproximaria aquela caracterização da espécie sensível desta caracterização do fantasma? Essa pergunta, parece-me, deve permanecer sem resposta definitiva, muito embora aponte para um possível caminho de aproximação entre o conhecimento sensitivo e o conhecimento imaginativo (ou, mesmo, intelectual).

No mais, a mesma temática da abstração como ação do intelecto agente pela qual o fantasma passa de algo inteligível em potência para algo inteligível em ato e, portanto, capaz de mover o intelecto possível é retomada em Quodl. 8, q. 12, co. (ed. 1613, f. 32ra-b): "Per eundem modum intellectus agens necessarius est ad acum intelligendi, eo videlicet quod phantasmata non sunt, nisi potentia intellecta, quia in ipsis natura, et quiditas rei est sub ratione esse materialis, et conditionibus particularibus, nec est aliquid natum movere intellectum, nisi sub ratione universalis $<\ldots>$. Quod appellatur denudare phantasmata $\mathrm{ab}$ istis conditionibus, et abstrahere eas, quae abstractio non fit per aliquam migrationem, vel generationem ab eis in intellectu possibili, praeter quod per huiusmodi abstractionem habent rationem universalis activi, et motivi intellectus possibilis, ut id quod moveat, nisi sub ratione universalis per motum agentis, ut dictum est. In intellectu autem possibili non est, nisi sicut movens in moto ante actum intelligendi, quia per suam actionem generat in intellectu possibili 
Mais uma vez, retornamos aqui à temática do paralelismo entre visão sensível e conhecimento intelectual. [1] O intelecto agente está para o intelecto possível como a luz para o diáfano; [2] já para o fantasma, o intelecto agente está como o diáfano com respeito às cores. Daí se pode depreender, respectivamente, [1] que o intelecto agente atualiza o possível para a recepção do inteligível tal como a luz atualiza o diáfano para a recepção da cor; e [2] que o intelecto agente torna o fantasma movente em ato do intelecto possível tal como o diáfano sob a luz torna a cor movente em ato do meio. Entretanto, o mais importante nessa passagem não é tanto a aproximação entre intelecção e visão, mas são principalmente as ressalvas que o Doutor Solene propõe a tal aproximação.

A primeira ressalva [i] retorna a um tema que já foi abordado algumas linhas acima, a saber, a consubstancialidade do intelecto possível e do intelecto agente. Muito embora se possa dizer que o intelecto agente está para o intelecto possível como a luz para o diáfano, é preciso atentar para o fato de que, enquanto a luz é algo acidental no diáfano - isto é, um acidente que, ao inerir no diáfano, o aperfeiçoa - o intelecto agente é substancialmente idêntico ao intelecto possível. Mais do que isso, ambos - intelecto agente e intelecto possível - são realmente idênticos à alma ${ }^{246}$. Como, porém, já estudamos esse tema pausadamente no cap. 2, torna-se mais importante neste momento para nós a segunda ressalva introduzida por Henrique de Gand.

Com efeito, no passo seguinte deste excerto, vemos nosso autor introduzir uma ressalva [ii] com respeito à segunda parte da comparação proposta, a saber, aquela segundo a qual o intelecto agente está para o fantasma tal como o diáfano com respeito à cor. Nesse caso, a diferença entre o sensível e o inteligível está no fato de que o diáfano atualizado pela luz, ao tornar a cor movente em ato do meio, recebe em si uma espécie impressa (como sabemos, já abstraída da matéria da cor). No caso do conhecimento intelectual, porém, não há a impressão de espécies. Pelo contrário, o intelecto agente age unicamente para tornar o fantasma que era inteligível em potência algo inteligível em ato - isto é, movente em ato do intelecto - e existente no

intellectionem, qua sibi ipsum assimulat, per quam est in intellectu sicut cognitum in cognoscente, et intellectum in intelligente”. Cf. BRAUN, Die Erkenntnislehre..., 1916, pp. 33-5.

${ }^{246}$ A importância da identificação entre intelecto agente e intelecto possível em Quodl. 5, q. 14, é enfatizada em BROWN, J. V. "Intellect and Knowing...", 1975, p. 693. Ainda sobre a consubstancialidade das potências da alma, cf. a nota 237, acima. 
intelecto "somente enquanto cognoscente [existentia in eo, ut in cognoscente solum]". Ora, essa oposição da locução "ut in cognoscente" à impressão de uma espécie nos traz de volta à oposição, que víamos em Quodl. 4, entre 'espécie expressiva' e 'espécie impressiva' - a primeira concebida enquanto algo presente à potência cognoscitiva tal como o conhecido no cognoscente (isto é, propriamente como objeto) e a segunda concebida enquanto algo presente como acidente em um sujeito ${ }^{247}$. Mencionamos novamente há pouco que, aqui em Quodl. 5, q. 14, a espécie expressa é estritamente intelectual ${ }^{248}$ - ou seja, só há, de fato, a presença de algo como conhecido no cognoscente no caso do conhecimento intelectivo (deixando de lado a polêmica em torno da imaginação, que estudamos no cap. 5).

Porém, o movente em ato do intelecto - que é no intelecto enquanto cognoscente e, portanto, deve se identificar à espécie expressa - não aqui nada mais do que o próprio fantasma tornado inteligível pelo intelecto agente. De fato, essa identificação entre aquilo conhecido pela imaginação e aquilo conhecido pelo intelecto (ou, melhor, entre o imaginável e o inteligível) é reforçada por Henrique nesse mesmo excerto: eles são "o mesmo na coisa [idem re]". O fantasma é realmente um único cognoscível para duas potências da alma - sob a razão do particular (sub ratione particularis), para a imaginativa e, posto sob a razão do universal (sub ratione universalis) pelo intelecto agente, para a intelectiva ${ }^{249}$. Essa identidade possui por consequência uma necessária ordenação das atividades da imaginativa e da intelectiva. Isso, porque, sendo primeiramente objeto da imaginação, o fantasma só poderá estar presente ao intelecto na medida em que já estiver presente à imaginação (nec est praesens intellectui, nisi quia praesens est imaginativae). Mais do isso, não somente o fantasma deve ser, primeiramente, presente à imaginação, como esta deve já conhecê-lo em ato (speculari) sob a razão do particular para que, só então, simultaneamente (simul) o intelecto também o conheça em ato (speculetur) sob a razão do universal. Por isso mesmo, o Doutor Solene pode dizer que o ato de inteligir um objeto é conjugado (coniunctum) ao ato de imaginar esse mesmo objeto. Assim,

\footnotetext{
${ }^{247}$ Cf., acima, notas 97 e 102 (Quodl. 4, q. 7), 181 (Quodl. 4, q. 8) e 185 (Quodl. 4, q. 21).

${ }^{248} \mathrm{Cf}$., acima, nota 238.

${ }^{249}$ Essa tese é retomada em Quodl. 8, q. 13, co. (ed. 1613, f. 33ra): "Dicendo, quod phantasma potest dupliciter considerari. Uno modo, ut habet rationem phantasmatis, et particularis.

Alio modo, ut per denudationem, et abstractionem praedictam habet rationem universalis, quod appellatur universale phantasmatis, licet non sit aliud re ab ipso phantasmate". Cf. BRAUN, Die Erkenntnislehre..., 1916, pp. 34-6.
} 
não somente há uma ordem estrita entre o conhecimento imaginativo e o conhecimento intelectivo, como há uma união cerrada entre os dois, uma vez que ambos dizem respeito ao mesmo - o fantasma -, ainda que sob razão diversas.

Nesse caso, a espécie expressa - cujo locus Henrique dizia ser o intelecto surge como o fantasma posto em presença do intelecto possível, pelo intelecto agente, sob a razão do universal. Mas, se isso não é um acidente em um sujeito, o que seria essa espécie expressa? Decerto, um objeto inteligível ou algo conhecido no cognoscente. Mas o que isso significa? Nas palavras de Michael Rombeiro, "as espécies expressivas não possuem o estatuto ontológico de formas inerentes com conteúdo objetivo; seu estatuto ontológico é simplesmente aquele de um objeto em um cognoscente - em outras palavras, um tipo de conteúdo objetivo puro. Esse conteúdo é sempre ligado a um inerente real, seja um ato de conhecimento ou um hábito, mas é de qualquer modo ontologicamente distinto disso" ${ }^{, 250}$. Por outro lado, esse mesmo movimento atrela inescapavelmente o intelecto aos sentidos, como parece claro pelo resumo dessa doutrina proposto por Jerome Brown: "Em sua análise sobre como a mesma coisa singular pode ser objeto da visão, da imaginação e do intelecto, Henrique diz que ela pode ser objeto do intelecto sob a ratio de um universal que o intelecto 'vê' no fantasma sem espécie impressiva",251. Assim, o mesmo movimento que permite ao intelecto um conhecimento universal a partir dos sentidos pela abstração de uma espécie expressa, o atrela completamente aos mesmos sentidos, uma vez que esta última não é senão o próprio fantasma sob a razão do universal.

Sem dúvida, o caminho que acompanhamos nesse Quodl. 5, q. 14, diz respeito unicamente à formação do conhecimento intelectual simples. Seu resultado - o objeto inteligido em ato - ainda é aquele verbum do conhecimento incomplexo que, muito embora não mencionado nos trechos estudados de Quodl. 5, q. 14, era bem destacado no Quodl. 4. Destarte, o próximo passo na narrativa da formação do conhecimento intelectual seria mostrar como, dessa intelecção simples que viemos estudando até

\footnotetext{
${ }^{250}$ ROMBEIRO, “Intelligible Species in the Mature Thought...", 2011, p. 211: "Expressive species do not have the ontological status of inherent forms with objective content; their ontological status is simply that of an object in a knower - in other words, a sort of pure objective content. That content is always tied to a real inherent, either an act of cognition or a habit, but is ontologically distinct from it nonetheless".

${ }^{251}$ BROWN, J. V. "Intellect and Knowing...", 1975, p. 511: "In his analysis of how the self-same singular thing can be the object of sight, of the imagination and of the intellect, Henry says that it can be the object of the intellect under the ratio of a universal which the intellect 'sees' in the phantasm without any impressive species" (grifo no original).
} 
aqui, forma-se o conhecimento complexo. De fato, Henrique de Gand dedica algumas linhas ao problema da formação do conhecimento intelectual complexo em Quodl. 5, q. $14^{252}$. Porém, cabe perguntar: se a intelecção simples permanece tão fundamentalmente atrelada ao sentido, a intelecção complexa pode dele escapar? Como vimos na leitura dos trechos expungidos de Suma, art. $34^{253}$, o Doutor Solene parece pessimista quanto a tal possibilidade - se conhecemos algo para além do conceito simples, tal conhecimento é sempre demasiado geral. Com efeito, esse era também um resultado que obtínhamos na leitura da doutrina da intelecção exposta nos primeiros artigos da Suma: se o conhecimento intelectivo se afasta do sentido ele não o faz, senão, por abstrair conceitos maximamente gerais. Mas, nesse caso, como podemos, para Henrique, escapar aos sentidos?

Não será meu objetivo neste trabalho responder a tal pergunta. No entanto, pretendo, ao fim desta segunda parte, apontar possíveis direções para uma resposta. Antes, porém, nos resta ainda ler certos trechos de sua obra a respeito da formação do conhecimento intelectual nos quais, parece-me, o estreitamente da relação entre intelecto e sentido no conhecimento simples atinge um paroxismo.

\subsubsection{Do fantasma à intelecção - e além}

Essa última etapa de nossa pesquisa sobre o conhecimento intelectual terá por base a leitura de Suma, art. 58, q. 2, onde Henrique de Gand pergunta "se gerar seria o mesmo que dizer [utrum generare sit idem, quod dicere]"254. A temática trinitária da questão é patente, de modo que não será nosso fim aqui desenvolver todos os elementos discutidos nesse texto. Muito pelo contrário, pretendo unicamente destacar um conjunto de passagens da resposta às objeções principais dessa questão no qual o Doutor Solene vê a oportunidade de desenvolver certos elementos de sua doutrina da intelecção ${ }^{255}$. Que tal discussão seja voltada estritamente para o intelecto humano e

\footnotetext{
${ }^{252}$ Henrique de Gand, Quodl. 5, q. 14, co. (ed. 1613, f. 262va): "Intellectus autem motus dicto modo ab obiecto ad simplicem intellectum essentiae rei vim habet ex se negotiandi circa illud, et circa rei adhaerentiam, postquam ea simpliciter simplici intelligentia comprehenderit, et componendo, et dividendo investigandi notitiam quod quid est, et propter quod est de re, qua per studium, et investigationem diligenter saepius percepta, generat in seipso habitum scientialem, ex quo prompte, et faciliter ad perceptionem obiectorum exit in actum ad illa, et consimilia percipienda $<\ldots$..”.

${ }^{253}$ Cf., em particular, nota 174 , acima.

${ }^{254}$ Henrique de Gand, Suma, art. 58, q. 2 (ed. 1642-6, p. 999).

${ }^{255}$ Sobre o trecho que leremos a seguir dessa questão, cf. BETTONI, Il processo astrattivo..., 1954, pp.
} 
não também para angélico (como era o caso em Quodl. 5, q. 14) fica patente pela própria sentença com a qual Henrique introduz o tema: “< ..> para que tratemos simultaneamente de toda a matéria que diz respeito a isso, é preciso examinar de que modo o nosso intelecto é passivo e de que modo <é> ativo"256. Outro elemento que nos introduz de imediato no campo da intelecção humana é o fato de que, já no início da exposição do tema, se coloca o problema da relação entre intelecto agente, intelecto possível e fantasma:

\begin{abstract}
"De fato, o intelecto possível necessita de um agente para inteligir as coisas universais, tal como a visão necessita da luz para ver as cores. De fato, $<_{0}$ Filósofo > compara o possível à visão, o agente à luz, a cor ao universal existente no fantasma. Porém, compara o agente à luz, quanto a dois: de fato, o agente está para os fantasmas tal como a luz para as cores, mas <está> para o possível como a luz para a visão. Se for totalmente semelhante, a luz está para as cores tal que, ainda que haja cores em ato nas trevas, elas porém não movem por sua espécie senão em potência. Mas a luz as faz mover o meio e a visão em ato. Já para o meio e a visão, a luz está tal que dê a eles a forma da iluminação, mediante a qual recebem o movimento da cor e também a informação dela, tal que sem a luz as cores não possam mover o meio ou a visão para a sua informação. Agora, similarmente está o agente para os fantasmas. Estes, de fato, enquanto particulares e sob condições materiais, não são espécies dos universais senão em potência; tampouco podem mover o intelecto possível senão em potência. Mas o lume do agente, resplendendo [splendens] espiritualmente sobre eles tal como o lume material resplende [resplendet] materialmente sobre as cores, os separa das condições materiais e particulares, bem como os propõe sob a razão de espécie universal para o intelecto possível, que tanto é movido mediante aquelas coisas universais [rebus universalibus], como é informado com a intelecção dos universais segundo o ato, do mesmo modo como as cores movem em ato, por sua espécie na luz, a visão para ver as cores"257.
\end{abstract}

51-9; e FRIEDMAN, In principio erat verbum..., 1997, pp. 138-42. Mais comentadores serão citados oportunamente. Sobre os aspectos teológicos e filosóficos centrais de Suma, art. 58, q. 2, cf. FRIEDMAN, In principio erat verbum..., 1997, pp. 135-7; FRIEDMAN, Intellectual Traditions at the Medieval University..., 2013, pp. 258-60.

${ }^{256}$ Henrique de Gand, Suma, art. 58, q. 2, ad 3 (ed. 1642-6, p. 1006a, n. 36): "Hic ad huius rationis dissolutionem, et declarationem quaestionis ultimae huius articuli, scilicet, utrum generare in divinis sit opus intellectus paterni, ut simul tangamos totam materiam hoc contingentem, oportet perquirere quomodo intellectus noster sit passivus, et quodmodo activus".

${ }^{257}$ Henrique de Gand, Suma, art. 58, q. 2, ad 3 (ed. 1642-6, p. 1006a-b, n. 38): "Indiget enim intellectus possibilis agente ad intelligendum res universales, quemadmodum visus indiget luce ad videndum colores, comparat $<s c$. Philosophus $>$ enim possibilem visui, agentem luci, colorem universali existenti in phantasmate. Comparat autem agentem luci, quoad duo, se habet enim agens ad phantasmata sicut lux ad colores, ad possibilem vero, ut lux ad visum. Ad colores sic se habet lux si simile sit omnino, quod licet in tenebris sint actu colores, non tamen movent specie sua nisi in potentia, sed lux faciat eos movere medium, et visum in actu. Ad medium autem, et visum se habet lux sic, quod dat eis formam illuminationis, mediante qua recipiunt motum coloris, et etiam informationis ab ipso, ita quod sine luce non possent colores medium, aut visum movere ad illorum informationem. Consimiliter autem agens se habet ad phantasmata. Ipsa enim, ut particularia, et sub conditionibus materialibus non sunt species universalium, nisi in potentia, nec possunt movere intellectum possibilem nisi in potentia. Sed lumen agentis splendens spiritualiter super illa sicut lumen materiale materialiter resplendet super colores, separat ea a conditionibus materialibus, et particularibus, et sub ratione speciei universalis proponit ea 
Como já vimos ocorrer por diversas vezes, mais uma vez as relações do intelecto agente para com o intelecto possível e para com o fantasma surgem aqui comparadas, respectivamente, àquela da luz para com a visão e àquela da luz para com a cor na matéria. Tal como ocorria em Quodl. 5, q. 14, também aqui há uma ressalva ao fim da passagem: o intelecto agente é um lume espiritual (spiritualiter), enquanto que a luz que incide no meio ou sobre a cor é um lume material (materialiter); veremos, além disso, que nas passagem que se seguirão Henrique de Gand desenvolverá outras dificuldades na aproximação entre sensação e intelecção. Aqui, porém, elas ainda não são capitais. Desse modo, o intelecto agente surge aqui como aquele que torna o fantasma inteligível em ato tal como a luz torna a cor algo que modifica o meio e a visão em ato (ou, pelo contrário, sem a ação do intelecto o fantasma só é inteligível em potência, tal como nas trevas a cor só pode modificar o meio em potência, sem modificá-lo em ato). Da mesma maneira, o intelecto agente torna o intelecto possível receptivo para o inteligível tal como a luz torna o meio e o órgão da visão receptivos da espécie sensível multiplicada desde a cor. Ou seja, aqui também em Suma, art. 58, o intelecto agente possui duas ações na produção da intelecção: [i] tornar o fantasma inteligível em ato e [ii] tornar o intelecto possível receptivo do inteligível em ato.

Em seguida, o Doutor Solene se volta para a temática da passagem do inteligível da potência ao ato. Os fantasmas são particulares e, por si mesmo, estão sob condições materiais - por isso mesmo, eles "não são espécies dos universais senão em potência [non sunt species universalium, nisi in potentia]" e, portanto, ainda movem o intelecto possível somente em potência. Ora, a referência à species do universal aqui parece ser uma remissão à noção de species expressa ou expressiva, uma vez que vimos o quão veementemente Henrique rechaça qualquer ocorrência de espécies impressas em sua doutrina da intelecção. Se for assim, mais uma vez vemos aqui confirmada uma identificação entre a espécie expressa e o inteligível em ato. Isso é retomado na etapa seguinte do trecho, onde se descreve o efeito da ação do intelecto agente sobre o fantasma.

intellectui possibili, qui et movetur mediantibus illis rebus universalibus, et informatur intellectione universalium secundum actum, quemadmodum colores specie sua in luce actu movent visum ad videndum colores". Cf. ROMBEIRO, “Intelligible Species in the Mature Thought...”, 2011, p. 202. 
Se, por si mesmo, o fantasma é particular e está sob condições materiais, a ação o intelecto agente sobre ele resulta justamente na abstração de tais condições materiais e particulares. Com isso, o fantasma é apresentado ao intelecto possível "sob a razão de espécie universal [sub ratione speciei universalis]". Note-se, porém, que Henrique de Gand passa com bastante facilidade da noção de fantasma 'sob a razão de espécie universal' para a noção de 'coisa universal' (rebus universalibus) que já encontramos, há pouco, em Quodl. 5, q. $14^{258}$. Com efeito, uma vez proposto o fantasma sob a razão do universal - ou, mais precisamente, sob a razão de espécie universal -, o intelecto possível é movido "mediante aquelas coisas universais [mediantibus illis rebus universalibus]" e informado com a "intelecção dos universais [intellectione universalium secundum actum]" em ato. Dessa maneira, o "fantasma sob a razão de espécie universal' ou a 'coisa universal' (res universalis) parecem ser o mesmo inteligível - isto é, já inteligível em ato, mas ainda inteligido somente em potência - que, em seguida, passa a ser o universal inteligido em ato (ou, na terminologia de Quodl. 4, passa a ser o verbum do conhecimento simples).

Poder-se-ia, porém, perguntar: se o intelecto agente abstrai o inteligível em ato e torna o intelecto possível receptivo deste, teria ele também um papel imediato na atualização da intelecção em ato? Surge uma pista para a resposta positiva a essa questão já na passagem citada, quando nosso autor afirma que o intelecto possível é informado pela intelecção em ato "do mesmo modo como as cores movem em ato, por sua espécie na luz, a visão para ver as cores [quemadmodum colores specie sua in luce actu movent visum ad videndum colores]". Note-se que as espécies sensíveis não são primeiro formadas pela ação da luz para, em seguida, moverem por si mesmas o sentido para o ato da visão; pelo contrário, quando move o sentido para o ato da visão, a espécie sensível é tomada como uma 'espécie na luz' (specie sua in luce). Ou seja, a cor move a visão por meio de sua espécie na luz, de maneira que cor, espécie e luz parecem mover - cada qual à sua maneira - a visão para o ato. Se isso for válido igualmente para a intelecção, teríamos que admitir que o intelecto agente não somente [i] produz o intelegível em ato e [ii] torna o intelecto possível receptivo do inteligível, mas também [iii] causa, junto ao fantasma sob a razão do univeresal, a própria intelecção em ato.

\footnotetext{
${ }^{258}$ Cf., acima, nota 229.
} 
Pois bem, que esse seja o caso parece ser afirmado em Suma, art. 60, q. 4, onde lemos que "pelo intelecto é causada em si mesmo a operação vital que é inteligir, na virtude do objeto co-agente com o intelecto e o move, como agente e movente primeiro. Por isso, o intelecto é uma força passiva e nada age sem que padeça primeiro" ${ }^{, 259}$. Como se vê, o objetivo principal desse curto excerto é defender a prioridade da passividade do intelecto sobre seu próprio ato - antes de ser intelecção em ato, o intelecto necessariamente recebe algo. $O$ que nela nos interessa principalmente, porém, é a referência ao objeto como 'co-agente' (obiecti coagentis) do intelecto. $\mathrm{O}$ intelecto age junto ao objeto ao mover-se a si mesmo - ou melhor, o

${ }^{259}$ Henrique de Gand, Suma, art. 60, q. 4, ad 1 (ed. 1642-6, p. 1099a, n. 8): "Et multum differunt inter se ista duo genera actionum $<s c$. natural e nocional $>$, quoniam operatio, quae est actio essentialis, ut intelligere, et velle, causantur a nuda potentia, et vi intellectus, et voluntatis in ipso intellectu, et voluntate a quibus causantur, licet differenter ab intellectu, et a voluntate. Quia ab intellectu in seipso causatur operatio vitalis, quae est intelligere in virtute obiecti coagentis cum intellectu, et moventis ipsum, ut agens, et movens primum, eo quo intellectus est vis passiva, et nihil agit nisi passa prius". Christian Trottmann considera que esse texto diz respeito, em especial, à visão beatífica: "Il pense la préséance de l'essence de Dieu dans l'acte bienheureux selon un ordre logique et non chronologique. Qui plus est il reconnaît un rôle 'co-agent' à l'intellect, mu toutefois à cette co-action même, para la divine essence" (TROTTMANN, "Henri de Gand, source de la dispute...", 1996, p. 324). Parece-me, porém, que Henrique aí busca principalmente clarificar o processo intelectivo como um todo para, em seguida, poder aplicar suas conclusões à temática teológica com que lida a questão.

Sendo assim, é possível por esse texto considerar, também, uma passagem de Valeria Sorge, onde ela afirma, com base em Quodl. 5, q. 14 (que vimos acima, no item 6.5.1), que "la caduta di tale determinante conoscitivo $<s c$. a espécie $>$ nell'ambito di tale problematica riveste un significato ben preciso: essa reppresenta, infatti, il tentativo, operato dal Gandavense, di attribuire all'intelletto, e ad esso solo, il ruolo di causa sine qua non del conoscere intellettivo <..." (Gnoseologia e teologia..., 1988, p. 92, grifo no orig.). Em primeiro lugar, Sorge não parece utilizar aqui a expressão "sine qua non" no sentido técnico que vimos Henrique de Gand adotar em sua discussão acerca da relação entre intelecto e vontade - cf., acima, nota 242 (onde se discute a possível causalidade sine qua non do fantasma na imaginação sobre o intelecto, antes da abstração) e cap. 3, nota 63. Pelo contrário, ela parece aqui utilizar tal expressão no sentido de 'causa necessária e suficiente'. Assim, para Sorge, a exclusão da espécie inteligível na doutrina da intelecção de Henrique de Gand tem por resultado a afirmação do intelecto como única causa necessária e suficiente do ato de conhecimento intelectivo. Bettoni parece ter sido de posição semelhante, pois ele nos diz: "L'oggetto sollecita, diremmo, la nostra facoltà intellettiva a conoscerlo, ma per quanto tale sollecitazione sia forte e irresistibile, è chiaro che l'atto stesso sgorga tutto intero dall'intelletto e solo dall'intelletto" (Il processo astrattivo..., 1954, p. 87). No entanto, pela leitura do excerto de Suma, art. 60, q. 4, destacado nesta nota, esse parece não ser o caso, pois o ato de intelecção é efetuado pela força do objeto em ação conjunta com o próprio intelecto. Como veremos na leitura do complexo trecho citado na nota 264, adiante, essa ação conjunta do objeto com o intelecto é necessária, porque o intelecto agente é indeterminado com respeito a qualquer universal, sendo necessário um objeto que determine sua ação com respeito a um universal em especial. Nas palavras de Quodl. 11, q. 5, o inteligível universal presente no fantasma inclina o intelecto para o ato de intelecção: “<...> ex parte autem intellectus nostri est ab ipso intelligibili universali, quod seipso est praesens intellectui in phantasmate actione intellectus agentis, propter quod seipso inclinat intellectum non mediante specie, quam solummodo ponimus in sensu, quia sensibile in seipso non potest esse praesens intra, ut inclinando sensum ducat ipsum in actum, et est haec inclinatio intellectus initium habitus cognitivi" - Quodl. 11, q. 5, co. (ed. 1613, f. 195rb). Cf. BRAUN, Die Erkenntnislehre..., 1916, p. 30.

Por fim, note-se que outro tema abordado no trecho de Suma, art. 60, q. 4, aqui citado inicialmente - a saber, a prioridade da passividade do intelecto com respeito à sua ação - é reiterado em Suma, art. 60, q. 4, ad 1 (ed. 1642-6, p. 1099b, n. 10) e ad 2 (ed. 1642-6, p. 1100b, n. 15). Voltaremos a esse tema adiante, na leitura do texto apresentado na nota 276. 
intelecto agente age junto ao objeto para mover o intelecto possível. Outro modo pelo qual Henrique de Gand expressa essa 'coagência' do objeto com respeito ao intelecto é a afirmação, em Quodl. 8, q. 12, de que “o fantasma move o possível como que misturado ao lume do agente [phantasma quasi mixtum cum lumine agentis movet possibilem], tal como a espécie da cor misturada à luz move a visão" ${ }^{260}$. Nesse último trecho, vemos inclusive a mesma referência à associação entre espécie sensível e luz no caso da visão que encontrávamos no último trecho indentado de Suma, art. 58, q. 2 , ad 3.

Como isso, portanto, podemos estabelecer que a ação do intelecto agente está presente em todas as etapas da produção do conhecimento intelectual em ato - algo que, aliás, já era estabelecido em trechos iniciais da $S u m a^{261}$, ainda que não de forma tão precisa quanto agora. Assim, o intelecto agente [i] produz o inteligível, [ii] torna o intelecto possível receptivo para o inteligível e [iii] age junto ao inteligível para a formação da intelecção em ato acerca desse mesmo inteligível. Estabelecido isso, o Doutor Solene introduz um dos trechos mais relevantes de sua obra para a compreensão de sua doutrina intelecção. Com efeito, no excerto a seguir, são condensadas diversas temáticas pertinentes a ela, como: a aproximação entre sensação e intelecção, a consubstancialidade das potências da alma, a abstração pelo intelecto agente e a atualização da intelecção em ato. Mais relevante, porém, a meu ver, é aqui a introdução de uma noção como que paradoxal, embora central para a concepção de intelecção aqui defendida. Já vimos que, para nosso autor, o fruto da abstração é a apresentação do fantasma ao intelecto possível 'sob a razão do universal' (sub ratione universalis), 'sob a razão de espécie universal' (sub ratione speciei universalis) ou, como ele também diz, enquanto um 'universal do fantasma' (universale phantasmatis $)^{262}$. Agora, porém, veremos esse mesmo inteligível ser descrito como um 'fantasma universal' (phantasma universale)! Porém, não obstante aparentemente

\footnotetext{
${ }^{260}$ Henrique de Gand, Quodl. 8, q. 12, co. (ed. 1613, f. 32rb): "Et quia agens est quasi lumen in possibili, phantasma quasi mixtum cum lumine agentis movet possibilem sicut species coloris mixta luci movet visum. Et est hic et ibi differentia, quod lux facit, ut praeter visionem faciat color speciem in medio, qua vice coloris informat pupillam actu visionis, agens vero non facit, ut praeter intellectionem [ed. $1518, f .324 r C \mid$ inteleictionem ed. 1613] faciat aliquam aliam speciem suam in possibili. Est etiam differentia ex parte visus, et intellectus respectu lucis, et agentis, quia ipsa lux est quoddam visibile natum per se videri, licet non videtur nisi cum permixta est colori propter suam maiorem simplicitatem Agens autem cum est potentia quaedam non est per se intelligibile sicut lux visibile, sed solum efficaciam dat intelligibili, ut intelligatur $<\ldots$.. $"$

${ }^{261}$ Cf. nota 29 , acima.

${ }^{262}$ Cf., respectivamente, notas 245, 257 e 249.
} 
compor um oximoro, nas palavras de Bettoni, a "expressão não provoca medo em

Henrique de Gand; pelo contrário, <ele> a usa com desenvoltura"263.

“ $<\ldots>$ os fosforescentes [noctilucae] de dia não movem a visão senão sob a forma da cor. E, assim, a luz, que é hipóstase sob condições particulares e materiais, possui o ser terminada, nos fosforescentes, na forma de cor. Mas, de noite, $<$ os fosforescentes $>$ movem a visão sob a forma de luz pura, como que abstraída da matéria e das condições particulares do corpo em que é. As cores, em $<$ algo $>$ terminado - por exemplo, na madeira e pedra - são totalmente sob um ser particular e material, ao modo dos fantasmas na fantasia, que, no que diz respeito a eles, aqui e agora, não são natos a mover senão segundo o ser material e particular. Assim, tal como se uma luz temperada irradiando sobre a cor da madeira ou da pedra fizesse tal cor mover a visão sob a forma de uma luz como que abstraída da matéria e das suas condições particulares, para que $<\mathrm{se}>$ veja a própria luz por sua espécie, assim a luz do agente irradiando sobre os fantasmas como que os separa da matéria e das condições materiais e os propõe ao intelecto possível $\mathrm{e}$, por eles, as coisas universais $-\mathrm{e}$, neles, $<$ as $>$ propõe àquele $<s c$. ao intelecto possível $>$. E, assim, segundo a razão do universal, movem o possível para inteligir o universal, que de acordo com isso é no intelecto, tal como o objeto conhecido no cognoscente. Ora, o agente está para o possível tal que, se ele não fosse no possível como sua luz conatural, <este> não seria receptível de nenhuma informação do inteligível, do mesmo modo como tampouco a visão da cor $<$ o seria $>$, se não fosse informada pela luz material. De fato, tal como a visão não recebe as espécies da cor senão misturadas ao lume - e como que determinando o próprio lume -, assim tampouco o intelecto possível recebe as

\footnotetext{
${ }^{263}$ BETTONI, Il processo astrattivo..., 1954, p. 57: "L'azione dell'intelletto agente dunque non produce una nuova imagine ideale dell'ogetto, ma fa in modo che il fantasma, da immagine di una cosa particolare, se presenti come immagine di una cosa universale, da fantasma particolare diventi fantasma universale. L'espressione non fa paura ad Enrico di Gand: la usa anzi con disinvoltura". Jerome V. Brown vê no fantasma universal uma tentativa de, simultaneamente, conservar um aspecto concreto e outro aspecto cognitivo para a mesma intenção que é dada ao intelecto: "Yet Henry, ever anxious to preserve the concrete as well as the cognitional being of the intentio, does not hesitate to continue to refer to this universal as the 'phantasm which has the ratio of a universal' and 'the universal phantasm"' (Abstraction and the Object of the Human Intellect...", 1973, pp. 88-9). Sobre a noção de fantasma universal, cf. tb. BOURGEOIS, "La théorie de la connaissance intellectuelle...", 1936, pp. 248-9 e 253 (onde se fala em um "phantasme spiritualisé"); BEHA, "Matthew of Aquasparta's Cognition Theory. Part II: Ideogenesis", 1961, p. 24; BROWN, J. V. "Abstraction and the Object of the Human Intellect...", 1973, pp. 88-9; SORGE, Gnoseologia e teologia..., 1988, pp. 99100; TACHAU, Vision and Certitude..., 1988, p. 33; FRIEDMAN, In principio erat verbum..., 1997, pp. 139-42; GOEHRING, Henry of Ghent on Cogntion..., 2006, pp. 151-2; WILLIAMS, "Augustine, Thomas Aquinas, Henry of Ghent, and John Duns Scotus...", 2010, pp. 52-5; ROMBEIRO, "Intelligible Species in the Mature Thought...", 2011, pp. 203-19; FRIEDMAN, Intellectual Traditions at the Medieval University..., 2013, pp. 261-6.

A bem dizer, Bettoni considera a noção de 'fantasma universal' um elemento extremamente problemático na doutrina da intelecção de Henrique de Gand: "Quanto male a proposito usi il termine universale Enrico di Gand, non è chi non veda. Infatti se una rappresentazione ideale è davvero universale, non è più un fantasma, e, viceversa, se è un fantasma, cioè una entità psichica di natura sensibile, non può più essere universale $<\ldots>$. È questo il fondamentale abbaglio, di cui, a nostro parere, è vittima Enrico di Gand. Chi disse universalità disse intelligibilità; ora, è chiaro, che la conoscenza sensibile, in qualunque modo e in qualunque circostanza avvenga, è sempre conoscenza sensibile: si gradui quanto si voglia, la conoscenza sensibile non diventerà mai conoscenza intelligibile $<\ldots$. . Il fantasma universale di Enrico di Gand non è che un fantasma imperfetto, indeterminato e confuso: ora questo è l'universale degli empiristi, non quello di Aristotele" (BETTONI, Il processo astrattivo..., 1954, p. 58 - grifo no original). Esta última frase é citada em SORGE, Gnoseologia e teologia..., 1988, p. 100.
} 
intelecções, que são espécies dos fantasmas universais e das próprias coisas universais no intelecto, senão misturadas à luz do agente - e como que a determinando -, como um hábito universal nele existente" ${ }^{\text {264 }}$.

Uma primeira dificuldade na leitura da passagem apresentada é seu difícil estabelecimento textual quando confrontamos as lições encontradas nas edições dos séculos XVI ou XVII e aquela que encontramos em um manuscrito do século XIV como Troyes, Médiathèque du Grand Troyes, ms. 493. Como se pode notar no texto latino apresentado aqui em nota, muitas são as diferenças entre essas duas lições (não havendo divergências senão tipográficas entre as edições modernas). Sendo assim - e, na ausência de uma edição crítica -, fio-me na lição do referido manuscrito para análise do texto em questão.

Como dito anteriormente, o objetivo do Doutor Solene nesse excerto parece ser, antes de tudo, resolver um problema urgente para a exposição de sua concepção de abstração que, afinal, forma a base de sua concepção de conhecimento intelectual. Fora-nos dito que o mesmo fantasma - sem perda de sua identidade real - é conhecido sob a razão do particular pela imaginação e sob a razão do universal pelo intelecto. Isso só possível porque a luz do intelecto agente retira do fantasma as condições materiais e particulares, apresentando-o sob a razão do universal - ou sob a

\footnotetext{
${ }^{264}$ Henrique de Gand, Suma, art. 58, q. 2, ad 3 (ed. 1642-6, pp. 1006b-7a, n. 39) [Troyes, Médiathèque $d u$ Grand Troyes, ms. $493=$ Q]: "Quod intelligo in simili maiori sic, videmus enim, quod noctilucae de die non movent visum nisi sub forma coloris. Et sic lux, quae est hypostasis sub [Qf. $56 \mathrm{va}, l .3$ | hypostasis coloris, sub ed. 1520, f. 129vE | hypostasis coloris, ub ed. 1642-6, p. 1006b] particularibus, et materialibus conditionibus habet esse in noctilucis terminata in forma coloris. De nocte vero movent visum sub forma lucis purae quasi abstractae a materia, et conditionibus particularibus corporis in quo est. Colores omnino in terminato $[Q, f .56 \mathrm{va}, \mathrm{l} .7 \mid$ colores ergo in corpore non terminato ed. $1520, f$. $129 v E$, ed. 1642-6, p. 1006b], puta in ligno, et lapide sunt sub esse particulari, et materiali, quemadmodum phantasmata in phantasia, quae quantum est de se, et hic et ibi non sunt nata movere nisi secundum esse materiale, et particulare. Quemadmodum ergo si super colorem ligni, aut lapidis lux aliqua temperata radians faceret colorem visum movere sub forma lucis quasi abstractae a materia, et a conditionibus $[Q, f .56 v a, l .13 \mid$ et conditionibus ed. 1520, f. 129vE, ed. 1642-6, p. 1006b] particularibus eius ad videndum ipsam lucem specie sua, sic supra $[Q, f .56 \mathrm{va}, l .14 \mid$ super $e d .1520, f$. $129 v E$, ed. 1642-6, p. 1006b] phantasmata lux agentis radians quasi separat ipsa a materia, et conditionibus materialibus, et proponit ea intellectui possibili, et per ea res universales, et in eis eidem proponit [Q, f. 56va, l. 14 | proponit propositum ed. 1520, f. 129vE, ed. 1642-6, p. 1006b], et sic secundum rationem universalis movent $[Q, f$. 56va, l. $17 \mid$ movet ed. 1520, f. 129vE, ed. 1642-6, p. $1006 \mathrm{~b}$ ] possibilem ad intelligendum universale, quod secundum hoc est in intellectu, sicut obiectum cognitum in cognoscente. Agens autem se habet ad possibilem sic, quod nisi ipse esset [Q, f. 56va, l. 19 | esset ipse ed. 1520, f. 130rE, ed. 1642-6, p. 1006b] in possibili, ut lux eius connaturalis, non esset receptibilis alicuius informationis ab intelligibili, quemadmodum neque visus a colore, nisi esset informatus luce materiali. Sicut enim non recipit visus species colorum, nisi admixtas lumini, et quasi lumen ipsum determinantes, sic nec intellectus possibilis recipit intellectiones, quae sunt species phantasmatum universalium, et ipsarum rerum universalium in intellectu, nisi admixtas luci agentis, et quasi ipsam determinantes, ut universalem habitum in illo existentem". Cf. WILLIAMS, "Augustine, Thomas Aquinas, Henry of Ghent, and John Duns Scotus...", 2010, pp. 52-4.
} 
razão de espécie universal - para o intelecto possível, de modo que tal fantasma deixe de ser inteligível em potência e passe a ser inteligível em ato. Pois bem, neste último trecho indentado, Henrique de Gand nomeia o fantasma sob a razão do universal como um 'fantasma universal', ao qual se oporá - no próximo trecho que leremos um 'fantasma particular' (phantasma particulare). Assim, a ação do intelecto agente passa a ser obter um fantasma universal a partir do fantasma particular sem que, no entanto, haja uma distinção real entre ambos. Com isso, finalmente temos formulado o problema que nosso autor pretende estudar nessa passagem, a saber: como pode o intelecto agente abstrair um fantasma universal a partir do fantasma particular sem ferir a identidade real do fantasma em ambos os casos? Em outras palavras, como é possível que fantasma particular e fantasma universal - apesar de distintos devido às suas respectivas particularidade e universalidade - mantenham uma identidade real?

Mais uma vez, a estratégia pela qual Henrique aborda tal tema é uma aproximação entre conhecimento sensível e conhecimento intelectual. Em especial, interessa a ele o curioso caso das coisas fosforescentes (noctilucae), que - mantendo uma identidade real - afetam o olho sob a forma da cor de dia, mas de noite o afetam diferentemente. O estudo dos fosforescentes se inicia por uma consideração acerca da luz. Ele nos diz: “a luz, que é hipóstase sob condições particulares e materiais, possui o ser terminada, nos fosforescentes, na forma de cor [lux, quae est hypostasis sub particularibus, et materialibus conditionibus habet esse in noctilucis terminata in forma coloris]". Não deixa de causar estranhamento uma referência à luz como 'hipóstase' (hypostasis). Aqui, porém, tal termo parece simplesmente reforçar o caráter particular que se atribui à luz. É enquanto algo particular e material que a luz atua sobre a cor das coisas fosforescentes, mesmo porque as "cores, em <algo $>$ terminado - por exemplo, na madeira e pedra - são totalmente sob um ser particular e material [Colores omnino in terminato, puta in ligno, et lapide sunt sub esse particulari, et materiali]". Ou seja, a luz, sendo um ente particular, atua sobre aquilo que há de particular visível no fosforescente, a saber, a forma da cor. Dessa maneira, durante o dia, as coisas fosforescentes afetam a visão tal como qualquer outra coisa material afetaria. De noite, porém, os fosforescentes não movem a visão da mesma maneira - ao que parece, porque não há no meio aquela luz particular e material que atualiza a forma da cor, também particular e material, no fosforescente visível. No entanto, ainda que não seja atualizado no que possui de particular e material visível, é característico do fosforescente que ele, mesmo assim - à noite - afete a visão. Agora, 
ele não o faz mais por uma forma particular e material como a cor, mas move "a visão sob a forma de luz pura, como que abstraída da matéria e das condições particulares do corpo em que é [De nocte vero movent visum sub forma lucis purae quasi abstractae a materia, et conditionibus particularibus corporis in quo est]". Pois bem, Henrique de Gand parece considerar o caso das coisas fosforescentes semelhante ao dos fantasmas: ambos podem, mantendo uma identidade real, afetar de maneiras diversas as potências cognoscitivas.

Há, porém, uma importante diferença entre os dois casos. Os fosforescentes, de dia ou de noite, movem somente a visão, pois eles sempre movem por meio da luz - de dia, pela luz particular e material no meio e, de noite, por aquela luz "como que abstraída da matéria e das condições particulares", cuja origem não fica muito clara para o leitor. O fantasma, por outro lado, move potências diferentes em cada caso: enquanto fantasma particular, é conhecido pela imaginação e, enquanto fantasma universal, é conhecimento pelo intelecto. Essa diversidade de potências cognoscitivas no caso do fantasma tem uma razão: diferentemente do que ocorre no caso dos fosforescentes (cuja luz como que abstraída possui uma origem pouco clara), sabemos muito bem donde provém a luz que abstrai o fantasma, pois ela é, a saber, a luz do intelecto agente. Em resumo, os fosforescentes afetam a mesma visão sob luzes distintas em cada caso, enquanto os fantasma afetam cada potência de um único modo: a imaginação sob a razão do particular e o intelecto sob a razão do universal, isto é, sob a luz do intelecto agente.

Por isso mesmo, para aproximar os dois casos - isto é, dos fosforescentes e dos fantasma - o Doutor Solene hipotetisa uma 'luz temperada' (lux aliqua temperata) que faria com que coisas como madeira ou pedra (isto é, normalmente não fosforescentes) pudessem ser vistas sob aquela mesma luz 'como que abstraída' sob a qual os fosforescentes podem ser vistos à noite. Ora, a irradiação dessa 'luz temperada' que torna fosforescente algo não-fosforescente seria um análogo sensível da luz do intelecto agente que, por sua irradiação, torna universal algo não-universal (com a diferença de que o fantasma, ainda que não-universal em ato, é universal em potência). Enfim, a comparação que Henrique de Gand propõe entre o conhecimento intelectivo e o conhecimento sensitivo é extremamente complexa: a passagem do fantasma particular para o fantasma universal não é exatamente semelhante ao caso de coisas fosforescentes, mas seria semelhante antes ao hipotético caso de coisas que, não sendo fosforescentes, aparecessem como tal sob uma 'luz temperada'. Não 
obstante as claras dificuldades em tal aproximação, parece-me que ela termina por, de fato, destacar os elementos importantes para a noção de 'fantasma' que Henrique pretende defender. Em particular, essa discussão mostra que, para nosso autor, é possível a manutenção de uma identidade real entre fantasma particular e fantasma universal, porque a passagem da particularidade para a universalidade diz respeito unicamente à diversidade da 'luz' que incide sobre o mesmo fantasma. Em outras palavras, poderíamos dizer que tal passagem é fruto das diversas potências cognoscitivas que se voltam para tal fantasma - ora a imaginação, que conhece nele um particular, ora o intelecto, que conhece também nele um universal. O fantasma, porém, permace o mesmo.

Pois bem, estabelecida tal identidade real do fantasma, o Doutor Solene se volta, ainda no último trecho indentado, para uma descrição mais minuciosa da maneira como, uma vez retiradas as condições materiais e particulares do fantasma, ocorre a atualização da intelecção em ato. Surge nesse momento, porém, um interessante problema textual na passagem: "secundum rationem universalis movent [Q, f. 56va, 1. 17 | movet ed. 1520, f. 129vE, ed. 1642-6, p. 1006b] possibilem ad intelligendum universale, quod secundum hoc est in intellectu, sicut obiectum cognitum in cognoscente". Como se vê, as edições modernas discordam do ms. Troyes, Médiathèque du Grand Troyes, 493, quanto ao número no verbo moveo naquelas, ele surgem no singular, neste, no plural. O problema é que, em princípio, qualquer uma das opções é válida, pois no singular o verbo pode estar remetendo ao intelecto agente (nesse caso, o intelecto agente move o intelecto possível) e, no plural, o mesmo verbo pode estar se referindo aos fantasmas ou às 'coisas universais' (res universales), ambos mencionados no plural. Somente uma edição crítica poderia dirimir tal dificuldade, porém, a meu ver, há uma razão doutrinária para justificar a lição plural, a saber, a menção ao fato de que isso que move o intelecto possível o faz "segundo a razão do universal [secundum rationem universalis]". Ora, não vimos em momento algum o próprio intelecto agente ou sua luz ser caracterizada como possuindo uma 'razão universal'. Já os fantasmas, pelo contrário, são constantemente associados a tal expressão. Mesmo que aceitemos a lição manuscrita, porém, resta ainda o problema: o sujeito plural do verbo movent seriam os fantasmas ou as coisas universais?

Em princípio, ambos - fantasmas e coisas universais - poderiam ser descritos como estando 'sob a razão do universal' (embora, sem dúvida, tal expressão tenha 
sido encontrada até agora associada ao fantasma). Em um primeiro momento, deveria ser admitida uma identidade entre 'fantasma universal' e 'coisa universal', uma vez que ambos - junto à espécie expressiva - têm sido descritos como o objeto presente ao intelecto como o conhecido no cognoscente, por meio do qual o intelecto possível passa da potência ao ato de intelecção ${ }^{265}$. Na passagem que ora lemos, porém, Henrique arrisca uma distinção entre os dois, pois afirma que "a luz do agente irradiando sobre os fantasmas como que os separa da matéria e das condições materiais e os propõe ao intelecto possível e, por eles, as coisas universais [supra phantasmata lux agentis radians quasi separat ipsa a materia, et conditionibus materialibus, et proponit ea intellectui possibili, et per ea res universales]". Ou seja, o intelecto agente torna o fantasma inteligível em ato, o propõe enquanto tal ao intelecto possível e, ao propô-lo, propõe por (per) ele a 'coisa universal'. Embora inesperada, tal distinção não é completamente alheia ao que já lemos sobre a relação entre 'coisa universal' e 'fantasma' se nos lembrarmos que este último é, também, caracterizado como species. Ora, como estudamos no cap. 4, a species traz consigo um caráter intencional, de remissão a algo. Assim, ela guarda simultaneamente identidade e distinção para com o objeto - ela afeta a potência cognoscitiva tal como o objeto, mas não é ela própria a conhecida e, sim, este último. Nesse sentido, podemos tomar o fantasma 'sob a razão do universal' como simultaneamente idêntico e distinto com respeito à 'coisa universal' - ele afeta o intelecto possível como o universal o faria, mas não é ele próprio (fantasma) o objeto, sendo antes algo que remete à coisa universal (tal como a espécie sensível remete à coisa sensível). É preciso admitir que, nesse ponto, Henrique de Gand ainda não oferece uma solução para essas diferentes tentativas de relacionar fantasma e coisa universal em sua doutrina da intelecção. Um pouco adiante, retornaremos ao assunto ${ }^{266}$. Em todo caso e retornando, agora, à nossa dúvida de leitura -, se nosso autor afirma que o intelecto agente propõe os fantasmas e, por meio destes (per), as coisas universais ao intelecto possível, parece que o sujeito plural que move o intelecto possível são os fantasmas. Assim, os fantasmas "movem [movent]" para a intelecção em ato do universal e este

\footnotetext{
${ }^{265}$ Cf., acima, nota 257.

${ }^{266}$ Cf., adiante, nota 269. Lembremos que, como lemos no Quodl. 11, q. 8 (cf. cap. 5, nota 107), a espécie na imaginação (nesse caso, não a espécie impressa) possui a mesma força para modificar a imaginativa que a própria coisa conhecida possuiria, se esta pudesse estar presente enquanto existente in re para a imaginativa.
} 
último vem a ser em ato no intelecto "tal como o objeto conhecido no cognoscente [sicut obiectum cognitum in cognoscente]".

Por fim, nessa riquíssima e complexíssima passagem, o Doutor Solene retorna à temática da consubstancialidade que há entre intelecto agente e intelecto possível. $\mathrm{O}$ primeiro é, em suas palavras, uma "luz conatural [lux eius connaturalis]" no último, sem a qual este não poderia ser atualizado, uma vez que não poderia receber o inteligível (lembremos que o intelecto agente não somente faz o inteligível em ato, mas também torna o intelecto possível apto para recebê-lo). Essa necessidade de um intelecto agente por parte do intelecto possível é explicada aqui pelo fato de que, tal como a visão só recebe espécies da cor misturadas ao lume material, também o intelecto possível só recebe as intelecções misturadas à luz do intelecto agente (admixtas luci agentis). Ou seja, da temática da consubstancialidade do intelecto agente e do intelecto possível, passamos àquela da co-agência do intelecto agente na produção da intelecção em ato. Há aqui, porém, três elementos novos na abordagem destas temáticas.

Em primeiro lugar, há uma curiosa descrição das intelecções como "espécies dos fantasmas universais e das próprias coisas universais no intelecto [recipit intellectiones, quae sunt species phantasmatum universalium, et ipsarum rerum universalium in intellectu]". Como disse há pouco, Henrique retornará a seguir à relação entre fantasma universal e coisa universal. Porém, não deixa de ser inesperado ver a intelecção descrita como species do fantasma! Talvez esse uso abrangente do termo 'species' se derive do fato de que o fantasma ou a própria intelecção podem ser entendidos como não sendo, eles próprios, os objetos de conhecimento, mas sim algo que remete aos objetos. Nesse sentido, afirmar que a intelecção seria uma species do fantasma $e$ da coisa universal, exige que tomemos a referência ao fantasma e à coisa universal como uma referência ao objeto de intelecção, de maneira que a operação de intelecção possa ser tomada como uma similitude de tal objeto. Dito isso, não me parece que tal interpretação se imponha claramente na sentença destacada. Por outro lado, ela chama novamente a atenção para a dificuldade que Henrique sente para estabelecer precisamente a relação entre 'coisa universal', 'fantasma universal', 'espécie (expressiva)' e a 'intelecção em ato' como uma operação intelectiva acerca dos três anteriores.

Em segundo lugar, as últimas linhas do trecho indentado mostram mais precisamente - ainda que de maneira sucinta - o que Henrique de Gand entende 
quando afirma que as intelecções ou, como vimos anterioremente, os fantasmas ${ }^{267}$ são recebidos no intelecto possível misturados à luz do intelecto agente. Aqui, ao retomar esse mesmo motivo, ele afirma que as intelecções recebidas no intelecto possível são misturadas à luz do intelecto agente "como que a determinando [quasi ipsam determinantes]", assim como as espécies da cor recebidas pela visão são misturadas ao lume material "como que determinando o próprio lume [quasi lumen ipsum determinantes]". Vemos, portanto, que essa mistura entre intelecção/fantasma e luz do intelecto agente é uma maneira de descrever o fato de que o intelecto agente age com respeito ao universal em geral, porém sua ação é determinada a um único universal pela intelecção/fantasma desse univesal, da mesma maneira como a ação da luz material diz respeito a qualquer cor, sendo determinada a provocar o conhecimento de uma cor específica pela espécie sensível dessa cor.

Isso nos leva ao terceiro e derradeiro elemento presente nas sentenças finais do último trecho indentado. Se o intelecto agente possui uma ação com respeito ao universal em geral - a qual deve, portanto, ser determinada por algo para agir com respeito a um universal preciso -, faz sentido que Henrique de Gand termine o trecho afirmando que o intelecto agente é um hábito universal existente no intelecto possível (universalem habitum in illo existentem). Ora, se tomarmos habitus no sentido geral daquilo que prontifica para uma determinada ação ${ }^{268}$, faz sentido enxergar o intelecto agente como um hábito que o intelecto possível possui para conhecer o universal a partir do particular - desde de que sublinhemos não se tratar neste caso de um acidente, mas antes de algo consubstancial ou conatural ao intelecto possível. Assim, em poucas palavras, o intelecto agente surge aqui como uma capacidade do intelecto para, em geral, conhecer o universal (mais precisamente, para produzir o inteligível em ato $e$ a intelecção em ato do universal), devendo ser tal capacidade geral determinada a agir com respeito a um único universal pela presença do próprio objeto no fantasma.

Dito isso, apesar da complexidade e detalhamento do excerto estudado, fica patente que restam problemas a serem compreendidos. Isso é particularmente válido para a relação entre 'fantasma universal' e 'coisa universal'. Assim sendo, Henrique de Gand retorna a esse tema sob dois aspectos distintos: [i] primeiro, explicando

\footnotetext{
${ }^{267}$ Cf. nota 260, acima.

${ }^{268}$ Cf. nota 129 , acima.
} 
melhor a distinção entre ambos; [ii] em seguida, acrescentando mais elementos (agora, sem se valer do caso dos fosforescentes) à discussão acerca da identidade real entre fantasma particular e fantasma universal. Para abordar esses dois temas, nosso autor novamente aproxima conhecimento sensitivo e intelectivo, introduzindo aqueles dois problemas como diferenças entre sensação e intelecção ${ }^{269}$. Com efeito, já vimos Henrique de Gand utilizar esse modo de apresentação do conhecimento intelectivo em Quodl. 5, q. $14^{270}$ - aqui, porém, os aspectos da inteleção que estão em jogo são outros.

Para melhor compreendermos a distinção entre 'coisa universal' e 'fantasma universal', o Doutor Solene introduz a consideração do fantasma como algo interno em oposição às cores sensíveis, que são externas à alma que as conhece:

\begin{abstract}
"Primeiro, que ali $<s c$. visão $>$ as cores particulares são existentes fora nas coisas - a luz material opera acerca delas, abstraindo delas suas espécies sem matéria para modificar a visão com o ato da visão; elas são os objetos nos quais termina o ato de visão. Já aqui os fantasmas particulares são existentes na fantasia acerca deles opera a luz do agente, separando-os das condições particulares e removendo-as [sequestrando illas] deles; isso é abstrair deles as espécies, que são os fantasmas universais [phantasmata universalia]. Digo, 'espécies' e 'similitudes' não tanto dos próprios fantasmas particulares, que são espécies das coisas particulares fora, mas das coisas universais daquelas coisas particulares [rerum universalium illarum rerum particularium]. De fato, os próprios fantasmas particulares, acerca dos quais assim opera a luz do agente modificando o intelecto possível para o ato de intelecção, não são os objetos nos quais termina o ato de inteleção, mas sim os próprio universais das coisas particulares existentes fora, cujas espécies e similitudes são os fantasmas particulares, tal como os fantasmas universais são espécies dos universais daquelas coisas particulares" ${ }^{271}$.
\end{abstract}

\footnotetext{
${ }^{269}$ Henrique de Gand, Suma, art. 58, q. 2, ad 3 (ed. 1642-6, p. 1007a, n. 40): "Est igitur hic tria considerare circa visum, scilicet lucem materialem, colorem sensibilem, visionem in visu, et tria correspondentia circa possibilem intellectum scilicet lucem agentis, phantasma, intellectionem. Et est agens sicut lux materialis, phantasma sicut color sensibilis, intellectio sicut visio. Et sicut lux materialis facit, quod colores materiales specie sua sine materia immutant visum ad actum visionis, quae terminatur ad colorem, ut ad rem visam, consimiliter lux agentis facit, quod phantasmata particularia sub ratione speciei universalis absque conditionibus materialibus immutant intellectum ad actum intellectionis [ed. 1520, f. 130rF | intentionis ed. 1642-6], quae terminatur ad rem universalem, ut ad ipsum quod intelligitur. Et non est differentia nisi in duobus".

${ }^{270}$ Cf. nota 245 , acima.

${ }^{271}$ Henrique de Gand, Suma, art. 58, q. 2, ad 3 (ed. 1642-6, p. 1007a, n. 41): "Primo in hoc, quod ibi colores particulares sunt extra existentes in rebus, circa quos operatur lux materialis ab eis abstrahendo species eorum sine materia ad immutandum visum actu visionis, quae sunt obiecta ad quae terminatur actus visionis. Hic vero phantasmata particularia sunt existentia in phantasia, circa quae operatur lux agentis, separando ea a conditionibus particularibus, et sequestrando illas ab eis, quod est abstrahere ab eis species, quae sunt phantasmata universalia. Species, et similitudines dico non tam ipsorum phantasmatum particularium, quae sunt species rerum particularium extra quam rerum universalium illarum rerum particularium. Ipsa enim phantasmata particularia circa quae operatur lux agentis sic ad immutandum intellectum possibilem actu intellectionis, non sunt obiecta ad quae terminatur actus
} 
Já vimos, em Quodl. 5, q. 14, aquilo sobre o que age o intelecto agente ser descrito como o "objeto particular imaginado dentro [obiectum particulare imaginatum intra $]^{, 272}$. Essa interioridade daquilo para que se volta o intelecto agente é retomada nessa passagem, em oposição à exterioridade da cor conhecida pelo sentido da visão. O paralelo, porém, não é perfeito, pois enquanto a cor é o próprio objeto da visão, o fantasma particular existente na fantasia não é o objeto de conhecimento intelectual. Com efeito, nem mesmo o fantasma universal - isto é, o fantasma particular espoliado das condições materiais e particulares - é propriamente objeto de conhecimento intelectual. Pelo contrário, aqui o fantasma universal é claramente descrito como 'espécie' ou 'similitude' da coisa conhecida. Mas, o que seriam precisamente essas coisas conhecidas? Nas palavras de Henrique, ela são 'as coisas universais das coisas particulares', de maneira que os fantasmas universais terminam por ser “'espécies' e 'similitudes' <..> das coisas universais daquelas coisas particulares [Species, et similitudines $<\ldots>$ rerum universalium illarum rerum particularium]". Note-se, portanto, a distinção estabelecida entre fantasma particular e fantasma universal: o primeiro é espécie da coisa particular fora, enquanto o segundo é espécie da coisa universal da coisa particular. Ou seja, o que há fora é somente a coisa particular; a coisa universal é algo da coisa particular - um universal da coisa particular existente fora (universalia rerum particularium extra existentium) -, no qual termina o ato de intelecção. Esse algo universal é dado a conhecer no momento em que, pela luz do intelecto agente, retiram-se as condições materiais e particulares do fantasma particular, colocando o fantasma universal em presença do intelecto possível. Destarte, vemos que fantasma universal e coisa universal diferem tal como, respectivamente, uma espécie e a coisa de que ela é espécie ${ }^{273}$.

intellectionis, sed potius ipsa universalia rerum particularium extra existentium, quarum species, et similitudines sunt phantasmata particularia, sicut universalium illarum rerum particularium species sunt phantasmata universalia". Cf. SPRUIT, Species intelligibilis I, 1994, p. 210. Maurice de Wulf (Études sur Henri de Gand, 1894, p. 87) chama a atenção para a expressão "sequestratio conditionum particularium" utilizada por Henrique de Gand em Quodl. 14, q. 6 (cf., adiante, nota 277), mas também neste trecho de Suma, art. 58, q. 2: "et sequestrando illas".

${ }^{272}$ Cf., acima, nota 239.

${ }^{273}$ Michael Rombeiro, por exemplo, identifica claramente 'fantasma universal' e 'espécie expressa': "Thus the operation of the agent intellect produces a universal phantasm, which exists only in the imagination <... $>$. So the universal phantasm is itself an expressive species, which is present to the intellect, moves it, and informs it according to the mode of an expressive species, that is, as in $a$ knower" - "Intelligible Species in the Meature Thought...", 2011, p. 205 (grifo no original). Cf. tb. GOEHRING, Henry of Ghent on Cogntion..., 2006, pp. 151-2. Há que se notar, porém, que essa 
Lemos em Quodl. 5, q. 14, porém, que não se deve concluir daí a ocorrência de espécies impressas - isto é, como acidentes - no intelecto, pois disso se seguiria que a espécie estaria presente ao intelecto antes do próprio objeto, o que é um absurdo, pois somente este último poderia ser causa daquela primeira. Ou seja, embora se admita que o fantasma universal remete à coisa universal da coisa particular, não se pode compreender daí que haja realmente no intelecto um fantasma universal que apresente um objeto universal realmente distinto do particular. Disso se seguiria que o universal deveria ter estado presente ao intelecto antes do fantasma universal. Porém, isso não ocorre, porque antes da abstração do fantasma universal só há o conhecimento sensível do particular. Como escapar a este imbróglio?

O Doutor Solene busca fazê-lo, justamente, por negar [i] uma distinção real entre fantasma particular e fantasma universal, bem como [ii] uma distinção real entre coisa particular e coisa universal. Com efeito, essa é a segunda diferença destacada em Suma, art. 58, q. 2, entre conhecimento sensível e conhecimento intelectivo: ali a cor e a espécie da cor são realmente distintos, aqui o fantasma particular e o fantasma universal (tal como a coisa particular e a coisa universal) são realmente idênticos:

"Em segundo lugar, porém, há uma diferença em que lá $<s c$. na visão $>$ uma na coisa [aliud re] é a cor e outra a espécie da cor e em que a própria espécie da cor é abstraída da cor por como que um separação real e geração, ou seja, uma multiplicação dela em todo meio que há entre a coisa vista e aquilo do olho no qual vige a força visiva da alma $<\ldots .>$. Mas, aqui $<s c$. no intelecto $>$ não é um na

descrição do 'fantasma universal' como espécie da 'coisa universal' não impede Henrique de afirmar (ao resumir o processo de conhecimento desde a sensação até intelecção) que o fantasma universal é o objeto próprio de conhecimento do intelecto possível, ainda que somente remeta este último à coisa universal: "Est igitur processus in actu visionis talis. Primo lux materialis super colorem particularem materialem existentem extra irradiat. Secundo coloris speciem abstrahendo sine materia in medium agit, et ipsum informat illa specie. Tertio medium specie illa actum visionis elicit. Et similiter in phantasia actum phantasiandi, qui terminatur quasi quodam circulo in colorem praedictum, licet differunt, quoniam visio non terminatur ad illum, nisi cum praesens fuerit sensui, phantasiatio vero terminatur ad illum ad absentiam eius a sensu. Quarto vero supra phantasma particulare quo sic phantasia existit in actu, irradiat lumen intellectus agentis. Et praedicto modo phantasma universale a particulari abstrahit, et intellectui possibili proponit, ut obiectum proprium illius immutativum, per quod actu immutatur intellectione, sive actu intelligendi ad cognitionem non sui, sed rei universalis, cuius est species, licet non ab illa abstrahitur, sed a phantasmate particulari abstracto a re extra particulari, in qua potentia existit universale, sicut neque species coloris immutat visum ad cognitionem sui, sed coloris a quo abstrahitur" - Suma, art. 58, q. 2, ad 3 (ed. 1642-6, p. 1007b-8a, n. 43), grifo meu. Essa passagem parece sugerir que a doutrina da intelecção de Henrique de Gand - tal como apresentada em Suma, art. 58 (e, parece-me, também em Quodl. 5, q. 14) - guarda uma relevante incerteza de fundo quanto à relação entre 'fantasma universal' e 'coisa universal'. Embora ele se volte para esse tema em diversas passagens de Suma, art. 58, tal problema parece persistir no trecho apresentado neste nota, quando o fantasma universal surge apresentado como objeto motivo da intelecção. Pois, com efeito, como pode o meio para o conhecimento (lembremos, aqui o fantasma universal é descrito como species da coisa universal) ser tomado como o próprio objeto que move a intelecção ao ato? 
coisa [aliud re] o fantasma particular e outro a espécie, que é o fantasma universal, tal como tampouco a coisa universal é outra que não a coisa particular, nem a própria espécie, que é o fantasma universal, é abstraído do fantasma particular pelo modo de uma separação real, geração ou multiplicação até o intelecto, como se informasse este para elicitar no intelecto o ato de intelecção, mas somente por uma separação virtual das condições materiais e particulares e $<$ por> retirada [sequestrationem] delas a ele, pela qual, a saber, possui a virtude de modificar o intelecto, não segundo condições particulares, para inteligir primeiro e principalmente a própria coisa particular (como dizem alguns), o que é impossível, mas segundo a razão do fantasma simplesmente e como que abstraído e separado da matéria e das condições particulares da matéria e, isso, para elicitar no intelecto um ato de intelecção inerente ao próprio intelecto e que o informe sem qualquer outra espécie da coisa universal inteligida que inira nele para inteligir a coisa universal" 274 .

No caso da sensação, a abstração, geração, separação ou multiplicação da espécie sensível da cor com respeito à própria cor é real (realis), sendo a espécie da cor e a própria cor diversas realmente (aliud re). Porém, a separação do fantasma universal a partir do fantasma particular não pode ser considerada real - como Henrique lembra ao fim da passagem citada, tal separação não pode resultar na impressão de uma espécie que inira no intelecto como em um sujeito. Com efeito, lembremos do que líamos em Quodl. 5, q. 14: a impressão real de uma espécie no intelecto inviabilizaria o conhecimento do universal por diversas razões. Além disso, uma separação real entre os fantasmas negaria, como parece claro, a identidade real entre fantasma particular e fantasma universal afirmada por Henrique de Gand a partir da referência às coisas fosforescentes, que lemos há pouco. Mas, se não é real, de que tipo seria tal separação?

Nas palavras de nosso autor, a abstração do fantasma universal a partir do fantasma particular é uma "separação virtual das condições materiais e particulares $<\ldots>$, pela qual, a saber, possui a virtude de modificar o intelecto [separationem

\footnotetext{
${ }^{274}$ Henrique de Gand, Suma, art. 58, q. 2, ad 3 (ed. 1642-6, p. 1007a-b, n. 42): "Secundo autem in hoc est differentia, quod ibi aliud est re color, et species coloris, et quod ipsa species coloris abstrahitur a colore per quasi quandam separationem realem, et generationem, sive multiplicationem ipsius in totum medium, quod est inter rem visam, et id oculi in quo viget vis animae visiva $<\ldots>$. Hic vero $<s c$. no intelecto $>$ non est aliud re phantasma particulare, et species, quae est phantasma universale, sicut nec res universalis est alia a re particulari, nec ipsa species, quae est phantasma universale, abstrahitur a phantasmate particulari per modum separationis realis, aut generationis, aut multiplicationis in intellectum, ut quem informat ad eliciendum in intellectu actum intellectionis, sed solum per quandam separationem virtualem conditionum materialium, et particularium, et illarum sequestrationem ab ipso, qua scilicet habet virtutem immutandi intellectum, non secundum conditiones particulares ad intelligendum primo, et principaliter ipsam particularem rem (ut aliqui dicunt) quod est impossibile, sed secundum rationem phantasmatis simpliciter et quasi abstrati, et separati a materia, et conditionibus particularibus materiae, et hoc ad eliciendum in intellectu actum intellectionis inhaerentem ipsi intellectui, et informantem ipsum absque omni alia specie rei universalis intellectae illi inhaerente ad intelligendum rem universalem". TACHAU, Vision and Certitude..., 1988, p. 33.
} 
virtualem conditionum materialium, et particularium, $<\ldots>$ qua scilicet habet virtutem immutandi intellectum]". Note-se o importante jogo de palavras que surge nessa passagem: pela separação virtual (virtualis) o fantasma adquire a virtude (virtus) de modificar o intelecto - em especial, como sabemos, o intelecto possível. Ou seja, o intelecto agente não cria algo real a partir do fantasma particular, mas somente dá a este último a força ou capacidade (virtus) de mover o intelecto para a intelecção. Como ele faz? Do modo que já vimos ser descrito diversas vezes: pela retirada das condições materiais e particulares que ainda caracterizam o fantasma particular. Com tais condições, repito, tal fantasma particular é inteligível somente em potência; porém, sendo elas retiradas pelo intelecto agente, há o fantasma universal inteligível em ato, isto é, o fantasma enquanto possui a virtus de mover o intelecto possível para a intelecção.

Como também já foi estabelecido, no entanto, tal intelecção não é acerca do fantasma universal, mas diz respeito antes à coisa universal de que tal fantasma é espécie. Porém, perguntávamos: se a espécie não pode anteceder a coisa, como é possível que a coisa universal só possa aparecer ao intelecto pelo fantasma universal? Em Quodl. 5, q. 14 - como, igualmente, em certos trechos de Suma, art. 58, q. 2 -, há uma certa tendência a afirmar uma identidade entre fantasma universal e objeto ou coisa universal. Entretanto, em Suma, art. 58, q. 2, são claras as tentativas de distinguir fantasma universal e coisa universal, sendo o primeiro descrito como espécie desta última. Ou seja, como já mencionado, parece ser retomada aqui a temática da intencionalidade da espécie - isto é, da compreensão da species como algo que remete a outro do qual depende causalmente. A situação agora, porém, é mais complexa, pois, enquanto no caso da sensação espécie e coisa podem ser tomadas como entes reais, que mantém uma relação constante de dependência causal (a saber, da espécie como permanentemente dependente da coisa de que é intenção), na intelecção o fantasma universal não é algo real, tal como tampouco a coisa universal. Por isso mesmo, parece mais difícil nesse caso descrever uma relação de intencionalidade semelhante àquela da sensação, pois nenhum dos termos da relação o fantasma universal como species e a coisa universal como causa daquele - é real.

Nesse caso, parece-me, a opção mais óbvia seria estabelecer uma identidade entre fantasma universal e coisa universal. O Doutor Solene, porém, como visto, reluta em defender veementemente tal posição. Tal relutância, a meu ver, provém do fato de que, para Henrique de Gand, o conhecimento intelectual, não obstante 
universal, deve dizer respeito ainda assim à coisa fora da alma - notemos o que era dita há pouco: a intelecção, por meio do fantasma, é o conhecimento da coisa universal da coisa particular. Ou seja, o universal conhecido é algo do particular. Mais do que isso, nos diz o mestre de Gand na última passagem indentada, a coisa universal não é distinta realmente da coisa particular (nec res universalis est alia a re particulari). Ora, nesse caso, se coisa particular e coisa universal são uma mesma coisa, pode-se dizer que a coisa está sim presente ao intelecto antes que seja produzido nele o fantasma universal. Acontece que, pelo fantasma particular, a coisa é conhecida como coisa particular pela imaginação, ao passo que, pelo fantasma universal, a mesma coisa é conhecida como coisa universal pelo intelecto. Em outras palavras, a ação do intelecto agente simplesmente dá ao fantasma - antes, particular a virtus de mover o intelecto para conhecer enquanto universal algo que, fora da alma, existe como particular. Nesse sentido, é possível tanto identificar a coisa universal ao fantasma universal como dele distingui-la: eles são idênticos enquanto a coisa universal não é senão algo representado sob a razão do universal pelo fantasma; distinguem-se, porém, porque a coisa representada sob a razão do universal não é, senão, a própria coisa particular existente fora da alma.

Por outro lado, é preciso corretamente descrever a identidade que há entre a coisa universal e a coisa particular, pois caso estreitemos demasiadamente tal identidade a presença da coisa universal seria o mesmo que a presença da coisa particular. Daí, só poderia haver conhecimento do universal se houvesse, igualmente, o conhecimento da coisa particular presente. O que impede essa completa identificação entre a presença da coisa singular fora e a presença da coisa universal é, precisamente, o conhecimento imaginativo. Este, como estudamos pausadamente no item 5.4, é um conhecimento do particular (como os sentidos particulares e ao contrário do intelecto) enquanto ausente fora da alma (ao contrário dos sentidos particulares e como o intelecto). É justamente por poder tornar presente seu objeto no fantasma que a imaginação pode conhecê-lo mesmo quando ausente fora da alma e, mais importante para nós nesse momento, apresentá-lo ao intelecto sob a luz do intelecto agente, mesmo que na ausência da coisa particular fora.

Destarte, a intelecção em ato do universal - ou, melhor, a presença em ato da coisa universal ao intelecto - não exige a presença em ato da mesma coisa, enquanto particular, fora da alma. Assim, uma vez que uma coisa particular tenha existido e estado presente aos sentidos particulares de maneira a, pelo processo de conhecimento 
sensitivo, produzir um fantasma particular na fantasia, esta última poderá conhecer tal coisa enquanto particular na ausência ou, mesmo, inexistência dessa coisa fora da alma. Da mesma maneira, o intelecto poderá conhecer enquanto universal tal coisa particular, mesmo que esta não mais esteja presente ou exista ${ }^{275}$. Em poucas palavras, da identidade entre coisa particular e coisa universal não se deve concluir uma necessária contiguidade sincrônica entre ambas - pelo contrário, a presença da coisa universal não diz respeito, senão em sua origem causal distante, à presença da mesma coisa enquanto particular fora; e, no entanto, Henrique afirma uma identidade entre coisa particular e coisa universal. Isso, parece-me, permanece como uma das tensões pouco exploradas de sua doutrina da intelecção.

Pois bem, uma vez que o intelecto possível tenha sido movido pelo fantasma universal de maneira a conhecer, por este último, a coisa universal da coisa particular, há uma inteligência simples ou do incomplexo:

\begin{abstract}
"Agora, tal intelecto da coisa universal sob a razão de incomplexo é chamado intelecto da inteligência simples. E é patente pelo já dito de que modo o intelecto agente é ativo em tal modo de inteligir e o intelecto possível é passivo, pois, como diz o Comentador no cap. sobre o agente $<$ Averroes, Comment. magnum in Arist. De anima III, comment. 18 (ed. Crawford, p. 439)>, são dois pela diversidade de suas ações. De fato, a ação do intelecto agente é gerar, enquanto a deste $<s c$. do intelecto possível $>$ é ser informado - e como isso ocorre, é patente pelo que já foi dito. Essa ação é puramente do agente natural e essa paixão é puramente do possível natural, tal que, uma vez informado por ela, será ulteriormente ativo - tanto no que diz respeito à inteligência dos simples, como no que diz respeito à inteligência dos complexos" 276 .
\end{abstract}

\footnotetext{
${ }^{275}$ Henrique de Gand, Suma, art. 58, q. 2, ad 3 (ed. 1642-6, p. 1008a, n. 43): "Et sic intellectus possibilis intelligit primo, et per se ipsam rem universalem abstractam a singularibus, non primo intelligendo singulare unum vel plura, et deinde intelligendo ex ipsis per abstractionem universale, ut commune quid super singularia, hoc enim est impossibile, quia impossibile est intellectionem singularium praecedere intellectionem universalium. Unde intellectus agens in abstrahendo phantasma universale a particulari, abstraheret universale quod est in intellectu, ut cognitum in cognoscente, etiam si nullum haberet singulare existens extra in re, dum tamen esset phantasma alicuius particularis eius quod aliquando fuit sensatum in ipsa fantasia. Quod si omnino deficeret, et similiter deficeret abstractio phantasmatis universalis ab illo, et per consequens universalis intellectus omnino, sicut deficiente sensu aliquo, omnino necesse est deficere scientiam quae est secundum illum sensum, ut vult Philosophus".

${ }^{276}$ Henrique de Gand, Suma, art. 58, q. 2, ad 3 (ed. 1642-6, p. 1008a, n. 44): “Talis autem intellectus rei universalis sub ratione incomplexi vocatur intellectus simplicis intelligentiae. Et patet ex iam dictis quomodo intellectus agens activus est in tali modo intelligendi, et intellectus possibilis passivus, quoniam, ut dicit Commentator super caput de agente <Averroes, Comment. magnum in Arist. De anima III, comment. 18 (ed. Crawford, p. 439)>, sunt duo per diversitatem actionis eorum. Actio enim intellectus agentis est generare, istius autem informari, et quomodo hoc, patet ex dictis. Et est ista actio pure naturalis agentis, et ista passio pure naturalis possibilis, qua postquam informatus fuerit, ulterius est activus, et quo ad simplicium intelligentiam, et quo ad intelligentiam complexionum". Cf. MARRONE, Truth and Scientific Knowledge..., 1985, pp. 83-8.
} 
Como já havíamos antecipado em diversos momentos, Henrique de Gand distingue atividade e passividade na intelecção do conceito simples, isto é, na inteligência do simples. Porém, como estabelecido nos capítulos 2 e 3, o principal aqui é a passividade - se o intelecto possível possui a luz conatural do intelecto agente, esta última só age para possibilitar a recepção passiva da intelecção. O intelecto agente gera aquilo que informará o intelecto possível, mas a produção da intelecção é estritamente essa recepção passiva do objeto na luz do intelecto agente. Esse é, com efeito, o modo natural de produção da intelecção em ato - há um agente que 'age' o objeto e um possível ou paciente que 'padece' tal objeto. E, no entanto, o fruto desse padecer não nada mais do que um momento inicial do conhecimento intelectual. De fato, a intelecção que surge ao cabo de todo esse processo de conhecimento que viemos estudando detalhadamente nesta segunda parte é ainda nas palavras que lemos em Quodl. 14, q. 6 - uma "primeira intelecção confusa, o mais simples [primam intellectionem confusam simplicissimam]"277. Como nos lembra Jerome V. Brown, o "universal abstraído, embora imaterial e fonte inicial de nosso conhecimento da quididade ou essência de uma coisa, permanece, enquanto objeto de simplex intelligentia, confuso e indistinto demais para servir como a ratio definitiva daquilo que buscamos saber"278. Por isso mesmo, uma vez que haja tal intelecção simples em ato, justamente por ser ela confusa e inicial, a vontade move o intelecto em busca de um conhecimento mais perfeito, como vimos no cap. $3^{279}$. A partir desse momento, o intelecto não é mais apenas passivo, mas age com respeito ao conhecimento que possui: "uma vez informado" pela ação que produz a intelecção simples, o intelecto "será ulteriormente ativo - tanto no que diz respeito à inteligência dos simples, como no que diz respeito à inteligência dos complexos [postquam

\footnotetext{
${ }^{277}$ Henrique de Gand, Quodl. 14, q. 6, co. (ed. 1613, f. 350rb): "Et dico, quod loquendo de primo actu intelligendi nequaquam esse quidditativum est ab intellectu possibili per eius actum, aut etiam universale intellectus quod est eius proprium obiectum immo e converso ipse intellectus possibilis quo ad talem actum habet esse ab ipso universali quod formatum est in phantasia per sequestrationem conditionum particularium lumine intellectus agentis, secundm modum pluries a me expositum.

$\mathrm{Ab}$ universali enim sic existente in phantasmate primo immutatur intellectus, et determinatur ad primam intellectionem confusam simplicissimam" (grifo meu). Cf. BRAUN, Die Erkenntnislehre Heinrichs von Gent, 1916, pp. 34-6. Sobre o caráter confuso do conhecimento simples, cf. tb. nota 280.

${ }^{278}$ BROWN, J. V. "Abstraction and the Object of the Human Intellect...", 1973, p. 90: "Such an abstracted universal, though immaterial and the initial source of our knowledge of the quiddity or essence of a thing, remains, as the object of simplex intelligentia, too confused and indistinct to serve as the definitive ratio of what we are seeking to know". Cf. tb. BROWN, J. V. "Intellect and Knowing...”, 1975, pp. 696-7; FRIEDMAN, In principio erat verbum..., 1997, pp. 141-2; FRIEDMAN, Intellectual Traditions at the Medieval University..., 2013, pp. 264-6.

${ }^{279}$ Cf. tb. nota 202 e 206 , acima.
} 
informatus fuerit, ulterius est activus, et quo ad simplicium intelligentiam, et quo ad intelligentiam complexionum]". Essa ação do intelecto é uma conversão dele sobre si mesmo - isto é, sobre o ato de intelecção simples pelo qual intelige confusamente seu objeto. Dessa conversa resultará, em última instância, o conhecimento perfeito e final $^{280}$ - na terminologia de Quodl. 4, não mais o verbo de um conhecimento imperfeito, mas um verbo perfeito e final.

Como já repetido diversas vezes, porém, não será meu objetivo aqui estabelecer precisamente como ocorre, segundo Henrique de Gand, a passagem do conhecimento simples, incomplexo ou confuso para o conhecimento complexo ou perfeito. Esse seria o tema para um trabalho ulterior, que tomaria este presente trabalho como ponto de partida. Interessa-me, no entanto, um último aspecto que, na doutrina da intelecção do Doutor Solene, ainda possui relação com a produção da intelecção simples. Com efeito, já estabelecemos que só há intelecção em ato na vida presente (isto é, quando a alma está conjugada ao corpo) quando há, igualmente, um ato da fantasia. Isto é, só se intelige como universal aquilo que simultaneamente se imagina como particular, pois, como dito em Quodl. 5, q. 14, algo só é presente como universal ao intelecto quando é presente à fantasia como particular ${ }^{281}$. Cabe perguntar, entretanto: ainda que todo ato de intelecção pressuponha um ato de imaginação, resta algo dessa intelecção no próprio intelecto?

Mais acima, quando estudávamos o conhecimento do beato, no item 6.3.2, lemos algo sobre o tema. Lá, vimos Henrique, em Quodl. 6, q. 8, "ser preciso propor que algo permanece na alma a partir do ato de inteligir desde os fantasmas, seja isso dito um hábito ou uma espécie [Oportet igitur ponere quod remaneat aliquid in anima ex actu intelligendi a phantasmatibus, sive illud dicatur habitus sive species]"282.

\footnotetext{
${ }^{280}$ Henrique de Gand, Suma, art. 58, q. 2, ad 3 (ed. 1642-6, p. 1008a-b, n. 45): "Quo ad simplicium intelligentiam, quia propter separationem suam a materia cum est informatus simplici intelligentia, statim convertit seipsum super se, et super actum intelligendi, et super obiectum intellectum, ut ipsum informet notitia declarativa, quae dicitur verbum. Et est ista conversio prima actio sua, sed quia ab eo ad quod convertitur non statim informatur notitia declarativa, ulterius agit in negotiando circa intelligibilia intellecta simplici notitia, ut intellecta fiant notitia declarativa. Licet enim agat in nobis intellectus agens circa intelligibilia intelligenda confuse in phantasmatibus secundum praedictum modum, non tamen solus agit circa intelligibilia intelligenda distincte in intellectibus confusis. Cum enim intellectus possibilis informatus fuerit simplici notitia confusa eius, cuius est quod quid est, puta hominis, aut equi albi, aut nigri, voluntas delectata in cognito, sed imperfecte, sicut imperfecte est cognitum flagrat per intellectum nosse quod restat, ut perfecte cognitum perfecte delectet $<\ldots>$... FRIEDMAN, Intellectual Traditions at the Medieval University..., 2013, pp. 268-71.

${ }^{281} \mathrm{Cf}$., acima, nota 245.

${ }^{282}$ Cf. nota 127 , acima.
} 
Assim, seja isso um hábito ou uma espécie, é necessário propor que algo permance na alma após o ato de inteleção. Entretanto, isso que permanece na alma após a intelecção não exime o intelecto de necessariamente buscar seu objeto na imaginação. Pelo contrário, ainda que utilize um hábito (ou uma espécie) que tenha restado de uma primeira intelecção acerca de um objeto, o intelecto em vias de inteligi-lo novamente deverá igualmente se voltar para o fantasma na imaginação em busca de tal objeto, pois o homem se utiliza desse habitus ou species somente "inclinando-se para o ato

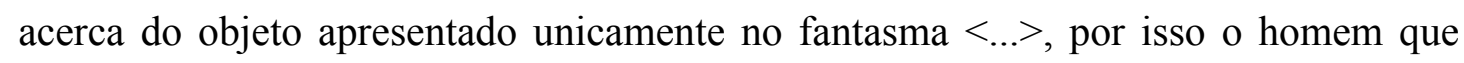
possui em si a espécie da coisa ou hábito na alma não inteligirá sem que apareça o inteligível no fantasma $[<\ldots>$ homo autem totus non potest uti habitu suo, praesentando sibi obiectum sed ipso inclinando solum in actum circa obiectum praesentatum nisi in phantasmate $\langle\ldots>$, sic homo habens in se speciem rei sive habitum in anima non intelliget nisi appareat intelligibile in phantasmate <..> ]"283. Ou seja, há sim algo que permanece na alma depois da primeira intelecção de um objeto, inclinando o intelecto a inteligi-lo novamente - sempre, porém, voltando-se para o fantasma desse objeto na imaginação. Mas, seria isso que resta da intelecção um hábito ou uma espécie? E, mais, onde esse hábito ou espécie permanece após a intelecção?

As respostas para tais perguntas podem ser lidas em um interessante trecho de Quodl. 11, q. 7, no qual Henrique de Gand se volta precisamente para elas:

"Para nós, porém, parece que aquilo inerente pelo que se apresentaria o objeto
seria o hábito que, igualmente, é impresso pelo objeto, tal como a espécie e o
ato. De fato, quanto a isto $<s c$. quanto a ser impresso pelo objeto $>$, é a mesma a
razão da espécie, do hábito e do ato. Mas, uma vez que o ato não é permanente
[manens], por isso não se pode a ele atribuir a apresentação. Porém, pode-se
atribuí<-la $>$ igualmente aos outros dois, pois são formados pelo mesmo em nós,
a saber, pelo objeto inteligível e retêm a virtude de apresentá-lo, tal como ele
próprio é nato a apresentar a si mesmo. Mas, isso não deve ser entendido de
maneira <que haja $>$, antes do primeiro ato de inteligir, algo inerindo em nosso
intelecto, proposto como um inteligível para o intelecto, e $<$ este $>$ seja por aquele
movido para o ato de inteligir, do modo como é apresentado pela fantasia no
primeiro ato de inteligir, mas $<$ deve ser entendido $>$ de maneira que aquilo que
foi impresso no intelecto pelo primeiro ato de inteligir, o qual é elicitado
somente pelo objeto que retém sua virtude, incline o intelecto para um
determinado ato de inteligir terminado num certo objeto e apresente o objeto.
Este último que inclina é o próprio hábito e só ele possui em si a força de
apresentar todos os objetos pelos quais foi impresso. De fato, daí tem a força

${ }^{283}$ Cf. nota 130 , acima. 
deles, mas a espécie não possuiria outra força e é supérfluo propor que algo se faz por dois quando se pode fazer por um $<\ldots>$.. 284 .

Nosso autor começa tal passagem admitindo que [i] espécies, [ii] hábitos ou [iii] atos podem inerir em algo ao serem impressos por um objeto. O que causa espanto nessa afirmação é seu contexto: discute-se aqui justamente o conhecimento intelectual! Ora, vimos pausadamente em Quodl. 5, q. 14, que não há espécies inerentes ao intelecto antes do ato de intelecção. Pois bem, essa é justamente a chave para compreender a presente passagem: não se admite aqui que haja algo inerente ao intelecto antes do ato de intelecção, mas sim que há uma impressão do objeto que inere no intelecto após tal ato. Como se dizia, em princípio, isso que inere dessa maneira poderia ser [i] uma espécie, [ii] um hábito ou [iii] um ato. Este último não vem ao caso, uma vez que não é algo permanente (manens) no intelecto, apresentando a este último o objeto de intelecção (lembremos, com efeito, que o intelecto criado discorre de um ato de intelecção acerca de um objeto a outro ato acerca de outro, de maneira que o próprio ato de intelecção não pode ser tomado como algo permanente no intelecto criado). Assim, resta que haja como inerente ao intelecto [i] uma espécie ou [ii] um hábito nele impresso pelo objeto. Já sabemos - e, nesta última passagem, se reitera - que não há qualquer espécie ou hábito inerente ao intelecto anterior ao ato de intelecção ${ }^{285}$. Resta, portanto, que, se for admitido algo de inerente ao intelecto, isso deverá ser posterior a tal ato.

\footnotetext{
${ }^{284}$ Henrique de Gand, Quodl. 11, q. 7, co. (ed. 1613, f. 204rb-va): "Nobis autem videtur, quod inhaerens per quod praesentetur obiectum sit habitus, qui aequaliter imprimitur ab obiecto sicut et species et actus. Eadem enim quo ad hoc est ratio speciei, habitus et actus. Sed quia actus non est manens, ideo ei non potest attribui praesentatio: aliis autem duobus aequaliter attribui potest, quia ab eodem in nobis scilicet ab obiecto intelligibili formantur, et virtutem eius retinent ad ipsum praesentandum, quemadmodum idem natum est praesentare seipsum. Sed hoc non sic intelligendum, ut ante primum actum intelligendi aliquid inhaerens intellectui nostro proponatur ut intelligibile intellectui, et illo moveatur in actum intelligendi, quemadmodum praesentatur per phantasiam in primo actu intelligendi, sed ut id quod impressum est intellectui per primum actum intelligendi, quem elicit solum obiectum virtutem eius retinens, inclinet intellectum ad determinatum actum intelligendi terminatum ad certum obiectum, et praesentet obiectum, quod quidam inclinans proximum est ipse habitus, et habet in se vim praesentativam solus omnium obiectorum a quibus impressus est. Ex hoc enim tenet vim illorum, nec aliam vim haberet species et superfluum est ponere aliquid fieri per duo cum potest fieri per unum, quia cum secundum omnes necesse est ponere habitus ad inclinandum, et non nisi inclinando potest quodcunque sit illud praesentare, superfluum ergo est ponere species in intellectu ad praesentadum obiecta alias ab habitu". Cf. NYS, De werking van het menselijk..., 1949, pp. 91-4.

${ }^{285}$ Por outro lado, vimos em Quodl. 4, q. 8, que a notícia na memória, anterior ao ato de intelecção, pode ser tomada como uma notitia habitualis (cf. nota 203, acima). Isso, porém, não vem ao caso aqui nesse trecho de Quodl. 11, q. 7, por duas razões: [i] uma vez que agora se considera a ocorrência de espécie ou hábito posterior ao ato de intelecção; e [ii] porque a notícia habitual na memória anterior ao ato de intelecção era tomada como o conhecido no cognoscente, a espécie expressa, e não como um
} 
Essa é precisamente a tese defendida por Henrique de Gand nesse trecho: algo é "impresso no intelecto pelo primeiro ato de inteligir, o qual é elicitado somente pelo objeto [impressum est intellectui per primum actum intelligendi, quem elicit solum obiectum]". Isso que é impresso no intelecto após o ato de intelecção permanece na potência intelectiva tal que "incline o intelecto para um determinado ato de inteligir terminado num certo objeto e apresente o objeto [inclinet intellectum ad determinatum actum intelligendi terminatum ad certum obiectum, et praesentet obiectum]", isto é, aquele objeto que causara a primeira intelecção acerca de si mesmo. Ora, isso que inclina para uma ação após um ato, nos diz Henrique, é um hábito ${ }^{286}$ que permanece impresso no intelecto após o ato de intelecção. Mais precisamente, o hábito inclina o intelecto exatamente para a intelecção daquele objeto que o imprimira no intelecto ao ser primeiramente inteligido. E, se já há um hábito que inclina o intelecto para a retomada de um ato de intelecção, parece supérfluo propor que haja igualmente espécies.

No fim, portanto, vemos em Quodl. 11, q. 7, que o Doutor Solene admite algo impresso no intelecto - se não antes do ato de intelecção, certamente depois, a saber, o habitus. Assim, se nada inere no intelecto antes do ato de intelecção, deste ato de intelecção que inere no intelecto como um acidente (mais precisamente, como uma operação segunda, tal qual determinamos no cap. 2) resta um hábito que, igualmente, permanece no mesmo intelecto como um acidente permanente seu. De outra parte, como lemos em Quodl. 6, q. 8, a permanência de um tal hábito no intelecto posterior à intelecção não libera o intelecto das amarras que o atam à fantasia ou imaginação. Pelo contrário, tal hábito é algo inerente ao intelecto - portanto, um acidente seu que o inclina para a retomada de um objeto já inteligido anteriormente. Isso, possivelmente, facilita as ações do intelecto que, movido pela vontade, busca aperfeiçoar seu conhecimento acerca de tal objeto. Não obstante, ainda que possua tal hábito, o intelecto deverá a cada renovada inteleção acerca do mesmo objeto, buscá-lo no fantasma. Nesse caso, a presença de tal hábito no intelecto em nada muda o que vimos antes acerca da produção do conhecimento intelectual. Se ele torna o intelecto mais apto ou pronto para atualizar novamente um certo conhecimento, ele não faz as vezes do fantasma universal. Somente este último pode, de fato, oferecer ao intelecto

acidente inerente a um sujeito, mas a espécie ou hábito que se busca aqui em Quodl. 11, q. 7, é deste último tipo.

${ }^{286}$ Essa conclusão segue de perto as considerações que lemos sobre o habitus acima, na nota 129. 
a coisa universal que é inteligida em ato. O hábito, ao que parece, apenas facilita para o intelecto a abstração renovada do fantasma universal a partir fantasma particular.

Essa última observação nos traz de volta àquilo que parece ser o Leitmotiv da doutrina da intelecção de Henrique de Gand, a saber, a inescapabilidade do conhecimento sensível por parte do conhecimento intelectual. Em Suma, art. 1, vimos que, se a abstração permite algum conhecimento para além da sensação, tal conhecimento intelectual se restringe às noções mais gerais, como 'ente', 'uno' etc. ${ }^{287}$. Em Suma, art. 34 - se bem que em um trecho expungido, é verdade -, vimos nosso autor questionar como seria possível inteligir algo para além dos sentidos, se estes últimos são a origem de todo conhecimento intelectual. Não seria todo o conhecimento humano o conhecimento de sensíveis ora enquanto particular ora enquanto universal ${ }^{288}$ ?. Por fim, em Suma, art. 58, é levado ao ápice tal movimento, quando o objeto de intelecção - ou, pelo menos, o meio para a intelecção de tal objeto - é descrito como um 'fantasma universal ${ }^{289}$. Na produção da intelecção não há nada no intelecto realmente distinto daquilo que há na imaginação ou na própria coisa, de modo que o conhecimento intelectual tem limites claramente impostos pelo conhecimento sensível. A bem dizer, o conhecimento intelectual que obtemos pelos sentidos não é mais do que um 'intelecto imaginário' (intellectus imaginarius), como lemos em Quodl. 9, q. 15:

“Portanto, naquela verdade eterna, desde a qual foi feito tudo o que é temporal,
observamos pelo uso da mente a forma segundo a qual somos e segundo a qual
operamos algo em nós e nos corpóreos com verdadeira e reta razão. E daí,
também, possuímos em nós o conceito da notícia verdadeira das coisas tal como
um verbo" <Agostinho, De trin. IX, c. 7.12>.
Pelo quanto posso inferir, este dito de Agostinho é tomado da filosofia de Platão,
que propôs que formas separadas são o princípio do conhecimento das formas
sensíveis existentes na matéria. De fato, como diz Agostinho - e o que eu
também considero que seja -, os sensíveis existentes na matéria, anunciados pelo
sentido e transferidos para a memória, fazem um intelecto imaginário
<Agostinho, De trin. IX, c. 6.11 (CCSL 50, p. 303, 11. 68-9): "faz uma
consideração imaginária"> quando a mente concebe os inteligíveis nos
fantasmas. Mas, quando a inabalável e estável forma da verdade, que é a arte da
divina sabedoria, cheia das razões dos viventes, inunda com a luz da razão
incorruptível e mais sincera tanto o olhar da mente como aquele intelecto
imaginário que Agostinho chama de "nuvem da fantasia', então naquela luz e por
isso naquela verdade eterna desde a qual tudo foi feito, concebemos pela mente a

\footnotetext{
${ }^{287}$ Cf., nota 37.

${ }^{288}$ Cf., acima, nota 174 .

${ }^{289}$ Cf., respectivamente, notas 273 e 271.
} 
forma segundo a qual somos e, universalmente, as formas segundo as quais possuem ser aqueles de que possuímos um intelecto imaginário; e, segundo elas, enquanto as observamos de acordo consigo, julgamos sobre aqueles mesmos, enquanto possuem ser na matéria e, por isso, possuímos deles uma notícia veraz, como determinamos com muitas autoridades nas Questões ordinárias, no princípio" 290 .

Ora, o par 'intelecto imaginário' produz um oximoro não menos desconcertante que 'fantasma universal'. No entanto, ambas as expressões parecem registrar muito bem a relação estreita e tensa que Henrique de Gand parece enxergar entre as potências sensitiva e intelectiva da alma. Quando concebe os inteligíveis a partir dos fantasmas - sempre provenientes das coisas particulares fora -, o intelecto não forma mais do que intelecções imaginárias. Neste excerto, porém, surge a esperança de escapar aos sentidos! As 'nuvens da fantasia', que são o intelecto imaginário, e o próprio olhar da mente podem ser elevados, pela luz divina, ao conhecimento das próprias formas a partir das quais nós mesmos e todos os outros adquiriram ser. Pelo conhecimento dessas formas - isto é, dessa 'arte da sabedoria divina' (ars divinae sapientiae) -, nosso intelecto pode julgar acerca daquelas coisas que antes conhecíamos somente na matéria pelos sentidos. É por esse juízo, nos diz finalmente Henrique de Gand, que atingimos uma "notícia veraz [veracem notitiam]" acerca de tais coisas.

Mas, nesse caso, parece que todo o caminho que percorremos até aqui é insuficiente para um conhecimento verdadeiro... Ainda que haja uma recepção natural do objeto pelo intelecto possível e, mais, ainda que haja uma ação natural pela qual o intelecto agente abstrai o fantasma universal, isso ainda não é suficiente para um

\footnotetext{
${ }^{290}$ Henrique de Gand, Quodl. 9, q. 15, co. (ed. De Wulf-Mansion Centre, vol. 13, pp. 263-4): “'In illa ergo aeterna veritate ex qua temporalia facta sunt omnia, forma secundum quam sumus et secundum quam in nobis vel in corporibus vera et recta ratione aliquid operamur, usu mentis aspicimus atque inde conceptus rerum veracem notitiam tamquam verbum apud nos habemus' < Augustinus, De trinitate IX, c. 7.12 (CCSL 50, p. 303-4)>.

Quantum conicere possum, dictum istud Augustini est acceptum de philosophia Platonis, qui posuit formas separatas esse principium cognitionis formarum sensibilium in materia existentium. Ut enim dicit Augustinus, quod et ita arbitror esse, sensibiles in materia existentes, per sensum nuntiatae memoriaeque transfusae, imaginarium faciunt intellectum <Augustinus, De trinitate IX, c. 6.11 (CCSL 50 , p. 303, 11. 68-9): "imaginarium conspectum facit" $>$, mente concipiente intelligibilia in phantasmatibus. Sed cum forma inconcussae et stabilis veritatis, quae est ars divinae sapientiae, plena rationum viventium, perfundit luce incorruptibilis sincerissimaeque rationis et mentis aspectum, et illum imaginarium intellectum quem Augustinus appellat phantasiae nubem, tunc in illa luce et per hoc in illa aeterna veritate ex qua facta sunt omnia, mente conspicimus formam secundum quam sumus, et universaliter formas secundum quas habent esse illa de quibus imaginarium habemus intellectum, et secundum illas, ut secundum se conspicimus eas, iudicamus de eisdem ut habent esse in materia, et per hoc habemus de eis veracem notitiam, secundum quod pluribus auctoritatibus in Quaestionibus ordinariis circa principium determinavimus".
} 
conhecimento intelectual, de fato, verdadeiro - isto é, que esteja para além do conhecimento meramente sensível. Ora, se ao fim da parte 1 notávamos que a passividade do intelecto é insuficiente para a explicação da formação do conhecimento intelectual, agora vemos que a atividade do intelecto é igualmente insuficiente para tanto. Com efeito, a atualização de um conhecimento estritamente verdadeiro no intelecto humano exige, para além da ação desse próprio intelecto, uma outra ação - superior ao intelecto e, no fim, superior ao homem como um todo. 
EPÍLOGO DA PARTE 2:

A INSUFICIÊNCIA DA ATIVIDADE DO INTELECTO

Na primeira etapa de nosso trabalho, havíamos estabelecido que o homem é um ente fundamentalmente potencial e, mais precisamente, em potência para o conhecimento intelectual - isto é, capaz de conhecer intelectualmente. Ao fim, porém, víamos que a potência para o conhecimento não bastava, pois (diferentemente do ser divino) o homem, enquanto criatura, deve ser movido por outro para seus atos, suas operações e, em geral, para seu aperfeiçoamento. Assim, na segunda etapa de nossa pesquisa, buscamos compreender como tal potência para o conhecimento se atualiza no homem. Curiosamente, notamos que o movimento a partir de algo externo não é o único na formação do conhecimento humano. Com efeito, seja tal conhecimento sensível ou inteligível, o próprio homem - por meio de certas potências ou forças de sua alma em cada caso - deve agir para a atualização desse conhecimento. Ou seja, a presença da coisa fora é o estopim de um processo no decorrer do qual a alma, agindo em si mesma acerca daquela coisa (ou melhor, acerca da marca que aquela coisa imprimira no corpo enquanto este é órgão da alma) forma para si conhecimentos cada vez mais abstraídos acerca daquela mesma coisa. Assim, o conhecimento dos sentidos particulares ocorre por meio de uma espécie abstraída da matéria, mas não da presença material da coisa particular fora; em seguida (e deixando de lado o elusivo sentido comum e o ato da memória que, a bem dizer, não é um ato de conhecimento), a imaginação abstrai da presença material, mas não das condições materiais, ao conhecer a coisa particular no fantasma; por fim, o intelecto, em face do fantasma, abstrai também as condições materiais e, assim, conhece a coisa particular enquanto coisa universal.

No início de sua Suma e nos seus primeiros Quodlibeta, Henrique de Gand se mostra satisfeito em compreender tanto o conhecimento sensitivo como o conhecimento intelectivo como atos que ocorrem acerca de uma coisa por meio de uma species - sendo esta uma species do particular no primeiro caso e uma species do universal no segundo. Em obras mais tardias - em especial, no Quodl. 5, q. 14 -, nosso autor busca esclarecer a distinção entre a espécie da sensação e a espécie da intelecção pelo par species impressa (ou impressiva) e species expressa (ou 
expressiva). Destas, a primeira diria respeito ao sentido, uma vez que é recebida como uma forma ou acidente em um sujeito. A espécie expressa, de sua parte, seria aquela típica do intelecto, pois é recebida neste como o conhecido ou o objeto no cognoscente e não como um acidente em um sujeito.

Mas, qual seria a vantagem da estratégia de Henrique de Gand? A meu ver, dois são os temas a serem destacados aqui. Em primeiro lugar, parece-me que a distinção entre as espécies impressa e expressa permite ao gandavense mostrar como o conhecimento intelectual do universal continua a ser, não obstante sua completa abstração da particularidade da coisa, um conhecimento acerca da própria coisa particular. De fato, toda a complexa caracterização da espécie expressa tende a um esvaziamento do universal com respeito ao singular. Assim, o universal não é algo realmente distinto do particular que existe fora da alma e que é conhecido pelos sentidos externos e internos. A bem dizer, nem mesmo a espécie do universal é realmente distinta da espécie do particular na imaginação - ambas são realmente o mesmo fantasma. Enquanto a potência imaginativa vê nesse fantasma um particular, o intelecto - que enxerga tal fantasma sob a luz do intelecto agente - vê nele um universal. Em poucas palavras, a mesma coisa é vista como particular sob a luz material e como universal sob a luz imaterial, assim como o mesmo fantasma é ora fantasma particular ora fantasma universal.

Isso nos leva ao segundo tema anunciado acima: esse esvaziamento do universal tem por resultado a completa dependência do intelecto com respeito ao sentido. Não somente o intelecto não pode conhecer nada além daquilo que o sentido lhe oferece, como mesmo após um primeiro conhecimento (isto é, quando já possui um hábito impresso em si) o intelecto terá que se voltar para o fantasma a cada vez que inteligir novamente um objeto já conhecido. O universal não é mais do que uma outra maneira de ver o objeto imaginado, de sorte que o ato de intelecção surge na filosofia de Henrique como o "intelecto imaginário" de Quodl. 9, q. 15². Como Marrone nos lembra ${ }^{2}$, expressão semelhante ressurge em Suma, art. 24, q. 8, quando se explica que são necessários dois para o aperfeiçoamento do conhecimento intelectivo: "o primeiro destes é o verbo do intelecto pelo qual é informado ao conceber o que é [quod quid est] sobre a coisa, enquanto o segundo é o juízo sobre tal

\footnotetext{
${ }^{1}$ Cf. cap. 6, nota 290.

${ }^{2}$ MARRONE, “Henry of Ghent's Epistemology”, 2011, p. 218.
} 
conceito, sem o qual o intelecto não é puro, mas permanece sempre fantástico [phantasticus]"3. Sendo assim, a concepção da quididade pelo intelecto ainda não escapa ao conhecimento sensitivo - estamos ainda no campo de um intelecto que não é puro, mas é um intelecto fantástico. De outra parte, porém, essa mesma passagem parece nos sugerir o modo pelo qual o intelecto pode escapar ao jugo da sensação, a saber, pelo juízo. Nesse caso, parece que a passagem do verbo incomplexo para o verbo complexo - isto é, a concepção do verbo perfeito após a conversão do intelecto sobre seu conceito confuso inicial - seria o modo pelo qual o intelecto escaparia ao campo da sensação. Mas, seria isso possível? Bem, se voltarmos aos trechos expungidos de Suma, art. 34, q. 5, parece que Henrique de Gand não era tão otimista quanto a esse tema no decorrer da elaboração de seus textos. Como vimos no item 6.4.1 ${ }^{4}$, esses excertos cancelados deixavam claro que, para nosso autor, ainda que o intelecto escape aos sentidos pela investigação silogística ou divisiva, ele só obtém ao fim conhecimentos muito gerais, cuja verdade não se pode conhecer. Ou seja, para Henrique, como estabelecemos a partir de Suma, art. 1, o conhecimento intelectual inicial é maximamente geral - não vai além de noções como 'ente', 'um em número' etc. O mesmo ocorre, além disso, com o conhecimento complexo. Enfim, o conhecimento intelectual não escapa aos sentidos - o máximo que ele obtém destes últimos são conceitos (incomplexos ou complexos) maximamente gerais, o que não nos leva muito longe na elaboração da ciência.

Há pouco, porém, eu perguntava qual seria a vantagem, para Henrique, em distinguir espécie impressa e espécie expressa. Como resposta, notamos que tal distinção permite a remissão do universal à coisa particular fora e, com isso, atrela o conhecimento intelectual fortemente aos sentidos. Pois bem, por que seria tal resultado uma vantagem? Sem dúvida, esse resultado não parece muito promissor para um autor que pretenda defender uma completa autossuficiência do homem no conhecimento da verdade, tal como Mieczysław Gogacz pensa ser o caso em Henrique de Gand, como vimos na introdução. Sem dúvida, o comentador parece acertar quando afirma, contra Étienne Gilson, que o Doutor Solene vê espaço para um

\footnotetext{
${ }^{3}$ Henrique de Gand, Suma, art. 24, q. 8, co. (ed. Decorte \& Teske, p. 256): "Et in hoc perficitur cognitio intellectiva, ad quam duo requiruntur. Quorum primum est verbum intellectus quo informatur concipiendo quod quid est de re. Secundum vero est iudicium de tali conceptu sine quo intellectus purus non est, sed semper phantasticus manet". Cf. tb. MARRONE, The Light of Thy Countenance..., vol. 2, 2001, p. 277. Já citamos esse texto em cap. 6, nota 176.

${ }^{4}$ Cf. cap. 6, nota 174 .
} 
conhecimento intelectual estritamente "por auxílio das forças naturais do homem [przy pomocy sit naturalnych człowieka $]^{, 5}$. Com efeito, no decorrer de todas as páginas do presente trabalho vimos Henrique de Gand pausada e detalhadamente descrever como ocorre a formação do conhecimento sensitivo e intelectivo, recorrendo sempre somente às ações da coisa existente fora e do próprio homem por meio de suas potências. Não obstante, o homem não parece capaz de escapar a um intelecto imaginário ou fantástico. Isto é, até o momento em que lemos, em Quodl. 9, q. 15, que o nosso intelecto, uma vez elevado pela luz divina, pode julgar as coisas materiais pelas formas exemplares e, assim, ultrapassar aquele intelecto imaginário, atingindo uma notícia propriamente veraz ${ }^{6}$ - aliás, daquele tipo que Gilson dizia ver no mestre de Gand.

Pois bem, ao fim da parte 1 do presente trabalho, a possibilidade ou capacidade humana de conhecer se mostrava insuficiente para que houvesse um ato de conhecimento. Agora, ao término da parte 2, a própria ação do homem com vistas ao conhecimento se mostra insuficiente para tanto, como já enfatizavam Faustino Prezioso e Valeria Sorge ${ }^{7}$. Sem dúvida, tal atividade da alma humana produz um conhecimento, porém ela não esgota a possibilidade de conhecimento do homem. Sendo assim, é necessário que algo outro aja para tal conhecimento. Em uma palavra, esse outro é Deus:

"E, assim, pelas formas que são as essências das coisas, enquanto são observadas de acordo consigo pela ilustração da luz não-criada, são conhecidas por notícia verdadeira aquelas mesmas formas, enquanto possuem ser na matéria, que são observadas nos fantasmas por ilustração da luz criada que é o intelecto agente, como expusemos em outra lugar. Tal que, dessa maneira, o próprio Deus seja dito um intelecto agente que ilustra a mente para conhecer a verdade sincera da

\footnotetext{
${ }^{5}$ Cf. Introd., nota 20.

${ }^{6}$ Sobre a noção de iluminação desenvolvida em Quodl. 9, q. 15, cf. MACKEN, "Le théorie de l'illumination divine...", 1972; MARRONE, Truth and Scientific Knowledge..., 1985, pp. 93-140; MARRONE, The Light of Thy Countenance..., vol. 2, 2001, pp. 382-8; MARRONE, "Henry of Ghent's Epistemology", 2011, pp. 236-7. Além disso, muitos trabalhos enumerados adiante, na nota 25, se voltam para tal questão. Para o contexto filosófico e teológico da discussão acerca da ação de Deus sobre a mente humana em Quodl. 9, q. 15, cf. EMERY Jr., "The Image of God Deep in the Mind...", 2001; FÜHRER, M. "Henry of Ghent on Divine Illumination". Bochumer Philosophisches Jahrbuch für Antike und Mittelalter 3 (1998), pp. 69-85 (esp. p. 72).

${ }^{7}$ PREZIOSO, F. A. La critica di Duns Scoto all'ontologismo di Enrico di Gand. Padova: CEDAM, 1961, p. 79: "Ma Enrico di Gand si trova anche di fronte ai razionalisti aristotelici, per cui s'impegna ora a provare contro di essi l'insufficienza della stessa ragione, nella conoscenza della verità ontologica della realtà creata"; SORGE, Gnoseologia e teologia..., 1988, p. 100: "È possibile d'altro canto individuare l'ambito limitato in cui si coloca l'accettazione della problematica aristotelica in Enrico, a partire anche dall'insufficienza del processo astrattivo che, per lui, è sostanzialmente incapace di fondare l'universalità l'immutabilità del vero $<$... ".
} 
forma material ao observar o universal na essência da forma abstraída de acordo consigo, embora não existente de acordo consigo, mas existente somente na notícia da mente (primeiro não-criada, depois criada). Do mesmo modo, uma virtude criada, enquanto potência da alma ou algo outro, é dita um intelecto agente que ilustra a mente para conhecer a verdade imaginária da forma material ao observar o universal no fantasma, abstraída da forma particular existente na matéria fora" $"$.

O intelecto agente que é a potência da alma humana - aquele que encontramos por diversas vezes no cap. 6 - produz o conhecimento de uma verdade imaginária (imaginaria veritas); porém, Deus pode elevar o nosso conhecimento a observar aquela forma a partir da qual a coisa conhecida foi criada. Destarte, o próprio Deus pode ser tomado como um intelecto agente que produz não o conhecimento de uma verdade imaginária, mas o conhecimento de uma verdade sincera (sincera veritas). Não deixa de ser marcante nessa passagem a referência aos dois intelectos agentes, mas o elemento fundamental aqui para a filosofia de Henrique de Gand é a distinção das duas verdades: uma imaginária, outra sincera ${ }^{9}$. Com efeito, o único modo de bem compreender tal distinção é seguir a sugestão de nosso próprio autor em Quodl. 9, q. $15^{10}$, e retornarmos ao início da Suma.

\footnotetext{
${ }^{8}$ Henrique de Gand, Quodl. 9, q. 15, co. (ed. De Wulf-Mansion Centre, vol. 13, pp. 264-5): "Et sic per formas quae sunt essentiae rerum, ut secundum se conspiciuntur illustratione lucis increatae, cognoscuntur vera notitia ipsae eaedem formae ut habent esse in materia, quae conspiciuntur in phantasmatibus illustratione lucis creatae quae est intellectus agentis, secundum quod alibi exposuimus. Ut secundum hoc intellectus agens illustrans mentem ad cognoscendum sinceram veritatem formae materialis in conspiciendo universale in essentia formae secundum se abstractae, licet non secundum se existentis sed in sola mentis notitia, primo increatae, deinde creatae, existentis, dicatur ipse Deus, quemadmodum intellectus agens illustrans mentem ad cognoscendum imaginariam veritatem formae materialis in conspiciendo universale in phantasmate, abstracto a forma particulari existente in materia extra, dicitur aliqua virtus creata, ut potentia animae vel aliquid aliud".

${ }^{9}$ Sobre a noção de sincera veritas, cf. PORRO, P. "Sinceritas veritatis. Sulle trace di un sintagma agostiniano". In: MERINO, P., TORRECILLA, J. M. (cur.). Augustinus. Charisteria augustiniana Iosepho Oroz Reta dicata. Tomus alter: Theologia. Madrid: Editorial Augustinus, 1994, pp. 413-30. Sobre a temática da duplicidade da verdade tal como desenvolvida por Henrique de Gand, cf. SPEER, A. "Doppelte Wahrheit? Zum epistemischen Status theologischer Argumente". In: MENSCHING, G. (Hrsg.). De usu rationis. Vernunft und Offenbarung im Mittelalter. Symposium des Philosophischen Seminars der Leibniz Universität Hannover vom 21. Bis 23. Februar 2006. Würzburg: Königshausen \& Neumann, 2007, pp. 73-90 (esp. pp. 79-88); BIANCHI, L. Pour une histoire de la "double vérité". Paris: Vrin, 2008, pp. 32-6. Além disso, note-se que a maior parte das fontes bibliográficas sobre a noção de iluminação divina em Henrique de Gand apontadas adiante, na nota 25, também discorre sobre a temática da duplex veritas tal como desenvolvida pelo Doutor Solene. Por fim, destaque-se que essa distinção entre duas verdades não é uma distinção entre uma verdade filosófica e outra verdade teológica, pois para Henrique "veritas igitur Theologica, et philosophica in omnibus concordant, et est veritas philosophica manuductiva ad veritatem Theologica, et gradus ad illam" - Suma, art. 7, q. 13, co. (ed. 1642-6, p. 155b, n. 8). Sobre isso, cf. SPEER, "Doppelte Wahrheit?...", 2007, p. 83; BIANCHI, Pour une histoire..., 2008, pp. 36-7.

${ }^{10}$ Henrique de Gand, Quodl. 9, q. 15, co. (ed. De Wulf-Mansion Centre, vol. 13, p. 264): “<..> secundum quod pluribus auctoritatibus in Quaestionis ordinariis circa principium determinavimus". Cf. cap. 6, nota 290.
} 
Pois bem, começamos nosso estudo pela leitura de Suma, art. 1, q. 1, onde vimos a afirmação da possibilidade de conhecimento sensitivo e intelectivo - a saber, o scire large accepto - para o homem. Buscamos, em seguida, compreender precisamente o que seria tal possibilidade e como o homem pode atualizá-la ao ser movido por algo externo. No entanto, notamos que somente a ação do homem é insuficiente para atualizar completamente tal possibilidade. De fato, já em Suma, art. 1, q. 2, lemos que o homem só pode chegar ao conhecimento da 'verdade sincera' por um auxílio divino (algo que, como vimos no Epílogo da Parte 1, já é sugerido na própria Suma, art. 1, q. 1).

A pergunta colocada nessa questão é justamente "Se ocorre de o homem ter ciência de algo sem a ilustração divina [Utrum contingat hominem aliquid scire sine divina illustratione]"11. A resposta será, a um só tempo, positiva e negativa, uma vez que passará por uma distinção dos diversos tipos de conhecimento que estão em jogo na atividade intelectual humana. Destarte, ainda no início de sua determinação, Henrique se esforça para delimitar o campo de conhecimento - sensitivo $e$ intelectual - que se pode, com certeza, atribuir ao homem sem auxílio da iluminação divina:

\begin{abstract}
“Assim, é preciso conceder absolutamente que o homem, por sua alma, sem qualquer ilustração divina, pode ter ciência de ou conhecer algo - e isso por puros meios naturais [ex puris naturalibus]. De fato, dizer o contrário derroga em muito a dignidade da alma e da natureza humana. Porém, digo 'por puros meios naturais’ sem exclusão da influência geral do primeiro inteligente, que é o primeiro agente em toda ação intelectual e cognitiva, tal como o primeiro movente em todo movimento de qualquer coisa natural"12.
\end{abstract}

\footnotetext{
${ }^{11}$ Henrique de Gand, Suma, art. 1, q. 2, co. (ed. De Wulf-Mansion Centre, vol. 21, p. 29). Note-se que, na ocasião do estabelecimento da edição crítica de Suma, arts. 1-5, o editor Gordon Wilson (ed. De Wulf-Mansion Centre, vol. 21, pp. xxxviii-lxvii) apontou a possibilidade da reconstrução de diversas camadas textuais a partir das correções registradas na lição desse início da Suma conservada no ms. Paris, BNF lat. 15355 (fenômeno semelhante ao que encontramos em Suma, art. 34, no item 6.4.1, acima). Alguns resultados iniciais desse aspecto do estabelecimento crítico do texto para o estudo da noção de iluminação desenvolvida pelo Doutor Solene podem ser lidos em GOEHRING, Henry of Ghent on Cognition..., 2006, pp. 21-4, 100-4.

${ }^{12}$ Henrique de Gand, Suma, art. 1, q. 2, co. (ed. De Wulf-Mansion Centre, vol. 21, p. 35): “Absolute ergo concedere oportet quod homo per suam animam absque omni speciali divina illustratione potest aliqua scire aut cognoscere, et hoc ex puris naturalibus. Contrarium enim dicere multum derogat dignitati animae et humanae naturae. Dico autem 'ex puris naturalibus' non excludendo generalem influentiam primi intelligentis, quod est primum agens in omni actione intellectuali et cognitiva, sicut primum movens movet in omni motu cuiuslibet rei naturalis". Note-se que a expressão "ex puris naturalibus" oferece um desafio ao tradutor, pois nela permanece subentendido algum substantivo caracterizado pelos dois adjetivos regidos pela preposição ex. Mas, qual seria esse substantivo? Em minha tradução, introduzo o substantivo 'meios', seguindo as opções de Pasnau: "by purely natural means" (The Cambrige Translations of Medieval Philosophical Texts, 2002, p. 114); Teske: "by purely natural means" (HENRY OF GHENT, Summa of Ordinary Questions. Article One, 2008, p. 21); e Demange: "par les seuls moyens naturels" (HENRI DE GAND, Sur la possibilité..., 2013, p. 127). Podemos citar também, porém, duas paráfrases de Gogacz: “ex puris naturalibus, przy pomocy więc
} 
Isso é, basicamente, aquilo que já havíamos lido em Suma, art. 1, q. 1, e viemos estabelecendo no decorrer de todo esse trabalho. Assim, o homem pode, pelas suas próprias potências cognoscitivas, adquirir conhecimento. Sem dúvida, Deus o move para tanto enquanto é causa primeira de todo movimento - isto é, como causa remota. Porém, o próprio homem pode agir, como causa próxima, para a atualização de seu próprio conhecimento. Mas, seria ele apto para produzir todo aquele scire large accepto para o qual, como vimos, o homem está em potência? Como era dito, a chave para a determinação de Henrique de Gand em Suma, art. 1, q. 2, está na distinção de um campo preciso de conhecimentos - dentro desse vasto terreno do scire large accepto - que não pode ser acessado pelo homem senão por auxílio divino.

Assim, nosso autor está pronto a admitir que, no campo do scire large accepto, o conhecimento certo que diz respeito aos sentidos é plenamente atingível pelo homem ex puris naturalibus ${ }^{13}$. Porém, o caso da intelecção - que Henrique agora afirma ser aquele conhecer que "propriamente se diz 'ter ciência' [proprie dicitur scire]" - é mais complexo, pois urge distinguir dois tipos de conhecimento intelectual: “embora, de fato, segundo Agostinho nas 83 Questões 'de nada se tenha ciência senão do verdadeiro [verum]', um é ter ciência, sobre a criatura, daquilo que é verdadeiro nela e outro é ter ciência de sua verdade, tal que um seja o conhecimento pelo qual se conhece a coisa, outro pelo qual se conhece a verdade dela" ${ }^{, 14}$. A essa

naturalnych władz poznawczych człowieka" e "Przedmioty poznawane przy pomocy sił naturalnych człowieka" (Problem istnienia Boga..., 1961, pp. 80 e 96, respectivamente). Como vemos, diferentemente dos outros intérpretes, Gogacz opta por introduzir os substantivos "władza [poder]" ou "siła [força]".

${ }^{13}$ Henrique de Gand, Suma, art. 1, q. 2, co. (ed. De Wulf-Mansion Centre, vol. 21, p. 35): "Si ergo large accipiamus scire ad omnem certam notitiam rei, ut comprehendat etiam cognitionem sensitivam, sicut dictum est in quaestione praecedenti, quantum est ex parte sensus et cognitionis sensitivae, patet quod simpliciter et absolute dicendum est quod contingit aliquid scire et cognoscere certa cognitione sensitiva, ut ostensum est in quaestione praecedenti, et hoc ex puris naturalibus $<\ldots$. ".

${ }^{14}$ Henrique de Gand, Suma, art. 1, q. 2, co. (ed. De Wulf-Mansion Centre, vol. 21, pp. 35-6): "Quantum autem est ex parte intellectus et cognitionis intellectivae, cuius cognoscere proprie dicitur scire, distinguendum est. Quamquam enim secundum Augustinum 83 Quaestionibus 'nihil scitur nisi verum', aliud tamen est scire de creatura id quod verum est in ea, et aliud est scire eius veritatem, ut alia sit cognitio qua cognoscitur res, alia qua cognoscitur veritas eius. Omnis enim virtus cognoscitiva per suam notitiam apprehendens rem, sicut habet esse in se extra cognoscentem, apprehendit quod verum est in ea, sed non per hoc apprehendit eius veritatem. Sensus enim etiam in brutis bene apprehendit de re quod verum est in ea, ut verum hominem, verum lignum, verum lapidem, et maxime proprium obiectum, 'circa quod de necessitate est verus', sed tamen nullius rei veritatem apprehendit sive cognoscit; propter quod de nullo potest iudicare quid sit in rei veritate, ut de homine quod sit verus homo, vel de colore quod sit verus color". 
distinção entre conhecer o 'verdadeiro na coisa' e conhecer a 'verdade da coisa', o Doutor Solene sobrepõe a distinção entre as duas operações do intelecto: "Portanto, no conhecimento intelectivo da coisa criada pode-se ter um duplo conhecimento. Um pela qual precisamente se tem ciência de ou se conhece, por simples inteligência, aquilo que a coisa é. Outro pelo qual se tem ciência de ou se conhece, pela inteligência que compõe e divide, a verdade da própria coisa" ${ }^{\prime 15}$. Destarte, para Henrique de Gand, o conhecimento intelectual simples dirá respeito àquilo que é verdadeiro na coisa, enquanto que o conhecimento proposicional nos dá a conhecer a própria verdade da coisa. Até agora, não parece muito claro qual seria a distinção precisa entre conhecer o verdadeiro na coisa e conhecer a verdade da coisa. Só sabemos, até o momento, que o primeiro é o conhecimento de um conceito simples e o segundo se segue à operação de composição e divisão. Ora, se o problema aqui é saber se algum desses dois conhecimentos exige um auxílio divino, é preciso melhor compreender o que seria cada um deles. Pois bem, esse é precisamente o caminho seguido pelo Doutor Solene.

O primeiro conhecimento intelectual - isto é, por inteligência simples "segue completamente o sentido e não há algo concebido no intelecto que não tenha sido antes no sentido. E, por isso, tal intelecto, enquanto é desse modo, bem pode ser verdadeiro concebendo ou conhecendo a coisa tal como é, do mesmo modo como o sentido que ele segue, muito embora não conceba ou intelija a própria verdade da coisa, percebendo por um juízo certo sobre ela o que é [quid sit] <... ${ }^{\text {16 }}$. Estamos ainda, portanto, no campo de conhecimentos que claramente podem ser obtidos ex puris naturalibus, pois se mantém no terreno da sensação. Ao que parece, essa primeira intelecção é ainda aquele intelecto fantástico ou imaginário de Suma, art. 24, e Quodl, 9, q. 15. Tal conhecimento, porém, não chega à verdade das coisas - que vemos, agora, ser caracterizada como um juízo certo (certo iudicio) sobre o que é (quid sit) a coisa.

\footnotetext{
${ }^{15}$ Henrique de Gand, Suma, art. 1, q. 2, co. (ed. De Wulf-Mansion Centre, vol. 21, p. 36): "Cognitione igitur intellectiva de re creata duplex potest haberi cognitio: una qua praecise scitur sive cognoscitur simplici intelligentia id quod res est; alia qua scitur et cognoscitur intelligentia componente et dividente veritas ipsius rei".

${ }^{16}$ Henrique de Gand, Suma, art. 1, q. 2, co. (ed. De Wulf-Mansion Centre, vol. 21, pp. 36-7): "In prima cognitione intellectus noster omnino sequitur sensum, nec est aliquid conceptum in intellectu quod non erat prius in sensu. Et ideo talis intellectus in quantum huiusmodi bene potest esse verus concipiendo sive cognoscendo rem sicuti est, quemadmodum et sensus quem sequitur, licet non concipiat vel intelligat ipsam veritatem rei certo iudicio percipiendo de ipsa quid sit, ut quod sit verus homo vel verus color".
} 
Por isso mesmo, Henrique introduz agora a menção àquele conhecimento que seria capaz de atingir, justamente, esse juízo certo, isto é, de alcançar a verdade da coisa. Ora, a verdade na coisa "não se pode apreender senão apreendendo a sua conformidade para com seu exemplar $<\ldots>{ }^{\prime 17}$. Ao que parece é justamente a essa conformidade que dirá respeito o juízo da razão que permite conhecer a verdade da coisa. Para nosso autor, afirmar que o conhecimento da verdade da coisa é um juízo já estabelece um ultrapassamento desse conhecimento com respeito à sensação, que não pode compor e dividir ${ }^{18}$. Assim, se o primeiro conhecimento intelectual - que diz respeito à inteligência simples - permanece no campo dos sentidos e, portanto, pode ser adquirido ex puris naturalibus, o segundo conhecimento intelectual vai além dos sentidos, pois, compondo e dividindo, produz um juízo acerca da verdade da coisa, isto é, acerca da conformidade entre a coisa e seu exemplar. Todo o problema está, nesse ponto, em saber se este último conhecimento intelectual pode ser obtido sem iluminação divina ${ }^{19}$.

Como vimos, tal conhecimento passa pelo estabelecimento de uma conformidade entre a coisa conhecida e o exemplar dessa coisa. Assim, para compreender se haveria ou não a necessidade de um auxílio divino em tal conhecimento, o mestre gandavense se propõe a estabelecer melhor qual seria o exemplar a que tal coisa deve ser comparada para que sua verdade seja conhecida. Há duas possibilidades, pois "segundo quer Platão em Timeu I, há um duplo exemplar: 'um feito e elaborado, outro perpétuo e imutável'. O primeiro exemplar da coisa é a sua espécie do universal que existe na alma $<\ldots>$ e é causada pela coisa. O segundo exemplar é a arte divina que contém as razões ideais de todas as coisas <... ${ }^{\text {,20 }}$.

\footnotetext{
${ }^{17}$ Henrique de Gand, Suma, art. 1, q. 2, co. (ed. De Wulf-Mansion Centre, vol. 21, p. 39): "Intentio enim veritatis in re apprehendi non potest nisi apprehendendo conformitatem eius ad suum exemplar $<\ldots>$ ".

${ }^{18}$ Henrique de Gand, Suma, art. 1, q. 2, co. (ed. De Wulf-Mansion Centre, vol. 21, p. 39): "In cognitione autem secunda, qua scitur sive cognoscitur veritas ipsius rei, sine qua non est hominis cognitio perfecta de re, cognitio et iudicium intellectus omnino excedunt cognitionem et iudicium sensus, quia, ut dictum est, intellectus veritatem rei non cognoscit nisi componendo et dividendo, quod non potest facere sensus, et ideo talis intellectus potest cognoscere de re quod non potest cognoscere sensus, neque etiam intellectus qui est simplicium intelligentia, quod est certo iudicio apprehendere de re quod in rei veritate sit tale vel tale, ut verus homo vel verus color et huiusmodi".

${ }^{19}$ Henrique de Gand, Suma, art. 1, q. 2, co. (ed. De Wulf-Mansion Centre, vol. 21, p. 39): "De isto ergo modo sciendi et cognoscendi aliquid per intellectum quo scitur veritas rei, quod est proprie scire, utrum ex puris naturalibus possit homo scire aliquid sine omni speciali illustratione divina, adhuc restat dubitatio".

${ }^{20}$ Henrique de Gand, Suma, art. 1, q. 2, co. (ed. De Wulf-Mansion Centre, vol. 21, p. 40): "Est enim, secundum quod vult Plato in $\mathrm{I}^{\circ}$ Timaei, duplex exemplar: 'quoddam factum atque elaboratum,
} 
Pois bem, caso a verdade da coisa possa ser conhecida a partir do exemplar causado pela própria coisa, então não há necessidade de uma iluminação divina para tal conhecimento. Esse, porém, não é o caso. Para comprová-lo, Henrique argumenta que nenhum dos três elementos envolvidos no conhecimento intelectual por meio do exemplar adquirido a partir da coisa permite a intelecção de uma verdade imutável e infalível. Com efeito, [i] a própria coisa de que se abstrai tal exemplar é mutável, de maneira que este último também é mutável; [ii] a alma, que conhece por tal exemplar, é igualmente mutável e passiva de erro, no mais não podendo ser corrigida por algo inferior a si, como a coisa material de que se abstrai o exemplar; por fim, [iii] o próprio exemplar provém de fantasmas que, se permitem um conhecimento verdadeiro na vigília e sanidade, também produzem conhecimento falsos no sono ou na loucura. Ora, uma vez que a verdade da coisa deve ser infalível, imutável e certamente distinguida do falso, vê-se que a coisa, o exemplar dela abstraído e a alma que o abstrai não são suficientes para o conhecimento da verdade da coisa ${ }^{21}$.

Por isso Henrique de Gand argumenta que é somente por um acesso ao exemplar não-criado, isto é, à arte divina que contém as razões ideais das coisas, que o homem pode chegar a conhecer propriamente a verdade da coisa. Assim, tal como víamos em nossa rápida leitura de Quodl. 9, q. 15, há uma dupla verdade de acordo com o duplo exemplar da coisa. Pelo exemplar abstraído, o intelecto segue o sentido e

quoddam perpetuum atque immutabile'. Primum exemplar rei est species eius existens apud animam universalis, per quam acquirit notitiam omnium suppositorum eius, et est causata a re. Secundum exemplar est ars divina continens omnium rerum ideales rationes, ad quod Plato dicit 'Deum mundum instituisse', sicut artifex ad exemplar artis in mente sua facit domum, non autem ad primum”.

${ }^{21}$ Henrique de Gand, Suma, art. 1, q. 2, co. (ed. De Wulf-Mansion Centre, vol. 21, pp. 42-5): "Unde per universalem notitiam quam in nobis habemus acquisitam de diversis speciebus animalis cognoscimus de qualibet re quae nobis occurrit an sit animal an non, et per specialem notitiam asini cognoscimus de quolibet quod nobis occurrit an sit asinus an non.

Sed quod per tale exemplar acquisitum in nobis habeatur a nobis certa omnino et infallibilis notitia veritatis, hoc omnino est impossibile triplici ratione, quarum prima sumitur ex parte rei de qua exemplar huiusmodi abstractum est, secunda ex parte animae in qua huiusmodi exemplar susceptum est, tertia ex parte ipsius exemplaris quod a re in anima susceptum est.

Prima ratio est quod exemplar tale, eo quod abstractum est a re transmutabili, necesse habet aliquam rationem transmutabilis $<\ldots>$.

Secunda ratio est quod anima humana, quia mutabilis est et erroris passiva, per nihil quod mutabilitatis aequalis vel maioris est cum ipsa potest rectificari ne obliqueretur per errorem et in rectitudine veritatis persistat. Ibi exemplar omne quod recipit a rebus naturalibus, cum sit inferioris graduas naturae quam ipsa, necessario aequalis vel maioris mutabilitatis est cum ipsa. Non ergo potest eam rectificari ut persistat in infallibili veritate $<\ldots$. .

Tertia ratio est quod huiusmodi exemplar, cum si intentio et species sensibilis rei abstracta a phantasmata, similitudinem habet cum falso sicut cum vero, ita quod, quantum est ex parte sua internosci non potest; per easdem enim imagines sensibilium in somno et in furore iudicamus imagines esse res ipsas, et in vigilia sani iudicamus de ipsis rebus. Veritas autem sincera non percipitur nisi discernindo eam a falso". 
conhece o que há de verdadeiro na coisa em uma inteligência simples; já pelo exemplar eterno, o intelecto ultrapassa o sentido, estabelecendo a conformidade da coisa com tal exemplar imutável, e chega ao conhecimento da verdade da coisa, isto é, a um juízo sobre aquilo que a coisa é. Curiosamente, portanto, Henrique de Gand deve admitir, ao fim, que os acadêmicos, ao negarem o conhecimento, tinham alguma razão! Não há, com efeito, um conhecimento da verdade da coisa a partir do exemplar abstraído $^{22}$.

De outra parte, porém, eles erraram ao não considerarem o conhecimento que se pode obter pelo acesso ao exemplar eterno. De fato, “a verdade sincera não pode ser observada senão no exemplar eterno" ${ }^{\text {23 }}$. Porém, os exemplares eternos estão para além dos sentidos e, com efeito, da própria alma - melhor, estão para além da criação -, pois são as próprias razões eternas na mente divina. Assim, o homem só pode ter acesso a eles por uma iluminação divina, isto é, pelo livre oferecimento divino de tais exemplares ao homem: "assim, cumpre dizer absolutamente que o homem não pode conhecer a verdade sincera sobre nenhuma coisa adquirindo sua notícia ex puris naturalibus, mas somente pela ilustração do lume divino, tal que, embora atinja isso constituído in puris naturalibus, ainda assim não pode atingi-lo naturalmente ex puris naturalibus, mas <tal lume $>$ se oferece aos que quer por vontade livre"24. Enfim, o

\footnotetext{
${ }^{22}$ Henrique de Gand, Suma, art. 1, q. 2, co. (ed. De Wulf-Mansion Centre, vol. 21, pp. 45-6): "Sic ergo patet quod duplex est veritas et duplex modus sciendi veritatem, quod innuit Augustinus <...>. Patet etiam quod certam scientiam et infallibilem veritatem, si contingat hominem cognoscere, hoc non contingit ei aspiciendo ad exemplar abstractum a re per sensus quantumcumque sit depuratum et universale factum. Propter quod primi Academici sententiam Platonis imitantes - 'idem quippe sunt Academici qui Platonici', ut dicit Augustinus in Epistola ad Dioscorum - negabant sciri omnino contra Stoicos $<\ldots>$...

${ }^{23}$ Henrique de Gand, Suma, art. 1, q. 2, co. (ed. De Wulf-Mansion Centre, vol. 21, p. 50): "Sincera igitur veritas, ut dictum est, non nisi ad exemplar aeternum conspici potest". Mas, se a "verdade sincera' - que é, aqui em Suma, art. 1, q. 2, ao que parece, a 'verdade da coisa' - só pode ser conhecida por iluminação, então como Henrique de Gand pode dizer em Quodl. 2, q. 6 (cf. cap. 6, nota 59) e Quodl. 1, q. 12-13 (cf. cap. 6, nota 63) que o intelecto ultrapassa os sentidos justamente ao conhecer a verdade no verbo ou quididade da coisa na alma (ainda antes da formação de juízos)? Com efeito, parece difícil conciliar a concepção de verbum que lemos nos Quodls. 1 e 2 com a noção de 'verdade sincera' que encontramos aqui em Suma, art. 1, q. 2.

${ }^{24}$ Henrique de Gand, Suma, art. 1, q. 2, co. (ed. De Wulf-Mansion Centre, vol. 21, p. 63): “Absolute ergo dicendum quod homo sinceram veritatem de nulla re habere potest ex puris naturalibus eius notitiam acquirendo, sed solum illustratione luminis divini, ita quod licet in puris naturalibus constitutus illud attingat, tamen ex puris naturalibus naturaliter attingere illud non potest, sed libera voluntate quibus vult se ipsum offert". A última frase é complexa para o tradutor, pois não está claro qual seria o sujeito que "se oferece aos que quer por vontade livre". Nesse caso, os tradutores consultados não concordam entre si. Em Pasnau lemos: "Instead, God bestows it, through free will, on whomever he wants" (The Cambrige Translations of Medieval Philosophical Texts, 2002, p. 132); em Teske: "<...> but it offers itself by free will to whom it wills" (HENRY OF GHENT, Summa of Ordinary Questions. Article One, 2008, p. 36); em Demange: “ $<\ldots>$ mais par la volonté libre de celui
} 
homem é naturalmente (in puris naturalibus) capaz de atingir um conhecimento da verdade sincera, mas não pode fazê-lo ex puris naturalibus. Tal conhecimento, com efeito, só é possível por uma iluminação divina que eleve o intelecto humano, para além do sentidos, aos exemplares ou ideias na mente de Deus.

Sem dúvida, essa doutrina que lemos em Suma, art. 1, q. 2, e Quodl. 9, q. 15, traz, nesse momento, mais dúvidas do que respostas. Em particular, é interessante que em Suma, art. 1, q. 2, a passagem do conhecimento simples ao juízo certo exija uma iluminação divina, quando não havia qualquer referência a tal iluminação nas menções à passagem do conhecimento simples para o verbo ou conhecimento perfeito em Quodls. 4 e 5 ou em Suma, art. 58. Caso se queira compreender a doutrina da intelecção de Henrique como um todo, será necessário conciliar o que estudamos nesses seis capítulos sobre o conhecimento humano enquanto possibilidade (parte 1) e enquanto fruto da atividade humana (parte 2), com o que podemos ler a respeito desse mesmo conhecimento humano como fruto de uma ação divina não somente em Suma, art. 1, q. 2, e Quodl. 9, q. 15, mas também em Suma, art. 1, q. 3, e em outras passagem da obra de Henrique de Gand ${ }^{25}$. Em todo caso, esse não é nosso objetivo aqui. O que

qui s'offre à ceux qu'il veut” (HENRI DE GAND, Sur la possibilité..., 2013, p. 189); em Kato: “<...> 自由意志によって [神が] 望む人にそれは与えられるのである| jiȳu ishi niyotte [kami ga] nozomu hito ni sore wa ataerareru no de aru $[<\ldots>$ mas isso é dado por livre vontade ao homem que <Deus> quer]” (GAN NO HENRIKUSU [ガンのヘンリクス]. “Utrum contingat hominem aliquid scire sine divina illustratione'. Henrici de Gandavo Quaestiones ordinariae (Summa), a. 1, q. 2 [神の照明な しに人間は何かを知りうるか (3) - ガンのヘンリクス『定期討論のスンマ』a. 1, q. 2]: Japanese translation with the Latin text, an introduction, and notes by Kato Masato [加 藤 雅 人]”. 外国語学部 紀要 | Foreing Languages Bulletin 11 (2014), pp. 137-66 [esp. p. 149]).

Pasnau e Kato ignoram a reflexividade de "se ipsum" - o primeiro introduz Deus como o sujeito do verbo offert, o segundo introduz Deus como o sujeito do verbo vult. Teske e Demange mantêm a reflexividade de "se ipsum" - o primeiro introduz o neutro it como sujeito de offert (reflexivo) e vult, assim como o segundo mantém o offert reflexivo e introduz o pronome il como sujeito de vult. Essas traduções também se diferenciam pelo papel que emprestam à expressão ablativa "libera voluntate" Pausnau, Teske e Kato a relacionam adverbialmente com offert; já Demange, a opõe ao ex puris naturalibus da oração anterior: não se atinge tal verdade ex puris naturalibus, mas libera voluntate. A solução de Demange, porém, exige a introdução de um genitivo ausente no texto latino, pois torna-se necessário explicar que a 'vontade livre' de que se fala não é do homem (como era o caso dos meios puramente naturais), mas daquele que se oferece ("de celui qui s'offre"). De minha parte, busquei não inserir um sujeito ausente das sentenças anteriores, mas arriscar ver neste último trecho a referência a algum sujeito (masculino ou neutro, devido aos pronomes "se ipsum") que surgisse em alguma passagem anterior do excerto. Esse sujeito, parece-me, é o lumen divinum, que se oferece e possui vontade livre, porque é o próprio Deus.

${ }^{25}$ A rápida leitura de Suma, art. 1, q. 2, apresentada acima de maneira alguma faz jus à complexidade da questão e, mais, à complexidade da literatura secundária existente a respeito do tema. De todo modo, este Epílogo não possui por fim desenvolver o tema da iluminação divina, mas somente introduzi-lo em linhas gerais, para mostrar os limites do trabalho exegético que realizamos no decorrer desses capítulos. Para maiores informações sobre a noção de 'iluminação divina' em Henrique de Gand, pode-se consultar a bibliografia a seguir, em cuja leitura também me baseei para a elaboração dessa etapa final da Parte 2: HUET, Recherches historiques et critiques..., 1838, pp. 123-4, 142; 
se pretendia com essa referência final à temática da iluminação divina era mostrar como, para o Doutor Solene, as próprias potências humanas são incapazes, por si só, de proporcionar ao homem todo o conhecimento de que ele é capaz. Se ao fim da parte 1 vimos que a mera possibilidade de conhecimento não era suficiente para o conhecimento em ato, agora ao fim da parte 2 notamos que a própria ação do homem movido por um objeto é, também, insuficiente para tanto. Tal ação proporciona algum conhecimento - a intelecção de um conceito simples, que segue o sentido e é, portanto, uma intelecto imaginário ou fantástico. Porém, para atingir um conhecimento propriamente intelectual, o homem deve ser alçado para além do sensível pela iluminação divina. Somente então, ele passa do conceito simples ao juízo. Mas, nesse caso, toda ciência pressupõe iluminação?

WERNER, Heinrich von Gent als Repräsentant..., 1878, pp. 25-30; WULF, Études sur Henri de Gand, 1894, pp. 119-52; WULF, M. de. "L'examplarisme et la théorie de l'illumination spéciale dans la philosophie de Henri de Gand". Revue néo-scolastique de philosophie 1 (1894), pp. 53-75; BRAUN, Die Erkenntnislehre..., 1916, pp. 42-103; PAULUS, "Henri de Gand et l'argument ontologique", 1935, pp. 271-5; PAULUS, Henri de Gand. Essai..., 1938, pp. 4-10; NYS, De werking van het menselijk..., 1949, pp. 117-35; BETTONI, Il processo astrattivo..., 1954, pp. 11-37; CAFFARENA, Ser participado y ser subsistente..., 1958, pp. 11-23; BEHA, "Matthew of Aquasparta's Cognition Theory. Part II: Ideogenesis" , 1961, pp. 53-61; GOGACZ, Problem istnienia Boga..., 1961, pp. 73-116; PREZIOSO, La critica di Duns Scoto..., 1961, pp. 79-112; SCHMITT, "Henry of Ghent, Duns Scotus and Gianfrancesco Pico on Illuminatio", 1963, pp. 235-9; MACKEN, R. "La théorie de l'illumination divine dans la philosophie d'Henri de Gand". Recherches de théologie ancienne et médiévale 39 (1972), pp. 82-112; BROWN, J. V. "Divine Illumination in Henry of Ghent". Recherches de théologie ancienne et médiévale 41 (1974), pp. 177-99; TERÄVÄINEN, “Henrik Gentiläisen tieto-oppi”, 1975, pp. 40-2; BROWN, J. V. "John Duns Scotus on Henry of Ghent's Arguments for Divine Illumination...”, 1976; BÉRUBÉ, De Dieu à l’homme..., 1983, pp. 41-54; MACKEN, R. "L’illumination divine concernant les vérités révélées chez Henri de Gand". Journal philosophique: Bulletin du Centre de Recherche Philosophique Saint Thomas d'Aquin 5 (1985), pp. 261-71; MARRONE, Truth and Scientific Knwoledge..., 1984, pp. 13-40, 93-140; SORGE, Gnoseologia e teologia..., 1988, pp. 109-39; HÖDL, "Zum Streit um die Illuminationslehre des Heinrich von Gent ( $\dagger$ 1293)...", 1994; PASNAU, R. "Henry of Ghent and the Twilight of Divine Illumination". The Review of Metaphysics 49.1 (1995), pp. 49-75; FÜHRER, "Henry of Ghent on Divine Illumination", 1998; HOFFMANN, Creatura intellecta, 2001, pp. 153-6; MARRONE, The Light of Thy Coutenance..., vol. 2, 2001, pp. 270-98; TROTTMANN, Théologie et noétique au XIII siècle..., 1999, pp. 158-9; EMERY Jr., "The Image of God Deep in the Mind...", 2001, pp. 59-62, 102-4; KANN, "Skepsis, Wahrheit, Illumination...", 2001; KANN, "Grenzen des Zweifels...", 2003; KANN, C. "Wahrheit und Wahrheitserkenntnis bei Heinrich von Gent". In: GULDENTOPS, G., STEEL, C. (eds.), Henry of Ghent and the Transformation..., 2003, pp. 157-75; STEEL, "Henricus Gandavensis Platonicus", 2003, pp. 24-35; GOEHRING, Henry of Ghent on Cognition..., 2006, pp. 100-5; PICKAVÉ, Heinrich von Gent über Metaphysik..., 2007, pp. 57-79; SCHUMACHER, L. Divine illumination in Augustinian and Franciscan Thought. PhD Divinity, The University of Edinburgh, 2009, pp. 246-53; BORING, W. P. "Revising ou Approach to 'Augustinian Illumination'. A Reconsideration of Bonaventure's Quaestiones disputatae de scientia Christi IV, Aquinas's Summa theologiae Ia. 84, 1-8, and Henry of Ghent's Summa quaestionum ordinariarum, q. 2, art. 1, 2 [sic]". Franciscan Studies 68 (2010), pp. 3881; MARRONE, "Henry of Ghent's Epistemology", 2011; TESKE, "Augustine's Influence on the Philosophy of Henry of Ghent", 2012, pp. 165-78; PAIVA, “A discussão acerca da possibilidade...", 2013, pp. 242-8; DEMANGE, "Introduction", 2013; AREZZO, Lumen medium. Enrico di Gand e il dibattito..., 2014, pp. 46-60; CONNOLLY, P. J. "Henry of Ghent's Argument for Divine Illumination Reconsidered". American Catholic Philosophical Quarterly 89.1 (2015), pp. 47-68. 


\section{CONCLUSÃO: \\ OS LIMITES DO CONHECIMENTO HUMANO}

Nesse ponto, se torna clara a fundamental relevância do problema colocado ao fim da parte 2 deste trabalho. Se a passagem do conceito ao juízo só pode ocorrer por iluminação, então parece que todo conhecimento estritamente científico dependerá não somente [i] da atividade abstrativa de nosso intelecto ou, mesmo, [ii] de sua conversão sobre si mesmo para produzir um verbo perfeito, mas junto a isso deverá contar com [iii] uma iluminação divina - para além da influência geral de Deus -, que o permita julgar o criado a partir do exemplar divino e, assim, chegar ao conhecimento da verdade sincera da coisa. Com efeito, já vimos que o scire large é qualquer conhecimento certo, seja sensitivo ou intelectivo; o scire proprie é precisamente o conhecimento intelectivo, seja inteligência simples ou juízo. Porém, há ainda uma noção de scientia mais própria, que se refere estritamente ao verbum scientiale ou habitus scientialis ${ }^{1}$ - isto é, ao hábito que permanece no intelecto após a investigação e o discurso silogístico desde os princípios às conclusões ${ }^{2}$. Ora, esse é precisamente o caminho pelo qual Henrique nos diz ser formado o verbo complexo, aplicando a quididade ou acidente àquilo de que isso é quididade ou acidente ${ }^{3}$, ou seja, formando um juízo. Se for assim, com efeito, todo conhecimento científico exige uma iluminação divina. E, no entanto, lemos em Suma, art. 1, q. 11, que tal investigação racional é realizada "pela potência natural da razão [per potentiam naturalem rationis]"4. Afinal, seria ou não necessária uma iluminação para passar [i] do conceito ao [ii] verbo complexo e hábito científico?

A bem dizer, o quadro não parece ser tão simples para o leitor de Henrique de Gand. Temos uma primeira pista da complexidade que essa questão ganha em sua

\footnotetext{
${ }^{1}$ Cf. cap. 6, notas 209 e 252, respectivamente.

${ }^{2}$ Henrique de Gand, Suma, art. 1, q. 11, co. (ed. De Wulf-Mansion Centre, vol. 21, p. 181): "Talis autem notitia principiorum supposita ex acquisitione tali, homo via investigationis rationalis rationaliter per potentiam naturalem rationis, ut est ratio, discorrendo acquirit sibi ex notitia illorum principiorum notitiam conclusionum, et per hoc etiam habitum eorum, quo de facili potest se homo, cum vult, convertere super eas intelligendas; qui dicitur scientia. Et dicitur proprie habitus acquisitus, quia per rationis investigationem et industriam advenit".

${ }^{3}$ Cf. citação de Quodl. 5, q. 25, em cap. 6, nota 211.

${ }^{4}$ Cf. nota 2 .
} 
obra quando nos voltamos para Suma, art. 3, q. 4, onde lemos que "por meio do sentido [mediante sensu]" e pela luz do intelecto podemos conhecer todos os objetos de ciência filosófica (scibilia philosophica) ${ }^{5}$. Mas, nesse caso, podemos ter ciência filosófica sem iluminação? Ou somente podemos ter um conhecimento inicial desses objetos ex puris naturabilibus para, em seguida e por iluminação divina, chegarmos a um conhecimento filosófico estritamente científico?

Vejamos o que o Doutor Solene nos diz sobre o tema Suma, art. 6, q. 1:

" $<1>$ Cumpre dizer, portanto, que qualquer notícia se chama ciência duplamente. De um modo estritamente, de outro modo amplamente.

$<1.1>$ Amplamente, chama-se ciência qualquer notícia certa da verdade $<\ldots>$. E a ciência dita assim se distingue da opinião, da dúvida e da suspeita, que são operações do intelecto e notícias sem qualquer certeza $<\ldots>$.

$<1.2>$ Mas, estritamente, chama-se ciência não qualquer notícia certa, mas somente $<$ a notícia $>$ daqueles cuja verdade aparece para o intelecto pela evidência da coisa, tal que o intelecto, nela, seja testemunho para si mesmo e possua para si a certeza por ver, não somente pelo testemunho de outro $<\ldots>$. E a ciência assim dita se distingue da fé $<\ldots>$. Mas, pode-se possuir tal intelecto duplamente e, assim, a ciência propriamente dita é dupla. $<1.2 .1>$ De fato, de um modo, pode-se possuí<-la $>$ pela força da razão natural operando de modo natural, somente com a ilustração do lume natural ou com a ilustração divina geral, de que se falou acima. $<1.2 .2>$ De outro modo, $<$ pode-se possuí-la $>$ pela força da razão natural operando de modo sobrenatural, com a ilustração especial do lume sobrenatural. Do primeiro modo, possui-se um intelecto sobre as coisas naturais nas ciências filosóficas, enquanto do segundo possui-se $<$ um intelecto $>$ sobre as coisas sobrenaturais nesta ciência $<s c$. a teologia $><\ldots>$..

\footnotetext{
${ }^{5}$ Henrique de Gand, Suma, art. 3, q. 4, co. (ed. De Wulf-Mansion Centre, vol. 21, p. 258): “Cum ergo illa notitia quae naturalis est sit adminiculo sensuum et sensibilium, lux homini connaturalis solum illustrat ad sciendum notitiam eorum quae mediante sensu nata sunt cognosci. Talia sunt illa quae sunt scibilia philosophica solum, praeter quae sunt plura alia, quae excedunt naturalem intellectum hominis <...>. Cf. MARRONE, Truth and Scientific Knowledge..., 1985, p. 23.

${ }^{6}$ Henrique de Gand, Suma, art. 6, q. 1, co. (ed. 1642-6, pp. 106b-107a, nn. 7-9): "Dicendum igitur, quod notitia aliqua appellatur scientia dupliciter. Uno modo stricte, alio modo large.

Large appellatur scientia quaelibet notitia certa veritatis $<\ldots>$. Et scientia sic dicta distinguit contra opinionem, dubitationem, et suspicionem, quae sunt operationes intellectus, et notitiae sine ulla certitudine $<\ldots>$.

Stricte vero appellatur scientia, non quaecunque certa notitia, sed solummodo eorum, quorum veritas intellectui ex rei evidentia apparet, ut intellectus in ea sibi ipsi sit testis, et certitudinem ex eo quod videt, habeat, non tantum ex testimonio alterius $<\ldots>$. Et scientia sic dicta distinguitur a fide $<\ldots>$. Sed intellectus talis dupliciter potest haberi. Et secundum hoc scientia proprie dicta est duplex. Uno enim modo haberi potest vi naturalis rationis operantis modo naturali illustratione solius luminis naturalis, aut cum divina illustratione generali, de qua dictum est supra. Alio modo vi naturalis rationis operantis modo supernaturali illustratione speciali luminis supernaturalis. Primo modo habetur intellectus de rebus naturalibus in scientiis philosophicis. Secundo autem modo habetur de rebus supernaturalis in ista scientia $<s c$. na teologia $><\ldots>$ ". Sobre a fé em Henrique de Gand, cf. MACKEN, "L'illumination divine concernant les vérités révélées...", 1985; FAUCHER, N. "La connaissance des objets de foi chez Henri de Gand, entre infusion, raisonnement et illumination”. Quaestio 14 (2014), pp. 273-98.
} 
Pois bem, no que lemos há pouco em Suma, art. 1, q. 2, a distinção entre inteleção ex puris naturalibus e intelecção por iluminação divina era paralela à distinção entre inteligência simples e intelecção de juízos. Nesse trecho de Suma, art. 6, q. 1, esse não parece ser mais o caso! Agora, a distinção entre intelecção "pela força da razão natural operando de modo natural [vi naturalis rationis operantis modo naturali]" e intelecção "pela força da razão natural operando de modo sobrenatural, com a ilustração especial do lume sobrenatural [vi naturalis rationis operantis modo supernaturali illustratione speciali luminis supernaturalis]" é paralela à distinção entre ciência filosófica e ciência teológica. Em princípio, não parece haver como conciliar ambas as apresentações do tema, pois seria improvável que Henrique de Gand considerasse que somente a teologia diz respeito a juízos, sendo a filosofia sempre o conhecimento de conceitos simples... Pelo contrário, ambas são racionais e, assim, devem dizer respeito a juízos, ainda que formados diferentemente - ora sem iluminação divina especial, ora com tal auxílio divino.

Começamos a entender, destarte, que o problema da insuficiência da atividade puramente natural do intelecto que colocávamos ao fim da parte 2 é muito mais complexo - e, de fato, muito mais profundo - do que poderíamos esperar em um primeiro momento. Sem dúvida, todo o caminho que percorremos no presente trabalho é possível para o homem ex puris naturalibus. Com efeito, vimos que, nessa longa explicação da formação da inteligência simples que lentamente percorremos, surge somente a referência à coisa externa como motor inicial do processo de atualização do conhecimento e às próprias faculdades da alma que agem para tal atualização, formando conhecimentos cada vez mais abstratos. Não há naquela exposição qualquer menção a uma iluminação divina, senão como forma de ultrapassamento do conhecimento abstrativo puramente natural. A pergunta que se põe agora é, então: em que momento, precisamente, tal ultrapassamento se torna necessário? Já seria ele necessário no momento que passamos do conceito simples ao juízo (como em Suma, art. 1, q. 2)? Ou seria ele necessário somente para a passagem de um juízo filosófico para um juízo teológico (com em Suma, art. 6, q. 1)?

Já em seu livro de 2007, Martin Pickavé colocava o problema do alcance (Reichweite) e dos limites (Begrenztheit) do conhecimento natural, associando tal temática à relação entre filosofia e teologia ${ }^{7}$. Mais recentemente, porém, ele chamou

\footnotetext{
${ }^{7}$ PICKAVÉ, Heinrich von Gent über Metaphysik..., 2007, pp. 46-57.
} 
atenção para a impossibilidade de identificar a luz divina de que se fala em Suma, art. 1, q. 2, àquela luz divina de que se fala em Suma, art. 6, ao criticar um igualmente recente artigo de Catherine König-Pralong. Neste texto, o comentadora vê, no início da Suma de Henrique de Gand, ao mesmo tempo, uma defesa de que "a infusão de uma iluminação habitual é requerida em todo conhecimento" 8 e de que "Henrique estabelece, com efeito, as condições de uma teologia racional que permite ler verdadeiramente e exaustivamente a metafísica e a ética de Aristóteles enquanto teólogo <..." ${ }^{9}$. Ou seja, König-Pralong parece associar a iluminação divina necessária para a passagem do conceito ao juízo àquela necessária para a passagem da filosofia à teologia. É justamente essa a identificação criticada por Pickavé: "Embora eu concorde até certo ponto com König-Pralong sobre Henrique redesenhar as fronteiras do que significa ser naturalmente cognoscível, eu tenho a impressão de que ela não distingue o suficiente entre as diferentes iluminações de que Henrique fala no começo de sua Summa quaestionum ordinariarum: a luz que é tema em Suma, art. 1, q. 2, não é a mesma que o, assim chamado, lumen theologicum (ou lumen medium), do qual supostamente o teólogo se beneficia"10. Como resultado, seria necessário

\footnotetext{
${ }^{8}$ KÖNIG-PRALONG, "Le désir naturel de connaître...", 2014, p. 20: "Selon les premiers articles de la Summa, l'infusion d'une illumination habituelle est requise dans toute connaissance. La satisfaction de l'appétit de connaissance ne procède pas de la pure naturalité des puissances humaines. L'appétit naturel n'est pas un appétit défini en termes de rationalité purement philosophique". Cf. tb. op. cit., p. 17: "Dans ce complexe problématique, Henri de Gand propose une nouvelle solution, qui est exposée dans le premier article de la Summa déjà. D'une part, par l'infusion d'une lumière surnaturelle spéciale qui prolonge l'étude de la théologie, le théologien peut acquérir une connaissance scientifique partielle de l'essence divine. Toutes les sciences sont ordonnées à la théologie envisagée comme une discipline scientifique. D'autre part, en ce qui concerne la naturalité du désir de connaître, l'homme a un désir naturel de connaître ce qui ne peut être connu que surnaturellement grâce à une illumination spéciale".
}

${ }^{9}$ KÖNIG-PRALONG, "Le désir naturel de connaître...", 2014, p. 23: "Henri établit en effet les conditions d'une théologie rationnelle qui permette de lire véritablement et exhaustivement la métaphysique et l'éthique d'Aristote en théologien $<$... ".

${ }^{10}$ PICKAVÉ, M. "A new book on Giles of Rome and Henry of Ghent. Critical Study of V. Cordonnier - T. Suarez-Nani (eds.), L'aristotélisme exposée...”. Recherches de Théologie et Philosophie Médiévales 81.2 (2014), pp. 387-98 (esp. p. 390): “Although I agree somewhat with König-Pralong that Henry redraws the boundaries of what it means to be naturally knowable, I have the impression that she does not distinguish enough between the different illuminations of which Henry speaks at the beginning of his Summa quaestionum ordinariarum: the light that is issue in Summa art. 1, q. 2 is not the same as the so-called lumen theologicum (or lumen medium), of which the theologian is supposedly benefitting". Esse lumen theologicum pode ser considerado um lumen medium, porque o conhecimento teológico está entre a fé e a visão in patria: " $<\ldots>$ sicut in disciplinis circa idem triplex est modus cognoscendi discipulo possibilis, unus ex solo auditu $<\ldots>$. Alius ex aspecto corporali $<\ldots>$. Tertius ex ratione sola $\langle\ldots\rangle$. Consimiliter in notitia eorum, quae sunt fidei in hac scientia triplex est modus cognoscendi, unus qui est solius fidei, quasi ex auditu assentiendo divinae auctoritati $<\ldots$. . Alius est ex rei creditae apparentia, quo modo cognoscunt eam Sancti in patria. Tertius modus est medius quo cognoscuntur credita, non solum auditu, nec apparentia rei quasi viso, sed ex rationis evidentia $<\ldots>$ " Suma, art. 13, q. 6, co. (ed. 1642-6, p. 235a-b, n. 5). Sobre a noção de teologia em Henrique de Gand, cf. BRANDARIZ, F. La Teología como ciencia según Enrique de Gante. Extracto de la tesis doctoral: 
distinguir duas iluminações distintas das quais Henrique de Gand falaria no início da Suma, sendo ambas relativas ao conhecimento estritamente científico - ou seja, a distinção entre tais iluminações não coloca em jogo nem a fé, nem a graça ou o arrebatamento.

Temos, portanto, duas posições muito bem marcadas quanto à interpretação da noção de iluminação que lemos no início da Suma. Por um lado, König-Pralong, considera que, em todo o início da Suma, fala-se consistentemente em [i] uma

"La ciencia Teológica y sus relaciones con las demás ciencias, según Enrique de Gante y sus contemporâneos (Parte 2a , caps. 1-4)”. Madrid: Estudios Eclesiasticos, 1948 [= Estudios eclesiásticos 22 (1948), pp. 5-57]; BRANDARIZ, F. "La teologia en relación con las demás ciencias según Enrique de Gante". Miscelanea comillas 19 (1953), pp. 165-204; BROWN, S. F. "Henry of Ghent's 'De reductione artium ad theologiam"”. In: GALLAGHER, D. H. (ed.). Thomas Aquinas and His Legacy. Washington D.C.: The Catholic University of America Press, 1994, pp. 194-206; BELLOSO, J. M. R. Introducción a la Teología. Madrid: Biblioteca de Autores Cristianos, 1996, pp. 92, 100-15; PORRO, P. "Lo statuto della philosophia in Enrico di Gand". In: AERTSEN, J. A., SPEER, A. (Hrsg.). Was ist Philosophie im Mittelalter? / Qu'est-ce que la philosophie au moyen âge? Akten des X. Internationalen Kongresses für mittelalterliche Philosophie der SIEPM, 25. bis 30. August 1997 in Erfurt. Berlin New York: De Gruyter, 1998, pp. 497-504; TYÖRINOJA, R. "Auriole's Critique of Henry of Ghent's lumen medium”. In: AERTSEN, J. A., SPEER, A. (Hrsg.). Was ist Philosophie im Mittelalter? / Qu'est-ce que la philosophie au Moyen Âge? / What is Philosophy in the Middle Ages? Akten des X. Internationalen Kongresses für mittelalterlichen Philosophie der SIEPM, 25. bis 30. August 1997 in Erfurt. Berlin - New York: De Gruyter, 1998, pp. 622-8; LAARMANN, Deus, primum cognitum..., 1999, pp. 53-77; TROTTMANN, Théologie et noétique au XIII siècle, 1999, pp. 157-92; TYÖRINOJA, R. "Lumen medium. Henry of Ghent on the Accessibility of Theological Truths". In: HOLMSTRÖM-HINTIKKA, G. (ed.). Medieval Philosophy and Modern Times. Dordrecht - Boston London: Kluwer Academic Publishers, 2000, pp. 161-82; SPEER, A. "Sapientia nostra. Zum Verhältnis von philosophischer und theologischer Weisheit in den Pariser Debatten am Ende des 13. Jahrhunderts". In: AERTSEN, J. A., EMERY Jr., K., SPEER, A. (Hrsg.). Nach der Verurteilung von 1277. Philosophie und Theologie an der Unversität von Paris in letzten Viertel des 13. Jahrhunderts. Studien und Texte. Berlin - New York: De Gruyter, 2001, pp. 248-75; SPEER, A. "Certitude and Wisdom in Bonaventure and Henry of Ghent". In: GULDENTOPS, G., STEEL, C. (eds.), Henry of Ghent and the Transformation..., 2003, pp. 75-100; LEONE, M. "Metaphysics, Theology and the Natural Desire to Know Separate Substances". Quaestio 5 (2005), pp. 513-26; LEONE, M. "Zum Status der Theologie bei Heinrich von Gent - Ist sie eine praktische oder eine theoretische Wissenschaft?". In: OLSZEWSKI, M. (ed.). What is "Theology" in the Middle Ages? Religious Cultures of Europe $\left(11^{\text {th }}-15^{\text {th }}\right.$ Centuries) as reflected in their Self-Understanding. Münster: Aschendorff, 2007, pp. 195-224; PORRO, P. "La teologia a Parigi dopo Tommaso: Enrico di Gand, Egidio Romano, Goffredo di Fontaines". In: BIFFI, I., MARABELLI, C. (cur.). Rinnovamento della "Via Antiqua". La creatività tra XIII e XIV secolo. Milano - Roma: Jaca Book - Città Nuova, 2009, pp. 165-262; PORRO, P. 'Tra il 'Convivio' e la 'Commedia': Dante e il 'forte dubitare' intorno al desiderio naturale di conoscere le sostanze separate”. In: SPEER, A., WIRMER, D. (Hrsg.). 1308: Eine Topographie Historischer Gleichzeitigkeit. Berlin - New York: De Gruyter, 2010, pp. 631-659 (esp. pp. 646-56); HÖDL, "The Theologian Henry of Ghent”, 2011; KÖNIG-PRALONG, Le bon usage des savoirs, 2011, pp. 69-104; AREZZO, Lumen medium. Enrico di Gand e il dibattito..., 2014; FIORENTINO, Conoscenza scientifica e teologia..., 2014, pp. 57-72; PORRO, P. "Tra l'oscurità della fede e il chiarore della visione. Il dibattito sullo statuto scientifico della teologia agli inizi del XIV secolo". In: BIANCHI, L., CRISCIANI, C. (cur.). Forme e oggetti della conoscenza nel XIV secolo. Studi in ricordo di Maria Elena Reina. Firenze: SISMEL - Edizioni del Galluzzo, 2014, pp. 195-256 (cf. esp. pp. 201-10).

Por fim, sobre o referido artigo de König-Pralong e sua crítica por Pickavé, cf. PAIVA, G. B. V. de. "Resenha de: CORDONIER, V., SUAREZ-NANI, T. (éds.). L'aristotélisme exposé...". Translatio. Caderno de Resenhas do GT História da Filosofia Medieval e a Recepção da Filosofia Antiga 7 (2015), pp. 24-41. 
iluminação necessária para a ciência teológica, sendo [ii] a ciência filosófica um conhecimento ex puris naturalibus ${ }^{11}$. De sua parte, porém, Pickavé chama a atenção para o fato - a meu ver, incontornável - de que a doutrina da iluminação desenvolvida em Suma, art. 1, q. 2, não é facilmente conciliada àquela doutrina da iluminação teológica que vimos há pouco em Suma, art. 6, q. 1. Com isso, vemos surgir um claro problema no coração da noção de iluminação desenvolvida por Henrique de Gand. Mas, de que maneira isso afeta o trabalho que viemos realizando até aqui?

Ora, vimos no decorrer do presente trabalho que o homem está em potência para o conhecimento (parte 1) e, uma vez movido por algo externo, pode agir para produzir tal conhecimento em si mesmo (parte 2). Ao fim, porém, notamos que essa ação por meios naturais é insuficiente para alcançar tudo aquilo que o homem é capaz de conhecer. É necessário algo outro que o auxilie, elevando o intelecto humano para além dos sentidos em direção à verdade eterna e imutável. Assim, voltando aos dois autores que consideramos na introdução, Gogacz está correto ao apontar que há um conhecimento puramente natural em Henrique de Gand, assim como Gilson está correto em apontar que há em nosso autor a necessidade de uma iluminação para que tal conhecimento chegue a uma verdade pura. Ou seja, sabemos que há conhecimentos que o homem obtém ex puris naturalibus e há outros conhecimentos que não se pode obter senão por iluminação divina. O grade problema é: qual o limite entre esses dois campos? Isto é, até que ponto podemos produzir de maneira puramente natural conhecimentos certos e verdadeiros a partir da inteligência simples que, como vimos no decorrer desse trabalho, obtivemos por abstração? E a partir de que ponto só podemos avançar em nosso conhecimento com o auxílio de uma iluminação divina? No presente trabalho, mostramos que o homem é naturalmente capaz de conhecer e, de fato, conhece em ato por meios puramente naturais. Mas, o que se pode fazer naturalmente com esse conhecimento abstrativo? E a partir de que ponto do conhecimento ele deve ser aperfeiçoado por uma ação divina? Enfim, o presente trabalho estabeleceu que há, para Henrique de Gand, um conhecimento intelectual estritamente natural, ainda que maximamente simples, geral e atrelado às sensações. Não sabemos, porém, de que modo precisamente se dá a passagem dessa

\footnotetext{
${ }^{11}$ Posição semelhante pode ser lida em MARRONE, Truth and Scientific Knowledge..., 1985, pp. $23-6$. Cf. tb. as discussões sobre os níveis de conhecimento humano segundo Henrique de Gand em LEONE, "Metaphysics, Theology and the Natural Desire...", 2005, p 519; e CONNOLLY, "Henry of Ghent's Argument...", 2015, p. 50 (onde se remete ao referido artigo de Leone).
} 
inteligência simples para o juízo, o verbo perfeito e a ciência. Para tanto seria necessário estabelecer precisamente quais os limites do conhecimento natural e, a partir de que ponto, um conhecimento torna-se tão elevando que só se possa alcançálo por iluminação. Esse seria um complemento imediato para o trabalho que aqui realizamos. 


\section{REFERÊNCIAS BIBLIOGRÁFICAS}

\section{MANUSCRITOS}

Madri, Real Biblioteca del Escorial, h.II.1, s. XIII-XIV.

Paris, BNF lat. 14312, s. XIIIf.

(gallica.bnf.fr)

Paris, BNF lat. 15355, s. XIIIf-XIVi.

(gallica.bnf.fr)

Paris, BNF lat. 15848, s. XIIIf.

(gallica.bnf.fr)

Tournai, Archives de la Cathédrale, Reg. 83 (martirológio do refeitório), s. XIV-XV.

Troyes, Médiathèque du Grand Troyes, 493, s. XIV.

(bibliotheque-virtuelle-clairvaux.com)

\section{EDIÇÕES}

a. de Henrique de Gand:

HENRICUS DE GANDAVO. Quodlibeta $<\ldots>$ cum duplici tabella. 2 vols. Parisiis: in aedibus Iodoci Badii Ascensi, 1518 (reprint - Louvain: Bibliothèque S. J., 1961).

. Summae Quaestionum Ordinariarum <..>. 2 vols. Parisiis: in aedibus Iodoci Badii Ascensi, 1520 (reprint - St. Bonaventure: The Franciscan Institute, 1953).

Aurea quodlibeta $<\ldots>$ commentariis doctissimis illustrata M. Vitalis Zucolii Patavini ordinis camaldulensis Theologi Clarissimi <... 2 vols. Seravalli Veneti: apud Marcum Claserium, 1608.

Aurea quodlibeta $<\ldots>$ commentariis doctissimis illustrata M. Vitalis

Zucolii Patavini ordinis camaldulensis Theologi Clarissimi <..>. 2 vols. Venetiis: apud Iacobum de Franciscis, $1613^{2}$ [1608] [Antecedido, no vol. 1, pela "Vita M. Henrici Goethals a Gadavo Doctoris Solemnis, Socii Sorbonici, Ordinis Servorum B. M. V. et Archidiaconi Tornacensis <..> per R. P. Magistrum Archangelum Piccionum de Venetiis eiusdem Ordinis Priorem Monasterii S. Iacobi a Iudaica, 2pp, não pág.]. 
. Summa in tres partes precipuas digesta $<\ldots>$ amplíssimo denique Indice, seu rerum omnium Medulla $<\ldots>$ Hieronymi Scarparii. 3 vols. Ferrariae: apud Franciscum Succium Typographum Cameralem, 1642-6.

- Sermo in die festi sanctae Catharinae 'Confessio et pulchritudo in conspectu eius'. Ed. E. Hocedez. In: HOCEDEZ, E. Richard de Middleton. Sa vie, ses oeuvres, sa doctrine. Louvain - Paris, Spicilegium Sacrum Lovaniense - Honoré Champion-Édouard Champion, 1925, pp. 484-489, 509-517.

. Opera omnia. Ed. G. A. Wilson et al. Leuven: Leuven University Press, 1979- (De Wulf-Mansion Centre, Ancient and Medieval Philosophy, series 2). Volumes já publicados:

Vol. 1: MACKEN, R. Bibliotheca Manuscripta Henrici de Gandavo. I. Introduction. Catalogue A-P, 1979.

Vol. 2: MACKEN, R. Bibliotheca Manuscripta Henrici de Gandavo. II. Catalogue Q-Z. Répertoire, 1979.

Vol. 5: Quodlibet I. Ed. R. Macken, 1979.

Vol. 6: Quodlibet II. Ed. R. Wielockx, 1983.

Vol. 8: Quodlibet IV. Ed. G. J. Etzkorn \& G. A. Wilson, 2011.

Vol. 10: Quodlibet VI. Ed. G. A. Wilson, 1987.

Vol. 11: Quodlibet VII. Ed. G. A. Wilson, 1991.

Vol. 13: Quodlibet IX. Ed. R. Macken, 1983.

Vol. 14: Quodlibet X. Ed. R. Macken, 1981.

Vol. 16: Quodlibet XII, qq. 1-30. Ed. J. Decorte, 1987.

Vol. 17: Quodlibet XII, q. 31 (Tractatus super facto praelatorum et fratrum). Ed. L. Hödl \& M. Haverals, 1989.

Vol. 18: Quodlibet XIII. Ed. J. Decorte, 1985.

Vol. 20: Quodlibet XV. Ed. G. J. Etzkorn \& G. A. Wilson, 2007.

Vol. 21: Summa (Quaestiones ordinariae), art. 1-5. Ed. G. A. Wilson, 2005.

Vol. 27: Summa (Quaestiones ordinariae), art. 31-34. Ed. R. Macken, cum introductione generali ad editionem criticam a L. Hödl, 1991.

Vol. 28: Summa (Quaestiones ordinariae), art. 35-40. Ed. G. A. Wilson, 1994. 
Vol. 29: Summa (Quaestiones ordinariae), art. 41-46. Ed. L. Hödl, 1998.

Vol. 30: Summa (Quaestiones ordinariae), art. 47-52. Ed. M. Führer, 2007.

Vol. 31: Summa (Quaestiones ordinariae), art. 53-55. Ed. G. A. Wilson \& Etzkorn, 2014.

Vol. 36: Lectura ordinaria super S. Scripturam (attributed). Ed. R. Macken, 1980.

Vol. 37: Syncategoremata Henrico de Gandavo adscripta. Ed. H. Braakhuis, G. J. Etzkorn \& G. A. Wilson, 2010.

Vol. 38: Quaestiones variae Henrico de Gandavo adscriptae. Ed. G. J. Etzkorn, 2008.

[adscripta]. Quaestiones supr VIII libros Physicorum III-IV. In: PERRON, R. Les livres trois et quatre des "Quaestiones super VIII libros Physicorum" attribuées à Henri de Gand. Texte inédit et introd. 3 vols. Louvain: Université Catholique de Louvain, Institut Supérieur de Philosophie, 1961.

[adscripta]. Quaestiones supr VIII libros Physicorum I-II. In: BELLEMARE, L. Les "Quaestiones super VIII libros Physicorum” attribuées à Henri de Gand. Étude sur l'authenticité de l'oeuvre. Étude et texte des Questions sur les livres I et II. 2 vols. Louvain: Université Catholique de Louvain, Institut Supérieur de Philosophie, 1964.

HENRY OF GHENT. "Summa". The Questions on God's existence and essence. Articles 21-24. Latin text, intr., and notes by R. J. Teske. Tr. J. Decorte and R. J. Teske. Louvain: Peeters, 2005.

. "Summa". The Questions on God's unity and simplicity. Articles 25-30. Latin text, intr., tr., and notes by R. J. Teske. Louvain: Peeters, 2006.

b. de outros autores:

ARISTOTELES. De anima (Translatio vetus seu Translatio Iacobi). In: ALBERTUS MAGNUS. De anima. Ed. C. Stroick. Monasterii Westfalorum: Aschendorff, 1968 (Alberti Magni Opera Omnia 7.1).

AUGUSTINUS. Contra academicos. De beata vita. De ordine. De magistro. De libero arbitrio. Ed. W. D. Green, K. D. Daur. Turnholti: Brepols, 1970 (Corpus Christianorum Series Latina, vol. 29).

. De trinitate. Libri $X V$. Cura et Studio W. J. Mountain, auxiliante Fr. Glorie. 2 vols. Turnholti: Brepols, 1968 (Corpus Christianorum Series Latina, vol. 50). 
AVERROES CORDUBENSIS. Commentarium Magnum in Aristotelis De anima libros. Recensuit F. S. Crawford. Cambridge: The Medieval Academy of America, 1953.

IOANNES DUNS SCOTUS. Opera Omnia. Vol. III. Studio et cura Commissionis Scotisticae. Civitas Vaticana: Typis Polyglottis Vaticanis, 1954.

IOANNES FRANCISCUS PICUS MIRANDULAE. Examen vanitatis doctrinae gentium et veritatis Christianae Disciplinae. Distictum in libros sex (...).Mirandula: Ioannes Maciochius Bundenius, 1520.

KANT, I. Logik. Akademie-Textausgabe, Bd. 9. Berlin - Leipzig: De Gruyter, 1923.

LEIBNIZ, G. W. Essais de théodicée sur la bonté de Dieu, la liberté de l'homme et l'origine du mal. In: GERHARDT, C. I. (Hrsg.) Die philosophischen Schriften von Gottfried Wilhelm Leibniz. 6. Bd. Berlin: Weidmannsche Buchhandlung, 1885 .

PETER OF SPAIN. Tractatus, called afterwards Summule logicales. First Critical Edition from the Mansucripts with an Introd. by L. M. de Rijk. Assen: Van Gorcum, 1972.

\section{TRADUÇÕES}

a. de Henrique de Gand:

GAN NO HENRIKUSU [ガンのヘンリクス]. “Utrum contingat hominem aliquid scire'. Henrici de Gandavo Quaestione ordinariae (Summa), a. 1, q. 1 [人間は 何かを知りらるか（1）- ガンのヘンリクス『定期討論のスンマ』a. 1，q. 1]: a Japanese translation with the Latin text, an introduction, and notes by Kato Masato [加 藤 雅 人]”. 外国語学部紀要 | Foreing Languages Bulletin 7 (2012), pp. 121-47.

"'Utrum contingat hominem aliquid scire'. Henrici de Gandavo Quaestione ordinariae (Summa), a. 1, q. 1 [人間は何かを知りうるか (2) - ガン のヘンリクス『定期討論のスンマ』a. 1, q. 1]: a Japanese translation with the Latin text, an introduction, and notes by Kato Masato [加藤 雅 人]”. 外国語学 部紀要 | Foreing Languages Bulletin 8 (2013), pp. 151-78.

. “Utrum contingat hominem aliquid scire sine divina illustratione'. Henrici de Gandavo Quaestiones ordinariae (Summa), a. 1, q. 2 [神の照明なし に人間は何かを知りうるか (1) - ガンのヘンリクス『定期討論のスンマ』a. 1, q. 2]: Japanese translation with the Latin text, an introduction, and notes by Kato Masato [加 藤 雅 人]”. 外国語学部紀要 | Foreing Languages Bulletin 10 (2013), pp. 141-66. 
."Utrum contingat hominem aliquid scire sine divina illustratione'. Henrici de Gandavo Quaestiones ordinariae (Summa), a. 1, q. 2 [神の照明なし に人間は何かを知りうるか (2) - ガンのヘンリクス『定期討論のスンマ』a. 1, q. 2]: Japanese translation with the Latin text, an introduction, and notes by Kato Masato [加 藤 雅 人]”. 外国語学部紀要 | Foreing Languages Bulletin 10 (2014), pp. 107-39.

. “Utrum contingat hominem aliquid scire sine divina illustratione'. Henrici de Gandavo Quaestiones ordinariae (Summa), a. 1, q. 2 [神の照明なし に人間は何かを知りうるか (3) - ガンのヘンリクス『定期討論のスンマ』a. 1, q. 2]: Japanese translation with the Latin text, an introduction, and notes by Kato Masato [加 藤 雅 人]”. 外国語学部紀要 | Foreing Languages Bulletin 11 (2014), pp. 137-66.

HENRI DE GAND. Sur la possibilité de la connaissance humaine. Textes latins introd., trad. et annotés par D. Demange. Paris, Vrin, 2013.

HENRY OF GHENT. "Can a human being know anything? (Summa quaestionum ordinariarum 1.1). Can a human being know anything without divine illumination? (Summa quaestionum ordinariarum 1.2)". In: PASNAU, R. (ed.). The Cambridge Translations of Medieval Philosophical Texts. Vol. 3: Mind and Knowledge. Cambridge: Cambridge University Press, 2002, pp. 93-135.

. "Summa". The Questions on God's existence and essence. Articles 2124. Latin text, intr., and notes by R. J. Teske. Tr. J. Decorte and R. J. Teske. Louvain: Peeters, 2005.

. "Summa". The Questions on God's unity and simplicity. Articles 25-30. Latin text, intr., tr., and notes by R. J. Teske. Louvain: Peeters, 2006.

- Summa of ordinary questions. Article one: On the possibility of knowing. Intr., tr., and notes by R. J. Teske. South Bend: St. Augustine's, 2008.

b. de outros autores:

KANT, I. Lógica. Trad. Guido Antônio de Almeida. Rio de Janeiro: Tempo Brasileiro, 1992.

LEIBNIZ, G. W. Ensaios de teodiceia sobre a bondade de Deus, a liberdade do homem e a origem do mal. Trad., introd. e notas de William de Siqueira Piauí e Juliana Cecci Silva. São Paulo: Estação Liberdade, 2013.

\section{BIBLIOGRAFIAS}

ESTÊVÃO, J. C. PAIVA, G. B. V. de. "Henrique de Gand: Bibliografia Disponível [principalmente em bibliotecas do estado de São Paulo, mas também de outros estados brasileiros]". Projeto Ariadne. São Paulo: CEPAME, última atualização em 04/2015 (endereço online: http://cepame.fflch.usp.br/bibliografia). 
HACHMANN, B., CARVALHO, M. A. "Henrique de Gand - Bibliografia". Mediaevalia. Textos e estudos 3 (1993), pp. 213-35.

LAARMANN, M. "Bibliographia auxiliaris de vita, operibus et doctrina Henrici de Gandavo”. Franziskanische Studien 73 (1991), pp. 324-366.

PORRO, P. "Bibliografia". In: universali. Bari: Levante, 1990, pp. 175-98.

. Enrico di Gand. La via delle proposizioni . "Bibliography" [até 1994]. In: VANHAMEL, W. (ed.). Henry of Ghent. Proceedings..., 1996, pp. 405-34.

. "Bibliography on Henry of Ghent (1994-2002)". In: GULDENTOPS, G., STEEL, C. (eds.), Henry of Ghent and the Transformation..., 2003, pp. 409-26.

SCHÖNBERGER, R., SÁNCHEZ, A. Q., BERGES, B., JIANG, L. (Hrsg.). Repertorium edierter Texte des Mittelalters aus dem Bereich der Philosophie und angrenzender Gebiete. Unter Mitarbeit von A. Schönfeld. Berlin: De Gruyter, $2011^{2}$ [HENRICUS DE GANDAVO, pp. 1823-31].

"Working Bibliography on Henry of Ghent". Henry of Ghent Series website (endereço online: https://philosophy.unca.edu/sites/default/files/documents/ HenryBibliographyWeb2015.pdf) [consultada em 19/12/2015].

\section{BIBLIOGRAFIA SECUNDÁRIA}

AAVV. Analytica 8.1: "Sobre Ciência e dialética em Aristóteles" (2004), 238p.

ADRIAENSSEN, H. T. "The Radical Cartesianism of Robert Desgabets and the Scholastic Heritage”. British Journal for the History of Philosophy 23.1 (2015), pp. 46-68.

AERTSEN, J. "Die Thesen zur Individuation in der Verurteilung von 1277, Heinrich von Gent und Thomas von Aquin". In: AERTSEN, J. A., SPEER, A. (Hrsg.). Individuum und Individualität im Mittelalter. Berlin - New York: De Gruyter, 1996, pp. 249-65.

. "Transcendental Thought in Henry of Ghent". In: VANHAMEL, W. (ed.). Henry of Ghent. Proceedings..., 1996, pp. 1-18.

. "'Von Gott kann man nichts erkennen, außer daß er ist' (Staz 215 der Pariser Verurteilung). Die Debatte über die (Un-)möglichkeit einer Gotteserkenntnis quid est'. In: AERTSEN, J. A., EMERY Jr., K., SPEER, A. (Hrsg.). Nach der Verurteilung von 1277. Philosophie und Theologie an der Unversität von Paris in letzten Viertel des 13. Jahrhunderts. Studien und Texte. Berlin - New York: De Gruyter, 2001, pp. 22-37.

“'Res' as Transcendental. Its Introduction and Significance". In: VESCOVINI, G. F. (éd.). Le problème des transcendentaux du XIV au XVII siècle. Paris: Vrin, 2002, pp. 139-56. 
. "Heinrich von Gent und Thomas von Aquin über die Transzendentalien. Ein Textvergleich". In: GULDENTOPS, G., STEEL, C. (eds.), Henry of Ghent and the Transformation..., 2003, pp. 101-25.

. "Tino-Logia. An Alternative for Ontology?". In: ATUCHA, I., et al. (éds.). Mots médiévaux offerts à Ruedi Imbach. Porto: FIDEM, 2011, pp. 72937.

- Medieval philosophy as transcendental thought: from Philip the Chancellor (ca. 1225) to Francisco Suárez. Leiden: Brill, 2012.

AIELLO, A., WIELOCKX, R. Goffredo di Fontaines aspirante baccelliere sentenziario. Le autografe "Notule de scientia theologiae" e la cronologia del ms. Paris BnF lat. 16297. Turnhout: Brepols, 2008.

. "La versione del Quodlibet IV, qq. 7-8, di Enrico di Gand nel ms. Paris BnF lat. 16297". Documenti e studi sulla tradizione filosofica medievale 19 (2008), pp. 371-499.

ALDROVANDUS, U. Monstrorum historia... Bononiae: typis Nicolai Tebaldini, 1642.

ALLINEY, G. "Introduzione". In: ENRICO DI GAND. Il nodo nel giunco. Le questioni sulla libertà di Enrico di Gand. A cura e con una Introduzione di Guido Alliney. Bari: Edizioni di Pagina, 2009, pp. 7-116.

. "La chimera e il girarrosto. Per una storia della libertà". In: TUGNOLI, C. (cur.). Libero arbitrio. Teorie e prassi della libertà. Napoli: Liguori, 2014, pp. 185-231.

AREZZO, A. "La felicità del teologo. Gloria, grazia e scienza in Enrico di Gand". In: BETTETINI, M., PAPARELLA, F. D. (ed.). Le felicità nel Medioevo. Atti del Convegno della Società italiana per lo studio del pensiero medievale (S.I.S.P.M.), Milano, 12-13 Settembre 2003. Louvain: FIDEM, 2005, pp. 41124.

. Lumen medium. Enrico di Gand e il dibattito sullo statuto scientifico della teologia. Bari: Edizioni di Pagina, 2014.

ARGOS, B. P. "La actividad cognoscitiva en los escolásticos del primer periodo postomista (1275-1320) - II/III”. Pensamiento 4 (1948), pp. 287-309.

ASHWORTH, E. J. “'Can I speak more clearly than I can understand?'. A problem of religious language in Henry of Ghent, Duns Scotus and Ockham". Historiographia linguistica 7.1-2 (1980), pp. 29-38.

BARDOUT, J.-C. Penser l'existence I. L'existence exposée. Époque médiévale. Paris: Vrin, 2013.

BARTH, T. "De tribus viis diversis existentiam divinam attingendi. Disquisitio histórico-collativa inter S. Thomam, Henricum Gandavensem, Duns Scotum". Antonianum 18 (1943), pp. 91-117. 
BARZAZI, A. "I servi di Maria dal cinque al seicento: tra antiche autonomie e centralizzazione romana". Studi storici dell'Ordine dei Servi di Maria 61-62 (2011-2012), pp. 453-88.

BAYERSCHMIDT, P. Die Seins- und Formmetaphysik des Heinrich von Gent in ihrer Anwendung auf die Christologie. Eine Philosophie- und Dogmengeschichte Studie. Münster: Aschendorff, 1941.

. "Die Stellungnahme des Heinrich von Gent zur Frage nach der Wesensgleichkeit der Seele Christi mit den übrigen Menschenseelen und der Kampf gegen den averroistischen Monopsychismus". In: AUER, J., VOLK, H. (Hrsg.). Theologie in Geschichte und Gegenwart. Michael Schmaus dargebracht von seinen Freunden und Schülern. München: Karl Zink, 1957, pp. 571-606.

BAZÀN, B. C., WIPPEL, J., FRANSEN, G., JACQUART, D. Les questions disputées et les questions quodlibétiques dans les facultés de théologie, de droit et de medicine. Turnhout: Brepols, 1985.

BEHA, H. M. "Matthew of Aquasparta's Theory of Cognition (preface and part I)". Franciscan Studies 20.3-4 (1960), pp. 161-204.

. "Matthew of Aquasparta's Theory of Cognition (part II)". Franciscan Studies 21.1-2 (1961), pp. 1-79.

"Matthew of Aquasparta's Theory of Cognition (part III and conclusions)". Franciscan Studies 21.3-4 (1961), pp. 383-465.

BELLEMARE, L. Les "Quaestiones super VIII libros Physicorum" attribuées à Henri de Gand. Étude sur l'authenticité de l'oeuvre. Étude et texte des Questions sur les livres I et II. 2 vols. Louvain: Université Catholique de Louvain, Institut Supérieur de Philosophie, 1964.

BELloso, J. M. R. La visión de Dios según Enrique de Gante. Barcelona: Seminario Conciliar - Editorial Casulleras, 1960.

. "Sobre el metòde teològic en Enric de Gand". Revista Catalana de Teologia 8 (1983), pp. 191-202. 1996.

. Introducción a la Teología. Madrid: Biblioteca de Autores Cristianos,

BERARDO, S. M. "Enrico di Gand ritorna all'Ordine dei Servi di Maria?". Il commune di Bologna 14.4 (1928), pp. 19-22.

BERNAU, A. "A Christian Corpus: Virginity, Violence, and Knwoledge in the Life of St Katherine of Alexandria". In: JENKINS, J., LEWIS, K. J. Katherine of Alexandria. Texts and Contexts in Western Medieval Europe. Turnhout: Brepols, 2003, pp. 109-30.

BÉRUBÉ, C. "La connaissance intellectuelle du singulier matériel au XIII siècle". Fransciscan Studies 11.3-4 (1951), pp. 157-201. 
. La connaissance de l'individuel au moyen âge. Préface de P. Vignaux. Montréal - Paris: Presses de l’Université de Montréal - PUF, 1964.

. "Henri de Gand et Matthieu d'Aquasparta interprètes de Bonaventure". Naturaleza y Gracia 21, 1-2 (1974), pp. 131-172.

. De l'homme à Dieu selon Duns Scot, Henri de Gand et Olivi. Roma: Edizioni Collegio S. Lorenzo, 1983.

. "Valérien Magni, héritier de Bonaventure, Henri de Gand et Jean Scot Erigène ou précurseur de E. Kant". Cuadernos salmantinos de filosofia 11 (1984), pp. 129-57.

BETTONI, E. Il processo astrattivo nella concezione di Enrico di Gand. Milano: Vita e Pensiero, 1954.

BEUMER, J. "Die Stellung Heinrichs von Gent zum theologischen Studium der Frau". Scholastik 32 (1957), pp. 81-5.

BIANCHI, L. Il vescovo e i filosofi. La condanna parigina del 1277 e l'evoluzione del'aristotelismo scolastico. Bergamo: Pierluigi Lubrina Editore, 1990.

. Pour une histoire de la “double vérité”. Paris: Vrin, 2008.

BIRD, O. "How to Read an Article of the 'Summa"”. The New Scholasticism 27.2 (1953), pp. 129-59.

BLAMIRES, A., MARX, C. W. "Woman Not to Preach: a Disputation in Britisch Library MS Harley 31". The Journal of Medieval Latin 3 (1993), pp. 34-63.

BOLZANI, R. "Acadêmicos versus Pirrônicos: Ceticismo Antigo e Filosofia Moderna”. Discurso 29 (1998), pp. 57-110. . Acadêmicos versus Pirrônicos. São Paulo: Alameda, 2013.

BORING, W. P. "Revising ou Approach to 'Augustinian Illumination'. A Reconsideration of Bonaventure's Quaestiones disputatae de scientia Christi IV, Aquinas's Summa theologiae Ia. 84, 1-8, and Henry of Ghent's Summa quaestionum ordinariarum, q. 2, art. 1, 2 [sic]”. Franciscan Studies 68 (2010), pp. 38-81.

BOULNOIS, O. Etre et représentation. Une généalogie de la métaphysique moderne à l'époque de Duns Scot (XIII $\left.-X I V^{e}\right)$. Paris: PUF, 1999.

. "Abstractio metaphysica. Le séparable et le séparé, de Porphyre à Henri de Gand". In: PICKAVÉ, M. (Hrsg.). Die Logik der Transzendentalen. Festschrift für Jan A. Aertsen zum 65. Geburtstag. Berlin - New York: Walter de Gruyter, 2003, pp. 37-59.

. "Ego ou cogito? Doute, tromperie divine et certitude de soi du XIV au $\mathrm{XVI}^{\mathrm{e}}$ siècles". In: BOULNOIS, O. (éd.). Généalogies du sujet de saint Anselme à Malebranche. Paris: Vrin, 2007, pp. 171-213. 
. Métaphysiques rebelles. Genèse et structures d'une Science au Moyen Âge. Paris: PUF, 2013.

BOUREAU, A. "Propositions pour une histoire restreinte des mentalités". Annales. Économies, Sociétés, Civilisations. 44.6 (1989), pp. 1491-504.

. "Droit et théologie au XIII ${ }^{\mathrm{e}}$ siècle". Annales. Économies, Sociétés, Civilisations. 47.6 (1992), pp. 1113-25.

. "La redécouverte de l'autonomie du corps: l'émergence du somnambule (XIIe-XIVe s.)”. Micrologus 1 (1993), pp. 27-42.

. "L'immaculée conception de la souverainété. Jean Baconthorpe et la théologie politique (1325-1345). (Postille sur Bernard Guenée, Entre l'Eglise et l'Etat, p. 189-201)". In: AUTRAND, F., GAUVARD, C., MOEGLIN, J.-M. (éds.). Saint-Denis et la royauté. Études offertes à Bernard Guenée. Paris: Publications de Sorbonne, Paris, 1999, pp. 733-749.

. Théologie, science et censure au XIII siècle. Le cas de Jean Peckham. Paris: Les Belles Lettres, $2008^{2}$ [1999].

. "L'immaculée conception de la souverainété. Jean Baconthorpe et la théologie politique (1325-1345). (Postille sur Bernard Guenée, Entre l'Eglise et l'Etat, p. 189-201)". In: AUTRAND, F., GAUVARD, C., MOEGLIN, J.-M. (éds.). Saint-Denis et la royauté. Études offertes à Bernard Guenée. Paris: Publications de Sorbonne, Paris, 1999, pp. 733-749.

BOURGEOIS, R. "La théorie de la connaissance intellectuelle chez Henri de Gand". Revue de philosophie 8 (1936), pp. 238-59.

. 'Une métaphysique de l'intelligible. La doctrine d'Henri de Gand selon M. J. Paulus". Révue de Philosophie 39 (1939), pp. 143-57.

BRANDARIZ, F. La Teología como ciencia según Enrique de Gante. Extracto de la tesis doctoral: "La ciencia Teológica y sus relaciones con las demás ciencias, según Enrique de Gante y sus contemporâneos (Parte 2a , caps. 1-4)". Madrid: Estudios Eclesiasticos, 1948 [=Estudios eclesiásticos 22 (1948), pp. 5-57].

. "La teologia en relación con las demás ciencias según Enrique de Gante". Miscelanea comillas 19 (1953), pp. 165-204.

BRAUN, R. Die Erkenntnislehre Heinrichs von Gent. Freiburg: Komminssionsverlag der Universitäts-Buchhandlung, 1916.

BROWER-TOLAND, S. "Instantaneous Change and the Physics of Sanctification. 'Quasi-Aristotelianism' in Henry of Ghent's Quodlibet XV, q. 13'. Journal of the History of Philosophy 40 (2002), pp. 19-46.

BROWN, J. V. Divine Illumination and the Theory of Knowledge in the Philosophy of Henry of Ghent. A thesis submitted in conformity with the requirements for the degree of Doctor of Philosophy in the University of Toronto, 1969. 
. "Sensation in Henry of Ghent: A late medieval Aristotelian-Augustinian synthesis". Archiv für Geschichte der Philosophie 53 (1971), pp. 238-266.

. "Henry of Ghent on Internal Sensation". Journal of the History of Philosophy 10 (1972), pp. 15-28.

. "Abstraction and the Object of the Human Intellect according to Henry of Ghent". Vivarium 11.1 (1973), pp. 80-104.

. "Divine Illumination in Henry of Ghent". Recherches de théologie ancienne et médiévale 41 (1974), pp. 177-99.

. "Intellect and Knowing in Henry of Ghent". Tijdschrift voor Filosofie 37.3-4 (1975), pp. 490-512, 692-710.

“John Duns Scotus on Henry of Ghent's Arguments for Divine Illumination: The Statement of the Case". Vivarium 14.2 (1976), pp. 94-113.

. "John Duns Scotus on Henry of Ghent's Theory of Knowledge". The Modern Schoolman 56.1 (1978), pp. 1-29.

. "The meaning of notitia in Henry of Ghent". In: KLUXEN, W. (Hrsg). Sprache und Erkenntnis im Mittelalter. Akten des VI. Internationalen Kongresses für mittelalterliche Philosophie der Société Internationale pour l'Étude de la Philosophie Médiévale. 29. August-3. September 1977 in Bonn. Berlin - New York, 1981, pp. 992-8.

. "The knowledge proper to the separated soul: Henry of Ghent and John Duns Scotus”. Franzikanische Studien 66 (1984), pp. 316-34.

"Henry's Theory of Knowledge: Henry of Ghent on Avicenna and Augustine". In: VANHAMEL, W. (ed.). Henry of Ghent. Proceedings..., 1996, pp. 19-42.

BROWN, S. F. "Avicenna and the Unity of the Concept of Being: the Interpretations of Henry of Ghent, Duns Scotus, Gerard of Bologna and Perter Aureoli". Franciscan Studies 25 (1965), pp. 117-50.

. "Henry of Ghent (b. ca. 1217; d. 1293)". In: GRACIA, J. E. (ed.). Individuation in Scholasticism. The Later Middle Ages and the CounterReformation, 1150-1650. Albany: State University of New York Press, 1994, pp. 195-219.

. "Henry of Ghent's 'De reductione artium ad theologiam"'. In: GALlAGHER, D. H. (ed.). Thomas Aquinas and His Legacy. Washington D.C.: The Catholic University of America Press, 1994, pp. 194-206.

. "Godfrey of Fontaines and Henry of Ghent: Individuation and the Condamnations of 1277”. In: WŁODEK, S. (éd.). Société et église. Textes et discussions dans les universités d'Europe centrale pendant le moyen âge tardif. Actes du Colloque international de Cracovie 14-16 juin 1993 organisé para la SIEPM. Turnhout: Brepols, 1995, pp. 193-207. 
. "Theology and Philosophy". In: MANTELlo, F. A. C., RIGG, A. G. (eds.). Medieval Latin. An Introduction and Bibliographical Guide. Washington, D.C.: The Catholic University of America Press, 1996, pp. 267-87.

. “Duo Candelabra Parisiensia: Prosper of Reggio in Emilia's Portrait of the Enduring Presence of Henry of Ghent and Godfrey of Fontaines regarding the Nature of Theological Study". In: AERTSEN, J. A., EMERY Jr., K., SPEER, A. (Hrsg.). Nach der Verurteilung von 1277. Philosophie und Theologie an der Unversität von Paris in letzten Viertel des 13. Jahrhunderts. Studien und Texte. Berlin - New York: De Gruyter, 2001, pp. 320-56.

CAFFARENA, J. G. “Cronología de la 'Suma' de Enrique de Gante por relación a sus 'Quodlibetos"'. Gregorianum 38 (1957), pp. 116-133.

Ser participado y ser subsistente en la metafisica de Enrique de Gante. Romae: apud Aedes Universitatis Gregorianae, 1958.

. "Metafísica de la inquietud humana en Enrique de Gante". In: L'homme et son destin d'après les penseurs du Moyen Âge. Louvain - Paris: Nauwelaerts - Béatrice-Nauwelaerts, 1960, pp. 629-34.

CANGUILHEM, G. La connaissance de la vie. Paris: Vrin, 2009 [1965]. . Le normal et le pathologique. Paris: PUF, $2013^{12}$ [1966].

CANNIZZO, G. "La dottrina del 'verbum mentis' in Enrico di Gand". Rivista di Filosofia Neo-scolastica 54 (1962), pp. 243-66.

CARVAlHO, M. A. S. "Sentido e alcance do pensamento de Henrique de Gand. Explicação da nona questão do Quodlibet I: a relação essência / existência". Mediaevalia. Textos e estudos 3 (1993), pp. 161-205.

. "Introdução". In: HENRIQUE DE GAND. Sobre a metafisica do ser no tempo: questões quodlibéticas I, 7/8-9 e 10. Tr., intr. e notas de M. S. de Carvalho. Pref. e restabelecimento crítico do texto latino de R. Macken. Lisboa: Edições 70, 1996, pp. 11-94.

. "A essência da matéria prima em Averróis latino (com uma referência a Henrique de Gand)". Revista Portuguesa de Filosofia 52 (1996), pp. 197-221.

. "The Problem of the Possible Eternity of the World according to Henry of Ghent and his Historians". In: VANHAMEL, W. (ed.). Henry of Ghent. Proceedings..., 1996, pp. 43-70.

. "La pensée d'Henri de Gand avant 1276: les erreurs concernant la création du monde d'après la 'Lectura ordinaria super sacram scripturam". Recherches de théologie ancienne et médiévale 63 (1996), pp. 36-67.

. "Sobre o Projecto do Tractactus de productione creaturae de Henrique de Gand". Mediaevalia. Textos e estudos 11-12 (1997), pp. 211-30. 
. "O que significa pensar? Henrique de Gand em 1286 e os horizontes da temática monopsiquista: 'contra fundamenta Aristotelis'?". Revista filosófica de Coimbra 19 (2001), pp. 69-92.

- "Para a história da possibilidade e da liberdade. João Duns Escoto, Guilherme de Ockham e Henrique de Gand". CARVALHO, M. A. S. Estudos sobre Álvaro Pais e outros franciscanos (séculos XIII-XIV). Lisboa: Imprensa Nacional - Casa Moeda, 2001, pp. 173-216 [ = Itinerarium 40 (1994), pp. 14580].

A Novidade do Mundo. Henrique de Gand e a Metafísica da Temporalidade no Século XIII. Coimbra: Fundação Calouste Gulbenkian Fundação para a Ciência e a Tecnologia, 2001.

. "O argumento antropológico. Henrique de Gand e Santo Anselmo. In memoriam intentionemque Raymundi Macken (†2008)". Philosophica 34 (2009), pp. 293-308.

. "Augustinismo e aristotelismo em Henrique de Gand". In: CARVALHO, M. S. de. O problema da habitação. Estudos de (história da) filosofia. Colibri Faculdade de Letras da Universidade de Coimbra, Coimbra, 2002, pp. 137-192.

CHARBONEAU, D. M. "The Servites of Barcelona”. Studi storici dell'Ordine dei Servi di Maria 30 (1980), pp. 5-87.

CHOSSAT, M. "Dieu (sa nature selon les scolastiques)". In: Dictionnaire de Théologie Catholique. Tome 4. Paris: Letouzey e Ané Éditeurs, 1911, cols. 1152-1243.

COLLI, A. "Ab utroque notitia paritur. Il De trinitate e il processo asttrativo aristotelico tra XIII e XIV secolo". Medioevo 37 (2012), pp. 231-59.

CONNOLLY, P. J. "Henry of Ghent's Argument for Divine Illumination Reconsidered". American Catholic Philosophical Quarterly 89.1 (2015), pp. 4768 .

COPLESTON, F. A History of Philosophy. Vol. II: Medieval Philosophy, from Augustine to Duns Scotus. New York: Doubleday, 1993 [1950].

CORDONIER, V. 'Une lecture critique de la théologie d'Aristote: le Quodlibet VI, 10 d'Henri de Gand comme réponse à Gilles de Rome". In: CORDONIER, V., SUAREZ-NANI, T. (éds.). L'aristotélisme exposé, 2014, pp. 83-180.

CORDONIER, V., SUAREZ-NANI, T. (éds.). L'aristotélisme exposé. Aspects $d u$ débat philosophique entre Henri de Gand et Gilles de Rome. Fribourg: Academic Press Fribourg, 2014.

CÔTÉ, A. L'infinité divine dans la théologie médiévale (1220-1255). Paris: Vrin, 2002

. "Siger and the Skeptic". The Review of Metaphysics 60.2 (2006), pp. 305- 
COUNET, J.-M. "Henri de Gand: la prudence dans ses rapport aux vertus morales". In: GULDENTOPS, G., STELL, C. (eds.). Henry of Ghent and the Transformation..., 2003, pp. 227-240.

COURTINE, J.-F. “Res”. In: Historisches Wörterbuch der Philosophie. Bd. 8. Basel: Schwabe \& Co., 1992, cols. 892-901.

CROSS, R. The Physics of Duns Scotus. The Scientific Context of a Theological Vision. Oxford: Oxford University Press, 1998.

- "Incarnation, Indwelling, and the Vision of God: Henry of Ghent and Some Franciscans" Franciscan Studies 57 (1999), pp. 79-130.

. "Henry of Ghent on the Reality of Non-Existing Possibles - Revisited". Archiv für Geschichte der Philosophie 92 (2010), pp. 115-32.

CUNNINGHAM, F. A. "Some presuppositions in Henry of Ghent". Pensamiento 25 (1969), pp. 103-43.

DANIELS, A. Quellenbeiträge und Untersuchungen xur Geschichte der Gottesbeweise im dreizehnten Jahrhundert mit besonderer Berücksichtigung des Arguments im Prologion des hl. Anselm. Münster: Aschendorf, 1909.

DAVENPORT, A. A. Measure of a Different Greatness. The Intensive Infinite, 12501650. Leiden - Boston - Köln, 1999.

DE RIJK, L. M. “Un tournant important dans l'usage du mot idea chez Henri de Gand". In: FATTORI, M., BIANCHI, M. L. (ed.). Idea. VI Colloquio Internazionale 'Lessico Intellettuale Europeo'. Roma, 5-7 gennaio 1989. Roma: Ateneo, 1990, pp. 89-98.

DECORTE, J. Een avicenniserend augustinisme: metafysica, wilspsychologie en vrijheidleer bij Hendrik van Gent. Tekstkritische uitgave: Henrici de Gandavo, Quodlibet XIII, qq. 1-12. 2 delen. Leuven: Katholiek Universiteit Leuven, Hoger Instituut voor Wijsbegeerte, 1983.

. "Der Einfluß der Willenspsychologie des Walter von Brugge ofm auf die Willenspsychologie und Freiheitslehre des Heinrich von Gent". Franziskanische Studien 65 (1983), pp. 215-40.

. "Thomas Aquinas and Henry of Ghent on God's Relation to the World". Mediaevalia. Textos e estudos 3 (1993), pp. 91-107.

. "Naar zijn beeld en gelijkenis: de ziel". STOFFERS, M. (red.). De middeleeuwse ideeënwereld, 1000-1300. Heerlen - Hilversum: Open universiteit - Verloren, 1994, pp. 201-232.

. "Henry of Ghent on Analogy. Critical Reflections on Jean Paulus' Interpretation". In: VANHAMEL, W. (ed.). Henry of Ghent. Proceedings..., 1996, pp. 71-105. 
. "Aristotelian Sources in Henry of Ghent". In: VANHAMEL, W. (ed.). Henry of Ghent. Proceedings..., 1996, pp. 107-120.

"Heinrich von Gent: Von einer Ontologie der Relation zur Relationsontologie". In: KOBUSCH, T. (Hrsg.). Philosophen des Mittelalters. Eine Einführung. Darmstadt: Primus, 2000, pp. 152-66 [trad. para o português: "Henrique de Gândavo - De uma ontologia da relação a um ontologia relacional". In: KOBUSCH, T. (org.). Filósofos da Idade Média. Uma Introdução. Trad. de Paulo Astor Soethe. São Leopoldo: Editora Unisinos, 2000, pp. 206-24].

. "Henri de Gand et la définition classique de vérité". Recherches de théologie et philosophie médiévales 68.1 (2001), pp. 34-74

DELMAIRE, B. "Les béguines dans le Nord de la France au premier siècle de leur histoire (vers 1230 - vers 1350)". In: PARISSE, M. (dir.). Les religieuses en France au XIII $I^{e}$ siècle. Table ronde organisée par l'Institut d'Études Médiévales de l'Université de Nancy II et le C.E.R.C.O.M., 25-26 juin 1983. Nancy: Presses Universitaires de Nancy, 1989, pp. 121-62.

DEMANGE, D. Jean Duns Scot. La théorie du savoir. Paris: Vrin, 2007.

. "Introduction". In: HENRI DE GAND. Sur la possibilité de la connaissance humaine. Textes latin introduits, traduits et annotés par D. Demange. Paris: Vrin, 2013, pp. 7-51.

DONDAINE, H. F. "L'objet et le 'medium' de la visium béatifique chez les théologiens du XIII ${ }^{\mathrm{e}}$ siècle". Recherches de théologie ancienne et médiévale 19 (1952), pp. 60-130.

DOYLE, P. J. "Between Transcendental and Transcendental: the Missing Link?". The Review of Metaphysics 50 (1997), pp. 783-815.

. "Supertranscendental Nothing: a Philosophical Finisterre". Medioevo 24 (1998), pp. 1-30.

DUBA, W. O. Seeing God: Theology, Beatitude and Cognition in the Thirteenth Century. A thesis submitted in partial fulfillment of the requirements for the Doctor of Philosophy degree in History in the Graduate College of the University of Iowa. May, 2006.

DUBRULE, D. E. Divine Infinity in the Writings of Henry of Ghent. A Thesis Submitted in Conformity with the Requirements for the Degree of Doctor of Philosophy in the University of Toronto, 1968.

DUDAK, K. “Zarys problematyki poznawczej w Summae quaestionum Henryka z Gandawy”. Roczniki filozoficzne 11.1 (1963), pp. 113-35.

. “Czy Henryk z Gandawy był esencjalistą?” Roczniki Filozoficzne. 14.1 (1966), pp. 34-41. 
DUIN, J. J. "La bibliothèque philosophique de Godefroid de Fontaines". Studia Lulliana 3 (1959), pp. 21-36, 137-60.

DUMONT, S. D. Henry of Ghent as a Source for John Duns Scotus's Proof for the Existence of God. Centre for Medieval Studies. A thesis submitted in conformity with the requirements for the Degree of Doctor of Philosophy in the University of Toronto, 1982.

. "Time, Contradiction and Freedom of the Will". Documenti e studi sulla filosofia medievale 3.2 (1992), pp. 561-597.

DWYER, E. Die Wissenschaftslehre Heinrichs von Gent. Inaugural-Dissertation verfasst und der hohen Philosophischen Fakultät der Bayer. Julius-MaximiliansUniversität Würzburg zur Erlängung der Doktorwürde. Würzburg: Rita-Verlag und Druckerei, 1933.

EARDLEY, P. S. "The Problem of Moral Weakness, the propositio magistralis, and the Condemnation of 1277'. Mediaeval Studies 68 (2006), pp. 161-203.

. "Conceptions of Happiness and Human Destiny in the Late Thirteenth Century”. Vivarium 44.2-3 (2006), pp. 276-304.

. "The Foundations of Freedom in Later Medieval Philosophy: Giles of Rome and his Contemporaries". Journal of the History of Philosophy 44.3 (2006), pp. 353-76.

EDELHEIT, A. "The 'Scholastic' Theology of Giovanni Pico della Mirandola: between Biblical Faith and Academic Skepticism". Recherches de théologie et philosophie médiévales 74.2 (2007), pp. 523-70 [cf. esp. p. 535, nota 23].

. "Henry of Ghent and Giovanni Pico della Mirandola: A Chapter on the Reception and Influence of Scholasticism in the Renaissance”. In: WILSON, G. A. (ed.). A Companion to Henry of Ghent, 2011, pp. 369-97.

EMERY Jr., K. "The Image of God Deep in the Mind: The Continuity of Cogntion according to Henry of Ghent". In: AERTSEN, J. A., EMERY Jr., K., SPEER, A. (Hrsg.). Nach der Verurteilung von 1277. Philosophie und Theologie an der Unversität von Paris in letzten Viertel des 13. Jahrhunderts. Studien und Texte. Berlin - New York: De Gruyter, 2001, pp. 59-124.

EHRLE, F. "Beiträge zu den Biographien berühmter Scholastiker. 1. Heinrich von Gent". Archiv für Litteratur- und Kirchegeschichte des Mittelalters 1 (1885), pp. 365-401 [trad. francesa: Recherches critiques sur la biographie de Henri de Gand, dit le docteur solennel. Trad. par J. Raskop. Tournai: Casterman, 1887].

FAUCHER, N. "La connaissance des objets de foi chez Henri de Gand, entre infusion, raisonnement et illumination". Quaestio 14 (2014), pp. 273-98.

FELD, A. N. Melancholy and the Othernesse of God. A Study of the Hermeneutics of Depression. Foreword by M. L. Raposa. Plymouth: Lexignton, 2011. 
FERNÁNDEZ, C. J. "Guilherme de Ockham: contra a Ideia como exemplar". Discurso 40 (2010), pp. 183-206.

FEYERABEND, P. Agains Method. Introduced by Ian Hacking. London - New York: Verso, $2010^{4}$ [1975].

FIORAVANTI, G. "Forma ed esse in Enrico di Gand: preoccupazioni teologiche ed elaborazione filosofica". Annali della scuola normale superiore di Pisa. Classe di Lettere e Filosofia, serie 3, 5.3 (1975), pp. 985-1031.

FIORENTINO, F. "Species nei secoli XIII-XIV”. Mediaevalia. Textos e estudos 26 (2007), pp. 81-135.

. Conoscenza scientifica e teologia fra XIII e XIV secolo. Bari: Edizione di Pagina, 2014.

FLORES, J. C. "Intellect and Will as Natural Principles". In: GULDENTOPS, G., STEEL, C. (eds.), Henry of Ghent and the Transformation..., 2003, pp. 277-305.

. Henry of Ghent: Metaphysics and the Trinity. Leuven: Leuven University Press, 2006.

. "The Roots of Love of Wisdom: Henry of Ghent on Platonic and Aristotelian Forms". In: EMERY Jr., K., FRIEDMAN, R. L., SPEER, A. (eds.). Philosophy and Theology in the Long Middle Ages. A Tribute to Stephen F. Brown. Leiden - Boston: Brill, 2011, pp. 623-640.

FOLGER-FANFARA, S. Das 'Super'-Transzendentale und die Spaltung der Metaphysik. Der Entwurf des Franziskus von Marchia. Leiden - Boston: Brill, 2008.

FOUCAULT, M. Les mots et les choses. Une archéologie des sciences humaines. Paris: Gallimard, 1966.

. Les anormaux. Cours au Collège de France. 1974-1975. Paris: Éditions du Seuil, 1999.

FREITAS, E. de., SINCLAIR, N. Mathematics and the Body. Material Entanglements in the Classroom. Cambridge: Cambridge University Press, 2014.

FRIEDMAN, R. L. "Relations, Emanations, and Henry of Ghent's use of the "verbum mentis' in Trinitarian Theology". Documenti e study sulla tradition filosofica medievale 7 (1996), pp. 131-82.

In principio erat verbum: the Incorporation of Philosophical Psychology into Trinitarian Theology, 1250-1325. 2 vols. A thesis submitted in partial fulfillment of the requirements for the Doctor of Philosophy degree in History in the Graduate College of The University of Iowa. May 1997.

. "Divergent Traditions in Later-Medieval Trinitarian Theology: Relations, Emanations, and the Use of Philosophical Psychology, 1250-1325". Studia Theologica 53 (1999), pp. 13-25. 
. Intellectual Traditions at the Medieval University. The Use of Philosophical Psychology in Trinitarian Theology among the Franciscans and Dominicans, 1250-1350. 2 vols. Leiden - Boston: Brill, 2013.

FÜHRER, M. "Henry of Ghent on Divine Illumination". Bochumer Philosophisches Jahrbuch für Antike und Mittelalter 3 (1998), pp. 69-85.

GABRIEL, A. L. "The Ideal Master of the Mediaeval Philosophy”. The Catholic Historical Review 60.1 (1974), pp. 1-40.

GARCEAU, B. Judicium. Vocabulaire, sources, doctrine de saint Thomas d'Aquin. Montréal - Paris: Institut d'études médiévales - Vrin, 1968.

GELISSEN, M. G. H. Natuur en Genade volgens Hendrik van Gent. 2 delen. Excerpta ex dissertatione ad Lauream in Facultate Theologica Pontificiae Universitatis Gregorianae. Tilburg: Henri Bergmans, 1965.

GENSLER, M. "Fides et ratio. Wiara a rozum w 'kwodlibetach' Henryka z Gandawy". Studia Warmińskie 37 (2000), pp. 141-50.

GERANDO, J.-M. de Histoire comparée des systèmes de philosophie. Tome IV. Paris: Eymery - Rey et Gravier - Aillau, $1825^{2}$ [1822].

GILBERT, N. W. Renaissance Concepts of Method. New York - London: Columbia University Press, $1963^{2}$ [1960].

GILSON, É. La philosophie au moyen âge. 2 vols. Paris: Payot, 1922.

. "Pourquoi saint Thomas a critiqué saint Augustin". Archives d'histoire doctrinale et littéraire du moyen âge (1926-7), pp. 5-127.

. "Les sources gréco-arabe de l'augustinisme avicennisant". Archives d'histoire doctrinale et littéraire du moyen âge (1929-30), pp. 5-149.

. "Roger Marston: un cas d'Augustinisme avicennisant". Archives d'histoire doctrinale et littéraire du moyen âge (1933), pp. 37-42.

. "Sur quelques difficultés de l'illumination augustinienne". Revue néoscolastique de philosophie 36 (1934), pp. 321-31.

. Le réalisme méthodique. Paris: Téqui, $2007^{2}$ [1935].

$1999^{2}$ [1937].

. La philosophie au moyen âge. Paris: Payot, $2011^{5}$ [1944²].

. L'être et l'essence. Paris: Vrin, 2008 ${ }^{3}$ [1948] [trad. para o português: GILSON, É. O ser e a essência. Trad. de C. E. de Oliveira, C. N. A. Ayoub, J. M. Madureira, L. M. da Silva Filho, P. C. Ferreira Filho, T. J. R. Leme. São Paulo: Paulus, 2016]. 
. Being and some philosophers. Toronto: Pontifical Institute of Mediaeval Studies, $1949\left[1952^{2}\right]$.

. Jean Duns Scot. Introduction à ses positions fondamentales. Paris: Vrin, $2005^{2}$ [1952].

. "L’infinité divine chez saint Augustin”. In: Augustinus magister. Congrès international augustinien. Paris, 21-24 septembre 1954. Vol. 1. Paris: Études Augustiniennes, 1954, pp. 569-74.

. History of Christian Philosophy in the Middle Ages. New York: Random House, 1955.

. "French and Italian Philosophy". In: GILSON, É., LANGAN, T., MAURER, A. (eds.). Recent Philosophy. Hegel to the Present. Vol. 1. Eugene: Wipf and Stock, 1966, pp. 169-373.

GLORIEUX, P. La littérature quodlibétique de 1260 à 1320. Kain: Revue des sciences philosophiques et théologiques, 1925.

. La littérature quodlibétique II. Paris: Vrin, 1935.

GOEHRING, B. Henry of Ghent on cognition and mental representation. A dissertation presented to the Faculty of the Graduate School of Cornell University in partial fulfillment of the requirement for the Degree of Doctor of Philosophy. August, 2006.

. "Henry of Ghent on the verbum mentis". In: GORDON, A companion to Henry of Ghent, 2011, pp. 241-72.

. "Henry of Ghent on Human Knowledge and Its Limits". Quaestio 12 (2012), pp. 589-613.

. 'Henry of Ghent's Use of Aristotle's De anima in Developing his Theory of Cognition". In: FRIEDMAN, R. L., COUNET, J.-M. (éds.). Medieval Perspectives on Aristotle's De anima. Louvain-la-Neuve - Louvain-ParisWalpole: Éditions de l'Institut Supérieur de Philosophie - Peeters, 2013, pp. 6399.

GOGACZ, M. "Czy według Henryka z Gandawy jest możliwe poznanie czystej prawdy bez pomocy oświecenia”. Roczniki Filozoficzne 8.1 (1960), pp. 161-71.

. Problem istnienia Boga u Anselma z Canterbury $i$ problem prawdy $u$ Henryka $z$ Gandawy. Lublin: Towarzystwo Naukowe Katolickiego Uniwersytetu Lubelskiego, 1961.

. “Chrześcijańska wartość osoby ludzkiej”. Collectanea Theologica 39.2 (1969), pp. 85-90.

GOICOECHEA Y VITERI, J. M. Doctrina mariana de Enrique de Gante [tese de doutorado apresentada ao Pontificio Ateneo Antoniano]. Lima: Scheuch, 1944. 
GOLDSCHMIDT, V. “Tempo histórico e tempo lógico na interpretação dos sistemas filosóficos". In: GOLDSCHMIDT, V. A religião de Platão. Prefácio introdutório de Oswaldo Porchat Pereira. Tradução de Ieda e Oswaldo Porchat Pereira. São Paulo: Difusão Europeia do Livro, $1970^{2}$, pp. 139-147. A publicação do artigo original, em francês, foi em 1953.

GORIS, W. "Die Kritik des Bernhard von Trilia an der Lehre von Gott als Ersterkanntem". Recherches de théologie et philosophie médiévales 65.2 (1998), pp. 248-319.

. "Heinrich von Gent und der mittelalterliche Vorstoß zu einem Ausgand vom Unbedingten". In: GULDENTOPS, G., STEEL, C. (eds.), Henry of Ghent and the Transformation..., 2003, pp. 61-74.

. Absolute beginners. Der mittelalterliche Beitrag zu einem Ausgang vom Unbedingten. Leinden - Boston: Brill, 2007.

. "Two-Staged Doctrines of God as First Known and the Transformation of the Concept of Reality in Bonaventure and Henry of Ghent". American Catholic Philosophical Quarterly 85.1 (2011), pp. 77-97.

. "De magistro - Thomas Aquinas, Henry of Ghent, and John Duns Scotus on Natural Conceptions”. The Review of Metaphysics 66 (2013), pp. 435-468.

GORIS, W., PICKAVÉ, M. "Von der Erkenntnis der Engel. Der Streit um die species intelligibilis und eine quaestio aus dem anonymen Sentenzenkommentar in ms. Brügge, Stadsbibliotheek 491”. In: AERTSEN, J. A., EMERY Jr., K., SPEER, A. (Hrsg.). Nach der Verurteilung von 1277. Philosophie und Theologie an der Unversität von Paris in letzten Viertel des 13. Jahrhunderts. Studien und Texte. Berlin - New York: De Gruyter, 2001, pp. 125-77.

GRABMANN, M. Die Geschichte der scholastischen Methode. Erster Band. Freiburg im Breisgau, Herdersche Verlagshandlung, 1909.

Mittelalterliche lateinische Aristotelesübersetzungen und Aristoteleskommentare in Handschriften spanischer Bibliotheken. München: Verlag der Bayerischen Akademie der Wissenschaften, 1928 [= In: GRABMANN, M. Gesammelte Akademieabhandlungen. 2 vols. Hrsg. Von Grabmann-Institut der Universität München. Einleitung von Michael Schmaus. Verzeichnis der benutzten Handschriften, Personen-, Orts- und Sachregister von Christoph Heitmann. Paderborn - München - Wien - Zürich: Schöningh, 1979, vol. 1, pp. 383-496].

. "Des heiligen Augustinus Quaestio de Ideis (De diversis quaestionibus LXXXIII qu. 46) in ihrer inhaltlichen Bedeutung und mittelalterlichen Weiterwirkung". In: GRABMANN, M. Mittelalterlichen Geistesleben. Abhandlungen zur Geschichte der Scholastik und Mystik. Bd. II. München: Max Hueber, 1936, pp. 25-34 (esp. pp. 32-3) [= Philosophisches Jahrhundert 43 (1930), pp. 297-307] [trad. para o português em: GRABMANN, M. "A quaestio de ideis de Santo Agostinho: seu significado e sua repercussão medieval". Trad. M. Novaes, C. R. Cezar, M. Sattin. Cadernos CEPAME 2.1 (1993), pp. 29-41). 
GRELLARD, C. "Comment peut-on se fier à l'exprérience? Esquisse d'une typologie des réponses médiévales au problème sceptique". Quaestio 4 (2004), pp. 11335 .

- Croire et savoir. Les principes de la connaissance selon Nicolas d'Autrecourt. Paris: Vrin, 2005.

. "Scepticism, Demonstration and the Infinite Regress Argument (Nicholas of Autrecourt and John Buridan)". Vivarium 45 (2007), pp. 328-42.

. "Do arquétipo à ficção: a ambivalência da ideia em João de Salisbury". Discurso 40 (2010), pp. 45-70.

. “Academicus”. In: ATUCHA, I., CALMA, D., KÖNIG-PRALONG, C., ZAVATTERO, I. (éds.). Mots médiévaux offerts à Ruedi Imbach. Porto: FIDEM, 2011, pp. 11-21.

GRONDEUX, A. "Res Meaning a Thing of Thought: The Influence of the Ars donati”. Vivarium 45 (2007), pp. 189-202.

GUERIZOLI, R. “Au-delà de la scientia transcendens? Le cas Henri de Gand”. In: PICH, R. H. (ed.). New Essays on Metaphysics as Scientia Transcendens. Proceedings of the second International Conference of Medieval Philosophy, held at the Pontifical Catholic University of Rio Grande do Sul (PUCRS), Porto Alegre / Brazil, 15-18 August, 2006. Louvain-la-Neuve: FIDEM, 2007, pp. 6989.

. "Sobre a refundação tardomedieval da metafísica. Os motivos de Henrique de Gand”. Discurso 40 (2010), pp. 207-36.

GULDENTOPS, G., STEEL, C. (eds.). Henry of Ghent and the Transformation of Scholastic Thought. Leuven: Leuven University Press, 2003.

HABERMAS, J. Der philosophische Diskurs der Moderne. Zwölf Vorlesungen. Frankfurt am Main: Suhrkamp, 1988.

HAGEMANN, G. De Henrici de Gandavo quem vocant ontologismo. I. Monasterii Guestfalorum: ex Typographia Ioannis Bredt, 1898.

. De Henrici de Gandavo quem vocant ontologismo. II. Monasterii Guestfalorum: ex Typographia Ioannis Bredt, 1898-1899.

HAMESSE, J. "Res chez les auteurs philosophiques des $12^{\mathrm{e}}$ et $13^{\mathrm{e}}$ siècles". In: FATTORI, M., BIANCHI, M. (ed.). Res. III Colloquio Internazionale. Roma, 79 gennaio 1980. Firenze: Olschki, 1982, pp. 91-104.

. "Imaginatio et phantasia chez les auteurs philosophiques du $12^{\mathrm{e}}$ et du $13^{\mathrm{e}}$ siècle". In: FATTORI, M., BIANCHI, M. L. (ed.). Phantasia-Imaginatio. V Colloquio Internazionale. Roma, 9-11 gennaio 1986. Roma: Edizioni dell'Ateneo, 1988, pp. 153-84. 
. "Idea chez les auteurs philosophiques des $12^{\mathrm{e}}$ et $13^{\mathrm{e}}$ siècles". In: FATTORI, M., BIANCHI, M. L. (ed.). Idea. VI Colloquio Internazionale. Roma, 5-7 gennaio 1989. Roma: Edizioni dell'Ateneo, 1990, pp. 99-135.

HAMILTON-BLEAKLEY, H. "John of Paris, Henry of Ghent, and the Will as a Rational Appetite". In: JONES, C. (ed.). John of Paris: Beyond Royal and Papal Power. Turnhout: Brepols, 2015, pp. 193-221.

HARRIS, C. R. S. Duns Scotus. Vol. 1: The Place of Duns Scotus in Medieval Thought. New York: The Humanities Press, 1959 [1927].

HEIDEGGER, M. Die Kategorien- und Bedeutungslehre des Duns Scotus. Tübingen: J. C. B. Mohr (Paul Siebeck), 1916.

HIPP, S. A. "Existential Relation as Principle of Individuation". The Thomist 72 (2008), pp. 67-106.

HOCEDEZ, E. Richard de Middleton. Sa vie, ses oeuvres, sa doctrine. Louvain Paris: "Spicilegium sacrum lovainiense" bureaux - Champion, 1925.

. "Gilles de Rome et Henri de Gand sur la distinction réelle (1276-1287)". Gregorianum 8 (1927), pp. 358-84.

. "Deux questions touchant la distinction réelle entre l'essence et l'existence". Gregorianum 10 (1929), pp. 365-86.

HÖDL, L. "Neue Nachrichten über die Pariser Verurteilungen der thomasischen Formlehre". Scholastik 39 (1964), pp. 178-96.

. 'Die 'doppelte Wahrheit' vom Unendlichen in den Quaestiones ordinariae (Summa) des Heinrich von Gent”. Mediaevalia. Textos e estudos 3 (1993), pp. 55-75.

. "Der Begriff der göttlichen Unendlichkeit in der Summa des Heinrich von Gent (†1293)”. In: CRAEMER-RUEGENBERG, I., SPEER, A. (Hrsg.). Scientia und ars im Hoch- und Spätmittelalter. Berlin - New York: De Gruyter, 1994, pp. 548-68.

. "Zum Streit um die Illuminationslehre des Heinrich von Gent $(† 1293)$. Text und Diskussion". In: ZUMKELLER, A., KRÜMMEL, A. (Hersg.). Traditio Augustiniana. Studien über Augustinus und seiner Rezeption. Festgabe für Willigis Eckermann OSA zum 60. Geburtstag. Wurzburg: AugustinusVerlag, 1994, pp. 203-40.

"Die Unterscheidungslehren des Heinrich von Gent in der Auseinandersetzung des Johannes de Polliaco mit den Gandavistae". In: GULDENTOPS, G., STEEL, C. (eds.), Henry of Ghent and the Transformation..., 2003, pp. 371-86.

"Die Opposition des Johannes de Polliaco gegen die Schüle der Gandavistae". Bochumer Philosophisches Jahrbuch für Antike und Mittelalter 9 (2004), pp. 115-77. 
. "The Quodlibeta of John of Pouilly ( $\dagger$ ca. 1328) and the Philosophical and Theological Debates at Paris 1307-1312". In: SCHABEL, C. (ed.). Theological Quodlibeta in the Middle Ages. The Fourteenth Century. Leiden Boston: Brill, 2007, pp. 199-229.

. "The Theologian Henry of Ghent". In: WILSON, G. A. (ed.). A Companion to Henry of Ghent, 2011, pp. 103-134.

HOENEN, M. J. F. M. "Propter dicta Augustini. Die metaphysische Bedeutung der mittelalterlichen Ideenlehre". Recherches de théologie et philosophie médiévales 64 (1997), pp. 245-62.

HOERES, W. "Wesen und Dasein bei Heinrich von Gent und Duns Scotus". Franzikanische Studien 47 (1965), pp. 121-86.

HOFFMANN, T. "Ideen der Individuen und intentio naturae. Duns Scotus im Dialog mit Thomas von Aquin und Heinrich von Gent". Freiburger Zeitschrift für Philosophie und Theologie 46 (1999), pp. 138-52.

Creatura intellecta. Die Ideen und Possibilien bei Duns Scotus mit Ausblick auf Franz von Mayronis, Poncius und Mastrius. Münster: Aschendorff, 2001.

. "Idées divines et essence: Henri de Gand". In: BARDOUT, J.-C., BOULNOIS, O. (éds). Sur la science divine. Paris: PUF, 2002, pp. 226-244.

. "Henry of Ghent's Voluntarist Account of Weakness of Will". In: HOFFMANN, T. (ed.) Weakness of will from Plato to the present. Washington D.C.: The Catholic University of America Press, 2008, pp. 115-37.

HOYE, W. J. "Gotteserkenntnis per essentiam im 13. Jahrhundert". In: ZIMMERMANN, A., VUILLEMIN-DIEM, G. (Hrsg.). Die Auseinandersetzungen an der pariser Universität im XIII. Jahrhundert. Berlin New York: De Gruyter, 1976, pp. 269-84.

. "Die mittelalterliche Methode der Quaestio". In: HEROLD, N. et al. (Hrsg.). Philosophie: Studium, Text und Argument. Münster - Hamburg London: LTI, 1997, pp. 155-178.

HUET, F. Recherches historiques et critiques sur la vie, les ouvrages et la doctrine de Henri de Gand. Gand - Paris: De Leroux - Paulin, 1838.

IMBACH, R. "Averroistische Stellungnahmen zur Diskussion über das Verhältnis von esse et essentia. Von Siger von Brabant zu Thaddaeus von Parma". In: MARIERÙ, A., PARAVICINI BAGLIANI, A. (ed.). Studi sul XIV secolo in memoria di Anneliese Maier. Roma: Edizioni di Storia e Letteratura, 1981, pp. 299-339.

JANSSENS, J. "Some elements of Avicennian Influence on Henry of Ghent's Psychology". In: VANHAMEL, W. (ed.). Henry of Ghent. Proceedings..., 1996, pp. 155-69. 
. "Henry of Ghent and Avicenna". In: WILSON, G. A. (ed.). A Companion to Henry of Ghent, 2011, pp. 63-83.

. "Henry of Ghent and Averroes". In: WILSON, G. A. (ed.). A Companion to Henry of Ghent, 2011, pp. 85-99.

KANN, C. "Skepsis, Wahrheit, Illumination. Bermerkungen zur Erkenntnistheorie Heinrichs von Gent”. In: AERTSEN, J. A., EMERY Jr., K., SPEER, A. (Hrsg.). Nach der Verurteilung von 1277. Philosophie und Theologie an der Unversität von Paris in letzten Viertel des 13. Jahrhunderts. Studien und Texte. Berlin New York: De Gruyter, 2001, pp. 38-58.

. "Grenzen des Zweifels. Skeptizismuskritik bei Augustinus, Heinrich von Gent und Descartes". Philosophisches Jahrbuch 110.2 (2003), pp. 226-240.

. "Wahrheit und Wahrheitserkenntnis bei Heinrich von Gent". In: GULDENTOPS, G., STEEL, C. (eds.), Henry of Ghent and the Transformation..., 2003, pp. 157-75.

KANTOLA, I. Probability and Moral Uncertainty in Late Medieval and Early Modern Times. Helsinki: Luther-Agricola-Society, 1994.

. "Henry Ghentiläisen omatuntokäsitys". In: HOLOPAINEN, T. M., HOLOPAINEN, T. J. Sielun liikeitä. Filosofianhistoriallisia kirjoitelmia. Helsinki: Gaudeamus, 1996, pp. 156-166.

KATO M. | 加藤 雅 人. “ガンのヘンリクスにおける<もの>の存在構造 $[\mathrm{A}$ estrutura de ser da 'coisa' em Henrique de Gand]”.『中世哲学研究』 VERITAS | Veritas: Kyodai Studies in Mediaeval Philosophy 14 (1995), pp. 4354.

KLIBANSKI, R., PANOFSKY, E., SAXL, F. Saturn and Melancholy. Studies in the History of Natural Philosophy, Religion and Art. Lichtenstein: Kraus, $1979^{2}$ [1964].

KLIMA, G. "Thomas Sutton and Henry of Ghent on the Analogy of Being". Proceedings of the Society for Medieval Logic and Metaphysics 2 (2002), pp. 34-44 [edição eletrônica].

KLIMKE, F. Institutiones historiae philosophiae. Volumen primum. Romae Friburgi Brisg.: Sumptibus Universitatis Gregorianae - Herder, 1923.

KLIMSKI, T. “Życie i działalność naukowa Profesora Mieczysława Gogacza”. Studia Philosophiae Christianae 32.2 (1996), pp. 7-10.

KNUDSEN, C. "Intentions and impositions". In: KRETZMANN, N., KENNY, A., PINBORG, J. The Cambrige History of Later Medieval Philosophy. Cambridge: Cambridge University Press, 1982, pp. 479-95.

KOBUSCH, T. "Heinrich von Gent und die neuplatonische Ideenlehre". In: BENAKIS, L. G. (éd.). Néoplatonisme et philosophie médiévale. Actes du 
Colloques international de Corfou 6-8 octobre 1995 organisé para la SIEPM. Turnhout: Brepols, 1997, pp. 197-209.

. "Gott und die Transzendentalien: Von der Erkenntnis des Inklusiven, Impliziten, Konfusen und Unbewußten" In: PICKAVÉ, M. (Hrsg.). Die Logik der Transzendentalen. Festschrift für Jan A. Aertsen zum 65. Geburtstag. Berlin - New York: Walter de Gruyter, 2003, pp. 421-32.

. "Willensschwäche und Selbsbestimmung des Willens: Zur Kritik am abendländischen Intellektualismus bei Heinrich von Gent und der franziskanischen Philosophie". In: HOFFMANN, T. et al. Das Problem der Willensschwäche in der mittelalterlichen Philosophie. Leuven - Paris - Dudley: Peeters, 2006, pp. 249-263.

. "Adaequatio rei et intellectus. Die Erläuterung der Korrespondenztheorie der Wahrheit in der Zeit nach Thomas von Aquin". In: ENDERS, M., SZAIF, J. (Hrsg.). Die Geschichte des philosophischen Begriffs der Wahrheit. Berlin New York: De Gruyter, 2006, pp. 149-66.

. "Der neue Weg der Metaphysik: Heinrich von Gent, Meister Eckhart, Duns Scotus". In: HONNEFELDER, L., MÖHLE, H., SPEER, A., KOBUSCH, T., BARRIO, S. B. del. Johannes Duns Scotus 1308-2008. Die philosophischen Perspektiven seines Werkes / Investigations into his Philosophy. Proceedings of 'The Quadruple Congress' on John Duns Scotus. Part 3. St. Boanventure Münster: Franscican Institute Publications - Aschendorff, 2010, pp. 125-38 (Archa Verbi 5) [trad. para o português de R. H. Pich em: Veritas 53.3 (2008), pp. 59-73].

KÖHLER, T. “Äusserungspflicht und Erörterungverzicht. Ethische Fragen akademischer Lehre und Wissensgewinnung in der Hochscholastik". In: BAZÁN, B., ANDÚJAR, E., SBROCCHI, L. G. (eds.). Les philosophies Morales et politiques au Moyen Âge: actes du $9 e$ Congrès International de Philosophie Médiévale, Ottawa, 17-22 aô̂t 1992 / Moral and Political Philosophies in the Middle Ages: proceedings of the 9th International Congress of Medieval Philosophy, Ottawa, 17-22 August 1992. Vol. 3. Ottawa: SIEPM, 1995, pp. 1327-40.

KÖNIG-PRALONG, C. Avènement de l'aristotélisme en terre chétienne. Paris: Vrin, 2005.

"Introduction". In: HENRI DE GAND, GILLES DE ROME, GODEFROID DE FONTAINES. Etre, essence et contingence. Textes de Henri de Gand, Gilles de Rome, Godefroid de Fontaines. Intr., tr. et notes par C. König-Pralong. Paris: Les Belles Lettres, 2006, pp. 7-126.

. "Corps, cadavre, matière. Autour de Gilles de Rome, Henri de Gand et Dietrich de Freiberg”. Quaestio 7 (2007), pp. 339-359.

. "Évaluations des savoirs d'importation dans l'université médiévale : Henri de Gand en position d'expert". Revue européenne des sciences sociales 46 (2008), pp. 11-28. 
. "Situations et fonctions sociales du croire dans la scolastique médiévale. Godefroid de Fontaines contre Henri de Gand". In: GISEL, P., MARGEL, S. (éds.). Le croire au coeur des sociétés et des cultures: différences et déplacements. Turnhout: Brepols, 2011, pp. 81-103.

. Le bon usage des savoirs. Scolastique, philosophie et politique culturelle. Paris: Vrin, 2011.

. "Le désir naturel de connaître. Autour des Questions métaphysiques attribuées à Gilles de Rome". In: CORDONIER, V., SUAREZ-NANI, T. (éds.). L'aristotelisme exposé, 2014, pp. 1-28.

. "Omnes homines natura scire desiderant. Anthropologie philosophique et distinction sociale". Quaestio 15 (2015), pp. 121-38.

KORIDZE, G. Intentionale Grundlegung der philosophischen Logik. Studien zur Intentionalität des Denkens bei Hervaeus Natali im Traktat 'De secundis intentionibus'. Inaugural-Dissertation zur Erlangung des Grades eines Doktors der Philosophie der Fakultät für Philosophie und Geschichte der Eberhard Karls Universität Tübingen. Dezember, 2004.

KUHN, T. S. The Structure of Scientific Revolutions. 50 ${ }^{\text {th }}$ Anniversary Edition with an Introductory Essay by Ian Hacking. Chicago - London: The Chicago University Press, $2012^{4}$ [1962].

LAARMANN, M. "God as primum cognitum. Some Remarks on the Theory of Initial Knowledge of esse and God according to Thomas Aquinas and Henry of Ghent”. In: VANHAMEL, W. (ed.). Henry of Ghent. Proceedings..., 1996, pp. 171-91.

. Deus, primum cognitum. Die Lehre von Gott als dem Ersterkannten des menschelichen Intellekts bei Heinrich von Gent (†1293). Münster: Aschendorf, 1999.

LAGARDE, G. de. "La philosophie sociale d'Henri de Gand et de Godefroid de Fontaines". Archives d'histoire doctrinale et littéraire du Moyen Âge (1943-5), pp. 73-142.

LAGERLUND, H. (ed.). Rethinking the History of Skepticism: The Missing Medieval Background. Leiden: Brill, 2010.

. "A history of Skepticism in the Middle Ages". In: LAGERLUND, H. (ed.). Rethinking the History of Skepticism, 2010, p. 1-28.

LAJARD, F. "Henri de Gand”. In: Histoire littéraire de la France. Tome XX. Paris: Académie royale des Inscriptions et Belles-Lettres, 1842 (Nendeln: Kraus Reprint, 1971).

LAMY, M. L'immaculée conception: étapes et enjeux d'une controverse au moyenâge (XII $-X V^{e}$ siècles). Paris: Institut d'Études Augustiniennes, 2000. 
LATZER, M. "The Proofs of the Existence of God. Henry of Ghent and Duns Scotus as Precursors of Leibniz". The Modern Schoolman 74 (1997), pp. 143-60.

LAUWERS, M., SIMONS, W. Béguins et Béguines à Tournai au Bas Moyen Âge. Les communautés béguinales à Tournai du XIII au XV siècle. Tournai Louvain-la-Neuve: Archives du Chapitre Cathédral - Unversité Catholique de Louvain, 1988.

LE GOFF, J. "Les Moyen Age de Michelet”. In: LE GOFF, J. Pour un autre Moyen Âge. Temps, travail et culture en Occident: 18 essais. Paris: Gallimard 1977.

. “Quelle conscience l'Université médiéval a-t-elle eue d'elle-même?". In: LE GOFF, J. Pour un autre Moyen Âge. Temps, travail et culture en Occident: 18 essais. Paris: Gallimard, 1977, pp. 181-97.

LECLERCQ, J. "L'idéal du théologien au Moyen âge. Textes inédits". Revue des sciences religieuses 21.3-4 (1947), pp. 121-48.

LEITE DE FARIA, F. 'L'attitude des théologiens au sujet de la doctrine d'Henri de Gand sur la conception de la Sainte Vierge”. Études franciscaines 5 (1954a), pp. 113-152.

"L'opinion d'Henri de Gand sur la conception de la Sainte Vierge". Marianum 16 (1954b), pp. 290-316.

LEONE, M. "Metaphysics, Theology and the Natural Desire to Know Separate Substances". Quaestio 5 (2005), pp. 513-26.

"Zum Status der Theologie bei Heinrich von Gent - Ist sie eine praktische oder eine theoretische Wissenschaft?". In: OLSZEWSKI, M. (ed.). What is "Theology" in the Middle Ages? Religious Cultures of Europe (11 ${ }^{\text {th }}$ $15^{\text {th }}$ Centuries) as reflected in their Self-Understanding. Münster: Aschendorff, 2007, pp. 195-224.

. "Moral Philosophy in Henry of Ghent". In: WILSON, G. (ed.). A companion to Henry of Ghent, 2011, pp. 275-314.

. "Henry of Ghent on Divine Law, Natural Law and Human Law". In: SPEER, A., GULDENTOPS, G. (Hrsg.). Das Gesetzt - the Law - la Loi. Berlin - Boston: De Gruyter, 2014, pp. 383-398.

- Filosofia e teologia della vita activa. La sfera dell'agire pratico in Enrico di Gand. Bari: Edizioni di Pagina, 2014.

. "Henry of Ghent and the Ethics of Intention". In: d'HOINE, P., Van RIEL, G. Fate, Providence and Moral Responsability in Ancient, Medieval and Early Modern Thought. Studies in Honour of Carlos Steel. Leuven: Leuven University Press, 2014, pp. 571-89.

LIBERA, A. de. "Introduction”, In: THOMAS D'AQUIN. Contre Averroès. Trad. d'Alain de Libera. Paris: Flammarion, 1994, pp. 9-73. 
. La référence vide. Théories de la proposition. Paris: PUF, 2002.

. Archéologie du sujet II. La quête de l'identité. Paris: Vrin, 2008.

. "Le présent roi du mogol et le baptême des siamois. Sur l'identité personnelle, du Moyen Âge à John Locke". In: BECCARISI, A., IMBACH, R., PORRO, P. (Hrsg.). Per perscrutationem philosophicam. Neue Perspektiven der mittelalterlichen Forschung. Loris Sturlese zum 60. Geburtstag gewidmet. Hamburg: Felix Meiner, 2008, pp. 418-46.

. Où va la philosophie médiévale? Leçon inaugurale prononcée au Collège de France. Paris: http://books.openedition.org/cdf/3634\#ftn2, 2014.

. L'invention du sujet moderne. Cours au Collège de France 2013-2014. Paris: Vrin, 2015.

LICHTERFELD, J. Die Ethik Heinrichs von Gent in ihren Grundzügen. InauguralDissertation zur Erlangung der Doktorwürde der hohen philosophischen Fakultät der Friedrich-Alexanders-Universität Erlangen, 1906.

LINDBERG, D. C. Theories of Vision from Al-Kindi to Kepler. Chicago - London: The University of Chicago Press, 1976.

. "Introduction". In: ROGER BACON. Roger Bacon's Philosophy of Nature. A Critical Edition, with English Translation, Introd. and Notes of De multiplicatione specierum and De speculis comburentibus. South Bend: St. Augustine's Press, 1998, pp. xv-lxxxi.

. The Beginnings of Western Science. The European Scientific Tradition in Philosophical, Religious, and Institutional Context, Prehistory to A.D. 1450. Chicago - London: The University of Chicago Press, $2007^{2}$ [1992].

LOTTIN, O. Psychologie et morale aux XII et XIII ${ }^{e}$ siècles. Tome I: problèmes de psychologie. Gembloux: Duculot, $1957^{2}$ [1942].

. Psychologie et morale aux XII et XIII siècles. Tome II: problèmes de morale. Louvain - Gembloux: Abbaye du Mont César - Duculot, 1948.

. Psychologie et morale aux XII et XIII siècles. Tome III.1: problèmes de morale, seconde partie. Louvain - Gembloux: Abbaye du Mont César Duculot, 1949.

. Psychologie et morale aux XII et XIII siècles. Tome III.2: problèmes de morale, seconde partie. Louvain - Gembloux: Abbaye du Mont César Duculot, 1949.

. Psychologie et morale aux XII et XIII siècles. Tome IV.2: problèmes de morale, troisième partie. Louvain - Gembloux: Abbaye du Mont César Duculot, 1954.

. Psychologie et morale aux XII et XIII siècles. Tome VI: problèmes d'histoire littéraire de 1160 à 1300. Gembloux: Duculot, 1960. 
LOVEJOY, A. O. The Great Chain of Being. A Study of the History of an Idea. Cambridge: Harvard University Press, 1936.

LUGT, M. van der. Le ver, le démon et la vierge. Les théories médiévales de la génération extraordinaire. Paris: Les Belles Lettres, 2004.

LYNCH, J. E. "The Knowledge of Singular Things According to Vital du Four". Franciscan Studies 29 (1969), pp. 271-301 [cf. esp. p. 290, nota 64].

. The Theory of Knowledge of Vital du Four. St. Bonaventure: The Franciscan Institute, 1972.

MACKEN, R. Hendrik van Gent's "Quodlibet I". Tekstkritische uitgave. Weerlegging van een mogelijke eeuwigheid der wereld. 2 delen. Proefschrift tot het behalen van de graad van Doctor in de Wijsbegeerte. Leuven: Katholieke Universiteit Leuven, 1968.

. "De radicale tijdlijkheid van het schepsel volgens Hendrik van Gent" Tijdschrift voor Filosofie 31.3 (1969), pp. 519-71.

. "La temporalité radicale de l'être selon Henri de Gand". Recherches de théologie ancienne et médiévale 38 (1971), pp. 211-72.

. "Le théorie de l'illumination divine dans la philosophie d'Henri de Gand". Recherches de Théologie ancienne et médiévale 39 (1972), pp. 82-112.

. "La volonté, faculté plus élevée que l'intelligence selon Henri de Gand". Recherches de théologie ancienne et médiévale 42 (1975), pp. 25-27.

. "La subsistence de la matière première selon Henri de Gand". In: POMPEI, A. (ed.). San Bonaventura. Maestro di vita franciscana di sapienza cristiana. Vol. 3. Roma: Pontificia Facoltà Teologica 'San Bonaventura', 1976, pp. 107-15.

"Vitale Zuccoli, commentateur des Quodlibets d'Henri de Gand". Bulletin de philosophie médiévale 10 (1976), pp. 84-90.

. "Heinrich von Ghent im Gespräch mit seinen Zeitgenossen über die menschliche Freiheit". Franziskanische Studien 59 (1977), pp. 125-82.

. "La liberté humaine dans la philosophie d'Henri de Gand". In: BÉRUBÉ, C. (ed.). Regnum hominis et regnum. Acta Quarti Congressus Scotistici Internationalis, Patavii, 24-29 septembris 1976. Dei. Vol. 2. Romae: Societas Internationalis Scotistica, 1978, pp. 577-584

. "Les sources d'Henri de Gand". Revue philosophique de Louvain 76 (1978), pp. 5-28.

. "Unité et dimorphisme de l'homme selon Henri de Gand". In: D'AMORE, B., GIORDANO, A. (eds.). Teoria e prassi. Atti del VI Congresso del Centro Internazionale di Studi e Relazioni Culturali e della Fondazione 
Balmesiana, Genova-Barcelona 8-15 settembre 1976. Vol. 1. Napoli: Edizioni Domenicane Italiane, 1979, pp. 177-182.

. "Lebensziel und Lebensglück in der Philosophie des Heinrich von Gent". Franziskanische Studien 61 (1979), pp. 107-123.

. "Le statut de la matière première dans la philosophie d'Henri de Gand". Recherches de théologie ancienne et médiévale 46 (1979), pp. 130-82.

. "Deseo natural y vocación sobrenatural del hombre en la filosofía de Enrique de Gante". In: La filosofía del cristiano, hoy. Vetera novis augere et perficere. Primer Congreso Mundial de Filosofía Cristiana, Córdoba, 21-28 octubre 1079. Vol. II. Córdoba: Publicaciónes de la Universidad, 1980, pp. 83946.

."Les diverses applications de la distinction intentionelle chez Henri de Gand". In: KLUXEN, W. (Hrsg). Sprache und Erkenntnis im Mittelalter. Akten des VI. Internationalen Kongresses für mittelalterliche Philosophie der Société Internationale pour l'Étude de la Philosophie Médiévale. 29. August - 3. September 1977 in Bonn. Berlin - New York, 1981, pp. 769-776.

. "God as primum cognitum in the Philosophy of Henry of Ghent". Franziskanische Studien 66 (1984), pp. 309-15.

"L'illumination divine concernant les vérités révélées chez Henri de Gand". Journal philosophique: Bulletin du Centre de Recherche Philosophique Saint Thomas d'Aquin 5 (1985), pp. 261-71.

. "Selbstverwirklichung in der Anthropologie des Heinrichs von Gent". In: GERWING, M., RUPPERT, G. (Hrsg.). Renovatio et reformatio. Wider das Bild vom 'finsteren' Mittelalter. Festschrift für Ludwig Hödl zum 60. Geburtstag. Münster: Aschendorf, 1985, pp. 131-140.

. "L'interpénétration de l'intelligence et de la volonté dans la philosophie d'Henri de Gand'. In: WENIN, C. (éd.). L'homme et son univers au moyen âge. Actes du septième congrès international de philosophie médiévale (30 août - 4 septembre 1982). Vol. II. Louvain-la-Neuve: Éditions de l'Institut Supérieur de Philosophie, 1986, pp. 808-14.

. "The Metaphysical Proof for the Existence of God in the Philosophy of Henry of Ghent". Franziskanische Studien 68 (1986), pp. 247-260.

. "Synderesis and Conscience in the Philosophy of Henry of Ghent". Franziskanische Studien 70 (1988), pp. 185-95.

. "La personnalité, le caractère et les méthodes de travail d'Henri de Gand. Les épanchements d'Henri dans ses oeuvres scholastiques". Theologische Zeitschrift 45.2-3 (1989), pp. 192-206.

"Will and Intellect in God according to the Philosophy of Henry of Ghent". Franziskanische Studien 71 (1989), pp. 159-67. 
. "Der geschaffene Wille als selbstbewegendes geistiges Vermögen in der Philosophie des Heinrich von Gent". MOJSISCH, B., PLUTA, O. (Hrsg.). Historia philosophiae medii aevi. Studien zur Geschichte der Philosophie des Mittelalters. Band II. Amsterdam - Philadelphia: Grüner, 1991, pp. 561-72.

. "The Superiority of Active Life to Contemplative Life in Henry of Ghent's Theology". Medioevo 20 (1994), pp. 115-129.

. "The Human Will as Decision-Maker in the Human Person, According to the Philosophy of Henry of Ghent". Mediaevalia. Textos e estudos 7-8 (1995), pp. 427-39.

. "The Sovereign, sometimes forbidden by the divine law to enjoy the money granted to him by the public justice, according to the philosophy of Henry of Ghent". In: MACKEN, R. Essays on Henry of Ghent II. Leuven: Editions Medieval Philosophers of the Former Low Countries, 1995, pp. 7-20.

. "God as Natural Object of the Human Will, According to the Philosophy of Henry of Ghent". In: MACKEN, R. Essays on Henry of Ghent II. Leuven: Editions Medieval Philosophers of the Former Low Countries, 1995, pp. 45-53.

MACKEN, [R.] S. "L'argumentation contre une éternité possible du monde chez Henri de Gand". In: De doctrina Ioannis Duns Scoti. Acta Congressus Scotistici Internationalis Oxonii et Edimburgi 11-17 sept. 1966 celebrati. Vol. I: Documenta et studia in Duns Scotum introductoria. Cura Commissionis Scotisticae. Romae, 1968, pp. 307-23.

MAHONEY, E. P. "Metaphysical Foundations of the Hierarchy of Being According to Some Late-Medieval and Renaissance Philosophers". In: MOREWEDGE, P. (ed.). Philosophies of Existence. Ancient and Medieval. New York: Fordham University Press, 1982, pp. 165-257.

. "Duns Scotus and Medieval Discussions of Metaphysical Hierarchy: the Background of Scotus's 'essential order' in Henry of Ghent, Godfrey of Fontaines and James of Viterbo". In: SILEO, L. (ed.). Via Scoti. Methodologica ad mentem Joannis Duns Scoti. Atti del Congresso Scotistico Internazionale. Roma 9-11 marzo 1993. Vol. I. Roma: PAA - Antonianum, 1995, pp. 359-74.

. "Pseudo-Dionysius's Conception of Metaphysical Hierarchy and its Influence on Medieval Philosophy". In: BOIADJIEV, T., KAPRIEV, G., SPEER, A. (Hrsg.). Die Dionysius-Rezeption im Mittelalter. Internationales Kolloquium in Sofia vom 8. bis 11. April 1999 unter der Schirmherrschaft der Société Internationale pour l'Étude de la Philosophie Médiévale. Turnhout: Brepols, 2000, pp. 429-475.

MANDONNET, P. 'Les premières disputes sur la distinction réelle entre l'essence et l'existence, 1276-1287'. Revue Thomiste (1910), pp. 741-65.

MANOVA, I. "Congrès terminés - 'Outsiders and Forerunners. Modern Reason and Historiographical Births of Medieval Philosophy'. Freiburg im Breisgau, 28.30. April 2016”. Bulletin de Philosophie Médiévale 58 (2016), pp. 492-504. 
MARMURSZTEJN, E. "Du récit exemplaire au casus universitaire: une variation théologique sur le thème de la profanation de l'hosties par les juifs (1290)". Médiévales 41 (2001), pp. 37-64.

- "Loi ancienne, loi nouvelle et normes chrétiennes dans la théologie scolastique du XIII ${ }^{\mathrm{e}}$ siècle". Revue de l'histoire des religions 228.4 (2011), pp. 528-529.

MARRONE, S. P. "Matthew of Aquasparta, Henry of Ghent, and Augustinian Epistemology after Bonaventure". Franziskanische Studien 65 (1983), pp. 25290.

. Truth and Scientific Knowledge in the Thought of Henry of Ghent. Cambridge: The Medieval Academy of America Press, 1985.

. "Henry of Ghent and Duns Scotus on the Knowledge of Being". Speculum 63.1 (1988), pp. 22-57.

. "Henry of Ghent in Mid-Career as Interpreter of Aristotle and Thomas Aquinas". In: VANHAMEL, W. (ed.). Henry of Ghent. Proceedings..., 1996, pp. 193-209.

. The Light of Thy Countenance. Science and Knowledge of God in the Thirteenth Century. 2 vols. Leiden - Boston - Köln: Brill, 2001.

. "Henry of Ghent's Epistemology". In: WILSON, G. (ed.). A companion to Henry of Ghent, 2011, pp. 213-239.

MARSCHLER, T. "Zum Selbstvertändnis des theologischen Magisters nach Heinrich von Gent im Ausgang von Quodlibet I, 35". In: OLSZEWSKI, M. (ed.). What is "Theology" in the Middle Ages? Religious Cultures of Europe $\left(11^{\text {th }}-15^{\text {th }}\right.$ Centuries) as reflected in their Self-Understanding. Münster: Aschendorff, 2007, pp. 517-31.

MARTIN, J. H. "The Ordination of Women and the Theologians in the Middle Ages". In: COOKE, B., MACY, G. (eds.). A History of Women and Ordination. Vol. 1: The Ordination of Women in Medieval Context. Lanham - Maryland London: The Scarecrow Press, 2002, pp. 31-160.

MAURER, A. "Henry of Ghent and the Unity of Man”. Mediaeval Studies 10 (1948), pp. $1-20$.

. "Ens Diminutum: a Note on its Origin and Meaning". Mediaeval Studies 12 (1950), pp. 216-22.

MAZZARELLA, P. "La critica di Enrico di Gand alla dottrina dell' 'inchoatio formae".. In: Ethos e cultura. Studi in onore di Ezio Riondato. Padova: Antenore, 1991, pp. 183-193.

McALEER, G. J. “Augustinian Interpretations of Averroes with Respect to the Status of Prime Matter”. The Modern Schoolman 73.2 (1996), pp. 159-72. 
McEVOY, J. "The Sources and the Significance of Henry of Ghent's Disputed Question, 'Is Friendship a virtue?'. In: VANHAMEL, W. (ed.). Henry of Ghent. Proceedings..., 1996, pp. 121-138.

METZ, W. Die Architektonik der Summa Theologiae des Thomas von Aquin. Zur Gesamtsicht des thomasischen Gedankens. Hamburg: Felix Meiner, 1998.

MICHALSKI, C. Le criticisme et le scepticisme dans la philosophie du XIV siècle. Éxtrait du Bulletin de l'Académie Polonaise des Sciences et des Lettres, Classe d'histoire et de philosophie - année 1925. Cracovie: Imprimerie de l'Université, 1926.

MICHAUD-QUANTIN, P. "L'emploi des termes logica et dialectica au moyen âge". In: MICHAUD-QUANTIN, P. Études sur le vocabulaire philosophique du moyen âge. Avec la collaboration de M. Lemoine. Roma: Ateneo, 1970, pp. 5972.

"Ordo et ordines". In: MICHAUD-QUANTIN, P. Études sur le vocabulaire philosophique $d u$ moyen âge. Avec la collaboration de M. Lemoine. Roma: Ateneo, 1970, pp. 85-101.

MINNIS, A. J. "The Accessus Extended: Henry of Ghent on the Transmission and Reception of Theology". In: JORDAN, M. D., EMERY Jr., K. (ed.). Ad litteram. Authoritative Texts and Their Medieval Readers. Notre Dame London: University of Notre Dame Press, 1992, pp. 275-326.

MOLLAND, A. G. "Colonizing the world for mathematics: the diversity of medieval strategies". In: GRANT, E., MURDOCH, J. E. Mathematics and its applications to science and natural philosophy in the Middle Ages. Essays in honor Marshall Clagett. Cambridge: Cambridge University Press, 1987, pp. 4566.

MONTAGNA, D. M. "I servi ed Enrico di Gand († 1293). Inchiesta sui manoscritti". Studi storici dell'ordine dei servi di Maria 32 (1982), pp. 197-204.

MONTAGNES, B. La doctrine de l'analogie de l'être d'après saint Thomas d'Aquin. Louvain - Paris: Publications universitaires - Vrin, 1963.

MÜLLER, J. "Willensschwäche im Voluntarismus? Das Beispiel Heinrichs von Gent". Archiv für Geschichte der Philosophie 89 (2007), pp. 1-29.

. Willensschwäche in Antike und Mittelalter. Eine Problemgeschichte von Sokrates bis Johannes Duns Scotus. Leuven: Leuven University Press, 2009.

. "Einleitung". In: HEINRICH VON GENT, Quaestionen zur Willens- und Freiheitslehre. Übersetzt von J. Müller. Freiburg: Herder, 2011, pp. 7-65.

MURALT, A. de "Kant, le dernier occamien. Une nouvelle définition de la philosophie moderne". In: MURALT, A. de La métaphysique du phénomène. Les origines médiévales et l'élaboration de la pensée phénoménologique. Paris: Vrin, 1985, pp. 138-59. 
NAAB, E. "Si recta ratio, et voluntas recta. Augustinus und die Pariser Verurteilung von 1277". In: FISCHER, N. (Hrsg.). Die Gnadenlehre als 'salto mortale' der Vernunft? Natur, Freiheit und Gnade in der Spannungsfeld von Augustinus und Kant. Freiburg - München: Karl Alber, 2012, pp. 146-166.

NASCIMENTO, C. A. R. do. Une théorie des opérations naturelles fondée sur l'optique: le 'De multiplicatione specierum' de Roger Bacon. Thèse presentée à la Faculté des Études Supérieurs en vue de l'obtention du Philosophiae Doctor (Sciences Médiévales). Institut d'Études Médiévales, Faculté des Arts et des Sciences, Université de Montréal. Decembre, 1975.

. De Tomás de Aquino a Galileu. Campinas: IFCH/UNICAMP, $1998^{2}$

NEGRI, S. “Veritatem humiliter investigare. Sul ruolo dell'umiltà in Enrico di Gand". Quaestio 15 (2015), pp. 607-17.

Notice sur Henri de Gand, fameux dans les annales ecclésiastiques et dans la république des lettres. Gand: Vanryckegem - Hovaere, 1828.

Notice sur Henri Goethals, célèbre dans l'histoire de l'église et dans les annales diplomatiques, par un Amateur de l'Histoire de sa Patrie. Gand: Vanderhaegen, 1829.

Notice sur quelques membres de l'ancienne famille Des Goethals. Gand: Hebbelynck, 1838.

NYS, T. [V.]. De psychologia cognitionis humanae secundum Henricum Gandavensem. Excerpta ex dissertatione ad lauream in Facultate Philosophica Pontificiae Universitatis Gregorianae. Romae, 1949.

. De werking van het menselijk verstand volgens Hendrik van Gent. Leuven: Nauwelaerts, 1949.

OLIVEIRA, C. E. de. "Ideias: formas, rationes e species. A Quaestio de ideis de Tomás de Aquino". Discurso 40 (2010), pp. 95-122.

OLIVEIRA, C. M. R. de. Metafísica e ética. A filosofia da pessoa em Lima Vaz como resposta ao niilismo contemporâneo. São Paulo: Loyola, 2013.

OSBORNE Jr., T. M. The Natural Love of God over Self: the Role of Self-Interest in the Thirteenth-Century Ethics. Dissertation submitted as partial fulfillment of the requirements for the degree of Doctor of Philosophy in the Department of Philosophy in the Graduate School of Duke Univesity, 2001.

PAIVA, G. B. V. de. "One Single Yet Manifold Soul. Agustine's De trinitate and Aristotle's De anima in John Duns Scotus's Doctrine of Intellection". Medioevo 37 (2012), pp. 261-89.

"A discussão acerca da possibilidade de conhecimento humano em Henrique de Gand e João Duns Escoto". In: CARVALHO, M., FIGUEIREDO, V. (eds.). ANPOF XV, vol. 1: Filosofia Antiga e Medieval. São Paulo, ANPOF, 2013, pp. 241-258. 
. "Prudência e caridade na ética de Henrique de Gand". Revista do Seminário dos Alunos do PPGLM/UFRJ 4 (2013), pp. 121-138.

"Sobre as duas utilizações do termo res no Quodlibet 7, q. 1-2, de Henrique de Gand". Revista do Seminário dos Alunos do PPGLM/UFRJ 5 (2014), pp. 62-78.

. "Étienne Gilson leitor de Henrique de Gand". Revista SOFiA - Semana de Orientação Filosófica e Acadêmica / UNIFESP 1.1 (2014), pp. 143-51.

. "Resenha de: TESKE, R. J. Essays on the Philosophy of Henry of Ghent. Milwaukee: Marquette University Press, 2012, 275 p. (Marquette Studies in Philosophy 76)". Translatio. Caderno de Resenhas do GT História da Filosofia Medieval e a Recepção da Filosofia Antiga 6 (2014), pp. 19-30.

. "Por uma ética do conhecimento: Henrique de Gand e seu Sermão para a festa de Sta. Catarina". Anais do Seminário dos Estudantes de Pós-Graduação em Filosofia da UFSCar 11 (2015), pp. 134-50.

. “'Res a reor reris' e 'res a ratitudine' na metafísica de Henrique de Gand". In: CARVALHO, M., PICH, R. H., OLIVEIRA DA SILVA, M. A., OLIVEIRA, C. E. (orgs.). Filosofia Medieval. Coleção XVI Encontro ANPOF. São Paulo: ANPOF, 2015, pp. 392-417.

"Resenha de: CORDONIER, V., SUAREZ-NANI, T. (éds.). L'aristotélisme exposé...". Translatio. Caderno de Resenhas do GT História da Filosofia Medieval e a Recepção da Filosofia Antiga 7 (2015), pp. 24-41.

PANACCIO, C. Le discours intérieur de Platon à Guillaume d'Ockham. Paris: Éditions du Seuil, 1999.

PANNENBERG, W. Analogie und Offenbarung. Eine kritische Untersuchung zur Geschichte des Analogiebegriffs in der Lehre von der Gotteserkenntnis. Göttingen: Vandenhoeck \& Ruprecht, 2007.

PASNAU, R. "William Heytesbury on Knowledge: Epistemology without Necessary and Sufficient Conditions". History of Philosophy Quarterly 12.4 (1995), pp. 347-66.

. "Henry of Ghent and the Twilight of Divine Illumination". The Review of Metaphysics 49.1 (1995), pp. 49-75.

. Theories of Cognition in the Later Middle Ages. Cambridge: Cambridge University Press, 1997.

PATTIN, A. "Les différents traités de Jean de Jandun sur le 'De sensu agente"”. In: WENIN, C. (éd.). L'homme et son univers au moyen âge. Actes du septième congrès international de philosophie médiévale (30 août - 4 septembre 1982). Vol. II. Louvain-la-Neuve: Éditions de l'Institut Supérieur de Philosophie, 1986, pp. 583-90. 
. Pour l'histoire du sens agent. La controverse entre Barthélemy de Bruges et Jean de Jandun, ses antécédents et son évolution. Leuven: Leuven University Press, 1988.

PAULUS, J. "Henri de Gand et l'argument ontologique". Archives d'histoire doctrinale et littéraire du Moyen Âge (1935), pp. 265-323.

. Henri de Gand. Essai sur les tendances de sa métaphysique. Paris: Vrin, 1938 .

. "Les disputes d'Henri de Gand et de Gilles de Rome sur la distinction de l'essence et de l'existence". Archives d'histoire doctrinale et littéraire du moyen âge (1940-2), pp. 323-58.

. “À propos de la théorie de la connaissance d'Henri de Gand”. Revue Philosophique de Louvain 47 (1949), pp. 493-6.

PAUW, N. de. "Dernières découvertes concernant le Docteur solennel Henri de Gand, fils de Jean le Tailleur (Formator ou de Sceppere)". Compte rendu des séances de la Commission royale d'histoire, ou recueil de ses bulletins 16 (1889), pp. 26-138.

PEGIS, A. "Toward a New Way to God: Henry of Ghent". Mediaeval Studies 30 (1968), pp. 226-247.

. “A New Way to God: Henry of Ghent II”. Mediaeval Studies 31 (1969), pp. 93-116.

. "Four Medieval Ways to God". The Monist 54 (1970), pp. 317-58.

. "Henry of Ghent and the New Way to God III". Mediaeval Studies 33 (1971), pp. 158-179.

PÉREZ-ESTÉVEZ, A. "La materia en Enrique de Gante”. Revista Española de Filosofia Medieval 8 (2001), pp. 155-75.

. "La materia primera de Enrique de Gante vista por Duns Escoto". Revista Española de Filosofía Medieval 14 (2007), pp. 33-46.

PERLER, D. Zweifel und Gewissheit. Skeptische Debatten im Mittelalter. Frankfurt am Main: Vittorio Klostermann, 2006.

. "Skepticism". In: PASNAU, R., DYKE, C. Van. (eds.). The Cambridge History of Medieva Philosophy. Vol. I. Cambridge: Cambridge University Press, 2010, pp. 384-96.

. "Dolor". In: ATUCHA, I., et al. (éds.). Mots médiévaux offerts à Ruedi Imbach. Porto: FIDEM, 2011, pp. 233-43.

PICKAVÉ, M. "Heinrich von Gent über das Subjekt der Metaphysik als Ersterkanntes". Documenti e studi sulla tradizione filosofica medievale 12 (2001), pp. 493-522. 
. "Henry of Ghent on Individuation". Proceedings of the Society for Medieval Logic and Metaphysics 5 (2005), pp. 38-49 [edição digital].

. Heinrich von Gent über Metaphysik als erste Wissenschaft. Studien zu einem Metaphysikentwurf aus dem letzten Viertel des 13. Jahrhunderts. Leiden - Boston: Brill, 2007.

. "Henry of Ghent and John Duns Scotus on Skepticism and the Possibility of Naturally Acquired Knowledge". In: LAGERLUND, H. (ed.). Rethinking the History of Skepticism, 2010, pp. 61-96.

. "Henry of Ghent on Metaphysics". In: WILSON, G. A. (ed.). A Companion to Henry of Ghent, 2011, pp. 153-79.

. "Henry of Ghent on Individuation, Essence, and Being". In: WILSON, G. A. (ed.). A Companion to Henry of Ghent, 2011, pp. 181-209.

. "Que signifie 'être libre'? Le cas Henri de Gand”. Médiévales 63 (2012), pp. 91-104.

. "A new book on Giles of Rome and Henry of Ghent. Critical Study of V. Cordonnier - T. Suarez-Nani (eds.), L'aristotélisme exposée...". Recherches de Théologie et Philosophie Médiévales 81.2 (2014), pp. 387-98.

- "Causality and Cognition. An Interpretation of Henry of Ghent's Quodlibet V, q. 14”. In: KLIMA, G. (ed.). Intentionality, Cognition, and Metal Representation in Medieval Philosophy. Amazon Kindle Edition. New York: Fordham University Press, 2015, pos. 1109-988.

PIERMEJUS, A. P. M. Memorabilium Sacri Ordinis Servorum B. M. V. Breviarum. Ed. A. M. Vicentini. Vol. 4. Romae: Buona Stampa, 1934.

PILTZ, A. "Birgitta profeten och uppenbarelsens dynamik". In: BESKOW, P., LANDEN, A. (red.). Birgitta av Vadstena. Pilgrim och profet 1303-1373. Stockholm: Natur och Kultur, 2003, pp. 29-44.

PINI, G. Categories and Logic in Duns Scotus. An Interpretation of Aristotle's Categories in the Late Thirteenth Century. Leiden - Boston - Köln: Brill, 2002.

. "Henry of Ghent's Doctrine of verbum in its Theological Context". In: GULDENTOPS, G., STEEL, C. (eds.), Henry of Ghent and the Transformation..., 2003, pp. 307-26.

. "Il dibattito sulle specie intelligibili alla fine del tredicesimo secolo". Medioevo 29 (2004), pp. 267-306.

. "The Individuation of Angels from Bonaventure to Duns Scotus". In: HOFFMANN, T. (ed.). A Companion to Angels in Medieval Philosophy. Leiden: Brill, 2012 pp. 79-115. 
PIRO, F. "Sensi interni e eziologia degli affeti. A proposito di due quaestiones sul dolore di Enrico di Gand". In: VESCOVINI, G. F. et al. (ed.). Corpo e anima, sensi interni e intelletto dai secoli XIII-XIV ai post-cartesiani e spinozani. Turnhout: Brepols, 2005, pp. 189-210.

PLEVANO, R. "Divine Ideas and Infinity". In: GULDENTOPS, G., STEEL, C. (eds.), Henry of Ghent and the Transformation..., 2003, pp. 177-97.

POPKIN, R. The History of Scepticism. From Savonarola to Bayle. Oxford: Oxford University Press, 2003.

PORCHAT PEREIRA, O. Ciência e dialética em Aristóteles. São Paulo: UNESP, 2001.

PORRO, P. "Enrico di Gand e il problema dell'unicità dell'aevum”. Medioevo 13 (1987), pp. 123-93. 1990.

. Enrico di Gand. La via delle proposizioni universali. Bari: Levante,

. "Ponere statum. Idee divine, perfezioni creaturali e ordine del mondo in Enrico di Gand". Mediaevalia 3 (1993), pp. 109-159.

. "Il Sextus Latinus e l'immagine dello scetticismo antico nel medioevo". Elenchos 15.2 (1994), pp. 229-53.

. "Sinceritas veritatis. Sulle trace di un sintagma agostiniano". In: MERINO, P., TORRECILLA, J. M. (cur.). Augustinus. Charisteria augustiniana Iosepho Oroz Reta dicata. Tomus alter: Theologia. Madrid: Editorial Augustinus, 1994, pp. 413-30.

. "Possibilità ed esse essentia in Enrico di Gand". In: VANHAMEL, W. (ed.). Henry of Ghent. Proceedings..., 1996, pp. 211-53.

. "An Historiographical Image of Henry of Ghent". In: VANHAMEL, W. (ed.). Henry of Ghent. Proceedings..., 1996, pp. 373-403.

. "Lo statuto della philosophia in Enrico di Gand". In: AERTSEN, J. A., SPEER, A. (Hrsg.). Was ist Philosophie im Mittelalter? / Qu'est-ce que la philosophie au moyen âge? Akten des X. Internationalen Kongresses für mittelalterliche Philosophie der SIEPM, 25. bis 30. August 1997 in Erfurt. Berlin - New York: De Gruyter, 1998, pp. 497-504.

. "Tempo e aevum in Enrico di Gand e Giovanni Duns Scoto". In: ALlineY, G., COVA, L. (ed.). Tempus Aevum Aeternitas. La concettualizzazione del tempo nel pensiero tardomedievale. Atti del Colloquio Internazionale. Trieste, 4-6 marzo 1999. Firenze: Olschki, 2000, pp. 89-129. 
. "Il vocabulário filosofico medievale del tempo e della durata". In: CAPASSO, R., PICCARI, P. (ed.). Il tempo nel medioevo. Rappresentazioni storiche e concezioni filosofiche. Atti del Convegno internazionale di Roma, 2628 novembre 1998. Roma: Società Italiana di Demodossalogia, 2000, pp. 63102 .

"Metaphysics and Theology in the Last Quarter of the Thirteenth Century: Henry of Ghent Reconsidered". In: AERTSEN, J. A., SPEER, A. (Hrsg.). Geistesleben im 13. Jahrhundert. Berlin - New York: De Gruyter, 2000, pp. 265-282.

. 'Le 'Quaestiones super Metaphysicam' attribuite a Enrico di Gand. Elementi per un sondaggio dottrinale". Documenti e studi sulla tradizione filosofica medievale 13 (2002), pp. 507-602.

. "Universaux et esse essentia: Avicenne, Henri de Gand et le 'troisième Reich'. Cahiers de philosophie de l'université de Caen 38-9 (2002), pp. 9-50.

. "Doing Theology (and Philosophy) in the First Person: Henry of Ghent's Quodlibeta". In: SCHABEL, C. (ed.). Theological Quodlibeta in the Middle Ages: The Thirteenth Century. Leiden - Boston: Brill, 2006, pp. 171-231.

. "La teologia a Parigi dopo Tommaso: Enrico di Gand, Egidio Romano, Goffredo di Fontaines". In: BIFFI, I., MARABELLI, C. (cur.). Rinnovamento della "Via Antiqua". La creatività tra XIII e XIV secolo. Milano - Roma: Jaca Book - Città Nuova, 2009, pp. 165-262.

. "Res praedicamenti e ratio praedicamenti. Una nota su Teodorico di Freiberg e Enrico di Gand”. BIARD, J., CALMA, D., IMBACH, R. (éd.). Recherches sur Dietrich de Freiberg. Turnhout: Brepols, 2009, pp. 131-43.

. "La (parziale) rivincita di Marta. Vita ativa e vita contemplativa in Enrico di Gand". In: TROTTMANN, C. (ed.). Vie active et vie contemplative au Moyen Âge et au seuil de la Renaissance. Roma: École Française de Rome, 2009, pp. 155-172.

. 'Tra il 'Convivio' e la 'Commedia': Dante e il 'forte dubitare' intorno al desiderio naturale di conoscere le sostanze separate". In: SPEER, A., WIRMER, D. (Hrsg.). 1308: Eine Topographie Historischer Gleichzeitigkeit. Berlin - New York: De Gruyter, 2010, pp. 631-659.

. "Essere o non essere? Dubbi amletici tra le questioni scolastiche". In: PERFETTI, S. (ed.). Scientia, Fides, Theologia. Studi di filosofia medievale in onore di Gianfranco Fioravanti. Pisa: ETS, 2011, pp. 342-352.

. "Res a reor reris / res a ratitudine. Autour d'Henri de Gand". In: ATUCHA, I., et al. (éds.). Mots médiévaux offerts à Ruedi Imbach. Porto: FIDEM, 2011, pp. 617-28. 
. "Review of: TESKE, R. J. Essays on the Philosophy of Henry of Ghent. [...]". Notre Dame Philosophical Reviews. May 19, 2013. Online: http://ndpr.nd.edu/n ews/40083-essays-on-the-philosophy-of-henry-of-ghent/ (consultado em 08/05/2014).

. "Tra l'oscurità della fede e il chiarore della visione. Il dibattito sullo statuto scientifico della teologia agli inizi del XIV secolo". In: BIANCHI, L., CRISCIANI, C. (cur.). Forme e oggetti della conoscenza nel XIV secolo. Studi in ricordo di Maria Elena Reina. Firenze: SISMEL - Edizioni del Galluzzo, 2014, pp. 195-256.

. "La totalité peut-elle être un attribut divin? Les questions De totalitate Dei d'Henri de Gand". Quaestio 16 (2016), pp. 209-223.

PREZIOSO, F. A. La critica di Duns Scoto all'ontologismo di Enrico di Gand. Padova: CEDAM, 1961.

PURNELL Jr., F. "Henry of Ghent as Medieval Platonist in the Philosophy of Jacopo Mazzoni". In: WENIN, C. (éd.). L'homme et son univers au moyen âge. Actes du septième congrès international de philosophie médiévale (30 août - 4 septembre 1982). Vol. II. Louvain-la-Neuve: Éditions de l'Institut Supérieur de Philosophie, 1986, pp. 565-72.

PUTALLAZ, F.-X. La connaissance de soi au XIII' siècle. De Matthieu d'Aquasparta à Thierry de Freiberg. Paris: Vrin, 1991.

- Insolente liberté. Controverses et condamnations au XIII siècle. Fribourg - Paris: Éditions Universitaires - Éditions du Cerf, 1995.

PYCKE, J. Le chapitre cathédral Notre-Dame de Tournai de la fin du XI à la fin du $X I I I^{e}$ siècle. Son organisation, sa vie, ses membres. Louvain-la-Neuve Bruxelles: Collège Érasme - Nauwelaerts, 1986.

- Répertoire biographique des chanoines de Notre-Dame de Tournai, 1080-1300. Louvain-la-Neuve - Bruxelles: Collège Erasme - Nauwelaerts, 1988 .

RENAULT, L. "Félicité humaine et conception de la philosophie chez Henri de Gand, Duns Scot et Guillaume d'Ockham". In: AERTSEN, J. A., SPEER, A. (Hrsg.). Was ist Philosophie im Mittelalter? Akten des X. Internationalen Kongresses für mittelalterlichen Philosophie der SIEPM, 25. bis 30. August 1997 in Erfurt. Berlin - New York: De Gruyter, 1998, pp. 969-76.

RENOUARD, P. Imprimeurs et libraires parisiens $d u X V I^{e}$ siècle. Tome II: BaaleuBanville. Paris: Service des Travaux Historiques de la Ville de Paris avec le de la Bibliothèque Nationale, 1969.

ROHLS, J. Theologie und Metaphysik. Der ontologische Gottesbeweis und seine Kritiker. Gütersloh: Gerd Mohn, 1987.

ROIG, V. L. "Cracking intencional en la metafísica de Enrique de Gand". Carthaginensia. Revista de estudios e investigación 33.63 (2017), pp. 1-62. 
ROMBEIRO, M. E. "Intelligible Species in the Mature Thought of Henry of Ghent". Journal of the History of Philosophy 49.2 (2011), pp. 181-220.

ROSIER, I. "Henri de Gand, le De Dialectica d'Augustin, et l'institution des noms divins". Documenti e studi sulla tradizione filosofica medievale 6 (1995), pp. 145-253.

ROSIER-CATACH, I. "Henri de Gand, le 'De Dialectica' d'Augustin, et la sémantique des noms divins". École pratique des hautes études. Section des sciences religieuses. Annuaire. 104 (1995-1996), pp. 409-415.

- "Henri de Gand, le 'De Dialectica' d'Augustin, et la sémantique des noms divins (2)". École pratique des hautes études. Section des sciences religieuses. Annuaire. 105 (1996-1997), pp. 381-388.

. "Le parler des anges et le nôtre". In : CAROTI, S. et al. (eds.). "Ad ingenii acuitionem». Studies in honour of Alfonso Maierù. Louvain-la-Neuve: Fédération Internationale des Instituts d'Études Médiévales, 2006, pp. 377-401.

RUDAVSKY, T. M. “A re-examination of Henry of Ghent's Criticisms in Light of his Predecessors". The Modern Schoolman 82 (2005), pp. 101-9.

RÜßMANN, H. Zur Ideenlehre der Hochscholastik unter besonderer Berücksichtigung des Heinrich von Gent, Gottfried von Fontaines und Jakob von Viterbo. Inaugural-Dissertation zur Erlangung der Doktorwürde genehmigt von der philosophischen Fakultät der Rheinischen Friedrich-WilhelmsUniversität zu Bonn. Würzburg: Konrad Triltsch, 1937.

RYLE, G. The Concept of Mind. London: Penguin, 2000 [1949].

SALAS, V. M. "Henry of Ghent, Duns Scotus, and Edith Stein on Essential Being". In: SALAS, V. M. (ed.). Hircocervi \& Other Metaphysical Wonders. Milwaukee: Marquette University Press, 2013, pp. 285-307.

SAN CRISTOBAL-SEBASTIÁN, A. Controversias acerca de la voluntad desde 1270 a 1300 (Estudio histórico-doctrinal). Madrid: Editorial y librería CUL., 1958.

SASSEN, F. "Een Nederlandsch wijsgeer: Hendrik van Gent”. De katholiek 153 (1918), pp. 20-40.

SCHINZER, R. "Gott und die Sprache bei Heinrich von Gent (1293)". Neue Zeitschrift für Systematische Theologie und Religionsphilosophie 15.2 (1973), pp. 148-171.

. "Objektivasion der Existenz. Versuch über die trinitarischen Personen bei Heinrich von Gent”. Neue Zeitschrift für Systematische Theologie und Religionsphilosophie 18.2 (1976), pp. 225-245.

SCHMITT, C. B. "Henry of Ghent, Duns Scotus and Gianfrancesco Pico on Illumination”. Mediaeval Studies 25 (1963), pp. 231-258. 
. Gianfrancesco Pico della Mirandola (1469-1533) and his Critique of Aristotle. The Hague: Springer, 1967.

SCHMUTZ, J. "Les paradoxes métaphysiques d'Henri de Gand durant la seconde scolastique". Medioevo 24 (1998), pp. 89-149.

. "L'existence de l'ego comme premier principe métaphysique avant Descartes". In: BOULNOIS, O. (éd.). Généalogies du sujet de saint Anselme à Malebranche. Paris: Vrin, 2007, pp. 215-68.

SCHÖLlGEN, W. Das Problem der Willensfreiheit bei Heinrich von Gent und Herveus Natalis. Hildsheim: Gerstenberg, 1975.

SCHULTER, A. "Die Bedeutung Heinrichs von Gent für die Entfaltung der Lehre von der Unbefleckte Empfängnis”. Theologische Quartalschrift 118 (1937), pp. 312-340, 437-455.

SCHUMACHER, L. Divine illumination in Augustinian and Franciscan Thought. PhD Divinity, The University of Edinburgh, 2009.

SCHWAMM, H. Das göttliche Vorherwissen bei Duns Scotus u. Seinen ersten Anhängern. Innsbruck: Felizian Rauch, 1934.

SIEMIANOWSKI, A. “Teoria istnienia realnego i tzw. sposoby istnienia u Henryka z Gandawy" Roczniki Filozoficzne 13.1 (1965), pp. 33-41.

. "Pojęcie nieskończoności u Henryka z Gandawy". Roczniki Filozoficzne 16.1 (1968), pp. 105-111.

SOLÈRE, J.-L. "Plus ou moins: le vocabulaire de la latitude des formes". In: HAMESSE, J., STEEL, C. (éds.). L'élaboration du vocabulaire philosophique au moyen-âge. Actes du Colloque international de Louvain-la-Neuve et Leuven 12-14 septembre 1998, organisé par la SIEPM. Turnhout: Brepols, 2000, pp. 437-88.

. "Les degrés de forme selon Henri de Gand (Quodl. IV, q. 15)". In: GULDENTOPS, G., STEEL, C. (eds.), Henry of Ghent and the Transformation..., 2003, pp. 127-55.

. "Tension et intention. Esquisse de l'histoire d'une notion". In: COULOUBARITSIS, L., MAZZÙ, A. (dir.). Questions sur l'intentionnalité. Bruxelles: Ousia, 2008, pp. 59-124.

SORGE, V. Gnoseologia e teologia nel pensiero di Enrico di Gand. Napoli: Loffredo, 1988.

. "Sensi interni e sensi esterni in Taddeo da Parma". In: PACHECO, M. C., MEIRINHOS, J. F. (éds.). Intellect et imagination dans la Philosophie Médiévale / Intellect and Imagination in Medieval Philosophy / Intelecto e imaginação na Filosofia Medieval. Actes du XI Congrès International de Philosophie Médiévale de la SIEPM. Porto, du 26 au 31 août 2002. Vol. 3. Turnhout: Brepols, 2006, pp. 1771-82. 
SPEER, A. "Sapientia nostra. Zum Verhältnis von philosophischer und theologischer Weisheit in den Pariser Debatten am Ende des 13. Jahrhunderts". In: AERTSEN, J. A., EMERY Jr., K., SPEER, A. (Hrsg.). Nach der Verurteilung von 1277. Philosophie und Theologie an der Unversität von Paris in letzten Viertel des 13. Jahrhunderts. Studien und Texte. Berlin - New York: De Gruyter, 2001, pp. 248-75.

. "Certitude and Wisdom in Bonaventure and Henry of Ghent". In: GULDENTOPS, G., STEEL, C. (eds.), Henry of Ghent and the Transformation..., 2003, pp. 75-100.

"Doppelte Wahrheit? Zum epistemischen Status theologischer Argumente". In: MENSCHING, G. (Hrsg.). De usu rationis. Vernunft und Offenbarung im Mittelalter. Symposium des Philosophischen Seminars der Leibniz Universität Hannover vom 21. Bis 23. Februar 2006. Würzburg: Königshausen \& Neumann, 2007, pp. 73-90.

SPRUIT, L. Species intelligibilis. From perception to knowledge. Volume I: Classical Roots and Medieval Discussion. Leiden - New York - Köln: Brill, 1994.

SPRUYT, J. "Henry of Ghent on the Use of Denials (a Chapter in the History of Negation)". Mediaevalia. Textos e estudos 7-8 (1995), pp. 441-71.

83.

. "Henry of Ghent on Teaching Theology". Vivarium 49 (2011), pp. 105-

. "Leren ordelijk te denken. Hendrik van Gent (ca. 1217-1293) over de fundamenten van onderwijs". Tijdschrift voor Filosofie 75 (2013), pp. 63-89.

. "Henricus Gandavensi. Mind Your Language! Henry of Ghent's Overzelous Attention to Linguistic Details". In: ANGOTTI, C., BRÎNZEI, M., TEEUWEN, M. (éds.). Portraits de maîtres offerts à Olga Weijers. Turnhout: Brepols, 2013, pp. 233-40.

. "Henry of Ghent and the Power of Inspiration. A Chapter in Neoplatonism". PsyArt 19 (2015), pp. 68-84.

STEEL, C. "Henricus Gandavensis Platonicus". In: GULDENTOPS, G., STEEL, C. (eds.), Henry of Ghent and the Transformation..., 2003, pp. 15-39.

STELLA, P. "La prima critica di Herveus Natalis O. P. alla noetica di Enrico di Gand: il 'De intellectu et specie' del cosiddetto 'De quatuor materiis'”. Salesianum 21.1 (1959), pp. 125-70.

STORCK, A. "Eternidade, possibilidade e indiferença: Henrique de Gand leitor de Avicena". Analytica 9.1 (2005), pp. 137-72.

SUAREZ-NANI, T. "Individualität und Subjektivität der Engel im 13. Jahrhundert. Thomas von Aquin, Heinrich von Gent und Petrus Johannis Olivi”. Das Mittelalter 11 (2006), pp. 29-48. 
SUlliVAN, M. B. The Debate over Spiritual Matter in the Late Thirteenth Century: Gonsalvus Hispanus and the Franciscan Tradition from Bonaventure to Scotus. A dissertation submitted to the Faculty of the School of Philosophy of the Catholic University of America in Partial Fulfillment of the Requirements for the Degree Doctor of Philosophy. Washington D.C., 2010.

SURZYN, J. "Stanowisko Henryka z Gandawy w sporze o realną różnicę istoty i istnienia w bytach stworzonych". Folia Philosophica 19 (2001), pp. 107-21.

TACHAU, K. H. Vision and Certitude in the Age of Ockham. Optics, Epistemology and the Foundations of Semantics, 1250-1345. Leiden - New York København - Köln: Brill, 1988.

TELLENBACH, H. Melancholie. Problemgeschichte, Endogenität, Typologie, Pathogene, Klinik. Vierte, erweiterte Auflage mit einem Exkurs in die manischmelancholische Region. Mit einem Geleitwort von V. E. Von Gebsattel. BerlinHeidelberg-New York-Tokyo: Springer, 1983.

TENNEMANN, W. G. Geschichte der Philosophie. Band 8.2. Leipzig: Johann Ambrisius Barth, 1811.

TERÄVÄINEN, J. "Henrik Gentiläisen tieto-oppi”. Tampereen Yliopiston Filosofian Laitoksen Julkaisuja / Reports from the Institute of Philosophy, University of Tampere 5 (1975), $47 \mathrm{pp}$.

TESKE, R. Essays on the Philosophy of Henry of Ghent. Milwaukee: Marquette University Press, 2012.

. "Henry of Ghent's Rejection of the Principle: 'Omne Quod Movetur ab Alio Movetur'". In: TESKE, R. Essays on Henry of Ghent. Milwaukee: Marquette University Press, 2012, pp. 9-40 [= In: VANHAMEL, W. (ed.). Henry of Ghent. Proceedings..., 1996, pp. 279-308].

. "Henry of Ghent's Criticism of the Aristotelian Arguments for God's Existence". In: TESKE, R. Essays on the Philosophy of Henry of Ghent, 2012, pp. 41-64 [=The Modern Schoolman 82 (2005), pp. 83-99].

. "Henry of Ghent's Metaphysical Argument for the Existence of God". In: TESKE, R. Essays on the Philosophy of Henry of Ghent, 2012, pp. 65-91 [=The Modern Schoolman 83 (2005), pp. 19-38].

. "Distinctions in the Metaphysics of Henry of Ghent". In: TESKE, Essays on the Philosophy of Henry of Ghent, 2012, pp. 93-115 [=Traditio 61 (2006), pp. 227-245].

. "Some aspects of Henry of Ghent's Debt to Avicenna's Metaphysics". In: TESKE, Essays on the Philosophy of Henry of Ghent, 2012, pp. 119-143 [=The Modern Schoolman 85 (2007), pp. 51-70].

. "Henry of Ghent on Anselm's Prologion Argument". In: TESKE, R. Essays on the Philosophy of Henry of Ghent, 2012, pp. 145-164 [=Traditio 4 (2009), pp. 213- 228]. 
. “Augustine's Influence on the Philosophy of Henry of Ghent". In: TESKE, Essays on the Philosophy of Henry of Ghent, 2012, pp. 165-189 [=In: CARY, P., DOODY, J., PAFFENROTH, K. (eds.). Augustine and Philosophy. Lanham: Lexington Books, 2010, pp. 197-218].

. "Henry of Ghent on the Freedom of the Will". In: TESKE, R. Essays on Henry of Ghent, 2012, pp. 199-220 [= In: WILSON, G. A. (ed.). A Companion to Henry of Ghent, 2011, pp. 315-35].

. "Henry of Ghent's Apophatic Theology". In: TESKE, Essays on the Philosophy of Henry of Ghent, 2012, pp. 221-46.

. "Henry of Ghent and the Analogy of Being". In: TESKE, R. Essays on the Philosophy of Henry of Ghent, 2012, pp. 247-63.

- "Augustinian Abstraction and Henry of Ghent's Metaphysical Argument". In: SALAS, V. M. (ed.). Hircocervi \& Other Metaphysical Wonders. Milwaukee: Marquette University Press, 2013, pp. 309-28.

TIEDEMANN, D. Geist der speculativen Philosophie. Band 4. Marburg: Akademische Buchhandlung, 1795.

TIERNEY, B. "Natural Rights in the Thirteenth Century: A Quaestio of Henry of Ghent". Speculum 67 (1992), pp. 58-68.

TROTTMANN, C. La vision beatifique des disputes scolastiques à sa définition par Benoît XII. Rome: École Française de Rome, 1995.

. "Henri de Gand, source de la dispute sur la vision réflexive". In: VANHAMEL, W. (ed.). Henry of Ghent. Proceedings..., 1996, pp. 309-42.

. Théologie et noétique au XIII siècle. À la recherche d'un statut. Paris: Vrin, 1999.

TYÖRINOJA, R. “Auriole's Critique of Henry of Ghent's lumen medium”. In: AERTSEN, J. A., SPEER, A. (Hrsg.). Was ist Philosophie im Mittelalter? / Qu'est-ce que la philosophie au Moyen Âge? / What is Philosophy in the Middle Ages? Akten des X. Internationalen Kongresses für mittelalterlichen Philosophie der SIEPM, 25. bis 30. August 1997 in Erfurt. Berlin - New York: De Gruyter, 1998, pp. 622-8.

. "Lumen medium. Henry of Ghent on the Accessibility of Theological Truths". In: HOLMSTRÖM-HINTIKKA, G. (ed.). Medieval Philosophy and Modern Times. Dordrecht - Boston - London: Kluwer Academic Publishers, 2000, pp. 161-82.

UEBERWEG, F. Grundriss der Geschichte der Philosophie. Zweiter Teil. Hrsg. von Matthias Baumgartner. Berlin: Siegfried Mittle und Sohn, $1915^{10}$ [1864].

VANHAMEL, W. (ed.) Henry of Ghent. Proceedings of the International Colloquium on the occasion of the 700th anniversary of his death (1293). Leuven: Leuven University Press, 1996. 
VAUCHEZ, A. La spiritualité du Moyen Âge occidental. VIII ${ }^{e}-X I I I^{e}$ siècle. Paris: Éditions du Seuil, 1994.

VELDHUIJSEN, P. van. "Hendrik van Gent (vóór 1240-1293) contra Thomas van Aquino (1224/25-1274). Over de mogelijkheid van een eeuwig geschapen wereld". Stoicheia 2.3 (1987), pp. 3-26.

VERWEYEN, J. Das Problem der Willensfreiheit in der Scholastik. Auf Grund der Quellen dargestellt und kritisch gewürdigt. Heidelberg: Carl Winter, 1909.

VOOGHT, P. "La méthode théologique d'après Henri de Gand et Gérard de Bologne". Recherches de théologie ancienne et médiévale 23 (1956), pp. 61-87.

WALLER, J. 'Spinoza's Attributes and the 'Intermediate' Distinctions of Henry of Ghent and Duns Scotus". Florida Philosophical Review 9.1 (2009), pp. 91-105.

WÉBER, E. H. La personne humaine au XIII siècle. Paris: Vrin, 1991.

WEI, I. P. "The Self-Image of the Masters of Theology at the University of Paris in the Late Thirteenth and Early Fourteenth Century". The Journal of Ecclesiastical History 46.3 (1995), pp. 398-431.

. "From Twelth-Century Schools to Thirteenth-Century Universities: The Disappearance of Biographical and Autobiographical Representations of Scholars". Speculum 86.1 (2011), pp. 42-78.

. Intellectual Culture in Medieval Paris. Theologians and the University c. 1100-1330. Cambridge: Cambridge University Press, 2012.

WERNER, K. Heinrich von Gent als Repräsentant des christlichen Platonismus in dreizehnten Jahrhundert. Wien: Carl Gerold's Sohn, 1878.

. Die Psychologie, Erkenntnis- und Wissenschafstlehre des Roger Baco. Wien: Carl Gerold's Sohn, 1879.

. Die italienische Philosophie des neunzehten Jahrhunderts. Zweiter Band: Der Ontologismus als Philosophie des nationalen Gedankens. Wien: Georg Paul Faesy, 1885.

WIELOCKX, R. "Commentaire". In: AEGIDIUS ROMANUS. Apologia. Ed. et commentaire par R. Wielockx. Firenze: Olschki, 1985 (Aegidii Romani Opera omnia III.1), pp. 67-225.

. "Henry of Ghent and the Events of 1277". In: WILSON, G. A. (ed.). A Companion to Henry of Ghent, 2011, pp. 25-61.

. "Preuves physiques et preuve métaphysique de l'existence de Dieu: Henri de Gand en contexte historique". In: PEREZ DE LABORDA, M. (ed.). Sapienza e libertà. Studi in onore del Prof. LLuís Clavell. Roma: Edizioni Santa Croce, 2012, pp. 457-526. 
. "Henri de Gand et Gilles de Rome à la lumière de la bibliothèque de Godefroid de Fontaines". In: CORDONIER, V., SUAREZ-NANI, T. (éds.). L'aristotélisme exposé, 2014, pp. 181-259.

WILLIAMS, S. M. "Augustine, Thomas Aquinas, Henry of Ghent, and John Duns Scotus: on the Theology of the Father's Intellectual Generation of the Word". Recherches de théologie et philosophie médiévales 77.1 (2010), pp. 35-81.

WILKINS, S. Henry of Ghent's Doctrine of Analogy. Its Origins and Interpretations. A thesis presented in partial fulfillment of the requirements for the degree of Licentiate (M.A.) in Philosophy - Hoger Instituut voor Wijsbegeerte, Katholieke Universiteit Leuven, 2007.

WILSON, G. A. Dymorphism and the Metaphysical Unity of Man in Quodlibeta magistri Henrici Goethals a Gandavo doctoris solemnis: socii sorbonici: et archidiaconi tornacensis cum duplici. A Dissertation Submitted on the First Day of June, 1975, to the Department of Philosophy of the Graduate School of Tulane University in Partial Fulfillment of Requirements for the Degree of Doctor Philosophy, 1975.

. "Henry of Ghent's Quodlibet III: A Response to Giles of Rome's Contra gradus". Proceedings of the Patristic, Medieval and Renaissance Conference 3 (1978), pp. 77-84.

. "Henry of Ghent and René Descartes on the unity of man". Franziskanische Studien 64 (1982), pp. 97-110.

. "Human Generation according to Henry of Ghent". Proceedings of the Patristic, Medieval and Renaissance Conference 9 (1984), pp. 59-68.

. "Non-Being: Eviternity and Time in the Ontology of Henry of Ghent". Mediaevalia. Textos e estudos 3 (1993), pp. 77-90.

. "Supposite in the Philosophy of Henry of Ghent". In: VANHAMEL, W. (ed.) Henry of Ghent. Proceedings..., 1996, pp. 343-372.

. "Henry of Ghent's Quodlibet I: Initial Departures from Thomas Aquinas". History of Philosophy Quarterly 16.2 (1999), pp. 167-80.

. "The Human Person in Henry of Ghent's Thought". Medieval Perspectives 17.1 (2002), pp. 151-66.

. "Henry of Ghent and John Peckham's Condemnation of 1286". In: GULDENTOPS, G., STEEL, C. (eds.), Henry of Ghent and the Transformation..., 2003, pp. 261-75.

. (ed.). A Companion to Henry of Ghent. Leiden - Boston: Brill, 2011.

. "Henry of Ghent's Written Legacy". In: WILSON, G. A. (ed.). A Companion to Henry of Ghent, 2011, pp. 3-23. 
. "Le Contra gradus de Gilles de Rome". In: CORDONIER, V., SUAREZ-NANI, T. (éds.). L'aristotélisme exposé, 2014, pp. 29-54.

WITTERBRUCK, W. Die Gewissenstheorie bei Heinrich von Gent und Richard von Mediavilla. Inaugural-Dissertation zur Erlangung der Doktorwürde der Hohen Philosophischen Fakultät der Rheinischen Friedrich-Wilhelms-Universität zu Bonn. Promoviert am 14. November 1928. Elberfeld: Wuppertaler Druckerei, 1929.

WIPPEL, J. F. “Godfrey of Fontaines and Henry of Ghent's Theory of Intentional Distinction between Essence and Existence". In: KÖHLER, T. W. (éd.). Sapientiae procerum amore. Mélange Médiévistes offerts à Dom Jean-Pierre Müller O.S.B. à l'occasion de son $70^{\text {ème }}$ anniversaire (24 février 1974). Roma: Editrice Anselmiana, 1974, pp. 289-321.

. "The Relationship Between Essence and Existence in Late-ThirteenthCentury Thought: Giles of Rome, Henry of Ghent, Godfrey of Fontaines, and James of Viterbo". In: MOREWEDGE, P. (ed.). Philosophies of Existence. Ancient and Medieval. New York: Fordham University Press, 1982, pp. 131-64.

. "Thomas Aquinas, Henry of Ghent, and Godfrey of Fontaines on the Reality of Nonexisting Possibles". In: WIPPEL, J. F. Metaphysical themes in Thomas Aquinas. The Catholic University of America Press: Washington D.C., 1984, pp. 163-189.

. "Divine knowledge, divine power and human freedom in Thomas Aquinas and Henry of Ghent”. In: RUDAVSKY, T. (ed.). Divine Omnscience and Omnipotence in Medieval Philosophy. Dordrecht: D. Reidel Publishing Company, 1985, pp. 213-41.

. "Bishop Stephen Tempier and Thomas Aquinas: A Separate Process against Aquinas?". Freiburger Zeitschrift für Philosophie und Theologie 44 (1997), pp. 117-136.

WIRTH, J. "Le cadavre et les vers selon Henri de Gand (Quodlibet X, 6)". Micrologus 7 (1999), pp. 283-295.

WOLTER, A. B. The Transcendentals and Their Function in the Metaphysics of Duns Scotus. St. Bonaventure: The Franciscan Institute, 1946.

. "Ockham and the Textbooks: On the Origin of Possibility". Franziskanische Studien 32 (1950), pp. 70-96.

WULF, M. de. Études sur Henri de Gand. Louvain - Paris: Uystpruyst-Dieudonné Félix Alcan, 1894 [= Histoire de la philosophie scolastique dans les Pays-Bas et la principauté de Liège jusqu'a la Révolution Française. Louvain - Paris: Uystpruyst-Dieudonné - Félix Alcan, 1895, pp. 46-272].

"L'exemplarisme et la théorie de l'illumination spéciale dans la philosophie de Henri de Gand". Révue néo-scolastique 1.1 (1894), pp. 53-75. 
. Le traité "De Unitate Formae" de Gilles de Lessines. Texte inédit et Étude. Louvain: Institut Supérieur de Philosophie de l'Université, 1901.

. "Méthodes scolastiques d'autrefois et d'aujourd'hui". Revue néoscolastique 10 (1903), pp. 165-184.

. "L'augustinisme 'avicennisant"”. Revue néo-scolastique de philosophie 33 (1931), pp. 11-39.

YLINEN, M. Pyrrhonismi renessanssifilosofiassa ja konstruktiivinen skeptisismi 1600-luvulla. Kuusi argumenttia Richard Popkinin tulkintaa vastaan. Tampere: Tampere University Press, 2016.

ZAVALLONI, R. Richard de Mediavilla et la controverse sur la pluralité des formes. Textes inédits et étude critique. Louvain: Éditions de l'Institut Supérieur de Philosophie, 1951.

ZIMMERMANN, A. Ontologie oder Metaphysik? Die Diskussion über den Gegenstand der Metaphysik im 13. und 14. Jahrhundert. Texte und Untersuchungen. Leuven: Peeters, 1998.

ZUCCOLIUS PATAVINUS, V. "Commentaria”. In: HENRICUS DE GANDAVO. Aurea quodlibeta $<\ldots>$ commentariis doctissimis illustrata M. Vitalis Zucolii Patavini ordinis camaldulensis Theologi Clarissimi <...>. 2 vols. Venetiis: apud Iacobum de Franciscis, $1613^{2}$ [1608], passim. 